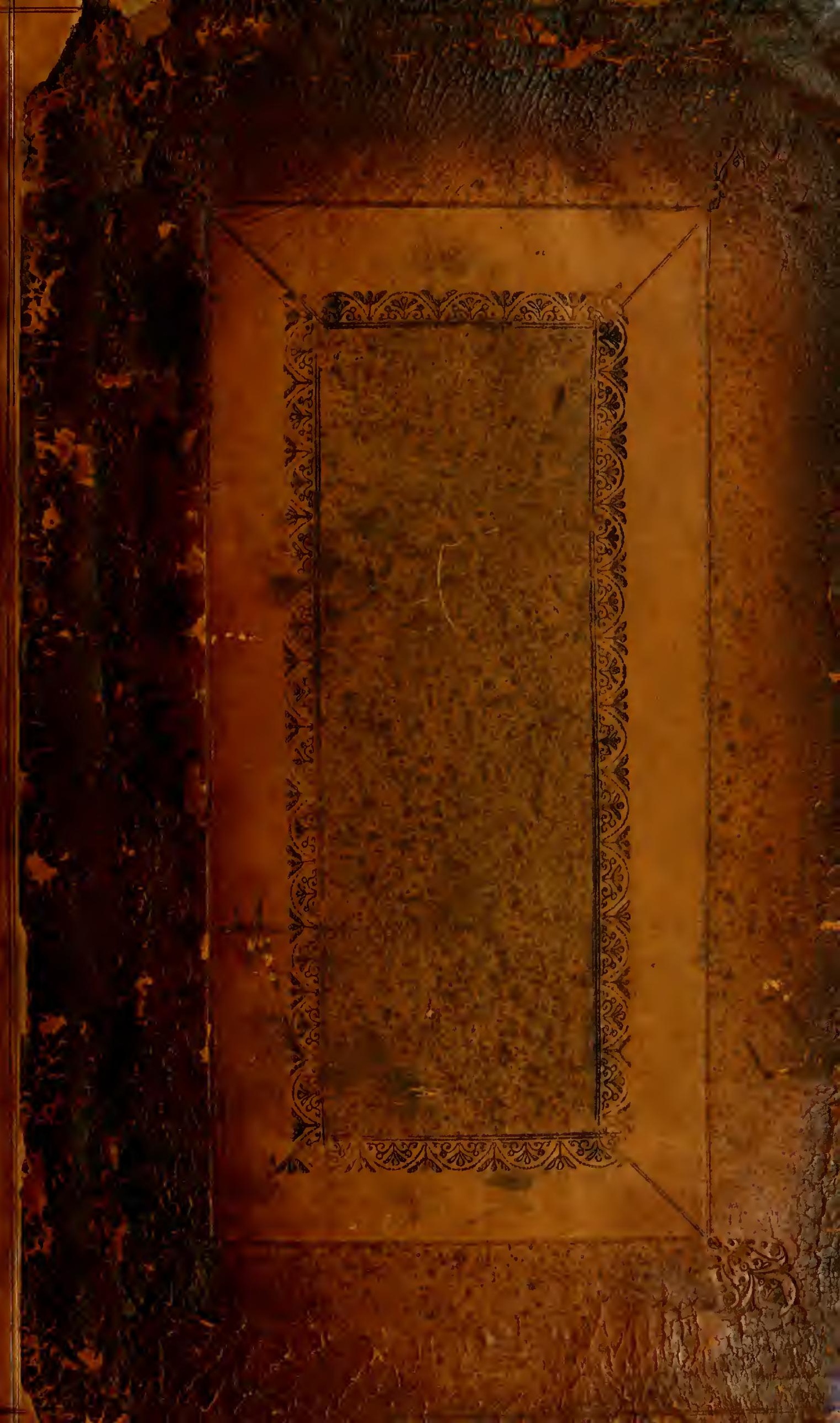


3lohnt Alinum

Tilnary.

IN THE CUSTODY OF THE

BOSTON PUBLIC LIBRARY.

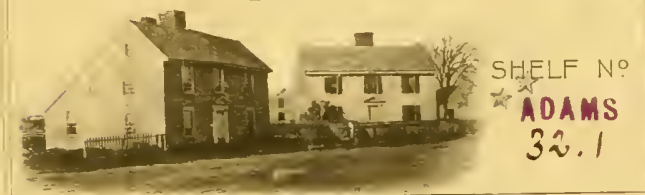






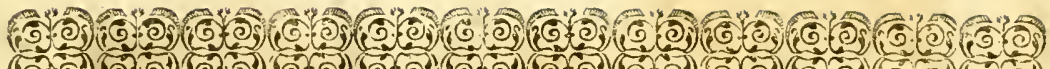

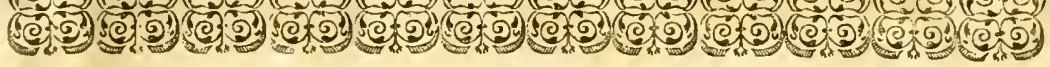

$$
\text { T R A V E L }
$$$$
G E O G R A P H I C A L \text {, }
$$

PHYSICAL and MISCELLANEOUS

s OBSERVATIONS \&. 6. 


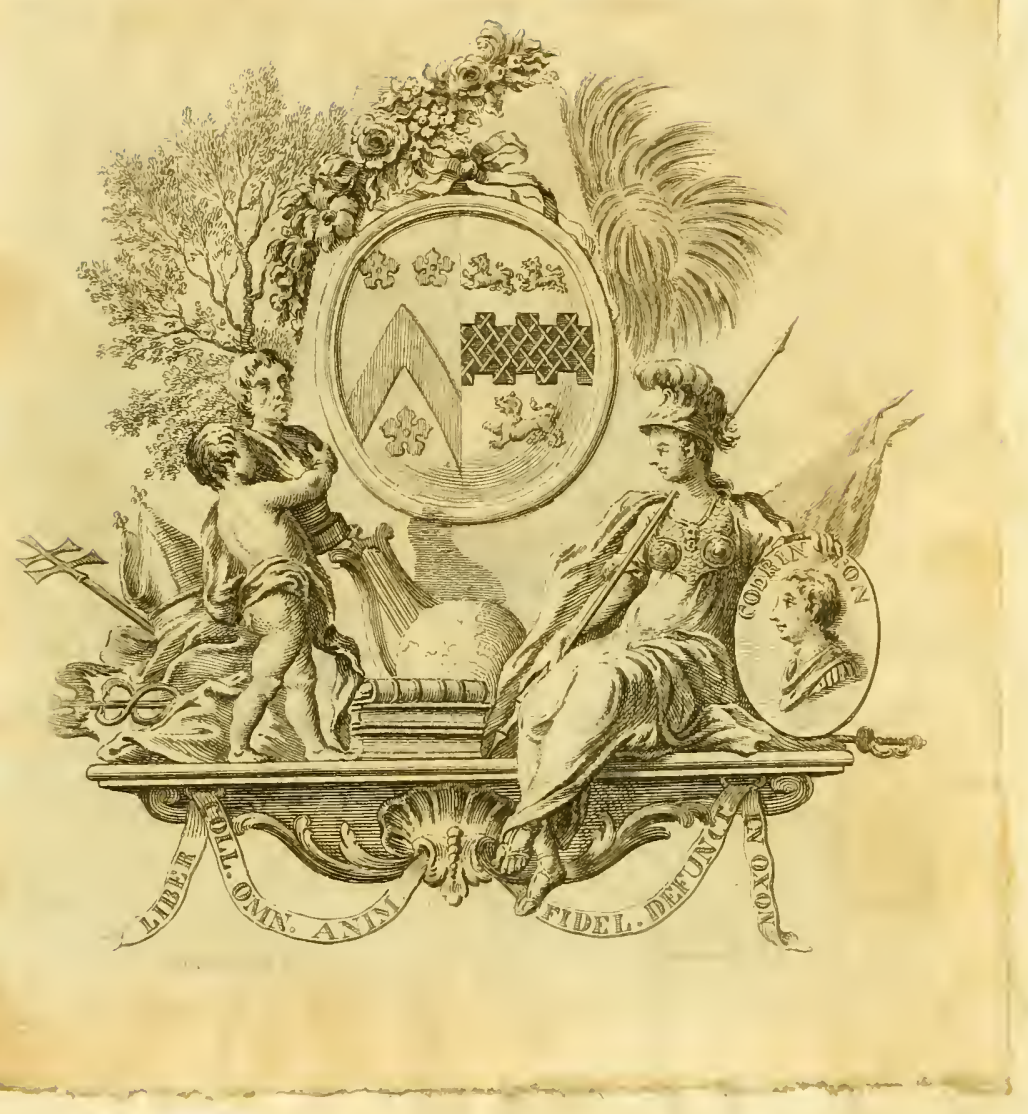




\section{TRAVELS, \\ O R}

O B S E R VA T I O N S RELATING TO

SEVERAL PARTS

O F

B A $\quad$ R A N D T H E

L E V A N T.

By THO M A S S H A W, D. D.

Fellow of Quenn's-College in Oxford, and F.R.S.

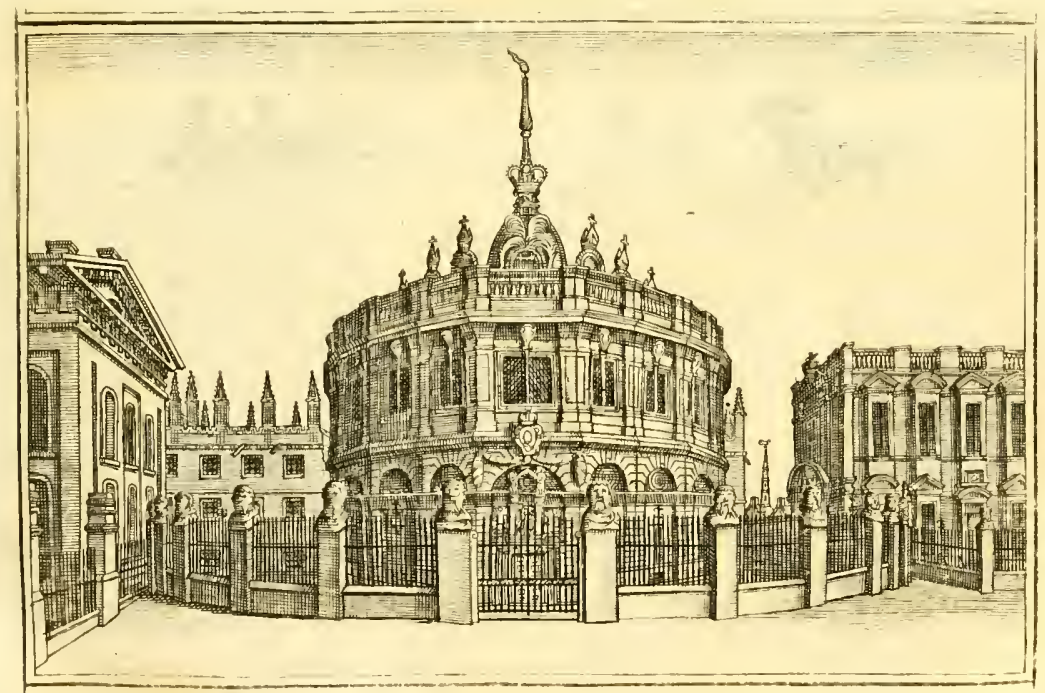

O X F R D,

Printed at the THEATRE, MDCCXXXVIII. 
TDAMS 32.1

Ctitent 4055

\section{Imprimatur,}

STEPH. NIBLETT,

Vice-Cancell. Oxon.

Apr. 25.1738. 


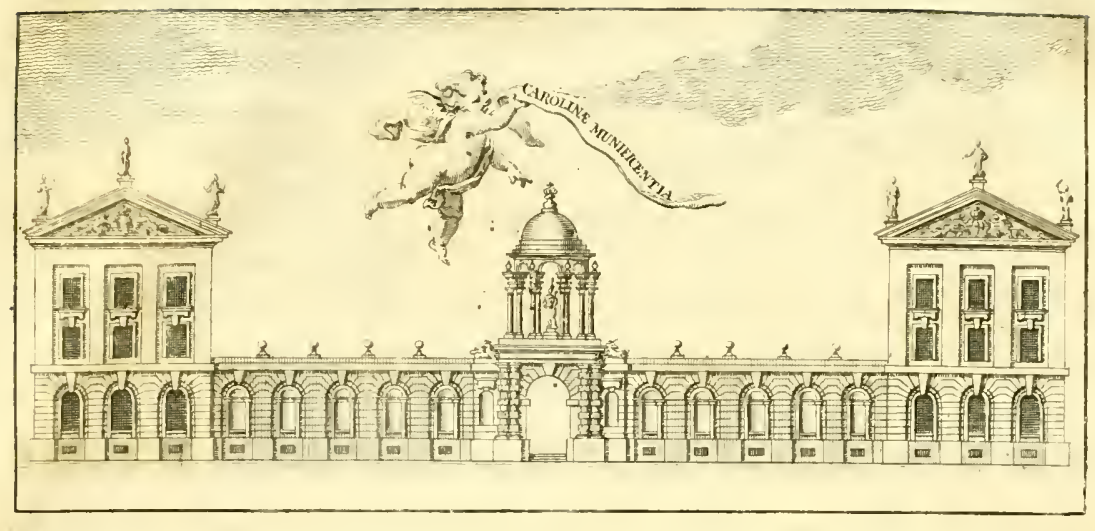

\section{T O T H E}

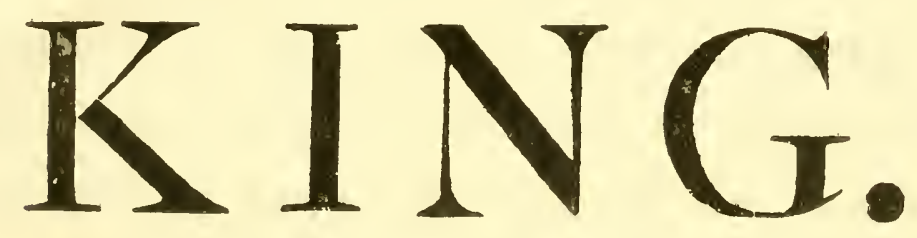

\section{Moft Gracious Sovereign,}

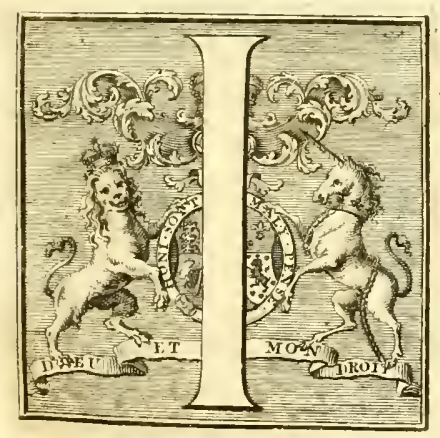

Beg Leave to approach Tour RoyalPerfon, with an humble Prefent in my Hand, after the Fafhion of thofe Countries, where I have long refided.

It is a Volume of Travels and Obfervations; wherein are defcribed the Situation, Polity, and Cuftoms of various Nations;-Nations unacquainted with Liberty, and whofe Government is the 


\section{The Dedication.}

the very Reverfe of Your Majefty's wife and gracious Adminiftration.

I had an Opportunity of making Thefe Obfervations, whilft I had the Honour of being Your Majefty's Chaplain at Algiers. It was in this Situation, that I firft collected Materials for the following Sheets; and fo extenfive is Your Majefty's Influence, that it procured me Safety and Protection, even in Countries remote and barbarous.

A Work, which owes it's Rife, it's Progrefs, and Completion to thefe Affiftances, feems in fome Degree entitled to Your Royal Favour, and is therefore with all Humility prefented to Your Sacred Majefty.

Whilf I was engaged in this Undertaking, it was a pleafing Encouragement to confider, that my well-intended Labours were approved by Her Late Majefty; and it did not a little enflame my Endeavours, when She was pleafed to promife me the Honour of Her Royal Patronage.

But I muft not prefume to mention private and perfonal Favours, when Whole Societies are indebted to That Illuftrious Princess. Particularly, That Antient Houfe of Learning (of which I have the Happinefs to be a Member,) ftands diftinguifh'd by Her Royal

Bounty, 


\title{
The Dedication.
}

Bounty, and owes it's Beauty and Ornament to Her Munificence.

If Heaven had fpared that invaluable Life, with what Zeal thould we have paid repeated Acknowledgments to our Royal Benefactrefs! But now-We can only joyn with Thoufands in lamenting the Publick Lofs, and with Gratitude tranfmit Her Memory to our lateft Succeffors.

That Providence may long preferve Your Majefty, and continue the many Bleflings of Your Reign to This Church and Nation, is the conftantPrayer of,

\author{
May it pleafe Your M AjE s Ty, \\ Your MA JEST Y's
}

Moft Humble

And Moft Devoted.

Servant and Subject,

THOMAS SHAW. 


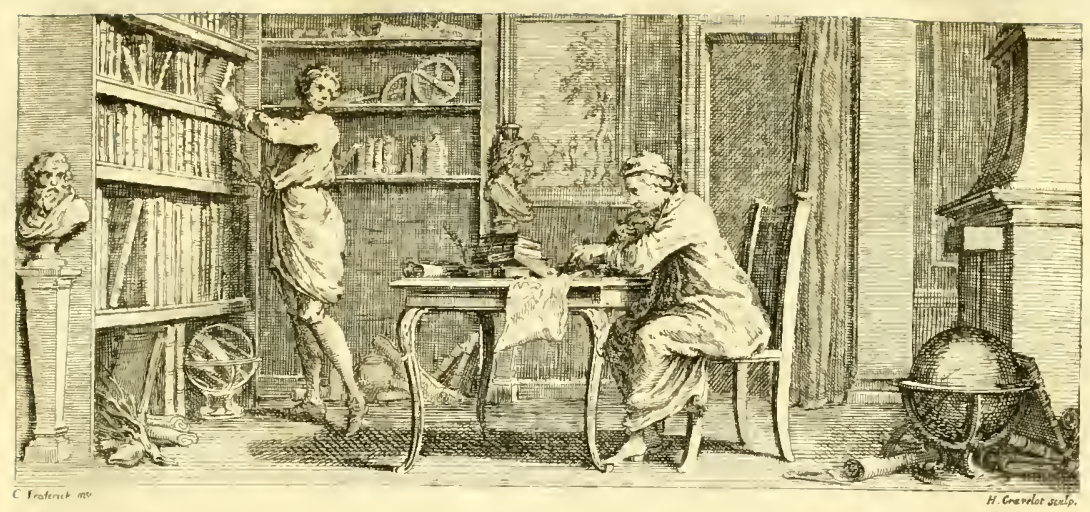

\section{$\begin{array}{lll}\mathrm{T} & \mathrm{H} & \mathrm{E}\end{array}$}

\section{P R E F A C E.}

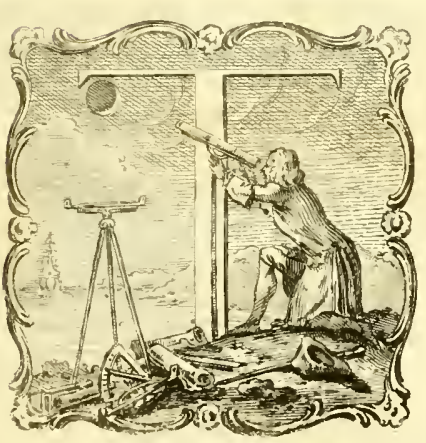

$H E$ following Obfervations are prefented to the Reader, as an Effay towards reftoring the antient Geography, and placing in a proper Light the Natural Hiftory of thofe Countries, where the Author has travelled. In purfunce of which Defign, the Geographical and Phyfical Obfervations, are not blended and mixed together, as they chanced to fall in his Way; but are ranged under difinit Heads, without repeating at every Turn and upon every Occafion, the Time, Place, or Manner, wherein they were made. However, as the Method of Jurveying the fe Countries; the Diet and Reception of the Traveller; the Hardifipips and Dangers to which he is exposed; with other Incidents of the like Nature, may be thought Matter of too great Curiofity to be paffed over in Silence; the Author propofes to Supply, all that may be wanting upon that Subject, by giving the Reader, in one Vierw; 
Such material Circumftances and Occurrences, as might have made up the Diary-Part of His Travels.

The Reader therefore is to be informed, that in the feveral maritime Towns of Barbary and the Levant, where the Britifh Factories are eftablifhed, I was entertained with extraordinary Marks of Generofity and Friendhip; baving the UJe not only of their Houses, but of their Horses alfo, their Janiffaries and Servants. My beft Acknowledgments therefore are due, upon this Account, to the worthy Gentlemen, Mr. Conful Carew and his Brother, at Tripoly in Syria; to the late Mefleurs Thomas Ufgate and French, and to Mr. John Ufgate, at Acre; to the late Mr. Conful Moore and his Deputy Mr. Damarel at Kairo and Alexandria; to Meffeurs Lawrence and Hudfon, the Britifh and Dutch Confuls, at Tunis; and to Mr. Edward Holden, my generous Friend and Benefactor during the twelve Years I refided at Algiers. I am indebted likewife to Jeveral Gentlemen of the French Nation, for many Inftances of their Civility and Politene Ss; particularly to the Merchants Jettled at Jaffah and Ramah; to Mr. Salve, Agent to the African Company at Bona; and to Mr. Fort the Governour of La Calle.

In the Inland Towns and Villages of Barbary, there is, for the most Part, a House Jet apart for the Reception of Strangers, with a proper Officer (the Maharak, Ithink they call him) to attend it. Here Perfons are lodged and entertained, for one Night, in the beft Manner the Place will afford, at the Expence of the Community.

Except at the $\int e$ and the Places above-mentioned, I met with no Khanns ${ }^{I}$ or Houfes of Entertainment throughout the whole Course of my Travels. To furnifh ourfelves with Tents, would have been bothcumber Some and expenfive; befides the Su/picion it might have raifed in the A rabs, that we were Perfons of Rank and Fortune, and con Sequently too rich and tempting a Booty to be fuffered to efcape. The unfortunate Gentlemen, who were concerned, not many Years

I Vid. Pref. Noto. p. Iv. 
ago, in an Embaffy to Abyflinia, found This to be true, at the Expence of their Lives.

If therefore in the Course of our travelling we did not fall in with the Hovels of the Kabyles, or the Encampments of the Arabs, we had nothing to protect us from the In. clemency either of the Heat of the Day, or the Cold of the Night, unless we met with fome accidental Grove of Trees, the Shelve of a Rock, or Sometimes, by good Fortune, a Grotto. At the Je Times, which indeed did Seldom bappen, our Horfes were the greate/t Sufferers: and as they were always our firft Care, we gathered for them Stubble, Grafs, Boughs of Trees, and fuch like Provender, before we fat down and examined what Fragments, of fome former Meal, were referved for ourfelves.

In travelling from Kairo to Mount Sinai, the Heavens were every Night our only Covering; the Sand, Spread over with a Carpet, was our Bed; and a Change of Raiment, made up into a Bundle, our Pillow. Our Camels (for Horses or Mules require too much Water to be employed in the Se Deferts) were made to lye round us in a Circle, with their Faces looking from us, and their respective Loads and Saddles placed behind them. In this Situation, they ferved us

I Nothing can give the Reader a more lively Picture of the jealous and infolent Behaviout of the Arabs, when they are Malters, than the following Account, which Mr. Lippi, the Phyfician to the Embaffy, gives of the Nubiuns, a little before this Maffacre is fuppofed to have happened. The Letter, which is preferved among other Papers of that unfortunate Gentleman, in the Shcrardian Library, is directed to Mr. Fagon, firft Phyfician to the French King, and dated from Korty in Nubia, Mar. 8. 1705. Les bruits, Monfieur, qu'on a repandu de nous, dés le Caire, ont fait un tel progres qu'il Jemble que l'Enfer n'a pu rien inventer de pis. Il y a plus de 4 mois que nous fommes en Nubie l'objet de la fureur des pouples. Ainfi nous faifons un fort manvais fang apres les immenfes fatigues dudefert. On attendoit un autre fort fur les Etats d'un Roy, vers le quel onva. On croyoit qu'en ecrivant des Lettres, ce Prince les receveroit, mais le Commandant du pays les a toutes retenues pour avoir occafion de nous ronger. Tout n'eft icy que mifere et convoitife infatiable: perfonne n'eft bonteuz de demander encore, et ce avec infolence. Il faudroit donner a tout le monde, et rien moins que des babits. La Tente eft tous les jours environnée d'une foule de canaille noire, arméc de lances, et mal peignée; dont on ne voit que les yeux et les dents, qu'ils montrent moitié de rage et moitié par etonnement. He, dirent ils, ces gens font etendus fur des lits comme nos Roys, et nous refterons nuds? toujours lire, toujours ecrire, chercher des herbes et des arbres que l'on feche dans du papier pour les enfermer, choifer une pierre entre mille et charger des chameanx de toutes ces chofes? qui a jamais veu cela? On a bien raifon de dire que ces mechants hommes vont fecher notrc Nil, ou l'empoifonner pour nousperdre. A quoi tient-il mintenant qu'on ne s'en défaife? *** Fugcz, Monfleur, de ce que j’ay pu faire. Fetois reduit a parcourir des yetux les environs de la Tente, ou je prouvois le fort de Tantale. $f$ c n'ay pu confier tout mon travail a cotte occafion; j'ay tranfmis feulement les nouveaux genres, tels que je les ay d'abord mis fur le papier, dans un etat d'alarme, de trouble, et de langueur. Bomncs ou mauvaifes que foient ces petites obfervations jofe, Monfieur, vous les prefenter; c'eft yous qui me donnes les forces, ou la temerité de les fuive. Fe fuis bc. 
as fo many Guards, being watchful Animals, and awaking with the Leaft Noife.

As there was no Chance of meeting, in the ele long and dreery Deferts, with the leaft Hofpitality or Entertainment, we were obliged to carry along with us all Things neceffary for fo long and tedious a Fourney. We took Care, in the first Place, to provide ourfelves with a Juflcient Quantity of Goat's Skins, which we fllled with Water, every four or five Days, or as often as we found it. Barley, with a few Beans intermixed; or elfe the Flour of one or other of them, made into Balls, was the Provender we laid in for our Camels. We provided for our felves Wheat-Flour, Bifcuit, Honey, Oyl, Vinegar, Olives, Lentils, potted Fle fh, and Such Things as would keep, during two Months, the Space commonly taken up in compleating this Fourney. Nor Should the Wooden Bajon or Copper Pot be forgotten, that made up our Kitchen Furniture; the latter whereof was the neceffary Utenfl for cooking our Provifion, the other for ferving it up, or kneading our unleavened Cakes.

When we were either to boyl or bake, the Camel's Dung that we found left by fome preceeding Cara van ${ }^{1}$, was our common Fuel; which, after it has been exposed a Day or two in the Sun, catches Fire like Touchwood, and burns as bright as Charcoal. No fooner was our Food prepared, (whether it was potted Fle/h, boyled with Rice; a Lentil Soup; or unleavened Cakes, ferved up with Oyl or Honey;) than one of the Arabs, after baving placed himself upon the bighest Station he could find, invites three Times, with a loud Voice, all his Brethren, The Sons of the Faithful, to come and partake of it; though none of them were in View, or perbaps within a bundred Miles of us. This Cuftom bowever they maintain to be always a Token of their

I Vox Perfica eft ulg, ls Cârvân, id eft, Negotiator, vel collective Negotiatores; fc. sota eorum Cohors fimul iter faciens, qux Arabicè diblä Cáfila vocatur. Hinc Mercatorum Hofpitia publica qux Arabibus audiunt خان Cân, Perfis J Ju ulg, U Cârvân Serâi nomiantur, i.e. Caravana hofpitium. Nam Serâi eft quxvis Domus ampla; unde in Conftantinopoli, Imperatoris Palatium foeminarum Turcis dicitur nomine Perfico Serâi, Europxis minus bene Serail \& Seraglio. Vid. Perit. Itingera Mundi. Ed. T. Hyde, p. Gr. 


\section{T H E P R E F A E.}

great Benevolence, as it would be of their Horpitality like: wife, if they had an Opportunity to hew it.

When we are fo fortunate, in travelling in Barbary, to find out the Encampments of the Arabs, (for we are not fond of vifiting the Kabyles, who are not fo eafily managed, ) we are entertainted, for one Night, upon free Coft: the A rabs, either by long Cuftom, the particular Tenure of their Lands, or rather perhaps from Fear and Compulfion, being obliged to give the Spahees, and thofe who are with them, the Mounah, ( $\infty, 0)$ as they call it, which is a Jufficient Quantity of Provifions for themfelves and their Horfes. Befides a Borcl of Milk, and a Basket of Figs, Raifins, Dates, or other dryed Fruit, which were prefented to us upon our Arrival, the Mafter of the Tent, where we lodged, fetcht us from his Flock, (accurding to the Number of our Company) a Kid, or a Goat; a Lamb, or a Sheep; balf of which was immediately feethed by his Wife, and ferved up with Cufcafowe; the reft, was ufually made $\mathrm{Kab}-\mathrm{ab}{ }^{\mathrm{I}}$, and referved for our Breakfaft or Dinner the next Day.

However, the Tents of the fe roving Herd/men, though they may fhelter us from the Weather, are notwithftanding attended with their Inconveniences. For the Cold, and the Dews that we are every Night expofed to, in the Deferts of Arabia, do not incommode us balf fo much as the $V$ ermin and InJects of allKinds, which never fail to moleft us here. Befides Fleas and Lice, which, without a Miracle, are here in all their Quarters, the Apprehenfions we are under, of being bit or ftung by the Scorpion, Viper, or Venemous-Spider, rarely fails, in fome Parts of the fe Comntries, to interrupt the Reft, that is So grateful and neceffary to a weary Traveller. Upon Sight indeed of one or other of the fe venemous Beafts, $a$ Thaleb or Writer, who bappened to be one of my Spahees, after he had muttered a few Words, exhorted us all to take Courage, and not be afraid of fuch Creatures, as he had made tame and harmless, by his Charms and Incantations. We are likerwife no less offended (from whence we might leaft expect it) by their Kids,

I ب. i. e. cut into Chops and roafted. 
Calves, and other young Cattle, that are tied up, every Night, under the Eaves of their Tents, to prevent them from fucking their Dams. For the Cords that are ufed upon the fe Occafions, being only made of loole-Spun Yarn, the fretful Creatures are every Moment breaking loose, and trampling over us.

When our Company was at any Time entertained in a courteous Manner, (for the Arabs will Sometimes part with nothing 'till it be extorted by Force) I ufed to give the Mafter of the Tent a Knife, a Couple of Flints, or a fmall Quantity of Englifh Gunpowder; which, being much fironger than their own, they have in great Efleem, and keep for the priming only of their Fire-Arms If the Lallah (or Lady) his Wife had been obliging alfo in her Way, by making. our Cufcafowe favoury and with Expedition, She would return a thoufand Thanks for a Skean of Thread; a large Needle; or a Pair of Sciffars; all of them great Rarities, and very engaging Prefents with the fe People.

During the exceffive Heats of the Summer, and efpecially when we were apprehenfive of being intercepted by fome Party of free-booting Arabs, we thentravelled in the Night; which having no Eyes, according to their Proverb, few of them dare then venture out, as not knowing the Dangers and Ambufcades, they may polfibly fall into. It is at this Time rue have frequent Opportunities of calling to Remembrance the Words of the Pfalmilt, PS.103.2. Thou makeft Darknefs that it may be Night; wherein all the Beafts of the Foreft do move. The Lyons roaring after their Prey; the Leopards, Hyxnas, and a Variety of other ravenous Creatures, calling to and anfwering each other, (the differeni Sexes perhaps, by this Means, finding out and corresponding with their Mates) break in very awfully upon the Solitude, and Safety likervife, that we might promife to ourselves, in travelling at this Seafon.

Our Stages or Days Fourneys were not always the fame. For when any Danger was apprehended, we then travelled through as many By-paths, as our Conduitors were acquainted with; riding, in this Manner, without refting, Jome- 


\section{T H E P R E F A C E.}

times truelve, fometimes ffteen Hours together. Nay, in returning from Jerufalem, ( So vigilant were the Arabs at that Time in diftreffing the Pilgrims, ) that notwithAanding we had the Sheck (or Saint) of Mount Carmel, with twenty of his Servants to proted us, we relled only one Hour in two and twenty: for fo long we made it in travelling betwixt Sichem and Nount Carmel. But in the Kingdoms of Algiers and Tunis, an ordinary Day's Fourney, (exclufive of the Time taken up in making Obfervations,) rarely exceeded eight or nime Hours. Our conftant Prafice was, to rife at Break of Day, Set forward with the Sun, and travel till the Middle of the Afternoon; at which Time ree began to look out for the Encampments of the Arabs; who, to prevent fuch Parties as Ours from living upon them, take Care to pitch in Places the least confpicuons. And indeed fometimes, unless we difcovered the Smoke of their Tents, obferved fome of their Flocks, or heard the barking of their Dogs', it was with Difficulty (if at all) that we were able to find them. Heve, as I obferved before, we were accommodated with Lodgings and Provifions for that Night; and if in the Course of our Travelling the next Day, as the Poet exprefles it,

$$
\begin{aligned}
& \text { A new Repaft, or an untafted Spring; } \\
& \text { We blefs our Stars, and think it Luxury. }
\end{aligned}
$$

In travelling along the Coast of Syria, and from Suez to Mount Sinai, we run little or no Rifque of being either robbed or inlulted, provided we keep Company with the $\mathrm{Ca}$ ravan, and do not firay from it. But a Neglect of this Kind, through the great Eagerness a Traveller may have in looking after Plants and other Curiolities, will expofe him, as it once did my felf, to great Danger. In the Holy Land, and upon the lithmus betwixt Ligypt and the Red Sea, our Conductors cannot be too numerous; whole Clans, from fifty to five Hundred, being fometimes looking out for a Booty. This was the Cafe of our. Caravan, in travelling (A.D. 1722.) from Ramah to Jerufalem; where four Bands 
of Turkifh Soldiers, with the Mofolem or General at the Head of them, were not able, or durst not at leaft proteit $u s$, againft the repeated Infults and Ravages of the Arabs.

But in Barbary, where the Arabs are more under Subjection, I rarely carried along with me more than three Spahees, and a Servant; all of us well armed: though we were fometimes obliged to angment our Numbers, particularly when we travelled among the independent Arabs, upon the Frontiers of the neighbouring Kingdoms, or where two contiguous Clans were at Variance. The fe, and Juch. like $(ح, 0)$ Harammees, as the Free-booters are ufually called, muft be, I conjecture, what the Europeans mean by Wild Arabs; notwith/tanding there is no Juch Name peculiar to any one Body of them; they being all of them the Same, and have all the like Inclinations, (wbenever a proper Opportunity or Temptation offers it felf, of robbing, Aripping, and murthering, not Strangers only, but alfo one another.

However, to prevent as much as polfible the falling into their Hands, the greateft Safety for a Traveller, at all Times, is to be difguifed in the Habit of the Country, or dreffed like one of his Spahees. For the Arabs are very jealous and inquifitive; Juspecting all Strangers to be Spies, and Jent to take a Survey of thofe Lands, which, at one Time or other, (as they bave been taught to fear,) are to be reftored to the Chriftians.

The Horfes and Camels of the e Countries keep generally one constant Pace; the latter at the Rate of two Miles and an half, the other of three Geographical Miles an Hour. Sixty of the e, according to my Calculation, conftitute one Degree of a great Circle. The Space we travelled was firft of all computed by Hours, and then reduced into Miles. Every Evening therefore, as Soon as we arrived at our Connack, (for fo the Spahees call the Tents or Places where we put up) I used to examine how many Hours and in wobat Direction we had travelled that Day; making proper 
Allowances for the feveral Windings and occafional Deviations that were made out of the direct Road. In our Paffage through the Mountains and Forefts, or where thiePlains were cut through with Rivers, (for we met with no Inclofures any where to moleft us) it frequently happened, that when we had travelled eight Hours, i. e. twenty four Miles, Ifound, by the Method above, that, as far as Longitude or Latitude were concerned, they were to be eftimated for no more than twenty or eighteen. As often alfo as 1 had an Oppor: tunity, I took the Meridian Altitude, with aBrals Quadrant of twelve Inches Radius, which was fo well graduated, that I could diftinguifh the Divifion upon the Limb to at least one I ${ }^{\text {th }}$ Part of a Degree. (This Operation the Arabs call The weighing of the Sun.) Towards the further carrying on likewife of the fe Geographical Obfervations, I had a Pocket Compafs, with the Needle well touched; the Variation whereof was, at a Mean, in the Kingdom of Algiers, (A D. 1727.) fourteen Degrees, to the Weftward, and in the Kingdom of Tunis fixteen; to which in like Manner I paid a proper Regard, in laying down the Maps and Geographical Obfervations.

The feveral Degrees of Longitude, that are marked in the Maps of the Kingdoms of Algiers and Tunis, have London for their firft Meridian. The Middle of the Eclipfe of the Moon, (July 28. 1 729.) being obferved by Mr.Profeffor Bradley, to fall out at Wanfted at I $3^{b}$. o'. I $\mathbf{s}^{\prime \prime}$. apparent Time; and by the French Miffonaries, and myfelf, at Algiers, at $13^{b} .14^{\prime}$ (proper Allowances being made for the Difference of the Meridians of Wanfted and London) will fituate Algiers, at 32'. 30" Eaft of the latter; or a ferw Minutes only more Wefterly, than it is laid down in the Maps and Globes of Mr. Senex.

The prickt, or double Lines that are traced out upon the Maps, herv the Places, they pafs through, to be laid down according to my own Obfervations. Mr. Sanfon, an unfortunate Surgeon and Native of Holland, who hath many rears attended the Viceroy of Conftantina as his Slave, hath 
Supplyed me with a great many Remarks, concerning the Geography of That Province.

The Civil War which raged in the Kingdom of Tunis, when I was there, (in the Year I 727.) prevented me from Jeeing the Frigêah, as they call the Weftern Part of the antient Zeugitania. I am indebted therefore for the Infcriptions and the Geographical Obfervations of thofe Parts to Father Francifco Ximenes, the Spanifh Adminifradior at Tunis.

The curious Mr. Bernard Juffeau, Brother to the Profeffor of that Name at Paris, gave me Liberty to copy the Infcriptions, which relate to Lambefe, from the Wanufcript of Dr. Poiffonel, who lately travelled over a great Part of these Kingdoms, at the Expence of the French King. The fe indeed, and feveral other Infcriptions, de ferve to be particularly confidered; but I had not Leifure at this Time to profecute So laborious an Undertaking.

The Provinces of Zaab, Wadreag, and other Southern Diftricts of the Kingdom of Algiers, are laid down from the repeated Accounts, which I had of thofe Places, from the Natives themfelves. We have frequent Opportunities of converfing with a Number of Persons of the fe different Countries, in almoft every City of Barbary; and as I rarely found them difagree in their Accounts, I am perfwaded that I have been very little, if at all, impofed upon by them. There was no other Way at leaft of Jupplying what was wanting to compleat the Geography of the se Parts; fince it would certainly bave been too dangerous an Experiment for a Chriftian to penetrate thus far into the Country.

The Several Names of Places and Tribes are all of them wrote according to our Englifh Pronunciation, and the Force of our own Alphabet. The Arabic Names aljo, as often as I could obtain them, are inferted in their proper Characters. The ArabicLetters a gijm, \&he, g waw, anfwering to our $\mathrm{j}, \mathrm{h}, \mathrm{w}$, make thofe Words, wherein they occur, bave an eafier Tranfition into our Language, than into That of the French or Italians; whofe Authors, for Want 
of Juch correfpondent Letters, generally mifcall the Arabic Appellations, and thereby render them useless to Travellers. Neither, will any of the fe Appellations, when thus wurote and pronounced, appear, I prefume, more diffonant to the Ear, than the greateft $P$ art of Thofe we meet with in the antient Geography. For, (if we are not prejudiced by the Latin and Greek Terminations, which bave been familiar to us from our Youth,) El Khadara, (to mention no more) will affect the Ear with no more Harfhnefs than the antient Name Zucchabbari; nor Beni-Zeneffel, than Herpiditani.

The Daggers ( $\left.{ }^{+}\right)$that are placed before feveral Cities of Barbary, denote thofe Places to have been Epilcopal Sees, when this Country profeffed the Chriftian Faith. We learn from the Notitia, (Exc.p.30.) that they were, at one Time or other, more than Six Hundred in Number; which, confidering the Smallnefs of the African Cities, bow nearly they were fituated to one another, and that each of them might enjoy the fame Ecclefiaftucal Privilege, I am perfwaded, does not exceed the Truth. But for want of Geographical CircumAances, 1 have not been able to adjust the Situation of above one bundred of them; all or moft of which, (notwithftanding they might bave been afterwards enlarged and adorned, ) were built long before the Chriftian- Æra, or even the firft Conquefts of this Country by the Romans.

In examining thele Ruins, I have often wondred, that there fhould remain fo many Altars and other Tokens of the Pagan Idolatry and Superfition; and fo very few Croffes or other Monuments of Chriftianity. As to the latter, bow zealous foever the African Church might bave been in putting them up, the Saracens bave been induflious enough in pulling them down. The A rabs certainly, whenever they attend their Flocks, near any of these Ruins, make it a Piece of Devotion as well as Amusement, to deftroy and obliterate as mich of them as they can. Wherein they are not a little encour aged by the Lead and Iron, which the Antients fometimes made ufe of in cramping of the Stones; and efpecially by a great Variety of Coins which they more frequently meet with.

c 2

of 
of These I had not the good Fortune to purchafe many that were either valuable or curious. Thofe that are purely African, or carry along with them at leaft the Infignia and Charaterifticks of that Country, may be accounted the rareft; though indeed fome of them have been already taken Notice of by Agoftini, Paruta, and other Authors. However as thoje which I bave collected, may perbaps be the compleateft Series of the Kind, I bave given the Drawings and Defcriptions of them in the Collection of Papers that are inferted after the Obfervations.

If we except the Miffilia, (as Jome Medalifts call the Small Brafs Coins of the Lower Empire, ) the moft common are thofe of the Antonines, of Alexander Severus, of the Tounger Gordian, and of Philip; in whofe Times Africa feems to have been the moft adorned with Roman Edifices. Some Pieces of Glafs-Money alfo are found now and then by the Arabs, in the Ruins of fuch of their antient Buildings, as are Jupposed to have been raised by Occ'ba and Ben Eglib. For thefe Buildings, no lefs than thofe erected by the Carthaginians and their immediate Succeffors, have been fubject to their Changes and Revolutions. All the Coins, which I have feen of this Kind, were flat on the one Side, and impreffed on the other, with the Ma-

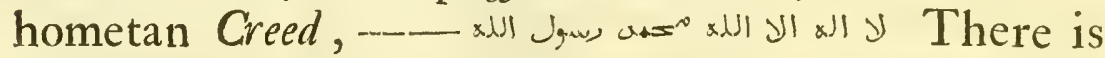
no God but God; Mo-hammed is the Apoftle of God.

In putting together the Phyfical and Mifcellaneous Obfervations, I have endeavoured to ufe all the Brevity and Method, the Subject would allow; avoiding alfo, as much as pofible, the Repetition of what has been already taken Notice of by former Authors. The Regifler of the Weather, (p. 2 I 9.) was kept at the Houfe of the French Mifionaries above-mentioned, and therefore I can plead only the Merit of being an Afliftant in that Branch of the Natural Hiftory.

In drawing up likewife the Catalogue of Plants, wobich contains near a hundred and forty unknown Species, I re. ceivedgreat Affitance from Mr. Profeffor Dillenius, whofe

Character 
Charaiter in Botanical Learning, is well known to the Publick. We carefully compared all my Specimens ${ }^{1}$, with that large and well-digefted Collection of dryed Plants, which Dr. W. Sherard bequeathed to the Phyfick Garden of the Univerfity of Oxford; where all curious Perfons bave an eafy Access, through the great Affability and communicative Temper of that worthy Gentleman, to whofe Care they are entrufted.

But lest any Miftakes Bould have been committed in the Defcriptions of The fe or of the marine Vegetables, the Author has depofited the Originals in the Sherardian Collection. Recourfe may be had likewife to the other Curiofities, taken Notice of in thiefe Obfervations ( $\mathrm{uuch}$ as Foffils, Medals, $\mathrm{SG}^{\circ} \mathrm{c}$.) in the Library of Queen's College; where they may be confulted by the inquifitive Reader.

The feveral Differtations that are occafionally interSpersed throughout this Work will not, I prefume, be thought Digreffions, as they flow naturally from the Subject. Neither need any Apology be made for the Collection of Papers, that are inferted after the Obfervations; fince they are all of them either fo many Branches themselves of the Natural Hiftory, or elfe ferve to illustrate Some Part or other of this Work.

The Excerpta particularly from antient Authors, will certainly plead for themfelves, as they give the Reader, in one View, all that was known to the Antients, of thofe Parts of Barbary, which I bave here undertaken to de fcribe. They are constantly appealed to, in the marginal Notes of the

I The following Plants, having been overlooked in placing the Phytographia alphabetically, are to be inferted according to their refpective Numbers: viz. after n $\mathrm{n}^{\circ} .78$. infert $78^{a}$. $\mathrm{O} \mathrm{c}$.

78a. Borrago floribus albis, foliis longis, folio fubtus, incano. I. R. H.25o. anguftis.

469a. Periploca foliis anguttis, confertis,

$15^{8 a}$. Clymenum pufillum, anguftifolium, floribus ex viridi flavefcentibus. Folia parva, vexillo rubro, alis flavefcentibus. rigida, obtufa, quedam acutiora, ad genicula

164. Colocynthis pumila \&c. Cucumis plurima nafcuntur. Flores pediculis brevibus Africanus echinatus minor: Hyftrix vegeta- harent $e$ petalis anguftis compofiti.

bilis vulgo Herm. Par. B.1 33. Defcr. Cucumis echinatus, Colocynthidis folio Ibid. Ic.

$22 I^{a}$. Eruca fylveftris minor lurea, Burfe Paftoris folio, Italica, Bar. Ic. Ior6. Defer. 422.

$55^{3 a}$. Sinapiltrum triphyllum breviore \& hirfutiori folio. Hac Species etiam, infar n. $557 \& 558$, vifcofa eft.

$62 \pi^{4}$. Virga aurea major, foliis glurinofis \& graveolentibus. I. R. H. 4I4. Madramam Arabum. vid.O6f. p'266.

$3^{\text {I }} 3^{a}$. Helianthemum Hifpanicum, Origani 
Geographical Part, whenever the prefent State of that Country is compared with the antient.

I have not followed the fame Method, in illuftrating the comparative Geography of thofe Parts of Syria, Egypt, and Arabia Petræa, that fell under my Obfervations. Whenever therefore I had Occafion to cail in the Authority of the Antients, I have always done it by way of Note, in the express Words of the Author. For, Books of this Kind being in ferw Perfons Hands, the Reference alone, without the Words referred to, muft frequently bave excited a Curiofity that could not be gratified, and confequently would bave been of little Service to the Reader.

The Same Reafon may be urged for the Variety of Notes and 2 uotations, that are occafionally made ufe of, in the Mifcellaneous Parts of the e e Obfervations For as it was neceffary to produce fuch Evidence and Authority, fo the Quotations themfelves can hardly be thought Superfluous.

Tнu s have I given a general Account of this Work, and of the Afiftances I received in compiling it: aWork, which will require the Reader's Candor and Indulgence. For, notwith/tanding every Sheet of it was looked over by feveral Learned Gentlemen of my Acquaintance; yet, upon reviewing, Ifind that fome Errors of the Prefs; and, I fear, many Slips and Inaccuracies of Stile have efcaped me.

The Reader will be likewije pleafed to put a favourable Conftruction, upon the lefs entertaining Paragraphs, that may too often occur in the Course of the Geographical Obfervations. The Nature of the Subject (wbich confifts chiefly in the Enumeration of Places, Tribes, and their Diftances from each other) would not permit them to be otherwife; and in This, we have both the Authority and Example of Strabo, Ptolemy, and other antient Geographers.

Yet how dry and tedious foever Difquifitions of this Kind may appear to fome Perfons, the curious, I bope, will not be displeafed to find feveral difficult Points, both of the antient and modern Geography, thus explained and itluftrated 
luftrated. It is very certain, that the adjufting the feveral Geographical Data, and laying down Maps correspondent to them, bave been attended with no Small Labour and Fatigue; as the collecting the Materials themselves had before expofed me to a Variety of Dangers and Difficulties.

The fe Dangers and Difficulties I happily overcame: and muft therefore return my humble Thanks to that Almighty Providence, which was gracioully pleafed to fupport me under them. And indeed I cannot conclude this Preliminary Difcourfe, without obferving, what a ferious Train of Thought a Traveller can farce fail of being engaged in, when be views fuch a large Scene of Ruin and Defolation, as I have here defcribed. He is ftruck immediately with the very Solitude of thofe few Domes, and Porticos that are left ftanding; which, Hiftory tells him, were once crozuded with Inhabitants: where Scy phax and Mafiniffa; Scipio and Cxar ; where the Orthodox Chriftians, and the Arians; the Saracens and the Turks, have given Laws in their Turns. Every Heap of Ruins points out to bim the Weakne/s and Inftability of all Human Art and Contrivance; reminding him further of the many thoufands that lye buried below, now loft in Oblivion, and forgotten to the World. Whillt He is full of the ese Meditations, Chriftianity Aleps in to bis Relief; acquainting bim, that We are only Strangers and Pilgrims upon Earth; feeking a City, (not, like Thefe, Jubject to the Strokes of Time and Fortune, but) which hath Foundations, whofe Builder and Maker is God.

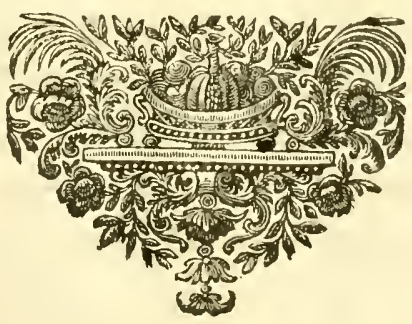




\section{E $\quad R \quad R \quad A \quad T \quad A$.}

In the O в SER VATI O NS.

\begin{tabular}{|c|c|c|}
\hline $\begin{array}{l}\text { Pag. } \\
33 . \\
34 . \\
34^{4} \cdot \\
35 . \\
36 .\end{array}$ & $\begin{array}{l}\text { Line. } \\
32 . \\
35 . \\
\text { ibid. } \\
8 . \\
25 .\end{array}$ & $\begin{array}{l}\text { for } \\
\text { E.N.E. } \\
\text { fifteen } \\
\text { Weftermolt } \\
\text { Sufellim } \\
*^{*} * *\end{array}$ \\
\hline $\begin{array}{l}\text { ibid. } \\
53 . \\
55 . \\
75 .\end{array}$ & $\begin{array}{l}28 . \\
29 . \\
31 . \\
22 .\end{array}$ & $\begin{array}{l}\text { doth } \\
\text { thirty } \\
\text { Marmol } \\
\text { Ain Atbreede } \\
\text { \&c. }\end{array}$ \\
\hline $\begin{array}{l}77 . \\
81 . \\
90 . \\
96 . \\
102 . \\
107 . \\
\text { ibid. } \\
108 . \\
109 .\end{array}$ & $\begin{array}{l}6 . \\
4 . \\
37 . \\
1 . \\
14 . \\
14 . \\
27 . \\
90^{\circ} \\
25 .\end{array}$ & $\begin{array}{l}\text { N. E. } \\
\text { twenty one } \\
\text { feventy } \\
\text { Mebomitans } \\
\text { Zmowab } \\
\text { W. } \\
\text { may be } \\
\text { Eirzoco } \\
\text { Welled Eifab: } \\
\text { and, near the } \\
\text { Fountains of } \\
\text { the Sigan to } \\
\text { the W.S.W. }\end{array}$ \\
\hline $\begin{array}{l}114 . \\
117 . \\
130 . \\
151 . \\
152 . \\
155 .\end{array}$ & $\begin{array}{l}16 . \\
25 . \\
33 . \\
29 . \\
9 . \\
16 .\end{array}$ & $\begin{array}{l}\text { fix } \\
\text { Advantages } \\
\text { E.S. E. } \\
\text { Granite } \\
\text { Dies } \\
\text { TYNETA }\end{array}$ \\
\hline
\end{tabular}

read. Pag. Line. for

N.N.E. read.

five. 159.14 .0 atrum antrum.

Eaftermoft. 162. 22. GERMANCI GERMANTCI。

Roo-eena. I91. 27. Adrametum Adrumetum.

The soil of it is 204. 9. TRANSIAT TRANSEAT.

fivking.

did. 245. 14. Taft orFlavour Taft and Fla-

thirteen.

\begin{tabular}{l|lll} 
Marmol $^{2}$. & 249. 6. & Spurge,Lawrel Spurge-Lawrel.
\end{tabular}

fouebb, a great 264. 3r. glutinous gelatinous. way to theEaft. 273. 25. dele Publick.

S. E.

twenty fix.

eighty.

Mabometans.

Zomoah.

W.S.W.

may have been.

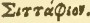

WelledEi $\{a b$, near

the Fountains of the Sigan:

and \&rc.

fixteen.

Advances.

S. S. E.

Granate.

Deis.

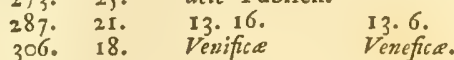

311. 21. Dymefty Dynafly.

312. 27. Fermew Ferment.

326. I2. extravagant romantic.

347. ult. inafmuch as, that.

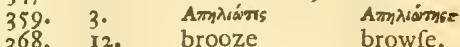

369. 20. Bettany Betony.

370. 4. luguminous leguminous.

371. 14. rarely feldom.

372. 25. Fleak Flake.

381.60 fower four.

386. 29. dele other.

397. 8. Animals, when Animals only

\&c.

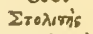

hindred when \&c.

TYNHTA.

403. I.

421.3.

In the NoTES.

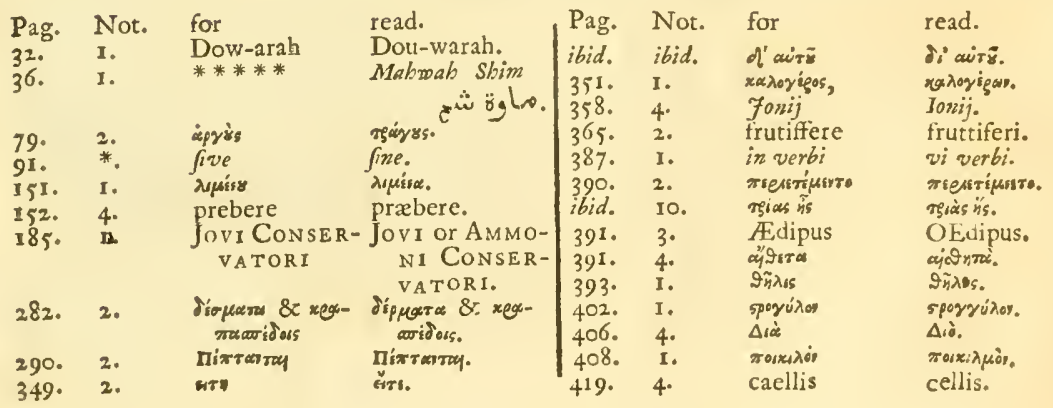

In the COLLECTION of PAPERS \&C.

\begin{tabular}{|c|c|c|c|c|c|c|c|}
\hline g. & $\begin{array}{l}39 . \\
8 . \\
50 . \\
58 .\end{array}$ & $\begin{array}{l}\text { rves } \\
\text { ritum } \\
\text { le CAP. III. }\end{array}$ & $\begin{array}{l}\text { read. } \\
\text { Servet. } \\
\text { Tretum. }\end{array}$ & $\begin{array}{l}\text { Pag. } \\
\text { 14. } \\
\text { I9. } \\
38 . \\
40 . \mathrm{n}^{\circ} .\end{array}$ & $\begin{array}{l}\text { Line. } \\
51 . \\
\text { ult. } \\
68 . \\
210 \text { \& }\end{array}$ & $\begin{array}{l}\text { for } \\
\text { SitapHIUS } \\
\text { Troglodytas } \\
\text { tenuiter } \\
\text { Elychryfum }\end{array}$ & $\begin{array}{l}\text { read. } \\
\text { SITT A PHIUS. } \\
\text { Troglodyta. } \\
\text { tenuibus. } \\
\text { Elichryfum. }\end{array}$ \\
\hline
\end{tabular}




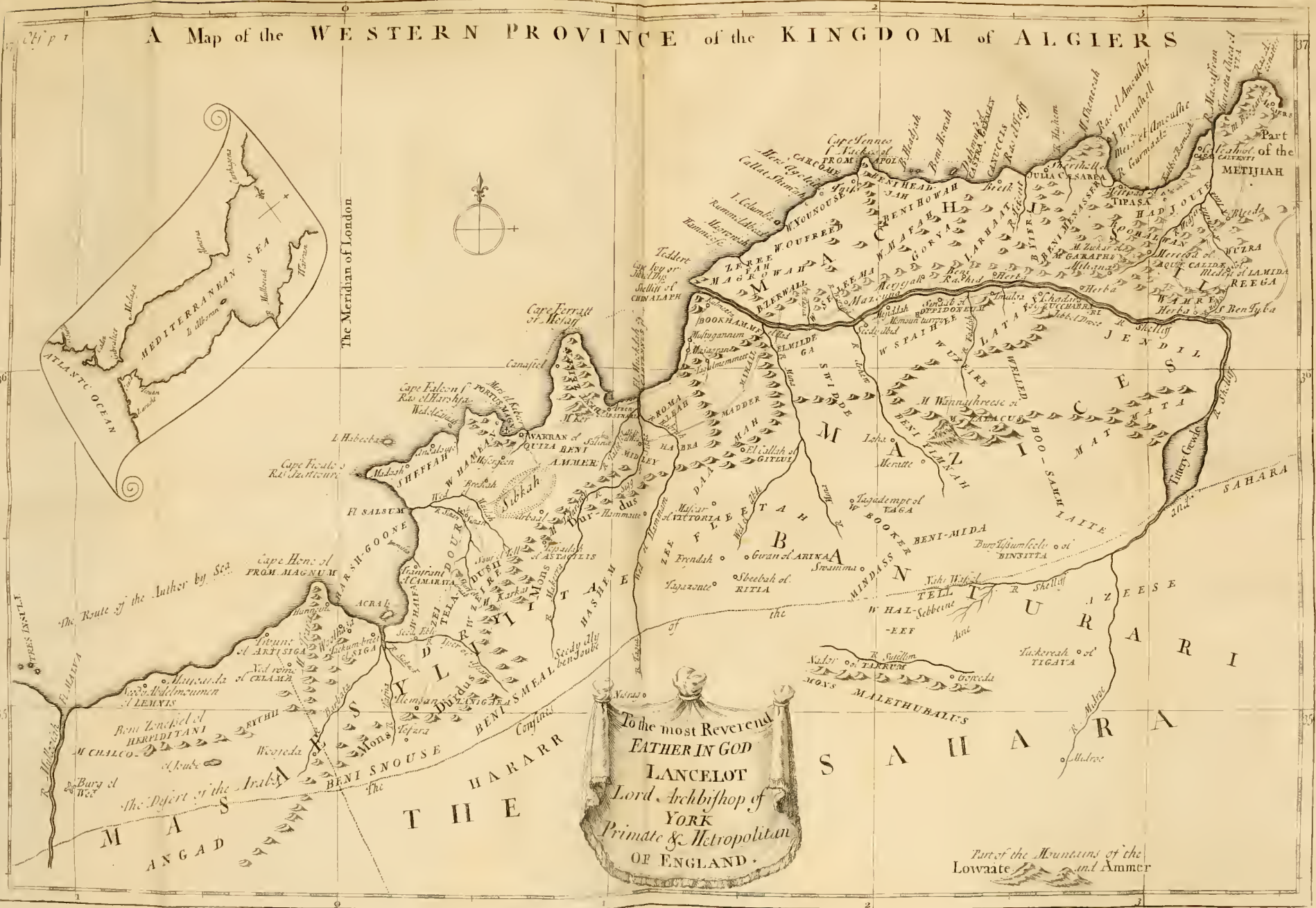





\section{GEOGR APHICAL}

\section{OBSE R VATIONS}

RELATING TO THE

K I N G D O $\mathrm{M}$

O F

A L G I E R S.

(5) G.

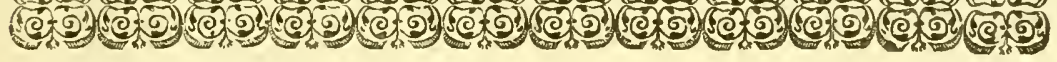




\section{The CONTENTS. \\ C H A P. I.}

Of the Kingdom of ALGIERs in general.

P. 3 .

C H A P. II.

Geographical Objervations in that Part of the Mauritania Cxfarienfis, which belongs at prefent to the Tingitanians or Weftern-Moors.

p. IO.

\section{$\mathrm{C} \mathrm{H}$ A P. III.}

Geographical Obfervations upon the Sea-Coafl of that Part of the Mauritania Cafarienfis, which is called at prefent the Weftern Province, or the Province of Tlem-fan.

\section{H A P. IV.}

p. $1 \%$

Of the moft remarkable Places and Inbabitants in the Inland Parts of the Weftern Province.

\section{H A P. V.}

Geograpbical Obfervations upon the Sea-Coaft of that Part of the Mauritania Cafarienfis, which is called at prefent the Southern Province, or the Province of Titterie.

\section{H A P. VI.}

p. 66 .

Of the moft remarkable Places and Inbabitants in the Inland Country of the Southern Province; together with the correspondent $P$ art of the Sahara.

\section{H A P. VII.}

Geographical Obfervations upon the Sea-Coaft of that Part of the Mauritania Cafarienfis and Numidia, which is called at prefent the Eaftern Province, or the Province of Conftantina.

p. 87.

\section{H A P. VIII.}

Of the most remarkable Places and Inbabitants in the inland Country of the Eaftern Province; together with the correspondent Part of the Sahara. 


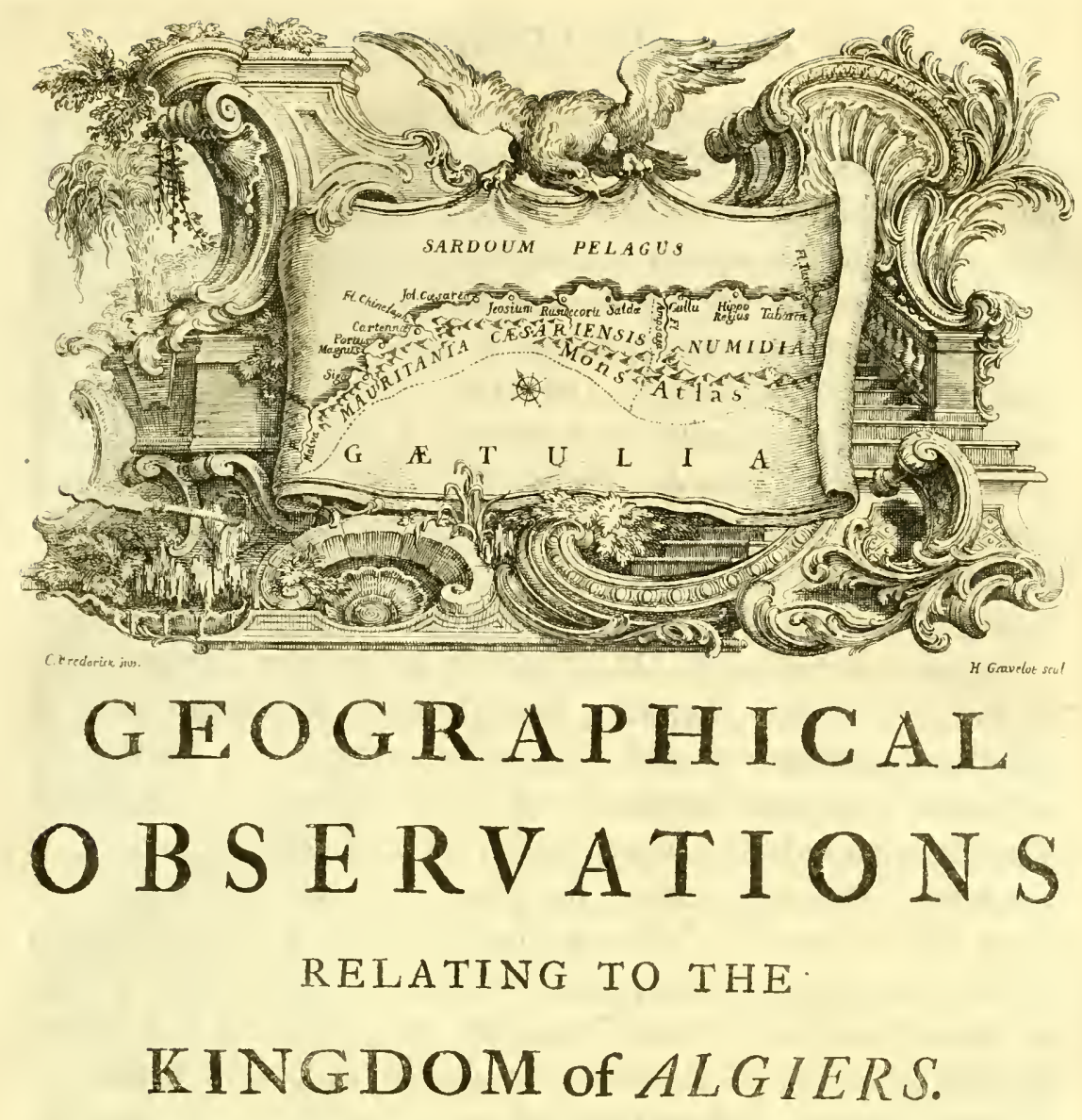

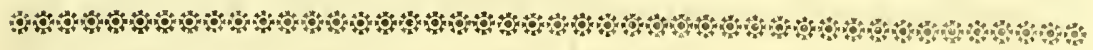

\section{H A P. I.}

Of the Kingdom of A L G I E R in general.

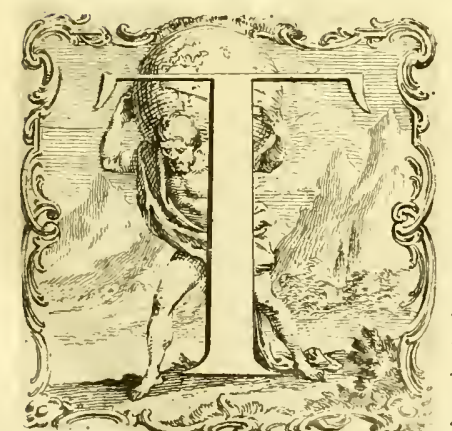

HE Country of the Algerines, com- The rimits of monly called the Kingdom of Algiers, hath, fince it became fubject to the Turks, been one of the moft confiderable Diftricts of that Part of Africa, which the later Ages have known by the Name of Barbary ${ }^{\mathrm{T}}$. It is bounded to the Weft, with T wount, and the MounSo the the Sabara, or Defert; to the Eaft, with the River Zaine, the antient $T u f c a$; and to the North, with the Mediterranean Sca.

I Africa veteribus proprie ditta, hodie Barbaria quibufdam rocatur, aliis Barbarie pars. Thuan. Hiff. 1.7. Moros, Alarbes, Cabayles, y algunos Turcos, todos gente puerca, fuzia, torpe, 
Sanfon', in bounding this Kingdom with the Rivers Mulvia and Barbar, as he calleth the Mullooiah and the Zaine, maketh it nine hundred Miles from Eaft to Weft; De la Croix ${ }^{2}$, feven hundred and twenty; Luyts ${ }^{3}$, by reckoning forty eight Miles and an half for one of his Degrees of Longitude, alloweth it to be about fix hundred and thirty; whereas others ${ }^{4}$ confine it to a lefs Extent. But according to the exacteft Obfervations I could make my felf, or receive from others, I find the true Length from Twunt to Ta-barka, to be only about four hundred and fixty Miles; the Firft of thefe Places being fituated, below the Mountains of Trara, in $0^{\circ} .16^{\prime} \mathrm{W}$. Long. from London; and the Latter, upon the River Zaine, in $9^{\circ} .16^{\prime}$. to the Eaft.

The Breadtl.

There is not the like Difagreement among our Geographers, in Relation to the Breadth; though none of thems make it lefs than one hundred and fifty Miles, where it is narroweft, nor more than two hundred and forty, where it is broadeit. The Breadth indeed, though much fhort of thefe Accounts, is not every where the fame: for near Tlem-fan, it is not above forty Miles from the Sabara to the Sea Coaft; near the Sources of the Rivers Sigg, Habra, and Shelliff; it is about fixty; which, in the weftern Part of this Kingdom, may be taken at a Mean, for the Extent of what the Arabs call [Tell, $1 . s]$ or Land proper for Tillage. But to the Eaftward of Algiers, the Breadth of this Kingdom is more confiderable; and in the Meridians particularly of Boujeiah, Fijel and Bona, it is never lefs than a hundred Miles: nay fometimes more; as from Fijel, in N.Lat.36 $6^{\circ} .55^{\prime}$, toLwo-taiah, fituated among the Mountains of Atlas, in $34^{\circ} .50^{\prime}$.

The Doninioss

The Dominion which the Algerines have beyond the Tell, of the Alge- or the more advanced Parts of the Mountains of Atlas $^{6}$, is Sahara. very uncertain and precarious: for which Reafon I have fixed the proper Boundaries and Limits of this Kingdom that Way,

indomita, inauil, inhumana, beftial: y por tanto tuuo porcierto razon, el que dit pocos anös aca acoftumbro llamar a efta terra, BARBARIA, pues \&c. D. Haelo de la captitidad, en fu Topogr. e Hiftor. de Argel.p. I26. Vallad.1612. I Le Royaume d'Alger eft feparé vers l'occident du Royaume de Fez, par les Riv. de Zhas et de Mulvia: vers l'Orient eft feparé de celuy de Tunis, par la Riv. Guadil Barbar: le midy eft couvert des montagnes d'Atlas, qui le feparent du Segclmeffe, du Tegorarin, et de Zeb parties de Biledulgcrid. Sa longueur d'Occident en Orient approche de 300 lieuës; fa largeur eft de 50,60 ou de 75 lieuës. L'Afrique en pluficurs cartes nouvelles \&c. p.23. par le $S^{r}$ Sinfon d' Abbeville \&c. a Paris.1683. 2 Son étendue de l' Eft a l' Ö̈eft eft de 240 lieuës; \& du Sud au Nord de $70 \mathrm{en}$ fa plus grande longueur. Nouvclle methode pour aprendre la Geograpbie Univerf. par le Sieur de la Croix. Tom. 5. p. 280. a Paris 1705. 3 Regnum Algerianum longiffime ab occafu in ortum diffunditur, a gradu circiter XVIII ad ufque gradum XXXI : at ab auftro in boream, ubi vel latifimum eft, latitudinem non habet IV graduum. F. Luyts Introd. ad Geograpbiam. p.669. Traj. ad Rhenum. I692. 4 Vid. Molls Geography Part.2. p.146. Lond.1722. Atlas Geograph. Vol.IV. p.182. 5 Vid. Not.2. \&c. 6 Exc. pag.2. E. p.30.A. A Barbaria ab auftro limes eft Biledulgeridia, a qua mons Atlas ipfum dividit. Luyts Introd. p.662. 
upon the northern Skirts of the Sabara. Some of the Villages indeed of Zaab, and others 'likewife, that have a more diftant Situation from the Ciapital, pay regularly their annual Taxes, or at leaft give fome Tokens of Submiffion to the Turks: but the other Communities are independent; and the Bedoween [ب [u ] Arabs of thefe Parts, the Nomades ${ }^{2}$ or Scenite ${ }^{3}$ as they were antiently called, are feldom to be brought under Contribution; taking always a particular Care to be upon their Guard, or at a Diftance, when the Turkifh Armies are abroad.

This Part of the Country, and indeed the whole Tract of Teridde or Land that lyes betwixt the Atlantic Ocean and Egrpt, is by Dry Country. moft of the modern Geographers called Biledulgerid, a Name they feem to have borrowed from the Blaid al Feridde [ut? $\omega,-1]$ of the Arabians, who thereby fignifie, The Dry Country: though, if we except the Feridde, a fmall Portion of it, that is fituated on this Side the leffer Syrtis, and belongs to the Tunifeens; all the reft of it is known by no other general Name than the Sabiara, or $\left[1, \infty^{\infty}\right]$ Salj-ra; amongtt thofe Arabs at leaft, whom I have converfed with.

The Epitomizer of Edrifi, the Nubian Geographer ${ }^{4}$ as he Tbe Prosinces is commonly called, places both the Cities and Villages of dom this Kingthis Part of Barbary, and thofe of the moreWeftern and Eaftern Diftricts of it, in his Third Climate, without any particular Divifion into either Kingdoms or Provinces. But Abulfeda', befides giving us in Ptolemy's Method, the Longitudes and Latitudes of the moft confiderable Cities, is more full and diftinct in his general Divifion; and that Part of this Country I am now treating of, will take in the whole of what he calls al Mag-reb

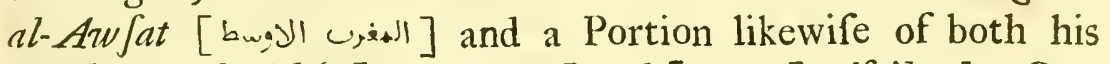

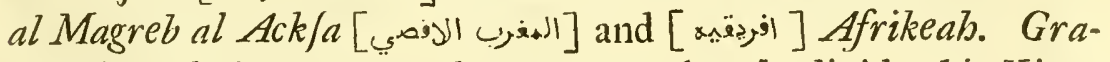
maye $^{6}$, and the more modern Geographers ${ }^{7}$, divide this King-

I Teucarte 1 go leucis ab Argelı diftans, Huergla 200 : utrumq; fubjugavit Sala imperato tributo huic 30 , illi quindecim Nigrorum annuatim. Gramaye Africa illuftrata 1.1.c.26. 2 Exc.p.23.

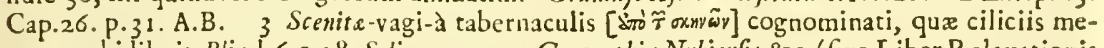
tantur, ubi libuit.Plin I.6.c.28. Solin.c.33. 4. Geographi. Nubienfis \&c. (five Liber Relaxationis animi curiofi) recens ex Arabico in Latinum verfa a Gabriele Sionita \&c. Paris. I6 19. 5 Al Ma-

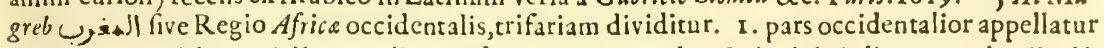

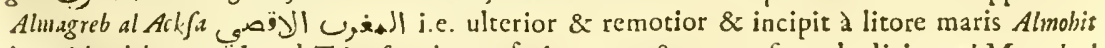
i.e. Atlantici pergeñdo ad Telemfan ab occafu in ortum \&c. pars fecunda dicitur al Magreb al

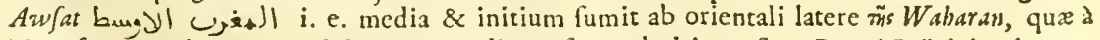
Telem an unius diei itinere diftat \& extenditur ufque ad ultimos fines Regni Bejiaiah orientem verfus. Pars tertia, eaq; orientalior vocatur Afrikeal xnës,jl, \& extenditur ad Barka, ufq; ad limites Provinciarum Mefr. Abulf. Geogr. ex Traduct. V.Cl. 7. Gagnier. 6 Regnum Algerienfe dividitur in Provinciam Gezeiranam, Bujeianam, Gigellanım, Conftantine, \& Bone a parte orientali, in occidentali in Sargelenfem, Tenezenfem, Portus magni, Harfgoliam. Gram. Afric. illuftr. L.7. C. II. \& I6. 7 Nous le diviferons en cinque partics, dont cêlle d'Alger fera le 
dom into a great many Provinces, according to the feveral petty Royalties which at one Time or other it was canton'd into, before and after the Time of the Turki/bConquefts. But at prefent there are only Three, viz. the Province of Tlem-fan, to the Weft; of Titterie, to the South; and of Conftantina, to the Eaft of Algiers. Each of thefe Provinces is governed by a Bey or Viceroy appointed and removed at Pleafure by the Dey of Algiers, who has a defpotick Power within his Jurifdiction, and at the Seafons of collecting the Tribute from the Arabs, or upon other Occafions, is affifted with a Body of Troops from Algiers.

This Kingdom
formerly the Thus ftands the general Defcription and Divifion of this Kingformerly the
of umidia \& $A$ d dom at prefent; which, upon Comparifon, we fhall find to cortients. refpond with the Geography of the Provincia Nova ${ }^{2}$ or Numi$d i a^{2}$ of the Antients. For if we bound it with the River Tufca ${ }^{3}$ or Zaine to the Eaft, it will then contain a Part of the Africa of Pomponius Mela ${ }^{4}$ and Ptolemy's, the Numidia properly fo called $^{6}$, or the Numidia of the MafJyli ${ }^{7}$ : and being bounded to the Weftward with the Mountains of Trara, it will take in the other Numidia, the Numidia of Mela ${ }^{8}$, or the Numidia of the MaJfelyli', called afterwards the Mauritania Cefarien$\mathrm{fis}^{\mathrm{io}}$, excepting only that Part, which for the Space of about

milieu: Telenfin \& Tenes feront a l'occident; Bugie \& Conftsntina a l'orient. L'Afrique \&c. par le $S^{r}$. Sanfon \&c. p.23. Difpelcitur communiter in V. Provincias, qux funt, Telenfinum, Teneza,Gezeira, Bugia, \& Conftantina. Luyts \&c.p.669. Le Roy،ume d'Alger a les Prov.de Bone, Conftantina, Gigeri, Bugie, Alger, Sargel, Moftogan, Horan, Harefgol, Hunaine, Tebeffa, Tenez, Labez,

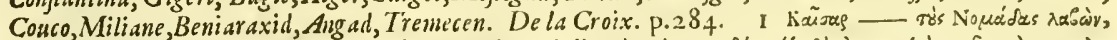

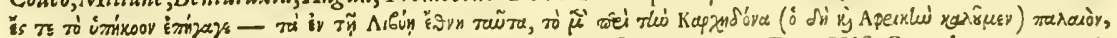

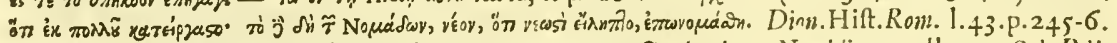
Ed.Steph. 2 Numide poffedere ea loca, qux proxuma Carthaginem Numidia appellatur. Sal. Bell. Fug. Cantab.1710. 2 I.p.287. Ad Mauritaniam Numide tenent. Id.922. 3 Exi.p.21.Cap.3.

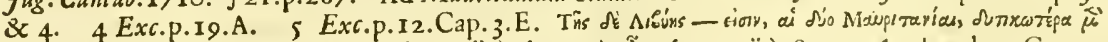

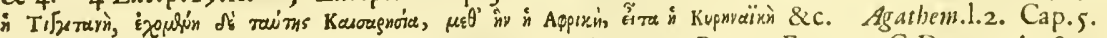
6 Exc. p.21. Cap.3. p.23. Cap.26. p.29.F. p.30. D. p.31. B. 7 Exc. p.5.C.D. p.7. A. \&c. Cum Syphace Rumanis juncta amicitia eft. Quod ubi Carthaginienfes acceperunt, extemplo ad Galam in parte altera Numidia (Maffla ea gens vocatur) regnantem, legatos mittunt. Liv.1.24. 5 4. Syphax erat Rex Numidarum. ibid. Mafjylii regnum paternum Mafanißa lati, ut ad regem diu defideratum conceffere. Syphax, pulfis inde prafectis prafidiifque fuis, vetere fe continebat regno, neutiquam quieturus. Id.I.30. S II. 8 Exc. p.18. Cap.6. 9 Exc. p.5. Not.d. p.21. Cap.2. vid.Not.7. Mafaniffa non in poffeftione modo paterni regni effet, fed etiam focios Cartbaginienfium populos, Maffafylorum fines (id Syphacis regnum erat) valtaret. Liv. I.29. S 32. Maffafyli gens affinis Mauris, Regionem Hifpunie, maxime qua fita eft Curthago nova, fpectant. Id.1.28. S I7.

Post hos immenfa Nomadum de Semine Gentes, Atque Mafxfylii nec non Mafylia Proles.

Prifcian. Perieg.1. I76-7.

Io Exc. p.21. Cap.2. p.23. Cap.25. p.29.A.G. p.30. A.B. C. p.31. C. P.35,36. o kradido

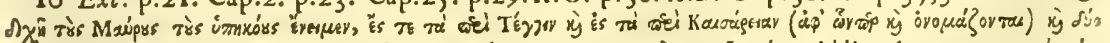

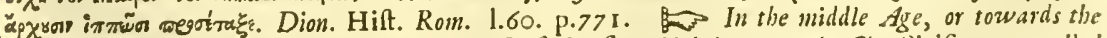
End of the Fourth Century, that Part of the Cxfarienfis which lay near the City Sitifi, was called the Mauritania Sitifenfis. Vid. Ex6. p.29. A. G. p.30. A. p.3 1. C. P.33.35, \& 36. paffim. 
fifty Miles, lyes beyond the faid Mountains towards the Mullooiah, the Malva' of the old Geography.

That remarkable Chain of Hills, which I fometimes find placed The Arountains betwixt thefe Countries, and the Sahara, and fometimes within the Tell, I take to be the Aftrixis ${ }^{2}$ of Orofius, and a Continuation or Part of Mount Atlas ${ }^{3}$ : though they are not always of that extraordinary Height, or Bignefs, which have been attributed to them by Antiquity ${ }^{4}$. Thofe Parts of them which I have feen, are rarely, if ever equal to fome of the greater Mountains of our own Ifland; and I queftion, whether they can any where ftand in Competition with either the Alpes, or the Appennines. If we conceive a Number of Hills, ufually of the perpendicular Height of four, five, or fix Hundred Yards, with an eafy Afcent, and feveral Groves of Fruit and ForreftTrees, rifing up in a Succeffion of Ranges one behind another; and if to this Profpect, we here and there add a rocky Precipice of a fuperiour Eminence and difficult Accefs, and place

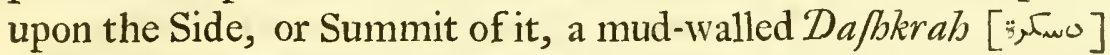
or Village of the Kabyles; we fhall then have a juft and lively Idea of thefe Mountains, without giving Heed to the nocturnal Flames, melodious Sounds, or the lafcivious Revels of fuch imaginary Beings, as the Antients ${ }^{s}$ have in a peculiar Manner attributed to this Place.

Some of the old Geographers have obferved, that thefe Moun- TheDyrise $\%$. tains were called Dyris and Adiris, or Dyrim and Adderim ${ }^{6}$ by $\begin{gathered}\text { of } t \text { tients } \\ \text {; }\end{gathered}$ or the Indigence or firt Inhabitants; but have not attempted to give us the Signification of thefe Words. Bochart' obferves, that Atlas was called Dyris by the Pbonicians, perhaps from [ Addir, great or mighty; and upon the Coatt of the Tingitania, we find Ruffadirum [Puarispoor, ] mentioned by Mela ${ }^{9}$, Pliny $^{10}$, Ptolemy ${ }^{11}$, and the Itinerary ${ }^{12}$; the fame Name the Moors give at prefent to Cape Bon, the Promontorium Mercurii; and by which they would denote a very large and confpicuous Cape, or Fore-Land.

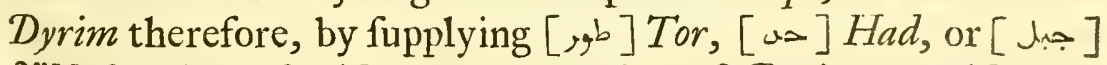
Fibbel, might fignify the Mountains of Dyris, or Atlas, or fimply, the Great Mountains only, or that remarkable Chain of them, which, in the Phrafe of Orofius, divided the fruitful Land

IExc.p.9.Cap.2. p.25.E. p.29.A. p.30.A.p.31.C.D. 2 Exc.p.30.A. 3 Vid.Not.6.p.4 4 Exc. p.2.E. p.20. Cap.r. p.23.A.B.C. \&c. p.30.C. 5 Exc. p.20. Cap.1.p.23.A. 6 Exc. p.5.D. p.2t.B. p.23.C. P.30.C. 7 Phal. Lib.2. Cap.13. 8 Vid. Lex. Schindler, in roce. 9 Exc. p.I8.D. 10 Exc. p.2t.E. II Ptol.1.4. Cap.1. 12 Exi. p.25.E.

$\mathrm{B} 2$ 
The Great or Soutbirn Boundary.

from the barren: Befides; as this Chain of Mountains runs for the moft Part Eaft and Weft, and confequently bounded the Profpect, as well as the Agriculture of the Mauritanians and Numidians to the South; we have Room for another Conjecture, in deducing the Name from their Afpect and Situation: Dohor [ ; s $^{\circ}$ ftill fignifying amongit the Moors and Arabians, the Place or Afpect of the Sun at Noon-Day; as the Derom [ רורים of of the Hebrews, was a Word of the like Import ${ }^{2}$. If then we choofe to call it Adderim with Solinus and Martianus; and not fimply Dyrim with Strabo and Pliny: Hadderim, by fupplying [un] $\mathrm{Had}$, will fignify either the Great, or elfe the Southern Eminence, Limit, or Boundary, fuch as Mount Atlas generally is with refpect to the Mauritanice and Numidia, or betwixt the Tell and the Sabara. We may poffibly have fome Rudiments, or Traces of this Name continued down to us, in the Dra el Hammar, Dra el Attafb, Dra el Maintenan, and Fibbel Deera, that are placed in the Neighbourhood, or make a Part of thefe Mountains; though the feveral Portions and Diftricts of them at prefent, are chiefly known and diftinguifhed by the particular Names of the Kabyles [ulig] or African Families, who refpectively poffefs them.

Gretulia, a Part of Ptolemy's Inner Libya ${ }^{3}$, is laid down in very indefinite Terms by the Antients; though by comparing their feveral Accounts and Defcriptions, we fhall find the Northern Limits thereof contiguous to, and frequently coinciding with the Southern Limits ${ }^{4}$ of the Mauritanire and Numidia. The Villages therefore of Zaab, the antient Zebe, with others that are fituated near the Parallel of the River Adge-dee, will belong to Gatulia properly fo called: as the Beni-Mezzab, and the Inhabitants of $W$ adreag and $W$ urglah, with their refpective Bedoween Arabs, may be the Succeffours of the antient Melanog cetuli, and perhaps of fome other Libyans, who were in a nearer Situation to the River Niger, and the Eithiopians.

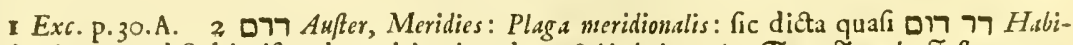
tatio alta: quad Sol in ifta plaga altius incedat. Scbind. in voce. Targ. Fonath. Fofh. 10.40. 3 Vid. Ptol. Geogr. 1.4. cap.6. 4 Exc. p. 5. E. p. 6. A. E. \& Not. a. p. 8. D. E. p. Io. D. P.I 4. A. p. 22. D. p.29. E. p.30. A. P.31. A.D. P.36. Cap.9. Libyes propius mare $A$. fricum agitabant: Getuli fub Sole magis, haud procul ab ardoribus: hique mature oppida habuere. Sall. Bell. Fug. 921 . p.286. Super Numidiam Getulos accepimus, partim in tugu-

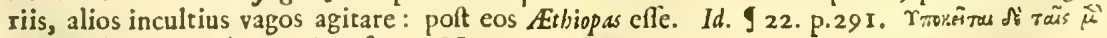

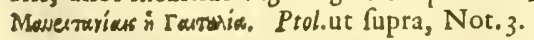

Porrigit o patulis Nigritx fimibus errant. 
I have met with nothing in the old Geography that de-The Difagreetermines the Bounds and Extent of Gretulia; but the Mauritanice and the Numidia Propria in Conjunction with Africa are new Geogra- $^{\text {now }}$ particularly marked out and circumfcribed; though, if we are to bound Them to the Southward ${ }^{2}$ with the Mountains of Atlas and the Sabara, the feveral Diftances will not always anfwer tolater Obfervations. Thus Pliny, who is followed herein by Martianus, maketh the Breadth of the Mauritanice to be four hundred and fixty feven Miles ${ }^{2}$. But This will be too much even for the Tingitania, where indeed the correfponding Part of Mount Atlas' lyeth confiderably to the Southward; and more than three hundred Miles beyond the utmoft Extent of any Part of the Cefarien/is ${ }^{4}$. The two hundred Miles, which the fame Author lays down for the Breadth of Numidias, is nearer the Truth, though twenty Leagues more than I have found it. Nor have the Antients faid any thing, more to be relied upon, of the particular Length either of the Mauritania Crefarien/is, or of the Numidia Propria. Pliny giveth us an hundred and feventy Miles, which are too few, for the Tingitenia ${ }^{6}$; and eight hundred and fixty nine (Martianus eight hundred and feventy three ${ }^{7}$ ) which are too many, for the Caefarien/is ${ }^{8}$; but is filent as to the particular Length of Numidia exclufive of Africa. The It $i$ nerary ${ }^{9}$ maketh the Coaft from the Portus Crecili (which we are to look for near the Great Promontory or Cape Hone as it is now called) to Tabarca, to be near a thoufand Miles; a greater Error than that of Sanfon's: and Ptolemy', who placeth the Crefarienfis between the Malva and Ampjaga (or Great River,) i. e. from Long. I I'. 10', to $26^{\circ}$. I5', extendeth that Province alone, (by allowing, as above, forty eight Miles and an half to a Degree, ) upwards of feven hundred Miles; a Miftake ftill greater than that in the Itinerary.

Neither muft we omit another Error of This Author in placing Prolemy mifHis Great Promontory in N. Lat. $35^{\circ}$. and the Amp Jaga in $31^{\circ}$. taken in the $45^{\prime}$. and fo in Proportion of the interjacent Places; whereby this sea coaff. Part of the Coaft is laid down nearly in an E. S. E. Direction. Whereas in Sailing from the Mullooia to Nakkos, we are to keep almoft a N. E. Courfe; after which, to the Ras Acconnatter,

I Vid. Not. 4. p. 8. 2 Exc. p. 2r. Cap. 2.E. p. 30.D. 3 Viz. à Tingi, cujus Lat. $35^{\circ} \cdot 25^{\prime}$

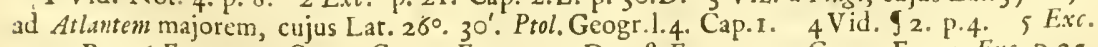
p.22. B. 6 Exc.p.21. Cap.2. C. 7 Exc. p.30. D. 8 Exc. p. 21, Cap.2. E. 9 Exc. p.25. 10 Exi. p.9. B. p. 10. C. 
and fo on to the Mers' elFabm, the Shore inclines a little to the Northward; the feveral remarkable Headlands continuing afterwards to lye in the fame Parallel. In fhort, there is fo great a Difference in the whole, that thofe Places which Ptolemy hath fixed in a Southern Inclination, hould have had a Northern one: and the Great Promontory, which He placeth $3^{\circ}$. I5'. to the Northward of His Amp a aga, will be found to lie $\mathrm{I}^{\circ} .37^{\prime}$. to the Southward of it; not to mention other Places in His Tables that are put five Degrees, or CCC Miles farther to the Southward, than They are found to be by Obfervation.

The Difagree- So much in general for the comparative Geography of this

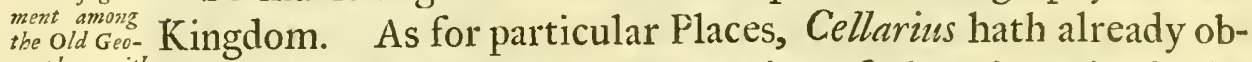
grappers mith
Regard topar-ferved, that the Order and Situation of them is varioufly fet

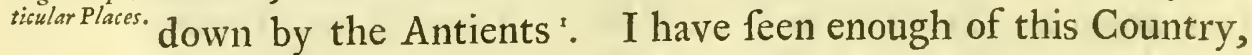
to be of his Opinion; and if we may be permitted to fix the Situation of the old Rivers, Ports, or Cities of It, by fome few antient Names, Ruins, or 'Traditions of them, that are continued down to our Times, we thall frequently have occafion to complain of the Want of Accuracy in thofe who have defcribed them.

The Metbod made ufe of in maferibing This
Kingdom.

The River Malva or Mullooia.
To make Way for the fubfequent Obfervations upon the Three Provinces of this Kingdom, I fhall begin with a fhort Account of that Part of the Mauritania Cre farienfis which belongeth to the Weftern-Moors; defcribing, as I go along, in Relation to Them All; Firf, The moft remarkable Places and Inhabitants upon the Sea-Coaft; Afterwards, Thofe in the InlandCountry corresponding to Them.

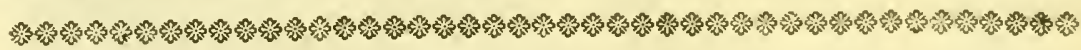

\section{H A P. II.}

Geographical Objervations in that Part of the Mauritania Crefarienfis, which belongeth at prefent to the Tingitanians, or Weftern-Moors.

$\mathbf{I}$

T hath been already obferved, that the Mauritania Crefathe Kingdom of Algiers, as far as the Malva; which being a River much taken Notice of, both in the old and new Geography, I thall begin the Account, I am going to give of this Country, from that River. The Malva then, Malua, Marĩa,

I Multa in Mauritania turbata \& confufa videncur, quod ad loca fingula demonftrabimus. Cellar. Geogr. Antig. 1. 4. Cap. 5. p.126.

and 
and [ $;$, lo $]$ Malouia or Mul-Zooia, according to the Pronunciation of the Moors, is a large and deep River, which empties it felf into the Mediterranean Sea, over againft the Bay of Almeria in Spain, and lyes about fifty four Miles to the SW6W of Cape Hone, and two hundred and forty from the Atlantic Ocean. Small cruifing Veffels are admitted within it's Channel, which by proper Care and Contrivance, might be made commodious for Veffels of greater Burthen, and as navigable as it was heretofore. The Sources of This River, are a great Way within the Sabara, at the Diftance of eight hundred Miles from the Sea, according to Abulfeda ${ }^{2}$; and the Courfe of it, contrary to that of moft other Rivers of this Country, lieth almoft the whole Way in the fame Meridian. From which Circumftances, the Mul-looia appears to be the moft confiderable River in Bar$b a r y$, and by far the fitteft for fuch a Boundary, as the antient Geographers and Hiftorians have made it.

But whether the Malva was different from the Mulucha, The MuluMolochath, and Chylemath: or, being one and the fame River, chath and were confequently ufed for one and the fame Boundary in the Chylematli old Geography, will admit of fome Difpute. The Boundary between the Mauri and the Mafrelyli, or the Subjects of Bocchus and Fugurtha, is by Strabo afcribed to the Molochath, and by Salluft, Mela', and Pliny' to the Mulucha: it is very probable therefore that thefe were one and the fame River. And the fame Situation that Pliny ${ }^{6}$ and Mela give to their Mulucha, in placing it near the Portus Magnus, is given by Ptole. $m y^{8}$ to his Chylemath; fo that the Mulucha, Molochath, and Chylemath, appear to be the fame River. Whether the Malva alfo be another Name for it, is the next Thing to be confidered.

Now the Malva, notwithftanding the Largenefs and great The Malva Extent of it's Stream, doth not appear to have been known to ver waith Ri- the the fane Ri$v \leftarrow r$. Mulucha \&.c.

I In Malouia influit fluvius Segelmefa, cujus Scaturigo elt ab Auftro Segelmefe ad magnam ab ea diftantiam, atque ibi in unum fluvium ambo coalefcunt qui in mare al Rum (fc. Mediterraneum) fe exonerant ad orientem \& auftum Sebta ad diftantiam ter centam \& decen milliariorum. Inter originem Aluvii Segclmefe \& oftum ejus quo in mare dilabitur funt circiter octoginta milliaria. Ebn Said in Abulfede Geogr. ex traduct.V. CI.F.Gagnier. 2 Exc. p.6.A. \&c. 3 Haud longe a fumine Mulucbe, quod fugurtb. Bocchique regnum disjungebar \&c. Sal. Bell. Fugurth. Cantab. 1>10. 997. p.471. Gatulorum magna pars \& Numida ad fumen ufque Mulucham fub Fugurtha erant; Mauris omnibus Rex Bocchus imperitabat. Id. I22. p.292. Ego Alumen Mulucham quod inter me \& Miripsam fuit, non egrediar, neque fugurtham id intrate finam. Bocchi Orat. Id. S. I I8.p.524. Ad Matritaniam Numide tenent: proxume Hipaniam Mauri funt. Id. \$22. P. 29I. Pauci ad Regem Bocchum in Mauritaniam abierant. Id. 66.p.398. 4 Exc.p.18.C.ap.5. in fine. 5 Exc.p.21.Cap.2. 6,7 Exc.ust fupra. 8 Exc. p.9.C.

C 2 
Strabo and Mela: at leaft they do not take notice of it under

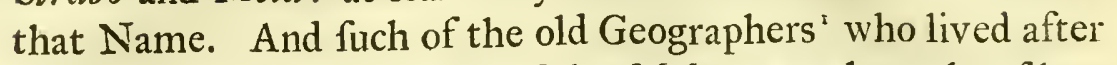
Pliny and Ptolemy and fpeak of the Malva, are altogether filent about the Mulucha. There muft then be fome great Error or Omiffion in the old Geography, with Refpect to thefe Rivers. For if the Malva and Mulucha are different, then the moft confiderable of them, (which doth not feem probable) muft have been entirely forgotten and omitted. But if the Error fhould lye, as it feems moft reafonable to think, in miftaking one Name for the other: or, if what the earlier Ages called Mulucha, (or perhaps Mulub-ha, as the antient Greeks and Romans pronounced it) was afterwards changed or foftened into Malva,

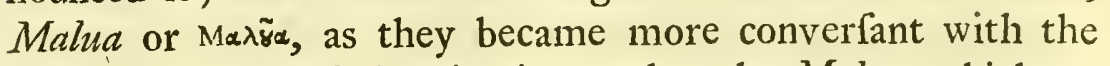
Moorifb Idioms and Terminations; then the Malva, which we now find to bound the Two Mauritanice, will be the fame River with the Mulucha, that bounded formerly the Moors and Numidians.

No Alteration

And indeed, by what we can collect from Hiftory, there does made in the
Boundaries of not feem to be much Reafon for fuppofing any Alteration to

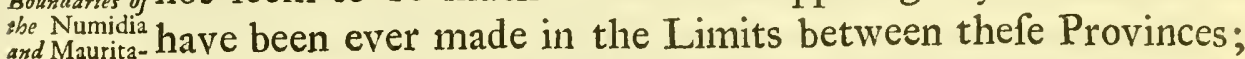
and Maurita- but that the fame, which were in the Time of Bocchus and $\mathcal{F}_{u \text { - }}$ gurtha, were kept entire and without any Alteration, through the feveral Succeffions of the Numidian Kings ${ }^{2}$ and Roman Prefects, till the Reign of Auguftus.

We find that Numidia was a Roman Province $^{3}$ in the Times of Ful. Crefar and Auguftus: but Bogud and Bocchus, fucceffive Kings of Mauritania, being Friends to thofe Emperours", muft be fuppofed to have kept their Kingdoms entire, without any Diminution or Augmentation, fo far as appears from $\mathrm{Hi}$ ftory. Dions acquaints us, that Auguftus gave the Younger Juba Egypt and his Father's Kingdom; and confequently, His Territories extended to the Mulucha, the old Weftern Bounda-

I Vid. Itinerarium in Exc.p.25.E.F. Atbicum \& Honorium in Exc.p.29.A Orofium in Exc. P.30. A. Ifidorum in Exc. P.31.D. \& Anonym. cx Ravennate in Exc. P.36. B \& G. 2 Capto Syphace, Populus Romanus quafcunque urbes \& agros manu ceperat, regi dono dedit (ic. Ma-

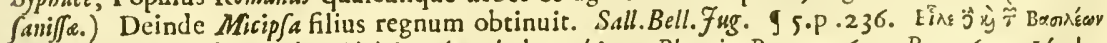

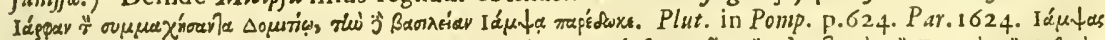

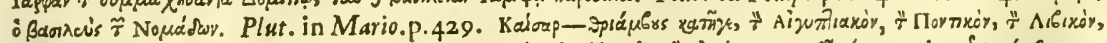

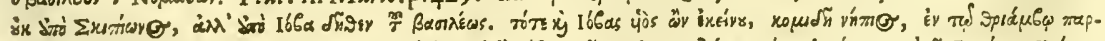

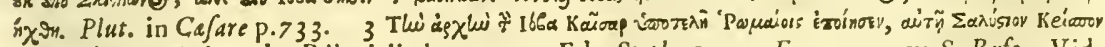
Eyxerashoxs. Appian. de Bell. civil. 1.2. p.490. Ed. Steph. 1592. Exc. p.29. ex S. Rufo. Vid.

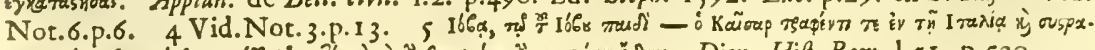

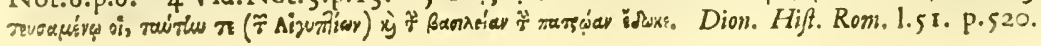


ry of it; whilf Mauritania remained a Roman Province: fo that no Alteration appears to have been made hitherto in this Boundary. Afterwards Auguftus gave $\mathcal{J}_{u b a^{2} \text { Mauritania in }}$ Exchange for his Father's Kingdom, as Dion obferves, or as an Addition to it, according to Strabo ${ }^{3}$, with whom Pliny ${ }^{4}$ and Solinus' feem to agree. During this Reign, whilft the two King. doms were under one Prince, or perhaps fooner, the Numidian Tribes might cohabit and intermarry with the Mauritanians; whilft feveral of the Mauritanian Families might fettle in $\mathrm{Nu}$ midia. Numidia therefore, or the Kingdom of the Ma/fe/yli in particular, might, by an Alliance in Intereft with the Moors under the Government of the Romans and their Friends, and from a continued Removal and Difperfion of its old Inhabitants, almoft from the Time of the elder $\mathcal{F}_{u b a}$, infenfibly lofe its old Name, and thereby make way for the New Title of Mauritania that fucceeded it. Accordingly we are told, that upon the Infurrection which happen'd amongt the Moors foon after the Death of Ptolemy, Claudius ${ }^{6}$, having reduced Them, divided Mauritania into two Provinces; viz. into the Tingita$n a$, fo named from Tingi the principal City of the old Mauritania; and the Ceefarien/is, fo named from lol Ceefarea the Capital City of the Maffe fyli. At this Time therefore, the two Countrys had obtained the one common Name of Mauritania; but the Provinces being diftinguifhed by the Names of the Principal Cities of the old Kingdoms, it is reafonable to believe, they were likewife divided by the antient Boundaries of the fame. So that the fame Limits, which formerly fubfifted betwixt the Moors and Numidians under Bocchar and Syphax, Bocchus and Fugurtha \&c. did probably continue betwixt the Mauritania Tingitana and Cefarienfis.

But befides this Probability, we may obferve that the $M u$ - Siga fruated lucha could not, for fome other Reafons, have the Situation that $\begin{gathered}\text { mithin the } \\ \text { Crenfis }\end{gathered}$ is given to it by Mela, and Pliny who follows him; and there-tre Mulucha. fore may be further fufpected to be the Malvá 'For befides a Matter of Fact, that there is actually no River at all in the Neigh-

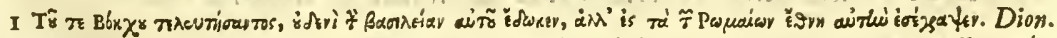

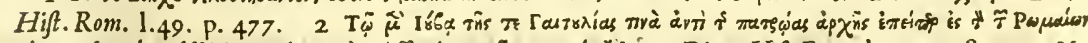

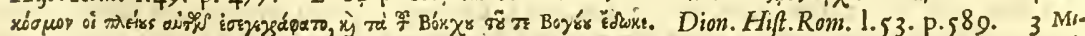

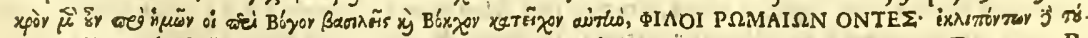

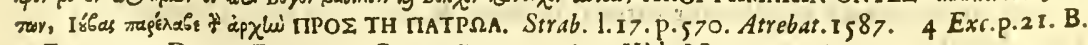
5Exc.p.23. D. 6 Exc.p.20. Cap.1. B. p.21. A. Vid. Nor.10. p.6. 
bourhood of the Portus Magnus where we are directed to look for the Mulucha; yet provided we fhould grant fuch a River near this Place which might be fit for a Boundary, we are ftill to fuppofe, that neither the Moors nor Numidians were to violate and tranfgrefs it. But Strabo ${ }^{1}$, Pliny ${ }^{2}$, and Solinus ${ }^{3}$ affure us, that Siga, which we fhall find to lye forty Miles at leaft from the Great Port (or the fuppofed Pofition of the Mulucha) to the Weftward, was one of the Royal Cities of the Numidian Kings; and Pliny more particularly, by reftoring only what may be prefumed to be the true pointing of the Text ${ }^{4}$, makes it belong to the Crefarienfis: it mutt therefore be probable, either that one Prince Thould have a large Extent of Country and a Royal City within the Territories of another, or elfe that Mela was not fufficiently acquainted with the Situation of the Mulucha, which, from this Circumftance, ought to lye to the Weftward of Siga, or in the Pofition of the Malva.

The MauritaMela likewife will furnifh us with another Argument for nia Cxfari-
enfis of the removing his Mulucha, to the Weftward of the Portus Magnus Same Extent and Siga, as far as the Malva; and that therefore the Mauri-

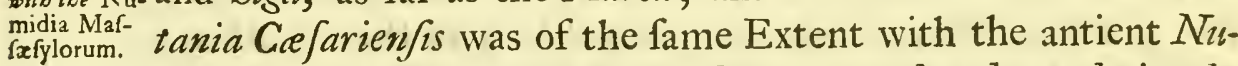
midia. He tells us', that Ceefarea was placed nearly in the Middle of the Coaft of Numidia; which Province he bounds with the Rivers AmpJaga and Mulucha. And agreeably to this Geographical Circumftance, I find by Obfervation, that Sherfhell, as Ceefarea is called at prefent, is placed as near as poffible in the Midft of the Coaft of the Crefarienfis, at about two hundred Miles Diftance from either the Amplaga, or the Malva. If then Mela's Authority in this Particular is to direct us, and we are to attend to the refpective Diftances of thefe Boundaries from Ceesarea; the Mulucha, by being made equidiftant with the Amp Jaga from it, but in a Weftern Direction, will fall in exactly with our Mullooía, or Malva. Whereas, in looking for the Mulucba at, or near the Portus Magnus, the Space that is required to lye between the Mulucha and Cee area to make up this fuppofed Equality, will fall fo fhort of it, as fcarce to amount to the Half of what it fhould be.

- Exc. p.6.D. 2 Exc. p.21. E. 3 Exc. p.23. Cap.25. ${ }_{4}$ Siga oppidur ex adrerfo Malache in Hiphania fit $x$, Syphacis regia, alterius jam Mauritanis, (namque diu regum nomina obtinuere, ut Bogudiana appellaretur extima, itemque Bocchi) qua nunc Cafarienfis. 5 Exc. p.18. Cap.6. E. 
Yet perhaps it may be ftill urged, that Pliny and Ptolemy Pliny follows mention both the Malva and the Mullucha or Chylemath, and Polfition of the therefore they may be prefumed to be different Rivers. The Malva, or Malvana as Pliny calls it, was certainly well known to Him', from His defcribing it to be a navigable River: a Property which no River within the Crefarien/is can boaft of. The Portus Magnus may be likewife fuppofed to have been better known in the Time of Pliny, than when Mela lived; becaufe there was now a Roman Town built and a Colony ${ }^{2}$ fettled in that Place, from whence the Geographers and Hiftorians of His Age might receive what additional Difcoveries fhould be made concerning the Nature and Situation of the neighbouring Country. But there being no remarkable River within twenty Miles at leaft of the Portus Magnus, Pliny could not receive any new Informations concerning the Pofition of a River which did not fubfift. All the Notice therefore which he may be prefumed to have had of the Mulucha, muft have been from fome preceding Authority; from that of Strabo, or Mela rather whom he always copies. Pliny then finding that $\mathrm{Mela}^{3}$ placed the Mulucha near the Portus Magnus, at a great Diftance from his Malvana, could by no means fufpect they were the fame; but relying altogether upon His Veracity and Exactnefs, adopted the fame Miftake, and thereby continued down to future Ages the fame Pofition to the Mulucha, which he found it placed in by Mela.

Ptolemy, befides the Authority of Mela, hiad That likewife Prolemy folof Pliny in this particular Circumftance; and from hence it itans and Pliny

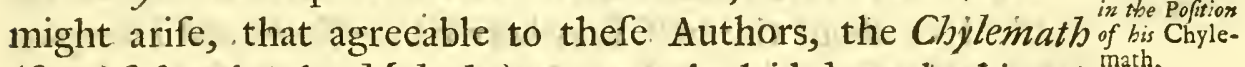
(fuppofed to be the Mulucba) came to be laid down by him as a different River, and at a great Diftance from the Malva to the Eaftward; whilft the Molochath, agreeably as he thought

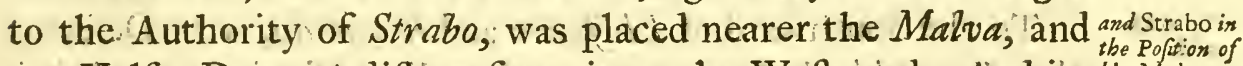

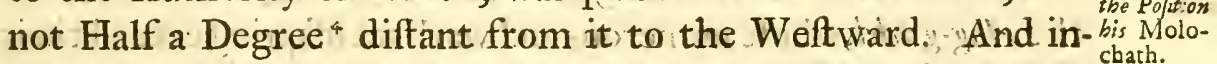
deed, provided Ptolemy had taken no Notice at all of the Malva, (and I doubt whether this Part of the Cauntry admits of any two fuch contiguous Rivers) the Pofition he gives bere to his Molochath, would have fufficiently anfwered to The Boundary.

I Exc.p.21. Cap.2. E. 2 Ibid. 3 Exc.p.18.Cap.5.D. 4 Ptoli Geog. l.4.Cap.1. viz in

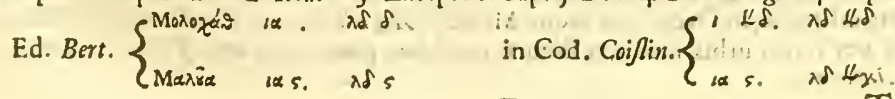

D 2 THREE 
TrESINSUTH R E E little Iflands, where there is good Shelter for fmall 25. E. Ex. P. Veffels, are fituated to the N W of the Mullooia, at the Diftance of ten Miles. Thefe are the Tres Infulae of the Itinerary.

vilageofsce- Six Leagues to the ENE, is the Village of Seedy ${ }^{*}$ Abdeldy Âbdelmoumen or LEMNIS. Excoibid.

\section{moumen, one of the tutelar Marab-butts ${ }^{*}$ or Saints of this Coun-} try, whofe Tomb they have here in the greateft Veneration. We have below it a fmall but commodious Road, which the Row-Boats of this Country frequently touch at.

Maifeards. We fall in with the like convenient Station for fmall Veffels at Mai-fear-da a little further to the Eaft. This is another of the leffer maritime Villages of Barbary, made up, like the reft, in a carelefs, flovenly Manner with Mud, Stone, Timber, and fuch Materials, as are the moft eafily procured. One of thefe Villages, and perhaps the Firft, may be the Lemnis of the Itinerary.

The cafle of The Tingitanians have upon the Banks of the Mullooia, in the Road from $\mathrm{Fe} z$ to Tlem-fan, a well fortified Caftle and a Garrifon of a Thoufand Men. They have another ftrong Caftle El-Joube or and Garrifon at [
sbecifernss. of Rain-water, that are built about twenty Miles to the Eaftward of the Mullooia. In the Wars betwixt the late Muley Ifbmael and the Regency of Algiers, thefe Caftles were of no fmall Confequence; as they ftill continue to be very ferviceable in awing the Ang-gadd and other factious Clans; Inhabitants unworthy of fo delicious a Country.

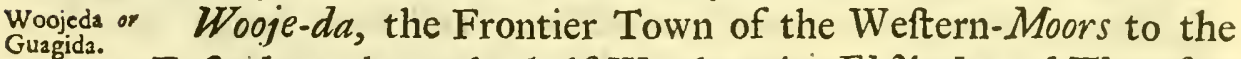
Eaft, lyes about the half Way betwixt El-Foube and Tlem-fan. This is the Guagida ${ }^{2}$ of Leo; but we are at a Lofs for the antient Name, Ptolemy not having taken Notice of any InlandCities between the Parallels of his Rivers Malva and Siga.

rbe Ang- To the Southward of El-Foube and Wooje-da, is the Defert of the Ang-gadd, whofe numerous and warlikeOffspring extend their Hoftilities and Encampments to the very Walls of Tlem-fan. To the Northward, we have the mountainous and rugged Diftrict of

\footnotetext{
* \# [usher or cum] Sid or Seedy. Dominus,Princeps. vid.Gol. in voce. This is the fame Appellation and Word of Refpet amongft the Moors.and Arabs, that Sir, Lord, or Mafter is with Us; but which They in a higher Degree artribute to their Marab-butteen; for fo they call fuch Perfons, who are, or have been remarkable for any extraordinary Sanetity of Life, or Aufterity of Manners. I Guagida antiquiffmum oppidum ab Afris, in Planitie fpatiofiffima exftructum, a mari Mediterraneo Meridiem verfus quadraginta, a Telenfino autem totidem fere diftat milliaria, in Occidente atque Meridie Angadi deferto clauditur, agros haber feecundiffimos, per hujus utbis medium flumen quoddam praterfuit \&c. F.Leo. Defcrip. Afric.1.4. p.190. Ant.1556.
} 
the Beni-Zeneffel, (or Fefneten ${ }^{\mathrm{L}}$ as Leo calls them) a no lefs Benizeneffel. powerful Tribe of Kabyles, who, fecure in their Numbers and Situation, have not hitherto been obliged to pay any Tribute to the Tingitanians. Ptolemy encourages us to fearch for the Montes Chalcorychian Mountains, and the Seat of the antient Herpidi-R Y YCHIItani at this Place. HERFIDITANI. Exc.

We fhould not leave This Country without obferving that p.ro.f. during the long Reign of the late Muley Ifbmael. The Te, The Safing in traduring the long Reign of the late Muley Ifbmael, The/e, as Reign of Muwell as the Parts of It more immediately influenced by the $\mathrm{Ca}$-ley lflmacl. pital, were under fo ftrict a Government and Regulation, that, notwithftanding the Numbers of Arabs who are every where in the Way, intent, every one of Them, upon Plunder and Rapine; yet a Child, (according to Their Manner of fpeaking) might fafely carry a Piece of Money upon his Hand from one End of the Kingdom to another, whilft the Merchant travelled from Salee to Woojeda, and from Tanger to Taffilett, without Danger, or Moleftation.

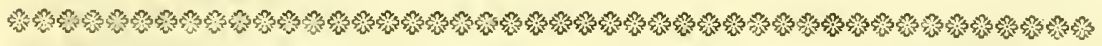

\section{H A P. III.}

Geographical Obfervations upon the Sea-Coaft of that Part of the Mauritania Cafarienfis, which is called at prefent the Weftern Province or the Province of Tlemfan.

EAving Maifearda and Woojeda at fome Diftance to the Tise general 1 Weftward, we enter upon Twunt and the Mountains of Thbir provinince. Trara. Thefe are the Confines of This Province to the Weft, as the River Ma-Jaffran, at near two hundred Miles Diftance, will bound It to the Eaft. The Whole is almoft equally diftributed into Mountains and Valleys; and had It been better fupplied with Rivers and Fountains, would be a more delightful, as It was always accounted a more fertil Diftrict ${ }^{2}$ in general, than the eaftern Part of This Kingdom.

\footnotetext{
* The Kabyles or African Tribes have generally Ebeni [Lịl] or Beni prefixed to the Names of their refpective Heads or Founders; as Beni-Zeneffel, Beni-Madooni \&cc. Whereas [Wg] Welled is the Term made ufe of amongft the Arabs; as Welled-Halfa, Welled-Zeire \&c. Both have the fame Signification and denote the Sons or Offfpring of Zeneffel, Halfa, \&rc. or the Zeneffelides, Halfides \&ic. as the antient Greeks, and Romans would have called Them. I Beni Fefneten, Telenfini mons diftat a Telenfino occidentem verfus quinquaginta fere paffuum Millia. - extendit in longum viginti quinque, in latum quindecim fere miliaria; altiffmus eft, arduus, afcenfuque difficillimus. J. Leo. P. 204. 2 Qux pars Numidia Mauritanism attingit, agro virifque opulentior \&c. Sall. Bell. Jug. 9.r9. p. 278.
} 
It will be difficult, from the Uniformity and the little Interruption there is amongft thefe Mountains, to diftinguifl that particular Chain of them, which we may take for the Continuation of Mount Atlas. The Coaft and the Sabara in fome Places, have each of Them large Borders of Mountains; and the Midland-Parts are no lefs diverfified with others, not inferiour to the former, either in their Height, Fruitfulnefs, or Number of Inhabitants. However, as the Mountains of Sachratain lye the neareft to the Sabara, and are continued quite through this Province by thofe of Souf el Tell, Tafarowy, Ellcalla, Benizerwall, Merjeja, Elcadara, and Miliana; confpicuous all along from the great Number of Plains through which we pafs: The fe feem to carry with them the greateft Pretence, and Appearance of being a Part of That noted Ridge of Mountains. --- But to purfue the Method we are in.

Twunt or

Twvnt, the Frontier Village of the Algerines to the Sea, ERx. P.25.F. is fituated about feven Leagues to the E.N.E. of Maifearda, and hath a funall Fort. The Artifiga of the Itinerary, lying twenty feven Miles only to the Weltward of Siga, will anfwer well enough to This Place. But the Diftance betwixt Lemnis and Artifiga; and indeed, the whole Diftance betwixt the Malva and Siga, as it is laid down in the Itinerary', fo much exceeds what it actually is, that little or no Account, I prefume, can be made Here of the Number of Miles affigned to particular Places, fo as to be fure of the Situation of any one of them.

Cape Hone, Cape Hone, called likewife Ras Hunneine and Mellack by Ras Hun-
neine, or the Inhabitants, lyes about four Leagues to the N.E. of Trunt, Mellack. and is a Continuation of the Mountains of Trara. As This is the largeft and one of the moft confpicuous Promontories to mise axpowi- the Eaftward of the Mullooia, we may take It for the Great

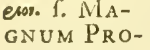
MONT. Exc Promontory of Ptolemy, which he places in This Poftion, though p.9.C. a few Miles more to the Weftward of Siga, than I find It. The little Port Hunneine*, the Crecili perhaps of the Itinerary, lyes a fmall Way within the Cape; and from Hunneine, for five Leagues, as far as Tackum-breet and the Influx of the Tafna, the Shore retires towards the S.E. Acra inf.
Exc. P.4. D.

I Exc. p. 25. F. * Hunain, oppidulum ab Afris conditum Structurx Elegantia, Morumque Integritate merito ab omnibus laudandum, portum habet turriculis utrinque munitifimum. J. Leo. p.r.92. 
lax, the Ifland that forms the Port of the Har/lo-goone, under which Veflels of the greateft Burthen may lye in the utmoft Safety.

From the Mouth of the River Tafna, the Sea-Coaft, for a little way, has an Eafterly Direction; after which, as far as the Ras ' Azintoure, (the Cape Figalo of our Sea-Charts) It inclines, by feveral Turnings, nine Leagues to the Northward. This remarkable Winding of the Shore, from Mellack all along to Azintoure, forms a confiderable Gulph, that is called Har/b-Harfiguone, goone by the Moors, the Laturus Sinus perhaps of Mela, and rerthe Latusus. the Hare frol ${ }^{2}$ of $L e 0$ a the later Geographers; though the Hareggol ${ }^{2}$ of Leo and the later Geographers; though miftaken, I prefume, by Them All, for the Name of a City.

The feveral Dafbkras to the Weftward of the Tafna, are Woolhara. called Wool-bafa, after the Name of Their Inhabitants. The Same may have been communicated by Them to the Mountain mentioned by $L_{-} o^{3}$.

Upon the weftern Banks of the Tafna, almoft contiguous to the Sea, are the Ruins of the antient Siga, once a Royal-City of the Numidian Kings ${ }^{4}$. It's prefent Name is Tackum-breet, Tackumthe Tebecritum ${ }^{5}$ probably of Leo; though from His calling $T e$ becritum a Village, placing It upon a Rock, and affigning the Africans as the Founders of It, it will by no means anfwer to Tackum-breet; but will better agree with the Defcription Leo has left us of His Harefgol.

The Tafna, the molt confiderable River of This Province The Tafna to the Weftward of the Shelliff; is compofed of feveral Branches; foumpored of $B$ ranchthe principal of which are the Bar-ba-ta, the Tafna, the Sik-ack, ${ }^{\text {es, viz. of the }}$ and the Iffer. The Bar-ba-ta defcends from the S.W; and, be- Barbata, fore It enters the Mountains of Trara, receives, as I judge from the Situation of the adjacent Parts, the River of Woojeda. The Tafna, which is the moft confiderable of thefe Branches Tafna, and receives the reft, continues It's Name to the Sea: and rifes in the Mountains of the Beni-Snoufe; an African Tribe, who inhabit Their feveral Dafbkras about thirty Miles to the South-

I 2 שר Schind. in voce. A Cape or Head-Land. 2 Harefgol maximum atque antiquiffimum in fcopulo quodam mati Mediterraneo undique cinctum fuit, præterquam in Meridie, ubi via erat quæ in oppidum ducebat. A Telenfino Septentrionem verfus, in $\mathbf{I}_{4}$ fitum fuit Milliario. J. Leo, p. 192. Atlas Geogr. Vul.1v. p. 212.3 Gualh.2 $a$ mons altifimus oppido Hunain vicinus eft. J. Leo.p.204. 4 Exc.p.6.D. P.22.E. P.23.cap.25. vid. Marian. Hift.Gen.de Hijp. 1.2.c.23.p.80. 5 Tebecritum exiguum oppidum ab Afris in quodam fcopulo ad mare Mediterranesm extruGum eft. J. Leo. P.I9I.

$\mathrm{E} 2$

ward 
Sikack, ward of the Harfh-goone. The Sik-ack is a rapid Stream five Miles to the Northward of Tlem-fan, in the Way to Tackumbreet. One of the Fountains is lukewarm, and well ftored with Fifh, fromt whence it has the Name of [ $ت{ }^{\prime} \mid \mathrm{cus}$, Ain el Houte] Iffer, the The Fountain of Fi/hes. The IfJer has It's Fountains, to the SE, among the Mountains of the Beni-Sme-al, a Tribe of Africans bordering upon the Sabara. Abulfeda' takes Notice of It as a confiderable River; which, by the Situation, and Affi-

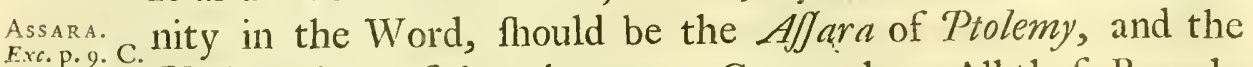

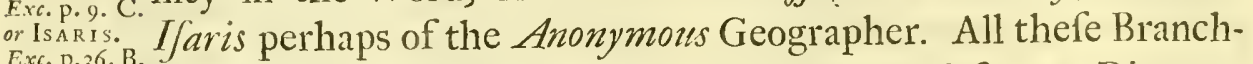
Exc. P. 36. B. es unite at a fmall Diftance from the Sea, and form a River as broad as the Ifis, where It paffeth by $O x f$ ord.

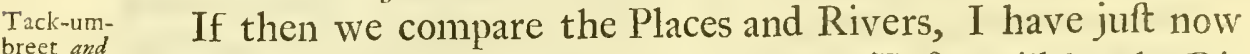
breet and The defcribed, with the old Geography; the Tafna will be the Ritas \& Flu- ver Siga of Ptolemy, and Tackum-breet the City of that Name. vius. Exc.p. Hunneine, if it be not rather the Portus Crecili of the Itinerary, Gypsaria. will be likewife His Gypfaria; for All Thefe Places are fituated
Ibid. Ibid. betwixt His Great Promontory and the River Affara. Pliny agrees with Ptolemy in placing Siga, to the Eaftward of the Malvana, in the Mauritania Ceefarien/is; but it will be difficult to account for His fixing It at the fame Time over againft Siga mong
placed by Pli- Malacha, the Malaga, as It is now called, in Spain. For This ny over a- - City, lying feventy Leagues to the W.N.W. only of Tackum-breet, cha. Exc. p. cannot have fuch an oppofite Situation. Moreover, if Sig a hould
21.

be in the fame Meridian with Malaga, (for fo I conjecture PLINY's ex adverfo will be generally interpreted) the Tingitania, fhort as He hath already made It, would, upon this Suppofition, be much more contracted; and the Malvana or Mal$v a$, the eaftern Boundary of It, could not be twenty five Leagues diftant from the Atlantic Ocean. The Contrapofition therefore mentioned by Pliny, muft have fome other Conftruction put upon It, as I hall have Occafion to obferve in another Place. Siga at fome
Diffance from Diftance from Exc. p.36.F. p. 25. F.A. ftance from the Malva, befides the Authority of the Anonymous Geographer, we have That likewife of the Itinerary; particularly where Siga is placed twenty feven Miles to the Weftward of the Flumen Salfum, or in the very fame Situation, that Tackum-breet hath, with Refpect to the Wed-el-Mailah. If This River then be the Flumen Salfum of the Antients, as will

I E monte Yiffer [يسر] fcaturit f. Iffer in iftis partibus celebris. Abulf. ut fupta. 
not, I prefume, be difputed, we cannot well require any further Proof, that the Tafna is the River, and Tackum-breet the City Siga. Both of Them feem to have been known to Scylax, Stcum. Ex. but the City He calls Sigum.

Leaving the Tafna and the Inland Acra to the S.S.W. we Im-mi-fez, come to a fmall Creek, commonly called the Port of Im-mi. fea. The Arabs have a Tradition, that This was formerly a Port belonging to the Town of Tranf-rant, now a Heap of Tranf-rant, Ruins, at two Miles Diftance from It, within the Plains of Zei-doure. By thefe Ruins gently paffeth a little Brook, which, after It hath refrefhed the Country of the Welled Halfa, empties Itfelf into the Port. One or other of thefe Places fhould be the antient Camarata, placed in the Itinerary at equal Di- $C_{A M a r a-}$ ftances from the Portus Sigen/is and the Salfum Flumen. TA. Exc, P.

Three Leagues to the N. by W. of the Port of Im-mi-fea, is the Mouth of the Wed el Mailah, a Stream fomewhat lefs The Wed el

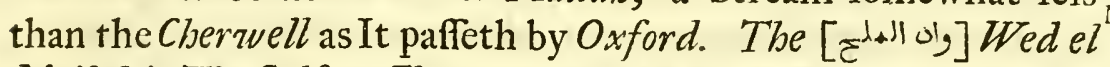
Mailab is The Salfum Flumen, or The Salt River of the Antients, FLUMEN and bears the fame Signification: fuch Appellations having been $E_{A \in C}$. . . 25. probably given to This River in all Ages, as were expreffive of the Saline 2uality of It's Water. The Sources of It are at Souf el Tell, a fmall Diftrict about ten Leagues to the SE; where It is ftrongly impregnated with Salt : but, receiving fome Rivulets of frefh Water in It's approaches to the Sea, becomes a little more diluted; though I found It much too heavy and brackifh to be drunk, when It paffed the Plains of Zei-doure. Yet notwithftanding this offenfive Quality, fuch is the Want of good Water in the Neighbourhood, that the Arabs, by habitual Cuftom, are reconciled to the Tafte and drink It without Reluctance. The Si-nan, the moft confiderable of the The Si-nan. Brooks falling into the Wed el Mailab, hath It's Sources at no greater Diftance, than the Southern Confines of the Plains of Zei-doure. It glides in a Variety of beautiful Windings through This fruitful Diftrict, and is known by feveral Names, according to the remarkable Places vifited by It in It's Courfe. The Wed el Mailah, when united with the Si-nan, runs but a little Way, before It difchargeth Itfelf into the Harg-goone.

\footnotetext{
* olg Wed, vallis; Alveus fluvii : \& ipfe Fluvius. vid. Gol. in voce. The Common Term in Barbary for a River: Nahar (jo J the general Word elfewhere, being rarely made ufe of
in This Country.
} 
The mountainous Diftrict to the N. and N.E. of the Wed el Mailah, is poffeffed by the Sheffa: and, upon the Sea.Coaft Nadagl The below Them, we meet with the fmall Port of Madagh, fiExc.p.25.A. tuated about three Leagues from the Ras Azintoure to the Eaft.

Five Miles over againft Madagh, is the Greater of the Iflands Tha Ifands Ha-beeba, where there is frefh Water and Shelter for fmail Ha-bueba.

Veffels: and upon the Continent to the S.E. below the MounAndaloure, tains of the Sheffa, is the fmall Town of Andalouse, built PGe CASTRA by a Colony of Thofe Andalufian Moors, who, in the Begin$\underset{\text { F }: 25 . A \text {. }}{\text { RUM. }}$ ning of the laft Century', were driven out of Spain. Six Miles to the N. by E. of Andaloufe, is the leffer Ha-beeba; and over

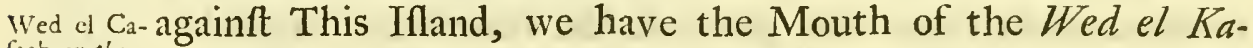

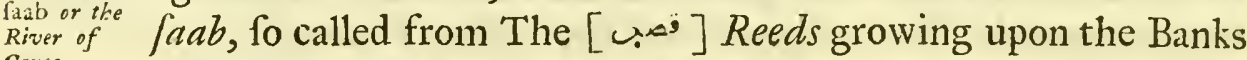
Cancs.

of It. This Rivulet hath It's Sources in the neighbouring Mountains, and falls into a Bay, that is bounded to the EaftCape Fal- ward with Cape Falcon, as our Mariners call It; but which is cl Harlhfa, known to the Moors by the Name of [Ras el [ [A, a ] Har $/ h$. not the ME- $f a$, The Rugged Head-Land. When I paffed by This Cape, ${ }^{E x x_{0} \text {. } .6 .{ }^{\prime} \text {. }}$ in the Month of December, there were feveral Pieces of Ground on each Side of It, which appeared to be fown with Wheat and Barley, but the Promontory Itfelf is barren and rocky. It may be difputed therefore, from Thefe Tokens of Fertility in the adjacent Country, whether This is the Metagonium of Strabo; and though the Situation indeed be oppofite to Carthago Nova, yet the Diftance from It, is only about thirty Leagues; that is to fay, not a third Part of the three thoufand Furlongs He gives It. On the eaftern Side of the Cape, there is a fine fandy Bay, expofed only to the N.E. Winds. This the Moors

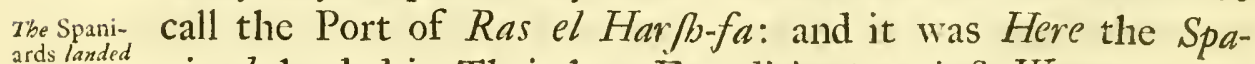
ards landed
rear Ras el niards landed in Their late Expedition Harfh-fa.

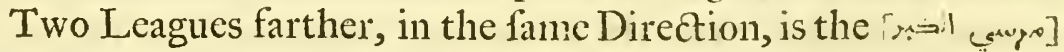
Mers'el Ke- Mers' el Kebeer, the Portus Magnus or Great Port of the Ro-

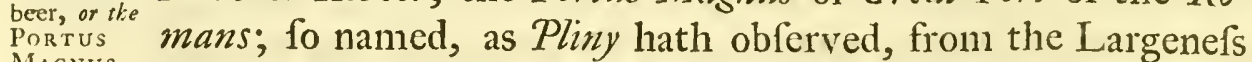
Magnus. Exc. F.25.E. and Capacity of It. In Contradiftinction to This, the Moors call another Port, lying five Miles from It, under the Walls of

1 Fue efte año [1610] mui notable, por la efpulfion qque el fe hizo de los Morifcos de toda Elpaña, gente obftinada, y que tenian intelligencia con los 7 urcos, y Moros de Berueria: continuofe la efpulfion efte, y los años figuientes: Salio gran numero dellos, dizen, que algunos otros quedaron defconocidos, y diftraçados. Hiffor. Gerr. de Efpaña por Iatan de Maitana Tom.2. p.775. Madr. 1635. 2 A.D. MDCCXXXII. 


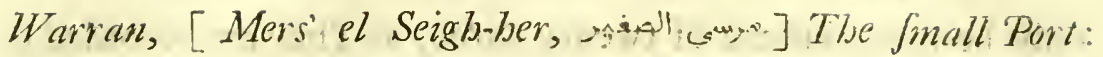
but being expofed to the Northerly Winds, very little Ufe is made thercof, except in favourable W Weather. The Mers' el Kebeer, Maz-al-quivir or Merfalcabir as the Spanifb Hiftorians call $\mathrm{It}$, is formed by a Neck of Land, which advanceth almoft a Furlong into the Bay, and thereby fecures It from the N. and N.E. Winds. The Caftle, built foi the Defence of This Port, was more remarkable, when I faw It, for Spacioufnefs and Extent, than for Strength and Beauty; though a great Part of It, particularly to the Weftward, is artfully enough hewn out of the natural Rock. Hard by the Caftle are fereral Ruins, but not fo many, as to cover any confiderable Space of Ground. It is poffible They may be fome Reniains of the Town mentioned by Pliny ${ }^{3}$, and later Authors.

If therefore we take the Mers' el Kebeer for the Portus Magnus The Antints of the Antients, and the Wed-el Mailats for the Salfum Flumen, place the sial(whereof, the Tradition of the fame Appellations from Time and $\mathrm{the}$ Purnes, immemorial, may be a fufficient Proof) we fhall have in Them a clear Demonftration, how little we are fometimes to depend upon the Diftances and Situations of Places, as They are tranfmitted down to us from Antiquity. For the Author of The Itinerary ${ }^{4}$ afligns one bundred and feren (Roman) Miles for the Diftance between the Salt River and the Great Port, whereas It will not exceed fifty, four. We fhall be likewife at a Lofs to determine the particular Situation of Crifper, Gilva Colonia, wits the interCaftra Puerorum, and the Portus Divini, which are ranged, in if the Itinerary, along This Part of the Coaft. For, if we take Madagh for Crifpce or Gilva rather; and Andalonfe for the Ca- jaike frons: fira Puerorum, whoever thall double the Ras Asintoure, will find the Diftance between the Salt River and Madag J3, amount to no more than twenty three Miles, inftcad of thirty, as They are given us in the Itinerary. The Proportion will be fill lets, both with Refpect to the Space between Giled and the Caftra Puerorum; and between the Caftra Puerorum and the Portus Divini; inafinuch, as the Diftance Here will be only feven Miles, inftead of eighteen; and, in the other Inftance, it will

I Marim. Hift. de Efpaña, ut fupra. p.656--7--8, paffim. 2 Gomecilts de rebusgentis $F_{\text {. }}$ Ximen. 1.4. p. I022. 3 Exc. p.2I. E. Merfcalcabir oppidulum noftris cemporibus a T'elenfini Rege conditum. F.Leo.p. I98. A Merzalquibir il y a un bon chaftean, outre la ville. Def rip. de l'Afrigue par P. D'Avity. Par.1643. P.529. 4 Exc. p.25.A. 
only be inine, inftead of twenty three, as They are recorded in the Itinerary.

The Por:us With Regard to the Portus Divini, there are other DifficulDivini diffe-
ristly placed ties. For, if the Antients thereby intend one Place only, it by Srrabo and
Proleny. Will then be impoffible to reconcile the contrary Situations, that Strabo and Ptolemy have given It, with Refpect to the Great Port. Aind, if They are in the Order of the Itinerary, and more than One, then, as They can be no other, than the two Bays at the Ras el Har $\beta-f a$, fo, if the Calculation is begun even from the weftermoft of Them, the Diftance, we find, of twenty Miles only, between That and the Great Port, will fall vaftly thort of the thirty fix allowed for It in the Itinerary. Though indeed, as Cellarius, hath in fome Meafure obferved before me, Strabo in placing His Portus Deorum fix hundred Furlongs to the Eaftward of the City Siga, fixes the Pofition of It near This Place.

The Portus But, notwithftanding what is here laid down by Strabo; and Divin the
Same probably that Veffels of all Kinds may lye covered, in one or other of withtbe PoR- Thefe Ports, from the N.W. and N.E.Winds, (the fierceft inGNUS and the Port of Arfenaria. deed, and the moft common upon Thefe Seas) yet unlefs the Terms Divini \& Deorum were impofed accidentally, (upon fome fuch like Occafion, we will fuppofe, as the late fortunate Defcent of the Spaniards) rather than in Confideration of Their Goodnefs and Capacity; fuch lofty Names plead ftrongly againft us, and fhould induce us to believe the Antients intended fome other Stations more fafe and commodious. May we not then take the Portus Divini (provided they were Two) to be only other Names for the Portus Magnus, and the Port of Arse-

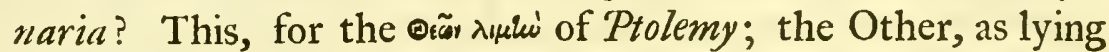

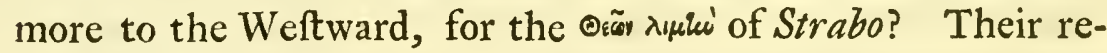
fpective Situations anfwer well enough to fuch Pofitions, and the Harbours Themfelves bid the faireft for fuch high Appellations.

Warran or Oran.

Five Miles to the S.E. of the Great Port, and fifty four to the N.N.E. of Tlem Jan' ${ }^{2}$, is Warran 3 , commonly called Oran, a

1. Quod ad Divinos Portus attinct, valde vereor, ne fint quem Ptolemaus Deorum portum adpellat. Nam \& Strabo Deorum Portûs meminir fexcentis Stadiis a Siga diftantis, qui fitus magis cum divinis Itinerarii Portubus convenir, quam cum Deorum portu Ptolemai. Unde judicare poffis, nomina hxc eundem portum fignificaffe, ab alterutro autem auctore fuiffe tranfpofita, ut alter circa Portum magusm, alter ultra illum locaverit. Cell. Geogr. Antig. 1.4. c.6. 2 Waharan abeft a Telenfino octoginta milliaria. Abulf. ut fupra. Orania a Telenfino centum \& quadraginta diftat milliaria. J. Leo. p.199. 3 Oranum variis nominibus vocatur 



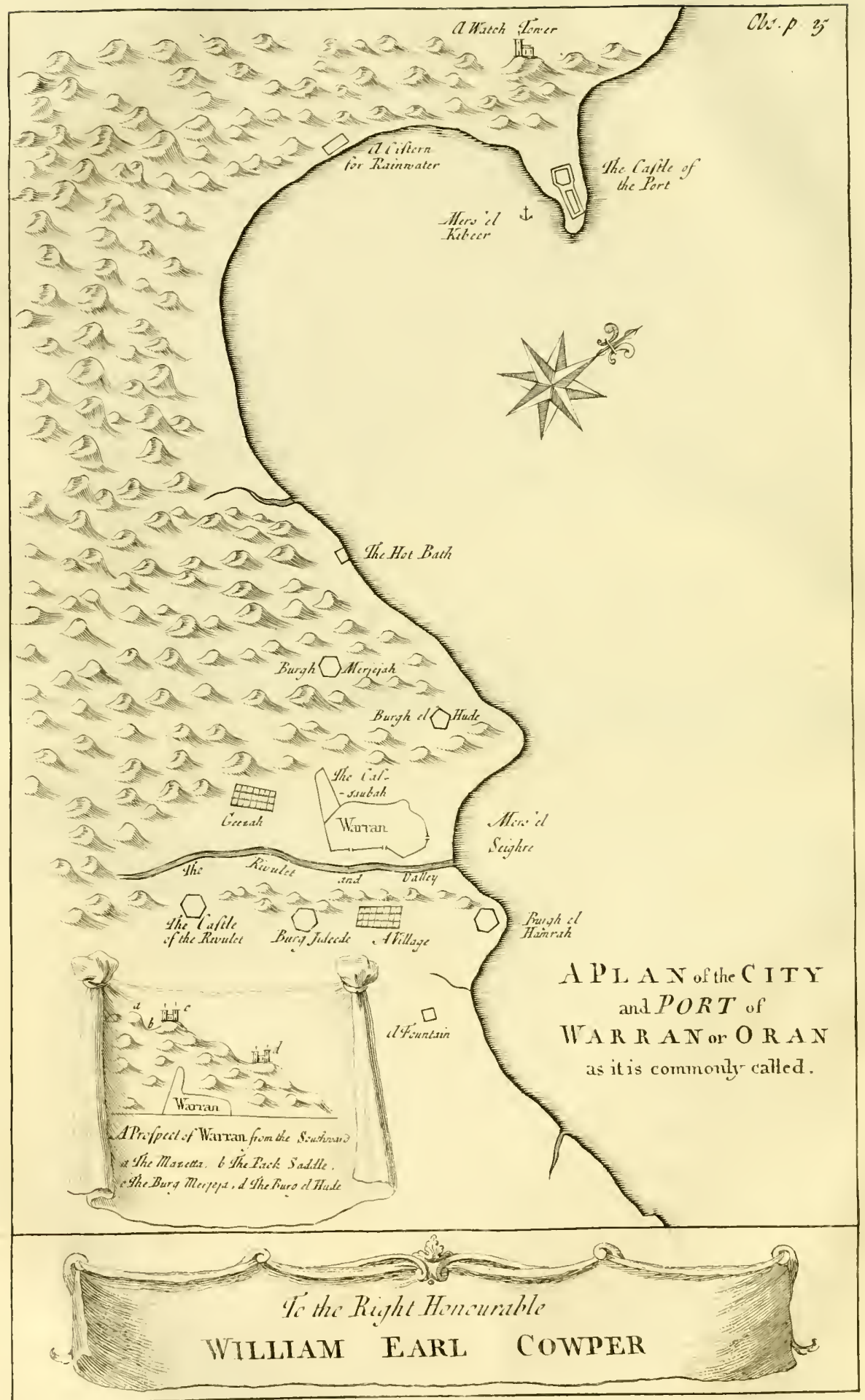


fortified Town of about a Mile in Circumference. It is built upon the Declivity, and near the Foot of a high Mountain, which overlooks It from the N. and N.W; and, upon the Ridge of This Mountain, there are tiwo Caftles, that command the Town, with the Mers el Seigh-bre; on the one Side; and the Mers el Kebeer, with the Bay, on the Other. Lefs than half a Furlong to the Weftward of This Mountain, there is another, (the Mazetta, I think, they call It) in a Situation fome: what higher than the Former; but, there lying a large Vale between Them, Their refpective Ridges are fo remarkably difunited, that They not only form a moft convenient Land-mark for Mariners, but render all Approaches to the Caftles, from the Mazetta, impracticable. To the S. and S. E. there are Tri Mazerta. two other Caftles, erected upon the fame Level with the lower Part of the Town, but feparated from It by a deep winding Valley. This may be confidered as a natural Trench to The Thathy ar.is the S. Side of the City; and in the upper Part of It, at three Warran. Furlongs Diftance from the Town, there is a Spring of excellent Water, more than a Foot in Diameter. The Rivulet, formed by This Fountain, conforms It's Courfe to the feveral Windings of the Valley, and, paffing under the Walls of the City, plentifully fupplys It with Water. We fee, at every Opening of the Valley, fuch a pleafingly confufed View of rocky Precipices, Plantations of Orange Trees, and Rills of Water trickling down from Them, that Nature rarely difplays Herfelf in a greater Variety of Profpects, and cool Retreats. Near this Fountain, there is another Caftle, which forbids all Approaches of an Enemy; and, at the fame Time that It guards the Mattamores $^{*}$, dug under the Walls of It to the Southward, is an important Defence to the City.

Three of the Caftles, I have mentioned, are regular Poly-The Cafless gons: viz. the Loweft of the Two upon the Ridge; the Caftle lions of is: of the Fountain; and the Weftermoft of the Two before the Town. But the other Two; viz. the Higheft upon the Ridge; and the Eaftermoft of Thofe that lye before the Town, are of a different Fafhion: a great Part of the Latter being built

à recentioribus, nam alii Madaurum, alii Aeram, Auranum nonnulli vocant; Afri hodie Gu. haran appellant. Omnia autem hxc nomina locum acclivem, [from, wa war (we mily fuppo(e) that fignifies a Place very difficult to be come at] \& ventis expolitum fignificant. Gomecius de rebus geftis Fr. Ximenii. 1.4. p.I022. Franc. 1603. Fovea fubterranea, crypta, is qua frumentum recondicur. vid. Gol. in Voce. A $\widetilde{P}_{\text {it }}$ :inder Ground zubercin the Arabs depofte ? heiv Corn. 
like our old Englifh Caftles, with Battlements and Loop-Holes; whereas the other is formed into diverfe Angles and Abuttments, as the Figure of the Eminence, upon which It is fituated, would permit. The Specula', taken Notice of by Gomecius, was probably at This Place: as the Vale, I have defcribed, to the Weftward of It, will be His Anguftice, and Sedes, (the Pack Saddle, as our Mariners call It,) through which the Spaniards were to make Their Affaults upon Warran.

The Gates I am to obferve further, that Warran hath only two Gates, both of which open to the Valley. The Gate of the Sea, (for fo They call the neareft of Them to the Port) hath a large fquare Tower built over It; which, upon Occafion, might be converted into a Fort. But, adjoyning to the Upper Gate, called the Gate of Tlem San, there is an oblong Battery, with feveral Ports for Cannon. The Cafauba or Cittadel, raifed upon the higheft Part of the City towards the N.W. was, though without much Order, mounted in all the Angles of It with Cannon; whilft the lower and oppofite Corner, towards the N.E. and the Mers' el Seigh-hre, was defended by a Regular Baftion. From all which Circumftances, Warran muft be confidered as a Place of fome Confequence: and, had not a furprizing Confternation infatuated the whole Country, upon the firft landing of the Spaniards, would have given no fmall Check to Their late fortunate Enterprize.

The churches The Spaniards, when They firft poffeffed This Place, built the spani- feveral beautiful Churches and other Edifices, in the Manner of ards. the Roman Architecture, but of lefs Strength and Solidity. They have imitated the Romans further, in carving upon the Frizes, and other convenient Places of Them, feveral Infcriptions, in large Characters, and in Their own Language. Over the Portal of one of the Churches, which, upon Warran's being recovered, in the Year MDCCVIII. by the Moors, was once again a Place of Fewift Worfhip, we have the following Infcription, that may ferve for a Specimen of the Lapidary Stile of the Spanifh Nation.

x Specula qux Eacis dicitur - eft in prarupto cliro qua noftris afcenfus ad Oranum erat futurus. Locus ipfe arduus eft, \& undique rupibus inacceflis invius, præterquam quibufdam Angufiis, quxe ex Forma, Sedes ab Incolis appellacur. Juxta has Specula quam diximus confurgit, quæ ex altera parte Oranm, Merfalcabir ex alterd profpicit, face continuo de Nocte pralucente Gracorum Pharis non admodum abfimilis. Scqucbatur ftatim Oranum urbs celfo quodam in colle pofita, monibus \& turribus ac loci fitu munita, qux mari altera parte alluieur, altera variis pomariis ac irriguis fontibus sinda, in fui cupidinem gquemvis regem pelli- 
REYNANDO LA MAGESTAD DE DN CARLOS SEGVNDO Y GOVERNANDO SVS REYNOS Y SEÑORIÓS POR SV MENOREDAD LA SERENISSIMA REYNA DA MARIANA DE AVSTRIA SV MADRE CON SV SANTO Y CATOLICO ZELO MOVIDA DE LAS INSTANTIAS Y REPRESENTATIONES DE DN FRANCISCO IOACHIN FAXARDO Y ZVNIGA MARQVES DE LOS VELEZ MOLINA Y MATVRVEL ADELANTADO Y CAPN MAYOR DEL REYNO DE MVRZIA GOVERNADOR Y CAPITAN GENERAL D' ESTAS PLAZAS FVERON EXPELIDOS D' ELLAS LOS IVDEOS QVE SE CONSERVAVAN NEL SV VEZINDAD DES DE ANTES QVE FVESSEN DE CHRISTIANOS A XVI DE ABRIL DE MDCLXXIX. EN ESTE SITIO DE SV SINAGOGA SE LABRO ESTA IGLEZIA CON LA INVOCATION DEL STO CHRISTO DE LA PACIENCIA - . . . Y SE ACABO ESTA OBRA EN EL MISMO GOVIRNO A XVI DE ABRIL DE MDCLX-.--

\section{THA T IS,}

In the Reign of His Majefty Don Carlos II. and in the Regency of His Kingdoms and Provinces during His Minority by the moft Serene Queen $D^{a}$ Mariana of Auftria, His Mother, out of Her Holy and Catholick Zeal moved thereunto at the Inftances and Reprefentations of Don Francifco Joachin Faxardo and Juniga, Marquiss of Velez, Molina, and Maturvel, Lord Lievtenant and Captain Major of the Kingdom of Murcia, Governour and Captain General of This Place; The Jews, who had kept themfelves in It's Neighbourbood before It belonged to the Chriftians, were expelled from thence the Xvi of April in the Year MDCLxxix. In This Situation of Their Synagogue was built This Church with the Invocation of the Holy Chrift of $P a$ tience -...- and this Work was finifhed under the Same Government the XvI of April MDCLX--.

cere poteft, nedum Ximenium, quem jam fatalis ardor ad eam gloriam obtinendam incitabat. Gomecius, ut fupra p.1022. DT Captuf fuit A.D.I509. ibid. \& p.1023.4. \&c.

G 2 Imet 
I met with no Roman Antiquities at Warran; or at Geeza,

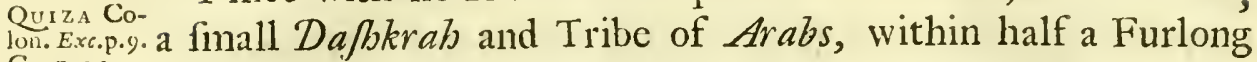
C. F. 2. ${ }^{1 .}$ of It to the Weft. The Latter hath no finall Affinity with the 2uiza [Colonia] of the Antients, placed by Them immediately after the Great Port; and therefore not far, as we may conjecture, from This Pofition.

No River Pliny fixeth His Mulucha, and Piolemy His Chylemath bewhere the An-
tients place twixt Quiza and the Great Port. In travelling indeed betwixt thc Muluchas the Great Port and Warran, we pafs over a very fimall Rill of Water, which hath It's Sources at a Furlong's Diftance from the Sea; but there is no River, properly fo called, nearer than the Wed el Mailah, on the one Side; or the Sigg, on the other. This River therefore, which hath hitherto fo much perplexed the antient Geography ${ }^{\text {, }}$ appears to be altogether imaginary; efpecially in This Situation, where we are directed to look for It.

Canaltel. Advancing four Leagues farther towards the N.N.E. we pafs by the fmall Village of the Canaftel, pleafantly fituated in the Midft of a fpacious Grove of Olive Trees, and at the Foot of a high Range of Mountains. The Gulphs of Warran and Arzew are feparated by This Ridge; which reacheth as Jibbel Ker. far as Fibbel Ker to the Southward, and ends in the Cape Ferratt towards the Sea. Ker is a round pointed Eminence, a little upon the left Hand, in travelling from Warran to Arzew. The Arabs place It among the chief Haunts of This Province, for the Lyon, and Wild-Boar; the Prints of whofe Feet, we did indeed often meet with, in traverfing the Thickets of the fmall adjacent Valleys.

Cape Ferratt Two Leagues to the N.N.E. of the Canaftel, is the Cape or Mefarf.

Ferratt, the Me aff ${ }^{2}$ of Edrifi. This Promontory is remarkable for a high Rock, which, aptly reprefenting a Ship under Sail, ftands out, at a fmall Diftance before It, in the Sea.

The Port of Twelve Miles to the S.S.E. of This Cape, is the Port of ArArzew or of $z e w$, called, by the Moors, the Port of The Beni Zeian', after Zeian. the Name of the neighbouring Kabyles, formerly a confiderable Community. It is of the fame Figure, though more capa-

I Vid.Pomp.Melam de Situ Orbis. curante V.C. Abr.Gronovio. Lug.Bat.1722,p.32. Not.3. l'offi Obfervat. ibid. p.336-7. \& Hag.Com. 1658. p.21-22. \& cum Notis Vadiani. Baf.1557. p.26. 2 Vaharan - diftat a Promontorio Mefafe 25 Milliaribus, linea recta; obliqua vero, 32. A Promontorio Mefafe ad portum Arzau habentur milliaria decem \& octo. Geogr. Nub. p. 85 . 3 Fuit penes Benizeiinos illius (Telenfmi fc.) regni Imperium 380 fere Annis. F.Leo.p.I88. 
cious than the Great Port: and, according to the Liberty of Expreffion in the Gentile Ages, might much better deferve the Epithet of Divine, than the Ports, I have mentioned, at Ras el Har/b-fa. Ptolemy we are fure, fituates His Deorum Portus the Portus betwixt 2uiza and Arfenaria, which, as I have before obferved, Deolum of can be no other than This, provided Geeza or Warran is the antient 2uiza, as Arzew is, without Doubt, the antient Arrenaria. But we are to take Notice at the fame Time, that Our Author placeth His Deorum Portus 10'. only to the Eaft, and I $s^{\prime}$. to the South of 2uiza; and with refpect to Arfenaria, $\mathrm{He}$ fituateth It $20^{\prime}$. to the Weft, and only $5^{\prime}$. to the South; a Polition altogether imaginary, and in no Manner correfponding with any of the Harbours or Windings of the adjacent Parts of the Sea-Coaft.

t Arzew, the antient Arfenaria, is at the Diftance of three Arzew, The Roman Miles from the Port, as Pliny placeth It. The Coun- AREENAtry, for fome Miles behind It, is made up of rich champain ${ }^{\text {p.2r. Cag.2. }}$ Ground : but we look down upon the Sea, from fome Precipices, which, in That Direction, muft have been always a natural Safeguard to the City. The Water made ufe of by the Inhabitants at prefent, lieth lower than the Sea; a Circumftance, that will perhaps account for the Brackifhnefs of It. They draw It, below the Precipices, from a Number of Wells, which, by the Mafonry, appear to be as old as the City. Yet They have a Tradition that Their Predeceffors were better fupplied, in having Water conveyed to Them by an Aqueduct. Some of the Arches of It were thewn me, as a Proof of This Tradition; yct, as Thefe want the Channel, and no farther Traces of Them appear in the Way to the Sigg and the Taleelet, the only Rivers that could furnifh the Water; we may imagine Them rather to have been a Part of fome other Edifice: but, of what Kind; This fimall Fragment is not fufficient to inftruct us. However; in fome Meafure to fupply the Want of fich a Conveniency, the Founders have made the ufual Provifion for the collecting of Rain Water, (inferiour indeed to what the former might have produced, ) by building the whole City upon Cifterns.' Thefe ftill fubfift, but are converted to a different Ufe; ferving the Inhabitants for fo many Hovels to dwell in. There are feveral Capitals, Bafes, Shafts of Pillars, and other antient Materials, that lye fcattered among the Ruins. A well finithed 
Corintbian Capital of Parian Marble, fupports the Snith's Anvil; and, in the Kaide's ${ }^{3}$ Houfe, I accidentally difcovered a beautiful Mofaic Pavement, through the Rents of a ragged Carpet fpread over It. The following Infcriptions were in a Hypogreum or Sepulchral Chamber, fifteen Foot fquare, built very plain, without Nitches, Columbaria, or any Ornament whatever. The North and the Eaft Walls were only infcribed; but the Corner Stone, and That Part of the Infcription is now wanting in Both.
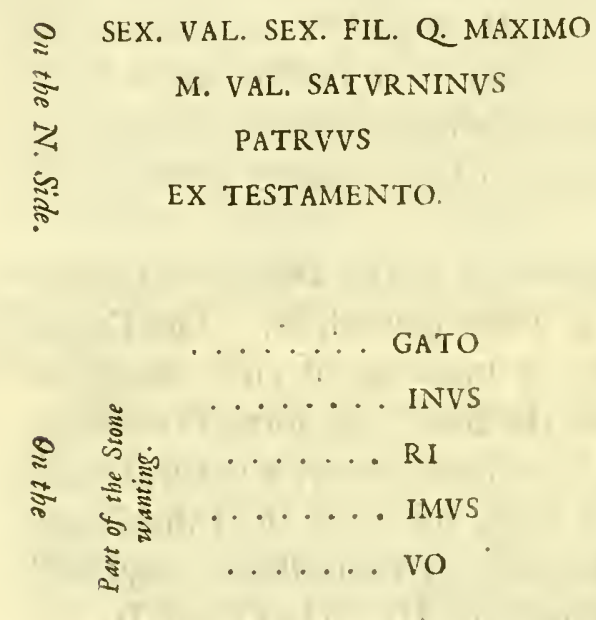

Q.VAL. SEX. FIL. Q.ROGATO

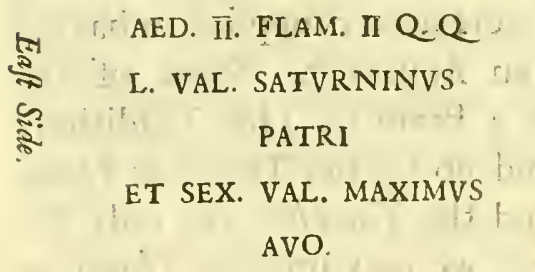

SEX. VAL. Q...
L. VAL. SAT. …
FRATRI
ET SEX. VAL. ...
PATRI

MVNDICIAE. Q. FIL.

SATVRNINAE

L. VAL. SATVRNINVS MATRI.

ET SEX. VAL. MAXIMVS AVIAE.

M. VAL. Q. FILIO. Q. GAVDO

L. VAL. SATVRNINUS

FRATRI

ET SEX. VAL. MAXIMVS

PATRVO. The Salt pits Five Miles to the Southward of Arzew, there is a large Com-
of Arzew. pafs of Ground, full of Salt-Pits; from whence the neighbouring Communities are fupplied with Salt. This Commodity, from the Facility of digging It, the Shortnefs afterwards of the Carriage, and the Advantage of the adjacent Port, would, under any other Govemment, be a Branch of Trade as invaluable, as the Pits Themfelves are not to be exhaufted.

* Kaide, The Name given in this Country ro the Governours of Cities, Vil. lages or. from whence the Spaniards bave their Aliayde or Alcalde. 
Under fome fteep rocky Cliffs, five Miles to the E. of $A r-$ Tro $_{\text {Catter }}$ zew, we pafs by two Galley Ports; one of which openeth to- ${ }_{a \text { arts }}^{\text {Fort }}$ with wards Mufty-gannim, the other towards the Port of Arzeww. Both feem to have been under the Protection of one and the fame Fort that is fituated above Them, and which formerly was conveniently fupplied with Water from an adjacent Mountain. A great Part of the Conduit ftill remaineth, and might be eafily repaired for Ufe.

A little farther, is the Mouth of the Rivers Sikke and Ha-Tie nouth of brah, which unite, about three Miles, before They fall into the the Silkenc and Sea. The Ta-leelet, which defcends from the Mountains $T a$ farowy, when It is not drunk up by the Plains, will likèwife lect. Ta-lecaugment the Stream; there being no other Channel to convey It to the Sea.

The Sikke or Sigg hath It's Sources at the Hammam of Seedy Tre Sikke or Aly Ben Foube, forty Miles to the S. W. In paffing by the ${ }^{\text {sigg, }}$ Plains of Tef-failah, It is called the River Makerra; and Sikke, when It begins to enter Thofe of Midly. The Sikke might be well taken for the antient River Siga; was only an Affinity in Sound to be regarded, and were not the old Geographers una. nimous in placing the Latter much farther to the Weftward. As

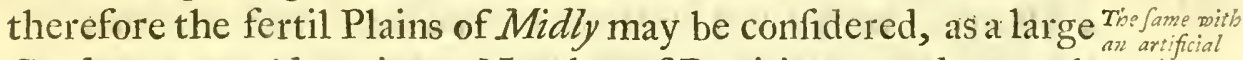

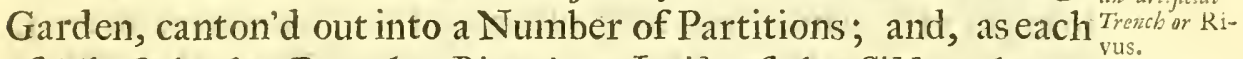
of Thefe hath a Branch, Rivus ${ }^{2}$ or Incile of the Sikke, always ready, when required, to overflow It; we may deduce the Name rather from ['Gu] Sikk, or Sakeab, whereby the Arabs fignifie fuch artificial Drains and Trenches, which This River, as Occafion ferveth, is derived into.

The Habrab hath It's Fountains fifty Miles to the South; The Habrah, the principal of which is at Nif-rag, where the Water burfts out with a furprizing Noife and Rapidity. When It arrives within eight Leagues of the Sea, It receiveth a Branch from the [ $\left.\mathrm{u}_{\mathrm{a}}\right]$ Hammaite, where there is a Hot Bath, (as the Name imports) and feveral antient Cifterns. Hitherto This River hath been known by the Name of The Tagia; but now or Tagin, affuming that of The [Wed el [r+ $]$ Ham-mam, ] River of or Wed e? the Baths, windeth Itfelf afterwards through feveral Moun-

I Incilia, foffe funt qua in Agris funt adAquasm deducendan; dicuntur ó derivationtes de Rivo communi facte. Vid. Columel. in voce Incilia.

Claudite jam Rivos Pseri, Sat Prata biberumt. Vir. Ecl.3. I. I I.

$\mathrm{H}_{2}$ 
tains and Valleys, 'till, entring the fame Plains with the Sikke, It is called Habrah, after the Name of the Bedoweens, who have Their Dou-qwars * upon the Banks of It.

The Conflux of the Rivers Sikke and Habrab formed a Stream, when I paffed It, as big as the Cherwell. The Mouth of It is called [El Muckdah or El Muchadhah xis‘ ل'] The Ford, in the Language of the Country; it being at this Place, in travelling from Arzew to Mufty-gannim, we pafs Theie Rivers; which, except in the rainy Seafon, are entirely loft in the Sand, and leave the Paffage without Water. Thefe Rivers thus The Sikke or united, from their Pofition with Refpect to Arfenaria, fhould be CuRTEN- Exo. the Cartennus of Ptolemy; in which Situation likewife Marmol p. 9. D.

placeth His Cirat; though I could not be informed of any fuch Name, upon the ftricteft Enquiry.

Mafagran or Mazachran, a fmall Town, with a Mud-walled Enclofure, is fituated, upon the Weftern Declivity of a Range of Hills, twelve Miles to the N.E. of The Ford, and within a Furlong of the Sea. It feems to denote a Place abounding with Water ${ }^{2}$; a Circumftance which will very juftly correfpond with the Situation.

+ Mufty-gannim, the adjacent City, is built in the Form of a Theatre, with a full Profpect of the Sea; but is clofed up, in every other Direction, with a Round of Hills that hang over It. It is fomewhat bigger than Warran, taking Place after TlemSan, among The Cities of This Province. The Inhabitants have a Tradition, (and fome vacant Spaces between the Streets feem to confirm It) that the prefent Mufty-gannim, is made up of feveral contiguous Villages. In the Middle of the City, near one of thefe vacant Spaces, are the Remains of an old Moorifs Caftle, erected, as appears from the Fafhion of It, before the Invention of Fire-Arms. The N.W. Corner, which overlooks the Port, is furrounded with a ftrong Wall of Hewn-Stone, where there is another Caftle, built in a more regular Manner, with a Turkifs Garrifon to defend It. But Mufty-gannim being too much expofed to whatfoever Body of Men hall lodge Themfelves upon the Hills behind It, the principal Strength will lye

Lo* aj, 0 Dozv-zvarall or Doo-zvaral, Tentoriorum orbicularis vicus pagufve, quales Scenite habitare folcnt. Vid. Gol. in rocc. So They call the Tents or Encampments of the Bedoweens, which are ufually pitched in the open Ficlds; in a circular Figure, with their

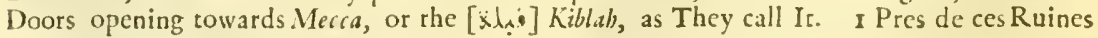
de Arzerv eft l' cmbouchure du fleuve Cirat. L'Afrique de Marmol. 1.5. C.2 I. 2 Vid. Gol. in yoce, $\leq \times$ (aqu implevit fc. fluvium) \& زخر (exundavit alveus.) 
in the Cittadel, erected upon one of thefe Eminences, having a full Command of the City and Country round about It.

In travelling betwixt Mafagran and Mufty-gannim, we are The Gardens entertained with the Profpect of a Number of Gardens, Or-Maragran chards, and Country Seats, ranged, in a beautiful Variety, all ganniuftyalong the Sea Shore. A Chain of Hills bounds Them to the S. and S.E. which not only intercepts the noxious Winds, in that Direction, from Thefe Plantations, but breaks out, every where, in Fountains, to cherifh Them during the hotter Seafons.

The Beauty and good Mafonry fo obfervable, even to This Mufty-ganTime, in the Walls and Caftle to the N.W. allow us to fup-gran, Tre pofe Them to have formerly belonged to fome Roman Fabrick: NARTENC.P.9. $_{\text {. }}$ otherwife, 1 had not the good Fortune to meet with any Thing D. p.2r.Cap. in This Place, that carries with it the leaft Appearance of the antient Architecture. Yet both Mufty-gannim and MaJagran are fo copioufly fupplyed with Water, and fo commodioufly fituated with regard to the fertil and extenfive Downs behind Them; and enjoy befides fuch a delightful Profpect of the Sea, and of the rich maritime Country, to a great Diftance, before Them; that, without Doubt, they were Stations too valuable to be neglected by the Romans. Pliny and Ptolemy place Their Cartenna in This Direction; and in the Itinerary, we have the fame Diftance betwixt ArJenaria and Cartenna, that I find betwixt Arzew and Thefe Places. One or other of Them therefore, nay perhaps Both, might have been formerly taken in by This Colony. For, confidering Their Situations are nearly contiguous, and the interjacent Plantations belong indifferently (as They perhaps always did) to Them Both, there is fome Probability at leaft of Their having had likewife the fame Intereft, and having been one and the fame Community, under the Name Cartenne, as Ptolemy writeth it in the plural.

Three Leagues to the E.N.E. of Mufty-gannim there is a Kulmeeta or Fountain of excellent Water, with a Heap of Ruins that en- Rhellum. $\mathrm{L}_{\mathrm{A}} \mathrm{C}_{\mathrm{c}}$

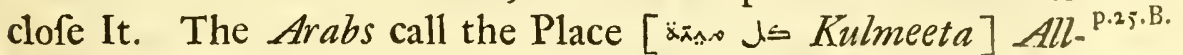
Dead, preferving the Tradition of a bloody Battle fought near It, wherein the weaker Party were all put to the Sword. The Form of thefe Ruins, (not unlike fome of our old Englifh Caftles) with Their Situation fourteen Miles from Cartenna, fhould induce us to believe Them to be the Traces of the Lar Caftellum of the Itinerary. 
The River Shellift or ChinaLAFH. Exc. p.9. D.

Three Miles to the N.W. of Kulmeeta, is the Mouth of the River Shelliff, a Corruption of the Chinalaph of the old Geography. This is the moft noted River of the Kingdom, and arifeth in the Sabara, at the Diftance of fourfcore Miles, to the S.E. The Fountains of It, called from Their Number and Contiguity, [ugss ugen Sebbeine Aine or Sebaoun Aioun] The Seventy Fountains, are no fooner united, than they fall into the Channel of the Nab'r Waffel, a little adjacent Brook, which, upon this Conflux; lofeth It's Name.

The Rivulet of The firft Courfe of the Shelliff, for the Space of thirty two Midroe. Miles, is to the Eaftward; where It takes in the Rivulet of Midroe, a Village of the Sabara, at the Diftance of ten Leagues from The Seventy Fountains. From the Influx of this Rivulet to the Precincts of the City Medea, forty Miles farther, the Shelliff hath a more Northerly Direction; 'till, receiving the The Har- Harbeene, It immediately changeth It's Courfe to the Weft-
beene. ward, and continueth afterwards to run nearly in a Parallelifin with the Sea Coaft.

The Wed el After the Harbeene, the next confiderable Contribution to River of
Plate. Plate, fourteen Leagues to the Weftward. This River hath It's Sources at $W$ an-nafb-reefer, a high rugged Mountain, generally covered with Snow, and remarkable for It's Mines of Lead Oar. In great Rains, many Fleaks and Sparkles of This Mineral are brought down by the River, which being afterwards left upon the Banks and glittering in the Sun, give Occafion to the Name. Several Geographers have been miftaken in deducing the River Shelliff ${ }^{2}$, inftead of This Branch of It only, from the Wan-na/b-reefe.

The Arhew. Seven Leagues to the W.S.W. of the Wed el Fuddah, over againft Mazouna, the Shelliff is further augmented by the Arhew, which hath It's Fountains fix Leagues to the N. N. W. of the Sebbeine Aine, and runs almoft parallel with the Mina.

The Mina. The Shelliff receives the Mina at the Diftrict of El-mildy-ga, five Leagues to the Weftward of Arbew, and fifteen to the S.E. of Fibbel Difs. It confifts of two Branches: the Weftermoft

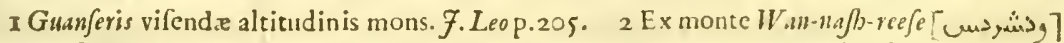
fcaturit fluvius Selif [ $\mathrm{el}_{\mathrm{w}}$ ] celebris._Eft Auvius magnus, qui increlcit dum cxtcri fluvii decrefcunt, inftar Nili Egypti. Ebn Said in Abulf. ut fupra. Selif magnus fluvius, ex Gutnferis montibus originem ducens, per incultas planities ad Confinia Regnorum $T_{c n e z}$ ac $T \varepsilon$ lenfin labitur, atque hinc Mazagranum a Muftegani diftermiuans [quo fallitur] marc Mediter- 
having It's Fountains forty Miles to the Southward of their Influx into the Shelliff; the other, called the Wed el Abdt, as many to the S.W. After each of them hath traverled, for the Space of fix Leagues, a rich level Country, They unite near the Tomb of Filelli Ben Omar, a Ma-rab-butt of great Reputation.

The Shelliff, when It had drunk up thefe Rivers, together Tbe Shellif with the Wariffa, the Tagia, the Sufellim, and other leffer as bigand as the Streams, was, when I faw It in Autumn, about the Bignefs of the I/is united with the Cherwell. Ebn Said' as quoted by Abulfeda, afcribeth to the Sheiliff the fame Property the Nile hath, of increafing It's Stream in the Summer Seafon; but, I am perfwaded, not the leaft Occafion could have been ever given for any Sufpicion or Appearance of this Kind.

A little to the N.W. of the Shelliff is the Cape Ivy of our Cape Ivy, or modern Sea Charts, The [Fibbel [ umo Di/s] Mountain of Ree$d y$-Gra/s as the Inhabitants call It. Four Miles farther, to the E. N.E. is the large fandy Bay of Teddert, where Veffels ride Teddert, or very commodioufly in Eafterly. Winds. The Haud-Farruch ${ }^{2}$ of Exic P.25. B. Edrifiand the Cartili of the Itinerary fall in with this Situation.

Ham-meefe, where there is a Creek and Rivulet, is a fmall Hammeese. Mart for Corn, two Leagues from Teddert to the E.N.E. The European Merchants are permitted to carry on the like Commerce at Magrowva, and The [ us! l.o, Rummel-abead] white Magrowa: Candy Bay a little farther to the Eaftward. Rummel

Three Leagues to the E.N.E. of Ham-mee e, at a fimall Di. Zour el Haftance from the Continent, is the Zour el Hamam, Ifola de Colum-geon, or Pland. $b a$, or The Pigeon Ifland. It is a rocky Place, about a Quarter of a Mile in Circuit, and receiveth It's Name from the Number of [Ha-mam r $\mathrm{H}$ ] Wild-Pigeons, that build in the Clifts of It.

Three Leagues farther are Callat Shimmah [the Light Houfe] Callat Shimand Mers' Agoleite, (the Merfalach of the modern Sea Charts) Mers' Agotwo fmall Creeks, with a Promontory between Them. They are often vifited by the coafting Veffels, and lye, near the half Way, betwixt the Pigeon Ifland and Tnifs. This Part of the Sea Coaft is remarkable for the Fibbel Mini/s, a Mountain of Jifs. Mi-

raweum ingreditur. F.Leo p.296. Zelif fort du Mont Gunnaceris, traverfe des plains defertes et fe jette dans la mer a l'orient de Mofteg.an fur les frontiers de Tremecen. De la Croix Atl. Geog.Vol.1V.p.207. I Vid.Not.ut fupra. 2 A Moftoganem ad Haud Farruch XXIV M.P. via obliqua, recta autem XV. cft vero Hand Forrub portus confpicuus, adjacetque ei oppidum populofum. Geog. Nub.p. 85 . 
WelledYou-Salt; here likewife the Welled Tou-noofe have their Encamp.
noofe. noofe. ments.

Tnifs, or Tnifs or Tennis hath a low dirty Situation, (as the Name
Tennis. may probably infinuate) lying fixteen Miles to the E.N.E. of the Zour el Ha-mam, at a fmall Diftance from the Sea. Before the Conquefts of the Barbarofje, It was the Metropolis of one of the petty Kingdoms of this Country; though a few miferable Houfes, built in the fame Manner with Thofe, before defcribed, at Maifearda, are all that remain of It at prefent. A little Brook runs winding by Them, which afterwards emptieth It felf, over againft a fimall adjacent Ifland, into the Sea. Tni/s hath been a long Time famous for the great Quantity of Corn fhipped off from thence to Chrifendom: but the Road before It, lying too much expofed to Wefterly and Northerly Winds, Veffels are frequently caft away, as at Hammee fe and Magrowa, unlefs They fall in with a Seafon of calm Weather.

The Charafier
of the Inababi-

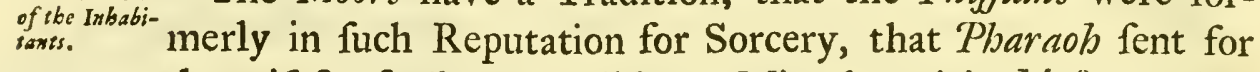
the wifeft of Them to difpute Miracles with Mo/es. They are ftill the greateft Cheats of all This Country, and as little to be trufted as Their Road. Hammet Ben UJeph, a late neighbouring Ma-rab-butt, hath thus ${ }^{2}$ branded the Place and Inhabitants.

Tennis is built upon a Dungbill,

$* * * * * * * * * * *$

The Water of it is Blood,

And the Air is Poifon,

And Hammet Ben Ufeph doth not come there.

I custis (Tennis) feems to be the fame Name with the Tanis of Egypt, from ¡' (Tin) Clay, or Mud; rendered by the Greeks m+arnor, froms minos, a Word of the like Signification in their Language.
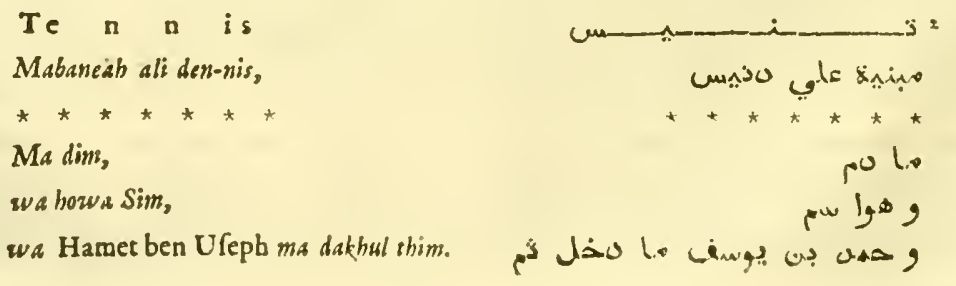
only Circumftance, which favours Their Opinion. Otherwife, there are not the leaft Traces to be met with of any fuch Haven, as Crefarea is reported to have had; neither have we here the Footfteps of thofe maffy Walls and capacious Cifterns, which are common to other Roman Stations, vaftly inferiour to what Crefarea muft have been, for Extent and Magnificence. However, if any of Ptolemy's Cities had This Situation, Carcome may plead the greateft Right to It, as following Cartennce and Carepula in the Order of His Tables.

A little Way from Tnifs, there is a high rocky Mountain, Nackos, or that ftretches out a great Way into the Sea. It is called by Montori-

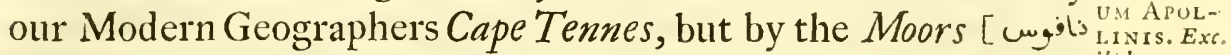
Nackos, or Nakoufe] The Bell, from the Figure of the Grotto, formed in the lower Part of It. This is one of the moft remarkable Promontories of This Country, and, in advancing towards It from the Coaft of Spain, appears (in the Mariners Stile) like the Head of a Wild-Boar. By the Order of Ptolemy's Tables, and by It's Diftance of $\mathrm{I}^{\circ} .4 \mathrm{O}^{\prime}$. only from ArJenaria, Nakkos may be well taken for the Promontorium Apollinis of the Antients.

Four Leagues from This Cape to the Eaftward, are the Beni Beni HeadHead-jab; and at the like Diftance from Them, are the $\mathcal{D} a / 3-$ - Beni Howkras of the Beni Howah, two powerful Tribes of Africans. The coafting Brigantines find Shelter under the Covert of a few Iflands, ranged along This Part of the Coaft: one of which, belonging to the Beni Horvah, is not inferiour, in Circuit, to the Pigeon Ifland. The Jutting out of the Mountain, over againft It, is diftinguifhed, very conveniently for Mariners, by a WatchTower.

Two Leagues to the Eaftward of the Beni Howah, we fall Dah-muss, in with a fmall Creek, and fome Ruins, which formerly might Germanohave belonged to the Caftra Germanorum. Thefe are called $\mathcal{D}$ ah- ${ }_{\text {p.g. }}^{\text {ru. D. }}$. $m u / s,\left[u_{n}>0\right]$ which, in This Language, fignifieth a dark Place or Cavern; a Name probably taken from fome of the antient Cifterns now buried under Them.

+ Two Leagues farther, near the Bottom of the fame Bay, Bresk or, we have the Ruins of Bresk, another Roman Station, of a larger Eaxvibid. p. Extent than Daß-muss. The Andalufian Moors had the laft ${ }_{B}^{21 . D .}$. P.25. Poffeffion of It; but the inconvenient Situation of It among the Goryah, Larbatt, Beni Yifrah, and other troublefome Kabyles, is the Caufe, that for fome Years, Bresk hath been left without 
an Inhabitant. Ptolemy's Canuccis, the Gunugi or Gunugus of Pliny and the Itinerary, anfwers to This Place.

Ras el Terff. A Neck of Land, projecting Itfelf from Thefe Ruins into the Sea, forms the Ras el Terff; betwixt which and Sherfbell there is a Bay of a moderate Depth. At the Bottom of It, is the The River Mouth of the Teffert, a River of no great Confequence in Summer, but deep, rapid and dangerous to be forded in the Winter Seafon. Edrifi ${ }^{1}$, (unlefs He calculates, contrary to His ufual Method, from E. to W.) makes His River Selef fall in Here, or at Tniss; and Ptolemy ${ }^{2}$, by placing His Iol Crefarea 20'. only to the Eaftward of the Chinelaph, feems to confirm it; though the Tradition of the fame Name, down to This Age, will, I prefume, fufficiently authorize the Pofition that hath been already given to It at Fibbel Difs.

Sher-fletll. $\quad+$ Five Miles from the Tefsert, and nine from Bresk, is the City of Sher-ßhell, in great Reputation for making Steel, earthen Veffels, and fuch Iron-Ware as are in Demand among the neighbouring Kabyles and Arabs. It is a Collection of low tiled Houfes of a Mile in Circuit; but was formerly much larger;, and a Seat of one of the petty Kings of This Country. What we fee of It at prefent, is fituated upon the lower Part of the Ruins of a large City, not much inferiour to Carthage for Extent; and we may conceive no fmall Opinion likewife of It's former Magnificence, from the fine Pillars, Capitals, capacious Cifterns, and beautiful Mo Jaic Pavements that are ftill remaining.

The Aque- The Water of the River Hafbem (according to the prefent Name, was conducted hither through a large and fumptuous Aqueduct, little inferiour to that of Carthage in the Height and Strength of It's Arches; feveral of the Fragments, fcattered amongt the neighbouring Mountains and Valleys to the S. E. continue to be fo many inconteftable Proofs of the Grandeur and Beauty of the Work. There are befides two other Conduits, brought from the Mountains to the S. and S.W. Thefe ftill fubfift, and, furnifhing Sher-fhell with excellent Water, (for That of the Wells is brackifh) may be confidered as two ineftimable Legacies of the Antients.

The Strength Nothing certainly could have been better contrived, for

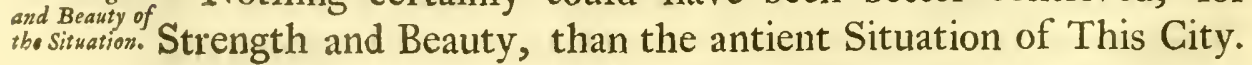

x Ab Infulis Albamam ad Oftium fluminis Selef xxm M.P. Geog. Nub. p.85. 2 Exc. p.9. D.E. 3 Serfel maximum, atque amplifimum elt oppidum a Romanis ad mare Mediterraneum ædificatum: continet in circuitu Milliaria plus minus octo. F. Leo. p. $5^{8 .}$ 
A ftrong Wall, forty Foot high, fupported with Buttreffes, and winding Itfelf near two Miles through the feveral Creeks of the Sea Shore, hath fecured It from all Encroachments from the Sea. The City, to the Diftance of two Furlongs from This Wall, lyeth upon a Level, and afterwards, rifing gradually for the Space of a Mile, to a confiderable Elevation, (as the antient Name Iol' may probably import) fpreads Itfelf over a Variety of Hills and Valleys, and lofeth the Profpect of the Sea. One of the principal Gates to the Landward, placed about a Furlong below the Summit of Thefe Hills, leads to the rugged Mountains of the Beni MenafJer; and, of the other two near the Sea Shore, the Weftern lyeth under the Shade of the high Mountains of the Beni Yifrah, and the Eaftern openeth towards the mountainous Diftrict of Shenooah.

Sherfbell being thus fhut up in the midft of Mountains and Tbe D:ffcult difficult Paffes, all Communication with It may be eafily cut off, whenever the neighbouring Tribes, (as it frequently happens even to This Day) are difpofed to be mutinous and troublefome. And, from This Circumftance, we may draw one Argument, that Sherflell is the Fulia Cee farea, by interpreting what Procopius ${ }^{2}$ relates of It in our Favour, viz. that the Romans could only come at It by Sea, Acce/s by Land being rendered impracticable, as all the Pafes were then feized upon by It's Neighbours.

They have a Tradition of the whole City's being deftroyed Defroyed by by an Earthquake; and that the Port, formerly very large and quake. commodious, was reduced to the miferable Condition It is in at prefent, from the Arfenal and other adjacent Buildings which were thrown into It by the Shock. The Cothon ${ }^{3}$, that had a Communication with the weftern Part of the Port, is the beft Proof of This Tradition. For, when the Sea is calm, and low (as it frequently happens after ftrong S. or E. Winds,) we then difcover, all over the Area, fo many maffy Pillars and Pieces

I Ab hy vel Syr.'ע vel'y quod celfum fonat. Boch.Chan.l. r.c. 34. unde Iliberis,Iliturgis,ci-

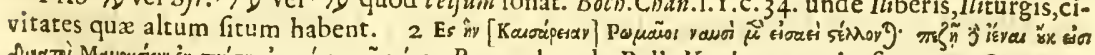

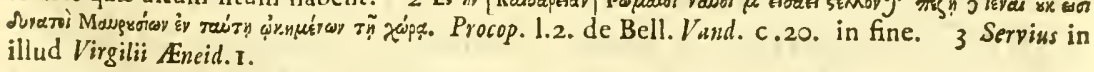

\section{Hic Portus alii effodiunt}

Portus non naturales fed arte \& manu factos Cothonns vocari afferit. Idem fcribit \& Feftus. viz. a $\square$ p katam vel Phanicio more katham incidere, unde $\square$ p kathum incifus \& $\square$ P kithum vel in ketbima Incifio: ita etiam apud Arabes. vid. Boch. ut fupra cap. 24. \& $B u x t$. in roce.

$\mathrm{K}_{2}$ 
of great Walls, that It cannot well be conceived, how They fhould come there, without fome fuch violent Concuffion.

The Cothon. No Place could be better contrived for the Convenience and Safety of Their Veffels, than the Cothon muft have been in It's primitive Situation. For, (befides the Capacity of It, which is at leaft fifty Yards fquare, fecure in every Part from the Wind, the Swell, and the Current, each of Them troublefome enough fometimes in the Port;) we cannot but admire the great Art and Contrivance of the Founder in fupplying It with Water. For This Purpofe, we difcover, upon a round peninfular Hillock that makes the Northern Mound of the Port and Cothon, feveral Floors and Pavements of Terrafs and Mofaic Work, laid, as it appears, on Purpofe to receive the Rain-Water, which was to fall from Them into fmall Conduits, and from Thefe again into greater, 'till at laft They were All to empty Themfelves into a large oval Ciftern. I only faw the Bottom of This Refervoir, and cannot therefore judge of the Capacity of It; however, according to the Quantity of Water that falls every Year in This Country, a Provifion of feveral thoufand Tons might have been collected by This Method. This Spot of Ground, nearly of an Hemifpherical Figure, is about a quarter of a Mile in Circumference, and hath a fmall Fort built upon the Top of It.

The Port, or The Port is nearly in the Form of a Circle, of two hundred Haven. Yards in Diameter: but the fecureft Part of It, which, 'till of late, was towards the Cothon, is now filled up with a Bank of Sand, that daily increafeth. There lyeth in the Mouth of It; a fmall Rocky Ifland, the main Shelter and Defence at prefent againft the N. and N.E. Tempefts.

Sherthellithe This Ifland therefore, with the large Circuit and fumptuous Iol or Julia
Cxrfrea. Ex. Remains of the antient City, will afford other Arguments for

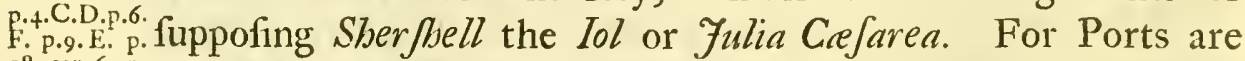
18. cap.6. P. very rare upon the Coaft of Barbary; efpecially, in This SiF.25. B. tuation, where we are to look for Crefarea; and an Haven with an Ifland at the Entrance into it, is only, I prefume, to be met with at Tackumbreet; a Place certainly at too great a Diftance to be taken for It. Tniss, which is conjectured by Sanfon ${ }^{2}$ and Others to have been the Fulia Cee farea, hath indeed an Inland before It, but not the leaft Rudiments of an Haven: and Al- 
giers, the other City brought by Dapper and later Geographers into the Difpute, was formerly in the like Situation with Tniss; the prefent Port having been made fince the TurkifbConquefts, by uniting to the Continent the Ifland that formerly lay before It. The principal Characteriftick therefore, whereby the Antients defcribe Their Iol Cee Jarea, cannot properly agree with any other Place than Sher-foell.

To the before mentioned Circumftances, we may add what Sherfhell and Procopizes' affirmeth concerning Cefarea, viz. that It was of Them exx thirty good Days Fourney from Carthage: and indeed, the Kha-Carthage. flahs* or Caravans make, to This Day, the fame Number of Stations from Tunis (in the Neighbourhood of Cartbage) to Sher-foell. In the fame Proportion likewife that Hippo-regius or Bona, which by the fame Author ${ }^{2}$ is faid to be Ten Days Journey from Carthage, is, in a direct Line, CXXVIII Miles from It; Crefarea, in being fixed at Sher-fhell, at thrice that Diftance or CCCLXXXIV Miles, will be exactly Thirty. From whence it will follow, that upon a Suppofition they travel at this Time in the fame manner as they antiently did: and that no greater Irregularities and Windings are to be met with in the Road from Sher-fhell to Bona, than are proportionably met with in the Road from Thence to Carthage, there will be the like Diftance betwixt Tunis and Sher-Jhell, which the Antients have laid down betwixt Carthage and Cre Jarea.

But It muft be confeffed, notwithftanding Thefe Arguments, The ltinerary that Ptolemy ${ }^{3}$ and the Author ${ }^{4}$ of the Itinerary, do not vouch my's Tables for This Situation of Crefaren; neither indeed do They agree dijagree in the thereupon between Themfelves. For the Latter fixeth It only feventy one Roman Miles from Arfenaria, thereby authorizing, in fome Meafure, the Opinion of Sanfon; though, I fuppofe, it hath been already proved, that Tniss could not be the Place. Ptolemy, by fixing It $3^{\circ}$. 10'. from Arfenaria, placeth It, at too great a Diftance to the Eaftward, in the Situation of $\mathrm{Al}$ giers, as Dappers and others feem to have done from His Au-

* Xla The common Name in Barbary for what are called Caravans in the Levant: being fach Companies of Merchants \&c. who, for the greater Seturity, travel together in Bodies. The ufual Time of travelling is eight or ten Hours: from Day-break till Noon; and fometimes to

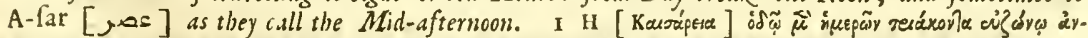

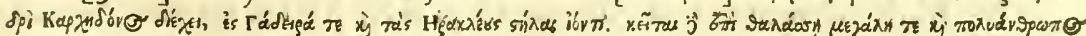

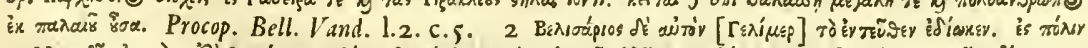

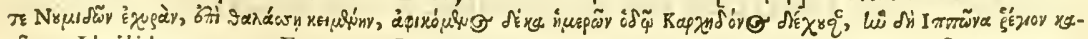
خ. 
thority. Yet if we may be allowed to make the fame Deductions xxxy ariles here, that feem neceffary to be made from the $5^{\circ}$. laid down eq:al to one of oremy's by the fame Author, betwixt his Crefarea and Saldis (the preDerrees of fent Bonjeiah;) Crefarea will have the Pofition, I have here
Long. given It, at Sher-/bell. For, the true Diftance of the Meridian at Arzew from That of Boujeiah, being (a little more or lefs) CCXC Roman Miles, there will be only about XXXV for one of His Degrees of Longitude; according to which Account, CX Miles (anfwering to $3^{\circ}$. 10'.) fhould be the proportional Parts, as within five or fix Miles they actually are, betwixt the Meridians of Arzew and Sher-fhell.

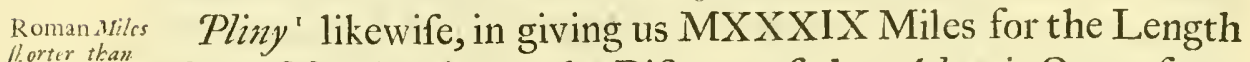

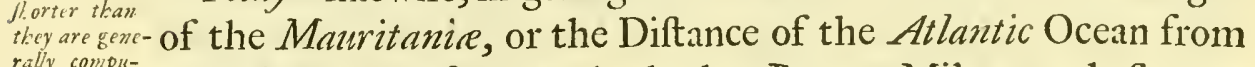
rally compu-
ted. than They are generally computed; and thereby will furnifh us with another Argument for the Proof of what we are endeavouring to afcertain. For the true Diftance being DCCCXXI, the CCCXXII affigned by Him for that Portion of the Mauritanice lying betwixt Crefarea and the River Amplaga, will be reduced to CCLX; which, by Obfervation, I find to be the Number of Miles betwixt the River Amplaga (or Great River as It is now called) and Sher-jhell.

River Fiafl- The Country round about This City is of the utmoft Fertility, and exceedingly well watered. We crofs the Brooks $\mathrm{Naf}$ fara, Billack, and fome others, before we come to the $H a / b$ em, the moft confiderable of Them, at the Diftance of feven Jimmell, or Miles from Sher-Jhell to the E. The Billack runs by Fim-mell, Exc. p.1I. F. an old ruined Town, the Chozala perhaps of Ptolemy, fituated under a high rocky Precipice, four Miles to the S.S.E. of SherBell, and at the like Diftance to the W. by N. of the Fountains of the Ha/h-em. A little Way to the Northward of The Zma-la, Thefe Fountains, the Algerines have a Fortrefs, with a (Zma-
or Garrifon of Mraoss.
And
Ana as They call the) Garrifon of Moors and Arabs, placed there

to interrupt the Incurfions of the Beni Menafjer. Nothing certainly can be more entertaining, than That Variety of Profpects, we every where meet with, all over this delightful Country.

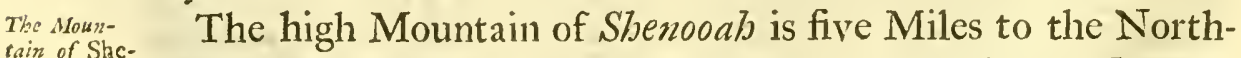
noual. ward of This Fortrefs, and fomething more to the E. N. E. of 
Sher-fhell. This Eminence ftretcheth It felf more than two Leagues along the Sea Shore, and is covered, to the very Summit of It, with a Succeffion of delicate Plats of arable Ground, hedged in, almoft every where, with Fruit Trees. The eaftern Point of It, known by the Name of the Ras el A-moufhe forms Ras el Aa large Bay, called the Mers' el A-moufhe, where Veffels lye fheltered from the W. and N.W. Winds. Edrifi calls the Promontory Battal, and the Atlas Geographus ${ }^{2}$ the Carapula and Giraflumar of the Mahometans; but Thefe Names are unknown, at this Time, to that peaceable Branch of the Beni Menaffer, who are the prefent Inhabitants.

Berin-/hell, a rocky Ifland, taken Notice of likewife by Edriff $i^{3}$, $1 /$ hind Beri. lyeth half a Mile to the N.by W. of the Ras el A-mou/he. In a late Revolt of the Beni MenafJer, This Place, 'till they were afterwards attacked by Sea,ferv'd fuch of Them, who could fwim over to It, as a Sanctuary from the Fury of the Algerines. They are very fond of telling Strangers, how, upon This Occafion, Hamett Shenooy, one of their Brethren, and an Inhabitant lately of El Coleah, faved Himfelf and a little Child, by taking It upon His Back, and fivimming with It from thence to the Port of El Coleah, at twenty Miles Diftance.

The River Gurmaat falls into the Sea a little to the Eaft- The Gurward of the Mers' el A-moufhe. It is made up of the feveral Rills of Watcr, that fall from the Mountain of Shenooah. One of Thefe Sources, received into a fquare Bafon of Roman Workmanfhip, goes by the Name of [Shrub we hrub بs, ب. Drink Shrub we and away, from the Danger of meeting with Rogues and Affaffins at This Place.

Two Miles to the Eaftward of This Fountain, under the Blecdan. Shade of Shenooah, we fee feveral Fragments of Mud-walls, the only Remains of Bleedah, fome Years ago a confiderable Village of the Arabs.

When we have paffed the Gurmaat, we fall in with a Num- Tefeniad or ber of Stone Coffins, of an oblong Figure, not unlike thofe that doore. are fometimes dug up in our own Ifland. A little farther to the Eaft, under a rifing Ground, are the Ruins of Tefeffad, or 'Tfeffad, called likewife Blaid el Madoone ${ }^{4}$, which extend Them-

I A Serfal ad Promontorium Battal, quod in mate procurrit, habentur xir M.P. Refpondet huic Promontorio parva quxdam Inlula in mare. Geogr. Nub.p.86. 2 Atl.Geogr. Vol.4. p.207. 3 Vid. Not. I. 4 Or $A$-madoone, from the High Buildings. vid. Gul in roce ulos.

$$
\text { L } 2 \text { felves }
$$


felves two Miles along the Sea Shore; though the Breadth is not equal to one third Part of the Length. At this Place and SherJhell, we meet with feveral Arches and Walls of Brick, not commonly found in other Places of Barbary; efpecially, where we may fuppofe the Work to be Roman. The Bricks are of a fine Pafte and Colour, two Inches and a half thick, and near a Foot Square.

Upon a large moulded Stone, brought from Thefe Ruins to Algiers, we have the following Infcription.

C. CRITIO. C.F.

QVIRIT. FELICI.

EX TESTAMEN

TO EIVS.

Teferfad, The +Tefeffad, being fituated thirteen Miles to the E. by S. of Sher-

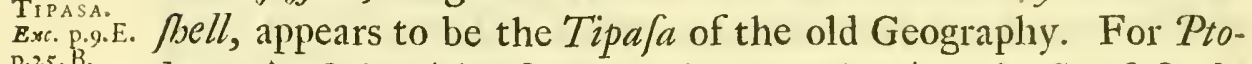
p.25. B. lemy, in fixing Tipala $30^{\prime}$ to the $\mathrm{E}$. and $\mathrm{Io}^{\prime}$ to the $\mathrm{S}$. of Ceefarea, differs very little from This Pofition. The Author likewife of the Itinerary, in placing His Tipafa Colonia fixteen Roman Miles to the Eaftward of Ceefarea, gives us the very fame Diftance. Moreover Tefeffad, by an eafy Tranfition or the changing $f$ into $p$, will have a Sound not very different from Tipa $a$.

Perfected by Several Writers ${ }^{\mathrm{T}}$ about the VI. Century give us a particular the Arians. Account, how fome of the Orthodox Citizens of Tipafa, after the Arians had cut out their Tongues, were notwithftanding endowed with the Gift of Speech, and capable to tell the Hiftory of their Misfortunes.

The Kubber The Coaft, all along from Tefe/fad to Algiers, for the Breadth Romeah, of two or three Leagues together in fome Places, is either woody or mountainous; whereby the fine Plains of the Mettijiah behind It, are conveniently fecured from the more immediate Influence of the Northerly Blafts of Wind from the Sea. The

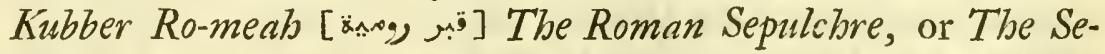
pulchre (as It will likewife fignify) of the Chriftian Woman,

I Viat. Vit. Hift. De perfec. Vandal. in Bibl. P.P. Tom. 7.1. 3. p.1920. Paris. 1589 . Procop. De Bell.Vand. I. 1.c.8. p.196. S. Gregor. Dialog.1.3.c.32. p.303. Ant. I615. vid. Hittoire de l'Arianifme. 1.9. p.286 \&c. par le P. Louis Maimbourg. a Paris. 1673. 
is fituated upon the mountainous Part of the Sea Coaft, feven Miles to the E. by S. of Tefeffad. According to the Difcoveries hitherto made, It is a folid and compact Edifice; built, in the following Manner, with the fineft Free Stone. The Height I computed to be a hundred Foot, and the Diameter of the Bafis ninety.

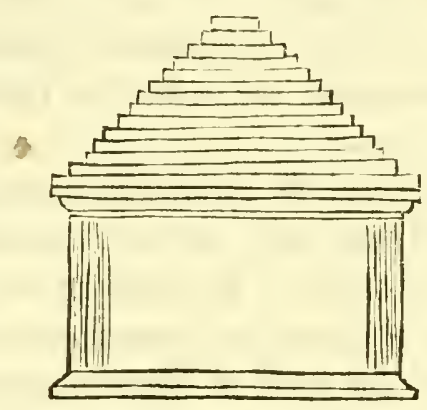

The Figure of this Structure and the received Opinion of It's or Maltapary. being erected over a large Treafure, might induce the Turks to call It Maltapafy [The Treafure of the Sugar Loaf.] The Point is now wanting; and, by the frequent Searches after This Treafure, feveral other Parts of It are broken down and defaced. However, It is ftill of a fufficient Height to be a convenient Landmark for Mariners.

The Kubber Romeab thould be the fame Structure, that Mar-The Monumol $^{*}$ informeth us to have been built over the Daughter of Commune Count Fulian, in the City Tignident: though Tignident, pro- Regise Gen- Exc. 13 . vided It be the Tigadempt of other Authors, is an Inland-City, at a great Diftance to the S.W. neither are there at This Place the leaft Traces to be met with of fuch Temples and other Edifices, as are, at the fame Time, taken Notice of by our Author. We may rather, in Confideration of the Elegancy of the Workmanfhip, and the Beauty of the Materials, fuppofe It much older than the Mabometan Conquefts; and to be the fame Monument, that Mela placing betwixt Iol and Icofium, appropriateth to the Royal Family of the Numidian Kings. Sepulchres of this Kind,

* Tignident (ou ville vicille) eft en une Baye que fait la mer, entre le Port qu' on nomme du Mont de Serfel et celuy des Caffines. Elle elt celebre dans l'Hiftoirc Romaine fous le nom de Cefaree. Il refte toutefois fus pied dcux anciens Temples, ou l'on facrifioit aux Idoles; en I" un defquels il y a un dome fort haut, que les Mutures appellent Colorruinia, ou fepulchre de Romain, \& les Chreftiens par corruption Cabaromia, ou ils difent qu' eft enterré la fille da Comte fulien. Elle eft fur une haute terre qui entre dans la mer: il n'y avoit point d'autre ville maritime en cette Province \& nous $n^{2}$ avons trouvè le nom de Cefaree que dans Aben R.ıquiq. L'Afrique de Marmol. 1.5. c. 34. 
and in the like Situation, have been taken Notice of by antient Authors ${ }^{1}$ at other Places.

El Co-le-ah. El Co-le-ab is fituated a Mile and a half from the Sea Shore, Calventi. upon the fame Tract of Mountains with the Kubber Romeah, $F$ vc. P.25.B. and at four Leagues Diftance to the N. E. by N. It is a neat open Village, three Furlongs in Circuit, built in a full Profpect of the Mettijiah, the Mountains of Atlas, and the City Bleedah at the Foot of them. This is the neareft Place, I am acquainted with, to Tipafa, that can be taken for the Cafee Calventi of the Itinerary.

The River Four Miles to the N. E. by N. of ElColeat, is the Mouth of M-faffiran. the Ma-faffran, a River very little, if at all inferiour to the Shelliff. The firft Branch of It comes from Miliana, which, uniting afterwards with another from Ham-mam Me-re-ga, is, from thence, called the Wed el Ham-mam. Four Miles farTheWed-jer. ther, It is known by the Name of the Wed-jer; and paffing through the feveral deep Valleys of This Part of Mount Atlas, runs in fuch a Variety of Windings, that $I$ croffed It fourteen

The Wed Shiftis. The Wed lleek.
Times in one Hour. The Wed Shiffa, and Ileek, are two other principal Branches. The firft of Thefe rifeth among the Mountains of the Wuz-ra, a little Way to the N.E. of Medea: the other derives It's Stream from a lefs Diftance, defcending from that Part only of the Mountains of Atlas, which hang immediately over Bleedah. The Union of Thefe Rivulets forms the Ma-faffran' a Name probably borrowed from the Tawny, or Saffron-Colour of the Water.

\section{H A P. IV.}

Of the moft remarkable Places and Inhabitants in the Inland Parts of this Province.

GEve R a L of the Inland Places of this Province have been $\checkmark$ already taken Notice of, in laying down the Courfe of the

I Pfylli Regis Sepulchrum in parte Syrtism majorum eft. Plin. 1.7. cap.2.

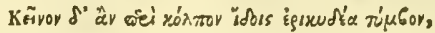

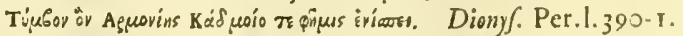

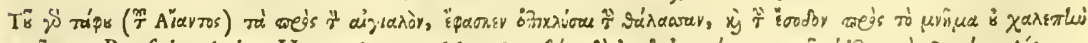

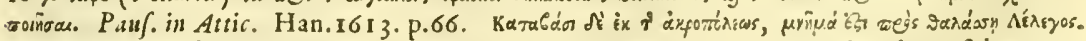
Id. ibid. p.82. vid.annot. V. Cl. Abr. Gronovo in P.Melam. 2 , escro, Mazafran, fulvus; ex fulvo rubens. vid. Gol. in voce

$\mathrm{Ri}$ - 
Rivers: to defcribe the reft of them in Order, or as they are $T$ the Montrfituated with Refpect to Thefe Rivers and the correfpondent ${ }_{r 2}$ ans of TraPart of the Sea Coaft, we are to return to the Mountains of Trara, which are a beautiful and confpicuous Knot of Eminences, furnifhing the Markets of Tlem-fan with all Manner of Fruit.

Nedroma' or Nedròme is placed hard by Thefe Mountains, Nedrome, or a little to the S. E. of Twunt. It is remarkable for nothing ExG,p.1.C. elfe at prefent befides It's Potteries; though the Fruitfulnefs of the circumjacent Country and the fine Situation, fhould induce us to believe It to have been formerly a Place of greater Confequence; the Celama, or Urbara perhaps, of Ptolemy.

Seven Leagues to the S.E. of Nedrôme, are the Mountains Beni-Snoure. of the Beni Snoufe, in as great Repute for the Goodnefs of Their Figs and Pomegranates, as the Beni Snoufe Themfelves are noted for the Number of Their Mud-walled Villages. Of Thefe, Tef-Tefzra. $z r a$ is the moft confiderable; though we cannot well receive It for the Aftacilis of Ptolemy, which will be more conveniently fixed at another Place.

Five Leagues to the S. S. E. of the Mouth of the Tafna, is Tlemfan. the City Tremefen, as the modern Geographers write It; The [ uhu+dis] Telemfan or Tlem-fan according to the Pronunciation of the Moors, and Arabs. It is fituated upon a rifing Ground, below a Range of rocky Precipices, the Sachratain (as we may Sachratain. take Them to be) of Edrifi ${ }^{2}$; and upon the firft Ridge of Them, (for there lyeth another much higher to the Southward) we have a large Strip of level Ground, that burfts out, in every Part of It, with Fountains. Thefe, uniting by Degrees, into little Streams, fall afterwards in a Variety of Cafcades in Their Approaches to Tlem-fan. The Annafrani ${ }^{3}$ of Edrifi feems to have Annarman. been made by the Weftermoft of Thefe Fountains, which ftill

I Ned-Roma in fpatiofilfimo campo extruetum, diftat à monte duobus fere milliaribus, atçue huic vicinum quoddam flumen non admodum latum. Scriptum reliquerunt iftius temporis Hiftoriographi ad unum eundemque quo Roma xdificata fuit modum, uride \& nomen [Ned enim apud Arabes idem prorfus atque fimilis nobis fignificat ] deductum arbitrantur. F. Lev. p.I6I. 2 Telemfan componitur duabus urbibus muro diftinctis; habet à meridie montem, qui vocatur Sacllratuin, [i.e. duo Saxa] atque in ifto monte contra nieridionalem urbis plagam porrecto funt vinex: \& ad ejus radices molendinæ fecus ingentem rivum aqu e dulcis, rapidæque, qui rivus appellatur Rivus Annafrani; [i.c. Chrifliani; ] ad hunc rivum extructa funt monafteria, oratoria, aliaque Religioforum ædificia, cum viridariis ampliffimis ; \& nominatur ibi rivus ille Alfuara [i.e. Scaturiginis] \& inde ad urbem ufque fe extendit. Non longe $\mathrm{ab}$ cadem urbe extat fons celebris, fons Om Iahia [i.e. Mutris Fohannis] dictus, è quo rivus in urbem influens concluditur in lacum, ac tum difpenfatur in domos, irrigationes hortorum, balnca, caupones \& fimilia. Geogr. Nubien. p.79. 3 Vid. Not. ut fupra. 
continue to form a Stream in that Direction, and to turn a Number of Mills, as They formerly are faid to have done. There is a large Source of Water likewife within the City, conducted hither, by a fubterraneous Channel, from fome other Place: but the Mountains to the Southward abounding fo plentifully with Water, there is no Neceffity of deducing It, with Marmol', from the Fouara in Numidia ${ }^{2}$. The ufual Demands of the City are chiefly fupplied from This Source: which, for that Purpofe, is diftributed through a Number of Conduits to the Caftle, the Mofques, and other Places of publick Refort.

The Bas'n. In the Weft Part of the City, we have a large fquare Bafon of Moorifs Workmanfhip, two hundred Yards long, and about half as broad. The Inhabitants have a Tradition, that the Kings of Tlemfan were accuftomed to take the Diverfion of the Water upon It, whilft their Subjects were at the fame Time taught the Art of Navigation. But the Water of the Sachratain, as Leo ${ }^{3}$ hath well obferved, being eafily turned off from It's ordinary Courfe, This Bafon might have been rather defigned for a Rejervoir in Cafe of a Siege: not to mention the conftant $U$ fe of It at all other Times, in preferving a Quantity of Water fufficient to refrefh the great Number of beautiful Gardens and Plantations below $\mathrm{It}^{4}$. Edrif ${ }^{5}$ takes Notice of a Structure of This Kind, where the Fountain of Om-Iabia difcharged Itfelf.

The Wialls made of Mor

Moft of the Walls of Tlem-fan have been moulded in Frames; and confift of a Mortar made up of Sand, Lime, and fimall Pebles; which, by being well tempered and wrought together, hath attained a Strength and Solidity equal to Stone. The feveral Stages and Removes of Thefe Frames are ftill obfervable, fome of Them being a hundred Yards Long and a Fathom in Height and Thicknefs: by which we may eftimate the Quantity of Mortar made ufe of at one Time.

Tle city di- In Order, as we may conjecture, to ftifle any inteftine Comvided into
Wards. feveral Wards or Partitions; of which there were two in the

I La ville de Tremecen eft embellie de pluficurs fontaines qui riennent toutes d' une feule (qu' on appelle Fourar.t) quel on conduit de Numidiat par des canaux fouterraines l' efpace de lus de trente lieucs. L' Afrigue de Marmol. 1.5. C.II. 2 N.B. The Nunidia of Marmol is the Gxtulia of other Authors. 3 Innumeri hic fontes qui omnes fcaturiginem non procul ab urbis mœniis habenr, adeo ut facillime ab hoftibus adimi poffunt aqueductus. F. Leo. p. 194. 4 Habet Telenfui territorium clegantiflima fanc rura, in quibus fe cives per xeftatem continerc folent : nam pretergnam quod hic omnia prata ridcant, fontes limpidifimi,omnium fructuum afflucntia oculos hunc in modum pafcunt, ut nunqquam in Vita quicquam amoenius me vidific memincrim. F. Leo.p.194. 5 Vid.Not.2.p.+7. in finc. 


\section{Of the Weftern Province.}

Time of Edrifit. Each of. Thefe might be confidered as a Diftinct City, being of a Square or oblong Figure, enclofed with a high Wall, of the fame Structure with that of the City. About the Year MDCLXX. Hafjan, then Dey of Algiers, laid moft of This City in Ruins, as a Punifhment for the Difaffection of the Inhabitants at that Time; fo that there is not above one The Extent of fixth Part remaining of the old Tlem/an, which, as I compute, might have been four Miles in Circuit.

Among Thefe Ruins, particularly in the Eaft Part of the City, ${ }_{\text {Traces of of }}^{\text {the }}$ the we meet with feveral Shafts of Pillars and other Fragments of chitefture. Roman Antiquities. In the Walls of an old Mofque, I faw a N!mber of Altars dedicated to the Dii Manes. The following was the only legible Infcription.

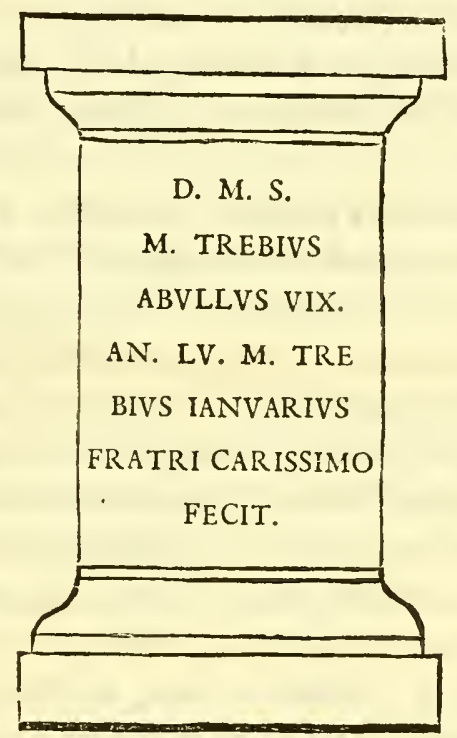

Gramaye informeth us, that Rabbi Abrabam had feen feve-Tlemfan, or ral Medals, dug up in This Place, infcribed Tremis. Col. a Lanco porr.C. City, I prefume, not known to the old Geographers: for $T i$ mice $^{3}$ (probably from fome fuppofed Affinity in the Name, ) hath been generally taken for Tlemfan. Yet provided Te/fai. lah proves to be the antient Aftacilis, (as may by and by appear probable) Timice, in lying half a Degree beyond It to the Eaftward, cannot fo well agree with This Situation as the $L a$ nigara of Ptolemy. There is fome Room likewife to conjecture,

1 Vid. Not.2.p.47. in principio. 2 Rabbinus Abrabumaddebat varia fe vidiffe numifmata in fuburb. merid. effoffa, cum inferiptione TREMIS COL.Gramaye Afric. illuftrat.c. 25.3 Vid.
Atlas Geogr. Vol.IV. P.3 3 . 
that Tlem fan may be an Appellation ' of no longer ftanding than the Incurfions of the Arabs.

Hub-bed. One Mile to the Eaftward of Tlemfan, is the Village of Hubbed, reverenced for the Tomb of Sede Boumaidian, which the whole Neighbourhood vifit with the greateft Devotion. At Manfoural. the fame Diftance, to the Weftward, is the City Manfourah, which, at prefent, hath neither Houfe nor Inhabitant. Thé greateft Part of the Wall, built in the fameManner with That of Tlemfan, is ftill remaining. But the enclofed Area, of two Miles in Circuit, is above half of It arable Ground; Abulbafen $n^{2}$, during His long Siege of Tlemfan, intending It, as we may conjecture from Thefe Circumftances, rather for a Blockade upon That City, than a Place to be inhabited. Near the Centre of the Area there is a plentiful Fountain, and a high beautiful Tower: but the Mofque it belonged to, hath undergone the like Fate of the other Buildings, in being entirely pulled down and demolifhed.

T\%e Hammam of Secdy Ebly.

Tibds. The Plains of Zeidoure.

Twelve Miles below Tlemfan, upon the Banks of the Iffer, we pars by the Ham-mam of the Mar-ab-butt Seedy Ebly: near which are fome Ruins, probably, of Tibda, taken Notice of by the Spanifh Hiftorians?. The Plains of Zeidoure begin at the Iffer, and extend Themfelves, through a beautiful Interchange of Hills and Valleys, to the Wed el Mailah, at thirty Miles Diftance. This delightful Diftrict, watered by a Number of Springs welled Zei- and Rivulets, is cultivated by the Welled Zeire and Halfa, two Teand Halfa. numerous Clans of Arabs, fome of the Succeffors, as we may sII. Exc.p. take Them to be, of the antient Teladufii.

Shurph' el graab.

About the Middle of thefe Plains, is The [Shurpli el graab ] Pinnacle of the Ravens, a high pointed Precipice, with a Branch of the Sinan running below It. Upon the N.E. Banks of This Rivulet, eight Miles farther, and thirty two to the N. N.E. of Tlemfan, we have the Traces of a large City of the fame Name ${ }^{4}$. This feems to have been inhabited in the Time of Edrifi, who placeth It two Stations from Tlemfan.

I Derived perbaps from [ [s ] Telem, (Sulcus terrax, fpeciatim factus fencentis crgo) and [ow ] San (formare, vid $G_{0 l}$. in voce) apon account of the Nature and Quality of the rich arable Ground round about It. vid.Not.4.p.48. 2 Quartus Rex Fefa Abulbafen, qui ex marinis orivinem traxerat, in fccundo milliario occidentem verfus oppidum conltruxit Telenfino vicinum. Deinde Telenfum oblidione triginta menfum cinxit \&c. $\mathcal{F}$. Leo.p.198. 3 Alfonce Martinez.. arriva au Tibde $\&$ aux Baims qui portent le nom de cette rivicre, \& qui font a cinq lieuc̈s de Tremecen. -- Tibde eltoir une ville fermée de murailles -. \&c. L'Afrique de Marmol.1.5.c.2.P.3+5. 4 Egredicns ì Telemf.n conficics ftationem unam ad Aufabe. AbHac ad Cafr [i. e. ades] Senili, tationem alceram. Gogrr. Nub. p.80. 
At fix Leagues Diftance, Fibbel Karkar, a high Range of jirbel Karrocky Mountains, bound our Profpect to the South: And at the like Diftance from Them, in the fame Direction, are the rugged Mountains of the Beni Smeal; beyond which, we fall Beni Smeal. in with the Encampments of the Har-arr, the Bedoweens of Har-arr. This Part of the Sabara. Fig-ig is a Knott of Villages, five Fig-ig. Days Journey beyond the Beni Smeal to the S.S.W. They are noted for Their Plantations of Palm-Trees, from which, all the Weftern Part of This Province, is fupplyed with Dates.

Three Miles from Sinan, is the Ford of the Wed el Mailah, wed el Maiwhole Banks, being of a gritty fandy Subftance, were wore down to the Depth of fifteen Foot where I paffed Them. A little on This Side, I was thewn the Place where the elder Barbaroffa ftrewed about His Treafure': His laft, though ineffectual Effort to retard the Purfuit of His Enemies. Upon an Eminence, at half a Miles Diftance on the other Side of This River, there is a Moorifb Sanctuary, with a great Number of Mattamores dug round about It. The Votaries or Religious of This Place drink no other Water than That of the Mailah.

Bre-deah, a fmall Diftrict, chiefly noted for a large Pond of Bredcah. good Water, lyeth fix Miles beyond the Wed el Mailab: after which is the fimall Village of Mefergeen, fix Miles to the N.E. Mefergeen. of Bredeah, and as much to the S. W. of Warran. Mefergeen is noted for a Rill of excellent Water ruming by It, which overflows a large Plat of Ground, that produced, when I faw It, Roots and Potherbs of all Sorts for the Market of Warran. The Sibkah, a large Plain of fandy Ground, lyeth a little to the Tke Sibkath. Southward of Mefergeen, and Bredeah. It extendeth It felf, from the Salt River, to beyond the Meridian of Warran; and is dry in Summer but covered with Water in the Winter Seafon. Upon the E. and S. E. Borders of It, as far as the Salt Pits of Arzew and the River Taleelet, we meet with the Doo-

I El Marques [de Comares] le [el Barbarroja] alanço ocho leguas de Tremecen, antes de palfar a un grande rio que fic dize Hucxd.r. [I fuppofe a corruption cnly of IVed] Burburroja vido al Marques a fus Elpaldas y tan cerca que ya renian los Chritianos rebueltos con fus turcos matando y degollando, dava fe prieffa por paffar en toto cafo cl rio y falvarfe. Y para mejor lo poder hazer y entretener al cnemigo, ulo de un lindo eltiatagema de gucria (fi lo huuiara con otra gentc) porque mando fembrar muchos varos de oro y de plata, muchas joyas y mucha moneda de que yuan todos cargados, con muchas otras cofas, y ropas inuy preciofas: pareciendole que topando los Chriftianos con efto, la cobdicia los harta cntretencr, para cogerlo, y anfi tendria tiempo para cl y fus turcos poder huyr y paffar aquel rio a fu falvo. \&c. Epitome de los Reges de Airgel. Cap.1.1r.p.54.p. Diego de Hacdo. \&c. I alladolid. I612. Pour Ics [Chrifticns] arrefter il laiffoit conler de tems en tems de l'or du de l'argent par le chemin. Marmol. l.s. c.II. p. 34 I 
Beni Ammer.

The Blowntains of $\mathrm{Te}$ Gailah and lafarowy.

Arbazl.

Tefrailah. The AstaCItis. Exc. P.II. C.

wars of the Beni-Ammer, a numerous and warlike Community; who, from Their former Intercourfe with the Spaniards, whilft in Poffeffion of Warran, fpeak the Spanifh Language to Perfection.

A long Chain of Mountains runs Parallel with the Sibkah, called to the Weftward Teffailah, and to the Eaftward Tafarowy. On this Side the Mountains of Tefjailah, fifteen Miles from Warran to the S. are the Ruins of Arbailah, or Arbaal, the Agobel of Marmol', formerly a confiderable City.

Six Miles behind Arbailah, are the Ruins of TefJailah, a City of the like Bignefs, though fituated in a richer Soil, upon the Plains, as They are called, of Te/failah. This being a Station of the Romans, and lying in the fame Meridian with (Worran or) Quiza, may lay a greater Claim to the antient Aftacilis than Tefzra above mentioned. TefJailab likewife varieth very little from what we may fuppofe to have been the old Pronunciation of Aftacilis, before It received a Greek or Latin Termination. All Thefe Mountains and Their adjacent Plains, are poffeffed by Welled Aly and Welled Moufa-Ben Abdallab, the hereditary Enemies of Welled Zeire and Halfa.

Tïe Huflcm. The Country adjacent to the Rivers Makerrah and Tagiah, before they enter the Plains of Midley and Romaleat, belongs to the Haßbem; who, according to the Eaftern, Middle, or Weftern Part of the Country They inhabit, and in Contradiftinction to the other Branches of the fame Name, are called the Ha/bem Shraaga, the Ha/bem Saba-rowy, and the Haßhem of Agreefe. They are one of the mott confiderable Tribes of the Weft, are obliged to the Payment of no Taxes, and ferve only as Volunteers, when the Algerines require Their Affiftance.

The Plains of Midley are the Property chiefly of the Viceroy of This Province, and cultivated at His Expence. Upon the Weitern Skirts of Them, we meet with the Sanctuary of Seedy Exr.g. ibid. Doud, and fome Ruins hard by It, called $+A b d t$ el Wed. Timice thould lye near This Place.

Tagulmein-

Tagulmemmett, the Tugilmac, I prefume, of our modern Sea Charts, is about four Miles to the S. S. E. of Muftygannim; and, by the Extent of Ruins, feems to have been a Place of Confideration. The large fertil Plains below It, particularly

I Arobel eft entre Tezel, \& Oran; on nommoit cctte villc ancienncment Viatuire. $L$ 'A. frique de Marmol. 1.5.c.14.

where 
where They border upon the River Habrah, are called Romaleah; perhaps from The [ lo, rummel] Sandy Quality of the Soil.

El Callah, the great Market of this Country for Carpets and El Callah, Burnoofes, lyeth about four Leagues to the S.E. of Thefe Plains, $\mathrm{Tbu}_{\mathrm{LU}} \mathrm{G}_{\mathrm{IT}} \mathrm{Tr}$ and eight to the S. S. E. of Mufty-gannim. It is a dirty ill con- ${ }_{\text {P.II }}$. Exc. trived Town, without any Drains or Caufeways, built, as the Name* imports, upon an Eminence, and in the Midft of a Chain of other Mountains. There are feveral Villages of the fame Nature and in a like Situation round about It, all of Them employed in the fame Manufactures. The Turks have here a fmall Garrifon and Citadel; and, from fome large Stones and Pieces of Marble, that are here and there to be met with, we have fome Reafon to believe It to have been formerly a City of the Romans, the Gitlui or Apfar perhaps of Ptolemy. Dapper' and Sanfon make It His Atoa or Urbara; but both Thefe Places are too near the Meridians of the River AfJura and the Great Port, to have any Pretenfions to El Callah.

Five Leagues to the S.W. of El Callah, is the Town of Maf-Mafcar, or car, or El Mafcar, another of the larger Collections of mud-Exc, ibid. walled Houfes of This Province. It is fituated in a fine Plain, and in the Neighbourhood of feveral leffer Villages like El Callah; but the little Fort that defends It from any fudden Revolt of the Arabs, is not allowed to have a Turkifb Garrifon. Sanfon ${ }^{2}$ may very juftly make This Place the antient Victoria, though in placing It fixty Miles to the S. W. of Warran, He gives It a very different Pofition from the true one, which is thirteen Leagues to the S. S.E.

Round about the Sources of the River $A b d t$, thirty Miles to Sbeebah, or the S. by E. of Mafcar, upon the Borders of the Sabara, is a Rim or ARIKnott of Dafbkras, as Frendah, Giran, Tagazoute, and Sbeebah, inhabited chiefly by Arabs. Sbeebah hath for fome Time been evacuated; but the others are built upon Places of fuch difficult Access, that the Turks could never oblige the Inhabitants to be Their Tributaries. There are feveral Fragments of Roman Walls at Sbeebah, which may therefore have the greateft Pretence to be the Ritia; as Giran, from a Similitude of Sound, may prove to be the Arina of the Antients.

\footnotetext{
* ¿lo [calat)] cacumen, vertex. \&c. vid. Gol, in voce. I Vid. Atlas Geogr. Vol. 4. p.2II. 2 Ibid.
} 
Zecdaamals. Befides the Zeedaamah and Mahall, who are Branches of the Mleetah. Sweede, we have in Thefe Parts the Arabs Fleetah, Mailiff, Bookhammel. and Boo-khammel. The Zee-daamah and Fleetah poffefs, as far as the Sahara, the greateft Part of the Country betwixt the Meridians of El Callah and Mafcar; whilft the Welled Mailiff are met with at Madder [ $\omega$. ] a fmall miry Diftrict (as the Name implyeth,) with a Rivulet, four Leagues diftant from the $\mathrm{Ha}$ brah. Five Miles farther, near the half Way to the River Mina, are the Doo-wars of the Maball, who drink of the Fretiffah, a Fountain and Rill of good Water, fhaded by a beautiful Grove of Poplar Trees. Beyond The fe again are the Bookhammel, the moft Northern of Thefe Communities, who rare$1 \mathrm{y}$ wander to the Southward of Kulmeeta and the Banks of the Shelliff:

Mons. Dvr- The Mountains hitherto defcribed, lying betwixt Thofe of

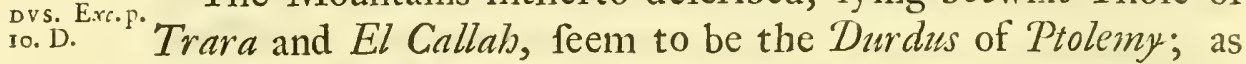
the Angad, the Beni Snouse, the Beni Smeal, with fome of MASESY- the Branches of the Sweede and Hajbem, may be taken for the LII, DRYI- Succeffors of the MafJeefylii, and Dryite.

Ir. A Brook Seven Miles to the Eaftward of the Mina, is the Brook TaTagia. Beni Zerwall. gia, which defcends from the Mountains of the Beni Zerwall, a little to the Northward of the Shelliff. Thefe Mountains fhade Al-Had and other Parts of the fruitful Diftrict of El Mildegah, and are noted for Their excellent Figs.

The Warifa. The Wariffa, another fmall Brook, to the Northward alfo of the Shelliff, is two Leagues from the Tagia. After It hath watered Mazouna, It is employed, like the Sikke, in overflowing the fertil Plains towards the Shelliff.

Mazouna. Mazouna is fituated four Miles to the Northward of the Shelliff, at the Foot of a long Chain of Mountains, which begins a little to the Weftward of the Beni Zerwall, and runs parallel with the Shelliff as far as Medea. It appears only to have been founded by the Moors, being of the fame Structure with El Callah, without the Footfteps of any fuch Roman Temples and fumptuous Edifices, as are mentioned by Dapper and Marmol: The Authors of the Atlas Geographus ${ }^{2}$ make this Village the Colonia Novi Caftri, and the Oppidoneum of Ptolemy, which,

I Vid. Atl. Geogr. Vol.4. p.208. La Contree de Mazuna eft forr eftendue \& l' on y voit les Ruines de plufieurs villes qui ont efte deftruites depuis les Romains, ou l'on remarque encore de grandes Tables d' albatre \& des ftatues de pierres avec des Inferiptions Latines. $L^{\prime}$ Afrique de Marmol. 1.5.c.35. 2 Vid. ut fupra. 
in the Tables, hath a Situation at too great a Diftance to the Eaftward, to be fixed at Mazouna.

The Country to the Northward of Mazouna and the Beni T:s YakatiZerwall, as far as Fibbel Difs, is called Ma-growah', after the Manss of the Name of an antient Tribe of Africans, who have been frequent-Magrowah, ly taken Notice of in the Hiftory of This Country, and ftill continue to poffefs a great Part of It. The Welled Oufreed, be-welled Oulonging likewife to This Diftrict, live near the Sca Shore, over againft the Pigeon Ifland: whilft the Ze-reef $a$ are poffeffed of the Zercefa, Parts farther to the Weftward, near the Rummel-Abead, and Hameefe. The Welled Seleema and Wheedam inhabit the Welled ScMountains betwixt Mazouna, and the Beni Zerwall; They welled alfo drink of the Tagia and Wariffa; and fometimes cultivate the plain Country along the Southern Banks of the Shelliff. I could not be informed, that the Country of the Magrowah, was remarkable for any Antiquities; however, I prefume, we may take Them, in Conjunction with the Neighbouring Com- The Machumunities, for fome of the Succeffors of Ptolemy's Machufii. SIr. A.

Betwixt the Rivers Mina and Arbew, are the Ruins of $T a$-Tagademp:. gadempt, the Tergdent, Tigedent, or Tigdentum of the Atlas Geographus ; placed by Sanfon CX Miles to the S. of Oran, and above CXX to the S. E. of Tlem fan. Yet neither Thefe Diftances nor Directions will fall in with our Tagadempt, which, being fituated a little to the Northward of the Sources of the Mina, is fixty Miles to the S. E. by E. of Warran, and ninety to the E. N. E. of Tlem fan. It hath been a very large City, abandoned only a few Years ago by the Arabs; who have taken Care, as ufual, to leave us feveral Marks of Their own Humility and Ignorance in Architecture, and to pull down and deface, whatever was beautiful and magnificent, in the Buildings of Their Predeceffors. If This fhould be the Tignident of Marmol, (and there is no other Place, as far as I could be informed, of the like Name) it will be difficult to account for His making It the Fulia Ceefarea, which undoubtedly was a Sea Port Town, far removed from the Pofition, wherein we find the prefent Tagadempt.

Swamma, another Heap of Ruins, lyeth twelve Miles to the Swarmma of S. of Tagadempt, upon the Borders of the Sabara. It is called

I Venit \& alia Zenetorum Familia ex Numidia, qux Magraoa dicta eft, hxe Macnafam cum omnibus ducibus regno pulfit. F. Leo. l.1. p.6. \& 205.2 Vid. Not. p.45.

$\mathrm{O}_{2}$

Swamma 
Swamma of Minda/s, according to the Name of the circumjacent Country.

Nador. Nador, a confiderable Town of the Gretulian Arabs, twenty Miles to the S. of Swamma, is built in the Sabara, upon a Chain Nons MA- of Mountains, which we may take for the Mons Maletbubalus LETHVBAL.VS. Exe.

of Ptolemy. Below It is the River Su-Jellim, which, after It hath paffed Gojeeda, is drunk up by the fandy Country, and becomes Rafbig, as the Arabs term It, i.e. runs no further; a Circumftance common to other Rivers in Barbary, and which Exc.p.s.E. Strabo was long ago acquainted with.

Go-jeeda. Go-jeeda, fituated upon the fame Ridge of Eminences with Nador, at the Diftance of fix Leagues to the E. by S. fhould be the Guagida of Sanfon, placed by him fifty three Miles to the S. of Warran, and eighty to the S. E. of Tlem fan: though This I am fpeaking of, lyeth more than a hundred Miles to the E. by S. of Tlemfan, and nearly at the like Diftance to the S.E. Vol.t.p.rrs of Warran. The Atlas Geographus maketh the Guagida of Dapper and Sanfon to be the fame; whereas the former, in being placed nine Miles to the Southward of the Mediterranean Sea, and almoft as much to the Weftward of Tlem an, (though both thefe Numbers are deficient) muft be the Woojeda of the Tingitanians.

Meratte. Upon the Banks of the Arberw, fix Leagues to the E. of Tagadempt, and ten to the $\mathrm{N}$. of Gojeeda, are the Ruins of $M e$ Lo-ka. ratte. Two Leagues farther, in the fame Situation, is Lo- 30 , another Heap of Ruins.

Tharrm, The Tarrum, Vage, and Garra of Ptolemy fhould be fomeTha Gojecda where in This Direction. Tarrum, by lying the fartheft to the VAG a. Tbe S. and near $2^{\circ}$. to the E. of Victoria, or Gitlui, fhould be our GARRA,The Gojeeda, or Nador: and Vagre, from the Pofition of It $\mathrm{I}^{\circ}$. far-

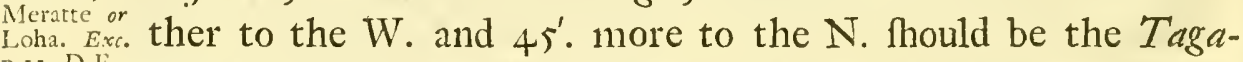
F.II. D.E. dempt or Swamma; whilft Garra, by having a Pofition ftill farther to the Northward, near the Meridian of Tarrum, may be taken for Meratte, or Lo-ba. But for Want of Infcriptions and other Circumftances to guide us, This as well as other Difficulties of the like Nature, muft be left undetermined.

7\% Swecde. The fertil Country below the Parallel of Lo-ha, is cultivated by the Sweede or Swidde, the molt powerful Tribe of Arabs in This Province. The Name [u,w] fignifies Black; and was occafioned, as I am told, by a Standard of that Colour, formerly 
difplayed in Their Marches and Engagements. They pay no Taxes, and, being of that Rank of Arabs which they call [ U Fow aide, ferve the Algerines only as Volunteers. Above the Sweede, from Tagadempt to the Sebbeine Aine, are the Encampments of the Welled Booker; behind which are thofe of the Welled Werled Boo. Haleef, a Tribe that tills no Ground, and being only intent upon Weef, $\mathrm{Wa-}$ the breeding of Cattle, keeps for the moft Part within the Sabara. The Surcefors Some of the antient Mazices and Banturari might have had ZiCES and Their Dwellings, thus far to the Weftward.

Two Miles to the Eaftward of the Arberw, is the Tomb of siredy Abid. Seedy Abid, built upon the Southern Banks of the Shelliff. Five Miles farther, are the Ruins of Mejiddah, formerly a Roman Mejidah. Station, feated upon a rifing Ground, with the Shelliff below It. Four Miles from Mejiddah, in the like Situation, but at a Leagues Diftance from the River, is Memoun-turroy, (as They Memouncall) an old fquare Tower, formerly a fepulchral Monument of the Romans. This, like many more antient Edifices, is fuppofed by the Arabs, to have been built over a Treafure. Agreably to which Account, They tell us, thefe myftical Lines were infribed ${ }^{\star}$ upon It.

\section{** My Treafure is in my Shade,} And my Shade is in my Treafure.

Search for $I t$; depair not:

Nay depair; do not Jearch.

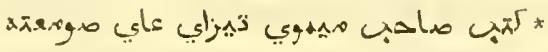

$$
\begin{aligned}
& \text { i. e. }
\end{aligned}
$$

* Prince Maimoun Tizai wrote This upon His Tower, viz.

\begin{tabular}{|c|c|}
\hline * Maily fe Thuslly & 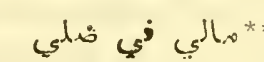 \\
\hline Wa Thully fe maily & وضلي في هالي \\
\hline Etmab la teis & ans $x$ X \\
\hline Wa teis la tetmah & وا تخس ل ليطهع \\
\hline
\end{tabular}

The Moorifh Secretary who gare me thefe Lines, added,

$$
\begin{aligned}
& \text { Hakeda keel; w' allah alim. plst xلlly hin lins } \\
& \text { So it is faid; but God beft knows how it is. }
\end{aligned}
$$

but whether thefe Words belonged originally to them, or are his own Comment, I cannot determine. 
Round about This Monument there are feveral Coffins, hewn out of maffy Blocks of Marble, in This Fafhion E. Memon and t The Ruins of Memon and Sinaab, formerly two contiguous sinaab. Cities, are ftill five Miles farther upon the Banks of the Shelliff. The latter, which I judged to be three Miles in Circuit, is by far the moft confiderable; though I faw Nothing more of It than large Pieces of Walls, and feveral capacious Cifterns. The Souk el Hameefe (or Thurfday's Market) is kept in the Neighbourhood of It.

$\underset{\text { Wann-nafl- }}{\text { reefe or } Z A_{-}}$Wan-nafo-reefe, the Gueneferis of Sanfon, and the Ganfer

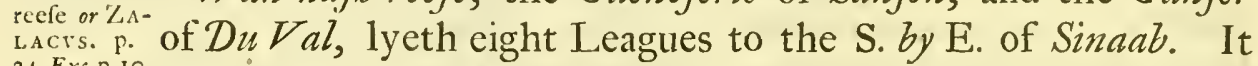
${ }_{\text {D. Ex.p.10. }}$ is one of the moft noted Land Marks of This Country, diftinguifhing Itfelf all the Way, from El Callab to Medea, over a Number of leffer Mountains, ranged far and near about It : but Edrift muft have been mifinformed concerning the Length of It. Wan-nafb-reefe, from being in the fame Meridian with $\mathcal{D}_{a}$ bmu/s,

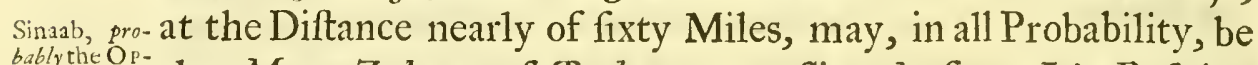

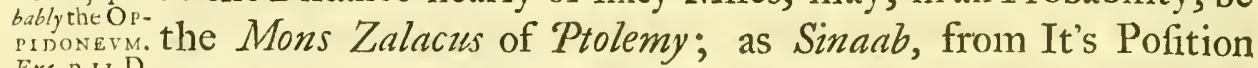
Exc. p.r.D. feven Leagues to the Northward ofIt, fhould be His Oppidoneum. Tifum-fee-
ly or BiN- $\quad$ Thirty Miles to the S.S.E. of Wan-nafb-reefe, upon the Bor-

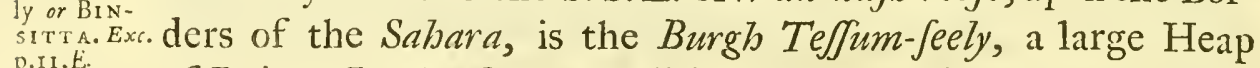
Pucke-reah, of Ruins. In the fame Condition and Direction, twenty Miles

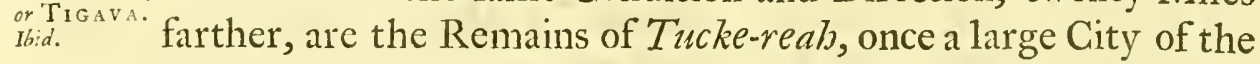
Gretulians. Binfitta and Tigava are placed by Ptolemy in This Situation.

Midroe. The Dafjkrah of Midroe, with an adjacent Rivulet, is fix Leagues to the Southward of Tucke-reah; and in the fame Diftance and Situation from Miaroe, are the Northern Limits The Lowat of the Lowaat and Ammer, both of Them powerful Tribes and Ammer. of Gretulians. The high and rugged Mountains of the Latter, The Monn- where the River Adge-dee hath It's Fountains, begin to diftin-
tains of the tains of the
Ammer , ge guifh themfelves in This Situation. Thefe, fucceeding imme-

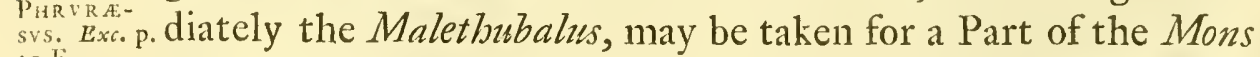
10.E. Phrurcelus of Ptolemy.

Tinulga. In returning to the correfpondent Part of the Shelliff, and leaving the River Fuddah one League to the Weftward, we pafs by the high Mountain of Tmulga. Upon the Banks of the Shelliff below It, are the Ruins of a little Town of the fame Name. The Brook Four Miles farther is the Brook Roo-ena, with the Ruins of Roo-dee-my. Ze-dee-my, another fmall Town, upon the Eaftern Banks of It. 


\section{Of the Weftern Province.}

+ El K'bada-rah, the Chadra of Edrifi', is the next remark- El Khadaable Place in This Situation, lying thirteen Miles only in a direct Line from the River Fuddah, though as much more in the Courfe of travelling. It is fituated, like Mejiddah, upon a rifing Ground, on the Brink of the Shelliff; and is equal to Sinaab in Extent of Ruins. A Range of Mountains, rifing immediately from the oppofite Banks of the Shelliff, fhelter It from the N. Wind; whilf Fibbel D wee, another high Mountain, at a Miles Diftance, fronting It from the S.E. fupplyeth the beautiful little Plains between Them, with a plentiful Rill of Water. The perpetual Verdure of Thefe Plains, may, in all Probability have communicated Their own Name of [celvill El Chubd-ary] The or the Green, Green to thefe Ruins, though the Rank and Figure It muft have formerly held among the African Cities, could well entitle It to another Etymology, from Chadra [ הาsח] The Town, as It might have been called by Way of Eminence. The Epitomizer of Edri/2 feems to have underftood His Chadra in the former Senfe: but if we could receive the latter Interpretation, It would probably be a ftronger Argument for fixing the Oppidoneum here, than at Sinaab, according to the Tenor of 'Ptolemy's Tables. The Itinerary certainly, in laying down only a Diftance

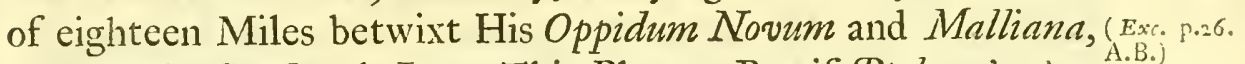
very obvioufly fixeth It at This Place. But if Ptolemy's Au-

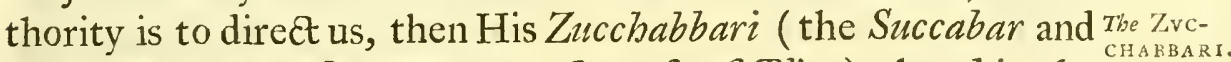

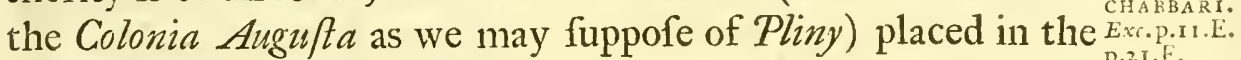
fame Lat. and so' to the E. of Oppidoneum, will better agree with This Situation. Fibbel Dwee likewife, upon the fame Suppofition, may be taken for the Mons Tranfcellen/is, which, according to Ammianus ${ }^{2}$, hung over It.

A few Paces to the $\mathrm{E}$. of Thefe Ruins, are the Remains of $\begin{gathered}\text { The Store } \\ \text { Bridge. }\end{gathered}$ a large Stone Bridge, the only one perhaps that was ever built over the Shelliff, notwithftanding the great Inconveniences Travellers are fometimes put to, efpecially in the Winter Seafon, of waiting a whole Month before They can ford It.

The Inhabitants of This Part of the Country, to the Eaftward Yhimnah, $_{\text {Then }}$ of the Sweede, and on This Side the Shelliff, are firft the Beni

I Egredicris ex urbe $T_{\text {enes, }}$ procedefque fpatio jufte ftationis ad filios Vazelefn, montes horridos, rupefque frequentes. A filiis Vazelefn ad Chadra [i.e. viridem] habes item ftationem. Et à Chadra ad urbem Miliana ftationem: \& tertia ab hac die, ex parte meridionali, cxtat mons Vanaferis diatus qui langitudine explet iter quatridui, attingit enim extrenitatibus fuis loca propinqua Tabart. Geog. Nub. p.8I. 2 Converfus hinc ( $f c$. a Cafarea) venit ad municipium Sugabarritanum Tranfcellenfi monti adcline. Ammian. Marcelliwas 1.29. c.5.

P 2

rimnah, 
Yimnah, who, roving betwixt the Southern Parts of the River Arbew and the Meridian of Wannafbreefe, extend Their EnBeni Mida, campments as far as the Beni Mida, who border upon the $S a$ bara. Below the Beni Yimnah, near Mejiddah and Sinaab, are Welled Spai- the Welled Spaibee; and a little to the Southward of Their hee,
Welled Uxe- Donwwars, are Thofe of the Welled Uxeire, who have the Beni ire, Yimnab, and the Mountain of Wannafbreefe to the South. The Latar; Lataff lye beyond the River Fuddah, at Tmulga, the Brook Roo-ena, and El Khadarab; and to the Southward of Them, near Ti/fum-feely, and the correfponding Part of the Shelliff, Welled Bco-are the Welled Boo-Samm, and I-aite. The Azeeje, the Arabs Welled 1-ai- of This Part of the Sabara, rarely wander to the N. of the Shelte, Azcefi, Mendill, the Jendill, the Naff. The Matma-ta, a factiousclan, with the Mountains of that Succeffors of Name, lye to the N. and N.E. of the I-aite; Wannaforeefe, at forty Miles Diftance, terminates Their Profpect to the Weftward. Below Them are the Fendill, who fpread their Encampments from the Curve of the Shelliff into the fine Plains before Maliana.

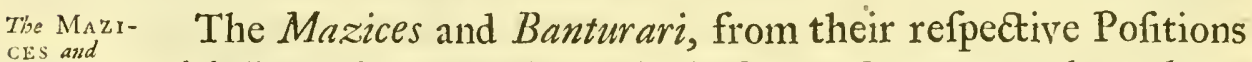
$\mathrm{CES}$ and
BANTVRARI. Exe. P.II.A. with Regard to the Mountain Zalacus, feem not only to have been poffeffed of the Country belonging to Thefe Tribes, but likewife of the Diftricts of the Sweede, Welled Booker and Haleef, that were already taken Notice of to the Weftward.

The Country \&c. to the $N$.
of the Shel- of the Shelliff, and which lyeth within the Meridians of the Ri-

The correfponding Part of This Country to the Northward lif: ver Arbew and Maliana, is poffeffed chiefly by Kabyles; who, from the Advantage of Their rugged and inacceffibie Mountains, have not hitherto fubmitted to the Turks. Tnifs and The Beni Ma- Sher/hell, which can be eafily annoyed by Sea; the Beni Madoony, Wel-
led ,airifs,
Beni Raflid, doony, Welled Fairifs, Beni Rafbid, and the People of Merjejah, Beni Raflfid,
s. Merjeje, who, having Their refpective Dwellings and Encampments over tributary to againft the Welled Spaibee, Uxeire, and Lataff, are every Summer expofed to the Pillage of the Turkifh Armies; (thefe I fay) are the only Communities brought under Subjection. Of the The Shiffa, independent Families; the Shirfa encamp to the Eaftward of the Welled Boofreed, and to the Northward of Mazouna: The $\mathrm{fa}_{\mathrm{f}}$, lled Ma-Welled Mafa and Gorya fucceed the Shirfa, having the MounGorya, tains of Merjejah, and of the Beni Rafbid to the South: The Lathaa, Larbaat lye over againft El Khadarab, near the Banks of the 
Teffsert; after which are the Gurbies, (as They call the Mudwalled Hovels ) of the Beni Yifra, and Beni Menafer, the In-Beni Yifra, habitants of the mountainous Country betwixt Maliana and fert, MenafSher/bell. The Boobalwan are met with ftill farther to the Boolalwan, E. near Hammam Mereega, and the Banks of the Wedjer: who dent Tribeses. likewife cultivate the rich hilly Country adjoyning to the Weftermoit Part of the Mettijiah. Thefe, in Conjunction with the Tre MacruMagrowah, and Their neighbouring Tribes, may probably in $\begin{gathered}\text { sil. E. Exc. } \\ \text { nid. }\end{gathered}$ herit the Country of the antient Machusir. F.55.

Merjejah, a mud-walled Village, is one of the Communities Merjejal. under the Turkif/s Yoke. It hath a high Situation, three Miles over againft, and in View of Sinaab, but is only remarkable for being under the Influence and Protection of a Family of $M a$ rabbutts, the greateft of This Country, who have fucceeded one another from Father to Son, through a Number of Ages and Defcents.

Beni Ra/bid, the Beni-Arax of the modern Geographers, is Beni Rallid. in the fame rugged Situation and miferable Condition with Merjejal. It lyeth eight Miles to the E. by S. of Merjejah, and two Miles N. of the River Fuddah, a Pofition quite different from what Sanfon and $\mathcal{D}_{u} V a l$ give It, to the S. or S. W. of Mafagran. This Place ${ }^{*}$ made fome Figure in former Ages, having had a Citadel, two thoufand Houfes, and a Race of warlike Inhabitants, who commanded as far as El Callah and Mafcar. But at prefent, the Caftle is in Ruins, the two thoufand Houfes and the large Territories are reduced to a few Cottages; and the People, from a like Courfe of Obedience, with their Neighbours, to a jealous and fevere Government, are become equally timorous and cowardly. However their Figs and Fruit, for which they were always famous, continue in the fame Repute, difputing Size and Delicacy of Tafte with Thofe of the Beni Zerwall. Marmol maketh This Place the Villeburgum, or Villa Vicus, and Sanfon, the Bunobora of Ptolemy; but the firft lying to the W. of the Portus Magnus, and the latter to the W. of Cartenne, neither of Them, I prefume can pretend to fuch a Situation.

I Atl.Geogr.Vol.IV.p.2ro. Extendit fefe Regio Beni Rafbid orientem verfus in longum 50 , in latum vero 25 fere millia paffuum. - Reperias in montibus illis aliquot pagos, atque inter hos duo funt præcipui,quorum alter Chalhat Haoara eft appellatus, in montis cujufdam colta ad arcis modum fabricatus; mercatorum atque artificum domos circiter quadraginta numerat: altcr vero Elmo Hafcar nuncupatur. 7. Leo. p. I96,7. 

to El Herba, formerly a Roman City, more than a Mile in Circuit. It is fituated upon the Brink of the Shelliff, two Leagues to the E.S.E. of the Village of the Beni Rafbid, having a narrow Strip of plain fertil Ground to the Northward. Here are feveral fmall Marble Pillars, of a blewifh Colour and good Workmanfhip, but the Capitals, which were of the Corintbian Order, are defaced. There are befides, feveral Tombs like Thofe at Memounturroy; and upon One of the Covers, fcouped, at the Top of It, in the following Fafhion, we have This imperfect Infcription.

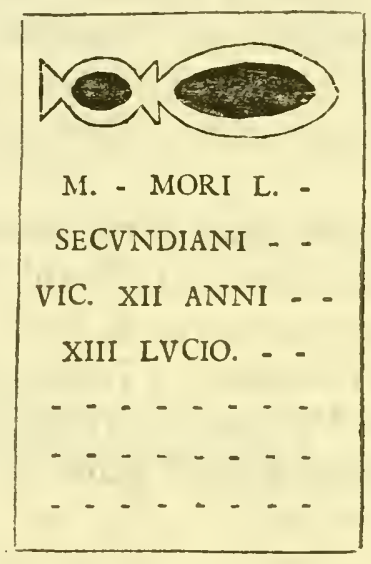

El Herba. Seven Miles to the E. of El Khadarah, at a little Diftance from the Shelliff, we have the Ruins of another Roman Town, of the fame Name and Extent with the former. Here the Shelliff begins to wind Itfelf through a Plain, not inferiour, in Extent and Fertility, to any of This Country: the Mountains likewife of Atlas, which, from the Beni Zerwall to El Khadarah, hung immediately over the Shellif; retire now two Leagues to the Northward.

Maniana, or + Maniana or Maliana, as It is indifferently called by the MANAYA Inhabitants, is fituated upon Thefe Mountains, half a Mile above . B. B. D.P.26. expofed to the S. and S. W. promifing a large Scene of Buildings and Antiquities at a Diftance; but the Fatigue of climbing up to It, is badly recompenfed with the Sight only of a fimall Village, whofe Houfes are covered with Tiles inftead of Terrafs, according to the ordinary Practice of the Country, How- 


\section{Of the Weftern Province.}

ever, if the Accefs to It was lefs troublefome, Maliana hath feveral Things to recommend It; being in the firft Place exceedingly well watered to the N.W. from Fibbel Zickar, having round about It a Number of Gardens and Vineyards, and enjoying befides a moft delightful Profpect of the Country of the Fendill, Matmata and other Arabs, as far as Medea. In the Spring, the Devotees of Algiers, Bleda, and the neighbouring Country come, with great Reverence, to kifs the Shrine of Sede Youseph, the tutelar Saint of This City.

There are feveral Fragments at Maliana of the Roman Ar- Fragnents of chitecture: and in a modern Wall, made up of Thefe antient dings. Materials, we have a Cippus with the following Infcription; which if we may fuppofe to relate to Pompey's Family, Martial's fine Thought upon Their Misfortunes ${ }^{\mathrm{r}}$, will receive an additional Force and Beauty from what we find Here, that His Grandfon* and probably Great Grandfont were buried at This Diftance from Their Anceftors, and in fuch an obfcure Place.

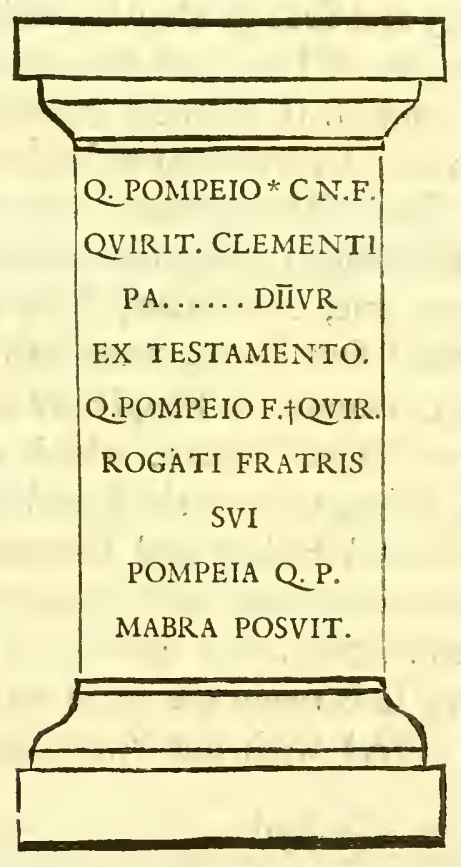

I Pompejos fuvenes Afia atque Europa, fed ipfunim

Terra tegit Libyes: fi tamen ulla tegit.

Quid mirum toto fispargitur orbe? jacere

Uno non poterat tanta ruina loco.

\section{Epig. 1.V. Ep.75.}

Q2 


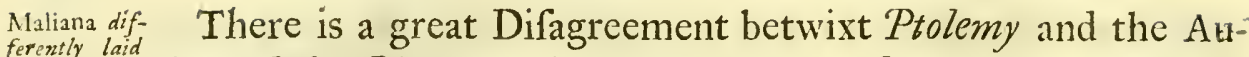
ferently laid down pro-thor of the Itinerary, in the Situation of Their Maniana, or linerrary. Malliana. For the firft placeth It Io'. to the Weftward of the Oppidoneum or Oppidum Novum, and the latter eighteen Miles to the Eaft. Nay Ptolemy maketh a Difference of near $4^{\circ}$. or 230 Miles in Their Latitudes. The Name then (which may be fuppofed to have been inviolably preferved) with a Prefumption that the Malliana of the Itinerary is the fane with the Maniana of Ptolemy, are the only Circumftances to determine us: which, at the fame Time They prove the Montes $G a$ raphi to be our Fibbel Zickar, thew us the great Errors that may have crept into Ptolemy's Tables; inafinuch as, by Them, we Exc.p.ro.1r.are to look for Maniana and the Montes Garaphi, at, I know not how great a Diftance, in the Sabara.

The Hammam Mereega,

The AQVE $C_{A L I D A}$ Col. Exc. p.12.A.

Eight Miles to the E. N.E. of Maliana, at nearly the half Way betwixt the Shelliff and the Sea, are The [Hammam] Batbs of Mereega, the Aque Calide Colonia of the Antients: The largeft and the moft frequented of Them, is a Bafon of twelve Foot fquare, and four in Depth: and the Water, which bubbles up in a Degree of Heat juft fupportable, after It hath filled this Ciftern, paffeth to a much fmaller one made ufe of by the Fews, who are not permitted to bathe in Company with the Mabometans. Both Thefe Baths were formerly covered with a handfome Building, having Corridores of Stone running round Their Bafons; but, at prefent, They lye expofed to the Weather, and, when I faw Them, were half full of Stones and Rubbifh. A great Concourfe of People are ufually here in the Spring, the Seafon of Thefe Waters: which are fuppofed to remove Rheumatick Pains, to cure the Jaundice, and to alleviate moft other inveterate ill Habits and Diftempers. Higher up the Hill, there is another Bath, of too Intenfe a Heat to bathe in: which is therefore conducted through a long Pipe into another Room, where It is made ufe of in an Operation ${ }^{2}$ of the Same Nature and Effect with our Pumping.

I Afperfionem in Balneis naturalibus Ducciam appellant. -.- Sunt crgo in Balneis, qux ad hunc ufum probantur, conftitutx fiftulx - qux digiti parvi magnitudine vel majori, ubi opus eft, volubili epiftomio claufx; è fuperiori alveo, qui infixas ex ordine habcat fiftulas, ac itatim a communi fonte finceras recipiant aquas, pro co ac quifquam voluerit, vel quantum voluerit, reclufo epiftomio, vel claufo infundant ftillicidium. Delabuntur autem fic aqux palmi unius, vel ad fummum cubiti fpatio, unde ex infultu convenientem faciant impreffioncm; vel in Balneum, vel in fubjectura ad cas recipiendas alveolum. \&c. Baccius de Thermis lib.z. cap. 16. 


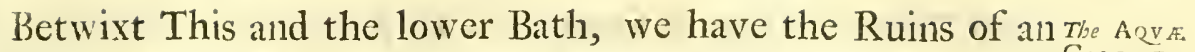
old Roman Town, equal to that of El Herba; and at a little Col. Exxce. Diftance from Them, there are feveral Tombs and Coffins of ${ }^{\text {p.r. } 2 . A . ~}$ Stone, fome of which, I was informed, were of an unufual Bignefs. Muzeratty, the late (Kaleef $a$ ) Lieutenant of this Province, affured me, that He faw a thigh Bone belonging to one of Them, which was near two of Their Draas or thirty fix Inches, in Length; the like Account I had from other Turks, who pretended, at the fame Time, to have meafured It. But when I was at Thefe Baths, half a Year afterwards, I could not receive the leaft Information about It: and the Graves and Coffins that fell under my Obfervation, were only of the ufual Dimenfions. However, the People of This, as well as of other Countries, are every where full of Stories and Traditions of This Nature'; which, provided Thefe fhould not be human Bones, (and the Africans are no nice Diftinguifhers) we may poffibly account for, from a Cuftom, that I have fome where read of, anong the Goths and $V$ andals, which might pafs over with Them into Africa, of burying the Horfe, the Rider and their A rmour together in the fame Grave. Long Swords, with large Handles in the Shape of a Crofs, have been often found in This Country: of which Sort, there is one ftill preferved in the Dey's Palace at Algiers, not many Years ago dug out of the Ruins of Temendfufe, the Rufgunice Colonia of the Itinerary.

The Country round about Thefe Baths, is made up of a Succef- The Plains of fion of exceeding rugged Hills and deep Valleys, each of Them jiah. in It's Turn very difficult and dangerous to pafs over. Yet this Danger and Fatigue is fufficiently anfwered, by our being conducted afterwards through the rich and delightful Plains of the Mettijiah, lying beyond Them to the Northward. Thefe are

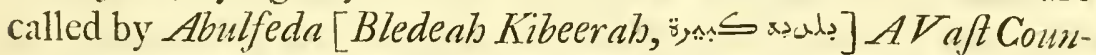
try, being near fifty Miles long and twenty broad, watered in every Part by a Number of Springs and Rivulets. The many Country Seats and [Ma/bareas] Farms of the principal Inha- Tbe Frrms or bitants of Algiers, are taken out of Thefe Plains; it being chiefly ${ }^{\mathrm{M}}$ t.

I Agricola incurvo terram molitus aratro,

Exefa inveniet fcabra rubigine pila:

Aut gravibus raffris galeas pulfabit inanes,

Grandiaque effoffis mirabitur offa Sepubchris. Virg.Georg.I. 1.494.\&c.

2 Giazaïer Mizghannan fita ad littus maris, eft admodum populofa \& mercatores lucri ad-

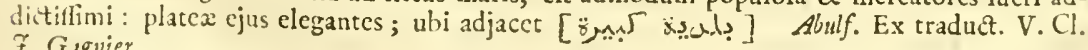
f. G.rgnier. 
from Them the City is fupplyed with Provifions. Flax and Al Henna, Roots and Pot-herbs, Rice, Fruit and Grain of all Kinds, are produced here to Perfection. Yet I am to obferve, that only the Hadjoute, ( as They call the Weftermoft Part of It) belongs properly to this Province; the reft, lying bounded by the Rivers Ma-Saffran and Budwowe, being claimed by the Southern Province, which I am now to defcribe.

ว

\section{H A P. V.}

Geographical Obfervations upon the Sea Coaft of that Part of the Mauritania Cæfarienfis, which is called at prefent the Southern Province, or the Province of Titterie. The General
Defcription of This Province. H is Province, which lyeth bounded to the Eaftward by the River Booberak, is much inferiour to the Weftern in Extent; being fcarce fixty Miles either in Length or Breadth. Neither is the Jurifdiction of the Viceroy, as extenfive as His Province. For the Superintendency of the Mettijiah, and of the fertil Country near the Banks of the TifJer, belong to particular Kaides, who are under the immediate Appointment and Direction of the Dey of Algiers. Neither is This Province, in general, fo mountainous as the Weftern. For the Sea Coaft, to the Breadth of five or fix Leagues, the Seat formerly of the The sea Coaff antient Machurebi, is made up chiefly of rich champain Ground: formerly fof for behind which indeed we have a Range of rugged Mountains, MACHUREBI.Exc.p.rI. B.

Province: but beyond Them, in the Neighbourhood of $M e$ dea, the Titterie Dofh, the Wed Afbyre, and particularly at And the mid-Hamza, the antient Territories, I prefume, of the Tulenfii and by the Tu- Baniuri, we have other extenfive Plains; though none of Them LENURI, Ba are equal to Thofe of the Mettijiah. To the Southward again of Thefe Plains, from Sour Guflan to the Titterie Dofh, the Country begins to be mountainous; but from the Titterie Do/h, towards the Burgh and the Frontiers of the Weftern Province, there appeareth to be a more eafy and commodious Accefs into the Sabara. And in This Situation were the Habitations perhaps of the Machures; as fome of the Salampfii and Malchubii inight 


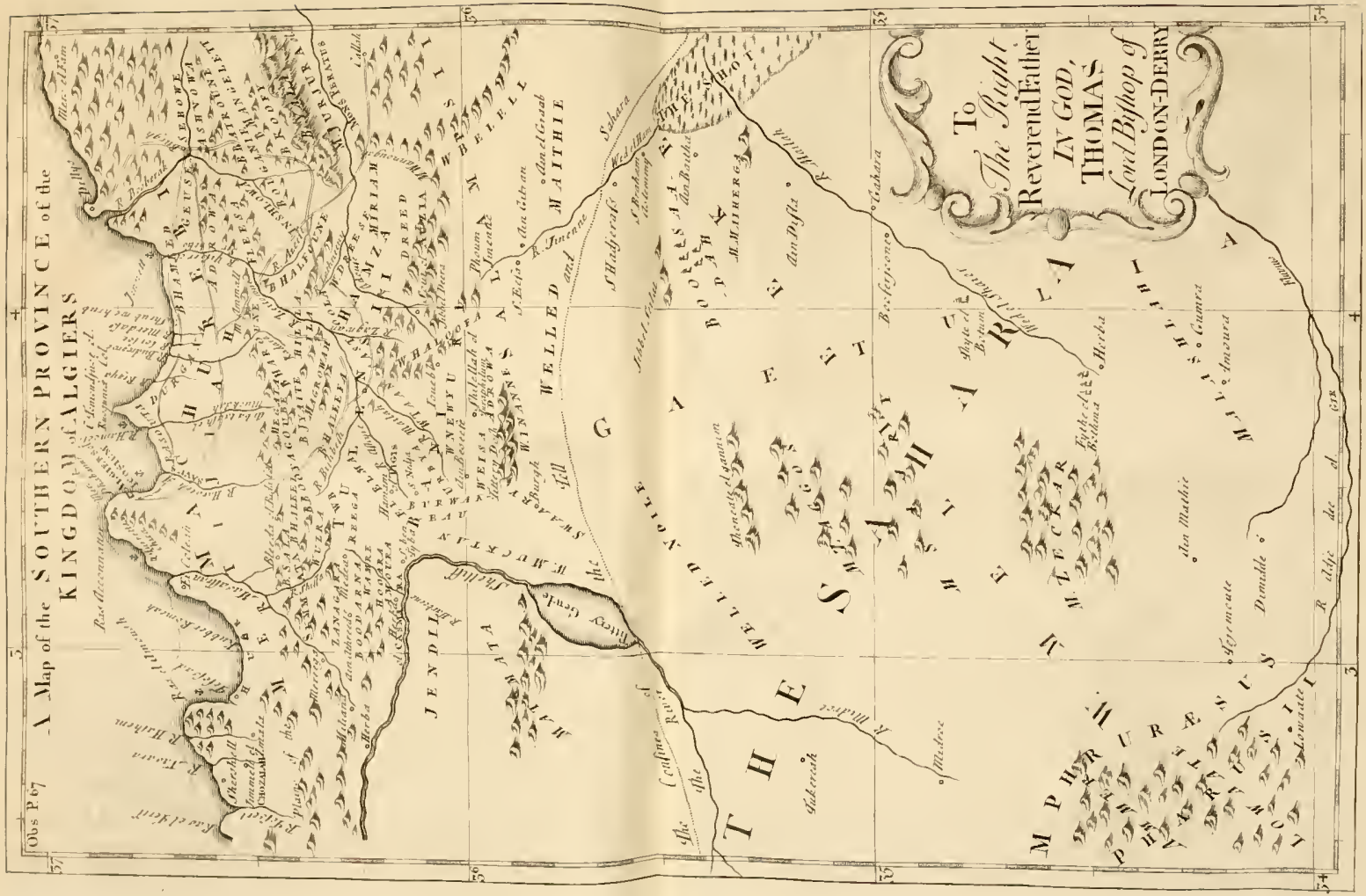



might lye ftill farther to the E. beyond the Frontiers of This Province.

I take that particular Chain of Mountains, which lyeth be- The Mowntween the maritime and midland Plain-Country, to be the Continuation of Mount Atlas. We have a full Profpect of Them all along the Mettijials; efpecially from the Hills in the Neighbourhood of Algiers. At the River Zeitoune, They begin to turn towards the S. E. and, joyning Furjura, alter Their Direction, and tend more to the Southward. In This Pofition They are continued through the Mountains of Wan-nougah, and; uniting afterwards with Fibbel I-aite, begin once more to run parallel with the Coaft.

A Few Miles to the N. N. E. of the Ma-faffran, the Turretta Weftern Boundary of This Province, we have a round watch Chica or Tower, built upon a rocky Cape, that ftretcheth Itfelf about a p.9. E. Furlong into the Sea. It is known in fome modern Sea Charts by the Name of [Turretta Cbica] The little Tower, but the Moors call It Seedy Ferje from the Name of the Marab-butt, who is there interred. Within the Cape there is a fmall Creek, with a little Bay on each Side of It, where Veffels fometimes put in for fhelter againft ftrong Eafterly Winds. We have at This Place fome few Walls and Cifterns of Roman Workmanfhip, which, by the Order of the Tables, may lay Claim to Ptolemy's Via. We meet with feveral Pieces of a Roman High Way betwixt Seedy Ferje, Ras Accon-natter and Algiers; and near the Tomb of Seedy Hallif, another Marabbutt, about the half Way betwixt Seedy Ferje and Algiers, we fall in with a Number of Graves, covered with large flat Stones, each of Them big enough to receive two or three Bodies.

The high Mountain of Boojereah, with It's three contiguous Boojereah. Dafbkras, are nine Miles from Seedy Ferje to the N. E. and about half a League from Them, to the W.N.W. is the Ras Ras AcconAccon-natter, the Cape Caxines of our modern Sea Charts. Be-Cape Caxifides a Fountain of good Water, we have likewife at This Place ${ }^{\text {ncs. }}$ fome Ruins, with the Traces of a fimall Aqueduct, that might formerly conduct a Part of the Water towards Seedy Ferje or Via. Edrifi fituateth His Hur' betwixt This Promontory and the Edrifis Hur.

I A Promontorio Battal incipit continens $H_{u r}$, qux per lineam rectam extenditur plufquam XL M. P. arcuatim vero LX. Tota hæc ora profundiffma eft, \& qui in eam labitur, nunquam evadit. Ab extremitate continentis Hur ad Infulas filiorum Mazaghana, XIII. M. P. Googr. A $u b$. p. 86 .

R 2

Ras 
Ras el Amoufbe. The Diftance indeed is the fame, but the Navigation in the Gulf betwixt Them, is not fo dangerous at prefent, as it is reprefented to be by That Author.

The Port of The [Mers' el [ [ ن $]$ Dhabanne $]$ Port of Flies is half a League Flics. to the Eaftward of the Ras Accon-natter; after which, directing our Courfe, for the Space of three Miles, towards the S.E. we turn into the Port of [Al Fezeire al Gazie or [ zie] A LGIERs ThE WA R L I E, as the Turks are pleafed to call It.

ALGIERS THE WARLIKE.

+ This Place, which for feveral Ages hath braved the greateft Powers of Chriftendom, is not above a Mile and a half in Circuit, though computed to contain about 2000 Chriftian Slaves, I5000 Fews, and rooooo Mabometans, of which only thirty rbe situation (at moft) are Renegadoes. It is fituated upon the Declivity or Ir. of a Hill, that faceth the North and North-Eaft; whereby the Houfes rife fo gradually above each other, that there is fcarce one in the whole City, but what in one or other of thofe Directions, hath a full View of the Sea. The Walls are weak and of little Defence, unlefs where They are further fecured by fome The Walls and additional Fortification. The Caffaubah, which is built upon
Fertiffeations. the higheft Part of the City, and makes the Weftern Angle of It, is of an octogonal Figure, each of the Sides in View having Their proper Port-holes or Embrafures. The North-Angle near [Bab [بl] el Wed] The Gate of the River; and the SouthAngle near $B a b A z$ oone', are each of Them guarded with a funall Baftion. [Bab [use] Fiddeed] The new Gate, lying betwixt $B a b$ Azoone and the $C a \int f a u b a b$, hath a fquare upright Battery: and betwixt the Caffaubab and Bab elWed, there are a few Jettings out of the Wall, with Port-holes, but with few or no Cannon belonging to Them. The Ditch, which formerly furrounded the City, is almoft entirely filled up, except at $B a b$ el Wed and Bab Azoone: where likewife It would be of little Confequence and Defence.

The Fortifica- From Bab el Wed and Bab Azoone to the Caffaubab, the the Walls. Diftance each Way is about three Furlongs, in an Afcent of fifteen or twenty Degrees. Betwixt Bab el Wed and the fandy Bay that lyeth a Furlong from It to the N. W. is the Caftlc of Sitteet Ako-leet, built for the moft Part in a regular Manner, and very capable of annoying an Enemy both in Their landing, and

I Ce fut par la Bab-Aazon que la Ville d'Algier fut aftegée par Aazon Prince de Mauritanie, \& cette Porte a retenue fon Nom Memoirs, du Cheralier D'Arvienx. Tom.s. p.220. 


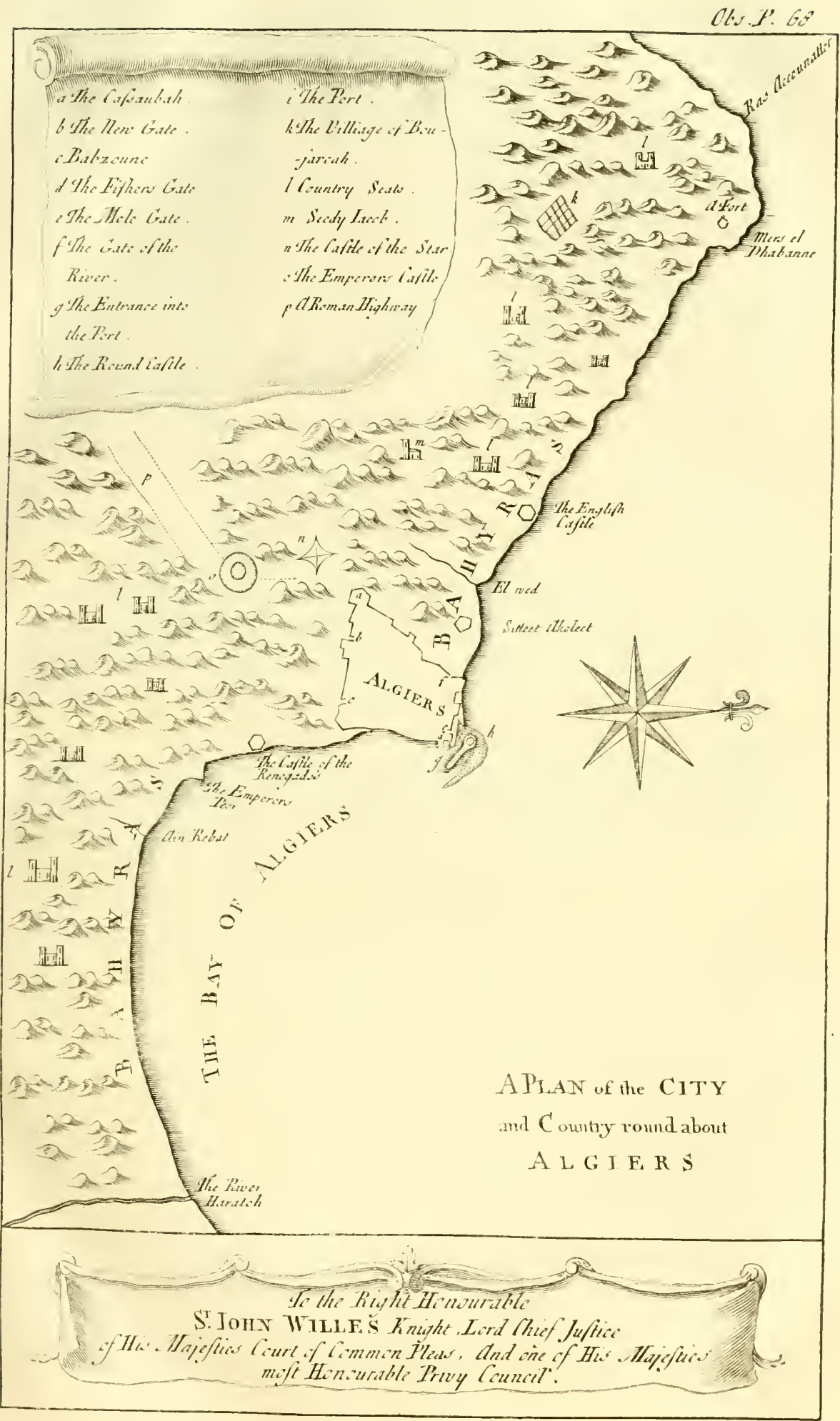



in lodging Themfelves afterwards in the Ba-byras, as They call the adjacent Plains and Gardens. Half a Mile to the W. of $B a b$ Azoone is the Ain Rebat, where there is likewife another fan-Ain Rebat dy Bay with Ba-byras: betwixt which and Algiers the Road is more ftraight and rugged than at $B a b$ el $W e d$, though in the narroweft Part of It, thirty Men may march in Front. There is alfo a Caftle for the Security of This Road, but inferiour, both in Strength and Extent, to that of Sitteet Akoleet.

Both Thefe Bays, with Their refpective Ba-byras are over-Aridge of looked by a Ridge of Hills, lying nearly upon a Level with the Caflles CaJ $a u b a b$. Two well built Caftles are placed upon It; one of which, called from It's five acute Angles, The Caftle of the Star, is within a Furlong of the Caffaubah and commandeth the fandy Bay and Ba-hyras at Bab el Wed: the other, called The Emperour's Caftle, at half a Mile's Diftance, hath a full Command of the Ridge, the Caftle of the Star, and the fandy Bay and $B a-$ byras towards Ain Rebat.

Beyond the Ba-byras of Bab el Wed, as far as Ras Accon-Where natter, the Shore is made up of Rocks and Precipices: but to Charles V. the Eaftward of Algiers, from Ain Rebat, round a large Bay to Temendfufe, the Shore is acceffible in moft Places. The E.mperour Charles $V$. in His unfortunate Expedition A.D. MDXLI againt This City, landed His Army at Ain Rebat, where there ftill remaineth a Fragment of the Peer, fuppofed to have been erected for that Purpofe. The better likewife to fecure a Correfpondence with His Fleet, and to fuccour His Troops in Their intended Approaches towards the City, $\mathrm{He}$ poffefled himfelf of the Ridge l have been defcribing, where $\mathrm{He}$ laid the Foundation and built the round or inner Part of the Caftle, that continueth to be called after His Name.

Such is the Strength and Situation of Algiers to the Land- The Fortificaward. But towards the Sea, we fhall find It better fortified and the seave capable to make a more ftrenuous Defence. For the Embrafures, in This Direction, are all employed: the Guns are of Brafs; and Their Carriages and other Utenfils in good Order. The Battery of the Mole Gate, upon the Eaft Angle of the City, is mounted with feveral long Pieces of Ordinance, one of which, if I miftake not, hath feven Cylinders, each of Them three Inches in Diameter. Half a Furlong to the W.S.W. of the Harbour, is the Battery of Fijher's Gate, or [Bab el Babar] The 
Gate of the Sea, which confifting of a double Row of Cannon, commands the Entrance into the Port, and the Road before It.

Th: Poit.

The Port is of an oblong Figure, a hundred and thirty Fathom long, and eighty broad. The Eaftern Mound of It, which was formerly The Ifland, is well fecured by feveral Fortifications. The Fort:fra- The Round Caftle, (built by the Spaniards whilft they were Ma-
tions of it. tions of fters of The I/land) and the two remote Batteries, (erected within this Century) are faid to be Bomb-Proof; and have each of them Their lower Embrafures mounted with thirty fix Pounders. But the middle Battery, which appears to be the oldeft, is of the leaft Defence. Yet it may be obferved, as none of the Fortifications I have mentioned are affifted with either Mines or advanced Works; and as the Soldiers, who are to guard and defend Them,cannot be kept up to any regular Courfes of Duty and Attendance, that a few refolute Battalions, protected even by a fimall Squadron of Ships, would have no great Difficulty to make Themfelves quickly Mafters of the very ftrongeft of Them.

The Nary. The naval Force of the Algerines hath been for fome Years in a declining Condition. If we except Their Row-Boats and Brigantines, They had A. D. MDCCXXXII only half a dozen capital Ships, from thirty fix to fifty Guns; and at the fame Time had not half that Number of brave and experienced Captains. A general Peace with the Three trading Nations, and the Impoffibility of keeping up a fuitable Difcipline, where every private Soldier difputes Authority with His Officer, are fome of the principal Reafons, why fo fmall a Number of Veffels are fitted out, and why fo few Perfons of Merit are afterwards willing to command Them. Their Want likewife of Experience, with the few Engagements They have been lately concerned in at Sea, have equally contributed to This Diminution of 'Their naval Character. However, if, by proper Difcipline and Encouragement, they fhould once more affume Their wonted Courage and Bravery, They have always in Readinefs fuch a Quantity of naval Stores, as will put Them in a Capacity of making confiderable Augmentations to Their Fleet: though, even at prefent, we find Them troublefome enough to the Trade of Europe. Fen Antigui- There is little within the City, that merits the Attention of

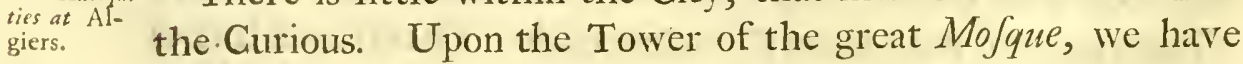
fome broken Infcriptions; but the Letters, (though of a fufficient Bignefs to be feen at a Diftance) are all of Them filled up 
to that Degree with Lime and White-Wafh, that I could never particularly diftinguifh Them. They may probably be the fame with Thofe taken Notice of by Gramaye'. The publick Buildings, fuch as are Their Bagnios, Kaflareas \&c. Their Officers, as the Mufty, Kady \&c. The Inhabitants, as Few/s and Moors \&c. have been already fufficiently defcribed by feveral Authors. The Additions therefore which I have to make, will relate chiefly to the Government, the Army, and the political Interefts and Alliances of This Regency: but of Thefe in Their proper Place.

Algiers, from the Diftance and Situation of It with Refpect AIgiers, T:e to Tefeffad, flould be the antient Icofrum, placed in the Iti-p.10.A.p.to.

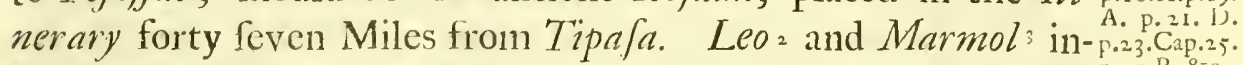

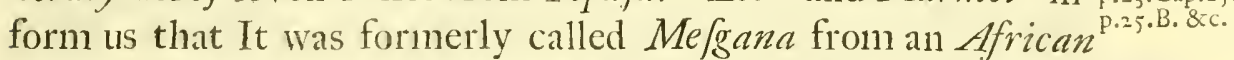
Family of that Name. The prefent Name [ Fe-zeire or $A l \mathcal{F}_{e}$-zeirah, (for fo we fhould pronounce It) figni- $11 \mathrm{Jezeire}$, fieth in This I anguage The Ifland; fo called from being in the or The IJand. Neighbourhood (not, as Leo+ acquaints us, of the Balearick Iflands, but) of the Eaftern Mound of the Harbour, which, 'till after the Time of the Turki/b Conquefts, was fevered from the Continent. In Their publick Letters and Records, They ftile It [Al Fe-zeire Megerbie] The Ifland in the Weft, to diftinguifh It from a City of the fame Name near the Dardanelles.

The Hills and Valleys round about Algiers are every where The Proffect beautified with Gardens and Country Seats, whither the Inha- of thend Contrty bitants of better Faflion retire, during the Summer-Seafon. The Algirs. Country Seats are little white Houfes, fladed by a Variety of Fruit Trees and Ever-Greens; whereby they afford a gay and delightful Profpect towards the Sea. The Gardens are well ftocked with Melons, Fruit and Pot-herbs of all Kinds; and, what is chiefly regarded in thefe hot Climates, each of Them enjoys a great Command of Water, from the many Rivulets and Fountains which every where diftinguifh Themfelves in This Situation. The Fountain-water made ufe of at Algiers, univerfally

I IVLIO CASONI. M.M. II LEG. MAVRIT. .
PRISCA F. ELIA. POS.

PTOLO. IVB. F. . P. O. MAVRIT. X. COH. IVL. M. F.
. IS RVFVS ET LETVS

P. D. ONV. MIS . .

Gram. Afr. illuft. 1.7.c. I.

2. Gefeir Afris idem atque nobis infula fonat, unde defumptum nomen putant quod infulis Majorica, Minoric atque Genife adjacet. Conditores habuit Afros, qui ex familia Mefgane originem traxerant, quare \& apud antiquos Mefgan fuit appellata. F. Leo. 3 Les Maures nomment Alger Gezeire de Beni Mofg،ne. Elle a elte baftic par de Bereberes de ce nom, fi bien que les anciens Hiftoriens l' appellent Mo/gane. Marm. 1.5. C.4I. 4 Vid.Not.2. 
efteemed to be excellent, is likewife derived, through a long Courfe of Pipes and Conduits, from Thefe Sources.

The Haratch, Four Miles to the S. E. of Algiers is the River Haratch, which rifeth behind the Mountains of the Beni Moujah; and, joyning The [Wed el Kermez] Fig-River, runs through the richeft Part of the Mettijiah. It is about half as big as the Ma-faffran and had formerly a Bridge built over It, at a fmall Diftance from the Sea. Marmol ${ }^{\prime}$ and fome later Authors acquaint us, that the Ruins of Safa, called otherwife Old Algiers, are to be feen near the Banks of It; but I could never meet with Thefe Ruins, nor receive the leaft Information about Them. This, or the Hameeje which falleth into the Sea feven Miles to the N. E. may perhaps be the Savus of Ptolemy, though neither the one nor the other anfwereth to the Latitude, which is $20^{\prime}$ to the Northward of Icofum.

or The $\mathrm{H}_{2}-$

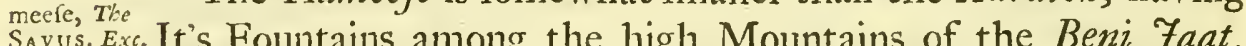
p.IO. A.

The Hameefe is fomewhat fmaller than the Haratch, having It's Fountains among the high Mountains of the Beni Faat,
eight L.eagues to the Southward. In paffing through the Diftricts of the Me-gata and El-Hbutbra, It goeth by the Name of [ Arba-taafs el Mukdab] The Fourteen Fords; and, entering the Mettijiah, is called the Hameefe, from The [ [س Souks el Hameele ] Fair that is kept every fifth Day, [or Thurfday] upon the Banks of It. Leo " calls This River Seffaia, a Word not very different from the antient Savus: but I could not be informed, that It was known by any fuch Name at prefent.

Temend- +Temendfufe or Metafus lyeth two Leagues N. of the $H a$ GUNA Col. meefe, being a low Cape with a Tabled Land, as the Marior Rusto- ners call a flat Hillock, that rifeth up in the Middle of It. UpA. or RU- on that Part of It which looketh towards Algiers, the Turks r.A.orRus-have a Imall Calle for the Security of the adjacent Road, once

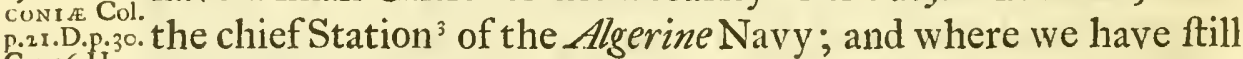
C.P. $36 . \mathrm{H}$.

fome Traces of the antient Cotbon. A Heap of Ruins, of the fame Extent with Thofe of Tefe/fad and whofe Materials have equally contributed to the raifing the Fortifications of Algiers, are fpread along This Part of the Sea-fhore. The Diftance of fif-

I Suça eft une ville dont on voit les ruines entre Algiers \& Mctafus, fur la Colte de la mer Mediterrance. Elle eft fur le bord d'une riviere (Hued el Harrax.) L'Afrique de Marmol l.5. cap. 42. Atlas Geogr. Vol.4. p.202. 2 Seffaia amniculus ex Atlante proveniens ac Metigic Planitiem Algeric vicinam afluens, juxta veruftum oppidum Temendful in mare Medierraneum fuit. F.Leo. p.286. 3 Ab Algezaier ad Tamendfas, orientem verfus, novem milliaria: eft autem Tamendfas Portus pulcherrimus. Geog.Nub.p.82. Temendfufe faris frequens hic eft Pottus, in quo Gefeir naves in tuto funt, his enim vix alius eft Portus. 7. Leo. p.204. 
teen Roman Miles, in paffing over the interjacent Bay betwixt Thefe Ruins and Algiers, is the fame we find in the Itinerary, between the Rufgunire Colonia and Icofurm.

To the Eaftward of Temendfufe, there is a large Bay, re- Tre Bay of markable for the feveral Rivers that empty themfelves into It. Turce. The Re-gia, at feven Miles Diftance from Temendfufe, runs on-The Re-gia. ly in the Winter Seafon. A little Ifland, at half a Miles Diftance, lyeth over againft the Mouth of It. The Budwowe is as big as Budwowe, the Haratch, falling into the Sea a League to the Eaftward of the Re-gia. This River when It paffeth through the rugged Mountain of the Ammall, is called by the Turks [Domus elor Domus el Wed] The River of the Wild Boar; but by the Moors and $A$ - Wedarah or Karabs, Ka-darah, from a mountainous Diftrict of that Name, where It hath It's Fountains. The Corfoe fucceeds the Bud-Corfoe. wowe; and the Merdafs the Corfoe, each at half a Leagues Merdafi. Diftance: and a little beyond the Merda/s, are the Fountains Shrub we hrub, where the Chriftian Row-Boats venture in Shrub we fometimes for frefh Water. Four Leagues from the Merdass, and about eight from Temendfufe, is the Mouth of the Yiffer, Yirfer, a much larger River than the Haratch, and which traverfeth as fruitful a Country. Some of the Sources of It are from the mountainous Diftriet to the S. S. W. where the weftermoft Branch is called Sburffa, after the Name of the Arabs; the other [Wed el Zeitoune] The River of Olives, from the great or SHUREQuantity They gather of that Fruit near the Banks of It. The el Zeiroune, Bißbe/h, A hyre, Mailah and Zagwan, fall into the Zeitoune.

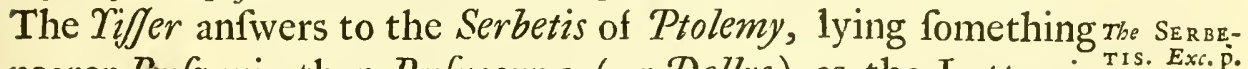
nearer Ru/gunia than Rufuccurce (or Dellys) as the Latter is $\mathrm{I0.A.}$. called at prefent.

The plain Country which bordereth upon Thefe Rivers, and ${ }_{\text {Rafrout } 3 \text {, }}^{T h s}$ lyeth betwixt the Mountains of Atlas and the Sea, is cultivated by the Rafouta, who live near the Hameefe; by the Dur-Durgana, gana and Mara/bda, who drink of the Budwowe and Corfoe; Maraflda, and by the El Fibeel, Geufe, Beni Hameed and Adrowa, who Adrowa,\&c. rove betwixt the Yiffer and Booberak. We are at a lofs for the antient Ruficibar, Modunga, Ciffe and Addume, placed by Pto- Exc. p.ro.A. lemy upon This Part of the Sea Coaft.

Finnett, from whence our Merchants fhip off a great Quantity Jinnett, or of Corn for Cbriftendom, is a League to the N.E. of the Tiffer. It is a fmall Creek, with a tolerable good Road before It; and 
Mers' el Da- was probably Edrifis' ' [Mers' el [₹:0] Dajaje] Port of Hens.

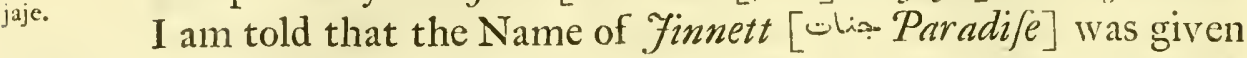
to This Place upon Account of a Row-Boat having been once very providentialy conducted within the Creek, when the Mariners expected every Moment to have perifhed. The Sea Shore, which from Temendfufe to This Place is very little interrupted with Rocks and Precipices, begins now to be rugged and mountainous: and below fome of Thefe Eminences, three Leagues farther to the E. we have the Mouth of the Booberak, the Eaftern Boundary of This Province.

The Boobe-

The Booberak hath It's principal Sources among the Znvowah, ten Leagues to the S. E. When It hath difengaged Itfelf, by a Number of deep Windings, from their mountainous Diftrict, and entreth the Se-bowe, It changeth It's Name to or Niffah, NifJah. Over againft the Burgh, It receiveth the Bugdoora, a confiderable Stream, collected from the feveral Rills that defcend from Furjura, and the neighbouring Mountains, and then continuing, for the Space of Three Leagues, to run in a wefterly Direction, turns at once, through the Mountains of the $A b$ delwairet, to the Northward, and carrieth the Name of Booberak to the Sea. I croffed This River in May, three Weeks afof the Bignefs ter any Rain had fallen in the adjacent Country, and computed oftbeShelliff. It to be equal to the Shelliff.

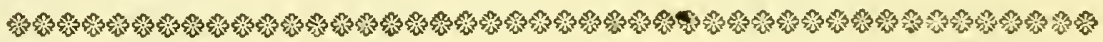

\section{H A P. VI.}

Of the moft remarkable Places and Inhabitants in the Inland Country of the Southern Province; together with the correspondent $P$ art of the $\mathrm{S}$ A H A R A.

Bleeda and Medea, The BI D A Col. and LAMI-

Reeda and Medea, the only Inland Cities of This Province, 1 are each of Them about a Mile in Circuit; but Their 1. E . Walls being made up chiefly with Mud, perforated in moft Places by the Hornet, cannot be prefumed to contribute much to Their Strength and Security. Some of their Houfes are flat roofed, others like Thofe of Maliana; with which They alfo

1. Hinc (viz. a Temedfos) ad Merfa Aldaging, milliaria viginti; habetque hec Portum fidiffimum. Googr. Nub. p.82. 
agree, in being well watered, and in having all around Them very fruitful Gardens and Plantations. A Branch of an adjacent Rivulet may be conducted through every Houfe and Garden at Bleeda; whilft the feveral Conduits and Aqueducts that fupply Medea with Water, (fome of which appear to have been the Work of the Romans) are capable of being made equally commodious. Both of Thefe Cities lye over againft the Mouth of the Ma-Saffran; viz. Bleeda at five Leagues Difance under the Shade of Mount Atlas; and Medea three Leagues beyond It, on the other Side of This Mountain. Bleeda therefore and Medea lying thus nearly in the fame Meridian, Their refpective Situations with Regard to the Ham-mam Mereega, the Aque Calide Colonia of the Antients, together with the little Alteration in Their Names, may induce us to take the one for the Bida Colonia, the other for the Lamida of Ptolemy. The Mabometan Hiftorians indeed, whom Marmol' feems to follow, are willing to have Medea of Their own Extraction, and to be named after Their Kaleef' el Mabadi: and Marmol obferveth further, that, before $E l$ Mabadis Time, It was called Elfara, a Name not very different from UJJara, another of Ptolemy's Cities in the Neighbourhood of Lamida. But UJJara feems to claim a Place at the Ruins of Ain Atbreede, a few Leagues to the Weftward. Medea hath had undoubtedly a Roman Foundation, and at moft, could have been only reftored by El Mabadi.

There is ftill remaining at Medea the Fountain taken Notice The Fountain of by Marmol $^{2}$; but I could not difcover any of the Letters, Marmol. which $\mathrm{He}$ read and tranfcribed upon the Spot. Leo feems to have intirely omitted both This City and Bleeda, which, in His Time, muft have made a fuperiour Figure to Mazouna, El Mafcar and other Cities He hath thought fit to defcribe. The Account indeed He hath left us of Medna ${ }^{3}$ the Medua ${ }^{4}$ of $M a r$ -

I Mehadie eft une ancienne ville baftie per les Romaines en une grande plaine, au deffus 'd'une haute montagne, qui eft a quinze lieües d'Alger du Coffe du Midi au dedans du pars. Fille a efté autrefois fort peuplée \& fut detruite par un Calife fchifmatique qui y baftit depuis un Chafteau nommè de fon nom Moabedin, dont la ville depuis s'eft appellée Mebedie: car elle fe nomma autrefois Alfara. C' eftoit autrefois une colonie Romaine, comme il paroilt aux antiquitès \& aux Inferiptions qui fe trouvent dans ces ruines. Il y a une vieille fontaine de Marbre ou font ecrites ces Letters.

D.

D. L. S. V. L'Afrique de Marmoi, 1.5. cap.35: 2 Vid. Not. ut fupra. 3 Medna non procul a Numidie terminis extructum, diftar à mari Mediterraneo milliaria fere 180 , in planitie quadam amxniffima, maximeque frugifera pofita eft, fluminibus hortifque fpatiofiffimis cingitur. Huic oppido præfuerunt quidam Tenez Principes, deinde BarbarofJa \&cc. J. Leo p. 20.3. 4 Medua grande Ville \& fort ancienne, baftie 
mol, correfponds in fome Refpects with our Medea; but the $\mathrm{Si}^{*}$ tuation cannot in any Manner be reconciled to It.

The Summa- The Summata, under the Protection of Seedy Braham Bata. rabeifa, are the Inhabitants of the Mountains to the Weftward of This Meridian and border upon the River Wedjer. To the

Mezzya. Eaftward are the Mezzya, who inhabit The Mountain of [Fernan, i, ] Cork-Trees. They have other Dafbkras likewife in that Part of Mount Atlas, which hangs over the Tis-moute, a noted Fountain of excellent Water. Upon the Summit of the Fernan, where we have a View of this Fountain to the N. and of Medea to the S. E. there is a Fragment of a large fquare Stone, with this broken Infcription.

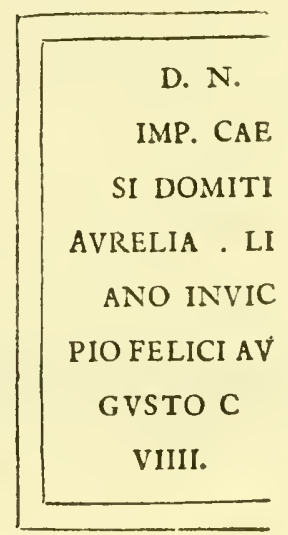

The feveral Clans upons tbis Part of Mount Atlas.
The Beni-Sala and the Beni Haleel are the principal Kabyles in the Neighbourhood of Bleeda; and to the Southward of Them are the Wuzra, where the River Shiff a hath It's Sources. To the Ealtward of the Beni Haleel and the Wuzra, are the Beni Mafoude, and the Beni Boo-Ya-goube; then follow the Beni Selim, and the Beni Haleefa, who poffefs a great Part of the plain Country, near the Banks of the Bifbbejs. The Beni Mous ab, and the Beni I-yaite are the next Kabyles; near which there is a Branch of the antient and numerous Tribe of the $M a$ growah, living in a full Profpect of the Plains of Hamza. The Zerwaila and Me-gata lye not far from The [Arbata/b el Mukdab] River of the fourteen Fords; as the Hillaila, and the Beni Haroune are fituated a little on the other Side of the Mountain

par ceux du pais dans une belle plaine fur la frontier de Getulie, a cinquante lieües d'Algier \& a foixante de Tremeren du Cofte du Lerant. Marmol. 1.5. cap.36. 
of the Ammall, not far from the River Zeitome. The Brook Lethneeny, which unites the Wed Adoufe, hath It's Springs among the Mountains of the Hillaila; and below the high and pointed Mountain of the Beni Halfoune, the Neighbours of the Ammall and Beni Haroune, the River Zeitoune joyns the $W e d$ el Azeefe, and affumes the Name of Yiffer. The Welled Azee Je, The Arabs the Arabs to the N.E. of the Beni Haroune, are fituated be-to to the $^{\text {Eables }}$ twixt the Beni-Halfoune and Mount Furjura; after which we Yrifter. of tbe have the Inflowwa, who, with the Bouganie, overlook the fertil Plains of the Caftoola. The Fleefa, the next confiderable Clan, reach from the Beni Halfoone and the Banks of the Tiffer to the River Bugdoura: and on the other Side of This River, under the Shade of Mount Furjura, are the Beni Koofy, the Beni Batroune, and the Beni Mangelett. Nearer the Sebowe, not far from the Banks of the Niffah, are the A/bnowa, Bobinoone, and Ferdewa, who are again fucceeded by the Adinee, Beni Rettin and Beni Frowfin, 'till we enter within the mountainous Diftrict of the Zwounah.

Furjura, the higheft Mountain in Barbary, is at leaft cight Monat JujiuLeagues long, lying nearly in a N. E. and S. W. Direction. It appears to be, from one End to another, a continued Range of naked Rocks and Precipices, and fecures, by It's rugged Situation, a Number of Kabyles from becoming Tributary to the Algerines. Of thefe, the Beni Alia and the Beni Sittaka are The clans of the moft noted, on the N.W. Side, towards the Beni Koofy; as the Beni Yala are, to the S. E. towards the Welled Manfoure: on which Side, near the middle, there is likewife a Pool of good Water, bordered round with arable Ground. In the Winter Seafon, the Ridge of This Mountain is covered with Snow; and it is very remarkable, that the Inhabitants of the one Side fhould carry on an hereditary and implacable Animofity with the other, whilft, by Confent, a fmall Border of Snow puts a full ftop to thefe Hoftilities, during that Seafon. Furjura, as Jurjura the well from It's extraordinary Ruggednefs, as from the Situation MONS SERof It betwixt (Rufucurium or) Dellys and (Saldis or) Boujeiah, Euxcs. C. D.2. fhould be either the principal Part, or the whole of the Mons Ferratus, taken notice of by the Geographers of the middle Age.

If we return back again to the Weftward, we fhall find to the Southward of Mount Atlas and the Summata, befides a Branch 
Boo-halwan of the Boo-balwan, the Arabs Zenaga-ra and Boodarna, with Boodarna. their Fountains Raf-elWed, Dim, and Atbreede. Thefe Tribes poffers a fine Country, made up of Hills and Valleys; and at Ain Atbreede there are the Traces of an old City.

TheDifritts of Eight Miles to the S.S. E. of the Boudarna, and at the like Wamre and Diftance to the S.W. of Medea, are the fruitful Diftricts of
Amoura. Wamre and Amoura, both of Them watered by the Harbeene. This Rivulet is chiefly collected from the Fountains of Medea; and near the weftern Banks of It, as It paffeth through AmouTherivulet of $r a$ to unite the Shelliff, there are fome confiderable Ruins wa-
Harbeene, Harbeene. tered by a plentiful Fountain. The Arabs call Them Herba, a Name common to other Places, and by which They denote Herba, the fomething $[y, ح]$ broken up or pillaged. Ptolemy's Cajmara, in

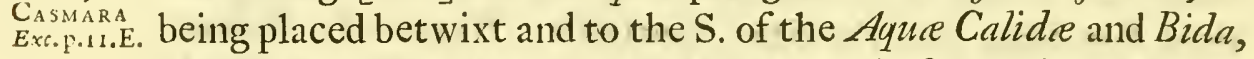
will rather agree with Thefe Ruins, than Thofe at Ain Atbreede.

The Reega, The Reega and Hooara, the Arabs in the Neighbourhood of and Hoo-ara. Medea, reach as far as Burvak-eab and the Sanctuary of Seedy Seedy Ben Ben Tyba, built eight Miles to the S. of Medea, upon the Welled Bra-eaftern Banks of the Shelliff. Welled Brabam and the Founham. tains of the Bifbefh, are three Leagues to the E. of Medea; Burwak-eah. and at the like Diftance to the S. is the Diftrict of Burquak-eah, fo named from the Abundance of The [Burwak ب, ب. Kings/pear E1 Elma. which it produceth. El Elma, are the principal Arabs of Burwakeah, whofe Diftrict is remarkable for a Hot Bath, called Herba, or Hammam el Elma, and for the Ruins of a large City known by p. 12. B. $\quad$ the Name of Herba; the Tigis probably of the Antients.

SeedyNedja. Near Burwak-eah is the Sanctuary of Seedy.Nedja and the Fountains of the Wed Afbyre or [ي:ش] Shai-er; to the Southward Urbya. of which, are the Urbya and Their Salt Pits, where the Wed el Wed el Mai- Mailab hath It's Fountains. This River is fomething brackifh, lals. and, before It joyns the Zagzwan, drinks up the Bifhbefo and Ain Be-feef the Wed Shai-er. Ain Be-feefe, lying betwixt Seedy Nedja and

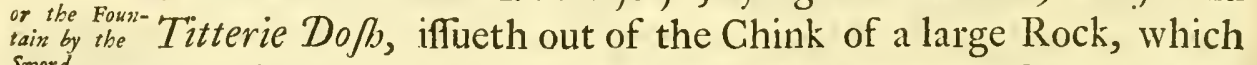
sword. the Arabs, among other foolin Stories upon the fame Subject, affirm to have been cleft by Aly, the Son in Law of their Prophet. Agreably to this Tradition, they give out that Ain [isme] Be-feefe is the fame with a Fountain that is forced or procured by the Sword.

Burgh Swa- The [Burgh Swaary] Caftle in the Diftrict of the Swaary, lyry. eth four Leagues to the S.W. of Ain Be-feefe and ten to the 
Southward of Medea. It is a frnall Fort, built upon the Skirts of the Sahara, and was, a few Years ago, one of the Frontier Garrifons of the Algerines. The Welled Muktan, the Neigh- Welled bours of the Azee/e, lye to the Weftward of the Burgh, near the Dya or Titterie Gewle, a large Pond and Mora/s formed by the The Dya or Shelliff. Three Leagues to the E. N.E. of the Burgh is the Gewle. eaftern Extremity of the Titterie Doflo, as the Turks call The Titterie

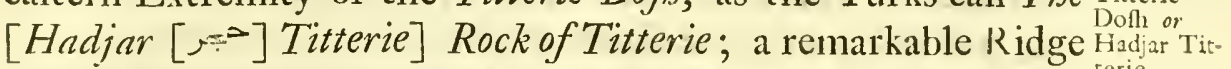
of Precipices, running parallel with the Plains of the Beni Haleefa. They are four Leagues in Length, and, if poffible, are even more rugged than Furjura. Upon the Summit of Them, there is a large Piece of level Ground, with only one narrow Road leading up to It, where, for the greater Security, the Welled Eifa have Their Granaries. Beyond the Welled Eiffa are Welled Eisa. the Encampments of the Welled In-anne, the principal Arabs of the Diftrict of Titterie, properly fo called, which lyeth in Walled Inthe Neighbourhood only of This Mountain.

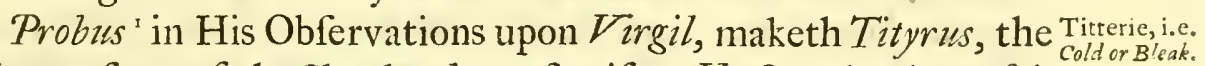
Name of one of the Shepherds, to fignify a He Goat in the African Language. The fame Interpretation, among others, is given to It by the Greek Scholiaft ${ }^{2}$ upon Theocritus. We likewife fee upon fome of the Etrufcan Medals, an Animal, not unlike a Fawn or Kid, with $[\exists \triangle \exists+\mathrm{V} \nmid]$ Tutere for the Legend $^{3}$; That particular Piece of Money being perhaps denominated, as Pecunia was from Pecus, from the Animal there exhibited. But I was informed by the People of This Diftrict, that Titterie, or Itterie, was one of Their Words for Cold or Bleak, a Circumftance indeed, which I often experienced, particularly in the Nights and Mornings, to be very applicable to This Region, and may therefore, fo far, juftify the Etymo$\log y$.

To the Eaftward of the Titterie Do $/$, are the Dounwars of the Adrowa, who are refrefhed by a Fountain of excellent Wa-Adrowa. ter. Hard by It there is a Heap of Ruins, known by the fame Shil-ellah or Name of Sbil-ellah. A League and a half farther to the E. S.E. E. are The [e $x^{-}$Merjab] Meadows of the Welled Newwy: and four Wey.ed Ne-

I Tityri \& Melibei perfonas de Theocrito fumplit (Virgilius) fed tamen ratio hæc nominum eft: Hircus Lybicâ lingud Tityrus appellatur \&c. Prob. Gramm. de Bucol. Carminis ratione.

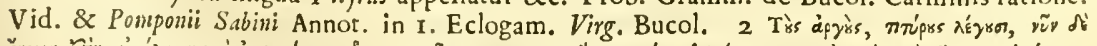

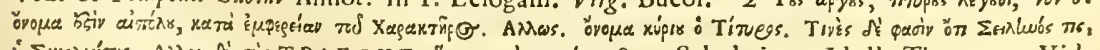

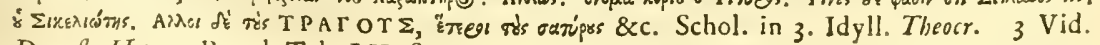
Dempft. Hetrur. Regal. Tab. LX. fig. 4 .

$$
\mathrm{U} 2
$$

Leagues 
The Kubbah Leagues from Them to the N.E. is the [ $\left.{ }^{-}-a_{0}\right]$ Kubbah ' of Seedy Habfhce. Habfhee, built upon a rifing Ground, near the Banks of the Wed el Mailah. The Beni Solyman and the Welled Taan belong to This Neighbourhood; to the Southward of which are the Arabs The Ruins Fou-ebb, with a large Heap of Ruins. Ptolemy's U/Jara, from Jou-ebb, the Situation of It in the Neighbourhood of Auzia, may be very Rke. Exc. p. well fixed at This Place: as His Turaphilum, for the fame Rea1:. C.

fon, will fall in with the Ruins at Shil-ellab.

The River Three Leagues to the Eaftward of the Kubbah, is the River Caitoola. Zagrvan, well known to a Branch of the Caftoola. It hath It's Welled Ha- Fountains among the Welled Haloofe, who inhabit properly
loofe. the mountainous Diftrict to the Southward, but fometimes wander as far as Fibbel Deera. Before the Zagzwan joyns the Zeitoune, It receiveth the Wed el Mailab.

The Plains of Leaving the Caftoola, we enter upon the rich and extenfive Plains of Hamza, which, reaching as far as the Mountains of The Arabs of $W$ annougah, are cultivated by $W$ elled Dreefe, Miriam, Fairah, It. Dreed, Maintenan, and other Bedoweens. Seedy Hamza, a Marab-butt of great Reputation, gave His Name to Thefe Plains; whofe Tomb is vifited upon the weftermoft Borders of Them, not far from the high pointed (Hadjar) Rock of the Magrowa.

Wod Ad- The Wed Ad-oufe, gliding along the eaftern Divifion of Thefe oufe.

Plains, receiveth feveral Rivulets: of which the two principal Jibbel Dee- ones are from Fibbel Deera. Thefe unite at about a Miles DiThe Phas- ftance from their Sources and form the Phaamab, the PhoeProemivs. mizes perhaps of Ptolemy; and upon the Neck of Land that lyExt. p. 12. B.
Burgh Ham-

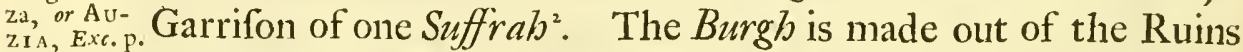
12.C. p. 26. of the antient Auzia, called by the Arabs [u, w, Sour Guflan] or Sour Gu-The Walls of the Antilopes, a great Part whereof, fortified at
llan.

proper Diftances with little fquare Turrets, is ftill remaining. The whole feems to have been little more than fix Furlongs in

I $\dot{x}_{1} \vec{j}$, Fornix, concameratum opus \& tale Sacellum. Gol. in Voce, from wubence perbaps the Cupola of the later Architects. The Marab-butts are generally buried under one of thefe Buildings, which have frequently an Oratory annexed to Them; and fometimes a dwelling Houfe, endowed with certain Rents for the Maintenance of a Number of Thul-by [Lalb] whbo are to fpend Their Time in reading and Devotion. I have often obferved, where there is an Inftitution of this Kind, that then the Place, including the Kubbah, the Oratory Coc. is called the Zwowah of futh or fuch a Marab-butt. 2 The Common Name, among the Algerines, for a Band or Company of Turkinh Soldiers, confifting for the moft Part of twenty Perfons, including a Cook, Steavird, and Licutenant : fo called, I prefume, from being fuch a Number or 9 ects, as for the Conveniency of

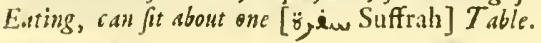

Circuit, 
Circuit, being fituated in a direct Line, eight Leagues to the S. W. of Furjura, the Mons Ferratus; fifteen to the S. E. of Algiers, the Icofium; twenty four to the S. E. by E. of Sherhell, the Iol Ceefarea; and twenty one to the W. of Seteef, the Sitifi of the Antients.

Tacitus ${ }^{1}$ hath left us a very juft Defcription of this Place. For Auzia, in a Auzia hath been built upon a finall Plat of level Ground, every tionen Sittaway furrounded with fuch an unpleafant Mixture of naked Rocks, and barren Forrefts, that I don't remember to have met with a more melancholy Situation. Menander, as $\mathrm{He}$ is quoted by Folephus ${ }^{2}$, mentions an African City of This Name, built by Ithobaal, the Tyrian: though Bochart ${ }^{3}$ feems to doubt, whether the Phrenicians were at all acquainted with the Inland Parts of Africa. Yet provided we could rely upon the Tradition recorded by Procopius ${ }^{4}$, that a Number of Canaanites fled from $\mathcal{F}$ / / $\mathrm{bua}$ into the weftermoftParts of Africa, (fome of which, upon fuch a Suppofition, might have refted at this Place) no ftrong Objection, I prefume, can be urged againft the Ruggednefs of the Situation, inafmuch as fuch an one, from the very Nature of It, would not only be the propereft for the firft Settlement of a Colony, but for the future Safety and Security of It. Due Regard might have been had to This Circumftance in the founding of Capfa, Feriana, and otherCities of Africa; whofe Founders mutt otherwife be fuppofed to have made an improper Choice, provided They were guided by any other Confiderations than the natural Strength of the Situation.

I Nec multo polt adfertur Numidas apud Caftellum femirutum, ab ipfis quondam incenfum, cui nomen Auzea, pofitis mapalibus confediffe fifos ${ }^{t} l o c o$, quia vaftis circum

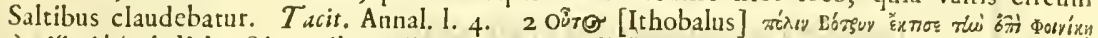

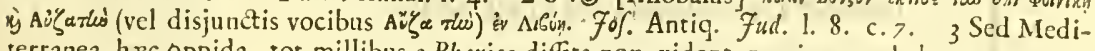
terranea hre oppida, tot millibus a Phanice diffita non videntur quicquam habere commune

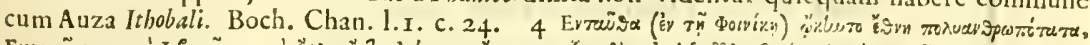

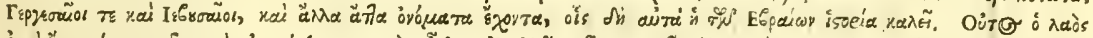

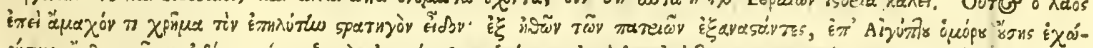

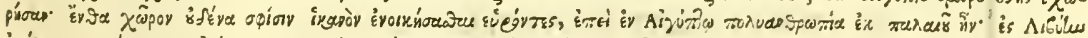

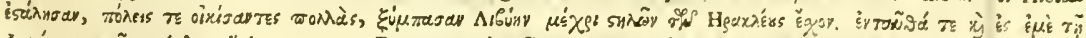

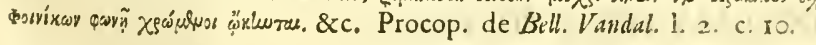


We have at Sour the following Infcriptions.

Upon a Stone adorned with Figures and Garlands.

AVZIO DEO GENIO ET CONSERVATORI COL -

EXTRICATVS - - - - . - . -

MAESIA - - . - - - - - - -

INSTITVTAE - - - - - IVCVNDAE

CONIVGI - - HONORATAE - - PRI

MOSAE HONORE - - - - VS SVIS DE CLAVDIO IVVE

NALE PATRE ET DECENNIO VICTORINO FRATRE INSTAN

TE L. CAECILIO VICTORINO AMICO KAL IANVARS PROV

CLXXXV

Upon the End of a $T$ omb Stone a quarter of a Mile from the City.

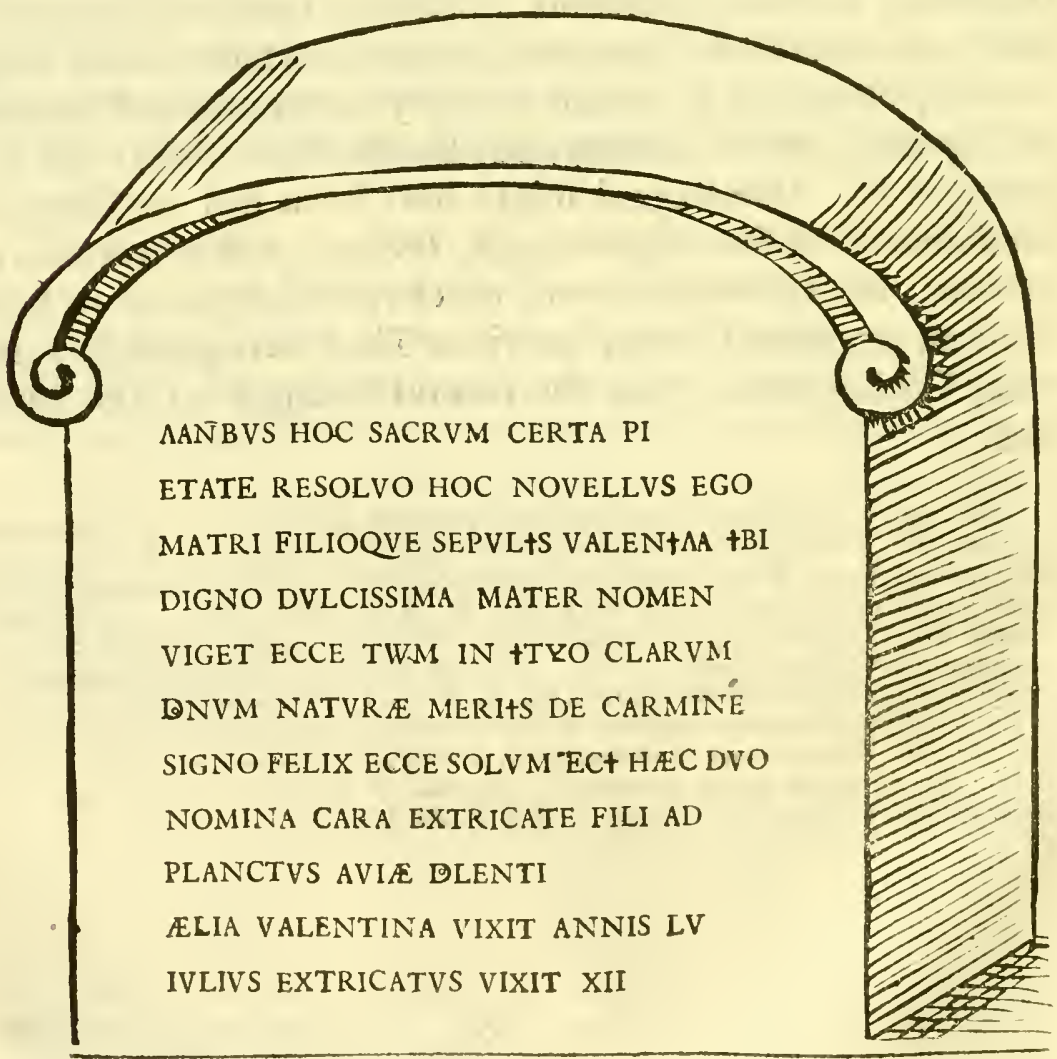

Upont 
Upon a moulded Stone.

Q. GARGILIO Q.F. - - - -

PRAEF COH - - - BRITANIAE

TRIB CO - - MAVRCAE

AMIL PRAE. COH. SING ET VEX

EQQ MAVROR IN TERRITORIO

AVZIENSI PRETENDENTIVM

DEC DVARVM COLL AVZIEN

SIS ET RVSCVNIENSIS ET PAT

PROV OB INSIGNEM IN CI

VES AMOREM ET SINGVLA

REM ERGA PATRIAM ADFEC

TIONEM ET QVOD EIVS VIR

TVTE AC VIGILANTIA FA

RAXEN REBELLİ́S CVMM SA

TELLITIBVS SVIS FVERIT

CAPTVS ET INTERFECTVS

ORDO COL AVZIENSIS

INSIDIIS BAVARVM DE

CEPTO PPEDD VIII KAL

FEBR. PR. CCXXI.

Upori a moulded Stone in half foot Letters.

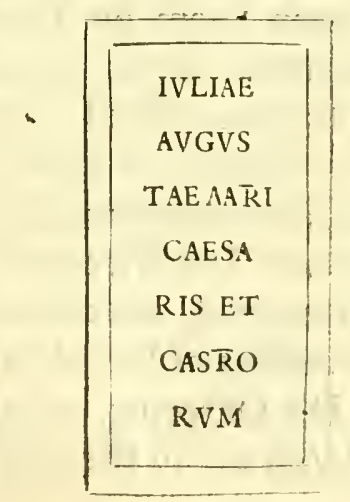

$\mathrm{X}_{2}$ 
Upon a Siture broken Stone.

DIV I

ET

CASTORVM SENATYS

IENSIS DEVOTA

Wpon a broken Stone in Half foot Letters.

LUIKIVIII LUI

III COS PRO COS

OTA MENTE QVA NVMINIBVS

SITEI EXCOLVIT DEDICANTI

Riverfin-ent- A League to the Southward of Fibbel Deera, we have The 32e.

[i] Phoum [the Mouth of the River] Fin-enne; which, after It hath run, for the Space of ten Leagues, through a dry fandy The Arabs Soil, lofeth itfelf gradually in the Shott. Moft of the Getulian near are $\mathrm{Z}$ wo- Arabs, who dwell upon the Banks of This River, are Zwowiah, wiah. as They generally call in this Country The Children andDependents of Their Marab-butts, who, like Thofe of the fame Denomination in all the Mabometan Dominions, enjoy great Privileges, and have their Poffeffions free from Taxation. The

Welled Seedy Eefa. Welled Seedy Eefa, the Northermoft of thefe Communities, have the Sepulchre of Their tutelar Saint, at the Diftance of five Leagues from Sour Guflan. There is hard by It, on the one Side, a large Rock, upon which Seedy Eefa was daily accuftomed to offer up his Devotions; and, on the other, is The Ain Kidran. [Ain [u, ii Kidran] Fountain of Tar, fuppofed to have been miraculoufly beftowed upon Them by Their Progenitor; and which They continually make ufe of, inftead of common Tar, for the falving of Their Camels. Six Leagues farther, are the

Welled Seedy Hadjetas.

Welled Seedy Braham Allemmy.

Hirmam.
Welled Seedy Hadjeras, called fo from another of Thefe Marab-butts. Here the Fin-enne changeth It's Name into that of [The Wed el [rs'] Ham] The River of Carnage, from the Number of People, as I am told, that have been at one time or other drowned in the fording of It. A little higher, is Seedy Braham Alemmy, and His Offspring, who fpread Themfelves to Hirmam, a noted Daßhkrah, in the way to Boofaadah.

Boofaadah, 
Boofaadah, a Collection of Da/bkras, fubfifting by Their Boofazah. Date Trees, lyeth under Fibbel Seilat, twenty Miles to the jibbel seilat. Wreftward of Seedy Braham. Twelve Leagues farther, in the fame Direction, are The [risl تي is Theneate el Gannim] Sheep-Cliffs, called likewife [Ede Tepelaar] The feven Hills by Theneare et the Turks. Thefe are fituated over againft the Burgh Swaary and the Titterie Do/k, at forty Miles Diftance. A little way beyond the Seven Hills, are the Eminences and Salt Pits of Zaggos, Zaggos. after which, we are to climb over the Saary, and then the M. Sary. Zeckar, two other noted Mountains; This twelve, the Other M. Zcckar. five Leagues only to the Southward of Zaggos. Thefe, with many other rugged and mountainous Diftricts within the Sabara, very well illuftrate, what Strabo may befuppofed to mean, by ${ }_{E x c \text { p. p. .c. }}$ the Hilly Country of Getulia.

Six Leagues to the Eaftward of the Zeckar, is Fythe ${ }^{e} l_{\text {Fythe el }}$ Bothmah, fo called perhaps from The broad or open Turpentine Bothman, Trees, that grow upon the Spot. Seven Leagues from thence to the Northward, is Thyte el Bo-tum [rbell (شsil] The thick or flady Turpentine Tree, as It is probably named, in Thyre et Contradiftinction to the Others. Thefe are two noted Sta- ${ }^{\text {Bo-tum. }}$ tions of the Beni Mezzab, and other Gretulians, in their Journeyings to Algiers.

At Herba, a Heap of Ruins a little to the Eaftward of ${ }_{\text {Herba. }}$ Fythe elBothmah, are the Sources of The [Wed el شs Shai-er $]_{\text {Wed }}$ Wed Barley-River, a confiderable Stream of This Part of Geetulia. Shai-er. The Courfe of It, from Herba to the $\mathcal{D} a / b k r a b$ of Booferjoone, Booferjonc. is ten Leagues in a N. N.E. Direction. At a little Diftance from Booferjoone, below a Ridge of Hills, there are other Antient Ruins called Gabara. Befides the Palm, which grow- ${ }_{\text {Gahara. }}$ eth in This Parallel to Perfection, Booferjoone is noted alfo for the Appricot, Fig, and other Fruit Trees.

To the Northward of Booferjoone The Wed el Shai-er acquires the Name of Mailah, from the Saltnefs of It's Water: and Wed el paffing afterwards to the Eaftward of The [Ain [u'b] Difla or Ain Defaily. Defaily ] Fountain of Oleanders, and of the Mountain Mai-herga, the Haunt of Leopards, Serpents, and other noxi- ${ }_{\text {Monut }}$ Maious Animals, lofeth Itfelf in the Shott. 
Gumra.

Six Leagues to the Southward of Fythe el Bothmah, are Amoura. Gumra and Amoura, two Da/bkras, with Their Springs and Fruit Trees: and beyond Them, at a greater Diftance to the S. W. is The Ain Maithie; and then Dimmidde, which, with the Low-arte. Da/bkras of the Low-aate, nine Leagues farther to the $\mathrm{W}$. are the moft confiderable Villages of This Part of the Sabara. They have likewife in all Thefe Places, large Plantations of Date, and other Fruit-Trees.

The numerous Families of Miaithie, Noile, and Mel-leeke, The Arabs of

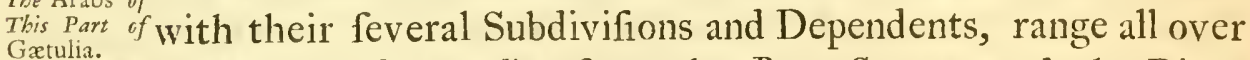
Getulia. This Part of Gretulia, from the Burg Swaary and the River Fin-enne, to the Dafbkras of the Low-aate, and the adjacent The Ammer. Mountains of the Ammer, another confiderable Clan, who fpread Themfelves over a mountainous Diftrict, a great way to the Weft. Their Mountains have been already fuppofed to be a Part of the Mons Phrurcefus; and indeed, provided the Pharufii, one of the leffer Gretulian Tribes, who have no fmall affinity in Name with It, can be brought thus far to the EaftTte Lowate Ward, the Low-aate and Ammer will fall in very well with Their and Ammer $_{\text {Arobaly }}$ the Situation. The Pharufii '
' by being placed in Ptolemy's Tables

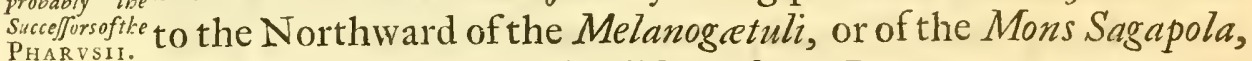
PhARVSII. could not certainly be far diftant from It.

Beni Mez- The Country of the Beni Mezzab is fituated thirty five zab. Leagues to the Southward of the Low-aate and Ammer, confifting of feveral Villages, which, having no Rivulets, are fup. Gardeiah. plyed altogether with Well-Water. Gardeiah, the Capital, is Bery-gan. the fartheft to the Weftward: Bery-gan, the next confiderable Grarah. Da/hkrah, is nine Leagues to the Eaft; and Grarab the neareft of Them to Wurglah, hath the like Diftance and Situation with Refpect to Bery-gan. The Beni Mezzab, notwithftanding they pay no Tribute, have been, from Time immemorial, the only Perfons employed in the Slaughter Houfes of Algiers; but as they are of the Sect of the Melaki, they are not permitted to enter the Mofques of the Algerines. It may be farther obferved of This Tribe, that They are generally of a more fwarthy Com-

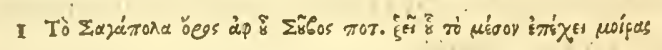
r. $x \in$ (MS. $x \cdot 3)$

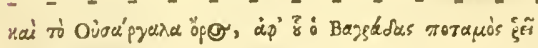

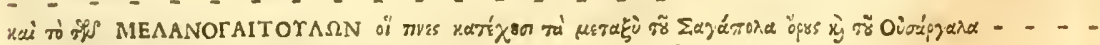

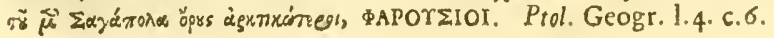




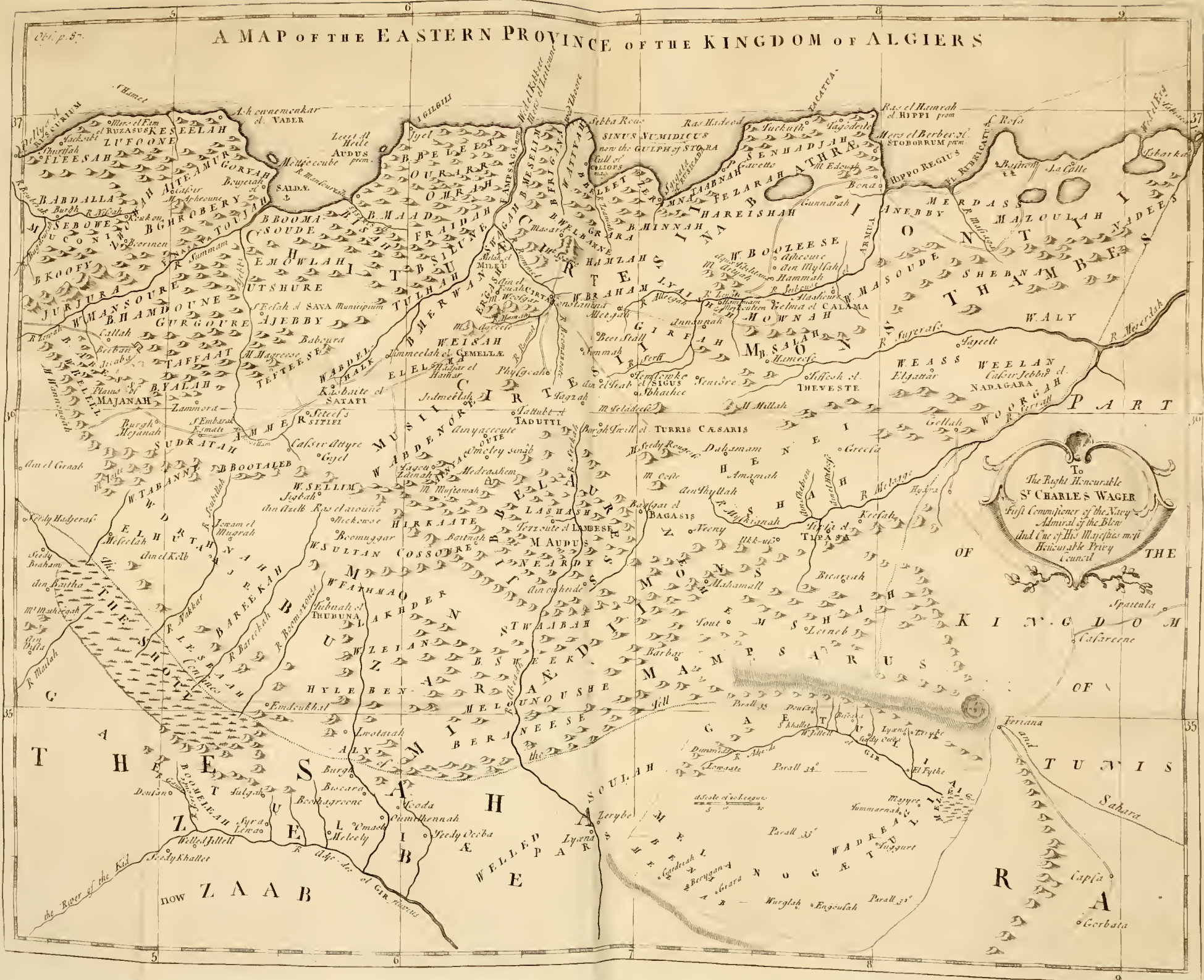




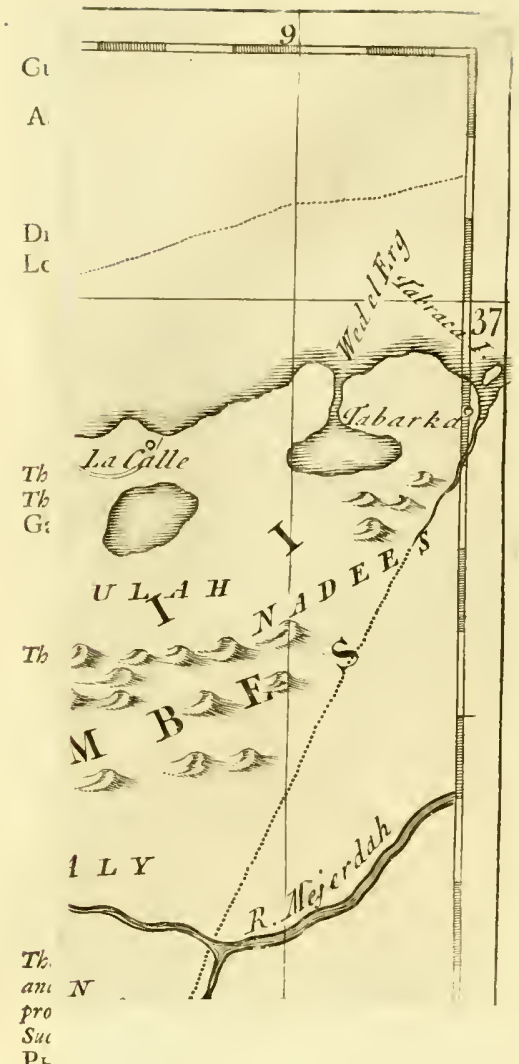

$\mathrm{P}_{\text {r. }}$

Be

Ga

$\mathrm{Be}$

$\mathrm{Gr}$

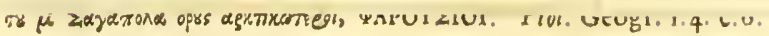




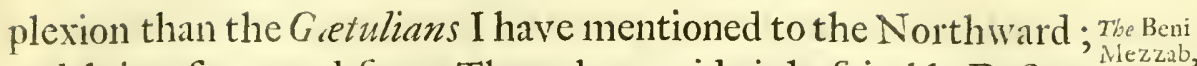
and lying feparated from Them by a wide inhofpitable Defert, without the leaft Traces of Dwellings, or even the Footfteps of any living Creatures, may in all probability be the moft weftern Branch of the Melanogretuli, as in treating of Wurglahs and some of the Wadreag will be further confidered.

The Welled Ya-Goube, the Lerba and the Seid el Graaba, The Arabs of are the Bedowveens of This Diftrict.

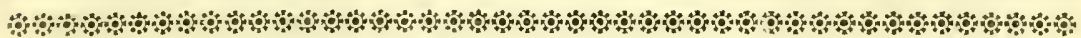

\section{H A P. VII.}

Geographical Obfervations upon the Sea-Coaft of that Part of the Mauritania Cxfarienfis and Numidia, which is called at prefent the Eaftern Province or the Province of Conftantina.

$\mathrm{T}$ H I s Province, lying betwixt the Meridians of the Rivers the general Booberak and Zaine, is nearly equal to the other two; $\begin{gathered}\text { Defription of } \\ \text { this rovinut. }\end{gathered}$ being upwards of CCXXX Miles in Length, and more than a Hundred in Breadth. The Tribute likewife collected by This Viceroy, is much greater, than that of the other Two; inafmuch as the Titterie Bey brings only every Year into the Treafury of Algiers about twelve thoufand Dollars, and the weftern Bey, forty or fifty thoufand; whereas there is paid in by the Viceroy of this Province never lefs than eighty and fometimes a hundred Thoufand.

The Sea Coaft of this Province from the Booberak to Bonjeiah, The Sea crast and from thence almoft entirely to Bona, is mountainous and Mountaninous. rocky, anfwering very appofitely to the Title of [El Adwah - Egus] The highor lofty, which Abulfeda hath given It; though It may be obferved at the fame Time, that the Province of Andalufia in Spain cannot, as that Author affirmeth, be either difcovered from hence, or from the moft weftern Part of this Kingdom.

I A Dollar of Algier, Tunis, \&ce. paffeth ufually for three Shillings and four pence or Six pence; and of the like l'alue are the Allance or current Dollars of the Levant. 2 Tractus ille continentis a cujus portubus eminus profpicitur al Andulos appellatur continens $e l$ Adwah r̈gus terra cminens; atque hic tractus comprehendit el Magreb el Aw at \& el Magreb el Aksa : porro Afrikea ex adverfo opponitur Infulæ Sikilea \& Terræ Magnæ Framizi. fc. \& Itali.e; led inde non eminus profpicitur Andalos. Avelfeda, ut fupra. 
The Midland In the Midland Parts, from the Mountains of Wannougab to Parts more Seteef and Conftantina, and from thence quite through the
level. Diftricts of the Welled Braham, Girfah, and Henneifah, there is a great Variety of hilly and champain Ground; though Fountains and Rivers, efpecially to the Weftward of Conftantina, are not fo commonly met with, as in the Southern Province.

TreMountains The Mountain of Atlas may probably be taken for that of Arlas. high Knot of Eminences which diftinguifh Themfelves to the Southward of the Plains of the Sudratab. They are continued by thofe of the Beni Bootaleb, Welled Abdy-nore and Hircaat; and taking in afterwards Fibbel Aurejs, and the mountainous Tract of the Nememflas, leave this Province a little to the Southward of Tebaifa. But the general Defcription of This Province, will be farther carried on in the next Chapter.

THE RIVER Booberak, the weftern Limit of this ProDelly's The RUSCURI- Vince, hath been already defcribed; after which we have, at

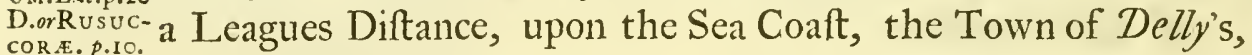
A. Rusuc- or Teddeles according to Leo ${ }^{\text {and }}$ and fome Sea Charts, built out curo.p. 26.

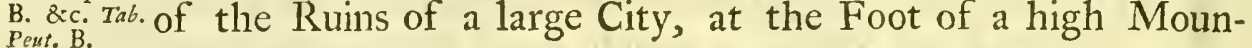
tain, that looks towards the N. E. The antient City, which appears to have been as large as that at Temendfuee, fpreads Itfelf quite over the N. E. Side of This Mountain; upon whofe Summit to the Weftward, there is a great Part of the old Wall, befides other Ruins, promifing, at a Diftance, a large Scene of Antiouities. In a Wall juft over the Harbour, we have a fmall Nitch, with an Image placed in It, in the Attitude of a Madona; but the Features and Drapery are defaced.

The Road be-

The Road before This Place, befides the Inconvenience of fore It. being fmall, lyeth alfo expofed to the N.E. Winds; though, under the S. E. Shore, there are fome Traces of a broad Wall, which formerly perhaps might ftretch out into the Sea, and form a Cothon. Dellys, from lying twelve Leagues to the $E$. of Temendfufe or Rufgunia, will be the Rufucurium of the Antients, a noted and confiderable City in former Time, as we may collect, not only from the prefent Remains of It, but from It's having the Courfe of feveral Roads directed to It in the Itinerary. I could meet with no Tokens of that Plenty of Water which Leo afcribeth to this Place; the Inhabitants, when I was there, complaining much for the Want of It.

I Teddeles oppidum muris antiquifismis atque munitifimis cinctum eft : bona pars civium panni tinctores funt, idque propter fluviorum atque fontium frequentiam, qui per hujus medium præterfluunt. F. Leo. p. 204. 
Six Miles to the S. E. of Dellys, not far from the Sea Shore, Shurfiat, The

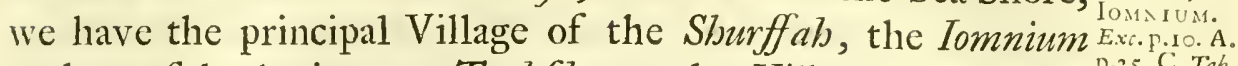
perhaps of the Antients; as Tackfibt, another Village belonging to pert: B. C. Teb.

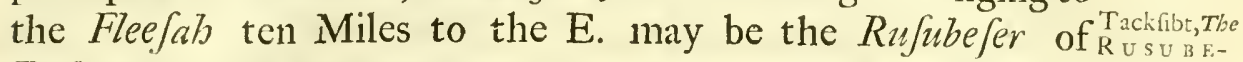
Ptolemy.

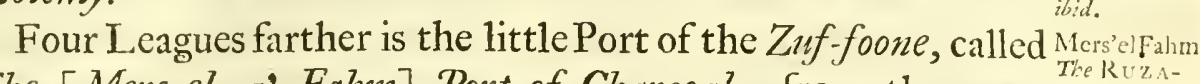

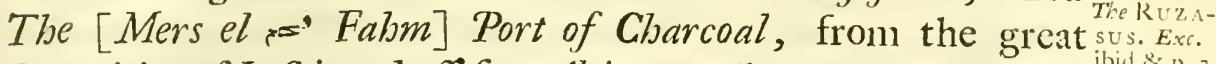
Quantities of It fhipped off for Algiers. There are fome Ruins D. p. p. 25. C. at a little Diftance from the Shore, which might formerly belong to the Ruzafus of the Antients.

Three Leagues farther is the River of Seedy Hamet ben Kefeelah. Youfef, with the adjacent Dafokras of the Kefeelah : and at the fame Diftance from thence, we arrive at $A / h$-oune-mon-kar, a Aft-oune-

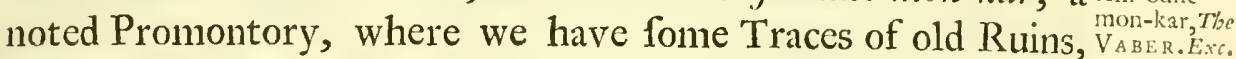
the Vabar perhaps of Ptolemy. Five Leagues to the S. E. of ${ }^{\text {p. 10. B. }}$ Afl-oune-mon-kar, not far from the Continent, there is a finall rocky Ifland; at a littleDiftance from which is The [Mett fe-coube Metric-

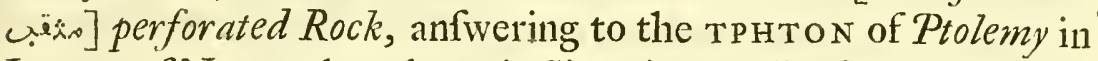
Import of Name, though not in Situation. The Spani/l Priefts, who have been for many Ages fettled at Algiers, have preferved a Tradition, that Raymund Lully, in His Miffion to Africa, was wont to retire frequently to this Cave for Contemplation.

At a finall Diftance from the Mett fe-coube, is the Port of $\begin{aligned} & \text { The Pere of } \\ & \text { Boujecith or }\end{aligned}$ Bonjeiah, called by Strabo the Port of Sarda, a much larger Boujeial, one than either That of Warran or Arzew. It is formed however, in the fame Manner, by a narrow Neck of Land running out into the Sea. A great Part of This Promontory was formerly faced with a Wall of hewn Stone, where there was likewife an Aqueduct for the greater Conveniency of bringing $\mathrm{Wa}$ ter to the Port. But at prefent the Wall, the Aqueduct, and the Bafons, where the Water difcharged Itfelf, are deftroyed: and the Tomb of Seedy Bu/gree, one of the tutelar Saints of greedy BurBoujeiat, is the only thing for which It is remarkable.

+ Boojeiab or Bugia, as the Europeans write It, is built upon The situation the Ruins of a large City in the fame. Manner, and in a like $\mathrm{Si}^{-o f}$ Boujeiah. tuation with Dellys, though of thrice the Circuit. A great Part of the old Wall is ftill remaining, which, like that of Dellys, is carried up to the very Top of a Mountain. Befides the Caftle, which hath the Command of the City, there are other Two, at 
the Bottom of the Mountain, for the Security of the Port. Upon the Walls of One of Them, feveral Marks are ftill remaining of the Cannon-Ball, left there by Sir Edward Spragg in His memorable Expedition againft This Place .

Bonjeiab is one of the garrifoned Towns of This Kingdom, where three Suffrabs conftantly refide; but who are of fo little Confequence, that the Goryah, the Toujah and other neighbouring Kabyles, lay It under a perpetual Blockade. Every Market Day efpecially, there are ftrange Diforders raifed by The Market. thefe factious Clans. As long indeed as the Market continueth, every Thing is tranfacted with the utmoft Tranquillity; but afterwards, the whole Place is immediately in an Uproar, and the Day rarely concludes, without fome flagrant Inftance of Rapine and Barbarity.

The Trade. The Inhabitants carry on a confiderable Trade in Plowfhares, Mattocks, and fuch Utenfils as They forge out of the Iron, dug out of the adjacent Mountains. Great Quantities likewife of Oyl and Wax, brought down every Market Day by the Kabyles, are fhipped off for the Levant and Europe.

Boujeiat, The Boujeiah, lying at the Diftance of XCI Roman Miles, or Ex.p.ro.B. I'. 4s'. from Dellys or Rufucurium, may be taken for the AnSALDE.p.2r. tient Saldee. It hath been already obferved, that Saldre, is p.25.C. placed by Ptolemy at too great a Diftance to the Southward; and Abulfeda, though nearer the Truth, yet in giving to His [يx:? Boujeiah $34^{\circ}$. Only of N. Lat. throws It $2^{\circ} .48^{\prime}$. farther to the S. than I find It to be by Obfervation. Bonjeiab being the only City of This Part of Barbary, that is taken Notice of by Abulfeda, will give us Room to fufpect, that Algiers was either not built, or of littlc Confideration in His Time.

Tke River of The adjacent River, the Nafava of Ptolemy, emptieth Itfelf Noujeial, The into the Sea a little to the Eaftward. It is made by a NumExc. p.r. B. ber of Rivulets, which fall into It from different Directions; though none of Them arife in the Neighbourhood of Mefeelah, The Phaamah. as fome late Geographers ${ }^{2}$ inform us. The Phaamah, called afterwards, in paffing through the Plains of Hamza, the Wed Ad-oufe, is the Weftermoft of Thefe Branches, having It's Sources at Fibbel Deera, feventy Miles to the W.S. W. In gliding below Mount Furjura, It is called Zowah, where It is 
augmented, firt, by The [Ma-berd] cold Stream, which floweth from That Mountain; and then, by The [Wed el Mailab] Salt River, which draineth from the Beeban, and fome other Mountains of the Beni Abefs. The other principal Branch of other BronThis River hath It's Fountains a little to the N. of Seteef, and" taking afterwards a large Sweep to the S.W. leaves the Plains of Cafir Attyre, and runs directly to the Northward. Hitherto It is called the Wed el Boofellam, containing a Number of excellent Fifh, not unlike in Shape, though more favory in Tafte, than our Barbel. Six Leagues farther, the Ajebby give Their Name to This River; which, advancing other fix L.eagues in the fame Direction, unites the Wed Ad-oufe, and is called Summam. If we except the Plains of Hamza and Seteef, the whole Country along the feveral Branches of This River, is very rocky and mountainous, thereby occafioning fuch a Number and Variety of Torrents in the Winter Seafon, that infinite Loffes and Calamities are fuftained by the Inhabitants upon every Inundation. The Beni Boo-Mafoude, who live near the Mouth of This River, have frequent Opportunities of making This Complaint; where we may very juftly apply the beautiful Defcription, that Horace hath left us of the Tiber *.

Five Leagues from the NaJava, is the Mouth of the Man-TheMan-foufou-reah, another large River, that feparateth the Diftricts of ARIS. Exsc. the Beni Ifah and the Beni Maad. The Nick-Name of Sheddy (the common word in Barbary for an Ape or Monkey) given two Centuries ago, by the Latter of thefe Tribes, to the Chief of the Beni IJah, was the occafion of that bloody and irreconcileable Animofity, which hath ever fince fubfifted betwixt Them. The greateft Part of the Plank and Timber made ufe of in the Docks of Algiers, is hipped off from the Man-fou-reah, which, as It immediately followeth the Nafava, may be the Sijaris of Ptolemy.

The Zeert' al Heile, a fmall Ifland, lyeth betwixt the Man-Zeer' al fou-reab and Fijel, but nearer the Latter. Over againt It there ${ }^{\mathrm{H}}$

\footnotetext{
$*$ - Cotera fluminis

Ritu feruntur, nunc medio alveo

Cum pace delabentis Etrufcum

In mare, nunc lapides adefos,

Stirpefque raptas, \&o pecus \&o domos

Volventis una, non five montium

Clamore, vicineque Sylva:

Quum fera Diluvies quietos
}

Irritat amnes. \&c. Lib. 3. Carm. Od. 29. 
Prom. AuDUS, and JARSATH. Exc.P.IO.C. Fijel or IGILGILI. Exc.ibid. The Great
River and It's Branches, viz. The Wed el Dhahab.

IVed el Rummel.

Boo-marzooke.

is a fmall Port and Promontory; This, the Audus, the Other, the Farfath perhaps of Ptolemy.

+ Fijel, the Igilgili of the Antients, lyeth a little beyond the Cape that formeth the Eaftern Boundary of the Gulph of Boujeiah. There is nothing left us of this antient City, but a few miferable Houfes and a fmall Fort, where the Turks have a Garrifon of one Suffiah. It will not, I prefume, be difputed that Borijeiah and Fijel are the Saldee and Igilgili of the Antients: though it may be difficult to reconcile the thirteen Leagues, which, in coafting, we find betwixt Them, with the $2^{\circ}$. of Ptolemy and the ninety three Roman Miles of the Itine. rary. Ptolemy likewife placeth Igilgili half a Degree to the Southward of Salde, in a Situation contrary to that of our Fijel, which lyeth $\mathrm{I}^{2}$ '. more to the Northward.

Beni Be-leit. The Beni Be-leit have Their Da/bkras betwixt Fijel and The [Wed el Kibeer] Great River, which falleth into the Sea, feven Leagues to the $\mathrm{E}$. or a little beyond the half Way between Fijel and Cull. It is made up of a Number of Branches, like the River of Boujeiah: the firft of which, called The [Wed el $\mathcal{D}$ fabab: [c:\$i] River of Gold, flows from Kaf-baite, a Heap of Ruins, fixty Miles to the S.W. The next is the Rivulet of Fimmeelah, in the fame Direction nearly with the Wed el D Jabab, but at little more than forty Miles Diftance. The other principal Contributions are from the Wed el Hammam, twenty Miles to the W. of Conftantina: from the Sigan, fifteen Miles to the S.W. from Phy fgeah, at the like Diftance to the S. and from the Springs of Hydrah, about half that Diftance, to the S.E. The Union of the Wed el Hammam and Sigan, with fome fmall Rills from FibbelWoo/gar, make The [Wed el Rummel or Rum-malab] Sandy River; as the other Two, with their additional Rills, conftitute the Boo-Mar-zooke, fo named from the Marab-butt, whofe Tomb It runs by. A Furlong to the S. of Conftantina, the Rummel joyns the Boo-Mar-zooke, where They begin jointly to have the Name, fometimes of Suf-jimmar, fometimes of Rummel, though the Latter is moft comThe Suf-jim- monly made ufe of. Below Conftantina, This River is augmented by the Wed el Mailah, where there are the Ruins of a Bridge of Roman Workmanfhip. Three Miles farther is the Influx of the Hammah, a lukewarm Stream, which fivells the Rummel to the Bignefs of our Chervell. It afterwards re- 
ceiveth other plentiful Supplies from the Boojer-aat, the Ain el Fouah, and the Fountains of Re-ja/s; and leaving the City Meelab a few Miles to the Weftward, joins the two Branches that were firtt taken Notice of. The Suf-jim-mar, Rummel or the River of Conftantina, as It is differently called by the Arabs, may be very well taken for the antient Amplaga, The AMpsawhich paffed under the Walls of Cirta ${ }^{*}$, and emptied Itfelf af- ${ }_{\text {IO. C. . . . 2. }}$, terwards into the Sea, betwixt Igilgili and Cullu. The mo- Cap. 3.p.23. dern Geographers have generally conducted the Channel of Their Ampfaga towards the Gulph of Cull; but Ours hath no fuch Direction, falling into the Sea fix Leagues to the Weftward. There is a great Affinity between the prefent Name of This River, and the Interpretation which Bochart hath left us of the Amp $\int a g a^{*}$.

A little to the Eaftward of the Wed el Kibeer, is The [Mers' Mers' el el Zeitoune] Port of Olives; in which Situation we are likewife to look for the Paccianas Mattidice of the Itinerary, and the Afifarat of Ptolemy: but the Beni Mefelim are the prefent Beni MereInhabitants.

Inmediately after the Mers' el Zeitoune, we pafs by The [Sebba Rous] Jeven Capes, called likewife Boujarone in fome mo. or Boujarone. dern Sea Charts. They are all very high, rugged and barren Promontories, extending Themfelves, with their narrow Bays and dangerous Inlets, as far as Cull.

The Influx of the River Zhoore is among the Eaftermoft of ${ }_{\text {The }}$ Zhoore. thefe Capes, where the Sinus Numidicus may be fuppofed to begin. It hath It's Sources among the Mountains of the Beni Welbaan, a few Leagues to the $\mathrm{N}$. of Conftantina; but, the Channel lying all the way through a mountainous Tract, It is thereby fo continually augmented with frefh Supplies, as to become a confiderable River, when It emptieth Itfelf into the Sea. The Welled Attyah, and the Beni Friganah, the welled At. two principal Clans of the Sebba Rous, drink of this River, Beni Figaand dwell not, like the other Kabyles, in little thatched ${ }^{\text {nah. }}$ Hovels, under the Shelter of fome Forreft or Mountain, but in the Caves of the Rocks, which They have either dug Themfelves, or found ready made to their Hands. Upon the Ap-

* Sui fratris uxorem ligato pondere lapidum in Ampfagam fluvium Cirtenfem famofum jact.ındo

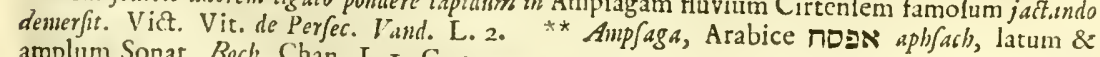
amplum Sonat. Bech. Chan. L.I. C. 24. 
Their Barsa-proach of any Veffel, either in the Courfe of Sailing, or by rity. Diftrefs of Weather, Thefe inhofpitable Kabyles immediately iffue out of their Holes, and covering the Cliffs of the Sea Shore with their Multitudes, throw out a thoufand execrable Wifhes that God would deliver It into their Hands. And probably the Name of Boujarone or Catamite, was firft given by the Italian Geographers to thefe Capes, in Confideration of the brutal and inhuman Qualities of the Inhabitants.

The Seven Capes, The

TRITUM Promont. F. Strabo, in being placed at the Diftance of three thoufand Fur-

The Tritum of Strabo, and the Metagonium of Mela, anfwer to thefe Promontories. And indeed, the Metagonium of METAGo- longs from Carthago Nova in Spain, will much better agree N.19.Cap.\%. with This Place, than with the Ras el Harflofa: at the fame Exc. p.6. в. Time the Contrapofition there mentioned, will better illuftrate Exc.p.2r. E. and be more in a Parallelifm with the like Pofition, laid down, by Pliny, between Siga and Malacha.

Cull, The

+ Cull, the Collops Magnus, or Cullu of the Antients, and Magnus, or one of the Maritime Garrifons of the Algerines, is fituated CULLU.E.xc. C.26.p.25.C. Great River. It is in the fame miferable Condition with Fijel, with as few Antiquities to boaft of. The fmall Haven before It, is in the fame Fafhion, though more capacious than that at Dellys, from which perhaps the adjacent City received It's Name*. Near the Bottom of It we have the River Ze-amah, Ze-amah. whofe Fountains, like thofe of the Zhoore, are at no great Diftance from the Sea. We have a few finall Capes that feparate the contiguous Gulfs of Cull and Sgigata; one of which fhould be the Tretum of Ptolemy.

Sgigata or Stora, The RusICADA. Exc.p.I3.A. quity; though a few Cifterns, converted at prefent into Magap. 25. D. . zines for Corn, are the only Remains of It. The Author of p. 25. D.

+ Sgigata (the Ru/icada) called likewife Stora by theModerns, is of a greater Extent than Cull, and difcovers more Tokens of Antithe Itinerary, in giving us fixty Miles betwixt Chulli and This Place, doth more than double the Space that lyes actually be-

Tapras A. twixt Them. The adjacent Rivulet may be well taken for the Tapfas ** of Sequefter.

* Viz. a $\mathrm{l} \leq$ Culla, Portus, tuta navium Statio, minde Italormm Scala. vid. Gol. in rocc. * $T$ apfas Africa fl. juxta Ruficadem. Vib. Sequeft. de fluain. 
Paffing by the little Port Gavetto, we come to the Ras [uss=] Portsaretto. Hadeed, rendered juftly Cape Ferro, or The Irow Promontory in Ras Hadect. the Modern Sea Charts. It is a white Precipice, twelve I eagues to the Eaftward of the Seven Capes, and maketh the Eaftern Extremity of the Gulf of Stora, the Sinus Numidicus, as I sinus Numihave obferved It was called by the Antients.

dicus.

Four Leagues from the Ras Hadeed, at the half way nearly Tuckufl,The to the Ras el Hamrah, is the Village of Tuckufh, (the Tacatua Excáp. pa. D. of the Itinerary and the Tacaccia * of Thuanus, ) with a fruitful and pleafant Country round about It. There is a Sandy Bay, with a little Inland, before It; but to the Eaftward, as far as the Ras el Hamrah, the Shore is one continued Range of Rocks and Precipices; among which is the fmall Port of Tagodeite, the Sulluco or Collops Parvus of the Antients.

The [Ras el Hamrah r,a] Red Cape, commonly called Ma-Ras el Ham-

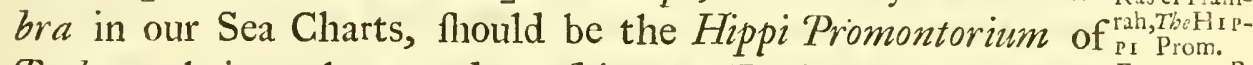
Ftolemy, being a large and confpicuous Head Land, with the ${ }^{E x c . p .13 \cdot B .}$ Ruins of two fmall Buildings upon It. Half a League to the S. is the Mers' el Berber, called, by the Europeans, Port Genoefe, where the Maltee $\int e$ and Italian Cruifers ufed frequently to lye in Ambufh for the Algerines, 'till the Latter, a few Years ago, built a fmall Fort to diftrefs Them. The Stoborrum Pro- -тововmontorium of Ptolemy will correfpond with the Southern Point EuM Pr. Prid. of this Road.

Four Miles farther, upon the Summit of an Eminence, the Bona or Blaid Algerines have a Caftle and Garrifon of three Suffrats: and el Aneb. upon the S. E. Declivity of the fame Hill, is the City Bona, called likewife by the Moors, The [Blaid el uhis Aneb] Town of Fujebs, from the Plenty of Them gathered in the Neighbourhood. Bona, is without doubt, a Corruption of Hippo or Hippona; though we are not to look for that antient City here, where the Name is preferved, but among a Heap of Ruins a Mile farther to the South. Leo** informeth us that Blaid el Aneb, was built out of Thefe Ruins; and It is certain, if we except one or two of the Streets, made, in the Roman Manner, with Caufeways, there is little befides, but what might have

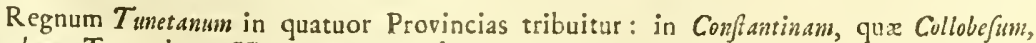
Ruficadam, Tacacciam, Hipponem \&c. Urbes continet. 1.7. in princip. * Novam quandam Urbem, in fecundo ab Hyppone Milliario ijfdem fere lapidibus extruxerunt, gui Bonc civitati detracti fuerant: nova autem Beld el Huneb, hoc eft, Ziziphorm civitas ct appellata, propter magnum ejus fructus copiam. $f$ Leo. p. 2 II.

A $a 2$

been 
The APHRObeen the later Work of the Mebometans. The prefent Bona therefore may be rather the Aphrodifum of Ptolemy, placed by

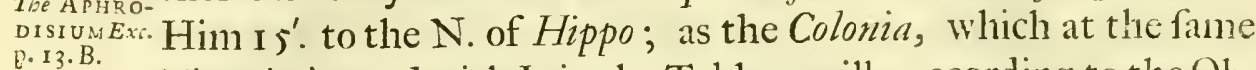

Time is joyned with It in the Tables, will, according to the Obfervation of Cellarius, be an Appellation more fuitable to the Latter :

Bona, befides the capacious Road before It to the E. had forThe Ports and merly a convenient little Port under the very Walls of It to the Bona.

Southward; but by the conftant Difcharge of Ballaft into the one, and the Neglect of cleanfing the other, both are rendred dayly lefs fafe and commodious. However a great Quantity of Corn, Wool, Hides, and Wax, are every Year fhipped off from This Place; which, by proper Care and Encouragement, might become the moft flourifhing City in Barbary; as by removing the Rubbifh, repairing the old Ruins, and introducing frefh Water ${ }^{2}$, It would be one of the moft convenient and delightful. Abulfeda ${ }^{3}$, in making Bona a Frontier City of His Afrikea, difagrees as well with Mela and Ptolemy, who place the Boundaries of the fame Province feventy Miles farther to the Weft; as with Pliny and Solinus, who place It nearly at the like Diftance to the Eaft.

The Antient

Betwixt Blaid el Aneb and Hippo, we have a large marfhy Haven of Plain, covered, in fome Parts of It, with Water. It appears to
Hippo. be an Acquifition from theSea, and might have been formerly the

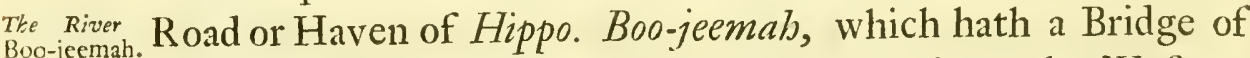
Roman Workmanfhip built over It, runs along the Weftern Side of This Marfb; and, being made up of the Wed el Da-ab, and feveral more Rills that defcend from the Edoug $b^{+}$and other adjacent Mountains, is, in the rainy Seafon, frequently fubject to Inundations. The many Roots, and Trunks of Trees brought down at Thofe Times by the Torrents, might have firft begun This Addition of Land to the Continent.

I Succedit apud Ptolemaum Aphrodifum colonia, de qua nihil aliunde notum eft ut putare

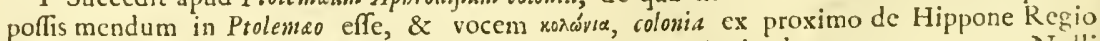
verfu in hunc, qui.Aphrodifimm habet, irrepfiffe. Cell. Geogr.Antiq. 1.4. cap. 5.p. I 12.2 Nulli hic fontes; nulla aqua præterquam pluvialis, quam illi cifternis quibufdam affervare folent. Ad orientale latus arx quædam eft munitiffima. F. Leo. 3 Bouma fita eft in initio regai Afrikea: habet fluvium modicum qui in mare ab occafu ejus delabitur. Abulf. ut fupra. vid. p. 6. 9. \& Exc. p. 12. cap. 3. p. 19. cap.7. \& ibid p. 21. cap. 4. p. 23. cap. 27. P.30. D. p. 3 I. A. 4 The River Ladogus or Yadog of the modern Geography, vid Atl. Gcogr. Vol. Iv. p. 184 . De la Croix ut Supra. Tom. 5. P. 282.) is the fame no doubt with the Boo-jecmah; and feems to be a Corruption of Edough, the Place w'here It hath It's Sources; there being no Riper, that I could be informed of, of the like Name.

The 


\section{Of the Eaftern Province.}

The Sei-boufe hath It's Influx into the Sea with the Boo-The Riv. jeemat, lodging in the fame Manner, Roots, and Trunks sei-boufe, or of Trees, upon the neighbouring Shore. The low Situation ${ }_{\mathrm{C}+\mathrm{p}, \mathrm{F} .21}$. of the adjacent Country, and the Inundations confequent thereupon, iufficiently juftify the Etymology which Bochart * hath given us of Hippo.

+ The Ruins of the antient Hippo are fpread over the Neck The Situations of Land, that lyeth betwixt Thefe Rivers; which, from being Hip the ancient near the Banks plain and level, rifeth afterwards to a confiderable Elevation. They are about half a League in Circuit, confifting as ufual, of large broken Walls and Cifterns; fome of which were fhewn by the Moors, who have an Intereft in keeping up fuch a profitable Tradition, for the Convent of St. Auftin. This City, was called Hippo Regius, not only in Contradiftinction to the Hippo Zarytus, but from being one of the Royal Cities of the Numidian Kings. For Silius Italicus** acquaints us, that it was formerly one of their favourite Seats: and indeed, if a City ftrong and warlike; *** commodiounly fituated, as well for Trade and Commerce, as for Hunting and Diverfion; that enjoyed a healthful Air, and took in, at one View, the Sea, a fpacious Harbour, a Diverfity of Mountains loaded with Trees, and Plains cut through with Rivers, could engage the Affections of the Numidian Kings, Hippo had all This to recommend It.

The River Sei-boufe wafheth the Eaftern Walls of Hippo, and The Branches is equal to the Boo-berak. The moft diftant Fountains of It oufe. are at Temlouke and Sbaibee, where It is called Wed el Serff: but upon receiving the Water of The [Ain el[براب] Trab] muddy Fountain, and running a few Leagues to the Northward, It changeth It's Name to Ze-nati. The Alleegah joyns It afterwards a little to the Weftward of the Hammam Mes: kou-teen : and then taking in the Water of The [Sebba Aioune] Seven Fountains, two Leagues farther, begins to be called Sei-boufe. The [Ain [D] Mylfab] Cloth Fountain, and the Waters of Hammah afford the next Contributions. Thefe lye,

* Nec ab equis aut equilibus Hipponem Græco nomine Phanices appellaffant-Hippo nempe a Phenicibus ubo vel ubbo dici potuit, quia in finu latet. Sinus enim Syris eft עubo vel אI ע ע ע Giggeins אל (alubbo) Simus, Stagmm. Clan. 1. 1. Cap. 24. - ** antiguis dilcetus

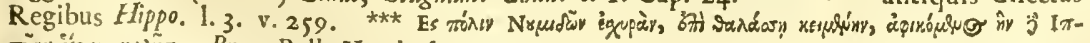

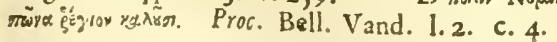


over againft Gelma, in the Boo-bammam. The Sei-boufe ftill contimuing in an Eafterly Direction, is augmented by the Wed el Mailab near the Meridian of Bona; and then altering It's Courfe to the Northward, traverfeth a moft delightful Country all the way to the Sea.

The Mufragg, Four Leagues farther is the Mouth of the Ma-fragg, a River or RUBRI- fomewhat lefs than the Sei-boufe, whofe Fountains are at no
CATUS A. Exc. p. 13. greater Diftance, than the Mountains which lye S. of the Merda/s. A high Bank of Sand, raifed by the N. and N.E. Winds, generally ftops up the Mouth of It, which, except after great Rains, is feldom open. The Sei-boufe and Ma-fragg, the principal Rivers betwixt Hippo and Tabraca, anfwer to the Armua and Rubricatus of the Antients. Thuanus * feems to have been badly informed concerning the Courfe of the Latter, in conducting It, below the Promontorium Apollinis, into the Gulph of Cartionge.

Cape Rosa. Doubling Cape Ro Ja, five Leagues from the Mafragg to the Baftion. N.E. we turn into the Baftion, where there is a finall Creek, and the Ruins of the Fort, which gave occafion to the Name. The Factory of the French African Company, had formerly Their Settlement at This Place: but the unwholfomenefs of the Situation, occafioned by the neighbouring Ponds and

La Calle. Marfhes, obliged Them to remove to La Calle. This is another Inlet, three Leagues farther to the Eaft, where Thofe Gentlemen have a magnificent Houfe and Garden, three hundred Coral Fifhers, a Company of Soldiers, feveral Pieces of Ordinance, and a Place of Arms. Befides the Advantage of the Coral Finhery and the whole Trade of the circumjacent Country, They have alfo at Bona, Tuckufh, Sgigata and Cull, the Monopoly of Corn, Wool, Hides and Wax; for which Privileges They pay Yearly to the Government of Algiers, to the Kaide of Bona, and to the Chiefs of the neighbouring Arabs, thirty thoufand Dollars, or about five thoufand Guineas of our Money. The Baftion, and La Calle, are, I prefume, too contiguous to be taken for the Diana and Nalpotes of the Itinerary.

* Rubricato fluvio, qui alijs Ardalio, hodie Ladogus paullum inverfo nomine rocatur, ad Hipponem continuo tractu orientem verfus ora porrigitur; inde paullum intra recedens ad Hipponitidem paludem \& Thinifsam olim dictam finuatus atque in mase excurrens Apollinis promontorium efficit. Thual. Hitt. 1.7. p. 612. 
The Wed el Erg, a Brook ouzing from the Lake of the wed el Erg. Nadies is five Leagues from La Calle to the Eaft. This hath been for fome Years the difputed Boundary betwixt the Regences of Algiers and Tunis; but as the Country lying betwixt It and the Zaine, four Leagues farther to the Eaft, is frequently laid under Contributions by the Algerines; I have placed the Eaftern Boundary of Their Dominions, at the Latter.

Zaine, the prefent Name of the Tufca, fignifieth in the Lan- The Zaine or

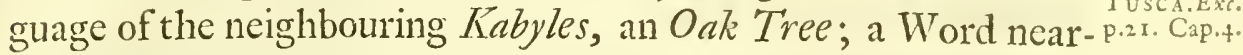
ly of the like import and fignificancy with Thabraca: 7. Leo and others after Him call This River Guadilbarbar ${ }^{2}$, deducing It from the City Urbs, a great way to the Southward: but This River is known by no fuch Name at prefent; and hath It's Fountains at no greater Diftance than the adjacent Mountains. The Ruins of the ancient Thabraca, or $T a$ - Ta-barka, or braca, called at prefent Ta-barka, are fpread over the Weftern Col. Exas p.

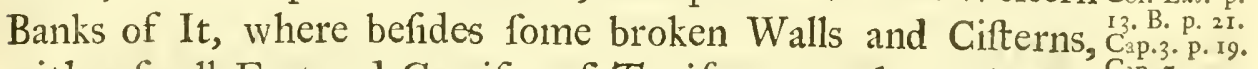
with a fimall Fort and Garrifon of Tunifeens, we have the following Infcription.

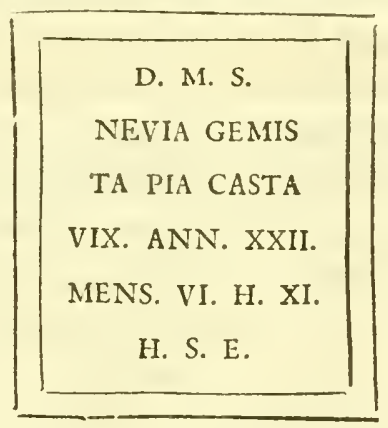

Among the principal Inhabitants of the Maritime Parts of The Maritime Numidia, we have along the Banks of the Zeamah, the Beni midida. of NuBe-leet: and after Them the Zeramnah, Taabnah, and Beni Minnah, who, with the Hajaitah and Senhadgah, the Bedoweens of Porto Gavetto and Ras Hadeed, are the chief Communities of the Gulph of Stora. But the Mountains from Tucku/s to Bona; and the Plains from thence to the Ma-fragg, are cultivated by the Citizens of Bona. The Merdass, who

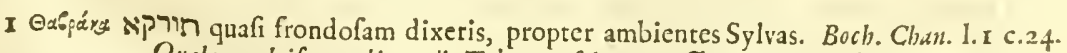
Quales umbriferos ubi pandit Tabraca faltus. Fuv. Sat. I0. 1. 194.

2 Guadilbarbar in montibus oritur, agrum Vrbs Civitatis attingentibus, \& per colles \& montes labens, tandam in Oceanum fefe juxta defertum Tabraca portum, quindecim circiter a Bege
Civitate paffum millibus cxonerat. $\mathcal{F}$. Leo. p. 287. 
have continued to live in This Situation from the Time of 7. Leo', are the Bedoweens of the champain Country betwixt the Ma-fragg and the Forrefts on this Side the Baftion: beyond which, are the Mazoulah, who have an unwholfome Diftrict, full of Ponds and Marfhes, quite along to the Nadies. Thefe, a mifchievous plundering Tribe, like moft others who dwell upon the Frontiers, are fome Part of Them Tributaries to the Titnifeens, fpreading Themfelves from the Wed el Erg, to the Mountains of Ta-barka.

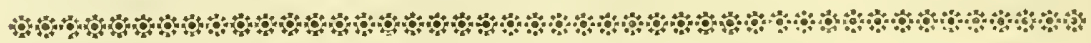

\section{H A P. VIII.}

Of the moft remarkable Places and Inbabitants in the Inland Country of the Eaftern Province; together with the correspondent Part of the Sahara.

The general $7 \mathrm{H} \mathrm{E}$ whole Tract of This Province which lieth between

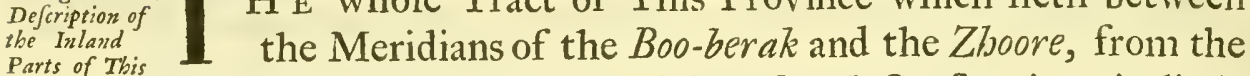
Parts of This
Province. Sea Coaft to the Parallels of Seteef and Conftantina, is little elfe befides a continued Chain of exceeding high Mountains. Very few of the Inhabitants to the Weftward of the Wed el Ajebby pay any Tribute to the $V$ iceroy; Their rugged and impracticable Situation being too difficult for the whole Strength of Algiers to penetrate. But among Thofe to the Eaftward, except near the Sea Shore, the Turks pafs every Summer with a flying Camp, and receive fome Tokens of Homage and Submiffion from Their refpective Kabyles; who notwithftanding are all of Them fo obftinate and tenacious of Their Liberty, that They give Nothing, 'till They are compelled to It by Fire and Sword. The Country near the Parallels of Seteef and Conftantina, is diverfified with a beautiful Interchange of Hills and Plains, which afterwards grows lefs fit for Tillage, 'till It ends, upon the Sabara, in a long Range of Mountains, the Buzara, I prefume, of the Antients. The Diftrict of Zaab Mons. Exc. lyeth immediately under Thefe Mountains; and beyond Zaab,
p. I. A. $^{\circ}$, is Wadreag, another Collection of Villages, at a great Diftance in the Sabara. This Part of the Eaftern Province, including

I Huic oppido (Bone) fpatiofifina quædam eft planities, cujus longitudo guadraginta, laticudo autem viginti quinque continet milliaria : hæc frugibus fetendis eft feliciflima, ab Ar.abibss quuibufdam colitur quoos Merdez appellant. F. Løo. p. 2 II. 
the Parallel of Zaab, anfwers to the Mauritania Sitifen/2s, or Viz. of the the Firft Mauritania', as It was called in the Middle Age. Mauritania

The Mountainous Country betwixt the Meridians of the The General Zhoore and Seiboule, is of no great Extent, rarcly fpreading Nefreititian of $_{\text {Numidia }}$ Itfelf above fix Leagues within the Continent; the Inhabitants whereof, near Tucku/b and Bona, are Tributaries to the Algerines: but in the Gulph of Stora, near Port Gavetto, Sgigata, and Cull, They bid Them Defiance. From the Sei-boufe to the Zaine, except in the Neighbourhood of Ta-barka where It begins again to be Mountainous, the Country is, for the moft Part, upon a level, though with fome Interruptions from Hills and Forrefts. The like Interruptions we meet with below Tuckufl, along the Encampments of the Hareifoah, Grarah, and other Bedoweens, as far as Conftantina. Beyond This Parallel, we have a Range of Mountains, the Thambes, as I take Them to Thambes be of Ptolemy, extending Themfelves as far as Ta-barka; be- Mons. Exc. hind which, there is again Pafture and Arable Ground, ending at Length upon the Sabara, as the Mauritania Sitifen/is did before, in a Ridge of Mountains; the Mampfarus probably of Mampsarthe Antients. Part of the Africa Propria of Mela and Ptolemy, Us Mons. the Numidia MafJylorum, the Metagonitis Terra², \&c. was comprehended formerly in This Part of the Province 3 .

The SE воW E, a plain fruitful Diftrict furrounded with Moun-The Sebowe, tains, lyeth five Leagues to the S. E. of Dellys. Here the ${ }^{\text {the }}$ seat of Turks have a Burgh and Zmaalab to hinder the Incurfions of the Zwowab. The antient Muconi probably had Their chief The MucoHabitations in This fine Country. NI. Exc.

The Zwowah, the richeft and the moft numerous Kabyles ThcZwowah. of This Province, poffefs a large and impenetrable Tract of Mountains to the Eaftward of the Sebowe. They have feveral Daßbkras, among which is The [Fimmah at Saritch] Church Jimmah at of the Ciftern, famous for the Sepulchre of Seedy Hamet ben Dreefe: where likewife There is a College, and Maintenance

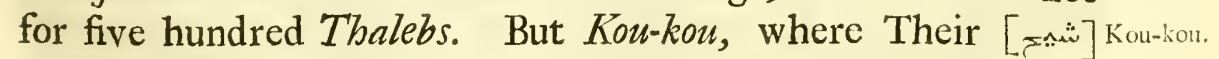
Shekb or Sultan as They call Him, refides, is Their Principal Village. Boori-nen, a high pointed Mountain, lyeth a few Boori-nen. Leagues to the S.S.W. of Koukou. Some Years ago the Turks

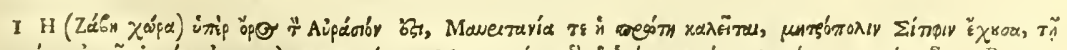

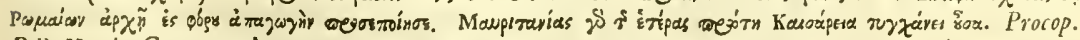
Bell. Vind. Cap. 20. 1.2. p. 287.2 Exc. p. 21 . cap. 3. 3 Vid. Not. 1. 2. Uc. p. 6.

C c built 
built a fmall Fort upon It, as a Check upon the Zwowvah, which They were in a little Time obliged to abandon.

Beni Groh- To the Eaftward of the Zwowah, below the Kefeelah, are AiteAmmer. the Beni Grobberry; and then the Aite-ammer; after which Beni Idel.
Miezz.iah. We have the Beni Idel, Mezzaiah, and other Tribes already taken Notice of in the Defcription of Boujeiah. Among the Beni Grobberry, to the Northward of Their Fibbel Afroone, Cafir. are the Ruins of a Roman City, called at prefent Caffir [the Caftle] by the Inhabitants: and upon the Mountain of the Toujah, they often dig up large Pipes of Lead, fuppofed to have been formerly employed in conveying Their excellent Water to the Neighbouring Salde. The Muconi might have probably extended Their Dwellings thus far to the Eaft.

Welledsian- Croffing the Wed Ad-oufe or Zwowah, (which here runfoure. neth parallel with the Sea Coaft) we meet with the Welled Manfoure, who, with Their Daßbkras, lye immediately under the S. E. fide of Mount Furjura, and to the S. S. W. of the Beni Ham- Zwouvah. To the Eaftward of Them, are the BeniHam-doune, doune. and other leffer Clans protected by the Beni Abbe/s.

Dra el Ham- To the S. of the Welled Manfoure and the Beni Ham-doune, mar. is The [Dra el Hammar] Red Cliff, the Seat of Boo Zeide, Beni Abbefs. the Shekb or Sultan of the Beni Abbefs. Thefe are almolt as powerful Kabyles as the Zwownah, bringing into the Field upwards of three thoufand Foot, and half the Number of Horfemen. They have likewife a great many Daßhkras; and at callah. Callah, the Metropolis, They not only make exceeding good Fire Arms, but carry on a confiderable Manufacture in Hykes and Burnoofes. However the Beni Abbe/s are not fuppofed to have the Riches; It is certain, They enjoy not the Quiet and Tranquillity of the Zwowah; who, from a more difficult Situation, have not, for many Years, been molefted by the Algerines. Whereas the Beni Abbe/s, lying directly in the great Road to Conftantina, are generally laid under Contributions; and whenever They have had the Rafhnefs to revolt, have been fo feverely chaftifed for their Breach of Faith, that They have been always left in a worfe Capacity of making the like Attempt for the future. The Beeban, Among the Mountains of the Beni Abbe $\int$ s, four Leagues to
or Dammer the S.E. of the Welled Manfoure, we pafs through a narrow $\underset{\text { Cappy. }}{\text { or Dammer }}$ the S.E. of the Welled Manfoure, we pafs through a narrow winding Defle; ; which, for the Space of near half a Mile, lyeth, 
on each Side under an exceeding high Precipice. At every Winding, the Rock or Stratum, that originally went acrofs It and thereby feparated one Valley from another, is cut into the Fafhion of a Door Cafe, fix or feven Foot wide, giving thereby the Arabs an Occafion to call Them the [Beeban] Gates; whilft the Turks, in Confideration of Their Strength and Ruggednefs, know Them by the additional Appellation of [Dammer Cappy] The Gates of Iron. Few Perfons pafs Them without Horror, a handful of Men being able to difpute the Paffage with a whole Army. The Rivulet of Salt Water, which glides through This Valley, might poffibly firft point out the Way, which Art and Neceffity would afterwards improve.

Two Leagues to the S. S. E. of the Beeban, is The [Accaba Tle Accaba, $\left.x_{1}: 25\right]$ Afcent, another dangerous Pafs, and the reverfe of the Beeban. For here the Road lyeth upon a narrow Ridge, with deep Valleys and Precipices on each Side; where the leaft Deviation from the beaten Path, muft expofe the Traveller to the almoft inevitable Danger of His Life. The common Road from Algiers to the Eaftward, (notwithftanding thefe Difficulties, ) lyeth over This Ridge and through the Beeban; being preferred to another, a little on the Right Hand, as being wider, and to that of $W$ an-nougab in being more direct.

Wan-nougah or Wan-nou-bah, a Part of Mount Atlas and The Moont, of the Seat of the Welled Boobeide and Beleel, is a Knot of Moun- wan. tains lefs rugged, and much better watered, than thofe of the Beni Abbe/s. They lye to the S. W. of the Beeban, and hang over the Plains of Hamza on the one Side, and over Thofe of Mejana on the other.

The Gurgoure a powerful Clan, are five Leagues to the Eaft-Gurgoure. ward of the Beni Abbe/s, and border upon the River of the Welled Ajebby. Above Them are the Meleltab and the Beni Selim; and then follow the Mountains of Neeny, and Taffaat, cultivated by Welled Nebbs and Shouke. The Rabamah, with Rahamah. Their high pointed Mountain, are to the Weftward of Taffaat; and in the like Situation we find the BeniWortelan, who have BeniWorteSaltoure, a confiderable Daßbkrab of the Beni Abbe/s, to the Northward. Two or three Leagues to the E.S.E. of the Beni Wortelan, are the Beni Yalah, of the fame Family with Thofe of Mount Furjura; and at the like Diftance to the S. E. is the Town of Zammorah, built over againtt the Tomb of Seedy Zam-morah. 
Embarak Ef-mati, where the Turks have a fmall Garrifon. Zammorah fignifyeth Olives in the Language of the Kabyles, and muft therefore be undoubtedly miftaken by Buno* and others, for the antient Zama. This large Tract of Mountains, which I have been hitherto defcribing, endeth at Zammorah, where we begin to defcend into the Plains of the Suderatah, in the Parallel of Seteef.

Emowlah. Above the Beni Boo-maf-oude, are the Emowlah, and UtWelled Arure, two large Tribes, the Neighbours of the Welled Ajebby. Ajebby. The Ajebby lye over againft the Gurgoure, near the half Way from Boujeiah to Seteef, being remarkable, as well for the Sanctuary of Their Marab-butt Seedy EeJab ben Habeeb, as for SAva Muni. the Ruins of an antient City, probably the Sava Municipium of the Antients.

Mount Meg- Three Leagues to the Southward of the Welled Ajebby, is reefe. the high Mountain of Megree Je, with fome few Remains of AnEXRREA. P.26.C. tiquity at the Foot of It. The Horrea of the Itinerary have this Situation.

Teftece. The Tefteefe and Their rugged Diftrict, lye four Miles to the Eaftward; and at the like Diftance from Them, ftill farMount $\mathrm{B}_{\mathrm{a}}$ - ther to the $\mathrm{E}$. is the high and fertil Mountain of Baboure, boure. from whence there is a diftant Profpect, over a long Succeffion of Mountains, of the Gulph of Boujeiah. This Mountain is cultivated by the Ammer, the Arabs properly of Seteef, and hath all over It feveral Footiteps of the Romans.

Six Miles to the Southward of Baboure, and a little more to

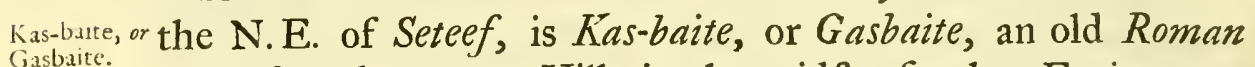
Gasbaite. City, feated upon an Hill, in the midft of other Eminences. Wed el The [Wed elD fahab] River of Gold, iffueth from among thefe Diabab. Ruins, and winding Itfelf afterwards through the exceeding Welled
Abde-Halk. rich Valley of the Welled Abdel-Halk, turns a Number of Abdel-Halk. Mills: Conveniences that are very rarely met with in this Part of the Country. Among the feveral Fragments of Ruins and Antiquities, there is a Part of the Portico of a fmall Temple, dedicated perhaps to one of the Roman Empreffes, as may be conjectured from this broken Infcription.

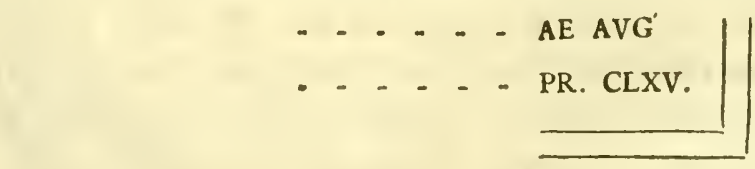


Upon the Declivity of the fame Hill, a little to the South-Thesepulckral ward, we have feveral Sepulchral Monuments and Infcriptions; ; Mcountenents. moft of which have been beautifully carved into a Variety of Figures in Baffo Relievo, reprefented either mourning, offering Incenfe, or performing fome Office to the Dead. The Infcriptions lye below the Figures, fome of which are as follow.

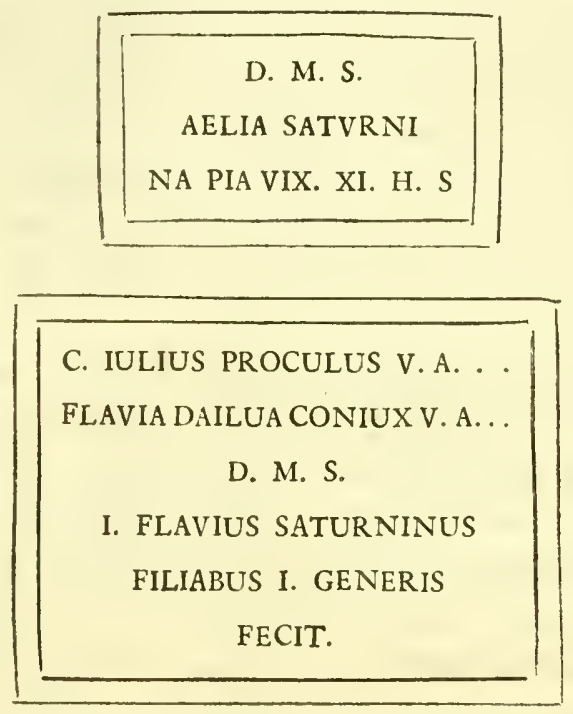

Kas-baite, from the Diftance and Situation It hath with re-TkesATAFI. fpect to Sitifi and Igilgili, fhould be the Satafi; as fome of ${ }^{\text {Ex.p. } .25 . D .}$ the Ruins at Baboure may prove likewife to be the Bafilica of the Antients.

Four Leagues to the N. E. of Kas-baite, is the Town of Fim-jim-meclah

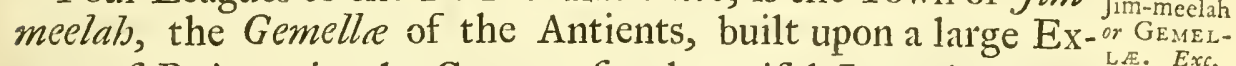
tent of Ruins, in the Centre of a beautiful Interchange of ibid. D.F. Valleys and Mountains. There are here feveral Fragments of Antiquities, particularly one of the old Gate of the City, and of an Amphitheatre.

The Wed el D fahab, upon uniting the River of Fim-meelah, ${ }_{\text {Tullah. }}$ feparateth the Encampments of the Tul-bah from thofe of the Beni Merwwan; and wafhing afterwards the Country of the Beni Silune and Fraidah, leaveth the Beni Omran and Ourarr ${ }_{\text {Beni silune. }}$ a great Way to the Weft. All thefe are confiderable Tribes; and the Laft lye directly in the Road from the City Meelab to Fijel. 
Meelah or MILEVUM Cr MILEU. Exc. p. 28. 2. Tab.Peut. H.

Deik or $\mathrm{Me}-$ deik Boueffah.
Near the Fraidah, five Leagues to the N. W. of Conftantina, and eleven to the S. E. of Fijel, is the City Meelah, the Milevum or Mileu of the Antients, built in the fame Manner and in the like Situation with Fim-meelah. It is furrounded with Gardens and plentifully ftocked with Fountains, one of which, bubbling up in the Centre of the City, is immediately received into a large fquare Bafon of Roman Workmanfhip. Conftantina is fupplyed chiefly from This Place with Herbs and Fruit: Whofe Pomegranates particularly are of fo large a Size, and have withal fo delicate a Mixture of the Tart and Sweet, that They are in great Efteem all over the Kingdom. Leo' and Marmol bear Teftimony likewife to the Goodnefs of the Apples, inafinuch as They have thought fit to derive the very Name from That Fruit.

Three Leagues above Meelab to the S. S. W. are the Ruins of Deik or Medeik Bou-e/Jah, formerly another antient City of the Romans, near the Confines of the Cirte $i j$. We have here, befides a Number and Variety of little Cells, cut out of the folid Rock with immenfe 'Labour and Expenfe, a Fountain of excellent Water, called Ain el Fouah, from the great Quantity AinelFouah. of [Fouab 84.$]$ Mather growing in the Neighbourhood. The Ergh-a/h, the Swa-gah, and Beni Afb-oure, traverfe the Country in the Neighbourhood of Meelah and Deik; to the S. E. of Jibbel Woof- whofe Encampments, is Fibbel Woofgar, a long Chain of MounChiтuд. tains, that reach to Conftantina. The Chiture were probably Exc.p.1r. B. the antient Inhabitants of the moft Part of the Country I have defcribed betwixt the Meridians of Boujeiah and Meelah.

Thefe are the remarkable Places and Inhabitants of the mountainous Diftrict of the Mauritania Sitifen/ts to the Seaward. The Midland $\mathrm{We}$ are to defcend now into a more level Part of It, lying Maurit.Sitif. near the Parallels of Seteef and Conftantina, where, returning to the weftern Frontiers, we firft enter upon the Plains of Plains of Ma- Ma-janah, fhaded to the Northward by the Dra el Ham-mar, janah. and to the W. by the Mountains of Wannougah. Thefe Plains are equally fertil and extenfive, but the many Pools of ftagnating Water (as the Name ${ }^{2}$ may probably import) left here in the rainy Seafon, and corrupting afterwards in the Spring,

I Maxima hic eft non fructum modo, unde deductum nomen putant, verum St carnium frugumque copia. F. Leo. p. 2 I I. Mila abonde en Fruit \& particulierment en Pomes d ou il femble qu' elle a pris ton nom. L'Afrique de Marmol. 1.6. cap. 9. 2 Viz. ab ual Ajan, alterata fuit aqua mutato sapore o calore. Corrupta fuit, fatuit \&c. Gol.

occa- 
occafion a Variety of Agues and fuch like Diftempers, as are common to other Places in the like Situation. We have feveral Heaps of Ruins difperfed over thefe Plains; out of whofe Materials, the Turks have lately built a [Burgh] Fort, where They have a Garrifon to watch the Motions of the Beni Ab-be/s, and Their Tributary Kabyles and Arabs.

The Country of the Sud-ratah borders upon the Plains of Sud-ratah. Majanab to the Eaft, and hath to the Northward the Mountains of Zam-morah. It is not quite fo level and fertil as the Plains to the Weftward, being chiefly remarkable for the Sanctuary of Seedy EmbarakEf-mati, a Marab-butt of the firft SeedyEmbaReputation. This Place, which we may have fometimes Occafion to fpeak of, lycth three Leagues to the E.S. E. of the Burgb Majanab, and feven to the W. of Seteef. The Sa-Malampsir,

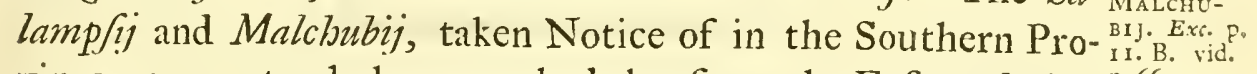
vince, may not only have reached thus far to the Eaftward, but ${ }^{\mathrm{p} .66 \text {. }}$ have fpread Themfelves likewife as far as Mefeelab and the Plains of El Huthnab to the South.

The Ammer, fucceed the Sud-ratah, fpreading Themfelves Ammer. along the Banks of the Kubber At-teab and Boofellam, a great Way beyond Seteef. They are a powerful, though infamous Tribe, proftituting in a very open Manner Their Wives and Daughters.

We have feveral Ruins in this Diftrict, but none worth taking seteef, The

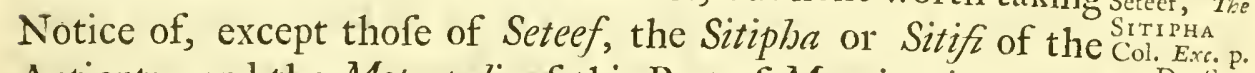
Antients, and the Metropolis of this Part of Mauritania. This Tin D. SI.

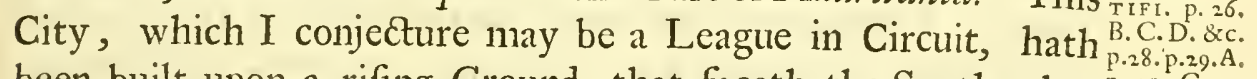
been built upon a rifing Ground, that faceth the South; but ${ }^{\mathrm{p} .3 \mathrm{r} \text {. } \mathrm{r} .29 . \mathrm{C} \text {. }}$ the Arabs have been fo very fevere to It, that there is fcarce one Fragment left us of either Wall, Pillar, or Ciftern of the Romans: the few remaining Structures, being obvioully the Work of the later Inhabitants. The Fountains in the Middle of the City are equally delightful and convenient; and without Doubt, gave formerly occafion to feveral ingenious and ufeful Contrivances in the Diftribution of the Water. I found here the two following Infcriptions; whereof the Latter is infcribed in Half-Foot Letters; and, provided It had been perfect, might have been of fome Confequence. 


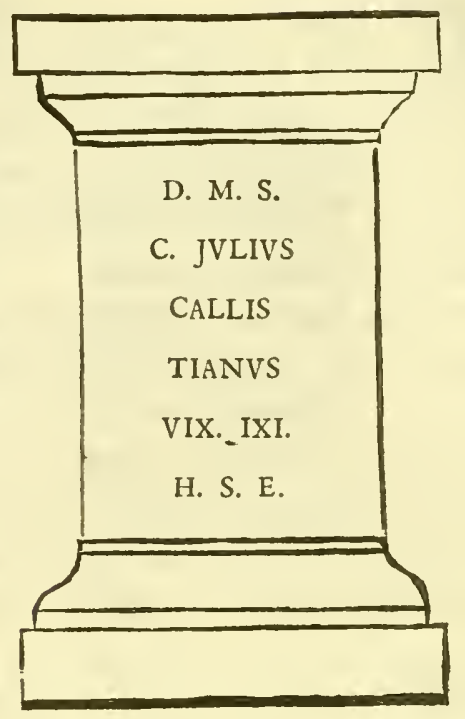

Raigah. To the Southward of the Ammer, are the Donwars of the Plains of Raigab, who, inhabiting the Plains of Caffir Attyre, reach Caffir Attyre. from the Mountains of the Beni Boutaleb, as far as Fibbel roufef. Thefe Arabs are noted for the breeding up of Cattle, having great Advantages and Encouragements to that Purpofe. For befides the Plenty of Water from the Kubber At-teah, Beidah, Berbe/s and other Fountains, They enjoy likewife the richeft Meadow and Pafture Ground of This Ciountry. The

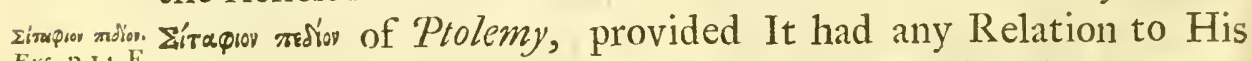
Exc. p.14.F. Sitipha, might very juftly be placed in This Situation.

El Elmah, The ElElmah, who fucceed the Ammer and Raigah, border to the Northward upon the Beni Merwan, and to the South upon the Welled Abdenore. We have few Ruins in This Diftrict. Among the more remarkable Places, is the Mountain and Tomb of Seedy Brabam, fituated a few Miles to the Southward of Hadjar el The [Hadjar el Ham-mar] Red Stone, at about the half Way Hamer. to Conftantina. At Hadjar el Ham-mar there is a Brook and 


\section{Of the Eaftern Province.}

noted Sanctuary, where the Zwowiah live in Mattamores: and betwixt It and Muftewah, a rugged Mountain of the Welled Abde-nore, we have the Hills of Tenou-teite, El-maiSai-rah and Tamagzah, with The [Ain el Kibfb] Sheep Foun-Ain elKabll. tain, and the Sbibkaib el Bazar a little to the Northward of Shibkah cl It. All the adjacent Rivulets, having Their Influx into the Shibkah, occafion continual Inundations, and render a confiderable Portion of thefe rich fpacious Plains both ufelefs and unhealthy. This Country, with That of the Ammer, the Raigah, CoEDamuand Their neighbouring Communities, feems to have been for- ${ }^{I}{ }^{\mathrm{B}} \mathrm{B}$. merly poffeffed by the Ceedamufij; as the Ducre may fall in with Duc... Exc, the prefent Encampments of the Welled Eifah, the Ziganeah, and thofe other Tribes who drink of the Rummel and Boomarzooke.

A few Leagues to the Eaftward of the Hadjar el Ham-mar, WeiledEifah are the Douwars of the Welled Eifah, who frequently incorporate with the El-Elmals and the Welled Abde-nore. However Their chief Abodes are, in the Neighbourhood of Fibbel Agreefe, upon the Banks of the WedelHammam; which, grbel $_{\text {greel }}$ Abeing a Branch of the Rummel, hath been already defcribed. At the Foot of Fibbel Agreefe, are the Baths that give Name to the River; where we have likewife the Ruins of a finall City.

The Welled Araimah live in the Neighbourhood of Fibbel WelledAraiFiltaan, towards the S. E. of the Welled Eifah: and, near the jibbel Fil- $^{\text {mal }}$ Fountains of the Sigan, to the W.S. W. of the Former Tribe, but to the Southward of the Latter, are the numerous Encampments of the Welled Abde-nore, a powerful and factious Tribe, welled Abwho, befides a largeExtent of plain and arable Ground, are poffeffed likewife of Muftewab and other impenetrable Mountains to the Southward. We have feveral Ruins in This Diftrict, but Thofe that are the moft worthy of our Notice, are of Taggah and Zainah, fituated, at half a Leagues Diftance from each other, Taggah, in a fruitful and champain Country, below Fibbel Muftewa Taggah and Zainah are rarely mentioned feparately, but, from Their Contiguity, are called joyntly Tagou-zainah by the or TagouArabs. A little Brook runs betwixt Them; and at the Latter, we have the Remains of a Triumphal Arch, fupported by two large Corintbian Pillars. The Frize is charged with the folE e lowing 
lowing Infcription, by the latter Part of which we may fix the The Draxia. Diana of the Itinerary at this Place.
Exc. p.26. F. Dian

IMP. CAES. M. SEVERO. PIO. FELICI. AVG. PUNT. MAX. TRI. POT. PROVIDENTISSIMO. ET SANCTISSIMO. PRINCIPI. ET ANTONINO. NOBILISSIMO. CAESARI. PRINCIPI. IUVENTUTIS. DIANENSICM. EX DECRETO. D. D. P. P.

Medraflem. Five Leagues to the E. of Tagou-zainah, upon the Northern Skirts of Fibbel Aure/s, we have a very remarkable fepulchral Monument, fituated betwixt two Eminences. It goes by the Name of Medrafbem, or Mail Cafhem, [The Treafure of Ca/bem] being nearly of the fame Fafhion with That of the Kubber Romeah, but differeth in being larger, and in having the Cornifh of the Bafe fupported with Tufcan-like Pilafters. The Arabs imagine, as They do with Regard to other large Piles, that an immenfe Treafure lyeth buried beneath It; and have therefore made the like Attempts, as at the Kubber Romeah, to lay It open.

The Difrict of The Diftrict in the Neighbourhood of This Manfoleum, is Ai-yac-coute called Ai-yac-coute; probably from The [Ain [-gil: $]$ Yac-conte' $]$ Diamond (or tranfparent) Fountain, that lyeth near the middle of It. Several Fragments of Roman high ways, and other Ruins, are fcattered all over It, whereof thofe of Om-oley Sinaab, a League or more to the Weftward of Medrafbem, in the Way to Tagou-zainah, are the moft noted.

Tatubt, The Tattubt, bordering upon the Ai-yac-coute to the N.E. is EADuT.P.26.G. about four Leagues from Om-oley Sinaab, and eight to the S. S. W. of Conftantina. This hath been formerly a confiderable City, but is at prefent almolt entirely covered with Earth and Rubbilh. Haffan, the prefent Bey of This Province, dug up lately out of thefe Ruins, feveral beautiful Granite Pillars, all of Them intire and of the fame Bignefs. They are about twelve Foot long, and may juftly be reputed the moft graceful Ornaments of the new Mofque, which he hath erected, at

I This is the ufual Name for the Diamond in the feveralPlaces, both of the Levant and Barbary, where I bave been. The ת'כi Zakoukit in the Book of Job (28. 17.) fecins to be the faime; and, being there joyned with Things of the greateft Price, may perbaps be inuch better rendred the Diamond than Chryltal, as It is in our Tranlation. However Golius and otbers interpret It differently. viz. Voce hac Orienci diverfx appellantur gemmx: Siquidem Hyacintbi fux pecies quatuor numerat; rubram, flavam, cxrulcam \& albam. Atque ita quoque Sappliris \& Chryfolitbus. Abfolute tamen intelligitur Hyacinthus rubra; qui lapis vulgo Rubinus dicitur. Vid. Gol. in voce $i g$ gil? 
Conftantina. Tattubt feems to be the fame Name with the Tadutti of the Itinerary; and lying betwixt Lambefe and Gemelle, as the antients called Tezzoute and Fim-meelah, will accordingly have the like Situation.

The Country to the W. and N. W. of Tattubt, at Sharla-taßb Sharla-tafl. and Fid-meelah, is either barren, woody, or mountainous, Jid-meelah. with little or no Water, except what is brackifh. It might therefore be a proper Boundary betwixt the Mauritania Sitifenfis, and the Diftrict of the Cirteflans, which, I prefume, we are Thew Limits to look for near This Meridian. But to the E. and N. E. of TESIJ. Tattubt, at Tagzah and near the Fountains of the Boo-mar. zooke, we have a fertil Soil, with more delightful Profpects; and which, I conjecture, might formerly belong to the Cirtefians.

WE ARE now to return once more to the Weftward and Tive soutbern enter upon That mountainous Part of the Mauritania Sitifen/is, Maunit. Siriwhich borders upon the Sabara. Four Leagues therefore to S.S.W. of Seedy EmbarakEf-mati, and five to the S. of the Burgh Ma-janah, is Fibbel I-ate, a Part of Mount Atlas, which ${ }^{\text {jibbel I-ate. }}$ reacheth from hence, with few or no Interruptions, as far as the Fereed of the Tunifeens. This Part of It, is poffeffed by the Welled Ha-ded; and at the Foot of It, towards the Sud-ratah, ded ded Hathere are fome Ruins called Burgh Smeefoah by the Arabs. $\quad$ Burgh Smee-

After Fibbel I-ate, over againtt the Country of the Sud-ratab, Jabbel Jourbwe have Fibbel Fourb-fab and the Welled Ta-banne, where Walled TaThe [Wed el Kafaab] River of Canes hath It's principal Foun- Wed el

tain. It is confiderably augmented in paffing under the Mountain of I-ate, from whence It inclines to the S. S. W, and wafhing afterwards the weftern Part of the City Mefeelah, lofeth Itfelf in the Shott. To the Eaftward of Fibbel Fourb-fah, is Fibbel Sou-billah, the chief Seat of the Welled Moufah ben billah.

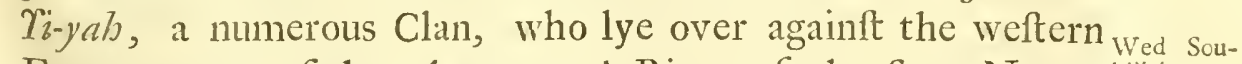
Encampments of the Ammer. A River of the fame Name, billah. very rapid in the rainy Seafons, hath It's Origine among thefe Mountains; which running parallel with the Kafaab and traverfing El Huthnah, leaves The Fow-am [rlga] el Mugrah, Jov-am el two Moorifhoratories, a little to the Eaft, and emptieth Itfelf afterwards in the Shott. 
Theroourtains The Soubillab is continued by the Anwaall, Geneefah, Monof the Beni
Boo-Taleb. kar and other Mountains of the Beni Boo-Taleb, who are powerful and factious Kabyles, living, beyond the Raigab, feven Leagues to the S. S. W. of Seteef. This Diftrict might Their Lead be the moft valuable in the Kingdom, provided the rich Lead
Mines.

Mines belonging to It, were managed to the beft Advantage; but the Beni Boo-Taleb, are either fo jealous or ignorant, that They will not permit any greater Quantity to be dug up at one Time, than will be fufficient for Their own Ammunition, and for the Difcharge of Their Tribute. Upon the lower Skirts of Thefe Mountains, near the Plains of CaJjer Attyre, are the Welled Seelab and the Welled Mahomet Ben Selyman. Thefe Ain Rum- Arabs drink of The [Ain Rummel] Sandy Fountain, a large mel. Flux of Water which difchargeth Itfelf into the Boo-fellam.

Welled Aly The Mountains of the Welled Aly Ben Sa-boure joyn Thofe Ben Sa-
boure. Jig-bah. Seteef. Fig-bah, a Heap of Ruins, is fituated at the Bottom of Them to the Eaftward; but we are at a lofs both for the antient Name of Thefe Ruins and of Thofe before mentioned at Smee/bah.

Ras el The [Ras el Aioune] Head of the Fountains, is two Leagues Aioune. to the Southward of $\mathcal{F i g}_{\mathrm{g}-\mathrm{b} a b}$ and eight from Seteef. It is the River of Nic-principal Fountain of the River Nic-kowese, called afterwards Bowere, or of Wed el Bareekah, from the Name of the Diftrict through which It paffeth. This River bends It's Courfe, in the Direction of the Soubillab and Kafaab, towards the S. S. W. and being made ufe of by the Inhabitants to meliorate Their Soil, the Remainder of It is drunk up by the Shott.

El Huthuah. Betwixt the Rivers Bareekah and Kafaab, to the Southward of the Mountains juft now defcribed, we have the fruitful and extenfive Plains of El Huthnah, cultivated by the Welled

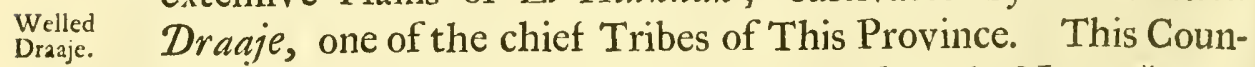
try, as It bordereth upon the Sahara, and as the Name * may likewife infinuate, is of a more dry and fandy Nature, than what generally lyeth to the Northward; however by watering It frequently with the Soubillab and Kajaab, diverted from Their proper Channels into a Number of Drains for that Purpofe, the Crops, which It produceth, are for the moft Part rich and copious.

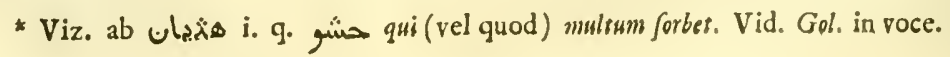


Mef-jeelah, the frontier Town of This Province to the Weft-Mef-feclat. ward, is built upon the Southern Skirts of El Huthnab, nine Leagues to the S. S. W. of Seedy Embarak EJ-mati, and fomething lefs to the Weftward of Fowam el Mugrab; fo that Abulfeda' muft be miftaken in placing It only eighteen Miles from Conftantina. It is a dirty Place, like moft of the Villages of This Country, having It's Houfes built, either with Reeds daubed over with Mud, or elfe with Tiles baked only in the Sun. The Algerines had formerly at This Place a Garrifon of three Suffrahs, changed at prefent into a fmall Body of Spahees, who have little Duty upon Their Hands, and upon any Infurrection or Difturbance, (there being no Caftle to protect Them) have nothing but Their Arms to truft to. The Air is too cold at This, as well as at other Places upon the Skirts of the Salsara, for the Production of Dates; and therefore the Gardens that furround It, are only furnifhed with Peach, Apricot, and fuch fruit Trees, as are common to the more northern Parts of Barbary. Mef-feelab ${ }^{2}$ denotes fuch a Situation as This, which borders upon a running Water.

Eight Leagues to the E.S. E. of Mef-feelats, and a little to The Plains of the S. W. of Fow am el Mugrah, is The [Ain el wis Kelb] Fountain of the Dog. From whence we crofs the Nak-kar, (as They call the River Soubillah near the Shott) and afterwards, at five Leagues Diftance ftill farther to the Eaftward, the Bareekah, and then enter into the Plains of that Name, which are cultivated, in the fame Method with El Huthnah, by the Welled Seedy Mahamet Ben Hadge. The Eaftern Parts of El Huthnah bound This Diftrict to the Northward; and to the S. W. we have the Les-baah, an Interchange of feveral little barren ${ }_{\text {Les-baah. }}$ Mountains and Valleys that border upon the Shott.

Fibbel Suffian, a rugged Mountain inhabited by the Welled Jibbel Suf- $_{\text {- }}$ Toufef, is fituated at three Leagues Diftance to the N.E. of tian the Bareekah, and to the S. S. W. of the Ras el Aioune. The Youref. little Rivulet of Boo-ma-zoofe, defcends from This Mountain, The Boomaand leaving the Bareekab three Leagues to the Weftward, lofeth Itfelf afterwards in The [Midar wo] Miry Plains of M'oufef. BenBen Toufef, to the Eaftward of the Shott.

I Al Kaicm Billab Fathemita condidit Mefecla An. Heg. 315. appellavitque eam Al mobammediab. Inter Coftinam \& Mefcelam octodecim Milliaria \& mons continuus. Abulf. ut fupra. 2 rhaur (viz. J J fluxit aqua) locus torrentis feu fluentis aqua. Vid. Gol. Gig. \&ic. in voce. 
Tubnah, The + At the fame Diftance, and in a like Direction from Fibbel

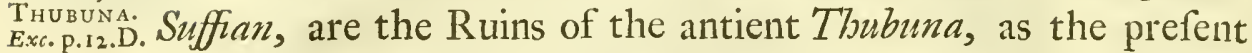
p. 33. Name Tubnab feems to infinuate, and the Pofition of It, with Refpect to Igilgili, doth farther confirm. It is fituated in a fine Plain betwixt the Rivers Bareekah, and Boo-ma-zoofe; but the few Walls, Pillars and other Ruins that have efcaped the Fury of the Arabs, are fo much covered with Sand and Rubbifh, that It will be difficult to determine the former Extent of It. TheOpivion of the Arabs, that great Quantities of Money lye buried in Thefe Ruins, might give Occafion to the following Rhap Jody'.

The Treafure of Tubnah lyeth under the Shade of what is joaded. Dig for It? Alas! It is not there.

Not a city of Tubnah, I prefume, cannot be rightly placed by Abulfeda ${ }^{2}$ Zaab. among the Cities of Zaab, from which It is divided by a great Diverfity of Valleys and Mountains.

Em-dou- Seven Leagues to the S. S.W. of Tubnah and fix to the S. E. khal. of Mef-feelah, is Em-dou-khal, a little Village furrounded with Mountains. Here we meet with the firft Plantation of Date Trees, though the Fruit doth not ripen to that Delicacy and Sweetnefs as in the Province of Zaab.

The Shott. The [ش] Shott is a large Valley, running, with few Interruptions, betwixt two Chains of Mountains, from the Neighbourhood of Em-dou-khal, to the Weftward of the Meridian of Mef-feelah. The Word commonly fignifieth The Sea Shore, or The Banks of fome Lake or River: but the meaning here is fomewhat varied, denoting The Borders or Area rather of fuch a Plain, as, according to the Seafons of the Year, is either covered with Salt, or overflowed with Water. Several Parts of the Shott, confift of a light oozy Soil, which, after fuddain Rains or the overflowing of the adjacent Rivers, are changed into fo many Quickfands, and occafion no fmall Danger and Difficulty to the unwary Traveller. La Croix ${ }^{3}$ hath been badly informed in afferting that all the Rivers of This Kingdom run from South to North; fince, befides feveral others in a quite contrary Direction, we have no fewer than Five, and Thofe very confide-

I Mel Tubma taat thul atbloulalo. Afer? Weis! la takoun toumals.

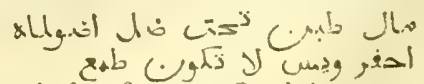
2 A Tubna Civitate Al Kab ad Boujeial fex Stationes. Abulf. ut fupra. 3 On doit icmarquer que toutes les Rivieres dn Royaume d'Alger coulent du find an Nord. De La Croix Metode pour aprender la Geogr. Tom. 5. P. 282-3. 
rable Streams, which empty Themfelves into This Place from the Northward.

Croffing the Boo-ma-zoofe, over againft Tubnah, we have a Muckat el large Mountain of excellent Free-Stone, with a Number of ${ }^{\mathrm{H} \alpha \mathrm{djar} .}$ fquare Blocks, ready prepared for the Builder, lying by It. It is called The [ Muckat ${ }^{2}$ bin] el Hadjar] 2uarry; the Arabs having a Tradition that the Stcnes employed in the building of seteef (and without Doubt of Nic-kowfe, Figbah, and other neighbouring Cities) were brought from This Place.

Four Leagues to the Northward of the Quarry, is Boo-Boo-muggar. muggar², a fruitful little Diftrict, with fome Traces of antient Buildings. Betwixt It and Ras el Aioune, is the Village of Nic-kowfe or Ben-cowfe as the Turks call It, where there is a Nic-kowfe. Garrifon of one Suffreh, a mud-walled Rampart and three Pieces of Cannon. The Inhabitants are chiefly Zworviah, under the Protection of Seedy LafJan, Their tutelar Saint: out SeedyLaffan. of the Revenues of whofe Sanctuary there are maintained two hundred Thalebs. Nic-kow Je is fituated in a Plain with a Circle of Mountains at a moderate Diftance from It. A Rivulet. glides by It to the $W$. but being impregnated with too many of the nitrous Particles, which the Soil It paffeth over is charged with, the Water is feldom made ufe of in the Offices of the Table or Kitchin. We have the Traces here of a large City, with the Remains, as ufual, of Pillars, broken Walls and Cifterns. But at prefent the Nic-korvfians make Themfelves famous for the Tombs, They pretend to have, of the Seven Sleepers ${ }^{3}$, Whom They ftrenuoufly maintain to have been Munfelmeen, and to have flept at This Place.

Half Way betwixt the Rasel Aioune and the Mountains of Ain Azell. Welled Aly Ben Sa-boure, we have other Ruins and feveral Troughs and Cifterns of Stone; all of Them the Work of the Antients, and into which the plentiful Fountain of Azell is conducted. Three Leagues to the S. S. E. of the Ras el Aioune, welled are the Mountains of the Welled Sultan, who are fucceeded, in Sultan. a like mountainous Tract, by the Welled Fathmah: and then by Fathnaa.

I Viz. a 3 Gecuit. $2 A$ Word like this, viz במנרי Bemuggarou w'e mect with in the H. Scriptures; rendred In His or Their Dwellings. Fob. 18. 19. Pf. 55. 16. Magalia etiam dicta quafi Magaria, quod Magar [D] Punice Novam Villam dicunt. Ifid. Orig. I. I5. Cap. I2. 3 The common Opinion is that They Slept in a Cavern of Mount Ochlon, near the City Ephefus, from A. D. CCLIII. to A. D. CCCCVIII, viz. from the Decian Perfecution to the Time of the younger Theodofius. vid. Gregoire de Tours de gloria Martyrum. C. 95. Didtion. de Moreri in Voc. Dormans.

Ff 2

the 
Lakh-dar. the Lakh-dar. The Latter are a Clan of Kabyles as inhofpitable as Their Mountains are rugged; fpreading Themfelves from the Booma-zoofe, through Coffoure and Me-der-ree, as far Welled
Zei-an. are the Neighbours of the Lakh-dar to the Southward: in which Situation we have the Village of Lwo-taiah, with a

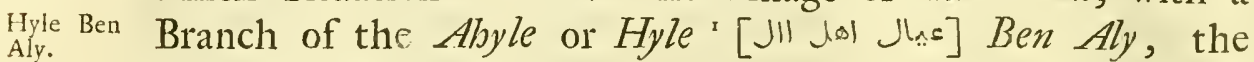
principal Arabs of This Province; who, befides Their extenfive Poffeffions in This mountainous Diftrict, fpread likewife Their Encampments to a great Diftance in the Sabara. The

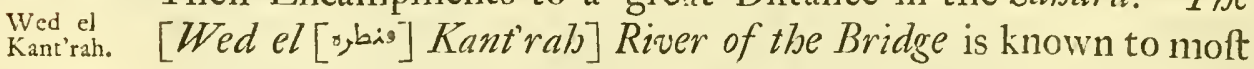
of Thefe Arabs and Kabyles; for rifing below the Welled Fathmah, and winding Itfelf through the Country of the Lakh. dar, (where we have the Bridge that giveth Name to the River) It is continued through the Diftrict of the Welled Zei.an and Lwotaiah, watering afterwards the Gardens of Bifcara, a noted Village of the Sahara.

JibbelYoufe. The Chain of Mount Atlas, that we left among the Welled Aly Ben Sa-boure, is continued by Fibbel Toulef, a fruitful Mountain, five Leagues to the S. by E. of Seteef. Upon the Declivity of It, near the eaftern Encampments of the Raigah, Gije-el. We have the little Village Gije-el, that was formerly a City of the Romans. Fibbel Toufef is joyned by the Mountains of Welled Sel- Welled Sel-lem, where there are other Ruins, called Zeryiah by Zeryiah.
Jibbel Muf the Arabs. The high and rugged Mountains of Muftewah tewah. follow Thofe of the Welled Sel-lem, inclining likewife, as They do, towards the S. E. I have already obferved that They beWelled Ab-long to the Welled Abde-nore, a powerful Tribe, who live in de-nore. the champain Country in Tents and on the Mountains, (whither Their Quarrels frequently oblige Them to retire) in mud-walled Hovels, like the Kabyles. Aly Ben Gy-doune, the Shekh of Shekh. lour and Conduct, the whole Force of Algiers, 'till They have, as ufual, invited the Hirkaat, Ziganeah and fome other neigh-

Hadjar Soudah. Welled Hirkaat. bouring Arabs to Their Affiftance. The [Hadjar Soudab] Black Rock, and the mountainous Diftrict of the Welled Hir-

I This Appellation, which, as far as I am informed, is peculiar to This Tribe, is rendred by Golius, Populus, Affcclx, Affines, familia, domettici, liberi \& pofteri : and is therefore another word only for Welled or Beni (Vid. Not. p. 17.) which have fo often occurred. Chaijl [ל' $\Pi$ ] which feems to be the fame, is tranglated in the H. Scriptures, (I Sam. 10. 26.) a Band of Men, (Pf. 33. 16.) an Army, (Pf. 136. 1 5.) an Hoft. 


\section{Of the Eaftern Province.}

kaat, in a S.E. Direction likewife from Fibbel Youfef and Muftewval, are the next in Order. At the Foot of Thefe Mountains, where They border upon Fibbel Aitre/s, we have Baitnah, Baitnah. a large Heap of Ruins, exceedingly well watered, and lying at the half Way nearly betwirt Conftantina and Bifcara.

Fibbel Aure/s (or Evrefs as the Turks pronounce It) the Mons Jibbel Aurefs,

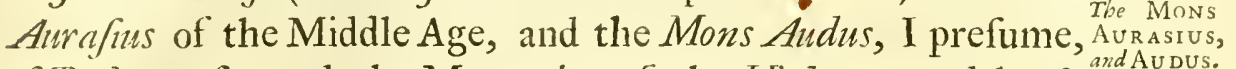
of Ptolemy, fucceeds the Mountains of the Hirkaat, and lyeth Exxc.p.t+D.D. to the Southward of Conftantina. It is not one fingle Mountain, as the Name would infinuate, and as Procopius ${ }^{1}$ feems to defcribe It, but a large Knot of Eminences, running one into another, with feveral little Plains and Valleys intervening. However both the higher and lower Parts of It, are moft of Them of the utmoft Fertility, and ftill continue to be the Garden of the Kingdom. The Whole may be a hundred and twenty Miles in Circuit, or three long Days Journey according to Procopits : and the northern Part alone, which is vifited every Year by a flying Camp of the Algerines, is poffeffed by fuch a the clans of Number of Clans ${ }^{2}$, that It requires forty of Their Stations to bring Them All under Contribution. The Turks rarely pals towards the Ain $\mathrm{O} u$ beide, an intermitting Fountain to the S. E. Ain Ouflowing only, as I am informed, on Fridays; at which Time, It difchargeth Itfelf, in a plentiful Flux of Water, into the River of Bag-gai. The like Ruggedneis of Thefe Mountains to the Southward, equally difcourageth Them from making any Advantages towards the Near.dee, a fturdy Community, fo well Near-dee. fortified by Nature, that one of Their Marab-buts expreffed the Danger of attacking Them, by the eating of Fire ${ }^{3}$. A high pointed impenetrable Rock, the Seat of Their Da/hkrah, feems to be the Petra Geminiani ${ }^{4}$ or the Tumar of Procopius, anfwering to all the Circumftances, that are recorded of one or other of thofe Places, by that Hiftorian.

There are a Number of Ruins fpread all over Thefe Moun-L'erba, or tains, the moft remarkable of which, are thofe of L'erba or

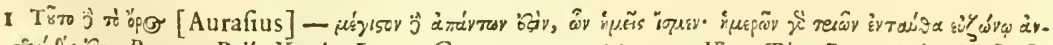
spi wéciodís ós. Procop. Bell. Fand. L. 2. Cap. 13. P. 266. 2 Viz. The Boozeenah, Lafba/h, Maifah, Boo-nerf, \&c. 3 La Shuff Neardy! Tackul el Nahar. Dont fee (fight with) the

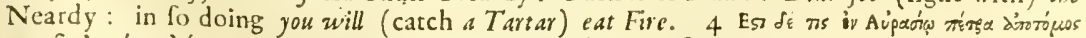

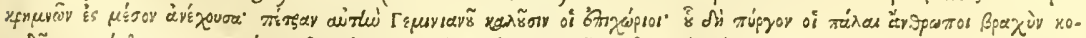

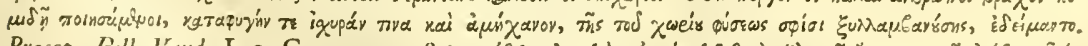

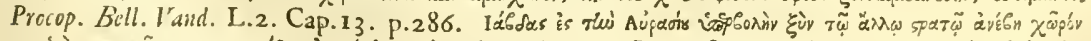

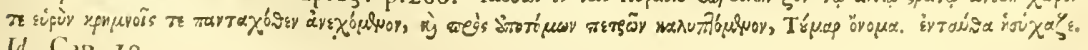
Id. Cap. 19. 
Tezzonte, three Leagues nearly in Circumference. We have here a great Variety of Antiquities; for befides the magnificent Remains of feveral of the City Gates, (which according to a Tradition of the Arabs, were forty in all, and that when the Place was in Profperity, It could fend out of each Gate forty thoufand armed Men,) we have the Seats and upper Part of an Amphitheatre; the Frontifpiece of a beautiful Tonick Temple, dedicated to Efculapiu; ; a large oblong Chamber, with a great Gate on each Side, intended perhaps for a triumphal Arch; and The [Cubb el [u,s] Ar-rofab] Cupola of the Bride, as the Arabs call a little beautiful Manfoleum, built in the Fafhion of a Dome, fupported with Corinthian Pillars.

Tbe Lambe- Thefe and feveral other Edifices of the like Nature, fufficiSA, or LAM${ }_{5}$.C. p. 26. in former Times; which alone, without the Authority of Infcriptions, might be a prefumptive Argument for what hath been already fuggefted, that Tezzoute or L'erba was t $\}_{\text {e }}$ Lambele of the Antients. The particular Notice taken of Lambefe in the Itinerary, fuppofeth It to be the moft confiderable City of That Part of the Country, where It was fituated: and the refpective Diftances and Directions laid down by the fame Author, in conducting us thither, point out to us the Situation of It in general, whereby It made with Therefte and Sitif an irregularKind of Triangle, whofe Height was to be determined by the Diftance of Cirta. Ptolemy indeed by placing Sitifi to the Southward of Cirta and Lambefa, or in the Situafion of the prefent Therefte, giveth each of thefe Places a Fofition very different to what They are placed in: however, by informing us, that the Legio Tertia Augufta was ftationed at Lambefa, He furnifheth us with a Matter of Fact, and fo far inftructeth us, that where we can find the Third Legion, as we do here at Tezzoute, there we may look for His Lambefa. We have the following Infcriptions at This Place.

Upon the Frize of the Temple of Efculapius.

AESCVLAPIO ET SALVTI IMP. CAES. MARCVS AVRELIVS ANTTONINVS AVG. PON. MAX. IMP. CAES. LVCIVS AELIVS VERVS AVG. 
Of the Eaftern Province.

Upon a fquare Stone burd by It.

DEONTEIO FONTINIANO

STERNIO RVTINO

LEGATO AVGVSTORVM

PR. PR. COS. DESIGNATO

SEX TERENTIVS SATVR

NINVS LEG. . . .

AVGVST.

In an old Mofque.

IMP. CAESARE

M. AVRELIO ANTONINO

ARMENIACO

PARTHICO

TRIB. POTEST - - PONT. MAX.

LAMBASENTIVM ....

D. D. P. P.

Near a triumphal Arch.

IMP. CAES.

ELIO HADRIANO

ANTONINO AVG.

PONT. II. MAXIMO

TRIB. POTEST. $\mathrm{X}$

IMP. II. COS. III. P. P.

DEDICANTE

INDVIO CR. . .

LEG. AVG. PR. PR. 


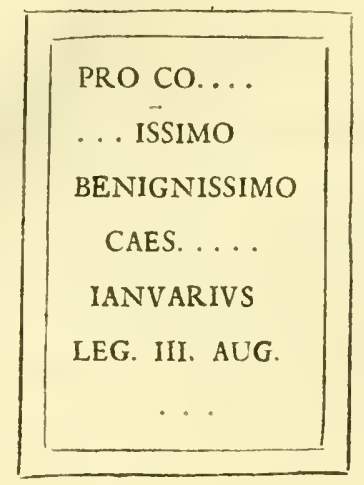

Near the Amplitheatre.

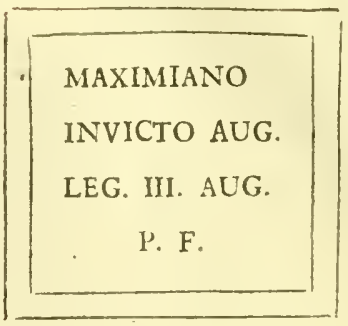

The Inkabitants yeliom baird.

We are not to leave the Mountains of Aurefs without obferving that the Inhabitants have a quite different Mein and Afpect from their Neighbours. For Their Complections are fo far from being fwarthy, that They are fair and ruddy; and Their Hair, which, among the other Kabyles, is of a dark Colour, is, with Them, of a deep Yellow. Thefe Circumftances, (notwithftanding They are Mahometans, and speak the common Language only of the Kabyles) may induce us to take Them, if not for the Tribe ${ }^{2}$ mentioned by Procopius, yet at leaft for fome Remnant or other of the $V$ andals ${ }^{2}$, who, notwithftanding they were difpoffeffed, in His Time, of thefe ftrong Holds, and difperfed among the African Families; might have had feveral Opportunities afterwards of collecting Misulam. Themfelves into Bodies, and reinftating Themfelves. If I am Exc. p.r. E. not miftaken, in making this Mountain the antient Audus, we may then prefume the Mifulami were the former Inhabitants.

Twabah. Beyond the Aurafians, are the Twaabah: then follow the Beni Sweek, and the Me-lou-noufbe; after whofe feveral Dafbkras and Encampments, are Thofe of the Bera-neefe, who Naxis. of all thefe Mountaineers lye neareft to the Sabara. The Exc.p.r.t.E. Miredij, I prefume, were formerly poffeffed of This Country.

Wod cl Ser- The River Serkah hath It's Fountains in the Hilly Country kah, The priz-
cital River of to the Southward of Tagzah and Burgh Twill; and, winding suress. Itfelf afterwards through Fibbel Aurefs, receiveth the Sootus, the Rivulet of Tezzonte and other Contributions. After which

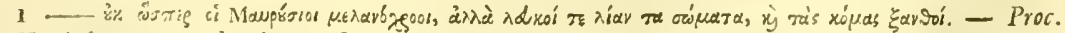

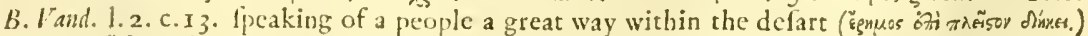

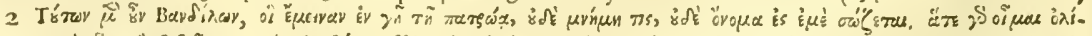

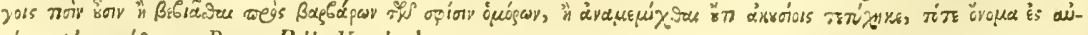

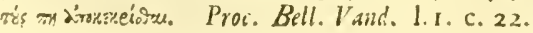


Additions It changeth It's Name, from the Colour of the Water, into that of The [Wed [uي!l] Abeadh] White River; and leaveing the Twaabah, a few Leagues to the W. falls to the Eaft-Twaabal: ward of the Bera-neefe, into the Province of Zaab. This River, as the general Courfe of It lyeth in the fame Meridian with ConAtantina, might have been made a proper Boundary betwixt the Mauritania Sitifen/ss and Numidia.

We are now to defcribe the Inland Parts and Inhabitants of Tbe Canztry of $_{\text {of }}$

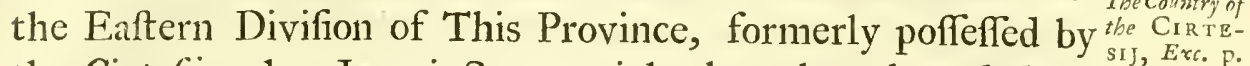

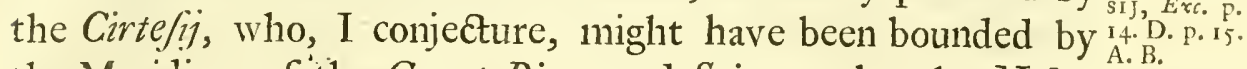
the Meridians of the Great River and Sgigata; by the Nabathree, who fucceeded Them, as far perhaps as the Meridian of THARA $E_{x \times c}$ Tuckufh: And by the Tontij, who were the Mafters of the fol- PonTit. D. Exc. lowing Part of Numidia, as far as Ta-barka.

Ion'TIJExc.
ibid.

Aböve the Beni Be-leet therefore are the Beni Wel-banne, a Beni Welconfiderable Clan, who live near the half Way betwixt Con- banne. ftantina and Skigata. The rugged Mountain of Sgowe be- jibbelsgowe: longs to Thefe Kabyles; and upon the Declivity of It to the Weftward, are the Ruins of an old City, called at prefent Ma-farah. The Grarah and the Hamzah, the next Inhabi-Ma-arala. tants to the Eaftward, are poffeffed of what feems to have been the N. E. Frontiers of the antient Cirtefij: being fucceeded, in a lefs mountainous Country, by the Hareißhah and $\mathrm{Fez}$ arah. Betwixt the large Pond of the Latter and Bond H Hareinlah. the Gun-nara, a Heap of Ruins, the moft remarkable of which Gun-nara. are thofe of an old Caftle.

The Welled Boo-zeefe have Their Douzwars, nearer the Sei-welled Booboufe, to the Southward of the Harei/bah. Their Diftrict is zeere. more woody and mountainous than the former; unlefs when They encamp in the Boo-bammam, near the Banks of the Seiboufe. Afls-coure, a finall Heap of Ruins, is fituated upon the Afl-coure. eaftern Skirts of the Boo-hammam, near the Ain Mylfah: and a little below Them there are other Ruins, and a Number of lukewarm Springs, bubbling up within a large fquare Bafon of Roman Workmanfhip. Thefe, which are called from Their Warmth and Quality Hammam or Hammah, feem to be the the AQU

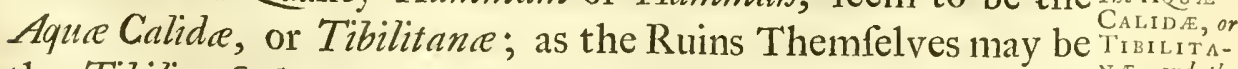
the Tibilis of the Antients. lying about ten Leagues to the Ta, and the

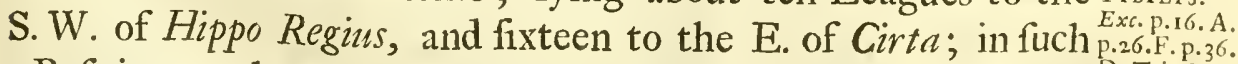
a Pofition nearly, as It is placed in by the Author of the Itinerary. Thab Pent: 
Welled Ma. In the fame Parallel with the Welled Boo-zeefe, but to the foudc. Eaftward of the Sei-boufe, are the Welled Ma-foude, who live Shebnah. over againft the Anebbians, and the Merdafs; as the Shebnah, who fucceed Them, are to the Southward of the Ma-zoulah. Both thefe Tribes poffefs a large and fruitful Country, although welled Aly. It be fomewhat mountainous. Welled Aly live above the Beni Salah. Shebnah; and the Beni Salab above the Welled Ma-foude; both of Them powerful Clans, and Inhabitants of the mountainous Diftrict that borders upon the Hameefe, the weftermoft Branch of the River Mejerda. The Difritz of To the N.W. of the Beni Salah, below Fibbel Saadah, we have the Diftrict of Mownah, a level and fruitful Spot of Ground, lying along the fouthern Banks of the Sei-boufe. The Boo-hammam and the Ain Mylfab lye over againft It. AlafsAlaftoure. oure, a Town of Roman Extraction, is fituated, upon the eaftern Borders of It, below the Beni Salah; and four Leagues Gelma, The farther, in View of the Aque Tibilitance, is Gelma, or Kalmah $C_{A L A M A}$.
Exc. p.28. F. 32. Rows of Pillars and other Fragments of Antiquities ftill remaining, which the Hoftilities apprehended from the Beni Salah, would not give me leave to examine. +Gelma is undoubtedly the Calama fo inuch wanted ${ }^{\mathrm{I}}$ in the Old Geography, lying betwixt Hippo and Conftantina, but nearer the Former, as St. Auftin ${ }^{2}$ hath placed It.

JibbelArtyah To the Northward of the Boo-hammam, are the Mountains Ly-aillah. of Artyab and the Arabs Ly-aifbah, who, reaching beyond the Wed el Ze-nati to the Southward, encamp fometimes in the Country of the Girfah. In Their Diftrict are The [Hammam Meskouteen. Meskouteen] filent or inchanted Baths, fituated on a low Ground, furrounded with Mountains. There are feveral Fountains that furnifh the Water, which is of an intenfe Heat, and falls afterwards into the Ze-nati. At a fmall Diftance from thefe Hot Fountains, we have others, which upon Comparifon are of as intenfe a Coldnefs; and a little below Them, fomewhat nearer the Banks of the Ze-nati, there are the Ruins of a few Houfes, built perhaps for the Conveniency of fuch Perfons, who came hither for the Benefit of the Waters.

I Situm certum bujus Civitatis demonftrare non poffumus. Cellar. Gengr. Antiq. 1.4. c.v. p. I22. 2 Inter Conftantinam quippe ubi tu es, \& Hipponem ubi cgo fum, Calama ubi ille [Crifpinus] eft, vicinior quidem nobis, fed tamen interpofita ctt. D. Auguft. contra Litteras Petiliani. 1.2. c. 99. 
The Girfah, the Neighbours of the Ly-aißhah, have the Girfab. Beni Salab to the Eaft, and the Grarah and Hamzah to the Northward. They are a numerous Tribe, the Succeffors perhaps of the antient Ze-nati; fpreading Their Douwars from the Banks of the Rivers Sei-boufe, Sebba Aioune and Ze-nati, to Thofe of the Serff and Alleegal. The River Ze-nati might probably have been named from Their fuppofed Predeceffors. All This Country is a fruitful Interchange of Hills and Valleys; and fome Parts of It, efpecially Thofe that are mountainous, are interfperfed with feveral Forrefts and Plantations of Olive Trees.

Upon an Eminence, two Leagues to the S. W. by W. of the Anounah. Hammam Meskouteen, under the Shade of one of thefe Plantations, there is a large Extent of Ruins, called at prefent Anounah, where we have a fmall fouare Building nearly entire, which by the Figure of a Crofs + ftill remaining upon the Door Cafe, we may conclude to have been fome Chappel of the Chriftians. Among the Ruins is the following Infcription.

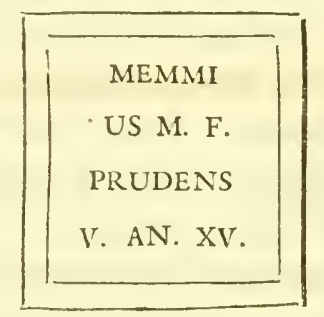

Alleegah, another City in Ruins, lyeth feven Leagues to the Allegath. W.N.W. of Anounah, and five to the Eaftward of Conftantina. It is fituated in a Plain, upon the weftern Banks of a River of the fame Name. Seni-ore, another Heap of Ruins, Seni-ore. lyeth ten Miles to the Southward of Anounah, not far from the River Serff: There is a large. Tower at This Place, befides a Fountain of excellent Water, and good Pafturage; but the Forrefts, all about It, are fo frequented with wild Beafts, that the Girfab very rarely fit down in the Neighbourhood of It.

The Welled Brabam, joyn the weftern Encampments of the $e_{\text {Welled Bra- }}$ Girfah, and extend Themfelves as far as Confantina. Their ham.

Diftrict is not fo much incumbered with Forrefts as the Former, and might have been formerly the eaftern Part of the Regio Cirtefiorum. The weftern Parts, near Tattubt, Fidmeelah \&c: 
have been already taken Notice of; among thofe which are Beer Staal. nearer the Meridian of Cirta, is [Beer Staal] where we have, as the Name [s Beer] infinuates, a Well, of Roman Workmanfhip, fituated betwixt the River Alleeegah and Hydrah, summah. one of the Fountains of the Boo-mar-zooke. Summah, a beautiful Plain, with a Heap of Ruins upon It, lyeth a little to the Southward of Hydrah; and ten Miles farther is The [Ain el Trap or Trab] Muddy Fountain, furrounded with a rich CounPhyrgeah. try belonging to the Welled Eefah. Phyf-geah, where we have other Footfteps of the Romans, is four Leagues to the W. of Ain el Trap, and five to the S. by W. of Conftantina. There is here a very plentiful Fountain, which formerly fupplyed Ziganeah. Conftantina with Water. The high Mountain of the Ziganeah is in this Neighbourhood; and at two Leagues Diftance from It, upon the Borders of the Welled Ee Jah, is Tagzah, a large Extent of Ruins, with a well watered Country round about It. Burgh Twill, A little farther, in the fame Direction, is The [Burgh lugb Trvill] ${ }_{\text {CESARIS. }}^{T}$ Tigh Tonver, the only Remains of another antient City of the Exc.p.26.F. Cirtefians, built in the fame fruitful Soil, and with the like Conveniences as Tagzah. One or other of Thefe Places, and perhaps the Latter, was the Turris Cre faris taken Notice of in the Itinerary to be forty Miles diftant from Cirta, in travelling thither by the Way of Sigus. We find Sigus placed fifteen Miles from the Towver of Ciefar, where the Roads united that conducted us from Thervefte and Tipafa to Cirta. We may take Termouke, It therefore for Temlonke, an old City in Ruins, built in a

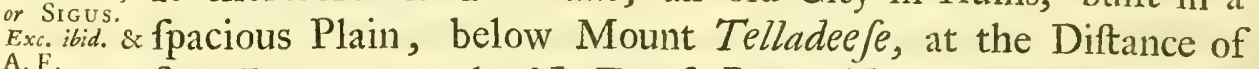
A.E. four Leagues to the N. E. of Burgh Twill and feven from Conftantina.

Shbai-hee. On the other fide of Mount Telladeefe, we have the Traces of another great City, called Shbai-bee, and fometimes (Shbaibee enta bent' Pharaoune) Shbaibee of the Sons of Pharaob, from a current Tradition, that the Pharaobs were formerly the Mafters of this Country, and that the Refidence of the $V$ iceroy, who was always one of Their Sons, was kept at This Place. This likewife is fituated in a fruitful Plain, perpetually verdant from the feveral Springs and Rivulets that water It. Seedy Rou- Seedy Rou-geife, a large fertil and well watered Sett of Emigeife. nences, lye above Shbai-hee, four Leagues to the S. E. of Burgh 
Twill. Among the Ruins upon This Mountain, we have the following Antiquity, and Infcription.

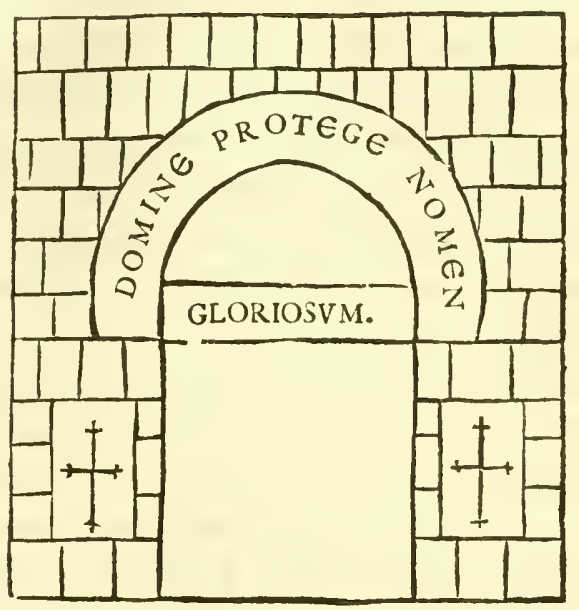

Near This Structure, there is likewife the following Infcription.

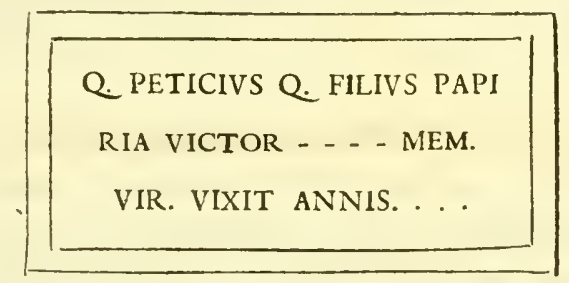

+ Cirta, or Conftantina as It was afterwards called ', is well Cirta, or fituated by Pliny, forty eight Roman Miles from the Sea. It $\mathrm{T}_{\text {Tina.stan- }}^{\text {Coxc. }}$ is defcribed in Hiftory to be one of the chief as well as one of A. $_{\text {. }}$. B. P. P. 18 . the ftrongeft Cities ${ }^{2}$ of Numidia: the firft of which Circum- Cap. 6.p.2r.

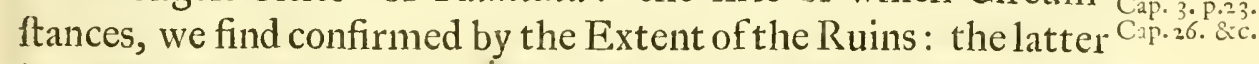
by It's particular Situation. For the greateft Part of It hath The situation been built upon a Kind of Peninfular Promontory, inacceffible of the Peninon all Sides, except towards the S. W. This I computed to be a good Mile in Circuit, lying a little inclined to the Southward; but ending to the Northward in a Precipice of at leaft a hundred Fathom in perpendicular. In this Direction we have a beautiful Landskip arifing from a great Variety of Vales, Moun-

I PerAfricam facerdotium decretum Flavis genti, Cirte que oppido, quod obfidione Alexandri ceciderat repofito ornatoque nomen Conftantina inditum. Atr. Victor in Vita Conftantini. Ko Cirta f. Cirtha, Punice, ה Partha, i. e. Civitas. Boil. Chan. 1.1. cap. 24. Kiriath joyned with Arba, Ferim \&c. in the H. Scriptures feems to be the fame Word. 2 Fugurthaneque propter Naturam loci Cirtam armis expugnare potelt. Sall. Bell. Fug. 9. 2 S. Exc. p. 7. B. 
tains and Rivers, which lye before It to a great Diftance. To the Eaftward, our Profpect is bounded by an adjacent Range of Rocks, much higher than the City; but towards the S. E. the Country is more open, entertaining us with a diftant View of the Mountains of Seedy Rougeife, and of Thofe of the Ziganeah. In this Direction the Peninfular Promontory (as I have called It) is feparated from the neighbouring Plains by a deep narrow Valley, perpendicular on both Sides, where the Rummel conveys It's Stream, and over which there was formerly a Bridge of excellent Workmanfhip.

and of the

The Neck of Land to the S. W. near which ftood the prinNeck of Land cipal Gate of the City, is about the Breadth of half a Furlong,
to the S.W. cipal being intirely covered with a Series of broken Walls, Cifterns and other Ruins, which are continued quite down to the River, and carried on from thence over a Strip of plain Ground that runs Parallel with the deep narrow Valley already defcribed. Such was the Situation and Extent of the antient Cirta. But the prefent City hath not the fame Dimenfions, being confined to that Part of It, which I have called the Peninfular Promontory.

The Ruins of Befides the general Traces of a Diverfity of Ruins fcattered the Cifferns,
and Aqueduct, all over This Place, we have ftill remaining, near the Centre of the City, that particular Sett of Cifterns, which I judge received the Water brought thither from $P h y$-geah by an Aqueduct. They are about twenty in Number, making an Area of fifty Yards fquare. The Aqueduct is ftill in a more ruinous Condition than the Cifterns; however the Fragments, which have continued down to this Time, fufficiently demonftrate the publick Spirit of the Cirtefians, in erecting a Structure that would require fuch an immenfe Quantity of Materials.

and of a large

Upon the Brink of the Precipice to the Northward, there Portico. are the Remains of a large and magnificent Edifice, where the Turkifh Garrifon is lodged at prefent. Four of the Bafes, each feven Foot in Diameter, with their refpective Pedeftals, are ftill in their Places, and feem to have appertained to the Portico. They are of a black Stone, little inferiour to Marble, hewn in all probability out of that very Range of Rocky Precipices, upon which They are founded. The following imperfect Infcription, placed in a Wall of modern Workmanfhip, ftrikes the Eye in viewing the Situation of the Portico. 



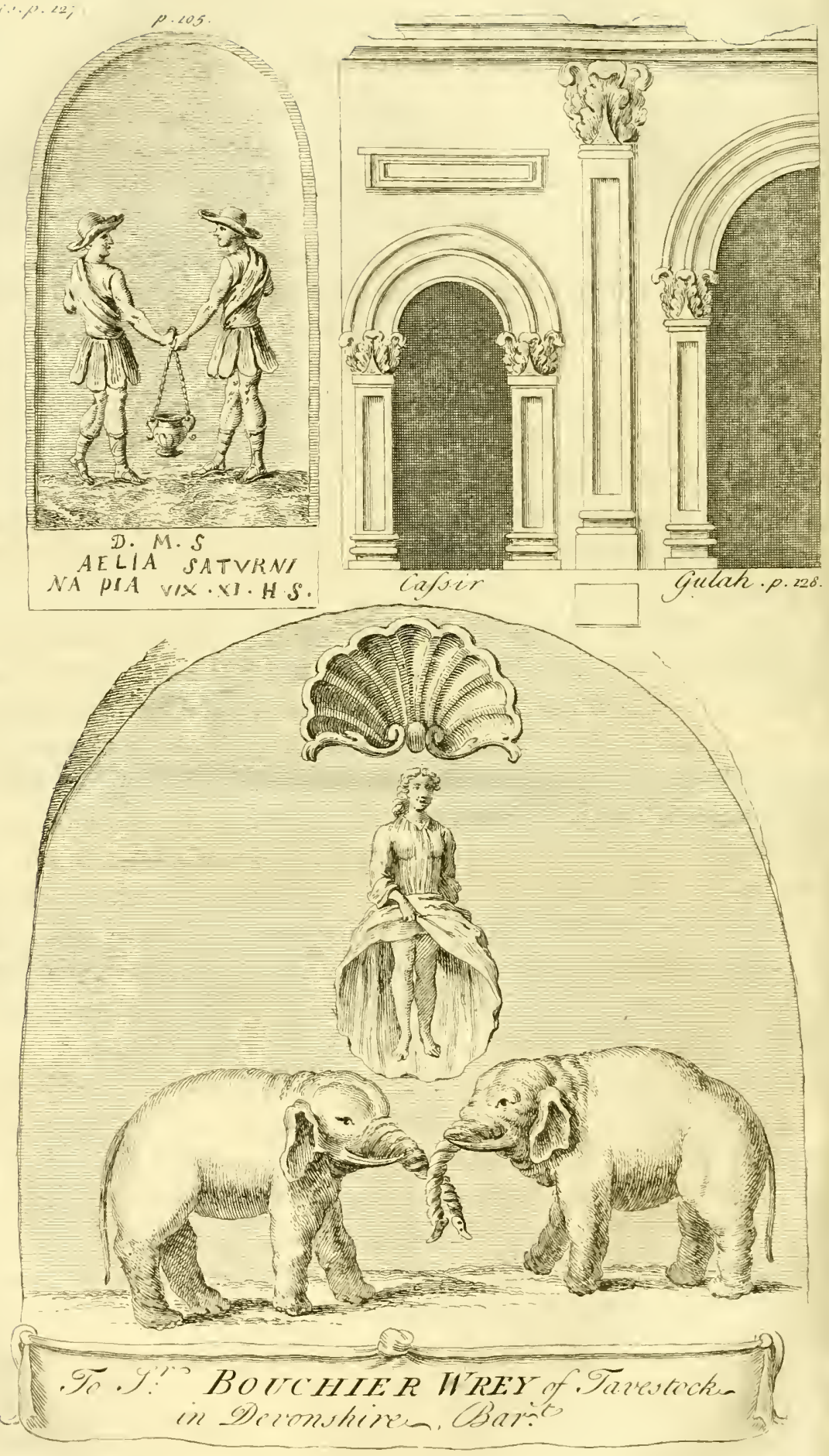




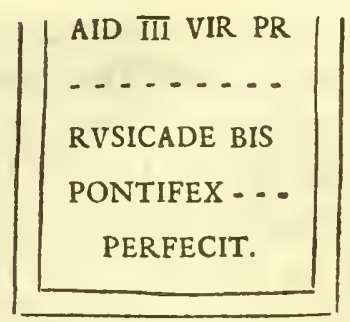

The fide Pofts of the principal Gate of the City, which are of Tbe Gates. a beautiful reddifh Stone not inferiour to Marble, are very neatly moulded and pannalled. An Altar of pure white Marble maketh Part of a neighbouring Wall; and the Side of It in View, prefents us with a well haped Simpulum in a bold Relief. The Gate towards the S. E. is in the fame Fafhion and Defign, though much fimaller: and lyeth open to the Bridge that I have mentioned to have been built over This Part of the Valley.

The Bridge was a Mafter piece in It's Kind, having had The Bridge. the Gallery and the Columns of the Arches adorned with Cornifhes and Feftoons, Ox Heads and Garlands. The KeyStones likewife of the Arches are charged with Caducei and other Figures. Betwixt the two principal Arches, we fee, in a ftrong Relief well executed, the Figure of a Lady treading upon two Elephants, with a large Efcallop Shell for Her Canopy. The Elephants, having their Faces turned towards cach other, twift their Trunks together; and the Lady, who appears dreffed in Her Hair, with a clofe bodied Garment like the riding Habit of our Times, raifeth up Her Petticoats with Her right Hand, and looks fcornfully upon the City. This Group, in any other Situation, might be fuppofed to belong to fome Fountain: it being well known, that They were fometimes laid out in fuch ludicrous and wanton Defigns. Upon a Stone, in the River below It, I traced out the following Words.

CAI. IVLI

SIGNINARI

Below the Bridge, the Rummel begins to turn to the North- The fubterraward; where It runs, for near a Quarter of a Mile in that of the RumaDirection, through a rocky fubterraneous Paffage, defignedly laid open in feveral Places, for the greater Conveniency of drawing up the Water, or cleanfing the Channel. According 
to all Appearance, It feems to be an extraordinary Provifion of Nature for the Admiffion of This River, which mult have otherwife formed a prodigious Lake, and thereby laid a great Part of the neighbouring Country under Water, before It could have found out any other Way to the Sea.

The Ruins of Among the Ruins to the S. W. of the Bridge, upon the a Triumpleal Arck. narrow Strip of Land juft now defcribed, we have the greateft Part of a triumphal Arch, called The [CaJjir Goulab] Caftle (as They interpret It) of the Giant, confifting of three Arches; the middlemoft where of is the moft fpacious. All the Mouldings and Frizes are curioufly embellifhed with the Figures of Flowers, Battle Axes, and other Ornaments. The Corintbian Pilafters, erected on each fide of the grand Arch, are pannelled, like the fide Pofts of the Gates of the City, in a Gufto, as far as I have obferved, peculiar to Cirta; but the Pillars of the fame Order, which fupported the Pediment, are broken down and defaced.

Infcriptions, Without the Precincts of the City, under the great Preci-

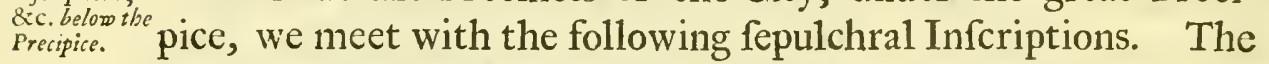
firft of Them, which is upon a Cippus, with the Figure of a loaded Ox in Baffo Relievo above It, and of a Crab below It, maketh one of the Steps, as we defcend to the lukewarm Springs of the Marab-butt Seedy Meemon, who lyeth there interred.

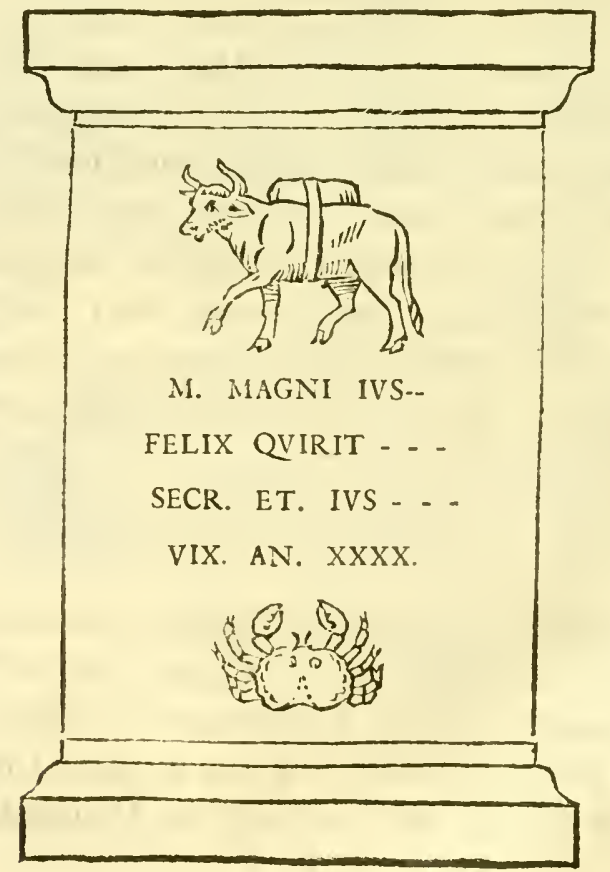




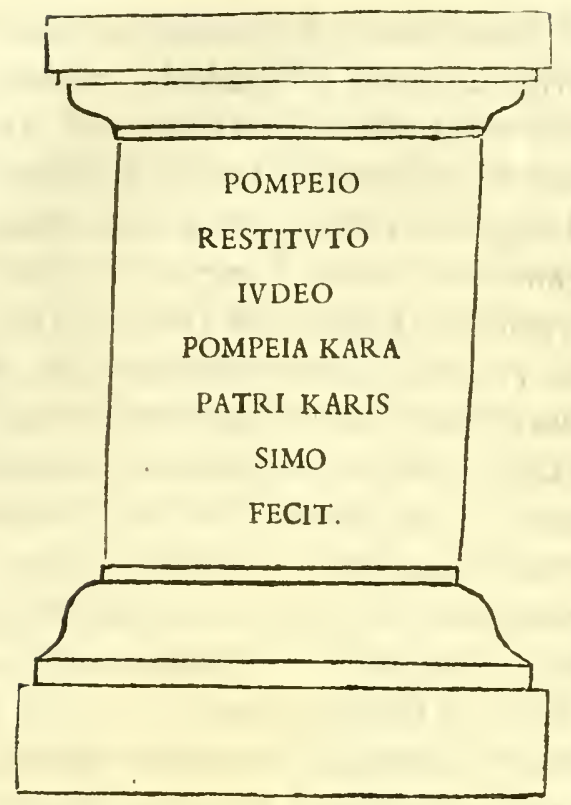

A Quarter of a Mile to the Eaftward of Seedy Meemon, The Carcade the Rummel falls, from It's fubterraneous Channel, in a large $\begin{gathered}\text { of the } \\ \text { mel. }\end{gathered}$ RumCafcade. The higheft Part of the City lyeth above It, from whence Criminals ftill continue " to be precipitated into (This Part of) the River. A little way beyond the Cafcade, is Kabat-beer-a-baal, for fo They call a neat tranfparent Foun-Kabat-beertain, full of Tortoifes. Several ftrange Stories ${ }^{2}$ have been re- ${ }^{\text {a-hall. }}$ lated of thefe Animals, without any Foundation.

Leaving Conftantina and the Welled Eefab to the N. and N. W. The cuntry we enter upon the Country of the Hen-neißah, who are not of the Henonly a powerful and warlike, but a genteel and comely Tribe." To Them and Their gallant Commander Bwoa-zeefe, the Algerines, in Their late Wars with Tunis, have been often indebted for a compleat Victory or honourable Retreat. Their Diftrict, the moft fruitful as well as the moft extenfive of Numidia, lyeth betwixt the Rivers Hameefe and Myski-anab; This, the moft fouthern, the Other the moft northern Branch of the Me-jerdah. There is fcarce an Acre of It, but what is watered by fome choice Fountain or Rivulet; and there are few of thefe Conveniences without having had fome City or Village

I Vid. Not. * p.93. 2 Eft quoguc huic oppido (Conftantine) vicinum quioddam balneum aqux calid $x$, qux inter rupes fluendo diffunditur: hic maxima eft teftudinum copia quas ejus Civitatis mulieres dæmones dicunt: \& quoties contingit aliquem corripi febre, aut alio quoris morbo, illud mox a teftudinibus profeaum putant. F. Leo. 1. 5. p. 2 ir.

Kk built 
built in the Neighbourhood; but which are found to be fo miferably defaced, that a Heap of Rubbifh, without either Name or Infcription, is what generally remains of Them at prefent. In this Condition, to mention no more, are the Ruins of $\mathcal{D} a b a-$ Daha-mam. mam, fixteen Leagues to the S. E. of Conftantina, in the Way Ama-mah. to Tipsa; at Ama-mab three Leagues farther to the SouthGreefah. Ward; and at Greefab fix Leagues to the E. by N. of Ama.mah. Tifferh, the +Tiffe/h, the Therefte of the Antients, is, I prefume, the THEVESTE. only City of This Diftrict which hath preferved It's old Name, A. B. p. 28 .
p. though, at the fame Time, It could not fecure It's Walls from A. B. p. 28. the Devaftations of the Arabs. It hath been fituated, like the reft, in a fine Plain, with a little Rivulet running by It, and may be computed to lye fix Leagues to the S. S. E. of Gelmah, eight to the N.E. of Daha-mam, and about nineteen to the E.S. E. of Conftantina.

Elgattar. Upon the eaftern Confines of the Hen-neifah, eight Leagues from Tiffe $/ \mathrm{h}$, is Elgattar; and three Leagues farther, towards Taje-elt. the N.E. is Taje-elt, another old City, not long ago famous Welled Ears. for It's rich Plantations of Fruit Trees. The Welled Ea s and Weelan. Weelan, cultivate moft of the plain Country round about Thefe Woorgah. Places; and after Them, are the Woorgah, whofe Douwars exCafir Jebbir tend as far as CaJjer Febbir, a little Village, eight Leagues from

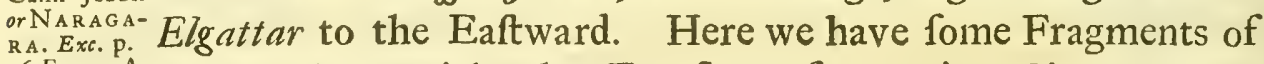

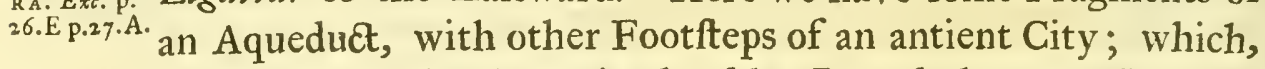
together with the Fountains hard by It and the great Scarcity of good Water in the adjacent Parts, fhould induce us to believe It to be the antient Naragara, or Nadagara', near which Scipio is faid to have encamped for the Benefit of the Water.

Wed el The River Serratt, the Midland Boundary of This Kingdom, Serratt. is ten Miles farther to the E. The Water of It is of a brackinh Quality, and falls into the Me-jerdah. Near the weftern Banks of It, five Leagues to the E. S. E. of Elgattar, is Callah, Gellah, Gellah. or Gellah at Snaan, a confiderable Village, built upon an high pointed Mountain, with only one narrow Road leading up to It. This Place, which is only to be conquered by Hunger or

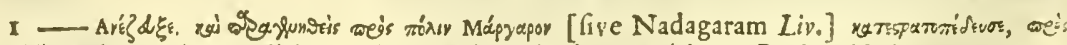

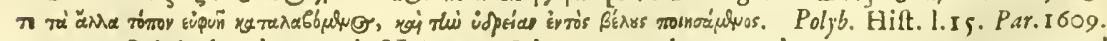
p. 694. Scipio haud procul Nadagara Urbe, tum ad catera loco opportuno, tum quod aquatio intra teli conjectum erat, confedir. Annibal tumulum a quatuor millibus inde, tutum commodumque alioqui, nifi quod longinqux aquationis erat, cepit. Lir. L. xxx. I. 29.

Surprize. 


\section{Of the Eaftern Province.}

Surprize, is a convenient Sanctuary for the Rebels and Villains of both Kingdoms; where They are hofpitably entertained, 'till their Friends have either procured their Pardons, or compounded for their Crimes. A little Way from the Foot of this Mountain, are the Ruins of Gafta, formerly a Place of fome $\mathrm{G}_{\text {afta. }}$ Confideration.

A little to the Eaftward of Gellah, the Serratt is united by Wed el the River Myski-anab, whofe principal Source is at Ain Thyllah, Min Thyllah. eighteen Leagues to the Weftward. This River, running nearly parallel with the Hameefe, at ten Leagues Diftance, divideth the Hen-neifhah from the Ne-mem-/hah, a Tribe equally powerful and numerous, though more factious and uncivilized. Six Leagues to the Weftward of Ain Thyllah, near the Confines of Fibbel Aure/s, are the Ruins of Ba-gai, formerly a confide- Ba-gai, Tr: rable City. A River of the fame Name paffing by It, empti- BAGASIs. eth Itfelf afterwards into the Mailab, an extenfive Pond of Salt Water, at the Bottom of Fibbel Oofte, a noted Mountain on that fide of Seedy Rou-geife. Thefe, as well from an Affinity in their Names, as from their Situations, may be taken for the Bagafis and Abigas mentioned by Procopius .

Neeny, formerly another of the larger Cities of Numidia, is Neeny. four Leagues to the Eaftward of Ba-gai: and feven Leagues to the Southward, is Tout $[\mathrm{y}, \mathrm{s}]$ a Village of the Ne-mem-/hah, borrowing It's Name from the Groves of Mulberry Trees which ${ }^{\text {Tout. }}$ thrive there to Perfection. Barbar, where there is a great Ex-Barbar. tent of Ruins, is fituated in a Valley, five Leagues to the S. W. of Tout: whilf Maba-mall, the Capital Village of Thefe Maha-mall. $_{\text {. }}$ Arabs, 1yeth in a more rocky Soil, at the half Way nearly betwixt Ba-gai and Tip $\int a$.

$U k-k u / s$, another of Their Villages, is built upon a Roman Uk-kurs. Foundation, on the Declivity of a large Mountain, fix Leagues to the N.E. of Maba-mall: and four Leagues to the Eaftward of Uk-ku/s, is + Tipfa or Tibe/Ja, the Tipa fa of the An-Tipra, Tho

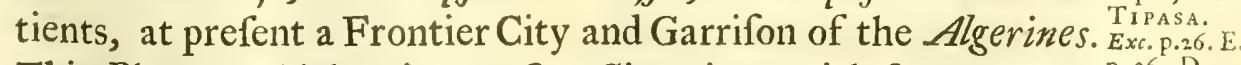
This Place, which enjoys a fine Situation, with fome Moun- ${ }^{\mathrm{P}} 36$. D. tains at a fmall Diftance, ftill preferveth the principal Gate, feveral Fragments of old Walls, and other Marks of the Rank and Figure It formerly held among the Cities of Numidia.

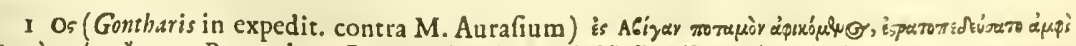

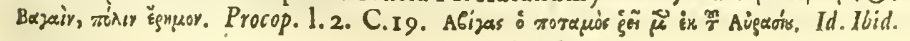

$\mathrm{K} \mathrm{k} 2$

There 
There is a large fubterraneous Quarry in the adjacent Mountains; the fame Place perhaps that Leo ' was informed had been formerly inhabited by Giants.

Tire River Me-lagge.

The Me-lagge paffeth by Tipfa, and joyning afterwards the Miliana, (as the Myski-anah is called below Uk-kufs) communicateth It's own Name to This River; which, by drinking up the Ain el Haloofe, Shebrou, and other plentiful Fountains in This Neighbourhood, becomes equal to the Boo-mar-zooke or Rummel.

Keefah.

Kee $\int a$ is at a little Diftance from Tip $\int a$ to the Eaftward: and then, four Leagues farther to the Southward, is Bi-cari-ah, built upon the Ruins of an antient City. In the fame Condition, and at the like Diftance towards the S. W. is Lerneb; after which, we have the Continuation of that Part of Mount

The Mountains of Atlas. Atlas, which hangeth over the Sahara.

7\%e Sabara. That Part of the Sabara, which correfponds to This Province, hath, befides the diftant City of Wurglab, and the Village En-goufah, the two confiderable Diftricts of $Z a a b$ and $W a d r e a g$. Each of Them containeth a Number of Villages; though, as It hath been already obferved, they are not all under the Jurifdiction of the Algerines. For $W$ adreag and the City of Wurg. lah, pay only an annual Tribute of forty black Slaves; whilft the weftern Communities of Zaab, viz. Doufan, Welled Fillel, and Seedy Khallett; and the eaftern, viz. Lyrena, Zerybe, and $B a b a s s$, give not the leaft Tokens of Homage or Submiffion. All Thefe Villages are built, in the fame Manner, with Mud Walls and Rafters of Palm Trees; whilft the Inhabitants are all of Them alike occupied in cultivating the Date Tree. Few of Them therefore require a particular Defcription.

TEe Digric of The Diftrict of Zaab, the Zebe of the Antients, a Part forZäbe. The merly of the Mauritania Sitifenfis and of Gietulia, is a narrow p. 28. P. 33. Tract of Land, lying immediately under the Mountains of Atlas. It reacheth from the Meridian of Mef-feelah to that of Conftantina, and confifts of a double Row of Villages, Douran. whereof Doufan is the fartheft to the Weftward. The Rivers Ganne and Fer-roufe run a little to the Eaftward of this Village, and empty Themfelves afterwards into the Wed Adje-de: upon the Banks of which River, three Leagues to the Southward,

I Eft huic oppido (Tibefse) mons quidam vicinus, antris profundifimis refertus, in quibus gigantes aliquando inhabitalic putantus. 7. Lco. Г. 212. 


\section{Of the Eaftern Prowince.}

are the Zwowiab of Seedy Khallet, whom the Arabs efteem as Seedy a Prophet. A little to the Eaftward of Them, are the Welled ${ }^{\text {Khallet, }}$ Fil-lell, a fturdy Clan, who, upon Occafion, can bring above lell, \&c. a thoufand Perfons, of Their own Fraternity, into the Field.

After we pafs the Boo-me-leah, a finall Tract of Arable The Plains of Ground, the Villages are more contiguous, rarely lying a quar-leala. ter of a Mile from each other. In which Situation is Lamree, Burgh, Tulgah, (called by fome Gengraphers Theolacha) Farfar, Tulga, \&c. Za-at/bah, Le-jhanah, Boo-jbagroone, Bifcara, Shit-mab, Bifara, \&ic. Toodah, and Seri-ana. In the like Pofition, but at two, three and fometimes four Leagues Diftance from each other, is the more fouthern Row of Villages: the Principal of which are Le-zvah, Sy-rah, Mu-badmah, Fef-bane-ah, Ban-teufe, Ou- Seedy Occ're-lan, Elme-nalah, Beegoe, Melee-ly, O-mafh, Oumil-hennah, ba. Seedy Occ'ba and Garta.

Lycena, Zerybt' el Wed, Zerybt' el Ha-mett, Cafjir Roma-Lyena, sic. $n a b$ and $B a d a j s$, are another Sett of Villages twelve Leagues to the Eaftward of Seedy Occ'ba: And at the like Diftance to the Southward, near the Confines of Wadreag, is El Fythe, El Fythe. watered by the fame River with Lycena, a Continuation perhaps of the Wed elSerkah, or Abeadh, that was taken Notice of in the Defcription of Fibbel Auress. Toodah, and Seedy Occ'ba, Bifcara, and Oumil-bennah, receive Their Rivers, as Doufan doth, from within the Tell; but the Fountains and Rivulets which refrefh the other Villages, rife within the Sabara, or elfe ooze immediately from the fouthern and adjacentSkirts of Mount Atlas. The [Wed su>Adje-dee or Fid-dee] Wed AdjeRiver of the Kid, receiveth thefe feveral Streams; and run- dee, or Gra. ning afterwards towards the S. E. lofeth Itfelf in the Miel-gigg, Mel-gigg. an extenfive Tract of the Sabara, of the fame faline and oozy Quality with the Shott. This fhould be the Garrar or Firad of Abulfeda'; and, as there is no other noted Stream on this Side the Niger, may probably be the fame River with Ptolemy's Gir $^{2}$; though placed by Him, among the Garamantes, a great Way farther to the Eaft.

Bifcara, the Capital of Zaab, is the Refidence of a Turkifh $h_{\text {Bifara. }}$ Garrifon, who have here a fmall Caftle, built lately by the

I Al $Z \in b$ eft territorium magnum, \& fluvius Garrar f. Firad in regione Al Megreb, cujus

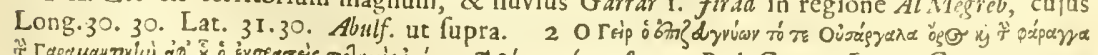

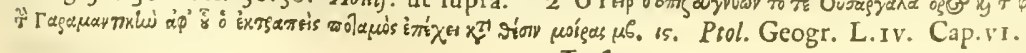


Bey of Conftantina. The chief Strength lyeth in fix fmall Pieces of Ordinance, with a few unwieldy Muskets, mounted likewife upon Carriages.

Lyæna. Lycena is the richeft of thefe Villages: for here the independent Arabs lodge their Money, and valuable Effects. It is welled under the Protection of Welled Soulah, a numerous Clan, to Soulah. whofe Bravery It is indebted for fo uninterrupted an Enjoyment of Liberty, and that the Attempts hitherto made upon It by the Turks, have proved unfuccefsful.

Seedy Occu- TheVillage of Seedy Occuba, or Occ'ba as the Arabs contract It, is not only famous for the Tomb of the Arabian General of Seedy Lafcar that Name, but for another likewife of Seedy Lafcar, the tutelar Saint of the Place. It is a common Report, that the Tower annexed to the Sanctuary of Seedy Occ'ba, will very fenfibly tremble upon calling out, TIZZA bil Ras Seedy Occ'ba; Shake for the Head of Seedy Occuba? An Effect, fomething like this, is produced in a Tower at Reimes by ringing one of the Bells; the conftituent Parts of the Fabrick being perhaps fo particularly and harmonioufly put together, as to act in Concert, and at Unifons with fuch Sounds.

The Traces of The Romans may be traced out all over This Province by the Roman fome Pieces of Walls, which have here and there efcaped the Fury of the Arabs: and at Ban-teufe, one of the fouthern Villages, there were lately dug up feveral Coffins of Stone. It is very much to the Honour of the Romans, to find how careful They have been, where any of thefe Rivulets ran through a loofe and oozy Soil, to fupport their Banks with Walls of hewn Stone, and to pave their Beds with Pebbles.

The People of The eating the Flefh of Dogs, from whence the Canarij Zaab Can- received their Name', and for which the Carthaginians were
arij. formerly remarkable ${ }^{2}$, continueth in Practice to this Day among the Inhabitants of this Diftrict.

The Difrict of WAD-REAG is another Collection of Villages, of the fame

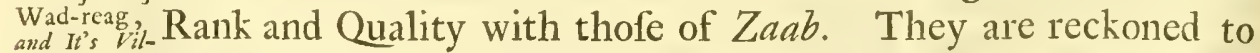
lages. be twenty five in Number, ranged in a N. E. and S.W. Direction. Ma-jyre, the neareft of thefe Villages to Zaab, is ten Leagues to the Southward of El Fythe; Tum-inarnah, the next Place of Note, is fix Leagues to the Weftward of Ma-jyre; and

I Exc. p. 21. B. 2 Legari a Dario, Perfarum Rege, Carthaginem vencrunt, afferentes edictum, quo Peni humanas holtias immolare, \& canina vefci prohibebantur. Fuft. Hift. L. 19. Cap. I. 


\section{Of the Eaftern Province.}

Tuggurt the Capital, lyeth twelve Leagues to the S. W. of Tum-Tuggur. marnat. This Place, according to the feveral Accounts, I have had of It's Situation, is built in a Plain ", without any River running by It. For the Villages of Wad-reag are fupplyed, in a particular manner, with Water. They have, properly fpeaking, neither Fountains nor Rivulets; but by digging Wells to the Depth of a hundred and fometimes two hundred Fathom, the Inhabitants never fail of obtaining a plentiful Stream. And to this purpole, they dig through different Layers of Sand and Gravel, 'till they come to a fleaky kind of Stone, like unto Slate, which is known to lye immediately above The [Bahar tâbt

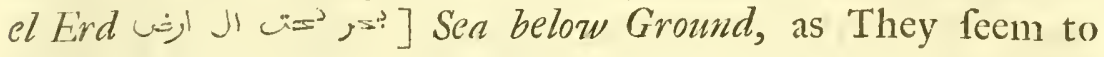
call the Aby/s. This is eafily broken through; and the Flux of Water which followeth the Stroak, rifeth generally fo fuddenly and in fuch $A$ bundance, that the Perfon let down to perform the Operation, hath fometimes been overtaken and fuffocated by It, though raifed up with the greateft Dexterity.

Thirty Leagues to the S. W. by W. of Tuggurt is En-gonfah, En-gourah. the only Village of many, which fubfifted in the Time of $\mathrm{LeO}^{2}$, in this Situation. After En-goufah, at five Leagues diftance to the Weftward, we have the noted and populous City of Wurglah, Wurglah. the Metropolis and, as far as I am informed, the moft diftant Community on this Side the RiverNiger. Thefe feveralCities and Exc.p. r. A. Villages, together with thofe of the Beni Mezzab, are very Nor. A. ribid. juftly compared by the Antients to fo many fruitful and verdent Iflands, in the vaft Expanfe of a large Defert; and might formerly, I prefume, be included in theCountry of the Melanogretuli.

For It hath been already fuppofed ${ }^{3}$ that the Mountains of the The constry of Ammer, were a Part of Ptolemy's Phrurefus; and that the In- the MELAhabitants, from a Similitude in Name, might be likewife the Pharufij. The Melanogetuli, the Lybians next in Order, are placed by the fame Author to the Southward of the Pharufij, between the Meridians and within the Parallels of the Mountains Sagapola and Huergla ; at the Latter of which, He placeth the Fountains of the Bagrada, the Me-jerdah, as It is now called. But as Thefe are well known to lye within the cul-

I Tegort vetuftifimum oppidum a Nunidis in monte quodam conditum, ad cujus radices fluvius praterfluit. - Diftat a mari Meditcraneo meridiem verfus quingentis milliaribus. F. Leo. p. 240. 2 Guargala aliquot fub fe haber Caffella, pagos propemodum innumeros. Hujus incolx, quoniam Agades regno adjacent, ditiffimi-omnes colore nigri. F. Leo. p.241. 3 Vid. p. 58.886 .4 Vid. Not. p. 86. 
tivated Parts of Numidia, at fome Diftance from the Sabara, the Country of the Melanogretuli, from This Circumftance, will only fall in with the Proper Gietulia, and confequently, the Pharufij can be no other, than the moft fouthern Inhabitants of the Tell, or of the Mountains of Atlas. But as this cannot be admitted, we are to argue from the general Tenour of Ptolemy's Tables, concerning the particular Situation of thefe Nations.

Gatulia nearer Mount Atlas.

Now, I prefume, It hath been already proved, that Gretulia was Situated immediately beyond the Mountains of Atlas and the Tell. That It reached likewife to no great Diftance within the Sabara, feems probable from the fame Accounts and Defcrip. tions. I have therefore bounded Gretulia to the Southward with the Wed Adje.dee.

The MELANOGFTULI a greater Di-mantes, the chiefeft of Them, take Place immediately after the

After Gatulia, Ptolemy reckons up the Nations that were fituated beyond It; among which, the Melanogretuli and Garafance. viz. (Proper) Getulians. They certainly extended Themfelves behind the greateft Part of that Country, which belongs at prefent to the Regencies of Algiers, Tunis, and Tripoly; or from the Meridian of Siga to the Cyrenaica, $35^{\circ}$. farther to the E. There being then no other Nations in this Direction, befides the Beni The Gara- Mezzab, the Inhabitants of Wad-reag, the Citizens of Wurglah,

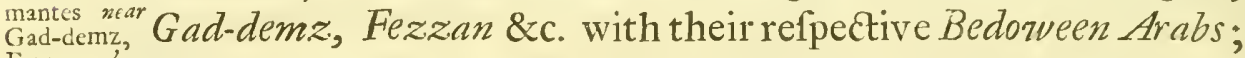
Fezzan, ${ }^{\prime}$ ' the Melanogretuli and Garamantes feem to be the only People, who can lay Claim to this Situation. And as the Garamantes, from their fuppofed Pofition with refpect to the Fountains of the $B a$ grada, (it is of no great Moment in this Difquifition, whether They are as Ptolemy hath placed them, or as we find them at prefent) may be prefumed to fall in with the Diftricts of Gad-dems, Fezzan, and fome of the other more diftant Cities and Villages rie MetanoWad-reag, Weftward of the Garamantes, will for the fame Reafon correfpond with the Beni Mezzab, the Inhabitants of Wad-reag, and the other more fouthern Communities of This Kingdon.

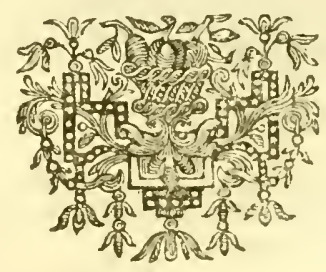




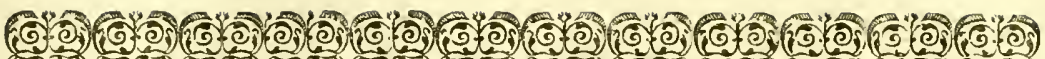

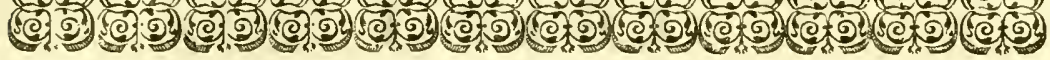

\section{GEOGRAPHICAL}

\section{OBSER VATIONS}

RELATING TO THE

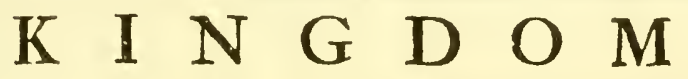

$$
\begin{aligned}
& \text { O F } \\
& T U N I S .
\end{aligned}
$$

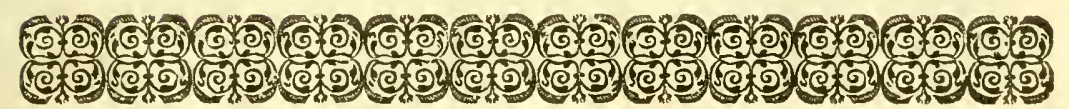




\section{The C O N T E N T S.}

C. H A P. I.

Of the Kingdom of T U N I s in general.

p. I39.

\section{H A P. II.}

Geographical Obfervations upon the Sea-Coaft of the Zeugitana or the Summer Circuit.

p. I4I

\section{H A P. III.}

Of the moft remarkable Places in the Inland Country of the Zeugitana or Summer Circuit.

p. 164 .

\section{C $\mathrm{H} \mathrm{A} \mathrm{P.} \mathrm{IV.}$}

Of the moft remarkable Places upon the Sea-Coaft of the antient Bizacium or Winter Circuit.

p. 185 .

\section{H A P. V.}

Of the molt remarkable Places in the Inland Country of the antient Bizacium, or Winter Circuit: together with the correspondent Part of the Sahara.

p. 198. 


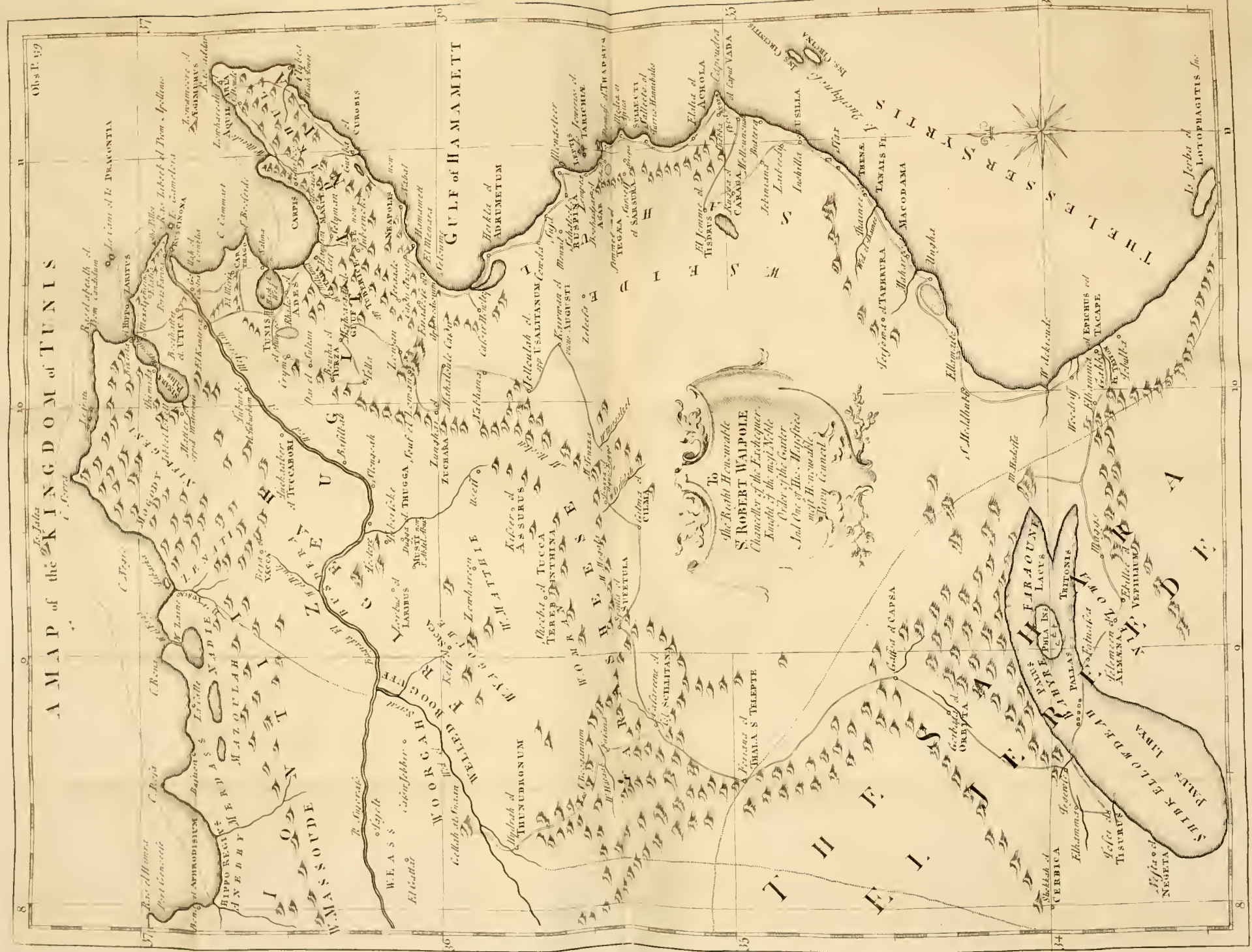




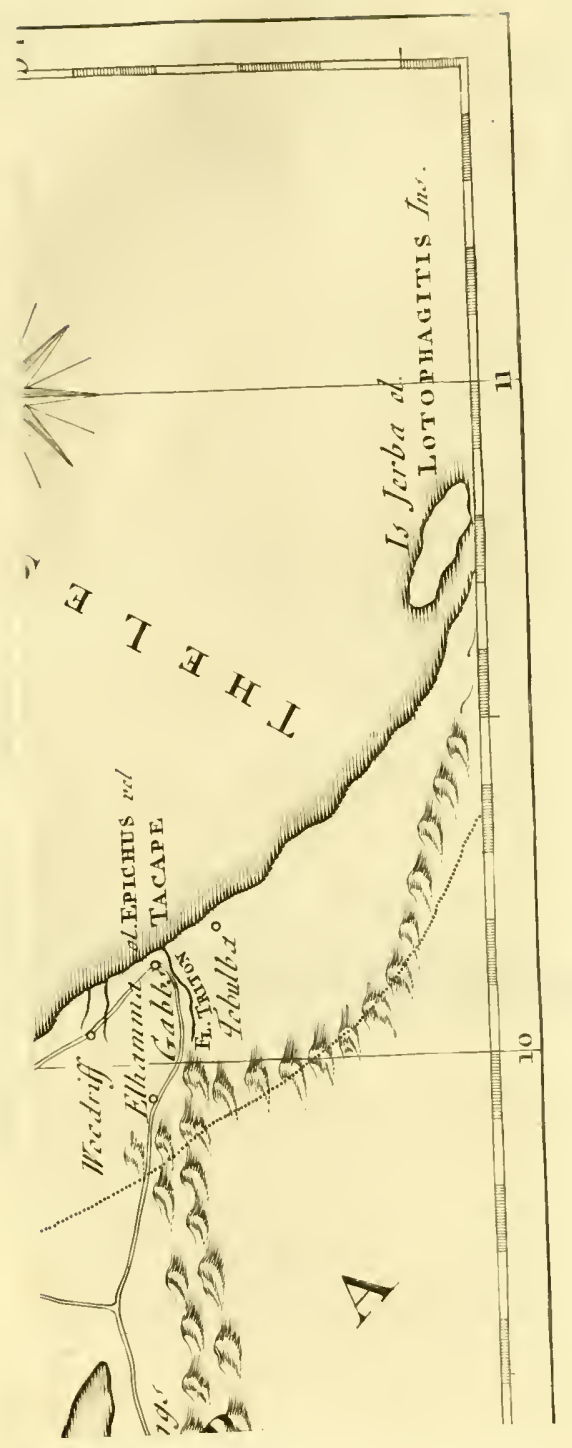




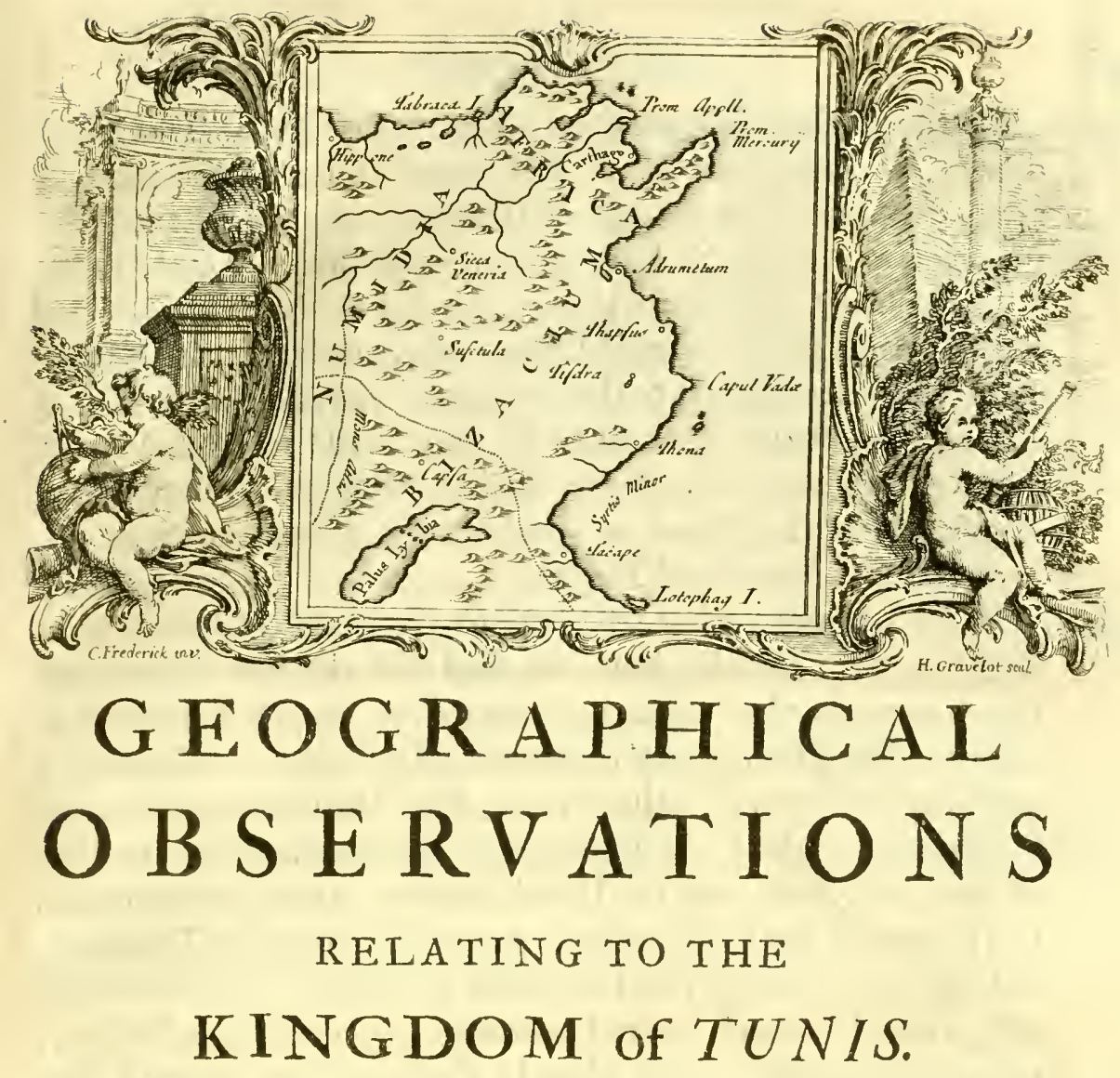

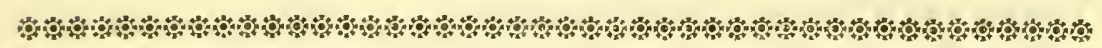

\section{H A P. I.}

Of the Kingdom of Tun rs in general.

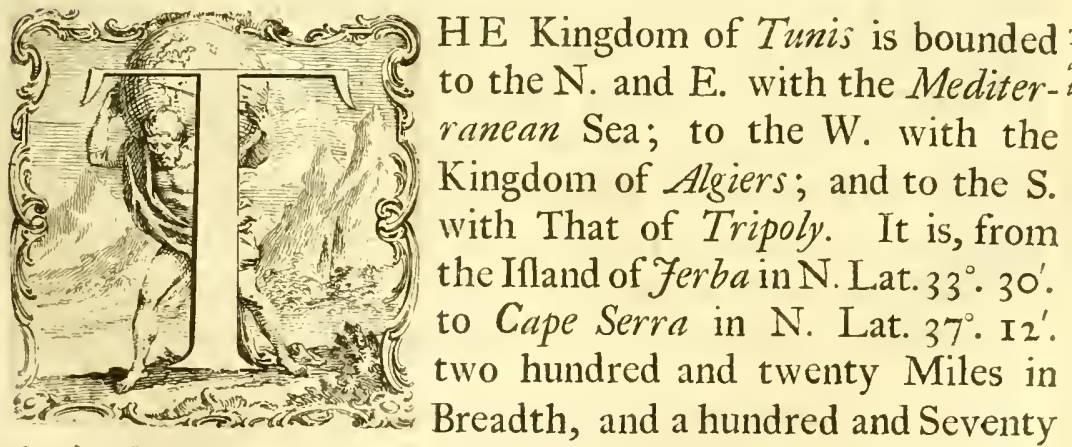
only in Length: Sbekkah, the moit advanced City of This Kingdom to the Weftward, lying in $8^{\circ}$. and Clybea, the fartheft to the Eaft, in $11^{\circ} .20^{\prime}$. E. Long. from London. 
The D: agree- Of the modern Geographers, Luyts ${ }^{2}$, by giving This KingMrent of the and dom $3^{\circ}$. of Long. and $4^{\circ}$. of Lat. feems to have been the beft acquainted with the Extent of It in general. For Sanfon, by placing Cape Bon in N. Lat. 34'. I $5^{\prime}$. and Capes or Gabs in N. Lat. $30^{\circ}$. fituateth It more than $3^{\circ}$. too far to the South. Moll indeed bringeth It, a few Minutes only, too far to the Northward; but extendeth It to the Southward beyond the Parallel of Tripoly; as Delifle hath likewife done in His Royal Map of Africa. Whereas a remarkable Chain of Mountains, in the fame Parallel with the Ifland of Ferba, are the Boundaries of the Kingdoms of Tunis and Tripoly.

Anticut Geo- If we attend to what the Antient Geographers have faid in ${ }_{\text {grapbersabout }}^{\text {Re }}$ Relation to This Kingdom, we fhall find the like Errors and Difagreements that were complained of in the Kingdom of Algiers. For Ptolemy, not to mention His Pofition of Carthage ${ }^{2}$, and fo refpectively of other Places, four Degrees too far to the Southward, maketh the Latitudinal Diftance betwixt the Promontory of Apollo, and the Ifland Meninx ${ }^{3}$, to be no more than ${ }^{\circ} .55^{\prime}$. though the Longitudinal, particularly betwixt Thabraca and Clypea, is nearly the fame that I find It. The Itinerarys alfo, though a much better Conductor in general than Ptolemy, may, as Ricciolius ${ }^{6}$ hath already obferved, be charged with Faults and Contradictions, which will be taken Notice of in their refpective Places: whilf Pliny ${ }^{7}$, by putting the greateft Part of the Cities of This Kingdom in an alphabetical Order, very little inftructs us. Even in the Enumeration of the maritime Towns of Bizacium ${ }^{8}$, where He feems to follow fome Method, yet, by placing Ru/pina after Leptis, He would infinuate, that the Latter, contrary to what appears from Hirtius and other Authors, was at a greater Diftance from the leffer Syrtis. There appears to be an Error of another Kind, in making the Province of Bizacium CCL Miles only in Compafs "; whereas, in bounding It to the N. and S. with the Parallels of Adrumetum and Tacape, and to the W. with Sufetula, (one of the weftern Cities of It,) we fhall have a Space of at leaft D.

I Regnum Tunetanum explicat fc ab Occafu in Ortum ultra tres gradus, atque ab Auftro in Boream ultra quatuor, proinde Regno Algeriano longe minus eft. Luyts Introd. ad Geogr. Scat. Iv. c. 19. p.673. 2 Exc. p. I3. C. F. 3 Exc. p. 17. C. 4 Exc. p. 13. B. D. sExc. p.25. \&c. 6 Vid. Ricr. Geogr. J.3. c.10. 7 Exc. p.22. C. D. 8 Jbid. B. 9 lbid. A. 


\section{Of TuN Is in general.}

Roman Miles in Circuit, which are twice the Number laid down by our Author.

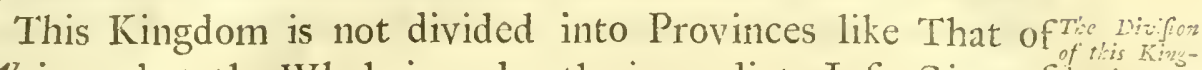
Algiers; but the Whole is under the immediate Infpection of duni $i x t=$ the Bey Himfelf; who collects the Tribute in Perfon. For which Purpofe, He vifits, with a flying Camp, once a Year, the principal Parts of It; traverfing, in the Summer Seafon, the The s.mancr fertil Country in the Neighbourhood of Kieff and Bai-jah; and, circuts, anin the Winter, the feveral Diftricts betwixt Cairnyan and the "Jwer:y to the Fereede. And as thefe two Circuits correfpond, as near as poffible, to the Regio Zengitana and the Bizacium of the An- Zcugitana tients, I fhall defcribe This Kingdom under Thofe Divifions, aidm of the The Regio Zengitana therefore, or the Summer Circuit, will take in that Portion of This Kingdom, which lyeth to the Northward of the Parallel of the Gulph of Hamam-et; as Bizacium, otherwife called the Country of the Libyphosnices, Ex. p.:z.A. will contain the other Part which is fituated beyond It to the $\mathrm{p}^{\mathrm{p} . \mathrm{P}}$. Southward.

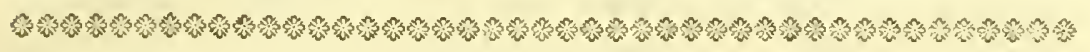

\section{H A P. II.}

Geograpbical Obferciations upon the Sea Coaft of the Zeugitana, or the Summer Circuit.

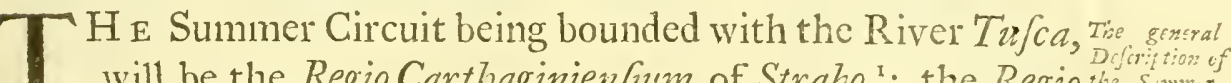

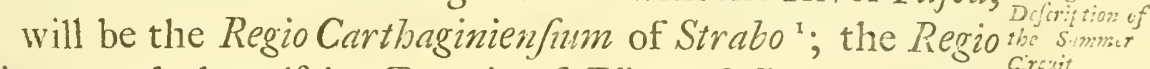
Zeugitana and the Africa Propria of Pliny, Solimus \&ic. the eaftern Part of the Africa of P. Mela ${ }^{3}$ and Ptolemy"; the Provincia Proconfularis of the Notitias, and the Provincia Vetus of the old Hiftorians ${ }^{6}$. It is much better inhabited, than any Part of the neighbouring Kingdoms of the like Bignefs; having a greater Number of Cities, Villages and Dounvars; where there is likewife a greater Appearance of Affluence, Profperity and Chearfulnefs, owing, no doubt, to fewer Inftances of Severity and Oppreffion from the Government. However, if we except theFri-geab', (as they ftill call the Parts about Keff and Bai-jah, with fome Meadow and Arable Ground in the Dakfunl, the reft

I Exc. p. 5. B. C. p.7. B. 2 Exc. p. 21. Cap. Iv. p. 23 . Cap. xxyrit. p. 29. E. P.30. D. p. 3r. A. 3 Exc. P. 19. Cap. vir. 4 Exc. p. 12. Cap. 3. 5 Exc. P. 350 6 Vith Not. I. p. 6. 7 A Corruption of Africa, the antient Name.

$\mathrm{Nn}$ 
of This Circuit is of no extraordinary Fertility; there being feveral Hills, Plains, and Marfhes difperfed all over It, which will fubmit to no manner of Cultivation and Improvement.

The Ifand of The River Zaine, with the antient Thabraca fituated upon Ta-barka. the weftern Banks of It, hath been already defcribed. The fimall Ifland which lyeth over againft It, is, at prefent, in the Poffeffion of the Genoe/e, who pay an annual Rent for It to This Regency; but the little Advantage that hath lately been made of the Coral Fifhery, the chief Reafon of Their Settlement, will poffibly oblige Them to abandon It in a fhort Time. They have here a tolerable good Fort, very capable to protect Them, as well againft any Surprize from the Ze-nati and other Arabs of the neighbouring Continent, as from the Infults of the cruifing Veffels of Algiers and Tripoly.

CapeNegro. Cape Negro, five Leagues to the N. E. of Ta-barka, is like- wife remarkable for a Settlement of the French African Company, who pay a confiderable Sum of Money to the Tunifeens for the fame Privileges They enjoy at La Calle. They likewife have a fmall Fortification to protect Them from the freThe adjacent quent Attacks of the Mo-gody, Nipbi-jeeny and other neighclans. bouring Arabs.

Jalta, The

Falta, the Galata or Calathe of the Antients, is a high rocky GaLAta, or Ifland, fix Leagues to the Northward of Cape Negro, and ten Exc. P.17.B. to the N. N.E. of Ta-barka. A very dangerous Shoal, un-

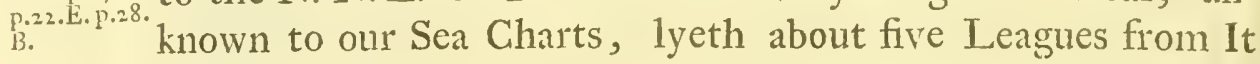
to the W.S. W.

Cape Serra. Five Leagues to the N. E. of Cape Negro, is Cape Serra, the moft advanced Part of Africa to the Northward; and Ii. Frati. then, four Leagues farther, are The [Frati] Brothers, Three rocky Iflands, lying near the Continent, at the half Way to Cape Blanco.

CapeBlanco, This Cape, which the Moors call The [Ras el Abeadb] White Promontory, is of a chalky Subftance; being without Doubt The Promon-the Promontorium Candidum of Pliny, and probably the Pro-

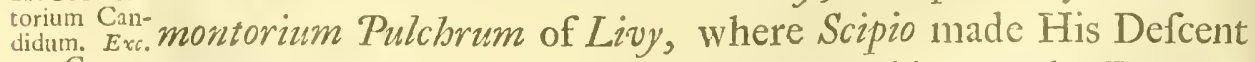
p.21.Cap.1v. in His firft African Expedition ". That This was the Promon-

I Jam terram cernebant, (ex Sicilia navigantes) haud multo poft gubernator Scipioni ait non plus quinque millia paffum Africam abeffe, Mercurij Promontorium fe cernere, fi jubea: eo dirigi, jam in portu fore omnem claffem. Scipio, ut in confpectu terra fuit, precatus Dcos, uti bono Reipublicx fuoque $A$ fricam viderit, dare vela $\&$ alium INFRA navibus ac- 
torium Candidum, befides the Colour of It and the Tradition of the fame Name to This Day, we have This further to urge, that Hippo Diarrhytus, according to the Defcriptions of Mela Exc.p.ro.B. and Pliny, lyeth in the very Gulph, which is formed by This ${ }^{\text {p.a. Cap.15. }}$ Cape and That of Apollo. If then It may be prefumed that Prilchrum and Candidum are Synonimous Terms, we want no farther Proof that This was alfo the Promontorium Pulchrum.

Befides, Livy informeth us, that when Scipio was in Sight andtbeP.Pulof the Promontory of Mercury, (or Cape Bon as It is now called) He did not think fit to direct His Courfe thither, but the fame Wind (an Eafterly one, I fuppofe, from the hazy Quality of It,) continuing, He ordered that fome other convenient Place fhould be pitched upon to Land at [infra] beloww, or (as I conjecture) to the Weftward. But as there are no other Promontories, befides That of Apollo and the Candidum in This Direction, there is no fmall Probability that the Promontorium Pulchrum and Candidum were the fame. Livy indeed mentions another Promontory " in the Bay of Carthage, where Scipio kept His Winter Quarters; which fome Perfons perhaps may urge to have been the Pulchrum here difputed. But as This Promontory [or Gellah according to the prefent Name] maketh the northern Point of the Haven of Utica, there would have been then no Occafion for ordering His Fleet toThatPlace"; a Circumftance doubtlefs which fuppofeth It to be at fome Diftance from the Promontorium Pulctorum, where He landed. Xylander however, as $\mathrm{He}$ is quoted by Sir Walter Rawleigh, p. 263. fuppofeth the Place to have been Cape Bon: which being without Queftion the Promontory of Mercury, cannot be infited upon; inafmuch as Livy Himfelf acquainteth us that Scipio did not Land there, but at fome other Place [infra] below It. Now as infra cannot be fuppofed to imply a fouthern Direction, as well from the Difficulty that Scipio would have had in landing upon the Eaftern Shore of Africk, as for the Neceffity there would be afterwards to pafs by Tunis and Carthage in His intended Journey towards Utica, (too daring an Enterprize certainly at this Time) fo there are not wanting

ceffum peterc jubet. Vento eoden ferebantur-Scipio quod effet proximum Promontorium percunctacus, quum Pitchri Promontorium id vocari audiffet: placet omen, inquit, huc dirigite naves. Eo claffis decurrit: copix omnes in terram expofitx funt. T. Liv. 1. 29. C. 27. I Scipio caftra Hiberna in Promontorio, guod tenui jugo continenti (prope Uticam) adherens in aliquantum maris fpatium extenditur, communit. \&c. Id. ibid. 9. 25 .

(2) Jam enim (expofitis nempe copijs) Scipio claffe Uticam miffa \&.c. Id. ibid. 9. 28. 
Authorities for rendering It, as I have fuppofed, to the Weftward. Thus the Courfe of Sailing from the Straits of Gibraltar to the Levant, is called going up the Mediterranean Sea; as in returning from thence to Gibraltar, we are faid to fail down. Virgil" likewife, in placing Italy betwixt the Adriatick and Tyrrbene Seas, and fituating the Latter (infra) below It, maketh ufe of infra, in the fame Senfe with Livy, to denote a Pofition to the Weftward.

Bizerta, The + Eight Miles to the S. by W. of Cape Blanco, at the Bottom Hrppo, Di-
rutus, Diar- of a large Gulph, is the City Bizerta, pleafantly fituated upon Zar.to. Exx. a Canal, betwixt an extenfive Lake and the Sea. It is about C.13.C.p.21. a Mile in Circuit, defended by feveral Caftles and Batteries, the B. p. $25 . \mathrm{D}$. principal of which are towards the Sea. Bizerta is a Corruption of the Hippo Diarrhytus or Zaritus of the Antients, though the prefent Inhabitants derive It from their own Language, affirming It to be Ben-fbertd [bشu Canal or Rivulet. Though This Etymology cannot be received, yet it is ingenious enough, as it in fome Meafure falleth in with the Meaning of the Diarrbytus of the Greeks, and with the Aquarum Irrigua, as That Appellation feems to have been tranflated by Pliny.

For the Lake, upon which Bizerta is fituated, hath an open Communication with the Sea; and, according to an Obfervation of the Younger Pliny ${ }^{2}$, is either continually receiving a brisk Stream from the Sea, or difcharging one into It. In the hotter Seafons (nay fometimes when the Weather is calm and temperate in Winter,) the fame Phenomenon that hath been taken Notice ${ }^{3}$ of betwixt the Atlantic Ocean, and the Mediterranean Sea, is to be obferved betwixt the Miditerranean Sea and this Lake; for what the Lake lofeth at thefe Times in Vapour, is proportionably fupplied from the Sea; which then runneth very briskly into the Lake, to make up the Equilibrium. The like happens when the Winds are Northerly, whereby a great Quantity of Water is ufually accumulated upon the Southern Coaft of thefe Seas. But when the Winds are

I An mare, quod Supra, memorem; quodque alluit infra? lïg. Gcorg. 2. I.Is\$. Supra i. e. ad partem fuperiorem, hoc eft orientem verfus adVenctias. infra i.e. a parte inferiori; hoc eft mare Tyrrhenum, quod inferum vocant, occideneem verfus. Vid. B. Afcenfis \& Donati Annot. in locum. 2 Eft in Africa Hipponenfis colonia, mari proxima: adjacet ei navigabile ftagnum $\mathrm{ex}$ quo in moduin fuminis xetuarium emergit, quod vice alterna, prouc xftus aut repreffit aut impulfit, nunc infertur mari, nunc redditur ftagno. Plin. Ep. 33. 1.9. ad Caninium. 3 Vid. Phil. Tranf. No. 189. p. 366. Lownth. Abridg. Vol. 2. p. 108. 
from the Southward, (whereby the Water is blown away front the Coaft of Barbary) or when any confiderable Rains have fallen in the Parts adjacent to this Lake; (whereby It receiveth a greater Supply of Water than is expended in Vapour) then, on the contrary, the Lake emptieth Itfelf into the Sea.

The Channel of Communication betwixt the Lake and the The Port. Sca, is the Port of Hippo, which ftill receiveth fmall Veffels; though it muft have formerly been the fafeft as well as the moft beautiful Haven upon the Coaft. There are ftill remaining the Traces of a large Peer, that was carried out a long Way into the Sca, to break off the N. E. Winds; the Want whereof, together with the great Averfion the Turks have to Repairs, will in a hort Time demolifh a Haven, that, in any other Country, would be ineftimable.

Scylax, in His Defcription of This City, calls It only Hippo, Exc. p. 4. C. and at the fame Time takes Notice of the Lake upon which It is Situated. Diodorus ${ }^{\text {r }}$ relateth the fame Circumftance, but giveth the Name of Hipponacra to It, in regard perhaps to the neighbouring Promontory. By the Direction of Scipio's Marches from the Promontorium Pulchrum to Utica, there is Room to conjecture, that This fhould likewife be the Rich anonymous Town mentioned by Livy2. And indeed provided the Turks were proper Encouragers of Trade and Induftry, no Place could lay a better Claim to That Title than Bizerta; inafmuch as It abounds with Filh and Fruit of all Kinds, with Corn, Pulfe, Oyl, Cotton, and a Variety of other Productions.

The Gulph of Bizerta, the Sinus Hipponen/is of the Antients, The Sinus is a beautiful fandy Inlet, near four Leagues in Diameter. The HIS. Bottom of It is low, permitting the Eye to penetrate through fome delightful Groves and Plantations of Olive Trees, a great way into the Country. But our Profpect afterwards is bounded by a high rocky Shore, reaching as far as Cape Zibeeb; Cape Zia Place fo called from the great Quantity of [Cي:j] Raifins that are made upon It. The eaftern Extremity is remarkable for the Whitenefs of It's Cliffs, and for having the Pil-loe, (as They the Pil-loe. call) a high pointed Rock, in the Shape of Their favourite Difh of That Name, which is placed below It.

I Eт⿻а丿 Diod. Sic. 1. 20. 2 Scipio (cxpolitis apud Promontorium Pulchrum copijs) non agros nodo circa vaftavit, fed urbem etiam proximam Afrorum fatis opulcntam cepit. Liv. 1.29. I.28. 
If.Cani, Tke Four Leagues to the N. N.W. of the Pil-loe, in the Mid-

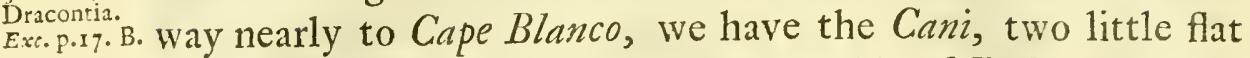
contiguous Inlands, the Dracontia probably of Ptolemy, where the Italian Row Boats lye frequently in Wait for the Tunifeens.

CapeZibeeb,

Cape Zibeeb is the Promontorium Apollinis of the Antients, Tore Promon- and maketh the weftern Point (as Cape Bon or Ras-addar, the linis. Exc.p. Promontorium Mercurij, at eleven Leagues Diftance, doth the Eaftern) of the Sinus Alter of Zeugitana, (as Pliny Stiles it) The Gulph of or the Gulph of Tunis, according to the prefent Name. ZowaTunis.

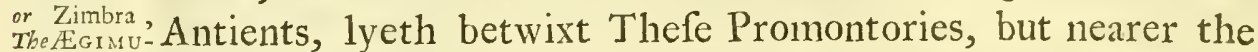
RUS. Exc. p. Latter, in the very Mouth of the Gulph '; which, being of a E. p. 28. B. Depth equal to the Breadth, might very juftly be named by En.r.1.1.163. Virgil, a long Recess. The Inland Gamelora is a little Way 1/2. Game- from Cape Zibeeb to the Eaft; and four Miles to the Weft.
lora. Porto Fari- ward, within the Cape, is Porto Farina, called, from an Antient Mailah, The Salt-Work hard by It, [Gar [,i- el Mailab] The Cave of Salt, Ruscriro- by the Inhabitants. Both This Place and Bizerta have been mittaken by feveral Geographers and Hiftorians ${ }^{2}$ for Utica; whereas It feems to be the Port, whither the Carthaginian Fleet retired, the Night before They engaged with Scipio near Utica. Livy calls It, from the Africans, Rufcinona , a Word doubtlefs of Phrenician Extraction; and as the Firft Part of It very well anfwereth to the Situation; the Latter, I prefume, may be of the like Import with the prefent Name, denoting probably the great Quantities of Corn and Provifions, that were fhipped off from This Place.

The Cothon. Porto Farina was fome Years ago a confiderable City, but lyeth under great Difcouragements at prefent, being chiefly remarkable for It's beautiful Cothon, where the Tunifeens have their Navy. This Place is fafe in all Accidents of Weather, and opens into a large navigable Pond, formed by the River The Me-jer- Me-jerdah, which at prefent difchargeth Itfelf this Way into Gah, or BA- the Sea.

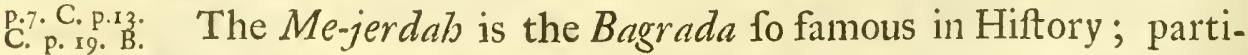
D.22.A.p.30. cularly for the monftrous Serpent, that is reported to have been

I Egimurus Infula — finum ab alto claudit, in quo fita eft Carthago, xxx ferme millia ab Urbe. Liv. L. xxx. 9. 24. 2 Utica hodie Farinx Portus. Thuan. 1. 7. p.605. Claffis Carthaginienfis fub occafum folis fegni navigatione in Portum (Rufcinonzm Afri vocant) claffem appulerc. Liv. L. xxx. 9. Io. 3 ראש אנונפ R. Promontorinm Amona vel Frumenti ut Annona forfan fignificet. Vid. Buxt. Lex. Rab. 
killed by Regulus ${ }^{\text {I }}$ upon the Banks of It. The moft diftant Branches have been already defcribed in the Country of the Hen-nei/hah; which, with other confiderable Additions from the Wed el Boule, Scilliana and fome other Rivulets of the Frig-eah, fwell the Stream to the Bignefs of the I/is united to the Cherwell. The late Geographers, in placing the Courfe of This River almoft directly N. and S. are in the like Miftake with Ptolemy, who deriveth It from the Mampfarus Mons in Long. $35^{\circ}$. and Lat. $27^{\circ}$. $50^{\prime}$. a Pofition by no Means to be reconciled with the Situation of the Eaftern Parts of This Kingdom.

The Me-jerdah, during It's whole Courfe, continueth to The Quality of run winding through a rich and fertil Country; becoming tabe Me-jerthereby fo well faturated with Soil', that It is of the fame Complexion with the Nile, and appears to have no lefs the Property of making Encroachments upon the Sea. To this Caufe we may attribute the many Changes and Alterations, which appear to have been made in the Channel of It: and that an open Creek of the Sea, into which the Me-jerdah, no longer than a Century ago, difcharged Itfelf, is now circumfcribed by the Mud and become a large Pond or Anti-Harbour, as we may call It, to Porto Farina.

That the Me-jerdah, in the Time of Scipio, lay betwixt the Changes Carthage and the Caftra Cornelia, and not where we find $\mathrm{It}_{\text {nel }}^{\text {in }}$ the Chanat prefent, appears, as well from the landing the Ambaffadours $^{3}$, after their Departure from Carthage, at the River Bagrada; (the neareft Place we may fuppofe for that Purpofe) as from Curio's " leaving Rebilus at the fame River, whilft $\mathrm{He}$ Himfelf is faid to have advanced farther to View the Caftra Corneliana. And agreeably to thefe Circumftances, Ptolemy

I Nota eft, in Panicis bellis ad flumen Bagradam a Regulo Imperatore baliftis tormentifque, ut oppidum aliģuod, expugnata Serpens $\mathrm{exx}$ pedum longitudinis. Pellis ejus maxillxque ufque ad bellum Numantinum duravere Romx in templo. Plin. Hitt. Nat. 1. 8. cap. I4. Liv. Epit. 18. Val. Max. 1. 8. 19. 2 Bochart deduceth the Name from ברכת Bracha, a Pond. Vid. I.I. cap. 24. agreeably to the Defcription of the Poct.

Turbidus arentes lento pede fulcat arenis

Bragada, non ullo Lybicis in finibus amme

littus limoras extendere latius undas,

Et ftagnante vado patulos involvere campos. Sil. It. I. 6. 1.140.

3 Legati petierunt a magiftratibus, ut naves mitterent, qux fe profequerentur. Dat $x$ triremes dux cum ad Bagradam flumen perveniffent, unde Romana Caftra confpiciebantur, Carthaginem rediere. Liv. I. xxx. I. IO. 2 Bidui iter ptogreffus (Curio fc. ex Aquilaria) ad flumen B.rgradam pervenit: ibi C. Caninian Rebilum Legatum cum Legionibus religuit: ipfe cum equitatu antecedit ad Caftra exploranda Corncliana. Caf. de Bell. Cir. 1.2. 9. 22. 
placeth the Mouth of It IO'. only to the weftward of Car thage; a Situation which falls in with the Sanctuary of Seedy Ammer Buck-tewah, where there is the antient Bed of a River, with a large Mountain, (perhaps one of thofe taken Notice of by Polybius') that ends in a Precipice above It.

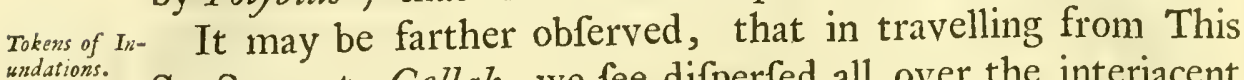

Sanctuary to Gellah, we fee difperfed all over the interjacent Plain, Pine-Apples, Trunks of Trees, and other Tokens of large Inundations. Befides the Channel likewife juft now mentioned, we pafs over others, which, to all Appearance, muft have been at one time or other, either the natural or accidental Beds of This River. For as the whole Extent of Shore, from Carthage to Porto Farina, is little higher than the ordinary Level of the Sea, lying expofed to the E. and N.E. Winds; It is poffible that the Mouth of This, as well as of other Rivers, we read of, in a like Situation, might have been from Time to Time ftopped up, as we find It actually was in the Time of Polybius ${ }^{2}$; and that after being obliged to find out one new Channel after ano. ther, as each of them in It's Turn was filled up, or the Communication with It cut off, It retired at laft under Cape Zibeeb, where thofe Winds could give It no Difturbance. Yet even under This Situation, there is Room to apprehend, that in a few Years the Channel will return again to the Southward. For the navigable Pond is every Day more and more choaked The shallow- up with Slime, and the Mouth (or Bar in the Mariners Stile) ${ }_{B a r}^{n e f s}$ of the of the River, which, 'till of late, admitted Veffels of the greateft Burthen, is at prefent too fhallow to receive one of Their Cruifers of thirty Guns, unlefs It be before-hand difcharged of It's Lumber and Ballaft.

Boo-fhatter, Such Revolutions as thefe having befallen the Bagrada, The UTICA Utica, which, by antient Authors, was fituated to the NorthExc P. B. ${ }^{4}$ C. C. ward of $I t$, is now to be enquired after in the contrary Direction. B. p. 22. A. This City then, fo much wanted in the Old Geography of This orc. Country, and which Bochart interprets [ $[$ Atica] The antient City, is placed by Ptolemy 30'. to the S. and $20^{\prime}$. to the E. of the Promontory of Apollo. But This is a Situation too

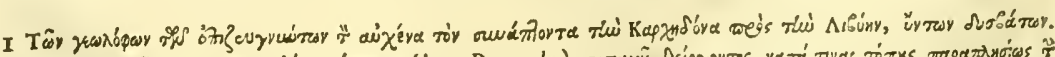

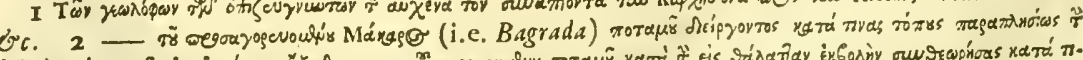

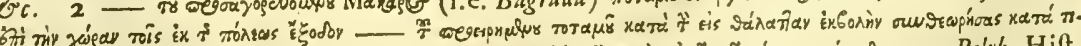

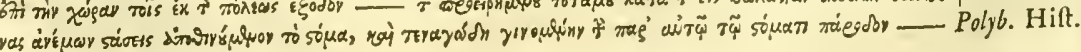
1.1. p. 75,76 . 


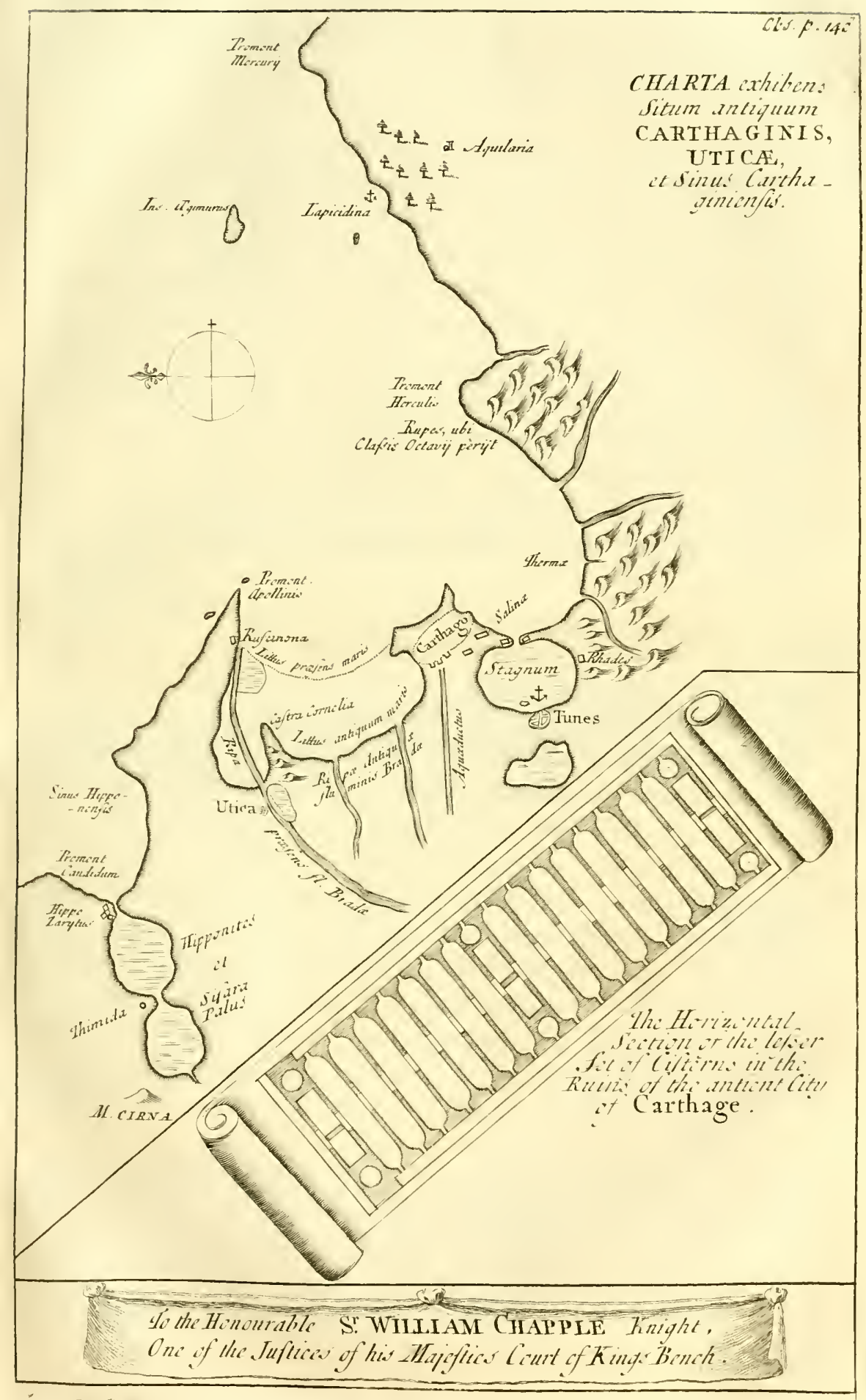



far to the Eaftward, even for Carthage, much more for Utica. which, lying in the Road betwixt Hippozarytus and Carthage, may undoubtedly be prefumed to incline towards the N.W. Laying afide therefore this Authority, let us examine the cther Geographical Circumftances that are lcft us of this City by the Antients.

As then all of Them agree, that Utica was a maritime City, Urica, matifituated betwixt Carthage and the Promontory of Apollo, we time atry: are to fearch for It fome where or other upon the interjacent Sea Coaft. But at prefent there are no Ruins at all to be met with in This Situation: there is no Eminence ', under which Utica was built; there is no Promontory ${ }^{2}$, which lay at a fmall Diftance to the E. or N.E. and formed the Harbour: the whole Extent of Shure, from Carthage to the Me-jerdah, lying in a femicircular Form; and the Land for fome Miles behind It, being very fmooth and level. Utica therefore cannot be found upon the Sea Coaft, as It is formed at prefent, by any of thofe Tokens and Characterifticks that are left us of It in the old Geography.

But if the Ground to the Breadth of three or four Miles Nom at fome from the Sea Shore, fhould be a Gift from the Sea, occafioned Diffance from by the cafterly Winds, and the copious Addition of Mud, left every Inundation by the Me-jerdah; if This River, by frequently fhifting It's Channel, took at laft the Advantage of the Lake $^{3}$ betwixt Utica and the Caftra Cornelia, and forced Itfelf that Way into the Sea; then we may very juftly place It at Boo-foatter; where, befides the Eminence taken Notice of by Livy, we have a great Variety of old Walls, a large Aqueduct, Cifterns to reccive the Water, and other Traces of Buildings of great Extent and Magnificence. Thefe Ruins lye about twenty feven Roman Miles from Carthage, as the Diftance is recorded in the Itinerary; and behind them, towards the S. W. we are entertained with a View of the Large Fields ${ }^{4}$, which the Romans have made famous by their military Exploits.

I Imminente prope iplis mxnibus (Utice) tumulo. Liv. 1.29. 9.35. 2 Scipio Caftra hyberna in promontorio quud tenu jugo continenti adhærens, in aliquantum maris fpatium extenditur, communit. Il. ibid. Id autem (Caftra Corneliana) eft jugum directum, eminens in mare, utraque ex parte prxruptum atque afperum, fed paullo tamen leniore faftigio ab ea parte qux ad Uticanvergit. Abeft directo itinere ab Vtica, paullo a mplius pafuum mille: fed hoc itinere eft fons, quo mare fuccedit; longe lateque is locus reftagnat; quem fi quis vitare volucrit, vi millium circuitu in oppidum perveniet. Caf. Bell, Civ. 1.2. 9. 22. 3 Vid. Not. ult. 4 Magni Campi. Liv. 1.30. 9. 8. 
Gellals, The CoRnelia. northern and rugged Part of that remarkable Promontory",

Two Leagues to the E. of Boo-flatter, is Gellah, the moft Exc.p.13.C. where P. Cornelius Scipio fixed his Winter Quarters, and which A. became therefore called the Caftra Cornelia or Cornetiana ${ }^{2}$. The whole is a narrow Neck of Land, near two Furlongs in Breadth; and continuing, from one End to another, in a mo. derate Elevation, maketh with the Hill that hangeth over Boo-fsatter, a beautiful Landskip, in the Figure of a Theatre, with the Me-jerdah winding Itfelf through the Midft. The Romans very probably extended Their Encampments all over This Promontory, which is more than a League in Length; fo that when Crefar acquainteth us, that the Caftra Corneliana, were only at one Mile's Diftance from Utica, He may be fuppofed to regard that Part of Their Encampments, which was the neareft to That City. At prefent the Me-jerdab runs below the S. W. as Gellab maketh the N. E. Extremity of this Neck of Land: and at a little Diftance from It, on the other Side, are the Ruins of Boo-foatter, the antient Utica, as hath been fuppofed, now fituated feven Miles from the Sea Shore. The Port of
Carthage popped up by the Sea and
the River.

Neither hath Carthage', the next Place to be defcribed, much better fupported Itfelf againt the Encroachments of the N. E.

Winds, and the Me-jerdab; which, together, have ftopped up It's antient Harbour, and made It almoft as far diftant from the Sea, as Utica. The Place ftill continueth to be called [El El Merra. Merfa] The Port, lying to the N. and N. W. of the City; and formeth, with the Lake of Tunis, the Peninfula upon which Carthage was built. Upon the other Side of the Peninfula, Water. towards the S. E. Carthage hath been a lofer to the Sea; for in that Direction, near three Furlongs in Length, and half a Furlong or more in Breadth, lyeth under Water. A little to the Northward of thefe Ruins, but to the S. E. of El Merfa, are the Traces of a Cothon, fcarce a hundred Yards fquare. This The new Port. Was probably the New Port ${ }^{4}$, which the Carthaginians built,

I Vid. Not. 2. p. 149.

2 Inde petit tumulos, exefafque undique rupes

Antæi que regna yocat non yalla vetufass. Erc.

Sed majora dedit cognomina collibus iftis

Scipio _- Luc. de Bell: Civ. 1. 4 .

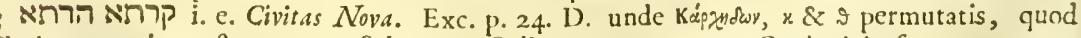
Siculum proprium eft, ut notat Salmas. in Solinum. P. 322. 4 Carthaginienfes, portu noro, (quia vetus a Scipione crat obftructus) facto \&rc. Liv. Ep. 5 I. 
after Scipio had blocked up the old; and might be the fame that was called the Mandracium' in the Time of Procopius.

The greateft Part of Carthage hath been built upon three The Sitsation Hills, fomewhat inferiour in Elevation to Thofe upon which cad Ratins of Rome was erected. Upon That which overlooketh the S. E. Shore, there is the Area of a fpacious Room, with feveral fmaller ones hard by It. Some of Them have had teffellated Pavements; but neither the Defign nor the Materials are worthy of our Notice. The Byrfa $a^{2}$, I prefume, had formerly Tbs Byra. This Situation. In rowing along the Sea Shore, the common Sewers difcover Themfelves in feveral Places; which, being The conzmon well built and cemented at firft, Time hath not in the leaft injured or impaired. The Cifterns are other Structures, which The ciferns. have fubmitted the leaft to the general Ruin of This City. Befides Thofe appertaining to particular Houfes, there were two Sets belonging to the Publick; the greater whoreof, which was the grand Refervoir for the Aqueduct, lay near the weftern Wall of the City, and confifted of more than twenty contiguous Cifterns, each of them about a hundred Foot long, and thirty broad. The leffer is in a higher Situation, near the Cothon; having been contrived to collect the Rain Water which fell upon the Top of It, and upon fome adjacent Pavements, made for that Purpofe. This might be repaired with little Expence; the fmall earthen Pipes, through which the Rain Water was conducted, wanting only to be cleanfed.

Befides Thefe, there are no other Tokens left us of the Fem AntiguiGrandeur and Magnificence of This antient City, and Rival of thes at carRome: we meet with no trimphal Arch, or fumptuous Piece of Architecture; no Granite Pillars, or curious Entablatures; but the broken Walls and Structures that remain to this Day, are either built in the Gotbick Manner, or according to That of the later Inhabitants. The following Lines, preferved by $\mathrm{M}^{\mathrm{r}}$.Balzac ${ }^{3}$, very juftly defcribe the prefent Condition of This Place.

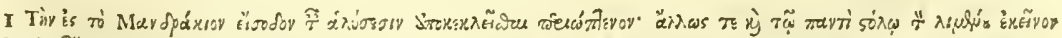

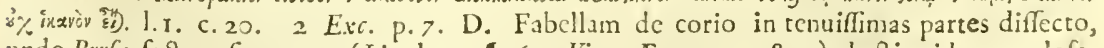
unde Byrfe factum fit nomen (Liv. 1.34. 9.61. Jirg. En.1. 37 I \&c.) doctipridem exploferunt, \& monucrunt a Gracis Búpzar dici pro הרצد Bofra, ad vitandam kxкopeoviay; quia Grace Lingux genius non patitur ut S \& R continuentur. Tale ánoos nemus pro Nibשs afa. Bofra Hebreis eft munimentum, a verbo רצ munirc. Boch. Chan. 3.1. cap.24. 3 In His Differtat. xxv. Chreftienne of moralc: in Imitation of the xv Canto of Tafjo's Gierufalemmine.

Giace l'alta Cartago, $e$ a pena i fegni

De l'alte fue rime il lido fcrba. $8 \mathrm{cc}$

\section{P p 2}


-. - 2ûa devictre Carthaginis arces

Procubuere, jacentque, infaufto in littore, turres Everfe; quantum illa metus, quantum illa laborum Urbs dedit infultans Latio \& Laurentibus arvis; Nunc paffim, vix relliquias vix nomina fervans, Obruitur, propriis non agnofcenda ruinis. Eoc.

$$
\text { Solatia fati }
$$

Carthago Mariufque tulit, pariterque jacentes Ignovere Dies__Lucan. de Bell. Civ. L. 2.1.9r.

Carthage, about fifteen Miles in Cir-

Pliny $^{2}$ feems to make the antient Carthage much bigger, than when It was a Roman Colony; which, according to what Livy ${ }^{3}$ informeth us, was twenty three Miles in Circuit. Strabo circumfribeth the Peninfula, upon which Carthage was built, with cccLx Furlongs, or forty five Miles, but doth not affign any. Number for the Extent of the City. According to an Eftimate made upon the Spot, I judge the Peninfula to be about thirty Miles round, and that the City may have taken up near half that Space; and more, I prefume, It could never lay Claim to. For Livy ${ }^{4}$ telleth us, that Carthage was twelve Miles nearly from Tunes; which is the Diftance that ftill fubfifts betwixt This City, and a Fragment (we meet with near the greater Cifterns) of the old Wall of Carthage. And as there are feveral Salt Pits immediately under This Wall, which reach as far as the S. E. Shore, Carthage could not have extended any farther to the W. or S. unlefs thefe Pits, (which cannot well be fuppofed, ) were received within the City. Nay, if Polybiuss is to be credited, who maketh the Diftance betwixt Tunes and Carthage fifteen Miles, the Boundary This Way will be thrown farther backward, and we may be induced to fufpect, that the Wall I have mentioned, was erected by the Romans, and took in a greater Space of the Peninfula, than might be the Area of the antient City. A large Morafs, that was formerly the Port, continues to be the fame Limit, It always was, to the N. and N.W.

I Marius curfum in Africam direxit, inopemque vitam in Tugurio ruinarum Carthaginienfun toleravit: cum Marius afpiciens Carthaginem, illa intuens Murium, alter alteri polfent effe folatio. Vell. Paterc. 2 Colonia Carthago MAGNe in vcfigijs Carthaginis. Exc. p. 22. A. 3 Carthago in circuitu viginti tria millia paffus patens. Liv. Epir. L. 51. 4 Scipio- in Carthaginem intentus occupat relictum fuga cuftodum Tuncta (abeft ab Carthazine duodecim millia ferme paffuum) locus quum operibus, tum fuapte natura tutus, \& qui ab Carthagine confpici \& prebere ipfe profpectum quum ad Urbem, tum ad circumfufum mare urbi poffet.

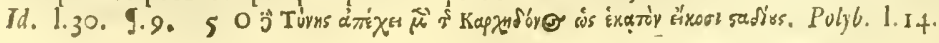

whilft, 
whilf, to the E. and N.E. the whole Extent of the Capes Carthage and Commart, to the Diftance of one, fometimes two Furlongs from the Sea Shore, do not appear to have been ever included in the City. If we may be then permitted to calculate the Extent of the antient Carthage from thefe Circunftances, fifteen Miles, I prefume, will be fufficient to circumfcribe It.

Adjoyning to the Greater Cifterns, we fee the firft Ruins of The Aqueducts the antient and celebrated ${ }^{1}$ Aqueduct, which may be traced, as far as Zow-wan, and Zung-gar, to the Diftance of at leaft fifty Miles. It hath been a work of extraurdinary Labour and Expence; and that Portion of It, which runs along the Peninfula, was beautifully faced with hewn Stone. At Arri-ana, a little Village two Leagues to the Northward of Tunis, feveral of thefe Arches are entire, which I found to be feventy Foot high. The Columns which fupported Them, were fixteen Foot fquare. The Water-Channel lyeth above thefe Arches, being vaulted over, and plaiftered with a ftrong Cement. An ordinary fized Perfon may walk upright in It; and at certain Diftances, there are Holes left open, as well for the Admiffion of frefh Air, as for the Conveniency of cleanfing Tt. The Water Mark, is near three Foot high; but to determine the Quantity that was dayly conveyed to Carthage by 'This Channel, It would be neceffary to know what Angle of Defcent there was given to It; which, from the many Breaches, fometimes for the Space of three or four Miles together, I had no Method to determine.

There was a Temple erected, both at Zow-wan and Zung-gar, Templescrectover the Fountains which fupplyed This Aqueduct with Water. Fcuntains. $^{\text {of }}$. That at Zung-gar, which, by the Ornaments, appears to have been of the Corintbian Order $^{2}$, ends very beautifully in a Dome, where there are three Nitches, leaning immediately over the Fountain. Thefe might probably receive fo many Statues of Water Nymphs or other Deities ${ }^{3}$. Upon the Frize of the Portal we have This broken Infcription.

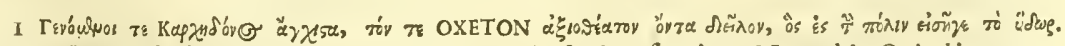
Procop. B. Vand. 1. 4. c. I. 2 Veneri, Flora, Proferpine fontium Nymphis Corintbio genere conftitutx xdes, aptas videbantur habere proprietates, quod his Diis propter teneritatem graciliata \& florida foliis \& volutis ornatu opera facta augere videbantur juftum decorem. Vitr. 1. I. c. 2. 3 Such as were Hercules, Minerva and Diana. Herculr (fontium prefidi)

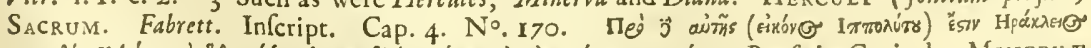

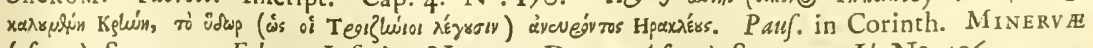

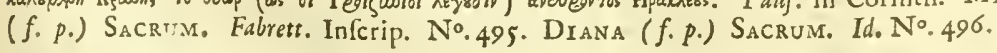


-.. - RORISII TOTIVSQVE DIVINAE DOMVS EIVS CIVITAS ZVCCHARA FECIT ET DEDICAVIT.

The Antiquit

The Aqueduct appears to be of much greater Antiquity than df the Aque- the Temple, having been probably a Work of the Cartbaginians; for, It will be difficult to conceive, how Carthage could well fubfift without fuch a Convenience. Befides the publick Refervoirs I have mentioned, there hath been great Provifion indeed made to receive the rain Water, by building all or moft of their Houfes upon Cifterns. At Saka-rab likewife, whither the Suburbs may be fuppofed to have extended, there is, for the Space of three Miles, a Continuation of Channels and Cifterns, contrived, as It appears, by omitting here and there a Brick in the lower Part of their Walls, to admit Water by Percolation; a Method we find allo made ufe of at Gibraltar. It will be difficult to determine, what extraordinary Supplies thefe Cifterns might have afforded; however, It is very certain, that at Algiers, a City built with the fame Conveniences as Carthage, the Rain Water will rarely fupply the neceffary Expences of a Family: much lefs, when fuch a Multitude of Elephants, Horfes and other Animals, as were conftantly kept at Carthage, are to be added to the Account.

The Guletta. Eight Miles to the W. S. W. of Seedy Boo-feide, the Cape Carthage of our Sea Charts, we have the Guletta; for fo the Italians feem to have tranflated The [Halck [ela] el Wed] Throat of the River, as the Inhabitants call the little Channel of Communication betwixt the Lake of Tunis and the Sea. The Tunifeens have, on each Side of this Channel, a tolerable good Caftle, contrived as well for the Security of this narrow Paffage, as of the Road to the E. and S. E. Within the Lake likewife, half a League from Tunis, and about two from the Guletta, there is another Caftle, built upon a fmall Inland; which, from the little Danger there is of being attacked that Way by Sea, hath been for a long Time neglected. The Place continueth in the fame dirty State and Condition, that It appears to have been in, in the Time of Abulfeda .

The Lake. This Lake was formerly a deep and capacious Port ${ }^{2}$, big enough to take in a large Navy; but at prefent, by receiving all the

I In hoc lacu Tunes eft Infula ad oblectationem \& difcutiendum animi mærorem: verum quoad latus ejus, quod ad Tunes fpectat, eo fordes $\&$ immunditix coacervantur. Avulf. ut

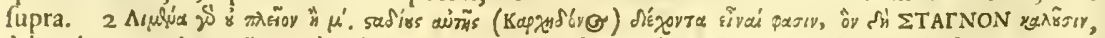

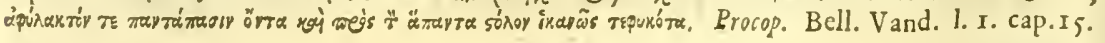

common 
common Shores of Tunis, the main Channel of It, in Summer Time, is reduced to fix or feven Foot Depth of Water; whilft the reft of It, for the fpace of a Mile or more within the Banks, becometh dry and naufeous. The Profpect of This Lake, receiveth no fmall Beauty from the many Flocks of the Flamant, or Phenicopterus, that frequent It. It is no lefs famous for the Number and Largenefs of It's Mullets, efteemed to be the fweeteft upon the Coaft of Barbary. The Roe, after being preffed and dryed, is accounted a great Delicacy, and known by the Name of Bo-targo:

Tunis, the Tunes of the Antients, and the Capital of This Kingdom, is the greateft Part of It fituated upon a rifing TUNEs. Ground, along the weftern Banks of this Lake, in a full Profpect (as the Antients have defcribed $\mathrm{It}^{2}$ ) of the Guletta, Carthage, and the Ifland Zowva-moore. Diodorus Siculus calls It [AEYKON TYNETA ] White Tunis, perhaps from the chalky Cliffs that appear round about It, in viewing It from the Sea. The many Lakes and Marfhes that furround this City, might probably render the Situation of It lefs healthy, were not thefe Inconveniences in fome Meafure corrected by the great Quantity of Maftick, Myrtle, Rofemary, and other gummy and aromatick Plants, that are daily ufed in the heating of Their Ovens and Bagnios, and which frequently communicate to the Air a fenfible Fragrancy. The want of Water is another Complaint of the Tunifeens; who, from the Brackinnefs of their Well Water, and the Scarcity of Cifterns, are obliged to fetch a great Part of what They drink from Bardo, arid other Places at a Miles Diftance. If we except This Inconvenience, no Place enjoys a greater Plenty of all the neceffaries of Life.

The Tunifeens, are the moft civilized Nation of Barbary. They have very little of that infolent and haughty Behaviour, The Tuniwhich is too common at Algiers. All Affairs likewife with the Regency are tranfacted in fuch a friendly complaifant Manner, that it was no fmall Pleafure to attend $\mathrm{M}^{\mathrm{r}}$. Conful Lawrence at His Audiences. This Nation, which for many Years hath been more intent upon Trade and the Improvements of Their Manufactures, than upon Plunder and Cruifing, hath always had the Character and Reputation, not of living like

I Botarge funt ex ovis Cephali (Latini mugilem dicunt) expolitis fe. in duabus veficis, cruorc ejufdem pifcis \& fale adhibito. Recentioribus corrupto verbo Boturcba vocantur,

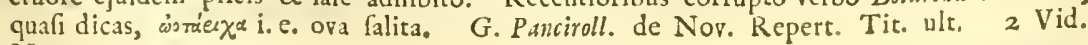
Not. 4. P. 152 . 
their Neighbours, in open War or perpetual Difputes with the Chriftian Princes, but of cultivating Their Friendfhips and coming readily into Their Alliances.

The Extent of Tunis, if we take in the Bled el Had-rah, as They call the Tunis.

Suburbs, may be three Miles or more in Circuit; however it is not fo populous as Algiers, neither are the Houfes in general fo lofty and magnificent. Upon a large Pillar, brought from the Neighbourhood of Carthage, and placed at prefent in one of Their Bagnios, we have the following Infcription.

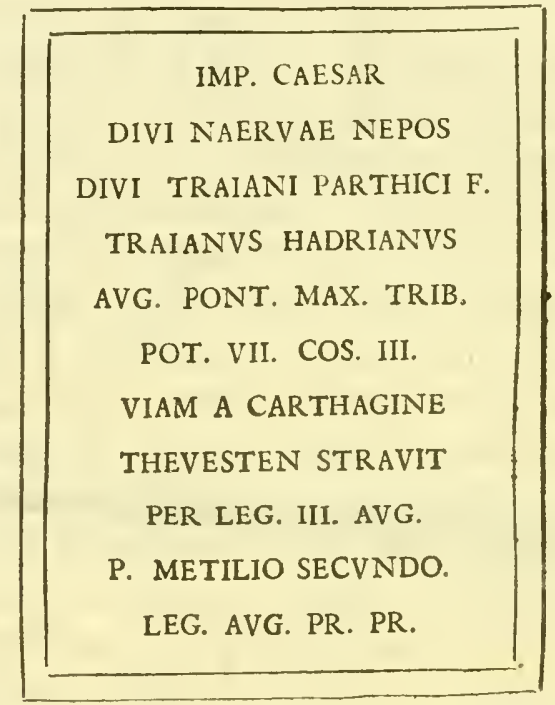

Rhades, The Two Leagues to the E.S. E. of Tunis, and at the like DiADEs. ftance to the S. W. of the Guletta, is the Town of Rhades, fituated upon a rifing Ground betwixt the Lake of Tunis and the Sea. This is the antient Ades, where M. Regulus defeated the Carthaginians; and hard by It on the right Hand, are thote Hills, where Hanno, (as Polybius ${ }^{1}$ obferveth,) very unskilfully placed His Elephants to oppofe Him. As the Road from Clypea to Tunes, lyeth, at a little Diftance from Ades, through a narrow Defile, the Carthaginian General, (faving that one Miftake,) could not have pitched upon a more convenient Place for the Security of This Pafs; neither could the Romans have carried It without Their ufual Bravery.

I Vid. Polyb. Hift. Lib.I.

Not 
Not far from Rbades, is the River Miliana, the Catada Tbe Milian, probably of Ptolemy; and about a League farther is Hammam Erap. . 13. C. Leef, a noted Hot Bath, very much reforted to by the Citizens of Tunis.' Two Leagues from Hammam Leef, near the Bottom of the Gulph, we pafs by the fmall Town of Solyman, Solyman. fituated upon the Skirts of a fine Plain, with a River, at two Miles Diftance, on each Side of It. This Place is chiefly inhabited by Andalufian Moors, who are more civilized than theirBrethren, being courteous toChriftians, and retaining the Spanifh Language.

+ Two Leagues to the N.E. of Solyman, is Mo-raifah, the Morraialt,

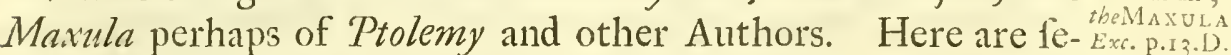
veral broken Cifterns, befides a finall Harbour, as Morai $a$ ah, (corruptly probably for Merfa, may denote. The Shore, which from the Guletta, all along by Rbades, Hammam Leef, and Solyman, is low and fandy, begins at This Place to be very rugged and mountainous: in which Situation, two Leagues farther, we fall in with the Creek of Gurbos, or Hammam Gurbos, Gurbos, The the antient + Carpis, where there is a Hot Bath and fome Ruins. Exricis. pris. Thefe are the Calide Aque of Livy ${ }^{2}$, which He very juftly placeth over againft Carthage; and at the fame Time acquainteth us that feveral Veffels, belonging to the Fleet of Octavius, were fhipwracked at This Place. Three Leagues to the Northward of Gurbos, we pafs by a very high and rugged Head Land, Promentothe Promontorium Herculis of the Antients. There is a fmall culis. Bay to the Eaftward of It, where the Wed el Abeyde difcharg- Wed et eth Itfelf into the Sea.

+ The Sanctuary of Seedy Doude, furrounded with the Ruins SeedyDoude, of the antient Nifua or Mifua, is five Leagues to the E. N. E. or Nissua. of the Promontory of Hercules. It hath This Name in Honour Exc. ibid. of David, (or Doude, as They pronounce It,) a Moori/b Saint, whofe Sepulchre, (as They pretend to fhew It,) is five Yards long. But This venerable Structure appears to be nothing more than a Fragment of fome Roman Prretorium: becaufe hard by It, there are three contiguous Mofaick Pavements, all of Moraick Them wrought with the greateft Symmetry and Exactnefs. Befides the general Contraft and Defign, (which is executed with all the artful Wreathings and Variety of Colours imaginable, )

1 Ipfe ( $\mathrm{C}$. Octavius) cum roftratis pel adverfos fluctus ingenti remigum labore enixus, Apollinis Promontorium tenuit; onorarix pars maxima ad Aegimurum,-alia adverfus urbem ipfam ad Calidas Aquas dclatx funt. Liv. 1.30.9.24.

$\mathrm{R} \mathrm{r}$

there 
there are the Figures of Horfes, Birds, Fifhes, and Trees fo judicioufly intermixed and curioufly inlaid, that They even appear more gay and lively than fo many tolerable good Paintings. The Horfe, the Infignia of the Carthaginians, is difplayed in the bold open Pofture It is obferved to be in upon the African Medals: The Birds are the Hawk and Partridge: The Fifhes, the Gilt-Head ${ }^{\text {I }}$ (called here Feraff $a$ ) and the Mullet: And the Trees, the Palm and Olive. The Contriver perhaps intending by This Choice, to point out the Strength, the Diverfions, the Fifhery, and the Plenty of Dates and Oyl, for which This Country continueth to be, as It hath always been remarkable. Mifua, by the Ruins, appears to have been of the fame Extent with Hippozarytus; where likewife there was formerly a capacious Harbour, very convenient for fuch $V$ effels to touch at, which, from contrary Winds or Diftrefs of Weather, could not reach Cartbage or Utica.

Two Leagues to the E. N. E. of Seedy Donde, and a little Lowha-real, The Adeur-to the Southward of the Promontory of Merciry, is Lowwhacaria. reah, the Aquilaria of the Antients, where Curio ${ }^{2}$ landed Thofe Troops, that were afterwards cut to pieces ${ }^{3}$ by Sabura. There are feveral Fragments of Antiquities at This Place, but Nothing remarkable: however, from the Sea Shore to This Village, which is at half a Miles Diftance, the interjacent Mountain, from the level of the Sea to the Height of twenty or thirty Foot, is all the way very artfully fcouped and hollowed; fimallOpenings being carried up, in feveral Places, to the Surface, for the Admiffion of frefh Air; whilft large Pillars and Arches are left ftanding, at proper Diftances below, to fupport the Mountain. Thefe are the Quarries which Strabo 4 takes Notice of; from whence the Buildings of Carthage, Utica, and the many other adjacent Cities, might receive Their Materials. Moreover, as the Mountain above is all over fhaded with Trees; as the Arches below lye open to the Sea, having a large Cliff on each Side, with the Inland Egimurus placed over againft Them; as there are likewife fome Fountains

I This is the Aurata of the Antients, which Leo mittakes for the Lactia, or Ieecby, of the Italians, a Firh of the Tunny or Mackel Kind. Poft men/em octobrem genus quoddam Pifis capitur, quod apud Afros Giarapha appellatur, etmdem Pifcem effe credidcrin, qui Romanis Laccia appellatur. f. Leo. p. 2 I4. 2 C. Curio in Africam profectus ex Sicilia-apellit ad eum locum qui appellatur Aquilaria. Hic locus abeft a Clupea, paffum xxI millia; habetque non incommodam æltate ftationem; \& duobus eminentiblis promontoriis continetur. Caf. de Bell. Civil. 1.2. 9.21. 3 Milites ad unum omnes interficiuntur. Id. 9. 38.4 Exr. p. 7. F. 
perpetually draining from the Rocks, and Seats for the weary Labourer; we have little Room to doubt, (from fuch a Concurrence of Circumftances, fo exactly correfponding to the Cave which Virgil placeth fomewhere in This Gulph, ) but that the following Defcription is litterally true, notwithftanding the Opinion of fomeCommentators ${ }^{\mathrm{t}}$, who have thought It fictitious.

Eft in fecefful longo locus; Infula portum

Efficit objectu laterum: quibus omnis ab alto

Frangitur, inque finus fcindit fe fe unda reductos.

Hinc atque binc vafte Rupes, geminique minantur

In Colum fcopuli: quorum fub vertice latè

Aquora tuta filent: tum Sylois fcena corufcis

Dejuper, borrentique atrum Nemus imminet Umbra.

Fronte fub adverfa fcopulis pendentibus atrum:

Intus Aqure dulces; vivoque fedilia faxo,

Nympharum Domus; \&c. Virg. AEn. I. I63.

Cape Eon, the Ras-addar of the Moors, and the Promon-Cape Bon, tory of Mercury or Hermes of the Antients, is fituated about Therium Meromone League to the Northward of Low ba-reab, and eleven to purij. Exc. the E. S. E. of Cape Zibeeb. I was well informed, that, fometimes in fair Weather, They could difcover the Mountains of Sicily from This Place. The two Zembrce or Zowa-moores lye Tbe ZowaunderThis Promontory; the Smaller one not far from the Shore, but the Larger is at four Leagues Diftance, in a W.N.W. Direction, from It. The fruitful Tract of Land that reacheth from hence to Solyman, is called The [lخu ] Dackbul] Corner: being cul- The Daskhul. tivated by the feveral Branches of the Welled Seide.

Five Leagues to the S. by E. of Cape Bon, is + Clybea, the Clybea, The

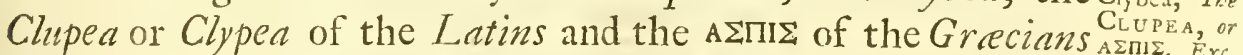

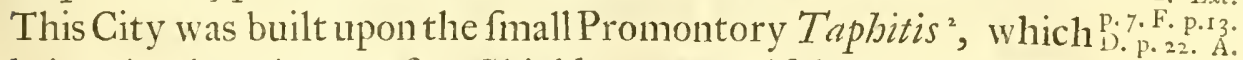
being in the Figure of a Shield ${ }^{3}$ or Hemifphere, gave Oc- ${ }^{\mathrm{P}}{ }^{24} \cdot \mathrm{B}$. cafion to the Name. There is nothing ftanding of This antient City: for the Caftle is a modern Structure; and what They now call Clybea, is a miferableKnet of Hovels, at a Miles Diftance.

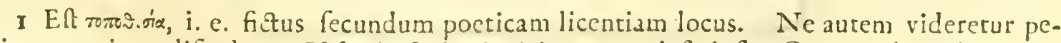
nitus a veritate difcedere, Hifpanienfis Cartharinis portum defcripfit. Cæeterum hunc locum in Africa nufquam effe conftat. Serv. in loc. Fictus hic locus eft, \& lublatus ab Homero (Ody? 13. 95.) aliqua ex parte ad formam Ithacenfis Portus. Pomp. Sab. ibid. Mr. Addifon (p. 7 I. of his Travels) fuppofeth that Virgil might have taken the Plan from the Bay of Naples. 2 Exc. p. 7. F.
}

3 In Clypei Speciem curvatis turribus Afpis. Sil. Ital. L. 3. 1. 243. 
The River.

A little Way to the Southward of This Village, we crofs a large River, where Mafaniffa was fuppofed to have been drowned in His Flight from Bocchar. Livy ${ }^{\prime}$ tells us, that the Latter was afraid to ford It, difcouraged no Doubt by the Depth and Rapidity of the Stream. For in the Month of $\mathrm{Fa}^{-}$ nuary, when it had not rained for feveral Days, we found the Channel very deep, of an uneven Bottom, and which we had much Difficulty to pafs over. A little on the other Side of This River, we come into thofe open Fields, where Bocchar killed forty fix of the fifty Perfons, who attended Ma Janiffa.

Gurba, The + Gurba, the Curobis or Curubis of the Antients, is feven

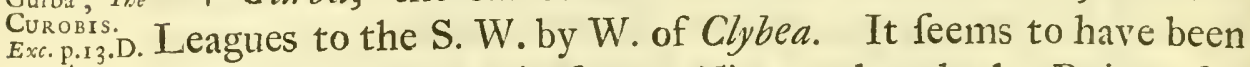
D. E. ${ }^{\text {P.2.A. }}$ a confiderable Place in former Times, though the Ruins of a large Aqueduct, and of the Cifterns which received the Water, are the only Antiouities It can boaft of at prefent. I was informed that the Port, and a great Part of This as well as of the neighbouring City $\mathrm{Nabal}$, were deftroyed by the Sea; and that fome Traces of each of Them might be feen in calm and clear Weather. A little Brook runs by Gurba to the Weftward, where we have the Remains of a Stone Bridge; and, at a FarmHoufe hard by It, there is an Altar with the following Infcription, which might have formerly belonged to It.

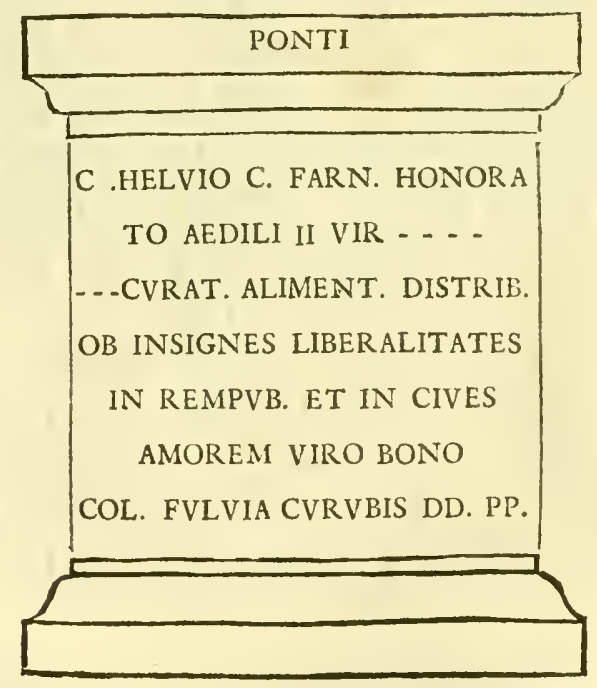

1 Mafaniffa cum quinquaginta haud amplius equitibus per anfractus montis ignotos fequentibus fe eripuit. Tenuit tamen veftigia Bocchar; adeptufque eum patentibus prope Clupean urbem campis, ita circumdedit, ut prxter quatuor equites, omnes ad unum interfecerit — amnis ingens fugientes accepit - is finis Bocchari fequendi fuit, ncc ingredi fumen aufo, nec fe \&.c. Liv. I. 29. 9. 32 .

+ Nabal, 
Leaving Gurba five Leagues to the N. E. we come to Nabal, Nabal, The.

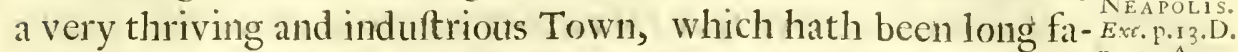
mous for It's Potteries. It is built, in a low Situation, at a Mile's " Diftance from the Sea Shore, and about a Furlong to theW eftward of the antient Neapolis, which appears to have been a large City, without taking in what is fuppofed to have been gained by the Sea. Here are a great Number of Infcriptions upon Stones of $f_{i x}$ Foot in Lcngth and three in Breadth; but They are either fo unfortunately defaced, or filled up with Rubbifh and Mortar, that It required more Time, than my Guides would allow me, to copy Them. On the Banks of the little Brook that runs through the old City, we have a Block of white Marble, with a Wolf, curioufly reprefented in Baffo Relievo, upon It.

Travelling, for the Space of two Leagues, through a rugged Hanam-et, Road, delightfully fhaded with Olive Trees, we arrive at $\mathrm{Ha}_{\text {- }}$ mam-et, which hath been miftaken by feveral Authors for the fo much difputed Adrumetum. It is a fmall but opulent City, compactly built upon a low Promontory, which an Enemy, efpecially by Land, would find great Difficulty to attack. But as ThisCircumftance ' will better agree with Herckla,placed at fome Diftance from It to the Eaftward, fo there are other Circumftances relating to Adrumetum, which will by no Means anfiver to This Place. For Hamam-et is built fo clofe to the Sea, abdrumertum. and hath to the Landward fo rugged a Situation, that there would be, (This Way particularly, the utmoft Danger and Difficulty to approach It; much more to be carried round about It, as Cefar is faid to have been ${ }^{2}$. Neither have we a View, cither from This City or the Road before It, of the Coaft of Clybea all which Circumftances agree with the Situation of Herckla. The Author likewife of the Itinerary placeth Adrumetum, not only ccccxu Furlongs from Neapolis ${ }^{4}$, but Lxxxv R. Miles, (i. e. at the fame Diftance with Clypea, ) from Carthage. Now, provided Adrumetum is to be fixed at Hamam-et, Neapolis will be fituated L Miles too near It in the one Cafe; as Carthage will be $x x x$, (i. e. more than one Third of the given Diftance, ) in the other. Hamam-et therefore may be rather the Siagul of Ptolemy, which was probably one of thofe

I Oppidi (Adrumeti) egregia munitio, diffilifque ad oppugnanduni erat acceflus. Firt. Bell. Afr. 2 Cofar circum oppidum vectus, natura loci perfpeta, redit in Caftra. IR. 9.3. 3 A Clupe fecundam oram maritimam cum equitatu Adrumeti, Ch. Pifo cum Maurorum circiter I I millibus apparult. Id. 9.3. 4 Exc: p̈: 28 . A. p. 27. E. \&rc. 
anonymous Town ${ }^{2}$ that Cre far vifited in His Way to Adrumetum. Hanam-et, Leo informeth us that Hamam-et was built about His Time; or the City of
IVild Plge- but the flourifhing Condition It enjoys at prefent, is of no ons. 1onger Date, than the latter End of the laft Century: the Pillars, Blocks of Marble, and fome few other Tokens of Antiquity, that are here and there to be met with, having been brought from Cafjir Afeite, the Civitas Siagitana of the Antients. As for the Name, (which, having no fmall Affinity with Adrumetum, might induce Buno ${ }^{3}$, the Sanjons and others to think It to be fo) It is in all Probability derived from the Number of [Hamam $r^{+\infty}$ ] Wild Pigeons, that are bred in the Cliffs of the adjacent Mountains. The two following were the only Infcriptions which I found fair and legible.

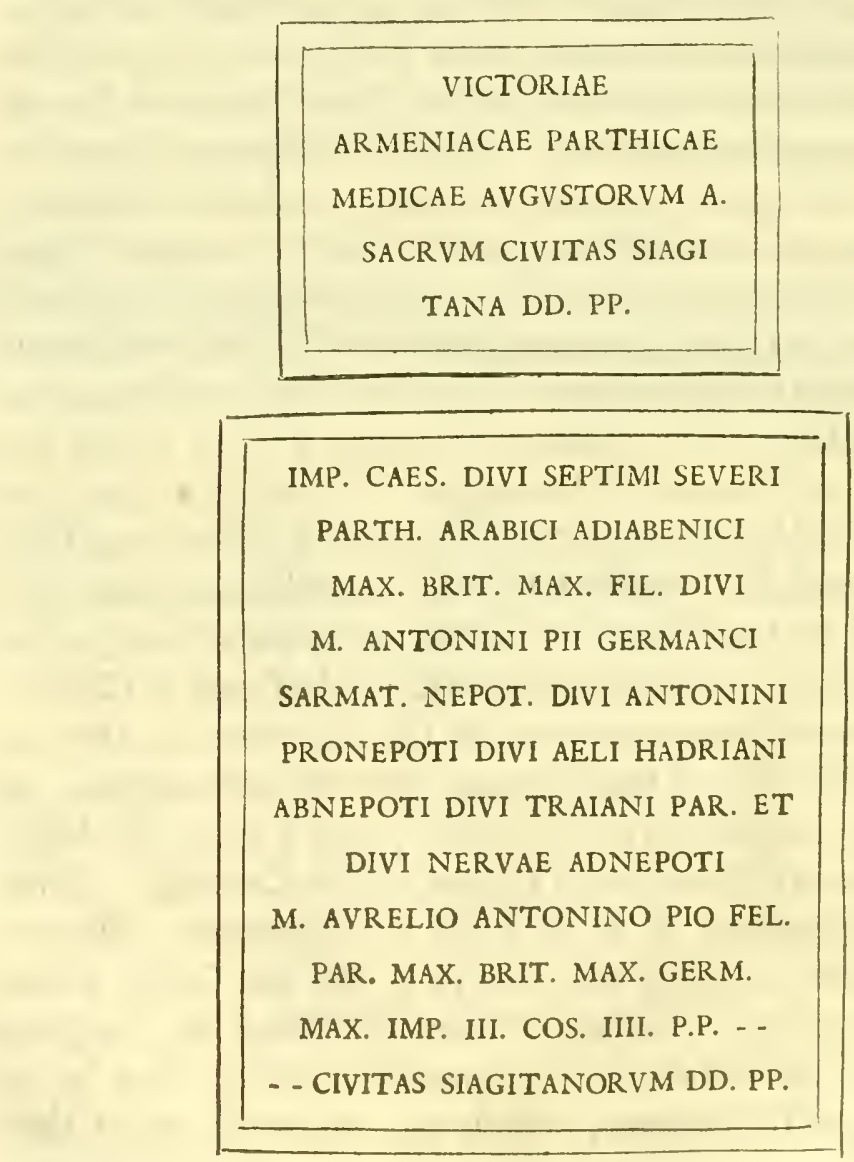

I Cafar Clupeam claffe prætervehitur; inde Neapolin, complura praterea caftella \& oppida non longe a mari relinquit. Hirt. Bell. Afr. I.2. 2 Hamam-et ante paucos annos a Mahometanis extructum, hujus incolæ miferrimi \&c. F. Leo. p. 22I. 3 Vid. Clup. Geogr. cum notis Bunonis. P.394 Ail. Geogr. Vol. Iv. P.173. 


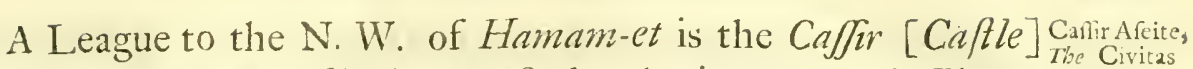
Afeite, the Civitas Siagitana of the Antients. This Place, Silgitana. notwithitanding the Figure It made in the Antonine Age, and perhaps before, is not mentioned by any of the old Geographers; and the only Notice, that, as far as I know, is taken of It, either by the Antients or Moderns, is in an Infcription preferved by Bochart'.

A little beyond Thefe Ruins, we come into a large extenfive ${ }_{\text {The Plain of }}$ Plain, cultivated by the Welled Seide, and reaching as far as ${ }^{\text {Hamiam-ct. }}$ Herckla. Upon the maritime Part of It, two Leagues to the W. by S. of Hamam-et, we have the Me-narah, a large Maufoleum, Tie Menear twenty Yards in Diameter, built in the Shape of a cylin- ${ }^{\text {aralal. }}$ drical Pedeftal with a Vault underneath. Several fimall Altars, fuppofed by the Moors to have been formerly fo many [3,io] Lamps for the Direction of the Mariner, are placed upon the Cornice; each of Them infcribed with the Name of a different Perfon. The following Infcriptions, which were all that were legible, feem to relate to the fame Family.

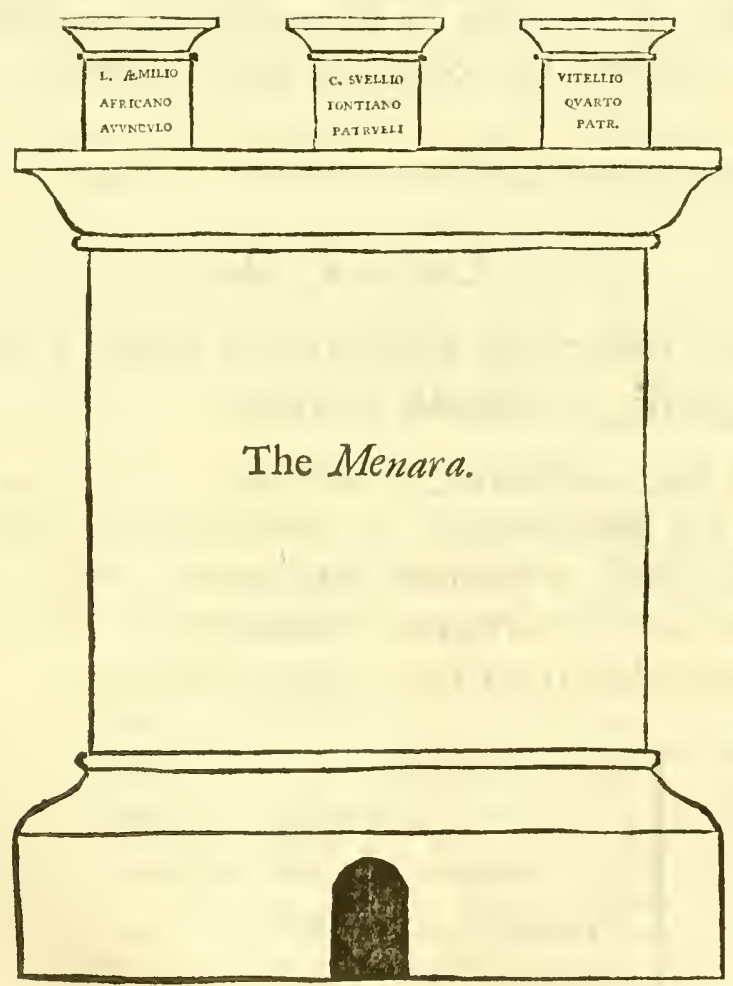

I Et pro Senatu Populoque Siagitano Celer Imilconis Guiliffe F. Suffes. Boch. Chan. 1. I. Cap. 24. 
A little nearer Hamam-et, are the Ruins of a Port formerly belonging to Faradeefe, an old Roman City, fituated, at a few Miles Diftance, upon the N. W. fide of This Plain. I was informed, that a Century ago, the Faradefans were the greateft Cruifers and the moft experienced Mariners of This Country; but that the greater Increafe of Trade, and the more Conveniences for Navigation at Hamam-et, had, of late Years, drawn The VENE- thither all the Inhabitants. This may be the Veneria of Solinus; P. Artarose
sius. Exc. placed by Ptolemy in the fame Latituide, but more to the Weft-
P.r. D. ward than Adrumetum.

Scl-loome. About the middle of This Plain, there is an hemifpherical Hillock, called Sel-loome, made by the Ruins of fome antient Caftle or Village. Two Leagues farther, not far from the Sea Shore, we have, for the fpace of a Furlong, a Piece of deep marfhy Ground, through which a large adjacent Lake difchargeth Itfelf into the Sea. There was formerly a Bridge, with a Caufeway, very conveniently carried along the whole Length of 'This Morafs; which, in all probability, was the maritime Boundary betwixt the Zengitana and Bizacium.

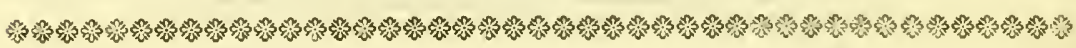

\section{H A P. III.}

\section{Of the mof remarkable Places in the Inland Country of the Zeugitana, or Summer Circuit.}

Al Aleah, THE moft northern City of Note, that I have met with The Cotuclivity of a Hill, at the half Way nearly betwixt Bizerta and Porto Farina. It was formerly known by the Name of Cotuza, as we may collect from This broken Infcription.

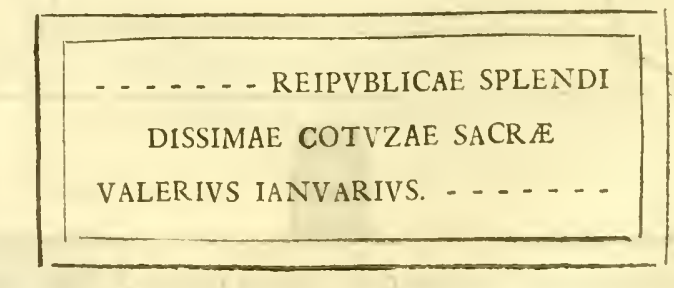


Thimida and Mezel-je-meine, the Theudalis and Thiniffa ${ }^{2}$ Thimido,Thof the Antients, are two Villages fituated upon the Lake of $t, 15 . \mathrm{Exx}$. p. Bizerta; This, at three Miles Diftance to the S.E. the Other, at feven to the S. W. of that City. of Antiquity at both Places; and near the former, the Lake is confiderably contracted, forming Itfelf (as it were) into TWO, SISARA. $_{\text {. }}$ whereof the Southermoft may be taken for the Sifara Palus, the other for the Hipponites of the old Geography.

Fibbel Iskell, a remarkable round Mountain, the Cirna, I jibbel lskell,

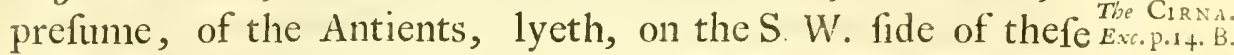
Lakes, five Leagues from Bizerta. At a little Diftance from It to the S. E. is Matter, the Oppidum Materenfe, rather perhaps + Matter, The than the antient Madaura, which, according to St. Auguftine ${ }^{2}$, Mppicium muft have been farther from Carthage. It is, at prefent, a fmall Village, fituated upon a rifing Ground, in the midft of a fruitful Plain: and a little below It, there is a Rivulet, which emptieth Itfelf into the Sifara Palus.

† Ten Leagues to the S. W. of Matter, is the City Beja or Bay-jah, Tke Bay-jah, which by the Name and Situation flould be the Orpanus

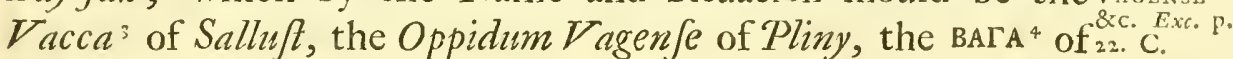
Plutarch, and the Vaccenfium Ordo Splendidiffimus, as the Title feems to run in the firft of the following Infcriptions. Cellarius s placeth It very juftly towards the N. E. of Cirta or Conftantina, but doth not quote His Authority. However fuch a Stuation feems to be implyed in the Defcriptions we have of It ; viz. that It lay to the right Hand, (as Keff or Sicca Veneria did to the left) of the Road ${ }^{6}$, which the Romans commonly made ufe of in their way to Numidia. After It revolted, Metellus ${ }^{7}$ is faid to have departed from His Winter Quarters in the Evening, and to have arrived before It, about the third Hour of the following Day: which Journey, confi-

1 Vide Agathodemonis Tabulam Ptolemaicam \& Cellar. Geogr. Ant. 1. 4. Cap. 4. p. 105. 2 Dum mihi reducto a Madauris, in qua vicina Urbe jam cœperani literaturx atque oratorix percipiendre gratia peregrinari, longinquioris apud Cartbaginem peregrinationis fumtus preparabantur. D. Auguf. 1. 2. Confefs. Cap. 3. 3 Erat haud longe ab eo itinere quo Metellus pergebat, oppidum Numidarum, nomineVacca, forum rerum venalium totius regni maxime celebratum, ubi \& incolere \& mercari confueverunt Italici generis multi mortales. Sall.

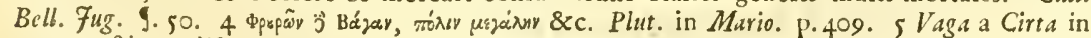
ortum xltivum diftat. Cellar. 1. 4. Cap. 5. p.114. 6 Vid. Not. 3. Sall. Bell. Fug. 9.6o. 7 Metellus, poftquam de rebus Vaccæ actis comperit__Legionem cum qua hiemabat \& quam plurimos poreft $N$ midas equites pariter cum occafu folis expeditos educit; \& poftera die circiter horam tertiam provenit in quandam planitiem-docet oppidum Vaccam non amplius mille paffuum abcffc. Id. 1.7 I. 
dering the Expedition wherewith It was performed, will very well agree with the Diftance of fifty Miles, that Bay-jab lyeth from Utica, where Metellus was at that Time ftationed. I know no other Circumftances in the antient Hiftory of This Country, that give us any further Information concerning the Geography of This City; for Ptolemy's $V$ aga, lying among the Cirtefij, cannot be the Place; and the Reafon perhaps why It is not taken Notice of in the Itinerary, or in Peutinger's Tables, may be, becaufe It was fituated at a Diftance from the Great Road that lead from Carthage, either to Numidia or Bizacium. A Place of Bay-jah keeps up the Character, that Salluft giveth us of
great Trade. His $V a c c a$, of being a Town of great Trade, and the chief Mart for Corn in the whole Kingdom. In the Plains particularly of Buf-dera, which lye below It along the Banks of the Me-jerdah, there is kept every Summer a publick Fair, frequented by the moft diftant Arabian Tribes; who refort hither, at that Time, with their Flocks and Families The prefent City is built upon the Declivity of a Hill, with the Conveniency of being well watered; and upon the higheft Part of It, there is a Citadel, but of no great Strength. Upon the Walls, which are raifed out of the antient Materials, we have the two following Infcriptions.

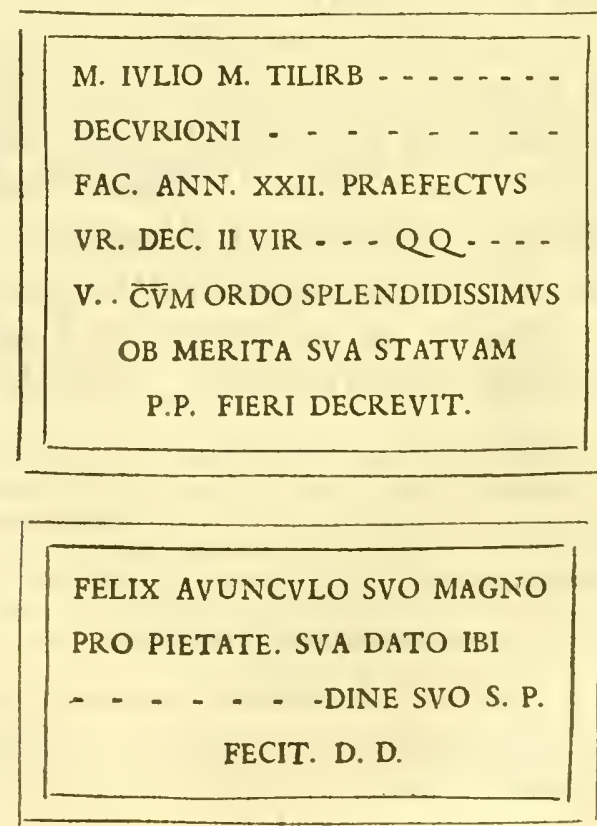


In a private Houfe.

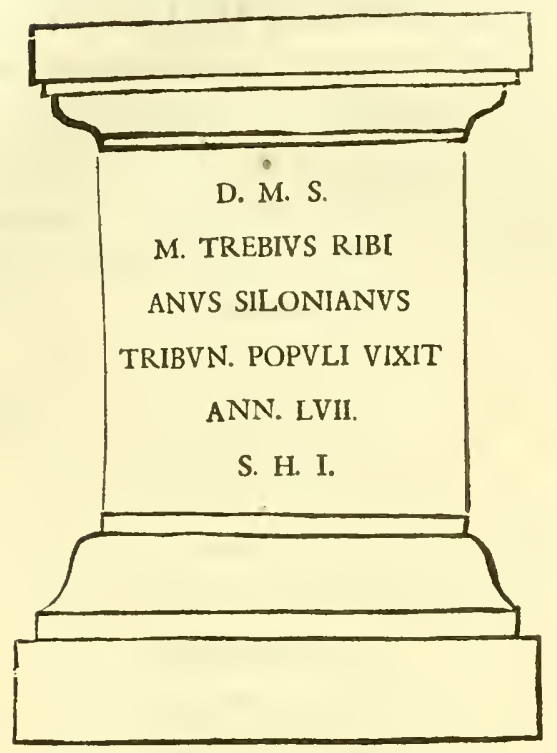

Tub-urbo, a fimall Town inhabited by Andalufian Moors, Tub-urbo, is fituated upon the Me-jerdah, fix Leagues to the S. E. of Bum Minus. Matter, and at the like Diftance to the W. of Tunis. This Eab.Peut.W. fhould be the Tuburbum Minus of the Antients: the Majus (where there feems to have been in Peutinger's Table fome remarkable Temple or Edifice,) lying at too great a Diftance to the Southward. Mahamet, a late Bey of This Kingdom, planted a great Number and Variety of Fruit Trees in the Neighbourhood of It, which He ranged in fo particular a Method, that Each Species, was confined to one Grove, and thereby removed from the Influence of Another. Thus the Orange Trees were all placed by Themfelves, without the Admiffion of the Lime or Citron; and where we gathered the Pear or Apple, we were not to expect the Peach or Apricot. In the adjacent Valley, where the Me-jerdab conveyeth It's Stream, the fame generous and publick fpirited Prince, erected, out of the Ruins that were here of an antient Amphitheatre, a large maffy Bridge or Damm, with proper Sluices and Floodgates, to raife the River to a convenient Height, for the refrefhing of His Plantations. But This was too laudable an Invention to fubfift long in Barbary, being at prefent intirely broken down and deftroyed. Upon a Stone, near the Remains of the Amphitheatre, we have This imperfect Infcription. 


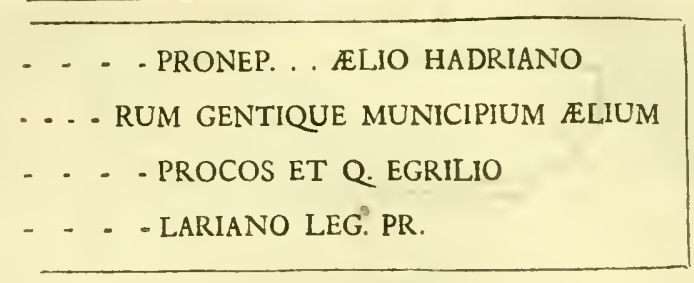

In a Mofque.

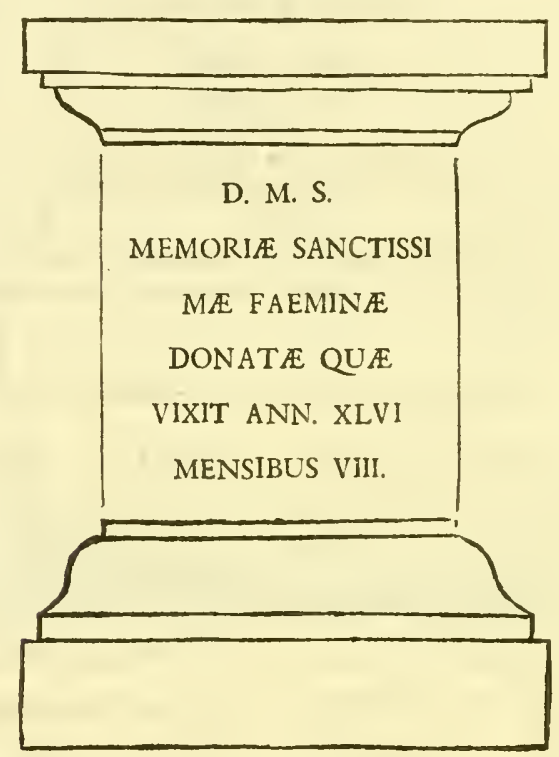

Tuc-caber. † Betwixt Tuburbo and Bazil-bab, is the little Village Tuc-caber, fituated likewife upon the Me-jerdah, but with few Antiquities to recommend It. It feems to be the fame City that is taken Notice of, by St. Cyprian' and St. Auguftine, under the Name of Tuccabori, or Thuccabori; and muft confequently be miftaken by Simler ${ }^{3}$ for the Tucca Terebintbina, which lay fixty Miles only from Sufetula; whereas Tuc-caber 1yeth nearly at twice that Diftance.

Me-zezil-bab or Bazil-bab is an old triumphal Arch, erected on the Eaft Side of the Me-jerdah, ten Leagues to the S. W. of Tunis. This Pile is of no extraordinary Beauty or Workman. fhip, yet hath been adorned with a Variety of Niches and Feftoons, that are now intirely defaced. It was built upon the De-

I Viz. In Concilio. Exc. p.32. 2 Lib. vi. Cap. 24. adverfus Donatiftas. 3 In Annot. ad Itincrarium. Vid. Cell. Geogr. Antiq. 1. 4. c. 4. p.107.

clenfion 
clenfion of the Roman Empire, as appears by the following Infcription.

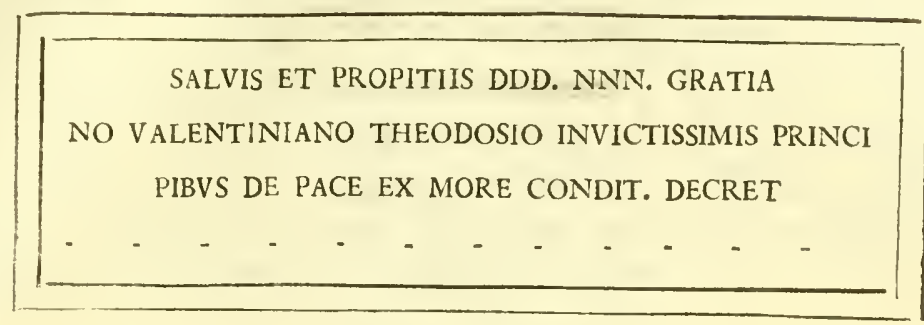

Upon an Altar.

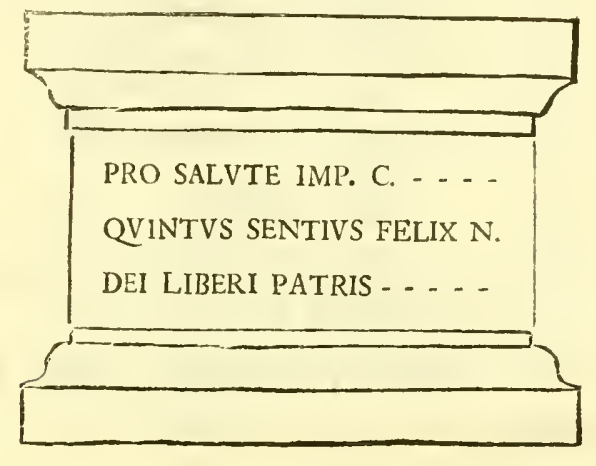

Tes-toure is a neat thriving Town of the Andalufian Moors, Teftoure, fituated upon the fame Side of the Me-jerdab with Bazil. Bre Colca $b a b$, at about two Leagues Diftance to the Weftward. By the firft of the following Infcriptions, This Place muft have been antiently called the Colonia Bifica Lucana. In a Mill a little above Bazil-bab, there is a broken Infription, where we find the Emperor Aurelian named Beficanus, as we may prefume, from This City.

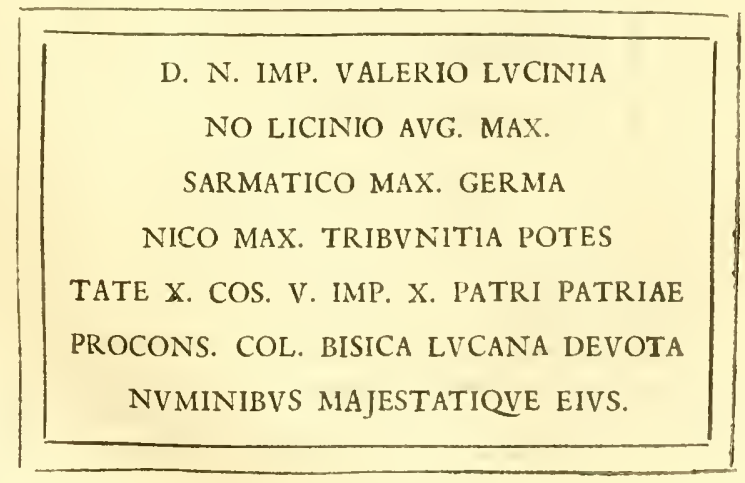

$\mathrm{U} u$ 
Upon a Pillar.

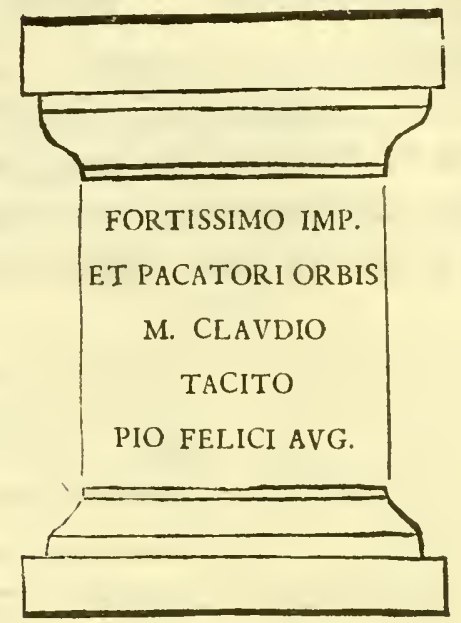

Upon a Square Stone.

\section{POLLENTES IN FINE IMPERIO}

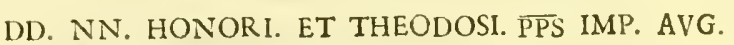
ADMINISTRANTE FELICI INNODIO - .....

PROC.

In a Mill near Bazil-bab.

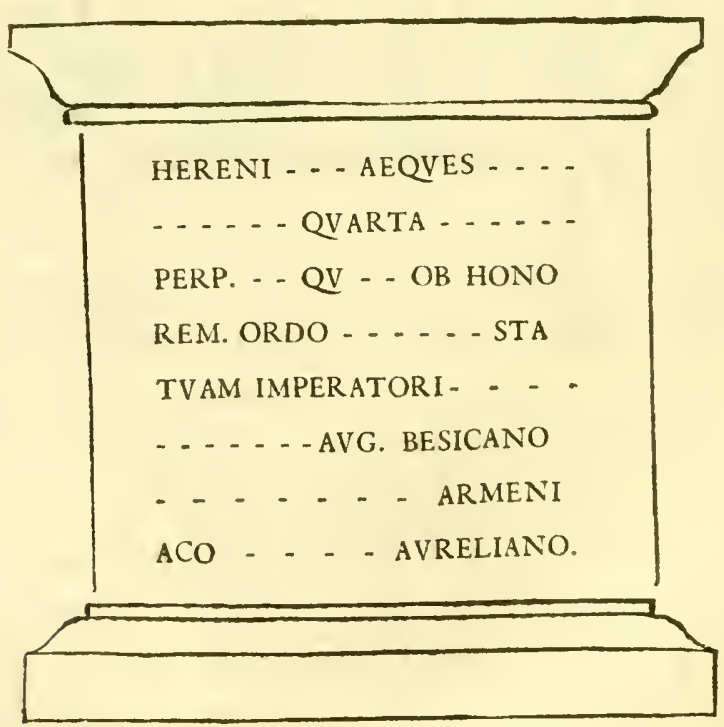

Slou-geats 


\section{Of the Summer Circuit.}

Slou-geah or Salow-keah, a fmall Village, formerly the $M u$-Slou-geah, nicipium Hidibelenfe or Chidibbelenfium, is built at the Bottom Phium CHilof a large Winding of the Me-jerdah, which reacheth from $\mathrm{DI}$ sI $\mathrm{BmE}$. Bazil-bab to Teftoure. It is chiefly remarkable for the two following Infcriptions; though there are here, as well as at other Places already taken Notice of or which will hereafter fall in our Way, feveral Rudiments of Cifterns, Shafts of Pillars, Capitals, Pieces of large Walls \&c. which it would be too tedious to enumerate upon every Occafion.
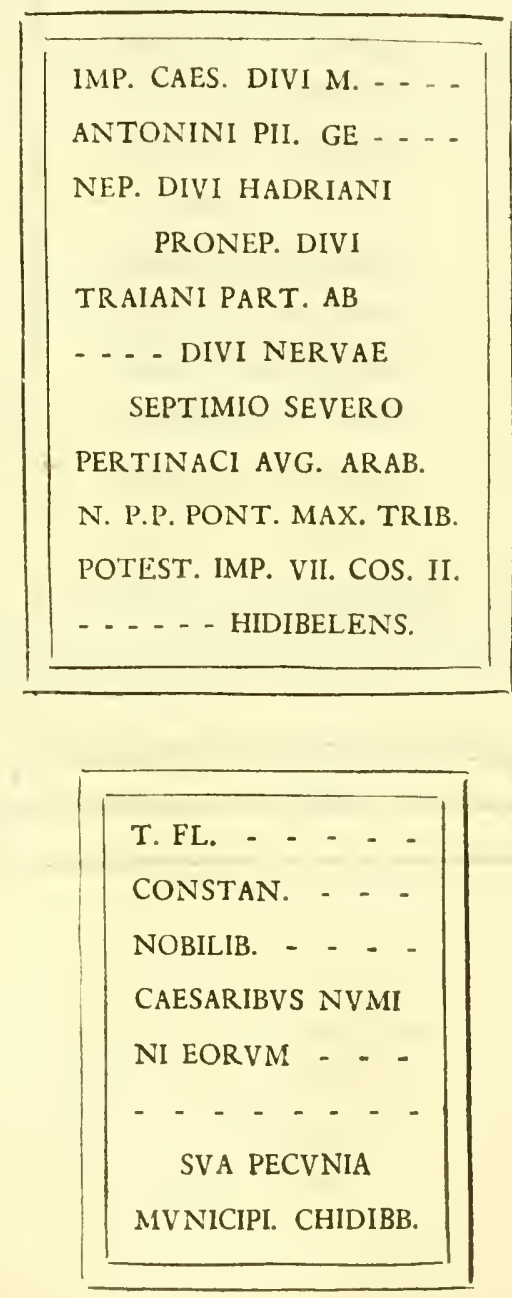

Tunga or Tannica, the Thignica or Thigiba Colonia of the Tunga, rbe

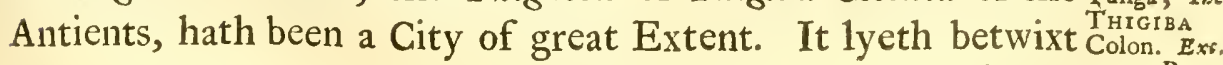
$\mathrm{U} \mathrm{u}_{2}$ Tef-toure P. $^{\text {. } 5 . \text { B. }}$. 
Tef-toure and Tuber-foke, at five Miles Diftance from the Latter, and to the Northward of It as hath been taken Notice of by Cellarius'. Among the Ruins, particularly of the antient Citadel, we have Thefe Infcriptions.

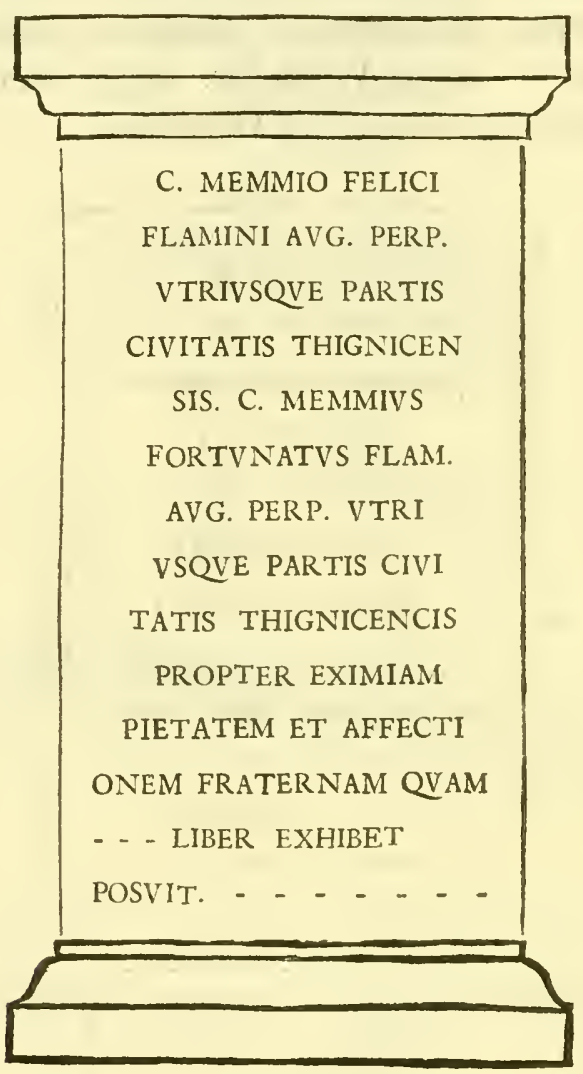

ANTONINI PII. -...

CASTRORVM ....

THIGNICA DEVOTVM.

I A Tuburfica in Septentrionem proxima Thigiba Colonia \&.c. Cellar. Geogr. Antiq. 1. 4. cap. 5. P. I16. 
ALTISSIMO SAECVLO DDD. NNN.

ORB. - - TORI - - INDVLTA PACE

CIVI - - THIGNICENSIS - - PROC.

CONSTANTINI MAX. V. - - -

NIA - - - FVNDAMENTIS ET S. - -

- - - TVDO DOMITICENO FILIO

Over the Portal of a Tomple.

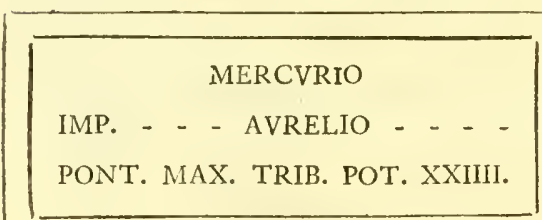

+ Two Leagues to the S. W. of Teftoure, is Tuber-foke, a Tuber-foke, fmall City, walled round, and fituated upon the Declivity of The THII- $_{\text {Bum- }}$ an Eminence. In the Centre of It, there is a very clear and plentiful Fountain, with fome Ruins of a Temple that was formerly built over It. It lyeth nearly in the fame Parallel with Tuber-noke, though at fifty five Miles Diftance, and cannot therefore be one and the fame City, as fome Authors ${ }^{\text {. }}$ have inagined. In the Walls, which are made out of the old Materials, we have the following Infcriptions; whereby we find It called Thiburficumbure, agreeable to the Title of Tuburficuburen/is in the Notitia. And as This was a See of the Provincia Proconjularis, we thall be at a Lofs for the Thuburficca of Ptolemy, which the Notitia placeth in Numidia.

I Supra Hipponem regium Tbuburnica Colonia, quod Tuburnicen/e Plinii oppidum eft, de quo veretur Harduinus ne eadem Thuburfica ejufdem Ptolemai fit, longe ab illa in meridicm verfus fita: propter quam diftantiam mihi fecus videtur, prefertim quod multa Africa oppida in nomine pænc conveniunt \& tamen feparata manent, ut etiam Tuburbo eft, idque geminum, majus \& minus. Cellar. 1.4. c.5. I 16. 
VRBI ROMAE AETERNAE AVG. RESP. MVNICIPI SEVERIANI ANTO NINIANI LIBERI THHBVRSICENSIVM BVRE

SALVIS DOMINIS NOSTRIS CHRISTIIANISSIMIS ET INVICTISSIMIS IMPERATORIBVS IVSTINO ET SOFIAE AVGVSTIS HANC MVNITIONEM THOMAS * EXCELLENTISSIMVS PRAEFECTVS FELICITER AEDIFICAVIT.

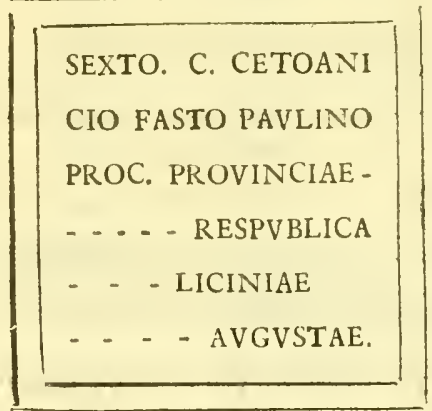

Q. ACILIO. C. PAPIR - - - - -

ANONAE. AVG.

SICENSIVM PROC

- . THEATRI PON. - . . ADVOCATO CODIC. - . - . - ADMINISTRATIONIS HEREDI IN ME ET CO ... ENTIVM C. ... LAVRENTIVM VICO AVGVSTINORVM SACERDOTI - . - . - REIP. MVNICIPI LIB. THIB. BVRE PATRONO.

* Et Thomas Lybica nutantis dextera terrx. Coripp. Afr. de laud. Fuft. Min. I. I. 


\section{Of the Summer Gircuit.}

Over the Foutiain.

NEPTVNO AVG. SAC. PRO SALVTE

IMP. CAESARVM.

Dugga or Tugga, by a Similitude in Name and the great Va-Dugga, The riety of Ruins, might be very well taken for the antient $E x \times$. p.r. $5 . \mathrm{B}$. Tucca, provided we had not found It called Thugga in the following Infcriptions. It is fituated upon the Extremity of a fmall Chain of Hills about two Miles to the Southward of Tuberfoke, having been formerly fupplyed with Water by an Aqueduct. Here are feveral Tombs, Maufolea, and the Portico of a Temple, very beautifully adorned with fluited Columns. On the Pediment of this Structure, there is the Figure of an Eagle finely difplayed, and below It we have this Infcription, in Commemoration as we may prefume of the Founders.

L. MARCIVS SIMPLEX ET L. MAR

CELLVS SIMPLEX REGILIANVS S.P.F.

Upon the Frize of the Portico.

IMP. CAES. DIVI ANTONINI - - -

MARC. AVRELIO SEVERO ALEXANDRO

PONTIFICI MAX. TRIBVNITIA POT.

ET CASTR. ET SENATVS ET PA

- - VM LIBERVM THVGGA.

Upon a Square Stone.

CLAVDIO CAESARI ANG - . .

MAXIMO TRIBVNITIA POT. - -

R. CRASSVS AEDIL. ORNAM --

TI VIR AVGVR II VIR QVINQVE

C. FAR. PERPETVVS SACERIVS

PAGI THVGGENSIS NOM. - . -

ET PERPETVI. - . . - - 

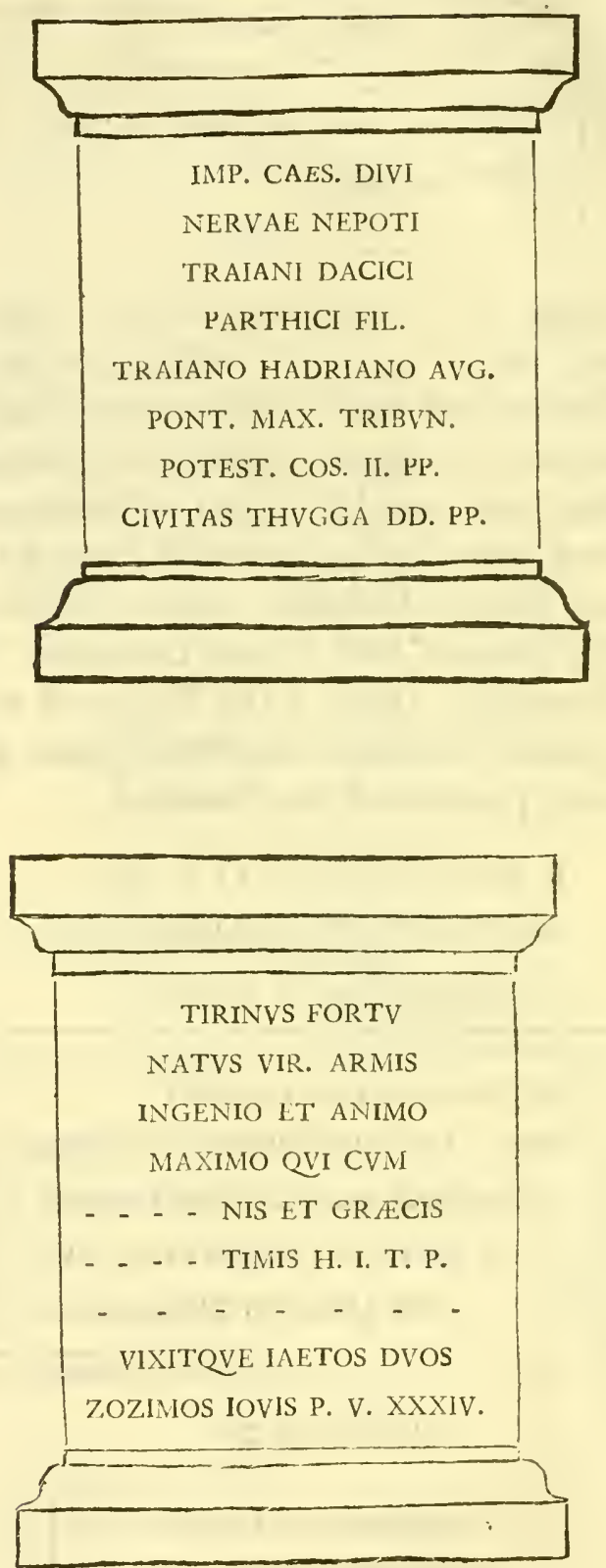

Lorbufs, The Lorbufs, the Laribus Colonia of the Anticnts, is remarkable EAR.P.25.F.at prefent for little elfe befides a fine Situation, being built upon an Eminence about five Leagues to the W. S. W. of Tefoure, and at the like Diftance to the N.E. of Keff. Leo and 
and Marmol, deduce the River of Ta-barka (the antient Tu/ca) from the Neighbourhood of This City; whereas Thefe Parts of the Fri-geah, from their very Situation, muft either difcharge Their Rivulets into the Me-jerdah, or elfe find other Channels for them to the Eaftward. There muft likewife be fome Error or Tranfpofition in theItinerary, with regard to This Place. For it is there ${ }^{2}$ fixed LxxirI Miles only, inftead of $\mathrm{cr}$ (as in a direct Line, without calling at Altieuros or Admedera, the Diftance actually is ) from Therefte.

Mef-tura, the Civitas II Tuggen/is, as Dugga above mention- Mef-tura, ed might be the Firft, is fituated in the Plains below Lorbu/s, II Tuggenat a fimall-Diftance from Dugga. Upon a Stone, which, by the Fafhion of It, appears to have been the Pedeftal of fome Statue, is This Infcription.

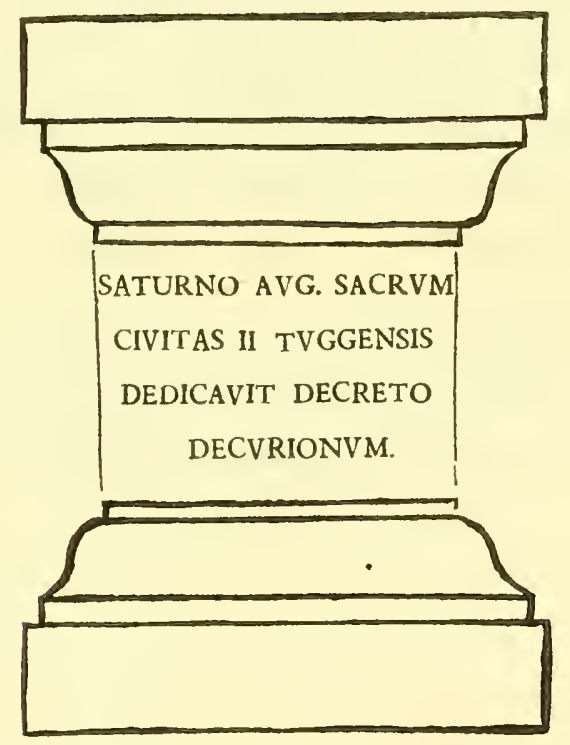

Beiffons, the Municipium Agbienfum, (and Baifa perhaps Beifrons, , The from the firft Infcription,) is built upon a Hill, about one Agnicipium League from Tuber-Joke and at half that Diftance from Dugga. We have here the Traces of two Temples, and of a Caftle of later Workmanfhip. Among the Ruins are the following In. fcriptions.

I Vid. Not.2. p. $99 . \quad 2$ Exc. p. 25. F. p. 26. A.

D. 


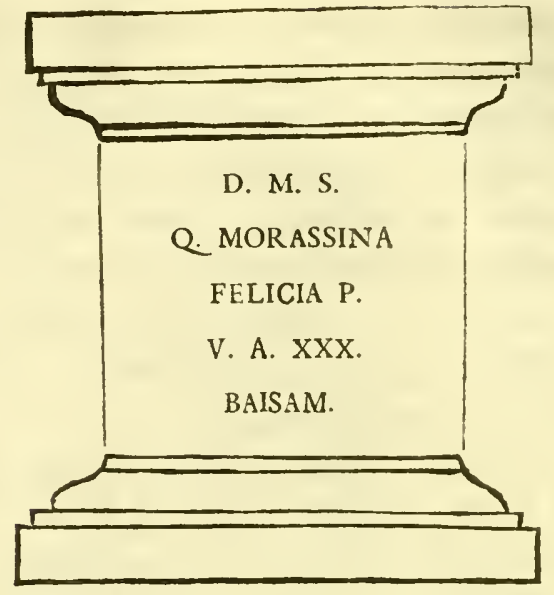

PRO SALVTE IMP. M. ANTONINI AVG. PII LIBERORVMQVE EIVS

CINTIVS C.F.R.N. VICTORVM AD TVENDAM REMPVBLICAM CONSENSV DECVRIO NVM OMNIVM IAM PRIDEM PATRONVS FACTVS ET TVTOR CVM - - RERVM VETVS TATE CONSVM ......... A SOLO MVNICIPI CIVILIS AGBIENSIVM ET VNIVERSIS CVRIIS DD. PP.

MAGNIS ET INVICTIS DDDD. NNNN. DIOCLETIANO ET MAXIMIANO PERPETVIS AVGG. ET CONSTANTIO ET MAXIMIANO NOBB. CAESARIBVS RESPVBLICA MVNICIPII AGBIENSIVM DEDICA - - M. IVL. - PROCOS - - MAIESTATIQVE EORV'M DIC. - - 
Mufti, called at prefent Seedy Abdel-abbufs from a Marab- Scedy Abbutt of that Name who is there interred, is fituated upon a Mustr.Exc. Plain in View of Dugga and Beiffons, near the half Way be-r.r. B. B. p.r.s. twixt Teftoure and Keff. We have here the Remains of a beautiful triumphal Arch; and upon a Stone that might formerly belong to It, there is This Infcription.

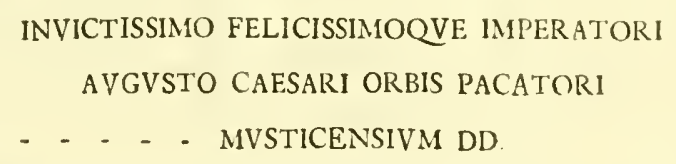

Vibius Sequefter ' hath been mifinformed in placing This City near the River Bagrada; the neareft Part of which is four Leagues to the N. E. The Author of the Itinerary maketh It rxxrv Roman Miles (Peutinger's Tables only xxxiI) or an eafy Days Journey from Sicca Veneria ${ }^{2}$; xcir from Sufetula ${ }^{3}$; Lxxxvi from Carthage All which Diftances, confidering the Roads are frequently indirect, will, by taking in the feveral interjacent Places, very well correfpond with the Situation of Seedy Abdel-abbuss.

Keff, the Sicca or Sicca Veneria ${ }^{6}$ of the Antients, lyeth Kicf, The

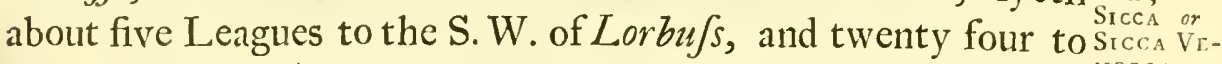
the W. S. W. of Tunis. It is a Frontier Town, and the Third for Riches and Strength in the whole Kingdom; though the greateft Part of the Caftle was, about nine Years ago, blown up in the Civil Wars. The Situation of This City, as the Name [iio] implyeth, is upon the Declivity of a Hill; and near the Centre of It, there is a plentiful Source of Water. The two following Infcriptions are at prefent the only furviving Antiquities of This noted Place.

I Bagrada Africa juxta oppidum Mufti, \&xc. 2 Exc. p. 27. A. 3 Illid. E. 4 llid. A. P. 26. E. 6 Summi viri Go. Seldemus de Diis Syris Syntagma 11. Cap.vir. \& Ger. Fo. Voffüs Theol. Gentil. I. 2. cap. xxi I. nomen Sicca Vonerie erudite deducunt ex Afyriorum numine vel Religione Succot Benot cujus ir Reg. xvi I fie mentio, guafi Tabernaculx filiarum five mulierum dicantnr, feu cultus Veneris Afjyia, quem Herodotus l. I cap. cxcix \& Str.abol. 16. defcribunt. Cellar. Gcogr. Antiq. 1. 4. cap. 5. p. $117>$ Sicce enim Fanum eft l'eneris, in quod fe matronx conferebant; atque inde procedentes ad quxettum; dotes corporis injuria contrahebant, honefta nimirum tam inhonefto vinculo conjugia juncturx. Vall. Ma.x. 1.2. cap. 6. I. Is.

$$
\text { Y y } 2
$$



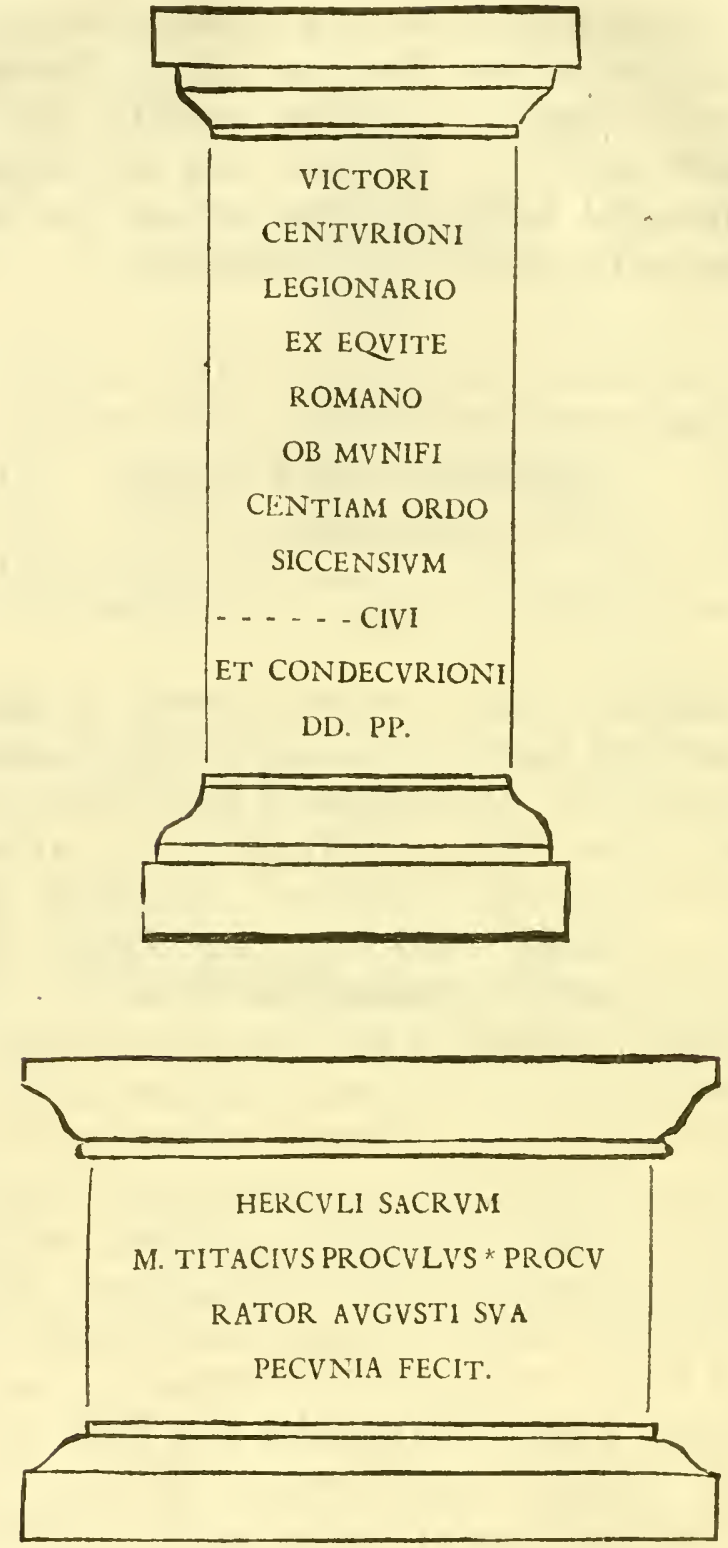

Boufla, The We find Boufba, (where there is a fmall Heap of Ruins, in Turceta. "r the fame Parallel nearly with Bazil-bab, at about fix Leagues to the S. W. by S. of Tunis. The Ordo Turcetanus occurring in the following Infcription, may induce us to believe that This Place was formerly called Turza, or Turceta.

Vid. Tertull. Lib. ad Scapalam. Baron. Annal. in Ànn. C. ร95. 
CATIO ALCIMO FELICIANO PV.

VICE PRAEF. PRET. PRAEF. ANNO

NAE VICE PRAEF. VIGIIVM MAG.

SVMMAE PRIVATAE MAGIST.

VM RATIONVMI CVRATORI OPER

TRI. PROC. HEREDITATVM

SACRAE MONETAE PER

PROV. NARBONENS. PROC. PRIV.: PER SALARIAM

TIBVRTINAM VALERIAM TVSCIAM PROC. PER

FLAMINIAM VMBRIAM PICENVM ITEM VICE

PROC. QVADRIG. GALLIARVM PROC. ALIMENT. PER - -

TRANSPADVM HISTRIAM TITVRNIAM

FISCI PROVINCIAR. XI OB EXIMIVM AMOREM IN

PATRIAM SPLENDIDISSIMVS ORDO TVRCET. PATRONO DD.

Mefherga or Elmefherka, is fituated in a Plain three Leagues Mefherga, to the Eaft ward of Bou/ha. This was formerly called Giuf or the Municipium Aurelium Alexandrinum Auguftum Magnum Guifitanum; where the Word Magnum is probably inferted to diftinguifh It from a Leffer Giuf, which I found upon the Mountain of Zowaan, called ftill Ziuf el Zowaan. There is nothing confiderable in this Extent of Ruins befides the following Infcriptions.

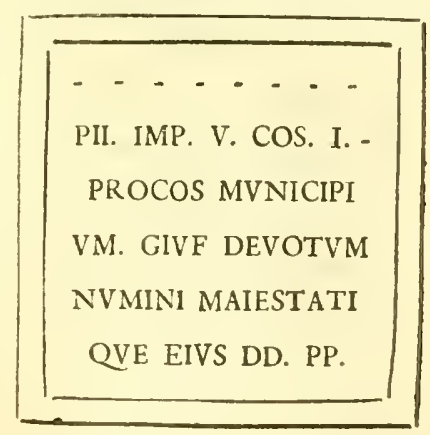

Z z 


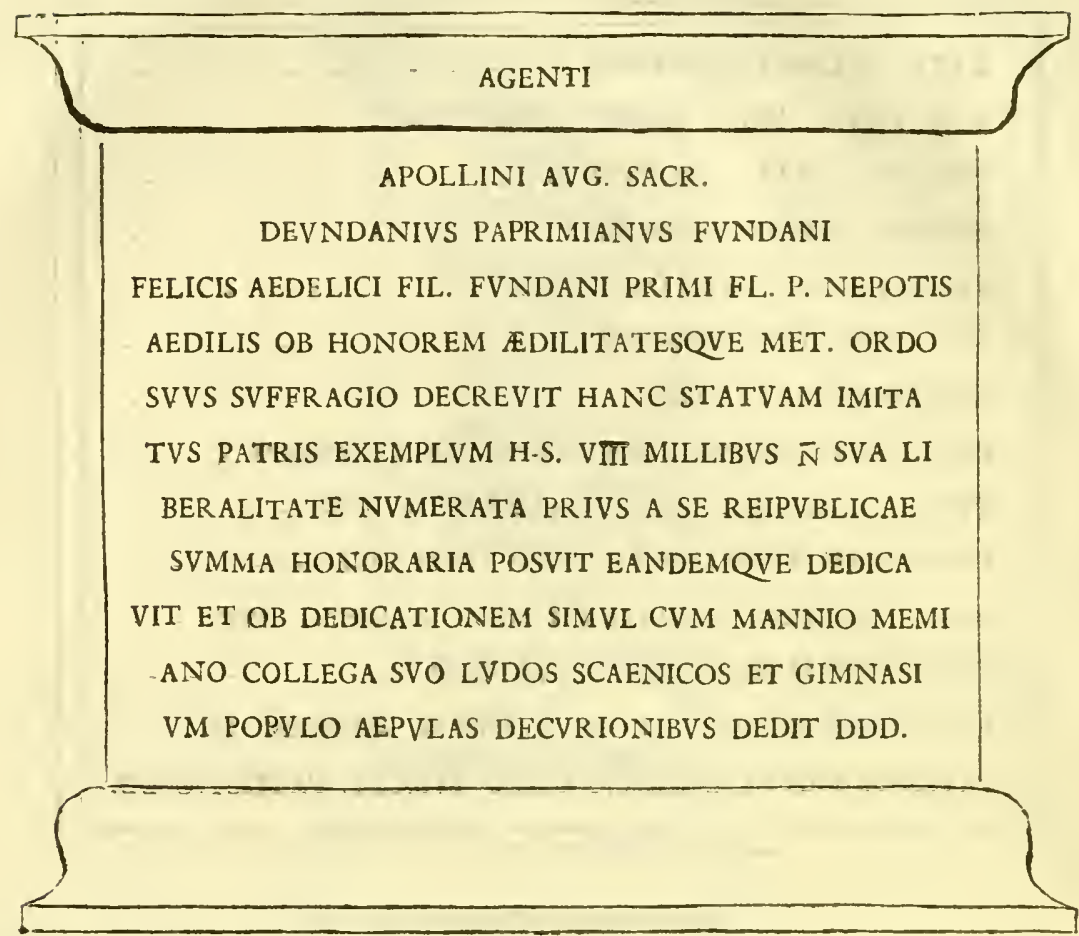

LVCINIAE SATVR NINAE AVRELI DIONISI PATRO NI CONIVGI MVNICIPES MVNICIPI AVRE LI ALEXANDRIA

NI AVGVSTI MAGNI GIVFITANI 
PESCENNIA QVOD VVLT DEVS

H. M. F. BONIS NATALIBVS

NATA MATRONALITER

NVPTA VXOR CASTA MATER PIA GENVIT FILIOS

III. ET FILIAS II. VIXIT ANNIS XXX. VICTORINA

VIXIT ANNIS VII. SVNNIVS VIXIT ANNIS

III. MARCVS VIXIT

ANNIS II. MARCEL

LVS VIXIT ANNO I. FORTVNATA VIXIT ANNIS XIII. M. VIII. MARCELLVS PROCOS - CIV. SED ET FILIIS ET FILIABVS NOSTRIS ME VI VO MEMORIAM FECI OMNIBVS ESSE PEREMNEM

\begin{tabular}{|c|}
\hline D. M. S. \\
PALLONIVS FELIX PIVS \\
VIXIT AN. XLI. D. IIII. \\
AMORE DVCTVS \\
PELAGI MERCIB. \\
INSISTEBAM \\
SVCCIDIS AETER \\
NOQVE SILENTIO \\
MAVRIS SVM.
\end{tabular}


Tuber-noke The OPP IDUM TUBURNICENSE. Exc. p. 22. C.

+ Tuber-noke, the Oppidum Tuburnicenfe of Pliny, is feven Leagues to the S. S. W. of Tunis, and about the half Way betwixt Solyman and Caffir Afeite. It is built in the Form of a Crefcent, between two Ridges of a very verdant Mountain, a Part probably of the Mons Balbus of Livy', which diverfifieth Itfelf, in This Neighbourhood, into the like Variety of Windings and narrow Defile's that are mentioned by that Author. A fpreading Pair of Stag's Horns, well delineated, in Ba/Jo Relievo, over the Gate of a large Edifice, is the only furviving Antiquity of 'This Place. If Tuber-noke anfwers to the Tuburnicen/is of the Notitia, as I prefume will not be difputed, it will be difficult to account for the placing of It among the Sees of Numidia; the neareft of which muft lye at a great Diftance to the Weftward.

Jcraado. Feraado, is fituated upon the Declivity of a Hill four Miles to the Northward of Faradee Je, and twelve to the S.W. of Tubernoke. We have here the Ruins of a fmall Aqueduct, with It's Cifterns; and upon the Portal of an'antient Temple, in the fame ruinous Condition with the reft of the City, there is the following Account of the Perfons who contributed to the Building of It.

Upon the right Hand of the Portal.

AVRELIVS RESTITVTVS I!CC

IVLIVS TERTIVS liCCCC ET SPATIVM - - -

AVRELIVS SEVERIANVS II D ET CALCIS -.- P. XX. M

AVRELIVS QVINTINVS IICCCC

Upon the left Hand.

CALPVRNIVS IICC

MARTIVS VENVSTVS IICC

L. AELIVS LARGVS IICC

AVRELIVS FROTIANVS IICC

Zow-w22n. Zow-aan or Zag-wan, a fmall flourifhing Town built upon the N. E. Extremity of a confpicuous Mountain of the fame Name, is in great Repute for dying of Scarlet Caps and

I Mafaniffa cum paucis equitibus ex acie in montem (Balbum incolx vocant) perfugit. Liv. 1. 29. 9. 3I. Bucchar digreffum jugis Mafaniffam perfecutus in valle areta, faucibus utrimque obfeffis, inclufit. Id. 9. 32 .

bleach- 


\section{Of the Summer Circuit.}

bleaching of Linnen; great Quantities of Both being daily brought hither for that Purpofe, from all Parts of the Kingdom. It hath been already obferved that the Stream, employed in this Service at prefent, was formerly conveyed to Carthage; and that a Temple, the Ruins of which continue to this Day, was built over the Fountain. Upon an antient Gate of this City, which looks towards the S. E. there is the Device of a Ram's Head, armed, with Auxicio infcribed below It; whereby It may be prefumed, that This City was formerly under the immediate Influence and Protection of Fupiter Ammon:

If we could be affured of having the leaft Traces of Zeugis Zeugitana or Zeugitana in the prefent Name of This City or Mountain, called from there would be no fmall Reafon to conclude, that the Name of tain. This Province was denominated from It. Solinus feems to ad. Exc. p.23. F. vance fomething in Favour of This Suppofition, by acquainting us, that Africa commenced (a pede Zeugitano) from the Foot, as I would interpret It, of the Mountain Zow-waan; or, in other Words, that Africa was that Space of Ground which lay to the Northward of the Parallel of This Mountain. It is certain, we have a Profpect of the greateft Part of the Kingdom from This Eminence; which might, in all probability, be the fame Place from whence Agathocles ${ }^{3}$ was entertained with aView both of the Country of the Adrumetines and Carthaginians. The Zygantes likewife of Herodotus feem to have had This Situation. Exc. p. 3. A.

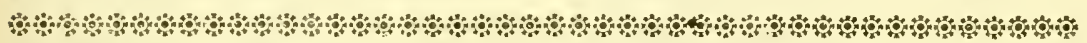

\section{H A P. IV.}

\section{Of the moft remarkable Places upon the Sea-Coaft of the} antient Bizacium, or Winter Circuit.

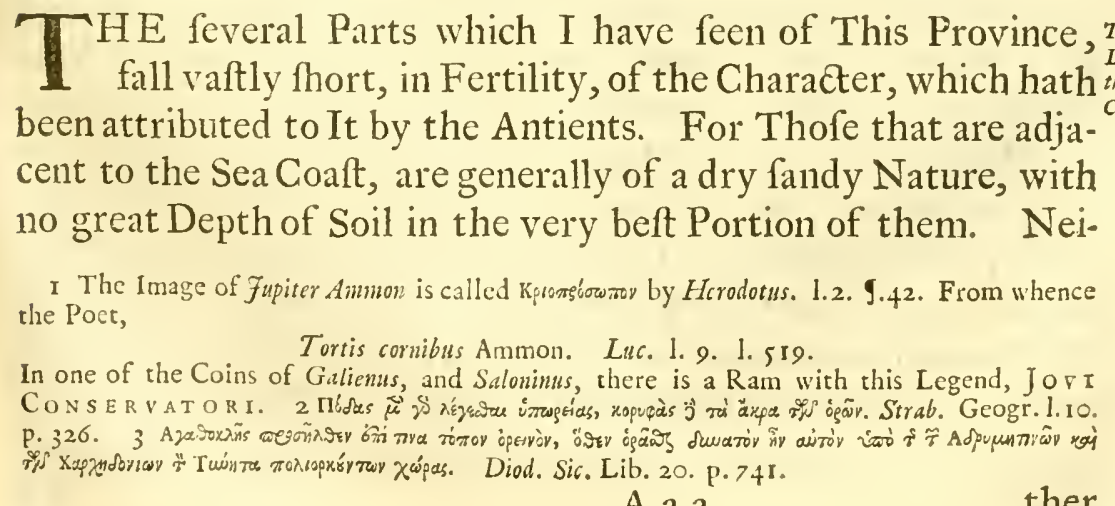
A a a

ther 
ther is the Inland Country in a much better State and Condition. For if we except the Plains which are watered by the Defailab, Derb, and Hat-taab, we have Mountains only and woody Tracts all along from Zung-gar by UJe-let, Truzza, Spaitla, Cafareen, and fo forward, in turning to the N.W. by the Sanctuary of Seedy Boogannim, as far as Hydrah, and the Frontiers of the Kingdom of Algiers. The Country round about Kairwan is low and marfhy, with Lakes and Shibkabs difperfed all over It, in the Winter Seafon; whilft near Gilma, Femme and fo on to the River Accroude, there is an Interchange of Hills and Valleys, differing very little in the Quality of Their Soils from That of the Sea Coaft. Beyond the Mountains of Cafareen, 'till we arrive at Ferre-anab and the Skirts of the Sabara, we travel for feveral Miles together over a barren Plain, with a Ridge of Eminences, at fome Diftance, on each Side of us. The Country continueth in the fame lonefome and barren Situation, from hence to $\operatorname{Cap} / a$, and fo forward to the Fereed; our Profpect on each hand being all the Way bounded with high Mountains: whereof the S. E. Ridge ftretcheth towards Fibbel Hadeff $a$ and the Lake of Marks; the Other, which may be taken for the Contination of the Mountains of Atlas, runs in a S.W. Direction, by Sbekkah, as far as the Eye can conduct us.

Herkla, The + Herkia, the Heraclea of the lower Empire, and the $A$ ADRUME-
TUM.E.E. drumetum as I conjecture of the Earlier Ages, was built upon
P.4.A. P. 8. A. p.r. E. an hemifpherical Promontory, like Clypea, at the Diftance of

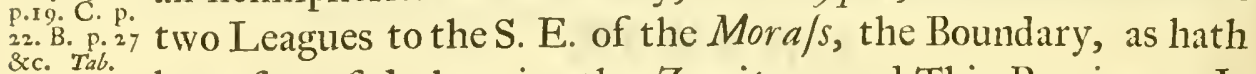
Peut. Z. been fuppofed, betwixt the Zengitana and This Province. It appears to have been little more than a Mile in Circuit: and provided we may be allowed to judge of the former Grandeur by the remaining Ruins, we fhould be induced to take It rather for a Place of Importance than Extent. That Part of This Promontory, which ftretched to the Northward and formed the Port, feems to have been walled in to the very Brink of the Sea: the reft, for the Space of a Furlong's Diftance from the Shore, doth not difcover the leaft Traces of Ruins. Crefar then might have all the Conveniency, he could wifh for, to obferve the Strength and Situation of This City ${ }^{1}$; efpecially as the Inhabitants declined all manner of Hoftilities at that Time.

I Cefar circum oppidum vectus, natura loci perfpcite, redit ad Calts. Hirt. de Bcll.
Afric. 9.3 . 
To the W. and S.W. of this Promontory were the Port and The Port and Cothon, which we find Caefar could not enter in His Purfuit of Varus, but was obliged to lay at Anchor without It, or to the Eaftward, as we may imagine, of the Promontory. Now it may be prefumed, as Crefar directed His Courfe from Leptis, (or Lempta as It is called at prefent) that no other than a Southerly or Wefterly Wind could have brought Him thus far to the Northward: it is certain, an eafterly one, provided It continued, would, from the very Situation of This Port and Promontory, have eafily conducted Him within Them. And from This Circumftance, I apprehend, we may draw another Argument, that Hamam-et, as was before pretended, could not be the Adrumetum; becaufe as That Place lyeth nearly in the like Direction with Lempta and Herkla, the fame Wind which brought Ceefar to the Promontory upon which That City is built, would have conducted Him within It.

Befides $V$ arus $^{2}$ is reported to have left Adrumetum in the Adrumetum fecond Watch of the Night and to have arrived at Leptis early $D^{a t}$ ifarize grom in the Morning. No confiderable Diftance therefore could have been betwixt thofe two Places. But as travelling by Sea is precarious and uncertain, we may with more certainty compute the Diftance by Cre Jar's Marches. Now It appears that Ceefar marched with His Army from Adrumetum to Leptis in two Days, and returned the third to Ru/pina ${ }^{3}$ where He had lodged the firft Night. If Hamam-et then was the Adrumetum and Ru/pina the half Way (as may be fuppofed) to Leptis, Their Marches muft have been nearly forty Roman Miles a Day; a Fatigue even too great for the hardieft Veterans of Cre/ar's Army, much more for fuch unexperienced ${ }^{4}$ Troops as He had then with Him; who were fcarce recovered from their Sea Sicknefs, and who had likewife a Variety of Skirmifhes and Difficulties to retard their Marches'. Neither indeed was This a Seafon for

\footnotetext{
I Varus celeritate $C$ cefaris audaciaque motus, cum univerfa claffe, converfis navibus, $A$ drumetum verfus fugere contendit. Quem Cafar in millibus paffuum IV confecutus _- triremem hoftium proximum — cepir: reliqux naves holtiun, Promontorium fuperârunt, atque Adrumsetuin in Cotbonem fe univerfe contulerunt. Cafar eodem vento Promontorium fuperare non potuit; atque in Salo in anchoris ea noßte commoratus \&rc. Hirt. Bell. Afric. 9. 56. 2 Varus, Vigilia fecunda Adrameto ex Cothone egreffus, primo mane Leptim unjverfa claffe vectus \&c. Id. 9.55. 3 Eo die caftra pofuit ad oppidum Rupinam, Kalendis Januar. (9.5.) inde movit \& pervenit ad oppidum Leptin. (9.6.) ad III Non. Jan. caftra movet; Leprique VI cohortium prefidio cum Saferna relicto ipfe rurfus, unde pridie venerat, Rufpinam cum reliquis copiis convertit. (9. 8.) 4 Ad oppidum oppugnandum non facis copiarum habebat \& cas tironum. 9.5. ibid. S Itaque caltra quam movere vellet, fubito ex oppido erupir multitudo — \& ejus agmen extremum infequi cœe corunt — quod cum fepius facerent; \& modo infequerentur, modo rurfus ab equitibus in oppidum repellerentur \&c. Id. ibid.
} 
long Journies, the Days at This Time confifting only of nine or ten Hours. Nay farther, as Ruppina lay within fix Miles of Leptis; the firft Days March (upon a Suppofition that $\mathrm{Ha}$ mam-et was the Adrumetum, muft have been near feventy Miles; which feems to be impoffible. There is no Room then to imagine that Hamam-et could have been the antient Adrumetum.

Monaiteer too near Leptis to be the Adrume-

Monafteer is indeed built upon a Promontory, and fo far agreeth with the Situation of Adrumetum; but then, befides feveral other Reafons to the contrary, It is too near Leptis and the Station of Crefar's Navy, to be fo much as thought of. Upon thefe feveral Confiderations therefore, Herkla is the only Place, wherewith the feveral geographical Circumftances, that are recorded of Adrumetum, will exactly agree.

Adrumetum batb often changed It's Name.

Another Argument, in Favour of This Suppofition, may be drawn from the Alteration that may be prefumed to have been more than once made in the Name. For as It was ufual, upon feveral Occafions, both with the Greeks and Romans, to change the old Names of their Cities in Honour of their Emperours or Empreffes; fo It was no lefs common for one Emperour, upon doing fome fignal good Offices to a favourite City, to have His own Name fubftituted in the Place of His Predeceffor's. Thus Procopius' telleth us, that Adrumetum, in Refpect to the Emperour Fuftinian, was called in His Time Fuftiniana; as It might afterwards have been changed into Heraclea, out of the like Sentiments of Gratitude to His diftant Succeffour Heraclius.

The Navigation fafe in This Gulph.

Herkla, in croffing the interjacent Gulph, lyeth feven Leagues only to the S. by W. of Hamam-et, though, in travelling by Land, the Diftance is upwards of thirty Geographical Miles, or a tedious Day's Journey. The Mariner may traverfe all Parts of this Gulph without the leaft Danger from Rocks, or Shallows; neither could He fail, even in the greateft Diftrefs of Weather, without fome extraordinary Accident, to reach either the Ports of Siagul and Apbrodifium, or the Cothon at leaft of Adrumetum. This City then, according to the Conjectures of Scaliger ${ }^{2}$ and others, could not well be called The

Vid. Procop. de Ėdificiis Dri. Fufiniani Cap. 6. 2 Quod dicit Solinus [Exc. p. 24. C.] de Hadramyto, id origine verbi confirmatur, qux plane Ptunica eft $\neg 1 \%-73$. Sed Arabice mclius

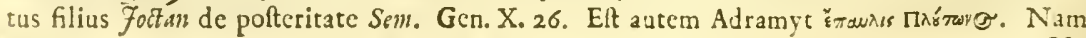


[Hadar or Hazar Mout] deadly or pefliferous City, upon Account of the Danger there might be in approaching It.

Neither could the Name have been impofed from the Un- The circuniar wholefomenefs of the Climate. The Country indeed which falnkriouss. lyeth behind This Gulph, ị low and marflyy in feveral Places; yet I could not learn that the Air was remarkable for any ill Temperature. Herkla too, at half a Miles Diftance, is almoft furrounded with Water: which however might have always been drained off, together with the fuperfluous Moifture of the adjacent Plains, provided They were attended with any noxious Vapours. The Channel taken Notice of betwixt This Place and Sel-loome, appears to have been a Contrivance of This Nature; though perhaps without any View to the Ufe juft now fuggefted. Bochart, from the remarkable Fertility of This Province, maketh Adruma or Adrumetum (the Metropolis of It) to denote a City of a hundred or of bundred Folds. But if we were fure that Adruma, without any farther Latin or Greek Termination, was the old Punic Name; and that it was an appellative and not indebted, like the Afiatic Adramyttium, to a Founder of the fame Name, we might from the Situation, prefume to

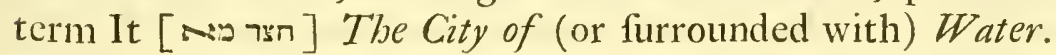

Sufa, the next remarkable Place upon the Coaft, is fituated sura. about five Leagues to the S. E. of Herkla. It is the chief Mart of This Kingdom for Oyl, hath a flourifhing Trade in Linnens, and may be reckoned one of the moft confiderable Cities of the Tunifeens. Here are feveral Vaults, Granite Pillars, and other Tokens of It's having been formerly a Place of fome Repute : probably one of thofe Towns ${ }^{1}$ which fubmitted to $C_{e}$ far in His March to Ruppina.

Suffa is built upon the northern Extremity of a long Range of The Situation Eminences, which, as Hirtius ${ }^{2}$ hath well defcribed Them, reach ${ }^{\text {of }}$ It.

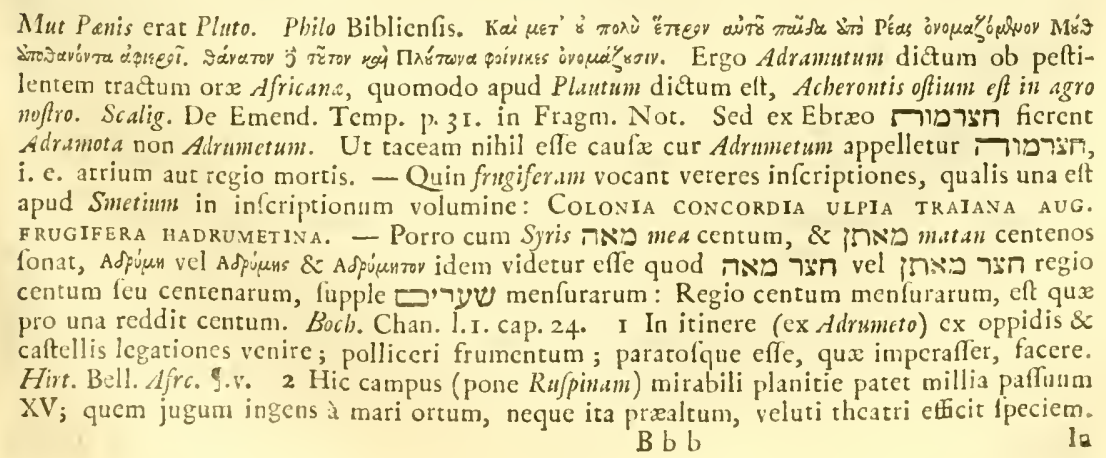


as far as Surfeff, the antient Sarfura. Behind It, all along to Sabaleel, we have a View of that extenfive Plain, which is taken Notice of likewife by the fame Author. But as there are no Traces of a Port either at This Place, or for feveral Miles on each Side of It: as It is fituated likewife too near the Sea ${ }^{\mathrm{x}}$ and at too great a Diftance from Leptis, Sufa doth not feem to agree with the antient Rujpina, to which Hirtius hath afcribed all or moft of thefe Circumitances.

Sahaleel, The RUSPINA. Exc. p.r 3.E. a brisk tranfparent Rivulet running through the middle of It.

A League and an half from Sufa, we pafs over a Valley with Peut. Z. Half a League further, upoin a Declivity of the fame Chain of Eminences with Sufa, is Sabaleel, where we have likewife fome Remains of Antiquities. This Village is fituated at a good Miles Diftance from the Sea, and therefore feems to have fairer Pretenfions to Rufpina than SuJa; efpecially as the Sea before It not only formeth Itfelf into a Bay, but hath alfo a Communication with a finall Lake, which was probably the Port mentioned by Hirtius ${ }^{2}$. Sabaleel having no other Water than what is drawn from a few Wells, will very well account for the Neceflity that Ceefar lay under of receiving further Supplies from another Place: which (from the many Difficulties He met with in the Way to $\mathrm{It}^{3}$, occafioned by Scipio's Army being poffeffed of all this Country to the Northward) feems to have been from the Rivulet I have juft now defcribed.

Monafteer. Five Miles over againft Sabaleel, upon the Extremity of a fmall Cape, is Monafteer, a neat thriving City, walled round like Sufa. Large Pieces of Marble, Pillars, and other antient Materials are not commonly met with at this Place; however from It's Situation, and the Command It would have thereby of the two Bays of Sufa and Leptis, we may fufpect It to have been of Carthaginian or Roman Extraction; though, from the prefent Name, It can lay claim to no extraordinary Antiquity.

In hoc jugo colles funt excelf pauci \&c. Hirt. Bell. Afric. 9.34. Scipio interim, cognito Cafaris difceffu, (a caftris prope Ru/pinam) cum univerfis copiis per jugum Cafarem fublequi cxpit - 9.58. Scipio confeftim Cafarem per fuperiora loca confecutus, millia paffuum VIII a Thapfo binis caftris confedit. 9. 68. Labienus per Jugum fummum Collis, dextrorfus procul milites fubfequi non defrftit. 9.63. I Porcus (Rufpina) abeft ab oppido millia Paffuum 1I. Id. 9.9. 2 Vid. Not, ut fupra. 3 Cafar-vallum ab oppido Rufpina ufque ad mare deducere \& a caltris alterum eodem - Equitatus corum (Scipionis \& 2 c.) circum Cafaris munitiones vagari; atque eos gui pabulandi aut aquandi gratia extra Vallum progreffi effent, excipere. Hirt. Bell. Afric. J.19 \& 22. 
t Lempta, the Leptis parva of the Antients, is fuppofed by Lempta, The Bochart ${ }^{2}$ to denote a Port or Station for Veflels. It hath been va. Ex: p. Mile or more in Circuit, but at prefent there is nothing left ${ }^{13}$. E. p.19. f of It, befides a fmall Part of the Caftle, with a low Shelf of Peut.AA. Rocks that probably made the northern Mound of the Cotbon. Buno telleth us that Leptis is what we now call Aracca: perhaps He meant Herkla, for there is no other Village of the like Sound upon the Sea Coaft.

+ A few Miles to the Weftward of Lempta are the Ruins of Boo Hadjar, Agar, another of Ceefar's Stations, which Hirtius telleth us or Agar. was fixteen Miles from Thap/us. The rocky Situation of this Place, and the Quantity we have here of Stones and Ruins, might give Occafion to the Arabs, (according to their Facility of Invention) to alter a little the old Name, and call It Boo Hadjar, [The Father of a Stone i. e.] The Stony City.

Between Boo Hadjar and Dema/s, but within four Miles of $A$ Lake of the Latter, there is a large Lake of Salt Water, which reacheth within half a League of To-bulba. This ${ }^{2}$ is the Lake taken To-bulb. Notice of by Hirtius; as To-bulba, a fmall maritime Village, may lye near the Place where Cafar erected a Fort to prevent Scipio's fending in frefh Succours by This narrow Paffage to Thap/us.

Dema/s, the antient Thapfus, is fituated upon a low Neck Demars, The of Land three Miles to the E. by S. of To-bulba. The great Exa.p.r.r. E. Extent of Ruins maketh It the moft confiderable City on this Pe.s. B. Tab. Side Carthage, though, by the Taxation ${ }^{3}$, It fhould have been much fmaller than Adrametum in the Time of Ceear. From thefe Ruins and thofe of Herkla, Sufa and Monafteer received large Contributions in building their.Walls, Caftles and Houfes of better Falhion.

There is ftill remaining, in Defiance of Time and the Sea, The Cothon a great Part of the Cothon, which was built in Frames, in the fame Manner with the Walls of Tlem-fan. The Compofition likewife is made up of fmall Pebbles and Mortar, which are fo well cemented and knit together, that a folid Rock could not be

I Viz. a רל quod punice ftationem fignificat. Boch. Chan. 1.r. cap. 24. Sic Lucan. Bell. Civ. L. 9. 1.95I.

Proxima Leptis erat cujus Statione quieta

Exegere hyemem.

2 Erat Stagnum Salinarum, inter quod \& make anguftix quxdam non amplius mille \& quingentos paffus intererant; quas Scipio intrare, \& Thapfitunis auxilium ferre, conabarur. 9.62. 3 Thapfitanis HS XX millia, conventui eorum XXX millia, Adrumetanis HS XXX, conventui corum HS L millia, mulctx nomine, imponit. S. Is. Exc. p.8. B. 
more hard and durable. This Cape and that of Monafteer, form the Bay of Lempta, which muft have afforded a Variety of Ports in former Times. For an Ifland runs parallel with the fouthern Shore, from Dema/s almoft as far as To-bulba: there is likewife another which reacheth from Monafteer, the half Way The Jowries nearly to Lempta; whilft the Gowries, the Tarichice as they the Inf. TA- feem to be of Strabo, lye over againft Lempta and To-bulba. B. ${ }_{\text {B. }}$.8. A. Crefar was fo well apprized of the Importance of the Latter, (and there are no other to the Northward) that He thought fit to appoint feveral Stationary Veffels ${ }^{1}$ to fecure Them. El Medea or
Africa, The Turris Han-is fituated upon a Peninfula five Miles to the S. of Dema/s,
ribalis. and appears to have been formerly a Place of great Strength and Confideration. The Port, which was an Area nearly of a hundred Yards in Square, 1yeth within the very Walls of the City, with the Mouth of It opening towards Cap-oudia; but is not capable at prefent of receiving the fimalleft Veffel. Leo ${ }^{2}$ fays that It was founded, (It might have been poffibly rebuilt) by Mabdi the firft Patriarch of Kair-wan, and therefore affumed His Name; but there is fomething too polite and regular in feveral of the remaining Capitals, Entablatures, and other Pieces of the antient Mafonry, (defaced as they are at this Time) to fufpect the Founder of Them to have been an Arabian. Thuanus ${ }^{3}$ hath given us a juft Defcription of This Place; at the fame Time he hath miftaken It for the antient Aphrodifium.

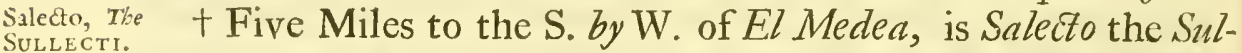
Exc. p. 33. lecti or Sublecte of the middle Age, where we meet with the Peut. A.A. Ruins of a very large Caftle, little inferiour in Extent to the Tower of London. It feems to have been erected in order to command a fmall Creek, or Port which lyeth below It to the S. W. This Place or El Medea ${ }^{4}$ fhould be the Tower or

I Claffe, circum infulas portufque difpofuit; quo tutius commeatus fupportari poffet. 9. 20, 2 El Mabdia oppidum noftris fere temporibus à Mabdi primo Cairaoan Pontifice conditum ad mare mediterraneum exftructum, muris, turribus atque portis munitiflimis ornatum, portum liabet frequentiffimum. F. Leo p. 222. 3 Ea Urbs (Aphrodifium) in humili ac plano Saxo fundata majorem partem mari alluitur, eoque plerumque vadolo, ur triremes ad eam commode accedere non poffent, qua parte terram attingit CCXXX tantum paffuum fpatio; valido muro crebris per intervalla turribus \& propugnaculis diftincto: Vallaca urbi collis inmminet acclivi a Septentrione defcenfu, fed à tergo undique præruptus, qui a prxfidiariis Turcis tenebatur. Thann. Hift. 1.7. 4 Quum equi, quo in loco juffi erant, prefto fuiffent, nocte via cita regionem quandam agri Vocani tranfgreffus (Hamibal) poftero die mane inter Acillam \& Thapfum ad fuam Turrim pervenic. Ibi eum parata inftructaque remigio excepir Navis. - Eo die in Circinam infulam trajecit. Liv. 1.33.9.34. Hannibal appropinquante vefpere, equum confcendit; \& Rus Urbanum, quod propter littus maris habcbar, ignatis fervis, juffitque ad portam revertenten opperiri, contendit. Fuff. Hift. I.3r. 
Country Seat of Hannibal, from whence He is faid to have embarked after his Flight from Carthage.

tElalia, a large Extent of Ruins, is fituated upon the Bor-Elalia, Tha ders of a fertil Plain, which reacheth from Salecto, to within Exc. p. . $13 . \mathrm{E}$. a few Miles of Sbe-ah. Befides fuch Ruins as It hath in com- 32 . 19. Tab. Peut. mon with other Places, we have here feveral Cifterns, with large Areas to receive the Rain Water. But Thefe, from the Workmanfhip and Contrivance, may be fufpected to have been built fince the Invafions of the Saracens. Elalia feems to be the Acbola or Acilla of the Antients, which Ptolemy hath fixed in this Situation, or betwixt Thaplus and Ruppre. In Peutinger's Tables likewife we fee Anolla, (corruptly no doubt for Achola) placed to the Southward of Sullecti and fix Miles to the N. of Rufpre. Now as Sbe-ah, from the Name and Situa-Sbe-ah, or tion, appears to be the antient Ru/pre, Achola, by lying at fix Rusc. P.r. Miles Diftance to the Northward of It, may with the greateft AA. Exactnefs be fixed at this Place. The Ruins of Sbe-ah reach as Shebbah. far as Shebbah, where there are at prefent a few miferable Cottages and Inhabitants.

A little farther is Ca-pondia, the Caput Vada of Procopizus, Cid poudia, $_{\text {The }}$ the Ammonis Promontorium of Strabo, and the Promontorium VADA. AMBrachodes of Ptolemy. It is a low narrow Strip of Land, which Proms. Exc. ftretcheth ltfelf a great Way into the Sea: and upon the Point CHODESA of It, there is a high Watch Tower, with the Traces of Poveral rum. Exc. Ruins, that might formerly belong to the City built here by Fuftinian:

Paffing by Melounu/h, a fimall Village three Leagues to the Melounuft. S. W. of Ca-poudia, and Butt-rah, a demolifhed Fort a little Butt-rah. farther to the S.S.W. we continue to travel near three Leagues in the fame Direction and arrive at Infbilla. This is the U/Illa Inflilla, The of the Antients, where we have a fmall Bay with a Heap of ExiL. P.I. Ruins hard by It; and upon the adjacent Promontory, there Peut. BB. is a watch Tower, like that at Ca-pondia. There is likewife another Building of the fame Kind a little to the Northward of $S f a x$; All of them very proper Guides to the Mariner in approaching this dangerous Coaft.

The two flat and contiguous Inlands of the 2uerkyne/s areтhe Ifands fituated to the Eaftward of Infbilla, at the Diftance of five Querkynefs, Leagues. Thefe are the Cercina and Circinitis of the old Geo- Crandrss. $^{\mathrm{Na}} \mathrm{C}$

I Vid. Procop. de Edificiis Dn. Fuftiniani Cap. 6.

$\mathrm{C} \mathrm{c} \mathrm{c}$ Exc. p. 8. B. p.17. C p. 22. E. p. 28. graphy, ${ }^{B}$. 
graphy, which are wrong placed by Agathemer : over againft Thena, from whence they lye at a great Diftance towards the N.E.

The Limits of Agatbemer, Strabo and others fix the Beginning of the Leffer the Lefler Syrtis. Exr. Syrtis at thefe Iflands, though, from the following CircumftanB.- D. D. F. C. ces, It may be fuppofed to extend as far as Ca-poudia; fince from This Cape, all along to the Ifland of Ferba, we have a Succeffion of little flat Iflands, Banks of Sand, oozy Bottoms or fmall Depths of Water. The Inhabitants make no fmall Advantage of thefe Shallows, by wading a Mile or two from the Shore, and fixing, as They go along, in various Windings and Directions, feveral Hurdles of Reeds, frequently enclofe a great Number of Fifhes. Something like This hath been taken Notice of by Strabo².

The Flu. and The eafterly Winds were too violent whilf I travelled along
Reflu. the Coaft of the LefJer Syrtis, to obferve the Flux and Reflux ${ }^{3}$ of It, from whence fome Authors have derived the Name+. However I was very credibly informed, that, frequently at Fer$b a$, the Sea rofe twice a day a Fathom or more above It's ufual Height.

Sfax. Sfax, Asfax, or El Sfakufs, is a neat thriving City ten Miles to the S. S.W. of Inflilla, and about twenty to the S.W. of the 2uerkyness. It is walled round like Sufa and Monafteer: where likewife, by the fame extraordinary Indulgence of their Faide, the Inhabitants enjoy the Fruits of their Induftry, carry on a good Trade in Oyl and Linnen-Manufactures, and know little of that Oppreffion, which is feverely practiced in moft other Places of Barbary. Bunos maketh Sfax to be the Taphree of Cluver; but It is more probably of modern Extraction, taking It's Name from the Quantity of [wgig Fakoufe] Cucumbers, that grow in the Neighbourhood.

Thainee, The Thainee, the Thena, or Thence of the Antients, is ten Miles THENA or THEN 死.

Exe. p. 8. B.

p. 13. E. p. 22. B. p. 27 $\mathrm{G}$.

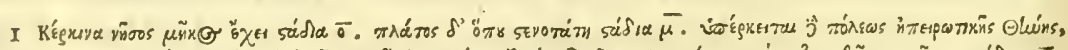

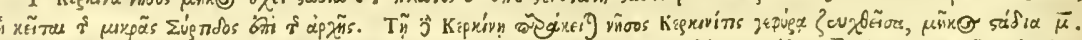

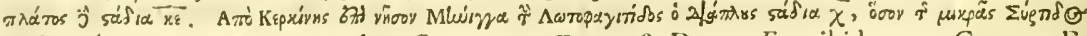
$\lambda^{\prime} \varepsilon_{2}$ 马 ro sóu. Agathem. Gcogr. 1. I. Cap.5. 2 Exc. p. 8. D. 3 Exc. ibid. p.22. C. p.23. F.

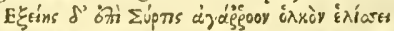

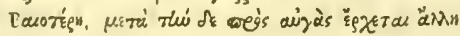

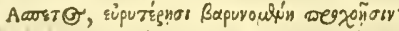

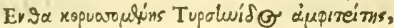

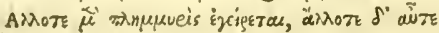

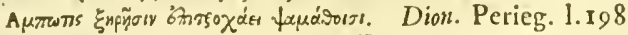

4 Viz. a oís traho, quod in acceffu \& receflu arenam \& cxnum ad fe trahit \& congerit. Vid. Enfath. Comm. 5 Clwv. Geogr. cum Notis Bun. \&c. p.394. 
to the S. W. of Sfax, and nearly at the half Way to Maba-refs. It hath been built upon a low and rocky Piece of Ground, near two Miles in Circuit; but as the antient Materials, have been employed in the building of Sfax; there is fcarce one Piece of Hewn-Stone to be met with. This maritime City, fo famous in the old Geography, is not only badly fituated, but feems never to have had either a Port or Cothon. The adjacent Country like. wife is dry and barren, without either Fountain or Rivulet to refrefh It.

Five Miles to the S. W. of Thainee, we crofs a pretty large Wed el Brook, the only running Water I remember to have met with on The TANAIS this Side To-bulba. This, if I miftake not, They call The [Wed el $l^{o f}$ Salluft. Thainee] River of Thainee: and provided Marius in His Expedition againft Capfa, continued his Marches along the Coaft of Bizacium, This or the Tarff; a few Leagues further to the S. fhould be the River Tanais, where (as Salluft ${ }^{\circ}$ informeth us) the Romans took in Their Provifion of Water.

+Maha-re/s, the Macodama perhaps of the Antients, is a Maha-refs, little Village four Leagues to the S. W. of Thainee. Here are the Ruins of a large Caftle, and the like Conveniences, which Dibus. Exx. have been mentioned at Elalia, for collecting of Rain Wa-D.G. ter. The Inhabitants inform us, that the Latter were built by Sultan ben Eglib, whom the People of this Kingdom have in the greateft Efteem and Veneration; and who hath been the like generous Benefactor at feveral other Places in this Circuit.

+ A little Way from Maha-re/s we crofs the River Tarff, The River which rifeth near the Ruins of Tarfowah, four Leagues to the Weftward of Maba-re/s. There is a great Affinity in Sound, betwixt This Village and the Taphrura of Ptolemy or the Tapa- Tarfowah,

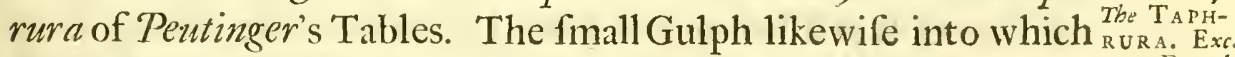
This River difchargeth Itfelf, might, for the fame Reafon, be Peut. BB. received for the Port of Tafra taken Notice of by Thuanus', were it not at a greater Diftance from the River Triton, than feems to be fuggefted by that Author.

The Caftle of Ungha, two good Leagues to the S. W. of Ungha Maha-ress, was built, according to the Tradition of the Inha-

I Cum ad flumen [Tanam al. Tanaim] ventum eft; maxima vis utrium effecta. lbi - jubet omnibus farcinis abjectis, aqua modo feque \& jumenta onerare. Dein —- noctem totam itinere facto confedit: idem proxuma facit. Dein tertia multo ante lucis adventum pervenit in locum tumulofum, ab Cap $\sqrt{a}$ non amplius duum millium intervallo. Sall. Bell. Jug. 9.96. 2 Tafre portum juxta Tritonis fluvium tenuit. 1.7.

$$
\mathrm{C} \text { c c } 2
$$

bitants, 
bitants, by Sultan ben Eglib; but It doth not appear for what Intent He made choice of This Situation, unlefs It was to fecure fome Wells of good Water that are near It. For it is immediately furrounded with a Morafs, all the Way from the S.W. to the N.W. whilft the adjacent Country is either entirely barren, or made ufe of only for Pafturage. Neither is there any Road or Station for Veffels before It. If This therefore, or That at Maba-refs fhould be the Caftle taken Notice of by $L \epsilon o^{\prime}$, It could be of little or no Service, either in the Defence of the Country or of the Sea Coaft.

Ellamate. At Ellamaite, four Leagues further to the W.S.W. there are a great Number of Sepulchres, as the Name, taken probably from $(-; \infty)$ mout, may import. Thefe are all without either Beauty or Infcriptions: and after Them we meet with nothing remarkable, 'till leaving Seedy Med-dub, a Moorifb Sanctuary, on the right Hand, and paffing over the dry Channel of the River $A c$ Woodrif. croude, we come to Woodriff and other contiguous Date-Villages of leffer Note. Thefe are each of Them watered by a Rivulet, and lye about three Leagues to the N.W. of Gabs, and nine, in travelling along the Sea Shore, to the S. by W. of Ellamaite.

Gabs, The EPICHUS. Exc.p.3. C. 1.ACAPE. P.
13. F. p. 22 . B. P.27. G. CC.

The Trade.

At Gabs, the Epichus probably of Scylax and the Tacape of other antient Geographers, we have a Heap of Ruins, that are chiefly remarkable for fome beautiful Square Pillars of Granate Marble, fuch as I have met with in no other Part of Africa. The old City, where we fee thefe Ruins, was built upon a rifing Ground at half a Miles Diftance from the New, having been formerly wathed by the Sea, which formed Itfelf here into a Bay of near half a Mile in Diameter. But at prefent the greateft Part of It is filled up and gained from the Sea; which, from the great Shallownefs of It, and the daily Difcharge of Mud, Roots \&c. into It by the River, will eafily fubmit to fuch Encroachments.

They have here feveral large Plantations of Palm Trees; though the Dates are much inferiour both in Size and Delicacy of Tafte to Thofe of the Fireed. But the chief Branch of Trade, for which This Emporium, as Strabo calls It, is famous

I Macbres caftellum noftris temporibus ab Afris eam ob caufam ad fretum Capes conditum ut regionem illam ab hoftium incurfionibus tutam fervarent. Diftat à Lotophagitis Infula quinquaginta fere paffuum millia. 7. Leo. p. 225. 2 Exc. p. 8. D. 
at prefent, arifeth from the great Number of Alhenna Plants, that are cultivated in Their Gardens; whofe Leaves, after being dryed and powdered, are difpofed of to good Advantage in all the Markets of This Kingdom. This Tree, no lefs than the Palm, reouires to be frequently watered; for which Purpole the Triton is canton'd out into a Number of artificial Channels, as It feems to have been in the Time of Pliny.

The River of Gabs, the Triton of the Antients, falls into The River the Sea to the Northward of the old City, and forms the TRrToN. Ground, upon which It was fituated, into a Peninfula. It hath ${ }_{13 .}^{\text {P. F. D. P. P. }}$. It's Sources three or four Leagues only to the S. S. W. of $G a b s$, A. p. p. C. A. (where perhaps we are to look for the Aquas Tacapitanas) and Exc.p.28.A. becomes at once (as is ufual with feveral other Rivers in thefe hotter Climates) a confiderable Stream, near as big as the Cherzvell. Two long Chains of Mountains, which reach from $\mathrm{El}$ Hammab to Maggs, and are continued from thence to the SeaCoaft over againft the Ifland Ferba, will neither admit of the Length nor of that Succeffion of Lakes which have been attributed to This River by antient as well as modern Geographers. It is impoffible likewife, that, according to Ptolemy, It fhould have It's Origine in the Mountain of Vafaletus. For if This Exc.p.r4.D. be the fame, as the Name feems to infinuate, with the prefent Uje-let, It will lye at too great a Diftance to be taken for it. And indeed if we except that fmall Space of Ground which is refrefhed by the Springs of El Hammah, (for the River Accroude is only a periodical Stream) all the reft of the Country in This Direction is parched up for Want of Water. If This therefore be the River Triton, as will not I prefume be difputed, Geographers have been greatly miftaken in their Defcriptions of It.

Three Miles from $G a b s$ to the S. E. by E. is the little Village To-bulba. To-bulba; and ten Leagues farther, in the fame Direction, we have the Ifland Gerba, or Ferba as the Tunileens pronounce It, Jerba, p.28. the moft fouthern Territory of This Kingdom. Ferba appears to DD. The be the Bracbion of Scylax, and the Meninx ${ }^{2}$ of Strabo and o- Exachro. . . . thers; though Ptolemy maketh the latter a City only of the ${ }_{\text {NINX. P. } 8 \text {. }}^{\text {and }}$ Lotophagitis, as He calleth This Ifland.

1 Tacape, felici fuper omne miraculum riguo folo: ternis fere mill. paff. in omnem parC. p. $24 . \mathrm{A}$. and LoToPHAGITIS InI. p.17. C. tem fons abundat, largus quidem, fed certis horarum fpatiis difpenfatur inter incolas. 1.18. cap. 22. Tacape a בn, locus humidus \& irriguus. Boch. Chan. 1.1. cap.25. 2 Fallor an meninx punice fcribebatur pps me-niks, quafi dixeris aquas defectus, $i$. e. deficentes vel ip 's me-nics, quafi dixeris aquas receffus, i. e. recedentes? Iil. ibid.
$\mathrm{D} d \mathrm{~d}$
C. H A P. 


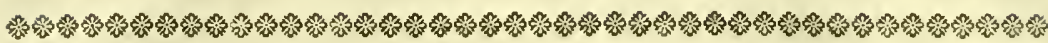

\section{H A P. V.}

Of the moft remarkable Places in the Inland Country of the antient Bizacium, or Winter Circuit.

Zung-gar, THe ZuCCHARA.

$\triangle$ CcorDING to the Boundary that hath been laid down 1 betwixt the Zeugitana and Bizacium, Zung-gar, the antient Zucchara, will be the moft northern City of this Circuit. The whole Extent of Ruins, and particularly the Tem+ ple, that hath been already defcribed ${ }^{2}$, are at prefent fo thick1y haded with Ever-green-Oaks and Locuft Trees, that there is no fmall Difficulty to come near Them.

Youfcph. Five League to the S.W. of Zung-gar, are the Ruins of YouThe Rivcr Seph; where the Scilliana hath It's Fountains. This River traScilliana. verfeth feveral fertil Plains and Valleys; and leaving Beiffons, Tugga and Tuber-foke at a fmall Diftance to the Weftward, falls into the Mejerdab not far from Teftoure.

Kiffer, The Three Leagues to the S. W. of Toufeph are the Ruins of Exsurus. .r. Kiffer, the Affurus or AfJuras probably of the Antients. Cel-

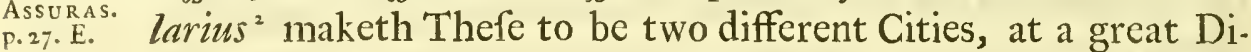
ftance from each other: whereas Ptolemy, in placing His $A$ furus $20^{\prime}$. to the E. and at the like Diftance to the S. of Sicca Veneria; the Author likewife of the Itinerary by fixing His Affuras xxx Miles from Mufti, in the Way to Sufetula; point out to us the very fame Situation, where we find at prefent the Ruins of KifJer.

Hydrah, Hydrab lyeth in the fame Latitude nearly with KifJer, at about forty Miles Diftance to the W. S. W. of Keff. It is fituated in a narrow Valley, with a Rivulet running by It, and appears to be one of the moft confiderable Places of This Country for Extent of Ruins. For we have here the Walls of feveral Houfes, the Pavement of a whole Street, with a Variety likewife of Altars and Mars folea ftill remaining. A great Num-

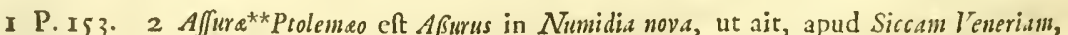
longo intervallo a loco, quem Auctor Itinerarii defignat. An eadem, per crrorem in Numidiam tranfducta fit, non habeo dicere. Invitus multiplico loca ejulden nominis; neque vero conciliari hæc, rationibus utriufque falvis poffunt. Geogr. Antiq. 1.4. Cap. 4. p.106. Inter Siccam \& Naraggaram Ptolemeo eft Aaspo, Aßsurns, alia ab Affuris Zengitma, qux in recto Afjura funt. Id. cap.v. p.II8. 


\section{Of the Winter Circuit.}

ber of the Latter are very well preferved, being fome of them round, or in the Figure of an Octogon, fupported by four, fix or eight Columns: whilft others again are fquare and compact Buildings, with a Nich in one of the Fafcades, or elfe a wide open Place, like a Balcony, upon the Tops of Them. But the Infcriptions which belonged as well to Thefe as to other Antiquities, are either defaced by Time or the Malice of the Arabs. Upon a triumphal Arch, more remarkable for It's Largenefs than Beauty, we have the following Infcription in Letters nearly of a Foot long: but there is not the leaft Notice taken, as ufual, of the City or People that erected It.

IMP. CAES. L. SEPTIMIO SEVERO PERTINACI AVG.

P. M. TRIB. POT. III. IMP. V. COS. II. PP. PARTHICO ARABICO

ET PARTHICO ADIABENICO. DD. PP.

Provided we could be fure that the leaft Tradition of the Tbe THunuformer Name was preferved, we might fufpect It to be the Col. Ex. P. Tynidrum or Thunudronum of the Antients, which, being placed by Ptolemy more than two Degrees to the Weftward of Sicca, will not be far diftant from This Situation.

For Want of fufficient Geographical Circumftances and In-Zowareen. ftructions, we fhall meet with the like Difficulties and Uncertainties in fixing the antient Name of Zowareen, fix Leagues to the E. S. E. of Keff; of Manfoufe, three Leagues to the Manfoufe. Southward of Youfeph; of Sbeebah, feven Leagues to the S. Sbeebah, The S. E. of Keff: of Nab-hanah, eight Leagues to the Weftward REBANTHIof Herkla: of Felloulah, five Leagues to the S. W. by S. of $27 . \mathrm{C}$. E. . F. $N a b-b a n a b ;$ and of $F_{u} f-\int a n a h$, eight Leagues to the S. E. of Jelloulanh, Hydrab; at all which Places there are confiderable Heaps of SALITA-

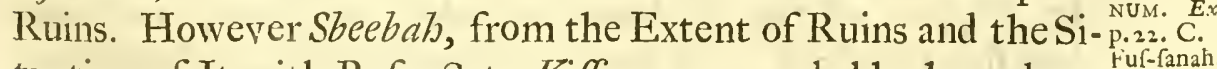
tuation of It with Refpect to Kiffer, may probably have been the Tucca Terebinthina; as Felloulah, from lying below the Mountains of U/e-let, may lay in the like Claim to the Oppidum Ufalitanum of the Antients. The following Epitaph is among the Ruins of Manfoufe.
$D d d 2$
D. M. S. 


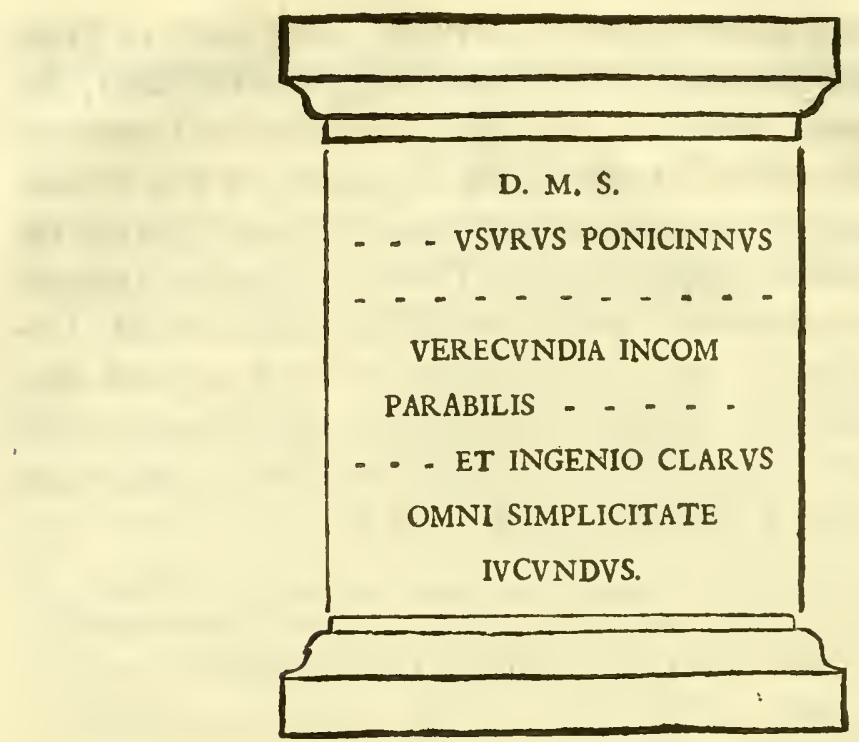

Kair-wan; The VICo AUgust? Exc. p.26.G. P.27. A. Tab. Plain, eight Leagues to the Weftward of Sufa, and about the Peut. T. fame Diftance to the S. W. of Herkla. There is, at half a Furlong's Diftance from the City, a capacious Pond and Ciftern, built for the Reception of Rain Water: but the Pond, which is the chief Provifion for their Cattle and ordinary Ufes, as the other, the Elmawabel of Abulfeda', is for their own drinking, being either dried up, or elfe beginning to putrify about the middle of the Summer Seafon, occafioneth a Variety of Agues and other Diftempers.

The Antigui-
ties of It. this Place; and the great Mofque, accounted to be the moft magnificent as well as the moft facred in Barbary, is fupported by an almoft incredible Number of Granate Pillars. The Inhabitants told me (for a Chriftian is not permitted to enter the Mofques of the Mabometans) that there were no fewer than five Hundred. Yet among the great Variety of Columns, and other antient Materials employed in this large and beautiful Structure, I could not be informed of one fingle Infcription; the Infcriptions likewife which I found in other Places of the City, were either filled up with Cement, or elfe defaced by the

Incolæ Urbis Kairwan bibunt aquam pluvialem qux hyemali tempore colligitur in pifcina magna dicta Elmazvahel (solgall i, e. Cifferna. Abulf. ut fupra.

Chiflel ; 
Chiffel; fo that we cannot collect the antient Name of This City from any of the Antiquities that have been hitherto difcovered. However as It is fituated betwixt Ti/drus and $A$. drumetim, though nearer the Latter; by the due Diftance of It likewife from the River Mergaleel, the Aquis Regiis of the Antients, It muft have been, I prefume, the Vico Augufti of the Itinerary. Thuanus' muft certainly be miftaken in making It the antient Curubis, which hath been already taken Notice of, as a maritime City, fixty Miles diftant to the N.E. It may be queftioned likewife whether It be the fame Name with Gairo or Kahiro in Egypt, denoting a Victory. For Kair-wan feems to be the fame Appellation with, what we call, $\mathrm{Ca}$ ravan, originally fignifying, as Leo and Marmol fuppofe, the Place where the Arabs had their Rendezvous ${ }^{2}$ in their Conquefts of this Part of Africa.

+ Spaitla, the antient Sufetula, lyeth about twelve Leagues Spaitla, The to the Southward of Keff, being one of the moft remarkable Exr., P. 27. Places in Barbary for the Extent and Magnificence of It's Ruins. paffim. p.28. For at a Furlong's Diftance to the Eaftward, there is a fumptuous triumphal Arch of the Corintbian Order, confifting of one large Arch, with a leffer one on each Side of It: but this Part only of the Dedication remaineth.

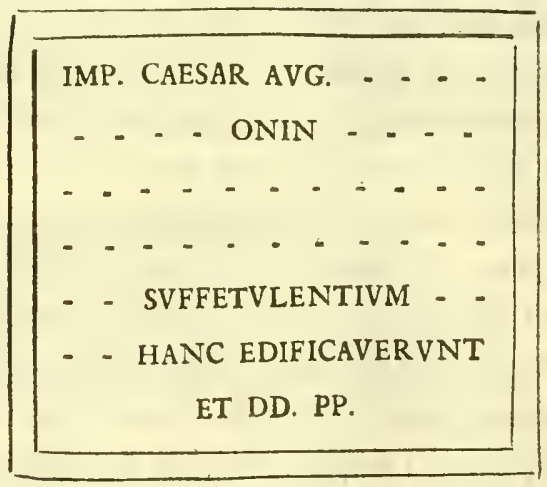

I. Calipha Africx Caruani five Curubi, urbe ab Occuba Nafici F. ante CC annos in Cyrenaica condita, polt unam \& alteram de Chriftianis reportatam ab Arabibus Victoriam, id enim nomen fonat, fedem habuit: cumque urbs confluentis ad habitandum multitudinis capax non effet, juxta eam \& altera civitas exftructa eft, Raqueda dicta. Thuan. 1. 7. Curubis qux \& Carvenna. ibid. 2 Cairaoan Conditorem habuit Hucba, qui univerfi exercitus dux ex Arabia deferta ab Hutmeno Pontifice tertio miflus fuerat; - neque aliam ob caufam conditum fuiffe dicunt, quam ut in eo exercitus cum omni præda Barbaris atque Numidis adempta, fecure fe continere poffent. - Eo tempore quo Elagleb Regno potitus eft, tam incolis quam ædínciis auctum. 7. Leo. p. 223. Marmol. Hilt. Afr. c.34.

E e e 
The A:tiquities and Situation of $\mathrm{It}$.

From This Arch, all along to the City, there is a Pavement of large black Stones, guarded on each Side with a Parapet Wall, for the more commodious Entry, as we may fuppole, of the Triumpher into the City. At a little Diftance from the End of This Pavement, we pafs through a beautiful Portico, which is built in the fame Manner with the triumphal Arch. This conducts us into a fpacious Court, where we have the Ruins of three contiguous Temples, whofe feveral Roofs, Porticos and Façades are broken down; but all the other Walls, with their proper Pediments and Entablatures, remain perfect and entire. There is in each of Them a Nich, which fronteth the Portico; and behind That in the middle Temple, we have a fmall Chamber, which ferved formerly perhaps for a Veftry. Spaitla is pleafantly fituated upon a rifing Ground, that is fhaded all over with Juniper Trees. A little Brook glideth along the N.E. Side of It, which lofeth Itfelf in the Sand, as it directeth It's Courfe afterwards towards Gelma.

Truzza, The Eight Leagues to the Weftward of Kair-wan, are the Ruins Exc. p.i6.E. of Truzza, the Turzo of Ptolemy, where we have fome Natural-Stews or fweating Places, that are much frequented by the Arabs. They are commonly called Hammam Truzza, (i. e. the Hot Batbs of Truzza;) whereas they are only fo many vaulted Chambers, perpetually full of fulphureous Steams, like the Grottos of Tritoli \&c. near Naples.

The AQUIS REGIIS
(Exc. p. 27 . upous the Banks of the Mergaleel.

+ A few Miles to the Southward of Truzza, we fee the Traces of a large City, very well watered by the River Mergaleel. As there is a great Scarcity of Water for feveral Leagues to the Eaftward of thefe Ruins; as thefe Ruins lyc at a proper Diftance likewife from Spaitla and in the Road from thence to Adrumetum and Tifdrus, It may in all probability be taken for the Aquis Regiis of the Antients. +For the fame Reafons Masclia- likewife, Mafclianis may be fixed at the Ruins upon the Banks NIS (Evc. P. 27. A. H.) tailah.

of the Defailah, four Leagues to the Weftward. This River iffueth from Fibbel Me-gala, a long Chain of Mountains which reach from Truzza to Spaitla; and as this Part of the Country is feldom refrefhed with Rain, the Arabs keep It conftantly emploied in overflowing the extenfive Plains which fpread themfelves along the Banks of It.

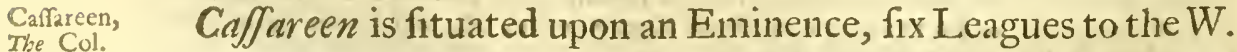
${ }_{\text {NAL }}$ SIITA- S.W. of Spaitla. The River Derb runs winding below It; and 


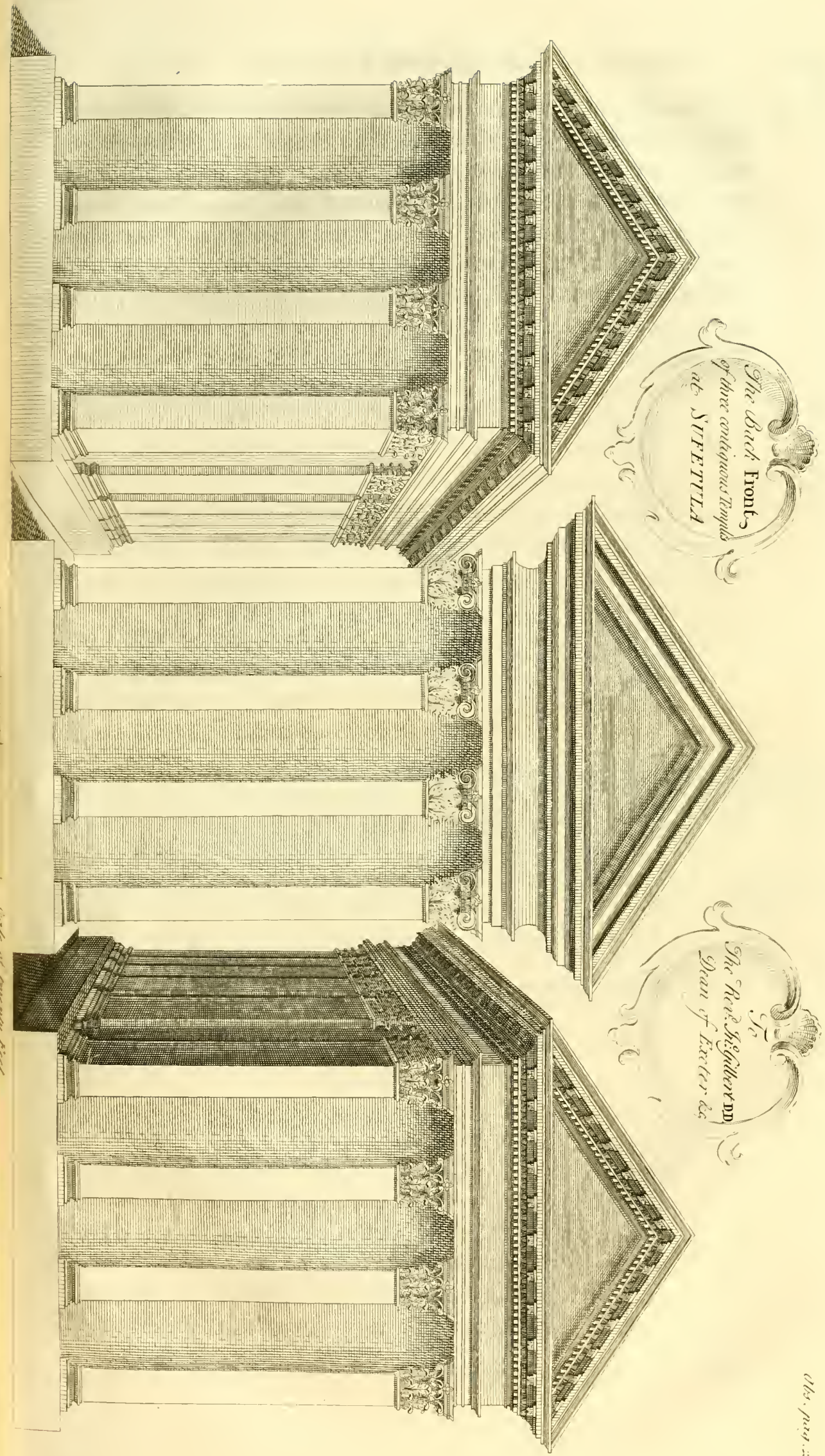





\section{Of the Winter Circuit.}

upon a Precipice that hangs immediately over this River, and faceth the N.E. there is a triumphal Arch, which is more remarkable for the Quantity and Goodnefs of the Materials, than for the Beauty and Elegance of the Defign. It confifteth of one large Arch with an Attick Structure above It, having fome Corinthian-like Ornaments beftowed upon the Entablature, though the Pillafters are entirely Gotbick. Yet notwithftandthe Rudenefs of the Workmanfhip and the Odnefs of the Situation, we find the Founder of It very gratefully commemorated in the following Infcription.

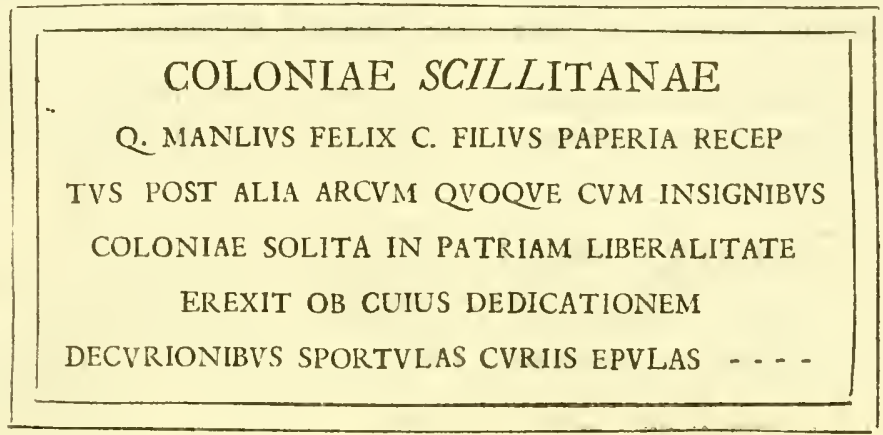

Below This Infcription, juft above the Key-Stone of the Arch, there is another in leffer Characters; but the only Words I could trace out, were

INSIGNIA CVRANTE M. CELIO AN. CV.

In the Plains below the City we are entertained with the Several Maulike Variety of Maufolea that have been defcribed at Hydrab; Place, at this where we have likewife the following Infcriptions.

Ipon tie Façadc of a Towcr-like Maufolcum with a Balcony on the Top of It.

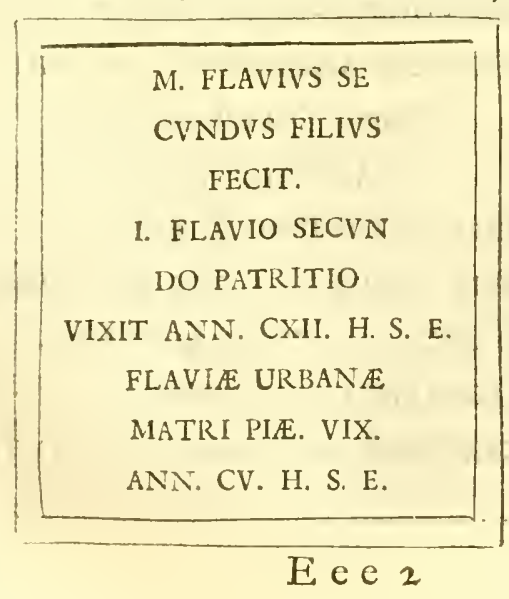


Upon the lower Part of the fame Manfoleum, in fnaller Characters, we have an Elegy, which begins with Hexameter Verfe, and concludeth alternately with Them and Pentameters. The following Specimen, fhort as It is, may convince us, that as the Infcription contains in It nothing material in point of Hiftory, fo It has no Title to be inferted on account of any poetical Excellence.

SINT LICET EXIGVAE FVGIENTIA TEMPORA VITAE

PARVAQVE RAPTORVM CITO TRANSIAT HORA DIERVM

MERGAT ET ELISIIS MORTALIA CORPORA TERRIS

ASSIDVE RAPTO LACHESIS MALE CONSCIA PENSO \&c.

Upon the Façade of a Square Maufoleum with Corinthian Pillafters.

MILITAVIT L. ANNIS IV. IN LEG. II. - - - LIB. - - TESSER. OPTIO. SIGNIFER. - - -

FACTVS EX SVFFRAGIO LEG. E

7 LEG. I. M. 7 LEG. X. GEM.

7. LEG. III. AVG. - - 7. LEG. XXX. VIP.

7. LEG. VI. VIC. 7. LEG. III. CYR. 7.LEG.XV. APOL.

7. LEG. II. PAR. 7. LEG. I. ADIVTRICIS

CONSECVTVS OB VIRTVTEM IN EXPEDITIONEM

PARTHICAM CORONAM MVRALEM VALLAREM

TORQVES ET PHALARES EGIT IN

DIEM OPERIS PERFECTI ANNOS LXXX.

SIBI ET

CLAVDIAE MARCIAE CAPITOLINAE

KONIUGI KARISSIMAE QVAE EGIT

IN DIEM OPERIS PERFECTI

ANNOS LXV ET

M. PETRONIO FORTVNATO FILIO :-

MILITAVIT ANNIS VI. 7. LEG. XVIII. PRIMIG -

LEG. II. AVG. - . - VIXIT ANN. XXXV - .

CVI FORTVNATVS ET MARCIA PARENTES

CARISSIMO MEMORIAM FECERVNT. 
This Place feems to have received It's prefent Name from the Cañureen, or Maufolea, which, at a Diftance, have the Appearance of fo many [ in the Infcription over the Triumphal Arch, the firft Letters in the Word after Colonice, upon which the antient Name dependeth. But PadreXimenes, the Spanifh Adminiftrador at Tunis, was more fuccefsful in vifiting thefe Ruins: for by drawing up His Interpreter as high as the Frize, He found It to be Scillitance: the fame Place probably that is fo memorable for the Martyrdom ${ }^{1}$ fuffered by It's Citizens.

Gilma, the antient Cilma, or Oppidum Chilmanenfe, is fix Gilma, rhe Leagues to the E. S. E. of Spaitla. We have here the Remains Exc. P.r. of a large City, with the Area of a Temple, and fome other ${ }^{\text {p.22.C. }}$ Fragments of large Buildings. According to a Tradition of the Arabs, this Place received It's Name in Confequence of a Miracle, pretended to have been wrought by one of Their Marabbutts, in bringing hither the River of Spaitla, after It was loft under Ground, as hath been before taken Notice of. For Fa Elma [1.0)l la] fignifieth in their Language The Water comes! an Expreffion, we are to imagine, of Surprife, at the Arrival of the Stream.

Menzil and Menzil Heire are two little Villages fix Miles to Menzil, The the Weftward of Sabaleel. Thefe may poffibly be the Zet $a^{2}$ and ZETA Ziren$V$ acca mentioned by Hirtius ${ }^{3}$, as they lye at the like Diftance, Jime VAcces; and in the fame Situation from Agar, that are given to them ${ }_{\text {Salluft. }}^{\mathrm{TEGA}}$ of by that Author. Fimmel likewife, fix Miles to the Southward of Menzil Heire, hould, from the Pofition of It below, or, as we may conjecture, to the S. W. of the Camp of Scipio, be the Tegrea ${ }^{4}$ of the fame Hiftorian. All Thefe Villages lye in an open champain Country, diverfified in feveral Places with Olive Trees.

I His adde Speratum, aliofque Martyrcs, fub Scillitanormm nomine celeberrimos apud Carthaginem Proconfuli oblatos, ac ab eo damnatos Martyrium compleviffe ut ex eorum actis patet, qux inter ACta Martyrum Sincera edidimus. p. 85 . \&c. Vid.T. Ruinarti Not. in Notit. Afric. p. 275.2 Vzita (Zeta Sall.) quam defcribit Ptolemaus fub Alrumeto \& parva Le-

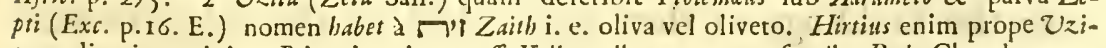
tam oliveti meminit. Prius, inquit, neceffe Vallem olivetumque tranfgredi. Boch. Chan l.1. cap. 24. 3 Cafar interim * caftris incenfis * pervenit ad oppidum Agar * Scipio intcrim, cognito Cafaris difceffu, cum univerfis copiis per jugum Cafarem fubfequi cxpit; atqne ab ejus caAtris millia paftuum VI longe, rtinis caftris difpartitis copiis, confedit. Hirt. Bell. Afric. I. 58. Oppidum erat Zeta; quod aberat a Scipione millia paffuum XI ad cjus regionem \& partem caftrorum collocatum; à Cafare autem diverfum ac remotum, quod crat ab eo longe millia paffuum XVIII. Id. 9. 59. Oppidum Vacca quod finitimum fuit Zete. Id. 9. 62. 4 Erat oppidum infra caftra Scipionis, nomine Tegaa. Id. 9.67. 
Surfeff (the Sarfura of Hirtius ${ }^{1}$ ) and Areejis, are two contiguous Villages, fix Miles to the Weftward of El Medea. They are fituated below a Ridge of Hills, which, reaching with few Intermiffions from Fimmel to Salecto, feems to be the fame that is taken Notice of by Hirtius; particulary when $\mathrm{He}$ defribeth the Oppofition that Crefar met with from Labienus in the taking of Sarfura.

Jenme, The From Sarfira we find that Crefar ${ }^{2}$ continued His Marches TISDRA, the next Day to Tifdra or Femme as It is called at prefent. or THYS: Thus. This Village lyeth about fix Leagues to the S. S. W. of Surfeff, P. 17 . A. p. . and five to the S. by W. of Elalia, which is the Situation that C.E. Ptolemy hath given to Thy/drus with Regard to Achola.

The Antiqui- At Femme there are feveral Antiquities; as Altars with de. ties of Jemme faced Infcriptions; a Variety of Columns; a great many Trunks and Arms of marble Statues; one of which is of the Colo/s Kind, in Armour; another is of a naked Venus, in the Pofture and Dimenfions of the Medicean; both of Them by good Mafters, but without Heads. But this Place is the moft remarkably diftinguifhed by the beautiful Remains we have 7he Amphi-
thbatre, theatre, four Arches and four Orders of Columns. The upper Order, which was perhaps no more than an Attick, hath fuffered by the Arabs: Mabamet Bey likewife blew up four of the Arches from Top to Bottom, in a late Revolt of the Arabs, who made ufe of It as a Fortrefs: otherwife, as to the Outfide at leaft, nothing could be more entire and beautiful. Within, the Plat Form of the Seats, with the Galleries and Vomitoria leading up to Them, are ftill remaining. The Arena is nearly circular: and in the Centre of It, there is a deep Well of hewn Stone, where the Pillar, that fupported the Velum or Awning, may be fuppofed to have been fixed.

probably built By comparing This with other Structures at Spaitla, probably buit
by the Emp. Hydrab \&
cordian. It feems to have been built about the Time of the

Antonines, agreeing exactly in Proportion, and Workmanfhip with the Buildings of that Age. And as the elder Gordian was proclaimed Emperor at this City, it is not improbable, but that in Gratitude to the Place where $\mathrm{He}$ received the

I Cafar * ad oppidum Sarfuram ire contendit ** Labienus per jugum fummum collis dexzrorfus procul milites fubfequi non defiftit. Hirt. ut fupra. 9.63. 2 Cafar ad oppidum Sarfuram venit * poltero die ad oppidum Tifdram pervenit. Id. 9.64.

Purple, 
Purple, He might have been the Founder of It. Upon one of the Medals of the younger Gordian we have an Amphitheatre, not hitherto accounted for by the Medalifts: but it may be too peremptory perhaps to fix it at Tifdra.

Rugga, the antient Caraga is about two Leagues to the Rugga, The S. S. E. of Femme, and nearly of the fame Extent. It is $\mathrm{fa}_{\mathrm{a}}$ Exr. P.17. B. mous for a capacious Damuss, as They call a Ciftern, whofe Roof is fupported by feveral Rows of maffy Pillars, and which formerly fupplyed the whole City with Water.

In the fame Parallel with Rugga, feven Leagues to the Ferre-annh, S.S.W. of Caffareen, is Ferre-anah, which appears to have been the largeft City of Bizacium; though all the Remains of It's antient Grandeur, confift in a few Granate and other Pillars, which, by fome extraordinary Chance or Renevolence of the Arabs, are left ftanding upon their Pedeftals. It hath been exceedingly well watered; for befides a plentiful Brook, that runs under the Walls, there have been feveral Wells within the City, each of Them furrounded with a Corridore, and vaulted over with a Cupola. This, and a good Air, are the only Bencfits and Conveniencies that Ferre-anah can urge in Favour of It's Situation; for, if we except a fimall Extent of Ground to the Southward, which the Inhabitants cultivate, by refrefhing It at proper Times with the Rivulet; all the reft of the circumjacent Country is dry, barren and inhofpitable. The Profpect likewife (which is the only one It enjoys) to the Weftward, terminateth upon fome naked Precipices; or elfe, where the Eye hath Liberty to wander through fome narrow Cliff or Valley, we are entertained with no other View, than of a Defert fcorched up with perpetual Drought, and glowing with the Sun Beams.

This lonefome Situation, and the great fcarcity of Water in The THALA the adjacent Country, may induce us to take this Place for the of Salluft, Thala of the Antients. For we are informed that Thala was of great Extent, fituated like Capfa' in the midft of Mountains and Deferts, and that there were fome Fountains without the City : all which Particulars agree with the Situation of

I Erat inter ingentes Solitudines oppidum magnum, atque valens, nomine Cap $\int_{a}$ : cujus Conditor Hercules Libys memorabatur, $k$ Metellus Thalam magna gloria ceperat, haud diff. militer fitum, munitumque: nif quod apud Thalum non longe a monibus aliguot fontes
erant. S.ll. Bull. Fug. 9. 94 . 
Ferre-anah. It is recorded likewife that Fugurtha', after $\mathrm{He}$ was defeated by Metellus, fled to the Defert, and from thence directed His Flight (all the Way as it may be prefumed to the Eaftward) to Thala. For had Thala been placed in the weftern Part of the Deferts of Numidia, Fugurtha ${ }^{2}$, as it is related in another Place, would not have had that exceeding long Journey, through a Succeffion of Deferts, to the Gretuli; inafmuch as Their Country lay immediately behind the Mauritanice. Salluft acquainteth us further that the neareft River to Thala was at fifty Miles Diftance ${ }^{3}$, and that Metellus, in His Purfuit of Fugurtha, took in there a Provifion of Water for His Journey over the interjacent Defert. Now whether (according to the Situation of the late Field of Battle at Cirta or Vacca,) Metellus directed His March to Thala by Tipaja or Sufetula, (for an Army cannot pafs conveniently through Caffareen, by Reafon of feveral impenetrable Mountains and narrow Defilees) we have either the Wed el Hataab, or elfe the River of Spaitla, which very well agreeth with this Geographical Circumftance. Whereas had Thala been fituated in the Sabara, (to the Weftward of Numidia, ) there would have been no Neceffity for making this Provifion of Water, inafmuch as, in none of thofe Parts of Getulia, there is any Intermiftion of Fountains or Rivulets, for half that Diftance. Neither indeed could Thala be fuppofed to have been a City of the Beni Mezzab, or of the Country of Wadreag, inafmuch as the neareft River to any of thofe Places, is at much more than fifty Miles Diftance; befides the Want there will ftill be of other Geographical Circumftances, which correfpond exactly with Ferre-anah.

and $T_{\text {ELEP- }} \quad$ Ferre-anah differs very little in Sound from Feraditana, of p. 32 . which Name there were two Sees in the Middle Age. Though it may be further obferved, that what is related of the Situation of Telepte, agrees likewife with this Place. And as Thala (I prefume) is not mentioned in Hiftory later than by Tacitus ${ }^{4}$, (for Florus' feems to fpeak of It as in the Time of Metellus,)

I Ea fuga fugurtha impenfius modo rebus fuis diffidens, cum perfugis \& parte cquitatus in folitudines, dein Thalam pervenit. Id. 9.78. 2 fugurha poltquam, amifla Thall, uihil fatis firmum contra Metellum putat, per magnas folitudines, cum paucis profectus, pervenit ad Gatulos. Id. 9.82. 3 Inter Thalam flumenque proxumum, in fpatio millium quinquaginta, loca atida atque vafta effe cognoverat (Metellus) igitur omnia jumcota farcinis levari jubet, nifi frumento dicrum decem: ccterum utres modo \& alia aqux idonea portari \&c. 9. 78 . 4 Prxfidium, cui Thala nomen. Tocit. Annal. 1.3. c. 3 I. 5 Thalum, gravem armis, Thefauroque regis, deripuit (Metellus). L. Flor. 1.3. cap. I. 
or Telepte earlier than by St. Cyprian', there may be fome Room perhaps to conjecture that they were one and the fame City. Procopius moreover defcribeth Telepte, as a Frontier Town ${ }^{2}$ of this Province; fuch as we find Ferresanah. The Author likewife of the Itinerary ${ }^{3}$, according to the Annotations of Cellarius ${ }^{+}$, placeth Tacape, Capfe (or Gafsa as it is now called) and Telepte in the fame Direction and at equal Diftances from each other. Now the firft of thefe Circumftances accordeth well cnough with Ferre-anah, as It lyeth in a N.W. and S. E. Direction nearly with Gabs and Gafsa, but the latter can be only admitted with fome Reftriction : inafmuch as $G$ afsa is removed as much too far from Gabs, as Ferre-anah is placed too near Gafsa; though the whole Diftance, which is CL Roman Miles, will anfwer well enough to the Space which lyeth actually betwixt Gabs, by Way of Gafsa, to Ferre-anab.

Twelve Leagues to the S. E. by E. of Ferre-anah, is Gafsa, Gafas, the antient Cap/a, another of the ftrong Cities of Fugurtha. It $\mathrm{C}_{a p s a}$ a is built upoin a rifing Ground, that is enclofed s, almoft in e- ex p.p. p. 22. very Direction, with Mountains; and hath the like melancho1y Situation with Ferre-anah, only with this Difference, that the Landskip here is fomewhat more gay and verdant by the Profpect we have from It of the Palm, Olive, Piftachio, and other Fruit Trees. But this agreable Scene is of fimall Extent, ferving only to refrefh the Eye in the View it is to have afterwards of an Interchange of barren Hills and Valleys. The Water which refrefh- It's Fourtains eth thefe Trees is collected from two Fountains; whereof the one arifeth within the Citadel, the other in the Centre of the City. The latter, which is probably the Fountain mentioned by Salluft ${ }^{6}$, and the Tarmid' of Edrifi; was formerly covered with a Cupola. It is ftill walled round, and difchargeth Itfelf afterwards into a large Bafon, defigned, as we may conjecture, to bathe in. This and theOtherFountain uniting before they leave the City, form a pretty large Brook, which from the Quan-

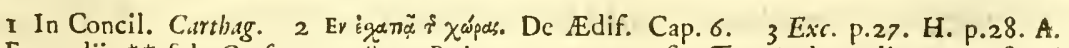
4 Ex medijs ** fola Cappe nota elt ex Ptolemao, per quam fi a Tacapis ducas lineam \& fimul milliaria attendas, qux inter Cappen funt \& Telepten, in plagam \& locum ubi Telepte fuit, linea perducet. Cell. Geogr. Antiq. 1.4. c.4. S Ebrai enim sפp cft conftingere. Hinc merito 7 ק Capsa dicitur, quam undique premebant \& in aretum cogebant vafte folitudincs, ut \& montes. Bocb. Chan. 1.x. c. 24. 6 Capfenfés una modo, atque ea intra oppidum jugi aqua, cxtera pluvia utebantur. Sall. Bell. Fug. 9.94. 7 Urbs Cafsa pulchra eft, habet mxnia, \& fluvium excurrentem, cujus aqua preftantior eft aqua Caffilia: haber etiam intra fe fontem, qui vocatur $A l$ Tarmid. Geogr. Nub. p.86. 
tity of the Water and the Rapidity of the Stream, might continue It's Courfe to a great Diftance, were It not conftantly employed by the Inhabitants in refrefhing Their Plantations. And as this was the Fugis Aqua of Salluft, fo It need not be difputed that the Capla of Sallu/t and Ptolemy were the fame, notwithftanding what Bochart ${ }^{1}$ and Cellarius ${ }^{2}$ have fuppofed to the contrary. The Antiqui- In the Walls of fome private Houfes, and particularly of the sies. Citadel, (a weak modern Building, that faceth the Fereed,) there is a great Confufion of Altars, Granate Pillars, Entablatures \&c. which when entire and in their proper Situations, muft have been great Ornaments to the City. The Infcriptions that fell in my Way were either unfortunately defaced, or imperfect; of which Number are the two following.

Upon a fquare Stone.

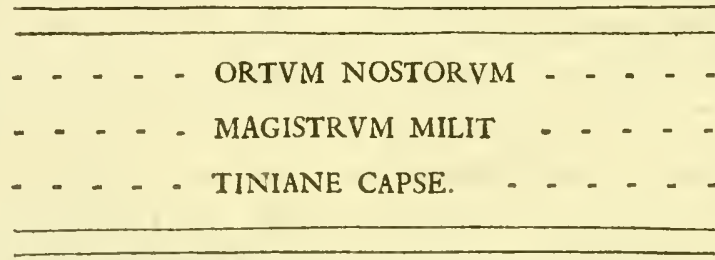

Upon a Pillar.

IMPERATOR M. AVRELIVS ANTONINVS PIVS AVGVSTVS PART. MAX. BRIT. MAX. TRIB. POT. COS. - - - FEST.

Gor-bata; Exc.p.r6.E. a Brook of brackinh Water gliding by $I t$ to the S. This

Gor-bata lyeth four Leagues to the S. S. W. of Gafsa, having Village is fituated upon an hemifpherical Hillock, that is furrounded with a great many more of the like Fafhion; affording, all together, a Profpect, which appears particular enough at a Diftance. If Gor-bata hould be the Orbita of Ptolemy, the Figure perhaps of thefe littleEminences might give occafion to the Name. The general We enter now more immediately upon that Part of the Sabara, Defrription of
Tbe Jereed. i.e. The Dry Country ${ }^{3}$. It is exactly of the fame Nature and Qua-

Chan. 1.1. cap. 24. 2 Geogr. Antiq. 4. 4. cap. 4. p.9r. 3 Vid. p. 5. 


\section{Of the Winter Circuit.}

lity with fome other Parts of It, that have been already defcribed in the Kingdom of Algiers: the Villages likewife are built in the fame manner with Mud Walls and Rafters of Palm Trees. Very little therefore will be required in the Defcription of this Part of the Country, befides an Account of the Lake of Marks; and the Enumeration of the principal Cities and Villages, formerly the Seats of the Cinetbij', Machlyes', Aufes's, and Maxyes ${ }^{4}$ of the old Geography.

There are few or no Antiquities (or indeed any thing worthy Sbekkah, The of our Obfervation,) to be met with at Sbekkah, the Cerbica EER Pr. P. I.C. probably of Ptolemy, eighteen Leagues to the S.W. by W. of Te-pewfe, Gafsa; at Te-gewfe, the Tichafa, twelve Leagues to the S.W. Eb. D. Th by S. at Ebba, the Thabba, in the Neighbourhood of Te-gewfe; Tozer, The at Tozer, the Tifurus, four Leagues to the S. W. of Te-gezwe Tisurus. at Nefta, the Negeta, five Leagues to the S. W. of Tozer. The Neffe, The likeRemark (in croffing the Lake of Marks into theDiftrict of $N$ if- P. T. $^{\text {. }}$. D. zowah) may be made at Telemeen, the Almcena, ten Leagues The. AL.MA. to the E.S.E. of Te-gervfe; at Ebillee, the Vepillium, two Vbellee, The Leagues to the S.E. of Telemeen; and at the many otherVillages UM. D. of the Fereed. Though by feveral Pieces of Granate and other Marble; by a Word or two likewife, that we fometimes meet with, of an antient Infcription, the Romans may be traced out through moft of thefe Cities and Villages.

The Trade and Intereft of Them all lyeth altogether in Dates, Their Trade. which They exchange for Wheat, Barley, Linnen Cloth, and other Commodities, brought to Them from all Parts of This and the neighbouring Kingdoms. At Tozer particularly, (whofe Dites are the moft efteemed, and which is become thereby the principal Mart;) there is a great Traffick carried on by feveral Merchants, who travel once a Year into the Country of the Ethiopians, and bring with Them from thence, a Number of Blacks, whom They ufually exchange for Dates, at the Rate of one Black for two or three Quintals.

The Shibkah ElLow-deah, or Lake of Marks, divideth the The Shibkah Villages in the Neighbourhood of Tozer from Telemeen, Fat- or Low Lake of naffa and others of the Province of Nif-zowabs'. It is fo called from a Number of Trunks of Palm-Trees, that are placed waysocalled.

I Exc. p.I4. E. 2 Exc. p. 2. C. 3 Ibid. D. 4 Exc. p.3. A. 5 Marmol deriveth this Name from the antient Nolamones. "Biludulgerid c'eft l'eftat de Carthaginois qui l'on "appelle Nazamonicns dont une de Places garde encore le Nom Nofzotyab. Cap. 53.

$$
\text { G g g } 2
$$


at proper Diftances, to direct the Caravans in their Marches over It. Without fuch Affiftances, travelling would be here both dangerous and difficult, as well from the Variety of Pits and Quickfands, that could not otherwife be avoided; as becaufe the oppofite Shore, (as we may call It,) either in paffing from Te-gewfe to the Province of Nif-zowah, or from hence to Te-gew/e, have no other Tokens to be known by, but their Date Trees. And as Thefe are rarely feen at above fixteen Miles Diftance; great Miftakes might be committed in paffing over a Plain of this Extent, (where the Horizon is as proper for Aftronomical Obfervations, as at Sea;) without fuch convenient Marks and Directions.

The Extent of This Lake reacheth near twenty Leagues from E. to W. 1t. and the Breadth, where I paffed It, was about fix. Yet it may be obferved, that it is not all of It a Collection of Water; there being feveral dry Places, which, like fo many Iflands, are interfperfed all over It. To the Eaftward efpecially, in the fame Meridian with Telemeen, there is One, which, though uninhabited, is very large and well ftocked with Date Trees. The Arabs tell us that the Egyptians, in one of their Invafions of this Country, halted fome Time at this Place; and that thefe Trees originally fprung from the Stones of thofe Dates, which the Army brought along with them for their Provifions.

The Palus

The Situation of this Lake with regard to the Sea, the Syrtes, PALLAS, or and the River Triton, fhould induce us to take It for the Palus Exc. P. 2. D. Tritonis of the Antients; and that the Ifland I have mentionP. A.B. p. 22. ne fus ${ }^{2}$ of the Sicilian Hiftorian. Pallas ${ }^{2}$ likewife, who, with PhLA Inf. Exc. p.2.D. the Lybian Women, attended Sefo/tris in His Afratic Expedition and is fuppofed to owe Her Origine to this Lake, might have had Her chief Refidence in This Situation. Mela placeth the Palus Tritonis near or upon the Sea-Coaft; and Callimachus, (as He is quoted by Pliny ${ }^{3}$ ) on This, (i. e. as I take it, on the Cyrenaic) Side of the leffer Syrtis; both which Circumftances agree with the prefent Geography of this Lake.

We may likewife account for the triple Divifion that Ptolemy

maketh of this Lake, by taking that Part of It, which reacheth

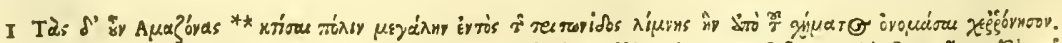

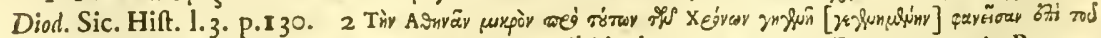

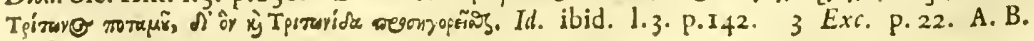


from Nefta to the Marks, to be the Palus Libya; and That, which lyeth betwixt the Marks, (where the Ground is generally dry) and the Ifland, for the Palus Pallas; whilft the Eaftern Portion of It might have been the Lacus Tritonis. Yet we fhall ftill be at a Lofs to account for the River Triton, which, according to Ptolemy and other antient Geographers, is made to pafs through This Lake, in It's Courfe to the Sea. I have already defcribed this River, and obferved that It hath no fuch Situation ; though, from It's falling into the Sea at Gabs, the antient Tacape, This, without doubt, muft be the Triton of the Antients.

Befides; the Water, both of the River Triton and of the Brook The Water of of El Hammah, is very fweet and wholefome, but That of this ${ }^{\text {It salts }}$ Lake (and indeed of molt others that I have tafted in Africa, ) hath a Saltnefs not inferiour to That of theSea; a Circumftance, which alone may be a fufficient Proof, that there could be no open Communication at leaft betwixt them.

To account therefore for this Difficulty, and to reconcile It, It batthroconeas far as poffible, with What hath been already taken Notice of, mithratberioniit may be added, that the Vicinity of the moft eaftern Parts of This Lake to the Rivulet of ElHammah; and the Nearnefs again of ElHammah to the Sources of the Triton, (though the feveral intervening Hills admit of no Communication, yet thefe Circumftances I fay) might have induced the Antients, (who feem to have defcribed this Part of Bizacium from Tradition only or fome uncertain Accounts,) to have imagined It to lye in fuch a Pofition.

Leaving Maggs, one of the leffer Villages of Nif-zowah three Maggs. Leagues to the E. N. E. of E-billee, we travel near thirty Miles through an uncomfortable Defert, without either Herbage or Water, 'till we arrive within a few Miles of El Hammah.

ElHammablyeth four Leagues to theWeftward of $G a b s$, being one of the Frontier Towns of the Tunifeens, where they have a fmall Caftle and Garrifon. The old City is at a little Diftance, ftill preferving fome Tokens of Antiquity, though nothing confiderable. The Infcriptions, in particular, that are mentioned by Dapper and Leo, no longer fubfift, having undergone the like Fate with the other antient Monuments and Structures of this Place.

El Hammah is fo named from one or other of the hot Baths, El Hammah, which are reforted to from all Parts of the Kingdom. It is gene- ${ }_{-1}^{\text {or Th }}$ Bath.

I Atl. Geogr. Vol. Iv. p. I64. Reperias \& hodie in marmoribus quibufdam infculpta quxdam antiquitatis monumenta. F. Leo. p. 22.5. H h h 
214 Geographical Objervations in the Inland Country \&re.

rally called El Hammah of Gabs, to diftinguifh it from another Town of the fame Name, a few Miles to the Northward of Tozer. The Baths are each of them fheltred from the Weather by having a miferable thatched Hovel built over It ; whilft their Bafons, which are about twelve foot Square and four Deep, have, a little below the Surface of the Water, fome maffy Benches of Stone for the Bathers to fit upon. One of thefe Baths is called the Bath of the Lepers: and below It, the Water ftagnates and forms a Pool, which perhaps may be the The Lake of fame with the Lake of Lepers, mentioned by Leo: The WaLepers. ter of thefe Fountains, when collected together, formeth a finall Rivulet, which, after being conducted in a Number of Subdivifions through the Gardens and united again, directeth It's Courfe towards the eaftern Extremity of the Lake of Marks and lofeth Itfelf, at a few Miles Diftance, in the Sand.

The Bedo-

The principal Arabs of the Winter Circuit, are the various

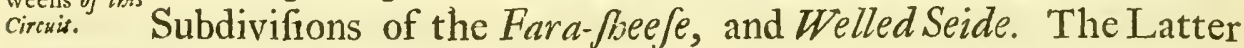
extend themfelves all along the $S a b u l^{2}$, as they call the eaftern Part of this Province from Herkla to Sfax: the Former poffefs the greateft Part of the Midland Country; but are more frequently met with near Spaitlo and Fuffanah. Welled Seedy Boogannim, with Their Sanctuary, 1ye to the Northward of the Plains of Fuf-fanah, as far as the Mountains of Ellou-leejah and Hydrab: and to the Eaftward of Them, near Sbeebah and the Mountain Megala, are the Douwars of the Welled Omran. The Welled Matthie cultivate the rich Country near Toufef and Zowareen; whilft the Welled $Y_{a-\text { goube enjoy as fertil a Situa- }}$ tion near the Walls of Keff. The Bedoweens upon the Frontiers, are the Welled Booguff, who frequently difpute the Paffage of the River Serratt, with the Woorgah, a formidable Clan under the Jurifdiction of the Algerines.

I In fefquimiliario meridiem verfus ab hoc oppido El Hamina [ut male fcribizur] originem habet fluvius quidam aqu $x$ calidiffim $x^{* *}$ tandem hxc aqua non procul ab co oppido lacum efficit qui leproforum appellari confuevit : habet enin fanandi hujufmodi morbum atque vulnera folidandi miram naturam. F. Leo ut fupra. 2 So called perhaps from law, Litus maris, quafi pro J 5 anos quod atteritur aut perfunditur aqua. Gi. apud Gol. II 49 . or from low, Planities. 


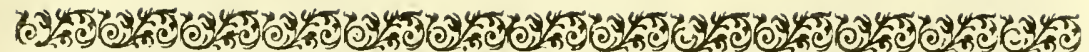
04

Pbyjical and Mifcellaneous

\section{OBSERVATIONS $\sigma^{\circ} c$.}

O R A N

\section{E S S A Y}

TOW A R S THE

\section{NATURAL HISTORY}

OF THE KINGDOMS OF

ALGIERS and TUNIS.

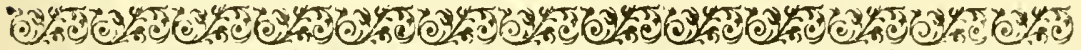

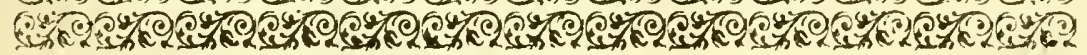




\section{The CONTENTS.}

C H A P. I.:

Of the Air, Products, Soil, Foffils, \&c. of thefe Kingdoms. p. 217.

C H A P. II.

Of their Quadrupeds, Birds, Infects, Fijhes, \&c. p. 238.

\section{H A P. III.}

Of the Learning, Manners, Manufactures, \&c. of the Inbabitants. p. $26 \mathrm{I}$.

\section{H A P. IV.}

Of the Government, Forces and Revenues of the Algerines; of their Courts of Fudicature and Punifments; and of their Interefts and Alliances with Chriftian Princes.

p. 309 . 


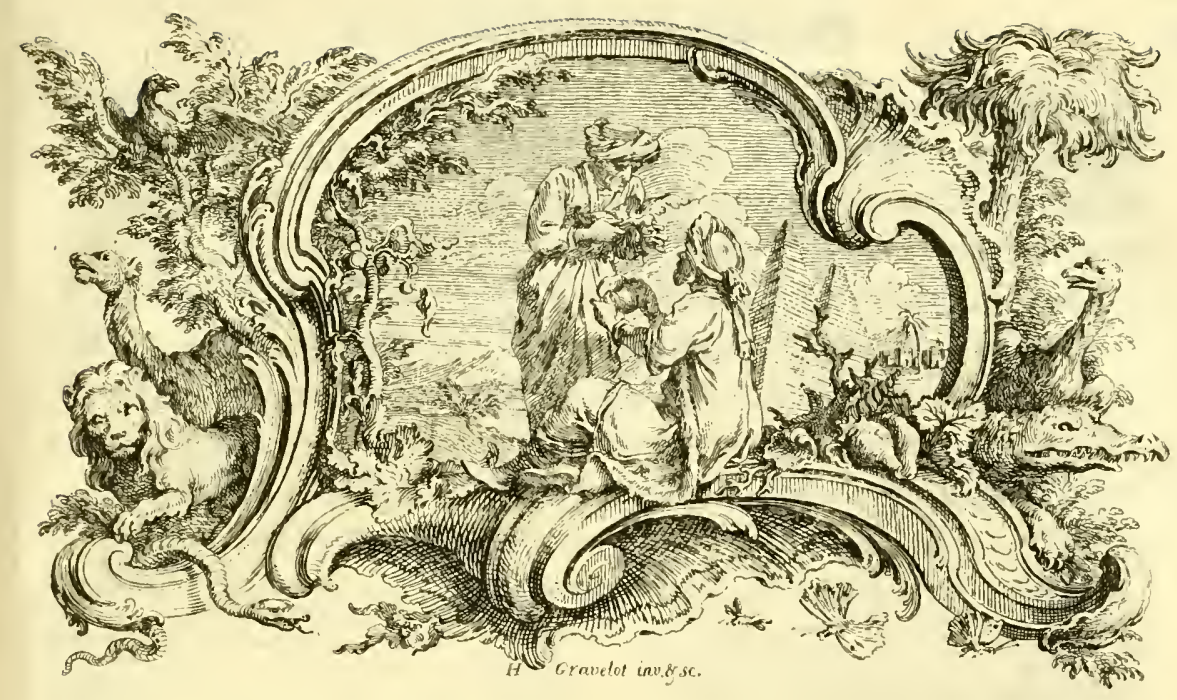

\section{Pbyfical and Mifcellaneous}

\section{O B S E R V A T I O N S}

RELATING TO THE KINGDOMS OF

\section{$A L G I E R S$ and TUNIS \&c.}

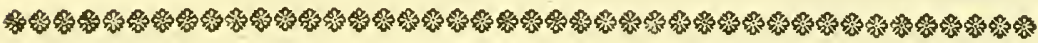

C H A P. I.

Of the Air, Products, Soil, Fofflils $\sigma^{\circ}$ c. of the ee Kingdoms.

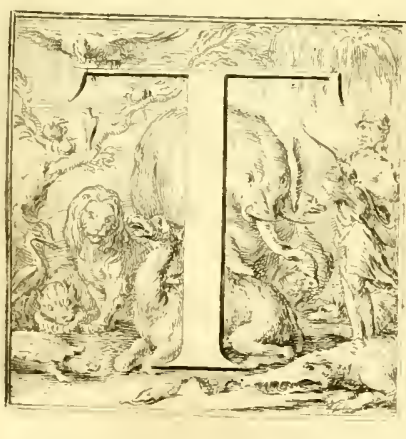

HE cultivated Parts of Thefe King- The Temperadoms lying betwixt $34^{\circ}$. and $37^{\circ}$. Alire of the N. Lat. enjoy a very wholefome and temperate Air, neither too hot and fultry in Summer, nor too tharp and cold in Winter. During the fpace of twelve Years that I attended the Factory of Algiers, I found the Thermometer, twice only, contracted to the freezing Point, and then the whole Country was covered with Snow: nor ever did it rife to that of fultry Weather, but when we had the hot Winds from the Sabara. The Seafons of 
the Year infenfibly fall into each other; and the great Equability in the Temperature of This Climate, appears from this Circumftance, that the Barometer fheweth us all the Revolutions of the Weather in the Space of I Inch and $\frac{3}{10}$, or from 29 Inches and $\frac{1}{10}$ to $30 \frac{4}{10}$.

The Winds are generally from the Sea; i.e. from the W. 2ke Winds. (by the N.) to the E. Thofe from the Eaft are common at Algiers from May to September; at which Time the wefterly Winds take place and become the moft frequent. Sometimes alfo, particularly about the Aquinoxes, we very fenfibly experience that Force and Impetuofity which the Antients have afcribed to the Africus ', or S. W. Wind, called La-betch by the Mariners of thefe Seas. The Southerly Winds, which are ufually hot and violent, are not frequent at Algiers. They blow fometimes for five or fix Days together in $\mathcal{F u l}_{\mathrm{l}}$ and Auguft, rendering the Air fo exceffively fuffocating, that, during their Continuance, the Inhabitants are obliged to fprinkle the Floors of their Houfes with Water. In the latter End of Fanuary 1730-3I, a violent hot foutherly Wind immediately followed the thawing of the Snow, which, for the fpace of two Months, had been lodged upon the neighbouring Plains and Mountains. But this was looked upon as a very furprizing and unufual Phenomenon by the Inhabitants.

Rain, with soefterly Winds.

The Winds from the W. the N.W. and the N. are attended with Fair Weather in Summer, and Rain in Winter. But the eafterly Winds, no lefs than the foutherly, are for the moft Part dry, though accompanied with a thick and cloudy Atmofphere in moft Seafons. It is particular enough, that the Mountains of Barbary and Thofe upon the S. Coaft of Europe, fhould be differently affected with the fame Wind. For I have obferved the Former to be conftantly clear in eafterly Winds, but clouded with wefterly; particularly a little before and during the Time of Rain; the contrary to which, if I am rightly informed, falls out in Spain and Italy.

The Barome- The Barometer rifeth to 30 Inches $\frac{2}{10}$ or $\frac{3}{10}$ with a northerly

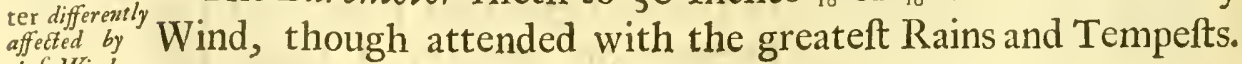
the fe Winds.

I Africus furibundus ac ruens ab Occidente hyberno. Scn. Nat. Quxlt. 5. Una Eurufque Notufque ruunt, creberque procellis

Africus.

Virg. Æn. 1. 1.89.

Luctantem Icarijs fluctibus Africum Mercator metuens.

Hor. Car. I. I Od. I.

There 
There is nothing conftant and regular in eafterly or wefterly Winds; though for three or four Months together in the Summer, whether the Winds are from one or the other Quarter, the Quickfilver ftands at about thirty Inches without the leaft Variation. But, with the hot foutherly Winds, I have rarely found It higher than 29 Inches, $\frac{2}{10}$, which is alfo the ordinary Height in ftormy wet Weather from the Weft.

$A$ T A B L E pewving the Quantity of Rain that fell at Algiers in the

Autumn 21730

Spring $\{1731$

Several

drizling
Showers

in Septem. Inches

and Octob. 0,73 .

Octob. $\left\{\begin{array}{l}29 \\ 30\end{array}\right.$

Nov. 310,35 .

II 0 , $45^{\circ}$

$28 \mathrm{I}, 00$.

$29 \mathrm{O}, 45$.

$30 \mathrm{I}, 53$.

Dec. I $2, \quad 15$.

$17 \mathrm{I}, 60$.

$240,63$.

$27 \mathrm{I}, 15$.

fan. $\quad 300,65$.

$4,1,6$.

5 o, 90.

$6 \mathrm{I}, 00$.

$7 \mathrm{I}, 43$.

$90,70$.

II $I, 10$.

$120,80$.

I $3 \mathrm{I}, 20$.

$18 \mathrm{I}, \mathrm{I} 6$.

210,35 .

Eeb. $300,35^{\circ}$

$\begin{array}{rr}1 & 0,85^{\circ} \\ 17 & 0,80 .\end{array}$

$190,25$.

220,33

$250,60$.

$260,80$.

280,20

March I $0,20$.

Afr. 290,25

I0 $0,20^{\circ}$

$130,15$.

152,03 .

$240,13$.

$30,68$.

\begin{tabular}{|c|c|c|c|}
\hline \multicolumn{4}{|c|}{$\begin{array}{l}\text { Autumn } \\
\text { Spring } \\
1732 \\
\text { Inches }\end{array}$} \\
\hline \multirow{6}{*}{ octob. } & 7 & $I$, & 35. \\
\hline & I I & 0 , & \\
\hline & 15 & 4, & \\
\hline & 20 & $\mathrm{O}$, & \\
\hline & 26 & $\mathrm{I}$, & \\
\hline & 28 & $\mathrm{I}$, & \\
\hline \multirow[t]{6}{*}{ Nor. } & I & $I_{2}$ & \\
\hline & 6 & $=2$ & \\
\hline & $1_{1}$ & 3, & \\
\hline & 15 & 0 , & \\
\hline & 18 & 2, & \\
\hline & 29 & 0 , & \\
\hline \multirow[t]{9}{*}{ Dec. } & 2 & $\mathrm{O}$, & \\
\hline & 6 & $\mathrm{O}$, & \\
\hline & 7 & I, & \\
\hline & $\begin{array}{r}8 \\
\mathbf{I}_{\mathbf{I}}\end{array}$ & $\begin{array}{l}\mathrm{O}, \\
\mathrm{O},\end{array}$ & \\
\hline & 20 & o, & \\
\hline & 24 & l, & \\
\hline & 26 & o, & \\
\hline & 28 & I, & \\
\hline & 30 & o, & \\
\hline \multirow[t]{3}{*}{ fan. } & $I_{3}$ & 0 , & \\
\hline & 16 & I, & \\
\hline & I9 & 0 , & \\
\hline \multirow[t]{5}{*}{ Feb. } & 7 & o, & \\
\hline & 10 & o, & \\
\hline & I I & I, & \\
\hline & $I_{3}$ & 0 , & \\
\hline & I9 & 0 , & \\
\hline \multirow[t]{8}{*}{ March } & 5 & 2, & \\
\hline & 6 & 0 , & \\
\hline & 7 & I, & \\
\hline & $\begin{array}{r}8 \\
I_{2}\end{array}$ & $\begin{array}{l}\text { O, } \\
\text { O, }\end{array}$ & \\
\hline & 13 & 0 , & \\
\hline & $I_{4}$ & 1, & \\
\hline & 15 & 0 , & \\
\hline & I9) & $\mathrm{O}$, & \\
\hline \multirow[t]{6}{*}{ Apr. } & I & $\mathrm{O}_{2}$ & \\
\hline & 4 & o, & \\
\hline & $\begin{array}{r}9 \\
16\end{array}$ & O, & \\
\hline & 17 & 0 , & \\
\hline & 30 & o, & \\
\hline & & 0 , & \\
\hline
\end{tabular}

44,27 .

The ordinary Quantity of The Quantity Water which falls at Algiers ${ }_{\text {that falls seve- }}^{\text {of Rain wat }}$ in Rain, is, at a Medium, one 'y rear. Year with another, twenty feven or twenty eight Inches. In the Years I723-4 and I724-5 (which were looked upon as dry Years) there only fell about twenty four Inches; whereas in $7730-$ I (which may be placed among the wet Years) the Quantitywas upwards of thirty. The Rains were ftill more copious $A n$.1732-3, amounting to imore than forty four Inches: but this was fuch an extraordinary Year forRain, that the like had been rarely known in This Climate. TheShowers, particularly Octob. Is. and Nov. I I. were fo remarkably heavy and frequent, that the Pipes, contrived to convey the rain Water from the Terraces, were not wide enough to receive $1 t$. In February and March 1727-8 it rained forty Daysfucceffively at Tunis; but I have not known the like Inftance at Algiers; where the ordinary Time feldomexceeds two or threeDays, after which we have ufually a Week, a Fortnight or more of fair and good Weather.

It is feldom known to rain in this Climate during the Summer The $_{\text {winter }}$ Seafon; and in moft Parts of the Sabara, particularly in the ${ }_{\text {Seafond }}^{\text {the onainy }}$ Jereed, They have rarely any Rain at all. When I was at 
Tozer in December (A.D. 1727) we had a fmall drizling Shower that continued for the fpace of two Hours; and fo little Provifion was made againft Accidents of this Kind, that feveral of the Houfes, (built only, as ufual, with Palm Branches, and Tiles baked in the Sun) fell down by imbibing the Moifture. Nay, provided the Drops had been either larger or the Shower of a longer Continuance, the whole City would have undoubtedly difolved and dropt to Pieces.

The firft Rains fall fome Years in September, in others a Month later; after which the Arabs break up Their Ground, and begin to fow Wheat and plant Beans. This commonly falls out about the middle of October: but the fowing of Barley, and the planting of Lentils and Garvancos, is a Fortnight or three Weeks later, or not 'till the End of November. and Latter If the latter Rains fall in the Middle of April, (as they ufually do) Rains. the Crop is reckoned fecure; the Harveft following in the latter End of May or in the Beginning of Fune, according to the preceeding Quality of the Seafons. The Quantity Two Bufhels and an half of Wheat or Barley, are judged here
of their crops to be fufficient to fow as much Ground, as a pair of Oxen will plow in one Day, which I have always found to be a little more or lefs equal to one of our Acres. I could never learn that any Part of Barbary afforded yearly more than one Crop; one Bufhel yielding ordinarily from eight to twelve; though fome Diftricts, I have been informed, afford a much greater Increale. For it is common to fee ten or fifteen Stalks arifing from one Grain. Even fome Grains of the Murwaany Wheat, which I brought with me to Oxford, threw out fifty. But Muzeratty, the late Kaleefa of the weftern Province, brought once with Him to Algiers, a Root that yielded fourfcore; telling us, that (in Confequence of a Difpute concerning the refpective Fruitfulnefs of Egypt and Barbary) the Emeer Hadge or Prince of the (weftern) Pilgrims, fent once, to the Bafbaw of Cairo, one that yielded fix fcore. Pliny " mentions fome that bore three or four hundred. It likewife happeneth that one of thefe Stalks fometimes bears two Ears: whilft

I Tritico nihil eft fertilius: hoc ei natura tribuit, quoniam eo maxime alat hominem: utpote cum e modio, fift aptum folum, quale in Byzacio Africa campo, centeni quinquageni (centum folsm memorantur Exc. p. 22. B.) modii reddantur. Mifit ex co loco Divo Augufto Procurator cjus ex uno grano (vix credibile dictu) quadringenta paucis minus germina, cxtantque de ca re Epiftolx. Mifit \& Neroni fimiliter cecxl ftipulas ex uno grano. Plin. 1. 18. cap. 10. 


\section{Obfervations \&c.}

the Ears as often fhoot out into a Number of leffer ones, thereby affording a confiderable Increafe; though never, as far as I could be informed, a hundred Fold, according to what hath been reported of This Country by the Antients.

There is one Kind only of Wheat and Barley, which is gene- Tiseirdififerent rally cultivated in this Country: for Rye, and a large pointed Grands of

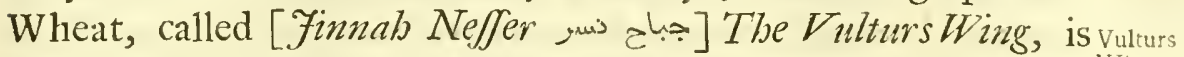
fown in too fmall Quantities to deferve our Notice. However ${ }^{\text {Wing. }}$ both thefe forts of Grain differ in their Quality according to the Nature of the Ground wherein they are fown. For That which is produced in the Plains of Bufdeerah, is accounted to be the beft in the Kingdom of Tunis: whilft at Algiers, the Corn of Teffailah and Zeidoure, but efpecially the Murwaany, Murwany. (as they call a larger Kind of Wheat at Medea,) keep up the greateft Reputation. In fome Diftricts, where they have a Command of Water during the Summer Seafon, as near the Sikke and Habrah, in the Mettijiah, at the River Hammah below Conftantina, and in feveral of the Plains along the Banks of the Mejerdah, the Inhabitants cultivate Rice, Indian Corn, and particularly a white fort of Millet, which the Arabs call Ricean Corn. Drah, and prefer to Barley for the fat'ning of their Cattle. Drah. Oats are not cultivated at all by the Arabs; (the Horfes of No Oats, or this Country feeding altogether upon Barley;) neither is Bigg Winterer. (or Winter Wheat) fo much as known in this Climate.

The Moors and Arabs continue to tread out their Corn after The treeding the Primitive Cuftom of the Eaft. It is a much quicker Method than Ours, but lefs cleanly. For as It is performed upon any level Plat of Ground, daubed over only with Cows Dung; a great Quantity of Earth and Gravel muft unavoidably be gathered up with the Grain : not to mention that the Straw, which is the only Fodder of thefe Climates, is hereby fhattered to Pieces. After the Grain is troden out, They winnow It, by The minnowthrowing It up into the Wind with Shovels, lodging It afterwards in Mattamores' or fubterraneousMagazines, as the Cuftom The lodging $_{\text {. }}$

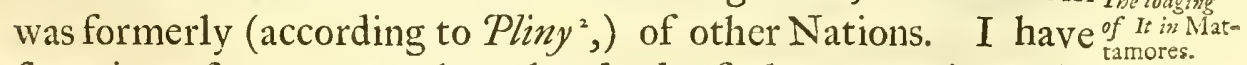
fometimes feen two or three hundred of them together, the fmalleft of which would contain four hundred Bufhels.

I Vid. Not. p. 25. 2 Utilifimè fervantur (frumenta) in fcrobibus, quos Siros vocant, ut in Cappadocia \& in Thracia. In Hifpania \& Africa, ante omnia, ut ficco folo fiant, curant: mox ut palea fubfternatur. Prxterea cum fpica fua conduntur, [non ita hodie mos Africa eff] Ita frumenta fi nullus fpiritus penetret, certum eft nihil malcficum nafci. Plin. I. 18. eap. 30.

$\mathrm{K} \mathrm{k} \mathrm{k}$

Hirtius 
Hirtius' acquainteth us that the Africans made ufe of thefe Pits for the greater Security of their Provifions from an Enemy: but it is more probable, that they were contrived in thofe earlier Ages, as They continue to be to this Day, for the greater Eafe and Convenience of the Inhabitants. For it cannot be fuppofed that the antient Nomades, any more than the prefent Arabs, would be at the Expence of erecting Storehoufes of Stone, when they might, at a much cheaper Rate, beferved with Thefe, at every Station, where they encamped to gather in their Harveft.

The forts of Beans, L.entils, and Garvansos, (the latter of which is the Pulfe. Cicer or Chich Pea) are the chief Species of Pulfe that are culPcafe. tivated in thefe Kingdoms. Peafe, 'till of late, were known in the Gardens only of the feveral Chriftian Merchants. They are fown with the firft Rains, and bloffom in the latter End of

Beans. February, or the beginning of March. Beans are ufually full podded at that Time; and being boyled up with Oyl and Garlick, are the principal Food, of Perfons of all Diftinctions, Lentlls. during the Spring. After them, Lentils, and Garvanşos, begin to be gathered. The firft are prepared for eating in the fame Manner with Beans, diffolving eafily into a Mafs, and making a Pottage of the Colour of Chocolate. This we find was the Red Pottage whichFfan exchanged for His Birth-right ${ }^{2}$, and from whence He was called Edom. Garvanços are dreffed and prepared in a different manner. They never foften into a Pulp, like the other Kinds of Pulfe, by boyling; and are not therefore ferved up alone, but areftrawed only over Cu/ca fowe, Pillowe and other Difhes. For they are in the greateft Repute and Demand, when Parched; being then a favourite Morfel to Perfons of all Ages and Diftinctions. There are in every Street of the Eaftern Cities, feveral Copper Panns and Ovens contrived for this Purpofe: the Garvancos lofing hereby their Leb-lebby, old Name, and affuming That of Leb-lebby This Method of Parching them, feems to be of the greateft Antiquity. Plantus ${ }^{3}$ fpeaks of it as a Thing very common in His Time; the like Obfervation we meet with in Ariftophanes: neither is there any

I Eft in Africa confuetudo incolarum, ut in agris \& in omnibus fere villis, fub terra fpecus, condendi frumenti gratia, clam habeant; atque id propter bella maxime, holtiumque fubitum adventum, prxparent. Hirt. Bell. Afric. 9. 57. 2 Gen.25. 30. and 34. 3 Tam frictum ego illum reddam, quam frictum eft Cicer. Plaut. in Bacch. 4. 5. v. 7.

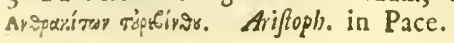

other 
other fort of Pulfe, as far as I am informed, that is prepared in this Manner. The Leb-lebby therefore of thefe Times, may probably be the ['ק Kali] parched Pulfe', of the H. Scrip-The parched

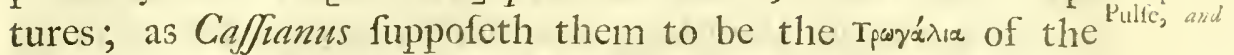
Greek Authors". They have likewife been taken by fome Writers $^{3}$ for the Pigeons Dung, that is mentioned at the Siege The Pigeons of Samaria. It is very certain, that this Pulfe is pointed at Dung of the one End and acquireth an Afh Colour in the parching. Now as the firft Circumftance anfwereth to the ufual Figure, the other, to the ufual Colour of Pigeons Dung, the Suppofition, I prefume, is by no means to be difregarded.

After the Corn and Pulie, we are to take Notice of the The Produce Roots, Potherbs, and Fruit of this Country; of which there Garden. is not only a great Plenty and Variety, but a Continuance or Succeffion at leaft of one Kind or other throughout the whole Year. To give therefore a fimall Specimen of the Kitchen and Fruit Gardens of Barbary; we are to obferve that Turneps, Carrots, and Cabbages, are equally good and common in moft Seafons. The Lift el Hafhoure, a fmall Parfnip like Turnep with fibrous Roots, hath a Tafte fo agreeably pungent, that it is held in the higheft Efteem, and fold by Weight. Lettice, [Cho/s miz] Endire, Greís, Chervil, Spinage, all forts of Beets, with the young Shoots of the Wild and Garden Artichoak, are in Scafon from October to Fune: and then follow, during the reft of the Summer, Calabafbas, Mellou-keabs, Bedin-janns, and Calabullas, Tomatas; each of Them, in it's Turn, giving a Relifh to their Soups and Ragohts. Neither fhould [Cazibar كزبر Coriander be onitted, as it hath always a principal Share in the Moorifh Cookery. Sellery and Colliflowers arrive to great Perfection Sellery, scc. in this Climate. They are fown in Fuly, yet are not fit for gathering 'till the February or March following. I have feen feveral of the latter, that were very white, folid and compact, meafuring a Yard or more in Circumference. About the latter End of Fune likewife, is the firft appearance of Musk and Melons. Water Melons; the firft of which are little Superiour to Ours in the Richnefs of their Tafte; but the latter, for the want of a due Heat, have never been raifed to Perfection in the Nor-

I 2 Sam. I7. 28. Vid. Hicronym. Verf. 2 Superintulit caniftrum babens cicer frictum, quod illi Tparária (i. c. Bullaria) vocant. CajJan. Collat. 8.3 Vid. Borb. Hieroz. Part. Poit. 1. 1. c. 7 . 
thern Climates. Doubtlefs the Water Melon (or Dillabas they call It) is providentially calculated for the fouthern Countries, as It affordeth a cool refrefhing Juice, affwageth Thirft, mitigateth feavourifh Diforders, and thereby compenfateth, in no fmall Degree, for the exceffive Heats of thefe Climates.

The Fruit Garden.

In fpeaking of the Fruit Garden, we are to begin with the Palm Tree, of which there are great Numbers in the Maritime as well as Inland Parts of this Country; though fuch only, The Palm as grow in the Sabara, bring their Fruit to Perfection. They Trec, are propagated chiefly from young Shoots, taken from the Roots of full grown Trees; which, if well tranfplanted and taken Care of, will yield their Fruit fix or feven Years after: whereas thofe that are raifed immediately from the Stone, will not bear 'till about their fixteenth Year.

Male and Fe- It is well known that thefe Trees are Male and Female; male.

and that the Fruit will be dry and infipid without a previous Communication with the Male. In the Month of March or April therefore, when the Sheaths that enclofe the young Clufters of the Flowers and Fruit, i. e. of the Male and Female, begin to open; (at which Time the Dates are formed, and the Flowers are mealy;) They take a Sprig or two of the Male

How the Female is feckn-Clufter, and infert It into the Sheath of the Female: or elfe dated. They take a whole Clufter of the Male Tree, and fprinkle the Farina of It over feveral Clufters of the Female. The Latter Practice is common in Egypt, where They have a Number of Males: but the Trees of this Country are impregnated by the Former Method, where one Male, is fufficient to impregnate four or five hundred Females.

Dethuckar, or The Africans call this Operation Dthuckar, $[\Leftrightarrow]$ which we may render the Fœcundating, or the Admiffion of the Male. The fame Word is likewife ufed, (inftead of the antient CapriCaprificatio. ficatio ${ }^{2}$ ) for the fufpending a few Figs of the Male or wild Fig Tree upon the Females, that their Fruit may not drop off or degenerate.

The Age of

I was informed that the Palm Tree is in It's greateft Vigour the Palm Tree. about thirty Years after Tranfplantation, and that It continu-

I Vid. Plin. Hift. Nat. 1. 15. cap. 19. Menfe Junio, circa folltitium caprificand $x$ funt arborcs Fici, id eft fufpendendi Groffi cx Caprifico, lino, velut ferra, pertugi. Pallat. de re Ruftic. Caprificari (inquit Sipontinus) eft adhibita Caprifico, ne fructus propinquz Ficus ante maturitatem decidant, providere. Vid. Steph. Thef. in voce. 


\section{Obfervations \&c.}

eth in full Vigour feventy Years longer, bearing yearly, all this Time, fifteen or twenty Clufters of Dates, each of them fifteen or twenty Pounds Weight. After this Period they begin gradually to moulder and pine away, ufually falling about the latter End of their fecond Century. They require no other Culture and Attendance, than to be well watered once in four or five Days, and to have the lower Boughs plucked off, whenever they begin to droop and wither.

It is ufual with Perfons of better Fanhion in this Country, Thb Honey of to entertain their Guefts upon a Marriage, at the Birth of $\mathrm{a}_{\mathrm{T}}^{\mathrm{t} \text { Tree. }} \mathrm{P}$. Child, or upon other extranrdinary Occafions, with the Honey (as they call It) of the Date Tree. This they procure by cutting off the Head of one of the more vigorous Kinds and fcouping the Top of the Trunk into the Shape of a Bafon. When the Sap afcends, it lodgeth in this Cavity, during the firtt Week or Fortnight, at the Rate of three Quarts or a Gallon a Day; after which the Quantity daily diminifheth, and, at the End of fix Weeks or two Months, the Juices are entirely confumed, the Tree becomes dry, ferving only for Firewood or Timber. This Liguor, which hath a more lufcious Sweetnefs than Honey, is of the Confiftence of a thin Syrop, but quickly groweth tart and ropy, acquiring an intoxicating Quality, and giving by Diftillation an agreeable Spirit, Steam, or Arîky, according to the gencral Name of thefe People for all hot and ftrong Liquors, extracted by the Alembick.

We thould not leave the Sabara without faying fomething The $_{\text {Lotus }}$ alfo of the Lotus, becaufe the Fruit of It is frequently men-and ${ }_{\text {phagi. }}$ pot tioned in Hiftory, and the Lotophagi', a confiderable People of thefe and the adjacent Deferts, received their Name from It. Herodotus ${ }^{2}$ informs us, that the Fruit was fweet like the Date; Pliny ${ }^{3}$, that it was of the Bignefs of a Bean, and of a Saffron Colour; and Theophraftus ${ }^{4}$, that it grew (thick) like the Fruit of the Myrtle Tree. From which Circumftances, the Lotus Arbor of the Antients appears to be the fame Plant with the

I Exc. p. 2. C. p. 3. C. p. 8. C. P. I4. E. Ec. 2 Exc. P. 2. C. Africu infignem Arborcm Loton gignit ${ }^{*}$ magnitudo qux pyro, quanquam Nepos Comelius brevem tradat. * Magnitudo huic Fabx, color croci, fed ante maturitatem alius arque alius, ficut in uvis. Nafcitur denfus in ramis myrti modo, non ut in ltalia, cerafi: tam dilci ibi cibo, ut nomen etiam genti terrxque dederit, nimis hofpitali advenarum oblivione parrix, \&c. Plin.l. I 3.c. I7.

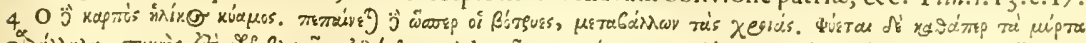

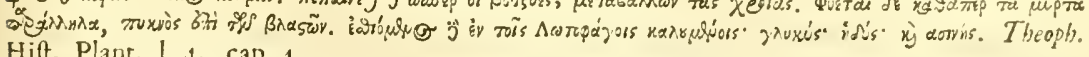
Hift. Plant. 1. 4. cap. 4. 
[Seedra was ] of the Arabs; a Shrub, which is very common in thefe Deferts and other Parts of Barbary; having the Leaves, Prickles, Flower, and Fruit of the [Ziziplous] Fujeb; only with this Difference, that the Fruit is round, fmaller and more lufcious, at the fame Time the Branches are not fo joynted or crooked, growing much like Thofe of the Paliurus. This Fruit is ftill in great Repute and fold in the Markets all over the fouthern Diftricts of thefe Kingdoms. The Arabs call It Aneb entaEl Seedra, or the Fujeb of the Seedra.

The Almond Moft of the other Fruit Trees of this Country are common Tree. in Europe: of which the Almond, the moft early Bearer, flowers in Fanuary, and giveth It's Fruit in the Beginning of April. The Apricot, Apricots are fit to gather in May, but the Saßhee, a Species of and Sallee. them, ufually of the Shape and Size of a Nectarine, with the like Property alfo of not parting from the Stone, is fomewhat later. The eating of the latter is never attended with a Surfeit ; whereas the common Apricot is very dangerous, occafioneth a variety of Fevers, and Dyfenteries, and goeth in the Frank Language by the Name of [Matza Franka] the Killer of Chriftians. In Fune They have two or three Species of The Plum, Plums and Cherries, yet none of them are either in plenty or
and Cherry. Plums delicious. However the Cherry hath been formerly in fo much Efteem, that It continueth to be called [SCAll ca Hab El The Mulber-Mellek] The Berry of the King. About this Time likewife ry Tree.
The Pear and Apple. the Height of the Seafon for the Latter is in Fuly and Augu/t, when both of them are in Plenty and Variety enough, though vaftly inferiour, in all Refpects, to the more ordinary Kinds of our Climate. The black and white Boccôre or early Figg, (the fame we have in England,) is a Fruit likewife of this Month; though the (Kermez) Fig, properly fo called, (which they preferve and make up in Cakes $^{2}$,) is rarely ripe before Auguft. I have alfo feen a lank dark coloured Fig, that hath fometimes hung upon the Trees all the Winter. Nectarines

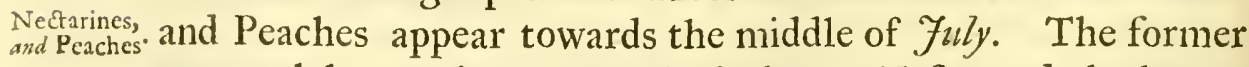
are much larger than ours and of a better Tafte; and the latter, befides their excellent Flavour, will commonly weigh ten Ounces. Anguft produceth the firft Pomegranates; fome of

I בעد, Hebr. Primus fructus \& precox. Gol. Significat ficum precocem, prodromum, five prothericam. Schind. Lex. Ferem. 24. 2. Hof.9.10. 2 I Sam. 25 . I8.

which 
which are three or four Inches in Diameter, and of a Pound PomegraWeight: neither ought we to omit the Prickly-Pear, or the Fruit of the Opuntia, called, perhaps from being originally PricklyPears? brought from Europe, [Kermez Naffarah,] The Fig of the Chriftians. Several Families live upon little elfe during this Month and September; though it is never known to tinge the Urine of a bloody Colour, as it is faid to do in America. The Wall Nut, and Olive (which bears copioufly every other wall Nut Year only,) are propagated all over Barbary. In fome Places and Olive. alfo they have the Chefnut, which is fmaller, though of as good a Relin as thofe that are brought from France or Spain. But the Hafel ', the Filbert, the Goosberry and Currant Tree are ${ }_{\text {bert, Goof- }}^{\mathrm{NoH} \text { Gel,Fil- }}$ not, as far as I know, the Productions of this Climate. The Grape ri- berry nor pens towards the latter End of Fuly, and is cut for the Vintage in The Vintrge. September. The Wine of Algiers, before the Locults, in the Years 1723-24. made fuch vaft Deftruction of the Vineyards, was not inferiour to the beft Hermitage, either in Brisknefs of Tafte or Flavour. But fince that Time, it is much degenerated, having not hitherto recovered It's ufual Qualities; though perhaps It may ftill difpute the Preference with the Wine of Spain or Portugal. The Lemon (and fometimes the Sevil Lemon and Orange) Tree is always in a Succeffion of Fruit and Bloffoms; but the China, as It is commonly called, is a Foreigner, and beareth only towards the latter End of Autumn. I need not mention the Quince, the Medlar, the Fujeb and Service Tree, The Quince becaufe their Fruit is no where in great Repute; at the fame Time the Trees themfelves are the leaft Ornaments of the Fruit Garden. The Plants likewife which would more immediately concern the Flower or Phyfick Garden, are in fo fmall a Number, that they may conveniently enough be referred to the general Catalogue of the more curious Plants of Barbary.

I am further to add with Relation to thefe Gardens, that No Regularity there is nothing laid out with Method, Beauty or Defign; the ${ }_{\text {dens. }}^{\text {in ther Gar: }}$ whole being only a Medly and Confufion of Trees, with Beds of Cabbages, Turneps, Beans, Garvancos, \&c. nay fometimes of Wheat and Barley difperfed among them. Fine Waiks, Parterres, and Flower Plats, would be to thefe People the Lofs of fo much profitable Soil; as planting in Order and

I il Heb. J Arab. [Lnz.] is interpreted (Gen.30. 37.) the Huffel Tree, inftead of the Almond Tree, according to the true Signification.

L11 2

Re- 
Regularity, the ftudy of Soil and Compofts, or the aiming at any new Improvements and Difcoveries, would be fo many Deviations from the Practice of their Anceftors, whofe Footfteps they follow with the utmoft Reverence and Devotion. The (⿴囗十) The lity Soil which fupports all thefe Vegetables, is, for the moft of the Soil. Part, of fuch a loofe and yielding Contexture, that an ordinaryPair of Oxen is fufficient, in one Day, to plow an Acre of the ftiffeft Sort of It. The Colour of It is not always the fame; for in the Plains of Zeidoure \&c. it is blackifh; whilft in thofe of Elmildegab \&c. it inclineth to be red; though both of them are equally fruitful, and impregnated alike with great Quantities of Salt and Nitre.

Salt Perre Earth.

In the Salt Petre Works of Tlemfan they extract about fix Ounces of Nitre from every Quintal of the common Mould, which is there of a dark Colour; and at Doufan, Kairwan and fome other Places, they have the like Quantity from a loamy Earth, of a Colour betwixt red and yellow. The Banks of feveral Rivers, to the Depth fometimes of two or three $\mathrm{Fa}$ thom, are ftudded, in Summer Time, with nitrous and faline Knobbs and Exudations; which, befides the Depth of the Soil, fhew us likewife how well it is faturated with thefe Minerals. For to this grand and inexhauftible Fund of Salts, we may in a great Meafure attribute the great Fertility, for which this Country hath always been remarkable ${ }^{r}$, and ftill continueth to be fo, without any other Manuring, than the burning, in fome few Places, of the Stubble. Though it is fomewhat extraordinary that the Province of Bizacium ${ }^{2}$, which was formerly held in fo much Repute for It's Fertility, fhould be at prefent the moft barren and unprofitable Part of 'Thefe Kingdoms.

Salt the pre- It appears farther, that Salt is the chief and prevailing Mineral valiling Mi- of thefe Kingdoms, as well from the feveral Salt Springs and
neral. Mountains of Salt, as from the great Number of Salinas and Shibkas, that are one or other to be met with in everyDiftrict. The Wed el Mailab near the weftern Frontiers of the Kingdom of $A l$. giers, and the Serratt upon the eaftern; the Hammam Mellwan, nine Leagues to the S.S.E. of Algiers; the Salt River of the Beni Abbe/s, which runneth through the Beeban; that of the Urbyah,

\footnotetext{
I Non quicquid Libyces terit

Fervens area meffibus.

Frumenti, quantum metit Africa.

Poffideat Lybicas meffes.

2 Vid. Not. 1. p. 220.
}

Senec. in Thycft.

Hor. Sat. 1. 2. Sat.3.

Mart. Epigr. 1. 6.86. 
near the Tittery Dofb; that from Fibbel Woofgar, in the Neighbourhood of Conftantina; the Mailah, that falls into the Shott over againft Me/feelah; the Bareekah, as It paffes by Nickowve; and the River of Gor-bata, upon the Confines of the Fereed; thefe, I fay, befides feveral leffer Rills and Fountains, are all of them either very falt or brackifh. The Water of the River of Gor-bata is made very palatable, by ftrain-

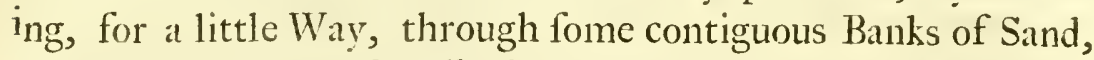
into little Pits, occafionally dug for that Purpofe; but the other Rivers, having deeper Channels and running through a richer Mould, are not capable of the like Filtration. However by long Ufe and Cuftom, the Arabs are very much reconciled to the Tafte; which indeed is not fo extraordinary as the Practice, 1 am told they have, of eating Cakes of Salt, in the Valley of Ao/ in Piedmont.

The Salt Pits of Arzerv lye furrounded with Mountains, The Saline. taking up an Area of about fix Miles in Compass. They appear like a large Lake in Winter, but are dry in Summer, the Water being then exhaled, and the Salts, left behind, chriftalized. In digging, they pafs through different Layers of this Salt; whereof fome are an Inch, others more in 'Thicknefs; in Proportion, I prefume, to the Quantity of faline Particles, the Water was impregnated with, before their refpective Concretions. This whole Area is made up of a Succeffion of fuch Similar Strata, heaped one upon another: and in the fame Manner are the Saline betwixt Cartbage and the Guletta, thofe of the Shott, and of other Places either bordering upon or lying within the Sabara.

Fibbel Had-deff $a$ is an entire Mountain of Salt, fituated The Mountains near the eaftern Extremity of the Lake of Marks. The Salt of Salt. of it is of a quite different Quality and Appearance from That of the Saline, bcing as hard and folid as Stone, and of a reddifh or purple Colour. Yet what is wafhed down from thefe Precipices by the Dews, attaineth another Colour, becoming as white as Snow, and lofing that fhare of Bitternefs, which is in the Parent-Rock-Salt. The Salt of the Mountains near Lwotaiab and Fibbel Miniss, is of a grey or blewifh Colour; and, without fubmitting to the like accidental Purification, as

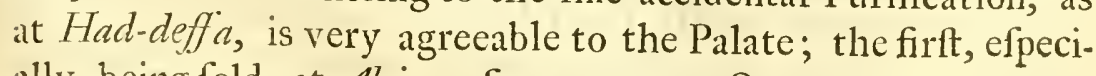
ally, being fold, at Algiers, for a penny an Ounce. 
Of the like Quality and Flavour is the Salt of the Lake of Marks, (called likewife Babirah Pharaoune, and of other lefier Plains of the fame Nature. Thefe are ufually called Sibkab or

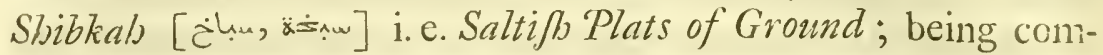
monly overflowed in Winter, (at which Time they appear like fo many extenfive Lakes) but are dry all Summer, (when they may be taken for the like Number of Bowling Greens prepared for the Turf.) Some of thefe Shibkas have a hard and folid Bottom, without the leaft Mixture of gritty Mould, retaining the Salt that lyeth chriftalized upon Them after Rain. But others are of a more owzy abforbent Nature, feldom preferving any faline Incruftations upon the Surface. The chief Subfratum of the Shibkab El Louv-deah is like a teffellated Pavement, made up of various little Cubes of common Salt; but in thofe Shibkas, that are of a foft and owzy Compofition, as near Warran and Kairwan, I could never obferve any Salt that was concreted, though the Earth of them all is very pungent to the Tongue, and, by a proper Solution, would yield, no doubt, a copious Portion of It.

The Mutlod of preparing
Salt Petre.

I have feen fome large Pieces of $\mathrm{Sal}$ Gem brought from the Country of the Beni Mezzab; but Salt Petre called (Mailab [s] baij) Live Salt by the Arabs, is never, that I know, found in Subftance or concreted, being always extracted by Art. For which Purpofe, They erect feveral Troughs of Brick or Stone, with wooden Grates for their Bottoms; and after having covered the Infides all over with Mats of Palmeta or Spartum, They fill them with Salt Petre Earth; fprinkling It every fix or eight Hours, for five or fix Days together, with Water. The Water, by foaking through the Earth, engageth all the nitrous Particles lodged in It's Way, and, draining afterwards through the Mats, falls into fmall Cavities, made on Purpofe below to receive It. When they have by this Means obtained a fufficient Quantity of Brine, they pour It into Caldrons, boyl it up and refine it. There are feveral Works of this Kind in Tlem-fan, Bifcara and Kairwan, befides others that are carried on privately among the Kabyles and Arabs. The principal Ufe that is made of Salt Petre thus prepared, is in the

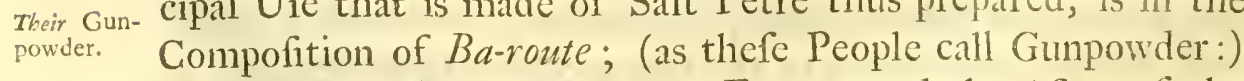
the Sulphur being moftly from Europe, and the Afhes of the [Burvak] Kings Spear, being rather chofen than Charcoal. 
They are well enough inftructed in the Art of graining It; though fomething is ftill wanting, either in the Ingredients themfelves, or in the Proportions of them; one Ounce, from our Powder Mills, being equivalent to more than a Quarter of a Pound of that which is made in this Country.

Befides the feveral Springs and Rivulets, I have here enume- Ticir Hot,

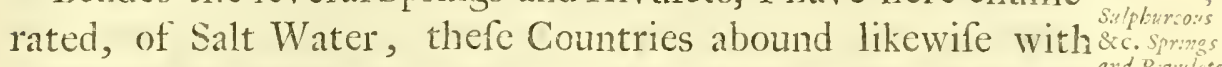
Thofe that partake of Sulphur and other Minerals. In which Clafs (befides the Ain Kidran, that hath been already mentioned '; and the Hamdh, a rich Spaw Water or Acidula near the River Bifhlsef.; ;) we may place the feveral Hammams", as They call the Thermce of This Country. The Ain el Houte, and the greateft Number of the Springs of the Fereed, are little more than lukewarm; but Thofe of Seedy Ebly, Warran, Hammaice, Meliwan, Agreefe, Elelma, El Hammah, and the lower Bath at Mereega, are of a more intenfe Heat, and very proper to bathe in; whilt the Hammam Meskouteen, and the upper Bath at Mereega, are much too hot for that Intention; the former boy ling a large Piece of Mutton very tender in a Quarter of an Hour.

The Ain el Houte, and the Springs of Gafsa and Tozer nou- The 2ality rifh a Number of fmall Filhes, of the Mullet and Perch Kind, ters. and are of an eafy Digeftion: of the like Quality are the cther Wraters of the Yereed; all of them, after they become cold, being the common Drink of the Inhabitants. That particularly of El Hammah is perfectly clear and tranfparent, being withal as foft to the Palate as Rain Water: unlefs therefore the fulphureous or other Effluvia, that It is fuppored to be charged with, do cafily fly off, all the great Virtues afcribed to the bathing in It, can confift only in their genial Heat, and in the Promotion that is thereby occafioned of a copious Perfpiration.

Befides the ftrong fulphureous Steams of the Hammam of the HamMeskouteen ${ }^{3}$, we are to obferve farther of them, that their Wa- man Merter is of fo intenfe a Heat, that the rocky Ground it runs over, to the Diftance fometimes of a hundred Foot, is diffolved or rather calcined by it. When the Subftance of thefe Rocks is foft and uniform, then the Water by making every

I Viz. p. 84. 2 From whence our Humums. 3 Vid., p. 122. perhips from cir.w filere.

$$
\mathrm{Mmm} 2
$$


Way equal Impreffions, leaveth Them in the Shape of Cones, or Hemifpheres; which, (being fix Foot high and a little more or lefs of the fame Diameter,) the Arabs maintain to be fo Stepprfea to be many Tents of their Predeceffors, turned into Stone. But a pertifyed
Durwar, when thefe Rocks, befides their ufual foft chalky Subftance, contain likewife fomeLayers of harder Matter, not fo eafy to be diffolved, then, in Proportion to the Refiftance the Water is thereby to meet with, we are entertained with a Confufion of Traces and Channels, diftinguifhed by the Arabs into Sheep, Camels, Horfes; nay, into Men, Women and Children, whom they fuppofe to have undergone the like Fate with their Habitations. I obferved, that the Fountains which afforded this Water, had been frequently ftopped up: or rather, ceafing to run at one Place, broke out immediately in another: which Circumftance feems not only to account for the Number of Cones, but for that Variety likewife of Traces, that are continued from one or other of thefe Cones or Fountains, quite down to the River Zenati.

Thes roonadbc- This Place, in riding over It, giveth back fuch a hollow low thefe Forizo. Sound, that we were affraid every Moment of finking through It. It is probable therefore that the Ground below us was hollow: and may not the Air then, which is pent up within thefe Caverns, afford, (as we may fuppofe, in efcaping continually through thefe Fountains, ) that Mixture of fhrill, murmuring and deep Sounds, which, according to the direction of the Winds and the Motion of the external Air, iffue out along with the Water? The Arabs (to quote their Strength of Imagination once more) affirm thefe Sounds to be the Mufick of the [fenoune] Fairies, who are fuppofed, in a particular Manner, to make their Abodes at this Place, and to be the grand Agents in all thefe extraordinary Appearances.

The incrufa- There are other natural Curiofities likewife at this Place.

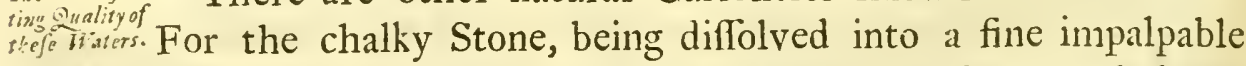
Powder and carried down afterwards with the Stream, lodgeth Itfelf upon the Sides of the Channel, nay fometimes upon the Lips of the Fountains themfelves; or elfe, embracing Twigs, Straws and other Bodies in It's Way, immediately hardeneth and thoots into a bright fibrous Subftance, like the Asbeftos, forming Itfelf, at the fame Time, into a Variety of glittering Figures and beautiful Chriftalizations

The 
The Water of the Hammam Mellwan, is not only remark- of the Hamable for being very brackifh and highly difagreeable to the ${ }_{\text {wan }}^{\text {man }}$, lellPalate, but alfo for being vaftly ponderous. The Water of the lower Bath at Mereega, is of an infipid Tafte when cold, Mereega, and would not evaporate, by an ordinary find Heat. The upper one, which is rarely cleanfed, befides tinging with a rufty Colour the Walls and whatever elfe It refteth upon, is full of a tawny ochre-like Sediment, and may pafs therefore for a Bath of the Chalybeat Kind, though the Water, a Week only after I took It from the Fountain, (for I had no Inftrument to examine It upon the Spot) would not anfwer to the Experiment of the Galls. However, whether the Baths of Mereega, El Hammah and Leef, (the three principal ones of this Kingdom) El Hammah contain any or no latent mineral Qualities and Efluvia, yet they are reforted to from all Parts, keeping up the Credit and Reputation at leaft, of being very beneficial in removing the Rheumatifm, Jaundice, and Diftempers of all Complexions.

The Rivulet of El Hammah and others in the Fereed, have The Situation their Sources in large extenfive Plains, far removed from any of thefe Baths. confiderable Chain of Mountains: and as little or no Rain falls in thefe Diftricts, This Circumftance feems to be no fimall Teftimony in Favour of that Syftem, which deduceth the O. rigine of Fountains from the great Abyfs. The Wells, which I have taken Notice of, in Wadreag ${ }^{\text {, }}$, feem likewife further to confirm It. The Situation of Capfa to the Weftward, is under the Shade of very high Mountains, though the Springs are in the eaftern Part of the City, at fome Furlongs Diftance. The Baths of Leef, Gurbos, Hammaite, Warran, and Mellwan, are each of them at the Bottom of a high Mountain; thofe of Mereega and Ain el Houte are about the Middle; whilft the Situation of the Hammam Meskouteen, of the Baths of Elelma, and Seedy Ebly, is in uneven Ground, neither plain nor mountainous, though inclining rather to the latter.

The Weight of theWater of the Hammam Mereega is to That The Hydroof Rain Water, as 836 is to 830 ; that of Warran as 837 : that of their Water. of Meskouteen as 850; and that of Mellwan as 910. I had no Convenience or Opportunity of weighing the reft.

Befides the hot mineral Effuvia that are continually dif- of the Eartb-

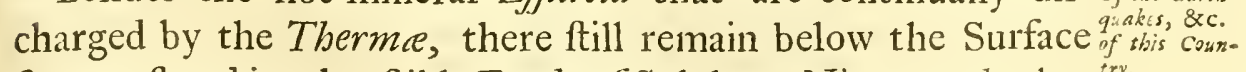
fome vaft and inexhauftible Funds of Sulphur, Nitre, and other ${ }^{t r y}$. I Vid. p. 135 . 
inflammable Bodies; of which, the Frequency and Violence of the Earthquakes of this Country, may be a fufficient Proof. The Earthquakes Ann. 1723 and I 724, thook down a Number of Houfes, and clofed up the Courfe of feveral Fountains: but by one of thefe violent Concuffions An.1716, a large Patch of Ground at Wamre, lying in an eafy Defcent, with a Well, a few Trees and a Farm-Houfe upon It, glided down, all together, for the Space of a Furlong, 'till they were one or other of them ftopped by the Channel of the Harbeene. Several of the Breaches, together with fome Pieces of the Houfe turned upfide down and lying at a Diftance from each other, are, to this Day, ftanding Monuments of This Cataftrophe. I was alfo informed, that the like Accident happned, at the fame Time, in fome of the mountainous Diftricts near Boujeiah and ElKhadarah. The great Shock in Ann. I724, was perceived from Miliana to Bona; the Air being then very clear and temperate, and the Quickfilver ftanding at the greateft Height; whilft, upon Enquiry, other Concuffions were only found to be local or of fimall Extent, the Quickfilver in thefe Cafes obferving no certain Period, and the Air being, as at other Times, either calm or windy, hazy or ferene.

Earthquakes

Earthquakes have been alfo felt fometimes at Sea. An. I724. when I was aboard the Gazella, (an Algerine Cruifer of fifty Guns, bound to Bona to renew the Garrifon) we felt three prodigious Shocks, one after another, as if a Weight, at each Time, of twenty or thirty Ton, had fallen, from a great Height, upon the Ballaft. This happened when we were five Leagues to the N.N.W. of the Sebba Rous, and could not reach Ground with a Line of two hundred Fathom. The Captain, Hafan Rice, told me, that a few Years before, he felt a much greater, at the Diftance of forty Leagues to the Weitward of the Rock of Lisbon.

The ufulatTime

The Earthquakes, during my ftay at Algiers, fell out geneThe ufualTime
of thake Earth-rally, a Day or two after a great Rain', at the End of the
arakes.

Summer or in the Autumn. The Caufe perhaps may arife from the extraordinary Conftipation or Clofenefs of the Surface at fuch Times, whereby the fubterraneous Steams will be either

I The Inhabitants of Famaica expect an Earthquake every Year; and fome of them think they follow their great Rains. Sir Hans Sloame's Introd. to the Hint. of Fambaica. P. 44. Phil. Tranf. 209. P. 77 . 


\section{Objervations \&r.}

fent back or confined; whereas in Summer, the whole Country being full of deep Chinks and Chafms, the inflammable Particles have an eafier Efcape.

We cannot trace any of the preceeding Phenomena, (or fcarce No 2uarrie any other Branch of the Natural Hiftory) much lower than the Surface. Thofe Quarries of Marble ' which are taken Notice of by the Antients, are not known at prefent; and indeed the finall Quantity of Marble that appears to have been made ufe of in the moft fumptuous Buildings of this Country, would induce us to believe, that either there never were fuch Quarries, or that the Marble was fent away to other Places. For the tha Stone made $^{\text {Tha }}$ Materials that are made ufe of in all the antient Edifices of $u f=0$ of in antithis Country, at Fol Cefarea, Sitifi, Cirta, Carthage \&c. are not much different, either in their Colour or Texture, from the foft and harder Kinds of the Heddington Stone near Oxford.

The Wells (except in Wadreag and fome other Parts of the тhe Layers of Sabara) are rarely of any great Depth; and, in digging them, I have often obferved, that after the Soil is removed, they pafs through feveral different Layers of Gravel, and fome. times, though rarely, of Clay, 'till they arrive at a foft fleaky Stone, Kind of Stone, the fure Indication of Water. When there is neither Soil nor Gravel, as in feveral Places near Algiers and Bona, this fort of Stone lyeth immediately upon the Surface, being frequently very beautifully guilded all over with Gold- Gold and sillike-Spangles; as the SparryMatter, which filleth up the Fiffures, ver-likeSpanglittereth with Thofe that imitate Silver. I could not learn that cither Agates or Stones of the like Beauty and Confiftence, were Natives of this Country. Even the common Flint Stone, which moft other Nations have in Plenty, occurreth fo very feldom in fome Parts of Barbary, that our Merchant Veffels have received fome of them in the Downs for Ballait, and difpofed of them at Algiers for feven Shillings the Quintal.

The Selenites, which fometimes fpreads Itfelf over whole Acres of the woody and mountainous Diftricts. a tranfparent Theselenites, ftriated, yellow and flefh coloured Talk or Gypfium, that lyeth ${ }_{T_{\text {all }} \text { and }}$ often expanded, in thin Cakes, over the rocky Parts of the Gyprum. Sabara; fome chriftal-like Irides or Briftol-Stones, found in Irides. the Mountains of Boujeiab; the dark-coloured double-coned Double-coned Chryftals from Zibbafs and Ellou-leejah; with a Variety of Chryftats.

I Exc. p. 21. cap.3. p. 23. cap. 26. \&:c.

$\mathrm{Nnn}_{2} \quad \mathrm{Cawk}$ 
Spars. Cawk and figured Spars; are the neareft Approaches, that the mi. neral Juices of this Climate can make, towards the Topaz and the Diamond.

The Earths. Neither have I had the good Fortune to meet with a Number or Variety of the Foffils of other Claffes. Thofe that are not primitively fuch, but owe their Origine to the Deluge, (fuch as are Foffil Shells, Sea Urchins, Corals \&c.) will be enumerated in a particular Catalogue. Of the proper Foflils there. fore; befides the common Mould or Soil that hath been al-

Pipe ond

Potter's

Clay.

Fuller's

Farth.

Soap Earih. ready treated of, there are two or three Kinds of Pipe and Potters Clay, the former of which generally burns red. Cimolia likewife or Fuller's Earth, is dug in great Abundance; where. unto we may joyn the Steatites, or Soap Earth, that is in great Efteem in the Bagnios for the cleanfing ' and foftning of Lac Lunx. the Skin. Steinomarga or Lac Lune, which the Arabs fometimes make ufe of in the ftaunching of Blood, lyeth ufually in the Sutures of fome laminous Rocks in the Sabara: whilit a

Umbre, Ochre, $\mathrm{Al}$ magra $\measuredangle c$.

The Minerals.

Talk. Micæ. coarfe Sort of Umbre and Ochre, with a hard Species of Almagra or Spanifb Bole, more frequently occur in the Tell.

The Minerals that I have difcovered, are ftill fewer in Number than the Earths; among which we may reckon a few Species of Talk, and the Gold and Silver-like Micre abovementioned. Some of the latter are found in great Quantities: and when they occur without any Mixture or Alloy of Talky or Selenitical Subftance; they are ufed, inftead of Sand, for the abforbing of Ink, by the Hojias or Writers of this Country. In pounding the Gypjum, we often meet with a Number of fmall Gold-likeNodules, not unlike, in Figure, the RegularBodics (as they are called) of the Mathematicians. But the Gold and Silver-like Marcafites or Pyrites of Zibbafs, Ellou-leejals and pyrites. Medea, are in no regular Form, being fometimes globular; fometimes in the Shape of the Mefentery, Kidney or fuch like Figures, as they ufually affume in other Places. I have Black Lead. a good Specimen of the Nigrica Fabrilis or Black Lead, which was taken up under the Walls of Gibraltar, and fuppofed to have been brought thither, from the Barbary Coaft, by theCurrent. The Oars and Lead and Iron are the only Metals that have been hitherto Metals. difcovered. The latter is white and good, though in no great
Iron.

Quantity, being dug and forged by the Kabyles of the moun1 Of this Kind probably and for this Ufe, were the two Mules Burrhen of Eartis. 2 Kings 5.15. tainous 
tainous Diftricts of Bou-jeiah; and brought, in fhort Bars, to the Markets of that Place, and Algiers. They have a great Plenty of the Oar upon the Mountains D wee and Zikkar. That of the latter is rich and ponderous, with a Mixture fometimes of Cinnaber; though no Works have been carried on, as far as I could be informed, at either of thefe Places. The Lead Oars at Fibbel Ri/-Sa/s near Hammam Leef, at Lead. Wannaforeefe, and among the Beni Bootaleb, are all of them very rich; and might certainly be obtained in great Quantities, provided their Mines were under a better Regulation. The Method they have to refine It, is by putting Layers of Wood and Oar alternately upon each other; and fetting the Pile afterwards on Fire, they will frequently extract, by thefe Means, eighty Pounds of Metal from one Quintal of the Oar.

The Silver and Copper Mines of the Tingitanians are looked ${ }_{\text {No }}$ Copper upon with an envious Eye by the Regencies of Algiers and Mines bitherTunis; though poffibly their own Mountains, by further Searches and Experiments, may be found to contain the like Materials. About thirty Years ago, the Deys of Algiers were encouraged, by fome Spanifls Renegadoes, to fearch for Silver Oar in the Mountain of Fernan. They would probably have Sune $_{\text {copper- }}$

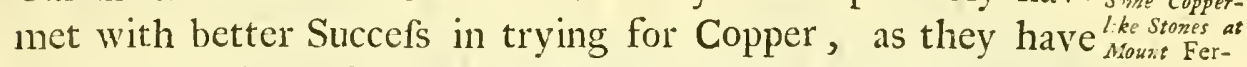
here feveral large Strata of ponderous Stones, tinged all over ${ }^{\text {nan, }}$ with green Efflorefcences. One of the Specimens, that I brought with me from that Place, feems alfo to fhoot into no fmall Quantity of Tin Grains. The Mountain likewife of and Tmolga. Tmolga abounds with Stones of the fame Quality with the former; being, in all Appearance, very ftrongly impregnated with Copper. But as none of thefe Oars (if they be really fuch) have been put to the Teft, a fimall Share only of fuch Riches, as may be called fubterraneous, can be claimed by thefe Regencies. For the Story, they are pleafed to tell, of Mabomet a good crop Bey's Plowflares, is applicable enough to This Branch of the the PlilcfoNatural Hiftory I am now explaining. This Perfon, (whom It thy o connhave had Occafion, more than once, to mention in the Kingdom of Tunis, had the Misfortune to be dethroned by his Subjects; but having the Reputation of being acquainted with the [ $[+\cdots=]$ Kymia, (as thefe People call the Philofopher's Stone, Ibrabim Hojiah, then Dey of Algiers, engaged to reftore Hin to His former Dignity, upon Promife of being let into the

$$
\text { O o o Secret. }
$$


Secret. The Matter was accordingly agreed upon, and Małsomet was reftored; who to fulfill His Covenant with the Dey of Algiers, forthwith fent Him, with great Pomp and Ceremony, a Number of Mattocks and Plowhares; thereby emblematically inftructing the Algerine, that the Wealth of His Kingdom was to arife from a diligent Attendance upon Agriculture and Husbandry; and that the only Philofophers Stone He could acquaint Him with, was the Art of converting a good Crop into Gold.

策

\section{H A P. II.}

\section{Of the Quadrupeds, Birds, Infects, Finhes $\sigma^{\circ}$.}

$c_{a^{2} t l e}$, the $\mathrm{S}$ the principal Riches of the Bedoween Arabs, no lefs chief Riches of this Country.

be cftimated from the Number ${ }^{x}$ and Quality of their Cattle, I fhall begin the Hiftory of the Animals of this Country, with the Defcriptions of fuch of them, as are domefticated, and therefore of more general Ufe to Mankind.

The Horfe. The Horfe formerly the Glory and diftinguifhing Badge of Numidia, hath of late Years very much degenerated in thefe Kingdoms; or rather the Arabs have been difcouraged from keeping up a fine Race, which the Turkifb Officers were fure at one Time or other to be the Mafters of. At prefent therefore the Tingitanians and Egyptians have juftly the Reputation of preferving the beft Breed, which no longer than a Century ago, they had only in common with their Neighbours. A valuable and well taught Barbary Horfe (befides the fuppofed Quality of never lying down, and of ftanding quiet, when the Rider quits him, by dropping the Bridle,) is to have a long Pace, and to ftop fhort, if required, in a full Carreer: the firft Quality fhewing the Goodnefs and Perfection of the Horfe, and a proper Management of the latter, the whole Dexterity and Addrefs of the Rider. No other Motions are either

I And Abraham was very rich in Cattle. Gen. I3. 2. and 5. Aind Lot alfo whibly svent with Abraham, had Flocks and Herds. Job's Sulftance was feven thoufand Sheep, and three thoufand Camels, and five hundred yoke of Oxen, and five bundred She AjJes \&c. Job I. 3. and 42. I2. Familix aliquot cum mapalibus pecoribufque fuis (ca pecunia illis eft) perfecuti funt Regem (Mafaniffam) cxtera Maffyliorum multitudo in ditionem Spplasis conceffit. Liv. 1. 29. S. $3 \mathrm{r}$.

practifed 
practifed or admired in this Country; it being accounted very impolite among the Arabs to trott and amble. But the Egyptian Horfes have defervedly the Preference of all others for Size and Beauty; the fimalleft of which are ufually fixteen Hands high, and all of them fhaped, according to their Phrafe, [Kiff el Gazel Jijilis] like the Antilope.

The Afs and the Mule are the moft hardy Creatures of Bar-Tbe Afs and bary, not requiring half fo much Attendance as the Horfe. The the Mule. firft is not fo generally trained up for the Saddle at Algiers as at Tunis, where they are frequently of a large Size; but the Mule is in general Demand at both Places, and preferred to the Horfe for common Ufe and Fatigue. It is certainly furer footed and vaftly ftronger in Proportion. I could never learn that the Mule was prolific; which Notion Pliny and fome other Authors feem to give into.

To the Mule we may joyn the Kumrah, as, I think, thefe ${ }_{T \rightarrow k}$ Kumrah. People call a little ferviceable Beaft of Burthen, begot betwixt an Afs and a Cow. That which I faw was fingle hoofed like the Afs, but diftinguifhed from It in all other Refpects, having a fleeker Skin, and the Tail and Head (excepting the Horns) in Fafhion of the Dam's.

Yet all thefe are vaftly inferiour to the Camel for Labour The Camel. and Fatigue. For this Creature will travel four ${ }^{2}$ or five Days together without Water; and half a Gallon of Beans and Barley, or elfe a few Balls made of the Flower, will nourifh It for a whole Day. This I faw often experienced in our Way to Mount Sinai; notwithftanding the Burthen of each Beaft was at leaft feven Quintals, and our Days Journey confifted fome. times of ten, fometimes of fifteen Hours, at the Rate of two Miles and an half an Hour. Thefe extraordinary Qualities, are, without Doubt, fufficient Encouragements for the Arabs of all Places to keep up and multiply the Breed: which, I have been

I Eft in annalibus noftris, peperiffe fepe (mulam) rerum prodigii loco habitum. Theophraftus vulgo parere in Cappaducia tradit: fed effe id animal ibi fui generis. Plin. 1. 8. cup. 44. 2 Sitim \& quatriduo tolerant (Camcli) implenturque, cum bibendi occafio eft, $\&$ in præteritum \& futurum, obturbaca proculcatione prius aqua: aliter potu non gaudent. Plin. Nat. Hift. 1. 8. cap. IS. At the Top of the fecond l'entricle (of the Dromedary) there ivere feveral fquare Holes, wobicb were the Orifices of about twenty Civities, made like Sicks placed between the two Membranes which compose the Subfance of this Venticle. The View of thefe Sacks made us think that they might well be the Refervatory's where Pliny fays that Camels do a long time keep the Water, which they do drink in great Abundance when they meet with it, to fupply the Wants wbich they may have thereof in the dry Deferts, where they are ufed to travel. Memoirs for the Natural Hiftory of Animals ofc. by the Academy at Paris. 
informed, is equal at leaft, if not fuperiour in Number to the other Beafts of Burthen already mentioned:

The Naihary, That Species of the Camel-kind, which is known to us by

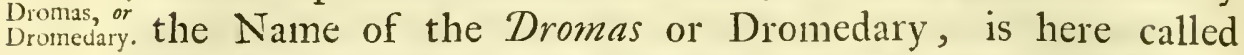
Maibary $_{a}$; though it is much rarer in Barbary than in the Levant. It is chiefly remarkable for It's prodigious Swiftnefs; the Arabs affirming, that It will run over as much Ground in one Day, as one of their beft Horfes will perform in eight or ten. The Shekh who conducted us to Mount Sinai rode upon a Camel of this Kind, and would frequently divert us with an Inftance of It's great Abilities. For He would depart from our Caravan, reconnoitre another juft in View, and return to us again in lefs than a quarter of an Hour. It differeth from the common Camel in being of a finer and rounder Shape, and in having upon It's Back a leffer Bunch or Protuberance.

The Came searetb in the lefs in all the other Seafons, become unruly in the Spring, the The Males of the Camel-Kind, from being tame and harmufual Time when they follicit the Females. Their Familiarity is generally in the Night, in the fame Manner with Creatures of the Cat-Kind: the Sheath of the Penis (in thefe, no lefs than in other Animals that reft a long time together upon their lower Belly) being then brought forwards, which, at other Times, Nature hath thrown backwards for the more convenient Difcharge of the Urine. The Females are pregnant near a whole Year, or from one Spring to the other; and the young Dromedaries, I am told, are blind, like Kittens or Puppies, feveral Days after their Birth.

The Black Cattle.

After the Beafts of Burthen, we are to defcribe the Black Cattle of this Country, which are generally very fmall and flender; the fattelt of them, when brought from the Stall, rarely weighing above five or fix Quintals. Neither is their Milk in Proportion to their Size: for notwithftanding the rich Herbage of this Country from December to $\mathcal{F}_{u}$ ly, the Butter hath never the Subftance or Richnefs of Tafte with what our Englifb Dairies afford us in the Depth of Winter. Abdy Bafbaw, the late Dey of Algiers, was no lefs furprized than His Minifters,

I Afabah rapporte que le Chameau dir Almabares ou de Mabral cft ainfi nommé a caufe

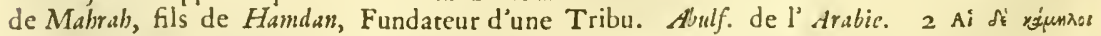

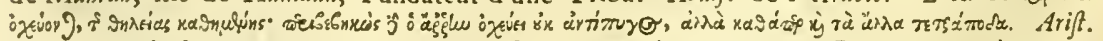
Hift. Animal. 1.5. cap. 2. Aliter fed male fcribit Plinius !. 10. cap. 63. Coitus (inquit) averfus elephantis, camelis, tigridibus, \&c. quibus averfa genitalia. Idcmi dicit Solinus. Cap. 40. 
when Admiral Cavendifh, a few Years ago, acquainted Him, that He had a Hampfire Cow aboard the Canterbury, (then in the Road of Algitrs, ) which gave a Gallon of Milk a Day: a Quantity equal to what half a dozen of the beft Barbary Cows would yield in the fame Time. The Barbary Cattle likewife have another Imperfection, that they always lofe their Calves and their Milk together.

The Sheep and the Goats contribute alfo to the Dairies of The Shecp this Country; it being chicfly of their Milk, that the Moors and Arabs make Cheefe. Inftead of Runnet, they make ufe, (in the Summer Seafon particularly, ) of the Flowers of the great headed Thiftle or wild Artichoak, to turn the Milk; putting the Curds, thus made, into fmall Baskets of Rufhes or Palmeta, and binding them afterwards and preffing them. I have rarely TheirCheefe, feen any of thefe Cheefes above two or three Pound Weight, being ufually of the Shape and Size of a Penny Loaf; fuch perhaps, as we may fuppofe thofe ten to have been, which David' carried, with other Provifions, to the Camp of Saul. They have no other Method of making Butter than by putting and Butter: their Milk or Cream into a Goat's Skin ; which, being fufpended from one Side of the Tent to the other and preffed to and frô in one uniform Direction, quickly occafioneth that Separation which is required of the unctuous and whayie Parts.

The Goat is the fame with that of other Countries; but rbe broadThey have two Sorts of Sheep, which are not known in Eu- ${ }^{\text {tailed Sheep. }}$ rope. One of them, which is common all over the Levant, as well as the Kingdom of Tunis, is noted for a broad Tail, which endeth in fome of Them in a Point, but, in others, continueth broad quite down to the Bottom. The Mutton of this Species tafteth generally of the Wool: neither hath It the tender Fibres of the fmaller tailed Sheep: yet the Tail itfelf is greatly efteemed in their Cufcafowes and Pilloes, confifting of a hard folid Fat, not inferiour in Tafte to Marrow. The The Sheep of $^{-}$ other Species, which is bred in the Neighbourhood of Gaddemz, ${ }^{\text {the Sahara }}$ Wurglah, and other Places of the Sabara, is near as tall as our Fallow Deer; and, excepting the Head, not much different in Shape. The Heat of the Climate, the Scarcity of Water, with the Coarfnefs of the Herbs they feed upon, may be the Occafion perhaps, why their Flefh is dry to the Palate, and their Fleeces are as coarfe and hairy as the Goats.

I I Sam. 17. 18. P P p

A 
A Gelding among the Horfes, or a Weather among the Sheep, is rarely if ever known in this Country. For fuch Males of Sheep or of the Black Cattle, as are more than fufficient for the Prefervation of the Species, have, when they are about three Months old, their Tefticles only fqueezed or difcompofed; the Mabometans accounting it an Act of great Cruelty, to caftrate any other Creatures, except thofe of their own Species.

The N:mber

Befides the great Variety of the Cattle of this Country, we

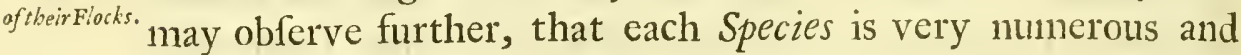
prolifick. Several Arabian Tribes can bring into the Field only three or four hundred Horfes, at the fame Time they are poffeffed of more than fo many thoufand Camels, and triple again that Number of Sheep and Black Cattle. The Arabs rarely kill any of their Flocks, living chiefly upon their Milk and Butter, or elfe upon what they get in Exchange for their Wool. Such Cattle likewife, as are brought to the neighbouring Towns and Villages, are a very inconfiderable Number, when compared with the yearly Breed and Increafe. By proper Care therefore and Attendance; nay if thefe numerous Flocks and Herds had Shelter only, during the Winter Seafon, from the Inclemency of the Weather, this whole Country, in a few Years, would even teem and be over-run with Cattle.

Of Cattle that are not naturally tame and domefticated, el Walls, or soild Cattle. thefe Kingdoms afford large Herds of the Neat Kind, called Bekker el $W a f b^{\circ}$ by the Arabs. This Species is remarkable for having a rounder Turn of Body, a flatter Face, with Horns bending more towards each other than in the tame Kind. It is therefore, in all Probability, the Bos Africanus of Bellonius", which He feems juftly to take for the Bubalus of the Antients; though, what He defcribeth, is little bigger than the Caprea or Roe Buck, whereas ours is nearly of the fame Size with the Red-Deer, with which alfo. It agreeth in Colour. The young Calves of this Species quickly grow tame, and herd with other Cattle.

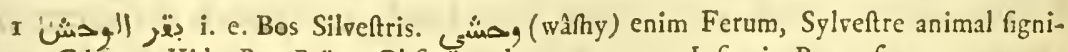
ficat. Gol. 2 Vid. Ret. Bellon. Obferviat. 1. 2. cap. 50. Infignia Boum ferorum genera, jubatos Bifontes excellentique \& vi \& velocitate Vros, quibus imperitum vulgus Bubalorum nomen imponit, cum id gignat Africa, vituli potius Cervive quadam fimilitudine. Plin. 1.8. cap. 15. Uros imperitum vulgus vocat Bubalos, cum Bubali pene ad cerrinam faciem in Africa procreentur. F. Solin. Polyhilt. cap.32. 
The Arabs place likewife among the Bekker el Wafh, a Theri Deer. Species of the Deer-Kind, which hath the Horns exactly in the Fafhion of the Stags, but is in Size only betwixt the Red and Fallow Deer. Thofe, which I have feen, were caught in the Mountains near Skigata, and appeared to be of the fame mild and tractable Nature with the Bekker cl Wa/s. The Female, having no Horns, is called in Derifion, [Fortafs wib, $]$ ] The Broad Scalp, or Scalld Head.

The Fifltill or Lerwee, is the moft timorous Species of the Tí Fintrall: Goat-Kind, plunging Itfelf, when purfued, down Rocks and ${ }^{\text {or Lerwee. }}$ Precipices. It is of the Bignefs of an Heifer of a Year old; but hath a rounder turn of Body; with a Tuft of fhagged Hair upon the Knees and Neck; this near aFoot, the other only about five Inches long. It agreeth in Colour with the Bekker elWafl; but the Horns are wrinkled and turned back like the Goats; from which likewife they differ in being more than a Foot long, and divided only, upon their iffuing out of the Forehead, by a fmall Strip of Hair as in the Sheep-Kind. The Fi/btâll, from It's Size, Shape, and other Circumftances, feems to be the Tragelaphus' of the Antients; an Animal, we are to fup- Tbe Tragelapofe, fuch as this is, betwixt a Goat and a Deer. Pliny in $-^{\text {phus. }}$ deed obferveth that It was peculiar to the Banks of the Pha/ts; a Miftake probably of the fame Kind with what immediately follows, that the Stag was not an Animal of Africa.

Befides the common Gazell or Antilope, (which is well The Gazell $_{\text {. }}$ known in Europe, ) this Country likewife produceth another ${ }^{\text {or Antilope. }}$ Species, of the fame Shape and Colour, though of the Bignefs of our Roe-Buck, and with Horns fometimes of two foot long. This the Africans call Lidmee, and may, I prefume, be the The Lidme, Strepficeros ${ }^{2}$ and Addace of the Antients. Bochart, from cerors, axt the fuppofed Whitenefs of the Buttocks, finds a great Affinity betwixt the Addace ${ }^{3}$, I have mentioned, and the [יישי $]$ Difon, which, in Deut. I4. 5. our Tranflation renders the Pygarg, after the Septuagint and Vulgate Verfions.

I Eadem eft Specic, (cum Cervo fc.) barba tantum \& armorum villo diftans, quem Tragelaphon vocant, non alibi, quam juxta Phafin amnem, nafcens. Cervos Africa propemodum fola non gignit. Plin. 1. 8. cap.33. 2 Cornua erecta, rugarumque ambitu contorta, $\&$ in leve faftigium exacuta (ut Lyras diceres) Strepficeroti, quem Addacem Africa appellat, natura dedit. Plin. I.Ir. cap. $27.3 \mathrm{~A}$ cincreo nempe colore, qui Hebreis $\boldsymbol{W}_{7}$ Difen dicitur. Boch. Hieroz. 1.3. cap. 2.

\section{P p p 2}


The Bekker el Wafls and the Gazell Kinds, are both of them gregarious, having the like Habit, in running, ftopping on a fudden, and facing the Purfuers. The Haunts alfo of them both are the fame, being for the moft Part upon the Confines of the Tell and Sahara. Gazell [ $[\mathrm{J}, \dot{\mathrm{l}}]$ is improperly interpreted by Bochart and others ", either the Hart, or the Fawn, It being always underftood, both in the Levant and in Barbary, of that Animal, which we call the Antilope.

The Lyon and Among the Quadrupeds of a lefs tameable Nature, we may Panther. give the firft Place to the Lyon and the Panther; the Tyger not being a Native, of thefe Parts at leaft, of Barbary. The Females of both Species have two Rows of Nipples like a Bitch, giving Suck to three, fometimes to four or five Whelps at a Time. The Arabs affirm, that when the little ones breed their Teeth, they are feized with a Fever, which generally carries off three in four: and that This is the Reafon, why their Numbers are fo inconfiderable at prefent. But whe. ther This is owing to fuch Difeafes, or to a greater Difperfion of the Arabs, or perhaps, fince the Invention of Fire Arms, to the much eafier Way of killing them; whatever I fay may be the Caufe, it is certain, there would be great Difficulty at prefent, to procure a fiftieth Part of the Number of wild Beafts, that Africa may be fuppofed to have formerly contributed to the Diverfions of Rome ${ }^{2}$.

The Lyon not afraid of $W_{0}-$ men.

I have read in fome Defcriptions of this Country, that the Women can be familiar with the Lyon; and that, upon taking up a Stick and calling Him (Ta-hoanne) Cuckold and fuch like Names, He will immediately lofe his Fiercenefs and fly from the Flocks they are attending. Something perhaps of this Kind may happen when they have been well fatiated with Food: at which Time, the Arabs tell us, the Lyons lofe their Courage, and that they can feize upon their Prey, and refcue It out of their Jaws. But thefe Inftances are very rare; it

I Caprex hinnulus غز Gazal Arabice dicitur (vulgo Gazella) ut Hebraice bil in Ponurrio \& Chaldaice אורו inferto R, ut paffim, \& prima gutturali Ajin in Aleph mutato. Boch. Hieroz. ibid. cap. Is. Nomen Gafel, five CERVR (equo impofitum.) Kempf. Amrnit. Exot. Fafc. 2. 2 Lconum fimul plurium pugnam, Rome Princeps dedit 2 . Screvola P. filius in curuli Edilitate. Centum autem jubatorum primus omnium L. Scylla, qui poftea Di\&ator fuit, in Prxtura. Poft eum Pompeius Magnus in Circo DC. in ijs jubatorum cccxv. Cafar Dictator cccc. Capere eos, ardui erat quondam operis, foveifque (ut \& nunc eft) maxime. Plin. 1. 8. cap.I6. Scaurus Edilitate fua Varias (i. e. Pantheras) centum quinquaginta univerfas (in Romam) mifit: dein Pompeius Magnus quadringentas decem: Divus Auguffus quadringentas viginti. Id. ibid. cap.17. 
oftner falling out, that Women as well as Men, have been ro of Fire. devoured for Want of other Creatures. Fire is what they are moft afraid of; and yet notwithftanding all the Precaution of the Arabs in this Refpect, notwithftanding the Barking of theirDogs, together with their ownCrys and Exclamations, all the Night long, it frequently happens, that thefe ravenous Beafts, out-braving all thefe Terrors, will leap into the Midft of a Douwvar, (where the Cattle are enclofed in the Night) and bring out along with them a Sheep or a Goat. If thefe Ravages The may of are repeated, then the Arabs, obferving where they enter, dig there a Pit, and, covering it over flightly with Reeds, or fmall Branches of Trees, in this Manner frequently decoy and catch them. The Lyon's Flen is in great Efteem, being fomewhat like Veal in Taft or Flavour. The Diftinction of Animals feems to have been little known or attended to by the antient Romans, when, according to an Obfervation of Lipfuns ${ }^{\mathrm{r}}$, they called the Lyon a Bear, and the Panther a Rat of Africa.

The Faadh [ $\left.\mathrm{Ur}^{\mathrm{G}}\right]$ agreeth with the Leopard in being fpotted, The Faadh, but differeth in other Refpects. For the Skin is not only of a deeperColour but alfo much coarfer; neither is theCreature Itfelf of fo fierce a Nature. However the Arabs imagine It to be a fpurious Offspring betwixt a Lyon and a Leopardefs. It feeds; as I have been informed, upon Carrion, fometimes upon Roots and Herbs, like the Deeb and the Dubbah, and muft be in great Neceffity when It attacks a Sheep or a Goat. It can then be fcarce taken for the ๑ĩs or Lupus Cervarius of the Antients, which is defcribed to be a much fiercerCreature: the Chamus ${ }^{2}$ or Chamus. of Pliny feeming better to agree with it.

There are two other Animals of this Country, that are The leffer marked like the Leopard, only their Spots are generally of ${ }^{\text {Panther. }}$ a darker Colour, and the Fur fomewhat longer and fofter. The firft is of the Cat-Kind, about one third lefs than a full grown Leopard, and may be taken for a Species of the Lynx, or rather, for the leffer Panther of Oppian.

I Peregrina cum ad Romanos advehebantur, ftupebant : \& nomen ijs dabant non fuum fed obvium aliquod \& e vicino fuo rure. ** Ita Pantheras vocarunt Mures, ut opinor, Africanos ** Tale in Leonibus eft. Cum primum vifi, non Leones externo eos nomine infignierunt, fed noto \& domeftico Urfos. * Virgilium quidem, dum Aceftem tegit-Pelle Libyfidos urfe, certum mihi intellexiffe Lconinam \&c. Vid. F. Lipf. Eleet. 1. 2. cap. 4. 2 Pompeij magni primum Ludi oftenderunc Chaum, quem Galli Rhaphium vocabant, cffigie lupi, Pardorum maculis. Plin. 1.8. cap.19. 
The Shibear- The other hath a fmall pointed Head, with the 'Teeth, dou, or Spa- Feet, and other Characterifticks of the Weefel-Kind. The Body is about a Foot long, round and flender, with a regular Succeffion of black and white Ringlets upon the Tail. 'This, as well as the IcTneumon, fearcheth after Poultry, and, provided It were tamer (as It is fometimes well fcented) we might take It for the Ginetta; though the Creature, I am defcribing, is fmaller, having alfo a finer Shape and fharper Nofe, than That which hath been defcribed by feveral Authors'. Gefuer fuppofeth the Ginetta to be a Species of the Thôs or Leffer Panther of Oppian; whereas the Marks left us by the Antients of the Former, are fo various and undetermined, that it will be difficult to reconcile them to any certain Family: whilft the Leffer Panther, befides being (as it may be prefumed) of the Cat-Kind, muft ftill be thought a more formidable Creature than This, which is lefs than a Foxe's Cub, according to His own Defcription ${ }^{3}$. Some of the Moors call the Animal I am fpeaking of [Gat el Ber-rany, the frange or foreign Cat; and others Shib-beardou.

The Dubbah, The Dubbah is about the Bignefs of a Wolf, but of a flatter or Hyena. Body, and naturally limpeth upon his hinder right Leg. Yet notwithftanding this Imperfection, it is tolerably fwift, and cannot be fo eafily run down as the wild Boar. The Neck of It is fo remarkably ftiff, that in looking behind or fnatching obliquely at any Object, it is obliged to move the whole Body, in the fame Manner with the Hog, the Badger, or Crocodile. It is of a buff or dun Colour, inclining to be reddifh, with fome tranfverfe Streaks of a dark brown; whilt the Hair upon the Neck is near a fpan long, though much fofter than the Briftles of the Hog. The Feet are large and well armed, ferving to lay open (in want of other Food) the Cephaglione or young Shoots of the Palmeta, to dig up the Roots of Plants, and fometimes the Graves of the Dead; which, particularly among the Bedoweens, are not fecured by either Walls, Trenches or Inclofures. When any of thefe Creatures are ta-

1 Vid. Gefnl. de Quadrup. p. 549, 550. Fonft. de Quadrup. Cap. 12. Raiij Synopf. Animal. Quadıup. P.20I. 2 Quærendum an genus aliquod tit Thois vel Pantheris Minoris quorum meminit Oppiamus. Conveniunt enim magnitudo, maculre, ingenium (nam \& Pantheraminoren innoxium effe Oppianus fcribit) \& ufus pellium ad veftes pretiofus \& infuper odor fuavis. Gefn. ut fupra. 3 Genetha vel potius Genetta aut Ginetta (Genocha apud Albertum perperam) elt beftia paulo major (minor, Alber. \& recte) vulpecula \&c. Id. ibid.

ken, 
ken, the Arabs are very induftrious to bury the Head, leaft the Brain, according to their Superftition, fhould be made ufe of in Sorcery and Enchantment. After the Lyon and Panther, the Dubbab is the fierceft of the wild Beaits of Barbary; which, from having a Mane, moving It's Neck with Difficulty, and difturbing the Graves of the Dead ', may lay in a greater Clain to be reckoned the Hycena of the Antients, than theCivetCat, which is fpotted and no Native of this Country; or the Badger, which is a leffer Animal, and not known, as far as I have heard, in Barbary.

The Deeb [ $4: \dot{j}$ ] or Fackall [lis Chathal] is of a darker The Dheep, Colour than the Fox, and about the fame Bignefs. It yelps every Night about the Gardens and Villages, feeding, as the Dubbah doth, upon Roots, Fruit and Carrion. Mr.Ray ${ }^{2}$ fuppofeth it to be the Lupus Aureus of the Antients: but what Oppian defcribeth as fuch, is of a much fiercer Nature ${ }^{3}$.

The Gat el Khallah, SiyahGhu/h, or Karrah Ku-lak, (i. e. The ${ }_{\text {The Back- }}$ Black Cat, or Black-ear'd Cat, as the Arabick, Perfian and Turkifh Names fignify,) is of the Bignefs of a Cat of the largeft Size. The Body is of a reddifh-brown, the Belly of a lighter Colour and fometimes fpotted, the Mouth black, the Ears of a deep grey, with the Tips of them diftinguifhed, by fimall Tufts of black ftiff Hair, as in the Lynx. The Figure given us of this Animal by Charleton ${ }^{4}$, is very different from the Barbary Siyah Ghu/h, which hath a fuller Face and black Chops, though in other Refpects it is exactly fhaped like a Cat.

This Animal, no lefs than the Fack all, hath been fuppofed to find ${ }^{n o t}$ the ${ }_{\text {on' }}$ Proviout Prey for the Lyon, and is therefore commonly called the der. Lyon's Provider; though it may be doubted, whether there be any fuch friendly Intercourfe betwixt two fuch different Creatures. In the Night time indeed, when, (agreeable to the $\mathrm{Ob}$ fervation of the H. Pfalmint's all the Beafts of the Forreft do move, Thefe, in like Manner with other Kinds, are prowling

I Hyanam quoque mittit Afria, cui cum fpina riger, collum continua unitate flecti ne-

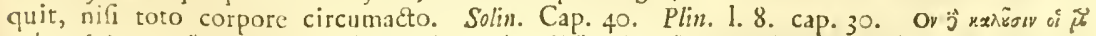

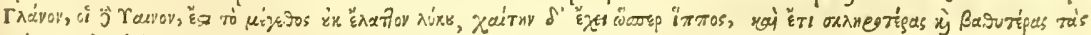

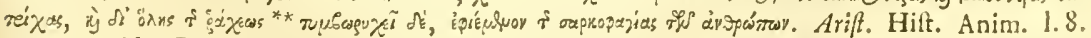
cap. 5. Vid. Boch. Hieroz. 1.3 cap. xI. 2 Vid. R.aij Synopf. Animal. p. 174.

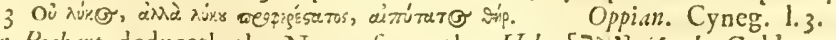

However Bochart deduceth the Name from the Heb. [Jirl] Laab, Gold. 4 Vid. Charl. Exercit. P. 23 . 5 P . $104.20,2$ : and 22. 
after Suftenance; and when the Sun arifeth, and the Lyon get. teth bimfelf away to bis Den, both the Siyah Gbu/b and the Fackall have been often feen gnawing fuch Carcafles, as the Lyon is fuppofed to have fed upon the Night before. This and the promifcuous Noife, which I have frequently heard the Fackall (at leaft) to make with the Lyon, are the only Circumftances I am acquainted with in Favour of this Opinion.

The Jird and

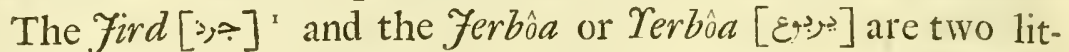
Jerbôa. the harmlefs Animals, which burrow in the Ground. They chiefly frequent the Sabara, though I have often feen the latter in the Neighbourhood of Warran. Each of them is of the Bignefs of a Rat, having their Bellies white, but their Bodies of a Sorrel Colour. The Ears likewife of them both, are round and hollow; agreeing with the Rabbit, in the $\mathrm{O}_{1}$ der of their Fore-teeth, and in the Briftles of their Chops. But they differ in other Refpects; for the Head of the Fird is fomewhat pointed, and covered all over with Fur; whereas the Noftrils of the Ferboa are flat and naked, lying nearly in the fame Plain with the Mouth; wherein it differeth from Thofe which have been brought from Aleppo, and are defcribed by $\mathrm{Mr}$. Haym $^{2}$. All the Legs of the Fird are nearly of the fame Length, with each of them five Toes; whereas the Fore-feet of the Barbary Ferboa are very fhort and armed only with three. The Hinder-feet are of the fame Length nearly with the Body, with each of them four, befides two Spurs, as we may call the little Toes that are placed at more than the Diftance of an Inch above them. The Tail of the Fird, though a little fhorter than in the common Rat, yet is better cloathed: whilft that of the Ferboa is as long as It's Body, of a yellowifh Colour, with a black annular Tuft near the Extremity. They are both good to eat: and the latter, notwithftanding the great Difproportion betwixt the fore and hinder Feet, runs or rather jumps along with an extraordinary Swiftnefs; the Tail, which It carrieth for the moft part erect or occafionally reclined, contributing all the while to the Regularity of the Motion.

I Bochart (Hieroz. 1. 2. p. 249.) renders it the Great Morfc. 2 Vid. Nic. Hirym. Teforo Britannico. Vol. 2. 


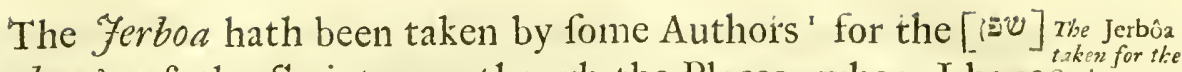
Sapban ${ }^{2}$, of the Scriptures, though the Places, where I have Sapphan; feen their Burrows, have never been among the Rocks; but either in a ftiff or loamy Earth, or elfe (where their Haunts ufually are) in the loofe Sand of the Sabara. Where there is any Tuft of reedy Grafs, Spurge, Lawrel, or other Plants peculiar to the Sabara, there efpecially we are fure to find the Ferboa. That very remarkable Difproportion betwixt the fore and hinder Legs of this Animal, (though I have never obferved It to run, only frequently to ftand upon the latter) probabbly thos

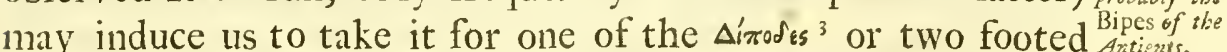
Rats of Herodotus, and other Authors.

Befides the Creatures above mentioned, Barbary alfo pro- Some ather duceth others which it hath more in common with other Places. Antis countity. Such is the Bear, [or Dubb ${ }^{4}$, the Ape, [or Sheddy, the Ichneumon, [or Tezer-dea,] the Porcupine, [or Tzur-ban's, the Hedge-Hog, [or Kun-foode viis] the Fox, [or Thaleb ciles'] the Ferret, [or Nimfe,] the Weefel, [or Fert el Heile,] befides the Mole, the Rabbit, the Hare and the wild Boar, which are every where in great Numbers. The Lyon is fuppofed to prey chiefly upon the latter, which notwithftanding hath fometimes been known to defend Itfelf with fo much Bravery, that the Victory hath inclined to neither Side, the Carcaffes of them both having been found lying dead together, all in Gore and mangled to Pieces.

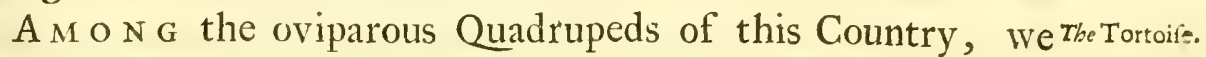
are to reckon the Land and Water Tortoife; the latter of which hath a flatter Body, and is unwholefome to eat. The Taitab $^{6}$, Bouiah or Chamreleon, may be difcovered by a good Teen. Eye, upon every Hedge. The Tongue is four Inches long,

I Vid. Boch. Hicroz. 1.3. cap.33. 2 The High Hills are a Refuge for the will Goats, and fo are the Stony Rocks for the [Saphliannim $\square$ שפ] Conies. Pf. ro4. 18. The Conies [ Saphannim] are but a feeble Folk, yet make they their Houses in the Rocks. Prov. 30.26.

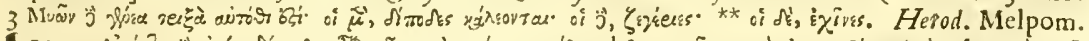

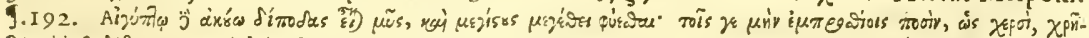

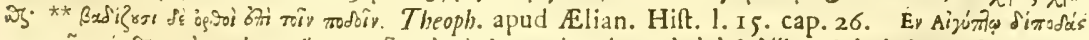

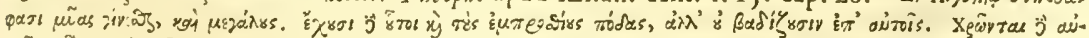

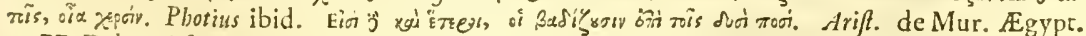
427 Dab. Urfus. Cus Dabila enim Arabice eft pilofam habese faciem, unde us Dab facici pili \& villi \&c. Boch. Hicroz. 1.3. cap.9. S (a (a concuffu jactuve. $\mathrm{B}$ of the many Porcupines I have feen in Africa, I never knew any one, thougl very much provoked, that would dart it's Quills; their ufual method of defence being to incline themifelves on one Side, and, upon the Enemy's near Approach, to rife up quickly and gore bin with the other. 6 Vid. Boch. Hicroz. 1. 4. cap. 4.

Rrr

and, 
and, in Shape, like a common Peftle, which it darts with a fur. prizing Swiftnefs upon Flies and Infects; retaining them afterwards by a glutinous Matter, occafionally excreted from the Tip of It. The Moors and Arabs, after they have dried the Skin, fufpend it upon their Bofoms to prevent the Infiuence of an evil Eye. The Taitah differeth not much in Name from the הeל Letaa, Tie Warral. which in Lev.I I. 3. is rendred theLizard. The [J,j] Warral, or Guaral, according to Leo', is a Lizard fometimes thirty Inches in Length; being ufually of a bright reddifh Colour, with darkifh Spots. Vanfleb ${ }^{2}$ very ferioufly affirms It to be ingendered from the rotten Eggs of the Crocodile.

The Dab. The [u:i]Dhab or Dab, another Lizard taken Notice of likewife by $\mathrm{LeO}^{3}$, agreeth nearly in the Shape and in the pointed Annuli or Scales of the Tail, with the Candiverbera, as it is reprefented in $G e f n e{ }^{4}$ and Fonfton. Tfab [Js] ${ }^{5}$ the correfpondent Word in the Hebrew Language, is tranflated (Lev. Ir. 29.) the Tortoije.

TheZermou- This Climate alfo produceth the common green Lizard, mealh. which differeth not at all from thofe of Europe. The Zermoumêth is no lefs common in the Hedges and High Ways; being a flender long tailed Lizard, of a light brown Colour and ftriated from Head to Tail, with three or four Streaks of Yellow. Thaskink, or The Skink (of the Shops) frequently hideth Itfelf under flat Scincus. Stones, or elfe in the Holes of old Walls and Ruins. In the like Situation (though they often come into Houfes, even fo far The Nije-dai as to crawl over Beds, ) may be found the Nije-daimah, or Boomah, $k a-\rho a j h$, which is of a dark Colour, feven or eight Inches long, with a flat Head and Body, and the Tail like the Dab's. I have often obferved, that whatfoever Wall, Floor or Ceiling this Animal refteth upon, It will beat it with It's Tail; a Circumftance that may induce us to take It for the Candiverbera orUromartix. or Uromaftix of fome Authors ${ }^{6}$. The Warral alfo, in running upon the Ground, ufeth the like Action; whilft the Arabs gravely tell us, that what Perfon foever is touched by one of the Vibrations, will become barren and unfruitful.

T н $\mathrm{E}$ moft remarkable Species of the Serpent Kind, is the

I F. Leo. Defcript. Africa. 1. 9. p. 297. 2 Vid. I'an/leb's Prefent State of Egypt. P. 47. 3 Vid. F. Leo ut fupra. $4 \mathrm{Gefn}$. de Quadrup. Ovip. p. 23. Fonf. Hir. Quadrup. Tab. LXXIX. 5 Boch. Hicroz. 1. 4. cap. I. 6 Vid. Not. 4. 
Thaibanne:, probably the Thebanus Ophites of the Antients. The ThaibanI have been informed that fome of them are three or four banus OphiYards long, approaching the neareft, of this Family, to that monftrous one which is faid to have been killed by Regulus ${ }^{2}$. I have feen fome Purfes, made of their Skins, which were four Inches or more in Diameter.

The Zurreike, another Serpent of the Sahara, is ufually a.TheZurreike; bout fifteen Inches long. It is of a flender Body, and, being remarkable, as the Name ' feems to infinuate, for darting Itfelf along with great Swiftnefs, may perhaps be the Faculus ${ }^{4}$ of the Antients.

The mont malignant of this Tribe, is the Leffah, which is Tise Leffah, of a lefs uniform Turn of Body than the Zurreike, and rarely above a foot long. The burning (torrida) Dipfas, as Lucan calls it, anfwereth very well both to the Names and Quality of the Leffah.

The Arabs report, that there is the fame Antipathy betwixt The Antipathe Leffah and the Taitah, which hath been ${ }^{6}$ long ago affign- thy betwixt ed betwixt the Chamæleon and the Viper; and that a little Bouiah. Drop of clammy Juice let fall by the latter upon the Leffah, will throw It into fuch violent Convulfions, as are attended with immediate Death.

I s defcribing the more curious Birds of Barbary, we may TbeKaraburadd, to the Eagle Kind, The Karaburno; an Afh-coloured Hawk of the Bignefs of our Buzzard, with a black Bill, red Iris, yellow fhort Feet, the Back of an Afh or fordid blew Colour, the Pinions of the Wings black, with the Belly and Tail whitifh.

The (Graab el Sabara) Crow of the Defert, is fomewhat Theredlegged bigger than our Raven; and from the rednefs of the Feet and Crow or $P_{\mathrm{yy}}$ Bill, may perhaps demand the Title of the larger Coracias or Pyrrbocorax.

The Shaga-rag, is of the Bignefs and Shape of a Fay, The Shaga* though with a fmaller Bill, and fhorter Legs. The Back is ${ }^{\text {ra }}$ brownifh; the Head, Neck and Belly, of a light green; and

I Pluribus ille notis variatam tingitur alvum

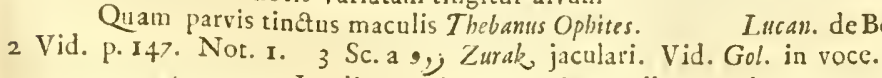

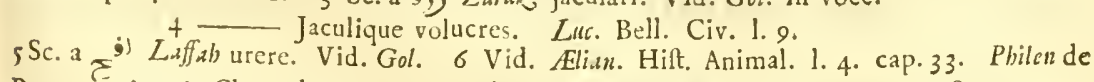
Propr. Annir. in Chamæleonte. Scalig. ad Cardanum de Subtilit. apud Gefra. ut fupra.

$\operatorname{Rrr} 2$

upon 
upon the Wings and Tail, there are feveral Spots or Rings of a deep Blew. It makes a fqualing Noife, and builds in the Banks of the Shelliff; Booberak, and other Rivers.

The Hou-

The Houbaara [or Houbaary $a, 1$ ] is of the Bignefs of a Capon, but of a longer Habit of Body. It feeds upon little Shrubs and Infects, like the Graab el Sabara, frequenting in like Manner the Confines of the Defert. The Body is of a light dun or yellowifh Colour, marked all over with little brown Taches; whilft the larger Feathers of the Wing are black, with each of them a white Spot near the Middle. Thofe of the Neck are whitifh with black Streaks; but are chiefly remarkable for their Length, and for being erected, as in the Ruff and Dung-hill Cock, when It is attacked or prevoked. The Bill is flat, like the Starlings, nearly an Inch and a half long; and the Legs agree in Shape and in the Want of the hinder Toe with the Buftard's. The Gall and the Contents of the Stomach are in great Efteem for fore Eyes, and have been fometimes fold for a great Price. Nothing can be more entertaining than to fee this Bird purfued by the Hawk; and what a variety of Flights and Stratagems It is obliged to make ufe of in Order to efcape. Golius mifinterpreteth Hoobaary, in calling It the Buftard; which anfwereth indeed in Colour, in the Habit of Body and in the Number of Toes, but differeth, in being twice as big as the Bird I am defcribing.

The Rhaad, The Rhaad or Saf-faf, is a granivorous and gregarious Bird, or Saff-faf. which wanteth the hinder Toe. There are two Species of It; the fmaller whereof is of the Size of an ordinary Pullet, but the larger is near as big as the Hoobaara, differing alfo from the leffer in having a black Head, with a Tuft of dark blew Feathers immediately below It. The Belly of them both is white, the Back and the Wings of a buff Colour fpotted with brown, whilft the Tail is lighter, marked all along with black tranfverfe Streaks. The Beak and the Legs are ftronger than in Birds of the Partridge Kind. Rbaad ', which denoteth Thunder in the Language of this Country, is fuppofed to be a Name that hath been given to This Bird, from the Noife It maketh in fpringing from the Ground; as $S a f-\int a f^{2}$, the other Name,

I Sc. a ua Rabad tonuit. 2 exese, tranflated Paffer only by Golius, is not unlike in Name to the Sachaph or Sah-haph, which Lev.11. I6. we render the Cuckow. 


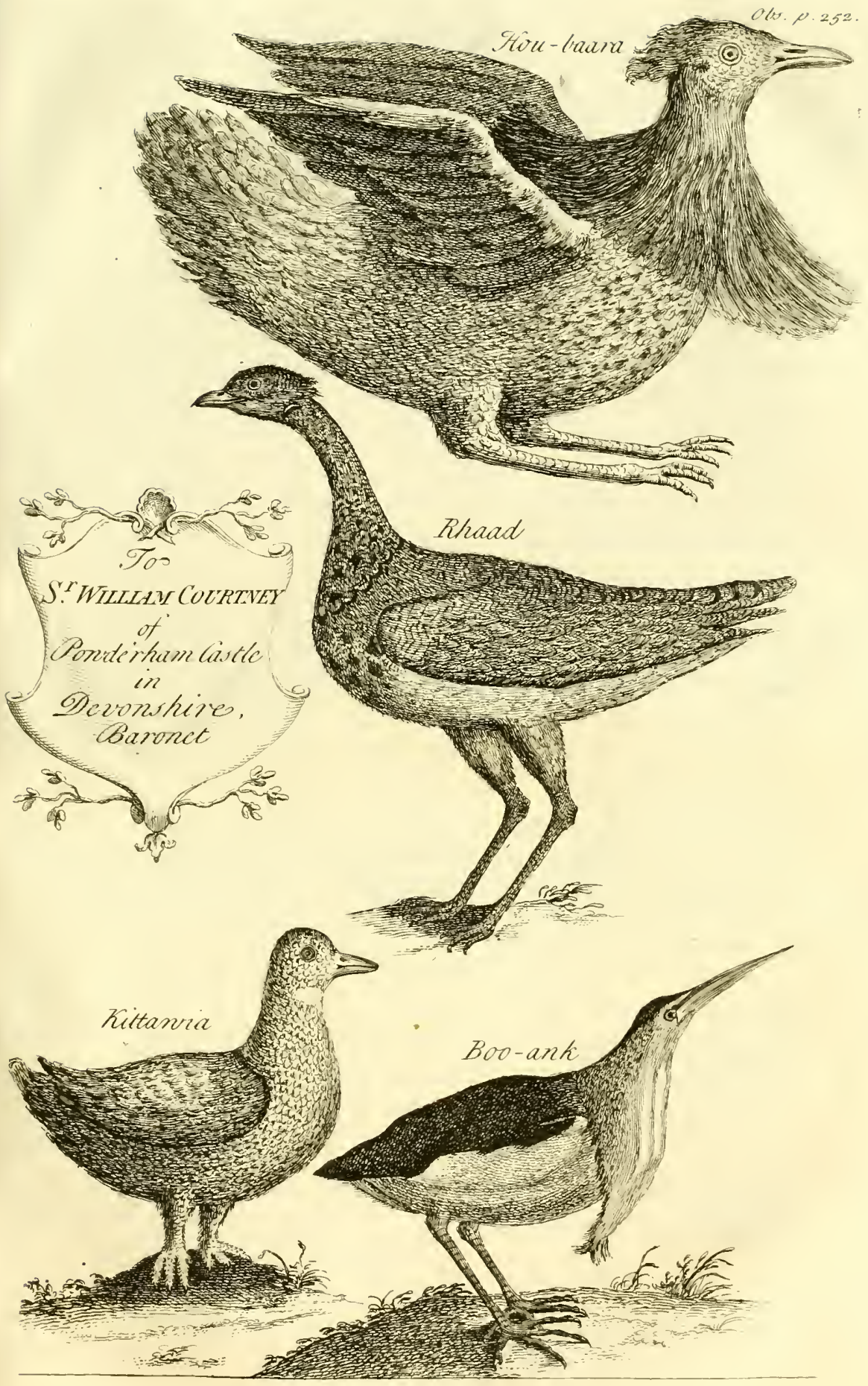





\section{Objervations \&c.}

very naturally exprefleth the beating of the Air, when It is got upon the Wing.

The Kitawiab or African Lagopus (as we may call It) is The Kitawianother Bird of the gregarious and granivorous Kind which like- ah, or Lago wife wanteth the hinder Toe. It frequenteth the moft bar. ${ }^{\text {nus. }}$ ren, as the Rbaad doth the more fertil Parts of thefe Countries, being in Size and Habit of Body like the Dove, with fhort feathered Feet alfo, as in fome Birds of that Kind. The Body is of a livid Colour, fpotted with black; the Belly blackifl; and, upon the Throat, there is the Figure of an half Moon in a beautiful Yellow. The Tip of each Feather in the Tail, hath a white Spot upon It, and the middle one is long and pointed, as in the Merops. The Flefh is of the fame Colour with the Rhaad's, red upon the Breaft and white in the Legs, agreeing further, in being not only of an agreeable Taft, but eafy Digeftion.

The Barbary Partridge is the fame with the greater, or red $T_{\text {Partridge, }}$ or legged Partridge, already known to our Naturalifts:. But Partridge, or there is a Species of the Quail Kind, that differeth from the ordina- $T$ he Quail. ry one, in having no hinder Toe, and in being of a lighter Colour. Both of them are Birds of Paffage; as is likewife the Woodcock which maketh It's firft Appearance in October and continueth 'till the March following. The Africans call it [Uجح Jl, Hammar el Hadjel] The A/s of the Partridges.

Among the leffer Birds we may place a Species of the Thrufh the Greets Kind, not inferiour to the American Birds in the Richnefs of ${ }^{\text {Thrufh. }}$ It's Plumage. The Head, Neck, and Back are of a fine light Green, the Wings of a Lark Colour, the Breaft white and fpotted like the 'Thrufh's, the Uropygium or Rump of an elegant Yellow, and the Extremity of the Feathers upon the Tail and Wings, tipped with the fame Colour. If we except the Feet, which are florter and ftronger, It agreeth in the Fafhion of the Bill, and in the whole Habit of Body with the Thrufh. This Bird is not very common, appearing only in the Summer Months, when Figs are in Seafon.

To the little thick billed Birds, we may add the Capfa Tbe Capfa Sparrow, which is as big as the common Houfe Sparrow, and as often feen in the Date Villages, to the weftward

1 Vid. Raij Synop. Avium. p. 57. 
of the Lake of Marks, as the latter is in other Places. It is all over of a Lark Colour, excepting the Breaft, which is fomewhat lighter, and fhineth like That of a Pigeon. This Bird hath an exceedingly fweet and melodious Note, infinitely preferable to That of the Canary Bird, or Nightingale. Several Attempts have been made by the Gentry of this Kingdom, to bring It to Kairwan, and other Places: but they have always found it of fo delicate a Nature, as immediately to languifh and pine away upon changing the Climate.

The AlibcoAn $A / b$ coloured Lark is common about Bizerta, and fome other Places.

Waterfowl. Befides fuch Water Fowl as we have common in our own Ifland, I have feen the following Species in this Country.

Tise Barbary The Anas Platyrynchos, or Barbary Shoveler, (as we Shoveler, or Anas Platy-may call It,) is of the Bignefs of a Wigeon. The Feet are rynchos. red, the Bill broad, flat, black and armed with Teeth; the Breaft, Belly and Head are of an Iron Colour, the Back much darker, and upon each Wing there are three contiguous Spots of blew, whitc and green.

The reanecked

The Barbary Shoveler with a lefJer Bill, is a little bigger Shoveler. than the former, having a reddifh Neck, and the Head adorned with a fmall Tuft of tawny Feathers. The Belly is white; but the Back is diverfifyed with a Number of alternate Streaks of black and white. The Feathers of the Tail are pointed, and the Wings have each of them a contiguous black and white Spot. The Tip of the Bill is black, and the Feet blewer than the Wigeon's.

The White Head.

The Black Head.

The Grey lail.
The Barbary broad, thick, blew-billed Duck or White-Head, is of the Bignefs of a Wigeon; of a rufty Iron Colour, except the Head, which is all over white.

The Black Headed Barbary Duck, hath the Wings fpotted like the narrow billed Shoveler. The Bill is of a dark Colour, long and narrow; the Feet are brownifh; the Neck inclineth to be grey; the Back and the Wings are blackifh; and the Belly of an Iron Colour mixed with white.

The Barbary grey Tail, is as finall again, as any of the former Kinds. The Belly is whitifh, the Legs dark, and the Body and Wings of a greyifh Colour. Upon each Wing there is a black and green Spot, bordered round with white.

Thefe 
Thefe with the Teal, Wigeon and other Species of the Duick Brak, the

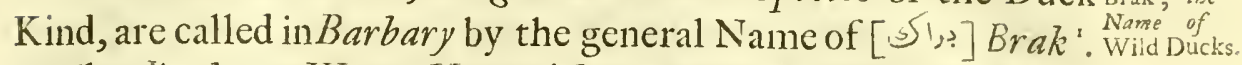

The Barbary Water Hen with a white Jpotted Wing, and Tbe Water dark green Feet, is lefs than a Plover. The Bill is black, an ${ }^{\text {Hen. }}$ Inch and a half long, the Belly and Brealt of a dark brown or rufty Colour, the Back of the fame, though much darker. The Rump is white below, and variegated above with black and white Streaks.

The Barbary Godwit with a white fpotted Wing, is rather Tie Godwit. lefs than the Lapwing, having long black Legs, with the middle Toe indented on each Side. The Bill is four Inches long, brown, though black in the Extremity. The Head is fimall, of a rufty Colour, as is alfo the Neck. The Rump is white; the Back and Wings of a duskifh Colour; and the Breaft fpotted like the Woodcocks.

The Emfeefy or $O x$ Bird is of the Bignefs of the Curlew, The Emfeery. being all over of a milk white Colour, except the Bill and Legs, which are of a fine red. It generally feeds, in the Meadows, along with Cattle, but the Flefh of It is unf:rory and foon corrupts.

The Boo-onk orLong Neck, is of theBitternKind, fomewhat lefs TheBoo-onk. than the Lapwing. The Neck, the Breaft, and the Belly, are of a light yellow; but the Back and upper Part of the Wings are of a Jett black. The Tail is fhort; the Feathers of the Neck long and ftreaked with White, or a light Yellow. The Bill, which, is three Inches long, is green, in Falhion like to the Stork's; and the Legs, which are fhort and flender, are of the fame Colour. In walking and fearching for Food, it throweth out It's Neck feven or eight Inches, from whence the Arabs call It Boo-onk [uisgll] The long Neck, or the Father of the Neck.

I N S E C T and Creatures under that Denomination, are Infects. more numerous than curious; there being few Species which have fallen in my Way, but fuch as are already defcribed by the Naturalifts. Butterflyes, Adderbolts, Beetles \&c. are in a Variety of Shapes, with Wings differently figured and coloured, but which it would be too tedious to enumerate; a Species or two of each Sort may be fufficient.

1 Golius and otbers make 5 th to denote fome particular Bird only of the Duck Kind, contyary to the received Acceptation of it in this Country, for the Family in general. 
The Butterfly The moft curious Species of the Butterfly Kind, is near fou noith Lappet
Wings. very beautifully ftreaked with murrey and yellow. Yet the Edges of the lower Wings are to be excepted, which being indented and ending in a narrow Strip or Lappet of an Inch long, are very elegantly bordered with yellow. Near the Tail there is a Spot of a Carnation Colour.

The troad tailed $\mathrm{Ad}$ derbolt.

The rareft Species of the Libellee or Adderbolts, is one of three Inches and a half long, broad tailed, of a rufty Colour, with bright fpotted Wings. There is another of the fame size, but of a more cylindrical Body, differing little in Colour from the common Locuft.

The Unicon The leaft frequent of the Beetle Kind, is a Species with one Bcetle. Horn, of the Colour and Size of a Chefinut. The Head is notched round or indented, and the Feet are broad like thofe of the Gryllo-Talpa's. The leffer Naficornes are every where met with, as alfo a Diverfity of Elaftic Beetles.

The Mantes. To that Species of Locufts, which are called Mantes by the Naturalifts, I am to add one of three Inches long, of a brown Colour, with the Fore Legs armed with ftrong horny Claws. There is another of the fame Size of the cucullated Kind, which hath the upper Wings ftreaked with a light green, and the membranaceous ones finely chequered with flefh, brown and fcarlet Colours: befides a third Species of two Inches long, with elegant green Wings. But the chief Characterifticks of the latter, are two Antenne, which project, like a couple of Feathers, from the Forehead.

The Locufts. I never obferved the Mantes to be gregarious; but the Locufts properly fo called, which are fo frequently mentioned, by facred as well as prophane Writers, are fometimes fo beyond Expreffion. Thofe which I faw Ann. I724. and 1725 . were much bigger than our common Grafshoppers, having brown Theirffrlt Ap- - fpotted Wings, with Legs and Bodies of a bright yellow. Their pearanse. firft Appearance was towards the latter End of March, the Wind having been for fome time foutherly; and in the Middle of April their Numbers were fo valty increafed, that in the Heat of the Day, they formed themfelves into large Bodies, appeared like a Succeffion of Clouds, and darkened the Thelaying and Sun. About the Middle of May, when their Ovaries were hatching of
their Eggs. turgid, each of Thefe Bodies began gradually to difappear, re- 
tiring into the Mettijiah, and other adjacent Plains to depofit their Eggs Accordingly, in the Month following, their young Broods began gradually to make their Appearances; and it was furprizing to obferve, that no fooner were any of them hatched, than they immediately collected themfelves together, each of them forming a compact Body of feveral hundred Thir $N$.mYards in Square: which marching afterwards directly forward, Marseches. climbed over Trees, Walls and Houfes, eat up every Plant in their way, and let nothing efcape them. The Inhabitants, to ftop their Progrefs, made Trenches all over their Fields and Gardens and filled them with Water ; or elfe placing in a Row great Quantities of Heath, Stubble, and fuch like combuftible Matter, they fet them on Fire upon the Approach of the Locufts. But all this was to no Purpofe; for the Trenches were quickly filled up, and the Fires put out by infinite Swarms fucceeding one another; whilft the Front feemed regardlefs of Danger, and the Rear preffed on fo clofe, that a Retreat was impoffible. A Day or two after one of thefe Bodies was in Motion, others were already hatched to glean after them; gnawing off the young Branches and the very Bark of fuch Trees, as had efcaped before with the Lofs only of their Fruit and Foliage. So juftly hath the infpired Writer ${ }^{-}$compared them to a great Army; and obferved, that the Land is as the Garden of Eden before them, and bethind them a defolate Wilderness.

Having in this Manner lived near a Month upon the Ruin Tie cafing of and Deftruction of every Thing that was green or juicy, they arrived at their full Growth, and threw off their Worm-like State, by cafting their Skins. To prepare themfelves for the Change, they clung by their hinder Feet to fome Bufh, Twig, or Corner of a Stone; when immediately, by an undulating Motion ufed upon the Occafion, their Heads would firft appear, and foon after the reft of their Bodies. The whole Transformation was performed in feven or eight Minutes; after which they lay for a fmall Time in a languifhing Condition; but as foon as the Sun and Air had hardened their Wings and dryed up the Moifture that remained upon them after the cafting of their Sloughs, they returned again to their former Voracity, with an Addition both of Strength and Agi-

I Viz. In the firft Part of the fecond Chapter of the Prophet Foel. 
lity. But they continued not long in this State, before they were entirely difperfed, as their Parents had been before, after the laying of theirEggs; and as theDirection of the Marches and Flights of them both was always to the Northward, it is probable they perifhed in the Sea: a Grave, which, according to thefe People, they have only in common with other winged Creatures.

The Locuits Thefe Infects fprinkled with Salt and fryed, are in Tait, not good to eat. much unlike the River Cray-Fifh. The Fews' were allowed to eat them; and Ludolplous ${ }^{2}$ hath an ingenious Differtation,

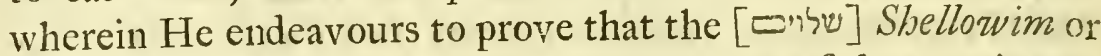
Miftaken for the Quiil.

Axpids: not the Tops of Plants,

6ut Infects.

TibeScorpion.

Quails as we render it, which the Ifraelites fed upon in the Wildernefs ${ }^{3}$, were only a Species of Locufts. But the H.Pfalmift, in calling them Feathered Fowls, feems entirely to contradict that Suppofition. Neither hath any Authority, I prefume, been hitherto produced for taking Axpisss, according to the Greek Name, for the Fruit of the Locuft Tree or the Tops of Plants ; the Name Itfelf being rather derived from the Defire which this Infect hath of living upon Them'. For the Axeists defcribed by Ariftotle and other Hiftorians, are the Locufts I am now fpeaking of: the LXXII always interpreting [חרב : Arbah, by the fame Word; confequently the Writers of the New Teftament may be fuppofed to have taken It in the fame Signification. The Axeiss then, which St. Foln Baptift fed upon in the Wildernefs, were thefe Locufts; and provided their Appearan. ces, in the Holy Land, were at the fame Time I faw them in Barbary, It may be prefumed that St. Fohn entered upon $\mathrm{H}_{i}$ Miffion at that Seafon.

The $[$ Ackrab 4 is] Scorpion, in Confideration of It's noxious Qualities, may claim the next Place after the Locuft. Some of the Species are long and narrow, others of a rounder Shape, and larger; having each of them a Tail confifting of fix Joynts. I never obferved any that had feven, according to what hath been afferted by fome antient Authors?. Thofe on this fide

I Lev.11.22. 2 Viz. in Comment. Hift. Ethiopic. p. 185. \& c. ${ }_{3}$ Exod. 10.13. Numb.11. 31.

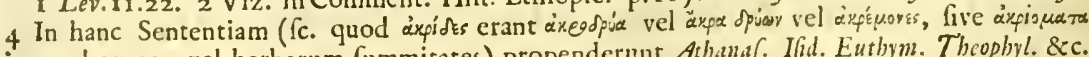
i. e. arborum, vel herbarum fummitates) propenderunt Athanaf. Ifud. Euthym. Thcophyl. \&ec.

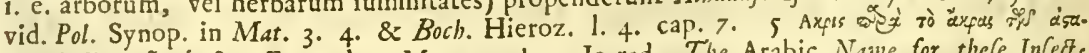

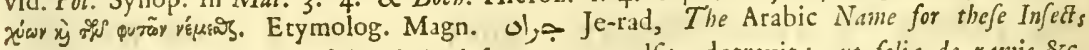
hatb the Same Signification; being derived from 0,7 avulfit, detraxit: "ut folia de ramis \&c. vid. Gol. in voce. 6 Arift. Hift. Animal. 1. 5. cap. 28.7 Conftat \& feptena caudx in-

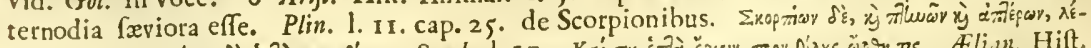

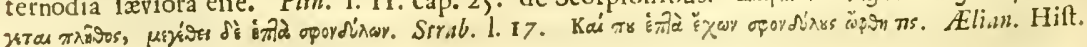
Anim. 1. 6. cap. 20.

Mount 
Mount Atlas are not very hurtful; for theSting being only attended with a fight Fever, the Application of a little Venice Treacle quickly affwageth the Pain. But the Scorpions of Zaab and moft other Parts of the Sabara, as they are generally larger in Body and of a much darker Complexion, fo their Venom is proportionably malignant, and frequently attended with Death.

Of the fame virulent Nature is the Bite of the Boola-kaz, Tbe Boolaa Phalangium of the Sabara, the Rhax probably which Elian obferveth to be an Animal of thefe Parts. It is computed, that twenty or thirty Perfons dye every Year, by the Hurt received from this Animal and the Leffah.

The Method of curing the Bite or Sting of thefe Creatures, is The Remedy either immediately to burn or make a deep Incifion upon thePart, Sting of these or elfe to cut out a Piece of the contiguous Flefh. Sometimes alfo the Patient lyeth buried quite up to his Head, in the hot Sands, or in Pits heated for that Purpofe. When no great Danger is apprehended, then they only apply hotAfhes, or the Powder of Albenna, with two or three thin Slices of an Onion, tying them upon the Part affected, in the Nature of a Cataplafm. I never heard that Oyl Olive was ever made ufe of, which being rubbed warm upon the Wound, has been lately found to be a Specific Remedy againt the Bite (particularly) of the Viper.

If we except a firm and well tafted frefh water Barbel, The Barbel. with only two Appendages on the lower Jaw; the fmall Perch ${ }^{\text {The Perch. }}$ of Capla, with a turned-up Nofe and chequered Fins; a broad ${ }_{\text {The Sea- }}$ Sea Feather, and a fmall Polypus of a circular Figure; there ${ }_{\text {Tee }}^{\text {Feather. }}$ Polypus. are few Species of Filh in thefe Seas but what have been long ago defcribed by Rondeletius, and ftill continue to be taken on the other Side of the Mediterranean Sea. A few Years ago an Orca or Toothed Whale of fixty Foot long, was ftranded $\begin{gathered}\text { Ar } \text { roocha, } \\ \text { Whale. }\end{gathered}$ under the Walls of Algiers; but this was looked upon as fo great a Prodigy, that the Algerines were apprehenfive It might portend fome direful Event to their Polity and Government.

A MONG the Cruftaceous Fifhes, the firft Place is to be Cruftaceous given to the Lobfter, though It is in no great Plenty upon Finb $\begin{gathered}\text { Finters. } \\ \text { Shrimps. }\end{gathered}$ this Coaft. But Shrimps and Prawns, a fmall thin-fhelled Crab, Prawns.

I Ali.m. Hift. Animal. 1. 3. cap. I 36.

$\mathrm{Ttt} 2$

like 
like the broad footed one of Rondeletius, with the Squilla lata Sea Cray (or Sea Cray Fifh) of the fame Author, are brought every Day Fith. to the Shambles.

Sea Eggas The Sca Eggs or Echini are in great Numbers, but in little Variety. I have only feen three Kinds, one of which is of the Pentaphylloid or Spatagus Kind, very beautiful to look upon, but of no Ufe. The other two are more common, fticking to every Rock we meet with. Each of them hath five Sutures, accompanied with feveral concentrick Rows of fmall Knobs; whilft each Knob fupporteth a Prickle of an Inch long in the

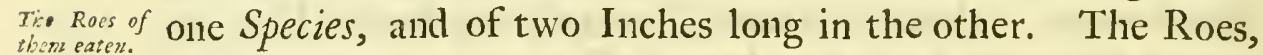
which lye between the Sutures, are the only Parts that are eaten; which, at the Time particularly of the Full Moon when they begin to be turgid, are, after being tempered with Pepper and Vinegar, efteemed as no fimall Dainty by thefe People.

Shell Fifl. Neither is there any great Variety or Plenty of Shell Finh produced upon the Barbary Coaft. The Exuvice indeed of a few Species of Whilks and Flithers, of the Sea Ear, the Spondylus, and a fmooth fhallow Chama, are what we commonly fee lying upon the Shore: whilft the greater Whilk or Buccinum, which is fornetimes eight or ten Inches long; a long narrow Pectunculus; the Mufcle of Mattbiolus; the Concha $V$ Vneris; a large thin ampullaceous Whilk, the $18 \mathrm{th}$ Species of Lifter; and the long-nofed muricated one, the $20 t h$ of the fame Oyfters. Author, may be reckoned among the Rarities. Tunis was formerly well fupplyed with Oyfters from the Haven of Bizerta, but fome copious Rains, which fell a few Years ago in this Neighbourhood, with the unufual Torrents confequent thereupon, are fuppofed, by making the Water too frefh, to have diminifhed the Breed. The Bottoms likewife, not only of the feveral coafting Veffels of Algiers, but of others that continue any Time in the Harbour, are frequently covered with thefe Shell Fifh; yet their Banks could never be difcovered, though, they have been often carefully looked after. This Coaft being no way remarkable for Banks of Sand, makes the Cockle a great The Mufcle. Rarity; but Mufcles are every where common, being the fame with thofe we have in England, without being attended, as ours frequently are, with Crabs or Cancelli. However, provided 
vided the Solitanna, which Varro "tells us contained five Gallons, ftill continued to be a Native of thefe Seas, It would make confiderable Amends, as well for the Want of fome, as for the Scarcity there is in feveral other Species of the teftaceous Clafs of Fifhes.

Thefe are the Obfervations, I have to offer, in Relation to Africa produthe Animals of thefe Kingdoms: in the Courfe of which, fome ferth few Perfons perhaps may be furprized, that they have been fo very little, if at all entertained with an Account of fuch ftrange and wonderful Objects, as might be expected from This Country. Now, in Anfwer to this, it may be obferved, that the natural, and ordinary Courfe of Things is much the fame in Barbary as in other Places; each Species, as far as ever I could be informed, keeping inviolably to Itfelf. For, if we except the Mule and the Kumrah, (which are procreated from Animals under the Direction of Mankind, and therefore not fo properly left to themfelves) few, I prefume, if any other Inftances can be fairly urged in Favour of the old Obferration, That Africa ${ }^{2}$ is always producing fome new Monfter.

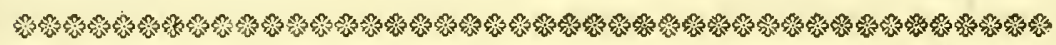

\section{H A P. III.}

\section{Of the Learning, Arts, Manufactures, Habits,}

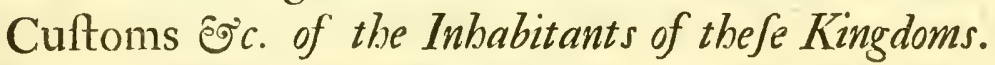

7. $\mathrm{HE}$ liberal Arts and Sciences continue to be, as they Arts and Scis 1 have been for many Ages, in a low State and Condition known or enamong the Mabometans. Philofophy, Phyfick, and Mathematicks, which a few Centuries ago, they had almoft entirely to themfelves, are at prefent very little known among them. The roving and unfettled Life of the Arabs, and the perpetual Grievances the Moors meet with from the Turks, will not permit either of Them to enjoy that Liberty, Quiet, and Security, which have at all Times given Birth and Encourage-

I Ex Africa quare rocantur Solitanne (Cochlex) ita magnx funt, ut in eas 80 quadrantes

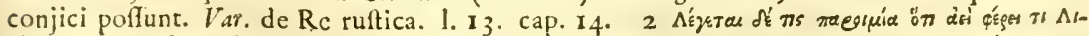
Gin rgavor. Arif. Hift. Anim. 1. 8. cap. 28. Ideo (fc. propter inopiam aquarum ad paucos amnes congregantibus fe feris) multiformes ibi animalium partus: varie fxminis cujufque generis mares, aut vi aut voluptate mifcente. Unde etiam vulgare Grasie dietum, SÉMPER ALICUID NOII AFRICAM AFFERRE. Plin. 1. 8. cap. 16. 
ment to Learning. As for the Turks, they are generally of fuch turbulent and reftlefs Difpofitions, or elfe engage Themfelves fo deep in Trade and in the Improvement of their Fortunes, that they have no Taft at all for Learning, being wonderfully aftonifhed, as they have often told me, how the Chriftians can take Delight, or fpend fo much of their Time and Money in fuch empty Amufements as Study and Speculation.

When the Moorifb and Turkifb Boys (for there is little or Their Metbod
of Education. no Education among the Bedoweens) are about fix Years of Age, they are fent to School, where they learn to read, to write and repeat at the fame Time. They make no Ufe of Paper, each Boy having a thin fquare Board to write upon, which being only flightly daubed over with Whiting, may be wiped off or renewed at Pleafure. After they have made fome Progrefs in the Coran, the principal Book that is taught them, they are initiated, with the like Care, in the feveral Ceremonies and Devotions of their Religion; the Mafter receiving of each Boy for his Trouble and Attendance about a Penny a Week. When a Boy hath laudably acquitted himfelf in any Branch of thefe Inftructions, he is forthwith decked out in the moft fumptuous Apparel, and being mounted upon a Horfe that is richly caparifoned, is conducted by his School-fellows, with Huz:za's, through the Streets; whilft his Friends and Relations are already met together to congratulate his Parents, and to load him with Gifts. After they have been employed at School for three or four Years, they are removed to Trades, or enrolled in the Army; in attending which Occupations, there are very few of Them, except the [Sanjacktars] Enfigns of the Army, and thofe who are employed in collecting the Tribute and Cuftoms, but who quickly forget what they learnt in their Childhood.

Befides their Coran and fome enthufiaftick Comments upon the Coran.

It, very few Books are read or enquired after by thofe few Perfons, of riper Years, who have both Time and L.eifure for Study and Contemplation. All that Variety of Learning which they formerly either invented themfelves, or adopted into their own Language, may be reduced at prefent to a few Sheets of blundering Geography, or to fome tirefome Memoirs of the Tranfactions of their own Times: for fuch Branches of 


\section{Objervations \&c.}

Hiftory as are older than their Prophet, are a Medley only of Romance and Confufion.

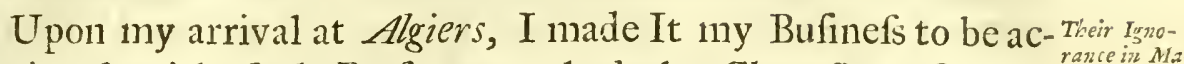

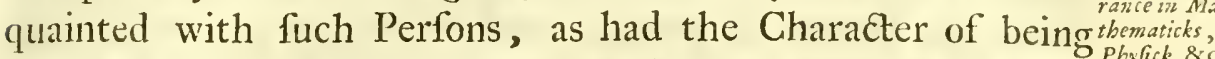
learned and curious; and though it is very difficult, (as well from their natural Shynefs to Strangers, as from a particular Contempt they have for Clriffians, ) to cultivate any real Friendfhip among them, yet in a little Time, I could find the chief Aftronomer, (who hath the Superintendance and Regulation of the Hours of Prayer) had not Trigonometry enough to project a Sun-Dial: that the whole Art of Navigation, as it is practifed at Algiers and Tunis, confifted in nothing more, than what is called the pricking of a Chart and diftinguifhing the eight principal Points of the Compafs. Even Chymiftry, formerly the favourite Science of thefe People, is no farther applied at prefent, than to the diftilling of Rofe-Water. I have rarely converfed with any of Their [Tibeebs uيpb] Phyficians who were acquainted with $R a / 1 s$, Averroes or others of their Compatriots. The Spanifs Edition of Diofcorides is chiefly ftudied; though the Figures of the Plants and Animals are more confulted than the Defcriptions. The Dey's Tibeeb (the E-mim [Noll] or Prefident of the Phyficians) once asked me whether the Chriftians had fuch an Author as Boo-Kratt ${ }^{x}$ (fo either out of Ignorance or Affectation they call Hippocrates;) adding, that He was the firft of the Arabian [Hackeems Lora] Doctors, and lived a little before Avicenna.

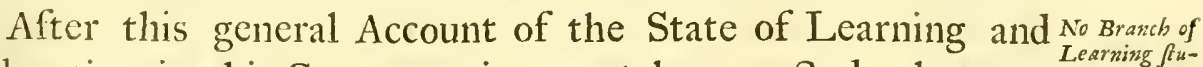
Education in this Country, it cannot be expected, that any diedrataris a suBranch either of fpeculative or practical Knowledge fhould be ftudied properly is an Art or Science. There are not indeed wanting feveral Perfons who prefcribe in Phyfick, play upon a Variety of Mufical Inftruments, and are concerned in other Actions and Performances which feem at leaft to fuppofe fome Skill in Nature or Mathematicks; yet all This is learnt merely by Practice, long Habit and Cuftom, affifted for the moft Part with great Strength of Memory and Quicknefs of Invention. For no Objection can be made againft the natural Parts and Abilities of thefe People, which are certainly fubtle and ingenious: only Time, Application and Encouragement are wanting to cultivate and improve them.

I i.e. The Father of Kratt, Suppofed to be an Arabian.

U u u 2

To 
The Hifory of To give then a more particular Account of what Arts and Pbyjick.

Sciences are ftill remaining in Barbary, I fhall begin with the Hiftory of Phyfick. And here It is to be obferved (for the Want no Doubt of proper Perfons duly and methodically bred up to thefe Arts) that there are few if any of the more dangerous Cafes and Diftempers, but fuch as either prove mor. tal, or of a long Continuance. It is to be obferved likewife, that few Perfons will admit either of Advice or Medicine, believing in ftrict and abfolute Predeftination; whilft 0 thers, who are lefs fuperftitious, prevent the Affiftance of both by their ill Conduct and Management; leaving all to the Strength of Nature, or elfe to Magar-eah, as they call Charms and Enchantments. The Hiftory therefore of Phy. fick will be expreffed in a few Lines: for if we except the following Remedies, together with the conftant Refort that is made to the Bagnio's in Diftempers of all Qualities and Complexions, there is little befides of general Ufe and Eftablifhment among them.

Their Reme-

Thus in Rheumatick and Pleuritick Cafes, it is ufual to make dies for the Rheuratifm, feveral Punctures, with a red hot Iron, upon the Part affected; Jaundice, which Operation is to be repeated according to the Strength of the Patient and the Violence of the Difeafe. A Decoction of the Ground Pine, or of the Globularia Fruticofa, is the orFeavers, dinary Medicine for Fevers: though I have known the common Scabious of this Country, taken either as a Salad, or in a ftrong Decoction, to remove violent tertian and quartanAgues. Flatulent A Dram or two of the Root of [Boruftum] the Round BirthDiftempers, wort, is an eftablifhed Remedy for the Cholick and other flatulent Diftempers: as the Root of [Bookoka] Arifarum, dryed and powdered, is for the Stone and Gravel. I once knew above a Pint of a glutinous Subftance brought away, by the Uretbra, from a young Boy of our Interpreter's, by only eating plentifully of the ordinary Bread of the Bedoweens, which is made of an equal Quantity of Barley or Wheat Flour, and the Roots of Bookoka dried in the Oven and pow. dered. One Dram of a dark coloured Drop-Stone, or the Bloody Flux, like Quantity of the Powder of the Orobanche Mauritanica, have been ufed with good Succefs in ftopping inveterate Diarrbeas. Little elfe is obferved in the Management of Small Pox, the Small Pox, than to keep the Patient moderately warm, giving 
giving him now and then fix or eight Grains of Alkermes in Honey, to throw out the Puftules. They make ufe of frefh Butter to hinder the Pitting; and prevent the Ulcers from falling upon the Eyes by keeping their Lids conftantly tinged with the Powder of Lead Oar. The Inoculation of them the Inoculais performed by making a finall Wound, upon the flefhy Part tion of their of the Hand, betwixt the Thumb and Fore-finger. The Perfon who is to undergo the Operation, receives the Infection from fome Friend or Neighbour, who hath a favourable Kind, and who is intreated to fell two or three of his Puftules, for the fame Number of Nuts, Comfits, or fuch like Trifles. This they call the purchafing of the Small Pox; and among the Ferws, the Purchafe alone, I was told, without Inoculation; was a fufficient Preparative for the Infection. However It $\mathrm{i}_{\mathrm{S} \text { difcourraged. }}$ in no great Repute in thofe Parts of Barbary or the Levant where I have been; moft People efteem It to be a tempting of Providence and the foliciting a Diftemper before Nature is difpofed to receive It. Accordingly they tell a Number of Stories to difcourage the Practice; particularly of a beautiful young Lady, who purchafed only a couple of Puftules. It happened indeed She had no more than were paid for; but the Misfortune was, they fell upon Her Eyes, and She was blind by the Experiment.

The Arahs attempt to heal all Simple and Gun-fhot Wounds Medicines by pouring frefl Butter, almoft boyling Hot, into the Part for Gunnllot affected; and I have been credibly informed, that Numbers of Perfons have been cured by this Method. For affwaging ${ }_{S w e l l i n g s}$ Swellings, Bruifes, Inflammations and Ailings of that Kind, the and lunfamLeaves of the [Opuntia] Prickly-Pear, roafted a quarter of an Hour in the Afhes, and applyed as hot as poffible to the Part affected, are, in this Climate, found to be very beneficial: they are noted alfo for fuppurating and bringing Boils, Plague- Boils; Sores, and fuch like Tumours to Maturity; and I have likewife known them fuccefsfully applyed, without the leaft Sufpicion of having any repelling Quality, in the Gout. In flight Wounds, Gout, Bruifes and Inflamations, or elfe in order to harden and confolidate the Parts, fome Perfons take the Powder of the ${ }_{\text {Wounds, }}^{\text {Slight }}$ Leaves of Albennah, and make it up, with warm. Water, into a Cataplajm. This, in being applyed, tinges the Skin with a tawny Orange Colour, which continueth for fome Months;

$$
\mathrm{X} \times \mathrm{X}
$$

nay, 
nay, what is more furprizing, the Tincture paffeth quickly; through the Pores, into the Blood, rendering the Urine in a Nights Time of a Saffron Colour. In green Wounds and fome other of the above mentioned Cafes, the Leaves likewife of (Madra-mam) the Virga aurea glutinofa have a good effect; whilft the Root of (Toufailet) Thapfia, roafted and applyed hot to the Hips, or made up into an Ointment, is reckoned a Scistica. Specific Remedy in the Sciatica.

No certain Thefe are fome of the principal Medicines ( go Douwas thefe Rule either
inprefribing People call them) that are made ufe of in this Country: in or taking thefe
Mcdicines. the prefcribing or taking of which, they obferve no uniform Practice nor exact Proportion. For thofe which regard external Cafes are fometimes applyed fo fparingly, as if it was indifferent, both to the Patient and Phyfician, whether or no any Benefit was intended by them: whilft others, in the fame Cafe, act quite the contrary, fuppofing the larger the Cataplafm, the fpeedier the Cure. Neither is there much more Caution ufed in fuch Medicines as are given inwardly: for a Handful, at Random, whether of dry or green Herbs, is the common Dofe; which, if taken in a Decoction, they ufually pound firft in a Mortar, and then pour, at a Venture, half a Pint, a Pint or more of boyling hot Water upon it. Compound Medicines are very rare. The Moors indeed pretend to have received feveral, by Tradition, from their Anceftors; but the few Ingredients, the Shops of their Tibeebs are furnifhed with, to anfwer fuch Prefcriptions, together with their great Refervednefs in converfing with them upon this Subject, appear to be ftrong Sufpicions, that They are no better verfed in the Materia medica than the Arabs. The only PreSeedy Maho-
metzeróke's
Remedyiption of this Kind that I have met with, is afcribed to a Remedy
gaing-
the famous Marabbutt of theirs, Seedy Mabomet Zerôke, who gainfl the
Plague.
recommends it in this Manner. "The Lives of us all are in " the Hands of God, and when it is written, we muft die. "However it has pleafed God to fave many Perfons from the "Plague, by taking every Morning, while the Infection rag"eth, one Pill or two of the following Compofition. Viz. Of "Myrrh 2 Parts, Saffron I Part, Aloes 2 Parts, Syrop of Myrtle "Berries Q.S. 
Neither are thefe People much more converfant in any of Tbefe People the Branches of Mathematicks. For in the firft Place they Mrangerszo are altogether Strangers to the fpeculative and abftracted Parts of them. Even fuch Quadrants, Aftrolabes, and other Mathematical Inftruments of their Anceftors, as have efcaped the Injuries of Time, are looked upon rather as Curiofities, than confulted as ufeful Inventions. Befides feveral of thefe Qua- and to the Ufe drants, defigned chiefly for taking Altitudes, I once faw one at ments, of $r$. Tozer in, what we call, Oughtred's Projection, well executed and of a Foot Radius. We are alfo fometimes favoured with a Sight of their Kalendars, (all of Them likewife the Works of former Ages) wherein the Sun's Place, the femidiurnal and nocturnal Arch, the Length of the Twilight, with the feveral Hours of Prayer for each Day in the Month, are calculated to a Minute and beautifully inferted in proper Columns. But thefe again are as little confulted, as the Inftruments; for in Cafe the Cloudinefs of the Weather will not permit them to adjuft their fmall and greater Hour-Glaffes, to fome inaccurate Meridian Lines they have made for that Purpofe, the Times of Devotion, which thould be punctual to a Minute, are left intirely to the Will and Pleafure of their (Mvezzims) Cryers; no other Methods being ftudied for the Menfuration of Time; and publick Clocks, from the great Averfion perhaps the Mabometans have to Bells, not being allowed of in this Country.

Nay not even the firft Operations, in either Numeral Arith. Fem Perfons metick or Algebra, are known to one Perfon in twenty thou-Arithmetick. fand, notwithftanding their Fore-fathers, if we may judge from the Name ', feem to have been the Inventors of the one, as they have given to all Europe the Characters ${ }^{2}$ of the other. However the Merchants, befides being fiequently very dextrous in the Addition and Subftraction of large Sums by Memory, have a fingular Method of Numeration, by putting their Hands into each others Sleeve, and there, touching one another with this or that Finger, or with fuch a particular Joynt of It, (each of them denoting a determined Sum or

I ج Fabar cft Reductio partium ad totum, feu fractionum ad integritatem. Et binc Algcbra nomen habet. Gol. 2 Our Numbers, viz. I. 2. 3. 4. 5.6. 7. 8. 9. o. being borrowed from the Arabian ' $\mu, \mathcal{H} \& 4 \vee \wedge q$. which were Originally from the Indians. Vid. Bernardi Tab. Literat. Seriera Vil. 
Number) will tranfact Affairs of the greateft Value, withou fpeaking to one another, or letting the Standers by into the Secret. Yet ftill of a much more extraordinary Nature, provided we could be equally affured of the Truth of It, is the Knowledge, which the Thalebs ${ }^{1}$ of this Country are fuppofed. to have in Numbers. For they pretend to fuch a powerful Infight into the Nature and Quality of them, that by differently joyning and combining them, they can bring to Light a Variety of Secrets, excite as well as break the Force of Charms, and perform a thoufand Tricks of the like Nature. The following Diagram, called [كرز Haraz el Mabîrak] The Bleffed Amulet ${ }^{2}$, is one of thefe Numeral Combinations, which, when hung about the Neck, is faid to procure the Favour of Princes, to infpire Courage, intimidate an Enemy, prevent Diftempers or whatever elfe is hurtful and injurious to the Perfon who bears It.
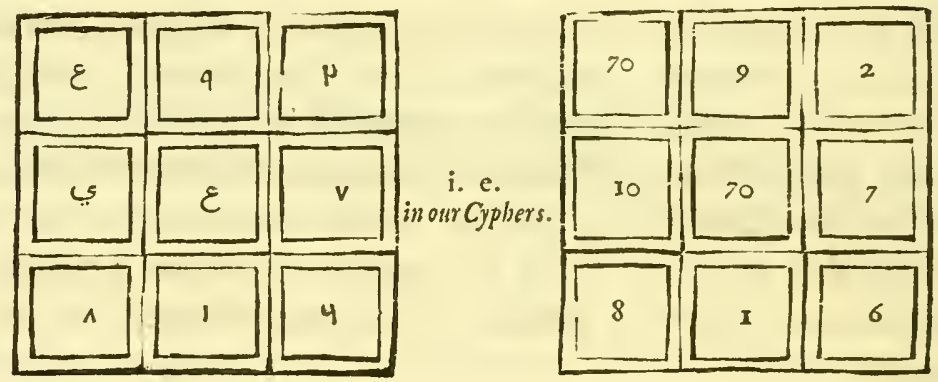

The Mufick It hath been already obferved, that thefe People play upon feveral Inftruments of Mufick: but as they do not write down their Compofitions, nor aim at any Contraft or Varicty of Parts, it may be difputed, whether even This Branch of the Mathematicks is to be confidered as a Science among them. of the Arabs. For the Mufick of the Bedoweens rarely confifts of more than one Strain, fuitable to their homely Inftruments, and to their The Arabeb- fimple Invention. The Arabebbah, as they call the Bladder bah. and String, is in the higheft Vogue and doubtlefs of great An-

I Or Thulbys (V. Not. p. 80.) Studiofi fapientix, from بل qux quivit. Vid. Gol.

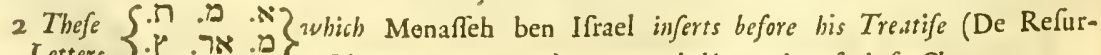

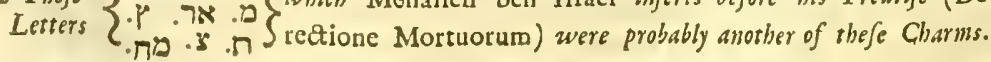


tiquity; as is alio the Gafpah, which is only a common Reed, The Garpath. open at each End, having the Side of It bored, with three or more Holes, according to the Ability of the Perfon who is to touch It: though the Compafs of their Tunes rarely or ever exceeds an Octave. Yet fometimes, even in this Simplicity of Harmony, they obferve fomething of Method and Ceremony. For in their Hiftorical Cantata's ' efpecially, they have their Preludes and Symphonies; each Stanza being introduced with a Flourifh from the Arabebbah, while the Narration Itfelf is accompanied with the fofteft Touches, they are able to make, upon the Ga/pab. The Tarr, another of their In-Tbe Turr, ftruments, is made like a Sive, confifting (as Ifidore ${ }^{2}$ defcribeth the Tympanum) of a thin Rim or Hoop of Wood, with a Skin of Parchment ftretched over the Top of It. This ferves for the Bafs in all their Conforts, which they accordingly touch very artfully with their Fingers, and the Knuckles or Palms ${ }^{3}$ of their Hands, as the Time and Meafure require, or as Force and Softnefs are to be communicated to the feveral Parts of the Performance. The Tarr is undoubtedly or Tympathe Tympanum of the Antients, which appears, as well from ${ }^{\text {num. }}$ the general Ufe of It all over Barbary, Egypt and the Levant, as from the Method of playing upon It, and the Figure of the Inftrument Itfelf, being exactly of the fame Fafhion with what we find in the Hands of Cybele and the Bacchanals among the Baffo Relievo's and Statues of the Antients.

But the Mufick of the Moors is more artful and melodious. The Moorifh For moft of their Tunes are lively and pleafant; and if the Mryfiremanents. Account be true, (which I have often heard ferioully affirmed, but could never fee a Proof of) that the Flowers ${ }^{4}$ of Mullein and Mothowort, will fall from their Stalks, at the playing of their Mizmoune, they have fomething to boaft of, which our modern Mufick doth not pretend to. They have alfo a much greater Variety of Inftruments than the Arabs; for befides

I The Strolling Bedoweens (like the antient AOI $\Delta O \mathrm{O}$ or Rhapfodifts) are cljiefly converfant in this fort of Mufick, who after they have got togetber a Crowd and placed them in a Circle, begin to chunt over the memorable Actions of their Prophet \&c. or elle laying before them the Plans of Mecca, Medina oc. flourifh over, in like manner, their feveral Defcriptions. 2 Tympanum eft pellis vel corium ligno ex una patte extenfum. Eft enim pars media Symphonix in fimilitudincm cribri. Tympanm autem diatum, quod medium cft. Ifd. Orig. 1. 3. cap. 21.

3 Tympana tenfat tomant Palmis \& Cymbala circum

Concava.

4 Something like this is mentioned by Ovid.

Lucret. 1. 2. 1. 618 .

licibus glandes, cantataque vitibus uva Decidit.

Ovid. 1. 3. Amor. El. 7. 1.33. 
The Rebcbb. feveral Sorts of Flutes and Hautboys, they have the Rebebb, a Violin of two Strings, which is played upon with a Bow: The A-oude. the A-oude', a Bafs double ftringed Lute, bigger than our Viol, which is touched with a Plectrum; with feveral fimaller Gittars (or 2uetaras according to their Pronunciation, ) of different Sizes, each of them tuned an Octave higher than another. They have alfo improved the Tarr of the Bedoweens, by fufpending loofely, upon Pieces of Wire, in the Rim of It, feveral Pairs of thin hollow brafs Plates, which, clafhing againft each other in the fereral Strokes and Vibrations given to the Parchment, form a clinking but regular Kind of Noife, which filleth up thofe little Vacancies of Sound, that would otherwife be unavoidable in thefe Conforts. Yet notwithftanding this Multiplicity of Inftruments, and that they learn all by Ear, paffing quickly from one Meafure to another, and haftening the Time, (as the Muficians term it) in them all; yet there is always great Uniformity and Exactnefs obferved throughout all their Performances. I have often obferved twenty or thirty Perfons together, proceed, in this manner, from one Air to another, during the Space of a whole Night, (the ufual Time of their Entertainments,) without making the leaft Blunder or Hefitation.

7he Turkifh Neither fhould I omit the Turkifh Mufick, which is inferiour Mufick \&c. indeed to the Moorifb in Life and Sprightlinefs, yet is ftill fomewhat more compounded than that of the Bedoweens. The Turks have been generally a profperous and thriving People, diftinguifhing Themfelves fometimes by brisk and chearful Tempers; yet there is a certain mournful and melancholy Turn, which runs through all their Compofitions. We may account for It perhaps from that long Intercourfe and Converfation, which they have had with their Grecian Subjects, whofe Airs, for the moft Part, are doleful and ferious, like thofe of a neighbouring Nation, infpiring in the Hearer Penfivenefs and Sorrow; which, as I have fomewhere read, hanging upon the Minds, cannot fail of being communicated to the Mufick of Perfons in Diftrefs and Captivity. They chiefly make ufe of two Inftruments; whereof the one is like a long necked Kitt,

I J.e A-oude, from whence the Spanin Land or Laut, and our Lute, fuppofed by Bochart (Hicroz. 1. 1. 4. cap. 8.) to be the X'xis or Teftudo of the Antients. 2 The fame Word and Inftrument no doubt with the antient Cithala. 
played upon like the Rebebb: the other, which is in the Fafhion of our Dulcimer, with Brafs Strings, is touched fometimes with the Fingers, fometimes with two fmall Sticks, or elfe with a Plectrum.

But the want of Inftruments in the private Mufick of The Mafcks the Turks, is amply made up in That of their Beys and ${ }^{\text {of aflawir }}$ Bagawes. For here (as in fome of the eaftern Ceremonies of old ',) are Inftruments without Number; Flutes, Hautboys and Trumpets; Drums and Kettle Drums; befides a Number and Variety of Cymbals, which they beat ${ }^{2}$, at certain Intervals, one againft another, thereby rendring a fhrill and jarring, but martial Sound, fuch as, we may fuppofe, was made by the Corybantes \&c. in the Ceremonies of Cybele ${ }^{3} \& c$. Here the Time is more haftened than in the Moorifl Mufick, the fame Note, which, in the Beginning, was held out the Time of a Minim, being in the Conclufion, quicker than a Semiquaver. I had not Art enough to note down any of thefe Airs: but in the following Page, there are fome Specimens of the other Kinds of Mufick.

I As in Dan.3. 5. where we bave mentioned the Cornet, Flute, Harpe, Sackbur, Pfalterie, Dulcimer, and all kinds of Mufick.

2 Cymbala dant flictu Sonitum. Pulfarent $x$ ribus $x$ ra.

Eraque tinnitus xre repulfa dabant. Non acuta

Sic geminant Corybantes æra.

Gemina xra fonant Idxaque terga. $\mathrm{X} \approx \lambda$ หั; $\delta i \zeta u \xi$.
Aufon. ad Paulin. Ep. 25. 1. 20.

Lucret. 1. 2. 1. 634 .

Ovid. Faft. 1.4. 1. 182 .

Horat. Lib. I. Od. 16. 1.7.

Stat. Theb. 8. $22 \mathrm{I}$.

Nonn. in Dionyf.

3 Tinnitufque cie \& Matris quate Cymbala circum. Virg. Georg. 4. 1. 64.

(Matris Cymbala) qux in ejus turela funt, ideo quod fimilia funt hemiciclis cæli, quibus cingitur terra, qux eft Mater deorum. Servius in locum.

Sancta Deum genitrix, tinnitibus xthera pulfis

Æris, \& inflati complevit murmure buxi. Ovid. Met. 14. 1. 537.

Tympana vos, buxufque vocat Berecynthia Matris

Idxx. $\quad$ Virg. An. 9. I.619.

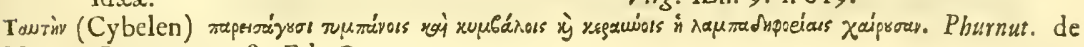
Natura Deorum. p. 8. Ed. Cant.

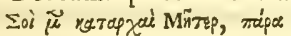

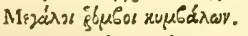

Pind. apud Strab. 1. Io.

- Attonitæ cum furta parentis

Ærea pulfantes mendaci Cymbala dextra,

Vagitus pueri (fovis infantis) patrias ne tangeret aures,

Didxi exercent Dominx famuli Corybantes. Arat. Phxnom. intcrp. Germ. p.2. I. Is. Bupótovov rérreus tides

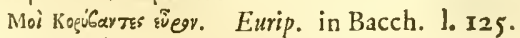

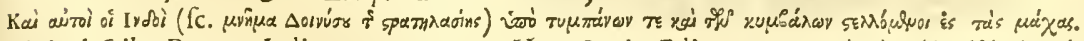

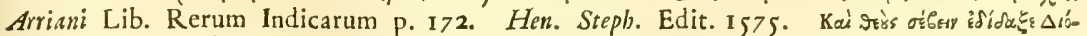

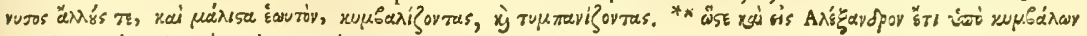

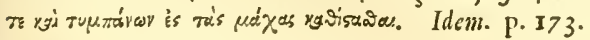


The Bedoween Airs.

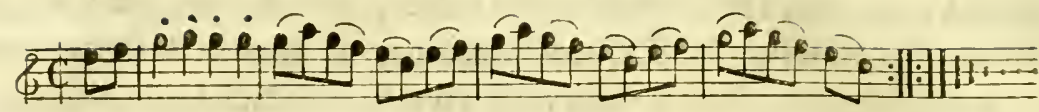

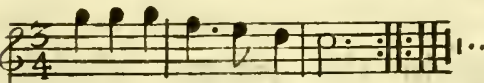

Prelude to the Mizmoune.

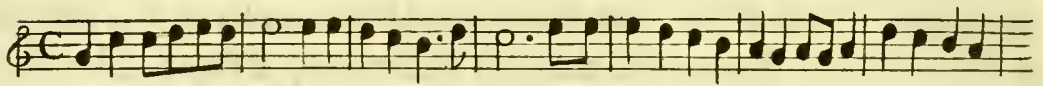

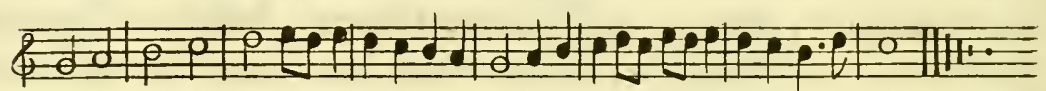
The Mizmoune.

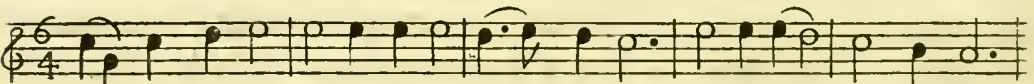

Ya men mellecḱ ana deery waat fa jebt Id:ellyish huye fa beb

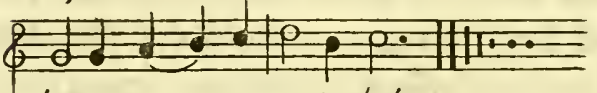

hatse az:::aa::at:ta:leb

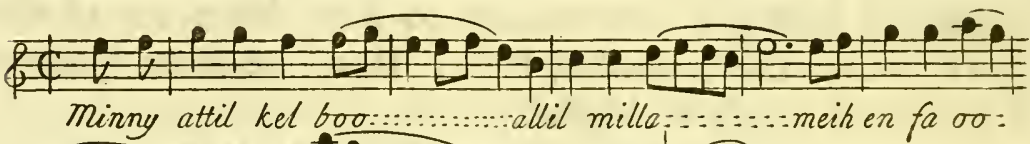

The Moorill
Airs.

: : : : : : se na sabe::::::::r $B a$ áfser roo ra roore ney kitten pppp

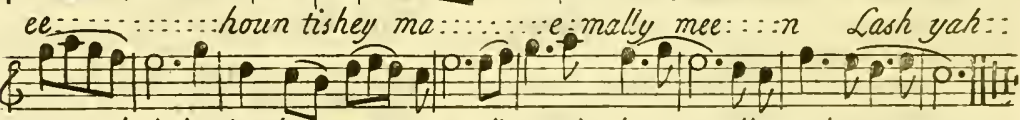
$:::$ : hah be :bee houn tey anee alla yah houn alla yah nee: :

\section{A Dance.}

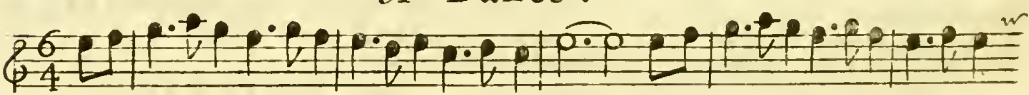

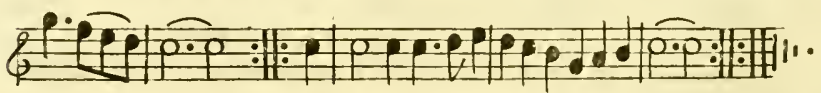

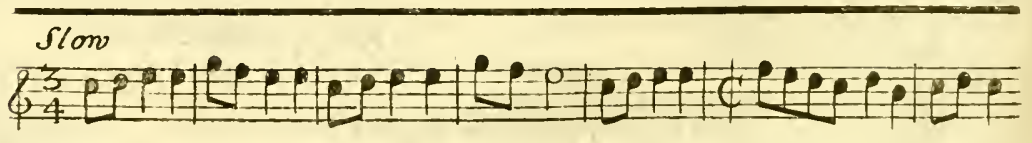

A Turkifh Air.

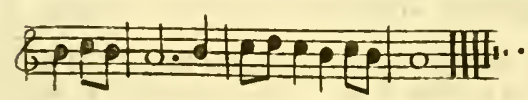





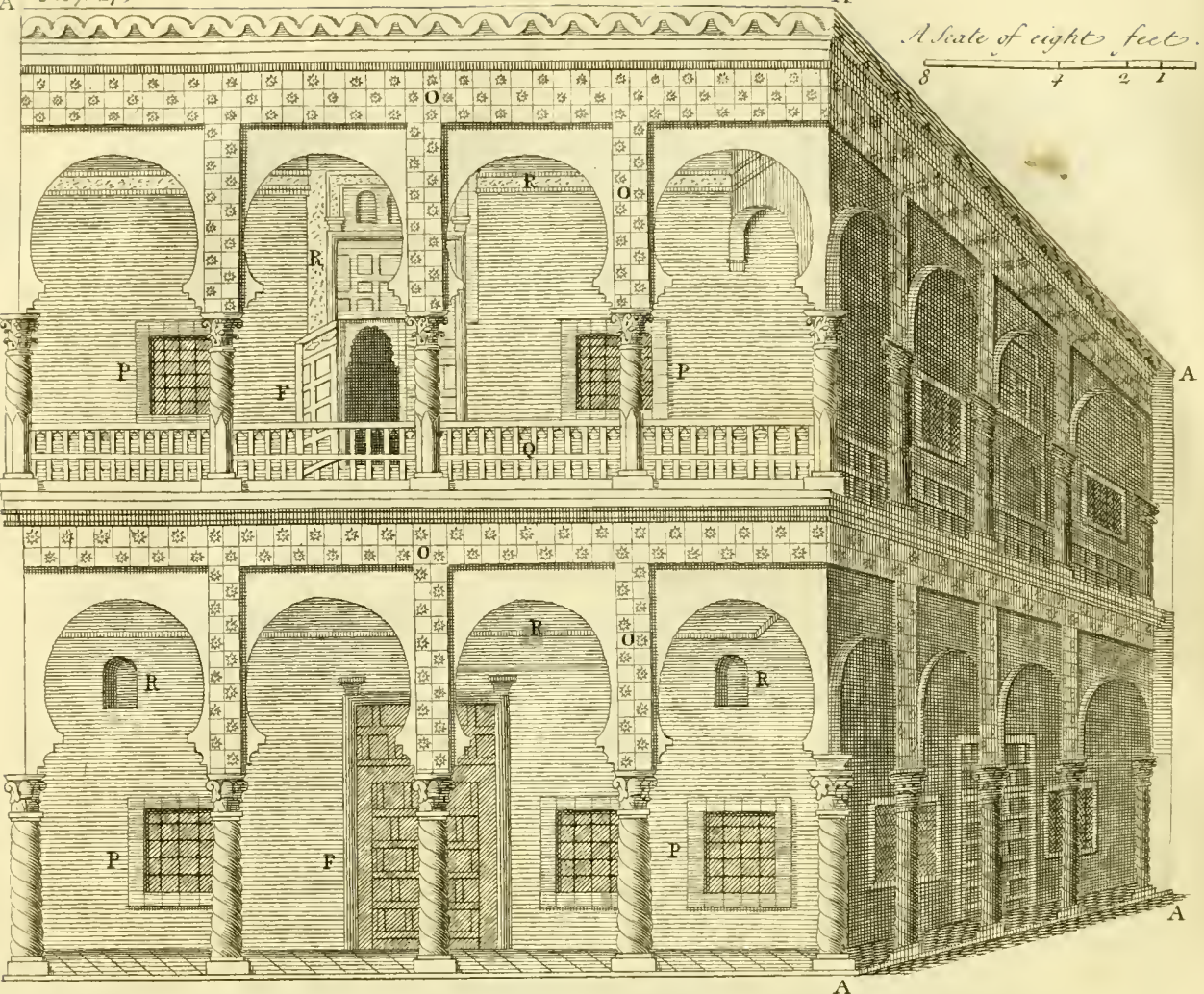

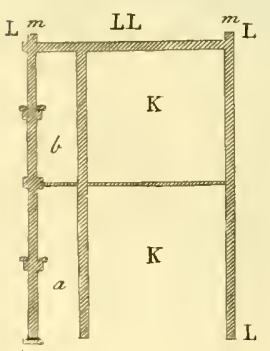

AA. The unriyht tien of if Sruside of one of the Kowises in Bardaty.B.The Ground Plan. (the Sale binu con = tracted.) C. The treas or noost el Dar. D. The Colonady E. Thi Cloyster: atoves.

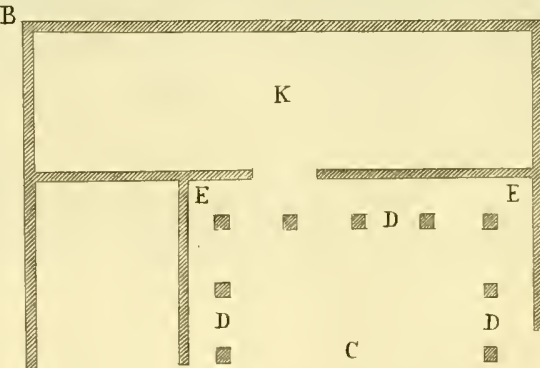

K

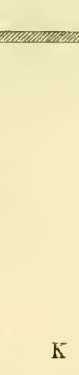

K

$\mathrm{B}$ Wrich in Howses of ine Storves, there is a fullery, of the like Fishion. F. The Dwers. G. The Stair-lizse.H. Whe Porch, over which the Olce is usually placet, nrih is privy Suir-Cave.h. leading inter y Porth, or into the encet $i$. I. Shes areat Deros into the envet. K. The chanters. L.. A peryendicular. Sirtion of ye Touse; thenriey if clowster

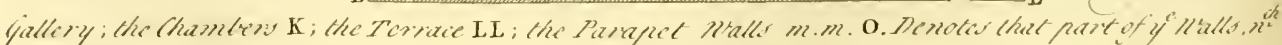

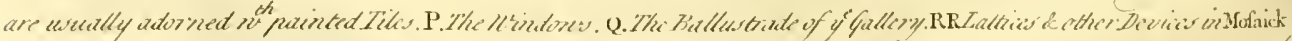

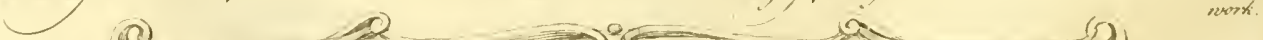<smiles>C=CC#COS(=O)(=O)O</smiles>
\%o the Cievirnd ROBERT THITTETHWAITE

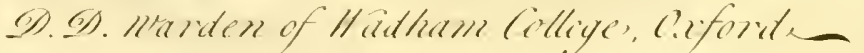


But the Art, wherein the Moors (efpecially) are the moft Thair skilt converfant, is Architecture: though, as Room and Conveni-tecture. ence are the only Points regarded in their Plans, the [clao] Mallums (as they call thofe Perfons who are skilled in the defigning and executing of them) are to be confidered rather as Mafters of a Craft or Trade, than of a Science or Liberal Profeffion. However as there is a near Relation betwixt the Buildings of this Country and thofe that are occafionally mentioned in the H. Scriptures, it may be prefumed, that a particular Account of the Structure and Contrivance of the one, will not a little contribute to the clearing up fuch Doubts and Difficulties as have arifen, from not rightly comprehending the Fafhion of the other.

Now the Method of building, both in Barbary and the Levant, The Folzion of feems to have continued the fame, from the earlieft Ages, with- Berratryy and out the leaft Alteration or Improvement. Large Doors, fpacious Chambers, Marble Pavements, cloyftered Courts, with Fountains fometimes playing in the Midft, are certainly Conveniencies very well adapted to the Circumftances of thefe Climates, where the Summer Heats are generally fo intenfe. Add to this, that the Jealoufie, which is commonly to be met with in Mafters of Families, is hereby lefs apt to be alarmed, whilft all the Windows open into private Courts, if we except fometimes a latticed Window or Balcony towards the Street. It is during the Celebration only of fome Zeenah [sisj] or publick Feftival, that thefe Houfes and their latticed Windows and Balconies are left open. For this being a Time of great Liberty, Revelling and Extravagance, each Family is ambitious of adorning both the infide and the outfide of their Houfes with the richeft Part of their Furniture: whilft Crowds of both Sexes, dreffed out in their beft Apparel and laying afide all Modefty, Ceremony and Reftraint, go in and out where they pleafe. The Account we have in the 2 Book of Kings (9.30.) of Fezebel's painting her Face and tiring her Head and looking out at a Window, upon Febuis Publick Entrance into Fez:reel, gives us a lively Idea of an Eaftern Lady at one of thefe Solemnities.

If we quit then the Streets of thefe Cities, (which are ufu-The Porko ally narrow, with fometimes a Range of Shops on each Side) and enter into any of the principal Houfes, we thall firft pafs 
through a Porch or Gate-Way, with Benches on each Side, where the Mafter of the Family receiveth Vifits and difpatcheth His Bufinefs; few Perfons, not even the neareft Relations, having Admiffion any further, except upon extraordinary Oc-

zhe court. cafions. From hence we are received into the Court, which lying open to the Weather, is, according to the Ability of the Owner, paved with Marble or fuch proper Materials, as will immediately carry off the Water. There is fomething very analogous betwixt This open Space in the Moorifh Buildings,

The Cava Edium,

and ro $\mu$ 's.ov of St. Luks 5. 10 .

The Colirt thaded by a Vell, and the Impluvium ' or Cava AEdium of the Roman Architecture; both of Them being alike expofed to the Weather and giving Light to the Houfe. When much People are to be admitted, as upon the Celebration of a Marriage, the Circumcifing of a Child or Occafions of the like Nature, the Company is rarely or never received into one of the Chambers, but into the Court, which is ftrewed accordingly with Mats and Carpets for their more commodious Entertainment. Now as this Part of the Houfe is always allotted for the Reception of large Companies, being alfo called [b.ugll El Wooft] The Middle of the Houfe, and fo far litterally anfwering to the т' $\mu^{\prime}$ or of St. Luke, it is probable that the Place, where our Saviour and the Apoftles were frequently accuftomed to give their Inftructions, might have been in the like Situation.

It is ufual in the Summer Seafon, and upon all Occafions, when a large Company is to be received, to have the Court fheltred from the Heat or Inclemency of the Weather, by a $V_{\text {Velum }}^{2}$, Umbrella or Veil, as I thall call It, which, being expanded upon Ropes from one Side of the Parapet Wall to the other, may be folded or unfolded at Pleafure. The Pfalmift feems to allude to fome Covering of this Kind in that beautiful Expreffion, of fpreading out the Heavens like a Curtain?

and furronnd- The Court is for the moft Part furrounded with a Cloyfter; ed with a as the Cava Adium of the Romans was with a Perifylium
Cloyter.

I Si rclictum erat in nedio domus ut luccm caperct, deorfum quo impluebat, Implurium dicitur. Varro de Ling. Lac. 1. 4. S. 33. Impluvium locus fine tecto in xdibus, quo implucre imber in domum poffit. Afcon. Pedin. Not. in Cicer. Orat. 1. in Verrem c. 56. Sub divo, quod Impluvinm dicitur. Serv. Not, in lirg. Æn.11. v. 512. Atri. ædificij genus fucre, continens mediam aream, in quam ex omni tecto pluvia recipitur, columnis quadrifariam per fingulos angulos difpofitis \& Epiltilijs. Alexand. ab Alexandro Genial. D. 1.3 cap. 6. Preter l'efibula fucre caves adium ó periffylia in quæ quifque fuo jute non vocatus admittcbatur. Id. Iib. 5. cap. 24. 2 This is the fame zuith the Arab. Gol, wwhich is interpretel, Vclum, aut quid funilc, quod obtenditur atrio domus, feu Carradio. Vid. Gol. in vocc. 3 The fame Exprefforn w'e bave in the Prophet Ifaiah 40.22 . 
or Colonmade; over which, when the Houfe hath one or more Stories, (and I have feen Them with two or three) there is a Gallery erected, of the fame Dimenfions with the Cloyfter, having a Balluftrade, or elfe a Piece of carved or latticed Work going round about It. From the Cloyfter and Gallery, we are conducted into large fpacious Chanbers, of the fame Length Trcckambers. with the Court, but feldom or never communicating with one another. One of them frequently ferveth a whole Family, particularly when a Father indulgeth his married Children to live with him; or when feveral Perfons joyn in the Rent of one Houfe. From whence it is, that the Cities of thefe Countries are fo exceedingly populous, and that fuch Numbers of People are always fwept away by the Plague. A Mixture of Families of this Kind feems to be fpoken of by Maimonides, as he is quoted by Dr. Lightfoot ${ }^{\prime}$ upon I Cor. x. I6.

In Houfes of better Fafhion, thefe Cliambers are hung with the FirniVelvet or Damisk from the Middle of the Wall downwards : ${ }^{\text {ture of them. }}$ the reft is adorned with the moft ingenious Wreathings and Devices in Stucco and Fret-Work. The Cieling is generally tieceling. of Wainfcott, either very artfully painted, or elfe thrown into a Variety of Pannels, with gilded Mouldings and Scrolls of their Coran intermixed. The Prophet Feremiab 22.14. exclaimeth againt fome of the Eaftern Houfes that were cieled with Cedar, and painted with Vermilion. The Floors Tis Floor. are laid with painted Tiles or Plaifter of Terrace; but the Eaftern Nations making no ufe of Chairs, (either fitting crofslegged, or lying at length upon thefe Floors, they have them conftantly fpread over with Carpets, which fometimes are moft beautifully defigned, and of the richeft Materials. For their further Eafe likewife and Convenience, there is a Row of Damask or Velvet Bolfters, ranged along each Side of the Floor: an Indulgence that feems to be alluded to by the forving of Pillows to Arm-boles, as we have It expreffed by the Prophet

\footnotetext{
I "Solomon appointed that each Place be appropriated to one Man there where there is " a Divifion into diverfe Habitations, and each of the Inhabitants receive there a Place "proper to himfelf, and fome Place alfo is left there common to all, fo that all have an "equal Right to It, as a Court belonging to many Houfes Ecc. (בiv'y) The conforting " together, which thofe that dwell among themfelves in the fame Court, make, (is called " "y nesvaria) The Communion of Courts. And that conforting together which " they make that dwell among themfelves in the fame Walk or Entry, or which Citizens of " the fame City make among themfelves is called (כיט) participating together."
} 
Tkeir Beds. Ezekiel (13. 18. and 20). At one End of each Chamber, there is a little Gallery, raifed four or five Foot above the Floor, with a Balluftrade in the Front of It. Here They place their Beds; a Situation frequently alluded to in the H. Scriptures .

The Stairs. The Stairs are fometimes placed in the Porch, fometimes at the Entrance into the Court. When there is one or more Stories, they are afterwards continued, through one Corner or other of the Gallery to the Top of the Houfe, whither they conduct us through a Door, that is conftantly kept fhut to prevent the domeftick Animals from fpoiling the Terrace, and thereby the Water which falls from thence into the Cifterns The Doors. below the Court. This Door, like moft others we meet with in thefe Countries, is hung, not with Hinges, but by having the Jamb formed at each End into an Axle Tree or Pivot; whereof the uppermoft, which is the longeft, is to be received into a correfpondent Socket in the Lintel, whilft the other falls into a Cavity of the like Fafhion in the Threfhold. The Stone Door taken Notice of by Mr. Maundrel ${ }^{2}$, in His Defcription of the Royal Sepulchres at Ferufalem, is exactly of this Fafhion.

No Stairsupon I do not remember ever to have obferved the Stair Cafe conzhe Outfide of therfes. ducted along the outfide of the Houfe; neither indeed will the Contiguity and Relation, which the Houfes bear to the Street, and to each other, (exclufive of the fuppofed Privacy of Them) admit of any fuch Contrivance. However we may go up or come down them, by the Stair-Cafe I have defcribed, without entring into any of the Offices or Apartments, and confequently without interfering with the Bufinefs of the Houfe; which will be explanatory enough of (Mat.24. 17.) Let bim that is upon the Houfe Top not come down to take any Thing out of the Houle, provided the Action there recorded requireth any fuch Interpretation.

The Tops of The Top of the Houfe, which is always flat, is covered the Houfes with a ftrong Plaifter of Terrace; from whence, in the Frank
far. Language, It hath attained the Name of The Terrace; a Word made ufe of likewife in feveral Parts of thefe Countries. It is furrounded by two Walls; the outermoft whereof is partly

I Thos aventeft up to thy Fatbers Bed- to my Couch. Gen. 49. 4. Thou fbalt not come dozvn frows that Bed on wubich thou art gone up. 2 Kings I. 6. and 16. I will not go up into my Bed. Pfal. 132. 3. 2 Vid. Maundrel's Journey from Aleppo to Fernfalem. p. 77. Ed. Ox. I707.

built 
built over the Street, partly maketh the Partition with the contiguous Terraces, being frequently fo low that one may eafily climb over It. The other, or the Parapet Wall, as we Tie Paraper may call It, hangeth immediately over the Court, being always Wall. Breaft high, and anfwereth to the הipy (Vulg. Lorica, which we render the Battlements in the H. Scriptures '. Inftead of this Parapet $W$ all, fome Terraces are guarded, in the fame manner the Galleries are, with Balluftrades only or Latticed-Work: in which Fafhion probably, as the Name feems to import, was the $[\mathrm{r}=2$, ] Net or Lattice, as we render it, that Abaziah (2 Kings 1. 2.) might be carelefly leaning over, when he fell down from thence into the Court. For upon thefe Terraces, feveral Offices of the Family are performed; fuch as the drying of Linnen; preparing of Figs and Raifins; where likewife they enjoy the cool refrefhing Breezes of the Evening ${ }^{2}$; converfe with one another and offer up their Devotions'. When one of thefe Cities is built upon a Plat of level Ground, we can pafs from one End of It to another, along the Tops of the Houfes, without coming down into the Street.

Such is the Manner and Contrivance in general of the Eaftern the Cafe of Houfes. And if it may be prefumed that our Saviour, at the explainer. healing of the Paralytic, was preaching in an Houfe of this Fafhion, we may, by attending only to the Structure of It, give no fmall Light to one Circumftance of that Hiftory, which hath lately given great Offence to fome Perfons. For among other pretended Difficulties and Abfurdities relating to this Fact, it hath been urged", that "as the uncovering or break"ing up of the Roof, Mar. 2. 4. or the letting a Perfon down "through it, Luk. 5. I 9. fuppofes the breaking up of Tiles, Spars, "Rafters $\sigma c$. fo it was well," (as the Author goes on in his ludicrous Manner, ") if Fefus and his Difciples efcaped with. " only a broken Pate, by the falling of the Tiles, and if the "reft were not fmothered with Duft." But that nothing of

-I When thou buildeft a new Houfe, then thou foalt make a Battlement ["Pyy] for thy Roof, that thou bring not blood upon thine Houfe, if any Man fall from thence. Dcut. 22. 8. MPy inde פער, quod fecundum Rabbi David in libro Radicum, erat $\mathbb{E}$ dificium quod facicbant in circuitu tecti ( $i$. partis fuperioris domus qux erat plana) ne quis inde caderet: \& erat altitudinis decem D'nמש (i. palmarum) quæ eft menfura quatuor digitorum fuper fe pofitorun vel amplius. v.Pagn.Lex. 2 And it came to pass in anevening Tide, that David rofe from off hisBed, and walked upon the Roof of the Kings Houfe. 2 Sam. xI. 2. So they fpread Ablolom a T che upon the Top of the House. V. xvr. 22. Samuel communed with Saul upon the Top of the Houfe. I Sam. Ix. 25. Samul called Sinl to the Top of the Houfe. V.26. 3 They that worjoip the Hoft of Fleaven upon the Houfe Top. Zeph. 1. 5. Peter ivent up upon the Houre Top to praty Acts 10.9. 4 Vid. Woolfon's 4 Difc. p. 57. 
this N'ature happened, will appear probable from a different Conftruction that may be put upon the Words in the Original. For it may be obferved with Relation to the Words of St. Mark,

İino, a likil.

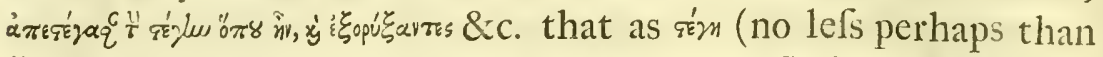
Marb tatlito", the correfpondent Word in the SyriacVerfion) will denote, with Propriety enough, any Kind of Covering, the Veil which I have mentioned, as well as a Roof or Cieling properly fo called; fo for the fame Reafon s'rorizan may be fuppofed to fignify nothing more than the Removal of fuch Covering.

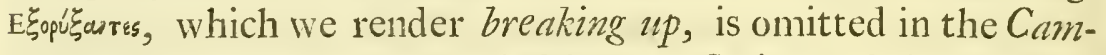
bridge MS. and not regarded in the Syriac and fome other Verfions: the Tranflators perhaps either not rightly comprehending the Meaning of it or finding the Context clear without it. In the Perfian Verfion indeed we have it fupplyed by quatuor angulis lectuli totidem funibus annexis, as if it was fuppofed to relate, either to the letting down of theBedftead or to the making Holes in it for the Cords to pafs through. Though it is ftill

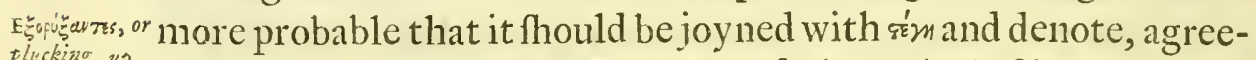
thecking
the Pofs
icc. flation, a further laying of it open, by breaking or plucking up the Pofts, Balluftrades, ParapetWall,or whatever elfe fupported it. The Context therefore, according to this Explication, will run thus. When they could not come at Jefus for the press, they drew back the Veil where be was, or they lay open that Part of it efpecially (" $\pi 8$ in) which was fpread over the Place where He was fitting, and having removed whatever fould keep it extended, (and thereby hinder them from doing the intended good Office,) they let down the Bed wherein the Sick of the Palfie lay.

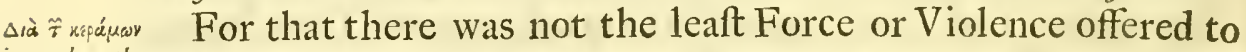

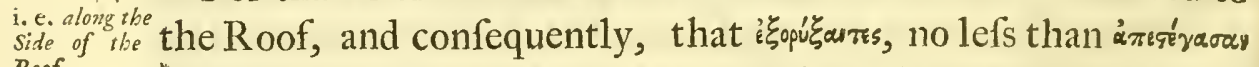
Roof.

will admit of fome other Interpretations than what have been given to them in our Verfion, appears from the parallel Place

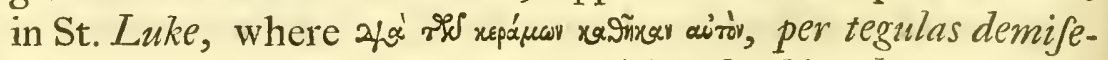
runt illum, (which we tranflate, They let bim down through the Tiling, as if That had actually been already broken up) fhould be rendred, they let him down over, along the Side or

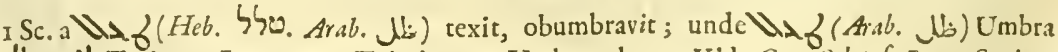
\& lhafl Tectum, Laqueare, Tabulatum, Umbraculum. Vid. Car. Schanf Lex. Syriac. p. 214-1 5. \& Caffell. Lex. P.1503. 
by the $W$ ay of the Roof. For as rearua or tegule, which origi-. nally perhaps denoted a Roof of Tiles, like thofe of the Northern Nations, were afterwards applyed to the Tectum ' or $\Delta \tilde{a}_{q} \mu \mathrm{z}$ in general, fo the Meaning of letting down a Perfon into the Houfe per tegulas, or 2ho' zis xepхxw, can depend only upon the Ufe of the Prapofition dix. Now both in Acts 9. 26. xarñxan

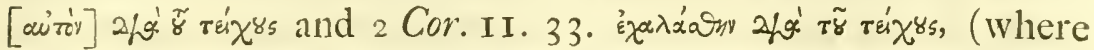
the like Phrafeology is obferved as in St. Luke) 2fo' is rendred in both Places by, that is, along the Side or by the Way of the

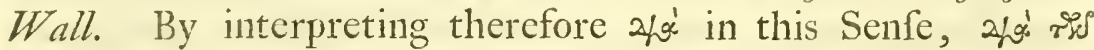
repápav xasñar aito', will be rendred as above, They let bim down over or by the $W$ ay of the $W$ all, jutt as we may fuppofe $M$. Anthony to have been, agreeable to a noted Paffage in Tully ${ }^{2}$. An Action of the fame Nature feems to be likewife implyed in what is related of Fupiter (Ter. Eun. 3. 5. 37.) where he is faid feje in hominem convertiffe atque per alienas tegulas veniffe clanculum per Impluvium. And of the Snake, which we learn (Ter. Phorm. 4. 4. 47.) per Impluvium decidiffe de tegulis. What Dr. Lightfoot alfo obferveth out of the Talmud, upon Mark 2. 4. will, by an Alteration only of the Præpofition which anfwereth to did, further vouch for this Interpretation. For, as It is there cited, "when Rabb Honna was dead, and "His Bier could not be carried out through the Door, being too "Jtraight, therefore" (in Order, as we may fupply, to bury It)

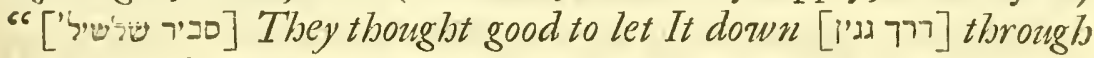
"the Roof, or through the Way of the Roof, as the Dr. renders It, but It fhould be rather, as in sià r's xepámay or six $\widetilde{8}$ réx ${ }^{8 s}$, by the Way, or over the Roof, viz. by taking It upon the Terrace, and letting It down by the Wall, that Way, into the Street. We have a Paffage in Aulus Gellius ${ }^{3}$ exactly of the fame Purport, where it is faid, that if "any Perfon in Cbains fbould "make his Efcape into the Houfe of the Flamen Dialis, that "he Gould be forthwith loofed: and that his Fetters gould be "drawn up through the Impluvium, upon the Roof (Terrace) "and from thence be let down into the Highway or Street."

I Quemque in tegulis videritis alienum-videritis hominem in noftris tegulis \&r. Plaut. Mil. 2.2. De tegulis modo nefcio quis infpectavit voftrarum familiarium per noltrum Impluvium intus apud nos Philocomafum, atque holpitem ofculantis. Plaut. Mil. 2. 2. 1.7. Vintum, fi $x$ des ejus [Flaminis Dialis] introierit, folvi neceffum eft; \& vincula per Impluvium in tegulas fubduci, atque inde foras in viam dimitti. Aul. Gell. Noot. Attic. 10. Is. Qum tamen tu nocte focia, hortante libidine, cogente mercede, per tegul.as demitterere. Cic. 2.

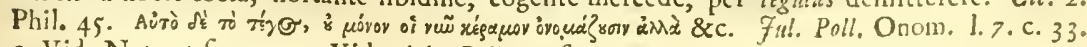
2 Vid. Not. ut fupra. 3 Vid. Aul. Gell. ut fupra. 
N'o Breach made in the Tiling.

Small Houfes annexed to the greater,

When the Ufe then of thefe Phrafes, and the Fafhion of thefe Houfes are rightly confidered, there will be no Reafon, I prefume, for fuppofing any Breach to have been made in the tegule or x'eguon, fince all that was to be done in the Cafe of the Paralytic, was to carry him up to the Top of the Houfe, either by forcing their Way, through the Crowd, up the Stair Cafe, or elfe by conveying him over fome of the neighbouring Terraces; and there, after they had drawn away the [ $\left.\varepsilon^{\prime} \cdot m\right]$ Veil, to let him down, along the Side of the Roof (through the Opening or Impluvium, into the Midft (of the Court) before Fefus.

To moft of thefe Houfes, there is a fmaller one annexed; which fometimes rifeth one Story higher than the Houfe; at other Times confifteth of one or two Rooms only and a Terrace; whilft others, that are built, (as they frequently are) over the Porch or Gate-way, have, if we except the Ground Floor, all the Conveniences that belong to the Houfe. There is a Door of Communication from Them into the Gallery of the Houfe, kept open or fhut at the Difcretion of the Mafter of the Family; befides another Door, which opens immediately from a Privy-Stairs down into the Porch or Street, without giving the leaft called Olces. Difturbance to the Houfe. Thefe Back-Houfes are known by the Name of ste Alee or Oleah, (for the Houfe properly fo called is Dar , lo or Beet cus) and in them Strangers are ufually lodged and entertained; in them the Sons of the Family are permitted to keep their Concubines; whither likewife the Men are wont to retire, from the Hurry and Noife of their Families, to be more at Leifure for Meditation or Diverfions: befides the Ufe, they are at other Times put to, in ferving for Wardrobes and Magazines.

The Hebrew The עy of the H. Scriptures is literally the fame Appellaand Arabick for tion with sule, being accordingly fo rendered in the Arabick themtbefame. Verfion. We may fuppofe it then to have been a Structure of the like Contrivance. The little Chamber ${ }^{2}$ then that was built by the Shunamite for Elifsa, (whither, as the Text inftructs us, he retired at his Pleafure, without breaking in upon the private Affairs of the Family, or being in his turn interrupted

I Let us make a little Chamber I pray thee on the Wall, and let us fet for him there a Bed and a Table and a Stool and a Candleftick: and it foall be when be cometh to us, that be foall turn in thither. 2 Kings 4. 10. 
in his Devotions:) The Summer Chamber of Eglon', (which, in the fame Manner with Thefe, feems to have had Privy-Stairs belonging to It, through which Ehud efcaped after he had revenged Ifrael upon That King of Moab:) The Chamber over theGate ${ }^{2}$ (whither, for the greater Privacy, King David withdrew himfelf to weep for Abfalom;) and, That upon whofe Terrace, Ahaz, for the fame Reafon, erected his ${ }^{3}$ Altars, feem to have been Structures of the like Nature and Contrivance with thefe Olees.

Befides, as each of thefe Places, which are called עליה or Olee of the על in the Hebrew Text, and suls in the Arabick Verfion, is with timportion.

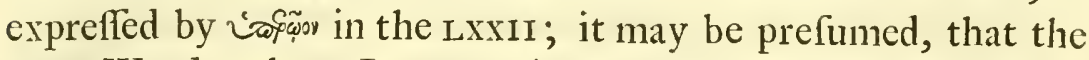
fame Word, where It occurs in the N.T. implieth the fame Thing. The upper Chamber therefore, where Tabitha was laid after her Death ${ }^{4}$, and where Eutychus ${ }^{5}$ fell down from the third Loft, befides other Inftances, may be taken for fo many of thefe Olees, as they are indeed called in the Arabick Verfion.

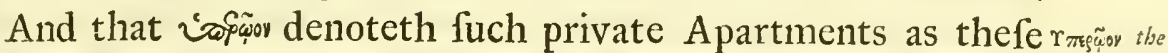
(for Garrets, from the Flatnefs of the Roof, are Structures ${ }_{B a c k ~ H o: f e}^{\text {Same }}$, not known in thefe Climates) feems likewife probable from the Ufe of the Word among the Claffick Authors. For the Loföw where Mercury ${ }^{6}$ carried on his Amours, and where Penelope ${ }^{7}$, and the young Virgins ${ }_{8}$ kept themfelves at a Diftance from the Sollicitations of their Woers, appear to carry along with them Circumftances of greater Privacy and Retirement, than are confiftent with Chambers in any other Situation than

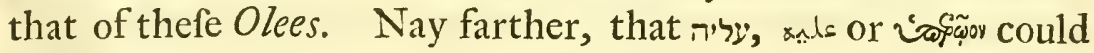
not barely fignify a fingle Chamber, Crenaculum, or Dining-and not a finRoom, but one of thefe contiguous Houfes, divided into feveral ${ }^{\text {gle chamber. }}$ Apartments, feems to appear from the Circumftance of the

I And Ehud came unto bim (Eglon) and be was fitting in a fummer Parlour, which be bad for bims clf alone - then Ehud went forth through the Porch. Judg. 3. 20--23. 2 And the King w'as much moved, and went up to the Chamber over the Gate and wept. 2 Sam. 18. 33. 3 And the Altars that were on the Top of the upper Chamber of Ahaz, which the Kings of $\mathcal{F}_{\text {udal }}$

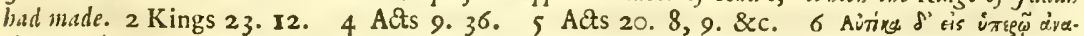

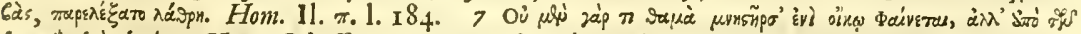

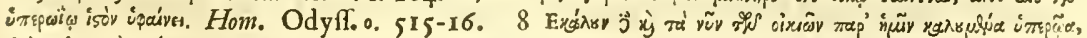

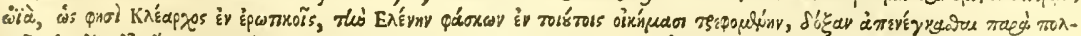

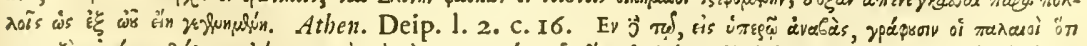

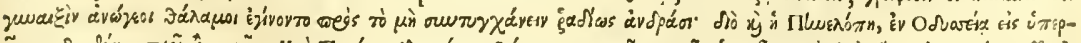

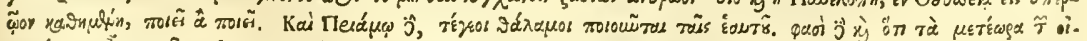

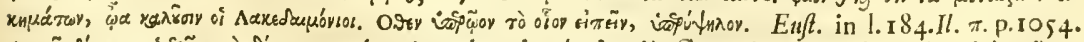

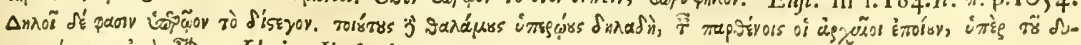

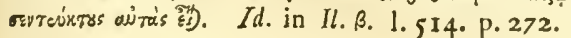


Altars, which Alsaz erected upon the Top of His. For, befides the fuppofed Privacy of his Idolatry, (which could not have been carried on undifcovered in any Apartment of the Houfe, becaufe under the perpetual View and Obfervation, as it may be fuppofed, of the Family) provided his על had been only one fingle Chamber of the [na] Houfe, it is reafonable to imagine, that the Roof would have been afcribed to the Latter, and not to the עיה, which, upon this Suppofition, made only one Chamber of It. A Circumftance of the like Nature may probably be collected from the Arabick Verfion of viهi⿻丷木 Acts 9. 39. where It is not rendered s.ls as in Ver. 37. but is Girfat; intimating perhaps that Part or particular Chamber of the sals where the Damfel was laid. The falling likewife of Eutychus from the third Loft (as the Context feems to imply) of the isøēov, (for there is no Mention made of an Houfe) may be received, I prefume, as a further Proof of this Suppofition.

The Olee built For it hath been already obferved that thefe Olees are built in the Same with the fame Conveniences as the Houfe; confequently, what
Faflion with with the Houf is.

The vispion ereffed upon another Build -

Pofition foever the vof feeming Etymology of the Name, will be applicable to the one as well as to the other. Though ftill vofí⿴囗十 will admit of another Interpretation in our Favour, denoting not fo much a Chamber remarkable for the high Situation of It, as Euftathius $^{2}$ and others after him give into, but fuch a Building, as is erected upon or beyond the Walls or Borders of another ${ }^{2}$; juft as thefe Olees are actually contrived in Regard to the [ [ Houfe. Neither will this Interpretation interfere with the The Afcent
into the high Situation that vosforor may be further fuppofed to have,

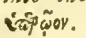
from being almoft conftantly joyned with arrabaivey or ralabaiver. For the going in or out of the Houfe, whofe Ground Floor lyeth upon the fame Level with the Street, could not be expreffed by Words of fuch Import: whereas the Olees, being ufually built over the Porch or Gate-Way, a fmall Stair Cafe is to be mounted before we can be faid properly to enter Them,

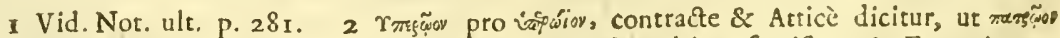

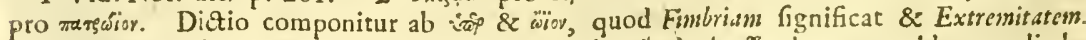

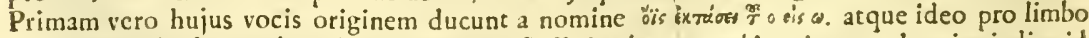

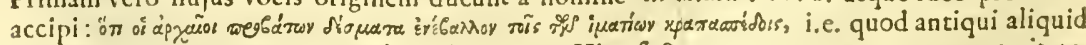
de pellibus ovium extremis veftibus adjicerent. Hinc factum, ut pro quacunque extremitate, ima, fumma, aut alia quavis accipiatul. Car. Gerardi Annot, in Plutum Arifophanis. P. 83. 
and confequently arvabaires and rarabajyay are very applicable to Structures in fuch a Situation.

The Eaftern Method of building may further affift us, in Tbe Timple accounting for the particular Structure of the Houfe of Dagon, ( $F u d g .16$ ) and the great Numbers of People that were buried in the Ruins of It, by pulling down the two principal Pillars. We read (Ver. 27.) that about three thoufand Perfons were upon the Roof to behold while Sampfon made Jport. Samplon mutt therefore have been in a Court or Area below them, and confequently the Temple will be of the fame Kind with the antient $T_{\varepsilon} u$ sin or facred Enclofures, furrounded only in Part or altogether with fome cloyftered Building. Several Palaces and Dou-wânas, as they call the Courts of Juftice in thefe Coun-The Fafbion tries, are built in this Fafhion; where, upon their Feftivals, a great Quantity of Sand is ftrewed upon the Area for the (Pello-wan) Wreftlers to fall upon, whilft the Roof of the Cloyfters, round about, are crowded with Spectators. I have often feen feveral Hundreds of People diverted in this Manner upon the Roof of the Dey's Palace at Algiers; which, like many more of the fame Quality and Denomination, hath an advanced Cloyfter, made in the Fafhion of a large Pent-Houfe, fupported only by one or two contiguous Pillars in the Front, or elfe in the Centre. In fuch open Structures as thefe, in the Midft of their Guards and Counfellors, are the Ba/has, Kadees, and other great Officers affembled to diftribute Juftice and tranfact the publick Affairs of their Provinces. Here likewife they have their publick Entertainments, as the Lords and others of the Pbilifines had in the Houfe of Dagon. Upon a Suppofition therefore that in the Houfe of Dagon, there was a cloyftered Structure of this Kind, the pulling down the Front or Centre Pillars only which fupported it, would be attended with the like Cataftrophe that happened to the Philifines.

The Mofques and Sepulchres of thefe Countries, are other The Fafhion

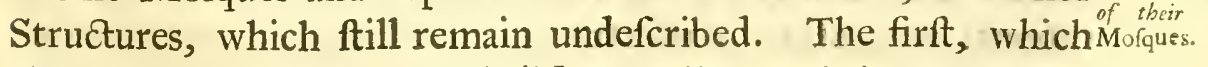
they pronounce [uجm ' $] M e / g-j i d$, are built exactly in the Fafhion of our Churches, where inftead of fuch Seats and Benches as we make ufe of, they only ftrew the Floor with Mats, upon

I i. e. The Place of Humiliation, from aș, [Heb. 70] Humiliavit fe, procubuit: pec. Reverentix ergo. Spec. frontem imponens terrx, ad commonttrandam fupplicis animi dejectionem atque abnegationem fui. Vid. Gol. in voce.

$\mathrm{B} \mathrm{b} \mathrm{b} \mathrm{b} 2$

which 
which they perform the feveral Stations, 'Sittings and Proftrations that are enjoyned in their Religion. Near the Middle, particularly of the principal Mofque of each City, there is a large Pulpit erected, which is balluftraded round, with about half a dozen Steps leading up to it. Upon thefe (for I am told none are permitted to enter the Pulpit) the Mufti or one of the Im-ams placeth himfelf every Friday, The ( $\left.+y^{\prime} y^{3}\right) D_{a y}$ of the Congregation, as they call it, and from thence either explaineth fome Part or other of the Coran, or elfe exhorteth the People to Piety and good Works. That End of thefe Mofques, which regards Mecca, whither they direct themfelves throughout the whole Courfe of their Devotions, is called the $K_{i b l a h^{2}}$, in which there is commonly a Nich, reprefenting, as a judicious $\mathrm{Writer}^{3}$ conjectures, the Prefence, and, at the fame Time, the Invifibility of the Deity. There is ufually a fquare Tower erected at the other End, with a Flag-Staff upon the Top of it. Hither the Cryer afcends at the appointed Times, and, difplaying a fmall Flag, advertifeth the People, with a loud Voice, from each Side of the Battlements, of the Hour of Prayer. Thefe Places of the Mabometan Worfhip, together with the Mufti, Im-ams ${ }^{4}$ and other Perfons belonging to them, are maintained out of certain Revenues ${ }^{5}$ arifing from the Rents of Lands and Houfes, either left by Will or fet apart by the Publick for that Ufe.

How they con- When anyPerfon is to be buried, it is ufual to bring the Corpfe, duct their Funerals.

at the Mid-day or Afternoon Prayers, to one or other of thefe Mofques, from whence it is accompanied, by the greateft Part of the Congregation, to the Grave. Their Proceffions, at thefe Times, are not fo flow and folemn as in moft Parts of Chriftendom; for the whole Company make what Hafte they can, finging, as they go along, fome felect Verfes of their Coran. That abfolute Submiffion which they pay to the Will of God, allows them not to ufe any confolatory Words upon thefe Occafions: no Lofs or Misfortune is to be hereupon regretted or

I i. e. The Churclb or Place where the People meet together, fo called from eta collegit, congregavit \&c. When there are feveral Mofques in one City, the lingeft is called the Jimmal, and fonretimes, El Jimmah Kibeerah, the Great or Mother Church, in which their Publick Devotions, \&c. are ufually performed on Fridays. 2 From $\mathrm{l}_{\mathrm{g}} \mathrm{e}$ e regione oppofitus fuit \&cc. Vid. Gol. \& Not. p.32. 3 Vid. Maundrell's Journ. to Ferufalem. p.I5. 4 rhol, I-mim, Em.am, or Im-am Præfes, Anteceffor, quem alij feetantur ac imitantur: peculiariter qui prxic populo facros ritus \& facrorum antiftes. Vid. Gol. in voce. 5 Thefe they call [urtạ] Hab-oufe, i. c. Things fer apart for pious ufes. 
complained of: inftead likewife of fuch Expreflions of Sorrow and Condolence, as may regard the deceafed, the Compliments turn upon the Perfon, who is the neareft concerned, (Berka fe rafjick) A Bleffing (fay his Friends) be upon your Head.

If we except a few Perfons, who are buried within the The Mazmer Precincts of fome Sanctuary, the reft are carried out at a sepplcires. fimall Diftance from their Cities and Villages, where a great Extent of Ground is allotted for that Purpofe. Each Family hath a particular Portion of it, walled in like a Garden, where the Bones of their Anceftors have remained undifturbed for many Generations. For in thefe Enclofures 'the Graves are all diftinct and feparate: having each of them a Stone, placed upright, both at the Head and Feet, infcribed with the Name of the Perfon who lieth there interred; whilft the intermediate Space is either planted with Flowers, bordered round with Stone or paved all over with Tiles. The Graves of the principal Citizens are further diftinguifhed by fome Square Chambers or Cupolas ${ }^{2}$ that are built over them. Now as all thefe Some Texts of different Sorts of Tombs and Sepulchres, with the very Walls $s_{\text {tod }}^{\text {ling }}$ ing therelikewife of the Enclofures, are conftantly kept clean, white. wafhed and beautified, they continue, to this Day, to be an excellent Comment upon that Expreffion of our Saviours, where he mentions the garnifling of the Sepulchres, Matt.23.29. and again (V.27.) where he compares the Scribes, Pharifees and Hypocrites, to whited Sepulchres, which indeed appear beautiful outward, but are zithin full of dead Mens Bones and all uncleanne/s. For the Space of two or three Months after any Perfon is interred, the Female ${ }^{3}$ Relations go once a Week to weep over the Grave and perform their Parentalia upon it.

We are to obferve further with Regard to the feveral Build- The cement ings and Structures which I have defcribed, that both the Buildings. Plaifter and Cement, which are made ufe of, (particularly where

I Thefe feem to be the fame with the Mreißonot of the Antients. Thus Euripides Troad. 1. I I $4 \mathrm{~T}$.

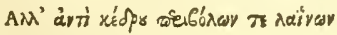

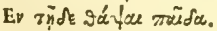

2 Such Places probably as thefe are to be underftood, when the Demoniack is faid to have bis Dwellings among the Tombs. Mar. 5. 3. 3 Notatum fuit in omnibus Sacris, foeminini generis Victimas effe potiores \&c. Vid. Alex. ab Alex. Gen. Dier. 1. 3. cap. 12. De parentalibus $f_{0}$ conis ferialibus. 4 Convivia qux in Parentum aut propinquorum funere fieri confueverunt. Vid. Alex. ab Alex. ut fupra. Lex. Pitifc. 
extraordinary Strength and Compactneis are required) are, to all Tryal and Appearance, of the fame Confiftence and Compofition with Thofe of the Antients '. Thofe Cifterns which were built, by Sultan ben Eglib, in feveral Parts of the Kingdom of Tunis, are of equal Solidity with the famous ones at Cartbage, continuing to this Day (unlefs where they have been defignedly broken,) as firm and compact, as if they were jult finifhed. The Compofition is made in this Manner. They take two Parts of Wood Afhes, three of Lime, and one of fine Sand, which, after being well fifted and mixed together, they beat, for three Days and Nights inceffantly, with wooden Mallets, fprinkling them alternately and at proper Times, with a little Oyl and Water, 'till they become of a due Confiftence. This Compofition is chiefly ufed in their Arches, Cifterns, and Terraces. But the Pipes of their Aquæducts are joyned, by beating Tow and Lime together with Oyl only, without any Mixture of Water. Both thefe Compofitions quickly affume the Hardnefs of Stone, and fuffer no Water to pervade them.

Their Glue. Inftead of common Glue, the Joyners frequently ufe a Preparation of Cheefe, which is firft to be pounded, with a little Water, in a Mortar, 'till the wheyie Matter is wafhed out. When this is done, they pound it again with a fmall Quantity of fine Lime, and apply it afterwards as quick as poffible to fuch Boards as are to be joyned together, which, after the Cement becomes dry, will not be feparated, I am told, even by Water itfelf.

The Habitation of the Bedoweens.

Having thus defcribed the feveral Buildings peculiar to the Cities of this Country, let us pafs on to take a View of the Habitations of the Kabyles and Bedoweens: Thefe, for the moft Part, the Inhabitants of the Plains, the Others of the Mountains. Now the Bedoweens live in Tents, called Hbymas $=$ [Nh] from the Shade they afford the Inhabitants, and [Beet el Shar شar in Houles of Hair, from the Matter they are made of. They are the fame, with what the Antients called Mapalia ${ }^{3}$, which being then, as they are to this Day, fecured

1 Sc. ex fabulone, \& calce \& favilla. Vitrur. Arch. 1.7. cap. 4. Plin. 1. 36. cap. 25. 2 Sc. a خ

3 Qualia Maurus amat difperfa Mapalia Paftor. Sil. Ital. Lib.17. Car. go. Et folitus vacuis errare Mapalibus Afer

Venator.

Lucan. 1. 4. 684 .

Familix aliquot (Numidarum) cum Mapalibus pecoribufque fuis (ea pecunia illis eft) perfecuti funt regem. Liv. 1.29. 9. 3 I.

Numidas pofitis Mapalibus confedilfe

Taf. Ann. 1.4.9.25. 
from the Heat and Inclemency of the Weather, by a Covering only of fuch Hair Cloth, as our Coal-Sacks are made of, might very juftly be defcribed by Virgil* to have thin Roofs. When we find any Number of them together, (and I have feen from three to three hundred) then, as it hath been already taken Notice of ", they are ufually placed in a Circle and conftitute a Dout-war. The Fafhion of each Tent is the fame, being of The Faflion an oblong Figure, not unlike the bottom of a Ship turned upfide down, as Sallu/2 ${ }^{2}$ hath long ago defcribed them. However they differ in Bignefs, according to the Number of People who live in them; and are accordingly fupported, fome with one Pillar, others with two or three: whilft a Curtain or Carpet placed, upon Occafion, at each of thefe Divifions, feparateth the whole into fo many Appartments. The Pillar which I have mentioned, is a ftraight Pole, eight or ten foot high, and three or four Inches in Thicknefs, ferving, not only to fupport the Tent, but, being full of Hooks fixed there for the Purpofe, the Arabs hang upon It their Cloaths, Baskets, Sadles and Accoutrements of War. Holofernes, as we read in Fudith 13. I6. made the like ufe of the Pillar of his Tent, by hanging his Fauchin upon It. It is there called the Pillar of the Bed, from the Cuftom perhaps, that hath always prevailed, of having the upper End of the Carpet, Matrafs, or whatever elfe they lye upon, turned, from the Skirts of the Tent, that Way. But the [Kaverẽoy] Canopy, as we render It (Ver. 9.) fhould, I prefume, be rather called the Gnat or Muskeeta-Net, which is a clofe Curtain of Gauze or fine Linnen, ufed, all over the Levant, by People of better Fafhion, to keep out the Flyes. The Arabs have nothing of this Kind; who, in The mettod taking their Reft, lye horizontally upon the Ground, without ${ }_{t b}^{\circ}$ him. Bed, Matrafs or Pillow, wrapping themfelves up only in their Hykes, and lying (as they find Room,) upon a Mat or Carpet, in the Middle or Corner of the Tent. Thofe who are married, have each of them a Corner of the Tent, canton'd off with a Curtain : the reft accommodate themfelves in the Manner I have defcribed. The Defcription which Mela $^{3}$ and

1 Vid. Not. *. p. 32. 2 Edificia Numidarum, qux Mapalia illi vocant, oblonga, incurvis lateribus te\&a, quafi navium carinx effent. Salluf. Bell. Jug. 9. 2I. 3 Vid. Exi. p. I9. cap. 3. * Not. I. P. 288 .

$$
\text { Cecca Tirgil }
$$


Virgil have left us of their Manner of Living and Decamp. ments, even to the Circumftance of carrying along with them their faithful Domeftick, are as juftly drawn up, as if they had made their Obfervations at this Time.

The Habitatous of the
Kabyles.

From the Dou-wars of the Bedoweens, we are to afcend to the Da/bkras of the Kabyles, which confift of a Number of Gurbies, as the Dou-wars do of Hhymas. Thefe Gurbies are generally raifed either with Hurdles, daubed over with Mud, or elfe they are built out of the Materials of fome adjacent Ruins, or with fquare Cakes of Clay baked in the Sun. The Roofs are covered with Straw or Turf, fupported by Reeds, or Branches The Fafbion of of Trees. There is rarely more than one Chamber in the theirGurbies. largeft of them; notwithftanding it is to ferve for a Kitchin, Dining Room, and Bed-chamber; befides one Corner of it that is referved, as I fhould have mentioned alfo in the Hbymas, Thefe Gur- for their Foles, Calves, and Kids. Thefe Hovels being always biest the anor Magaria.

called Magalia ${ }^{2}$ : according to Virgil ${ }^{3}$ therefore, Cartbage itfelf, before the Time of Dido, was nothing more than one of thefe Dafbkras, which I have defcribed.

The Showiah The Kabyles, from their Situation ${ }^{4}$ and Language, (for all or Language
of the Kaby-the reft of the Country fpeak the Arabick Tongue) feem to les. be the only People of thefe Kingdoms, who can bear any near Relation to the antient Africans. For, notwithftanding the great Variety of Conquefts, to which the low and cultivated Parts of this Country have been fo often fubject, yet it is more than probable, that all or the greater Part of the mountainous Diftricts, were, from their rugged Situation, in a great Meafure left free and unmolefted. Whilft the Nomades therefore and Inhabitants of fuch Cities and Villages, as were of eafy Accefs, fubmitted by Degrees to the Lofs of their old Language, and to the Introduction of fuch new Laws and

1 Quid tibi paftores Libya, quid pafcua verfu

Profequar, \& raris habitata mapalia tectis.

Sxpe diem noctemque \& totum ex ordine menfem

Pafcitur, itque pecus longa in deferta fine ullis

Hofpitijs: tantum campi jacet: omnia fecum

Armentarius $A f e r$ agit, tectumque, laremque

Armaque, Amycleumque canem, Croffamque Pharetram. Georg. 3. 1. 339.

2 Magalia dicta quafi magaria, quod magar Punici novam villam dicunt. Iffid. Orig. I. is. cap. 12. Vid. Boch. Chan. I. I. cap. 24. Magalia qux a Vallo Caftrorum Magar vel Magul inftar villarum fixx erant \&c. Vid. Cl. Waßsai Not. in Sall. Bell. Jug. p. 285.

3 Miratur molem Aneas, Magalia quondam.

4 Vid. P.7.8.120. \&c.

AEII. I. 425 .

Cuftoms, 


\section{Objervations \&c.}

Cuftoms, as were confequent upon thefe Invafions; thofe Africans who retired to the Mountains and there formed them-

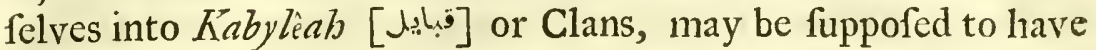
been the leaft affected with thofe Novelties. It may be farther urged, that as They would be hereby obliged to converfe chiefly among themfelves, fo, for thefameReafon, they would continue to be much the famePeople, and, in all probability, preferve, their Original Language without any confiderable Alteration. But what this was, he muft be a very bold Conjecturer who can at this Diftance of Time pretend to afcertain. For indeed it is farce conceivable but that the Carthaginians, who poffeffed all Africa ${ }^{1}$ from Cyrene to the Atlantic Ocean, muft, in confequence of their many Conquefts and Colonies have in fome Meafure introduced their own Language, of which we have a Specimen ${ }^{2}$ in the Prenulus of Plautus. And a ftill greater Change muft it probably have fuffered from the fucceffive Admiffion of Romans and $V$ andals into thefe Countries. Thus much however is certain that there is noAffinity at all betwixt, what may hath no Relabe fuppofed to be, the primitive Words in the Showiah ${ }^{3}$ (as they ${ }_{\text {Arabiek }}^{\text {Her or }}$ call this Language at prefent) and the Words which convey the Troxgues. fame Meaning in the Hebrew and Arabick Tongues. For Thamurt, Arghaz, Thamtuth, Agarum, Akfum \&c. their Names for Earth, a Man, a Woman, Bread, Fle / \&c. cannot, I prefume, be any way related to the Oriental Languages. But the Reader is referred to a Vocabulary of this Language, which is inferted after the Excerpta.

Having thus defcribed the different Habitations of thefe The Hyke, People, I thall now give an Account how they employ themfelves in Them. Under this Head therefore will be comprifed their Manufactures, Habits and Manner of Living. Now the chief Manufacture among the Kabyles and Arabs is the making of Hykes (as they call Woollen Blankets) and Webs of Goats Hair for their Tents. The Women alone are employed in this Work, as Andromache and Penelope were of old, who make no ufe of a Shuttle, but conduct every Thread of the Woof with their Fingers. One of thefe Hykes, is ufually fix

I Vid. Boch. Chan. in Prefat. 2 Ibid. I. 2. cap. I. 3 The Language of the Mountaineers in S.W. Barbary is called Shillah, differing in fomeWords from the Showwiah; but the meaning of the Names I could never learn, unlefs perhaps they were called after fome confiderable Clans, who might be either the Authors or Confervators of them. 4 Probably derived from sexuit. 
Yards long and five or fix Foot broad, ferving the Kabyle and Arab for a compleat Drefs in the Day, and for hisBed and Covering in the Night. It is a loofe but troublefome Kind of Gareafilydifforr ment, being frequently difconcerted and falling upon the certed. Ground, fo that the Perfon who wears it, is every moment obliged to tuck it up, and fold it anew about his Body. This hews the great Ufe there is for a Girdle in attending any active Employment, and in Confequence thereof, the Force of the Scripture Injunction, alluding thereunto, of having our Loyns girded". The Method of wearing thefe Garments 2, with the Ufe they are at other Times put to, in ferving for Coverlets to their Beds, fhould induce us to take the finer Sorts of them at leaft, fuch as are wore by the Ladies and Perfons of Di-

The Peplus Sc. of the Antients.

The Burnoore. ftinction, to be the Peplus of the Antients. It is very probable likewife, that the loofe folding Garment (the Tog $a^{3}$ I take it to be ) of the Romans, was of this Kind: for if the Drapery of their Statues is to inftruct us, This is actually no other than what the Arabs appear in, when they are folded up in their Hykes. Inftead of the Fibula, they joyn together, with Thread or a wooden Bodkin, the two upper Corners of this Garment, which being firft placed over one of their Shoulders, they fold the reft of it afterwards round their Bodies.

The Burnoofe, (as they call their Cloak or upper Garment,) is likewife made in thefe Dou-wwars and Dafbkras: though there are Looms, both for It and the Hyke, in moft of the Towns and Villages. It is of one Piece, thaped like the Gar-

I Thus wer? çrvou is ufed Luke 17.8. Acts 12. S. Eph. 6. I4. Rev. I. I3. and 15. 6. And

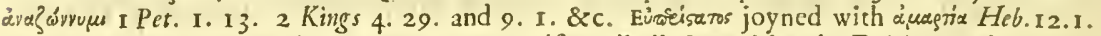
i. e. Sin which is fo well fitted to gird $u$ s $i n$, is alfo well illuftrated by the Fafhion, and Manner

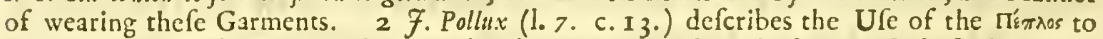

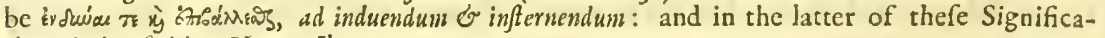
tions it is ufed by Homer. Il. E. v. 194.

$$
\text { חíîarau. }
$$

The Scholiaft upon Il. E. v. 734. makes the Peplus to be a Garment that was fitted to the Body by a Fibula, juft as the Hyke is, of (fays he) rid 'irsdiovro, dis' imporârto: and fo Callimach. in Lavacr. Pallad. v. 70.

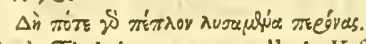

Lutatius upon Statits's Thebais v. IOr. Calls it Veftis Candida. That it was alfo a large Garment, hanging down to the Feet, \&c. appears from the following. Epithets that are given

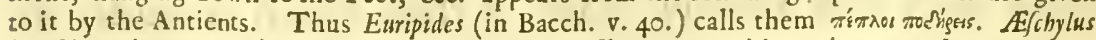

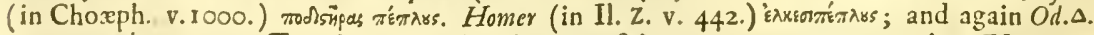

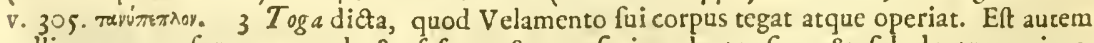
pallium purum forma rotunda \& fuftore, \& quafi inundante finu \& fub dextro veniens, luper humerum finiftrum ponitur: cujus fimilitudinem in operimentis fimulachrorum vel piaturarum afpicimus, eafque ftatuas togatas vocamus. Menfura Togæ iuftx, fi fex ulneas habeat. Ifid. Orig. 1. 19. cap. 24. 
ment of the little God Tele phorus; i.e. Atrait about the Neck, with a Cape or Hippocrates's Sleeve for a Cover to the Head, and wide below like a Cloak. There are fome of Thein like- T\%e Fapions wife which are fringed round the Bottom like that of Partbenafpa's, and Trajan's, upon the Bafjo Relievo's of Conftantine's Arch'. The Burnooje, without the Cape, feems to anfwer to somenkat like the Roman Pallium ${ }^{2}$, and, with it, to the Bardocucullus ${ }^{3}$, being Pardocuculprobably the fame with our Saviour's Cloak, which (Fob.i 9.23.) lus. was wove without Seam from Top to Bottom; and with the Cloaths of the Ifraclites, (Ex. I2. 34.) wherein they folded up, their kneading Troughs, \&c. as the Moors, Arabs and Kabyles, (for It is wore by them all) do, to this Day, Things of the like Burthen and Incumbrance.

If we except the Cape of the Burnoofe, which is only occa-Several cians fionally made ufe of during a Shower of Rain or in very cold beaded. Weather, feveral Arabs and Kabyles go bare-headed all the Year long, as Mafaniffa did of old ${ }^{4}$, binding their Temples only with a narrow Fillet, to prevent their Hair from being Their Temples troublefome. As the antient Diademas might originally ferve Fillet. for this Purpofe, fo it appears from Bufts and Medals, (unlefs when It is adorned with precious Stones;) to have been no other Ornament. But the Moors and Turks in general, with fonve of the richer Clans of Arabs, wear, upon the Crowns of Tbe cafs wore their Head, a fmall hemifpherical Cap of Scarlet Cloath, which by the Moors is to be taken Notice of, as another chief Branch of theirent Tiara. Woollen Manufacture. The Turbant, which is a long narrow Tbe Turbant. Web of Linnen, Silk or Mullin, is folded round the Bottom of thefe Caps, and diftinguifheth, according to the Order and Fafhion of the Folds, the feveral Orders of Soldiers not only from the Tradefinen and Citizens, but from one another. We find the fame Drefles and Ornaments for the Head upon antient

I Vid. Veteres Arcus Auguftorum \&c. antiquis nummis notifque Fo. Petri Bellori illuftrati \&rc. Rom. 1690. Tab. 24. 28. 38. \&rc. 2 Pallium (iuánov) quia palam geftetur : quod palam fit \& foris: fub eo enim Tunica fumebatur \&c. Vid. Stepls. Thef. Ling. Lat. 3 Penulæ Gallicæ genus, qux cucullum habet. Hinc Martial. 1. I4. 178.

Gallia Santonico veftit te bardocucullo.

Vid. Raynund. de Pil. S. I 5. Ferrar. de ReVeft. 2. 1. 21. Salm. Exercit. Pl.p.392. IJ/fi. Lex. Etym. vel Lex. Pitifc. 4 Arbitror te audire, Scipio, hofpes tuus avitus Mrifariffa, qux faciat hodie, nonaginta annos natus: cum ingreffus iter pedibus fit, in cquum omnino non afcendere : cum equo, ex equo non defcendere: nullo frigore adduci, ut capite operto fit \&c. Cic. de Sencetute. 5 Diademi etat Falcia candida, qux regum capitibus obligabatur. Cal. 1.24. cap. 6 . 
Medals, Statues and Baffo Relievo's; the former of which appears to be the fame with the Tiara ${ }^{2}$ of the Antients.

Straight bodied Frocks.

Some of thefe People wear, underneath their Hykes, a clofe bodied Frock or Tunick (a Fillebba I think they call lt) with or without Sleeves, not unlike the Roman Tunica, or the Habit in which the Conftellation Bootes is painted. This, no lefs than the Hyke, is to be girded about their Bodies, efpecially when they are engaged in any Labour, Exercife or Employment; at which Time they ufually throw off their Hykes and Burnoofes, and remain only in their 'Tunicks. Of this Kind probably was the Habit, which our Saviour might ftill be cloathed with, when $\mathrm{He}$ is faid to lay afide bis Garments (irária Pallium Jc. Wo Peplum. Joh. 13.4.) and to take a Towel and gird bimSelf; as was likewife the Fifhers Coat ${ }^{2}$, (Joh. 2I. 7.) which St. Peter girded about Him, when $\mathrm{He}$ is faid to be naked; or what the fame Perfon, at the Command of the Angel, (ACZ.I 2.8.) might have girded upon Him, before $\mathrm{He}$ is enjoyned to ca/t His Garment (imátiou) about Him. Now the Hyke and Burnoofe being probably, at that Time, the (ina'roor) proper Drefs, Cloath. ing, or Habit of the Eaftern Nations, as they continue to be to this Day, of the Kabyles and Arabs, the laying them afide, or appearing without them, might, according to the Eaftern Manner of Expreffion, be other Words only for being naked.

The Fafbion of The Girdles of thefe People are ufually of Worfted, very skeir Girdles. artfully woven into a Variety of Figures and made to wrap feveral Times about their Bodies. One End of them, by being doubled and fown along the Edges, ferves them for a Purfe, agreeable to the Acceptation of the word Zorm ${ }^{3}$ in the H. Scriptures. The Turks and Arabs make a further Ufe of their Girdles by fixing their Knives and Poiniards ${ }^{4}$ in them: whilft the Hojias (i. e. the Writers and Secretaries) are diftinguifhed

I Quartum genus veftimenti eft rotundum pileolnm, guale piaum in Ulyffeo confpicimus, quafs, fphæra media fit divifa: \& pars una ponatur in capite : hoc Græci \& noftri Tiagear, nonnulli Galerum vocant, Hebræi טצנפת Miznepheth : non habet acumen in fummo, nec totum ufque ad comam caput tegit, fed tertiam partem a fronte inopertam relinquit. \&c. Hieronym. de Vefte Sacerdot. ad Fabiolam. 2 The Original Word is inzrdins, which the

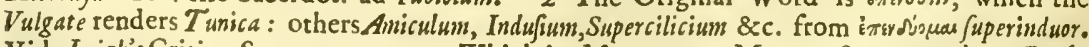
Vid. Leigh's Critica Sacra. P. 149. 3 Which in Mat. 10. 9. Mar. 6. 8. we render a Purfe. 4 The Poiniard of the Arab is made crooked, like the Copis or Harpe of the Antients. Q. Curt. 1. 3. de reb. Alex. Copidas vocant gladios leviter curvatos falcibus fimiles. Bonarotx Ptxf. in Dempft. Hetrur. Regal. Brevis gladius in arcum curvatus Harpe dittus. 
by having an Inkhorn', the Badge of their Office, fufpended in the like Situation.

It is cuftomary for the Turks and Moors to wear Linnen The Arabs underneath their Tunicks; but the Arabs, in general, wear nothing but Woolen. There is a Ceremony indeed, in fome Douwars, which obligeth the Bridegroom and the Bride to wear each of them a Shirt, at the Celebration of their Nuptials; but then, out of an odd Piece of Superftition, they are not afterwards to walh or put them off fo long as they laft. The Sleeves are wide and open, without any Folds at the Wrift, whilft thofe of the Women are made with Gauze and different coloured Ribbands, interchangeably fown together. Neither ${ }_{n o r}$ Draxers. are the Bedoweens accuftomed to wear Drawers, a Habit which the Citizens. of both Sexes do conftantly appear in, efpecially when they go abroad or receive Vifits. The Virgins are diftinguifhed from the Matrons in having Theirs made of Needle-work, ftriped Silk or Linnen, juft as Tamar's Garment is defcribed, 2 Sam.13.18. But when theWomen are atHome and in Private, then they lay afide their Hykes and fometimes their Tunicks, and, inftead of Drawers, bind only a Towel ${ }^{2}$ about their Loyns. A Barbary Matron in her Undrefs appears exactly in the fame manner, that Silenus doth in the Admiranda ${ }^{3}$.

We are to obferve further with Regard to the Habits of the The Vilis scic. Moorifs Women, that, when they appear in Publick, they al-ifl Womenn. ways fold themfelves up fo clofely in their Hykes, that without theAddition of a Veil, there is very little to be feen of their Faces. But in the Summer Months, when they retire to their Country Seats, they walk abroad with lefs Caution and Refervednefs, and, upon the Approach of a Stranger, let only their Veils fall over their Faces, as Rebekab may be fuppofed to have done upon the Sight of Ifaac. (Gen. 24. 65.) They all affect to have their Hair hang down to the Ground, which they

I That part of thefe Inkhorns (if an Inftrument of Brafs may be fo called) which paffeth betwixt the Girdle and the Tunick and holdeth their Pens, is long and flat; but theVeffel for the Ink, which refts upon the Girdle, is fquare, with a Lid to clafp over it. They make no ufe of Quills, but of fmall Reeds (Calami) which they cut into the fame Shape with our Pens; and in the Country Villages, no lefs than among the Kabyles and Arabs, where Galls, Copperas \&c. are not to be procured, they have Wool calcined into Powder, which they mix afterwards with Water. The Manner of carrying thele Inftuments in their Girdles, (Y'נפני (Ezek. 9. 2.) ad lumbos fuos, by His Side) feems to have been as early as the Propher Ezekiel. 2 This is called both in Barbary and the Levant, a Footah [rb,g] which Camus (in Golius) makes to be a Perfian Word, denoting, Genus vefis friate, ex Sindia deportari folitum. pec. pracinctorium. 3 Vid. Admirand. Roman. Antiq. Tab. 44.

E e e e

collect 
collect into one Lock, upon the hinder Part of the Head; binding and plaiting (I Pet.3.3.) it afterwards about with Ribbons. Where Nature hath been lefs liberal, there the Defect is to be fupplyed by Art, and foreign Hair interwoven with the natural. Some Commentators have imagined that Abfalom's Hair, which was fold (2 Sam. 1 4. 26.) for two bundred Shekels, was to be applyed to this Ufe. After their Hair is plaited up in this Manner, they proceed to drefs their Heads by tying clofe together, above the Lock I have defcribed, the feveral Corners of a triangular Piece of Linnen, wrought into a Variety of Figures by the Needle. Perfons of better Fafhion wear above this a Sarmah, as they call it, which differeth not much in Shape from the former Head Drefs, but is made of thin flexible Plates of Gold or Silver,varioufly cut through and engraved in Imitation of Lace. A Handkerchief of Crape, Gauze, Silk or painted Linnen, bound clofe about the Sarmah, and falling afterwards, without any Order, upon the Lock, compleats the Head Drefs of the Moorifl Ladies.

But none of thefe Ladies take themfelves to be compleatly Ore. dreffed, 'till they have tinged the Hair and Edges of their EyeLids with [Al Ka-bol' $\mathrm{H}_{\mathrm{s}}=\mathrm{l}$ '] the Powder of Lead Ore. Now as this Operation is performed by dipping firft into the Powder a fmall wooden Bodkin of the Thicknefs of a Quill, and then drawing it afterwards, through the Eye Lids, over the Ball of the Eye, we fhall have a lively Image of what the Prophet (Fer. 4. 30.) may be fuppofed to mean by renting the Eyes with (פead Ore) painting. The Sooty Colour, which is in this manner communicated to the Eyes, is thought to add a wonderful Gracefulnefs to Perfons of all Complexions. The Practice of it, no Doubt, is of great Antiquity: for befide the Inftance already taken Notice of, we find that when Fezebel is faid

I This Word is rendred by Golius and others, Stibium, Antimonij Species; and fome-

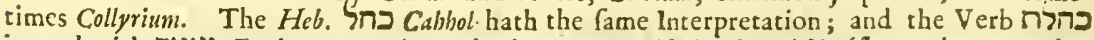

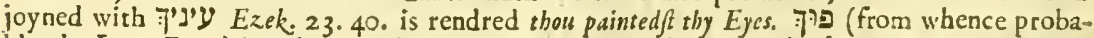
bly the Lat. Fucus) is taken in the like Signification, being rendred Antimonium, Stibium, quo ad tingenda nigrore cilia, feu ad venuftandos oculos, peculiariter utebantur, color fubniger ex pulveribus Stibij confeetus. Sclindl. Lex. St. Ferom likewife upon thefe Words

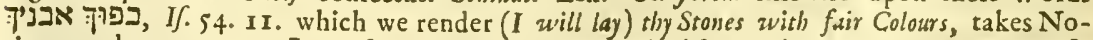
tice, quod omnes præterLXX. fimiliter tranftulerunt: viz.(fernam) in Stibio lapides tuos, in fimilitudinem comptre mulieris, quæ oculos pingit Stibio, ut pulchritudinem fignificet civitatis. 7' therefore and $5 \pi$, h hes denoting the fame mineral Subltance or Collyrium, it may be prefumed that what is called to this Day by the latter of thefe Names (which is a rich Lead Ore, pounded into an impalpable Powder, was the Mineral which they always made ufe of. 
(2.Kings 9. 30.) to have painted her Face, the Original Words

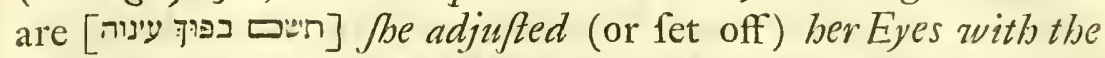
Powder of Lead Ore. The like Ornament was made ufe of not only by other Eaftern Nations, but by the Greeks and Romans alfo, as appears from antient Authors . Among other Things relating to theEgyptian Women, I have likewife feen taken out of the Catacombs at Sakara, a Joynt of a common Reed, which contained one of the Bodkins, and an Ounce or more of the Powder that I have defcribed; both of them agreeable to the Fafhion and Cuftom of this Time.

Carpets are another Branch of the Trade and Manufacturies Carpets, of this Country. They are made of much coarfer Materials, and are not fo beautifully defigned as thofe of Turkey; but being cheaper and fofter, they are preferred by thefe People to lye upon. At Algiers and Tunis there are Looms for Velvet, Tafitas, and feveralKinds of wrought Silks. A coarfe Sort of ${ }_{\text {silks, }}$ Linnen is likewife made all over thefe Kingdoms, though $S_{u} \int_{a_{\text {Limen }}}$ is noted for producing the fineft. The greateft Part of the Manufactures I have mentioned are confumed at Home; fome of which are fo fmall and inconfiderable, particularly the Silks and Linnen, that the Deficiencies are frequently made up from the Levant and Europe. It may be further obferved, that Branthes of thefe Parts of Barbary fend very few of their Commodities to Trade. foreign Markets. Oyl, Hydes, Wax, Pulfe and Corn, are the general Produce; but the firft are either in fuch fmall Quantities, or fo much wanted at Home, that Corn may be reckoned the chief and indeed the only Branch of Trade for Exportation. Before the Lofs of Warran, I have known our Merchants, fhip off, fome Years, from one or other of the Ports of thefe Kingdoms, feven or eight thoufand Ton. There is likewife fo great a Confumption of Oyl among the Natives themfelves, that, in the Kingdom particularly of Algiers, it is feldom permitted to be fhipped off for Chriftendom. Greater Quantities indeed are produced near Tunis and SuJa, but then the

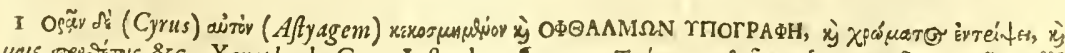

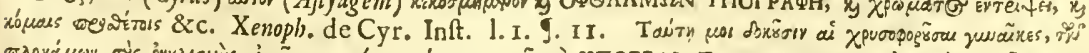

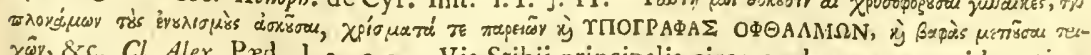
$\chi_{\hat{a}}^{a v}, \&$ c. Cl. Alex. Pxd. I. 3. c. 2. Vis Stibij principalis circa oculos; namque ideo ctiam plerique Platyophthalmon id appellavere (Diofcorid. 1.5. c. 99.) quoniam in calliblepharis mulierum dilatet oculos. Plin.1.33. c.6.

Eeeg 2

Moorifs 
Moorifh Merchants alone are allowed to buy it: obliging themfelves at the fame Time to difpofe of it at Alexandria, Damiata, or fome other Ports of the Mahometan Dominions.

The cheaprefs Commodities of all Kinds are fold very cheap in this Counof their Pro-
vifions. try. We can have a large Piece of Bread, a Bundle of Turneps, a fmall Basket of Fruit \&c. for the fix hundredth and ninety fixth part of a Dollar, i. e. of three Shillings and Six-pence of our Money. Fowls are frequently bought for three half-pence a Piece; a Sheep for three Shillings and fix-pence; and a Cow and a Calf for a Guinea. It is happy likewife for thefe People, that they can have, one Year with another, a Bufhel of the beft Wheat for fifteen or eighteen-pence. For the Inhabitants of thefe Countries, no lefs than the Eaftern People in general, Thefe People are great Eaters of Bread '; it being computed that three Pergreat Eaters
of Brend. fons in four live entirely upon It, or elfe upon fuch Compofitions $^{2}$, as are made of Barley and Wheat-Flour. Frequent mention is made of this fimple Diet in the H. Scriptures?.

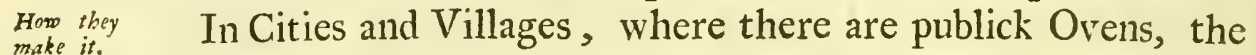
Bread is ufually levened; but among the Bedoweens, as foon as the Dough is kneaded, it is made into thin Cakes, which are either immediately baked upon the Coals, or elfe in a Ta-jen ${ }^{4}$. Such were the unleavened Cakes, (Ex. 29.2. Fo/h. 5. I I. Fudg. 6. II. and 19. 2 Sam. 13. 8. I Chr.23.29. \&c.) and the Cakes which Sarab made quickly upon the Hearth, Gen. 18.6.

How they grind their Corn.

Moft Families grind their Wheat and Barley at Home, having two portable Grind-Stones for that Purpofe, the uppermoft whereof, is turned round by a finall Handle of Wood or Iron,

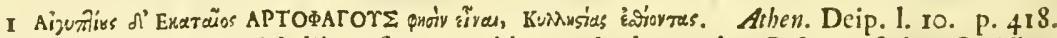
Ed. Dalechamp. Maffaniffa likewife, agreeable no doubt to the Cuftom of the Numidians

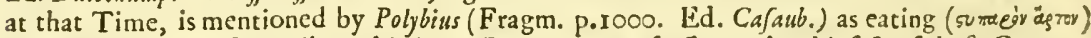
brown Bread very favourily at his Tent Door. $2 \mathrm{Cu}$ caffowe, the chicfeft of thefe Compopofitions, is well defcribcd in Plit. Tranf. No 254. and in Lowth. Abridg. Vol.3. P. 626. When the Grains of Cufcaffowe are large, then the Compofition is called Hamza. What they call Dweeda is the fame with Vermezzelli; as their Bug-reah differs not much from our Pancakes, only that inftead of rubbing the $\left(T_{a-j e n}\right)$ Pan they fry it in with Butter, they make ufe of Soap to make it honey-comb. 3 Gen. 18. 5. and ISam. 28. 22. I will fetch a morfel of Bread. Ch. 21. 14. And Abraham took Bread and a bottle of Water, and gave it unto Hagar. Ch. 37.25. They fat down to eat Bread. Ch. 43. 31. And Jofeph faid, fet on Bread. Ex. 2. 20. Call bim, that he may eat Bread. Ch. 16. 3. We did eat Bread to the full. Deut. 9. 9. I neither did eat Bread nor drink Water I Sam. 28. 20. Saul had eaten no Bread all the Day. \&c. 4 This is a fhallow Earthen Veffel, like a Frying Pan, made ufe of not only for This but Other Purpofes. What is baked therein is called Ta-jen, after the Name of the Veffel; juft as mizaroy (Hefych. raiglwor) a Word of the fame Sound and Import, is taken by

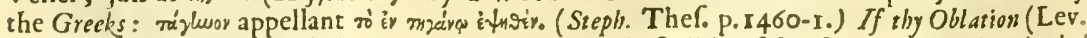

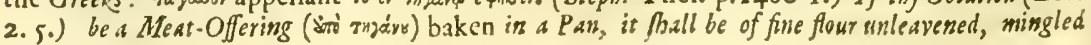
with $O y l$. 
placed in the Edge of It. When This Stone is large, or Expedition is required, then a fecond Perfon is called in to affift; and as it is ufual for theWomen alone to be concerned in thisEmploy, fitting themfelves down over againft each other with the Mill Stones between them, we may fee not only the Propriety of the Expreffion, Ex. Ir. of fitting bebind the Mill, but the Force alfo of the other, Mat.24. 40. that two Women foall be grinding at the Mill, the one Jall be taken and the other left. Athenceus ${ }^{2}$ has preferved an Expreffion of Ariftophanes, which takes Notice of the fame Cuftom that is obferved to this Day among the Bedoween Women, of finging all the while they are thus employed.

Befides feveral different Sorts of Fricafees, and of Roaft, Thair fercural Boiled, and Forced-Meats, (the firft and laft of which are always made very favory,) the richer Part of the Turks and Moors, mix up a variety of Difhes with Almonds, Dates, Sweet-Meats, Milk, Honey, \&c. which it would be too tedious to enumerate. I have feen at fome of their Feftivals, more than two hundred Difhes, whereof forty at leaft were of different Kinds. But among the Bedoweens and Kabyles there are neither Utenfils nor Conveniences for fuch Entertainments; two or three wooden Bowls, a Pot and a Kettle, being the whole Kitchin Furniture of the greateft Emeer. However all Their Method the Orders and Degrees of thefe People, from the Bedoween to the Baflaw, eat in the fame Manner; wafhing firft their Hands, and then fitting crofs-legged, round a Mat, or low Table, upon which their Difhes are placed. They make no Ufe of a Table Cloth, each Perfon contenting Himfelf with a Share of a long Towel that lyes round the Mat. Knives and Spoons are little in Ufe: for the Food, being well roafted and boyled, requires no Carving. Cufcaffowe, Pilloe and other Difhes likewife, which we fhould reckon Spoon Meats, are ferved up, in the fame Manner with all their other Sorts of Food, no better than lukewarm, fo that the whole Company dipping their Fingers together in the Difh, (making ufe of their right Hand only,) take what Portion of it they can conveniently difpofe of for a Mouthfull, making it firft into little Balls or Pellets in the Palms of their Hands. No fooner is any Perfon

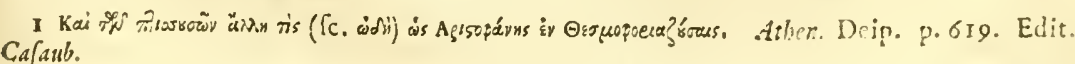
Ffff fatisfied, 
fatisfied, than he rifes up and wafhes himfelf, without paying the leaft Regard to the Company; whilft another, that very Moment, takes his Place; the Servant fometimes (for there

Saing Bifmillah then they fit doson, \& $\mathrm{xc}$. is no Diftinction of Tables) fucceeding his Mafter. When they fit down to thefe Meals or eat and drink at any other Time; and indeed when they enter upon their daily Employ, or undertake any Bufinefs whatfoever, they always pronounce, with the greateft Serioufnefs and Reverence, the Word Bifmillab,

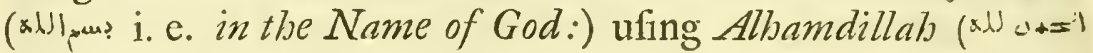
i. e. God be praifed, ) after Nature is fatisfied, and their Affairs are attended with Succefs.

The Times of rifing and eatning among the
lloors and lirks.

The Turks and Moors are early Rifers, conftantly attending the publick Devotions at Break of Day. Each Perfon employs himfelf afterwards in the Exercife of his proper Trade and Occupation 'till ten in the Morning, the ufual Time of dining; returning again to his Bufinefs 'till $\left(A \int a\right)$ the Afternoon Prayers, at which Time, all Kind of Work ceafeth, and their Shops are fhut up. The Supper commonly follows the Prayers of (Magreb) Sun fet, and then repeating the fame at the fetting of the Watch, when It begins to be dark, they go to Bed immediately after. Some of the graver People, who have no The Diverfi- conftant Employ, fpend the Day, either in converfing with ous of the old one another at the Haf-effs
and young. Houfe: whilft a great Number of the Turkifs and Moorifh Youths, with no fmall Part of the unmarried Soldiers, attend their Concubines, with Wine and Mufick, into the Fields; or elfe make themfelves merry at one of the publick Taverns; a Practife indeed exprefsly prohibited by their Religion, but what the Neceffity of the Times, and the uncontroulable Paffions of the Tranfgreffours oblige thefe Governments to difpence with.

The Arab follows no regular Trade or Employment. His the Arab. Life is one continued Round of Idlenefs or Diverfions. When no Paftime calls him abroad, he doth nothing all the Day, but loyter at Home, fmoke his Pipe ${ }^{2}$, and repofe himfelf under fome

I The holding Converfations at the Haf-effs i. e. the Barber's Shop, feems to be of great Antiquity; for Theopbrafus (as we read in Plutarch. Sympof. L. 5. Q.5.) calls them ădva oupróne

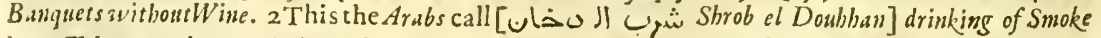
i. c. Tobacco; the Arabick and our Name being the fame according to what Hernandez relateth. Plantam quam Mexicenfes Pycielt $\int e u$ Yelt vocant, $a b$ Haitinis appellatur Tobacus, $a$ quibus nors ad Indos folum fed ad Hifpanos id dofluxit nomen, eo quod Suffumigiis admifceretur, que Tobacos ctiam nuncupare confueverunt, a Brafilianis Petum, ab aliis Herba Sacra, a nonnullis Nicotiana dicitur. Hift. Mexican. I. 5 cap. 5 I 
neighbouring Shade. He hath no Relifh at all for Domeftick Pleafures, and is rarely known to converfe with his Wife, or play with his Children. What he values above all, is his Horfe: for in this he placeth his higheft Satisfaction; being feldon well pleafed or in good humour, but when he is far from Home, riding at full Speed and hunting.

The Arabs, and indeed the eaftern Nations in general are Thir Dextecertainly very dextrous at this Exercife. I have feen feveral Perfons at Grand Cairo, who could take up a Ferrid, at full Speed, from the Ground: and there are none of them but The banting who can quickly hunt down a wild Boar. We have, upon Boar, one of the Medallions of Conftantine's Arch', a very beautiful Reprefentation of this Sport, as it is performed, to this Day, by the Arabs; who, after they have rouzed the Beaft from his Retirement and purfued it into fome adjacent Plain, endeavour there, by frequently overtaking and turning it, to tire and perplex it; and then, watching an Opportunity, either launce it, at fome Diftance, or elfe, coming clofe by it's Side, fix their Spears in it's Body. At the hunting of the Lyon, a and Lyon. whole Diftrict is fummoned to appear; who, forming themfelves firft into a Circle, enclofe a Space of three, four or five Miles in Compafs, according to the Number of the People, and the Quality of the Ground, that is pitched upon for the Scene of this Action. The Footmen advance firft, rufhing into the Thickets, with their Dogs and Spears, to put up the Game; whilft the Horfemen, keeping a little behind, are always ready to charge, upon the firft Sally of the wild Beaft. In this Manner they proceed, ftill contracting their Circle, 'till they all at laft either clofe in together, or meet with fomething to divert them. The accidental Paftime upon thefe Occafions is A Variety of fometimes very diverting; for, the feveral different Sorts of Pafitime ocupon Animals that lye within this Compafs, being, by this Means, drove together, they rarely fail of having a Varicty of agreeable Chaces after Hares, Fackalls, Hycenas, and other wild Beafts ${ }^{2}$.

I Vid. Vet. Arcus Augaftorum \&c. Tab. 36. 2 We have in the following Lines of Statius (Achill. 1.459.) a beautiful Defeription of the like Diverfion.

\footnotetext{
Si curva feras indago latentes

Claudit, \& admotis paulatim cafjous arctat.

Ille ignem fonitumque pavent, defufaque linqum

Avia, mir anturique fuum decrefiere montem.

Inque vicem flupuere greges, focioque timore

Manfuefont, finul hittus Aper, fimul Urfa, Lupufque

Cogitur, of captos contemnit Cerva Leones.
}

$\mathrm{F} f \mathrm{ff}_{2}$ 
It is a common Obfervation in this Country, that, when the Lyon perceives himfelf in danger, nay fometimes the very Moment he is rouzed, he will feize directly upon the Perfon who is the neareft to him, and, rather than quit his Hold, fuffer himfelf to be cut to Pieces.

The Arabs \&c. delight in Hawking.

Hawking is one of the chiefeft Diverfions among the Arabs and Gentry of the Kingdom of Tunis. Their Woods afford them a beautiful Variety of Hawks and Falcons; for which this Kingdom feems to have been remarkable Two Centuries Their Method ago ". Thofe who delight in Fowling, do not fpring the Game of shooting with Dogs, but flading themfelves with a Piece of Canvafs
\&.c. ftretched, upon two Reeds, into the hhape of a Door, walk through the feveral Brakes and Avenues, where they expect to find it. The Canvafs is ufually fpotted, or painted with the Figure of a Leopard; and, a little below the Top, there is one or more Holes for the Fowler to look through and obferve what paffes before him. It is remarkable, that the Rbaad, Kitawiah, Partridge, and other gregarious Birds, will, upon the Approach of the Canvafs, covey together, though they were before at fome Diftance from each other: the Woodcock, Quail and fuch Birds likewife, as do not commonly feed in Flocks, will, upon Sight of the fame, ftand ftill and look aftonifhed. This gives the Sportfman an Opportunity of coming very near them, and then refting the Canvafs upon the Ground, and directing the Muzzle of his Peice through one of the Holes, knocks down fometimes a whole Covey at a Time. The Arabs have another, though a more laborious Method of catching great Numbers of Partridges: for obferving, that after thefe Birds have been haftily fprung twice or thrice, they become languid and fatigued, they immediately run in upon them, and knock them down with their Zerquattys ${ }^{2}$.

The Manners With Regard to the Manners and Cuftoms of the Bedoweens, of the Bedo-it is to be obferved that they retain a great many of thofe we weens. read of in facred as well as profane Hiftory; being, if we except their Religion, the fame People they were two or three thou-

I Reges Tunetenfes Cafarea Majeftati ejufque fuccefforibus Hifpania regibus, fingulis annis in xquum, lex equos Mauros cofgue exquifitiffimos ac duodecim eximios falcones in ærirernam beneficiorum ab ejus Majeltate acceptorum memoriam danto \& offerunto. Etrob. Diar. Exped. Tunet. a Carolo V. Imp. MDxxxv. 2 Thefe are fhort Sticks, fuch probably as the

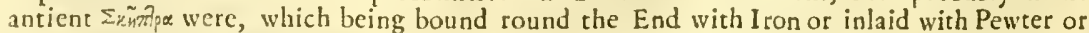
Brals, ferve thofe Arabs who are not Mafters of a Gun, for an oftenfive and defenfive Weapon. 
fand Years ago; without ever embracing any of thofe Novelties in Drefs or Behaviour, which have had fo many Periods and Revolutions in the Moorifls and Turkifh Cities. U'pon Tbeir Salutameeting one another, they ftill ufe the primitive Salutation tions. of (Salem Alekum ') Peace be unto you: though by their Wit or Superftition they have made it a religious Compliment ${ }^{2}$, as if they faid, Be in a State of Salvation. Before the Mabometan Conquefts, the Expreffion was, (2.) God prolong your Life, the fame with Havo Adoni, the Punic Compliment, in Plautus. The Inferiours, out of Deference and Refpect, kifs the Feet, Knees, or Garments of their Superiours; whilft the Children or Kinsfolks pay the fame Refpect to the Heads of their Parents and aged Relations. The Pofture they obferve in giving one another the A/slem-mah, is to lay their Right Hand upon their Breaft; whilft others, who are more intimately acquainted, or are of equal Age and Dignity, mutually kifs the Hand, Head or Shoulder of each other. At the Feaft of their Byram and other great Solemnities, theWife compliments her Husband by kiffing his Hand.

It is no Difgrace here for Perfons of the higheft Character to No Employbufy themfelves in what we fhould reckon menial Employments. ment rectoned The greateft Prince of thefe Countries, is not afhamed to fetch ${ }^{\text {the Arabs. }}$ a Lamb from his Herd ${ }^{3}$ and kill it ${ }^{4}$, whilft the Princefs is impatient'till the hath prepared her Fire and her Kettle to drefs it. The Cuftom, that ftill continueth, of walking either bare. foot or only with Sandals, requireth the antient Compliment of bringing Water, upon the arrival of a Stranger, to wafh his Feet $^{s}$ : whilft the Perfon who prefents himfelf the firft to do this Office, and to give the $\left[M a r-b a b b a h, s_{: \rightarrow, \infty}\right]$ Welcome, is the Mafter of the Family; who always diftinguifheth himfelf by

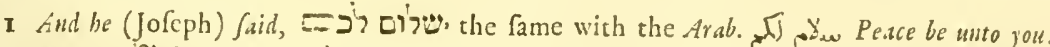
Gen. 43. 23. Fudg. 6. 23. and 19. 20. I Sam. 25. 6. \&c. Foh. 20.19. Peace be unto you. \&c. 2 The Mahometans love to call their Religion I-Ramifwe, from the Arab. Salama (Eha.)

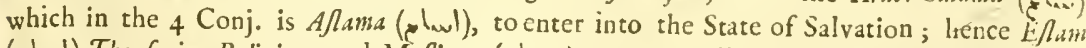
(l) The faving Religion, and Mufinon (phumo) or as we call it, Mufleman, be that believeth therein. Prid. Life of Mahomet. P.I I. 3 Thus we read Gen. I8. 7. that Abraham ran to the Herd and fetcht a Calf, upon the arrival of the three Angels. 4 In this manner we find Achilles and Patroclus employed. Hom. 11. 9.205. 6c.

Achilles at the genial Feaft prefides;

The Parts transfixes and with Skill divides.

Mean while Patroclus fwents the fire to rails. Pope.

5 Thus V. 4. as above, Let a little Water, I pray you be fetched and waflo your feet. Luk.7.44 I entered into thine houfe, thou gaveft me noWater for my feet; but be hath wafhed my fect svith
Tears.

\section{Ggg g}


being the moft officious; and who, after his Entertainment is prepared, thinks it a Shame to fit down with his Guefts, but will ftand up all the Time and ferve them ${ }^{\mathrm{r}}$ :

Yet the outward Behaviour of the Arab frequently gives the Lye to his inward Temper and Inclination. For he is naturally thievifh and treacherous ${ }^{2}$; and it fometimes happens that thofe very Perfons are overtaken and pillaged in the Morning, who were entertained the Night before, with all the Inftances of Friendfhip and Hofpitality. Neither are they to be accufed for plundering Strangers only, and attacking almoft every Perfon, whom they find unarmed and defencelefs, but for thofe many implacable and hereditary Animofities, which continually fubfift among them, literally fulfilling to this Day, the Prophefy of Facob, (Gen.I 6. I 2.) that Ifbmael fould be a wild Man; bis hand fbould be aguinft every Man, and every Mans band againft bis. However it mult be mentioned to the Honour of the Weftern Moors, that they ftill continue to carry on a Trade with fome barbarous Nations bordering upon the River Niger, without feeing ${ }^{3}$.the Perfons they Trade with, or The Weorterde
Moors
mith People mitb a People Commerce, which from Time immemorial has been fettled never fee. between them. The Method is this. At a certain Time of the Year, (in the Winter, if I am not miftaken,) They make this Journey in a numerous Caravan, carrying along with them feveral Strings of Coral and Glafs-Beads, Bracelets of Horn, Knives and Sciffars, and fuch like Trinkets. When they arrive at the Place appointed, which is on fuch a Day of the Moon, they find, in the Evening, feveral different Heaps of Gold Dut, lying at a fmall Diftance from each other, againft which the Moors place fo many of their Trinkets as they judge will be taken for the Value. If the Nigritians, the next Morning, approve of the Bargain, they take up the Trinkets and leave the Gold, or elfe make fome Deductions from the Gold Duft \&c. \&c. and in this Manner tranfact their Exchange without the leaft Inftance of Difhonefty or Perfidioufinefs.

I As we find the Patriarch did, in the Hiltory above, V. 8. And Abraham took Butter and Milk and the Calf which be had drefed and fot it before them; and he food by them under the Tree and they did eat. 2 Like their Predeceffors the Carthaginians, who are called by Tully (Orat. 2. contra Kull.) fraudulenti of mendaces. 3 In like Manner the Seres are faid never to fee or fpeak with the People they traded with. Euftatbius likewife upon the Faith of Herolotus rclates, that the Carthaginians traded after the fame Manner with fome People beyond Hercules Piliars. Vid. Arbuthnott on Coins. P.230. 


\section{Obfervations \&c.}

The Cuftom which the Nafamones' had formerly of plight-The Algerine ing their Troth, by drinking out of each others Hands, is, at this Time, the only Ceremony that is ufed by the Algerines in their Marriages. But the Contract is to be firft of all agreed upon betwixt the Parents, wherein exprefs Mention is made

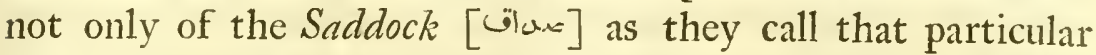
Sum of Money which the Bridegroom fettles upon the Bride, but likewife of the feveral Changes of Raiment, Quantity of Jewels ${ }^{2}$, and Number of Slaves ${ }^{3}$, that the Bride is to be attended with, when She firft waits upon her Husband. The Parties never fee one another 'till the Marriage is to be confummated, at which Time, the Relations being withdrawn, the Bridegroom proceeds firft to unveil his Bride, and then to undrefs her. Upon Forfeiture of the Saddock, the Husband can put away his Wife when he pleafeth; though he cannot take her again, notwithftanding the ftrongeft Sollicitations are made in his Favour, 'till She be married and bedded to another Man.

The Civility and Refpect which the Politer Nations of Europe The IVffedeth pay to the weaker Sex, are looked upon here as Extravagances, all tore of orted and fo many Infringements of that Law of Nature which affigns to Man the Preeminence. For the Matrons of this Country, (as a great Perfon of the Law hath determined with Relation to thofe of England) are confidered only as Servants of better Fafhion; yet who notwithftanding are to have the greateft Share of Toil and Bufinefs upon their Hands. Whilft the lazy Husbands repofe themfelves under fome neighbouring Shade, and the young Men and Maidens ${ }^{*}$ attend the Flocks, the Wives are all the Day taken up either in attending their Looms,

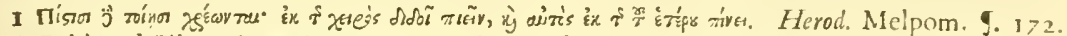
2 A Gold and Silver Sarmah, one or two Setts of Ear Rings, Bracclits and Shekels, a Gold Chain to hang over their Brealts, with half a dozen Vefts, fome of Brocade, others of rich Silk, are ufually the Wedding Cloaths of a Lady of Fafhion. Habirs and Ornaments of the like Kind were given to the Bride in the Time of Abrabam. Thus a golden ear Ring of balf a Shekel weight was given to Rebekab, and tw'o Bracelets for ber Hands of ten Shekels w'eisht of Gold. Gen. 24. 22. Abraham's Servant alfo brought forth Jewels of Silver, and Fewels of Gold, and Raiment, and gave them to Rebekah. V. 53. 3 Every Woman that is married has at leaft one Female Slave (who is ufually a Black) to attend her; whilit others have two or more according to their Rank and Quality. In this Manner we find that Hagar was Sarab's Handmaid; that Rebelals when She was betrothed to Ifalac, was attended by ber Nurfe (Gen. 14. 59.) and ber Damfels. V. 61. that Laban (Gen. 24.24.) gave unto bis Dangloter Leah, (whon nhe was married to Faceb) Zilpah bis Maid, for a Haidmaid; and unto Racbel (V.29.) (upon the like Occafion) Bilhah bis Handmaid to be ber Maid. 4 It is cuftomary, even to this Day, for the Childreu of the greateft Emeer to attend their Flocks; as we find (Gen. 29. 9.) Rachel kept the Sheep of ber Father Laban. 
grinding at the Mill, or elfe in preparing their Flour into $C_{u f}$ caffowe, Drveeda and fuch like Compofitions. Neither is this all; for, to finifh the Day, at the Time of the Evening, even the Time that Women go out to draw Water, (Gen. 24. I I.) they are ftill to fit themfelves out with a Pitcher or a Goats Skin " ; and tying their fucking Children behind them, trudge it in this Manner two or three Miles to fetch Water. Yet in the Midft of all thefe Labours and Incumbrances, neither thefe Country Ladies, nor thofe of better Fafhion in Cities, will lay afide any of their Ornaments; neither their Nofe-Jewels, (which are ftill ufed by the Levant Arabs:) neither their Bracelets, Shackles 2, or Ear Rings, which are all very Cunberfome; neither the tinging their Eyelids with Lead Ore; fo prevalent is Cuftom, even in Barbary, and fo very zealous are thefe Ladies to appear in, what they call, the Mode and Fafhion. The Mooril The greateft part of the Moorifh Women would be reckon'd Women and - Ben beau-Beauties, even in Great Britain; as their Children certainly tiful.

have the fineft Complexions of any Nation whatfoever ${ }^{3}$. The Boys indeed, by wearing only the Tiara, are expofed fo much to the Sun, that they quickly attain the Swarthinefs of the Arab; but the Girls, keeping more at Home, preferve their Beauty 'till they are thirty, at which Age they are ufually paft Child-bearing. It fometimes happens that one of thefe Girls is a Mother at eleven, and a Grandmother at two and twenty: and as their Lives are ufually of the fame Length with thofe of the Europeans, there have not been Inftances wanting among thefe Matrons of fome who have lived to fee their Children of many Generations.

The crys the At all their principal Entertainments, and to fhew Mirth Women make at their Feafls and Gladnefs upon other Occafions, the Women welcome the

I There is frequent Mention made of thefe Skins in the H. Scriptures. Thus

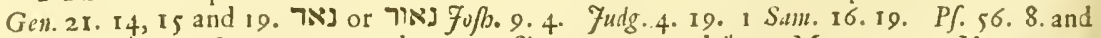
I19.83. נכל I S.lm. I. 24. and 10. 3. Ger. 13. I2. and arxos Mat. 9. 17. Mar. 2. 22. Luk. 5.37. which fhould be rendered Skins, are improperly interpreted Botcles. 2 The tinkling Ornaments of their Feet. If. $3 \cdot 16.3$ The Word Moor is generally fuppofed to convey the Idea of a Perfon of a dark and fwarthy Complexion: whereas it only denotes theSituation of the Country he inhabits. For רעכמ Gignifies a Ferry, or Narrow part of the Sea, Fretnm, Trajectus, \&c. פעכרי (Mivi) confequently will be the fame as (Trajectanews feu ad Trajectum vivens) a Perfon who lives near fuch a Place; juft as the Moors are fituated with Refpect to the Straights of Gibraltar, the Fretum Gaditanum or Herculewm of the Antients. Vid. Peritfol. Cofmogr. Edit. T. Hyde. P. 48. But Bochart deduceth the Word from another Original. מוחר Mauri, quafi poftremi vel occidentales diati, ab quod \& pofterius \& Occidentem fonat. Plenc feriberetur Maubarin, fed Gutturales paftim elidi nemo eft qui nefciat. Boch. Chan. 1. I. cap. 25. 
Arrival of each Gueft, by fqualling out, 200, 100:, feveral Times together; at their Funerals alfo, and upon other melancholy Occafions, they repeat the fame Noife ${ }^{2}$, making it only more deep and hollow', and ending each Period of it with

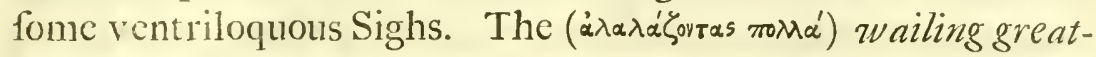
ly (as our Verfion expreffeth It, Mar. 5. 38.) upon the Death of Fairus's Daughter, was probably performed in this Manner. For, there are feveral Women hired, upon thefe lugubrious Occafions, for the Purpofe, who like the Prefice ${ }^{+}$or mourning Womens of old, are Miftreffes of thefe melancholy Expreffions, and indeed perform their Parts with fuch proper Geftures and Commotions, that they rarely fail to work up the Affembly into fome extraordinary Pitch of Thoughtfulnefs and Sorrow.

No Nation in the World is fo much given to Superftition as the Arabs the Arabs, or even as the Mabometans in general. They given to Sihang ${ }^{6}$ about their Childrens Necks the Figure of an open Hand, which the Turks and Moors paint upon their Ships and Houfes, as an Antidote and Counter-Charm to an evil Eye: for five is with them an unlucky Number, and Five (Fingers perhaps) in your Eyes, is their Proverb of Curfing and Defiance. Thofe who are grown up, carry always about with them fome Paragraph or other of their Koran, which, like as the Fewv did their Phylacteries, (Ex.I3.16. Numb. I 5.38.) they place upon their Breaft, or fow under their Caps, to prevent Fafcination and Witchcraft, and to fecure themfelves from Sicknefs and Miffortunes. The Virtue of thefe Charms and Scrolls is fuppofed likewife to be fo far univerfal, that they fufpend them upon the Necks of their Cattle, Horfes and other Beafts of Burthen.

I A Corruption as it feems to be of הללייה Hallelniah. Aarki, a Word of the like Sound was ufed by an Army, either before they gave the Onfet, or when they had obtained the

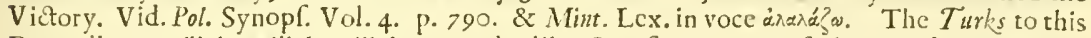
Day call out Allat,, Allath, Allab upon the like Occafion. 2 As if the Word now was related to the Heb. '>', ejulari, from whence perhaps our Englifl Word to howl. 3 Plut.tich

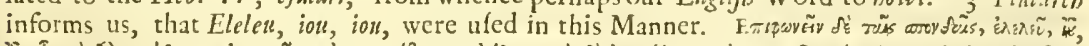

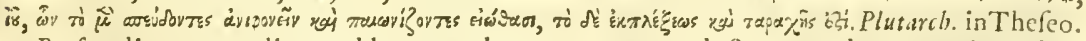
4 Prafica dicuntur mulieres ad lamentandum mortuum conducte, qux dant creteris modum plangendi, quafi in hoc ipfum præfectx. Vid. P. Feft. \& Non. Marcell. in voce. 5 Call for

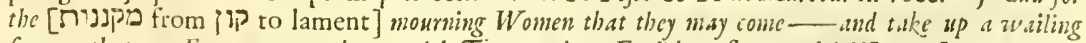
for us, that our Eyes may run down with Tiars and our Eyelids guff out with Water. Jer.9.17. I 8 . 6 This Cuftom of hanging Things about the Neck to prevent Mifchief, Diftempers, \& ec. feems to be of great Antiquity, and was common to other Nations. Thus larro de Ling. Lat. I.6. in fine. Prabia, a prabendo, ut fit tutum: quod fint remedia in collo pucreis. Faf cimum, collis nempe puerorum fulpenfun, Inf antinu cuftodem appellat Plinius. 1.28. c. +. The Bull $x$ was wore upon the fame Account, as Macrobius tells us, Satt. 1. I. Bulla geff.cmen erat trismpphatiotium, incbufis intra cam remediis, qua crederent adverfum invidiam valentiffira. 
They place great Faith and Confidence in Magicians and Sor: cerers $^{1}$, as the Nations ${ }^{2}$ did, who in old Time were their Neighbours: and upon fome extraordinary Occafions, particularly in a lingring Diftemper, they ufe feveral fuperftitious Ceremonies in the facrificing of a Cock, a Sheep or a Goat, by burying the whole Carcafs under Ground, or by drinking a part of the Blood, or elfe by burning or difperfing the Feathers. For it is a prevailing Opinion all over this Country, that a great many Difeafes proceed from fome Offence or other that hath been given to the [ $\mathrm{Uli}$ ] Fenoune, a Sort of Creatures, placed by the Mahometans betwixt Angels and Devils. Thefe, like the Fairies of our Forefathers, are fuppofed to frequent Shades and Fountains, and to aflume the Bodies of Toads, Worms, and other little Animals, which, being always in our Way, are liable every Moment to be hurt and molefted. When any Perfon therefore is fickly or maimed, he fancies that he hath injured one or other of thefe Beings, and immediately the Women, who, like the antient Venificre, are dextrous in thefe Ceremonies, go, upon a Wedne/day, with Frankincenfe and other Perfumes, to fome neighbouringSpring, and there facrifice, as I have already hinted, a Hen or a Cock, an Ewe or a Ram \&c. according to the $\mathrm{Sex}^{3}$ and Quality of the Patient, and the Nature of the Diftemper.

Tibeir Marabbutts much efteemed.

The Mahometans have a greatVeneration for their Marabbutts, who are generally Perfons of a rigid and auftere Life, continually employing themfelves either in counting over their Beads 4, or elfe in Meditation and Prayer. This Sainthip goes by Succeffion; and the Son is entitled to the fame Reverence and Efteem with the Father, provided he can keep up and maintain the fame Gravity and Decorum. Some of them

I The feveral Claffes of which are enumerated in Deut. IS. IO, II ; viz. fuch as ufe Divination, or is an Obferver of Times, or an Enchanter, or a Witcl, or a Charmer, or a Confulter zvith familiar Spirits, or a Wizard, or a Necromulucer. They pretend to have daily Inftances in thefe Countries of the Power and Efficacy of onc or other of thefe Perfons, particularly

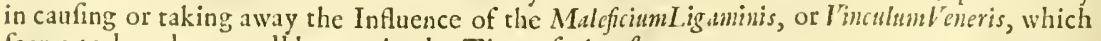
feems to have been well known in the Time of Auguftus.

Necte tribus nodis ternos Amarilli colores,

Necte, Amarilli, nodos \& Veneris dic vincula neito. Virg. Ecl. 8. 1. 77.

2 Viz. the Egyptians, (Vid. Aufon. Epift. 19. Jofeph's divining Cup. Gen.44. 5) Moabites, (Balaam went not as at otber Times to feek for Enchuntments. Numb. 24. I.) Urc. ơc. 3 Viz. A Male being Sacrificed for the Female Sex \&c. 4 In touching each Bead of their Chaplet, confifting ufually of ninety nine, they either fay (Alhandill.al) God be proifecl, (Allah Kibeer) God is great, or [xلdl g,isiwl Staffour Allab] God forgive me. 


\section{Objervations \&c.}

alfo fhare in the fame Reputation with their Prophet, of re- Smmerptond ceiving Vifions and converfing with the Deity, whilft others, taveres, viz: who are fuppofed to work Miracles, are endowed with Gifts, which Malsomet' himfelf durft not pretend to. When I was with Seedy Muftafa the Kaleefa of the weftern Province, (near the River Arbew ) he told me, in the Prefence of a number of

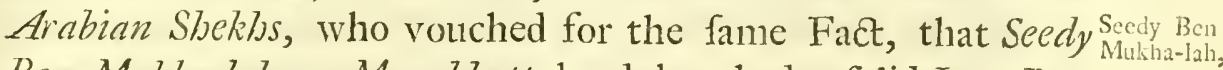
Ben Mukba-lah, a Marabbutt hard by, had a folid Iron Bar, which, upon Command, would give the fame Noife, and do the like Execution, as a Cannon, and that once, the whole $A l$ gerine Army, upon demanding too exorbitant a Tax from the Arabs under his Protection, were put to Flight by the Miracle. Yet notwithftanding the Frequency, as they pretended, of the Experiment, the Merit I urged there would be in the Conviction of a Chriftian concerning the Truth of it, and the Sollicitations of the whole Company, the Marabbutt had too much Policy to hazard his Reputation at that Time. But I had betterSuccefs, near Seteef, with Seedy Afboure, the Ma-Scedy Alitrabbutt of the Ammer, a Perfon famous all over the caftern Province for the vomiting of Fire. This Operation, as he performed It, I faw feveral Times: the firft Inftance whereof did very much furprize me, to obferve his Mouth to be all of a fuddain in a Blaze, and the violent Agonies that were counterfeited at the fame Time. But when the fame was repeated a little afterwards, (for he pretended to have frequent Illapfes of the Deity) I plainly faw the great Dexterity and Artfulnefs he made ufe of in drawing his Head and Hands within his Burnoofe, which, as he told us, was in order to converfe with the Deity, but, as I fufpected, to kindle the Fire. For as foon as he had got all Things ready for the difplaying of the Flame, fuch a Quantity of Smoak attended his Head and Hands in withdrawing them from under his Burnoole, fo ftrong a Smell was there likewife of Tow and Sulphur, befides fome Threads of the former, that were engaged to his Beard, that none but an ignorant and bigotted People, could be deceived by the Impofture. This I took Notice of to fome Turks, that were with me, who faw through the Contrivance; but the Arabs ftill infifted upon the wonderful Gift of Seedy Afboure, and that [Ma Kan Jby kiff hoo] there was none like bim.

I Vid. Prideutx's Life of Mabomet. p. 18. 19.

$\mathrm{Hhhh} 2$

Thofe 
Tlocir pretenres to the Knowoledge of futtre Events. the Knowledge of future Events and Contingencies. It is not hitherto indeed agreed among them by what extraordinary Means they come at thefe Revelations, though the Difcoveries they would be believed to make, are in fuch general Terms, fo falfe for the moft Part, and at the beft dubious, and never particularly circumftantiated, that it farce deferves the Gravity or Attention to enquire after their Original. However I never knew any Perfon, who afferted them to be from Divine Infpiration, though there are a Number of Enthufiafts in this Religion, who pretend to be full of the Deity upon other Occafions. Some attribute them to Maga-reah, for fo they call Witchcraft and Inchantment; others to Aftrology or the Doctrine of the Stars; whilft their Thalebs pretend to have the Prophecies of Aly the Son in Law of their Prophet, wherein they give out, that he hath left them a general and chronological Account of the moft remarkable Occurrences, which have happened in the World fince his Time, or which are to fall out in future Ages.

When I was at Tunis, in the Spring of 1727 , there were feveral Prophecies handed about, partly as was alledged from this Book, partly from their Faffar-eah, that Hafan Ben Aly, the Bey at that Time, was to be immediately depofed by his Nephew Aly Bafbaw. The Myftery of it was, that HafJan Ben Aly, otherwife a good and wife Prince, had a mighty Inclination to fleece and opprefs the richelt of his Subjects; and, by a Piece of ill-timed Policy, as it might have proved, had, fince the Beginning of his Reign, neglected the Turks, and placed his chief Confidence in Moors and Renegadoes, upon whom he beftowed the greateft Honours and Preferments. On the other Hand, Aly Bafbaw, while he acted under him, as Aga of the Fanizaries, behaved himfelf with fuch Courtefy, Generofity and Juftice, that he gained the Affections of that Body, and the good Will of the whole Kingdom. Now as Aly Bafbaw, upon fome Mifunderftanding with his Uncle, was at this 'Time fled to the Mountains of Ufelett, where he had the Courage to proclaim himfelf Bey, publifhing at the fame Time, the great Injuftice and Oppreffion that Haffan Ben Aly had always exercifed over his Subjects, together with the unjuft

Contempt 
Contempt and Difregard he had for the Turks, adding further, that he would immediately apply proper Methods for the Satisfaction of them both, there was Probability enough, without the Concurrence of a Prophecy, that fuch a Revolution might be brought about at this Time. Yet notwithftanding trovedfalfe. all thefe unfavourable Circumftances, notwithftanding the Day and Hour were confidently prefixed for his Deftruction, Haffan Ben Aly was too Atrong for their Faffar-eah, and, provided the Algerines had not lately (1735) interpofed, would in all Appearance have left a peaceable Poffeffion of that Kingdom to his Son.

It would be too tedious to recount any more of their pre- $A$ Prophcy tended Prophecies, fome of which, the Event very obvioufly thar tbe MTafhewed to be falfe, whilft others, at the beft, were uncertain minions are to Gueffes only or probable Conjectures. We are to wait there- the Chritti- $_{\text {ans. }}$ fore 'till Time and Futurity determine the Veracity of that very remarkable one, which promifeth to the Chriftians a Reftoration of all thofe Kingdoms, which they formerly loft to the Turks and Saracens. Thus much may be obferved of it already, that there is no Part of the Maßometan Dominions, where this Tradition is not univerfally received, and that, in Confequence thereof, the Gates of their Cities, are carefully fhut up, every Friday, from ten 'till twelve o' Clock in the Morning, that being, as they fay, the Day and Time prefixed for this notable Cataftrophe.

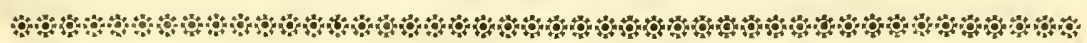

\section{H A P. IV.}

Of the Government, Forces and Revenues of the Algerines; of their Courts of Fudicature and Punifhments; and of their Interefts and Alliances with Chriftian Princes.
A $\mathrm{S}$ the Arabs have had no fmall Share in the foregoing The Form of fhould be premifed, with Regard to the Form of Government Arabian. that fubfifts among their Tribes. Now though the greateft Part of them have been, for many Ages, under the Turkifh Yoke, yet they are rarely interrupted, either in what may concern the Courfe of Juftice, or in the Succeffion to thofe few Offices and Dig- 
nities that belong properly to themfelves. For, provided they live peaceably, pay regularly the eighth Part of the Produce of their Lands, together with a fmall Poll Tax; that is annually demanded by the Turks, they are left in full Poffeffion of all their private Laws, Privileges and Cuftoms. Every Dou-zvar therefore may be looked upon as a little Principality, over which it is ufual, for that particular Family, (which is of the greateft Name, Subftance and Reputation) to prefide. However this Honour does not always lineally defeend from Father to Son, but, as it was among their Predeceffors the Numidians ${ }^{\mathrm{r}}$, when the Heir is too young, or fubject to any Infirmity, then they make Choice of the Uncle or fome other Relation, who, for Prudence and Wifdom, is judged to be the fitteft for that Employ. Yet, notwithftanding the defpotic Power which is lodged in this Perion, all Grievances and Difputes are accomodated in as amicable a Manner as poffible, by calling to his Affiftance one Perfon or two, out of each Tent: and as the Offender is confidered as a Brother, the Sentence is always given on the favourable Side; and, even in the moft enormous Crimes, rarely any otherPunifhment is inflicted than Banifhment. When one of thefe Perfons hath the Superintendance over one Dou-zwar only, he is commonly called the $S h e k b^{2}:$ but the Ruler or chief Perfon of a Tribe; whofe Authority reacheth over feveral Dou-wars, hath the Title either of The (Shekh el Kibeer) Great Lord or Elder, or elfe of The (Emeer ${ }^{3}$ ) Prince.

The Government of the Algerines, which differeth little from that of Tunis, confifts of the Dey, who is to be confidered as the Stadtholder, and of a Dou-wanne, or Common Council. The Dou-wanne is principally compofed of the thirty Yiab Bafhees, though the Mufti, the Cady and the whole Soldiery fometimes, are called upon to affift. All Affairs of Moment ought to be agreed upon by this Affembly, before they pafs into Laws, and before the Dey is entrufted with the putting them in Execution. But for fome Years there hath been little Ac-

I Militante Mafaniffa pro Carthaginienfibus in Hifpania, pater ejus moritur (Gale nomen erar:) regnum ad fratrem regis Defalcem, pergrandem natu (mos ita apud Nunidas eft) pervcnit. Liv. 1. 29. 9. 29. 2 ش. Senex. Semior. Doctor: aut authoritate, principatu pietatc $\&$ arte confpicusus. Vid. Gol. in voce. 3 , rol, ab, nol mandarit, juffit, precepit. Idem. 


\section{of the Algerines.}

count made of this Body; which is indeed ftill very formally convened, but then it is only to confent, with the fame Formality, to fuch Propofitions, as have been before hand concerted, betwixt the Dey and his Favourites: fo that, in Effect, the whole Power is lodged in one Perfon.

This Perfon, who, at Algiers, is called the Dey, is chofentioe office, out of the Army; each Order, even the moft inferiour, having of thection sey. an equal Right and Title, to thatDignity, with the higheft. Every bold and afpiring Soldier, tho' taken Yefterday from the Plough, may be confidered at Algiers, as the Heir apparent to the Throne, and, with this further Advantage likewife, that he lyeth under no Neceffity to wait'till Sicknefs or old Age remove the prefent Incumbent: it is enough that he is able to protect himfelf with the fame Cymiter, which he hath had the Hardinefs to theath in the Bowels of his Predeceffor. The chief Command here, as it was in the Declenfion of the Roman Empire, lyeth open and expofed to every bold Pretender, who, if he hath the Refolution only to attempt, will rarely fail to carry it. To the $\tau_{b e}$ DeysfraTruth whereof, we need only appeal to that quick Succeffion, which there hath been always among the Deys, ever fince the Turkifb Dynefty; rarely one in ten having the Fortune to dye in his Bed; i. e. without a Muskett Ball or a Cymiter. Even thofe few Perfons who have made thefe peaceable Exits, cannot attribute them to any fuperiour Regard and Efteem, which the Army had for them in particular, but rather to their own fuperiour good Fortune, in preventing an Infurrection, by cutting off the Confpirators before they could put their Defigns in Execution. This bloody Method of fucceeding to the Dey/bip, and of continuing peaceably in it, will doubtlefs appear ftrange and furprizing to Perfons long accuftomed to regular Succeffions and civilized Governments, yet is what may be very well accounted for at this Place, where a ftrict and regular Difcipline hath been a long time wanting; and where, even a private Soldier, after a fmall Exercife and Tryal under thefe Colours, hath the Ambition to think himfelf confiderable enough, either to pufh for the Kaftan himfelf, or to contribute at leaft in the Promotion of another to It. However this factious and difcontented Humour feems, at prefent, to be fomewhat purged and allayed, by the many feafonable Executions that have been 
lately made of thefe afpiring Members: yet in fuch an ungovernable Conftitution as this, there will always remain fome Seeds of their old tumultuous Principles, which, upon the leaft favourable Opportunity, will break out a frefh, in Rebellion and Affaffination.

The Algerine The whole Force of Algiers, in Turks and Cologlies, is comForces. puted, at prefent, to be about fix thoufand fire hundred; two thoufand whereof are fuppofed to be old and excufed from Duty; and of the four thoufand five hundred that remain, one thoufand are conftantly employed in relieving annually their Garrifons, whilft the reft are either to arm out their Cruifers or elfe form the three flying Camps, which are fent out every Summer under the Command of the provincial Viceroys. To the Turkifl Troops we may joyn about two thoufand Zwowah, as the Moorifh Horfe and Footmen are called: yet notwithftanding thefe are kept in conftant Pay, and may be fuppofed to augment the Number of Arms,yet, being all of them hereditary Enemies to the Turks, they are little confidered in the real Safeguard and Defence of the Government. The Method there. fore that is obferved in keeping this large and populous Kingdom in Obedience, is not fo much by Force of Arms, as by diligently obferving the old political Maxim, "divide and command. For the provincial Viceroys are very watchful over the Motions of the Arabian Tribes, who are under their feveral Diftricts and Jurifdictions; and as thefe are in continual Jealoufies and Difputes with one another, the Beys have nothing more to do than keep up the Fermew, and throw in, at proper Times, new Matter for Difcord and Contention. There are a Number of Arabian and African Tribes, who, in Cafe their Neighbours fhould obferve a Neutrality, would be too hard for the whole Army of Algiers, notwithftanding each Turk valueth himfelf in being a Match for twenty Arabs. When therefore there is any Mifunderftanding of this Kind, the Viceroys play one Tribe againft another, and, provided the Quarrel proves equal, a few Turks feafonably thrown in, will be more than a Ballance for the Enemy. By thus continually fomenting the Divifions, which always fubfift among the Arabian Princes, and by drawing on afterwards one Family to fight againft another, thefe four or five thoufand Turks maintain their Ground againt all Oppofition, and lay even their Neighbours, the Tunifeens, 
and the Weftern Moors under great Obligations, for not extending their Conquefts into their Dominions.

To make up the Deficiencies in the Army, their cruifing Veffels How their are fent out, every five or fix Years, to the Levant for Recruits. Armersitited. Thefe generally confift of Shepherds, Outlaws, and Perfons of the meaneft Condition. Mahomet Bafbaw, who was the Dey when 1 arrived at Algiers, was not afhamed to own his Extraction, in a notable Difpute he had once with the DeputyConful of a neighbouring Nation; My Mother, fays he, fold Sheep's Feet, and my Father Neat's Tongues, but they would have been a fhamed to bave expofed to Sale fo worthle/s a Tongue as Tours. Yet thefe Recruits,after they have been a little inftructed by their Fellow Soldiers, and have got Caps to their Heads, Shoes to their Feet, and a Pair of Knives to their Girdle, quickly begin to affect Grandeur and Majefty, expect to be faluted with the Title of [Effendi] Your Grace; and look upon the moft confiderable Citizens as their Slaves, and the Confuls of the allied Nations as their Footmen.

But befides thefe Levant-Turks, the Dey may, at his Plea-Cologlies fure, and efpecially upon any Emergency, enroll the Cologlies, enrolled Army. as they call the Sons of fuch Soldiers, who have been permitted to marry at Algiers; though fince the Time they made an unfuccefsful Attempt upon the Government, by endeavouring to feize upon the Caffaubat), they have not been much encouraged, and when they are, they are always excluded from the Honour of being Dey, Aga of the Fanizaries, and other confiderable Offices and Employments.

The Officers that command this fimall Army, (and it would Teffectrocral be the fame if it amounted to it's former Complement of twelve Army and thoufand ) are the Aga or General, thirty Yiab Bafhees or thair PromoColonels, eight hundred Bulluck Bafhees or Captains, and about half that Number of Oda Ba/hees or Licutenants. The' Method of arriving at thefe Pofts, is not by Money and Intereft, but by Age and Seniority, the oldeft Soldier being advanced upon the Death of his Captain, \&c. \&c. though by the Permiffion of the Dey, a younger Soldier may purchafe the Rank of an elder, the latter degrading himfelf in Return. There is another Method alfo of haftening thefe Promotions: for the $A g a$ is removed as often as the Soldiers are paid, which is every two Months, being fucceeded by the Chials, who is the $\mathrm{Kk} \mathrm{k} \mathrm{k}$ eldeft 
eldeft of the Yiab Bafsees, whereby there is a Place vacant in the Dou-wanne, which is immediately filled up by the eldeft Bulluck Ba/bee; \&c. \&c. The Aga after having thus paffed through the whole Courfe of his Duty, is from thence forward confidered as (Mazioule) fuperannuated, quietly enjoying his Pay, and, according to the old Poet,

\section{Senio confectu' quiefcit. Enn.}

The Revenues I could never learn that the yearly Taxes of this great and of this King- fertil Kingdom bring more into the Treafury than three hun-
dom. dred thoufand Dollars: but it is computed, that the eighth Part of Prizes, the Effects of Perfons dying without Children, the Contributions from the independent Kaides, and the frequent Avar-eas and Oppreffions, may bring in as much more. The Pay of To compenfate this, the Pay is but fmall, the youngeft Soltheir soldiers. dier receiving only four hundred and fix Afpers every two Months, and the eldeft, or thofe in full Pay, no more than five thoufand eight hundred; whereof fix hundred and ninety fix make a Dollar ". Now as they arrive not at full Pay, but in the Space of a Number of Years, the young Soldiers receiving an Augmentation only of an hundred and fixteen $A /$ pers $^{2}$ every Year, the whole Army may be reduced to about three thoufand five hundred in full Pay, whereby a Sum, lefs than tivo hund red thoufandDollars, will defray the wholeExpence. Though we are to obferve at the fame Time, that, befides the Pay, fuch riab and Bulluck Bafbees as are unmarried, have each of them eight Loaves of Bread a Day, and the Oda Bafbees and private Soldiers, who are in the fame Condition, have four; each Loaf being about five Ounces in weight, and three $A$ /pers in value.

of their Courts of Fudicature.
In the ordinary Diftribution of Juftice, there is in This as in all other Turkiff Governments, an Officer whom they call the Cady, who, for the moft Part, hath had his Education in the Seminaries of Stamboule or Grand Cairo, where, I am told, the Roman Codes and Pandects, tranflated into the Arabick Tongue, are taught and explained as in the Univerfities of Europe. The

I Sive Thalero, qui Germanis Sic dicitur a Thale feu Dale i. e. V'allis; unde Thaler feu Daler, q. d. Vallenfis nummus, a Valle Sancti foachimi ubi primo cufi funt. Hinc factum ut tandem Scutati omnes (quos nummos Imperiales vocamus) Thaleri hodic vocantur. Vid. Hyd. Annot. in Bobovij Liturgiam Turcarum, p. Io. 2 Ifte nummulus, Turcice dicitur $\alpha=$; i. e. Albulus; unde a Grecis fua lingua hodierna vocatur Aøés i. e. Albus \&c. Aasér pecuniam albam in genere notat. Id. ibid. 3 Confantinople is called all over the Levant, Stamboule or Stanpôte, which feems rather to be the Corruption or Contraction of the antient Name, as Fambol is of Formopolis, than of wis tim roxin, as fome Authors give into. Vid. Hyd. Not, in Colmogr. Perits. p. 52. Sir George Wheeler's Trav. p. I78.

Cady 
Cady is obliged to attend at the Court of Juitice once or twice a Day, where he hears and determines the feveral Suits and Complaints that are brought before him. But as Bribery is too often (and perhaps juftly enough) charged upon the Cady, all Affairs of Moment are laid before the Dey, or elfe, when he is abfent or otherwife employed, they are heard by the Treafurer, Mafter of the Horfe, and other principal Officers of the Regency, who fit conftantly in the Gate ${ }^{\mathrm{t}}$ of the Palace for that Purpofe. At all thefe Tribunals, the Caufe is quickly decided, nothing more being required than the Proof of what is alledged; fo that a Matter of Debt, Trefpafs, or of the higheft Crimes will be finally decided, and theSentence executed in lefs than anHour.

In Cafes of Debt, the Debtor is ufually detained in Prifon, 'till of their $P_{u-}$ the (Choufes) Bayliffs have feized upon his Effects and fold" them. If the Sale amounts to more than the Debt, then the Overplus is returned to the Prifoner; if it comes fhort, he is notwithftanding releafed, and no future Demands are made upon him. Leffer Offences are punifhed with the Baftinado: i. e. the Offender is to receive fo many Stroakes (fometimes two or three hundred) upon his Buttocks or the Soles of his Feet, with Sticks of the Thicknefs of ones little Finger. But in greater Crimes, particularly for unnatural Luft, not only the Parts already mentioned, but the abdominal Mufcles likewife are to be chaftifed: a Punifhment which is generally attended with Death. For clipping or debafing the publick Coin, the old Egyptian Punifhment ${ }^{3}$ is inflicted, which is to cut off the Hands of the Tranfgreffor. Whatfoever Fewv or Chriftian-Subject is guilty of Murder or any other capitalCrime, he is to be carried without the Gates of the City, and burnt alive: but the Moors and Arabs are either impaled for the fame Crime, or hung up by the Neck, over the Battlements of the City, or elfe thrown upon the Hooks ${ }^{4}$ that are fixed in the Walls below, where fometimes they hang, in the moft exquifite Agonies and Torments, thirty or

1 Thus we read of the Elders in the Gate. (Deut. 22. I5. and 25. 7.) and (If. 29.2I. Amos 5. 10.) of Him that reproveth and rebuketh in the Gate. The Ottoman Court likewife feems to have been called the Port, from the Diftribution of Juftice, and the Difpatch of publick Bufinefs that is carried on in the Gates of it. 2 It was in this Manner probably that St. Paul was beaten with Rods: (2 Cor.1r. 25.) as the Choufes, whofe Office it is to inflict this Punifhment, appear to be no other than the like Number of Rom.n Lidtors armed out with their Fafces. 3 Diod. Sic. 1. I. p. So. 4. The faftning of the Body of Saul to tise Walls of Bethrian. (I Sam. 31. 10.) might be the fixing it only to fuch Hooks as were placed there for the Execution of Criminals. 
Turks not punifbed in Publick.

forty Hours, before they expire. The Turks are not punifhed in Publick, like other Offenders; but are, out of Refpect to their Characters, fent to the Houfe of the $A g a$, where, according to the Quality of the Mifdemeanour, they are baftinadoed or ftrangled. Out of Modefty likewife to the Sex, when the Women offend, they are not expofed to the Populace, but fent to fome Private Houfe of Correction; or, if the Crime is Capital, they are then tyed up in a Sack, carried out into the Sea, and drowned '. The weftern Moors ftill ufe the barbarous Punifliment of fawing afunder the Tranfgreffor. For which Purpofe they prepare two Boards, of the fame Length and Breadth with the unfortunate Perfon, and having tyed him betwixt them, they proceed to the Execution, by beginning at the Head. I am informed that Kardina/h, a Perfon of the Firft Rank in that Country, who had formerly been Ambaffador at the Britifl Court, and was well known to the Gentlemen of our Navy and Garrifon of Gibraltar, fuffered lately in this Manner. For it may be very juftly obferved, with Regard to the Punifhments of thefe Countries, that there is little or no Regard had to the Quality of the Offender. Sometimes indeed a pecuniary Mulct will ftop the Courfe of Juftice, but if the Crime is flagrant, no other Atonement is to be made for it, than to fubmit to the Punifhment which the Tranfgreffion is thought to deferve.

Of their Alliances with Chriftian The Naval Force of this Regency, which, for two Centuries, hath been, at one Time or other, a Terror to all the Trading Nations of Chriftendom, was taken Notice of in the Defcription of Algiers. With Relation therefore to Chriftian Princes, this Government hath Alliance with Us, the French, the Dutch, and the Swedes. Great Application hath been often made by the Port, in behalf of the Emperor's Subjects; though all their Interceffions have hitherto proved ineffectual, notwithftanding the Algerines acknowledge themfelves to be the Vaffals of the Grand Senior, and, as fuch, fhould be intirely devoted to his

I Tacitus (De Morib. Germ.) takes Notice of This, as a Punifment among the Germaits.

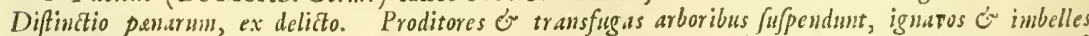
do corpore infanmes, cano ac palude, injecta infuper crate. The like Punifament is mentioned by Plantus. Coqui abfulermit, comprebendite, vincite, verberate, in Puteum condite. Anlul. Act. 2. Sc. 5. v. 21. Furca \& Foffa Ang. Pette and gallotes, in antiquis privilegijs fignificut jurifdictionem puniendi fures: fc. viros fu/pendio, foeminas fubmerfione-quad o in Scotia hodie obfervatum intelligo. Sce Spelman's Gloffary in the Word Furca \&ic. where he quotes an Inftance of this Punifhisent, out of the Monuments of the Church of Rochefler. 
Orders and Commands. The Swedes purchafed Their Peace, How the at the Rate of 70,000 Dollars: and, as thefe Cruifers rarely Dutres and

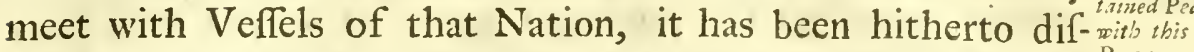
courfed of as a great Myftery. The Succefs which the $D_{u t c}$ b met with, during a War of twelve Years, to deftroy a few of their Veffels; the magnificent Prefent of naval Stores that was promifed, upon ratifying the Peace; together with the natural Timoroufnefs of the Dey, leaft, by further Loffes, he fhould be reckoned unfortunate, (a dangerous Character in this Country for a Commander;) were the chief and concurring Reafons for extending their Friendfhip to That Nation. It is certain, that the greateft Part of the Soldiers, and the Sea Officers in general, very ftrenuoufly oppofed it : urging, that it would be in vain to arm out their Veffels, when they had Peace with the three trading Nations; that their Lofs was inconfiderable, when compared with the Riches obtained by the War; concluding with a very expreffive Arabian Proverb, that fuch Perfons ought never to fow, who are afraid of the Sparrows. As the younger Soldiers cannot well fubfift, without the Money that arifes from theirShares in Prizes, there has been no fmall Murmuring at the little Succefs they have lately met with. And it is very probable, (as a little Time perhaps will difcover,) that, the very Moment any confiderable Addition is made to their Fleet, nay perhaps without any further Augmentation, the prefent Dey will be obliged to leffen the Number of his Alliances, from thofe very Principles, which a few Years ago, engaged his Predeceffor to increafe them.

The Algerines have certainly a great Efteem and Friend-How thefe fer fhip for our Nation; and provided there could be any Secu- vecep un tations rity in a Government, that is guided by Chance and Humour, Iiterefests ziith more than by Counfel and mature Deliberation, it is very probable, that, which of the trading Nations foever they may think fit to Quarrel with, We have little to apprehend. The Dutch are very induftrious in cultivating a good Underftanding with them, by making an annual Prefent; a Method hitherto very prevalent and fuccefsful: whilft, on the other Hand, the French may perhaps influence them as much, by putting them in Mind, of the Execution which their Bombs did formerly to this City, and of a later Inftance of their ReL 111

fentment 
The Intereft Britain tath with it.

fentment at Tripoly. But as there is rarely any great Prudence in ufing high Words and Menaces at Algiers, it is certain, provided the Algerines are to be fwayed with Fear, that We have as much Intereft in Sir Edward Sprag's Expedition at Bou-jeiah, as the French can have in That of the Marquis d' E/trees at Algiers. Notwithftanding likewife all the Arguments that may be urged in behalf of Marfeilles and Toulon, thefe People are not to be perfwaded, but that Minorca and Gibraltar are in a more convenient Situation to give them Difturbance. But Reafon and Argument will not always be good Politicks at this Court, where the Firft Minifter is the Cook, and where an infolent Soldiery have too often the Command. In critical Junctures therefore, the Ground is to be maintained by the nice Management and Addrefs of the Conful; by knowing how to make proper Application to the particular Paffions of thofe who have the Dey's Ear; by flattering one, placing a Confidence in another, and efpecially, by making a proper Ufe of thofe invincible Arguments, Money, Kaf-tans and Gold Watches. For according to an old and infallible Obfervation; Give a Turk Money with one Hand, and he will permit his Eyes to be plucked out by the other.

Aly Ballaw's Such was the Political State and Condition of this Regency, ful Cole. when I left it, A.D.1732. How long it may continue fo, will be hard to determine; becaufe what little there is here of Juftice, Honefty, or publick Faith, proceeds rather from Fear and Compulfion, than from Choice and free Election. For, the Acknowledgement is very juft, which Aly Bafbaw, a late Dey, made to Conful Cole, upon complaining of the Injuries that our Veffels met with from his Cruifers: The Algerines, fays he, are a Company of Rogues, and I am their Captain.

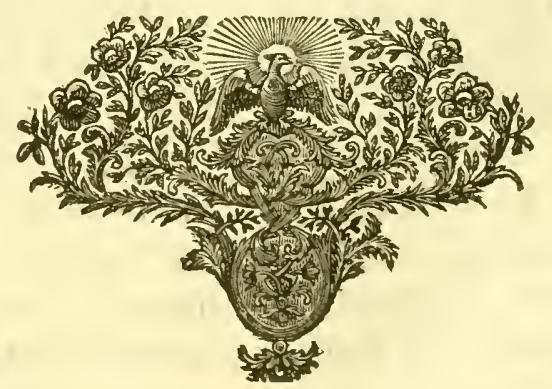

Geographical 
6.

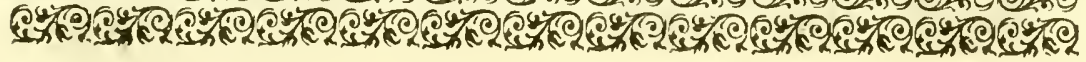

Geograpbical, Phyfical and Mifcellaneous

\section{OBSERVATIONS,}

RELATING T O

$S Y R I A, \& \mathrm{c}$.

EGYPT, and $A R A B I A P E T R A A$.

6. 9.2. 


\section{The CONTENTS。}

C H A P. I.

Geographical Obfervations relating to Syria, Phœnice, and the Holy Land.

p.321.

\section{H A P. II.}

Geographical Obfervations relating to Egypt, Arabia Petræa, and the Encampmentsof the Ifraelites. P.336.

\section{H A P. III.}

Phyfical Obfervations \&c. or an Effay towards the $N a$ tural Hiftory of Syria, Phœnice, and the Holy Land. p.358.

\section{H A P. IV.}

Phyfical Obfervations \&c. or an EJfay towards the $N a-$ tural Hiftory of Arabia Petræa.

p.377.

\section{H A P. V.}

Phyfical and Mifcellaneous Obfervations in Egypt. p.389. 



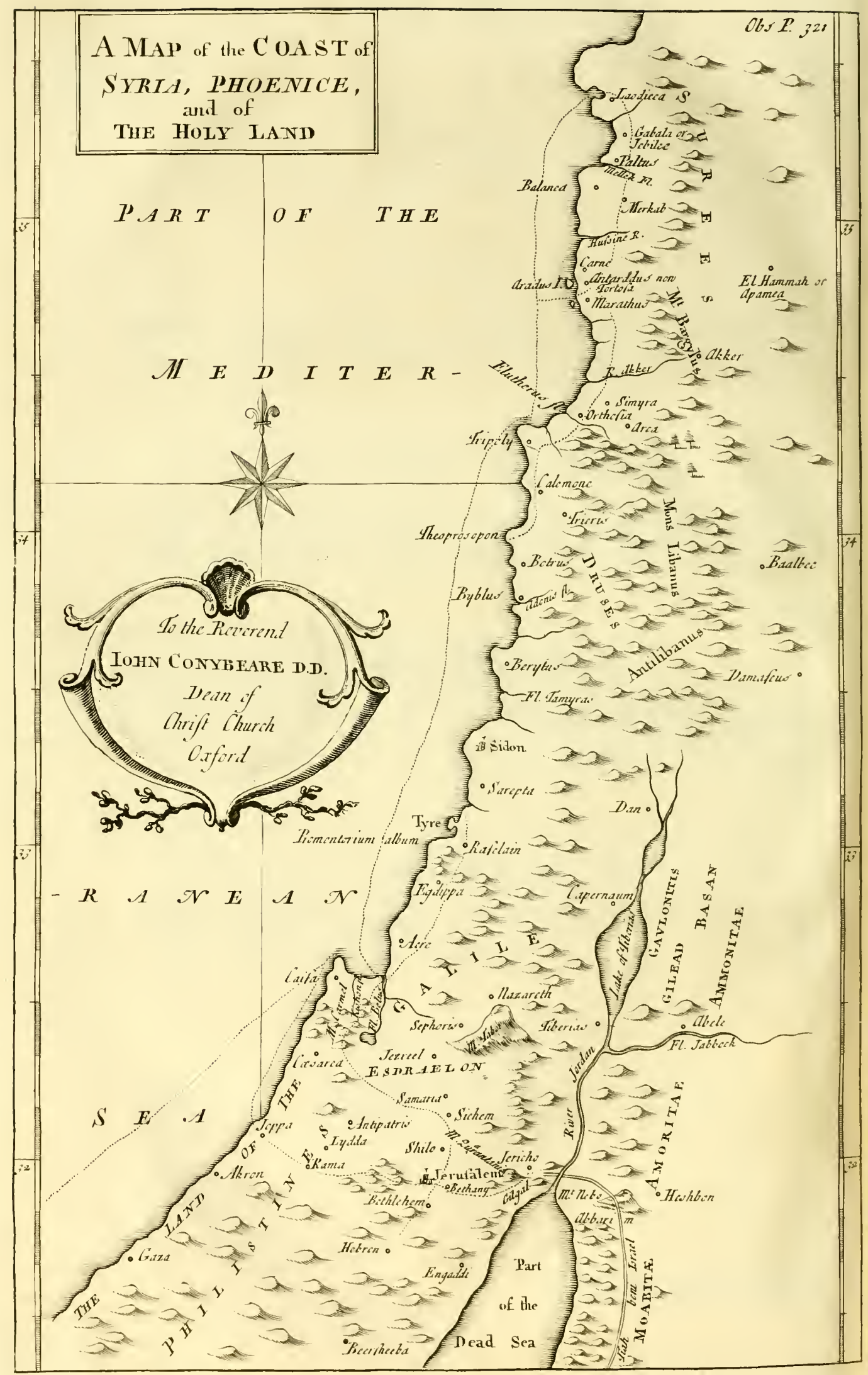




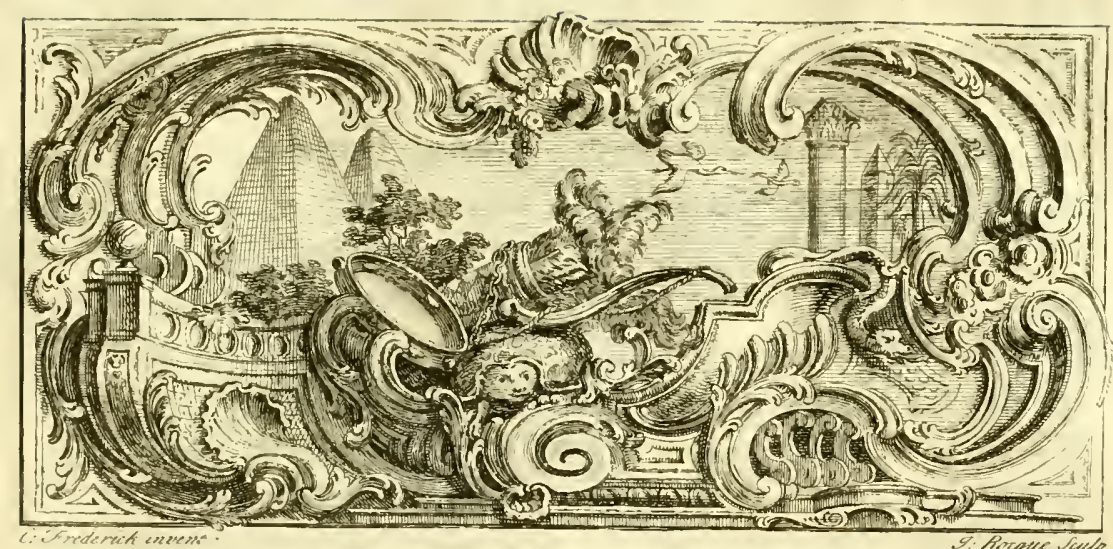

GE O G R A P H I C A L \&

O B S E R V A T I O N S R E L A T I N G T O

$S Y R I A, \& c . E G Y P T, \& c$.

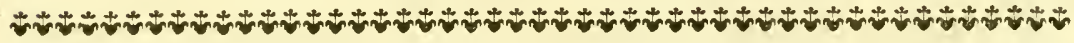

C H A P. I.

Geographical Obfervations relating to Syria, Phœnice, and the Holy Land.

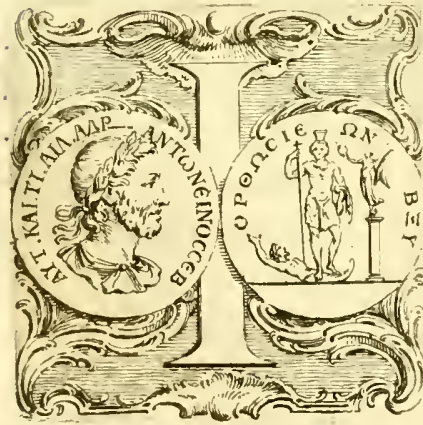

AM entering now upon the Defcrip- $\frac{\text { Mrr. Maun- }}{\text { drell hath al }^{2}}$ tion of thofe Countries, where Mr. reatld defribMaundrell hath been already before $\operatorname{try}^{2}$. me. As it may be prefumed, that every curious Perfon is acquainted with that accurate and judicious Author, I fhall only take Notice of fuch Things, as feem to have been either miftaken or omitted by Him.

Now Latikea, the firft maritime City which He defcribeth, ratikes or was alfo the moft northern Part of Syria, that I had an Op-admare portunity to touch at. It is fituated upon a rifing Ground, $\mathrm{M} \mathrm{mmm}$ 
with a full Profpect of the Sea, and was called by the Antients Laodicea ad mare', and Aeuxg' Axtri, from the white Cliffs that lye on each Side of it. From the Cittadel, we have a pleafant, though diftant View of the Mountains of Caramania, and Caffius to the North; and of Febilee, Merkab, Bannias and Tortofa to the South. The Founder could not have pitched upon a more agreeable Situation, affording at the fame Time, Delight and Security.

The Ruins of Here are ftill remaining feveral Rows of Porphyry, and Granate Pillars; with a large Fragment of an Aqueduct, the fame perhaps that, as Fofephus ${ }^{2}$ informs us, was built by Herod. It is a maffy Structure without Arches, and ftretches towards the S.E. But the chief furviving Monument of the antient Grandeur and Magnificence of this Place, is a large triumphal Arch, fupported by Pillars of the Corintbian Order, which they have converted at prefent into a Mofque. The Architrave is adorned with Trophies, Shields, Battle-Axes, and other military Weapons, whilft the reft of the Entablature is exceeding bold and fumptuous. We fee difperfed all over thefe Ruins, feveral Fragments both of Greek and Latin Infcriptions, but they were all of them fo miferably defaced, that it would have been to little Purpofe to have copied them.

The Cothon. A Furlong to the Weftward of the Town, are the Ruins of a beautiful Cotbon, built in the Figure of an Amphitheatre, and capacious enough to receive the whole Briti/s Navy. The Mouth of It, opens to the Weftward, being about forty Foot wide, and defended by a fmall Caftle. The whole appears to have been a Work and Structure of great Labour and Defign, though, at prefent, it is filled up to that Degree with Sand and Pebbles, that half a dozen fmall Veffels are all that can conveniently be admitted at one Time. The like Accidents, arifing chiefly from the large Billows that attend the wefterly Storms, have intirely ruined the Cothon of Febilee, That a little to the Northward of Torto fa, Thofe of Rou-zvadde, Tripoly,Tyre, Acre and Faffa. At all thefe Places, we cannot fufficiently admire the great Induftry and Contrivance of the Antients, in

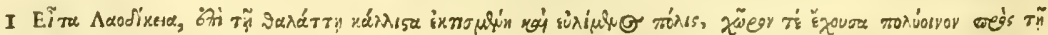
är,y sủxapraix. Strab. Geogr. 1. 16. p. 109 1. Exclufus ab Antiochia Dolabella ** Laodicea1n qux eft, in Syria, ad mare, fe contulit. Cic. Epift. 1. 12. Ep. 14.

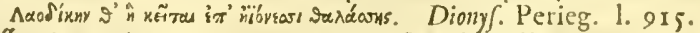

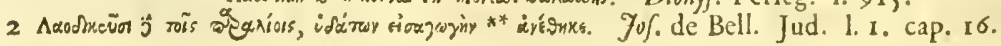

making 
making fuch ufeful Encroachments upon the Sea, at the fame Time we muft have the utmoft Contempt for the later Mafters of them, who out of Avarice, Idlenefs, and want of publick Spirit, have fuffered them to become either altogether ufelefs, or elfe of very little Service to the Trade and Navigation of this rich and plentiful Country.

About two Furlongs to the Northward of the City, near several Sarthe Sea Shore, there are feveral Sarcophagi, fome of which copliagt, on have preferved their Covers. They are generally of the fame Shape, though larger than thofe that are commonly found in Italy, being adorned, in like Manner, with feveral beautiful Decorations in Shells and Foliage, or elfe with Bufts of Men and Women, Ox-Heads and Satyrs; befides others that are pannell'd, having moreover their Covers fupported by Pilafters of the Ionic and Corinthian Orders.

The rocky Ground where we find thefe Sarcophagi, is hollow- Cryper, or ed below into a Number of Cryptee or Sepulchral Chambers, chamulcurs. fome of which were ten, others twenty or thirty Foot fquare; but the Height doth not anfwer in Proportion. The Defcent into them is fo artfully contrived, that the ingenious Architect hath left upon the Front and Side Walls of each Stair Cafe, feveral curious Defigns in Sculpture and Baffo Relievo, like thofe the Sarcophagi are charged with. A Range of narrow Cells, wide enough to receive one of thefe Sarcophagi, and long enough for two or three, runs along the Sides of mott of thefe Sepulchral Chambers, and appear to be the only Provifion that has been made for the Reception of the Dead.

The Greeks have one of thefe Cryptre in great Efteem and The Crypta Veneration. They call It St. Teckla, in Commemoration of of St.Teckla. fome Acts of Pennance and Mortification that are faid to have been performed by that firft Virgin Martyr in this Place. In the Middle of It there is a Fountain, fuppofed to be inftrumental in producing miraculousVifions, and extraordinaryCures. For hither they conftantly bring fuch Perfons or Children, as have the Rickets, Jaundice, or other Diftempers; and after having tranfacted feveral Ceremonies, by wafhing them in Holy Water and perfuming them, they return with a ftrong Faith in the fpeedy Cure of the difeafed. Here likewife the aged and decrepid pretend to receive the Warnings of their approaching Deaths; whilft the young forefee a long Train of Circum.

$$
\mathrm{M} \mathrm{m} \mathrm{m} 2
$$

ftances 
ftances and Events, that are to fall out in the future Courfe of their Lives.

otberCrypte The Sepulchral Chambers near Febilee, Tortofa and the Serof the like Nature.

pent Fountain, together with thofe that are commonly called the Royal Sepulchres at Ferufalem, are all of them exactly of the fame Workmanfhip and Contrivance with the Cryptre of Latikea. And in one of the Chambers of the Royal Sepulchres, there is one of the antient Sarcophagi remaining, which is of a Parian-like Marble, in the Fafhion of a Trunk, very elegantly carved all over with Flowers, Fruit and Foliage. Inftead likewife of thote long narrow Cells that are common in the other Cryptec; fome of thefe have feveral Benches only of Stone, placed one over another, upon which the Coffins were placed.

Paltus. The greateft Part of the Country betwixt Latikea and Febilee is ftony and mountainous; but at the latter, we begin to enter upon a moft delightful Plain, that was formerly theNorthernLimit of the Diftrict of the Aradians'. At the Mouth of the River Melleck, fix Miles from Febilee, the Sea forms Itfelf into a fimall Bay, where we have the Ruins of an antient City, the Paltus probably of the Antients: and a little to the E.N.E. of thefe Ruins, there is a large fubterraneous Conduit, with a Number of leffer ones detached from it, which fpreading themfelves, for the Space of feveral Furlongs, through a Piece of low marfhy Ground, might have been the Drains that were formerly made ufe of to render it fit for Tillage.

$\mathrm{C}_{\mathrm{ARNE}}$, or Seven Leagues to the S. by W. of the River Melleck, and a the Navale little to the Northward of Torto Ja, are the Traces of a Cothon,
of Aradus. with a fmall Pottery hard by It. Here probably was the antient Carne, as the Cothon Itfelf might be the Dock that Strabo ${ }^{2}$ tells us belonged to the Aradians. Betwixt the Pottery and Torto a, are the Cryptre that have been already taken Notice of.

Tortofa the Tortofa, or Deir-dofe as the Inhabitants call It, is very well Antara- defcribed by Mr. Maundrell, though miftaken, l prefume, by
Dus. him and others, for Orthofia, which we are to look for a great way to the Southward, upon the Confines of Syria and Phonice. For though Orthofia may indeed feem to have an eafy Tranfition into Tortofa, yet confidering there was at this Place a large Convent, and two very Magnificent Cloriftian Churches,

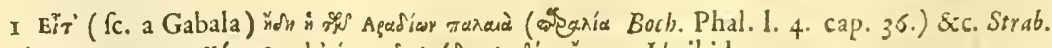

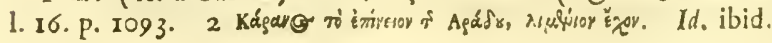


it is more probably a Corruption of the prefent Name Deir-dofe, which, I am told, fignifies The Place of a Church or Convent. Provided the Name had any Relation to the Synonymous City in Spain, the Deduction of It from [Nישרי] it's rocky Situation, would have been extremely applicable to it. However, as it lyeth at about half a Leagues Diftance, over againft the antient Aradus, there is noDoubt, but that it muft be the Antaradus of Pliny and other Geographers.

The Ifland Aradus, the Arpad of the Scriptures, is called Ron-wadde at prefent Rou-quadde; which, with El Hammah's, the Seat of a and ARATurkifb Bafloaw, ten Leagues to the Eaftward, are the moft northern Settlements of the Sons of Canaan. The Profpect of Rou-wadde from the Continent, is wonderfully magnificent, promifing at a Diftance a continued Train of fine Buildings, and impregnable Fortifications. But This is intirely owing to the Height and Rockinefs ${ }^{3}$ of It's Situation; for at prefent all the Strength and Beauty it can boaft of, lyeth in a weak unfortified Caftle, with a few fmall Cannon to defend It. Yet we are not to judge of the antient Strength of this Place by the miferable Condition it is in at prefent ; for it was formerly furrounded with a large ftrong Wall, confifting of Stones of an immenfe Bignefs; which (as in many other Specimens of the antient Buildings) fo exactly tally and correfpond with each other, that the Architect might very juftly eftimate the Weight and Symmetry alone of the Materials to be fufficient to withftand the Violence of the Sea, and the Engines of an Enemy. During the Time of It's Profperity, both Art and Nature feem to have confpired in making it a Place of the utmoft Confequence: confiderable enough to juftify the Boaft, which Sennacherib4 made of the Conqueft of It.

The antient Marathus may be fixed, I prefume, at thofe MARARuins, near the Serpent Fountain, which are taken Notice of ${ }^{\mathrm{THUS}}$ by Mr. Maundrell, and make with Rou-wadde and Torto fa, almoft an equilateral Triangle. For Strabos tells us, that Aradus was

I From whence the Aradite. I Chron. 1. 16. 2 The Hamath of the Scripturcs. Numb. I3.21. 2 Kings 17.24. and 23.33. Ifa. 10.9. $\mathrm{\sigma c}$. the Metropolis of the Country of the Hamathite, the youngelt of the Sons of Canan. Amathis five Amath, Hemath, Emath; quam alii interpretantur Antiochiam magnam, alii Epiphaniam: maluerim Apamiam, quxetian nunc Hwina : propius enim ad Terram promiffam accedit, nec longe eft ab Arphad hodie Refafa. Sanf. Ind. Geogr. in voce Amuthis. 3 Rout-wadde or Arpad being probably derived from 7 'ר firmus fuit \&c. + Where is the King of Hamath and the King of Arpad. 2 Kings

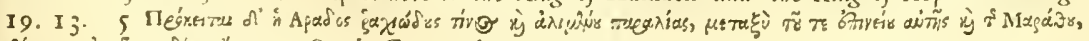

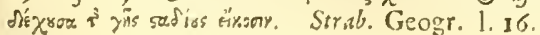


fituated betwixt it's Navale and Marathus, and that the oppo. fite Shore had not the leaft Shelter forVeffels. The latter of thefe Obfervations is very juft; and provided the Navale be the Cothon, which hath been taken Notice of to the Northward of Torto $\int a$, no Place can better fall in with the Situation of Marathus, inafmuch as Rou-wadde, upon this Suppofition, will lye not only between, but very nearly equidiftant from thofe Places.

The Maguz- Five Miles to the S. S. E. of the Serpent Fountain, are the zel or Spin-
dles. Maguzzel Jjiso] Spindles, as they call thofe pointed and cylindrical little Buildings, that are erected over the Cryptre defcribed by Mr. Maundrell. The Situation of the Country round about them, hath fomething in it fo extravagant and peculiar to Itfelf, that It never fails to contribute an agreeable Mixture of Melancholy and Delight to all who pafs through It. The uncommon Contraft and Difpofition of Woods and Sepulchres, Rocks and Grotto's; the Medley of Sounds and Echo's from Birds and Beafts, Cafcades and Water Falls; the diftant Roaring of the Sea and the compofed Solemnity of the Place, very naturally remind us of thofe beautiful Defcriptions which the antient Poets have left us of the Groves and Retreats of their Rural Deities.

The Jeune or The Plain or Feune, (as the Arabs call it,) commences a
Plain. little to the Southward of the Maguzzel, and ends at Sumrah, fpreading itfelf, all the Way, from the Sea to the Eaftward, five, fix or feven Leagues, 'till it is terminated by a long Chain of Mountains. Thefe feem to be the Mons Bargylus of Pliny ${ }^{x}$; as the Plain may be the fame with thofe Fields, which he placeth to the Northward of Mount Libanus. There are difperfed all over the Feune a great Number of Caftles and Watch Towers, befides feveral large Hillocks, which are of the fame Figure, and raifed undoubtedly upon the like Occafion, with thofe Eminences that we call Barrows in England. No Place certainly can be better fupplyed with Water and Herbage; and confequently more proper either for a Field of Battle, or for an Army to encamp in.

I In ora fubjecta Libano Berytus * Trieris, Calamus, Tripolis, qux Tyrii \& Sidonii \& Aiadii obtinent. Orthofia, Eleutheros flumen. Oppida Simyra, Maratbos, contraque Aradum Antaradus. ** Regio in qua fupra dicti definunt montes (Libamus f. ) \& interjacentilus campis, Bargylus mons incipit. Hinc rurfus Syria, definente Phanice, oppida Carne, Balanea, Palios, Gabale; promontorium in quo Laodicea libera. Plin. 1. 5. cap. 20. 
The moft confiderable of the Rivers, which run through Akker, the the Feune, is the Akker, called fo perhaps from a City of the fame Name it runs by. The latter is fituated upon Mount Bar. gylus about nine Leagues to the S.E. of Tortofa, and muft have been formerly as noted for It's Strength, Extent and Beauty, as it is at prefent for the Goodnefs and Perfection of the Apricots, Peaches, Nectarines, and other Fruit which it produceth. Akker may probably be the Ker (i.e. the City) which is mentioned in the Book of Amos (9. 7.) and elfewhere in Scripture, where it is faid, Have not I brought up Ifrael out of the Land of Egypt and the Philiftines from Caphtor, and Aram from Ker; where the fimple reading of Aram, without the Diftinction of Padan, or Nabaraim, may induce us to believe that Ker was of Syria or Aram, properly fo called, and not of Media or Melopotamia, the Padan Aram and the Aram Nabaraim of the Scriptures.

About a League and a half from the River Akker and Sumrab the eight to the S.S.E. of Tortofa, there are other Ruins, ftill Seat of the known by the Name of Sumrah. Thefe may be very well taken for the Remains of the antient Simyra or Taximyra as Strabo calls it, the Seat formerly of the Zemarites. Pliny' makes Simyra a City of Coele-Syria, and acquaints us at the fame Time, that Mount Libanus ended there to the Northward: but as our Sumrab lyeth in the Feune, at leaft two Leagues diftant from any Part of that Mountain, this Circumftance, will better fall in with Arca, where that long Chain of Mountains is remarkably broken off and difcontinued.

Five Miles from Sumrab to the Eaftward, are the Ruins Arкa, the of the antient Arca, the City of the Arkites, the Offspring Arkat of the likewife of Canaan. It is built over againft the Northern Extremity of Mount Libanus, in a moft delightful Situation: having a Profpect to the Northward of an extenfive Plain, diverfifyed with an infinite Variety of Caftles and Villages, Ponds and Rivers; to the Weftward, it feeth, the Sun fet in the Sea, and, to the Eaftward, rife over a long and diftant Chain of Mountains. Here likewife are not wanting Thebaic Columns and rich Entablatures to atteft for the Splendour and Politenefs that it was fometime poffeffed of. The Citadel was ereet-

I A tergo ejus (Sidonis) mous Libsnus orfus, mille quingentis fadiis Simyram ufque porrigitur, quà Cole Syria cognominatur. Plin. ibid.

$\mathrm{Nnnn} 2$ ed 
ed upon the Summit of an adjacent Mount, and, by the Situation, muft have been impregnable in former Times. For the Mount is in the Figure of a Cone, in an Afcent, by the Quadrant, of fifty or fixty Degrees, appearing not to have been the Work of Nature, but of Art. In the deep Valley below the City, we have a brisk Stream more than fufficient for the Neceffities of the Place; yet it hath been judged more convenient to fupply it with Water from Mount Libanus. For which Purpofe, they have united the Mountain to the City by an Aqueduct, whofe principal Arch could not be lefs than a hundred Foot in Diameter.

Nahar el Berd, the THERUS.

Two Leagues to the W.S.W. of Arca, we pafs over the Nabar el Berd, the Cold River, or, according to Mr.Maundrell, the Cold Waters. This Stream arifeth from among the Northern Eminences of Mount Libanus, and fwelling, at certain Times of the Summer, by the extraordinary Liquefaction of the Snow, might from thence have givenOccafion to the Name. We may fix here, I prefume, the River Elentherus, which is fo much wanted in the old Geography. For 'Ptolemy' placeth it, according to the prefent Pofition of the Nabar el Berd, fix Miles to the Northward of Tripoly, in the very Latitude ahmoft Or-tora, the that I find it. In like Manner, Strabo placeth Orthofia, imOrthos IA. mediately after it, to the Northward: agreeable whereunto we ftill find, upon the Banks of this River, the Ruins of a confiderable City, whofe adjacent Diftrict pays Yearly to the Bafbaws of Tripoly, a Tax of fifty Dollars by the Name of Or-tofa. The Situation of it likewife is further illuftrated, by a Medal of Antoninus Pius, ftruck at this Place, upon the Reverfe of which, we have the Goddefs Aftarte treading upon a River. For this City hath been built, upon a rifing Ground, on the Northern Banks of the River ${ }^{2}$, within half a Furlong of the Sea; having fome of the rugged Eminences of Mount Libanus at a little Diftance to the Eaft: whereby it muft have always

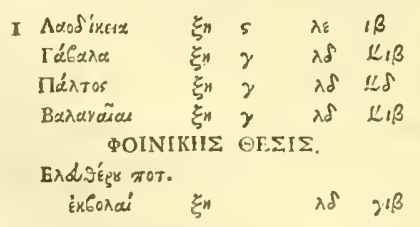

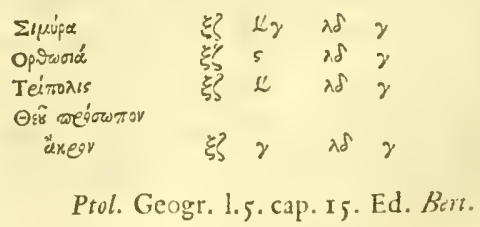

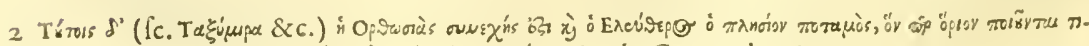

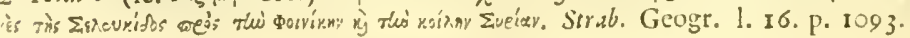


been a Place of the greateft Importance, as it would have the intire Command of the Road, that lay betwixt Phrenice and the maritime Parts of Syria. The Port which Orthofia may be prefumed ' to have formerly enjoyed, is reduced at prefent to an exceeding finall Creek, not capable of receiving the Fifhing Veffels that frequent the Coaft.

The Mountains of Libanus, which, from Arca hither, lye zoe Rive in a W. S. W. Direction, begin now either to run parallel, at at athe Bounz Mile or half a Miles Diftance, with the Sea Coaft, or elfe they dand of Shrit ftretch themfelves out, in fmall Promontories, into the Sea, As there is hereby made a remarkable Alteration in the Face and Difpofition of the whole Country, we have Room to conjecture, that the Boundary betwixt Syria and Phoenice was fixed at this Place. Mela ${ }^{2}$ indeed placeth Simyra and Marathus among the Cities of Pbrenice; whilft Stephanus, by making Balanea, now Bannias, to be a City of it, extends this Province into the very Neighbourhood of Febilee. Even Pliny, notwithftanding he calleth Simyra a City of Coele-Syria, yet afcribeth Marathus and Aradus, which are fituated feveral Leagues beyond it, to Phoenice. However Ptolemy's Authority is intirely in our Favour, which is the more to be credited, as an old Extract from Strabo ${ }^{3}$, and even Strabo himfelf feems to confirm it.

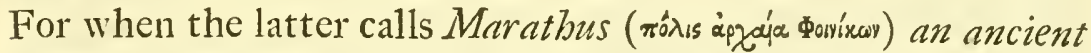
City of the Phrenicians, nothing more perhaps is meant, than that it originally belonged to that People, before they were excluded by the Seleucide. If this Interpretation is admitted, then we may likewife clear up the other Difficulties that were raifed before by Mela, Stephanus and Pliny.

About two Leagues from the Nabar el Berd, are the Ruins of Tbe antient Tripolis, which, being founded, by the united Intereft of ${ }^{\text {TRI PoLIS. }}$ Aradus, Sidon, and Tyre ${ }^{4}$, might have been intended for a common Mart to thofe maritime Powers. It is fituated upon a low Cape, called a Peninfula by Scylax', and hath formerly enjoyed a large and fafe Harbour, though at prefent a few Iflands, lying to the N. W. are the only Shelter that Veffels re-

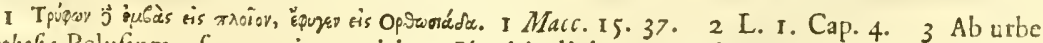
Orthofin Pelufium ufque regio maritima Phanicin dicitur, angulta exiltens. Chryf. ex Strab.

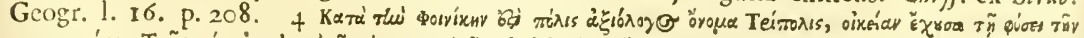

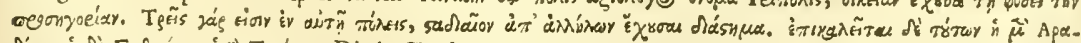
Siar, 1. 16. P. $51 \%$ Plin. 1. 5. cap. 20. 5 Vid. Scyl. Perip. ut fupra. 
ceive from that Quarter. There are no Traces to be met with of any other Walls, than fuch as may be fuppofed to belong to one and the fame City. This, I take Notice of, becaure fome antient Geographers ${ }^{1}$ have obferved, that Tripoly was not one, but three Cities, built at a Furlong's Diftance from each other.

That, which at this Time, is known by the Name of Tripoly, is built at half a Leagues Diftance from the other, upon the Declivity of a Hill, that faceth the Sea. It enjoys a confiderable Trade, arifing as well from It's own Manufactures in Silk and Cotton, as from thofe that are continually brought hither from Aleppo and Damafcus. I could obferve Nothing in the City-Walls or Caftle, that could give either of them a Title to a Greek or Roman Foundation, the Appearance of both being altogether modern and Gotbic. The greateft Rarity of this Place, at prefent, is an Aqueduct, with it's Refervoirs, fome of which, are twenty or thirty Foot high, and, by being placed at proper Diftances in the Town, very conveniently fupply the greateft Part of the Houfes, to their fecond and third Storics, with Water. Over the Prince's Bridge, which is the principal Arch of the Aqueduct, there is an Efcutcheon charged with what appears to be a Cro/s-Crofslet: which being the Bearing of the Family of Lorrain, may vouch perhaps for the Tradition that it was built by Godfrey of Bulloign. At Bellmont, two Leagues to the Southward of Tripoly, there is a famous Convent of Greek Kalories founded by the Croifades. We fee upon the fouthermoft Declivity of it, a large Heap of Ruins, which might probably belong to the TRIERIS. antient Trieris; and betwixt Thefe and Tripoly, is the fmall Calamos. Village Kalemony, the Calamos of Pliny.

The Port of Tyre.

I am not acquainted with that Part of Phcenice, which ly-

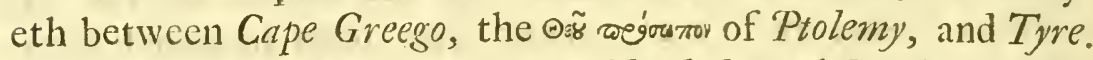
At the latter of thefe Places, I vifited feveral Creeks and Inlets, in Order to difcover what Provifion there might have been formerly made for the Security of their Veffels. Yet, notwithitanding that Tyre was the chief maritime Power of this Country, I could not obierve the leaft Token of either Cothon, or Harbour, that could have been of any extraordinary Capacity. The coafting Ships indeed, ftill find a tolerable good Shelter from the northern Winds, under the fouthern Shore,

I Vid. Diod. ut fupra. Tria fuerunt fingulis inter fe Stadiis diftantia: locus cx numero Tripolis dicitur. Pomp. Mela I. I. cap. 12.

but 
but are obliged immediately to retire, when the Winds change to the W. or S: fo that there muft have been fome better Station than This for their Security and Reception. In the N.N.E. Part likewife of the City, we fee the Traces of a fafe and commodious Bafon, 1ying within the Walls: but which, at the fame Time, is very fmall, fcarce forty Yards in Diameter. Neither could It ever have enjoyed a larger Area, unlefs the Buildings, which now circumfcribe it, were Encroachments upon it's original Dimenfions. Yet even this Port, fmall as it is at prefent, is notwithftanding fo choaked up with Sand and Rubbifh, that the Boats of thote poor Fifhermen, who now and then vifit this once renowned Emporium, can, with great Difficulty only, be admitted.

All the Nations of the Levant call Tyre by it's antient Name Tyre called Sur [7x], from whence the Latins feem to have borrowed Sur. their Sarra:. Sur, I find, layeth Claim to a double Etymology, each of them very natural; though the rocky Situation, (the s's of the Phonicians) will prevail, I am perfwaded, with every Perfon, who feeth this Peninfula, beyond the $S_{a}{ }^{2}$ or Purple Fifh, for which It might have been afterwards in fo much Efteem. The Purple Finh (the Method at leaft of extracting the Tincture) hath been wanting for many Ages: however, amongft a Variety of other Shells, the Purpura of Rondeletius is very common upon the Sea Shore. Several of thofe I faw had their Infides beautified with purplifh Streaks; a Circumftance which may perhaps fo far inftruct us, that they once belonged to fuch an Inhabitant.

There is nothing remarkable betwixt this Place and Mount The Soures of Carmel, but what hath been taken Notice of by Mr. Maundrell. In travelling under the S. E. Brow of this Mountain, I had an Opportunity of feeing the Sources of the River Ki/bon. Three or four of the principal Ones, which lye within lefs than a Furlong of each other, are called The [Ras el Kifhon] Head of Ki/hon, difcharging alone, without the leffer Contributions nearer the Sea, Water enough to form a River half as big as the $I /$ fs. During likewife the rainy Seafon, all the Water, which

I Sarre nomen deduci notum eft ex Hebræo Tyri nomine 7 'צ $T$ for; in quo literam $T$ fade, qux medii eft foni inter $T$ \& $S$ Graci in $T$ mutarunt: \& Romani in S. Ita factum ut ex eodem ר's Tfor \& Túpor nalceretur \& Sarra. Boch. I. 2. Chan. cap.1o. 2 Qux nunc Tyrus dicitur, olim Sarra vocabatur, a pifce quodam qui illic abundat, quem lingua fua Sar appellant. V'et. Scholiaft. in 4 Georg. I'irg.

$$
\mathrm{O}_{0} \mathrm{OO}_{2}
$$


falls on the eaftern Side of the Mountain, or upon the rifing Ground to the Southward, emptieth Itfelf into It in a Number of Torrents; at which Conjunctures It overfloweth it's Banks, acquireth a wonderful Rapidity, and fweeps away ${ }^{2}$ all before It. But thefe Inundations are extemporaneous only, without any Duration; for the Courfe of the Kiflon, which is not above feven Miles in Length, is continued all the Way, 'till within half a League's Diftance of the Sea, in a great Defcent. It may be further obferved, that, when the Kifbon is not augmented by thefe accidental Torrents, it never falls into the Sea in a full Stream, but lofeth Itfelf in a Bank of Sand, which the North Winds throw up againft the Mouth of It. In this Manner I found It, in the middle of April, when I paffed It.

The River BELUS or Kar-danah.

Beyond the Sources of the Kiffon to the S. E. and along the Banks of it to the N. E. there are feveral Hillocks, which feparate the Valley, through which it runs, from the Plains of Acre and Efdraelon. The River Belus, the Kar-danab as it is called at prefent, hath it's Sources about four Miles to the Eaftward of the Ras el Kifbon, on the other Side of thefe Hillocks, where there are feveral Ponds, the largeft whereof, may in all Probability, be the Cendevia ${ }^{2}$ of Pliny. Now the RiverBelus lying open to the Plains of Acre and Efdraelon, there is Room to fuppofe that fuch Brooks as arife from Mount Tabor may communicate with it; but the Kifbon, I prefume, for the Reafons already given, cannot: neither indeed doth it run in the fame Direction, that hath been hitherto afligned by Geographers. The Tribe of Leaving Mount Carmel to the N. W. we pafs over the S. W.
Ifrachar. Corner of the Plain of EJdraelon, the Lot formerly of the Tribe of IfJachar, and the moft fertil Portion of the Land of Canaan. The moft extenfive Part of it lyeth to the Eaftward, where our Profpect is bounded, at about fifteen Miles Diftance, by the Mountains of Hermon and Tabor, and by thofe, upon which the City of Nazareth is fituated. Advancing farther into the Half Tribe of ManafJeh, we have ftill a fine arable Country, though not fo level as the former; where the Landskip is changed every Hour by the Intervention of fome Piece of rifing

I It might be at fuch a Conjuncture as this, that the River Kinon fu'ept the Holt of Sifera away, that antient River, the River Kimon. Fudg. 5. 21. 2 Rivus Pagida five Belus, vitri ferriles arenas parvo litori mifcens. Ipfe e palude Cendevis a radicibus Carmele profluit. Plin. 1. 5. cap. 19.

Ground, 
Ground, a Grove of Trees, or the Ruins of fome antient Village. The Country begins to be rugged and uneven at $S a$ maria, the N. Boundary of the Tribe of Ephraim; from whence, through Sicbem, all the way to Ferufalem, we have nothing but Mountains, narrow Defilee's, and Valleys of different Extents. Of the former, the Mountains of Ephraim are the largeft, being moft of them fhaded with large Foreft Trees, whilft the Valleys below are long and fpacious, not inferiour in Fertility to the beft Part of the Tribe of Iffachar. The Mountains of the Tribe of Benjamin, which lye ftill further ${ }_{\text {Benjamine }}^{\text {The }}$ Trib of to the Southward, are generally more naked, having their Ranges much fhorter, and confequently their Valleys more frequent. In the fame Difpofition is the Diftrict of the Tribe The Tite of $_{\text {. }}$ of $\mathcal{F u d a h}$; though the Mountains of Quarantania, thofe of $E_{n}$-Judal. gaddi, and others that border upon the Plains of Fericho and the Dead Sea, are as high, and of as great Extent, as thofe in the Tribe of Ephraim. Some of the Valleys likewife, that belong to thisTribe, fuch asThat of Repbaim, E/locol, and others, merit an equal Regard, with that Parcel of Ground which Jacob gave to his Son Jofeph. (Gen. 48. 22). But the weftern Diftrict of theTribe of Ephraim, in the Neighbourhood of Ramals and $L y d d a$, is nearly of the fame arable and fertil Nature, with that of the Half Tribe of Manaffeh; and equally inclineth to be plain and level. The latter of thefe Circumftances agreeth alfo with the Tribe of $\mathcal{D} a n$, whofe Country, notwithftanding, Tbe ribb of is not fo fruitful, having in moft Parts a lefs Depth of Soil, and bordereth upon the Sea Coaft in a Range of Mountains. From theMountains of Quarantania, we have a diftinctView of theLand of the Amorites, of Gilead and of Bafan, the Inheritance " of

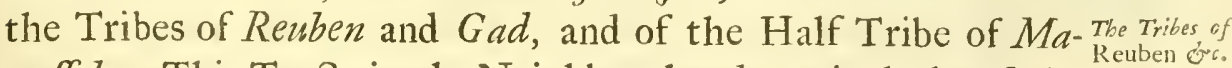
naffer. This Tract, in the Neighbourhood particularly of the River Fordan, is, in many Places, low and fhaded, for want of Culture perhaps, with Tamarisks and Willows: but at the Diftance of two or three Leagues from the Stream, it appears to be made up of a Succeffion of Hills and Valleys, fomewhat larger and feemingly more fertil than thofe in the Tribe of Benjamin. Beyond thefe Flains, over againft Fericho, where we are to look for the Mountains of Abarim², the northern Boun-

I Deut. Chap.3. 2 Nebo and Pifgah were fome particular Parts or Summits of this Moun. tain, from whence Mofes belseld the Laint of Canaan, before he atizs gatherell to his Prople. Numb. 27. 12, 13. and 32.47. Deut. 3.27. and 32. 49. and 31. I.

$$
\text { P p p p }
$$


dary of the Land of Moab, our Profpect is interrupted by an exceeding high Ridge of defolate Mountains, no otherwife diverfifyed than by a Succeffion of naked Rocks and Precipices, rendred in feveral Places more frightful, by a multiplicity of Torrents which fall on each Side of them. This Ridge is continued all along the eaftern Coaft of the Dead Sea, as far as our Eye can conduct us, affording, all the way, a moft lonefome melancholy Profpect, not a little affifted by the intermediate View of a large ftagnating unactive Expanfe of Water, rarely if ever enlivened by any Flocks of Birds that fettle upon it, or by fo much as one Veffel of Paffage or Commerce that is known to frequent it. Such is the general Plan of that Part of the HolyLand which fell under my Obfervation.

The situation The Hills which ftand round about Jerufalem, make it ap-
of Jerufalen. pear to be fituated, as it were, in an Amphitheatre, whofe Arena inclineth to the Eaftward. We have no where, that I know of, any diftantView of It. That from the Mount of Olives, which is the beft, and perhaps the fartheft, is notwithftanding at fo little Diftance, that, when our Saviour was there, he might be faid, almoft in a literal Senfe, to have wept over It. There are very few Remains of the City, either as it was in our Saviour's Time, or as it was afterwards rebuilt by Hadrian; Jcarce one Stone being left upon another, which bath not been thrown down. Even the very Situation is altered. For Mount Sion, the moft eminent Part of the Old Ferufalem is now excluded, and It's Ditches filled up; whilft the Places adjoyning to Mount Calvary, where Chrift is faid to have Juffered without the Gate, are now almoft in the Centre of It.

A Tradition kept up of the
remarkable remarkable
places.

Yet notwithftanding thefe Changes and Revolutions, it is highly probable that a faithful Tradition hath always been preferved of the feveral Places that were confecrated, as it were, by fome remarkable Tranfaction relating to our Saviour and his Apoftles. For it cannot be doubted, but that among others, Mount Calvary and the Cave where Our Saviour was buried, were well known to his Difciples and Followers: and not only fo, but that fome Marks likewife of Reverence and Devotion were paid to them. Thefe, no lefs than the Grotto at Betblebem, where Our Saviour is fuppofed to have been born, were fo well known in the Time of Hadrian', that out of Hatred 


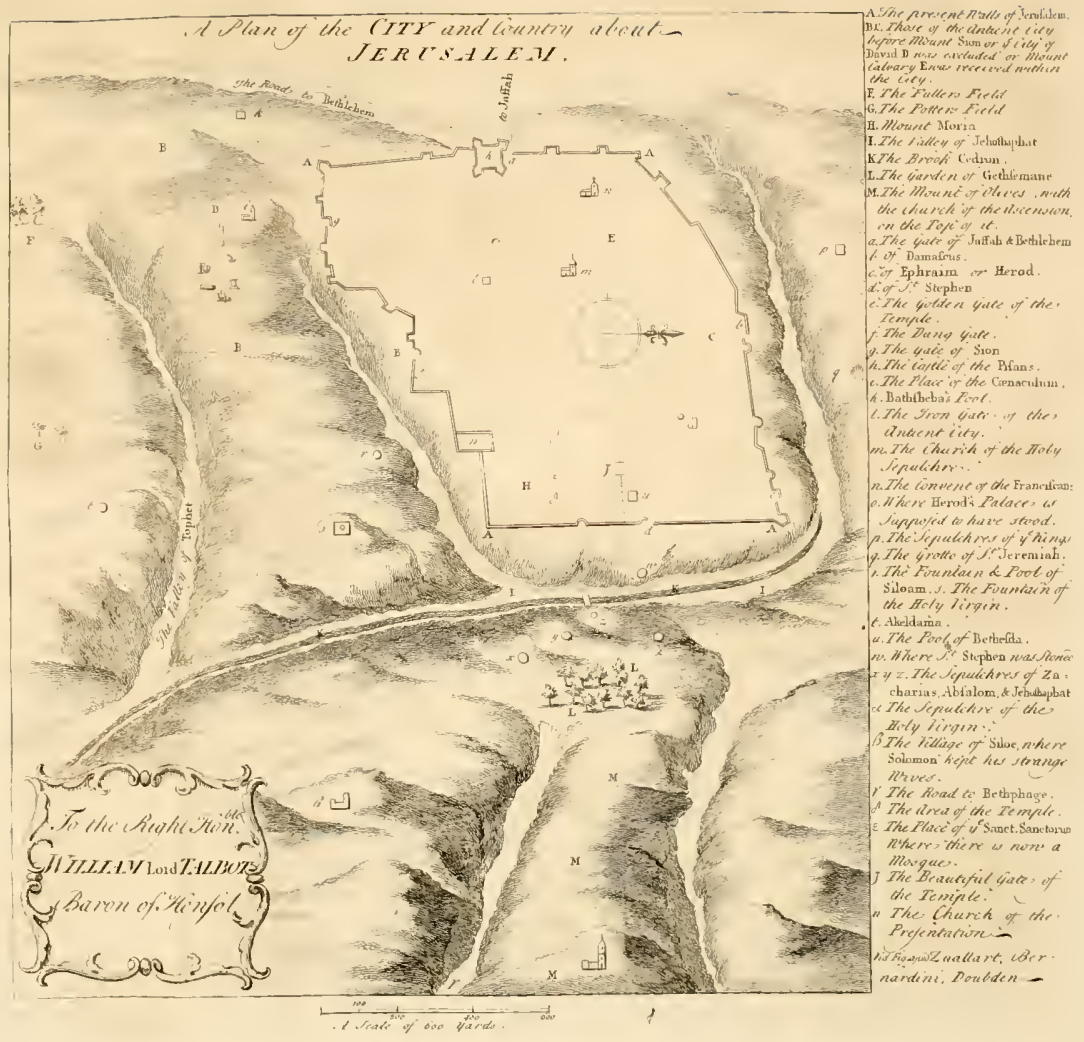



and Contempt to the Chriftian Name, there was a Statue erected to Fupiter, over the Place of the Refurrection, another to Vemus upon Mount Calvary, and a third to Adonis at Bethlebem. All thefe continued, 'till Conftantine the Great and his Mother St. Helena, out of their great Efteem and Veneration for Places fo irreligioufly prophaned, erected over them thoie magnificent Temples, which fubfift to this Day. An uninterrupted Succeffion, it may be prefumed, of Chriftians who refided at Ferufalem, or who ${ }^{2}$ were conftantly reforting thither out of Devotion, would preferve the Names, not only of the particular Places I have mentioned, but of others likewife that are taken Notice of in the Hiftory of Our Saviour: fuch as are the Pools of Bethe/da, and Siloam; the Garden of Geth/emane; the Field of Blood; the Brook Cedron; \&c. which have all been well defcribed by nur Countrymen Sandys and Maundrell. All that I can pretend to add, is to give the Reader, in one View, the particular Situations of them.

The Lot of the Tribe of Fudab was nearly equal in Extent The great Exto That of all the other Tribes; and being too much for them, Tibe of the Tribe of Simeon had their Inheritance taken out of it ${ }^{3}$. It's Southern Boundary ${ }^{4}$ was to be from the Bottom of the Salt Sea, all along by the Border of Edom, to the River of Egypt the soutut to and the Mediterranean Sea. Now as the River of Egypt (from feveral Arguments that might be urged if there was Occafion) could be no other than the Pelufiac Branch of the Nile, we may, from thefe Geographical Circumftances, receive no fimall Inftructions towards the right fettling the Northern Border of the Land of Edom, and in Confequence thereof, the Defert of Zin and Kadefo Barnea, which made a Part of it: all of them Places, that feem not to have been hitherto well laid down by Geographers. For the Extent and Situation of the Salt Seas, being no lefs known, (at leaft as far as concerns the prefent Difquifition,) than the Eaftern Branch of the Nile, an imagi-

\footnotetext{
ginta, in loco refurrcetionis fimulacrum Jovis, in crucis rupe ftatua ex marmore Veneris a gentibus pofita colebatur, exiftimantibus perfecutionis auctoribus, quod tollerent nobis fidem refurrectionis \& crucis, $f_{1}$ loca Sancta per idola polluiffent. Bethlehem nunc noltrum \& auguftiffimum orbis locum, de quo Pfalmilta canit, Veritas de Terra orta eft, lucus inumbrabat Thammz, i. e. Adonidis; \& in fpecu, ubi quondam Chriftus parvulus vagiit, I'eneris Amafius plangebatur. Hieron. Ep. xIIn. ad Paulin. Eufeb. de Vita Conftant. 1. 3. cap. 25. 2 Longum elt nunc ab afcenfu Domini ufque ad prefentem diem per fingulas xtates currere, q̣ui Epıfcoporum, qui Martyrum, qui eloquentium in doctrina Ecclefiaftica virorum venerint Hierololymam, putantes fe minus religionis, minus habere fcientix, nifi in illis Chriftum adoraffent locis, de quibus prinam Evangelium de patibulo cornfcaverat. Hieron. Ep. 17. ad Mircell. 3 Fo/3. 19.9. 4 Numb. 3+. 3, 4, 5. Fo/h. 15.1, 2, 3, 4. 5 Commonly called the Afphaltic Lake or Dead Sea.

P p p 2

nary
} 
nary Line drawn betwixt thofe Places as they are particularly marked out in the Scriptures, will give us the Boundary required. Kadefl lay Kadefo Barnea then (which may be prefumed to lye, fomewhere upon the $S$. Boundary of it. near or upon this Boundary, in the direct way from Edom to the Land of Promife, ) will probably be fixed at about an hundred Miles Diftance to the S. W. of Ferufalem, at the half W'ay nearly betwixt Rbinocolura and the Elanitic Gulph of the Red Sea.

The Weftern Coaft of this Tribe lay, along the S. E. Gulph along the sea of the Mediterranean Sea ', from Ekron to the River of Egypt,
coaft. being the moft Part of it low, of a barren fandy Quality, and very dangerous forVeffels to approach. Several of the antient Cities, particularly thofe of the Philiffines, have pretty nearly preferved their old Names: for Ekron is called Akron, Afcalon is contracted into Scalon, Gath into Fet, and Gaza, which lyeth about feven Leagues to the S. W. of Akron and eleven, in the fameDirection, from $\mathcal{F} a f a$, is pronounced Gazy. Rbinocolura was probably fituated near the Bottom of the Gulph, fixteen Leagues to the S. W. by W. of Gazy, and eighteen to the Eaftward of the Nile. The Lake Sirbonis lay betwixt It and the Nile, at fix Leagues Diftance only from the Latter, being formerly of great Extent, and having a Communication with the Sea. Though indeed, what I have faid of Kadeflo Barnea, Rbinocolura, and this Lake, is barely conjectural, by comparing what I my felf have feen of Fudea, the Nile and Arabia, with the Accounts that have been left us of thefe Places by different Authors.

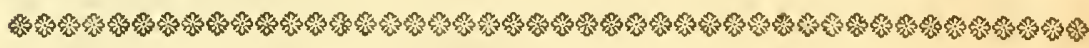

\section{H A P. II.}

Geographical Obfervations relating to Egypt, Arabia Petrxa, and the Encampments of the Ifraelites.

The coaft of Egypt and the Seven Mouths and Branches of
the Nile.

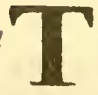
H ERE is no Part of the Coaft of Egypt, which fell under my Obfervation, that could be feen afar off. The Mariners, in approaching it, eftimate the Diftance by the Depth of Water: fuch a Number of Fathoms ufually anfwering to the fame Number of Leagues. All that Portion of it particularly, which

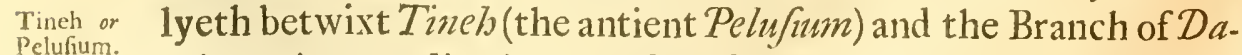
mi-ata, is exceeding low and full of Lakes and Moraffes; agreeing fo far, even to this Day, with the Etymology ${ }^{2}$ of the Name. The Numb.34.6. 7o/3.15. 12. and I3.2,3. 2 Vid. p.36. Not.r. Lakes 
Kadeflı

upone the

Boundar

it.

The mef

Border:

along the

Coaft.

The Coa

of Egypt

the Sevi

Mouths a

Brauches

the Nile.

Tineh 0

Pelufium 
Lakes abound with a Variety of excellent Fifh, which they difpofe of among the neighbouring Villages; or elfe falt up and fell to the Grecian Merchants.

Dami-ata is one of the moft confiderable Cities for Trade in Dami-sta or Egypt. It lyeth upon the eaftern Banks of the Nile, at five $\mathrm{T}_{\text {HHS. }}^{\text {THA- }}$ Mile's Diftance from the Sea, and about fixty to the N. N.W. of Tineh. The Branch that runs by it, has been generally re. ceived for the Pelufiac, by miftaking, no Doubt, this City for the antient Pelufium; whereas Dami-ata feems rather to be a Corruption of Thamiathis, it's former Name. This Branch therefore, as well from the Situation as theLargenefs of it, fhould be the Pathmetic, (or Phatnic as Strabo calls it,) betwixt which and the Pelufiac, were the Mendefian and the Tanitic; but of thefe I could receive no Informations.

Sixteen Leagues to the N. N.W. of the Patbmetic Mouth, is Cape BrulCape Brullos, where the Sebennitic Branch is fuppofed to have $e^{\text {los. }}$ difcharged itfelf: after which follows the Bolbutic, at feventeen Leagues Diftance to the S. W. by W. This is called at prefent the Branch of Rozetto (or Rafid, as the Inhabitants pronounce Rozetto. it,) from a large and populous City, that is fituated about a League from the Mouth of it.

At Me-dea, the antient Heraclium, four Leagues further, Me-dea or there is another Branch, though much fimaller than the former; HMR. $_{\mathrm{R}}$ ACLIand two Leagues beyond it, in the fame wefterly Direction, we have an Inlet and fome Ruins known by the Name of Bikeer. Bikeer or As this Place lyeth five Leagues from Alexandria, and the ${ }^{\mathrm{C} A \mathrm{Nop} u S}$ Branch of Me-dea feven, we may be induced, from the $\mathrm{Au}$ thority of Strabo', to take the one for the antient City Canopus, the other for the Branch of the fame Name. But This, no lefs than the Sebennitic and Pelufrac Branches, are, at prefent, of little Account, except at the Time of the Inundation; the Nile difcharging Itfelf chiefly at other Times, through thofe of Rozetto and Dami-ata.

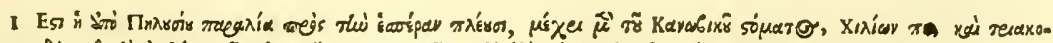

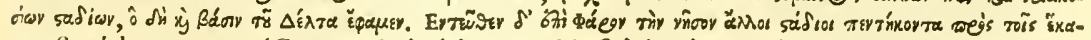
zov. Strab.l. I7.p. I 140 . (Canopus inde (ab Alexandria fc.) duodecimo disjungitur lapide. Ammian.

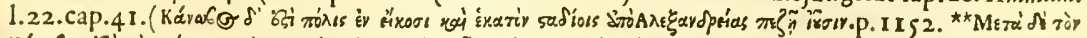

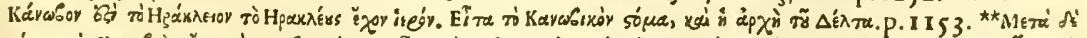

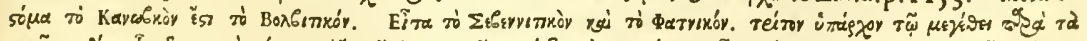

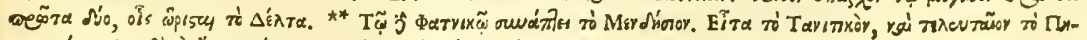

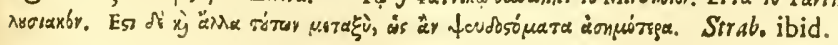


scandarea or Scandarea, as Alexandria is called at prefent, hath two

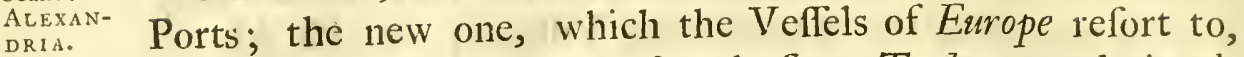
and the old one, where thofe only from Turkey are admitted. Portus Mag-The former is what Strabo calls the Great Port', lying to the nus, Portus Eunofti \& Cibotus.

Eaftward of the Pharos: the other is his Port of Eunoftus, where was alfo the Cibotus, which is faid to have had a Communication with the Lake Mareotis, that lay behind it to the South. The prefent Scandarea is fituated betwixt them, upon SErtem what was probably the Septem Stadium ${ }^{2}$ of Strabo; whereas STADIUM the old City lay further towards the N. and N. E.

Tik Rim tim of

Confidering the great Devaftations which have attended the Alesandria. Saracen Conquefts in other Places, it is fomewhat extraordiThe ancient nary, that the greateft Part of the antient Walls of this City, Walls. together with their proper Turrets, fhould have remained fo compact and intire quite down to this Time. In the fame ConThe ciferns. dition likewife are the Cifterns, which, at the overflowing of the Nile, were annually fupplyed with Water. Thefe are of a great Depth, having their Walls raifed by feveral Stages of Arches, upon which the City was built. The Grandeur and Sumptuoufnefs of the antient Alexandria, may be further eftimated from two Rows of beautiful Granate Pillars, (feveral whereof are ftanding) which may be fuppofed to have conftituted the Street, that is taken Notice of by Strabo, and reached from the Necropolitic ${ }^{3}$ Part of the City to the Gate of Canopus. We have both at Latikea and Hydra, Cities already defcribed, Rows of Pillars difpofed in this Fafhion.

Pompey's Pillar lyeth at a little Diftance to the Southward of thefe Walls. It is of the Corintbian Order, though the Foliage of the Capital is badly executed. A great Part of the Foundation, which is made up of feveral different Pieces of Stone and Marble, hath been removed, in Expectation, as may be fuppofed, of finding a Treafure. At prefent therefore the wholeFabrick feems to reft intirely upon aBlock of whiteMarble,

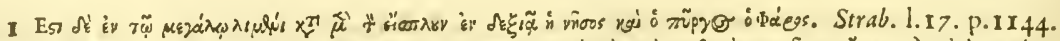

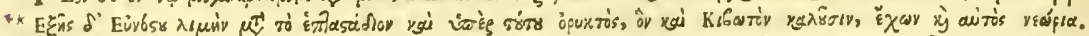

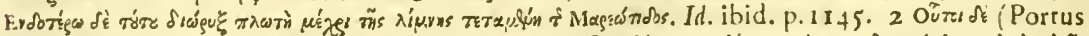

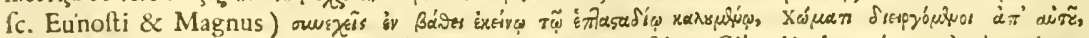

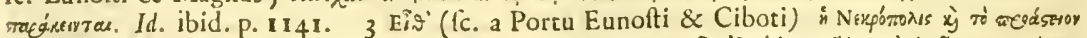

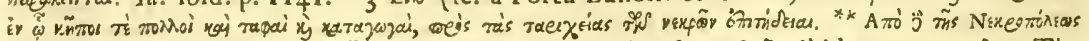

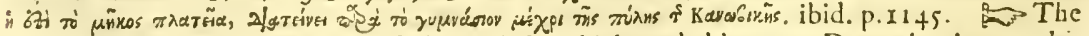
Crypte or Catacombs as they are ufually called, which probably gave Denomination to this Part of the City, are molt of then remaining, being little different from thofe that hase been defcribed at Latikea, and probably were intended for the lame Ufe, and not for the Reception of Munmies or embalmed Bodies, like Thofe at Sakara neat Memphis. 


\section{in Egypt, Arabia Petræa $\widehat{乛} \vec{c}$.}

fcarce two Yards fquare, which, upon being touched with a Key, gives a Sound like a Bell. Some of the broken Pieces of Marble are infcribed with Hieroglyploicks; a Circumftance which may induce us to fufpect, that this Pillar, was not erected by the Egyptians, but by the Greeks or Romans; nay, later perhaps than Strabo, who otherwife, it may be prefuried, would not have omitted the Defcription of it.

The Delta was computed to commence from the Canopic Tbe Delta Branch of the Nile, which hath been fuppofed to fall in at fromm treed Me-dea. From hence to Rozetto, the Caravans are guided, Barmpic for the fpace of four Leagues, by fuch a Range of Pofts; as have been mentioned in defcribing the Shibkab El Lowdeab'. The Channel which fupplyed Alexandria with Water, lyeth all the Way upon the right Hand; and, for Want of being employed as in former Time, difchargeth Itfelf chiefly into That of Me-dea. There are few or no Tokens of the Nile's Inundation to be met with from Alexandria to Rozetto, the whole Tract appearing to have been originally either a Continuation of the fandy Coaft of Lybia, or elfe an Ifland. In Sailing That mights likewife to the Eaft, we fee, befides other fmaller ones, a a have orgiginal. Hillock of fandy Ground, to the Eaftward of the Bolbutic Mouth ${ }^{2}$ of the Nile, another at Cape Brullos, and a third to the Weftward of Damiata. Thefe, may be prefumed, to have been all of them originally Iflands, ferving, from their Situation, to give the firft Check to the Stream, and to have thereby gradually collected and retained the Mud, that might lay the firft Foundation of the Delta. Before this was formed, it is probable that all or the greateit Part at leaft of the Lower Egypt, was nothing more than a large Gulph of the Sea: and confequently, the Inland of Pharos, according to an Obfervation of Homer's ${ }^{3}$, might lye at the Diftance of a good Day's Sail from what was called Egypt at that Time.

Except at the Time of the Inundation, when the whole Coun- Tse Banks of try is covered with Water, no Navigation can be attended with of tillases. fo much Pleafure as that upon the Nile. There is, at every

1 Vid.p.2Ir. 2 This fecms to be the fame, that is taken Notice of by Strabo, under

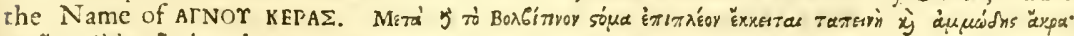

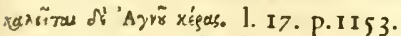

3 Nî̄os हैं

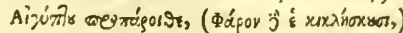

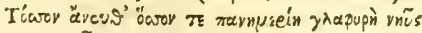

Hrua:v,

Qqqa 2

winding 
winding of the Stream, fuch a Variety of Villages and Planta. tions which prefent themfelves to ourView, that from Rozetto to Kairo, and from thence all the Way down the other Branch, to Dami-ata, we have a continued Scene of Plenty and Abundance. The many Turnings of the River, make the Diftance from Kairo, either Way, to be near two hundred Miles, though in a direct Road, it will fcarce amount to half that Number.

Kairo, the Kairo, or Al Kabirab', commonly called Al Meffer, lyeth antient $\mathrm{BA}$ BYLON.

nearly two Miles to the Eaftward of the Nile, and fifteen to the Southward of the Delta, as Memphis ${ }^{2}$ is faid to have done. It is built in the Form of a Crefcent, under the Northern Shade of that Mountain, upon which the antient Caftle of the Babylonians was fituated. The Khalis (which is the Amnis Trajanus ${ }^{3}$ of the Antients, and annually fupplieth the City with Water) runs from one Point of it to another, being, in all, about five Miles in Length. Grand Kairo therefore, according to the Name it ufually goes by among the Europeans, is much inferiour in Extent ${ }^{4}$ to feveral Cities of Chriftendom. However it muft be allowed to be exceeding populous; for feveral Families live in one Houfe, and a Number of Perlons in each Chamber of it ; during likewife the bufy Time of the Day, all the Streets are fo crowded with People, that there is Difficulty enough to pafs through them.

The cafle of The Caftle ${ }^{s}$, which might afterwards give Name to the City ${ }^{6}$, Kairo, for-
merly the $\mathrm{Ca}$ - is built, as I before obferved, upon this Mountain; theWay up to fle of the Ba-
bylonians. It being cut all the Way through the Rock, from whence perhaps

I tion hath been put upon Kair-wan, notwithftanding what hath been already obferved, p. 201. Occuba, fays D'Avity, baftit au mefine lieu ou il avoit defait le Conte Gregoire, une ville qu' il nomma Cayre, c'efl a dire Victoire; puis on l' appelle Cayravan, $c^{\prime}$ eft a dire deux Victoires, a caufe d' une autre que les Arabes y obtinerent depuis. Vid. La Defcription generale del' Afrique par P. D'Avity. p. 49. But the Inhabitants of Egypt, and of all the Levant, ufually call Kairo Meffer, a Name taken from Mizraim the Son of Cham, the firtt Planter of this Country. Urbs Foflat eft ipfamet Metfr fic dicta a Mifram filio Cam, flii Nố, cui pax: ipfe enim eam ædificaverat primitus. * Dicitur autem appellata fuiffe Foftat, quod volente Amro filio Aas, poft captam Metfr, proficifci Alexandriam, præceperit ut precederet eum Alfoftat (i.e. tentorium) \& figeretur aut tranfportaretur ante fe : quare accidit utColumba defcenderet, ovum in ejus vertice pareret. Quo ad Amrum delato, juffie tit relinqueretur tentorium eodem in firu, donec Columba ovum fuum perficeret. Grogr. Nub. p. 97.

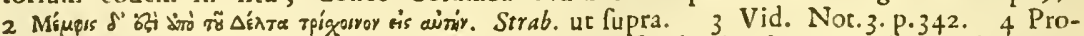
vided the Villages of Old Kairo and Boulac, (whereof This lyeth two Miles to the N.E. the Other at the fame Diftance to the W.) Mould have formerly belonged to this City, (and indeed the many interjacent Ruins feem to point out fomething of this Kind,) then Kairo would not have been inferiour in Extent to the Metropolis of Great Britain.

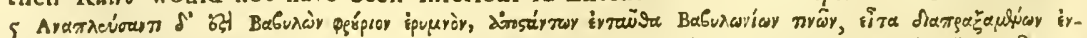

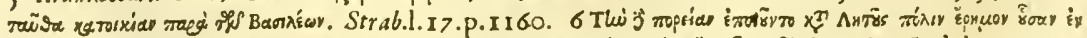

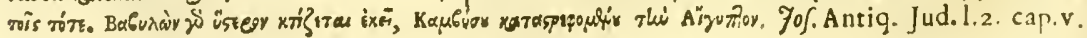


this Ridge of Eminences came to be called Fibbel Moc-catte, or Mocattem, i. e. the Mountain that is hewn or cut through. Befides other Places, of lefs Account, within the Caftle, we are fhewn, firft, a fpacious magnificent Hall, fupported by a Number of large Thebaic Columns; then, the [Beer el Hallazoune Uata " that goes winding round it, are hewn out of the natural Rock. Both the Hall and the Well are looked upon, by the Inhabitants, to be Works of fuch Grandeur and Expence, that the Patriarch Fo/eph, whofe Prifon they pretend likewife to fhew us, is fuppofed to have been the Founder. But, in all Probability, the Well was contrived by the Babylonians, and there are fo many Guildings and Improprieties in the other, that the Foundation of it may be well attributed to the Mabometans.

Over againft Kairo, on the Lybian Banks of the Nile, is the Gceza, the Village Geeza, where Memphois was formerly fituated, but pHss. which is now intirely buried in Soil. In the fame Direction The Situation likewife are the Pyramids ${ }^{2}$, twelve Miles further, being erected ${ }_{M 1 D S}^{\text {of the }}$ P RAupon that Ridge of the Lybian Mountains, which bounds the Inundation of the Nile to the Weftward. The Caftle of Kairo hath the like mountainous Situation on the Afatick Side of the River; and, in this Manner, the Nile is confined, for the The Upper Space of two hundred Leagues, all the Way down from the Eaypt confsCataracts; a long Chain of Eminences, fometimes at four, of Alountatias s fometimes at five or fix Leagues Diftance, conftantly bounding the Inundation on each Side.

Such, in general, is the Plan, fuch likewife is the Extent The Land of of the Land of Egypt. That Part of it, which is called in Scripture the Land of Go/hen or Ramefes, is fituated in the Heliopolitan Nomos, particularly, upon the Arabian Banks of the Nile, in the Neighbourhood of Matta-reah. For Fofeph, when he invited his Father and Brethren into Egypt, tells them, (Gen. 45. 10.) that they fould dwell in the Land of Golhen, and be near bim. Go/ben then mutt have been adjacent to the Seat of the Egyptian Kings. Now, as a Weft Wind the Seat of (Ex. 10.19.) took away the Locufts and caft them into the Red ${ }_{M \text { Ming }}^{K \text { at }}$ as. Sea, This Place will be better fixed at Memphis, whofe Situation

I This Well confifts of two Stages, being in all about $4+$ Fathom decp. The upper Stage is 16 Foot broad one way and 24 the other. The Water, which is brackin, is drawn

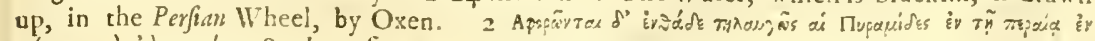

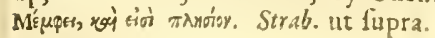

Rrrr exactly 
exactly anfwereth to this Circumftance, than at Zoan, a City of the Tanitic Nomos, where the fame Wind could not have blown thofe Infects into the Red Sea, but into the Mediterranean, or elfe into the Land of the Philifines. For the Land of Zoan, as it is mentioned in the Book of Pfalms, (viz. 78 . v.I2 and 43.) is probably nothing more than another Appellation for the Land of Egypt, by taking, as is ufual in fuch poetical Compofitions, a Part for the Whole, and fubftituting one noted Place, fuch as Zoan was in the Time of David, inftead of the whole Country.

Zoan lay at a Nay further, provided $7 a c o b$ had directed his Journey from Diffance from
the Rsad that Beer $\$ b e b a$, towards that Part of Egypt, which was called Zoan, Jacob took into Egypt. it will be difficult to account for what is recorded by the LXXII and Fofephus', that his Son Foseph met him at Heroopolis. For as this was a City of the Heliopolitan Nomos, which bordered upon the Red Sea, where we have at prefent the Caftle and Garrifon of Adjeroute, it would lye directly in the Road to Memplois, but, out of it, in the Way to Zoan. The The Heliopo- LXXII ${ }^{2}$ likewife (Gen.46.28.) inftruct us, that Heroopolis was a litanNonios,
the fame with
City of the Land of Rame/es; which therefore could be no Ramefes. other than the Heliopolitan Nomos ${ }^{3}$, taking in that Part of Arabia, which lay bounded, near Heliopolis, by the Nile, and, near Heroopolis, by the correfpondent Part of the Red Sea.

The Land of The Land of Go/ben then was that Part of Ramefes or of theneigigbour - the Heliopolitan Nomos, which bordered upon the Banks of the hood of He- Nile, near Heliopolis. For the Scriptures call It (Gen. 47. 6.)
liopolis. the beft of the Land: and again, v. Ir. we are informed, that Joleph gave bis Father and bis Brethren a Pofjefion in the Land of Egypt, in the beft of the Land, in the Land of Ramefes; i.e. Gofben was the beft and the moft fertil Portion of that Jurifdiction. Now this could be no other than what lay within two or three Leagues at the moft of the Nile: becaufe the reft of the Egyptian Arabia, which reacheth beyond the Influence of this River to the Eaftward, is a barren, inhofpitable Wildernefs.

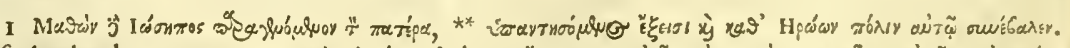

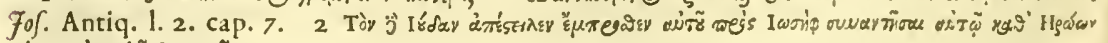

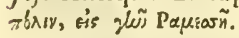

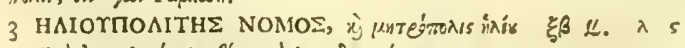

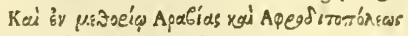

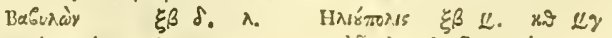

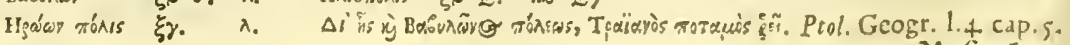


Fofeprus gives us a further Teftimony, that the Land of Tro Hebrews Go/ben had this Situation, by placing the firft Settlement of Hellopolis. the Hebrews at Heliopolis ' or $\mathrm{On}^{2}$, as the Scriptures call it. The Ruins of this City are known at prefent by the Name of $[x$, , $x$ ] Matta-reah, from a Fountain, we have there, of excellent Water ${ }^{3}$, lying about three Miles to the Eaftward of the Nile, and five to the N.E. of Kairo. But, in Proportion as the Hebrews increafed, it may be prefumed, that they fpread themfelves further towards Bifbbe/s (the antient Bubaftis) and Kairo, along the Arabian Banks of the Nile. For we are inftructed, (Ex. I. I r.) that the Ifraclites built Pithom, (the Patumus probably, which Herodotus ${ }^{+}$placeth in the Neighbourhood of Bubaftis) and, in Confequence thereof, they may be fuppofed to have inhabited, at leaft to have lived in the Neighbourhood of It. As their Departure likewife was from $L a$ topolis(or Babylon' as it was afterwards called) it may be prefumed, that This was aPortion of theLand, which they were permitted to inhabit. Go/ben then was that Part of the Heliopolitan Nomos or Their DetarLand of Rame es, which lay in theNeighbourhood of Kairo, Mat- Kairos $t a-r e a b$ and $B i / b b e / b$; as the former of thefe Cities might be $R a$ mefes, the Capital of the Diftrict of that Name, where the Ifraelites had their Rendezvous, before they departed out of Egrpt.

Now, left peradventure when the Hebrews faw war, they Two Roats to Mould repent and return to Egypt, God did not lead them throught the way of the Land of the Philiftines, (viz. by Bifhbeflo, Tineh, and, fo along the Sea Coaft, towards Gaza and Afcalon) although that was the neareft: but He led them about through the way of the Wildernefs of the Red Sea. Ex.I3.I7. There are accordingly two Roads whereby the Ifraelites might have been conducted, through the Way of ThisWildernefs, from Kairo (or Ramefes as it is fuppofed to have been,) to Pibabbiroth, upon the Banks of the Red Sea. The one is continued

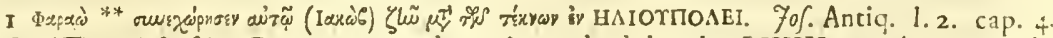

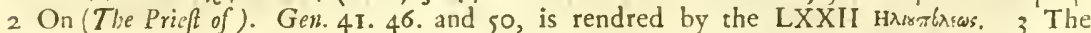
Nubian Geographer feems to call the City, from the Fountain, Ain (Semes) Shims, The Foum. tain of the Sun, placing it to the Northward of Foffat: ad plagam Foltat feptentrionalem Trobs Ain Semes diac.a. p. 98. Quod etiam Confantinus L'Empereur ad Tudelenfem p. 224. con-

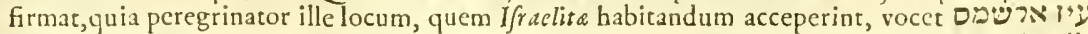
fontem Solis. Cellar. Geogr. Antiq. 1. 4. p. 35. What the Prophet Feremiah (43. 13.) calls (2) Beth/Bemefh, i. e. The Houfe of the Sun, the LXXII interpret Haristonss. 4 Hrow

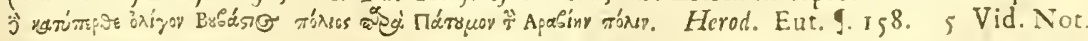
6. p. 340 .

$\operatorname{Rrr} 2$

through 
through the Valleys of Yendily, Rumeleab and Bedeah, that are bounded, on each Side, by the Mountains of the Lower Thebais; the other lyeth higher or to the Northward, having theie Mountains, for feveral Leagues, on the right Hand, and the Defert of the Egyptian Arabia on the left, 'till we turn, into the laft of the Valleys I have mentioned, through a remarkable Breach or Difcontinuation in the northermoft Range of thefe Mountains.

The Ifraclites The Latter, I prefume, was the Road which the Ifraelites ${ }_{\text {Road. }}^{\text {took }}{ }^{\text {Pper }}$ took to the Red Sea; being fomewhat longer than what leads us directly to Suez, which is a fmall City in Ruins, fituated upon the Extremity of the Red Sea, at the Diftance of thirtyHours Travel, or ninety Roman Miles, from Kairo. Fo/ephus ' then, and other Authors who Copy after him, feem to be too hafty in making the Ifraelites perform this Journey in three Days, by reckon-

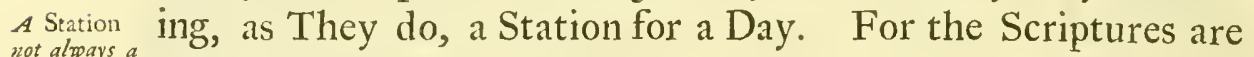

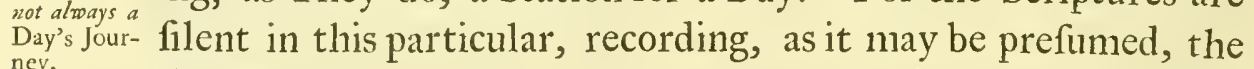
ney.

Stations only. The Fatigue likewife would be too great, for a Nation on Foot, incumbered with their Dough, their Kneading Troughs, their little Children and Cattle, to walk, at the Rate of thirty Miles a Day. Another Inftance of the fame Nature occurs, Ex.33.9. where Elim is mentioned as the next Station after Marah, though Thefe Places are further diftant from each other, than Kairo is from the Red Sea. Several intermediate Stations therefore were omitted; the Holy Penman contenting himtelf with laying down fuch only as were the moft remarkable.

Succoth. Succoth then, the firft Station ${ }^{2}$ from Ramefes, fignifying only a Place of Tents, may have no fixed or unalterable Situation; being, probably, nothing more, than fome confiderable Dou-zvar of theIfbmaelites or Arabs, fuch as we meet with, to this Day, at fifteen or twenty Miles Diftance from Kairo, in the Road to the Red Sea. The Rendezvous of the Caravan, which conducted our Company to Suez, was at one of thefe Dou-wars; at the fame Time we faw another, about fix Miles diftant, near the Mountains of Moc-catte, in the fame Direction, the Ifraelites may be fuppofed to have taken, in their Marches towards the Red Sea.

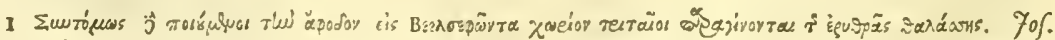
Antiq. 1. 2. cap. 5. in fine. 2 And the Children of Ifrael removed from Rameles, and pitched in Succoth. Numb. 33.5

Neither 
Neither is the Geography of Etham, the fecond Station, Etham, fifigy much better circumftantiated: though if we may fuppofe itfriom Rameto belong to the Wildernefs ' of the fame Name, which fpread Eaff. itfelf round the Heroopolitan $\mathrm{Gulph}^{2}$, and made afterwards the Saracene of the old Geography, then, the Edge of it bordered, in all Probability, upon the mountainous Diftrict of the lower Thebais. It may therefore be further prefumed, that the Ifraelites did not take the lower, but the upper Road, which lyeth, for about half the Way, intirely difengaged from Mountains: inafnuch as the Ifraelites, upon their removing from the Edge of the Wildernefs, are ordered to turn ${ }^{3}$ (from the Courfe, as we may fuppofe, of their former Marches) and to encamp before Pihahhiroth, (Ex. I4. 2.) which, as we may conjecture, muft confequently lye to the right Hand of the Wildernefs of Et tham. Whereas had they continued their Marches all along, through the Mountains of Egypt, in one and the fame Road, both thefe Geographical Circumftances will be difficult to account for. The fecond Station therefore may be fixed about fifty Miles from Kairo, at the Breach which I have mentioned: theNorthern, or nigher Range of Mountains, as I have called it, continuing afterwards, without any Interruption, to the Banks of the Red Sea, a little to the Southward of Suez.

That the Ifraelites had travelled hitherto in an open Coun-Tbe ralley be-

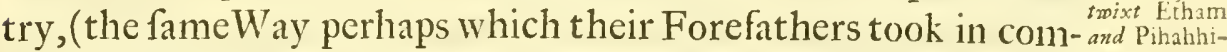
ing into Eg $y p t$, ) appears to be further illuftrated from this Circumftance, that, immediately upon their being ordered to remove from the Edge of the Wildernefs, and to encamp before Pibabbiroth; it followeth, that then Pharaohs fhould fay, they are intangled in the Land, the Wildernefs (betwixt the Mountains of Moc-catte and Suez,) have fout them in. (Ex.14. 3.) In thefe Circumftances indeed, the Egyptians might very well imagine that the Ifraelites had no Way to efcape; inafmuch as the Mountains of Moc-catte would deny them a Paffage to the Southward, as thofe in the Neighbourhood of Suez would be a Barrier, to the Northward, towards the Land of the Philiftines; the Red Sea was before them to the Eaft, whilft

I And they departed from Succoth and pitched in Etham, which is in the Edge of the Wildernets. Numb. 33. 6. Exod. 13. 20. 2 They went three Days fourney in the Wildernefs of

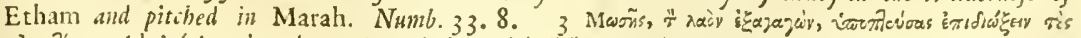

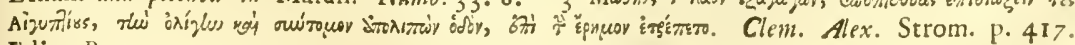
Edit. Pott. 
Pharaob clofed up the Valley behind them with his Chariots and Horfemen. This Valley ends, at the Sea, in a fmall Bay, made by the Eaftern Extremities of the Mountains I have defcribed: and is called (Tiah [sis] Beni Ifrael) The Road of the Ifraelites, (from a Tradition, kept up by the Arabs to this Day, of their having paffed through it;) and Baideah [es. perhaps] from the new and unheard of Miracle that was wrought near it, by dividing the Red Sea and deftroying therein Pharaoh, his Chariots and his Horfemen.

Pibahhiroth. The third notable Encampment then of the Ifraelites, was at this Bay. It was to be before [בהירות] Pihahhiroth, betwixt Migdol and the Sea, over againft [ביז'B] Baal-tzephon. Ex. 14. 2. and in Numb. 33. 7. it was to be before Migdol; where the Word ['s] Liphne being applyed alike to them both, may fignify no more than that they pitched within Sight of, or at a finall Diftance from either the one or the other of Baal-tze- them. Now whether Baal-tzephon may have Relation to the phon. northern ${ }^{2}$ Situation of the Place itfelf, or to fome Watch Tower or Idol Temple that was erected upon it; we may, in all Probability, take it for the eaftern Extremity of the Mountains of Suez, the moft confpicuous of thefe Deferts, which commands the View of a great Part of the Lower Thebais, as well as of the Wildernefs that reaches towards the Land of the Philiftines. Migdol. Migdol, I fuppofe, lay to the South, as Baal-tzephon did to the North of this Station. For the Marches of the Ifraelites, from the Edge of the Wildernefs, being to the Seaward, i e. towards the S.E. their Encampments betwixt Migdol and the Sea, or before Migdol, as it is otherwife noted, could not well have another Situation.

Pihahhiroth, Pibahbiroth, or Hhiroth rather, may have a more general

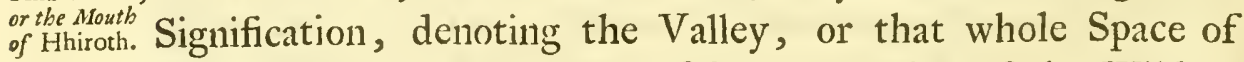
Ground, which extended itfelf from the Edge of the Wildernefs to the Red Sea. For that particular Part only of this

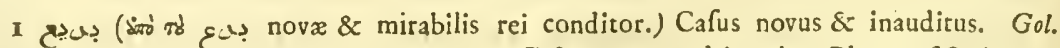
2 plas is rendred the North, Exod.26.20. 70\%. 8. I1. and in other Places of Scripture. Accordingly Baal-tzephon may be interpreted the God or Idol of the North, in Contradiftinction perhaps to others of the Lower Thebais, whofe Places of Worhip were to the S. or E. If Tzephon be related to הפ' to fpy out or obferve, then B.al-tzephon will probably fignify the God of the Watch Tower or the Guardian God, fuch as was the Hermes or Terminus of the Romans, the Eqopos Gròs of the Greeks \&c. The Wor/bipping upon Mountains is mentioned

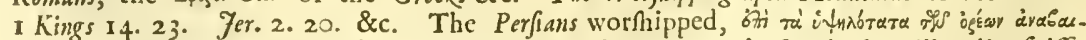
órzes. Herod. Cl. 9. 1 3 I. Hebraicc eft, Dominus Specula, quod oftendit loca illa edita fuiffe \& prerupta. Menoch. in locum. Vid. Seld. de D. Syr. Cap. 3. Synt. r.

Tract, 
Tract, where the Ifraelites were ordered to Encamp, appears to have been called Pibabbiroth, i. e. the Mouth of Hbiroth. For when Pharaoh overtook them, it was (with Refpect to

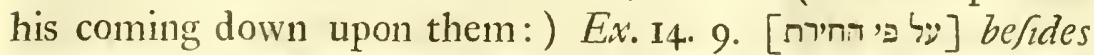
or at the Mouth, or furtheft Part of Hhiroth to the Eaftward. In the Book of Numbers likewife Ch.33.v.3. where we have the Relation of the Encampment of the Ifraelites before Migdol, v. 7. it follows v. 8. that they departed [פני החירת] from before Hbiroth, and not before Pibabhiroth, as it is rendered in our Tranflation. And in the fame Signification it is taken by the LXXII, Eufebius and St. Ferome, the former interpreting

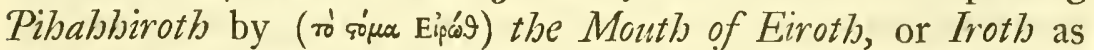
St. Ferome writes it. For 'a (as Ben Ezra criticizeth upon the Word) relateth to what lyeth before us, being called in

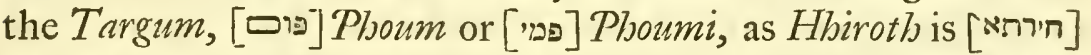
Hirata, and therefore both of them are to be confidered as diftinct Terms and Appellations.

Hhiroth therefore, if it be taken for an Appellative, may have Hhiroth detwo Significations. It hath been already obferved that this row Defile. Valley is clofely confined betwixt two rugged Chains of Mountains. If then we deduce Hbiroth from [ ח [ Hhor, or [ר] Hhour, a Hole or Gullet, (as the Samaritan and Syriac Copies underftand it) it may, by a Latitude very common in thefe Cafes, be interpreted fuch a narrow Defile or Paffage, as this is. Pibabbiroth therefore, upon this Suppofition, will be the fame as the Mouth or the moft advanced Part of this Defile. But as the Ifraelites were properly, at this Place only, delivered from their Captivity and Fear of the Egyptians, Ex. I4. I3. or the Place we may rather fuppofe, that Hhiroth denoteth the Place where of Delivirthey were reftored to their Liberty; both [חיר] Hhorar and [nim] Hhiroth being Words of the like Import in the Chaldee. In Rafbi's Commentary, we have a further Confirmation of this Interpretation. Pibabbiroth, fays he, is fo called, becaufe the Children of Ifrael were made [כנים Beni Hhorim] Freemen at that Place. In the Targum likewife [?ירזי[ Ben Hhorin is ufed to explain [eפgr] Hhaphfee, Ex. 2I. 2. and 5. a Word which denoteth Liberty and Freedom in thefe and other Parts of the Scripture. And it may be once more urged in Favour of this Explication, as well as of the Tradition that the Ifraelites paffed through this Valley, inafmuch as the eaftern Extremity 
of the Mountain, which hath been fuppofed to beBaal-tzepbon, is called (*ias Fibbel At-tackah) The Mountain of Deliverance, even to this Day.

The Ifraclites There are likewife other Circumftances to induce us to be-

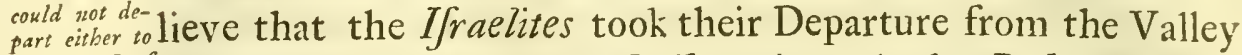
the N. or $S$. of
thiroth. they could not have done it any further to the Northward; becaufe, as this mut have been on the other Side of the Mountains of Suez, where theWildernefs, in thatDirection, is, for a great Way, plain and level, fo they could not have been there, either fout in or intangled. Neither could it have been attempted any further to the Southward; inafmuch as, upon this Suppofition, (befides the infuperable Difficulties, the Ifraelites would have met with, in climbing over Precipices, and the Egrptians, in purfuing them) the Defert of Arabia that lyeth over againft this Part of Egypt, would not have been Shur, where the Ifraelites are faid to have landed, Ex.15.22. but Marah, which lay beyond it to the South. Corondel, I prefume, made the SouthernPortion of the Defert of Marah; from whence to the Port of Tor, the Shore, which hitherto was low and fandy, begins now to be rocky and mountainous, whilft that of Egypt is ftill more impracticable, and neither of them afford any convenient Place, either for the Departure or the Landing of a Multitude. Moreover, from Corondel ${ }^{x}$ to Tor, the Channel is ten or twelve Leagues broad, too great a Space certainly for the Ifraelites, in the Manner at leaft they were encumbred, to traverfe in one Night. And, at Tor, the Arabian Shore begins to wind itfelf, (round what we may fuppofe to be Ptolemy's Promontory of Paran) towards the Gulph of Eloth; at the fame Time the Egyptian retires fo far to the S. W. that it can fcarce be perceived. The Ifraelites therefore could neither have landed at Corondel or Tor, according to the Conjectures of feveral Authors.

The Defort of Over againft Fibbel At-tackah, at ten Miles Diftance, is the Sdur orShur. Defert, as it is called, of Sdur, the fame with Shur, Ex.15.22. where the Ifraelites landed, after they had paffed through the interjacent Gulph of the Red Sea. The Situation of this Gulph,

I Ebn Said (Cod. MS. Seld.) makes the Sea at Corondel to be feventy Miles over, whereas it is little more than fo many Furlongs. "Amplitudo maris Alkolzum ad locum dictum Berkat el Corondel eft circiter feptuaginta Milliariorum". Vid. Vol. I1r. Geogr. l'ct. Min.

which 
which is the [Fam Suph פס ס'] The Weedy Sea, in the Scriptures, the Gulph of Heroopolis in the Greek and Latin Geography, and the weftern Arm, as the Arabian Geographers call it, of the Sea of Kolzum ', lyeth nearly North and South; in a Pofition very proper to be traverfed by that frong Eaft Wind which was fent to divide it. Ex.14.21. The Divifion that was thus made in the Channel, the making the Waters of it to ftand on a Heap (Pf.78. 13.) their being a Wall to the Ifraelites on the right Hand and on the left, (Ex. 14.22.) befides the Diftance of at leaft twenty Miles, that this Paffage lyeth below the Extremity of the Gulph, are Circumftances which fufficiently vouch for the Miraculoufnefs of it, and no lefs contradict all fuch idle Suppofitions as pretend to account for it, from the Nature and Quality of Tides, or from any fuch extraordinary Recefs of the Sea, as it feems to have been too rafhly compared to by Folephus.

In travelling from Sdur towards Mount Sinai, we come into the Defert, as it is ftill called, of Marah, where the Ifraelites Corondel. $_{\text {Marat of }}$ met with thofe bitter Waters, or Waters of Marah, (Ex.15.23.) And as this Circumftance did not happen, 'till after they had wandred three Days in the Wilderne Ss, we may probably fix it at Corondel, where there is a fmall Rill of Water, which, unlefs it be diluted by the Dews and Rains, ftill continues to be brackifh. Near this Place, the Sea forms itfelf into a large Bay, called Berk el Corondel', which is remarkable for a ftrong Current, that fets into it, from the Northward. The Arabs preferve a Tradition, that a numerous Hoft was formerly drowned at this Place, occafioned, no doubt, by what we are informed of Ex. 14. 30. that the Ifraelites faw the Egyptians dead upon the Sea Shore.

I Sues vulgo non habct Abulfeda, fed ejus loco Alkolzum : videntur tamen duo loca difincta : nam nolter Kalkaghandi mox poft Sues ponit Alkolzum ad meridiem ejufdem Sues in litore Egyptiaco: at vero Mekrifi expreffe ait Alkolzum effe dirutum \& loco ejus hodie Sues effe. V.C. Joh. Gagn. Not. in Abulf. Geogr. Ad oram extimam brachij orientalis maris Alkolzum fita cft Ailah \& ad oram extimam brachij occidentalis fuitUrbs Alkolzum; utriufque Latitudines ferme exdcm funt. Vid. Abulf. Defcript. maris Alkolzum. ${ }^{* *}$ Haud procul ab Alkolzum cft locus in mari ubi demerfus fuit Faraone. Id. Alkolzum, or Kolzum without the Article, fecms to have fome Affinity with Cly $\int m a$, another Name that this Gulph was former-

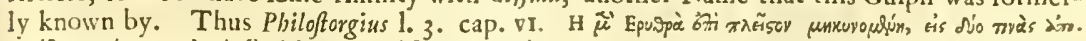

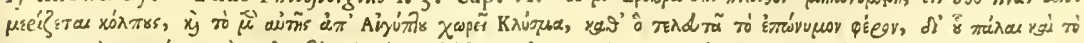

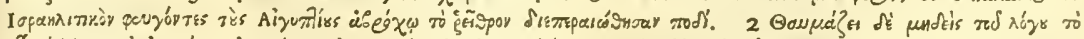

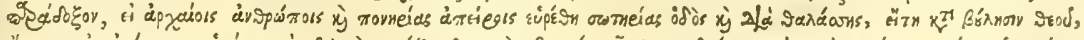

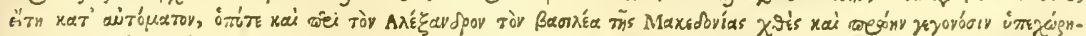

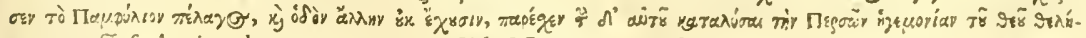

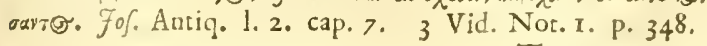


There is nothing further remarkable, 'till we fee the Ifraelites encamped at Elim. Ex.15. 27. Numb.33. 9. upon the northern Skirts of the Defert of Sin, two Leagues from Tor, and near thirty from Corondel. I faw no more than nine of the twelve Wells that are mentioned by MoJes, the other three being filled up by thofe Drifts of Sand, which are common in Arabia. Yet this Lofs is amply made up by the great Increafe of the Palm Trees, the Jeventy having propagated themfelves into more than two thoufand. Under the Shade of thefe Trees is The (Hammam Moufa) Bath of Moles, which the Inhabitants of Tor have in extraordinary Efteem and Veneration; acquainting us, that it was here, that Mojes himfelf and his particular Houfhold, were encamped.

The Defert of We have a diftinct View of Mount Sinai from Elim; the Sin. Wildernefs, as it is ftill called, of Sin, lying betwixt us. We traverfed thefe Plains in nine Hours, being diverted, all the Way, with the Sight of a Variety of Lizards and Vipers, that are here in great Numbers. I had not the good Fortune to fee the famous Infcription, that is faid to be engraven upon the Rocks, juft as we turn into the Valley that conducts us to Mount Sinai. Sin was the firft Place where God gave the Ifraelites Manna, Ex. I6. I4. and therefore fome Authors have imagined, that thefe Characters were left, as a ftanding Monument of that Bleffing, to future Generations.

The Plain of We were near twelve Hours in paffing the many Windings Sinai. and difficult Ways, which lye betwixt the Deferts of Sin and Sinai. The latter is a beautiful Plain, more than a League in Breadth, and nearly three in Length, lying open towards the N.E. where we enter it, but is clofed up to the Southward by fome of the lower Eminences of Mount Sinai. In this Direction likewife the higher Parts of it make fuch Encroachments upon the Plain, that they divide it into two, each of them capacious enough to receive the whole Encampment of the Ifraelites. That which lyeth to the Eaftward of the Mount, may be the Defert of Sinai, properly fo called, where Mojes faw the Angel of the Lord in the burning Bu/h, when he was guarding the The Convent Flocks of Fethro. Ex. 3.2. The Convent of St. Catharine is
of St. Catha- built over the Place of this Divine Appearance. It is near three
rine. rine. hundred Foot Square, and more than forty in Height, being partly built with Stone, partly with Mud only and Mortar mixed 


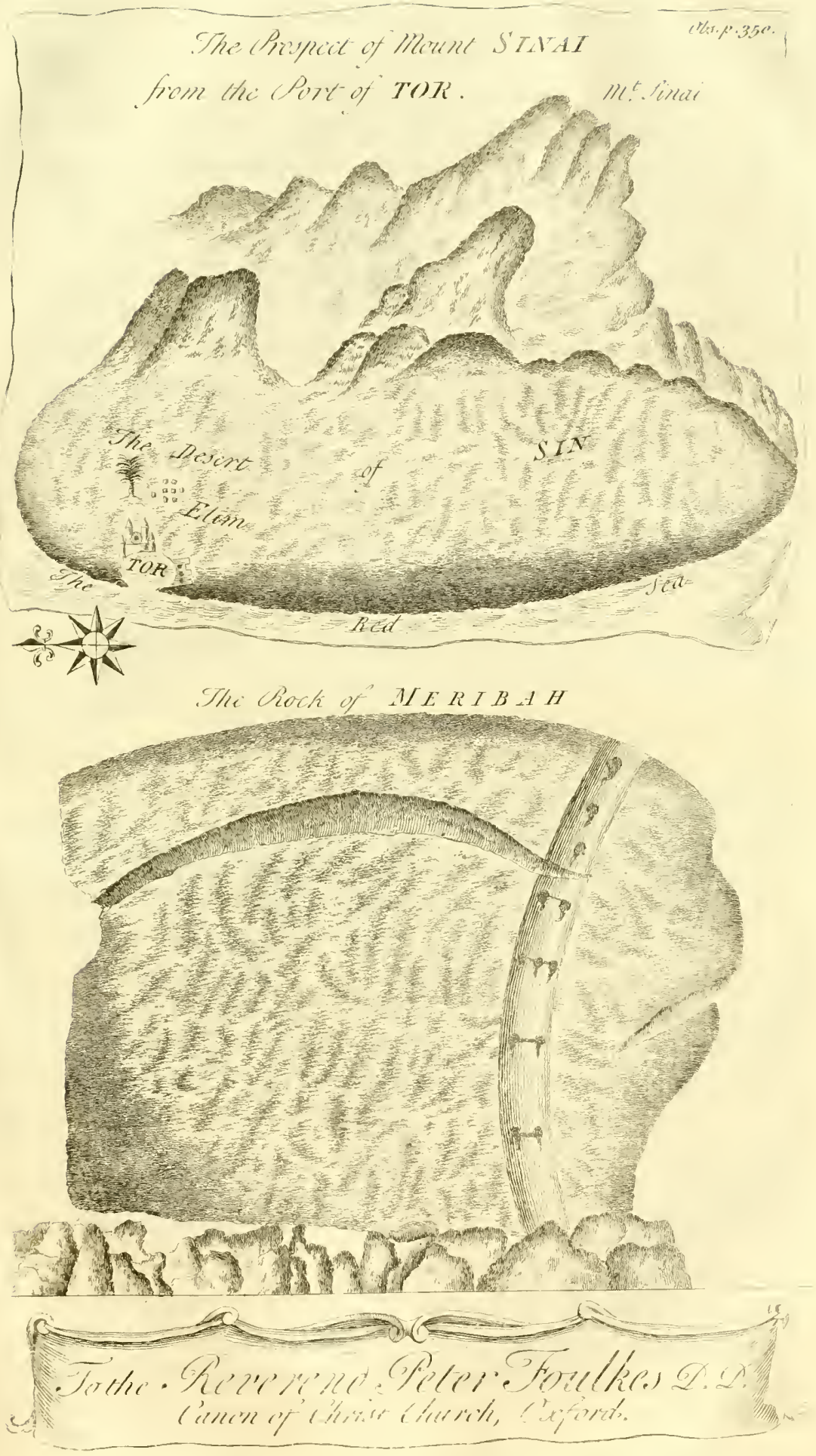



together. The more immediate Place of the Shekinats is ho- The church of noured with a little Chappel, which this old Fraternity of St. gurationst$B a f i l$ hath in fuch Efteem and Veneration, that, in Imitation of Mofes, they put off their Shoes from off their Feet, when they enter or approach it. This, with feveral other Chappels, dedicated to particular Saints, are included within the Church, as they call it, of the Transfguration, which is a large beautiful Structure, covered with Lead, and fupported by two Rows of Marble Columns. The Floor is very elegantly laid out in a Variety of Devices in Mofaic Work: of the fame Workmanfhip likewife are both the Floor and the Walls of the Presbyterium, upon the latter whereof is reprefented the Figure of the Emperor Fufinian, together with the Hiftory of the Transfguration. Upon the Partition, which feparateth the Presbyterizm from the Body of the Church, there is placed a fimall Marble Shrine, wherein are preferved the Skull and one of the Hands of St. Catbarine.

The Pilgrims are not admitted into this Convent by the Pilgrims not Door, (which is never open, unlefs when the Arch-Bifhop, advinitted boor. who ufually refideth at Kairo, is to be inftalled) but we are drawn up, by a Windlafs, near thirty Foot high, and then taken in, at a Window, by fome of the Lay Brothers, who attend there for that Purpofe. Thefe, and the Papaffes or Presbyters, who are commonly called Kalories ', make in all, about a hundred and fifty in Number, fubfifting chiefly upon fuch Provifions as are fent them monthly from Kairo. They live a very ftrict and The Aufferity auftere Life, abitaining not only from Flefh, but alfo from ${ }^{\text {of this } \text { Order. }}$ Butter, Milk, and Eggs; nothing of which we were permitted to bring into theConvent, though we could have purchafed them of the Arabs. The leaft Mortification they undergo, is upon thofe Their Dice. Days, (which indeed are not many,) when they receive, from theirSifter Convent at Tor, or from Meenah el D $\int a h a b$, aQuantity of Shell Finh, Crabs or Lobfters, all other Finh being prohibited by their Inftitution. For Bread is the main Article of their Suftenance, to which is added fuch a Portion, as is meafured out to each Perfon, either of Olives, Oyl and Vinegar, Sallad and Potherbs; or elfe of Dates, Figs, Almonds, parched Pulfe and fuch like Food as was the (anposiria ${ }^{2}$ ) Dry Diet of the Primitive Chriftians.

I Kàrgíess. i. c. a good oldMan. Vid. Tournef.Voy. vol.x. p.rzr. z Vid. Teriul. de Jejunio. 
Moont Sinai. Mount Sinai hangs over thisConvent, being called by the Arabs, (Fibbel Moufa) The Mountain of Mofes, and fometimes only, by Way of Eminence, (El Tor) The Mountain. St. Helena was at the Expence of the Stone-Stair-Cafe, that was formerly carried up entirely to the Top of it; but, at prefent, as moft of thefe Steps are either removed, wathed out of their Places, or defaced, the Afcent up to it is very fatiguing, and freouently impofed upon their Votaries as a fevere Penance. However, at certain Diftances, the Fathers have erected, as fo many breathing Places, feveral little Chappels, dedicated to one or other of their Saints, who are always invoked upon thefe Occafions, and, after fome fmall Oblation, are engaged to lend their Affiftance.

The Summit of Mount Sinai is fomewhat conical, and not

The remarka ble places up- very fpacious, where the Mahometans as well as Chriftians
on it. on it. have a fmall Chappel for Publick Worfhip. Here we were thewn the Place where Moles fafted forty Days, Ex. 24.18. and 34. 28. where be received the Law, Ex.31. 18. where be bid bimfelf from the Face of God, Ex. 33. 22. where his Hand was fupported by Aaron and Hur, at the Battle with Amalek, Ex. 17. 9. I 2. befides many other Stations and Places that are taken Notice of in the Scriptures.

The Valley of After we had defcended, with no fmall Difficulty, down the Rephidim. Weftern Side of this Mountain, we come into the other Plain that is formed by It, which is Rephidim. Ex. 17. I. Here we The Rock of ftill fee that extraordinary Antiquity, the Rock of Meribah, Meribah. Ex.17. 6. which hath continued down to this Day, without the leaft Injury from Time or Accidents. It is a Block of Granate Marble, about fix Yards fquare, lying tottering as it were and loofe in the Middle of the Valley, and feems to have formerly belonged to Mount Sinai, which hangs, in a Variety of Precipices, all over this Plain. The Waters which gufbed out, and the Stream which flowed withal, Pfal. 7. 8. 2I. have hollowed acrofs one Corner of this Rock, a Channel about two Inches deep, and twenty wide, appearing to be incruftated all over, like the Infide of a Tea-Kettle, that hath been long in Ufe. Befides feveral Moffy Productions, that are ftill preferved by the Dew, we fee all over this Channel, a great Number of Holes, fome of them four or five Inches deep and one or two in Diameter, the lively and denonftrative Tokens of their having been 
been formerly fo many Fountains. It likewife may be further obferved, that Art or Chance could by no means be concerned in the Contrivance. For every Circumftance points out to us a Miracle, and, in the fame Manner with the Rent in the Rock of Mount Calvary at Ferufalem, never fails to produce a religious Surprize in all who fee it.

The Monks thew us feveral other remarkable Places round the remarkaabout this Mountain; as where Aaron's Calf was molten, Ex. round aboyt 32. 4. (but the Head only is reprefented and that very rudely) tain. where the Ifraelites danced at the Confecration of it, Ex.32.19. where Corab and his Company were fivallowed up, Num.16.32. where Elias hid himfelf when he fled from fezebel, 2 Kings 8. 9. But the Hiftory of thefe and other Places is attended with fo many Monkifb Tales, that it would be too tedious to recite them.

From Mount Sinai, the Ifraelites directed their Marches, The Defert of Northward, towards the Land of Canaan. The next remarkable Stations therefore were in the Defert of Paran, which feems not to have commenced, 'till after they departed from Hazeroth, three Stations from Sinai, Numb. 12. I6. Now as Tradition hath preferved to us the Names of Shur, Marah, and Sin, fo we have alfo That of Paran, which we enter at about the half way betwixt Sinai and Corondel, in travelling, The City of through the Midland Road, along the Defle's of What were probably the Black Mountains of Ptolemy. In one Part of It, ten Leagues to the Northward of Tor, there are feveral Ruins, particularly of a Greek Convent, (called the Convent of Paran) which was not long ago abandoned, by Reafon of the continual Infults which they fuffered from the Arabs. Here likewife we fhould look for theCity of that Name, though, according to theCircumftances of it's Situation, as they are laid down by Ptolemy ${ }^{2}$, Tor, a fmall maritime Village, with a Caftle hard by it, fhould rather be the Place.

From the Wildernefs of Paran, Mofes fent a Man out of Kadeft Barevery Tribe, to BPy out the Land of Canaan, Numb. 23.3. who returned to bim, after forty Days, unto the Jame Wilderne/s,

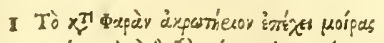

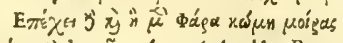

$\xi$ in 5

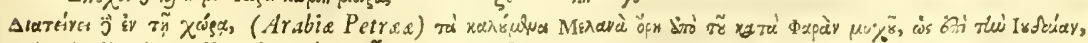

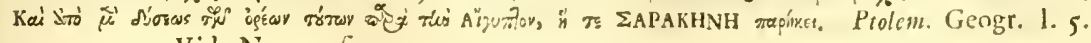
cap. 17. 2. Vid. Nor. ut Supra.

\section{$\mathrm{U} u \mathrm{u} u$}


to Kadefs Barnea, Numb. 33 8. Deut. 1. 19. and 7.23. Fo/t. 14. 7. ThisPlace, which in Numb.20. I. 27.14. and 33.36. is called Tzin Kade $/ h$, or fimply Kade $h$, was eleven Days Fourney from Mount Horeb, Deut. 1. 3. and, being afcribed both to the Defert of Tzin and Paran, we may prefume that it lay near or upon the Confines of them Both.

Petra. $\quad$ Petra, the Metropolis of Arabia, lying cxxxv Miles to the Eaftward of Gaza', and four Days Journey from Fericho to the Southward, may probably be fixed, near the Confines of the Country of the Midianites and Moabites, at fifty Miles Diftance to the Eaftward of Kade/l. According to Fo/ephus, it was formerly called Arce ${ }^{3}$, which Bochart fuppofeth to be a Corruption of Rekem ${ }^{4}$, the true and antient Name. The Amalekites', who are frequently mentioned in Scripture, were once feated in the Neighbourhood of this Place, being fucceeded, in Procefs of Time, by the Nabathreans, a People no lefs famous in profane Hiftory.

The compaf-

But to purfue, as far as we are able, the Journeys of the Fing of Monnt Ifraelites: from Kadefh, they were ordered to turn into the Wir. Wilderne s, by the Way of the Red Sea, Numb. 14.25. Deut. I. 40. i e. They were at this Time, in Punifhment of their Murmurings, Infidelity, and Difobedience, to advance no further towards the Land of Canaan. Now thefe Marches are called the compaffing of Mount Seir, Deut. 2. 1. and the paffing by from the Children of Elau, which divelt in Seir, through Aan betmen the Way of the Plain of Eloth, and Ezion-gaber. (v. 8.) The Eloth and Wandering therefore of the Children of Ifrael for thirty eight Heroopolis. Years, (Deut. 2. I4.) was confined, in all Probability, to that Neck of Land only, which lyeth bounded by the Gulphs of Eloth and Heroopolis. For Mount Seir, here fpoken of, (which

I Nabatbaorum oppidum Petra abeft a Gaza, oppido litoris noftri DC. M a finu Perfico cxxxv. M. Plin. 1.6. cap. 28. Inverte nomina: a Gaza cxxxv \&c. Sic numeri melius conftabunt \& ceteris, tam geographis qtum hiftoricis, conciliari poterunt. Cellar. Geogr. Antiq.

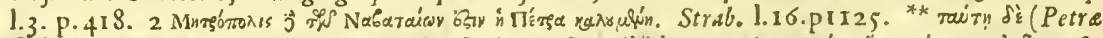

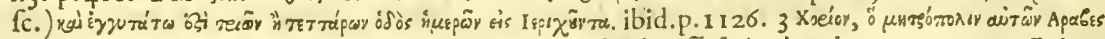

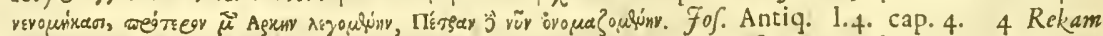
vel Rakim eft Pctra Urbs, aliis Rocom, Recem, Receme, \& præfixo Articulo Areceme, \& per apocopen Arce, Petræx fcilicet Metropolis 7 Hagar i. e. Petra a fitu dicta, quia in ea domus excife funt in Perra. Et Rekem a conditore rege Madian de quo Num. 31. 8. Hinc

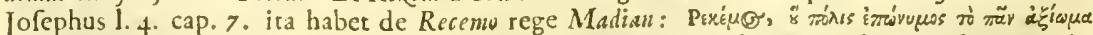

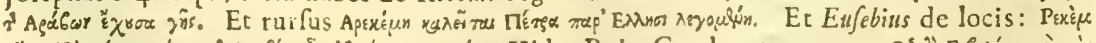

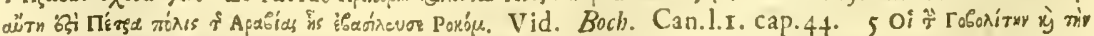

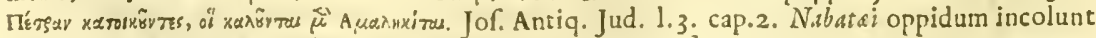
Petram nomine \&c. Plin. 1.6 can. 28 . Vid. Not. 2, ut lupra. 
was perhaps the firft and the proper Poffeffion of the Children of Efau, before they extended their Conquefts further towards Petra, ) could not lye to the Northward of Kadefh, becaufe then, their Journies would not have been towards the Red Sea, but the Land of Canaan, which was exprefsly forbidden. This Situation of it likewife is further confirmed, by what we read (Gen. I4.) of Chedorlaomer and the Kings that were with bim, how they fmote the Horites in their Mount Seir unto Elparan, and how they returned from thence to Kadefo. Mount Seir then, as well as Elparan, mult lye to the S. or S. W. of Kadefts. If then we could adjuft the true Pofition of Eloth, we fhould gain one confiderable Point towards the better laying down of this mountainous Tract, where the Ifraelites wandred fo many Years.

Now there is an univerfal Confent among Geographers, that Eloth and [n'y] Eloth, the fame with Elana, Ailat, or Aelana, as it nearly motle is differently wrote by them, was fituated upon the Northern ${ }^{\text {tumee }}$ Extremity of the Gulph of the fame Name . Ptolemy ${ }^{2}$ indeed placeth it $45^{\prime}$. to the Southward of Heroopolis, and near $3^{\circ}$. to the Eaftward: whereas Abulfeda, whofe Authority, I prefume, may be greatly regarded in this Particular, maketh the Extremities of the two Gulphs to lye nearly in the fame Parallel, though he is altogether filent as to the Diftance between them. I have been often informed by the Mabometan Pilgrims, who, in their Way to Mecca, pafs by them both, that their Marches are all the Way in an Eaftern Direction from Kairo, 'till they arrive at (Callab Accaba) The Garrifon, fituated, below the Mountains of Accaba, upon the utmoft Point of the Red Sea. Here they begin to travel directly towards Mecca, which ther had hitherto kept upon their right Hands, having made in all, from Adjeroute, ten Miles to the N.N.W. of Suez, to this Garrifon, a Journey of feventy Hours. But as this whole Tract is very Mountainous, the Road muft confequently be attended with a great Variety of Windings and Turnings, which would hinder them from making any greater Progrefs than at the Rate of about half a Leaguie an Hour. Eloth then, (perhaps the ${ }_{\text {of Eloth. }}^{\text {The Sitio }}$

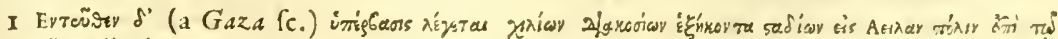

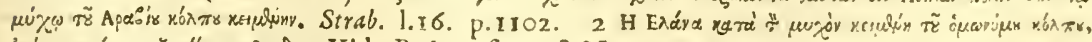

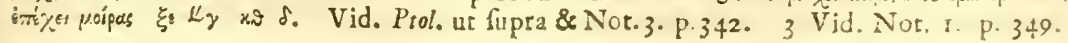

U i u

very 
very Place of the Turkifb Garrifon, as it was a Prrefidium ${ }^{2}$ of the Romans in former Time) will lye, according to this Calculation, about forty fix Leagues from Adjeroute, in an E. by S. Direction. This Pofition of Eloth will likewife receive further Confirmation, from the Diftance that is afligned it from Gaza, in the old Geography. For, as this was a hundred and fifty Roman Miles according to Pliny ${ }^{2}$, or a hundred and fifty feven according to other Authors ${ }^{3}$, Eloth could not have a more Southern Situation than where I have placed it, as the bringing it more to the Northward, would fo far invalidate a juft Obfervation of Strabo's, who maketh Hercopolis and Pelu/um to be much nearer each other, than Eloth and Gaza.

Ezion-

Gaber.

It would be too daring an Attempt to pretend to trace out all the particular Encampments that are mentioned, Numb.33. the greateft Part whereof were confined to this finall Tract of Arabia Petrea, which I have juft now defcribed. However, thus much may be added, that, after the Ifraelites left Mount Sinai, the moft Southern of their Stations feems to have been at Ezion-gaber; which being the Place from whence Solomon's Navy went for Gold to Ophir, (I Kings 9.26. 2Chron.8. I7.) we may be induced to take it for the fame with What is called at prefent, (Meenab elD /abab) The Port of Gold. According to the Account I had of it, from the Monks of Sinai, it lyeth in the Gulph of Eloth, at the Diftance of two Days Journey from them, enjoying a fpacious Harbour, which fupplyeth them fometimes with Plenty of Lobfters and Shell Fifh. Mount Hor, From Ezion-gaber the Ifraelites turned back again to Kade/h,
or Accaba.

(Numb.33. 36.) with an Intent to direct their Marches that Way, into the Land of Canaan. But upon Edom's refufing to give Ifrael Paffage through his Border, (Numb. 20. 18. \&c.) they turned awvay from him, to the right Hand, towards Mount Hor, (Numb. 20. 2I.) which, as I conjecture, lay to the E.S.E. of Kadefl, in the Way from thence to the Red

I Scdet ibi (apud Ailat) Legio Romana cognomento Decima : \& olim quidem Ailat a veteribus diccbatur; nunc vero adpellatur Aila. Hieronym. in locis Hebraicis. In litore maris inter Abila (pro Ailat ut fupra) pofita eft, ubi nunc moratur Legio \& Prxfidium Romanorum. Id. in Cap. 47. Ezech. 2 Heroopoliticus vocatur, alterque AElaniticus finus Rubri maris in Egyptum vergentis CL millia paffum intervallo inter duo oppida Fland \& in noftro mari Gazam. Plin. 1. 5. cap. 11. 3 Vid. Nor. 1. P. 355 . Et Marcian. Heracl. in Petiplo.

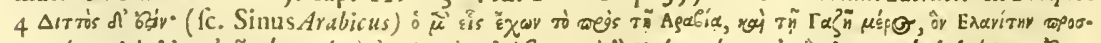

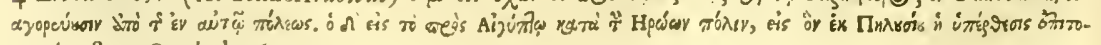

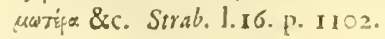

Sea, 
Sea, (Numb. 21. 4.) Now as the Children of Ifrael are faid Mownt Hor to have been here difcouraged becaufe of the Way, it is very Accabar. probable, that Mount Hor was the fame Chain of Mountains that are now called Accaba by the Arabs, where, from the Badnefs of the Road and the many rugged Paffes that are to be furmounted, the Mabometan Pilgrims are greatly fatigued and conftantly lofe a Number of Camels.

From Mount Hor, the Direction of their Marches, through Tbo DireftiZalmona, Punon, \&c. feems to have been betwixt the N. and Marches

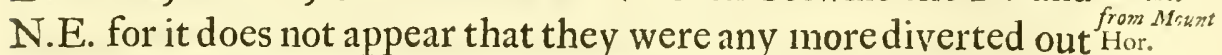
of the direct Road, which was to conduct them, through theCountry of Moab, (Numb. 33.48, 49.) into the Land of Promife.

In the Rabbinical Geography', feveral of the Places, which tós Rabbinihave been taken Notice of in This and the foregoing Chapter, $\begin{gathered}\text { cal } \\ \text { the H. Hap } \mathrm{Hand}\end{gathered}$ are laid down in the following Manner.

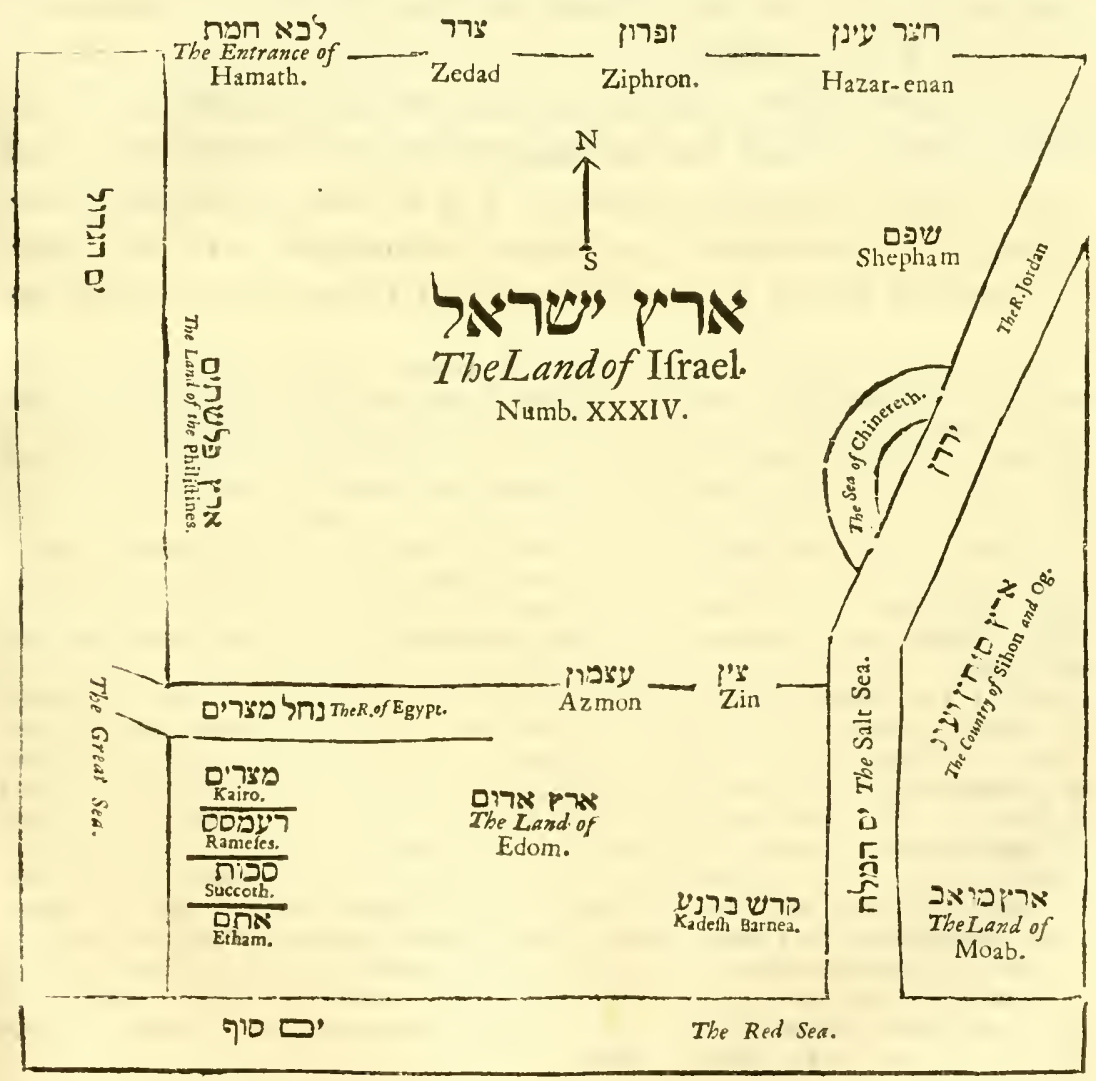

3 Vid. Rabbi Flia Mizracbi Comment, in Pentateucbum Ven. 1545. F. פר.

$\mathrm{X} \times \mathrm{xx}$

Pby/acal 


\section{H A P. III.}

Pbyfical Obfervations \&c. or an Effay towards the Natural Hiftory of Syria, Phœnice, and the Holy Land.

The Air and Weatber the fame as in Barbary.

T $\mathrm{HE}$ Air and Weather, in thefe Countries, differ very little from the Defcriptions that have been given of them in the Natural Hiftory of Barbary. For, among many other Particulars, of the like Nature and Quality, which need not be repeated, we find the wefterly Winds to be here attended with Rain'; whilft thofe from the Eaft, are ufually dry, notwithftanding they are fometimes exceedingly hazy, and

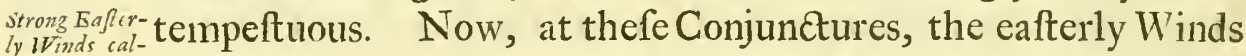
Ied Levan-
ters confined to any one fingle Point, but blowing, in all Directions, from the N.E. to the S.E.

The Eurocly-
don mas $r$ roo bably oue of Paul, (Acts 27. 14.) was nothing more, as I conjecture, than tbon. fcribeth it) ärewos ropourxios", a violent, or tempeftuous Wind, bearing away all before it; and, from the Circunftances which at-

I Vid. p. 217, 218. \&c. 2 This Branch of the Natural Hiftory is occufionally taken Notice of in the Scriptures. When ye fee a Cloud rife out of the $W_{e}$ ef, ftraightway ye fay, there cometb a Shower and fo it is. Luke 12. 54. Elijah went up to the Top of Carmel, *x and faid to his Servant, go up now, look tow ords the Sea, (i. c. to the Weftward.) ** And be fail, behold there arifeth a little Cloud out of the Sea, like a Mans Hand. And he faid, Go up, fay unto Ahab, prepare thy Chariot and get thee down that the Rain fop thee not. And it came to pits in the mean while, that the Heaven was black with Clowds, and there was a great Rain. 3 Eugoxaidow, accord. ing to the Annotations of Erafwus, I'atablus and others, is faid to be, loox binc ducta, quod ingentes excitet fuctus; as if rhofe Commentators underftood it to have been, as Phavorinus writes it (in voie Tupày) Euguriudar, and, as fuch, compounded of zugìs, (latus, amplus \&c.) and xaudow, fluctus. But rather, if an Etymology is requircd, as we find xividuy ufed by the LXXII, (Fon. I. 4. 12.) inftead of 7עס, which always denotes a Tempct, as I conjecture, proper-

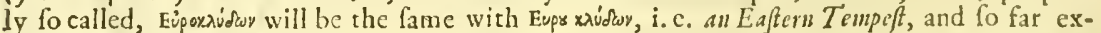
prefs the very Meaning that is affixed to a Levinter at this Time. 4 Tliongh Tusovy or Tuques may fometimes denote a Whirlwind, yet it feems in general to be taken for any violent Wind or Tempeft. According to an Obfervation of Grotius upon the Placc, Fudris Helleniffis Tupiss

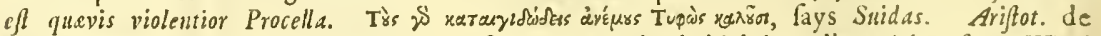
Mundo. cap. 4. fcems to diftinguin it from the חensrie, (which he calls a violent frong Wind)

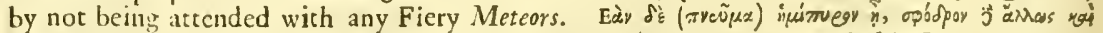

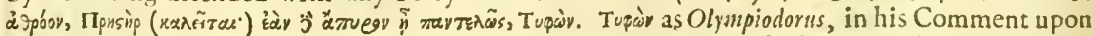

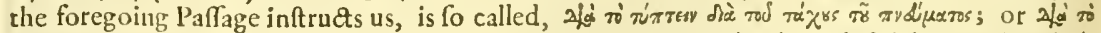

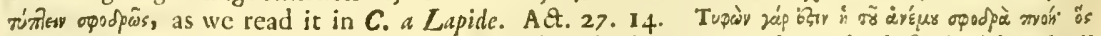
xy supunuíduy rancizas. Phavor. in Lex. One of thefe Levanters is elegantly deferibed by Virgil (Gcor. 2. 1. 107.) in the following Lines.

Ubi navigijs violentior incidit Eurus,

Nofte, quot Jonii veniant ad litora fuctus. 



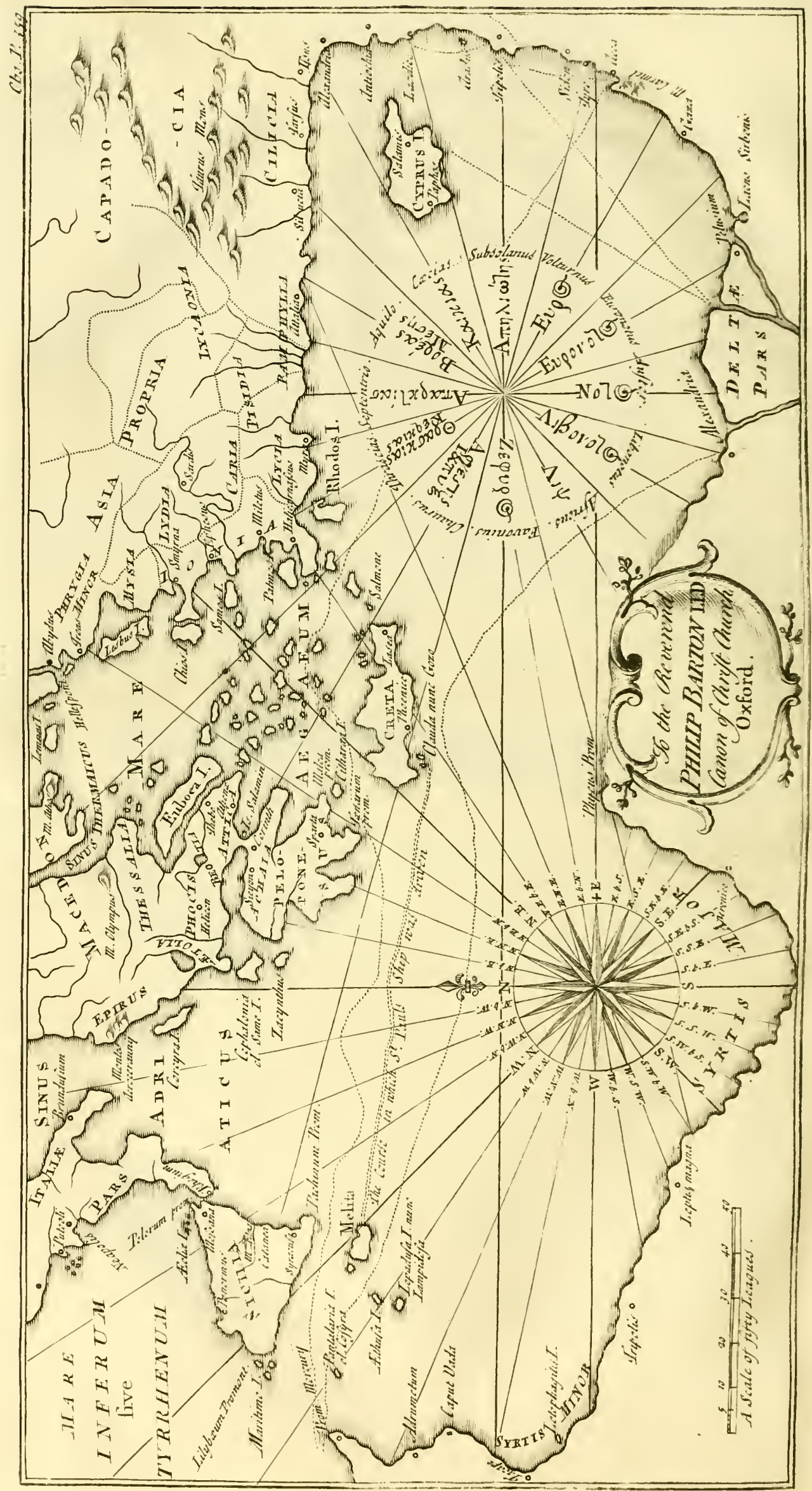


tended it, appears to have varied very little, throughout the whole Period of it, from the true Eaft Point. For after the

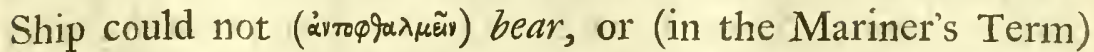
loof up againft it, (v.1 s.) but they were obliged to let her drive, we cannot conceive, as there are no remarkable Currents in this Part of the Sea and as the Rudder would be of little Service, that it could follow any other Courfe, than as the Winds directed it. Accordingly, in the Defcription of the It variedvery Storm, we find the Veffel firft under the Inland Clauda, (v. 16.) Eaft Point. a little to the Southward; then it was toffed along the Bottom of the Gulph of Adria, (v. 27.) and afterwards broken to Pieces (v.41.) at Melita, a little to the Northward of the Parallel of that Part of the Coaft of Crete, from whence it may be fuppofed to have been driven. The Direction therefore of this particular Euroclydon, feems to have been firft at E. by N. and afterwards about eight Degrees to the Southward of the Eaft.

But Grotius ', Cluver ${ }^{2}$ and others, authorized herein by Euroclydon the Alexandrian MS and the Vulgate Latin, are of Opinion fuppofed to be that the true Reading fhould be Euposwinaw, Euroaquilo, a Word the fame with indeed as little known as Euroclydon, though perhaps lefs entitled to be received. Now, we are to fuppofe this Euroaquilo, agreable to the Words of which it is compounded, to be the Name of a Wind, lying betwixt the Eurus, (the true Eaft Point) and the Aquilo, and to have been fubftituted in the Place of the Kayisis (Crecias) of the Greeks, which, according to Seneca ${ }^{3}$, had no Name among the Romans. But, allowing this Obfervation to be true, nothing more, I prefume, can be intended by it, than that the Crecias had no Latin Name affigned to it by the Romans, as, among the reft, Subfolanus was their Name for the Ammiciores, and Africus for the sít. For, from the ${ }_{\text {known to the }}^{\text {The }}$ Notice that is taken of the Cecias by the Roman Authors, it appears Romans. to have been a Term fo familiar to them, that it feems, in Fact, to have been adopted into their own Language. Thus we find Vitruvius ${ }^{4}$, long before Seneca, defcribing the Pofition of the

I Vid. Grot. Annot. in Att. 27. 14. 2 Ego amplectendam heic omnino cenfeo vocem guam divus. Fieronymus \& ante hunc auctor Vulgatæ Sacrorum Bibliorum Verfionis, in fuis exemplaribus legerunt Eugeaxínav, Euroaquilo, quod vocabulum ex duabus vocibus, altera

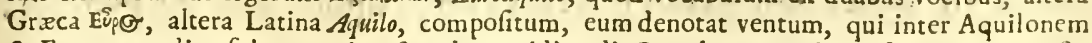
\& Eurum medius fpirat, qui recta ab meridionali Creta latere navim infra Guudum verfus Syrtin abripere poterat. Cluv. Sicil. Antiq. 1.2. p. 442. 3 Aboriente folftitiali excitatum, Graci Kouniay appellant : apud nos fine nomine eft. Senec. Nat. Quxet. 1. 5. cap.16. 4 Euri vero medias partes tenent; in extremis, Cacias \& Vulturnus. Vitr. Arch. 1.1. cap.6.

Cecias, 
Crecias, without diftinguifhing it, as Seneca doth, by Greek Characters, or making any Apology for the Introduction of a foreign Name. Pliny ${ }^{2}$ likewife, who was nearly contemporary with Seneca, doth the fame ${ }^{2}$, calling it alfo Helle/pontias ${ }^{3}$, as blowing probably from that Quarter. The Crecias therefore muft have been known very early in the Roman Navigation; and confequently, even provided the Mariners had been Romans, there could be no Neceffity, at this Time, and upon fuch an Occafion, for the Introduction of a new Term.

The Ship na-

But as we learn, (ACts 27. 6.) that the Ship was of Alexanvigated by
Gracians.

dria, failing to Italy, we may fuppofe the Mariners to have been Grecians, and, as fuch, too well acquainted with the received and vernacular Terms of their Occupation, to admit of this Greco-Latin, or barbarous Appellation, as they might think

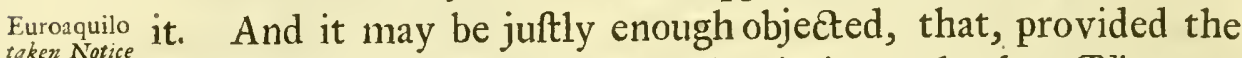

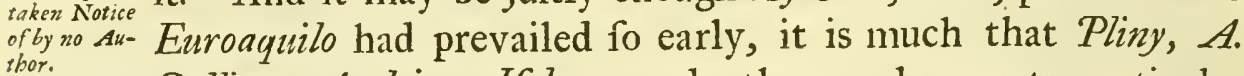

Gellius, Apuleius, Ifidore, and others, who wrote particular Differtations upon the Names and Diverfities of Winds ${ }^{4}$, hould not have taken the leaft Notice of it. Whereas Euroclydon being perhaps no other, than fome peculiar Word among the Mariners, denoting one of the ftrong Levanters which I have been defcribing, we are to be the lefs furprized, why St. Luke, (who was actually prefent in the Storm and may be fuppofed to have heard the very Expreffion) is the only Author who records it. Befides, when we are told, that this tempeftuous Wind was called Euroclydon, the Expreffion feems to fuppofe it, not to have been one of the common Winds, fuch as were denominated from their Site and Pofition, but fome extraordinary one, with Regard chiefly to the Quality and Circumftances of it.

The Euroaquilo would bave drove them into the Sidra.

It likewife may be ftill further infifted upon, in Vindication of the received Reading, that provided the Pofition of this Euroaquilo, even at the Beginning of the Tempeft, (how much foever it might have varied afterwards to the Eaftward) had been at E. N.E. or N. E. by E. (and the Euroaquilo, as falling in, by Suppofition, betwixt the Eurus and the Aquilo, could have no other Direction) yet even, upon this Hypothefis,

I Vid. Plin. Nat. Hitt. 1.2. cap.47. 2 Cacias media inter Aquilonem \& Exortum Æquinoctialem, ab Ortu Solftitiali. Plin. ut fupra. 3 Cacian aliqui vocant Hellefpontian. Plin.

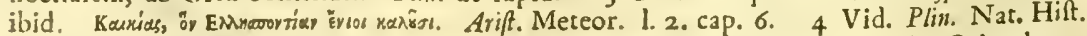
1. 2. cap. 47. Aul. Gell. Noct. Attic. 1. 2. cap. 22. Apul de Mundo. Ifid. Orig. 1. 13. cap. I I.

the 
the Veffel, which, at this Juncture, muft have been to the Leeward of Phonice, the Port they were endeavouring to make up to, could not have paffed under the Ifland Clauda, which was fituated, at feveral Miles Diftance, almoft directly to theWeftward of it. Upon this Suppofition likewife, the Danger they apprehended of falling into the (Syrtis) 2uickfands, (v. 17.) would have been inevitable, which, by the Event, appeared to be altogether groundlefs, occafioned no doubt, from their not having been able to obferve the Sun or the Stars for many Days, (v. 20.) and continuing thereby ignorant of the Courfe, wherein they were driven.

But to purfue the Natural Hiftory: I never obferved any The Cixcias Phcenomena, that were more peculiar to the Ceecias, (the N. E. of the Same by $\mathrm{E}$. Wind, as we will fuppofe it) than to any other Levanter other LeAriftotle indeed, (who is partly followed herein by Pliny ${ }^{\circ}$ ) defcribeth it ${ }^{2}$ to have a Property, contrary to all other Winds, àvargemen eis airiv, of drawing, as $A$. Gellines 3 interprets it, the Clouds to itfelf: an Expreffion as well as Quality which it will be difficult to comprehend, unlefs we may prefume to explain it, by (what indeed it hath only in common with other Levanters, ) either the Hazinefs that accompanies it, or elfe by the great Accumulation of Clouds, which, to ufe the MarinersPhrafe, frequently hang, without diffipating, for feveral Days together, in the Winds Eye. For at other Times, thefe, no lefs than the oppofite Winds, are, even by Ariftotle's Confeffion", attended with long Succeffions of Clouds, driving each other forward with great Force and Velocity.

We are to obferve further with Regard to thefe Levanters, Several Rocks that when they are of a long Continuance, the Water is blown the Lavanaway, to fuch a Degree, from the Coaft of Syria and Phonice, that feveral Ranges of Rocks, which, in Wefterly Winds, lye concealed, do now become dry, and leave expofed, to the Water Fowl, the Urchins, Limpets, and fuch like Shell Fifh, as ftick

I Narrant \& in Ponto Cacian in fe trahere nubes. Plin. Nat. Hift. 1.2. cap. 48.

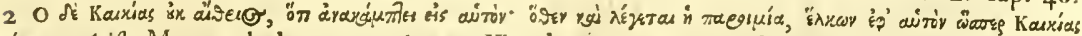

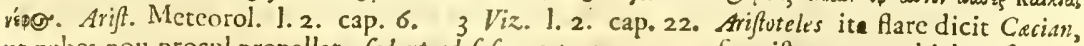
ut nubes nou procul propellat, $\int e d$ ut ad $\int_{\text {Kà }}$ e vocet, ex quo verfum iftum proverbialem factum
ait : ait :

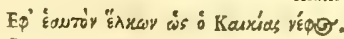

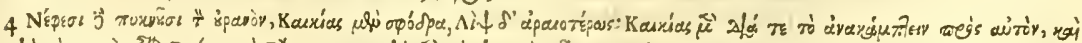

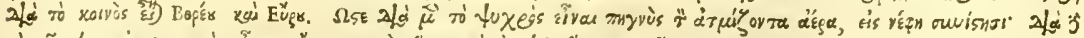

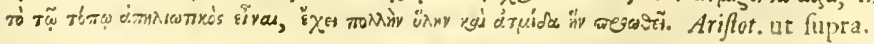


upon them. I obferved, in the Port of Latikea, that there was two Foot lefs of Water, whilft thefe Winds raged, than afterwards, when the Weather was moderate, and the Winds blew foftly from the weftern Quarter: and it is very probable, that the remarkable Recefs of Water, in the Sea of Pamphylia ', may be accounted for from the fame Caufe, operating only in an extraordinary Manner.

Ships appear magnified in Eafterly

We are likewife to obferve further with Regard to thefe Winds.

ftrong Eafterly Winds, that Veffels or any other Objects which are feen, at a Diftance, appear to be vaftly magnified, or loom, according to the Mariners expreffion. Neither are we to omit a fuperftitious Cuftom, which I have feen practifed more than The Malo- once by the Mahometans, during the Raging of thefe and other frea a s beep to tempeftuousWinds, that, after having tied to theMaft or EnfignIappafs: " Staff fome appofite Paragraph of their Koran ${ }^{2}$, they facrifice a Sheep, and throw it immediately over-board, to afwage the Violence of the Waves, and the Fury of the Tempeft. We learn from Ariftophanes and Virgil ${ }^{3}$, that the Greeks, fome thoufand Years ago, are faid to have made ufe of the fame Ceremony, upon the like Occafion.

The Witts from Mount Libanus ex-
ceeding Cold.

The Mountains of Libanus are covered all the Winter with Snow, which, when the Winds are eafterly, affects the whole Country, from Tripoly to Sidon, with a more fubtil and piercing Cold, than what is known in our northern Climates. Whereas the other maritime and inland Places, either to the N. or S. of thefe Mountains, enjoy a Temperature of the Atmofphere, which is much milder and attended with a more regular Change in the Seafons.

The Frequency It is obfervable that in cloudy Weather, efpecially when the of Water Winds are tempeftuous and blow at the fame Time in feveral Di-
spouts. rections, W ater Spouts are more frequent near the Capes of $L$ atikea, Greego, and Carmel, than in any other Part of the Mediterranean Sea. Thofe which I had the Opportunity of feeing,

1 Vid. Not. (2). p. (349). 21 had the Curiofity once to take down one of thefe Scrolls, and found it to be of the fame Import with the latter Parr of our 107 P Salm, viz. Thofe that go down to the Sea in Slips and occupy their Bufinefs in great Waters \&rc.

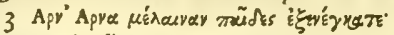

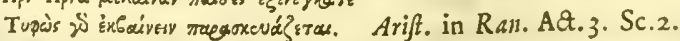

- Meritos aris mątavit honores:

Taurum Neptuno; taurum tibi, pulcher Apollo:

Nigram Hyemi Pecudem, Zephyris felicibus albam.

Tres Eryci vitulos, \& tempefatibus agnam

Cædere deinde jubet.

Id. Ibid. 5. 772 .

Virg. An. 3. 118.

feemed 
feemed to be fo many Cylinders of Water, falling down from the Clouds; though, by the Reflection, as I take it, of the defcending Columns, or from the actual dropping of the Water contained in them, they may fometimes appear, efpecially at a Diftance, to be fucked up from the Sea. Nothing more perhaps is required towards the Production of this Phcenomenon, than that the Clouds fhould be firft crowded together; and then, that contrary Winds, whirling them about and preffing violently upon them, fhould oblige them to condenfe. They cannot, I prefume, be accounted for, according to Lemery's Suppofition', from fubmarine Earthquakes and Eructations: neither will the Siphonic Winds ${ }^{2}$, if there be any fuch, much better folve the Dificulty.

In travelling by Night through the Valleys of MountEpbraim, A Aremarkable we were attended, for above the fpace of an Hour, with an Ignis fatuus, that difplayed itfelf in a Variety of extraordinary Appearances. For it was fometimes globular, or like the Flame of a Candle; immediately after it would fpread itfelf, and involve our whole Company in it's pale inoffenfive Light; then at once contract itfelf, and fuddenly difappear. But in lefs than a Minute it would again exert itfelf as at other Times, or elfe, running along from one Place to another, with a fwift progreffive Motion, would expand itfelf, at certain Intervals, over more than two or three Acres of the adjacent Mountains. The Atmofphere, from the Beginning of the Evening, had been remarkably thick and hazy; and the Dew, as we felt it upon our Bridles, was unufually clammy and unctuous. In the like Difpofition of the Weather, I have obferved thofe luminous Bodies, which, at Sea, skip about the Mafts and Yards of Ships, and are called Corpufanfe 3 by the Mariners.

The firft Rains ufually fall about the Beginning of November, T:e Former the latter fometimes in the Middle, fometimes towards the and ians. End of April. It is an Obfervation in the Country round about Ferufalem, that, provided a moderate Quantity of snow talls in the Beginning of February and the Fountains overflow a little afterwards, there is the Profpect of a fruitful ind plentiful Year : the Inhabitants making, upon thefe Occafions, the like Rejoycings which the Egyptians do, upon the cutting of the Nile.

I "When Hurricanes come from thofe Places of the Earth which are under the Sea, they "raife the Waters into prodigious Pillars, ** the fame are called Spouts at Sea." Z, mery's

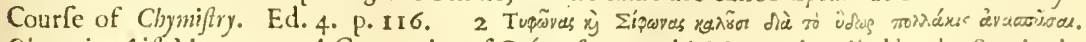
Olymp. in Arift. Meteor. 3 A Corruption of Cuérpo fanto, as this Meteor is called by the Spaniards.

$$
\text { Y y y y } 2
$$

During 
During the Summer Seafon, thefe Countries are rarely refrefhed with Rain", but enjoy the like Serenity of Air, that hath been taken Notice of in Barbary.

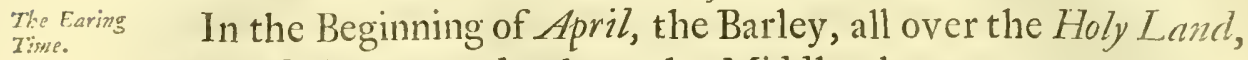
was in full Ear, and, about the Middle, began to turn yellow in the fouthern Diftricts. For it was as forward near Fericho, in the latter End of March, as I found it to be, in the Plains of Acre, a Fortnight after. But the Wheat was very little of it in Ear, at one or other of thofe Places: and, in the Fields nearBethlehem and Ferufalem, the Stalk was little more than a Foot high. The Boccôre The Boccôres likewife, or firft Ripe Figs, were hard and no big-
are bard and smallin April. ger than our common Plums; though they have then a Method of making them palatable, by fteeping them in Oyl. According therefore to the Quality of the Seafon, (An. 1722.) when I travelled in the Holy Land, I very much doubt, whether the Firft-Fruits could have been offered at the Time appointed, without intercalating ${ }^{2}$ the $\left[\mathrm{T}_{\mathrm{T}}\right] \mathrm{Ve}$-adar, and poftponing thereby the Paffover, for at leaft the Space of a Month.

The soil and The Soil both of the maritime and inland Parts of Syria and Produce.

Phoenice, is of a light loamy Nature, rarely requiring more than one Pair of Oxen to plow it. Befides all Sorts of excellent Grain and fuch vegetable Diet as hath been defcribed in the Fruit and Kitchen Gardens of Barbary, the chief Produce is Silk and Cotton. The Inhabitants fend the Eggs of the Silk-Worm, as foon as they are fhed, to Cannobine, or fome other Place upon Mount Libanus, where they are kept cool, without Danger of being hatched, 'till the Mulberry Buds are ready for them in the Spring. The fame Caution is ufed at Lime fole and other Places in the Ifland of Cyprus, by preferving them upon what they call (Fibbel Krim) The Great Mountain. The whole Oeconomy and Management of the Silk Worm is at prefent fo well known in England, that nothing need be faid upon that Subject.

\footnotetext{
I This known Quality of the Summer Seafon is appealed to x S.2nt. 12. 17. Is it not Wheat Harveft to Day? I will call anto the Lord, and be fball fend Thander and Rain: which mult have been looked upon as an extraordinary Phanomerion at that Time of the Ycar. 2 על של שהח סימנין מעברי? את השנה. \&. i. e. Propter tres cafus intercalabant in anno; propter Epocham anniSolaris; propter fruges maturas \& propter fructus arborum. Si Judices animadvertiffent nondum maturas effe fruges, fed adhuc ferotinas effe, neque fructus arborum, quibus mos eft tempore pafchali florere; illis duobus argumentis nitebantur \& intercalabant in anno. Ac quanquam Epocha anni antevertebat fextam decimam menfis Nifan, tamen intercalabant, ut frumentum maturum effet, ex quo offerretur manipulus in xvi Nilan, $\&$ ut fructus forerent more omnium. ** Judices computo inito fciebant fi Tekupha Nifal effet in fextadecima Nifan aut poft; \& intercalabant in eo anno, mutato Nifan in $A d d r$ geminum, nimirum ut Pefach incideret in tempus frugum maturarum \&cc. Maimonid. apud 7. Scalig. de Emendat. Temp. I. 2. p. 104 .
} 
Though the Corn which is produced near Latikea, is the Tobicco beft and the moft early of that Part of Syria, yet, of late, the cultivateded at Inhabitants have neglected This Branch of Husbandry, together with That of the Vine, (for both which, it was formerly famous ', ) and employ themfelves chiefly in the more profitable Culture of Tobacco. This is a very confiderable, and indeed the only Article of Trade, which hath in al few Years fo greatly enriched this City, and the Country round about It. For there is fhipped off, every Year, from hence to Dami-ata and Scandarea, more than twenty thoufand Bales, to the no finall Diminution of that Branch of Trade at Salonica.

The Holy Land, were it as well peopled and cultivated, as The Holy in former Time, would ftill be more fruitful, than the veryf Lansil more beft Part of the Coaft of Syria and Pboenice. For the Soil Shria and itfelf is generally much richer, and, all Things confidered, yields a more preferable Crop. Thus the Cotton that is gathered in the Plains of Ramah, Ejdraelon and Zabulon, is in greater Efteem, than what is cultivated near Sidon and Tripoly; neither is it poffible for Pulfe, Wheat or any fort of Grain to be more excellent, than what is commonly fold at Ferufalem. The Barrennefs, or Scarcity rather, which fome Authors ${ }^{2}$ may either ignorantly or malicioufly complain of, does not proceed from the Incapacity or natural Unfruitfulnefs of the Country, but from the Want of Inhabitants, and the great Averfion there is to Labour and Induftry in thofe few who poffefs it. There are befides, fuch perpetual Difcords and Depredations among the petty Princes, who fhare this fine Country, that, allowing it was better peopled, yet there would be fmall Encouragement to fow, when it was uncertain, who fhould gather in the Harveft. Otherwife the Land is a good Land, and ftill capable of affording it's Neighbours the like

1 Vid. Not. I. p. 322. 2 Micharel (Villanovanus) Servetus, in his Edition of Ptolemy, Lugd. 1535. hath, in the Defcription which he annexes to the Table of the Holy Land, the following Words. Scias tamen Lector optime, injuria aut jactantia pura tantam buic Terrabunitatem fuifse adfcriptam, co quod ipsa Expcrientia mercatorum o peregre proficifcentium, ban incultam, ftcrilem, ommi dulcedine carentem depromit. Quare promiffam Terram pollicitan o nun vernacula Lingu. l.andantem pronuncias \&c. Vid. New Memoirs of Literature. Vol.1. p.26. doc. But among many other Travellers, who haveftrongly afferted the Contrary, I fill fubjoyn the following Obfervations of $P$. de La Valle upon this Country, which agree exactly with minc. Il parefe, per donde caminavamo era belliffma. Tutte collini, valli e monticellifruttiferi. Le convalle de Mambre $e$ a punto comme tutti gli altri paefi dintorno, che quantunque montuofie faffofi fono pero fertiliffimi. Let.13. Le Montagne e Valli bien che fiano alpeftri fono nondimeno tutte frutiffere per l.2 diligenz.2 degli agricoltori. Id. Let. 3 . 
Supplies of Corn and Oyl, which it is known to have done in the Time of Solomon:

The Parts, particularly about Ferufalem, being defcribed to Thenountain- The Parts, particularly about ferufalem, being defcribed to
ous Countrya-
boundeth mith be rocky and mountainous, have been therefore fuppofed to be and Vines. barren and unfruitful. Yet granting this Conclufion, which is far from being juft, a Kingdom is not to be denominated barren or unfruitful, from one Part of it only, but from the Whole. Nay further, the Bleffing that was given to $\mathcal{F}_{\text {udah, }}$ was not of the fame Kind, with the Bleffing of Afber or of IfJachar, that bis Bread Should be fat, or bis Land fbould be plea fant, but that bis Eyes Bould be red withWine, and his Teeth fould be white with Milk. Gen.49. I2. Mofes alfo maketh Milk and Honey, (the chief Dainties and Subfiftence of the earlier Ages, as they continue to be of the Bedoween Arabs,) to be the Glory of all Lands: all which Productions are either actually enjoyed, or at leaft might be, by proper Care and Application. The Plenty of Wine alone is wanting at prefent; yet from the Goodnefs of that little, which is ftill made at Ferufalem and Hebron, we find, that thefe barren Rocks (as they are called) might yield a much greater Quantity, if the abftemious Turk and Arab would permit a further Increafe and Improvement to be made of the Vine.

The Q Quatity The Wild Honey, which is mentioned to have been a Part of ividHony. of the Food of St. Fobn Baptift, may infinuate to us the great Plenty there was of It in the Deferts of Fudea, and that confequently, by taking the Hint from Nature and enticing the Bees into Hives and larger Colonies, a much greater Increafe might be made of It. As the Mountains likewife of this Country abound, in fome Places, with Thyme, Rofemary, Sage, and fuch like Aromatick Plants ${ }^{2}$ as the Bee chiefly looks after; fo they are no lefs ftocked in others, with Shrubs and a delicate fhort Grafs ${ }^{3}$, both which the Cattle are more fond of, than of fuch Plants as are common to fallow Ground and Meadows. Neither was this Method of grazing peculiar to thisCountry; inafmuch

I Solomon gave Hiram tzventy thoufand meafures of Wheat for food to bis Houffold, and tzventy meafures of pure Oyl: thus gave Solomon to Hiram year by year. I Kings 5 . I I.

2 Hec circum (alvearia) cafie virides, of olentia late

Serpylla, \& graviter fpirantis copia tlyymbre

Floreat : irrigumuque bibant violaria fontem.

3 At cui lactis amor, cytifum lotofgue frequentes Ip fe manu, falfafque fer.ut prefepibus herbas. Si tibi lanicium care:

fuge pabula lieta.

Virg. Gcorg. 4. 1. 30.

Iirg. Georg. 3. 1. 394.

Id. ibid. $1.3^{3} 4$. 
as it is ftill practifed all over Mount Libanus, the Caftravan Mountains and Barbary; in all which Places the higher Grounds are fet apart for this Ufe, and the Plains and Valleys for Tillage. For, befides the good Management and Occo-Manztains nomy, there is this further Advantage, that the Milk of Cattle for graseing fed in this Manner, is far more rich and delicious, as their than Plasins. Flefh is more fweet and nourifhing. But even laying afide the Profits that might arife from grazing, fuch as Butter, Milk, Wool, and the great Number of Cattle that were to be dayly difpofed of, at Ferufalem, for common Food and Sacrifices; thefe Mountainous Diftricts, I fay, would be highly valuable upon other Confiderations, efpecially as they feem formerly to have been planted all over with Olive Trees; one Acre of which, Tise Monz-

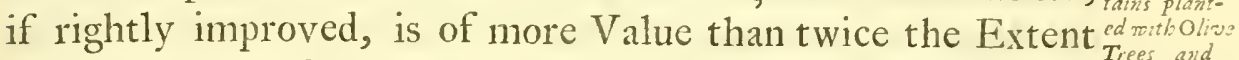
of arable Ground. It may be prefumed likewife, that the $V$ ine was not neglected, in a Soil and Expofition ${ }^{\prime}$ fo proper for it to thrive in. The latter indeed, not being of fo durable a Nature as the Olive Tree, and reouiring moreover a continual Culture and Attendance ${ }^{2}$; the Scruple likewife, which the Mabometans entertain, of propagating a Fruit that may be applyed to Ufes forbidden by their Religion, are the Reafons perhaps, why there are not many Tokens to be met with, except at Ferufalem and Hebron ${ }^{3}$, of the antient Vineyards. Whereas the general Benefit arifing from the Olive Tree, the Longrevity and Hardinefs of it, have continued down, to this Time, feveral thoufands of them together, to mark out to us the Poffibility of greater Plantations. Now if to thefe Productions, Sevoral Vales we joyn a great many hundred Acres of arable Ground, that Ground. lye fcattered all over the Dales and Windings of the Mountains

\footnotetext{
I - Fuvat If mura Baccho

Conferere, atque olea magnum veftire Taburnm. Virg. Georg. 2. 1.37.

2 Fam vincte vites, jum falcem arbufta reponum,

fam canit extremos effatus vinitor antes;

Sollicitanda tamen tellus, pulvifque movendus :

Et jam maturis metuendus Fupiter wvis.

Contra, non ulla efo oleis culturat : neque illa

Procurvam expectant falcom, raftrofque tenaces,

Cum fimel beferunt arvis.

Id. ibid. 1. 46.
}

3 Befides the great Quantity of Grapes and Railins, that ate, one or other of them, brought dayly to the Markets of Gerufalem and the neighbouring Villages, Hebron alone lends every Year to Egypt three hundred Camel-Loads, (i. e. near two thoufand Quintals) of the Robb, which they call cumo (שר) Dibfe, the fame Word that is rendred Honcy in the Scriptures. Hebron has the Title of Hhalea $\mathrm{ln}_{\mathrm{a}} \mathrm{i}$. e. the chofen or beloved among the Arabs: the (M.tg-gar glis el Mamra) Cave of Mamre or Mackpelah, (Gen.23. 17.) being ligbec ug with Lamps, and held in extraordinary Veneration by the Mahometans. 
of Fudab and Benjamin, we fhall find that the Lot, (even of the fe Tribes which are fuppofed to have had the moft barren Part of the Country,) fell to them in a fair Ground, and that Their's was a goodly Heritage.

The Mount. tains better imbabited than the Valleys.

The mountainous Parts therefore of the Holy Land were fo far from being inhofpitable, unfruitful, or the Refufe of the Land of Canaan, that, in the Divifion of this Country, the Mountain of Hebron, was granted to Caleb as a particular Favour. ( $70 / \mathrm{h}$. I4. I2.) We read likewife, that, in the Time of Afa, the Hill-Country of Fudah (2 Chron. I4. 8.) muftered five bundred and eighty thoufand Men of Valour; an Argument, beyond Difpute, that the Land was able to maintain Them, befides double the Number, that may be fuppofed, of old Men, Women and Children. Even at prefent, notwithftanding the Want there has been for many Ages of a proper Culture and Improvement, yet the Plains and Valleys, though as fruitful as ever, lye almoft intirely neglected, whilft every little Hill is crowded with Inhabitants. If this Part therefore of the Holy Land was made up only of naked Rocks and Precipices, how comes it to pafs, that it fhould be more frequented, than the Plains of Efdraelon, Ramah, Zabulon, or Acre, which, to borrow an Expreffion from Mr. Maundrell, is a Country very delightful and fertil beyond Imagination? For it cannot be urged, that the Inhabitants live with more Safety in this Situation, than in the Plain Country; inafmuch, as there being no Walls or Fortifications to fecure either their Villages or Encampments; there being likewife few or no Places of difficult Accefs; both the one and the other lye equally expofed to the Infults and Outrages of an Enemy. But the Reafon is this, that they find fufficient Conveniences for themfelves, and much greater for their Cattle. For here they themfelves have Bread to the full, whilft their Cattle brooze upon a richer Herbage, and both of them are refrefhed by Springs of excellent Water, too much wanted, in the Summer Seafon, not only in the Plains of This, but of Other Countries in the fame Climate.

The Plants of I travelled in Syria and Pbonice in December and Fanuary, Syria, $s c_{0}$ and therefore had not a proper Seafon for Botanical Obfervations. However the whole Country looked verdant and chearful: and the Woods particularly, which abound chiefly with the 
Gall-Oak, were ftrewed all over with a Variety of Anemones, Ranunculuffes, Colchicas, and Mandrakes. Several Pieces of Ground near Tripoly were full of the Liquorice-Plant; and at the Mouth of the famous Grotto near Bellmont, there is an elegant Species of the Blew Lilly, the fame with Morifon's Lilium Perficum florens. There are fo many Dangers and Difficulties which attend a Traveller through the Holy Land, that he is in too much Hafte to make many curious Obfervations, much lefs to collect the Plants and other Curiofities of that Country. However, in the Beginning of March, I could not avoid obferving, that the Plains betwixt Faff $a$ and Ramal, and indeed feveral other Places in the Road to Ferifalem, were particularly diftinguifhed by feveral beautiful Beds of Fritillaries, Tulips, and other Plants of the fame Clafs.

The Mountains of Quarentania afford a great Quantity of Tte Plants of yellow Polium, and fome Varieties of Thyme, Sage, and Rofemary. The Brook likewife of Elifba which flows from It and waters the Gardens of Fericho, together with it's Plantations of Plum ' and Date Trees, hath it's Banks adorned with feveral Species of Brooklime, Ly/imacbia, Water Crefs, Bettany, and other aquatic Plants; all of them very like thofe that are the Produce of England. And indeed the whole Scene of Vegetables and of the Soil which fupports them, hath not thofe particular Differences and Varieties, that we might expect in two fuch diftant Climates. For I do not remember to have feen or heard of any Plants, but fuch as were Natives of other Places. The Balfam Tree doth no longer fubfift, and the Muf $a^{2}$, which fome Authors ${ }^{3}$ have fuppofed to be the (Dudaim Dירור) Mandrakes of the Scriptures, is equally wanting; neither could it, I prefume, ever grow wild * and uncultivated as the Dudaim muft be fuppofed to have done. What the Chriftian Inhabitants of Ferufalem take at prefent for that Fruit, are the Pods of the Felathon, a leguminous Plant, that is peculiar to the Corn Fields, and, by the many Defcriptions I had of it, (for it

I Of the Fruit of this Tree is made the Oyl of Zacconc. Vid. Maundrell's Journ. p. 86. Edit. 2. The Tree is thus defcribed, Cafp. Batub. Pin. p. 444. Prunus Hiericonthica folio anguffo fpinofo. Zaccon dicitur quia in planitie Hierichontis non longe ab Edibus Zacchxi creforit. Caft. $2, \infty$, Mouz, commonly called the Bandama or Plantain Tree. 3 Vid. Ludolphi Hift. Atthoop. I. I. cap. 9. \& Comment. P. I 39 \&c. 4 And Reuben avent in abe Days of Wheat Harveft, and found Mandrakes in the Field, and brought them to bisMother Leall. Gen. 30.14. 
was too early, when I was in the Holy Land, to fee it,) fhould be a Species of the WingedPea; perhaps the Hierazune or the Lotus tetragonolobus of the Botanifts. It is certain that the Bloom of all or moft of the luguminous Plants yields a grateful Smell; a Quality which the Scriptures " attribute to the Plant we are looking after.

The mitddle of The Boccòre, as I have before obferved, was far from being
Junc the Seas four for Figs. in a ftate of Maturity in the latter end of March: for, in the Scripture Expreffion, the Time of Figs was not yet, or not before the middle or latter end of Fune. However it frequently falls out in Barbary, and we need not doubt of the like Circumftance in this much hotter Climate, that, according to the Quality of the preceding Seafon, fome of the more forward and vigorous Trees will now and then yield a few ripe Figs a Month, fix Weeks or more before the full Seafon. No fooner The Summer
Fig is not ripe
doth the Boccöre draw near to Perfection, than the Kermez or 'till Auguaf. Summer Fig (the fame that is preferved and fold by the Grocers,) begins to be formed, though it rarely ripeneth before Auguf: about which Time the fame Tree frequently throws. The whinter out a third Crop, or the Winter Fig as we may call it. This Fig bangs sp-
on the Trce is ufually of a much longer Shape, and darker Complexion than 'tith spring. the Kermez, hanging and ripening upon the Tree, even after the Leaves are fhed; and, provided the Winter proves mild and temperate, is gathered as a delicious Morfel in the Spring. It is well known that the Fruit of this prolific Plant doth always precede the Leaves; and confequently when Our Saviour, Saw one of them, in full Vigour, having Leaves, (Mar. I I. I 3.) he might, according to the common Courfe of Things, very juftly look for Fruit, and haply find fome, of the former or the latter Kind, in Perfection.

The H. Land Several Parts of the Holy Land, nolefs than of Idumea ${ }^{2}$ that Iypifyed by a Palm Tree. lyes contiguous to it, are defcribed by the Antients to abound with Date Trees. Thus Fudea, which denoted the whole Country of the Fews, is typified, in feveral Coins ${ }^{3}$ of $V$ eppafian's, by a difconfolate Woman fitting under a Palm Tree. Upon the

1 The Mandrakes give a Sinell. Cant.7. I 3.

2 Primus Idamæas referam tibi Mantua Palmas. Tirg. Georg. 3. 1. I2. -_Arbuftis Palmarum dives Idume. Luc. I. 3. Frangat Idumxas triftis Vidtoria Palmas.

Mart. Ep. 1.r3. Ep.so.

3 Vid. Occonis Imperat. Roman. Numifm. exhibita Atudio \& cura Franc. Mediobarbi \&re. p. T10, III, I12, II3. Amft, 1717 . 
Greek Coin likewife of his Son Titus ", ftruck upon a like Occafion, we fee a Shield, fufpended upon a Palm Tree, with a Victory writing upon it. The fame Tree is made an Emblem of Neapolis 2, (formerly Sichem, or NaploJa, as it is now called) upon a Medal of Domition; and of Sepphoris ${ }^{3}$ (or Saffour according to the prefent Name,) the Metropolis of Galilee, upon one of Trajan's. It may be prefumed therefore that the Palm Tree was formerly very much cultivated in the Holy Land. We Jericho alone have indeed feveral of thefe Trees ftill remaining at Fericho $0^{+}$, them where there is the Convenience they require of being often watered: where likewife the Climate is warm, the Soil fandy, and fuch as they delight to grow in. But at Sichem and other Places to the Northward, I rarely faw above two or three of them together; and even thefe, as their Fruit doth rarely or ever arrive to Maturity, ferve more for Ornament than Ufe. Upon that Part of the Sea Coaft, which I am acquainted with, there were ftill fewer; and even thofe I met with, grew either out of fome Ruin, or elfe fhaded the Retreat of one or other of their Shekbs, as they call the Saints of This Country. From the Condition and Quality therefore of thefe Trees at prefent, it is very probable (provided the Climate and the Sea Air fhould be, contrary to Experience, affifting to their Increafe) that they could never be either numerous or fruitful. The Opinionthen of fome Authors's that Phoenice is the fame with a Country of $f_{0}$ ocalled from Date Trees, doth not appear to be well grounded, for weing a CornDate Trees, doth not appear to be well grounded, for we try of Palm may jutly imagine, that in Cafe fo neceffary and beneficial a Plant had been once cultivated to Advantage, it would have

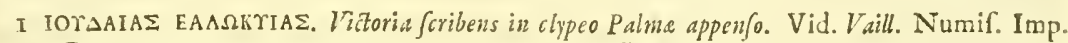

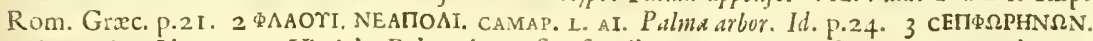
Palma arbor. Id.p. 30.4 Hicrichus Palmet is confra, fontibus irrigua. Plin. l.s.cap.14. Exuberant fruges, ( (Jays Tacitus, Speaking of this Country) noftrum in morem; prxterque eas Balfamum

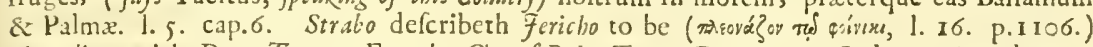
abounting with Date Trees. For the City of Palm Trees. Deur.34.3. Judg. I. I6. and 3. I3. the Targmm puts the City of Fericho. 5 Quod ad nomen attinct Phonices, id a Palmis effe ductum mihi videtur veri fimile; alii a Phanice quodam id ducunt. Reland. Palxet. p. 50. Palma arbor Urbis (Aradi) eft fymbolum, guo plerxque Phonicia urbes utebantur, quod $\Phi O I N I \Xi$ arbor provincix Plscnicix nomen dederit. Vaill. de Urbib. p. 257. Of the fame Opinion was Califthenes, according to the Author of the Hiftory of the World. p. 205. But the moft probable Conjecture for the Name is as follows. "Edom, Erythra, and Phenicia, are "Names of the fame fignification, the Words denoting a red colour: which makes it proba" ble rhat the Erythrcans who fled from David, fettled in great Numbers in Pharicia; i.e. in " all the Sea Coalts of Syria, fromEgypt to Zidon: and by calling themfelves Phonicians, in rhe "Language of Syria, inftead of Erytbreans, gave the Name of Phanicia, to all rhat Sea Coaft, " and to that only. Sir If. Nezwton's Chron. p.108, 109. Bochatr very ingenioufly fuppofeth the Phanices to be a corruption of PJy 'I Beni Anak, (The Children of Anak.) Lib. 1. Cluan. cap. I. 
been conftantly kept up and propagated, in the very fame Manner, we find it to have been in Egypt and Barbary.

The Rocks up- From the Vegetable Kingdom, let us pafs on to give an Acon the sea
shore bewn count of fuch Rocks, Foffils, Fountains, Rivers, and Animals into Salt Pans. of thefe Countries, as are the moft remarkable. Now the Rocks, in feveral Places upon the Coaft of Syria and Phonice, have been hollowed into a great Number of Troughs, two or three Yards Long, and of a proportionable Breadth, feeming to have been originally intended for fo many Salt Works; where, by continually throwing in the Sea Water to evaporate, a large Quantity of Salt would in Time be concreted. We fee feveral of thefe Troughs at Latikea, Antaradus, Tripoly and other Places; which at prefent, notwithftanding the Hardnefs of the Rock, are moft of them worn fimooth, by the Waves continually dafhing upon them.

The bigher Above this Bed of Hard Stone, in the Neighbourhood of

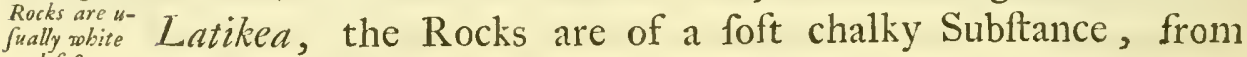
and fofter.

whence probably the adjacent City borrowed the Name of

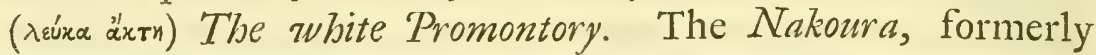
called the Scala Tyriorum, is of the fame Nature and Complexion; both of them including a great Variety of Corals, Foffil Fifles. Shells, and other Remains of the Deluge. Upon the Caftravan Mountains, above Barroute, there is another curious Bed likewife of whitifh Stone, of the Slate Kind, which unfolds, in every Fleak of it, a great Number and Variety of Fifhes. Thefe, for the moft Part, lye exceeding flat and compreft, like the Foffil Fern Plants, yet are, at the fame Iime, fo well preferved, that the fimalleft Stroakes and Lineaments of their Fins, Scales, and other fpecifical Diftinctions, are eafily diftinguifhed. Among thofe that were brought to me from this Place, I have a beautiful Specimen of the Squilla, which, though the tendereft of the Cruftaceous Finhes, yet hath not fuffered the leaft Injury from Length of Time or other Accidents.

Moft of the

The greateft Part of the Mountains of Carmel, and of thofe

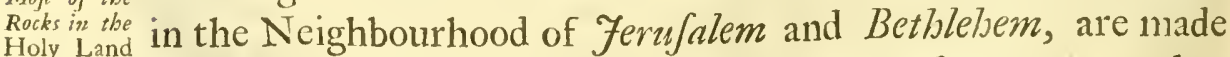
of tbe like up of the like white chalky Strata. In the former we gather
ouality. a great many Stones, which being in theForm, as it is pretended, of Olives, Melons, Peaches and other Fruit; are commonly impofed upon Pilgrims, not only for fuch Curiofities, but as 
Antidotes likewife againft feveral Diftempers. The Olives, Ptrived $_{\text {Olives }}$ Methe Lapides Fudaici of the Shops, have been always an ap-lions \&ac. proved Medicine againft the Stone and Gravel: but little can be faid in Favour of their Melons and Peaches, which are only fo many different Sizes of round hollow Flint Stones, beautified in the Infide with fuch fparry and ftalagmitical Knobbs as are made to pafs for the like Number of Seeds and Kernels. The little round Calculi, commonly called the Virgins Peas; the chalky Stone of the Grotto near Bethlehem, called her Milk; the Waters of Fordan and Siloam; the Oyl of Zaccone; the Rofes of Fericho; Beads made of the Olive Stones of Gethoemane; with various Curiofities of the like Nature, are the Prefents which Pilgrims ufually receive in Return for their Charity.

In calm Weather, feveral Fountains of excellent Water difcover themfelves, upon the Sea Shore, below Bellmont. They rbe Foratain

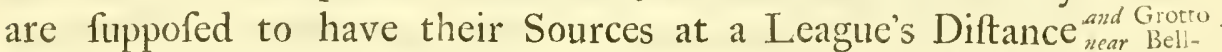
to the Eaftward, where there is a large Grotto, which is become mont. very remarkable uponAccount of a plentiful Stream of Water, that burfts out at once, and lofeth itfelf immediately under the fame Cave. This Place, which is near half a Mile long, and fometimes fifty, fometimes a hundredYards broad, is vaulted, by Nature, in fo regular a Manner, that Art alone may feem to have been concerned in the Performance. The Ras el Ayn near Tyre, the Sources of the Ki/bon, and the fealed Fountain of Solomon, are of the fame gufhing Quality with the Fountains of this Grotto. To thefe we may add The (Nahar el The River of Farah) River of the Moufe, which hath it's Sources about a the Manfe. League to the N.E. of Ferufalem. The Reafon of the Name may arife from hence, that no fooner doth the Stream begin to run, than it is immediately loft under Ground, then rifeth again, and in this Manner purfueth it's Courfe, all the Way, into the Valley of Fericho. Yet provided all thefe Fountains and Rivulets, which I have juft now mentioned, together with the Kardanah, the Ki/bon, the Brook of Sichem, and other leffer ones difperfed all over the Holy Land, fhould be united together, they would not form a Stream in any degree equal to the Fordan, which, excepting the Nile, is by far the moft

1 One of them will ufually ferve for two Dofes, corroding it firn in fo much Lemon Juice as will juft cover it ; and afterwards drinking of it up. Profper Alpinus gives us another Method. Hift. Egypt. Nat. 1.3 cap.6. Egyptii lapide Judaico, ex cote cum aqu. ftillatitia ex Ononidis radicmm corticibus detrito, utuntur ad calculos in renibus of in vefic comminnendos, atque ad wrinam movendam.

$\mathrm{B} \mathrm{b} \mathrm{b} \mathrm{b} \mathrm{b}$

coll- 
confiderable River that I have feen either in the Levant or Barbary. However I could not compute it to be more than thirty Yards broad, though this is in a great Meafure made up by the Depth, which, even at the Brink, I found to be three. If then we take This, during the whole Year, for the mean Depth of the Stream, (which, I am to obferve further, runs about two Miles an Hour,) the Fordan will every Day difThe Q Q wantity charge into the Dead Sea about 6,090,000 Tons of Water. fed from it in
a Day. any vifible Increafe in the ufual Limits of the Dead Sea, hath made fome conjecture ', that it muft be abforbed by the burning Sands; others, that there are fome fubterraneous Cavities to receive it; or elfe that there is a Communication betwixt it and the Serbonic Lake; not confidering that the Dead Sea alone, will lofe every Day, near one third more in Vapour, The Extent of than what this amounts to. For provided the Dead Sea the DeadSea. fhould be, according to the general Computation, feventy two Miles long and eighteen broad, then, by allowing, according to Dr. Halley's Obfervation, 69I4 Ton of Vapour for every fquare Mile, there will be drawn up every Day above $8,960,000$ 'Tons. Nay further, as the Heat of the Sun is of more Activity here than in the Mediterranean Sea, exalting thereby a greater Proportion of Vapour than what hath been eftimated by our Profeffor: fo the Fordan may, in fome Meafure, make up this Excefs, by fwelling more at one Time than another. though, without Doubt there are feveral other Rivers ${ }^{2}$, particularly from the Mountains of Moab, that muft continually difcharge themfelves into the Dead Sea.

The Bitumen
raifed from I was informed, that the Bitumen, for which this Lake hath the Bottom of it in $\mathrm{H} c$ mifpheres.

been always remarkable, is raifed, at certain Times, from the

I Origo Lacus Afphaltitis ex aquis Jordanis derivari poteft, qux delabentes continuo alicubi colligi debuere, quod olim ante natum hunc lacum videtur infra terræ fuperficiem factum fuiffe, ita ut in ampliffmas voragines aut ipfum oceanum defcenderint. Poft incerrum, qua ratione, arctiorefque videntur facti fuiffe illi meatus, fic ut aquæ Jordanis quum non ita copiofx defluere poffent, partem terrx inundaverint, atque ita lacum hunc effecerint, cujus aqux \& ipfæ per meatus aliquos fe exonerant, quum aquis Jordanis non augentur. Rel. Palaft. p. 2.57-8. Sandy's Trav. p. II r. 2 Galenus quamvis nomen Arnonis non ad-

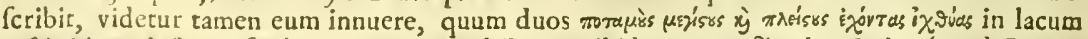
Afphaltitem influere fcribir. Galen. apud Reland. ibid. p. 292. Facobus Cerbus (apud Reland. p. 281.) octo hos fluvios illabi monet in lacum Apphaltitem. 1. Fordanem. 2. Arnonem. 3. Flumen cum Arnohe de magnitudine certans a monte regali procedens, attingens Oronaim. 4. Fluvium prope puteos bituminis \& vallem falinarum. 5. Fluvium de Cadesbarne venientem. 6. Fluvium ab Artara egreffum qui Thecuam irrigat. 7. Cedronem. 8. Charith torrentem ex monte Quarentano ortum \& prope Engaddim in lacum Afphaltitem fe exonerantem. Sanutus (ibid. p. 280 .) hos fluvios recenfer in lacum Afphalsitem illabi. Arnonem alium qui in principio mare mortunm intrat. Alium qui novem leucis inde mare mortuum ingreditur.

Bottom, 
Bottom, in large Hemifpheres; which, as foon as they touch the Surface and fo are acted upon by the external Air, burft, at once, with a great Smoke and Noife, like the Pulvis fulminans of the Chymifts, and difperfe themfelves round about in a thoufand Pieces. But this happens only near the Shore; for, in greater Depths, the Eruptions are fuppofed to difcover themfelves only in fuch Columns of Smoke, as are now and then obferved to arife from the Lake. And perhaps to fuch Eruptions as thefe, we may attribute that Variety of Pits and Hollows which are found in the Neighbourhood of this Lake, and compared very juftly by Mr. Maundrell to thofe Places in England, where there have been formerly Lime Kilns. The Bitumen, in all Probability, is accompanied from the Bottom, with Sulphur, inafmuch as both of them are found promifcuoufly upon the Wafh of the Shore. The latter is exactly the fame with ${ }_{i t}^{\text {Tis }}$ Quality of common native Sulphur; the former is friable, heavier than Water, yielding, upon Friction or by being fet on Fire, a fætid Smell. Neither doth it appear to be, as Diofcorides defcribeth his Aphaltus', of a purplifh Colour, but is as black as $\mathcal{F}$ t, and exactly of the fame fhining Appearance.

Game of all Kind, fuch as Partridge, Francoleens, Wood-Thefe conncocks, Snipes, Teal, \&c. Hares, Rabbits, Jackalls, Antilopes, roith all forts \&c. are in great Plenty all over This Country. The Method ${ }^{\text {of Game. }}$ made ufe of by the Inhabitants to take them, is either by Courfing or Hawking. For which Purpofe, whenever the Turks and Arabs of better Falhion travel or go out for Diverfion, they are always attended with half a Dozen Hawks, and the like Number of Gray Hounds. The latter are ufually fhagged and much larger than thofe of England; but the Hawks are for the moft Part, of the fame Size and Quality with our Gofs-Hawks, being fufficiently ftrong to pin down a Buftard and ftop an Antilope in full Career. They perform the latter of thefe Actions, by firft feizing the Animal by the Head, and then making a continued fluttering with their Wings, 'till they are relieved by the Gray Hounds.

But the only curious Animals that I had the good Fortune Thbkinkôre. to fee, were the Skinkôre, and the Daman Ifrael; both of

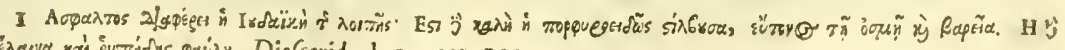

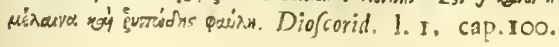


which are, I prefume, already delineated 'though not defuribed. The former are found in great Numbers in a Fountain near Bellmont, being of the Lizard Kind, all over fpotted, and differ from the commonWater Efts, in the Extent and Fafhion of theirFins. Thefe, in the Males, commence from the Tip of the Nofe, and running the whole Length of the Neck and Back to the very Extremity of the Tail, are continued afterwards along the under Part of the Tail quite to the Navel; whereas the Tails only of the Female are finned. The Body and Tail of this Animal are accounted to be great Provocatives, and are therefore bought up by the Turks at an extravagant Price.

The Daman

Ifrael, the

The Daman Ifrael ${ }^{2}$, is an Animal likewife of Mount Liba-

nus, though common in other Places of this Country. It is a harmlefs Creature, of the fame Size and Quality with the Rabbet, having the like incurvating Pofture and Difpofition of the Fore Teeth. But it is of a browner Colour, with fmaller Eyes, and a Head more pointed. The Fore Feet likewife are fhort, and the Hinder near as long in Proportion, as thofe of the Ferboa ${ }^{3}$. Though it is known to burrough fometimes in the Ground; yet, as the ufual Refuge of it is in the Holes and Clifts of the Rocks, we have fo far a more prefumptive Proof that this Creature is the Sapban of the Scriptures than the Ferboa. None of the Inhabitants, whom I converfed with, could inform me why it was called Daman Ifrael, i. e. Ifrael's Lamb, according to their Interpretation.

The Inkabitavts of this cokntry.

Befides Greeks, Maronites, and other Sects of Chriftians, this Country is inhabited by Turks, Turkmans, Arabs, Suories, and Drules. The Turks are the Mafters of the Cities, Caftles and Garrifons: the Turkmans and Arabs poffefs the Plains; the latter living, as ufual, in Tents; the other in moveable Hovels: whilft the Suories, (the Defcendents perhaps of the Indigence or original Syrians, ) cultivate the greateft Part of the Country near Latikea and Febilee; and the Drufes maintain a Kind of Sovereignty all over the Caftravan Mountains.

I Vid. Thefaur. Rer. Natural. Alberti Sebs. p. 22. Vol.r. Pl.r4. fig.I. \& p.67. Pl. 4r. fig. 2. the firft exhibits the figure of the Skinkôre, calling it Lacertus Africanus dorfo pectinato, amphibios mag. Femina pectinata caret pima in dorfo. The latter gives us the figure of the Cuniculus Americanus, which is very like our Daman Ifrael. 2 Animal quoddam humile, cuniculo non diffimile, quod Agnum filivorum Ifrael nuncupant. Profp. Alpis. Hilt. Nat. Egypt. pars I. cap. 20. p. 80. \& 1.4. cap.9. 3 Vid. p. 248. 
The Schneumon ols.p.249.

ISule of Sncher.

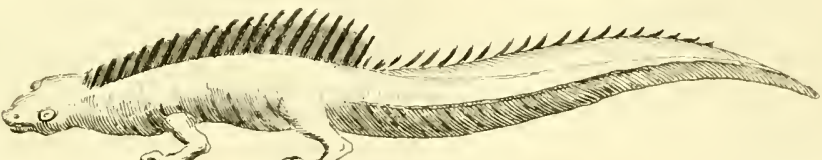

$$
\text { a }
$$

The Alate and Fe male Shintione ob.p.376.

E
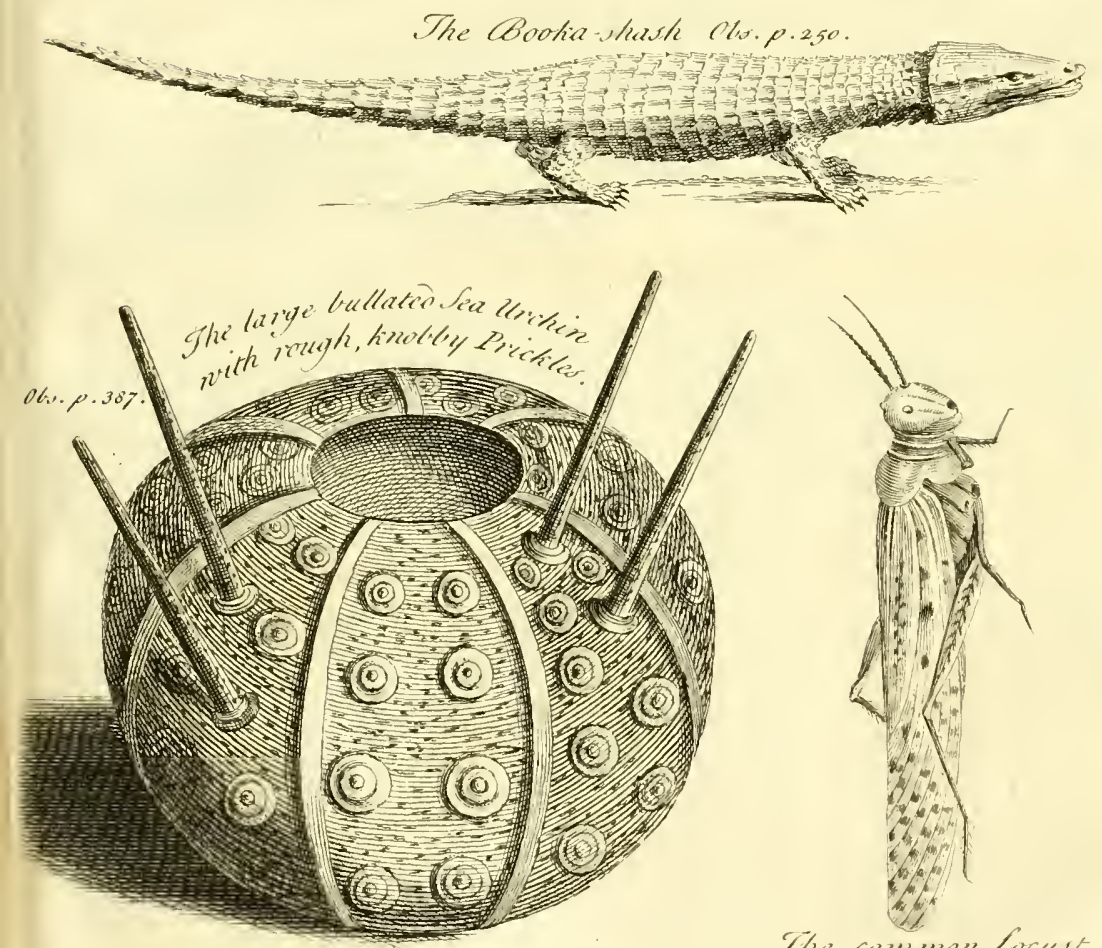

The commen Locuit.

of Barlery ots. P.25r.

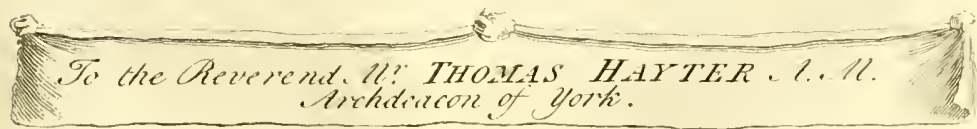



As far as I could learn, the Drufes and the Surees differ very The Relizion little in their Religion, which is a mixture of the Chriftian and Drulues. and Mahometan, the Gofpels and the Koran being equally received as Books of Divine Authority and Infpiration. For to omit, what is commonly reported, of their being circumcifed, worfhipping the rifing and fetting Sun, inter-marrying with their neareft Relations, and making their Children pafs through the Fire, (as fome of the Eaftern Nations did formerly to Moloch;) we may be convinced, I prefume, from their indulging themfelves in Wine and Swine's Flefh, that they are not Mabometans; at the fame Time, the Names, they are known by, of Hanna, You $\int e p h$, Meriam \&c. (i. e. Foln , Fofeph, Mary \&c.) will not be fufficient Arguments in Favour of their being Chriftians.

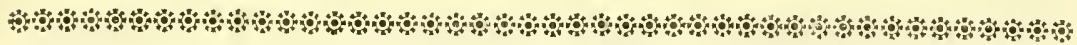

\section{H A P. IV.}

\section{Pbyfical Obfervations \&c. or an Effay towards the Natural} Hiftory of Arabia Petræa.

I

F we leave Egypt upon the right Hand, and purfue thefe The Land of $^{2}$ Obfervations directly forwards into the Iand of $F$ Edom is of a W we fhall be prefented with a Variety of quite different Profpects, H. H. Land. from thofe we have met with in the Land of Canaan. For we are not here to be entertained with any Paftures cloathed with Flocks, or Valleys ftanding thick with Corn; here are no Vineyards, or Olive Yards; but the whole is a lonefome, defolate Wildernefs, no otherwife diverfified than by Plains that are covered with Sand, and Mountains that are made up of naked Rocks and Precipices. Neither is this Country, ever, unlefs fometimes at the Equinoxes, refrefhed with Rain; but the few hardy Vegetables, which it produceth, are ftunted by a perpetual Drought; and the Nourifhment which is contributed to them, by the Dews, in the Night, is fufficiently impaired, by the powerful Heat of the Sun, in the Day. The Intenfenefs of the Cold and Heat at thefe refpective Times, very emphatically Accounts for the Provifion of Providence in fpreading out for the I/raelites, a Cloud to be a Covering by Day, and Fire to give Light (and Heat) in the Night Seafon. Pf.ro5.39.

$$
\text { Cicce }
$$

But 
The Atmofphere ufually jerene.

areat Storm at Mount Sinai.

The Mo: $n$ tains of sand.
But to be more particular: When I travelled in this Country, during the Months of September and October, the Atmopphere was perfectly clear and ferene all the Way from Kairo to Corondel; but from thence to Mount Sinai, the Tops of the Mountains would be now and then capped with Clouds, and fometimes continue fo for the whole Day. This Difpofition of the Air was fucceeded, foon after, by a violent Tempeft, when the whole Heavens were loaded with Clouds, which difcharged themfelves, during nearly the Space of a whole Night, in extraordinary Thunderings, Lightnings, and Rain. But thefe Phrenomena are not frequent, rarely falling out, as the Monks informed me, above once in two or three Years.

The Quality Except at fuch extraordinary Conjunctures as thefe, there is the fame uniform Courfe of Weather throughout the whole Year; the Sky being ufually clear, and the Winds blowing briskly in the Day and ceafing in the Night. Of Thefe, the Southerly ones are the gentleft; though Thofe in other Directions are the moft freouent; and, by blowing over a vaft Tract of this fandy Defert and bearing away the fandy Surface along with them, make continual Encroachments upon the Sea, and frequent Changes upon the Continent. For to thefe we may attribute the many Billows and Mountains of Sand, which lye fcattercd all over thefe Deferts. For the fame Caufe likewife, not only the Harbour of Suez, is, at prefent, intirely filled up, but the very Channel of the Sea, which extendeth itfelf two or three Miles further to the Northward, nay once perhaps reached as far as Adjeroute, (the Heroopolis as it is fuppofed to be, ) is now dry at half Ebb, though fometimes the Sea floweth here near the Height of a Fathom.

The plain Part Where any Part of thefe Deferts is fandy and level, the

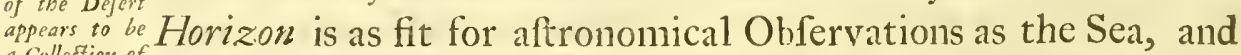
a collection of Viatir. appears, at a fmall Diftance, to be no lefs a Collection of Water ${ }^{\text {. }}$ It was likewife equally furprizing, to obferve, in what an extraordinary Manner every Object appeared to be magnifyed within it; infomuch that a Shrub feemed as big as a Tree, and a Flock of Achbobbas might be miftaken for a Caravan of

I The like Obfervation is taken Notice of by Diodorus Siculus in his Account of Africa.

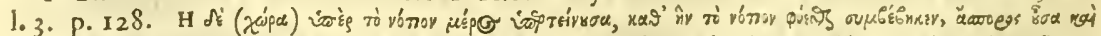

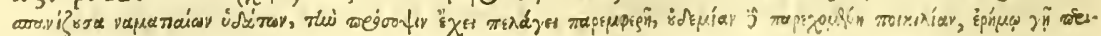

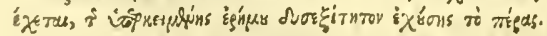

Camels. 
Camels. This feeming Collection of Water, always advances, about a Quarter of a Mile before us, whilft the intermediate Space appears to be in one continued Glow, occafioned by the quivering undulating Motion of that quick Succeffion of Vapours and Exhalations, which are extracted by the powerful Influence of the Sun.

The fame violent Heat may be the Reafon likewife, why carcafesrarithe Carcaffes of Camels and other Creatures, which lye expofed thefo $D$ fertso in thefe Deferts, are quickly drained of that Moifture, which would otherwife difpofe them to Putrefaction; and, being hereby put into a State of Prefervation ', not much inferiour to what is communicated by Spices and Bandages, they will continue a Number of Years without mouldring away. To the fame Caufe alfo, fucceeded afterwards by the Coldnefs of the Night, we may attribute the plentiful Dews, and thofe thick offenfive Mifts, one or other of which we had every Night too fenfible a Proof of. The Dews particularly, (as we had the Heavens only for our Covering,) would frequently wet us to the Skin: but no fooner was the Sun rifen, and the Atmo/phere a little heated, than the Mifts were quickly difperfed, and the copious Moifture, which the Dews communicated to the Sands, would be intirely evaporated.

Fountains and Wells of Water are fo very rare in thefe Parts, Fouztains that we may very well account for the Strife and Contention ${ }^{2}$, very rarely that there was formerly about them. In the Midland Road betwixt Kairo and Mount Sinai, I do not remember to have heard or tafted of more than five, and thofe were, all of them, either brackifh or fulphureous. Yet this Difagreeablenefs in the Tafte, is vaftly made up by the wholefome Quality of the Waters; for they provoke an Appetite, and are remarkably lenitive and diuretick: and it may be owing to thefe Qualities, that few Perfons are feized with any Illnefs, during their Travels through thefe lonefome, fultry Deferts.

I I have been credibly informed, that, at Saibah, (fo if I miltake not the Place was called) which lyeth about the half Way betwixt Ras Sem and Egypt, there are a Number of Men, Affes and Camels, which have been preferved from Time immemorial in this Manner. They are fuppofed to have belong to fome Caravin or other, which, in paffing over thefe Deferts, was fuffocated by the hot burning Winds that now and then infeft thefe fandy Countries. 2 And Abraham reproved Abimelech becaufe of a Well of Water, which Abimelech's Servants had violently taken awway. Gen. 21. 25. And the Herdfmen of Gerar did frive with Ifac's Herdfmen, faying, the Water is ours: and he called the Name of the Well Eleck, (Contention) becaufe they frove with bim. Gen. 26. 20. 
The Quality of The Fountains called Ain el Monfa are lukewarm and fulthe Waters
of Ain el phureous, boyling up three or four Inches above the Surface, Moufa. as if they were agitated below by fome violent Heat. The of the Forn-Fountain, two Leagues to the Weftward of Suez, where there tain near are feveral large Troughs for the Convenience of watering
Suez. their Cattle, is brackifh; and therefore the Inhabitants of that Village are obliged to drink of the Ain el Monfa, which lyeth, at the fame Diftance, on the other Side of the Red Sea. The Exchange indeed is not extraordinary, yet preferred by being of the Ham-more wholefome. The Waters of Hammam Pharcoune, near mam Phara-
oune. of a fower, vitriolick Steam : our Conductors affirming, at the fame Time, with great Gravity and Serioufinefs, that they would boyl an Egg in one Minute, and macerate it in the next. But I had not an Opportunity of trying the Experiof the Ham-ment. The Water of Hamman Moufa, among the Wells of mam Moufa. Elim, is moderately warm and fulphureous: but that of theWells is brackifh, and of a crude Digeftion, creating thofe fcrophulous Tumours, that Sallownefs of Complexion, and thofe Obftructions in the Bowels, which are too much complained of of the Waters by the Inhabitants of Tor, who drink them. The Waters of of Corondel
and Paran. Corondel, and thofe near Paran were lukewarm, and feemed to be impregnated with a fmall Mixture both of Salt and Sulphur; though both of them, from being fituated in the midft of Mountains, may have their original Taftes and Qualities frequently foftned, efpecially in the Morning, by the plentiful Dews, which are difcharged into them in the Night.

The situation The brackifh Waters of Elim and Suez, and the fulphureous of thefe Foun- Waters of Ain el Moufa, are fituated, upon level Ground, a
tains. tains. great Way removed from any Range of Mountains. Thofe particularly of Ain el Moula, cherifh and refrefh the higheft Part of an extenfive Plain. The throwing of themfelves up therefore in Fet d'eaux, will be a Circumftance the more extraordinary; and which perhaps is to be no otherwife accounted for, than by deducing their Origine from the great Abyfs. But the Fountain within the Convent of St. Catharine, That of the Forty Martyrs, in the Plain of Repbidim, and another, which we find in the Valley of Hebron, near the half Way from thence to the Defert of Sin, are Sources of excellent Water; which the Palate finds to be the more delicious, as it hath for 
fifteen Days before, been acquainted with what was intirely difagreeable.

If then we may prefume to determine the State of the Earth The Farth

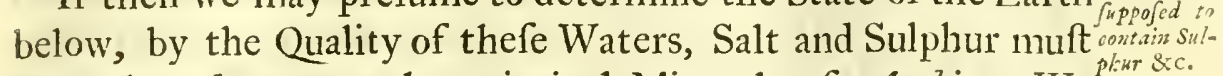
be reckoned among the principal Minerals of Arabia. We might in like Manner conclude from the naufeous fowcr Smell, and the pretended Corrofivenefs of the Waters of the Hammam Pharaoune, that there was lodged in that confiderable Range of Mountains, fome large Fund of vitriolick Salts, with a fmall Portion of Sulphur and Arfenick. The Number of Vegetables being too inconfiderable to interfere in the Difpute; the particular Smell of Sulphur and Arfenick which attend the Mifts I have mentioned, may perhaps give us fome further Hints with Regard to the Minerals below, from whence they are detached. The ruddy Appearance alfo of the Sun and Moon through this Medium, as the like Phrenomenon is obferved through the Smoke of Turf and Coal, fhould no lefs inftruct us, that there was fomewhere or other, in this Neighbourhood, a great Quantity of bituminous Matter. Yet I do not pretend to lay any Strefs upon thefe Reafonings; for I never faw either Salt, Sulphur, Vitriol, Arfenick or Bitumen in fubftance, or concreted, at or near any of thofe Places, which, by other Symptoms, feem to contain them.

But of the more fixed and permanent Foffils, there are feve-Great Quanral which are not common in other Places. Thus the Selenites ilitense of Seis obferved to floot itfelf fometimes for the Space of thirty or forty Yards together, in a great Variety of Shapes and Colours. A beautiful Kind of Cawk, the Pfendo-Fluor of the Naturalifts, Preudogives likewife a wonderful Glaring to the Rocks, and frequently diftinguifheth itfelf in large Expanfions, like the Selenites. The Marble which is called fometimes Thebaic ${ }^{2}$, from being dug in the Mountains of that Diftrict, fometimes Granate, and Granate from the Number of little Grains whereof it feems to be compounded, is much more common, than the P/eudo-Fluor and Selenites. It appears to be nothing elfe than a Congeries of Cazwky Nudules, of different Shapes and Sizes, beautifully united

I Several of the Quarries are Atill remaining, from whence the Egyptians received their Obelisks and other large Pieces of the fame Kind of Marble. There was a Canal detatched from the Nile to each of thefe Quarries, fo that by putting the Obelisk \&rc. upon a Float, they could eafily convey it, efpecially at the Time of the Inundation, to the Place where it was to be erected.

\section{Ddddd}


together: which from the Likenefs they bear to a Compofition of Mortar and Gravel, might occafion feveral ingenious Perfons to imagine, that Pompey's Pillar, the Obelisks at Rome and Alexandria, with other the like extraordinary Lumps of this Sort of Marble, were factitious, and produced by Fufion. That Kind of it which I faw in the Neighbourhood of Mount Sinai, and in the Midland Road from thence to Corondel, is generally of a light gray Colour, with little black Spots interfperfed; though, in fome Places, I have feen it much blacker, and, in others, of a reddifh Complexion. Sometimes alfo the conftituent Particles were fo fmall and well compacted, that the Contexture was not inferiour either to Serpentine Marble or Porphyry.

That Part of Mount Sinai, which lyeth to the Weftward of the Plain of Repridim, and is called the Mountain of St. Catharine, confifts of a hard reddifh Marble, like Porphyry, but is diftinguifhed from it, by the Reprefentations, which every Part of it gives us, of little Trees and Bufhes. The Naturalifts call this Sort of Marble Embufcatum or Bufby Marble ; and, for the fame Reafon, Buxtorf ${ }^{2}$ deriveth the Word Sinai, from the Bufh (or Rubus) that was figured in the Stones of it. It feems to have been hitherto left undecided to what Species of Plants this Bufh is to be referred; yet if thefe impreffed Figures are to inftuct us, we may very juftly rank it among the Tamarisks, the moft common and flourifhing Trees of thefe Deferts. I have feen fome Branches of this Foffil Tamarisk, as I thall call it, that were near half an Inch in Diameter. Yet the conftituent Matter, which was of a dark mineral Appearance like the Powder of Lead Ore, was of no Solidity, crumbling away, as the Armenian or any other Bole would do, by touching it.

The Strata The feveral Strata in thefe and moft of the other Mountains clofely joyned. which I have feen in Arabia, are generally fo many Kinds of

I Embufcatum ex monte Sinai (Hicrofolymitano male additur) depromptum; quod albicans eft (nofrum rubefcit) ad flavedinem tendens; \& quocunque modo fecetur aut dividatur, in co arbufta \& frutices, colorc nigricante, fubtiliter a Natura depicti apparent. Si fupra ignem ponatur, brevi cvanefcit pictura \&c. Ego Anglice 1 Hof falem nominarem. Charlt. Exercit. de Foffil. p.19. 2 'J'O Sinai montis nomen, a רנס Rubus, quod lapides inventi in eo figuratum in fe babnerimt rubum, ut fcribunt commentatores in librum More nebhuchim, p. 1. cap. 66. adeo ut criam in fragmentis lapidum iftorum, figuræ rubi apparuerint, quod fe Ephodeus, alter iftorum commentatorum, vidilfe fcribit. Burtorf. in voce הנת. Horeb בר, the other Name, by which this Mountain is likewife known in Scripture, fccms very juftly to exprefs the burren defolate Condition of it, from הרב, Siccarus, vaftatus, defolatus; in folitudinem red.uctus fuit \&e.

Marble, 
Marble, cemented, as it were together, by thin fparry Sutures of various Textures and Colours. There are likewife a great many remarkable Breaches in thefe Strata, fome of which lye twenty or thirty Yards afunder, the Divifions on each Side tallying exactly with each other, and leaving a deep Valley in the Midft.

Betwixt Kairo and Suez we meet with an infinite Number of Probeantiful Fbints andPebbles, all of them fuperiour to the Florentine Marble, tbefedesfirts. and fiequently equal to the Moca Stone, in the Variety of their Figures and Reprefentations ${ }^{2}$. ButFoffil Shells and other the like Fofitsbillsare

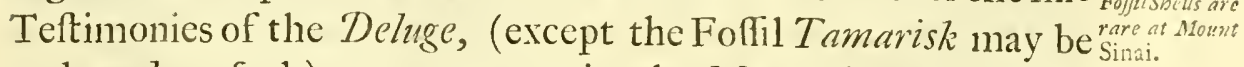
reckoned as fuch) are very rare in the Mountains near Sinai, the Original Menftrum perhaps of thefe Marbles being too corrofive to preferve them. Yet at Corondel, where the Rocks approach nearer to our Free Stone, I found a few Chamce and Pectunculi, and a curious Echinus, of the Spatagus Kind, but rounder and flatter. The Ruins of the fimall Village at Tic Walls of Ain el Monfa, and the feveral Conveyances we have there for Suezeril shcilss. Water, are all of them full of Foffil Shells. The old Walls of Suez, and the Remains that are left us of it's Harbour, are likewife of the fame Materials: all of them feeming to have been brought from the fame Quarry. Betwixt Suez and Kairo likewife, and all over the Mountains of Lybia, every little rifing Ground and Hillock that is not covered with Sand ${ }^{2}$, difcovers great Quantities of the Echini, as well as of the Bivalve and Turbinated Shells, moft of which exactly correfpond with their refpective Families, ftill preferved in the Red Sea.

There is no great Variety of Plants to be met with in thefe $v_{\mathrm{r}} \mathrm{ry}, \mathrm{fm}$ Deferts. Thofe Acacias, Azarolas, Tamarisks, Oleanders, Prabuts. Laureolas, Apocynums, and a few other Plants which I have feen, are generally indebted to the Clift of fome barren Rock or to the fandy Plains, for their Support; and to the nightly

1 Profp. Aipinus (Hift. Nat. Aggypt. cap. 6. p. I 47.) calls thele Pebbles Silices Silvifere, in quibus Japidibus five, herbarum, fruticum \&c. pictx imagines cernuntur. 2 For the fame Rcaion the moveable Sands in the Neighbourhood of Ras Sem, in the Kingdom of Barca, frequently conceal a large Scene of Palm Trees, Echini, and other Petrifications, which otherwife are ulually lcen at that Place. Ras Sem, i. c. The Head of Poyfon, is what we com. monly call the Petrifyed lillage, where, it is pretcnded, that they find in different Poftures and Attitudes, Men, Women and Children, their Cattle alfo, Food, Hounold-Stuff, \&c. turned into Stone. But there is nothing at this Place befides fuch Remains of the Deluge as are common at other Places: all other Stories being vain and idle, as 1 was fully inftructed, not only by M. Le Muire, who, when Conful at Tripoly, fent feveral Pertons to make Difcoveries, but allo by two grave fenfible Perfons, who had been upon the Spot.

\section{$\mathrm{Ddd} d \mathrm{~d} 2$}

Dews, 
Dews, for their Nourifhment ; for Soil, properly fo called, is not The Garden of to be found in thefe Parts of Arabia. The Monks indeed of Mery fruitful. Sinai, in a long Procefs of Time, have covered over with Dung and the Sweepings of their Convent, near four Acres of thefe naked Rocks; which produce as good Cabbage, Roots, Salad, and all Kinds of Pot-Herbs, as any Soil and Climate whatfoever. They have likewife raifed Olive, Plum, Almond, Apple and Pear Trees, not only in great Numbers, but of excellent Kinds. The Pears particularly, are in fuch Efteem at Kairo, that there is a Prefent of them fent every Seafon to the Baflow, and Perfons of the firft Quality. Neither are their Grapes inferiour in Size and Flavour to any whatfoever: it being fully demonftrated by what this little Garden produces, how far an indefatigable Induftry can prevail over Nature; and that feveral Places are capable of Culture and Improvement, which were intended by Nature to be barren, and which the lazy and flothful have always fuffered to be fo.

The Corals \&c. of the Red Sea.

Yet the Deficiencies in the feveral Claffes of the Land-Plants, are amply made up in the Marine Botany : no Place perhaps affording fo great a Variety as the Port of Tor. In rowing gently over it, whilft the Surface of the Sea was calm, fuch a DiverThe branched fity of Madrepores, Fucufes, and other marine Vegetables prefented themfelves to the Eye, that we could not forbear taking them, as Pliny ' had done before us, for a Forreft under Water. The branched Madrepores particularly, contributed very much to authorize the Comparifon; for we paffed over feveral that were eight or ten Foot high, growing fometimes pyramidical, like the Cypress; at other Times had their Branches more open and diffufed, like the Oak; not to fpeak of others, which, like the creeping Plants, fpread themfelves immediately over the Bottom of the Sea.

The Fungi, To thefe Species, which are branched, we may joyn the Juc.

I Nafcuntur \& in mari ( $\dot{R} u b r o)$ frutices arborefque, minores in noftro. Rubrum cnim, $\&$ totus Orientis Oceanus refertus eft Sylvis. $* *$ ln mari vero $R$ ubro Sylvas vivere, laurum maxime \& olivam ferentem baccas; \& cum pluar, fungos, qui fole tacti mutantur in pumicem. Fruticum ipforum magnitudo, ternorum eft cubitorum, caniculis referta, ut vik profpicere e navi tutum fit, remos plerumque ipfos invadentibus. Plin. 1.x 3. cap.25. * Quod per totam Rubri Maris oran maritimam arbores in profundo nafcantur, lauro \& olex perfimiles; qux in refluxibus ex toto deteguntur, in affluxibus nonnunquam ex toto obruunrur, quod eo fir mirandum magis, quia tota fuperjacens regio arbuttiscarer. Quod Mare Rubrum profunditatem non habet; nam duas orgyas non excedit; unde herbida elt fuperficies, dum plantz fefe exferant. Chryfof. cx Strab. Geogr. l. I6. p. 2 I 3. Ed. Hudf.

Coralline 
Coralline Bodies, which frequently grow into Maffes of an extraordinary Size, and ferve, not only for Lime, but alfo for the chief Materials in the Buildings of Tor. The Fungus, properly fo called, is always joyned to the Rock, by a feemingly fmall Root, being the Reverfe of the Land Mufhroom, in having it's Gills placed upwards. This and the Brain-Stone are obferved to preferve conftantly a certain fpecifick Form in theirConfigurations : the other CorallineBodies alfo have each of them their differently figured Afterisks impreffed upon them, whereby they likewife may be particularly diftinguifhed. But thefe only regard their Surfaces; for, having not the leaft Appearances of Roots as the Fungus and the Brain Stone feem to have, they are to be confidered as certain rude Maffes only of this Coralline Subftance, which, at the feveral Periods of their Growth, mould themfelves into the Figures of the Rocks, Shells, and other Matrices, that lye within the Reach of their Vegetation.

All thefe Species are covered over with a thin glutinous of the VegeSubftance, or Pellicule, as I fhall call it; which is more thick Mation of the and fpongy near and upon the Afterisks, than in any other Part. For, if we may be allowed to offer a few Conjectures concerning the Method of their Vegetation, it is probable, that the firft Offices of it are performed from thefe Afterisks; cfpecially if thofe Setts of little Fibres, which belong to them, fhould prove to be, as in all Appearance they are, fo many little Roots. Now thefe little Roots, if carefully attended to, while the Madrepore is under Water, may be obferved to wave and extend themfelves like the little Filaments of Mint preferved in Glaffes, or like the Mouths or Suckers of the Sea Star, or of the fimall floating Polypus. But the vely inftant they are expofed to the Air, they become invifible, by a Power they have then of contracting themfelves and retiring within the Furrows of their Afterisks.

In the true Coral, and Lithophyta, (to hint fomething alfo Tbe Vegctaof their Hiftory) the Method is a little different. For thefe $\theta c_{c}$ of Coral are not marked with Afterisks like the Madrepores, but have their little Roots iffuing out of certain finall Protuberances, that are plentifully difperfed all over their Pellicules; ferving, as the Afterisks do in the other Clafs, for fo many Valves or Cafes, to defend and thut in their refpective little Roots. We 
may take Notice further, that thefe Protuberances are generally full of a milky, clammy Juice, (perhaps juft fecreted by the little Roots) which in a fimall Time coagulates, then becomes like unto Bees Wax, in Colour and Confiftence, and afterwards, as I conjecture, is affimilated into the Subftance of the Coral or Lithophyton itfelf.

The different Method of $V_{e}$ getation be- Root, as it hath dene to thofe of the Land, how wifely hath Plants cand it fupplyed That Mechanifm by a Number of little ones, which thefe Coral-
line Bodies. are diftributed, all over the Plant, in fo juft a Proportion, that they are lodged thicker upon the Branches, where the Vegetation is principally carried on, than in the Trunk, where it is more at a Stand, and which therefore is often found naked, and feldom increafing in the fame Proportion with the Branches. The Terreffrial Plants could not fubfift without an Apparatus of great and extenfive Roots; becaufe they are not only to be hereby fupported againft the Violence of the Wind, which would otherwife blow them down; but their Food alfo is to be fetcht at a great Diftance. Whereas the marine Vegetables, as they are more fecurely placed, fo they lye within a nearer Reach of their Food, growing as it were in the Midft of Plenty, and therefore an Apparatus of the former Kind, muft have been unneceflary, either to nourifh or fupport them.

The Red Sea called the

The Fucufes, which I have mentioned, feem to have given the Name of Suph or Souph to this Sea, being otherwife called, the Sea of Edom, and improperly, the Red Sea, by taking Edom for an Appellative. The Word 90 is alfo rendred Flags by our Tranflators, (Ex. 2.8. and Ifa. I9.6.) and Funcus or Funcetum by Buxtorf. I did not obferve any other "pecies of of theFlag-Kind; but there are feveral Thickets of theArundinaceous Plants, at fome fmall Diftances from, though never, as far as I could perceive, either upon the immediate Banks, or growing out of the Red Sea. We cannot then well fuppofe, that this Sea fhould receive a Name from a Production, which

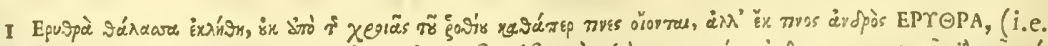

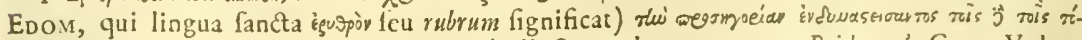
mots. Suid. in voce. Vid. Nic. Fuller. Milccll. Sacra. I. 4. cap. 20. Prideaux's Conn. Vol. 1.

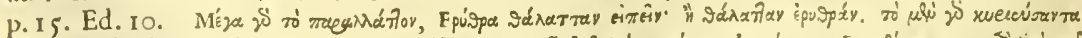

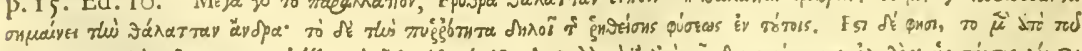

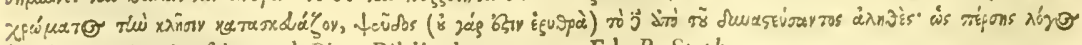
ôngsizzor. Agath.urful. apud Phot. Biblioth. p.1324. Ed. P. Steph. 
doth not properly belong to it. It hath been thought more proper therefore to tranflate 0 . The Sea of Weeds, or The Weedy Sea', from the Variety of Algre and Fuci, that grow within it's Channel, and, at low Water particularly, are left in great Quantities upon the Sea Shore.

Though the marine Botany is very entertaining, yet there other marine is an additional Pleafure in obferving the great Variety of Productions; Urchins, Stars, and Shells, which prefent themfelves at the fame Time. The Firft are moft of them beautiful and un- U:chins. common. We find fome that are flat and unarmed, of the Pentaphylloid Kind: others that are oval, or elfe globular, very elegantly ftudded all over with little Knobbs, which fupport fo many Prickles. This Sort of Armour is fometimes thicker than a Swan's Quill; fmooth and pointed in fome Species; but blunt and rongh, like the Lapides Fudaici, in others. The moft curious Star which I faw, made, with it's Sea Sars. five Rays, (or Fingers as we may call them) a Circumference of nine Inches in Diameter. It was convex above, guarded all over with Knobbs, like fome of the Echini, but the under Side was flat and fmoother, having a flit or furrow, capable of expanding or contracting itfelf, running the whole Length of each Finger. For this Part of the Finh always lyeth open, difplaying an infinite Number of finall Filaments, not unlike in Shape (what we commonly call) the Horns of Snails. Thefe are fo many Mouths, continually fearching after Nourifhment; and as the Coralline Bodies have been obferved to be all Root, the Star may be faid to be all Mouth; each of the little Filaments, I have mentioned, performing that Office. By applying the Hand to thefe little Mouths, we quickly perceive the Faculty, which each of them hath, of fucking like a Cupping Glafs: but no fooner is the Fifh removed into the Air, than they let go their Holds, and the Furrow, which was before expanded, is now immediately fhut up. There would be no End Shells. of enumerating the great Diverfity of Shells which adorn the Banks, or lye in the Shallows of the Red Sea. The Concha

I However it fhould not be omitted, that Lipenius furnifheth us with a very ingenious conjecture in fuppofing This, in Contradiltinction perhaps to the ל'רנד. Great Sea or Mediterranean, to be the Same with a Sea that is circumforibed by (vifible) Botnds on both Sides. Dicitur mare Suph Hebraice ex Rad. ๆ 0 deficere, finire, unde eft nomen feu extremitas. Eccl. 3. I1. Hinc mare Suph eft in verbi mare finitum, limitatum, terminis \& littoribus circumfeptum. Vid. Lioenij Navigat. Salomonis Ophirit. Illnftrat. Witt. I660. p. 286 .

E e e e 2

Veneris 
Veneris is feen in a great Variety of Spots and Sizes: whilft the Turbinated and Bivalve Shells, of all Kinds, are not only common and in a great Luxuriancy of Colours, but are alfo fometimes fo exceedingly capacious, that there have been found fome, of theFormerSort, which were aFoot and an half Long, and of theLatter, that were as much in Diameter. I have already obferved, that the Port of Tor hath greatly contributed towards the Buildings of the adjacent Village. But this is not the only Conveniency and Advantage which the Inhabitants receive from it: inafmuch as they are almoft intirely nourined and fuftained by that Plenty of excellent Finh which this Port affords them. Neither is this all; for the very Furniture and Utenfils of their Houfes are all fetched from the fame plentiful Magazine; the Nautilus fupplying the Place of a Cup, and the Buccinum that of a Jar, whilft the Concha Imbricata is what they ufually ferve up their Food in.

Fim Species

The fhort Time our Conductors would allow us to ftay at of Animals in
this Part of Tor and Suez, would not give me an Opportunity of making Arabia.

any further Obfervations either in the Botany or Zoology of the Red Sea. As we were likewife frequently obliged, for Coolnefs, to travel in the Night, feveral Foffils, Plants and Animals, befides other Curiofities, muft undoubtedly have efcaped my Notice. Yet I fhould not omit obferving, that we were now and then offended with feveral little Swarms of Locufts and Hornets, both of them of an unufual Size, though of the ordinary Colours. Vipers, efpecially in the Wildernefs of Sin, were very dangerous and troublefome; not only our Camels, but the Arabs who attended them, running every Moment the Rifque of being bitten. But the Lizard Kind, in their Variety of Shapes and fpotted Coverings, afforded an Amufement far more inno-

The Ach Bobba, or Percnopterus. cent and diverting. Near Kairo there are feveral Flocks of the $A c h B o b b a^{\prime}$, which, like the Ravens about our Metropolis, feed upon the Carrion and Naftinefs, that is thrown without the City. This Bird is the fame with the Percnopterus or Oripelargus of the Naturalifts ${ }^{2}$, the $[a+\dot{x}$,$] Rachamals of the$ Arabs $^{3}$, and the

I Ach Bobba, in the Turkißh Language, fignifies W/ite Futher; a Name given it partly out of the Rererence they have for it, partly from the Colour of it's Plumage: though, in the other Refpeet, it differs little from the Stork, being black in feveral Places. It is as hig as a large Capon, and exactly like the Figure which Gefner Lib.3. de Avib. p. 176. I tath given us of it. 2 Vid. Gefn. ut fupra. Ariff. Hift. Anim. 1.9. cap. 32. Quarti generis (Aquilarum) eft Percnopterus: cadem Oripelargus vulturina fecic, alis minimis, rcliqua magnitudine antecellens, fed imbellis \& degener, ut quam verberet corvus. Plin. 1.10. cap.3. 3. This hould be the Same with $\square$ Lev.II. IS. and המרז Deut.I4. 17. which in our Tranllation, isrendred in both Places the Geer Eagle. 


\section{in Arabia Petrã 0 c.}

Egyptian Hawk perhaps, which Strabo ' defcribeth, contrary to the ufual Qualities of Birds of that Clafs, to be of no great Fiercenefs. For the $A c b$ Bobbas are very harmlefs Birds, and efteemed by the Mahometans to be facred; upon which Account the Bafbaw diftributeth among them, every Day, two Bullocks; a Relick, as it feems to be, of the antient Egyptian Superftition ${ }^{2}$. At Corondel I faw a Pair of Doves, and the fame Number of Doves. Antilopes; befides which, and fome few Species of Infects, I Antilopes. did not meet with any other Animal.

For there is no Place in the World that abounds lefs with Animals trave living Creatures than This; and indeed, where hath Nature little ${ }^{u_{f}{ }^{0} \text {. }}$. made lefs Provifion for their Suftenance? The Quails muft have been fed, as well as brought, by a Miracle, if they had continued alive with the I/raelites: and might they not, without the like Miracle, have died of Thirft in the Wildernefs? We can- The cand not therefore fufficiently admire the great Care and Wifdom of ally, created God, in providing the Camel for the Traffick and Commerce for the of servere of Thefe, and fuch like defolate Countries. For, if this ferviceable Creature was not able to fubfift feveral Days without Water; or if it required a Quantity of Nourifhment in Proportion to it's Bulk, the travelling in thefe Parts would be either cumberfome and expenfive, or altogether impracticable.

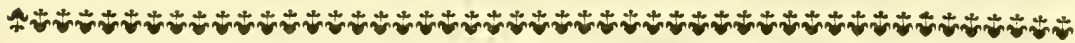

\section{H A P. V.}

\section{Phyfical and Mifcellaneous Obfervations in Egypt.}

$B^{\mathrm{B}}$ EsIDES the great Variety of Arts and Sciences that Egypt the were known to the Egyptians, we read of no other Na-Learying, tion in Hiftory that could boaft of the like Number either of natural or artificial Curiofities. It was the Fame and Reputation, which Egypt had acquired, of being the School and Repofitory of thefe feveral Branches of Knowledge and Ingenuity, that engaged Orpheus, Pythagoras, and other Perfons of the firft Rank in Antiquity s, to leave their own Country to be acquainted with This. And thefe Philofophers were fo artful

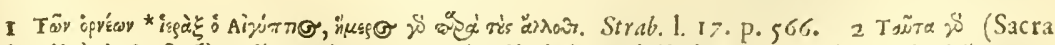

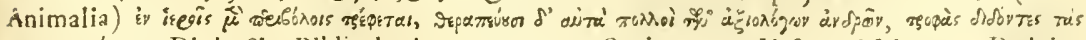

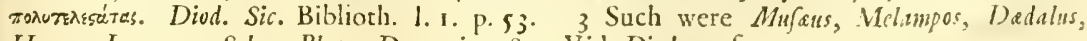
Homer, Lycurgus, Solon, Plato, Democritus \&ec. Vid. Diod. ut fupra. 
in firft introducing themfelves ', they complyed fo readily with the Cuftoms of the Country ${ }^{2}$, and were fo happy in addreffing themfelves to the Perfons ${ }^{3}$ who were to inftruct them, that, notwithftanding the Jealoufy and Refervednefs ${ }^{4}$, which the Egyptians may be fuppofed to have entertained towards Strangers, they generally returned Home with Succefs, bringing along with them either fome new religious Rites or ufeful Difcoveries.

Greece reseived from thence $\mathrm{H}_{\mathrm{c}}$ Theology, Arts \&c.

Thus Herodotuss acquaints us, that the Greeks borrowed all the Names of their Gods from Egypt; and Diodorus ${ }^{6}$, that they not only derived from thence their Theology, but their Arts and Sciences likewife. For, among other Inftances, he tells us, that the Ceremonies of Bacchus and Ceres, who were the fame with $O$ firis and $I f i s$, had been introduced very early among them by Orpheus: that, from the fame Source, Pythagoras, received the Doctrine of the Tranfmigration of Souls; Eudoxus, no lefs than Thales ${ }^{7}$, Mathematicks; and Dodalus Architecture, Sculpture and other ingenious Arts. According to the fame Author ${ }^{8}$, Greece was further obliged to Egypt, not only for Phyfick and Medicines ${ }^{9}$, but for a great many Laws, Maxims, and Conftitutions of Polity, which had been introduced among them by Plato, Solon, and Lycurgus. Even their more abftracted Learning, fuch as related to the Effence of the Deity, to the Power and Combination of Numbers, to their MONAs and TPIAs, with other Difquifitions of the like Nature, feem

I lt might be for this Reafon that Plato \&ce. took upon him the Charaster of an Oyl-

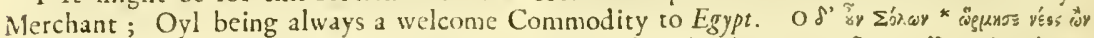

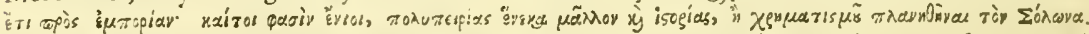

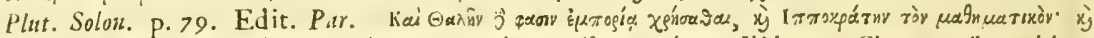

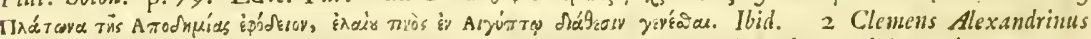
acquaints us, that Pythagoras was circumcifed in Order to be admitted into their Adyta;

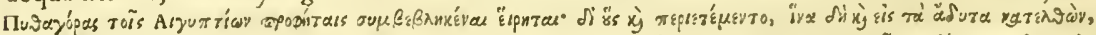

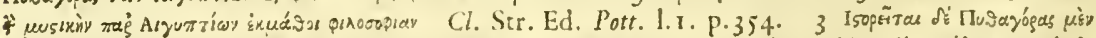

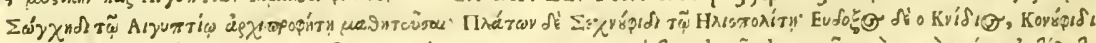

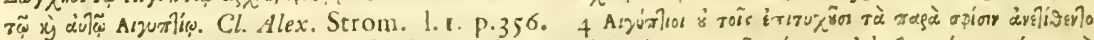

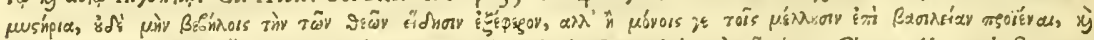

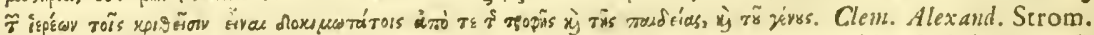

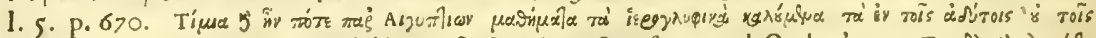

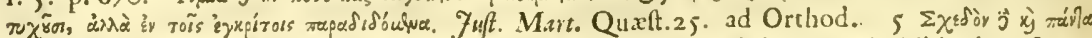

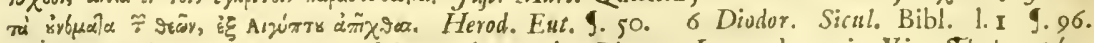

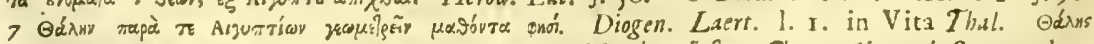

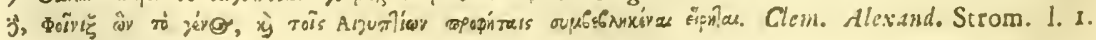
p. 221. 8 Diod. Sic. Bibl. ut fupra.

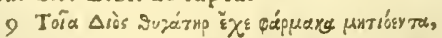

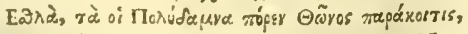
Alyurtin. \& $\mathrm{C}$.

Hom. Odyff. $\triangle .1 .227$.

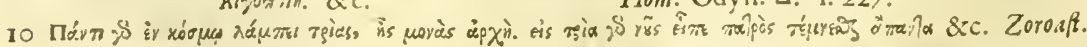
apud. Kirch. Edip. Egrpt. Svnt. 1. p.100. 
to have been tranfcribed from thence into the Works of Plato and Pythagoras.

Their fymbolical Learning alone, either as it was conveyed, None of the in Sculpture, upon their Obelisks \&c. or in Colours, upon the $\begin{gathered}\text { Egyptial } \\ \text { Herogly- }\end{gathered}$ Walls of their Cryptre:, Mummy-Chefts, Boxes for their phicks stranfacred Animals \&c. appears not to have beenknown in Greece; ;necce. though, among the Antiquities of Hetruria ${ }^{2}$, we meet with fome faint Imitations of it; enough perhaps to prove, either that this Nation was originally related to Egypt, or that Pythogoras, or fome of his School, introduced it among them. However, though none of the Grecian Travellers, have tranflated into their own Country the Figures and Symbols themfelves; yet Diodorus in particular, in Conjunction with Porphyry, Clemens Alexandrinus, and other Authors, hath obliged us with the Defcription and Interpretation of the moft remarkable of them. But ftill, as a proper and faithful Key is want- The Dificilly ing to the whole Science, the Purport and Defign of any fingle them. Specimen of it, muft, of Courfe, remain a Secret, or be, at leaft, exceedingly dubious, uncertain, and obfcure.

Now, from what is prefumed to be already known of this what Bramfymbolical Learning, it is fuppofed, that the Egyptians chiefly ing of Learer recommitted to it, fuch Things as regarded the Being and Attri-corded in this butes of their Gods ${ }^{3}$; the Sacrifices and Adorations that were ${ }^{\text {ting. }}$ to be offered to them; the Concatenation of the different Claffes of Beings; the Doctrine of the Elements, and of the good and bad Diemons, that were imagined to influence and direct them. Thefe again were reprefented by fuch particular Animals ,' Plants, Inftruments \&c. as they fuppofed, or had

I Several of thefe Crypte, painted with fymbolical Figures, are feen ncar the Pyramids.

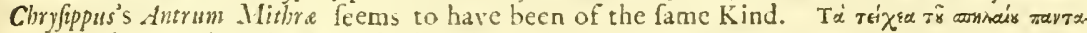

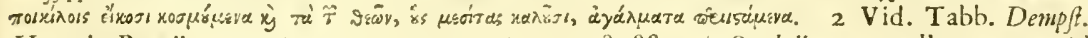
Hetrurie Regalis. 19. 26. 35. 39.47.63.66.77.78.88. * Symbolicum appello, cum quid colitur, mon quia creditur Deus, led quia Deum fignificat. ${ }^{* *}$ Quomodo Sol culcus in igne Veftali, Hercules in Statuâ 8rc. G. F. Vod. de Idolol. 1. I. cap. 5. 3 Hieroglyplitia Agyptiurum fapientia, reftantibus omnibus veterum fcriptorum monumentis, nihil aliud erar, quam fcientia de Deo, divinifque vittutibus, fcientia ordinis univerf, fcientia intelligentiarum mundi prefidum, quam Pythagoras \& Plato, notante Plutarcho, ex Mercurij columnis i. e. ex obelifcis didicerunt. Kirch. Ad. Ffgypt. Tom. 3. p. $\{67$. Agyptii per vortina Deorum univerfam rerum naturam, juxta Theologiam naturalem intelligebant. Macrob. Sat. l.t.cap.20. 4 According to an old Oblervation, the great Principle upon which the Symbolic Method

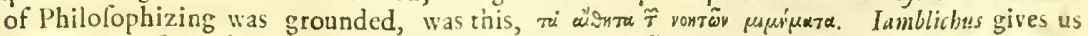

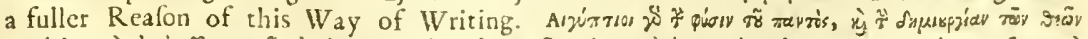

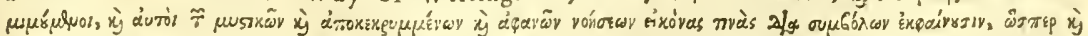

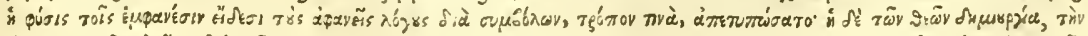

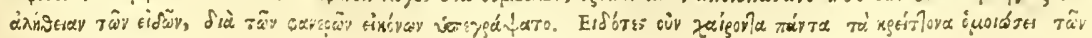


actually found, by a long Courfe of Obfervations, to be emblematical of, or to bear fome typical, or phyfical Relation to them. Every Portion therefore of this Sacred Writing, may be prefumed to carry along with it fome Points of Doctrine, relating to the Theology or Phyficks of the Egyptians; for Hiftory doth not feem capable of being delivered in fuch Expreffions.

Ofiris's Symbols, were the

In order therefore to give a few Inftances of this myftical Science, I thall begin with fuch of their Sacred Animals as were fymbolical of their two principal Deities, Ofiris and I/is; who are the fame with Baccbus and Ceres; the Sun and the Moon; and the Male and Female Parts of Nature ${ }^{2}$. The serpent. Serpent ${ }^{2}$ therefore, which is fometimes drawn with a turgid $\mathrm{Neck}^{3}$, as it was obferved to be an Animal of great Life and

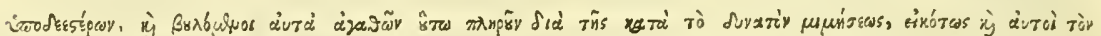

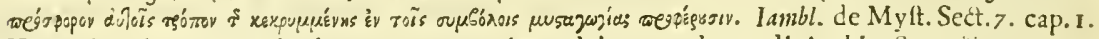
Hæc miranda naturx vis elevare corum animos debuerat ad mundi Architectum ** naturamque ob mirandas vires \& admirabilem ordinem colere cæperunt veluti principem Deum: partes vero Naturæ venerati funt, veluti Deos minores, quos \& ipfos pro præftantia \&

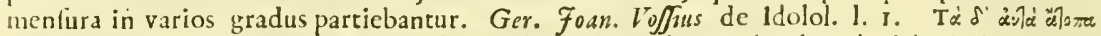

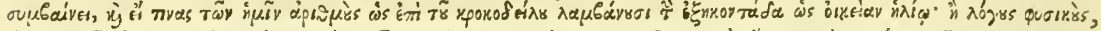

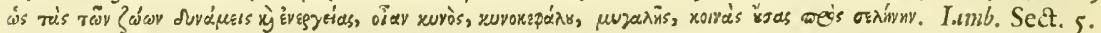

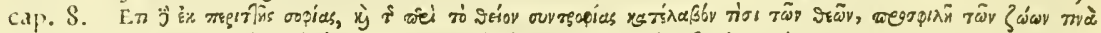

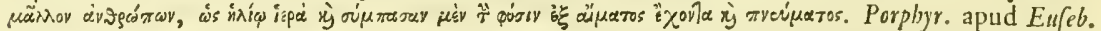

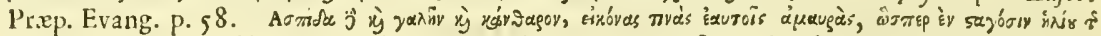

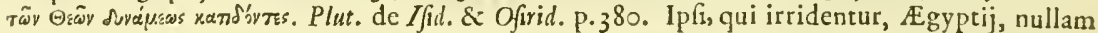
belluam, nifi ob aliquam utilitatem, quam ex ea caperenr, confecraverunt. $T$ ull. Nat. Deor.

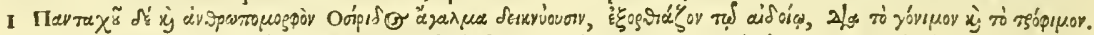

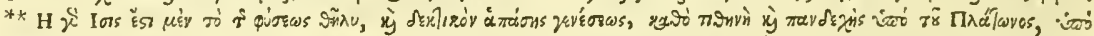

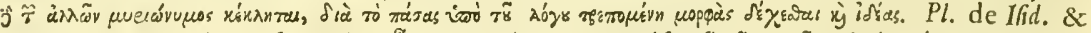

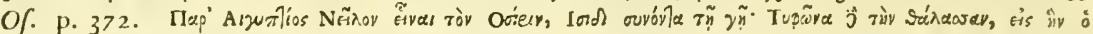

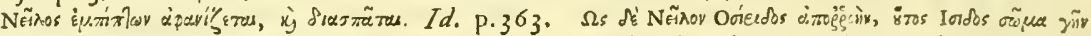

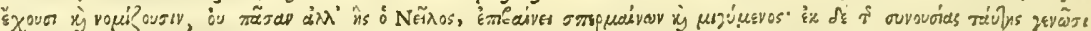

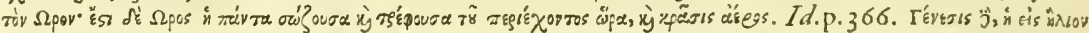

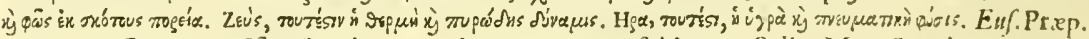
Ev. p. 52. Lat.1 544. IGs elt vel terra vel natura rerum fubjacens Soli. Mac. Sat. 1. r. cap. 20.

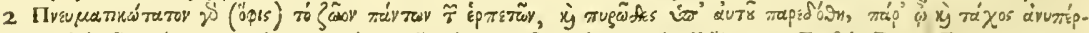

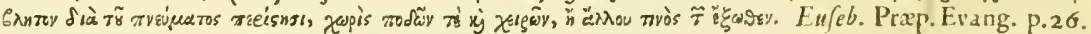

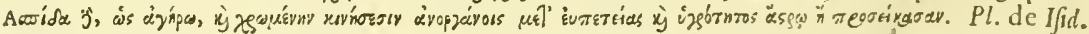
p. 381. Ut virefeunt dracones per annos fingulos pelle fenectutis exuta, propterea \& ad iplum Solem fpecies draconis refertur, quia Sol femper velut a quadam im depreffonis fenecta in altitudinem fuam ut in robur revertitur juventutis. Marrob. Sat. 1. r. cap. 20. Solis meatus, licet ab ecliptica linea nunquam recedat, furfum tamen ac deorfum ventorum vices certa deflexione variando iter fuum velut flexum draconis involvit. Id. ibid. cap. 17. Unde Euripides

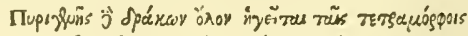

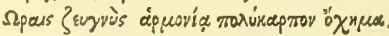

Afpida fomnifcram tumida cervice levavit. Lu. 1. 9.

Cymbij anfulx infurgebat Afpis, caput extollens arduum, cervicibus late tumefccntibus. Apul. Met. 1.1 r. p.258. Afpis, fquamex cervicis ftriato tumore fublimis. Id. ibid. p. 262. This Defcription agrees with the female Afpics according to the following Obfervation of Solinus. Subtiliora lunt capita fominis, alvi tumidiores, peftis nocention: mafculus æqualiter teres eft, fublimior ctiam, mitiorque. Solin. Polyhift. 1.40. de Afpidc. 
Sprightliness, moving along with many winding, circulatory Girations, and waxing young again, every Year, by the cafting of it's Skin, was one of the fymbolical Reprefentations of the Sun. The Beetle ${ }^{2}$ was alfo fubftituted for the fame Deity; Tro Beetle. inafmuch, as among other Reafons, all the Infects of this Tribe were fuppofed to be Males; that, in Imitation of the Sun's continuing fix Months in the Winter Signs, they continued the fame Time under Ground; and again, in Conformity alfo to the Sun's Motion, after having inclofed their Embryos in Balls of Dung, they rolled them along, with their Faces looking the contrary way. The Hawk', the Thauftus and Baieth The Hawk. as the Egyptians called it, was another Symbol, being a Bird of great Spirit and Vivacity, having a moft piercing Eye, looking ftedfaftly upon the Sun, and foaring, as they imagined, into the Region of Light. In like Manner, the Wolf 3, upon Tbe Wolf, Account of it's penetrating Sight and Voracity, was another ${ }_{\text {The Lyon and }}$ Emblem; as were alfo the Lyon ${ }^{4}$, and the Goofes, both of the Goofe?

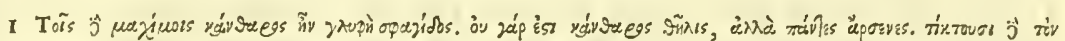

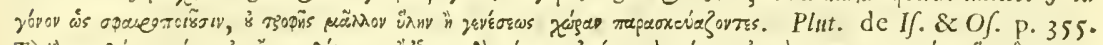

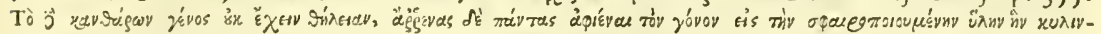

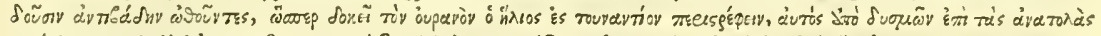

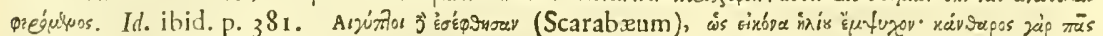

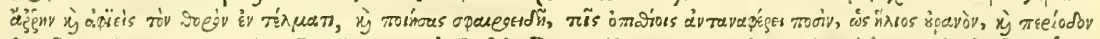

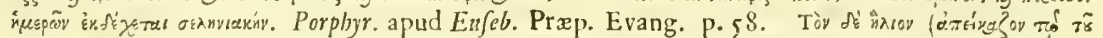

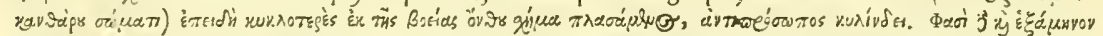

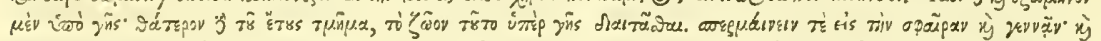

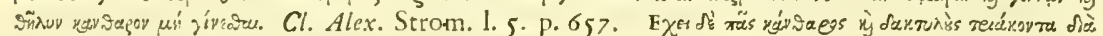

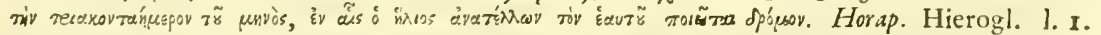

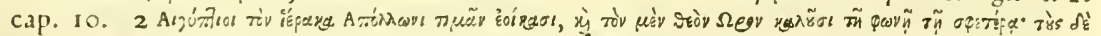

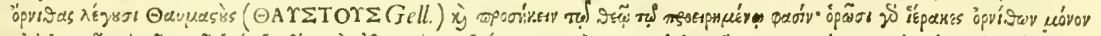

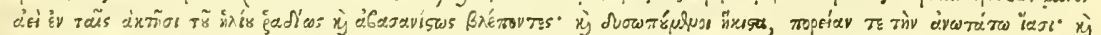

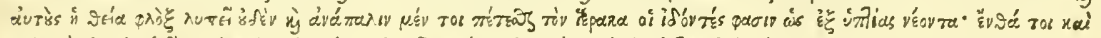

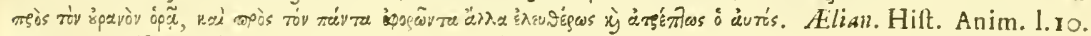

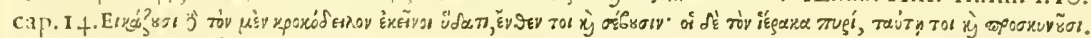

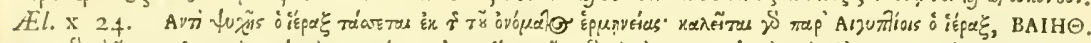

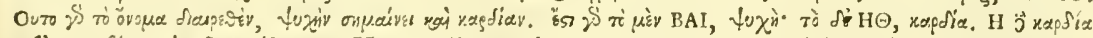

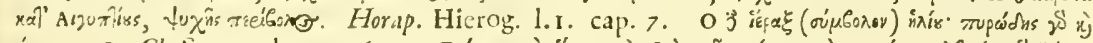

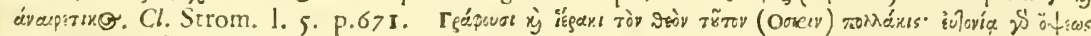

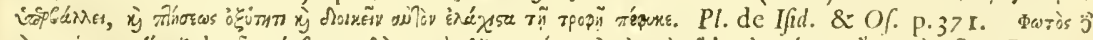

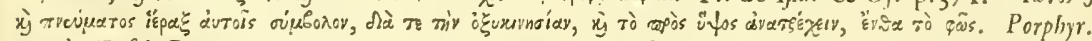
apud. Enfel. Prep. Evang. p.70. $3 \wedge$ rKON autem Solem vocari etiam Lycopolisum Thebidos civitas teftimonto eft: quæ pari religione Apollinem itemque Lupum, hoc eft, núxsv colit, in utroque Solem venerans, quod hoc animal rapit \& confumit omnia in modum Solis, ac plurimum oculorum acie cernens tenebras noctis evincit. Macrob. Sat. I. I. cap. 17. 4 Kapanì

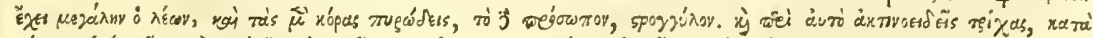

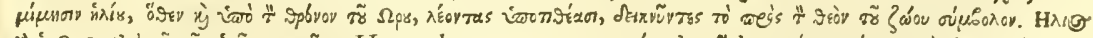

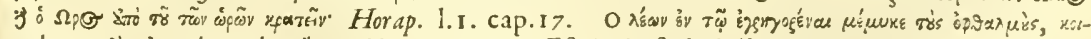

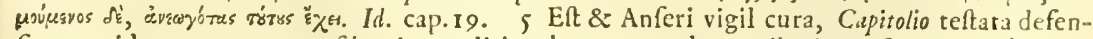
fio, per id tempus canum filentio proditis rebus, quamobrem cibaria Anferum cenfores in primis locant. Plin. I. 10. cap. 22. Anferem Egyptij Chenofirin, non a Junco, quem qoivov Grxei vocant, eo quod thyrfis junceis hedera circumplicatâ folennitatem Dionyfij feu Ofiridos

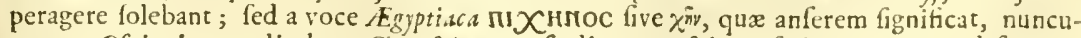
pant. Ofirim itaque dicebant Chenofrim, quafi diceres Ofirin Anferinum, eo guod fumma, uti Anfer, rebus fidei fux commiffs cura invigilare foleat. Kirch. Edip. Agypt. Synt.3. p.242.

$$
\text { G g g g g }
$$

them 
them moft watchful Animals; the former whereof was obThe Croco- ferved to fleep with his Eyes open. To thefe we may add dile. the Crocodile", which, like the Supreme Being, had no need of a Tongue, and lived the fame Number of Years, as there were Days in the Year. And again, as Ofiris was the Nile=, He was typified alfo, in that Refpect, by the Crocodile, which otherwife was looked upon as a Symbol of Impudence ${ }^{z a}$; of an evil Damon ${ }^{3}$; and of Typhon ${ }^{4}$, who was always fuppofed to The Bull. act contrary to the benign Influences of Ifis and Ofiris. How. ever the Bulls, the Apis' or Mnevis, and the fruitful Deity ${ }^{6}$, of the all-teeming Earth, as Apuleius calls it, was the principal Symbol of Ofiris. It was accounted facred, for the great Benefit and Service it was of to Mankind; and becaufe, after Ofiris was dead, they fuppofed his Soul to have paffed into it.

lis's symbols, The Bull too was one of Ifis's Symbols ; who was alfo repre-

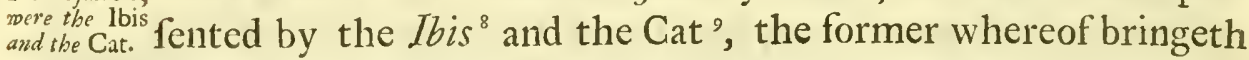
forth, in all, the fame Number of Eggs, the latter of young Ones, as there are Days in one Period of the Moon. The Mixture alfo of black and white Feathers in the Plumage of

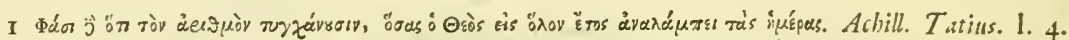

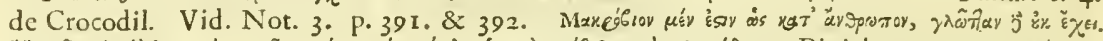

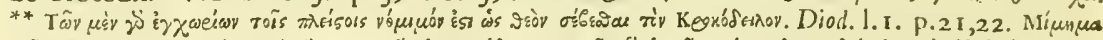

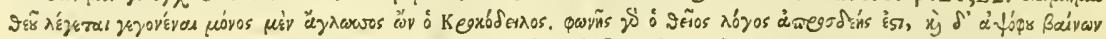

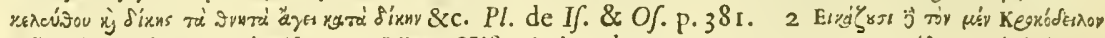

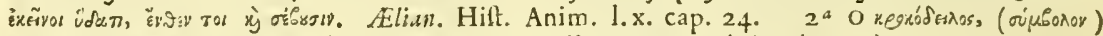

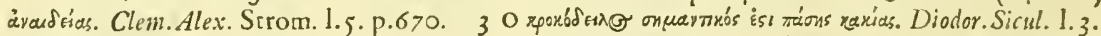

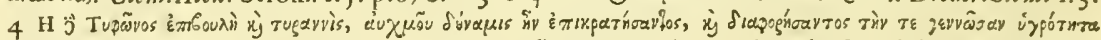

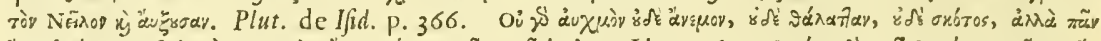

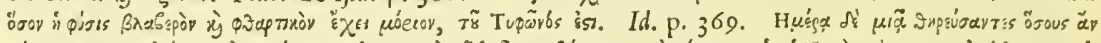

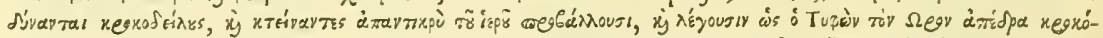

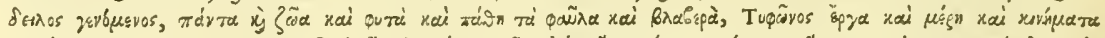

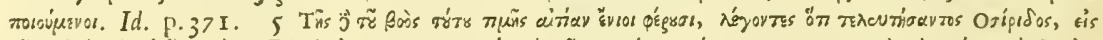

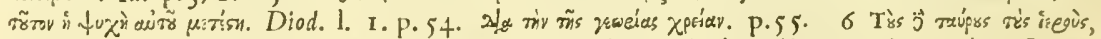

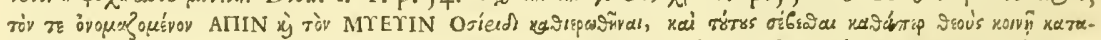

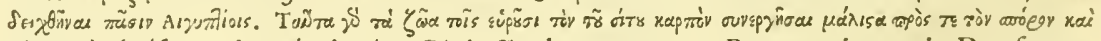

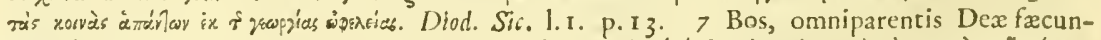

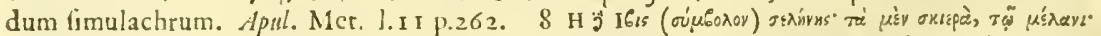

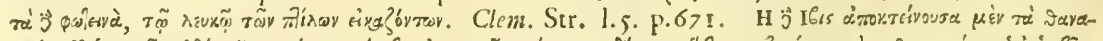

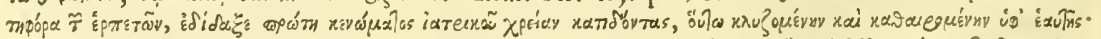

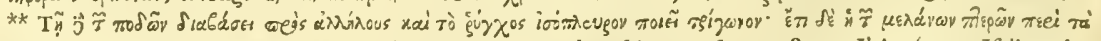

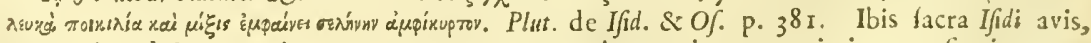
tum quia ad Lunx rationem, quam pennarum etiam varietate cxprimit, ova fingit; tum quia tot diebus ova excludit, quot Lunx crefcit \& decrefcit. cjufdem inteftium Luna deficicntc comprimitur. ad hxc extra fines $\not$ Egpti non progrcditur, exportata vitam citius, quan patrij foli defiderium adjicit. Confecrationis caufa fuit utilitas. Serpentibus enim alatis ex Arabia in Egyptum adventantibus obviam procedens cas conficit, earumque ova

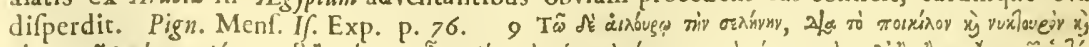

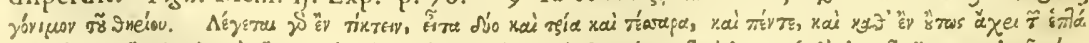

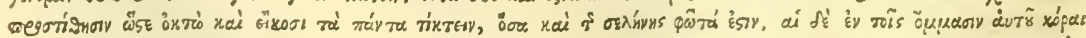

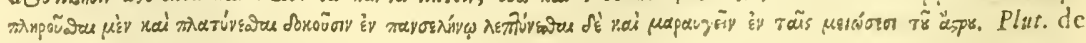
Ifid. \& OF. p. 376. 
the one, and of Spots in the Skin of the other, were fuppofed to reprefent the Diverfity of Light and Shade in the Full Moon; as the Contraction and Dilatation in the Pupil of the Cat's Eye, were looked upon to imitate the different Phafes themfelves of that Luminary. The Dog ' and the Cynocephalus ${ }^{2}$ were ${ }_{\text {and }}^{\text {Tbe }}$ tbe $\mathrm{Cg}_{\mathrm{C}}$ other Symbols; the Dog, as it was a vigilant Creature, kept noccphalus Watch in the Night, and had been of great Affiftance to Her, in fearching out the Body of Ofiris; the Cynocephalus, as the Females of this Species had their monthly Purgations, and the Males were remarkably affected with Sorrow, and abftained from Food, when the Moon was in Conjunction with the Sun.

Thefe were the principal Animals, which the Egyptians ac- ${ }^{-T h e E g y p t i a n s}$ counted facred, and fubftituted in the Place of their Deities; ${ }^{\text {thefe }}$ mals An not that they directly worflipped them, as Plutarch ${ }^{3}$ obferveth, but adored the Divinity only, that was reprefented in them as in a Glass, or, as he expreffeth it in another Place, juft as we fee the Refemblance of the Sun in Drops of Water. But Lucian ${ }^{*}$ hath recorded fomething more extraordinary with Regard to the Introduction of thefe Animals into their Theology. For he informs us, that in the Wars between the Gods and the Giants, the former, for Safety, fled into Egypt, wibere they affumed the Bodies of Beafts and Birds, which they ever afterwards retained, and were accordingly worflipped and reverenced in them.

Befides thefe Animals, there are others alfo which the Egyp-Tin Owl. tians received into their SacredW ritings. Such, among the Birds, was the $\mathrm{Ow1}^{5}$, which generally ftood for an evil Dremon: as the

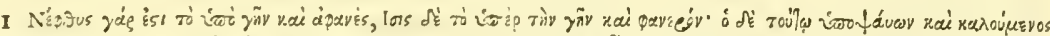

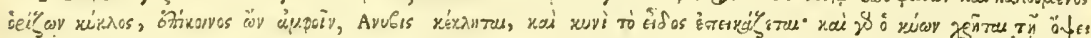

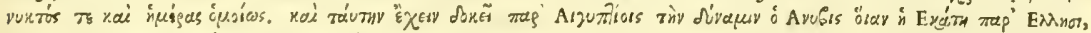

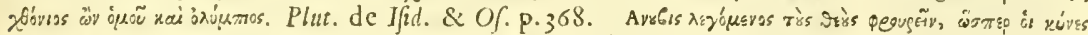

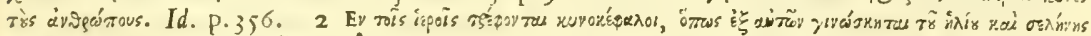

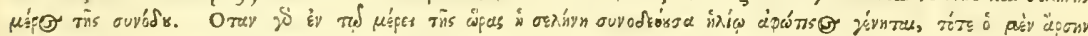
Ruroxis

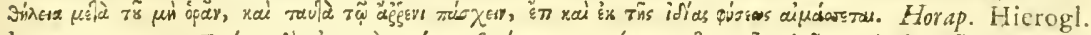

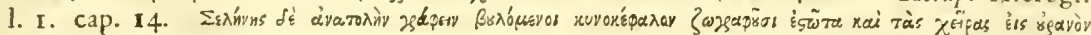

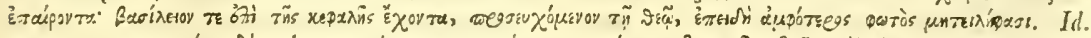

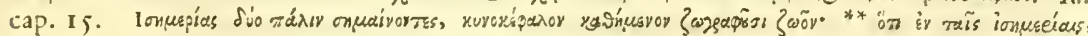

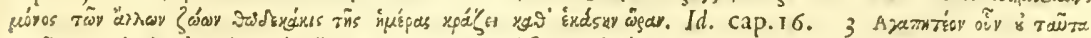

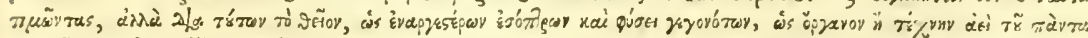
roquoñ

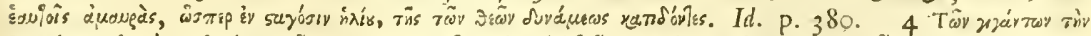

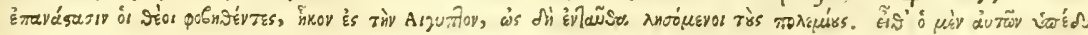

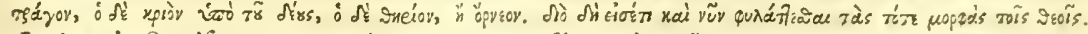

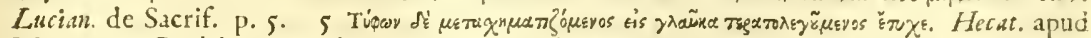
Malchim. Credebant quod Noctua nuncia fit numinis Hempbta, qux eft prima apud cos divinitas, \& annunciatrix omnium, qux eventura effent hominibus. Alvenephis item apud Kirch. Obel. Pamph. p.3 I7.

Ggggg 2

Conni: 
The Cornix Cornix ' did for Concord; and the Quail, for Impiety ${ }^{a}$ : alledging or Jack Daw
and ske Quail thefe Reafons, that Typhon had been transformed into the or Rail. firft; that the fecond kept conftantly to it's Mate; whilft the latter was fuppofed to offend the Deity with it's Voice. The The Hoopoc. Upupa ${ }^{2}$, from being dutiful to it's aged Parents, was an Emblem of Gratitude; or elfe, uponAccount of it's party-coloured Plume, of the Variety of Things in the Univerfe. The fame The Guinea Pn- Quality was fuppofed to be denoted by the Meleagris ${ }^{3}$ : though tado. Abenepbius ${ }^{3}$, makes it to reprefent the Starry Firmament. The Goat. By the Goat, their Mendes ${ }^{4}$ or Pan, was underftood the fame generative Faculty and Principle, that was expreffed by the The River Phallus'. By the Hippopotamus ${ }^{6}$, they either typified Impu-
Hoife. dence, from the Cruelty and Inceft which this Creature was guilty of, or elfe Typhon, i. e. the Weft which devoureth and The Frog. drinketh up the Sun. An Embryo or the imperfect Productions of Nature, were expreffed by the Frog ${ }^{7}$; an Animal which appears in different Shapes, before it arrives to Perfection, and A Fint. was fuppofed to be ingendred of the Mud of the Nile. A Fiffo, fays Plutarch, was typical of Hatred, becanfe of the Sea, i.e. Typhon, wherein the Nile is loft and abforbed. The Butterfly ${ }^{8 a}$,

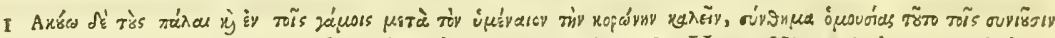

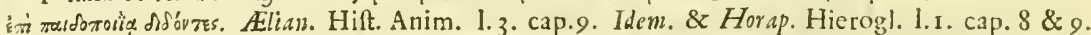

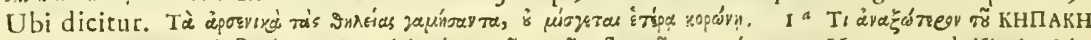

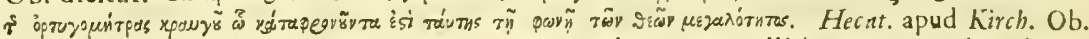

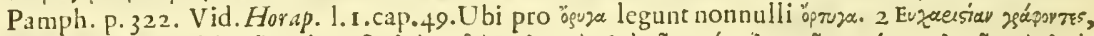

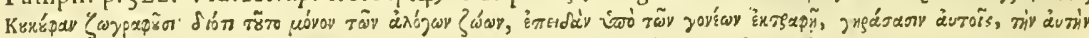

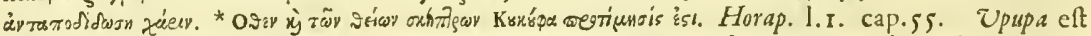
fepticolor, regimen habens in capite, altitudine digitorum duorum, quod aperitur \& contrabitur, cftque quatuor colorum, convenientium ad quatuor anni renpora. Keranides apud Kirch. Obel. Pamph. p.329. 3 Meleagris avis propter pennas diverficolores varietatem univerfx naturx denotat. Kirch. Edip. Aggyps Synt. I. p.91. $3 x$ Gallina Pharaun, illud eft fignum firmamenti five ftellarum fixarum. Aveneph. Uti enim Firmamentum variis ftellis ornatum clt, fic Gallina Plar aonis maculis veluri ttellulis quibufdam variegata eft. Kirch. Ad. Egypt.

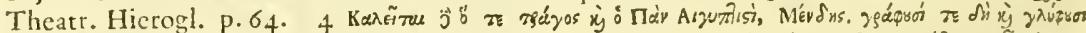

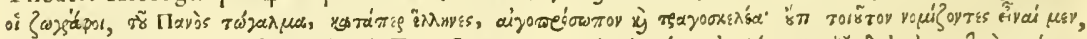

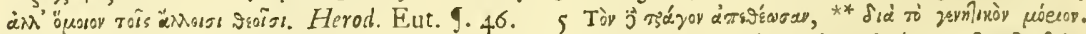

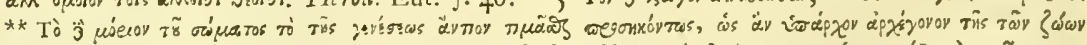

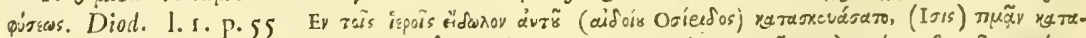

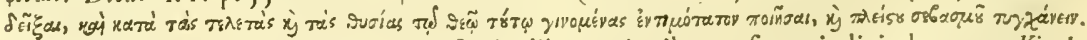
Diod. 1. I. P. I 3. Phallo, res omnes feminalibus rationibus refert $x$ indigitabantur. Kirch.

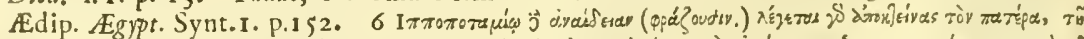

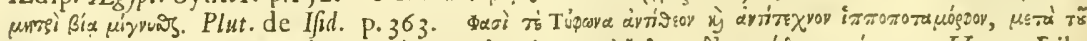

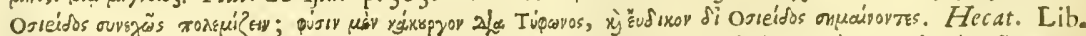

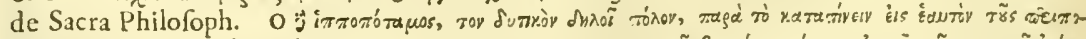

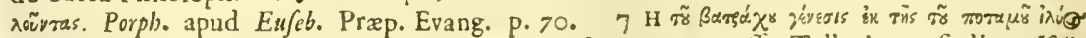
å

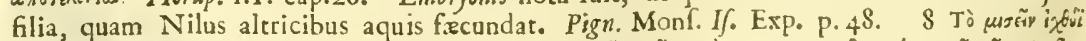

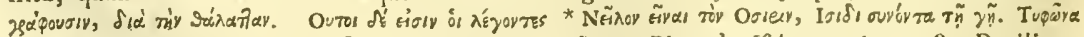

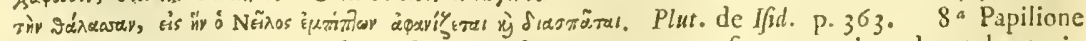
dracontomorpho pantamorpham feu omniformem naturam feu potentiam denotabant, in quam proxime \& immediate fupremum numen influit. Adjunctum babet papyraceum feu junceum thyrfum, quo rerum neceflariarum ubertas, quam in mundorum entia, pantamorpha Natura confert. Kirch. Æd. Ægypt. Synt. 2. p. $\pi \$_{3}$. Vid. plura in Obel. Pamph. p. 500. 
from undergoing a Variety of Transformations, was, accord-TreButeray. ing to Kircher, expreffive of the manifold Power and Influence of the Deity. The fame Author calls it, Papilio Dracontomorphous, and, at the fame Time, very juftly obferveth, that The (Thyrfus Papyraceus or Funceus) Bearded Bullrufh, is ufually placed before it, typifying thereby the Plenty and Affluence which flows from the Divine Being.

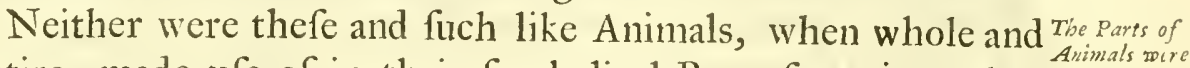

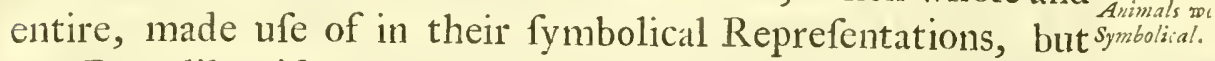
the Parts likewvife and Members of fome of them. Thus the Horns of the Bull, which are ufually gilded', were typical both of the Horns of the Moon ${ }^{2}$, and of the Beams of the Sun', according as they were placed upon the Head of $1 /$ is or Ofiris. The Eye ${ }^{4}$ denoted Forefight and Providence; and, being joyned Tos Eye. to a Sceptre, fignified alfo the Power of Ofiris. The right the Hands. Hand', with the Fingers open, typified Plenty; but by the left, were underftood the contrary Qualities. Wings " were Wings. emblematical of the Swiftnefs and Promptitude, which the Deities, Genij andSacred Perfons, to whom they are given, may be fuppofed to make ufe of, for the Service of the Univerfe.

But, befides the Parts already mentioned, we often fee the тьs Head and

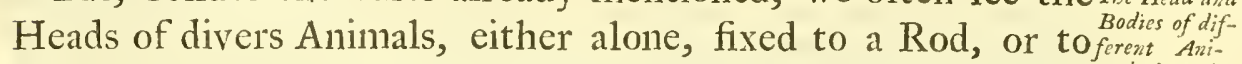

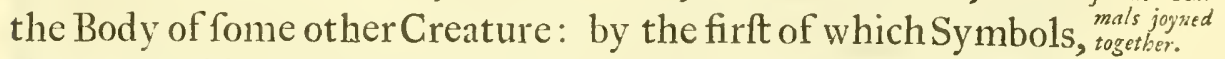
they probably typified the principal Character of the Creature' itfelf; by the other, the united Characters of them both. Thus the Head of the Hawk, Ibis, Lyon, Dog, \&c. is frequently joyned to the human Body; the Head of a Woman, or

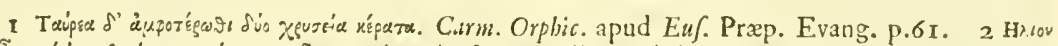

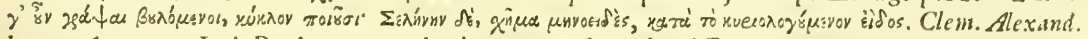
1.5: p.657. 3 Imi Panis cornua, barbxque prolixa demiftio naturam lucis nftendunt, qua Sol $\&$ ambitum cxli fuperioris illuminat $\&$ inferiora colluftrat. Macrob. 1. 1. cap.22. Ad indicandam radiorum projectionem aurcis cornibus Liberi Frontem infignibant: ex quo cum Greci xguoxípery cognominarunt. Sic Hor.t. Carm. 1. 2. Od. I9. Te vidit infons Cerberus anreo Cornu decormm.

Item Sidon. Apollinar.

\section{Caput aureal rumpunt}

Cornna, $\mathcal{O}$ indigenam jaculantur fulminis ignem.

Vid. Aleand. Explic. Tab. Heliacx. p. 23.

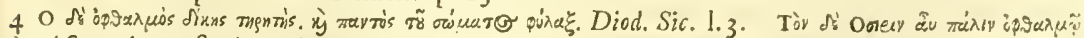

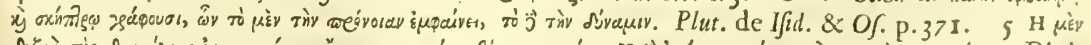

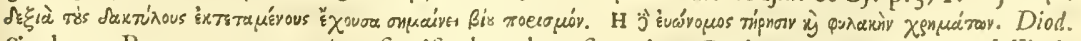
Sic. 1.3. Pcr manum extenlam fignificabant beneficcntiam Geniorum. Abeneph. apud Kirch.

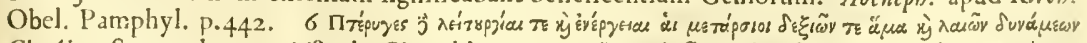

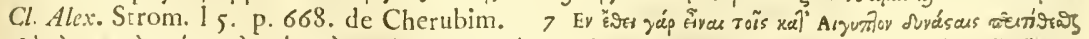

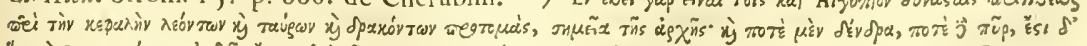

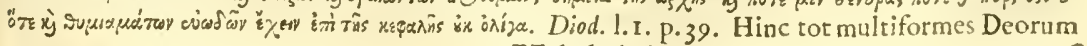
$\mathrm{Hhhhh}$ 
of a Hawk, to the Body of a Lyon; the Head of Orus ${ }^{14}$, who is always reprefented young, to the Body of a Beetle; and the The Reafon of Head of the Hawk, to the Body of a Serpent. Now, accordit. ing to Porphyry ${ }^{2}$, we are to underftand by this Mixture and Combination of different Animals, the Extent of God's Care and Providence over all bis Creatures, and as we are all bred up and nourifhed together, under the fame divine Power and Protection, great Tendernefs and Regard ought to be fhewn to our Fellow Creatures.

The Human Body with the Hawk's Head,

Of thefe compound fymbolical Reprefentations therefore, the Human Body ${ }^{3}$ with the Hawks Head, was typical of the firft, incorruptible, eternal Being. Porphyry \& fpeaks of an Image of this Kind that was of a white Colour, whereby the Moon was reprefented, as receiving her (pale) Light from the with that of Sun. When the Head of the Ibis was annexed, then it was the Ibis, their Mercuribis, or Hermanubis, prefiding, accurding to Kircher, over the Element of Waters. The like Quality and Character might be alfo implyed, when they added the Head of the Lyon sa; a Creature that was typical of the Nile's Inundation. No one Figure certainly is more common than this;

imagines, qux quidem nihil aliud, quam multiplicem Dei virtutem diverfis animalium proprietatibus adumbratam notat. Kirch. Ed. Egypt. p. 2I4. Cur Genij transformati jam in faciem hominis, modo in accipitrinam, Ibiacam, felinam, bovinam, caninam formam ex. hibeantur? Refpondeo, hôc eos fignificare voluiffe, diverfa officia, quibus omnia, qux in mundo funt, adminiltrant, \& partim infenfibiles, partim fenfibiles Genij funt; per illos, qui humana facie pinguntur, infenfibiles Genios exhibent, folo intellectu \& invifibili quadam affiftentia omnia moderantes: per reliqua vero fub formis animalium comparanres, fenfibiles Deos indicant, qui fub formis animaiium torum orbem circumeuntes, tefte Trifmegifto, humanum genus erudiunt. Sic Mercurium fub forma Canis, fub forma Bovis Ofirin, fub forma Felis Ifidem: hinc transformatos illos, ut plurimum, indumento tectos videmus, reliquos vero infenfibiles nudo \& fubtili corpore, utpote fimplices, \& ab omni materix conragione disjunctos. Kirch. Ob. Pamph. 497. I* Per Scarabxum, quod ad mundi figuram ejus accedat fxtus procreatio, AEgyptij mundum, ejufque converfiones ac motus fiderum cxlorumque indigitare folebant. Facie humana, Orum feu Solem, mundi mentem, intellectu \&

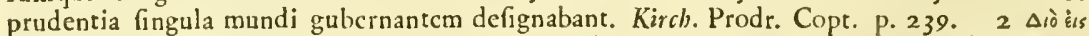

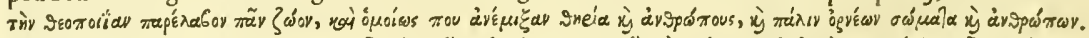

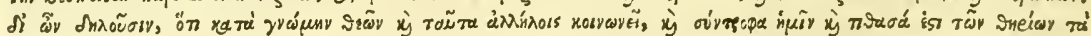

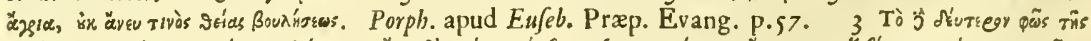

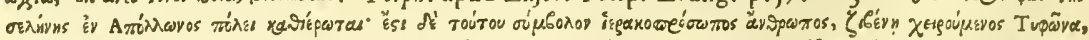

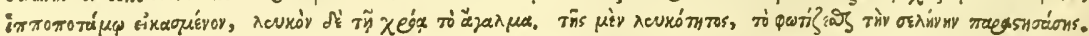

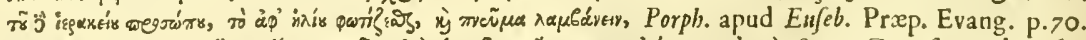

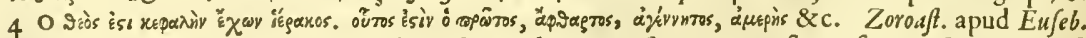
Prxp. Evang. 1. 1. p. 27. 5 Ibidis Caput humanx figuræ appofitum femper Mercuribin f. Hermanubin, humidx fubltantix Numen indicat. Kirch. Obel. Pamphyl. p. 348 . 5* Erat autem Momplsta nihil aliud, quam Numen quod humidx Naturx præfidet, Genius Incrementi Nili \&c. Pingebatur varijs modis, nunc fub forma hominis $\lambda$ \&or тopóg̨r, nunc fub fimplici cubantis Leonis figura. Kirch. Ed. Agypt. Claff. 7. p. I 55. Situ eft Ypfilomorpho, i. e. in formam literx $Y$, ad influxus a fupremo Numine immiff receptionem, \& in inferiorem Mundum, diffufioncm indicandam. Id. Synt.7. p.32I. Momphta i. e. aquarum Numen, quod componitur ex exws aqua \& $\$+$ Deus, eundem effe puto cum co, quem Nephte Plutarchis vocat. Kirch. Ob. Pamph. p. 284. 
being ufually feen in a fitting inclined Pofture, as if cut fllort by The Egyppian $^{2}$ the Legs, and was called Momphta, the fame with Emeph or ${ }^{\mathrm{N}}$

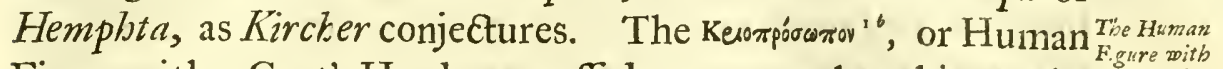

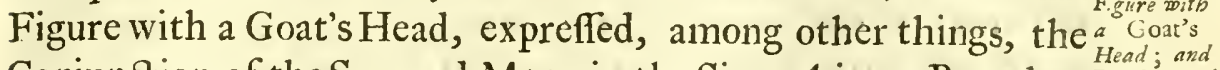
Conjunction of the Sun and Moon in the Sign Aries. But when ${ }_{\text {Dog's 'Hacad. }}$ the Head of the Dog was affixed, then it was the Anubis or Hermes $^{1}$, reprefenting the Horizon ${ }^{2}$ and guarding the two Hemifpheres.

The Head of a Woman, joyned to the Body of a Lyon, was $t b e$ Sphinx. called the Sphinx, being, in general, an Emblern of Strength ', united to Prudence. When fuch Figures were placed near the Nile, they denoted the Inundation to fall out, when the Sun paffed through the Signs of $\mathrm{LeO}^{3 \text { a }}$ and Virgo; but when they adorned the Portico's ${ }^{36}$ and Gates of their Temples, then they fignified, that the Theology taught and reprefented within,

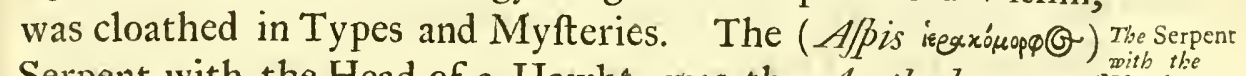
Serpent with the Head of a Hawk ${ }^{4}$, was the Agatbodcemon of oith thes $_{\text {Head }}$ the Phonicians, and the Cneph, (Kircher likewife calls it the Thermutis of the Egyptians,) being fuppofed to carry along with it greater Marks of Divinity s than any other fymbolical Figure whatfoever. We fometimes fee an Egg, the Symbol of the World ${ }^{6}$, iffuing out of it's Mouth ${ }^{7}$, which the Egyptians maintain to be productive of the Deity Ptha, but the Greeks, of Vulcan; who were both the fame according to Suidas. In

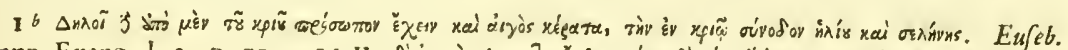

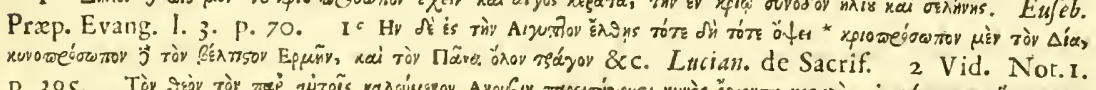

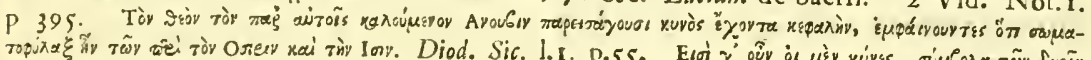

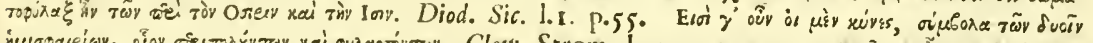

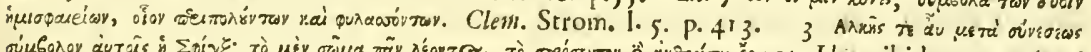

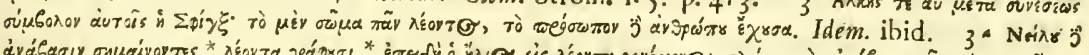

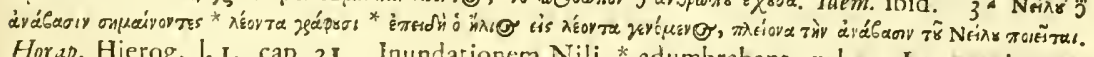
Hor ap. Hierog. I. I. cap. 2I. Inundationem Nili * adumbrabant, vel per Leonem incumbentem, vel per eundem humana feu Virginis facie confpicuum, co quod hxc inundario contingeret, Sole \& Leone in Ifadis five Virginis fignum intrante. Kirch. Obel. Pamph.

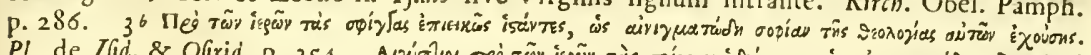

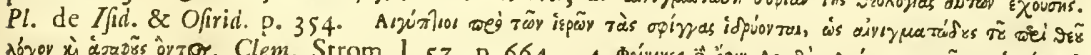

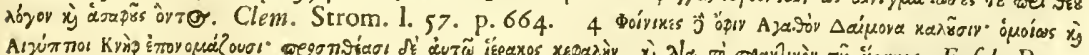

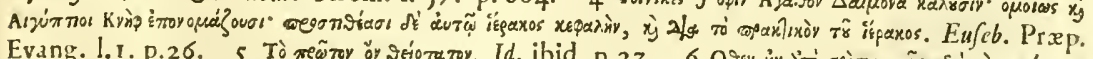

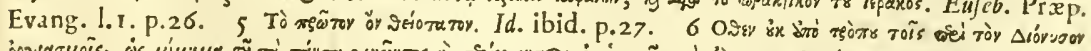

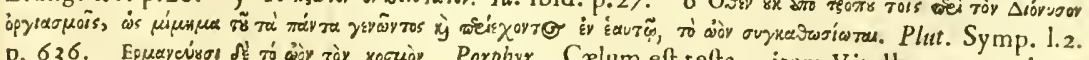

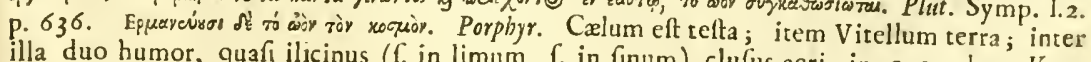
illa duo humor, quafi ilicinus ( $f$ in limum, $f$. in finum) clufus aeri, in quo calor. Varo

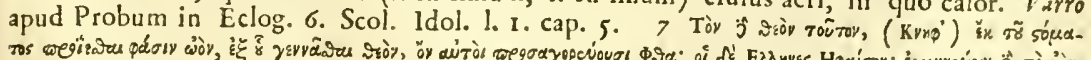

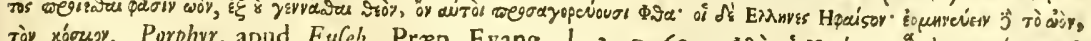

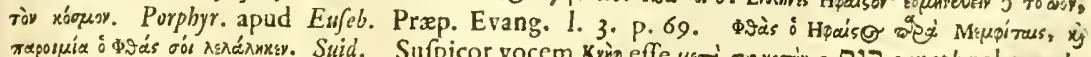

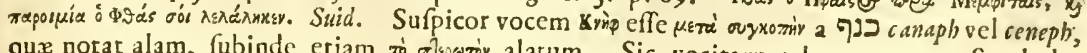
qux notat alam, fubinde etiam ro mispariv alatum. Sic vocitarunt hoc numen a Symbolo,
quod cx Serpente \& volucre componeretur. G. F. Voff. de Idol. 
The Heads like Manner, the Union of the Heads and Bodies of other the evil $\mathrm{D} x$-different Creatures, may, according to their refpective Qualimons. ties, be prefumed to reprefent fo many Genij; the Heads, efpecially of the facred Animals, being added, as Kircher imagines ', to ftrike Terror into the Evil Dremons. The Skins of the Dog and the Wolf, which, Diodorus tells us ${ }^{2}$, Anubis and Macedon put over their Heads in the Wars of Ofiris, in Order, as we may fuppofe, to excite Fear in their Enemies, will probably confirm this Opinion of Kircher. Diodorus indeed gives us a different Interpretation, and affirms that it was owing to the wearing of thefe Helmets, that thofe Animals were efteemed and honoured by the Egrptians.

TheirSymbo- After thefe different Species of Animals, we are to take lical Plants. Notice of fome of the moft remarkable Plants, that were received into their Sacred Writing. Thus Diodorus tells us, The Agroftis. that the Agroftis, in Token of Gratitude ${ }^{3}$, was carried in the Hands of their Votaries; but, as this is the general Name for the Culmiferous Plants, it will be uncertain to which of them we are to fix it. The Plants likewife of the Ifiac Table, called by Pignorius and Kircher, the Perfea, Acacia, Melilot, Wormwood, Purflain \&c. appear to be much liker other Kinds, fuch probably as were no way concerned in the Egyptian Phyficks or Theology, than thofe to which they are afcribed. The The Purlain. Purflain particularly, or Motmoutin ${ }^{4}$, feems, by the Figure, to be the Sugar Cane, which this Country might anciently, The Poppy. as it doth at this Time, produce. But among thofe that may be better diftinguifhed; by the Head of the Poppy s, or Pomegranate, which is divided into a Number of Apartments, The Reed. full of Seed, they denoted a City well inhabited. By the Reed, (the only Inftrument they antiently wrote with, as they continue to do to this Day,) they fignified the Invention of Arts and Sciences ${ }^{\circ}$, together with the Culture of the Vine,

I Omnes Statux, facrorum tantummodo animalium vultibus, ad incuticndum ảvtrí: $\chi^{\text {yots }}$ ijs terrorem, transformatx conficiebantur. Kirch. Ad. Egypt. Synt.18. p.516. 2 Tov $\mu$ iv

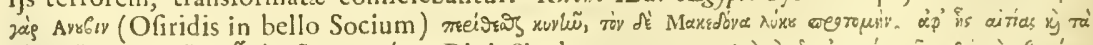

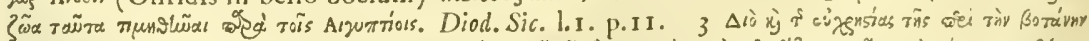

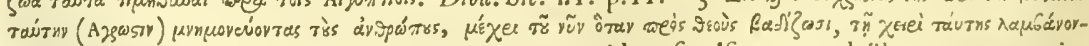

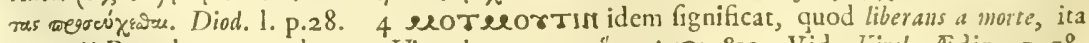
Egyptij Portulacam vocabant. Hierophantes vero ámua Ag̨@. \&c. Vid. Kirch. Edip. p. 78.

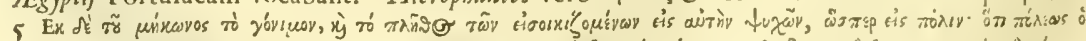

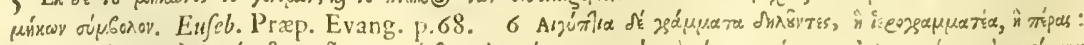

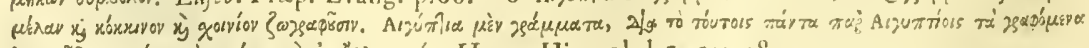

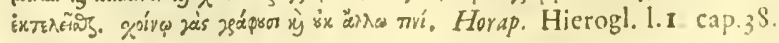




\section{Obfervations in Egypt.}

according to Kircher'. This Plant is frequently feen, with the The Bullrult Top of it bending down ${ }^{2}$, in the Hands of their Deities, and aind Papyius. was the fame Symbol, according to Kircher ${ }^{3}$, with the Bullrufh and Papyrus, expreffive likewife, of the various Neceffaries of Life. The Palm Tree+, from thooting forth one Branch every The Palm Month, i. e. twelve in a Year, fignified That Period of Time. The Boughs of it, that were equally emblematical with thofe of otherKinds, of the firft Productions of Nature's or of thePrimitive

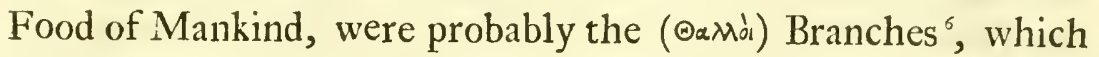
the Votaries carried in their Hands, when they offered up their Devotions. It is certain, that other Nations made ufe of thefe Boughs in particular, upon a civil ${ }^{7}$, as well as religious ${ }^{8}$ Ac-

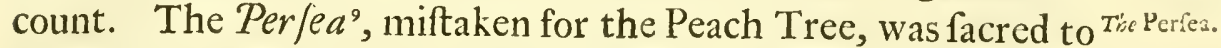
If $i s$, as the Ivy was to $O$ firis $^{9 a}$. Now theLeaves of the former being made ufe of to typify the Tongue, and the Fruit the Heart, intimate the Agreement there ought to be betwixt our Sentiments and Expreffions; and, that the Deity is to be honoured with both. The Figure 96 , which we often fee, among the Hieroglyphicks, not unlike a Trident, is fuppofed by Kircher, to be a triple Branch of this Tree, typical of the three Seafons, the Spring, the Summer and Winter, into which the Egyptians divided

1 Thyrfus ferulaceus Ofiridi feu Dionyfiv Egyptio attribuitur, eo quod docuerit primo vitem plantare ac eam thyrfo ferulacco veluti ftatumini fuftentand $x$ viti aptiffimo applicare. Kirch. Ed. Egypt. Synt. 3. p. 232. 2 Sceptro recurvo non obfcure potentiam rerumque ab Ofiride \& Ijide inventarum vini \& muficx feu harmonix preftantiam fignificare voluerunt. Idem. ibid. p. $24^{+} 3$ Junco Nilotico, fcirpo levi \& cnodi papyro, Agyptij nihil aliud fignificare voluiffe videntur, nifi litcrarum ac fcription is nobilcm inventioncm, a Mercurio Egyptiv, feu mavis, Ofiride \& Ifide 'primo repertum, ut teltatur Diodoris : fecundo rerum omnium neceffariarum fuppeditationem; fi quidem ex papyro \& fcirpo, omnium prope rerum ufui humano neceffariarum copia fuppedirabatur; unde eum fempcr Damoni Polymorpho, per Papilionem dracontomorphum indicato, tanquam rerum neceffariarum prefidi, oppofitum

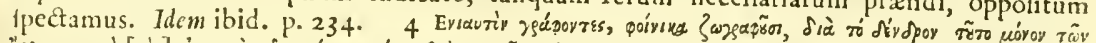

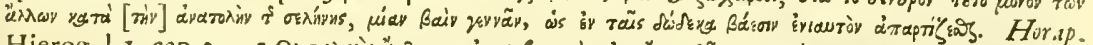

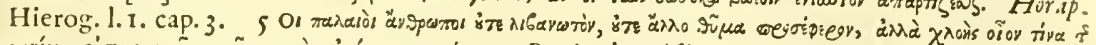

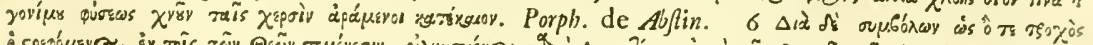

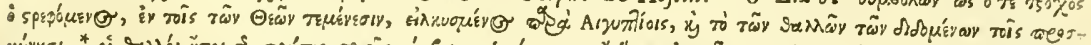

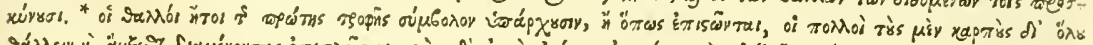

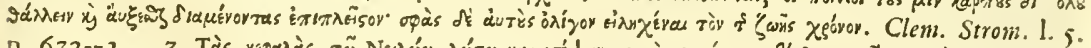

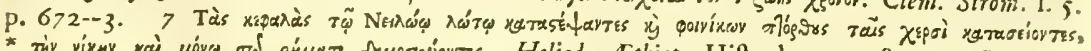

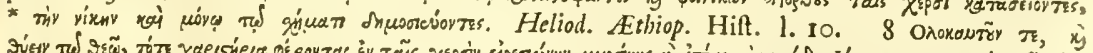

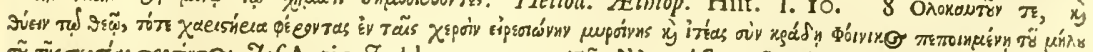

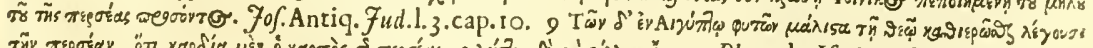

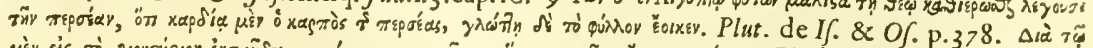

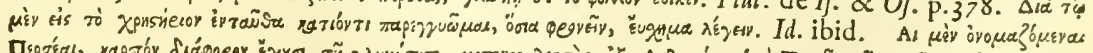

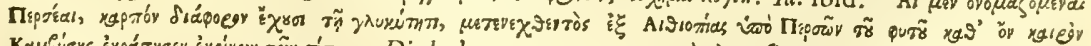

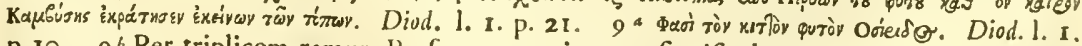
p. IO. $9^{6}$ Per triplicem ramum Perfer tres anni partes fignificabant, quorum primus Ofiridi, i.e. foli ; fecundus Ifidi. i. e. lunx; tertius Mercurio f. Oro facer fuit. Per 12 folia duodecim menfes fignificabantur. Vid. Kirch. Æd. Agypt. Synt,3. p.228. 
The Lotus. the Year. But the Lotus" is the moft common and fignificative among the Vegetable Symbols, being obferved to attend the Motion of the Sun, to lye under Water in it's Abfence, and to have the Flowers, Leaves, Fruit, and Root of the fame round Figure with that Luminary. Ofiris therefore was not only fuppofed to be reprefented, in an extraordinary Manner, by the Lotus, but to have his Throne ${ }^{2}$ likewife placed upon

Flowers.

it. By a Flower', (it is not material perhaps of which Species) the Power of the Deity was typified, as having thereby conducted a Plant (and therein emblematically any animal or vegetable Production) from a Seed (or fmall Beginning) to The Ane- a perfect Flower (or State of Maturity.) However we read,
mone. that the Anemone ${ }^{4}$, in particular, was an Emblem of Sicknefs. The Onion. The Onion ${ }^{4}$ a too, upon Account perhaps of the Root of it, (which confifteth of many Coats, envelopping each other, like the Orbs in the planetary Syftem,) was another of their Sacred Vegetables. The Priefts' would not eat it, becaufe, among other Reafons, it created Thirft, and, contrary to the Nature of other Vegetables, grew and increafed when the Moon was in the $W$ ain. Utenfis o o. Among the great Variety of Utenfils, Inftruments, Mathematical Figures \&c. that we meet with upon their Obelisks and other Pieces of Sacred Writing, we may give the firft Place TheCalathus, to the (Calathus) Basket. This is ufually placed upon the Head of Serapis, who was the fame ${ }^{6}$ with Ofiris, and denoted, the various Gifts that were received from and conveyed back to The Situla. the Deity. The (Situla) Bucket, which Ifis carrieth fometimes in her Hand, might probably denote the Fæcundity of the

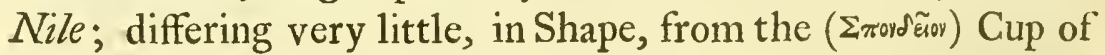

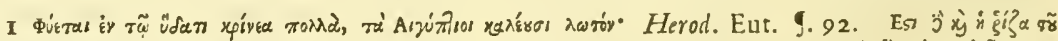

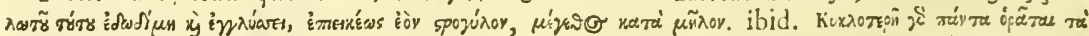

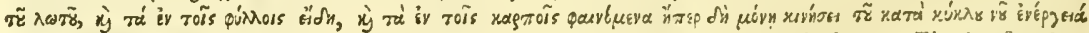

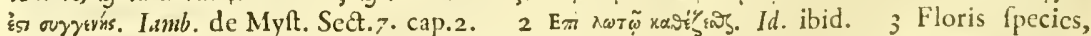
florem rerum proteftatur, quas hic Deus infeminat, progenerat, fovet, nutrit, maturatque.

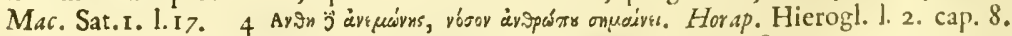

$4^{a}$ Porrum \& cepe nefas violare \& frangere morfu.

O fanctas gentes quibus lixc nafcuntur in hortis

Numina.

Fuv. Sat.1 5. 1.9.

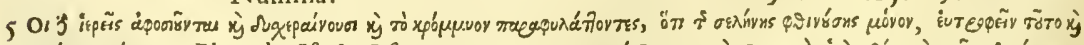

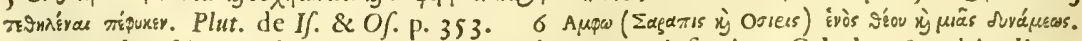
Plutarcb. de Ifid. \& Of. p. 376. 7 Serapidis vertex infignitus Calatho \& alcitudinem fideris monftrat \& potentiam capacitatis oftentat; quia in eum omnia terrena redeunt, dum immiffo calore rapiuntur. Macrob. Sat. 1. I. cap. 20. O fí xína

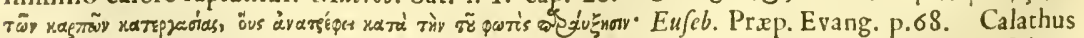
aureus furgens in altum monftrat ætheris fummam; unde Solis creditur effe fubftantia. Macr. ut Supra. Ifedis capiti infidet calathus cum manubrio, Ofiridis communis, ut amborum vis frugifera \& caparitas omnia in fublime trahentium declarctur. Pignor.Tab. If. Exp. p.49. 
Libation', that was one of the Attributes of the (Erodirns) Ornator. The (Crater) Bowl ${ }^{2}$ was another Emblem of the fame ${ }^{\text {The Cratcr. }}$ Kind, being alfo placed fometimes upon the Heads of their Deities, thereby typifying the great Plenty and Beneficence, that flowed from them. The Canopus ${ }^{3}$ was of the fame ${ }^{\text {The }}$ Canopus. Clafs, reprefenting, in all Probability, the Element, or Divinity of Water *. Under a Sphyngopedes ${ }^{\text {s }}$, upon the Ifac Table, we fee three of them together, denoting the three Caufes ${ }^{6}$, that were then affigned, for the Inundation of the Nile.

Inftruments, and fuchThings as may be referred to that Clafs, Intruments are in great Numbers. Among thofe of Mufick, we fee the Siftrum ${ }^{7}$, Tie Sittrum. and the Plectrums, the former whereof was ufed, in their religious Ceremonies, to fright away the evil Dcemons, being at the fame Time expreffive of the Periods of the Nile's Inundation, and that all Things in the Univerfe are kept up by Motion. The Plectrum was either emblematical of the Poles, Tó Plecupon which the Globe of the Earth is turned, or elfe of the Air, which communicated Life and Motion to the Univerfe. Inftruments of Punifhment, fuch as the Hook and the Fla-Tise Flagelgellum, are fometimes feen in the Hands of their Genij Averrunci, expreffive, no doubt, of the Power, they are fuppofed to make ufe of, in driving away the evil Dremons. But the Flagellum, in the Hands of O/iris', may further denote his Character, as guiding the Chariot of the Sun. The $\Sigma$ xoinos, and the $\Sigma$ wire Sacred Cubit, (the latter ${ }^{20}$ whereof was the Badge of theCubi-

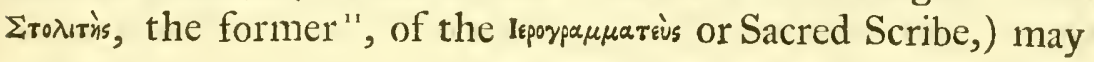

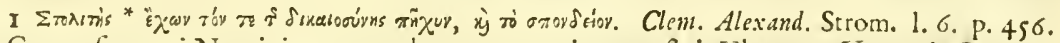
2 Crater fupremi Numinis, ex quo bonorum omnium profluit Ubertas. Hermes in Pirmandro, apud Kirl). p. 97. Menf. Ifiac. 3 Ipfius (Canopi) fimulachrum pedibus perexiguis, attracto collo, \& quafi fugillato, ventre tumido in modum hydrix, cum dorfo xqualiter

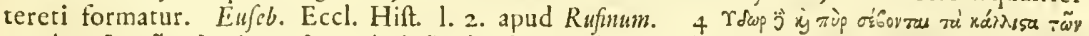

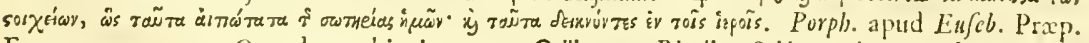
Evang. p. 57. 5 Orus decumbit in quem Callixcnus Rbodius Sphingupedem apud Athencum

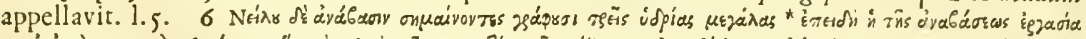

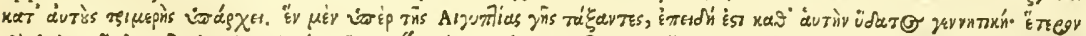

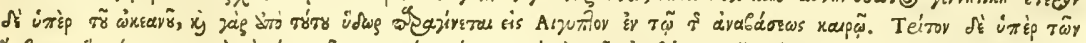

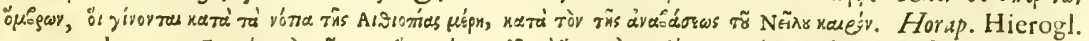

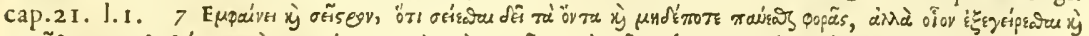

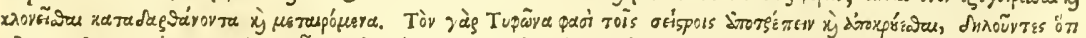

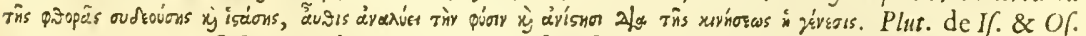
p. $376 . \quad$ Siftrum indicabat Nili accelfum \& receffum. Serv. in Virg. En.8.

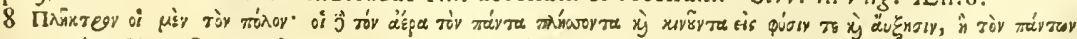
manpomixóy. Clem. Strom. 1.5. P.4I s. \& Simulachrum (Solis) inftat dextra elevata cum flagro in aurigx modum, læva tenet fulmen \& fpicas qux cuncta Jovis folifque confociatam potentiam

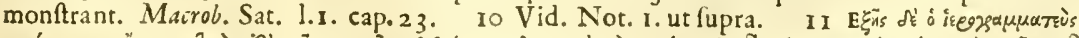

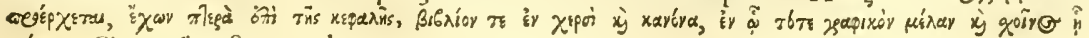
záqsor. Clem. Alex. Strom. 1. 6. p. 757. 
be likewife placed among the Inftruments of Juftice; to which The Sceptre. we may add the Sceptre, that hath before been taken Notice of, as the Symbol of Government, Steadinefs and Conduct. $A$ Wheel. But the Wheel ', was the Reverfe of the Sceptre, fignifying the The Hafta Inftability of human Affairs. A long Rod, like the Hafta pura
pura. of the Romans, "was probably a Symbol of the fame Importance with the Sceptre. It is generally afcribed to the $\mathrm{Sun}^{2}$, though we fee it held in the Hands of their other Deities. The Top The Top of it
with the Head of lfis $\sigma^{\prime} c_{0}$ Goat, Orus, I/ $/ s$, or the Lotus, whereby it may be prefumed, that fome new Character is fuperadded. Thus, among other Inftances, a Rod with the Head of Ifis or Orus upon it, expreffed, in all Probability, fome Branch of Power and Authority, which we may fuppofe the Perfon who holds it, to have received from one or other of thofe Deities.

Mathemati- Among the Mathematical Figures, we meet with the Circle cal Figures;
as the Circle, and Crefcent, which reprefent the Sun and the Moon (Kuevoroyixäs) Crefcent, as Clemens Alexandrinus ${ }^{3}$ expreffeth it, i.e. properly fpeaking, or without any Anigmatical Meaning. But the Circle, denoting the Year, is equally fymbolical with the Serpent, biting Globe. his Tail. A Globe or Disk is often placed upon the Heads of their Deities, as all of them bear fome Relation to the Sun : it is fixed alfo, upon the Head ${ }^{4}$, and between the very Horns of $I / t s$, whofe Attributes and Ceremonies were frequently the Wings given fame
to the Globe. to the Globe. Globe, with a Serpent hanging from it, being all of them together fymbolical of what is prefumed to be the Anima Mundi; i. e. a Power, Spirit, or Faculty, that diffufeth Life, Vigour, and

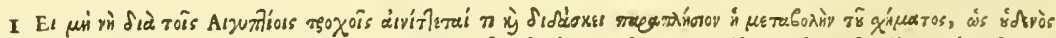

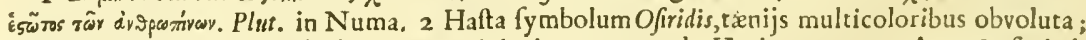
hæ Lunam denotabant, halta Solcm. Pigh. in Mułonogia de Horis. p. 170. Arcu \& fagitris Apollinis fimulachra decorantur, ut per lagittas intelligatur vis emiffa radiorum. Macrab. Sat.

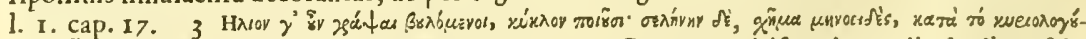
usvor जิ limem diftrinxerat verticem (Ifidis) cujus media quidem fuper frontem plana rotunditas in modum fpeculi vel immo argumentum Lunx candidum, lumen emicabat. Apul. Metamorph.1.11. p.258. Crines intorti per divina colla paffim difperf., ibid. $4^{\text {a }}$ Quanquam enim connexa, immo vero unica ratio numinis religionifque effet, (viz. Ifadis \& Ofidis) tamen teletæ difcrimen intereffe maximum. Apul. Met. l. II. p. 27. 5 Cum vellent indicare tres divinas virtutes feu proprictates, fcribebant circulum alatum, ex quo Serpens egrediebatur: per figuram circuli fignificantes naturam Dei incomprehenfibilem, infeparabilem, xternam, omnis principij \& finis expertem; per figuram Serpentis, virtutem Dei creatricem omnium; per figuram alarum duarum, virtutem Dei motu, omnium, qux in mundo funt, vivificatricem. Abeneph. lib. de Relig. Aggptiorum. apud. Kirch. Obel. Pamph. p. 403. Jupiter fplizra eft alata, ex ea producitur Serpens: circulus divinam naturam oftendit fine 
Perfection throughout the Univerfe. A Serpent, furrounding The Serpent a Globe, carried along with it the fame Meaning ". Whenthe Globe,

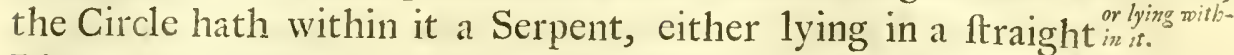
Line, or forming the Figure of a Crofs, by the expanding of it's Wings, then it is fuppofed to be the Symbol of an Agathodremon ${ }^{2}$, otherwife expreffed by the Greek $[\Theta]$ Theta. The The sacrod Hieralpha $\mathrm{A}^{3}$ likewife, which is frequently held in the Hands of their Deities and Genij, might carry along with it the like Signification. Of the fame Kind alfo was the [o] Crux An $\int a t a^{4}$, The Crux which confifted of a Crofs, or fometimes of the Letter T only, fixcd to a Circle. Now as the Crofs's denoted the four Elements of the World, the Circle will be fymbolical of the Influence, which the Sun may be fuppofed to have over them: or, as Kircher ${ }^{6}$ explains it, by the Circle is to be underftood

principio \& fine: Serpens oftendit verbum ejus quod mundum animat \& fxcundat: ejus ala Spiritum Dei, qui mundum motu vivificat. Fragm. Sanchun. de Religione Pbonicum. ibid. Per Globum, infinitum, xternum, immenfum; per Alas, motum quo omnia penetrat; per Serpentem, vitam omnium: per Sccptrum rectilincum, omnia in illo, curvum, rectum, magnum, parvum \&c. unum effe: per tres nodos, unitatem, xqualitatem, \& connexionem; item principium, medium \& finenı omnium innuebant. Kirch. OEdip. Agypt. Clar.7. cap.r. p. 96. Globus alatus, Serpentibus circundatus dum pingebatur, fymbolum erat animæ feu ipiritus mundi. Abeneph. Lib. de Religione Agyptiorum apud Kirch. OEdip. Agypt. Claf. 7. cap. 4. P. II7. I Per figuram fpherx, virtutem igneam in fole elucefcentem, \& per figuram Alpidis fphxram circumdantem, vitam \& motum \& fxcinnditatem mundi defignabant.

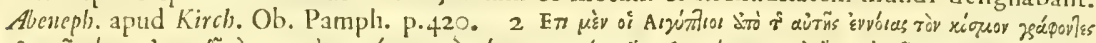

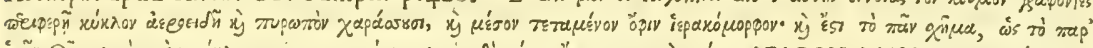

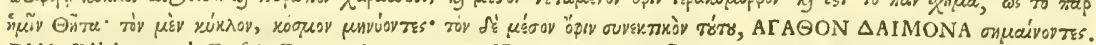

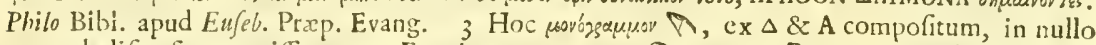
non obclifco frequentiffmum, Agyptiacarun vocum $\lambda$ ए \& $\theta$ oc $\mathbf{\lambda}$ cesolt quibus bonum Genium Delte Nili feu 2 Egyti fignanr, index; cum prarer dictarum vocum capitales literas, ejus quoque Eggpti portionis figuram quam $\Delta$ paffim vocant, clare dictum rovórgaupov exprimat. Kirch. Prodr. Copt. p. 23I. \& Figuram Crucis, in cujus capite Circulus in modum anfre, accepit Mefra a Chamo, \& Cham a Noe \& Noe ab Hanuch, (ipfe Idris,) Hanuch a Seth, Seth ab Allamo, Adam ab Angelo fuo Ruziel. Cham vero ope ejus fecit mirabilia magna $\& \mathrm{ab}$ eo accepit Hermes, \& pofuit eum inter literas avium; eft autem hic charaster fignum proceffus motufque Spiritus mundi: ( $f$. divinæ mentis in rerum omnium productione motns \& diffufionis. Kirch. p.369.) \& fuit magicum figillum \& fecretum in telefmatis corum, \& annulus contra demones \& malignas poteftates. Abeneph. apud Kirch. Obel. Pamph. p. 440. 5 Philofopli o Medici Ægyptij, partiun Indix c Grxcix, indicaturi quatuor Elementa, Quadratum fub fgura Crskis pingebant. Cabala Saracenica apud Kirch. Obel. Pamph. p. 372. Outws

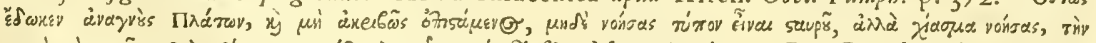

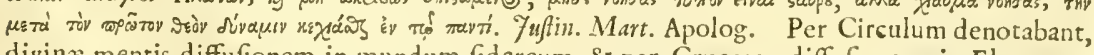
divin $x$ mentis diffufionem in mundum fidereum \& per Crucem, diffulionem in Elementa. Id.p.370. 6 Sicut nomen Dei הiה' juxta Rab. Hakadof cl, Deum generantem fignificat, fic \& hoc ( $\Phi$ †) non apud Coptitas tantum; fed apud Egyptios antiquos quoque Emepht, feu cum afpiratione Hemepht, feu $\delta$ est\$t quod nos ex Copto interpretamur (in Phtha), quafi diceres, Deum omnia peragentem in Phtha filio, quem produxit; vel, ut cum Iamblicho loquar, Emepht nimirum producentem ex ovo Phtha, hoc eft, intelligentiam ad exemplar fium $1 \mathcal{X}$ oost generantem fapientiam, omnia cum veritate artificiofe difponentem, nempc Taat-

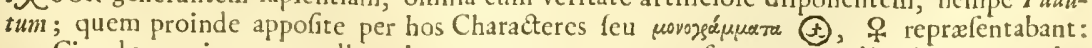
per Circulum primum mundi genitorem, xeternamque confervatorem, divinitatemque ejus ubique diffufam, per I vero fapientian mundum gubernantem intelligentes. Kirch. Prod. Cop. p.169. 
The Meaning the Creator and Preferver of the World, as the Wifdom, which of the ? Crux is derived from Him, and directs and governs it, is fignified by the,$+ \mathrm{T}$, or $\mathrm{t}$, as Hewrites it, the Monogram, as He further conjectures, of Mercury, Thoth, Taant, or ( $\$ f$ ) Phtha. It is certainly extraordinary, that this Figure fhould be fo often found in their fymbolical Writings, being feen alone, held in the Hands, or fufpended over the Necks of their Deities. I have often obferved, that Beetles and fuch other Sacred Animals and Symbols, as were bored through and intended for Amulets, had this Figure impreffed upon them. The Crux Anfata therefore, was, in all Probability, The Name of the Divine Being, as Iamblichus records it ${ }^{\prime}$, that travelled through the World. We may further fuppofe it to be the venerable Effigies of the Supreme Deity, which, Apuleius ${ }^{2}$ informs us, was not made in the Likenejs of any Creature; or, the Phy. lactery of I/is, which, not unlike the Thummim in the Breaft Plate of the High Prieft, fignified, according to Plu$t_{\text {tarch }}{ }^{3}$, The Voice of Truth. But the Interpretation of this Figure, (the Crofs-Part of it at leaft,) is recorded, in Sozomen and other Chriftian Authors, as expreffive of The Life to come $^{4}$ : being the fame, with the ineffable Image of Eternity ${ }^{*}$, that is taken Notice of by Suidas; and which the learned Herwart, in a very elaborate Differtation, hath endeavoured to prove to be the Acus Nautica, or the Mariner's Compafs of the Antients ${ }^{46}$.

But to return to the Mathematical Figures. The He-

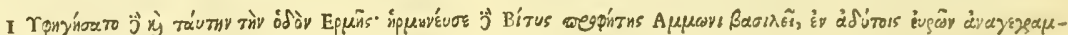

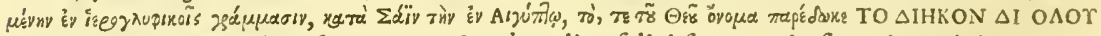
Tor kosmor. I. $\mathrm{mbl}$. Sect.8. cap.5. 2 Gerebat alius felici fuo gremio fummi numinis venerandam effigiem, non pecoris, non avis, non feræ, ac ne bominis quidem ipfus confimilem : fed folerti repertu, etiam ip£a novitate reverendam altioris utcunque \& magno filentio tegendx re-

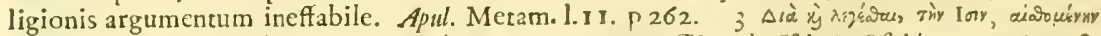

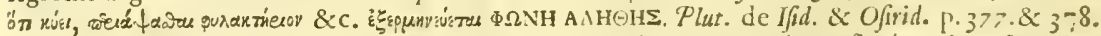

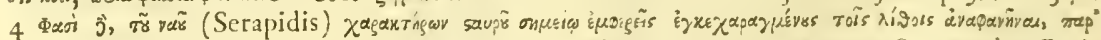

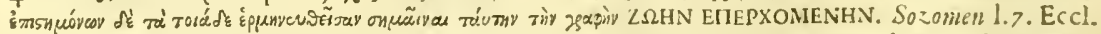
Hift. cap. I 5. Ruffin. Eccl. Hift. 1. 2. cap. 29. Suid. in Theodof. Socrut. 1. 9. Hift. Tripar.

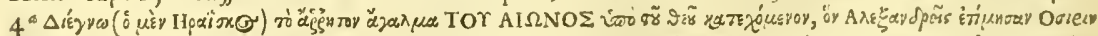

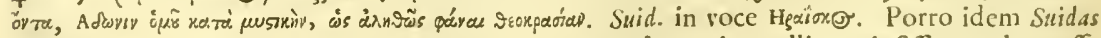
eadem repetit in verbo $\Delta$ iay $\omega \mu \omega \%$. Quo ex utroque Inco rite colligas, ipfifimum hoc effe fignum, T fcilicet Anfatum, AEVI, fxculi ineffabile, quod Serapis Alexandria manu teneat:

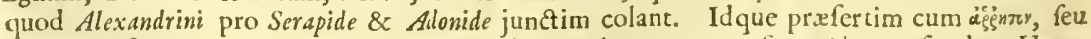

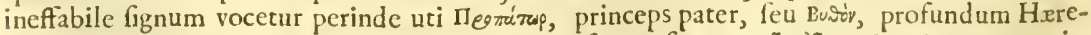

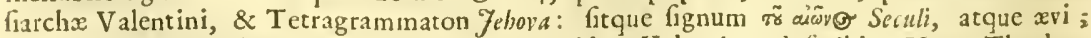
quorum 4. \& 8. primæva; \& deinde 30. \& 2. idem Valentinus defcribit. Herw. Theolog. Ethnic. p.rr. $4^{6}$ Apud me conftitui, illud fignum $T$ veteribus fuiffe preftitiffeque, quicquid noftris modo gubernatoribus eft, preftatque Anus Nautira. Id ibid. p.60. 
mi/pheres of the World, were probably reprefented by half Disks, ${ }^{T h b}$ Hemir

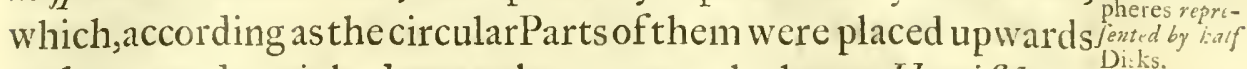
or downwards, might denote the upper or the lower Hemi/shere.

A Pyramid or Obelisk, i. e. an equilateral, or an acute angled Pyramids Triangle with two equal Sides, denoted the Nature and lisks obere Element of Fire'; but, by a right angled Triangle ${ }^{2}$, was un- Sircols of derftood the Nature and Conftitution of the Univerfe, the perpendicular expreffing Ofiris, or the Male; the Bafis, I/is, or the Female; and the Hypotheneufe, Orus,i.e. the Air or fenfible World, the Offspring of them both. The Mundus Hylcus, as Troutorld re-

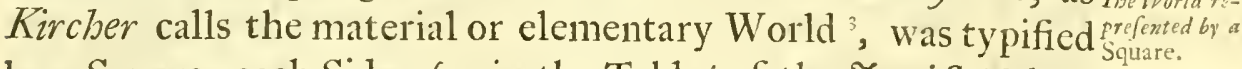
by a Square, each Side, (as in the Table ${ }^{4}$ of the Fewi/s Tabernacle,) reprefenting one Quarter of it.

But there was not only a Myftery couched under thefe and The Pofure, fuch like Images themfelves, but the very Pofture, Drefs, and Dreis of of of Matter of fome of them, were not without a Meaning. For Deities were when I/fs, Ofiris \&c. are reprefented fitting, This is a Type of sititing. the Deity's being retired witbin itfelfs; or, that his Power is firm and immoveable: as the Throne itfelf, when chequered with black and white, might be emblematical of the Variety of fublunary Things ${ }^{6}$. When the Deities and Genij ftand up-standing. right, as if they were ready for Action, but, at the fame Time, have their Legs placed clofe together, This $>$ is to reprefent them gliding, as it were, through the Air, without eitherLet or Impediment ${ }^{8}$. But, when the World is typified by a Human Figure, with it's Legs in the fame Pofture, This is a Token of it's Stability. No lefs fymbolical was the Drefs of their Deities.

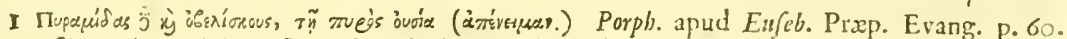

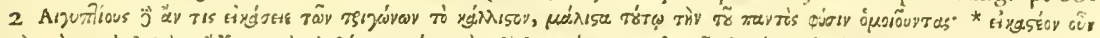

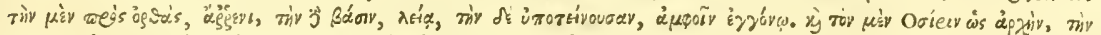

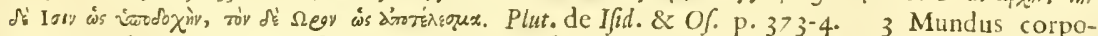
reus, ex elementis compolitus, in quo proceffus rerum fit per lineas reatas, per quadrangulum fuit indigitatus a prifcis. Plat. in Alcinoo. cap.I 1. \& I2. apud Kirch.OEd.Agyds. Cla1.7.

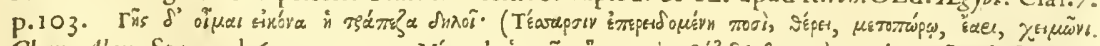

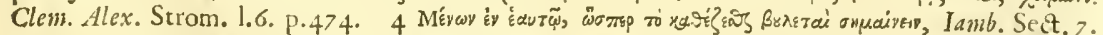

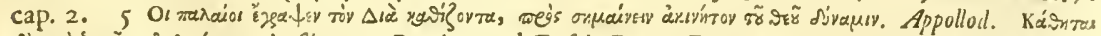

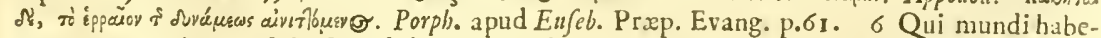
nas tenet, variegata fede fplendidus. Orph. de Mercurio apud Kirch. Synt. I. p.95. Hinc, arbitror, Greci Mercurio virgam ex albo \& nigro variatam attribuunt. ibid. 7 Kai rậ

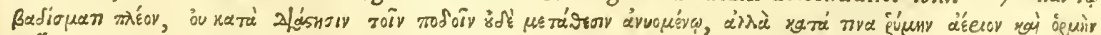

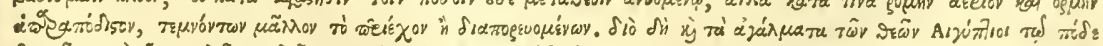

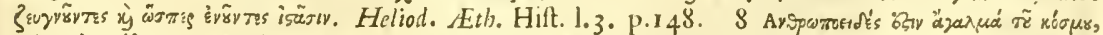

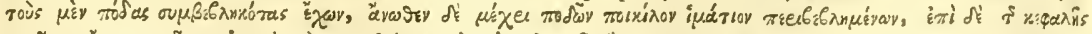

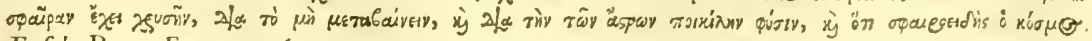
Eufeb. Prxp. Evang. p.69. 
The Sun of a For the Sun, being a Body of pure Light, his Garment, accord. light coloir. ing to Plutarch", was to be of the fame Colour, uniformly bright and luminous: though Macrobius ${ }^{2}$ cloaths the winged Statues of the Sun, partly with a light, partly with a blue Colour, the latter whereof was emblematical of that LumiIfis's Gar- nary in the lower Hemifphere. Whereas Ifis being confidered gated. as the Earth, ftrewed over with a Variety of Productions; being alfo Light and Darknefs \&c. Her Drefs, agreeable to thefe Qualities, was either to confift of a Lcopard's Skin, or elfe to be otherwife fpotted and variegated with diverfe Colours 3 . Ifis's Fillets. The Fillets ${ }^{4}$, which make part of her Drefs or are held in her Hands, reprefent the Phafes of the Moon; as the Trefles of her Hairs, when they are of a dark blue Colour, do the Hazi-

The Ornaments upon the Heads of their Deities. nefs of the Atmo/phere. The Rays, Flames ${ }^{6}$, Horns, Veils", \&c. that are placed immediately upon the Heads of thefe Figures; the Serpents ${ }^{8}$, which ftand upright upon them, or iffue out of their Hair ${ }^{9}$; together with the Globes, Mitres ${ }^{10}$, Fea-

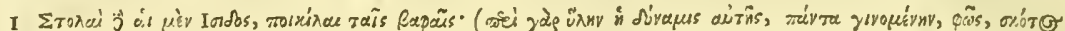

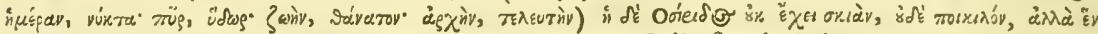

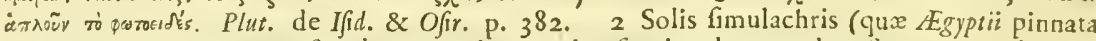
fingunt) color non unus eft, alterum enim cærulea fpecie, alterum clara tingunt : ex his clarum fuperum \& cæruleum inferum vocant. Inferi autem nomen Soli datur cum in inferiore hemifphærio i.e. hyemalibus fignis curfum fum peragit : fuperi, cum partem Zodiaci ambit xeltivam. Macrob. Sat. 1.r. cap. 19. 3 Vid. Not. 1. 4 Multicoloribus tæniis five fafciis ftatuam Ifidis veftiebant, ad fignificandum varias Lunx pdozss. Heliodor. Candidx vittx candorem Lun $x$ denotabant. Pigh. in $\mu$ vonozia de Horis. p. I7I. Hinc tænix illæ variæ multiplicefquc Ifidi dedicatx, non feptem tantum eas Lunæ facies, quas Heliodorus nuncupat oivodor,

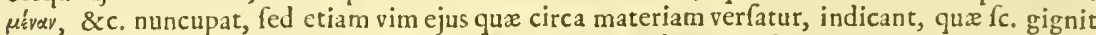
omnia \& omnia concipit, lucem quippe \& tenebras, diem, noctem, vitam, mortem, prin-

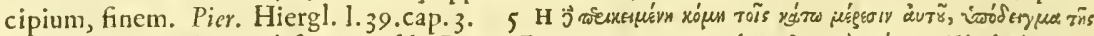

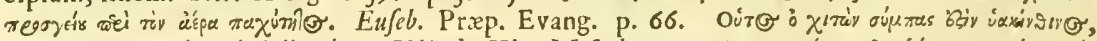

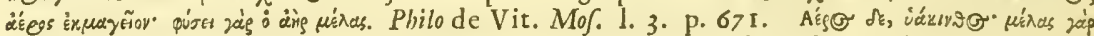
ช̈ror pise: Pbilo. de congreffu quærendx erudit. gr. p. 441. de Tabernaculi aulxis agens. apud Clem. Alex. p.665.

\section{6 - Caput autea rumpunt}

Cornua \& indigenam jaculantur fulminis ignem. Sidon. Apollin.

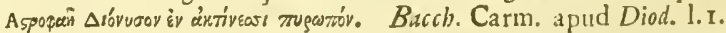

Sic Apollo, deinde Liber fie videtur ignifer.

Ambo funt flammis creati, profatique ex ignibus.

Ambo de comis calnrem, \& ambo radios conferunt.

Noctis hic rumpit tenebras, hic tenebras pectoris. I'ctus Pocta apud Aleand. Explic. Tab. Heliace P. 22. 7 Vertex velatus divinitatis latent is Symbolum eft.

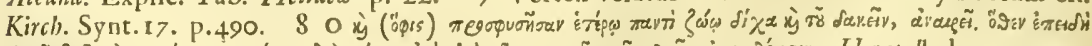

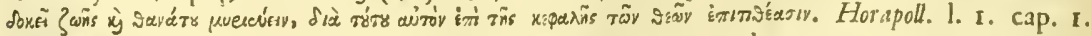
9 Jo-aspide cincba comas. Val. Flacc. Argon. 1.4.

10 Tutulos, (mithras, cydares) in capita gerebant, foribus, pennis, ferpentibus, ftellis, animalibus, flammis, circulis, vafis aliifque fimilibus, quibus Geniorum proprietates \& ideales rationcs exprimuntur, compactos: quos in facrificiis pariter imitabantur facerdotes, illifque notabatur, facerdotem continuo fupernas Deorum ideas, qux per cutulos notantur, fpeculari deberc: hoc enim facto, fc in eam intelligentiam, quam continuo mente volvebant, transformari, eidemque uniri \& quodammodo identificari fibi perfuadebant; unitos vero \& jam confortio Deorum adf́criptos, omnem fe felicitatis metam wेopo pass attigiffe rebantur. Kirch. Synt. r. p. I 57. 


\section{Obfervations in Egypt.}

thers', Palm-Leaves " \&c. that are fet above them, have each their fymbolical Meaning and Defign; being, in general, fo many Types of the Power, Nature and Attributes of that Deity or Genius, upon which they are placed 3. The Beard, that is Ofiris's fometimes given to O/iris ${ }^{4}$, hath likewife it's Meaning, being fymbolical of the Summer Solftice, at which Time the Sun, having afcended to it's greateft Height, is, as it were, arrived at a State of Puberty. But Silenus's bufhy Beard's was the fame Symbol with the Treffes of $1 /$ is's Hair. Nay, the Statues of very black Marble, out of which fome of thefe Figures are blec. made $^{6}$, typified, by it's Colour, the Invifibility of their Effence; as in others, the Head and Feet being black and the Body of a lighter Colour, might probably be fymbolical of the Deity's lying concealed to us in his Defigns and Actions, though he is apparent in his general Providence and Care of the Univerfe.

Thus have I given a fhort Sketch, and That chiefly from the Kircher kath

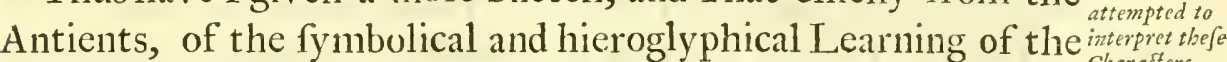
Egyptians; a fmall Portion, no Doubt, of what ftill remains to be difcovered. Kircher indeed, an Author of extraordinary Learning, indefatigable Diligence, and furprizing Invention, hath attempted, in his OEdipus and Obelifcus Pamploylius, to interpret ${ }^{7}$ all the Sacred Characters and Figures that came to his Hands. But as it cannot certainly be known, whether $\mathrm{He}$ might not take the outward Figures themfelves, for fuch Things as they were not intended, by the Sacred Scribes, to reprefent, miftaking, for Inftance, one Animal, Plant, Inftrument, Utenfil \&c. for another; all Reafonings and Inferences, drawn from thence, can be little more than mere Conjectures, and therefore the remarkable Boaft of $I / i s$, will ftill hold true, that no mortal bath hitherto taken off her $V$ eil.

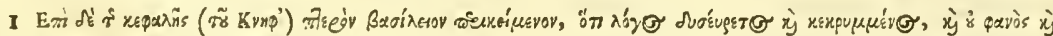

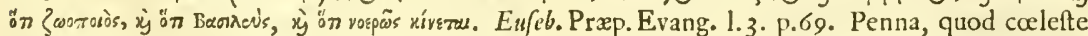

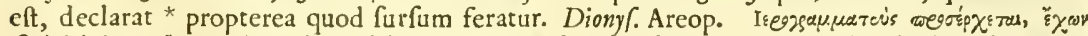

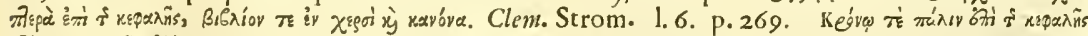

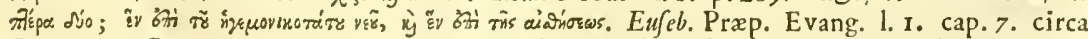
finem. 2 Caput decora corona cinxerat, Palmx candidx folijs in modum radiorum profiftentibus. Apul. Metam. 1. I I. p. 269. fic ad inftar folis exornato \& in vicem fimulachri conftituto \&c. 3 Vid.Not. Io. p.408. 4 Statuitur Solis f. Bacchi xtas pleniffima effigie barbx folltitio xltivo, quo tempore fummum fui confequitur argumentum. Mstrob. Sat. l.I. cap. I 8.

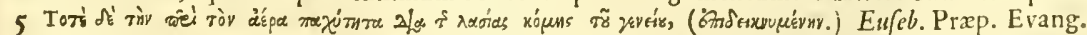

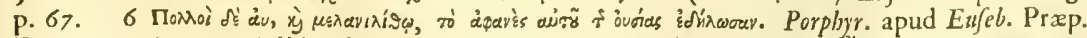

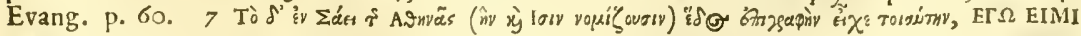

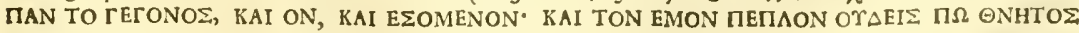

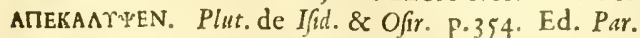


This Sacred Writing conveyed cbiefly upon Obclisks.

The Shape and Faflion of the fe Obelisks.

The Pedeftal. I had no Opportunity to fee them. I have been told indeed, that when the Pedeftal of the former was fome Years ago laid open by $\mathrm{M}^{\mathrm{r}}$. Conful Le Maire, they found it to be eight (French) Foot high, and in the like Fafhion, with thofe of the Grrecian and Roman Architecture. But this perhaps will require a further Examination; although the Draught, which I had the Perufal of (and from whence $\mathbf{I}$ borrowed the Characters in the following Page,) was agreeable to fuch Ornaments and Proportions. To reaflume therefore the Defcription of what is more in View :

The Shaft. it is obferved ${ }^{3}$, that the Shaft is in a decuple Proportion of it's greateft Breadth; as the whole Figure is nothing more than the Fruftum of a Pyramid, whofe Sides incline towards each other

I This is likewife called the Tabula Bembina, from being once in the Poffeftion of Cardinal Bembo. It has been publifhed by Pignorius, Herwart and others, and is now in the Poffeffion of the Dukes of Savoy. Vid. Kirch. OEd. Egypt. in menfa Ifraca. 2 Iambliclus inftructs us (Scat.1. cap.2. de Myfterijs Aggyt.) that Plato and Pythagoras learned rheir Philo-

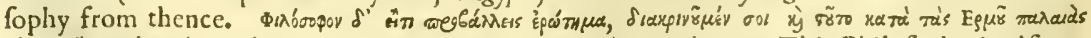

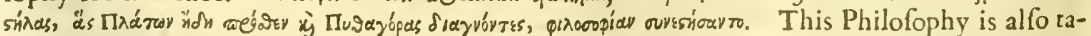
ken Notice of by Pliny (1.36. cap.9.) Infcripti (Obelifci) rerum naturx interpretationem Egyptiorum opera philofophiæ continent. 3 Obelifci altitudo in decupla proportione conItituerunt, ad latus quadratx bafis inferioris. Sic fi Obelifci cujufquam latus fit Io paimarum, altitudo erit 100. Pyramidion vero terminans Obelifcum altitudine fua xquabar latitudinem inferiorem five latus bafis infimx Obelifi. Kirch. Ob. Pamph. p. 52. 
in an Angle of about one Degree. This Fruftum terminates The Pyramiin a Point, that is ufually made up (by the Inclination) of equilateral Planes, as in the common Pyramids, from whence it has received the Name of the Pyramidion, or little Pyramid. It hath likewife been obferved ', that the Height of this Part, is equal to the greateft Breadth of the Obelisk; but this, I prefume, will not always hold true, otherwife it would be of great Importance in eftimating the Quantity of any of thefe Pillars that lyes buried under Ground. But the Bafis or Foot, the Foor of may perhaps be the moft remarkable Part of thefe Obelisks, ronnd. efpecially if that at Alexandria is to inftruct us. For This, as the late worthy Perfon, above-mentioned, informed me, had not a fquare Bafe, like thofe we fee at Rome, but an Hemifpherical one, that was received (in this Manner $(u$ ) into a correfpondent Cavity in the Pedeftal; upon which likewife were thefe odd Characters, fuch as the wheel-like, capreolated ones of Apuleius ${ }^{2}$ may be fuppofed to have been.

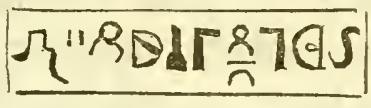
It is certain, that thefe Pillars, by being thus rounded at theBot- Obelisks and tom, would bear a nearer Refemblance to Darts and miffive Wea- dracted to to the pons, than if they were fouare; and confequently would be more expreffive of the Rays of the Sun, which they were fuppofed to reprefent; as it was the Sun itfelf to which they were dedicated 3. It may likewife be prefumed, as the Pyramids ${ }^{4}$, which are Obelisks only in obtufer Angles, were equally emblematical of Fire, fo they may be confidered under the fame religious View, to have been no lefs confecrated to the fame Deity.

I Vid. Not. 3. P. 410.2 De opertis adyti profert quofdam libros, literis ignorabilibus prenotatos; partim figuris cujufmodi Animalium, concepti fermonis com. pendiofa verba fuggerentes; partim nodofis \& in modum rote tortuofis, capreolat timque condenfis apicibus, a curiofa profanorum lectione munita. Apul. Met. I. II. p. 268. 3 Obelifci enormitas Soli profticuta. Hermut. apud Tertull. de Spect. cap. 3 . Trabes ex eo fecere Reges quodam certamine, Obclifcos vocantes, Solis numini facratos. Radiorum ejus argumentum in effigic eft; \& ita fignificatur nomine Egyptio. Plin. 1. $3^{6 .}$ cap.8. (литєВлнрн forfan i.e. digitus Solis. Kirch. Obel. Pamph. p.44.) Mefplres* duos Obelifcos Soli confecravit. Ifid. I. I8. cap. 3I. Finis denique principalis, quem AEgyptij in Obelifcorum erectione habebant, erat, ut Ofiridem \& Ifidem, hoc eft, Solem \& Lunam in his figuris, veluti myltica quadam radjorum reprefentatione colerent, quafi hoc honote tacite beneficiorum, per hujufmodi fecundorum Deorum radios acceptorum magnitudinem infinuantes. Kircl. p. I6r. ut fupra. Other Deities likewife, viz. Jupiter, Venus, Apollo éc.

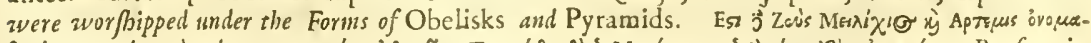

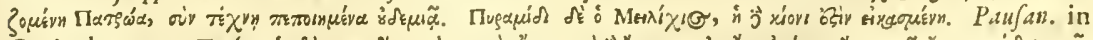

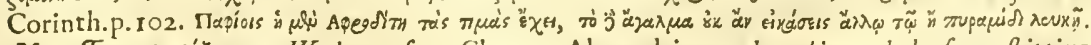

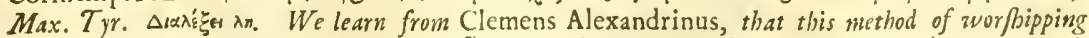

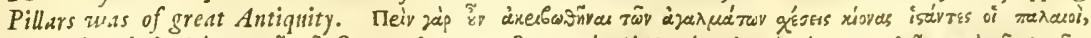

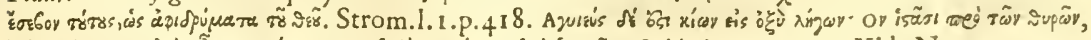

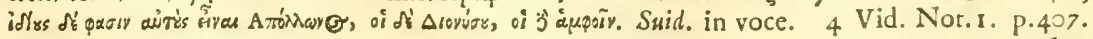


The Obclisk of Alexandria and Matta-reah or Heliopolis.

The Hieroglyphical Characters upon the Heliopolitan Obelisk.
The Obelisks which I have mentioned at Alexandria and Heliopolis, have been defcribed by various Authors. The Hieroglypbicks upon the latter, (which are the fame on all Sides,) are exceedingly fair and legible; and indeed the whole Pillar, is as intire and beautiful, as if it were newly finifhed. But the Alexandrian Obelisk, lying nearer the Sea, and in a moifter Situation, hath fuffered very much; efpecially upon that Side, which faceth the Northward: for the Planes of thefe Pillars, no lefs than thofe of the Pyramids, feem to have been defigned to regard the four Quarters of the World. It may likewife be further obferved with Regard to this Pillar, that the Height of it, which is found to be fifty (French) Foot, three whereof are buried under Ground, agrees, almoft to a Nicety, with the Length of one or other of the Me/phean Obelisks', that were erected at this Place. Several of the Characters upon the Heliopolitan Obelisk, are filled up with a white Compofition, as if they had been enamelled; which, at firft Sight indeed, engage us to imagine, that all of them, originally, were intended to be fo. But, upon a ftricter View, this appeared to have been done by the Hornets, that, in the Summer Seafon, fix here their Nefts.

The Copy which I took of this Pillar, is agreeable to the annexed Defign; wherein A.B.C.D. reprefents the Shaft of the Obelisk, E. the Pyramidion, F. G. H.I. the four Quarters of the World, K. K. K. fo many Amulets or Talefmans. Among the Heroglyphicks, a. is Ofiris or the Sun, b. the Crux Anfata, $c$. the triple Branch of the Perfea, $d$. the upper Hemifphere, e. a Quail, $f$. the Thyrfus Papyraceus, g. the Pantamorpha Natura, h. the Disk and Beetle, k. a Faviffa or Ciftern, l. the $I b$ is, $m$. the lower Hemifphere, $n$. the Goofe, o. the Sceptrum Agimorphum, p. the Sceptrum Arundinaceum or इxoivo, q. a Sceptre, with two Ferulas, denoting the Union of two Powers, r. a Hydrofchema or Water Courfe, f. a Rudder, t. the Situla, u. the Influx of the four Elements, w. an Agathodremon, x.a Feather, $y$. the Serpent, $z$. a Hatchet, or O/iris's Hook, a. an Arm, with the Tendril of a Vine, $\beta$. a Gate, $\gamma$. an Eye, \&. the Ceraftes, E. a Pyramid. But for a particular Explication of thefe Characters, the greateft Part whereof have received their very Denominations from Kircher, the Reader is referred to that learned Author.

I Et alii duo funt (Obelifci) Alexandria in portu ad Cafaris templum, quos excidit Mefplores rex quadragenûm binûm cubitorum. Plik. 1.36. cap. 9 .

Diodorus 
She olediik at . Nubtriate.
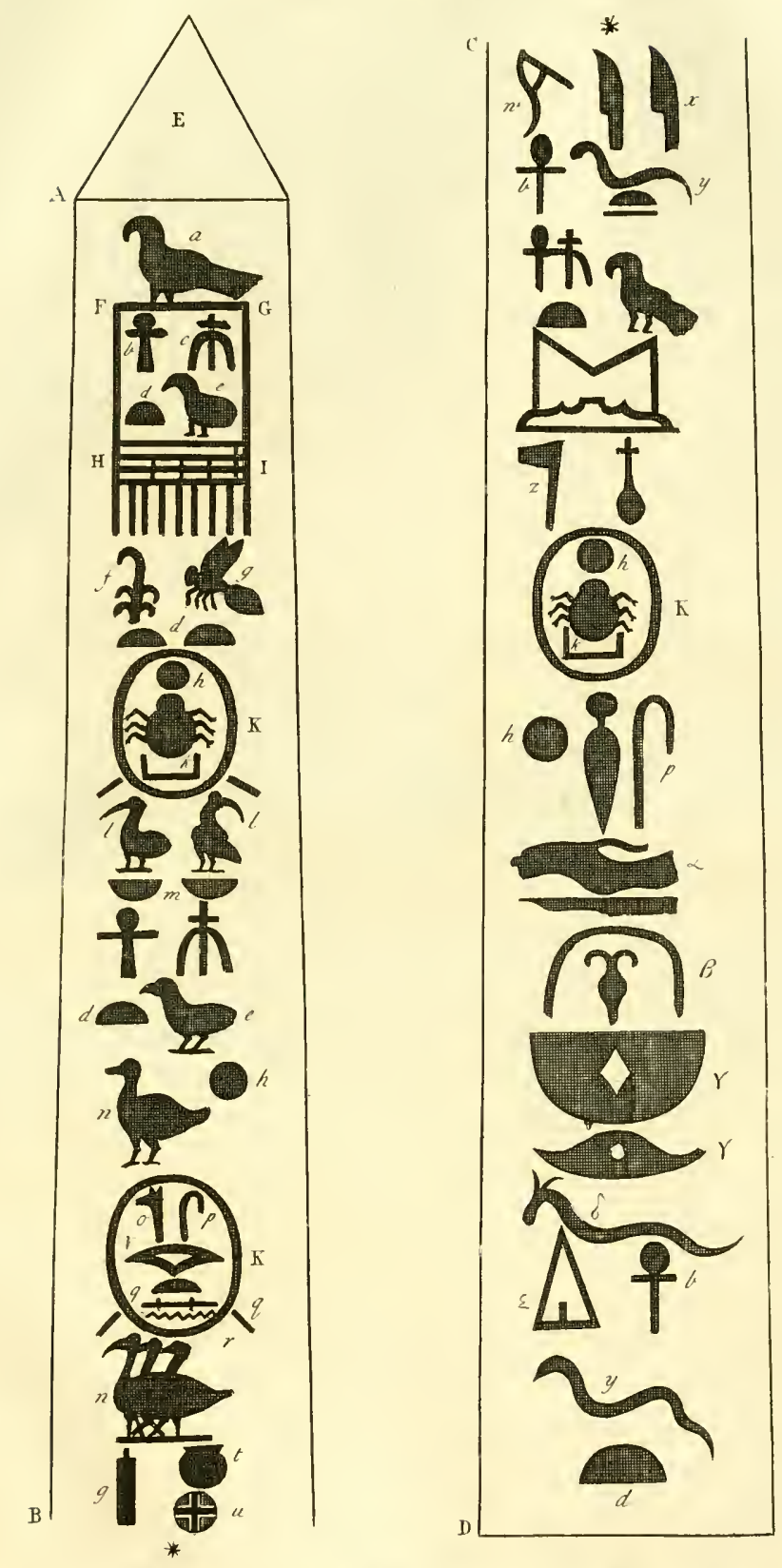

(1)

\%.Y" ROBERT BIRDETTIF Frmalch in \%" rinnty of Onily. Chatimete 



\section{Obfervations in Egypt.}

Diodorus' inftructs us, that Sefoftris erected two Obelisks at This Obelists Heliopolis, which were an hundred and twenty Cubits high, pas probed ably and eight broad. We learn alfo from Pliny ${ }^{2}$, that Sochis and Ramifes erected each of them four; whereof thofe of Sochis were forty eight, and thofe of Ramifes, forty Cubits only in Height. The Breadth of the loweft Part of This, I am fpeaking of, is fix Foot, and the whole Height, according as I meafured it by the Proportion of Shadows, was no more than fixty four; though other Travellers have found it upwards of feventy. Provided then we could know, which of the above-mentioned Pillars This remaining one fhould be, together with the exact Height of it, we might thereby compute the Quantity of Mud, that hath been left upon the adjacent Soil, fince the Time it was erected. Now thofe that were raifed by Sefoftris, are vaftly too high, as thofe of Ramifes are too low, to make any Pretenfions to it. For with Regard to the former, even granting the Pillar, I am defcribing, to be feventy Foot high, yet ftill as the much greater Part of it muft remain under Ground, This will exceed, by far, any Acceffion of Mud or Ruins, that could poffibly have been accumulated, in the Time, above the Foundation of it. Ramifes's Obelisks, being only forty Cubits (i. e. fixty Foot) high, are even fhorter than This is found to be by Obfervation. In all probability therefore, This, which I am defcribing, muft be the furviving Obelisk of thofe that were erected by Sochis, whofe Height, by taking in alfo what may be allowed for the Pedeftal, will anfiver in Grofs, to fuch Accidents and Alterations, as have happened to the Soil of Egypt fince the Erection of it. But further Notice will be taken of This in another Place.

There is no Point in Hiftory that hath been fo often, and The Pyramids at the fame Time fo varioufly treated of, as That which relates sarious fribed. to the Pyramids of Memphis. The Antients abound with a Diverfity of Accounts and Defcriptions concerning them; whilft the Moderns, after a much longer Courfe of Obfervations, have yet notwithftanding rather multiplied the Difficulties, than cleared them.

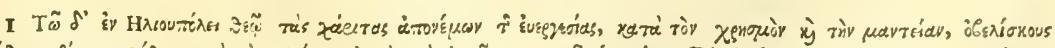

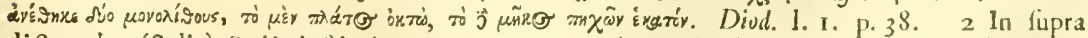
dicta urbe (Solis) Sochis inltituit quatuor numero (Obelifcos) quadragenûm octonûm cubitorum longitudinc: Ramifes autem is, quo regnante Ilimm captum eft, quadraginta cubitorum. Plin. 1.36. cap. 8 . 
Neitber the Antients nor Moderns agree about the Dimenfous of the Great Pyramid.
The Dimenfions of the great Pyramid, have given Occafioxi to one Difpute. Herodotus " makes the Bafe of it to be eight hundred Foot long; Diodorus ${ }^{2}$ feven hundred; and Strabos only fix hundred. Among the Moderns, Sandys ${ }^{4}$ found it to be three hundred Paces; Bellonius ${ }^{5}$ three hundred and twenty four; our Profeffor Greaves ${ }^{6}$, fix hundred and ninety three Englifh, and Le Brun' ${ }^{7}$ feven hundred and four Feet, (as we may fuppofe, ) of France, which make about feren hundred and feventy of our Meafure. There is no Way, I prefume, to reconcile thefe Differences, and it would be unjuft to charge any of thefe Authors with a defigned Miftake. Thus much then, in general, may be faid, in Defence and Vindication of None of the Errors and Difagreements of this Kind, that none of the Sides Sides of it are
upon an exact of this Pyramid are exactly upon a Level. For there is a Lervel.

Defcent in paffing, from the Entrance into it, all along by the eaftern Corner, to the fouthern; there is again an Afcent from This to the weftern Point; at the fame Time the Sides, which regard theWeft and theNorth, have been encroached upon by fuch Drifts of Sand, as the Etefian Winds, from Time to 'Time, have brought along with them. As therefore it will be difficult to find a true Horizontal Bafe; it being likewife uncertain, (which is the chief Thing to be confidered,) how far thefe Drifts of Sand may have been accumulated above the Foundation of it; all Calculations of this Kind muft be exceedingly precarious, agreeable only to the Time, and to the particular Circumftances of the Situation, when they were made.

None of the Pyramids were ever froifficed.
Neither doth it appear that either This, or any other of the three greater Pyramids, was ever finifhed. For the Stones, in the Entrance into the greateft, being placed archwife and to a greater Height than feems neceffary for fo fmall a Paffage;

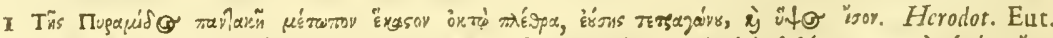

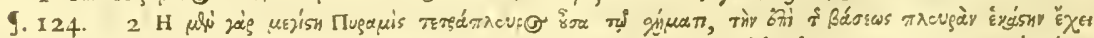

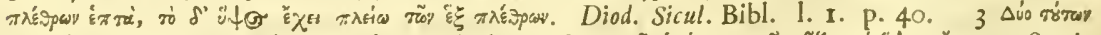

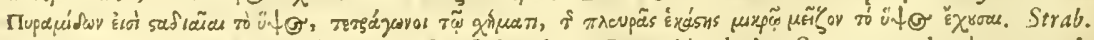
Geogr. 1.17. P.555. 4 The greateft of the three Pyramids, being Square at the bottom, is fuppofed to take up cight Acres of Ground ; every Square being 300 fingle Paces in Length. Sand.Trav. p.99. Ed.vr. s Nos maximx Pyramidis bafim dimenff fumus, qux quatuor angulorum paribus intervallis cum fit, trecentos viginti quatuor paffus habet in fingula latera, paululum extenfis cruribus, gradiendo fingulos paffus numerantes. Bellon. Obfervat. I.2. p. 269. 6 See his Pyramidographia. 7 Je contai trois cens bons pas d'un coin a l'autre du grand Pyramide. Plus je donnai a deux Arabes une corde que j'avois pour cet effet prife avec moi \& je leur fis mefurer la diftance de ces coins de l'un a l'autre, qu'ils trouverent qui montoit a cent vingt braffes qui font fept cens $\&$ quatre pieds. La Hauteur par devant cent douze braffes f. fix cent feize pieds : un braffe cinque pieds \& demi. Le Brun. Voyag. eap. 36.

there 
there being alfo a large Space left on each Side of it, by difcontinuing feveral of the parallel Rows of Steps, which, in other Places, run quite round the Pyramid; thefe Circumftances, I fay, in the Architecture of this Building, feem to point out to us fome further Defign, and that originally there might have been intended a large and magnificent Portico. Neither The Stpps to were the Steps or little Altars, as Herodotus ' calls them, to wo fith prififaremain in the fame Condition they have been in from the earlieft Records of Time. For thefe were all of them to be filled up, in fuch a Manner, with prifmatical Stones, that each Side of the Pyramid, as in That of Ceftius at Rome, was to be fmooth and upon a Plane. Now nothing of this Kind appears to have been ever attempted in the leffer or greater of thefe Pyramids, (the latter of which wants likewife a great Part of the Point, where this filling up was probably to commence;) but in the fecond, commonly called Chephrenes's Pyramid, which may hint to us what was intended in them all, we fee near a Quarter of the whole Pile, very beautifully filled up, and ending, at the Top, like the Point of a Diamond. Thefe Stones, agreeable perhaps to the Depth of the Strata from whence they were hewn, are from five to thirty Foot ${ }^{2}$ long; and from three to four Foot high. Yet, notwithftanding the Weight and Maflinefs of the greateft Part of them, they have all been laid in Mortar, which, at prefent, is eafily crumbled to Powder, though originally perhaps it might be of greaterTenacity, as the Compofition of it feems to be the fame with That of Barbary 3.

The Antients ${ }^{+}$inform us, that the Stones of the Pyramids ${ }_{\text {The Pyrami- }}$ were brought from the Mountains of Arabia. Yet, notwith- dal stones not ftanding the great Extravagance and furprizing Undertakings or the Arabian of the Egrptian Kings, it doth not feem probable, that they Mo:satains. would have been at the vaft Labour and Expence of bringing Materials from fo great a Diftance, when they might have been fupplyed from thofe very Places, where they were to employ them. Now the Stone which makes the Bulk and

I Eroiñ Eut. 9. 125. 2 Herodotus affirms that none of thefe Stoncs were lefs than thirty Foot long.

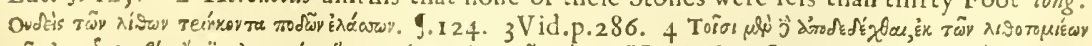

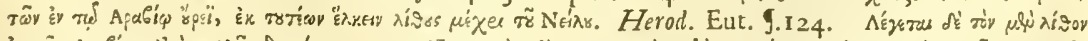

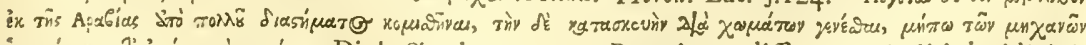

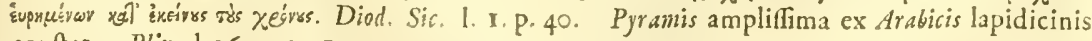
contat. Plin. 1.36. cap. I2

$\mathrm{Mmmm} 2$

Outfide 
They mere ta-Outfide, at leaft, of all thefe Pyramids, is of the fame Nature ken from the
Mlountains upon wobich they are $\mathrm{cm}$ ployed.

Spars, Foffil Shells, Coralline Subítances ${ }^{\prime} \& \mathrm{c}$. as are common to the Nountains of Lybia. In like Manner Folepl's W'cll, the Quarries of Moccat near Kairo, the Catacombs of Sakara, the Sploinx, and the Chambers, that are cut out of the natural Rock, on the Eaft and Weft Side of thefe Pyramids, do all of them difcover the fpecifick Marks and Characterifticks of the Pyramidal Stones, and, as far as I could perceive, were not to be diftinguifhed from them. The Pyramidal Stones therefore, were, in all Probability, taken from this Neighbourhood; nay perhaps they were thofe very Stones, that had been dug away, to give the Splinx and the Chambers, I have mentioned, their proper Views and Elevations.

The great Py- It may be farther obferved, that the Pyramids, efpecially ramid is it at at the greateft, is not an intire Heap of hewn Stones; inafmuch Heap of bem as that Portion of it, which lyeth below the Horizontal stous. S. Section of the Entrance, may probably be no more than an Incruftation of the natural Rock, upon which it is founded. For, in advancing through the narrow Paffage, the natural Rock is twice difcovered: the lower Chamber alfo, together with the Well, (whofe Mouth lyeth upon a Level with it,) appear to be of the fame; whereby a confiderable Abatement is to be made in fuch foreign Materials, as would have been otherwife required in the building of this Pile.

No certain Account when or by whom thefe Pyramids mere fourded.

It is very furprizing, that the Pyramids, which from their firft Foundation, muft have been looked upon with Wonder and Attention, fhould not have preferved a more certain Ara, and Tradition of the Time of their Foundations, or of the Name of their Founders. Pliny ${ }^{2}$ reckons up a Number of Authors, who have wrote of the Pyramids; and all of them, He tells us, difagree in the Accounts they give us of thofe who built them. Cheops 3 , Chephrenes, and Mycerinus have been

I Efpecially of fuch as Strabo calls petrified Lentils, telling us, that they were originally

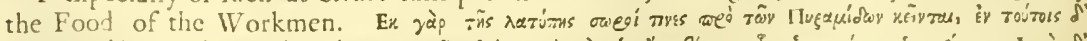

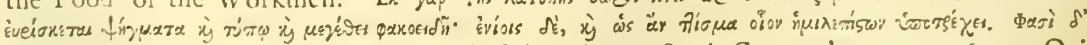

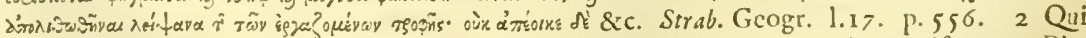
de ijs (Pyramidibus) feripferunt, funt Herodotus, Eulcmerus, Duris Samius, Ariftagoras, Dionyfius, Artemidorts, Alexander Polybifor, Butorides, Antifthenes, Demetrius, Demotiles, Apion: inter omnes eos non conflat a quibus fagte funt, jultiffmo cafu obliteratis tantx vanitatis

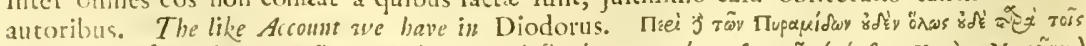

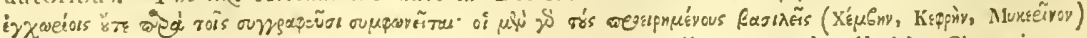

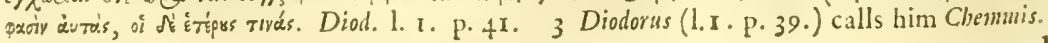


generally taken for the Perfons'. Now as Egypt had been, from Time immomorial, the Seat of Learning; where it was likewife pretended, that a regular and chronological ${ }^{2}$ Account had been kept of all the remarkable Tranfactions of their Kings; it is much, that the Authors of fuch great Undertakings, fhould be fo much as even difputed. Yet we find there were other Accounts, and Traditions concerning them. For it is faid ${ }^{2 \text {, }}$, that Suphis built the firft, and Nitocris the third; that the fecond was raifed, as Herodotus ${ }^{3}$ acquaints us, from the Money which the Daughter of Cheops procured at the Expence of her Chaftity; whilft the two greater were the Work of the Shepherd Philition; and the leaft had the Harlot Rbodope for it's Foundrefs. Herodotus indeed, who hath preferved thefe Reports, doth not give much Credit to them; however it may be juftly enough inferred from hence, that as the Chronology of the Pyramids, (thofe Wonders of the World,) was thus dubious and obfcure, there is fufficient Ground to fufpect the Correctnefs and Accuracy of the Egyptian Hiftory in other Matters.

Neither is there an univerfalConfent, among the Antients, It is not afor what Ufe or Intent thefe Pyramids were defigned. For greed for phyas Pliny afferts, that they were built for Oftentation and to mids morre inkeep an idle People in Employment; others, which is the moft received Opinion, that they were to be the Sepulchres of the Egyptian Kingss. But if Cheops, Suphis, or whoever elfe was the Founder of the great Pyramid, intended it only for his Sepulchre, what Occafion was there for fuch a narrow, crooked Entrance into it; for the $\mathrm{Well}^{6}$, as it is called, at the End of the Entrance; for the lower Chamber, with a large Nitch or Hole in the eaftern Wall of it; for thelong narrow Cavities in the

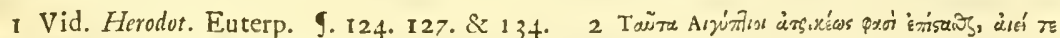

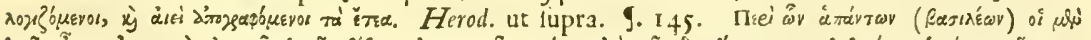

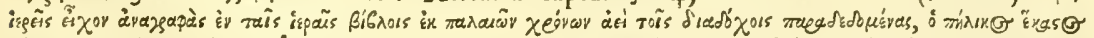

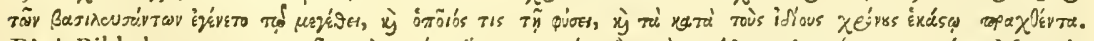

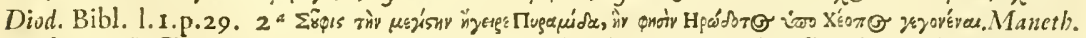

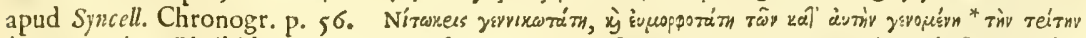
"ystęs Mugauida. Id. ibid. P. 58. 3 Vid. Not.r. 4 Pyramides regum pecunix otiola ac ftulta oftentatio; quippe cum faciendi eas caufa, a plerifque tradatur, ne pecuniam fuccefforibus aut æmulis infidiantibus præberent; aut ne plebs effet otiofa. Plin. 1.36. cap. 12.

5 - Pyramidum tumulis evulfus Amafis. Luc.1.9. 1.155.

Cum Ptolcmaorum manes fericmque pudendam

Pyramides claudant indignaque Muufolea. Id. 1. S. 1. 698.

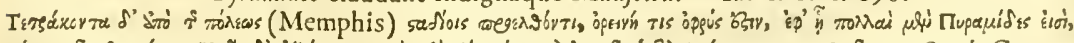

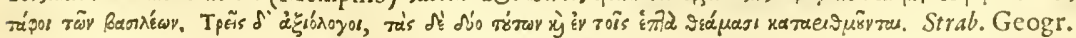

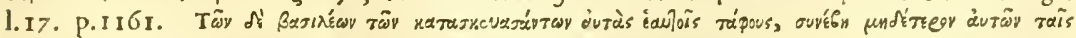

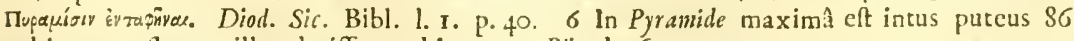
cubitorum, tlumen illo admiffum arbitrantur. Plin. 1.36. cap. 12.

Nnnnn

Walls 
Walls of the upper Room; or for the two Ante-Chambers, and the lofty Gallery ${ }^{\text {, }}$ with Benches on each Side, that introduce The Great us into it? As the whole of the Egyptian Theology was cloathed Pyramid roas probably in-
tended for a Timple. in myfterious Emblems and Figures, it feems reafonable to fuppofe, that all thefe Turnings, Apartments, and Secrets in Architecture, were intended for fome nobler Purpofe, (for the Catacombs are plain, vaulted Chambers, hewn out of the Rock) and that the Deity rather, which was typified in the outward Form of this Pile ${ }^{2}$, was to be worfhipped within. The great Reverence and Regard, which Suphis ${ }^{3}$, one of the fuppofed Founders, is faid to have paid to the Gods, will perhaps, in the firft Place, not a little favour fuch a Suppofition. Yet even if this at laft thould not be granted, no Places certainly could have been more ingenioufly contrived for the Adyta, that had fo great a Share in the Egyptian Myfteries.

The fecont and third $\mathrm{Py}$ ramids were for Sciulcbrcs.

It has been before obferved, that Chephrenes built the fecond Pyramid, and Mycerinus the third: but for what Intent? not to be their Sepulchres; inafmuch as no Paffage being left open into Them, as into the Great Pyramid, they mut have been pulled down, and built again after their Deceafe, before their Bodies could have been there depofited. If indeed we had any authentick Tradition, that thefe Pyramids had been built, by fome pious Succeffors, over the Tombs of their Anceftors, there would then be lefs Occafion to call in Queftion an Opinion, that hath been fo generally received: but if no Report of this Nature occurs in antient Hiftory, if the Founders made no Provifion in them for their Interments, (which is fuppofed to be the principal Intent of thefe Structures, ) but contrived them, as far as we know, and are informed from Antiquity, to be clofe, compact Buildings, it may fo far, I prefume, be difputed, that the two leffer Pyramids, at leaft, could never have been intended for Sepulchres.

The chef in The fquare Cheft likewife of Granate Marble, which is the Great Py- ramid ans

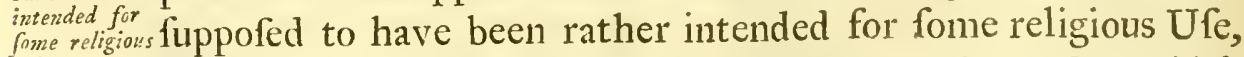
Ufe. than for the Coffin of Cheops. For among other Ufes, which at this Diftance of Time, and in fo fymbolical a Religion, we cannot expect to trace out in Hiftory, This Cheft may be fup.

I See the Defcription of thefe feveral Places in Greaves's Pyramidographia. 2 Vid.

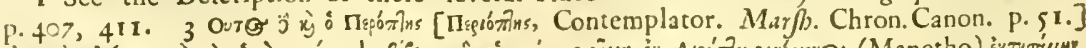

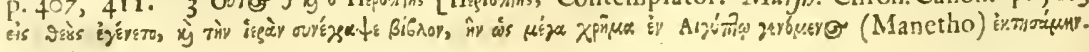
Syncell. p. 56 .

pofed, 
pofed, to have been concerned either in the myftical Worfhip of O/iris ${ }^{\text {}}$, or to have ferved for one of their (Kísay iega ${ }^{2}$ ) Sacred Chefts, wherein either the Images of their Deities, or their Sacred Veftments ${ }^{3}$ or Utenfils were kept; or elfe that it might have been a Faviffa or Ciftern ${ }^{4}$, fuch as contained the Holy Water, made ufe of in their Ceremonies. The Length ${ }^{4 a}$ of it, which is fomewhat more than fix Foot, does indeed favour the received Opinion of it's having been defigned for a Coffin; yet both the Height and the Breadth, which are each of them about three Foot, very far exceed the Dimenfions, that perhaps were ever obferved by the Egrptians, upon fuch Occafions. Thofe Stone Coffins, which I have feen in Egrpt, (and by them, Tre Stone I prefume, we may judge of others,) were all of them of a coffins of Equite different Form from this pretended one of Cheops; being $\begin{gathered}\text { in the fame } \\ \text { Forme }\end{gathered}$ infcribed with Hieroglypbicks, and made exactly in the Fafhion of the Mummy Chefts, juft capacious enough to receive one Body. Whereas This, which I am fpeaking of, is an oblong Square, not ending, as the Mummy Chefts do, in a Kind of Pedeftal, whereupon it might have been erected; neither is it adorned with any Sacred Characters, which, from the great Number of Coffins that are never known to want them, feem to have been a general as well as neceffary Act of Regard and Piety to the deceafed.

The Manner likewife, in which this Cheft is placed, is quite Tbe Murndifferent from what was perhaps ever obferved by the Egyptians, miecsed horriin the depofiting of their Dead. For the Mummies always zontrally, but ftand uprights, where Time or Accident have not difturbed them: whereas This Cheft lyeth flat upon the Floor, and thereby hath not that Dignity of Pofture, which, we may fuppofe, this wife Nation knew to be peculiar, and therefore

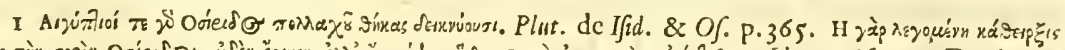

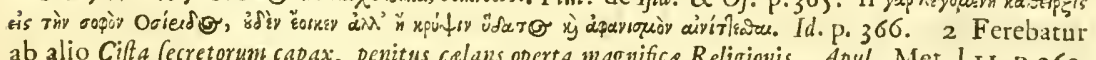
ab alio Cifta fecretorum capax, penitus calans operta magnifica Religionis. Apul. Met. J.I 1.p.262.

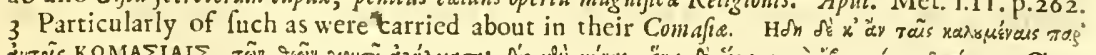

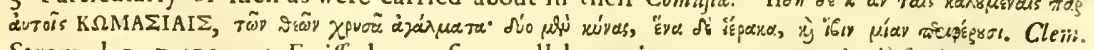
Strom. 1.5. P.413. 4 Faviffa locum fic appellabant, in quo erat aqua inclufa circa Templa. Sunt autem, qui putant Favifas effe in Capitolio caellis cifternifque fimiles; ubi reponi erant folita ea, qux in Templo vetuftate erant facta inutilia. Feft. Fuit autem in Templo Pifiua fub figura convenienti mylterijs corum. Abeneph. de Relig. Agypt. apud Kirch. Obcl. Pamph.

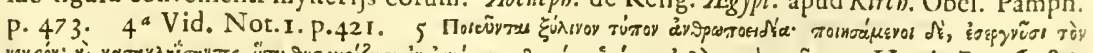

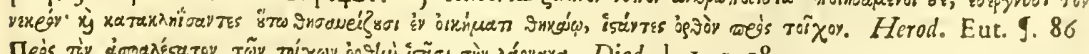

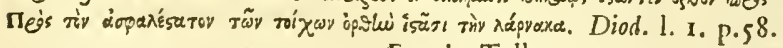

Claudit odorato poft funus itantia (bufto) faxo

Corpora.-—— Sil. Iial. 1.13.1.475.

Nnnnn2 would 
The chef rot would be very forupulous to deny to the human Body. Now intended for
the coffin of if this Cheft was not intended for a Coffin, (and indeed HeroCheops. dotus ${ }^{\mathrm{r}}$ tells us that Cheops's Tomb was in the Vaults below) we have fo far a prefumptive Argument, that neither could the $\mathcal{P}_{y}$ ramid itfelf have taken the Name of a Sepulchre from it. Nay provided even that Cheops and others had been buried within the Precincts of This or any other of the Pyramids, yet ftill this was no more than what was practifed in other Temples ${ }^{2}$, and therefore would not deftroy the principal Ufe and Defign for which they were erected. And indeed, I am apt to think, that there are few, who attentively confider the outward Figure of thefe Piles; the Structure and Contrivance of the feveral Apartments in the Infide of the Greateft; together with the ample Provifion, that was made on each Side of it, for the Reception, as may be fuppofed, of the Priefts; but will conclude, that the Egyptians intended the Latter for one of the Places, as all of them were to be the Objects at leaft, of their Worfhip and Devotion.

The Antients Strabo3, as far as I know, is the only Perfon among the

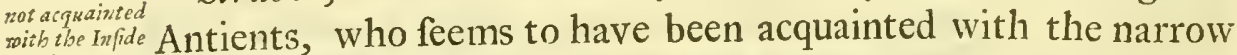
of the Great Entrance, that conducts us into the Great Pyramid. We have only a fmall Afcent up to it at prefent; and, as it may be prefumed, that the Situation of it in his Time 4 , was nearly half Way up the Pyramid, we are fo far inftructed, what extraordinary Encroachiments have been fince made, by the Sands, in that Direction. However if there had been a Paffage left open, fo early, into this Pyramid; if this Paffage was not continued directly forward, in the fame Angle of Defcent, quite down to the fubterraneous Cavities, (as the many Breaches and Irregularities in the Architecture of that Part of it, where we firft begin to afcend, will give us Room to fufpect;) it is much, that no particular Account hould have been left us, by antient Hiftorians s, of the feveral Apartments that have been fince defcribed

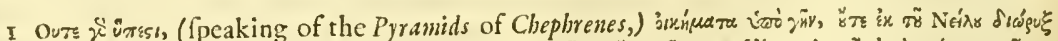

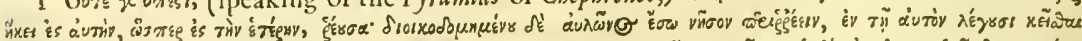

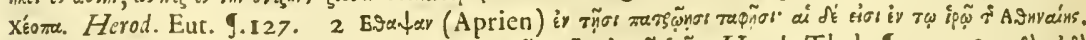

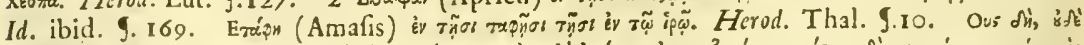

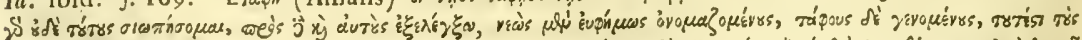

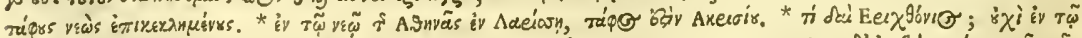

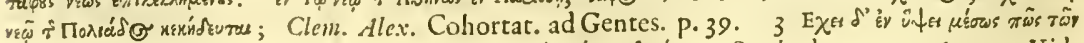

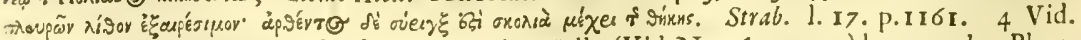
Not. ut fupta. 5 Pliny indeed mentions the Well, (Vid.Not.6. p.4i7.) but no other Place. 
by the Moderns; and of the Cheft which is placed in the uppermoft of them. An Arabian Hiftorian " acquaints us, that this Pyramid was opened, only about nine hindred Year's ago, by Almamon, the Calif of Babylon; and that "they found in "it, towards the Top, a Chamber, with an hollow Stone, in "which there was a Statue like a Man, and within it a Man, " upon whom was a Breaft-Plate of Gold, fet with Jewels; upon "this Breaft-Plate was a Sword of ineftimable Price, and at "his Head a Carbuncle of the Bignefs of an Egg, fhining like "the Light of the Day, and upon him were Characters writ "with a Pen, which no Man underftood". But this, it may be prefumed, is of the fame Authority, with what he obferves in another Place, "That he who built the Pyramids, was "Saurid ibn Salhouk, the King of Egypt, who was before the "Flood 300 Years". But letting alone thefe furprizing Accounts, it is remarkable, that the Cheft, in ftriking it, gives the fameMufical Note, (E-la-mi, if I miftake not,) with the Chamber ; and thereby may be fuppofed to have fimilar Dimenfions: though, by Menfuration, our accurate Profeffor ${ }^{2}$ found their refpective Proportions to be different. We are to obferve further, that this Cheft is fixed fo ftrongly in the Floor, that a Number of Perfons were not able to move it; being fituated, (perhaps not without a Myftery,) in the fame Direction, with the Mouth of the Pyramid, directly to the Northward; a Pofition, that was likewife given to the Doors of other Egyptian Edifices ${ }^{3}$.

Befides what hath been already mentioned with Regard to There are the Sphinx, we are to take Notice, that (in $\mathcal{F} u l y, \mathbf{I} 72 \mathrm{I}$.) the Holes upon Sands were accumulated to that Degree round about it, that Sumphins. we could but juft difcover the Ridge of the Spine; at the End of which, juft over the Rump, there was a fquare Hole, about four Foot long, and two broad. But this was fo clofely filled up with Sand, that we could not lay it open enough to obferve,

1 Ibn Abd Albokm, as he is recorded by Mr. Greaves in his Pyramidographia. 2 The exreriour fuperficies of this Tomb contains in Length, feven Feet three Inches and an half. In Depth it is three Feet, three Inches, and three Quarters, and is the fame in Breadth. The hollow Part within is in Length on the W. Side, 6 Feet and ${ }_{705}^{405}$. In Breadth, at the N. End 2 Feet and $\frac{218}{1000}$. The Depth is 2 Feet and $\frac{860}{1000}$ Parts of the Englifh Foor. The Length of the Chamber on the S. Side is 34 Feet and $\frac{380}{8000}$. The Breadth is 17 Feer and

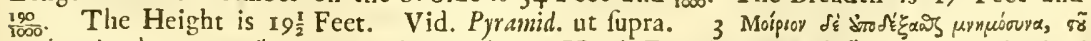

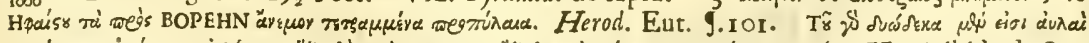

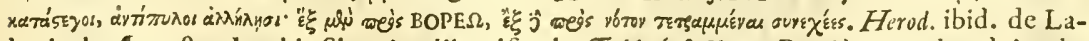
byrintho 9. 148. In this Situation likewife the Table (of She -Bread) was placed in the Tabernacle. Exod, 40. 22. 
whether or no it had been originally contrived (like the Well in the Great Pyramid) for a Stair-Cafe. Upon the Head likewife there is another Hole, of a round Figure, which, I have been told, is five or fix Foot deep, and wide enough to receive a well grown Perfon. The Stone, which this Part of the Head confifts of, feems to be adventitious; but the reft of the Figure is There Holes hewn out of the natural Rock. It muft be left to future'Travellers a communica- to find out, whether thefe Holes ferved only to tranfmit a Pyramids. Succeffion of frefh Air into the Body of the Spbinx, or whether they might not have had likewife a Communication with the Great Pyramid, either by the Well, or by the Cavity in the Wall of the Chamber, that lyes upon the fame Level with it. Nay it will fometimes perhaps appear, that there are Chambers alfo in the two other Pyramids; and not only fo, but that the Eminence likewife, upon which they are erected, is cut out into Cryptre, narrow Paffages and Labyrinths, which may, all of Them, communicate with the Chambers of the Priefts, the artful Contrivers of thefe Adyta, where their initiatory, as well as other myfterious Rites and Ceremonies, were to be carried on with the greater Awe and Solemnity.

The Ca:acombs at Sakara.

The Accounts that have been hitherto given us of the Mummies, feem to be very imperfect; and indeed the Catacombs at Sakara, which are commonly vifited, have been fo freguently rifled and difturbed, that nothing hath preferved it's The Uras in primitive Situation in Them. There are ftill remaining, in mbich the Ibis
is preferved. fome of thefe Vaults, a great Number of Urns, of baked Earth, in a conical Figure, $a$, which contain, each of them, an Ibis. The Bill, the Bones, nay the very Feathers of this Sacred Bird are admirably well preferved even to this Time. For (if we except the Hieroglyphical Writing) the fame Bandage and Mixture of Spices, that was applyed to the human Body, feems to have been beftowed upon This. But the Skull and fome other Bones of an Apis, (as it may be prefumed to have been,) that were brought from thence, difcovered not the leaft Token of their having been embalmed. There were feveral little wooden Figures alfo, of the fame Quadruped, that were painted white, with their Legs tyed together, as if ready to be facrificed. 1 was fhewed at the fame Time, a fmall Veffel, like a Sloop, with the Mafts and Sails intire, and the Men tugging at their Oars. 

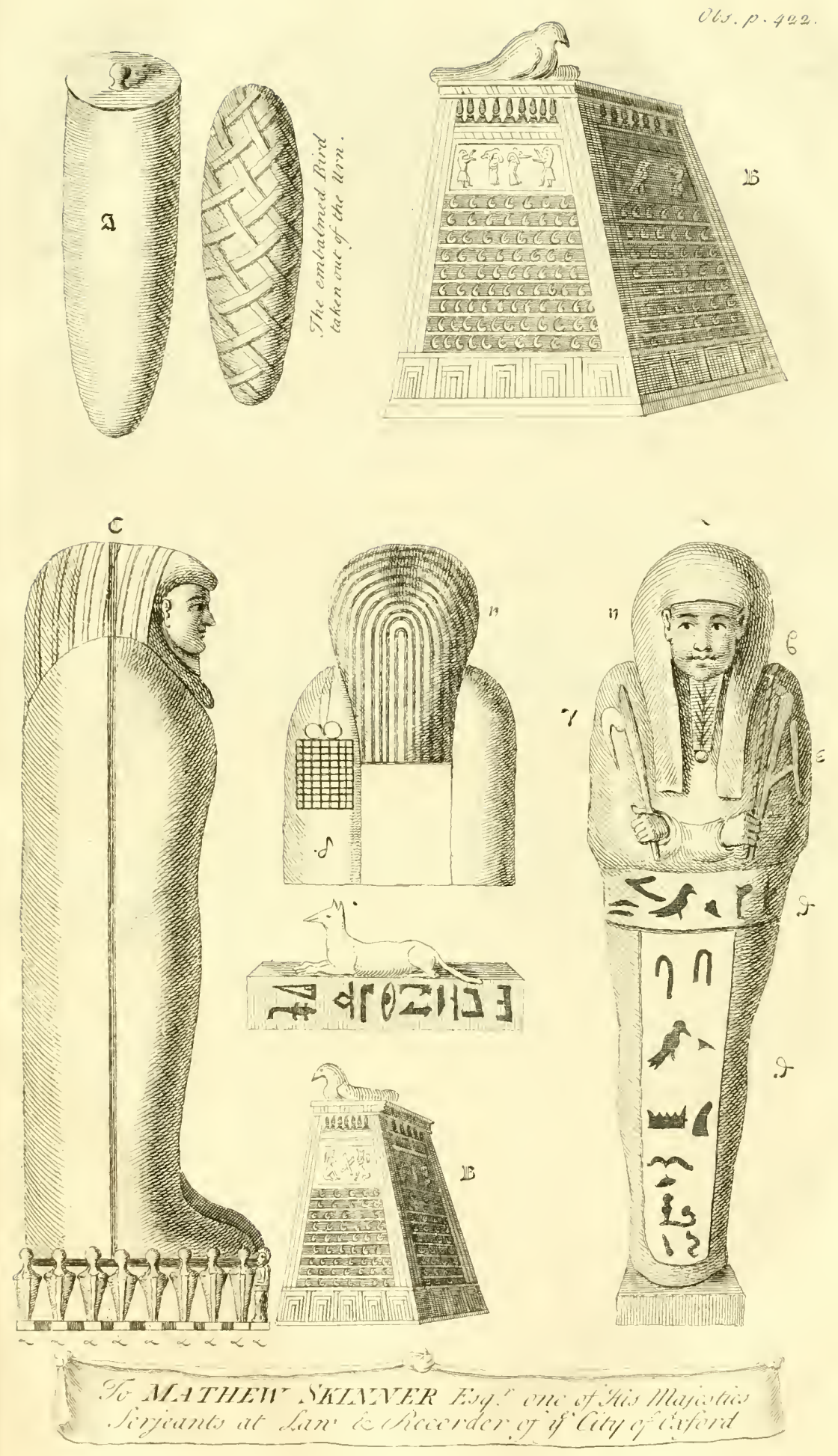



\section{Obfervations in Egypt.}

Little fquareBoxes, like 1 , ufually painted either with fymbo- Boves p'ace. lical Figures or Hieroglyphicks, are found in thefe Catacombs. Feet of the The Figure of a Hawk is commonly fixed to each of their Lids; Numnic.. though I had one that was furmounted with a Dogr ${ }^{2}$, and another with an Owl; both of them painted in proper Colours. I was at a lofs to know, for what other Ufes thefe Boxes could have been defigned, than to be the Coffins of their Sacred Animals; when $\mathrm{M}^{\mathrm{r}}$. Le Maire, (who had been at the opening of a new $V$ ault, ) informed me, that there was one cf them placed, as in the adjoyning Table, at the Feet of each Mummy c; wherein were inclofed the Inftruments and Utenfils, in Minia- varions $I_{I-}-$ ture, which may be fuppofed to have belonged to the Trade $f_{t k a n n}$ in and Occupation of the embalmed Perfon, when he was alive. He hewed me one of them, which contained a Variety of Figures in lafcivious Poftures; and had therefore appertained, as he conjectured, to one of their Curtizans. Among others, there was the Figure of a Bacchus in Copper; a hollow Phallus, in Alabatter; feveral fmall earthen Veffels, for Paint; and the Joynt of a Reed, which had within it a Pencil, and fome pounded Lead Oar, the fame that is ftill ufed by the Women of thefe

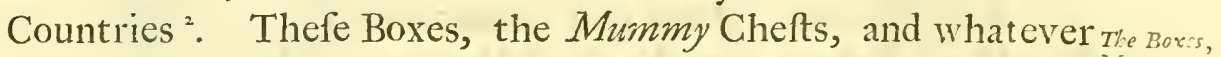
Figures and Inftruments of Wood are found in the Catacombs, Mlummy are all of them of Sycamore, which though fpongy and porous madcartire to Appearance, hath notwithftanding contimued intire and un- Wood. corrupted for more than three thoufand Years. A little behind the Boxes, there are a Number of little Images, $a, \alpha, \alpha, \& c$. of baked Earth, made nearly in the Form of the Mummy Chefts; fome whereof are blew, others white, others again are pied, or in the Habit of a Nun. Thefe are ranged round about the Little Imanes Pedeftals of the Mummy Chefts, as if they were defigned for $\begin{gathered}\text { plased rount } \\ \text { about }\end{gathered}$ fo many Guardian Genij and Attendants. The feveral Attri-che/s. butes of thefe Images; fuch as the Flagellum $(\beta)$, Hook $(\gamma)$, Net $(\delta)$, Hieralpha $(\varepsilon)$, \&c. the female Countenance $(\zeta)$, together with the Veil (n), fhould induce us to believe it to be the I/is Averrunca, or I/is the Driver away of Evil Dremons. The Scroll of Hieroglypbical Writing (9), that runs ciown the Breaft, differeth very little from what we commonly fee painted upon the correfpondent Part of the Mummy. But the

I This is expreffed in Plate xxiv. Gig. 4. of Mr. Alex. Gorden's Colleation of Egyptian Antiquitics. 2 Vid. p. 294.

$$
\mathrm{O} 00002
$$

little 
little Idol (פD), (which feems to be of the fame Kind, though without the ufual Symbols) hath the Scroll upon the Back of it, with Characters alfo of a different Fafhion.

The Comporition of the Aummics: their Bandages, \&rc.

The Compofition ' that is found in the Heads of the Mummies, looks exactly like Pitch, but is fomewhat fofter: the Smell of it alfo is the fame, though fomething more fragrant. In examining two of thefe Mummies, by taking off the Bandage, I found that the Septum Medium, of the Nofe, was taken away in them both; and that the Skulls were fomewhat thicker than ordinary ${ }^{3}$. There were few or none of the mufcular Parts preferved, except upon the Thighs, which crumbled to Powder upon touching them. The like happened to that Part of the Bandage, which more immediately envelloped the Body; notwithftanding that more than fifty Yards of the exteriour Part, was, upon unfolding it, fo ftrong to Appearance, that it feemed to have been juft taken from the Loom. Yet even Iddols faid to
be found in their Breaffs. ther Money in the Mouths nor Idols in the Breafts of thefe Mum. mies. Yet the greateft Part of the little Images, that are fold in Egypt, are commonly reported to have been lodged in fuch Repofitories. What may favour this Opinion is, that the People of Sakara are the chief Venders of thefe Antiquities at prefent; of whom likewife I purchafed the Vafe $\mathbb{E}$, which $\underset{\substack{\text { An } \\ \text { Cenfer. }}}{\text { Egytian was probably an Egyptian Cenfer, being of a beautiful Slate-like }}$ cenfer. Stone, with the Handle very artfully contrived to imitate the Leg of a Camel, tyed up in the fame Fafhion, the Arabs ufe to this Day, to prevent thofe Creatures from ftraying away. Pendants. $\quad f_{f f}$ are two Pendants of the like Materials and from the fame Place. Of this Kind perhaps were the ( $\left.\lambda_{i \text { ivia }} \chi^{u \tau a \dot{ }}\right)$ Stones, which

I Apud sgyptios Cadaver fit rapizo i.c. falfura, five Mummia ( $\left.\varsigma^{\infty} \mathrm{g}^{\circ}\right)$ uti appellant recentiores medicorum filij, ab Arabico (Perfic. potius) موم Mum, i." e. cerầ; quia ceromate etiam in co negotio utebantur. Gatak. Annot, in M. Anton. p.175. Lanogo Mummia rulgo;

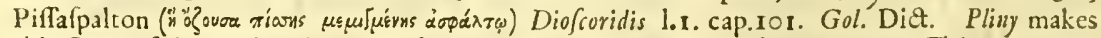
this Compofition to be the Tar of the Torch Pine. Pix liquida in Europa e Teda coquitur, navalibus muniendis, multofque alios ad ufus. Lignum cjus concifum, furnis undique igni extra circundato, fervet: primus fudor, aqux modo, fluit canali : hoc in Syria Cedrimen vocatur, cui tanta vis eft, ut in Egypto corpora hominum defunctorum eo perfufa ferventur. Plin. Hitt. Nat. 1. I6. cap. I I. From being called Cedrium by Pliny, we may rather take it

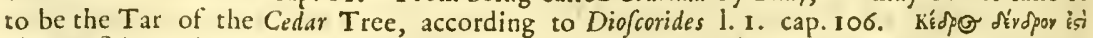

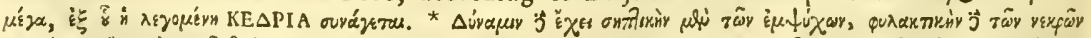

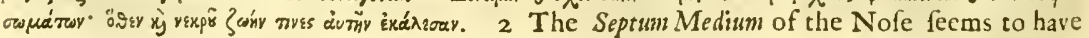
been taken away, as well for the eafier Extraction of the Brain, as for the Injection of the

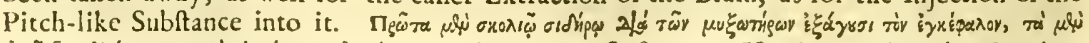

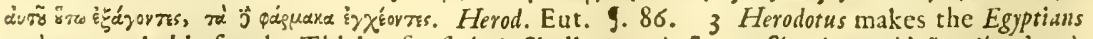

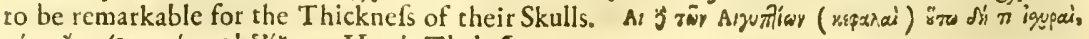

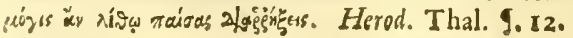


Ola. p.t2t.

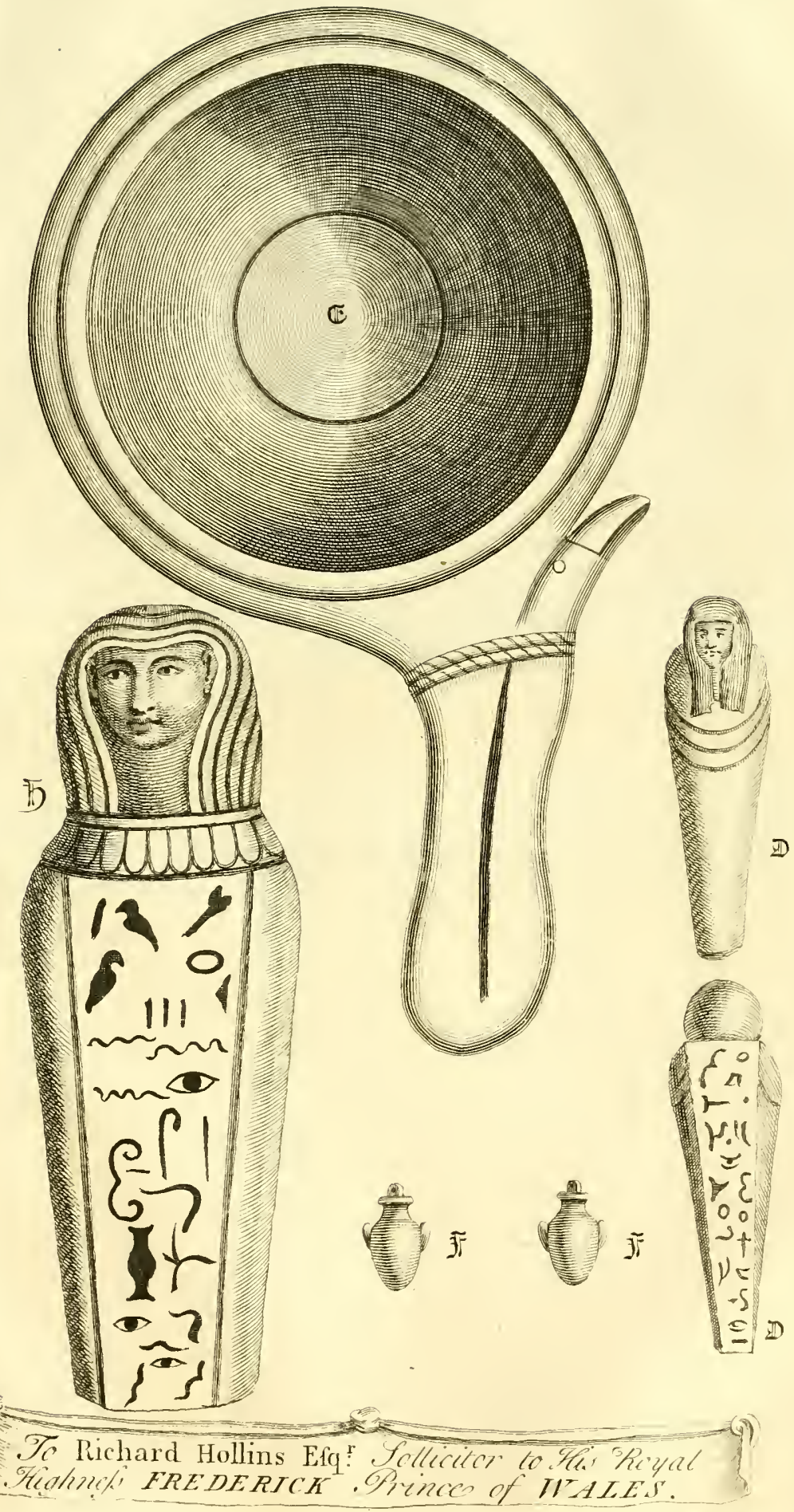





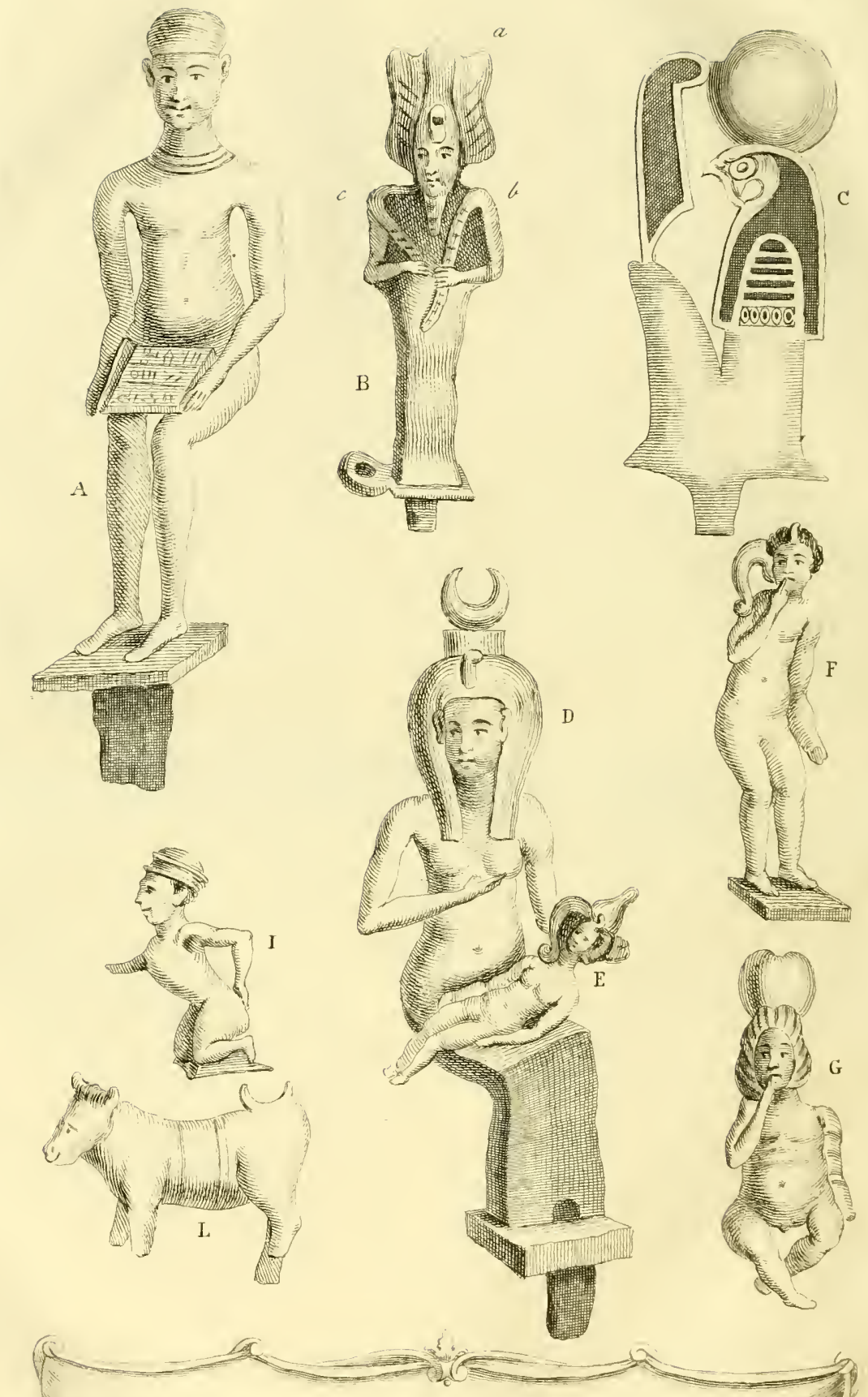

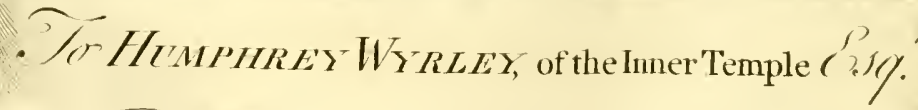


they fufpended upon the Ears of their facred Crocodiles '. The Tre Canopus. Canopus v, with two others', that are now in the Poffeffion of Dr. Mead, were likewife from Sakara. This of mine, which is of an almoft tranfparent Alabafter, is feventeen Inches long; and fix in Diameter; having a Scroll of facred Characters painted upon the Breaft, and the Head of I/ss veiled, for the Operculum. The Veffels ${ }^{3}$, that were carried about in their Proceffions, either to denote the great Bleffing of Water, or that Water, the humid Principle, was the Beginning of all Things, may be fuppofed to have been of this Fafhion, or rather, as the Canopues ufually are, fomewhat more turgid. In the famous Conteft alfo, betwixt the Chaldeans and Egrptians, concerning the Strength and Power of their refpective Deities, Fire and Water, the Latter was perfonated by a Canopus; the Story whereof is humouroufly told by Suidas ${ }^{4}$.

The following Icuncule, were intended, in all Probability, The Attbor's to be fo many of their Lares or Amulets': where of the firft A, collectien of is an Egyptian Prieft with his Head fhaven, and a Scroll of Hieroglyphicks upon his Knees. B, is Ofiris, with his Tutulus a, Flagellim b, and Hook c. C, is the fame Deity, (ieeróropp(a)

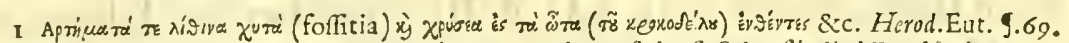
2 Thefe are figured by Mr.Gorden, Tab. xirns. whercof the firft is of baked Earth, the other of Alabalter. 3 Quintus auream vannum aureis congeftam ramulis: \& alius fercbat Amphoram.

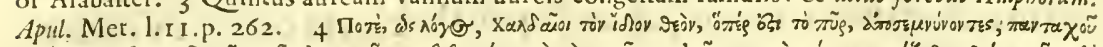

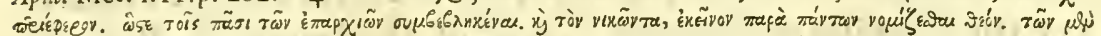

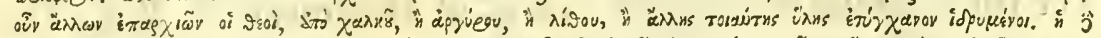

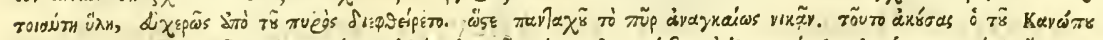

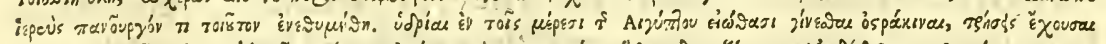

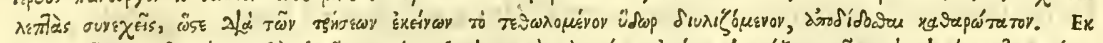

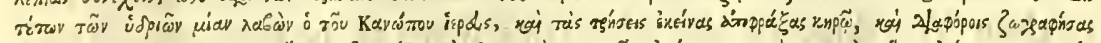

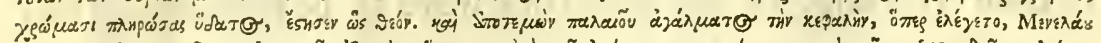

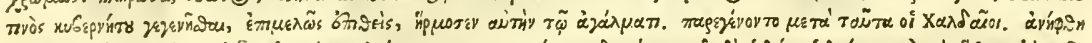

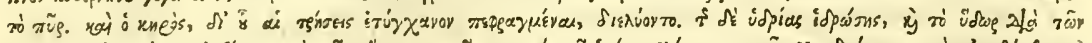

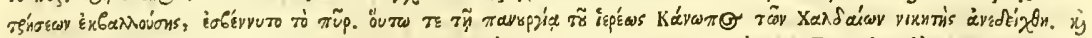

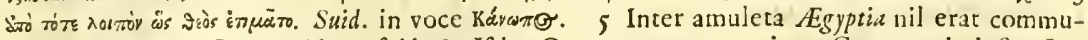
nius Harpocrate, Horo, Apide, Ofiride \& Ifide, Canopo; quorum primus Cornucopia inftructus fub forma pueri nudi digito filentia fuadente confpiciebatur; alter ibidem fub forma pueri, fed fafcibus, aut reticulato amictu involutus; tertius fub forma bovini capitis; quartus fub varijs formis, nunc iepaxópeppor, nunc xurópospo, modo Leoniformis; quinta fub mulicris habitu, fcutica \& reti inftructa, alijfque inftrumentis. Per Harpocratis amuletum, arcanorum per varias divinationum fpecies fe confcios futuros fperabant, religiofe geftatum: geftatum autem fuiffe, anfule fatis demonitrant. Per Hori amuletum naturæ mundanæ notitiam fe habituros putabant; per Apidis amuletum, fecunditatem; per Ofiridis influxus fuperni abundantiam; per Ifidis, quæ ad Tetram \&. Nilum pertinent, bonorum omnium temporalium ubertatem fe confecuturos fperabant. Per Accipitrem, fe confecuturos fperabant claritatem luminis tum oculorum, tum intellectus; per Bovem, domefticx fubftantix amplitudinem; per Canem fcientiarum \& artium notitiam; per Cynocephalum \& Elurum Lunaris Numinis attractum. Erat ex Infectis quoque Scarabeus, certis \& appropriatis lapidibus incifus, potentiffimum Amuletum \& paffim ufurpatum, ad Solaris Numinis attractum, contra omnes tum corporis, tum animi morbos inftitutum. Kirch. Gymn. Hierogl. Claf. xI. p. $447^{-8}$.

Ppppp

with 
with the Hawk's Head; having been formerly enammelled, upon the Breaft; and holding either a Palm Branch or a Feather; which feems likewife to have been enammelled. $\mathrm{D}$, is the horned Ifis, or Iois unvest's. In her Lap the carries her Son Orus, E; the fame with F, the Sigalion or God of Silence, who is accordingly feen with his Finger upon his Mouth, and known by the Name of Harpocrates. G, is another Figure alfo of Harpocrates, in the fame fitting Pofture, that is ufed, to this Day, by the Eaftern Nations. H, is fuppofed to be Orus ', (i. e. the Earth, turgid with the Variety of Things, which it is ready to produce. J, (provided the Turn of the Body and the Pileus do not fuppofe it to have originally belonged to fome other Nation andWorfhip,) may perhaps, from it's Pofture, be the Egyptian Crepitus ${ }^{2}$ : as, among others of a leffer Size, K, is the Anubis; L, M, the Apis; $\mathrm{N}$, the Cat; O, the Cynoceptsalus; $\mathrm{P}$, the Hawk; $\mathrm{Q}, \mathrm{R}$, the Frog; S, the Beetle; T, the Phallus Oculatus ${ }^{3} ; \mathrm{U}$, a Nilofcope; X, a Pyramid; and Y, a Plectrum.

The Matter of Of thefe Icuncule, the laft is of Alabafter; $\mathrm{Q}$, is of brown sobich thefe lcuncu! a are made.

Marble, fpotted with yellow; A, B, C, D, E, F, G, J, K, $I, M, N, P, R$, are of Copper, and the reft of baked Earth. All of them, except $A, G, J, O, P, R$, are either bored through, or elfe have little Rings fixed to them, whereby, we may conjecture, that they were fufpended upon the Necks of theirVotaries. Yet the Spindles or Pivots $a, a, a, a$, of the Images A, B, C, D, may give us Room to fufpect, that They, in particular, were either to be erected, in fome convenient Place of their Houfes, as Objects of their Worfhip, or elfe that they were to be fixed upon their

I Horus femper fub puerili forma referebatur, \& myfticè, Plutarcho tefte, nihil aliud eft, quam fenfibilis mundi machina, guam Sol feu Ofiris per Scarabeum $(x)$ indicatus, continua Solarium Numinum per binos accipitres ( $\lambda$ ) \& terteftrium Geniorum, per Penates ( $\mu$ ) lateribus affiftentes indicatorum, minifterio, fumma Sapientia gubernat \& moderatur. Pueri forma pingitur, quia Mundus generabilium rerum innovatione continuo veluti rejurenefcit: tumido corpore $(v)$ pingitur, quia genitalium rerum fxtura \& ravarppuix perpetuo turget: fub utroque pede Crocodilum ( $\xi$ ) calcat, i. e. Beboniam feu Typhoniam malignitatem mundo adeo perniciofam, ne invalefcat, cohibet; fcuticaque (o) i. e. virtutis fur efficacia in officio continet. In poftica parte per figuram $\Delta$, Ifss, feu Luna exprimitur, quod cornua \& velum quibus femper exhibetur, oftendunt; ubere turget, quia mater omnium inventionum eft, \& Hori a Typhone extincti vindicatrix \& refufcitarrix; dum mundum ficcitate \& aduftiva quadam vi oppreffum, humido fuo influxu, per radios apte indicato, tempetiem \& vitam revocat. Kirch. ibid. p. 449. 2 Nec Serapidem magis quam Strepitus, per pudenda corporis cxpreffos, contremifcunt (Aggyptij) Minut. Felix. 9. 28. Crepitus ventris inllati, qux Pelufiaca religio eft. S. Hieron. in Ifai. 1. 13. cap. 46. 3 Ofirin per brachium extenfum, beneficentire \& liberalitatis notam, multis locis oftendimus; atque adeo Phallus hic oculatus [cum brachio occulte ex eo emergente] nihil aliud innuit, quam providentiam beneficam divini Ofridis, in frecunda generatione elucefcentem; qua occulta \& infenfibili operatione omnia frecundat cratque potifirmum apud Eggyptios Amuletum \&c. Kirch. OEdip. Egypt. Synt. $13 \cdot$ P.415. 

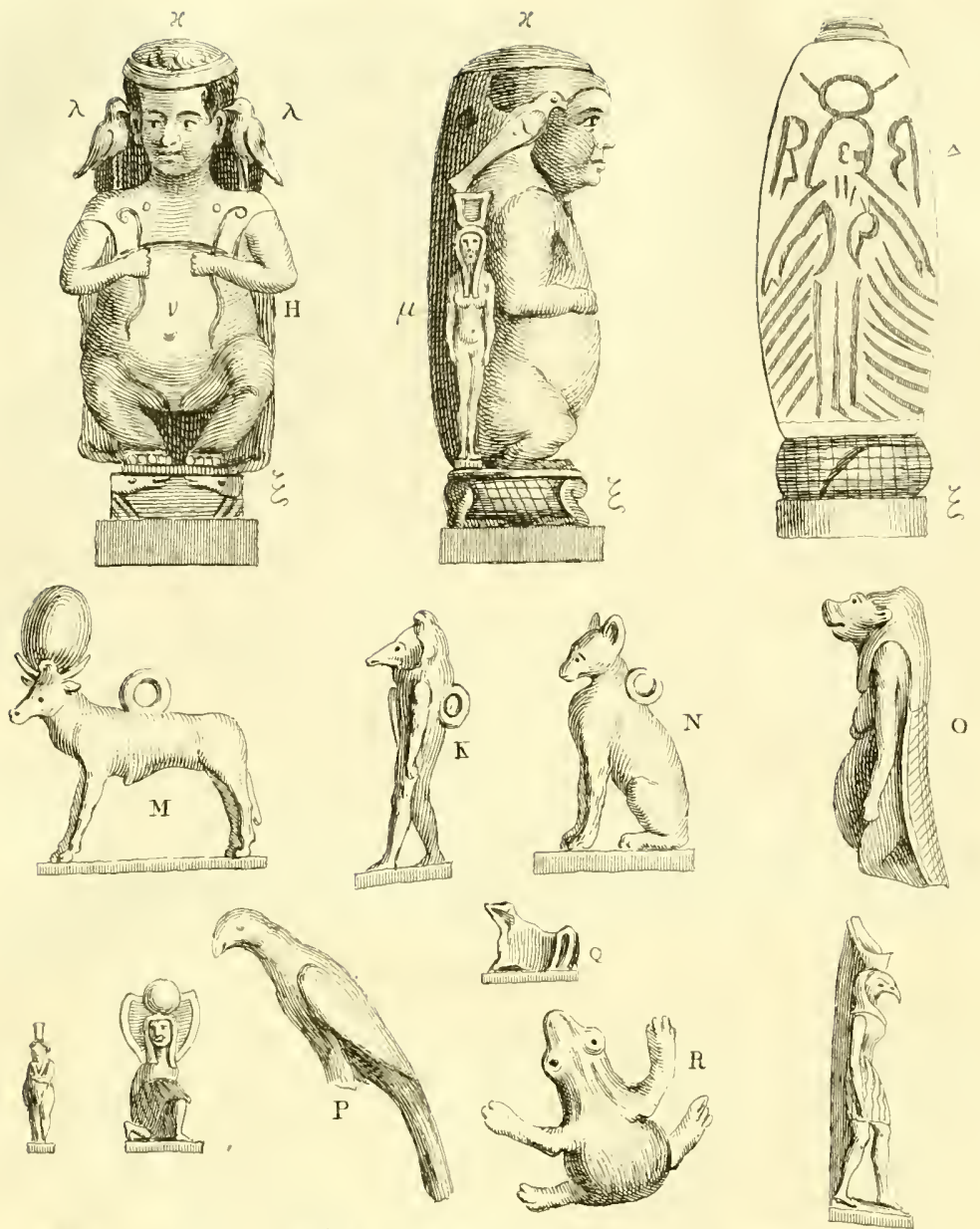

(6) 1 (1912)
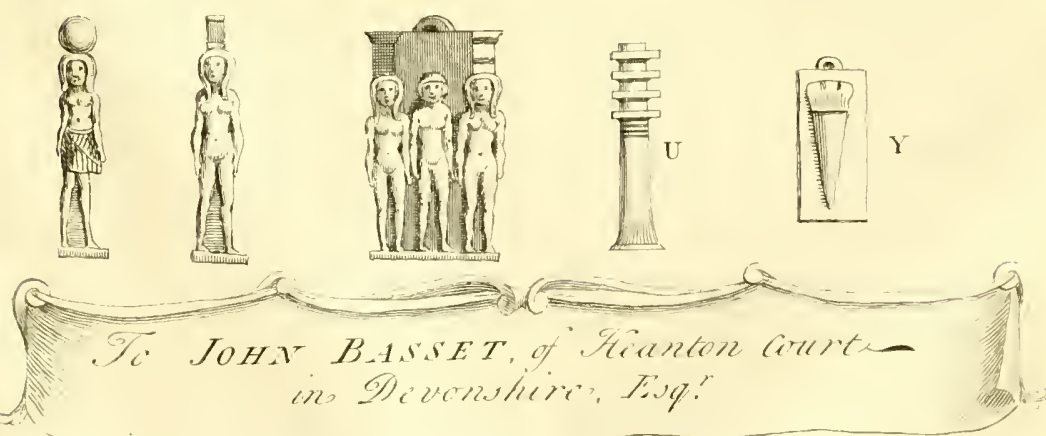

Symbolical Rods and Sceptres, and carried about, in that Manner, in their folemn Proceffions.

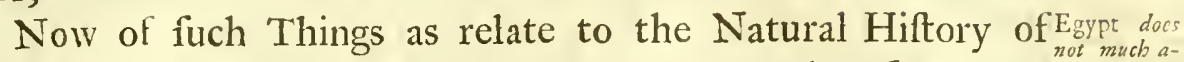

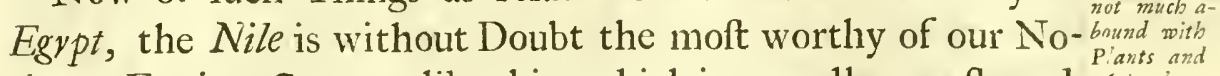

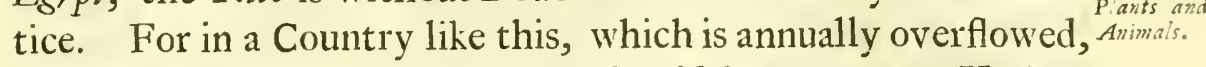
it cannot be expected, that there fhould be any great Variety either of Plants or Animals. However Proßper Alpinus, Bellonius, and other Authors of great Reputation, have been very copious upon both thefe Subjects; though, it may be prefumed, if the aquatick Plants and Animals are excepted, there are few other Branches of the Natural Hiftory, that are coeval with Egypt. The Mula, the Date Tree, the Caffia Fijfula, the

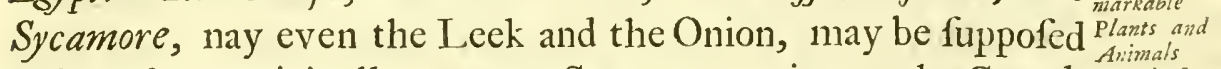

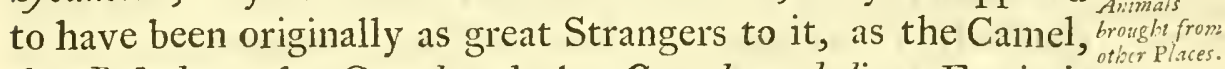
the Bubalus, the Gazel and the Camelopardalis. For it is highly probable, as will appear by and by, that the Soil of Egypt cannot claim the fame Antiquity with That of other Countries, but, being made in Procefs of Time', all thefe Animals and vegetable Productions, muft have been by Degrees tranfplanted into it.

Yet even fome of thofe Plants and Animals, that may be ${ }_{a l m o f}^{\text {The }}$ Papyereckoned among the Indigence, or to be, at leaft, of great Antiquity, almofofd. are now either very fcarce or altogether wanting to this Country. For the more indigent Sort of People have left us very little of the Papyrus, by continually digging up the Roots of

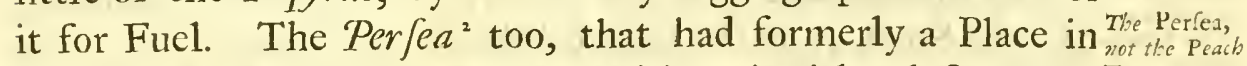
moft Pieces of their Symbolical Writing, is either loft at pre-Tree. fent, or the Defcriptions of it do not accord with any of the Egyptian Plants, that are known at this Time. It cannot certainly be the (Perfica or) Peach Tree, as it is commonly rendred, becaufe the Leaves of it are perennial, and fall not; like Thefe, every Year.

And then, among the Animals, the Hippopotamus, is what the $\underset{\text { The Hippo- }}{\text { poramus }}$ prefent Race of Egyptians are not at all acquainted with. Nay poracodus as,

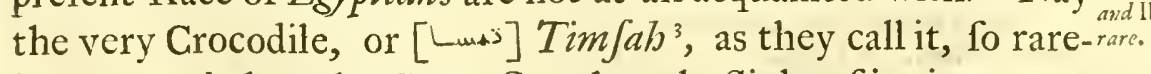
ly appears below the Cataracts, that the Sight of it, is as great a Curiofity to Them, as to the Europeans. In like Manner the

I Debet Agyptus Nilo non tantum fertilitatem terrarum, fed ipfas. Senec. Quxef. Nat. 1.4. cap. 2. 2 Vid. Clut. Hift. Plant. 1. T. p.2. 3 This Name hath nearly the fame Sound with

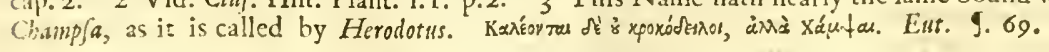

$$
\text { Pрррр2 Ibis, }
$$


Ibis, that was once known to every Family, is now become exceedingly rare; though the Want of it is fufficiently fupThe Storks plied, by the Stork. For, befides a great Number of thefe
are Numbers in Birds, that might undoubtedly efcape my Notice, I faw, in the Egypt. Middle of April, (1722.) (our Ship lying then at Anchor under Mount Carmel,) three Flights of them, each of which took up more than three Hours, in paffing by us; extending itfelf, at the fame Time, more than half a Mile in Breadth. They were then leaving Egypt, (where the Canals, and the Ponds that are annually left by the Nile, were become dry, ) and directed themfelves towards the N.E.

They afemble It is obferved of the Storks, that, for about the Space of a sogether before
theg pafs fran Fortnight, before they pafs from one Country to another, they one Country to
snother. conftantly refort together, from all the circumjacent Parts, in a certain Plain; and there forming themfelves, once every Day, into a Dou-wanne, (according to the Phrafe of thefe People,) are faid to determine the exact Time of their Depar-

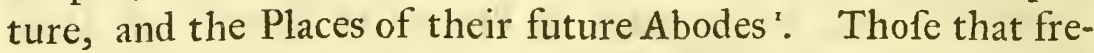
quent the Marhes of Barbary, appear about three Weeks fnoner, than the Flights above-mentioned, were obferved to do; though they likewife are fuppofed to come from Egypt; whither alfo they return a little after the Autumnal Equinox, the Nile being then retired within it's Banks, and the Country in a proper Difpofition to fupply them with Nourifhment.

Thes.ork at at by the Maho-call the Stork ${ }^{2}$, in the highef Ffteem and Veneration. It is

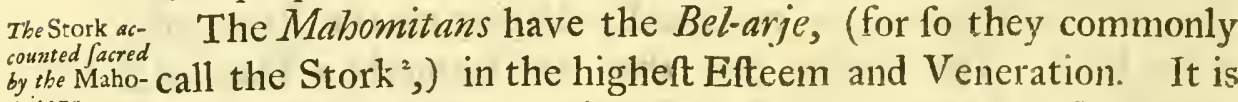
mitans.

as facred among them, as the Ibis was among the Egyptians; and no lefs profane would that Perfon be accounted, who fhould attempt to kill, nay even to hurt or moleft it. The great Regard that is paid to thefe Birds, might have been perhaps firft obtained, not fo much from the Service they are of to a moift, fenny Country ${ }^{3}$, in clearing it of a Variety of ufelefs Reptils and Infects, as from the folemn Gefticulations, they are

I This Account agrees with what we read, Fer. 8. 7. The Stork in the Heaven knatwh hat appointed Times. 2 [elii) or elil] Leklek or Legleg is the Name, that is commonly uled by the Arabian Authors, though Bel-arje prevails all over Barbary. Bochart (Hieroz. I. 2. cap. 29.) fuppofeth it to be the fame with the Hafide of the Scriptures, a Bird, which was!o called from the Piety of it. Nam Mר'ס piam \& benigmam fonat. Id. ibid. Eximia Ciconijs inef Pietas. Etenim quantum temporis impenderint fotibus educandis, tantum \& ip fe a pullis fuis invicem aluntur. Solin. Polyhitt. cap. 53 Elian. Hift. Anim. 1.3. cap. 23. Horsp. 1. 2.

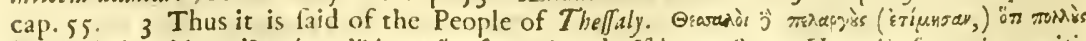

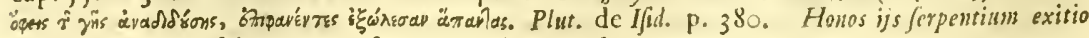
eantus, th in Theffalia capitale fucrit ocsidiffe. Plin. 1. 10, cap. 23 
obferved to make, as often as they reft upon the Ground or re- Thicy make eye

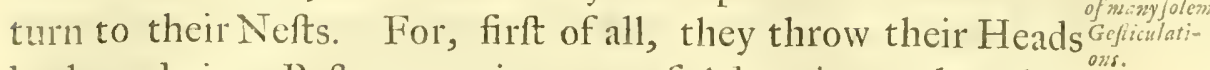
backwards in a Pofture, as it were, of Adoration; then they ftrike, as with a Pair of Caflanets', the upper and lower Parts of their Bill together; and afterwards proftrate their Necks, in a fuppliant Manner, quite down to the Ground; always repeating the fame Gefticulations three or four Times.

As the Acl-Bobba, (the Oripelargus of the Antients, the sevoral of tbe Camel, the Bubalus or Bekker el Wafh, the Gazell or Antelope, Barbbary Arut the Ichneumon, Chameleon, Dab, Warral,Thaibanne, Ceraftes \&c. have been already taken Notice of, I have very little to add to the Natural Hiftory of the Animals of Egypt. However it may be obferved, that the Sands and mountainous Diftricts on both Sides of the Nile, afford as great a Plenty, both of the

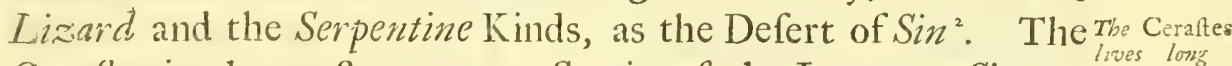
Ceraftes is the moft common Species of the Latter. Signore wotitsout tood. Gabrieli, (a Venetian Apothecary, who had lived a long Time at Kairo, ) fhewed me aCouple of thefe Vipers, which he had kept five Years in a Bottle, well corked, without any Sort of Food, unlefs a fmall Quantity of fine Sand, wherein they coiled themfelves up in the Bottom of the Veffel, may be reckoned as fuch. When I faw them, they had juft caft their Skins, and were as brisk and lively as if newly taken.

Of the Lizard Kind, the Warral is of fo docible a Nature, The Warral

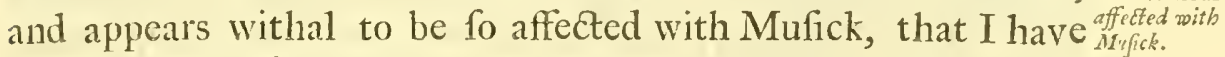
feen feveral of them keep exact Time and Motion with the Dervifhes, in their circulatory Dances; running over their Heads and Arms; turning, when they turned; and ftopping when they ftopped. This, I prefume, (as there is no fmall Affinity betwixt the Lizard and the Serpent, ) may bear fome Relation to the Quality which the Latter is fuppofed to have, of being naturally affected with Mufick. The Pfalmift alludes to it, $\left(P \int a l .58 .4,5.\right)$ when he mentions the deaf Adder, which floppeth her Ear, and refufeth to hear the Voice of the Charmer, charm be never fo wifely.

I From this Noife it was called Crotaliftrin by the Antients, the Crotalum being likewife fuppofed to have been taken from it.

- crepitante Ciconia roftro. Ovid. Met. 1.6.

Sonus, quo irepitant, oris potius, quam vocis eft. Solin. Polyhift. ut fupra. Kai gì menagies,

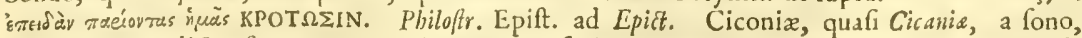
quo crepitant, dicte funt; quem roftru quatiente faciunt. Ifid. Orig. 1. I2. P.II34. 2 Vid. p. $3^{88}$. 
Thc Ophiophagi or Eat ers of Ser- fand Perfons in Kairo and the neighbouring Villages, who pents. live upon no other Food than Lizards and Serpents. This Singularity entitles them, among other religious Privileges, to the great Honour, of attending more immediately upon the embroidered Hangings of black Silk, which are made every Year for the Kaaba of Mecca, and conducted with great Pomp and

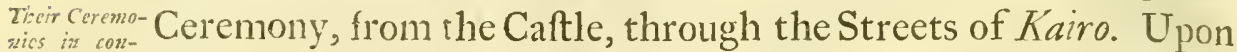
ducting the Hangings of the Kaaba.

Plants of all Kinds orpe their Growth

Sc. to tho Nile.

thefe Occafions, there are Numbers of this Order, who fing and dance before it; throwing their Bodies, at certain Intervals, into a Variety of enthufiaftick Geftures. Such like Acts of Devotion, how ludicrous foever they may appear to us, have been always looked upon with Reverence by the Eaftern Nations. Thus we find, Pfal. I +9.3 . that the Lord's Name was to be prailed in the Dance. And again, P/. I50.4. that be was to be praifed with the Timbrel and Dance. Agreeably to which Injunctions, all the Women went out after Miriam with Timbrels andD ances. Exod. 15.20. and David, in bringing the Ark from the Houle of Obed Edom, danced before the Lord. 2 Sam. 6. I4.

If we except the Natron, Sal Armoniac, and the Folfil Shells that have been occafionally taken Notice of in the Defcription of the Pyramids, there are few other Branches of the Natural Hiftory of Egypt, that remain to be explained, but what may be referred to the Nile. For, as it feldom rains in the inland Parts of this Country, the different Species of Grain, Pulfe, and other vegetableProductions, are all of them intirely indebted to theRiver for their Grow th and Increafe. How ever thefe feveral Kinds of Plants are not all raifed and nourifhed the fameWay. For

Barley and Wheat. Barley and Wheat, (which are ufually ripe, the one, about the Beginning, the other, at the latter End of April,) require no further Culture and Refrefhment, than, in fome Part or other of October, (the Inundation being then over, to be either thrown upon the Mud, or elfe to be beat or plowed gently into it. At this

Flax. Time alfo they fow Flax and so, or Rice, as I fuppofe it may be rendered, Exod. 9. 31. Now Wheat and Rice being of a flower Growth, than Flax and Barley, it ufually falls out, in the Beginning of March, that, when the formerKinds are not as yet grown up or begin only to fpindle, the Barley is in the Ear, and the Rice. Flax is bolled. The Plantations of Rice are kept, almoft conftantly, under Water; and therefore the larger Crops of it are 


\section{Obfervations in Egypt.}

produced near Dami-ata and Rozetto, where the Plains are low, and confequently more eafily overflowed, than thofe which lye higher up the River.

Now fuch vegetable Productions, as require more Moifture, Their Fingines than what is occafioned by the Inundation, are refreflhed by water. Water, that is drawn at certain Times out of the River, and lodged in large Cifterins, made for that Purpofe. Archimedes's Skrew', feems to have been the Inftrument that was antiently made ufe of upon thefe Occafions; though, at prefent, it is not known; the Inhabitants ferving themfelves either with various Kinds of leathern Buckets, or elfe with a Sakiah, (as they call the Perfian Whecl,) which is the moft general and ufeful Machine. Engines and Contrivances of both thefe Kinds, are placed all along the Banks of the Nile, from the Sea to the Cataracts; their refpective Situations being higher and confequently the Difficulty of raifing Water the greater, in Proportion as we advance up the River.

When therefore theirPulfe,Safranon (or Carthamus,) Melons, the Method Sugar Canes \&cc. (all which are commonly planted in Rills,) re- of meir Pratang quire to be refrefhed, they ftrike out a Plug, that is fixed in theBot-" tom of one of thefe Cifterns; and then the Water gufhing out, is conducted, from one Rill to another, by the Gardiner; who is always ready, as Occafion requires, to ftop and divert the Torrent, by turning the Earth againft it with his Foot, and opening at the fame Time, with his Mattock, a new Trench to receive it. This Method of conveying Moifture and Nourifhment to a Land that is rarely refrefhed with Rain, is often alluded to in the H. Scriptures; where alfo it is made the diftinguifhing Quality betwixt Egypt and the Land of Canaan. For the Land, (fays Mofes to the Children of Ifrael, Deut.I I. IO, II.) whither thou goeft in to poffes sit, is not as the Land of Egypt, from whence ye came out, where thou fowedf thy Seed, and wateredf it with thy Foot, as a Garden of Herbs: but the Land whither ye go to poffess it, is a Land of Hills and $V$ alleys, and drinketh Water of the Rain of Heaven.

I have already obferved, that it feldom rains in the inland The Nile's $_{\substack{\text { Then } \\ \text { dataion }}}$

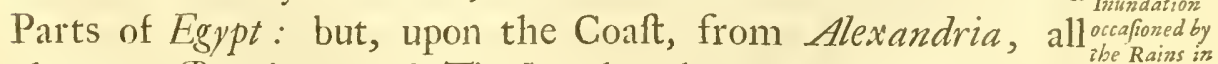
along to Dami-ata and Tineh, they have their former and $\begin{gathered}\text { ibe Rains in } \\ \text { thiop. }\end{gathered}$ latter Rains, as in Barbary and the Holy Land. The periodical

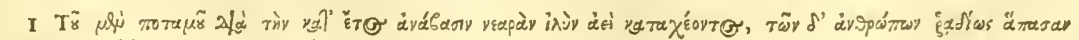

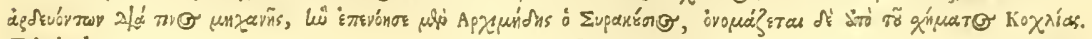
Diod. 1. I. P.2 I. 
Augmentation therefore of the Nile muft be owing to fuch Torrents, as difcharge themfelves into it, in the Regions to the Southward. Now Etbiopia is agreed upon to be the Place: inafmuch as the Nile is here fuppofed to have it's Sources; where alfo the Sun, when it draws near the Northern Tropick, brings on the rainy Seafon. The Portuguefe Miffionaries ${ }^{1}$ claim the Honour of this Difcovery; though, among others, we find fome of the Gracian as well as Arabian Philofophers ${ }^{2}$, who have embraced the fame Opinion.

The Quan-

Yet how wonderful foever this large Confux of Water may tity of Alud brought down
by the River.

have been accounted, in all Ages, the great Quantity of Mud, that hath, from Time to Time, been brought down along with it, will appear to be no lefs ftrange and furprizing. Surely the Soil in Athiopia (provided the Nile reacheth no further,) muft be of an extraordinary Depth, in having, not only beftowed upon Egypt fo many thoufand annual Strata, but laid the Foundation likewife of a future Adaition to it in the Sea, to the Diftance of twenty Leagues. So far at leaft, by Sounding, this Mud is found to extend.

The Soil that is conveyed in this Manner, by being imbibed and buoyed up by the River, is of an exceedingly light Nature, and feels to the Touch like an impalpable Powder. Phutarchs tells us, that the Colour of it is black; fuch a black, fays he, as is that of the Eye; though, in another Place ${ }^{4}$, he makes every Thing to be black, where Water is concerned. The Appellations alfo of MEAAE and שח (Sichor) are fuppofed to have

I To the immenfe Labours of the Portugucfe, Mankind is indebted for the Knowledge of the real Caufe of the Inundations of the Nile, fo great and regular. Their Obfervations inform us, that Aby/fnilu, where the Nile rifes, and waters valt Tracts of Land, is full of Mountains, and in it's natural Situation, much higher than Egypt; that all the Winter, from Fune to September, no Day is without Rain; that the Nile receives in it's Courfe all the Rivers, Brooks and Torrents which fall from thofe Mountains; thefe neceffarily fwell it above the Banks, and fill the Plains of Egypt with the Inundations. This comes regularly about the Month of $Z_{u l y}$, or three Weeks after the beginning ot the rainy Seafon in

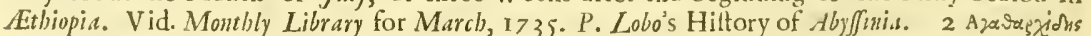

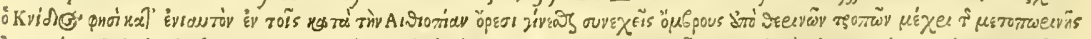

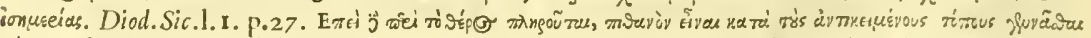

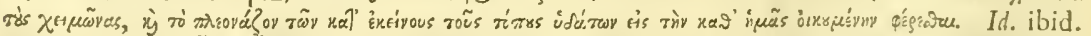

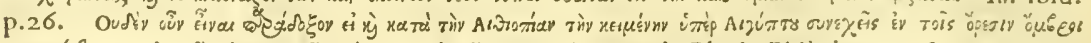

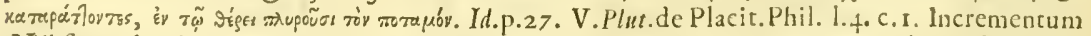
Nili fit e pluvijs qui in illa Regione (fc. Aby/fmia) decidunt. Ebn Sinn apud Abulf. Geogr. ex traduct. V.Cl. \%. Gagnier. Incrementum Nili oritur cx imbribus copiolis; quod quidem dignofcitur ex acceflu \& receffu, feu ortu \& occafu fiderum \& pluviarum abundantia, nubiumque confiftentia. Al Khodai apud Kalkafend. de incremento Nili, ex traduét. ut fupra.

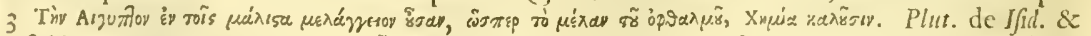

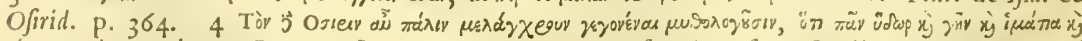

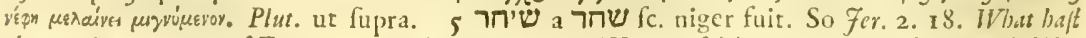

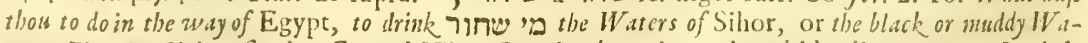

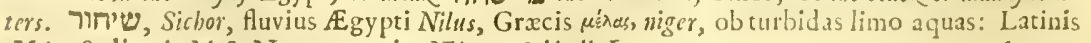
Melo, \& literis M \& N permutatis, Nilus. Scbindl. Lex.

been 
been given to it upon the fame Account; or rather perhaps from the Muddinefs of the Stream. For the Specimens of it, which I have often examined, were of a much lighter Colour, than our common Garden Mould; neither doth the Stream itfelf, when faturated with it, appear blacker than other Rivers under the fame Circumftances. As for the Nile, (or Nil, as it is pronounced by the Inhabitants,) it is, in all Probability, nothing more than a Contraction of Nabbal, [ל] ] i. e. The River, as we may fuppofe it to have been called, by way of Eminence.

In order to meafure the Nile's Increafe, there is built upon The Mikens, the Point of an lfland, that lyes betwixt Kairo and Geeza, Nilefcope, large Room, fupported by Arches, into which the Stream ${ }_{\text {Pllar. }}$ hath free Admittance. In the Middle of it is placed the Mikeas [ul:̈e] or meafuring Pillar, which is divided, as the antient Nile fopes ${ }^{\mathrm{x}}$ may be fuppofed to have been, into Cubits. But the Cubit itfelf, or Peek, $\pi \tilde{n} \chi^{u s,}$ as it is ftill called, hath Tbe Cubits int not continued the fame. For Herodotus acquaints us, that, in divided, gave his Time, the Egyptian Cubit was the fame with the Samian ${ }^{2}$; the contine which, being no other, as we may conjecture, than the common Grecian or Attic Cubit ${ }^{3}$, contained very little more ${ }^{4}$ than a Foot and a half of Englifh Meafure. Three or four Centuries afterwards, when the famous Statue of the Nile, that is ftill preferved at Rome, may be fuppofed to have been made, the Cubit feems to have been of about 20 Inches: for fuch, according to the exacteft Meafure that could be taken, is the Height of one or other of the fixteen little Children, that are placed upon it, and which reprefented, according to Pbilo/tratus', fo many Cubits. The prefent Cubit is ftill, of a much greater Extent; though it will be difficult to determine the precife Length of it. And indeed, with Regard to the Meafures of the Arabians, as well as of other Nations, we have very few Accounts or Standards that we can truft to.

For Kalkafendas ${ }^{6}$ makes the Hafemcean or Great Peek to be Great Diveronly twenty four Digits; but the Arabian Author, quoted by ons concerning the Length of

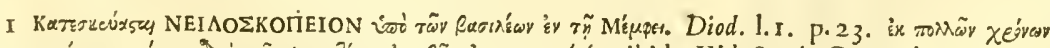

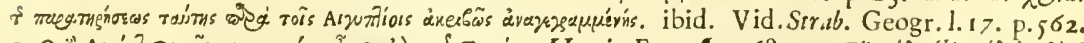

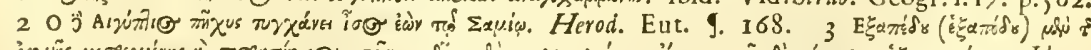

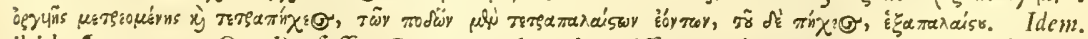
ibid. I. I 49. 4 Our Profeffor Greaves makes the Difference betwixt the Englifh and Greek Foot, (and fo in Proportion of the Cubit) to be as 1000 is to $1007 \frac{29}{105}$. 5 Mrei riv Niñor os

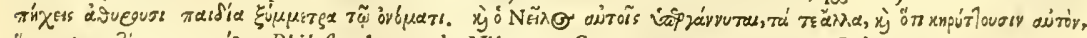

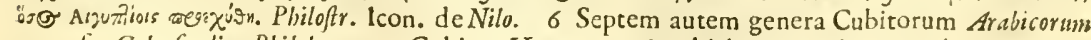

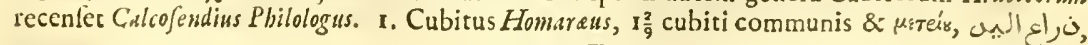


Golies ", will have it to be thirty two. The [Drah el Soudah, ogull الن Black Peek likewife, which the former obferves to be no more than twenty one Digits in Length, is made by the latter to be twenty feven. And moreover, the Digit of Kalkafendas is equal to a Space taken up by feven Barley Corns, placed fide-ways; whereas $f \mathrm{x}^{2}$ is the Meafure according to Golins's Author. Now as Kalkafendas is quoted by our Profeffor Bernard, the Drab el Soudah, (i. e. the Cubit of twenty one Digits,). is.that, by which the Nile was meafured: whereas in the fame Author's Differtation upon the Nile fcope 3 , the Cubit is there defined to be exprefsly of twenty eight Digits. Therenot ${ }^{4}$, in giving us an Account of the dayly Increafe, reckons by a Peek of twenty four Digits; though according to a like Account, which I had from Signore Gabrieli, the Venetian Gentleman above-mentioned, the Peek is there exprefsly of

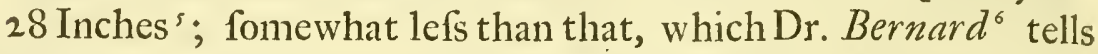
us he faw the Model of in Marufidas. By the Length and Divifion of the Mikeas, the Peek fhould be ftill longer. "The Mikeas, "(fays a curious Perfon", in a Letter to me from Kairo,) is a "Pillar of 58 Englifh Feet high, divided into three Geome-

Hoc menfus eft olim Homarus Eln Cottabi fpatium inter Bufram \& Cufam. 2. Hafemeus, qui \& Cubitus Major nuncupatur, digitorum 24. Digitus vero occupat 7 Hordea lata, aut $7 \times 7-49$ Pilos burdonis. Illo vero Cubito xitimatio verfat in Jure Mobammedico. Idem teltatur Maruphidas. 3. Belalaus, Hasemeo minor. 4. Cubitus Niger, Belalao ceder digitis $2 \frac{z}{3}$, ab Etbiope quodam Rafidi Principis a latere nomen \& modum fuum habet. Menfura Adificiorum, Nilometri, merciumque pretiofarum. 5. Fofippaus, $\frac{2}{3}$ digiri minor Cubito Nigro. 6. Chorda five Afaba, brevior Cubito Nigro $\mathbf{I}_{3}^{2}$ digiti. 7. Maliaranius Cubitus, $2_{3}^{2}$ Cubiti Nigri, foffis menfurandis Mamone Principe imperatus. Vid. Edv. Bernard. de Menfuris. P. 217. I Vid. ut fupra. p.218. 2 Vid. ut fupra. p. 220. 3 Quiliber Cubitus continet viginti octo digitos donec compleatur elevatio aqux ad duodecim Cubitos. Deinde Cubitus fit viginti quatuor digitorum. Quando igitur volunt fupponere hanc elevationem pertigife ad fexdecim Cubitos, diftribuunt duos Cubitos redundantes, qui continent viginti octo digitos, inter duodecim Cubitos, quorum unufquifque continet viginti quatuor digitos, ficque fit quilibet Cubitus viginti octo Cubitorum. Kalk. ex tradud. V. Cl. F. Gagnier. 4 Sce his Travels in Englifh. p.232. 5 June 29. N.S. I 74 . The Nile was 5 Cubits high. Fume $30 t h$ it increafed 3 Inches.

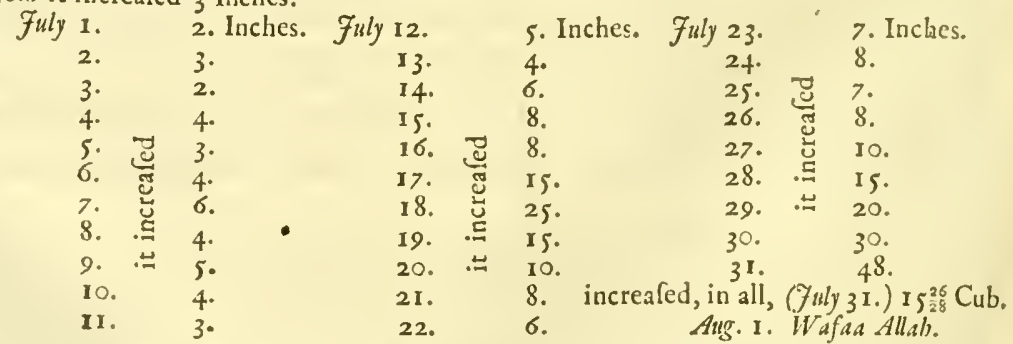

6 Potent ex modulo Marufida in MS. Arabico Bibliothecx noftra Cubitus Hafemeus uncias Anglicanas 28, 9. De Menl. p. 219. 7 This Genteman was the late Mr. Thomas Huntes, who had been a great many Years a Factor at Kairo, and took the Mcafures and Defigns of molt of the Egyptian Antiquities. 
"trical Pikes, called Soltani Beladi e Facke/, in all 24 Stambole "Pikes: though in another Letter, " 16 of thefe Peeks are only "made equal to I 2 Englifl) Yards". But as I was informed, (for It is probably could not get Admittance into the Chamber of the Mikeas, to Peek of thirty make the Obfervation myfelf, ) the Stamboline or Great Peek, the fame with the Hajemrean, of thirty two Digits, is what they compute by at prefent'. 'Till fuch Time therefore as this Meafure can be better adjufted, we will fuppofe it to be the Great Cubit, or Cubit of Conftantinople, which being, according to our Profeffors Greaves and Bernard, $2{ }_{1003}^{20}$ Foot long, or betwixt $2^{\frac{1}{10}}$ and $2^{\frac{8}{6}}$, as I meafured it, we may take it, in round Numbers and to avoid Fractions in the future Calculations, to be a Meafure of twenty five Inches.

In the Month of December, the Channel of the Nile above The Dipth of the Mikeas, was, at a Medium, about three of thefe $\mathrm{t}_{\text {the }}^{\text {the Nile }}$ Wint Cubits in Depth, and, as far as I could judge by the Eye, little more than half a Mile in Breadth. But in falling down the Branch of Dami-ata, in the fame Month, (and the River might probably be fhallower in the Three following, ) we frequently ftruck upon the Ground, in the very Middle of it, though our Veffel drew lefs than three Foot of Water. In the ${ }_{\text {the }}^{\text {The Depth of }}$ in Middle of Fune, when the Nile was confiderably augmented, (for thune. neither the Beginning, nor the End of the Inundation falls out every Year at the fame Time ${ }^{2}$ ) there were few Parts of the

I M. Maillet makes the Peek, by which the Nile is meafured, to be equal to twoFrencis Feet, i. c. to two Feer two Inches nearly of our Meafure. La mefure dont on fe fert aut Kaire, pour comoitre l' clevation de l' eau, contient vingt quatre pouces, ou deux picds de Roy. ** Pour etre iapable de cosvrir toutes les terres, il fuut que l' accroiffement du Nil monte jufqu' a vingt quatre Druts, c'eft-a-dire quaraute huit pieds. Defeript. de l'Egypte. p.6o. But as none of the Ealtern Mcalures, which I have feen, are commenfurate to the Frencls Foot, the Meafure he mentions, may be well fuppofed to be the Stamboline Peek that I am fpeaking of. 2 According to the following Account, which was kept by Signore Gabrieli for thirty Years, the Nile arrived at the Height of fixteen Cubits, viz.

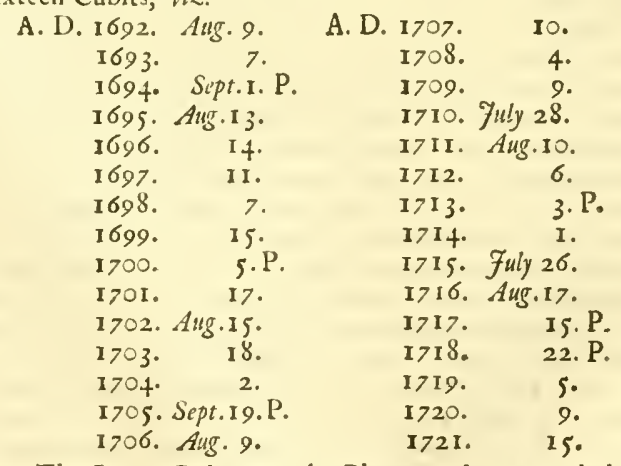

Wo The Letter P denotes the Plague to have raged that Year. 
main Channel, but we could pafs over, by thrufting our Boat The dayly In- forward with a Pole of eight Cubits in Length. Each Days Increafe,
arrives to fix reen Cubits: or four Digits, and then it would be fometimes ten, fometimes twenty or thirty, 'till it rofe (Aug.15. 1721.) to fixteen Cubits; which (with the artful Introảuction, no Doubt, at fome proper Juncture, of a larger Meafure of the fame Denomination') feems to have been received as the Standard, that portended Plenty; and the Condition whereupon the Egyptians were to pay their Tribute, for many Generations.

The cutting of For no Addition appears to have been made, during the the Nile at
fixteen Cubits. Space of five hundred Years, to the Number of Cubits, that are taken Notice of by Herodotus. This, we learn, not only from the fixteen Children that attend the Statue of the Nile above-mentioned; but from a Medal alfo of Trajan, where, we fee the Figure of the Nile, with a Boy ftanding upon it, who points to the Number is (16.). This Account we have likewife confirmed by Pliny ${ }^{3}$; though, in the fourth Century, fifteen Cubits only are recorded by the Emperor Fulian ${ }^{4}$, as the Height of the Nile's Inundation. About three hundred Years afterwards, when Egypt was fubdued by the Saracens, ftill the Amount s was no more than fixteen or feventeen: and, at prefent, notwithftanding the great Accumulation of Soil, that hath been made, fince thofe Times, yet, when the River rifeth to fixteen Cubits, (though nineteen or twenty are required to prepare the whole Land for Cultivation, ) the

I Something of this Kind is probably implied in the following Remark of Kallkafendas. Obferva quod nofro tempore facta eft corruptio flupiorum \& imminutio ftatus rerum; cujus Argumentum eft, quod Nilometra antiqua regionis Al Said a primo ad ultimum conftenter babuerunt riginto quatuor digitos pro unoquoque cubito fine ulla additione ad bunc numermin. The fame Aurhor mentions the changing and pulling down feveral of thefe Nilometra, (for the more eafy Introduction perhaps of another Meafure;) the Particulars whereof are inferted after the Excerpta. 2 Vid. Not. 5. p. 433 . Nunquam hic major repertus eft, quam in Tcmplo Pacis ab Imperatore Vefpafiano Augufto dicatus: Argumento Nili xv1 liberis circa ludentibus, per quos totidem cubita fummi incrementi augentis fe amnis intelliguntur. Plin. de bafalte. 1. 36. cap. 7. 3 Incipit crefcere (Nilus) Luna nova, quxcunque polt folftitium eft, fenfim modiceque, Cancrum fole tranfeunte, abundantiffine autem Leonem. Et refidit iu Virginc, ijfdem, quibus accrevit, modis. In totum autem revocatur intra ripas in Libra, ut tradit Herodotus, centefimo die. Cum crefcit, reges aut præfectos navigare eo, nefas judicatum eft. Auêus ejus per puteos menfurx notis deprehenduntur. Juftum incrementum eft cubitorum xvr. Minores aquæ non omnia rigent: ampliores detinent, tardius recedendo. ** In duodecim cubitis famem fentit, in tredecim etiamnum efurit: quatuordecim cubita hilaritatem afferunt: quindecim fecuritatem: fexdecim delicias. Maximum incrementum ad hoc ævi fuit cubitorum decem \& octo; Claudio Principe; minimumque (quinque MS. V. Ch.) Pharfalic. bello, veluti necem Magni prodigio quodam flumine avertente. Plin.

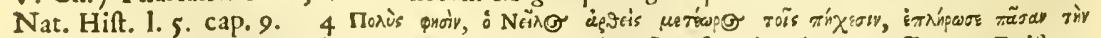

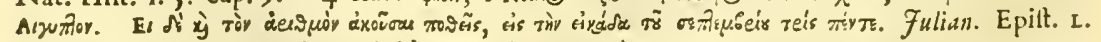
Ecdicio Prafecto Agypti. 5 Vid. Kalkafendas as above. 
Egyptians make great Rejoycings, and call out (Wafaa Allab a.l (is,) God bas given (them) all they wuanted. At this Time alfo is performed the Ceremony of Cutting the Nile, which is the breaking down a Bank of Earth, raifed at the Beginning of the Increafe, and thereby admitting the River into a Khalis, as they call the artificial Canal, that runs through the City of Kairo.

This Khalis, which hath been obferved before to be the Laks dug in Amnis Trajomus of the Antients, empties itfelf into The tioveral Pialuces (Bergue el Hadge) Lake of the Pilgrims, at twelve Miles Di-Depth of the ftance to the Eaftward. The Lake of Myris', the Mareotis and others of the fameKind, feem to have been the like Contrivances of the antient Egyptians, either to divert, or to carry off the Superfluity of Water, which, in the earlier Ages, when there was a lefs Extent and Height of Soil, muft have frequently broke down their Mounds; and would have always been more than fufficient to prepare the Land forCultivation.

Now as the Change of Seafons and the natural Courfe of The Nile bas Things may be prefumed to have been always the fame, the alarays difbe Nile, from the fettled State of Things after the Deluge, to this of Wartertiritio Time, muft have conftantly difcharged the fame Quantity of Water into the Sea. But the Country, which it now overflows, being not only nourifhed and refreflhed by the River, but even, as Herodotus ${ }^{2}$ fays, it's very Gift, a greatVariety of Changes and Alterations muft have been all the while incident to it. Whilft therefore the Lower Part of Egypt, where we now find the Delta ${ }^{3}$, may be fuppofed to have been a large Gulph of

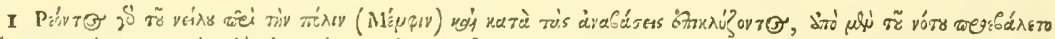

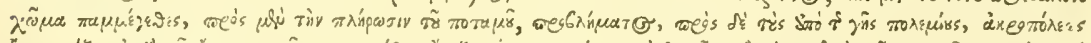

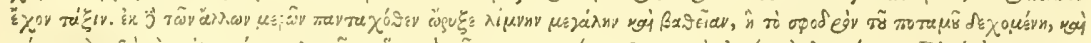

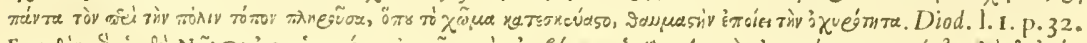

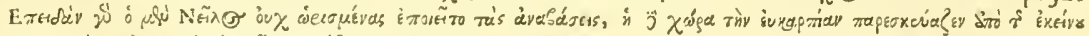

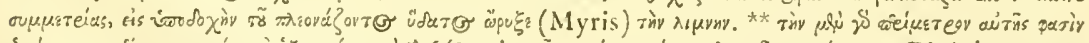

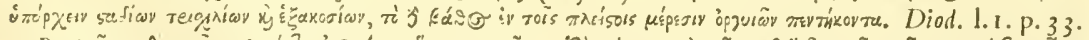

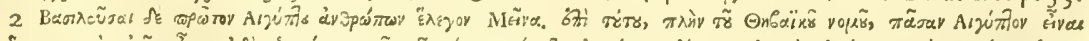

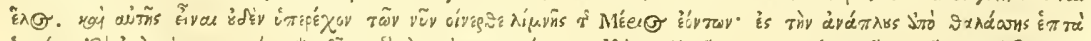

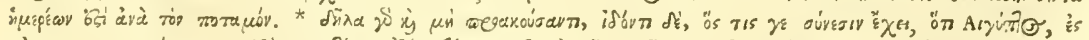

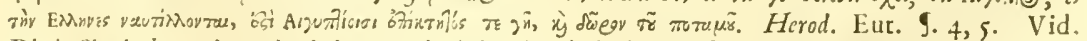

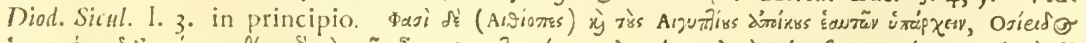

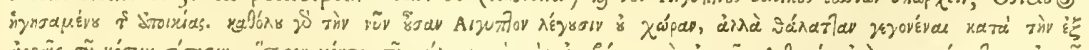

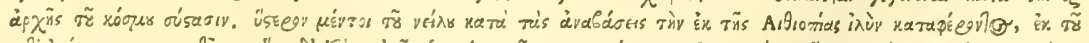

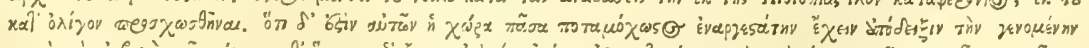

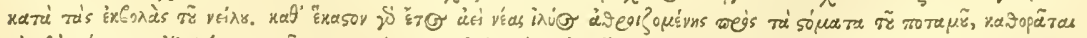

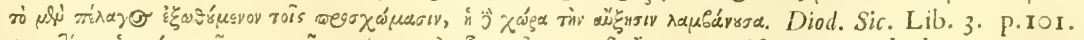
Algutiliar 3 Nafcuntur cnim terrx nec fluminum tantum invectu, ficut Echinades infulx ab Acheloo amne congeftz: majorque pars Egypti a Nilo, in quam a Pharo infula noctis \& diei curfum fuife Homero credimus; fed \& receffu maris, ficut eidem de Circeijs. Plin. Hift. Nat. 1.2. cap. 35 . 
the Sea, the Upper is to be confidered as a deep Valley, bounded on each Side with Mountains.

The Althod in wobich the Land of Egypt may be juppofid to have been r.aijed.
Let the annexed Figure be a Section of this Valley, with a

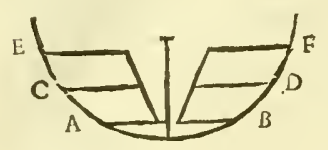

Nilo fope placed, in that Part of it, where the Nile afterwards directed it's Stream.

For about the Space therefore of one or two Centuries after the Deluge, or 'till fuch Time as the Mud, brought down by the Inundation, was fufficiently fixed and accumulated to confine the River, we may imagine the Bottom of this Valley A, B, (i. e. the whole Land of Egypt,) to have been entirely overflowed; or elfe, being in the Nature of a Morafs, was not fit to be either cultivated, or inhabited. Egypi therefore at this Time, was in a proper Condition to receive the Affiftance of $O$ firis', who by raifing Mounds, and collecting the Water into a proper Channel, kept the River from ftagnating, and thereby prepared the Land for that Culture and Tillage, which he is fuppofed to have invented. But, in Procefs of Time, the annual Strata would raife the Country as high as C. D. whereby the Nile would not only be fufficiently confined within it's own Banks; but the fuperfluous Moifture alfo, that was left by the Inundation, would be eafily drained off. Agriculture therefore and Husbandry, would have now their proper Encouragements: And in this Condition we may conceive the Country to have been, at the building of Thebes ${ }^{2}$; the Parts, where Memphis and Zoan were afterwards founded, having not yet obtained a fufficient Depth of Soil to bring down a Colony to till it. Some Centuries after, when Memplois and other Cities of the Lower Egypt were built, the Banks, together with the Land on each Side of them, may be fuppofed to be raifed as high as $\mathrm{E}, \mathrm{F}$, whereby a ftill greater Height of Water would be required to refrefh them; which, in the Time of Herodotus, was fixteen Cubits. In this Manner therefore it may be prefumed, that the Foundation of the Land of Egypt was firft laid and afterwards augmented; the Tnundation bringing along with it, every Year, an Addition of

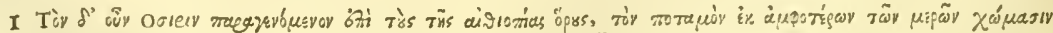

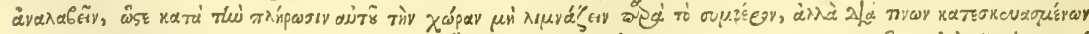

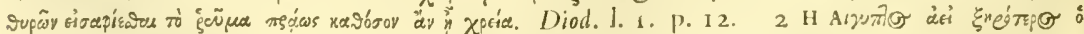

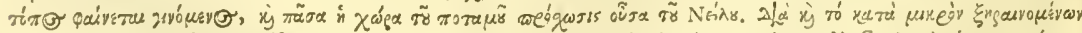

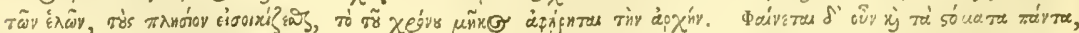

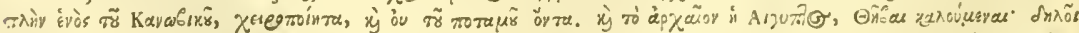

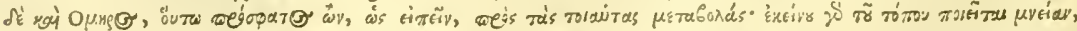

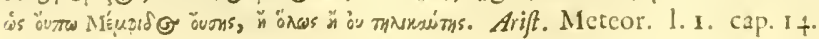

Soil, 
Soil, whereby not only the Land, already made, would be raifed, but the Soil would be likewife extended to the very Skirts of the Valley, the Sea gradually excluded, and confequently a Foundation laid for new Plantations.

That Egypt was raifed and augmented in this Manner, ap- Ttat Egypt is pears from feveral Circumftances. For, whereas the Soil of Nife, of and

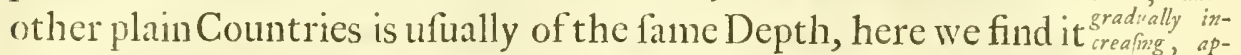

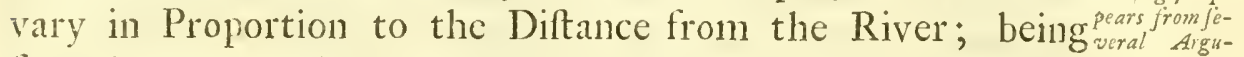
fometimes, near the Banks, more than thirty Foot high, whilftenents. at the utmoft Extremity of the Inundation, it is not a Quarter Part of fo many Inches. The Method of raifing Mounds', in order to fecure their Cities from the Violence of the Inundation, is another Argument. For as it may be prefumed, that all the Cities of Egypt were originally built upon artificial Eminences $^{2}$, raifed for the Purpofe, fo, when the circumjacent Soil came to be fo far increafed, as to lye nearly upon a Level with thefe Cities, the Inhabitants were then obliged either to mound them round, or elfe to rebuild them. The former Experiment feems to have been often repeated at Memplis; the Want whereof hath been the Reafon, no Doubt, why we are not fure, at prefent, even of the Place, where this famous City was founded. The Situation likewife of the Temple, in the City of Bubaftis, is another Circumftance in Favour of this Hypothe/is. For when the City was rebuilt and raifed higher, to fecure it from the Inundation; the Temple ${ }^{3}$, for the Beauty of it ${ }^{4}$, was left ftanding in it's primitiveSituation, and being therefore much lower than the new Buildings, they looked down upon it from every Part of the City. In like Manner Helio. polis, which, Strabo tells us, was built upon an Eminences, is now onc of the Plains of Egypt, and annually overflowed with fix or eight Foot of Water. Neither is there any Defcent,

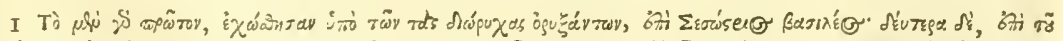

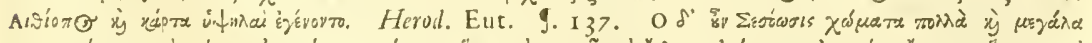

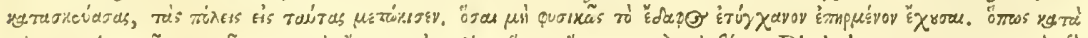

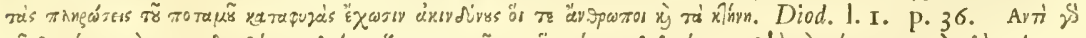

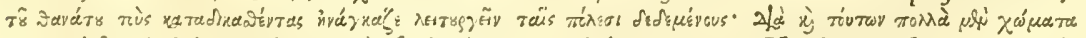

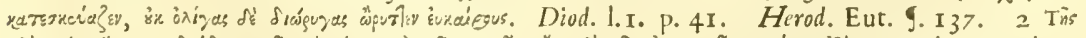

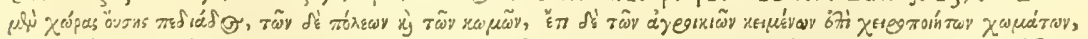

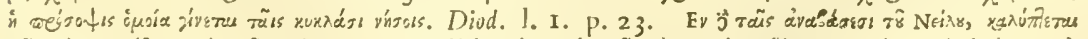

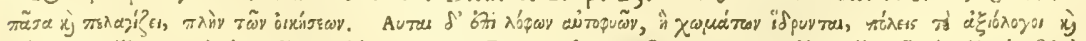

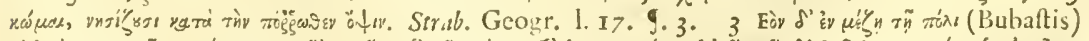

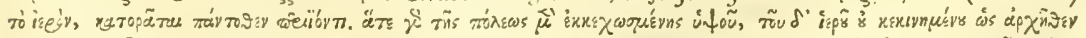

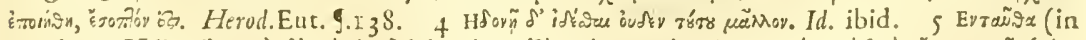

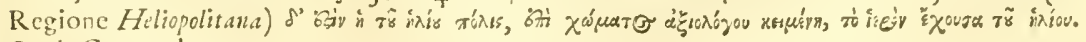
Strab. Geogr. 1. I7. P. 553 . 
as formerly, from Babylon to the River ${ }^{2}$; but the interjacent Space is all of it upon a Level. Upon the Skirts likewife of the Inundation, where the Spbinx is erected, the Soil, even there, is fo far accumulated, that, if the Sand had not already done it, very little is wanting to cover it's whole Body. With Regard alfo to the Exclufion of the Sea, (the expelling of Typhon, as it was narned in their antient Mythology,) we are told ${ }^{2}$, that Dami-ata lyes now ten Miles diftant from the Sea, which, in the Time of St. Lervis, (A.D. I 243.) was a Sea-Port Town; that Fooah, which 300 Years ago, was at the Mouth of the Canopic Branch of the River, is now more than feven Miles above it: and again, that the Land, betwixt Rozetto and the Sea, hath, in forty Years Time, gained half a League. Such large Acceffions being continually made to the Soil, would occafion feveral of the more antient Cities, fuch as Dami-ata, Tineb, \&c. (for Grand Kairo \&c. is of a later Date and built in a higher Situation;) to be in the fame Condition with Memphis, were they not, in a great Meafure, fecured by fome neighbouring Mounds; ${ }^{3}$ at the fame Time the Stream itfelf is diminifhed, by being carried, in fo convenient a Manner, through a Number of Channels, that every Part of the Country receives the Benefit of the Inundation.

The Quantity However, it will be difficult to determine, with any Exact-

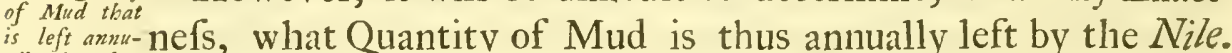
ally by the A late Anthor ${ }^{4}$ makes it equal to a tenth Part of the Water; a Weight certainly too great to be buoyed up by the Stream. According to the Quantity of Sediment that is precipitated, in their Water Jars, by rubbing the Sides of them with bitter Almonds, the Proportion feemed to be fcarce one thirtieth Part or about one Quart of wet Mud to eight Gallons of Water. But by putting fome of the fame Water to fettle in a Tube of thirty two Inches long, I found the Mud, when perfectly dry, to be nearly $\frac{1}{200}$ Part. And as in moft Places that are overflowed, the Water

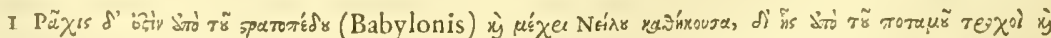

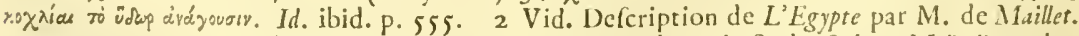
p. 96. \&c. 3 It was, by the pulling down fuch Mounds as thefe, by Sultan Melludine, that the Chriftian Army, then encamped near Kairo, were drowned, A.D. 1199.4 La viteffe de cet accroiffement eft aifée a comprendre, lorfque on fe reprefente, que les caux du Nil font fi troublees \& $\mathrm{fi}$ bourbeufes dans le tems de l'Augmentation de ce fleuve, que les boues \& les fables font au moins la dixiéme partie de fon Volume. Defiription de L'Egypte par M. Maillet. P. IOZ. 
ftagnates, or continues at leaft without any confiderable Motion; being ufually admitted by Sluices, and kept in on every Side by Banks, it is probable, that a proportionable Quantity of Soil, (the Depth of the Water being always regarded) may have been left upon the Surface. But I am fenfible, that Tryals and Experiments of this Kind ought to be carefully examined and repeated, before any Hypothefis is built upon them. I therefore dare propofe it only as a conjecture at prefent, that, according to the Computation of Time by the Vulgar Era', the Acceffion of Soil, fince the Deluge, muft bave been in a Proportion of fomewhat more than a Foot in a bundred Years.

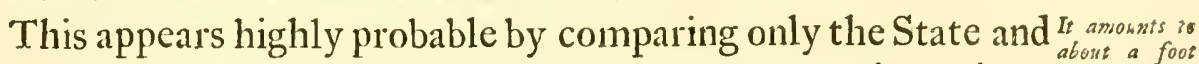

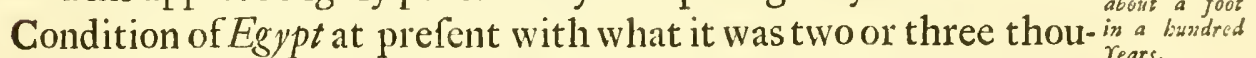
fand Years ago. For Herodotus ${ }^{2}$ acquaints us, that in the Reign of Myris, if the Nile rofe to the Height of eight (Grecian) Cubits, all the Lands of Egypt were fufficiently watered; but that in $\mathrm{His}$ Time (which was not quite 900 Years after Myris) the Country was not covered with lefs than fifteen or fixteen Cubits of Water. The Addition of Soil therefore, by fuppofing them to have been fifteen only, will be feven (Grecian) Cubits or 126 Inches in the Space of 900 Years. But, at prefent, the River muft rife to the Height of 20 (Stamboline) Cubits, (and it ufually rifes to 24) before the whole Country is overflowed. Since the Time therefore of Herodotus, Egypt has gained 230 Inches Depth of new Soil. And, if we look back from the Reign of Myris to the Time of the Deluge, and reckon that Interval by the fame Proportion, we fhall find, that the whole perpendicular Acceffion of Soil, from the Deluge to A.D. I72I, muft be 500 Inches: i. e. The Land of Egypt, agreably to the $E r a$ and Conjecture above, has gained forty one Foot eight Inches of Soil, in 4072 Years ${ }^{3}$. Thus, in Procefs of Time, this whole Country may be raifed to fuch a Height, that the River will not be able to overflow it's Banks; and Egypt confeouently, from being the moft fertile, will, for Want of the annual Inundation, become one of the moft barrenParts of theUniverfe.

Thefe are the chief Remarks and Obfervations I have to offer The The Examina-

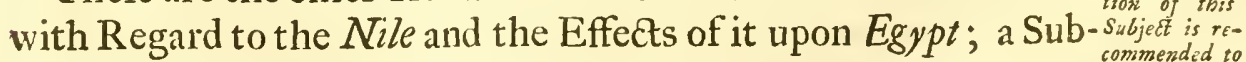

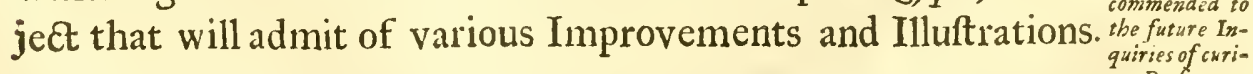

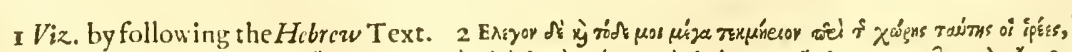

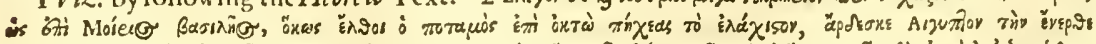

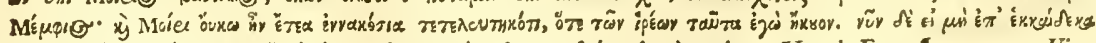

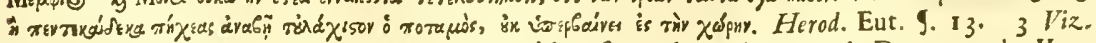
by reckoning, according to Mr. Bedford's Tables, from the Deluge to A. D. I72I, the Year when I was in Egypr.

Tttt

The 
The further Examination of it therefore is recommended to fuch curious Perfons, as may have more Leifure and better Opportunities, than $I$ had, of meafuring the feveral Periods of the Inundations, the Height of the Mikeas, the Cubit by which it is divided, the Depth of the Soil, and the Quantity of Sediment fucceffively left by the River.

Herodotus's However among the many Doubts and Difficulties, that have Egcount of Egree- been already mentioned, or may be hereafter raifed, upon this

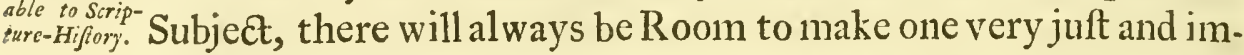
portant Obfervation; That if Herodotus had duly confidered the annual Increafe of the Soil and carried back bis Remarks but a thoufand Years beyond tbe Time of Myris, he could not bave given the leaft Credit to that long Succefion of Dynafties ', whichmake up the Egyptian Hiftory. For fince, according to his own Reflections, Egypt is the entire, though gradual, Gift of the Nile, there muft have been a Time (and that not long before the Period laft mentioned) when it was either of the fame barren Nature with the Deferts that furround it, or elfe quite covered with Water; and confequently, there could be no habitable Country for thefe pretended Princes to reign over. Our Hiftorian himfelf fuppofes it to have been an Arm of the Sea; and the Time, pretty nearly, when it was fo, he had learnt from the Egyptians, who affured. him, that Menes $^{2}$, was the firft King, who reigned in the World; that, in his Time, all Egypt, except the Country of Thebes, was one continued Morafs; and that no Part of the prefent Land then appeared below the Lake of Myris. Now, as this Menes or Ofiris 3 was the fame with Mizraim the Son of $\mathrm{Cham}^{4}$, the firlt Planter of Egypt; as all the foregoing Circumftances fo well agree with the Mo faic Account of the Flood and the Difperfion of Mankind; it muft be allowed, that Herodotus hereby confirms the Truth andCertainty of theScripture-Chronology; and at the fame Time overthrows the Authority of all thofe extravagant Annals and Antiquities, that have been fo much boafted of by the Egyptians.

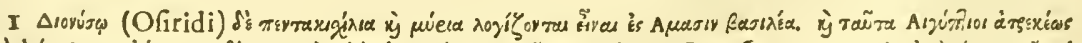

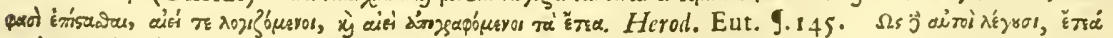

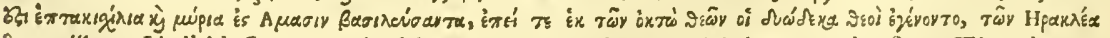

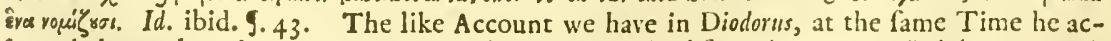

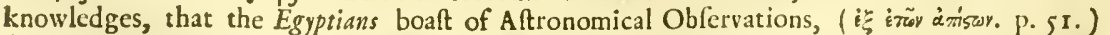

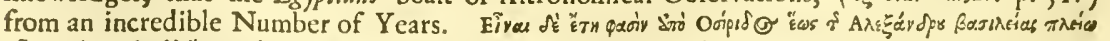

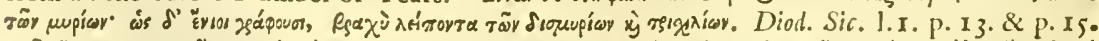

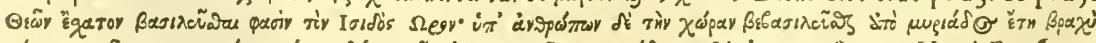

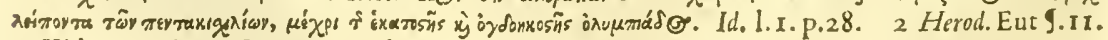
3 Vid. Shuckford's Connect. Vol. I. p. 205. 4 Gen. 10.6. 


\section{A \\ C O L L E C T I O N O F S U C H \\ P A P E R S \\ A S SERVE TO \\ I L L U S T R A T E THE FOREGOING \\ O B S E R V A T I O N S.}

6.0.6.0.6.

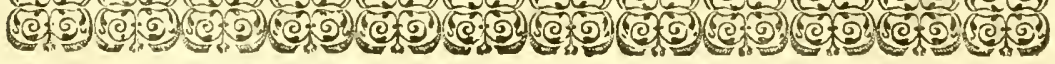




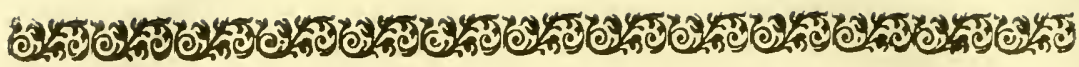

\section{The CONTENTS.}

$\mathcal{E}^{\text {Xcerpta e Veteribus Geographis \&c. p. I. }}$

2 Specimen Phytographie Africane \&c. p.37. Obf. p.227.

3 Appendix de Coralliis \& eorum Affinibus. p.47. Obf p. 384.

4 Catalogus Foflilium. p. 49. Obf. p. 236.

5 Catalogus Piccium. p. 50. Obf. p. 259.

6 Catalogus Conchyliorum. p. 51. Obf. p. 260.

7 AVocabulary of the Showiah Tongue. p. 52. Obf. p. 289.

8 Infcriptio Antiqua, de Pluvia Manne. p. 53. Obf. p. 350.

9 The feveral Stations of the Mahometan Pilgrims, in their Fourney to Mecca. p. 53 . Ob1. p. 355.

10 Mefure de la Grande Pyramide de Mempbis, par le Pere Siccard', P. 54.

II Remarques fur le Natron, par le mefmé, p.55. Obf. p. 430.

12 The Method of making Sal Armoniac ${ }^{3}$. ibid.

13 An Account of the Weather at Alexandriat. ibid.

14 Excerpta e Kalkafenda de Nilo \& Nilumetro, e traductione V. Cl. J. Gagnier. p. 57. Obf. p. 436. Not. I.

Is Nummi nonnulli ab Auctore in Africa collecti. vid. Pref.

I Thefe Meafures, taken by Pere Siccard, were communicated to me by Dr.Mead, and are intended to illuftrate Not. 2. P. 421 . Obf. 2 Vid Memoires des Mefrons \&rc. Vol.viI. p. 64. 3 The Rev $^{d}$ Mr. Li le, Fellow of Magd. College Oxford, favoured me with this Account. 4 'This hort Journal I copied out of Mr. Greaves's Pocket-Book, that is depofited in the Savil Study, and ferves to prove what regards the Weather. Obf. p. $43 \mathrm{I}$. 


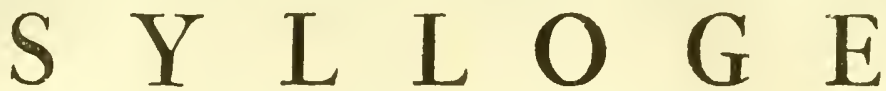

EXCERPTORUM EX VETERIBUS

GEOGRAPHIS, HISTORICIS \&

O R

A COLLECTION of fuch ExTRACTS from the

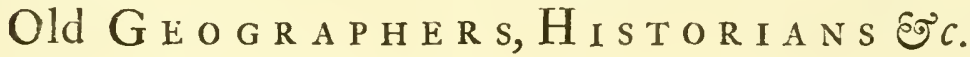

As chiefly relate to that P A R T of

\section{$A F R I C A$ or $B A R B A R Y$}

Known at prefent by the Name of the

\section{Kingdoms of ALGIERS and TUNIS.}

Herodoti Halicarnaff. Hiftor. Libro IV. Lug. Bat.1715. vid.p. 2.

Scylacis Caryandenfis Periplo. Oxon. 1698 . v. p.3.

Strabonis Rerum Geographic. Libris II \& XVII. Amft. 1707. v. p.5.

Cl. Ptolemxi Geographix Libro IV \& VIIl. Amft. I6r9. v. p.9.

Pomponio Mela de Situ Orbis. Ifcæ Dunmon. y 7 rr. v. p. 18.

C. Plinii Secundi Hift. Naturalis Libro V. Par.1685. v. P.20.

J. Solini Polyhiftore. Traj. ad Rhen.r689. v. p.22.

Antonini Augulti Itinerario. Lug. Bat. 1735 v.p.25.

Æthici Cofmographia. Lug. Bat. 1696. v. p.28.

J. Honorii Oratoris excerptis. Ibid. v. p.29.

Sexti Rufi Breviario Hilt. Romanx. Hanov. 16 Ir. v.p. 29.

I Pauli Orofii adverfus Paganos Hiftoria. Col. Is82. v. p. 30.

Martiani Minei Felicis Capellx de Nuptiis Philofophix Libro VI. Baf. i 77 .

v. p. 30 .

Ifidori Hifpalenfis Originum Libro XIIII. Ibid. v.p.3r.

\pm Collatione Carthaginenfi,Notitia Epilcoporum Africæ fub Huneri-

co, Concilio Carthaginenfi fub Cypriano \&c. five Notitia ommium Epifcopatuum Ecclefire Africana; quæ præfigitur S. Optati de >V. p.3I. Schifm. Donatiftarum Libris feptem. Opera \& Studio M. Lud. Ell. Du Pin. Antuer. r 702 .

Notitia utraque Dignitatum cum Orientis, tum Occidentis, ultra Arcadii Honoriique tempora. Lugd. 1608. p. 35.

Ravennate Anonymo. Amft. I696. p.35.

Tabula Peutingeriana. ex edit. G. Hornii. Amit 1654 . 


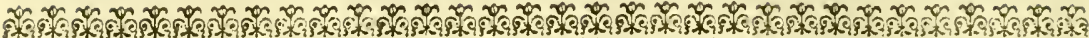

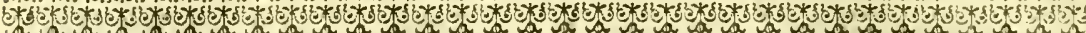

\section{ExcER P T A ex Herodoto.}

$L$ I B YU M multx funt \& varix natio-A nes. Pertinent Adjrmacbide ab $\mathcal{E}$ sypro ad portum úque nomine $P$ leunum. His confines funt Gioame, regionem verfus occafum incolentes, Aphrodifiade cenus infula. In hujus loci medio adfita eft Infula Platea, quam condiderunt Cyrenci. Atque in continente eft porcus Menelaius \& $A$ zaris, quam Cyrenci incoluerunt. Et dehinc Silphium incipit, ab infula Plitea pertinens ufque ad fauces Syrtis. Gigamus ab occafu contingunt Asby/tec, qui fupra Cyvenem incolentes non pertinent ad mare: nam maritima Cyrenaz incolunt. Horum funt occafum verfus confines Aufchifa, qui fupra Barcam inculentes ad mare pertinent prope Eue/peridas. Aufchifarum quod ad occafum vergit, contingunt Nafarwones, grandis natio. Nafamonibus confines funt $P$ Sylli. Erat autem omnis corum regio, qtix intra Syrtin eft, aquarum inops. $\mathscr{P} \int y / l i$ s extinctis, eorum terram $N a$ famones obtinent. Garamantes fupra Najamoses incolunt. Circa maritima verò, occafun verfus, confines funt Maca. Per eos flumen Cinyps è colle, qui vocatur Gratiarsim, fluens, in mare influit. Ducentorum ab eo ad mare ftadiorum eft intercapedo. Horum $\mathrm{Ma}$ carum finitimi funt Gindanes. Horum Gindanum oram in mare porrectam incolunt $L_{0}$. lopbagi, qui è folo Loti fructu victitant: cujus fructus eft magnitudine inftar lentifci, fuavitate afrimilis fructui palmarum. Ex hoc fructu Lotophagi vinum etiam conficiunt. Lotophagis fecundum mare vicini funt Machlyes, Loto \& ipfi utentes, fed minus quam fupe. riores. Pertinent autem ufque ad ingentem amnem nomine Tritonem, qui in grandem paludem Tritonidem influit, in qua eft infula nomine Pbla. Juxta hos Machlyes habitant Aufes: \& circum paludem Tritonidem utrique habitant, ita ut medio Tritone dirimantur. Ifti quidem maritimi Libyum Nomadum dicti funt. Supra hos autem, ad partem mediterraneam, Libya eft, feris abundans; \& Ammonii; \& Augila; \& Garamantes; \& Atlantes; \& mons nomine Allas, qui anguftus $\&$ undique teres eft; \& (ut fertur) adeo cel. E fus, ut ejus cacumen nequeat cerni, quod a nubibus nunquam relinquatur, neque $x$ tate neque hyeme: quem effe columnam coli indigenæ aiunt. $\mathrm{Ab}$ hoc monte cognominantur [Atlantes fcilicet] hi Homines. Porrigitur autem id Supercilium ad columnas ufque Herculeas, atque extra illas. Supra autem hoc Supercilium, Notum verfus ac mediterranea

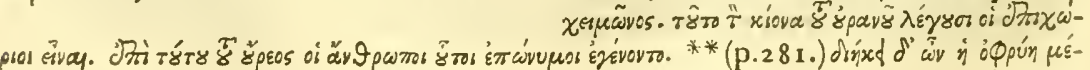

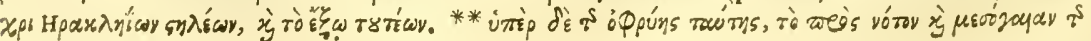

$\Lambda$

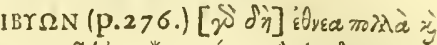

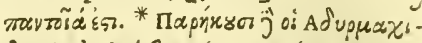

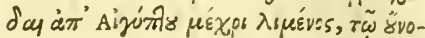

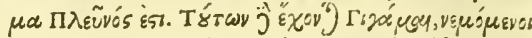

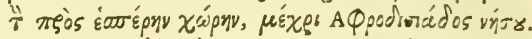

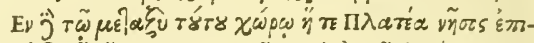

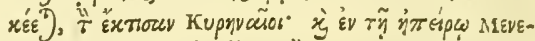

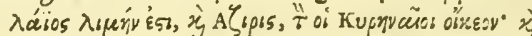

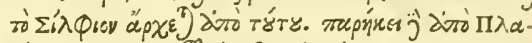

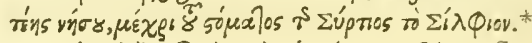

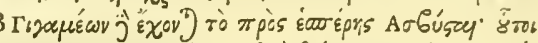

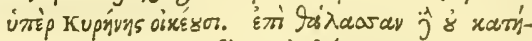

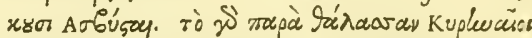

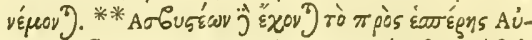

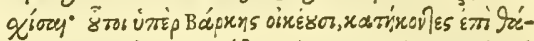

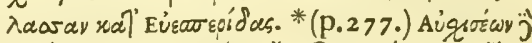

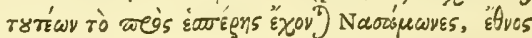

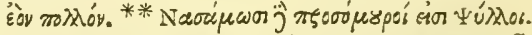

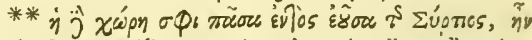

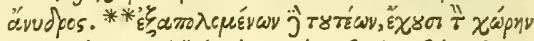

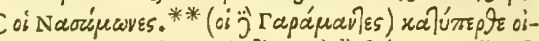

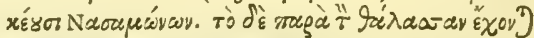

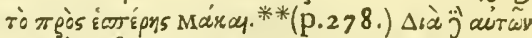

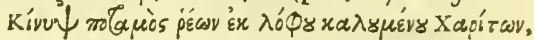

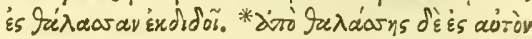

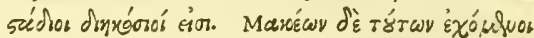

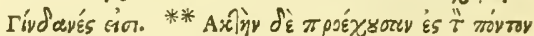

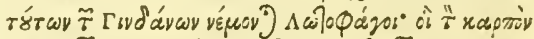

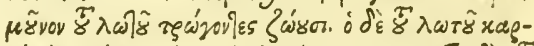

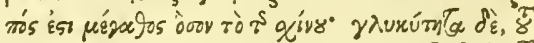

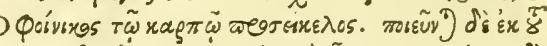

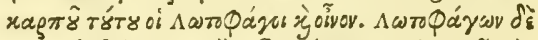

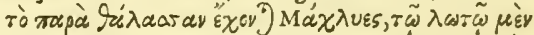

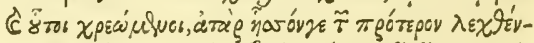

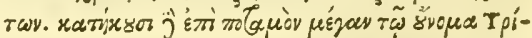

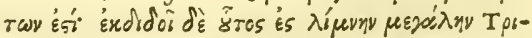

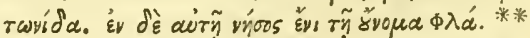

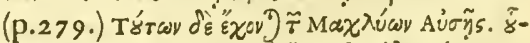

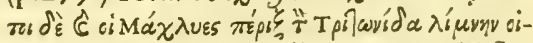

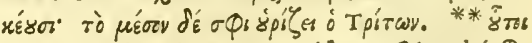

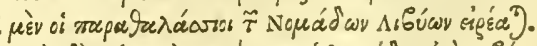

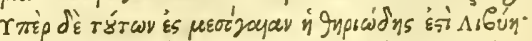

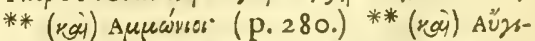

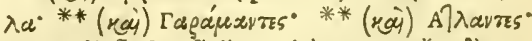

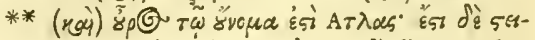

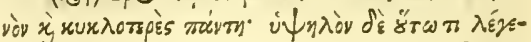

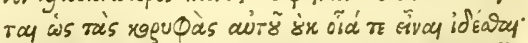

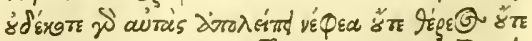

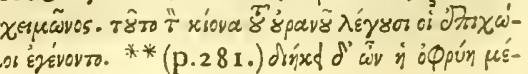
A6- 


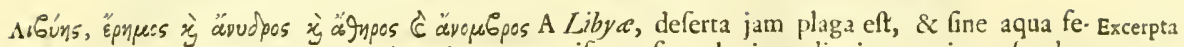

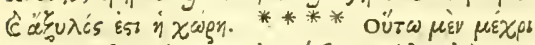
ร T

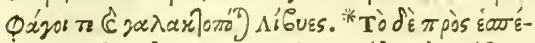

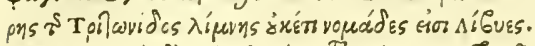

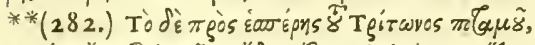

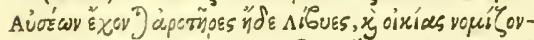

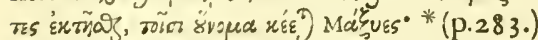

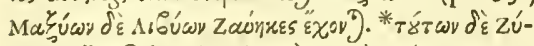

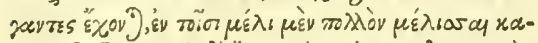

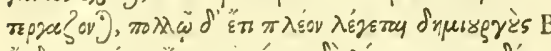

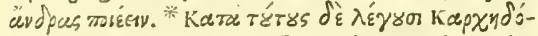

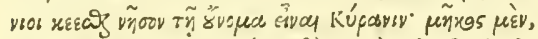

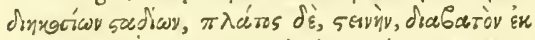
จ

rifque, fine pluvia ac lignis, omni prorfus hu- ex more vacans. Ita ab Eggpto ad Trizon. Herodoso. dem paludem paftoricii Libyes fune carne victitantes ac lacte. Ad occafum vero $7 \%$. tonidis paludis jam non func pafcuales Libyes. Coningunt quidem hos Aufes ab occidentali parte Trizonts fluminis, ii Libyes qui lune aratores, \& domos poffidere confueverune, quibus nomen impolitum eft Mlaxyes. CHaxyarn autem Libyum confines funt Zasseces. His finitimi funt Zygantes, ubi magnam vim mellis apes conficiunt, led multo plus opifices viri facere dicuneur. Juxta hos aiunt Cirtha. ginierfes fitam efle infulam nomine Cyranin, ducentorum ftadiorum longitudine, arctam latitudine, in quam tranfiri è continente poteft, oleis refertam, ac vitibus. ***

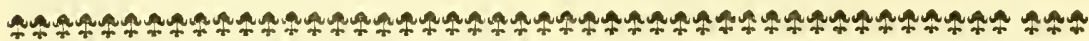

\section{Ex CER P TA ex Scylace.}

$\mathrm{A}^{\mathrm{n}}$

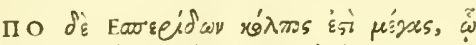

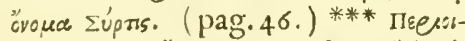

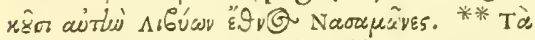

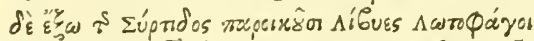

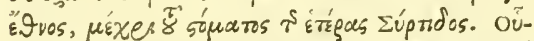

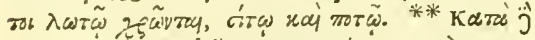

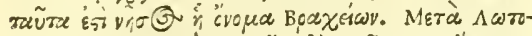

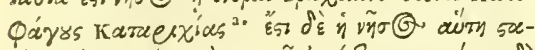

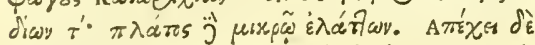

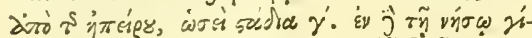

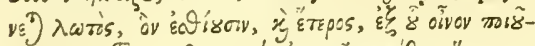

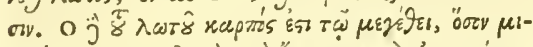

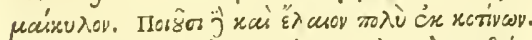

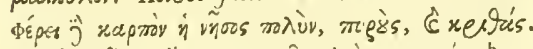

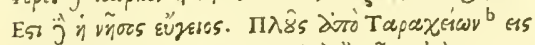

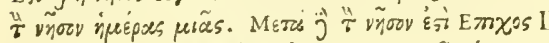

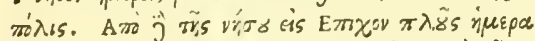

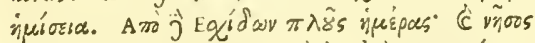

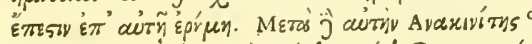

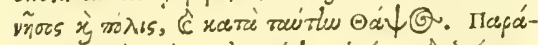

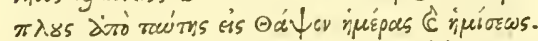

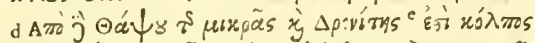

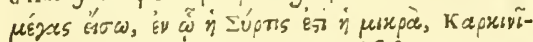

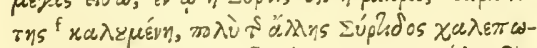

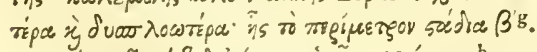

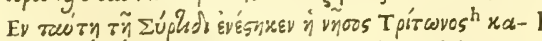

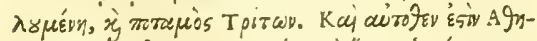

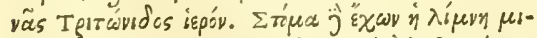

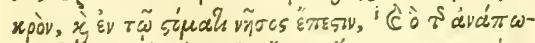

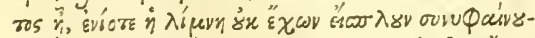

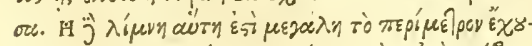
ow is sedíw

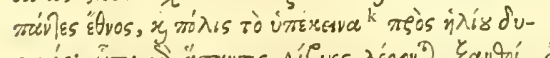

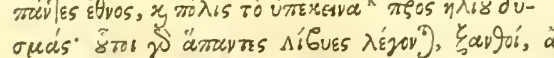

DOST Herperidas eft finus magnus, qui ap. pellatur Syrtis. Accolunt eam Nafamones, gens Libyca. Qux funt extra Syrtm, incolit $L$ ? byenn Lotophagorum natio, ufque ad os alterius Systidis. Hi Lnto utuntur, pro cibo \& potu. Deinde infula Bracbion eft. Poft Lotophagos Cataricbias: eft autem infula hæc ftadiorum ccc. latitudine vero paulo minor. Abeft à continenti ftadiis circiter ir I. In bac infula nafcitur Lotus, quem edunt : aliaque ejus eft fpecies, ex qua vinum conficiunt. Loti autem fructus magnitudine fimilis eft fructui arbuti. Oleum mulcum ex oleaftris faciunt. Producit autem hxc infula fructum mulsum, triticum, \& hordeum. Eftque hæc infula uberis terræ. Navigatio autem a Taricbiis in hanc infulam diei unius. Poft infulam hanc eft Epictous urbs. $\mathrm{Ab}$ infula ad Epicbusn navigatio diei dimidiati. Ab Efc brdibus diei navigatio: \& infula circa hanc eft deferta. Polt hanc eft Cercznnitzs infula cum urbe, circaque eam eft Thap/us. Prxtervectio ab hac in 7 bap/um diei unius $\&$ dimidix. A Thaplo vero minore intra eft $\mathcal{T}$ ritonites finus magnus, in quo eft parva Syrtis, Cercinnitica appellata, altera $S)^{\prime} t ı$ multo fxvior, navigatuque difficilior; cujus ambitus eft ftadiorum crocrs. In hac Syrti eft infula Tritonis appellata, \& fluvius Truon. Et illic elt Minerve Tritonze fanum. Os vero hic lacus exiguum haber, \& in eo infula apparet, fi quando mare refugiat; at ubi inunder, non amplius acceffum navibus præbet. Lacus autem hic eft magnus, ambitum habens ftadiorum circirer mille. Cingit vero eum Libyunn omnis natio; urbfque eorum eft in ulteriori ripa, verfus Solis occafum: omnes enim hi Libyes appellantur, flavi, abfque fuco pulcherrimi. Regio hæc optima eft, \& a Legendum xark Taeszes vel wata Tagxiar. Bochan. Geogr. Sacra. P. 494. b Taexion.

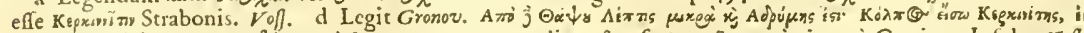
$\tilde{\omega}$ मे $\Sigma$ v́gs

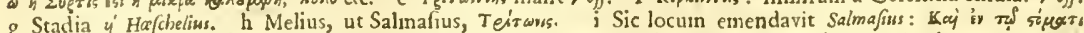

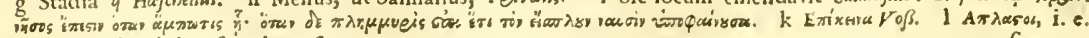
vere pulchri, minime fucati. $V 0 \Omega$. 


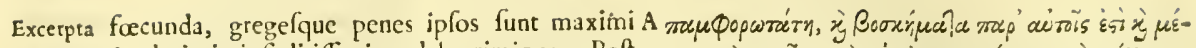
ex \& plurimi, ipfi ditifimi, puicherrimique. Poft

Scylace. hanc Syrtin fequitur Neapolis. Prxtervectio vero ab Hadrjmeto ad Neapolin eft dierum 11. Poft Neapolin eft Hermaum promontorium, \& urbs. Prætervectio à Neapoli ufque Hermaum eft diei unius, ac dimidiati. A Neapoli ad Ithmum pedeftri itinere ftadia funt clxxx, ufque ad alterum mare, quod Carthayinem alluit. Eft vero peninfula, qux habet anguftias. Pretervectio à flumine ex hoc Joco ad Cartbaginem, eft diei unius \& dimidix. Carthaginienfium autem regio eft in finu. Pot Ifthmum elt Cartbago, urbs Pbialon cum portu. Prætervectio vero ab Hermaco ufque Carthaginem eft dimidiati diei. Hermeo promontorio adfitx lunt infulx, Pontia \& Colyrus. Navigatio ab Hermaco ufque Cofyrum eft diei. Ultra Hermeum promontorium paululum, verfus folem orientem, tres ei adjacent infulix, exigux, a Cartbaginien/ibus habitatx; Melita urbs cum portu, Gaulus urbs, Lampas; in hac turres binæe aut tres. A Co/pro vero ad Lilybaum promontorium Siciha, na-C vigatio diei unius. Poft Cartbaginem Utaca urbs cum portu. Prxternavigatio à Cartbagine ad Uitcam diei unius. Ab Utica ad Equi ptomontorium **** Equi urbs, \& palus ei ad. fita eft, infulieque in ea, \& urbes circa paludem in infulis hx funt $* * * *$ Collops Magnus urbs, ex adverfo ejus multx infulx Naxice, Pubecufa cum porru. Ex adverfo earum eft infula, in qua Eubaa eft civitas, Thap fa urbs $\&$ portus, Cuncacis urbs cum portu, Sida urbs, Iol promontorium, urbs \& portus, Hebdomus urbs cum portu, Acium infula, in qua urbs $\&$ portus, P Jamaibus infula, urbs cum porıu, \& finus. In hoc finu Bartas eft infula cum portu, Chalca urbs in fluvio, Arylon urbs, Mles urbs cum portu, Sigum urbs in fluvio, cui ob. jacet infuld Acra, urbs Me - . cum portu, Aurus urbs, is qua eft finus, deferta infula ap pellara Drinaupa, Herculea columna, Libya promontor:um, Apanilye urbs in fluvio. Ex adverfo hujus lunt Gades inlulx. A Cartbagne hucufque ad columnas Herculeas quam profperrime pretervehuntur diebus \& noctibus fepeem. Gudium auten he Infulx ad Europ.sm pertinent. Harum una Urbem habet. In his quoque funt columnse Herculece; ea quidem, que in Libya, humilis; Europea vero excella eft. Contrarii fibi invicem funt hi vertices, diftantque inter fe diei navigatione. Prxtervectio Libya ab oltio Canobi, quod in $\mathcal{E}$. gypto ufque Herculeas columnas, circumnaviganti finus eft dierum $\operatorname{Lx} \times \frac{1}{4}$. Omnia vero oppida \&c emporia ante memorata in Libya, a Syrii qux ad Hefperidas, ufque columnas Herculeas, quie in Libya, funt Cartbaginenfium.

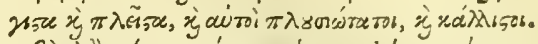

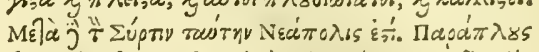

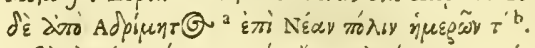

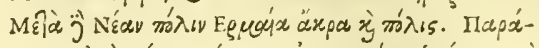

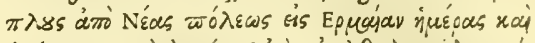

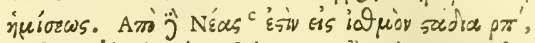

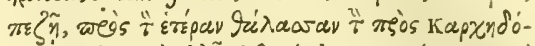

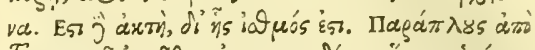

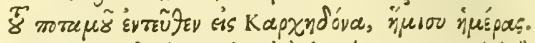

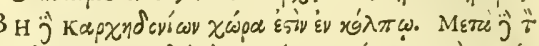

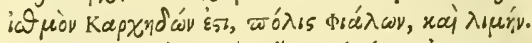

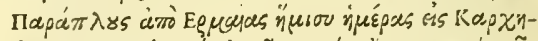

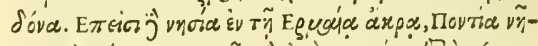

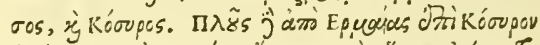

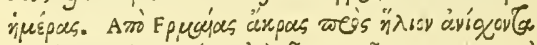

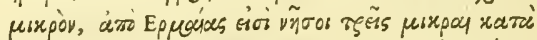

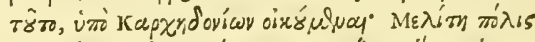

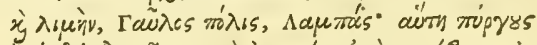

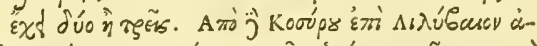

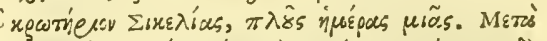

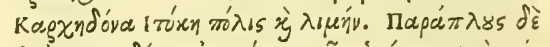

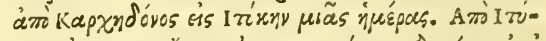

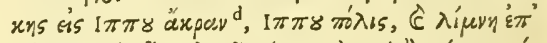

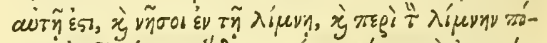

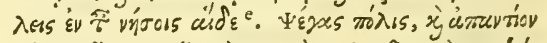

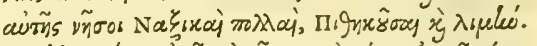

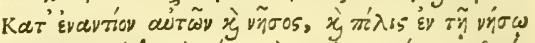

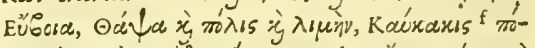

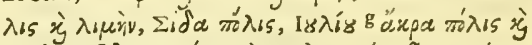

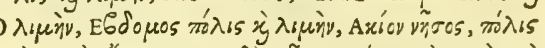

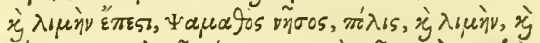

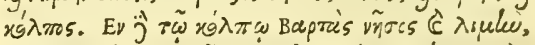

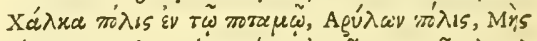

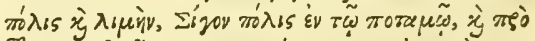

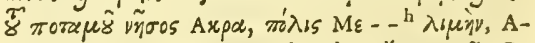

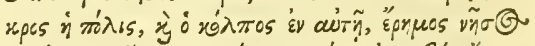

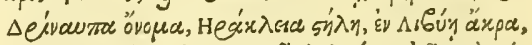

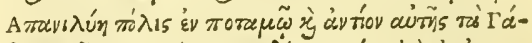

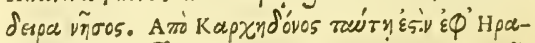

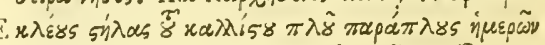

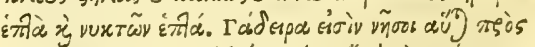

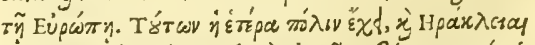

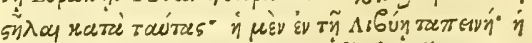

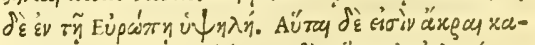

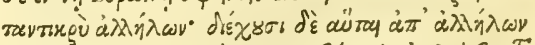

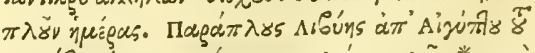

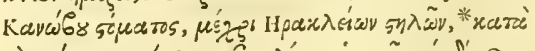

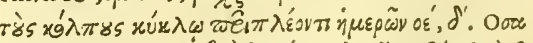

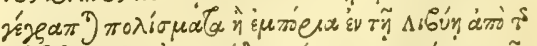

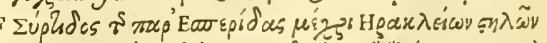

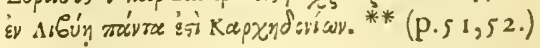

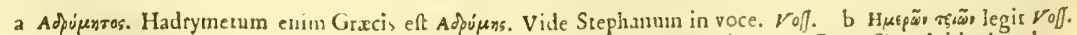

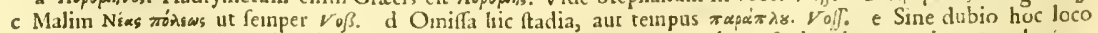

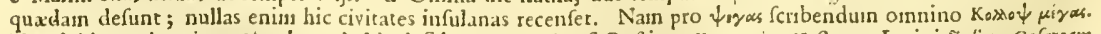

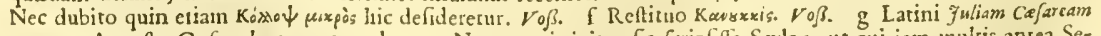
vocant, Augufto Cafare hoc nomen dante. Non potuic igitur fic feripliffe Scylax, ut qui jam inulris antea Se-

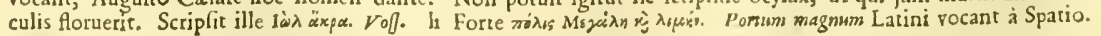

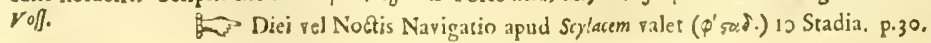

EXCER- 


\section{ExcER P T A ex Strabone.}

$\mathrm{M}$

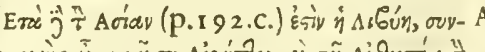

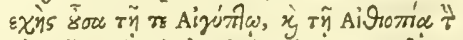

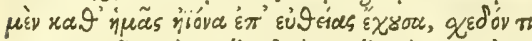

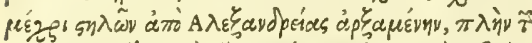

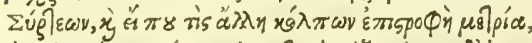

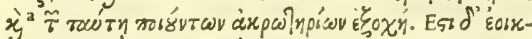

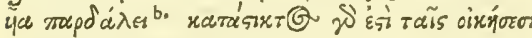

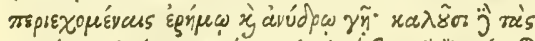

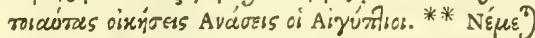

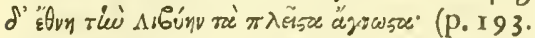

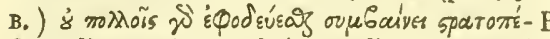

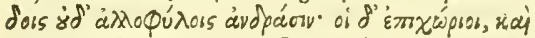

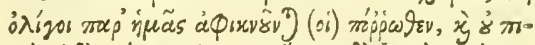

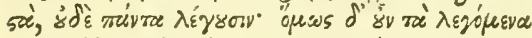

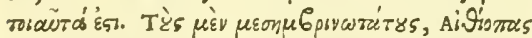

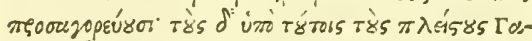

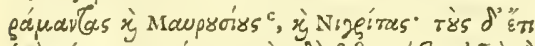

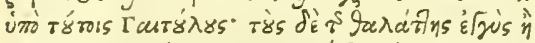

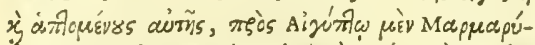

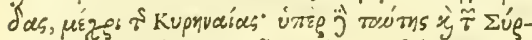

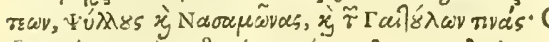

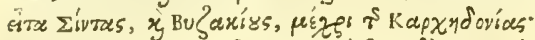

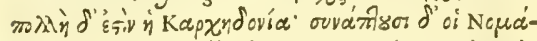

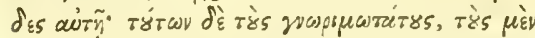
Maora

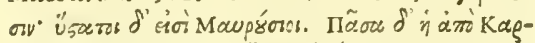

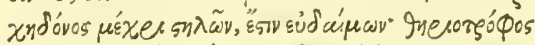

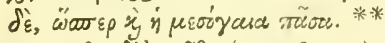

оікช்

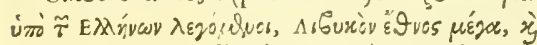

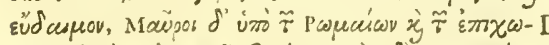

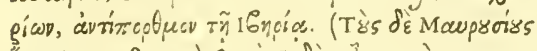

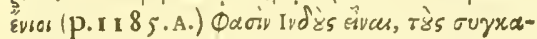

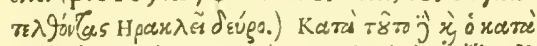

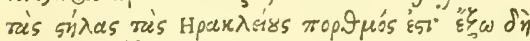

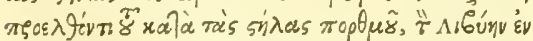

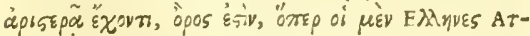

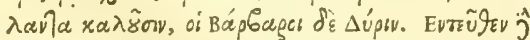

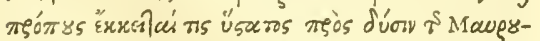

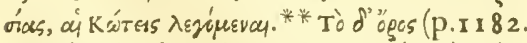

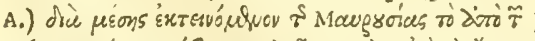

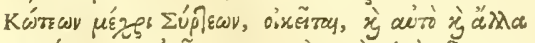

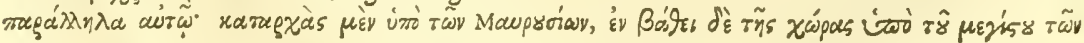

LIE.

II. - pto \& Etbropia: ejus littus quod no bis clt obverfum, ab Alexandria ufque ad Co. lumnas propemodum in recta linea producitur, cxceptis Syrtibus, \& ficubi alibi medio. cres finus funr, \& promontoria prominenr. Eft autem Africa Pardali fimilis, interpuncta habitationibus, qux circumdantur terra deferra, $\&$ aquæ inopi: atque hujufmodi habitationes ab Egyptizs vocantur Awafes. Incolunt $L_{l-}$ byam gentes pleræque ignotæ: neque multi ed ducti funt excrcitus, aut peregrini advenerunt : incolæ autem cum pauci ad nos perveniunt, tum neque credibilia narrant, neque omnia qux tamen ii narranr, talia funt. Maxinè verfus meridiem diffiros, appellant Etbropas : fub his plerofque Guramantas, Pbar 1 ios, Nigritas: his adhuc inferiores Gatulos: deinde vicinos aut etiam contiguos mari, ad Egyptum quidem Manmasidas, ufque ad Cyrenam: fupra hos \& Syrtes, Pfyllos, Nafamonas, \& quofdam Gatulos, tum Sintas \& Byzacios ufque ad regionem Cartbaginen em, quæ ampla Cet, eamque Nurnide attingunt; quorum celeberrimos Mafylenfes, (vel MaJylos) alios Mafaefylios appellant: ultimi funt Maurufiz. Omnis eft felix, feras tamen producit ut \& Mediterranea omnis Africa.

Ibi ergo (fc. in Africe partibus Occidentalibus) habitant, qui a Grzcis Gifauru/2i ap- XVI
XVIl. Romani \& indigine Mauros vocant: ab $\mathrm{Hi}$. Spania oppolita Mari angufto diremptos. (Sunt, qui dicunt, Mauros Indos effe, qui cum Hercule in hunc locum defcenderunt.) Juxta eft etiam fretum, ad Herculis Columnas. Extra Columnarum fretum procedenti, ita ut ad finiftram fit Africa, mons eft, quem Græci Atlan. tein nominant, barbari Dyrim. Inde procel fus quidam eminet, excrema Mauritanice Pars, occidentem verfus, \& Cotes appellatur. Mons qui a Cotibus ufque in Syrtes per mediam Mauritaniam tendit, \& ipfe, \& Montes qui cum eo paribus porriguntur Spatiorum Diftantiis, commode habitantur, in initio quidem a

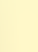

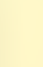

a
autcm a Carthagine ad Columnas ufque Regio pellantur, Lybica Gens \& magna \& opulenta; 


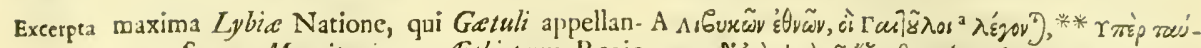
ex tur. Supra Mauritaniam Etbiopum Regio Strabone. eft, qui Hejperii (nimirum occidui) vocantur, magnà ex parte male habitata. Columnarum Fretum Longitudine dicitur ftadiorum centum \& viginti, minima vero Latitudine Sexaginta juxta Elepbantem. Ulterius naviganti funt Urbes \& Flumina complura ufque ad Amnem Molocutb, qui Maurorum, Maffesyliorumque Regionem diftinguit. Nominatur etiam Pro. montorium Magnum flumini proximum, \& locus aridus, ac fterilis Metagonium: ac fere Mons a Cotibus huc ufque pertendit. Longitudo a Cotibus ufque in Majfesyliorum fines eft Stadiorum quinque millia. Metagonium nova Carthagini refponder, in adverfa Ripa oppofitx. Timofthenes male pronunciavit, verfus Maffelyliam effe. A Nova Cartbagine Metagonium effe Stadiorum ter mille traje. cum, prxternavigationem ab ea Malfesyliam ufque amplius fex Millibus Stadiorum. $C_{\mathfrak{x}}$ terum Mauri etfi adeo uberem Regionem inhabitant, tamen ad hoc ufque Tempus magna ex parté incertis vagantur Sedibus. Ii \& lequentes MafJe/ylii \& Libes magna ex parre cultu eodem utuntur $\&$ in cateris perfimiles funt, parvis equis utentes, celeribus tamen $\&$ manfuetis, adeo ut fola vergula gubernentur. Cotiveniunt nonnunquam Giauros Phaurafit, fed raro, per Deferra aquarum urres equarum ventribus fubligatos vehentes, nonnunquam per loca quxdam paluftria \& lacus Cirtam veniunt. Polt Mfaritaniam eft Ma/Jafyliorum Regio, a Molocbuth flumine initium fumens: finiens vero in Promontorium quod Ma/fasyliorum \& Maficlybium Confinium dicitur. A Metagonio Trituan ufque funt Stadiorum fex M!illia: funt qui pauciora numerent. Ora $\mathrm{Ma}$ ritima complures Urbes \& fluvios habet, \& Regionem valde commodam, fed fatis fir mentionem eorum facere qux funt clariora. Diftat itaque Siga Civitas à dictis Finibus CIJ Stadiorum intervallo, \& Syphacis Regia q̨uæ nune diruta eft. Polt Sypbacem Ma/fini]Ja obtinuit Regionem, poltea Micipja, poltea ejus Succeflores, noltra Tempeftate Fuba, Fuba Pater, nuper mortui. Diruta eft etiam a Roinanis Zama hujus Regia. Poft Siga in Sexcentis Stadiis elt Deorum Portus, ac porro alia loca obfura: qux vero in interiore $j a$ cent Regione, montana funt atque deferta: quibus interdum inferuntur, quæ Getuli tenent ufque etiam ad Syrtes. Ibi vero ad Mare \& Campi uberes funt, \& urbes multæ, fluminaque \& Lacus. In hac Ora fuit urbs quxdam No. minc Fol, quam Fuba Plolemai Parer a fe inftauratam, mutato Nomine Cefaream rocavit, ea Portum habet, \& infulam ante Portum. Inter Cafarean atque Tritum eft magnus Portus, quem Sardam (Saldam melius) vocant. Atque hæc funt Confinia $\mathcal{J}_{u b c}$, \&

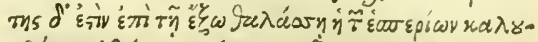

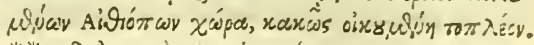

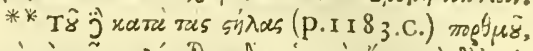

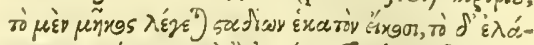

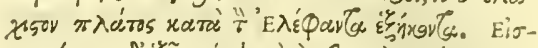

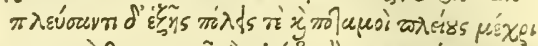

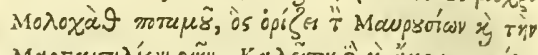

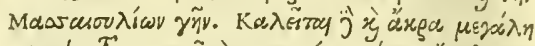

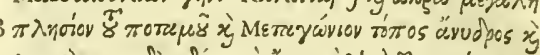

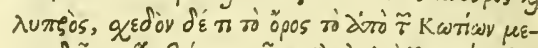

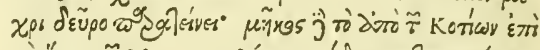

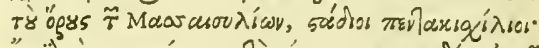

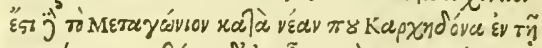

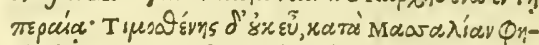

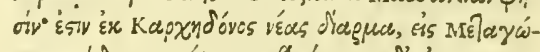
vrov, súdos ŗ'qui

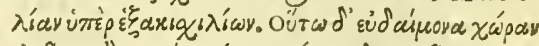

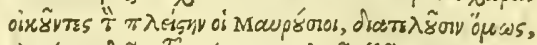

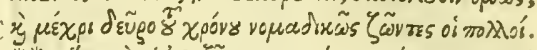

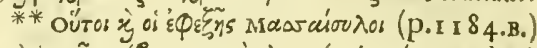

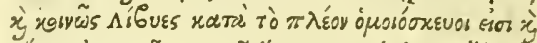

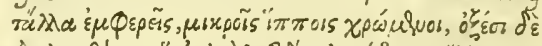

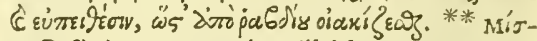

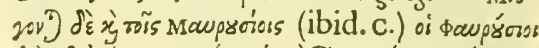

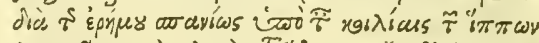
ітирт

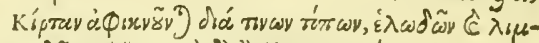

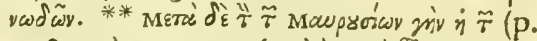

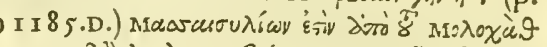

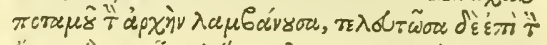

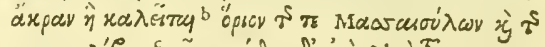

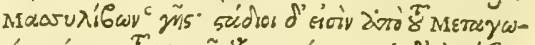

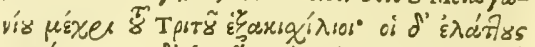

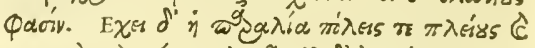

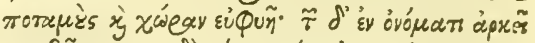

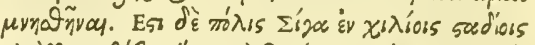

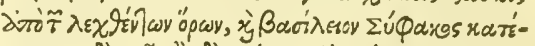

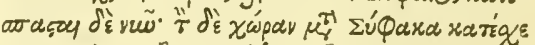

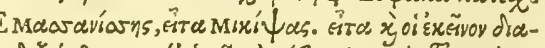

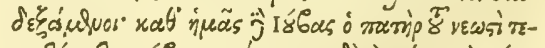

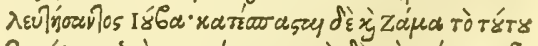

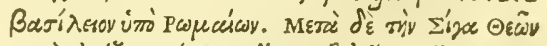

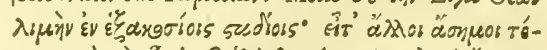

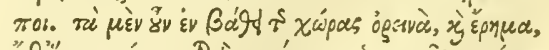

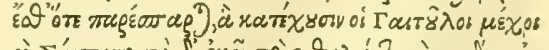

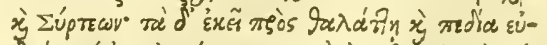

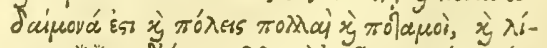

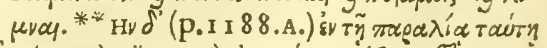

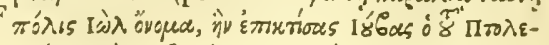

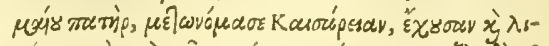

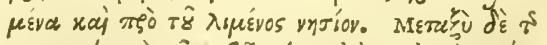

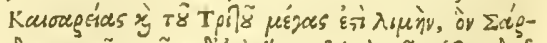

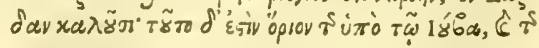

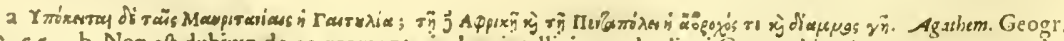
1.2. c.5. b Non eft dubiun de co promontorio hac intelligi, quod reliqui Geographi Trium rocant; quare le-

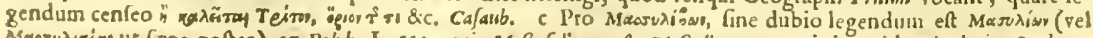

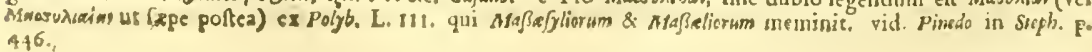




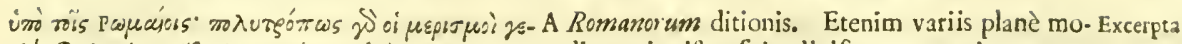

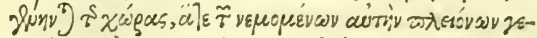

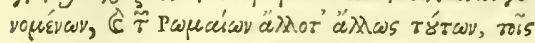

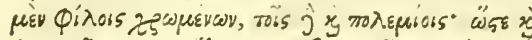

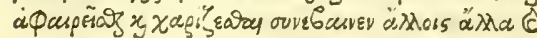

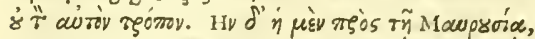

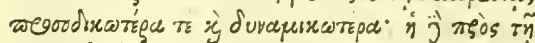

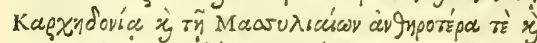

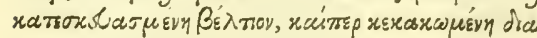

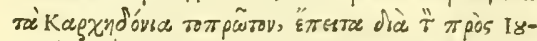

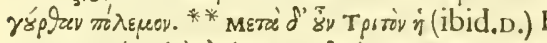

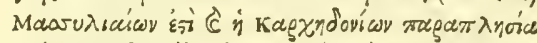

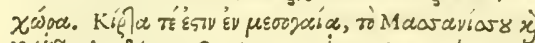

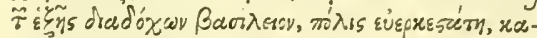

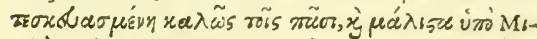

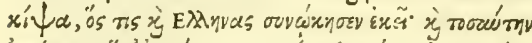

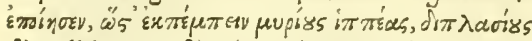

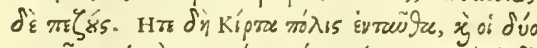

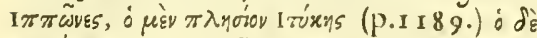

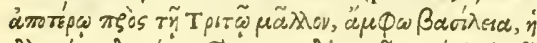

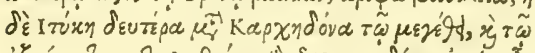

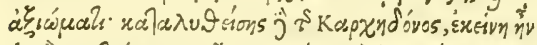

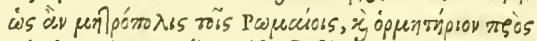

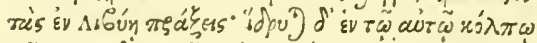
$\tau \tilde{\omega} \mathrm{K} \alpha \rho x \eta \delta$ ov

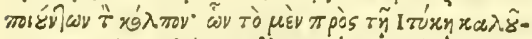

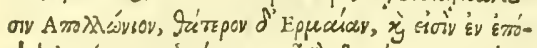

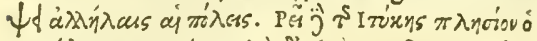

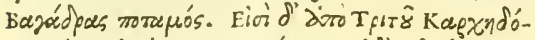
vos súdros digín

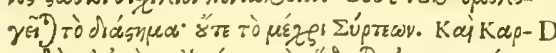

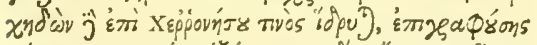

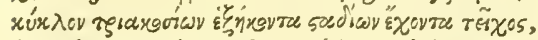

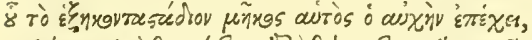

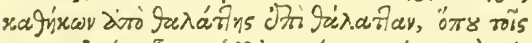

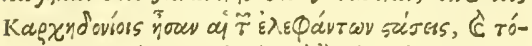

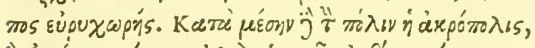

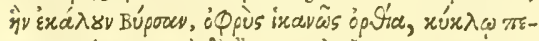

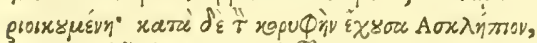

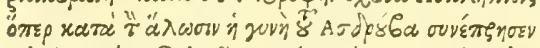

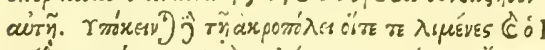

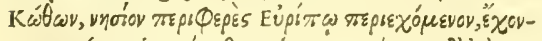

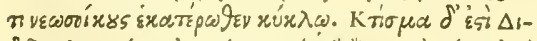

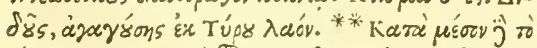

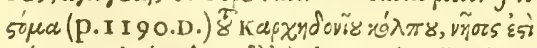

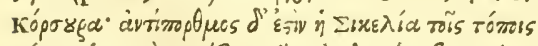

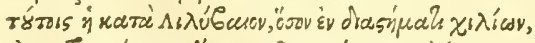

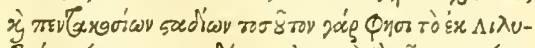

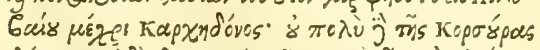

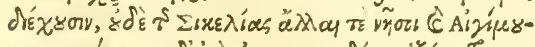

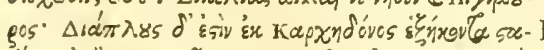

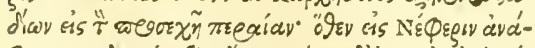

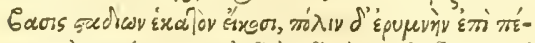

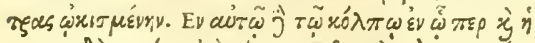

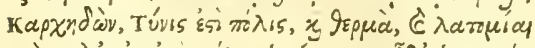

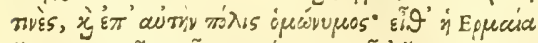

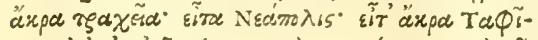
dis rcgio ilta fuit divifa, cum qui eam te- ex micis, alii hoftibus diverfo tempore uterentur, ideoque \& darent \& auferrent aliis alia. Regio lane Mauritanie proxima, vires ac proventus majores habebat: qux vero Cartbaginem \& Ma/fylecorum (vel MaJjylorum) terram contigit, florentior eft, \& melius apparata, quanquam primo Cartbagmien $/ 2$ bello adflicta, ac deinde bello contra. Fugurtbam gefto. Poft Tritum elt Ma/fylecorum \& Carthaginenjium regio. Cirta MafinifJe, \& Succeffotum regia eft in mediterraneis, urbs munitiflima, \& optime omnibus rebus inftucta, maxime a $\mathrm{Mi}$ cipja, qui \& Grecos in eam habitatum deduxit: \& tantam cffecit, ut decem equitum millia, peditum $\mathrm{xx}$ emitteret. Cirta itaque hîc eft, \& duo Hippones, alter Utica proximus, alter remotior, \& Trito propinquior, ambx regix. Utica \& magnitudine, \& dignitate fecunda eft poft Caribaginem : atque hac excifa caput regionis fuit, \& receptaculum Romanorutn ad res in Africa gerendas. In eodem fina fita eft, in quo Carthago, ad alterum ex promontoriis qux finum faciunt: horum id quod juxta Uticam eft, Apollonitum vocatur, alterum vero Hermaa. Urbes ipfæ ita funt fitæ, ut unam poffis ex altera cernere. Prope Uticam Bagrada amnis labitur. A Trito Cartbaginem funt ftadia bis mille \& quingenta: quanquam neque de hoc intervallo, neque de eo quod ad Syrtes eft, confentitur. Cartbago in peninfula quadam jacet, qux am. bitum habet ftadiorum CCCLx, muro cinctum, cujus fexaginta ftadiorum longitudinem collum occupat, quod à mari in mare pertinet, ubi Cartbaginenfium elephantes ftabula habebant, \& locus ampliffimus eft. In media urbe Arx fuit, quam Byrjam vocarunt (boc eft tergus) lupercilium latis erectum, circumcirca habitatum, in cujus vertice $E$ fculapii templum erat, quod Afdrubalis uxor captí urbe fecum concremavic. Arci portus lubjacent, \& Cotbon, parva infula, ac rotunda, Euripo circumdata, ad cujus utramque partem funt in orbem navalia. Eam urbem Dido condidit, Tyro colonis co adductis profecta. In medio oftio Cartbaginenfis finus infula eft Co/fura. His locis d regione opponitur Lilybaum Sicilia CIDIo fere ft:Idiorum intervallo; tanta eft enim inter Lilybaum \& Cartbaginem intercapedo. Non procul a Colfura \& Sicilia diftant, cum alix complures infulx, tum etiam Aegimurus. Navigatio autem LX ftadiorum eft Cartbagine in proximam oppofitam continentem, inde ad Nepberin adfcenfus eft ftadiorum cxx: urbem naturá munitam, \& fuper petra quadam xdificatam. In finu Carthaginien $/ t$ eft $T$ unis civitas, \& Agrice calide, \& Lapicidine quxdam, dcinde Hermea promontorium afperum: ac pone Urbs cognominis: $\operatorname{mox} \Lambda^{\top} e a-$ polis: inde Tapbitis promontorium, \& in eo collis quidam Afpis nomine, a fimilitudine fcuti appellatus, quem Agathocles Sicitia tyran-

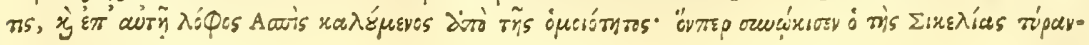


Excerpta nus condidit, quo tempore adverfus Cartha-A ex ginierifes claffem duxit. Hæ urbes a Romanis strabone. una cum Cat thagine funt everfx. Stadiis quadringentis a T Tapbitide eft Co/fura infula, con. tra Selinustem Sicilice fluvium potita, ambitum habens cL ftadiorum, \& Urbem eodem nomine: diftat à Sicilia ad fexcenta circiter ftadia. Melite etiam infula abeft à Coffura ftadiis quingentis: deinde eft Adrume civitas, in qua etiam erant navalia. Sequuntur infu. læ mult $x, \&$ inter fe vicinæ omnes nomine Taricbic; hinc urbs Thapsas, ( $\dot{\sigma}$ proximus ei lacus) poltquam infula eft in pelago $\mathrm{LO}$ padufa. Sequirur Ammonis promontorium ad fpeculandum thynnos; poftea Thana urbs circa parvæ Syrtis initium. Alia quoque oppidula pernulta interjacent non digna memoratu. In principio Syrtis infula quxdam eft oblonga, nominc Cercinna, juftx magnitudinis, qua Urbem halet eodem nomine. Iten altera minor, Cercinnitis. His continua eft minor Sytzs quam Lotophagitim Syrtion etiam dicunt. Hujus finus ambitus eft fere crэrวc. Oris latitudo 10c. Juxta utrumque promontorium, quæ os efficiunt, infulx adjacent continenti, Cucinna fcilicet, de qua diximus, $\&$ Mentnx, magnitudine xquales. Nentngem Lotophagorum terram putant, cujus Homerus meminit: \& figna quxdatn extaut, \& Uly Jjis Ara, \& Fructus ipfe. Nam Lotus arbor crebra in eà eft, fructu fuaviffmo; plura etiam in ea oppida funt, fed unum eodem nomine quo infula. Quin \& in ipfa Syrti oppidula plurima funt. In rcceffu ipfo eft ingens Emporium, quod flumen allabitur, in finum exiens. Maris autem $x$ ftus hucufquc pertendunt : quorum tempore funitimi maximo fudio ad captandos pifces cxcurrunt. Poftea eft promontorium alium \& fylrofum, magnx Syrtis initium, quod (epbalas (id eft capita) vocant. A Cartbagine ad hoc promontorium funt paulo plura CIJ CIว CIว CIว CIJ ftadia. Imminet autem orx a Carthagine ufque $C e-$ phalas \& Ma/felylios Libophonicum terra, ufque ad Getulice montana, qux jam Africa eft. Supra Gotuliarn eft Garamantum regio, qux cum illa xqualibus fpatiis porrigitur, unde Carcbedonii lapilli afferuntur. Dicunt Garamantas ab Eibiopibus, \& Oceani vicinis abeffe $I x$, aut $x$ dierum itinere, ab Ammone xv. Inter Getuliam \& noftram oram multi cam. pi interjacent, \& multi montes, \& magni lacus, \& flumina, quorum quædam in terra demerfa evanefcunt. Hi $\&$ in victu, \& ornatu frugales funt, uxores multas, \& multos filios habent, cætera Arabun Nomadibus perfimiles. Eorum equi \& boves ungulas aliis longiores habent. Reges plurimum equis ftudent, itaque ad centena pullorum millia quotannis accurata inquifitione facta recenfentur.

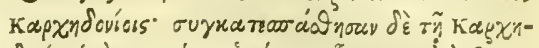

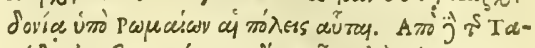

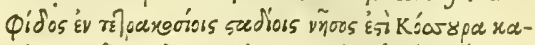

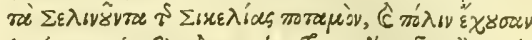

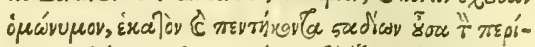

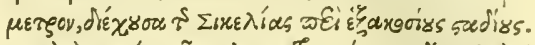

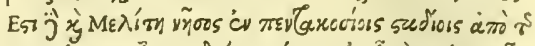

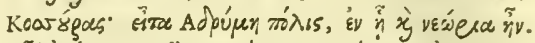

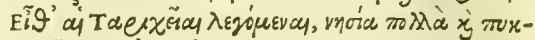

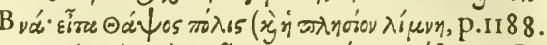
C.) $\dot{y}^{\prime} \mu_{r}^{\text {th }}$ тwi

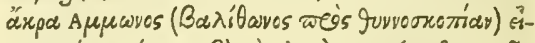

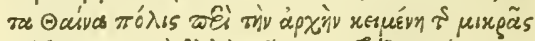

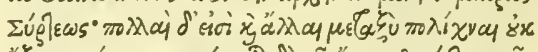

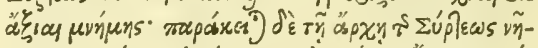

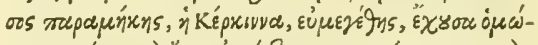

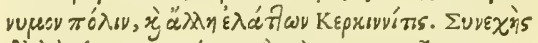

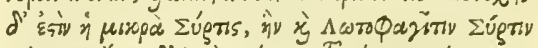

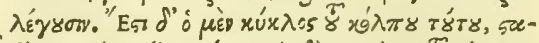

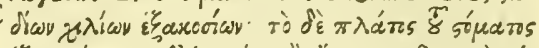

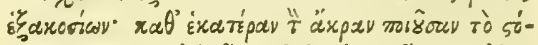

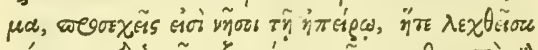

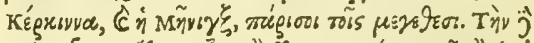

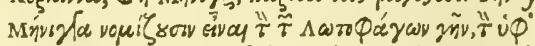

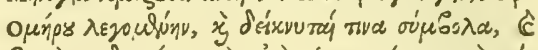

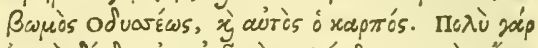

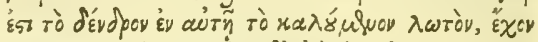

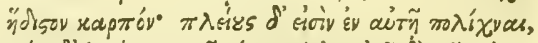

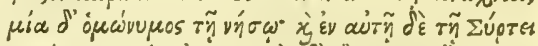

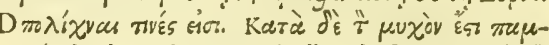

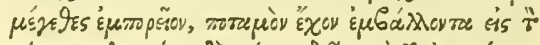

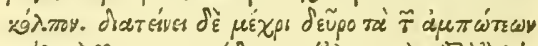

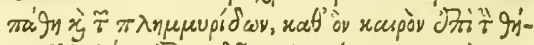

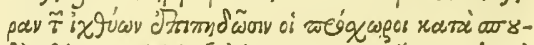

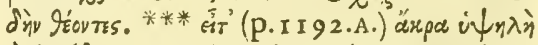

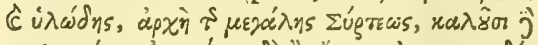

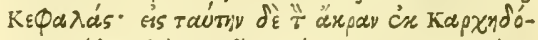

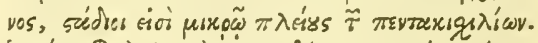

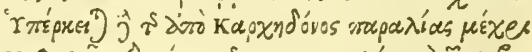

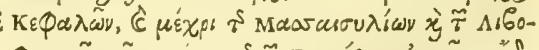

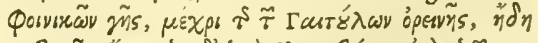

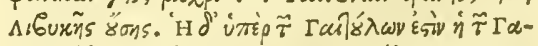

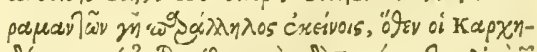

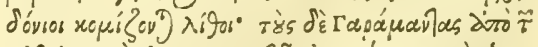

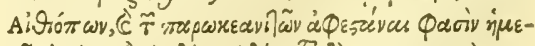

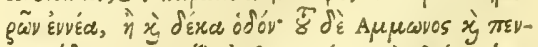

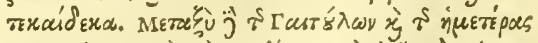

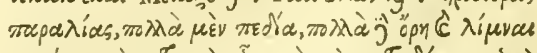

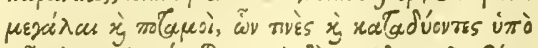

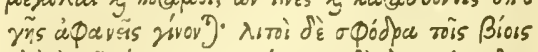

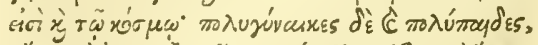

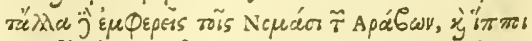

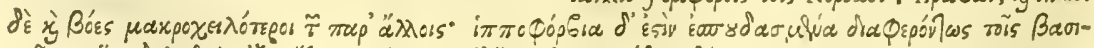

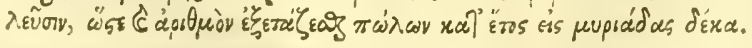

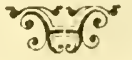




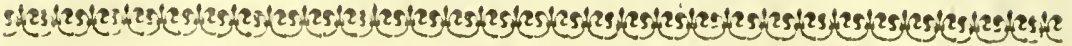

\section{Excerpta ex Ptolemeo.}

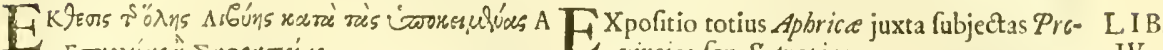

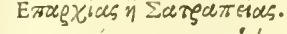

Masestavian Trqaravkú.

* Mawertavial Karraplevoíav.

* Nrundiar.

* AQexrlé.

rupluaixlé.

Mappesesilé.

* Tlic idius nibulew.

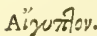

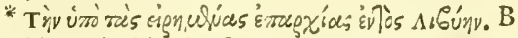
Thi ivo thi A"zotiov AiStotiav.

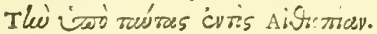

- vincias feu Satrapias.

Mauritaniam Tingitanam.

Mauritaniam Cecjarienfem.

Nurnidiarn.

Aphricam.

Cyrenaicain.

\section{Marmaricam.}

Eam quæ proprie nuncupatur Libya.

Agyptum.

Libyasn Interiorem fub præfatis Provinciis. Atbiopian qux fub Agrpto eft. Atbiopiam Interiorem fub iftis.
IV.

$$
* * * * * * * * * * *
$$

\section{MAURITANIE C $\mathbb{E}$ SARIENSIS SITUS.}

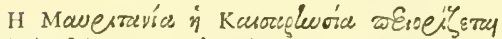

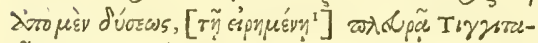
iñs Mawerrayias.

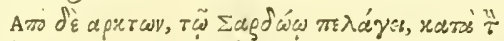

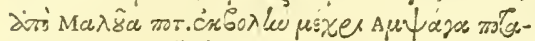

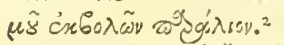

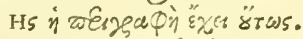

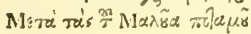

$$
\text { éxbonás } 3
$$

Mízea àkforifor

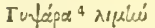

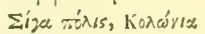

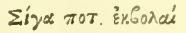

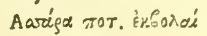

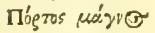

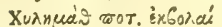

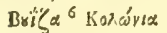

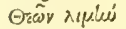

Aprovaéa Kox ávia

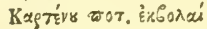

Kap Tह่vVos.

Kарй $\pi<\lambda \alpha$

Kарка́й

$\Lambda a ́ z$ vio"

A

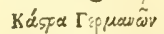

Karyexis

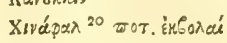

İंA Kaurípets

Tímada

Oüik

Manritania qux Cefarien/is dicitur, definitur C A P. ab Occafu [præfato] Tingitanica Mauritanice II. latere.

A Septentrionibus vero Sardoo pelago juxta Gralve fluv. oftia ufque ad Amplage fluvii oltia.

C

Ejus circumferiptio fic fe habet.

5 Pof Malvæ fuv. ofia

Ls Gypfaria Portus

ro Siga Civitas Colonia

sy Sigx fuvii oftia

\& Aftaræfloflia

\& Portus Magnus

Chilemath fuv.oftia

Quiza Colonia

${ }^{7} \psi$ Deorum Portus

Ly D Arfenaria Colonia

ro Cartenni flu. oftia

yo Cartennæ

$\gamma$ Carepula

${ }^{12} \gamma$ Carcome

${ }^{15} \gamma$ Lagnutum

${ }^{17} \mathrm{~s}$ A pollinis Promont.

${ }^{19} \mathrm{~s}$ Caltra Germanorum

$19^{3} 5$ Canuccis

${ }^{22} s$ Chinalaph flu. oftia

$\gamma$ E Iol Crefarea

${ }^{24} y$ Tipafa $\begin{array}{lllr}\text { II } & \text { IO. } 34 & \text { IO } \\ \text { II } & 30 . & 35 & 0\end{array}$

II $50.3+45$

I2 00. 3440

I 2 I 3440

1230,3430

I $45 \cdot 3430$

I 300.3400

1320.3400

I 330.3345

1350.3350

1415.3340

1450.3340

1430.3340

Is 10. 3330

1530.3320

I5 30. 3340

Is 50. 33 I0

I6 Io. 33 IO

I 640.3320

I7 00. 3320

$1730.33 \quad 30$

1740.3300

I Viz. juxta Meridianum qui à Malve fl. oftiis eft, cujus politio habet II 30.34 I0, ufque ad finem, cujus pofitio habet il 40.26 is. Cap.1. 2 In MISS. trapariav. 3 Vid.Cap.r. ut fupra. 4 In cod.Pal. \& omnibus

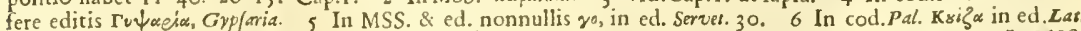

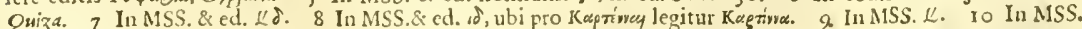

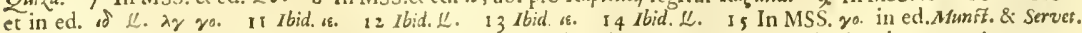

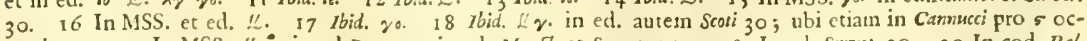
currit 30. 19 In MSS. Li.: in ed.Rom. 25 . in ed, Ahunst. et Serves. 35. I $9^{\mathrm{a}}$. In ed. Servot. 30.20 In cod. Pal.

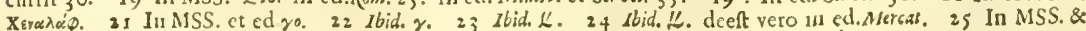
ed. go. 265 ibid, deeft. 


\begin{tabular}{|c|c|c|c|c|c|c|c|c|c|c|}
\hline \multirow{3}{*}{$\begin{array}{c}\text { Excerpta } \\
\text { ex } \\
\text { Ptolemso. }\end{array}$} & \multirow{2}{*}{$\begin{array}{l}\text { Icofium } \\
\text { Saviflu. ofia }\end{array}$} & \multirow{2}{*}{\multicolumn{2}{|c|}{$\begin{array}{ll}18 & 00 . \\
18 & 10 .\end{array}$}} & \multicolumn{3}{|c|}{33 oo A I rónor } & \multicolumn{2}{|l|}{ in } & \multicolumn{2}{|l|}{$\lambda y$} \\
\hline & & & & 33 & 20 & 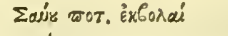 & in & 5. & $\lambda y$ & 1 \\
\hline & Ruftonium & 18 & 30. & 32 & 45 & Prśivioy & 2 in & s. & $\lambda \gamma$ & \\
\hline & Ruficibar & I 8 & 45. & 32 & 50 & Prórisap & in & ${ }^{3} \delta$. & $\lambda 6$ & $\delta$ \\
\hline & Modunga & 19 & ro. & $3^{2}$ & 25 & Mof́zyex & $i v$ & ${ }^{4}$ s. & $\lambda 6$ & $4^{2} \gamma^{16}$ \\
\hline & Serbetis flu. oftia & 19 & 30. & $3^{2}$ & so & 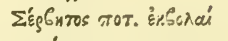 & $\sqrt{3}$ & ss. & $\lambda 6$ & 5 \\
\hline & Ciffe & 19 & 45. & 32 & 50 & Kıӑ்́ & is & «S. & $\lambda 6$ & ${ }^{6} 5$ \\
\hline & Addume & 20 & อ. & 32 & 50 & $A \delta \Omega^{\prime} \mu n$ & $x$ & & $\lambda 6$ & $7 \mathrm{~s}$ \\
\hline & Rufuccorx & 20 & 15. & $3^{2}$ & 45 & Pвовкхо́раs & $x$ & $\delta$. & $\lambda 6$ & $8 \delta$ \\
\hline & Iomnium & 20 & 30. & 32 & 45 & Iópuviov & $9 \times 5$ & & 2.6 & $\delta$ \\
\hline & Rufubefer & 20 & Is. & 32 & $40 \mathrm{I}$ & 3 РчгъСитір & $10 \times 5$ & & $\lambda 6$ & $" \gamma$ \\
\hline & Ruzafus & $2 I$ & o. & 32 & 40 & 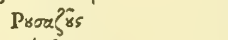 & $x \propto$ & & 26 & 22 \\
\hline & Vabar & $2 I$ & Io. & 32 & 30 & O'valap & $k x$ & 13 s. & $\lambda 6$ & $14 \gamma$ \\
\hline & Saldx Colonia & 22 & $\infty$. & 32 & 30 & 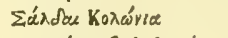 & $x .6$ & & $\lambda 6$ & 155 \\
\hline & Nafavx $f l$ oftia & 22 & Io. & 32 & 30 & 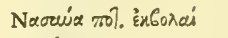 & x: & ${ }^{36} s$. & $\lambda 6$ & ${ }^{17} \mathrm{~s}$ \\
\hline & Chobat & 22 & 40. & 32 & 20 & X $\omega_{0}^{f} a ́ t \tau$ & $x_{0}^{e}$ & ${ }^{18} \gamma$. & $\lambda_{0}^{e}$ & $\gamma$ \\
\hline & Sifaris fu. oftia & 23 & o. & 32 & Is & 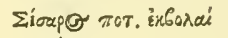 & $x y$ & & $\lambda 6$ & $\delta$ \\
\hline & Iarfach & 23 & 20. & 32 & 5 & Iaporis & $r y$ & $\gamma$. & $\lambda \epsilon$ & 16 \\
\hline & Audi Promont. & 23 & 20. & 32 & 20 & Aĩ்ou áryou & $x y$ & ${ }^{19} \mathrm{\gamma}$. & $\lambda 6$ & ${ }^{20} \mathrm{\gamma}$ \\
\hline & Et in NUMIDICO SINU & & & & & Ka' है NorMH & $\mathrm{K} \Omega \mathrm{K}$ & $\Lambda \Pi \Omega$. & & \\
\hline & Audi fl. oflia & 23 & 50. & 32 & $\infty<$ & 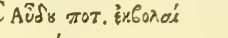 & $x . \gamma$ & ${ }^{21} s$. & $\lambda \theta^{*}$ & \\
\hline & Jgilgili & 24 & oo. & 32 & ০০ & Irinzingt & $x \delta$ & & $22 \times 6$ & \\
\hline & Guli fu. oftia & 24 & 20. & $3 \mathbf{I}$ & 50 & 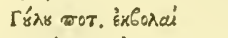 & nf & ${ }^{23} \gamma$ & $\lambda \alpha$ & $23^{3} 5$ \\
\hline & AGfarath & 25 & IO. & 3 I & 45 & Anrapas 23 b & $24 x i$ & & $\lambda \alpha$ & $\delta$ \\
\hline & Amplagx flu. oftia & 26 & 15. & $3 I$ & 45 & 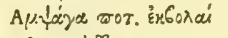 & ${ }^{25} \times 5$ & & $\lambda \alpha$ & $\delta$ \\
\hline & Ejufdem fontes & 26 & oo. & 26 & O० & Ai тираi $\frac{\pi}{7}$ тот. & $26 \times 5$ & & $x=5$ & \\
\hline
\end{tabular}

Ab oricnte verd clauditur Apbrica juxta Amplagam $\mathrm{Al}$. ufque ad finem, cujus gradus funt

2750.2600

A Meridie autem Libycis tcrminatur gentibus juxta lineam qux fupra Getuliam auftrales $D$ terminos jungit.

In Provincia vero montes infigniores hi funt,

Durdus mons, cujus orientalis pars continet partes

Occidentalis autem pars Io 00.2930

Zalacus mons

Garaphi mons

I6 00.3140

Malethubalus mons, cujus fines

habent

\&

I6 00. 2840

Cinnaba mons

Herun mons

Phruræfus mons, cujus fines

gradus habent

\&

Garas mons

Valva mons

Buzar.e montis occidua, quorum

fitus

8

$\begin{array}{llll}13 & 00 . & 26 & 40 \\ 17 & 30 . & 26 & 20 \mathrm{E} \\ 16 & 10 . & 26 & 30 \\ 20 & 30 . & 31 & 00\end{array}$

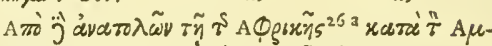

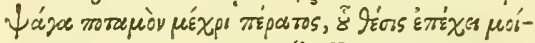
pas

$x_{\zeta}^{\prime} \quad{ }^{27} \ll \gamma . \quad$ x.

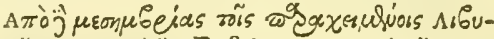

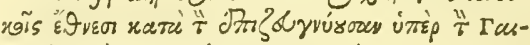

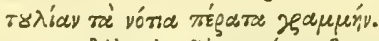

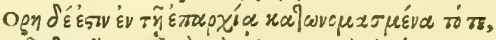

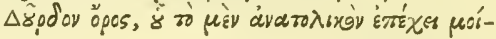
pas

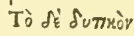

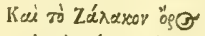

Kai тxi Гápape opon

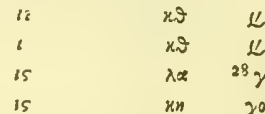

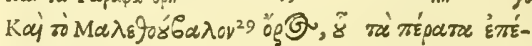

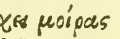

y.

Kai Kervába oeg

Kai .ro Hew 34 oegs

$30 \mathrm{dr}$

16 $35 \quad \gamma$

jo. 3100

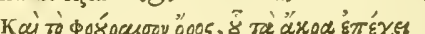

18 30. 2840 roípas in ${ }_{36}$

$2 \mathrm{I} 00.2630 \mathrm{Ka}$

2300.2800

2200.2600

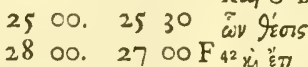

Kai ó rápas öess

$x \times c$
$39 \times 6$

${ }^{40} \mathrm{xy}$

2.. ${ }^{32} x 5$

xs

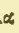

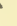

2

25

75

$\delta$

$\gamma$

$\gamma$

${ }^{\prime} s$

(n)

16

\section{5}

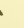
(1)

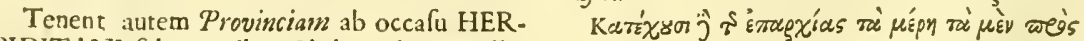

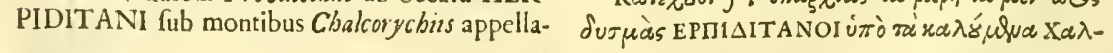

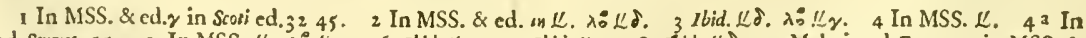

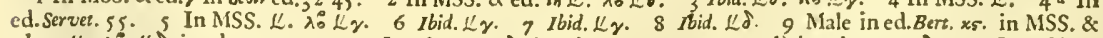

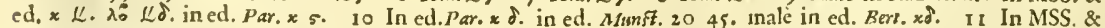
ed. yo. 12 Ibid. yo. 13 In MSS. \& ed. Scoli, \& Servet. 30. in ed. Munft. 20.14 In MSS. \& ed.L. 15 Ibid. L. 16 In MSS. $\gamma$ in ed. Servet. 30. 17 In MSS. \& ed. $\angle .18 \mathrm{Ibid}$. ${ }^{\circ} .19$ In ed. Servet. 40.20 In MSS. deeft $\gamma$. in ed. Servet. 15. 21 In MSS. \& ed. $K_{\gamma} .22 \mathrm{Ibid}$. $\lambda \alpha \mathrm{K} \delta$. in ed. Scoti 3200.23 In ed. Servet. $40.23^{3}$ In

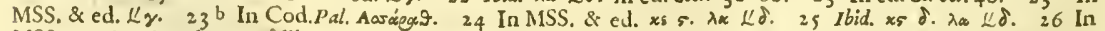
MSS. $x_{5} \mathrm{~K}_{\gamma}$. in ed. nonnullis 26 30. in ed. Servet. 2650.3135 .26 . In Cod. Pal. $\tau \tilde{y}$ A $\varphi_{p} 6 \tilde{y}$. 27 In MSS.

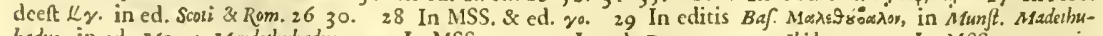
badus, in ed. Mercal. Mardeshubadus. 30 In MSS, $x y$. 31 In ed. Rom. 29.32 Ibid 29.33 In MSS. as. $x 5$. in ed. Servel. 19 30. 26 o0. 34 In ed. Servel, \& Mfunf, Byren. 35 Male in ed. Bert, $x 5$. in MSS. \& ed. $x$ L. 36 In

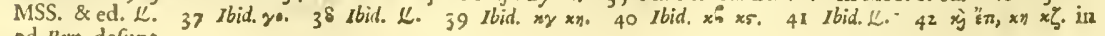
ed.Bert. defunt. 


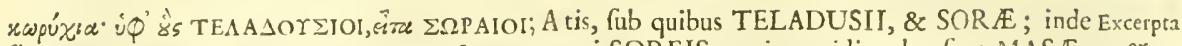

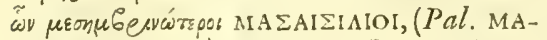

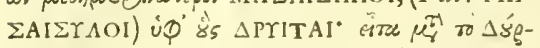

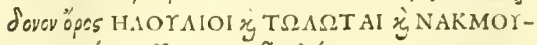

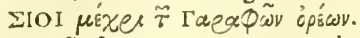

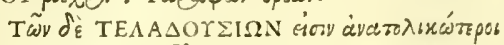

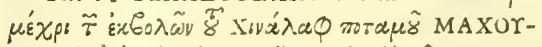
sIOI, ¿Q⿱

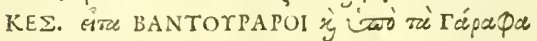

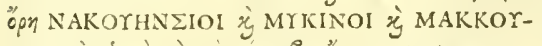

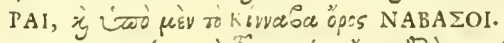

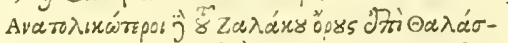

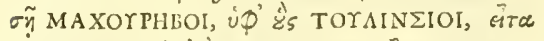

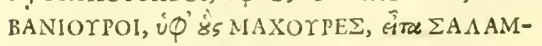
$\Psi$ IOI yे MAAXOYBIOI.

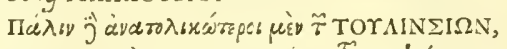

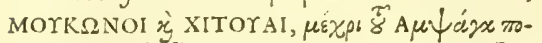

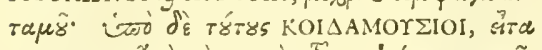

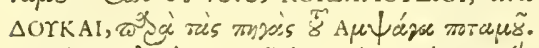
$\delta \varepsilon$,

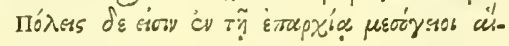

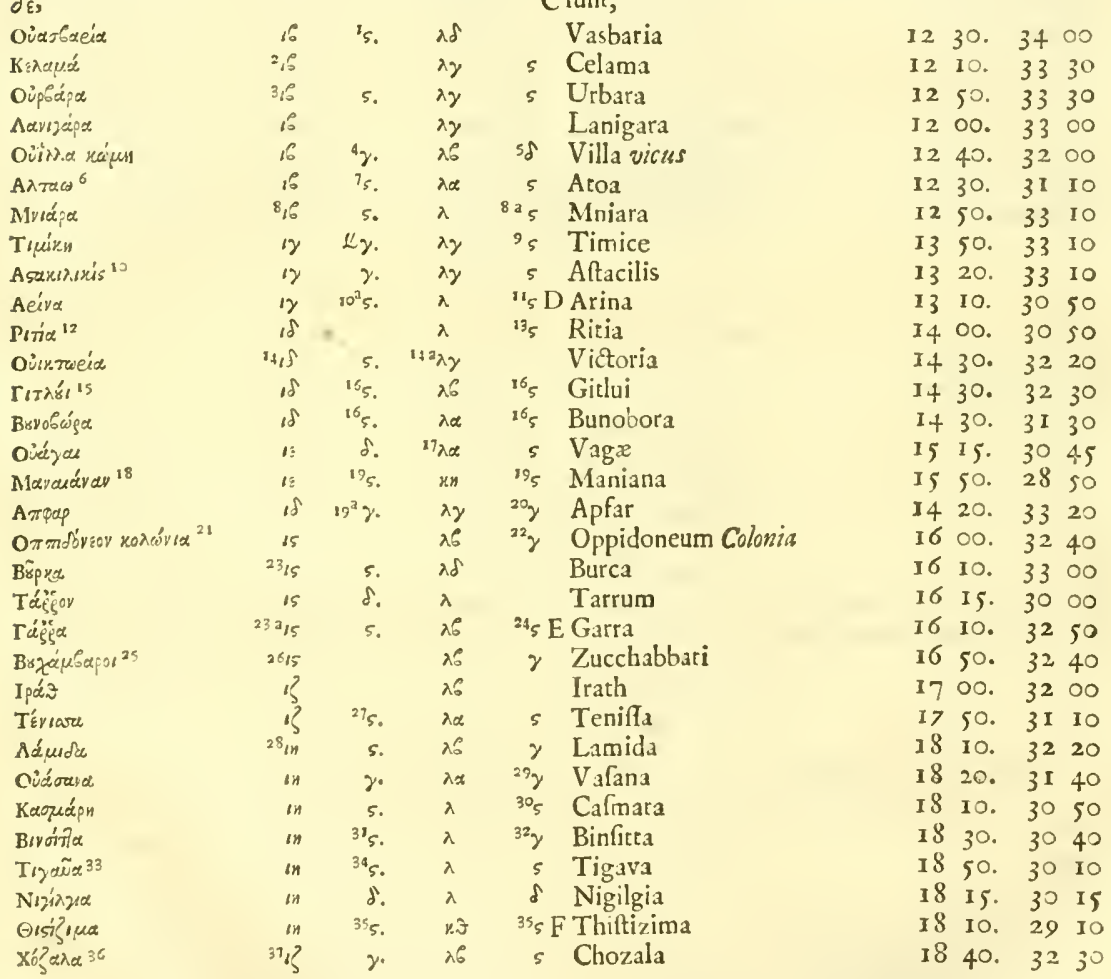
qui SOREIS magis meridionales func MASE- ex duin montem ELULII \& TOLOT $\mathbb{A}$ ac NACMUISII ufque ad montes Garaphos.

TELADUSIIS antem magis orientales funt, ufque ad oftia Chimalaph flu. MACHUSII ; fub quibus Zalacus mons. Et poft hune, MAZICES, poftea BANTURARI; et fub Garaphis montibus NACUENSII \& MYCENI \& MACCURE \& fuper monte Cinnaba NABASI.

Magis vero orientales quam Zalacus mons fupra mare funt MACHUREBI, liub quibus TULINSII, poft BANIURI, fub quibus MACHURES, poft SALAMPSII \& MALCHUBII.

Iterumque magis orientales TULIN SIIS funt MUCONI \& CHITUÆ ufque ad Aimplagam fluvium. Sub his autem COEDAMUSII, poft DUCE juxta fontes Amplage fluvii.

Civitates autem in Regione mediterraneà hx C funt,

Celama

Urbara

Lanigara

$\delta$ Villa vicus

5 Mniar

5 Timice

5 Aftacilis

D Arina

Ritia

G Gitui

s Bunobora

s Maniana

$\gamma$ Apfar

Oppidoneum Colonia

Burca

Tarrum

$s$ E Garra

Zucchabbari

Tenifta

Lamida

$\gamma$ Vafana

$0_{5}$ Cafmara

$\gamma$ Binfitta

5 Tigava

ss F Thittizima

1840.3230

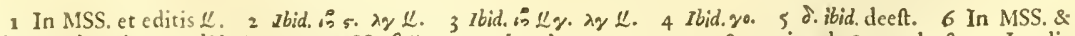
ed. (Aioa) Arár. 7 Ibid. $L$. $\delta$ In MSS. in $\mathcal{L}_{y} \lambda \gamma 5$. in ed. 1250.3300 .8 a 10 in ed. Servet. deeft. 9 In editis nonnullis 30 , in aliis 50 . Io In ed. nonnullis Astacilis. 1o a In ed. Servet. 30 . II In MSS. et ed. Kr. I2 In cod.Pal.\& aliis (Aripa) Aesra. is In MSS. et ed. $\mathcal{r}$. I4 In MSS. if $\mathcal{L} . \lambda \gamma$, in ed. 1430.3220. I 4 a In ed. Server. 3220 . 15 In ed. nonnullis Giglue. 16 In MSS.et ed. L. $171 b i d . \lambda \ll \delta .13$ In ed. Mavaiára. 19 In MSS. et ed. pros adeft $\Perp \gamma .19$ a In ed. Serves. 40.20 In MSS. $\gamma \delta$. 21 In editis nonnullis $0 p-$ pidum nornm Colonia. 22 In MSS. et editis yo. 23 In MSS. $45 \not \gamma . \lambda\llcorner\delta$. in edit. nonnullis 1650.3050 in ed. Scosi pro $\angle \delta$ adeft is \& in ed.Rom. $45.23^{3}$ In edit. Server. 15.24 In MSS. et edit. $\angle \gamma$. 25 In cod. Palo et aliis

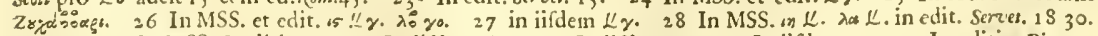
31 20. 29 In MSS. \& editis $\%$. 30 In iifdem $\angle y .3$ I In iffdem $\underline{\not L} .32$ In iifdem yo. 33 In editis, Pigava.

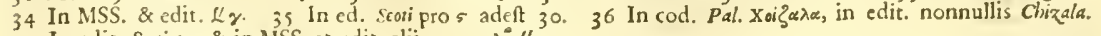
37 In edit. Scoti 17 , \& in MSS. et edit. aliis $n \% 0 . \lambda^{\circ} L^{2}$. 
Excerpera Aqux calidx Colonia

ex Phloryia

Psotemeo. Oppidium

Laudia

Tucca

Badel

Gafnara

Bida Colcnia

Symitha

'Thibinis

Jzatha

Auximis

Er juxta Phoemii fluvii fontes, qui amni Savo admifcetur,

21 00. $28 \quad 20$

18 00. 32 ro A Tdata Trpuá"

I9 20. 3 I 40 Inaguï:

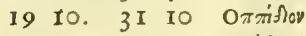

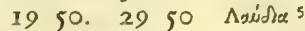

2000.3 I 45 Báften?

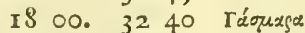

1830.32 Io Bídec roxićrice

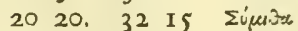

21 00. 3 I IO Gityis

$2 I 00$. $3020 \mathrm{BI}$ 'as ise

21 00. 2930 Aǚtuis

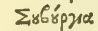

Subulgia

2000.3130 T'́rke

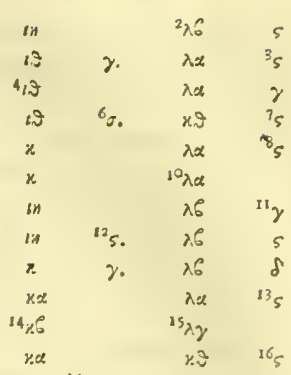

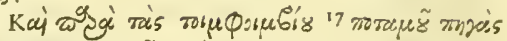

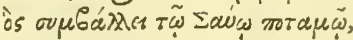

Poltea autem ab alio principio civitates hx,

Thudaca

Tigis

Turaphilum

Sudaua

Tufiagrath

Uffara

Vazıgada

Auzia

Tubufuptus

Rhobond $x$

Aufum

Zarattha

Nababurum

Vitaca

Thubuna

Thansarita

Augala

Suptu

Ippas.

Vamiceda

Siripha Colonis

Tumarr 3

Germiana

Pxpiz

Vefcether

Ægæa

Tarudz

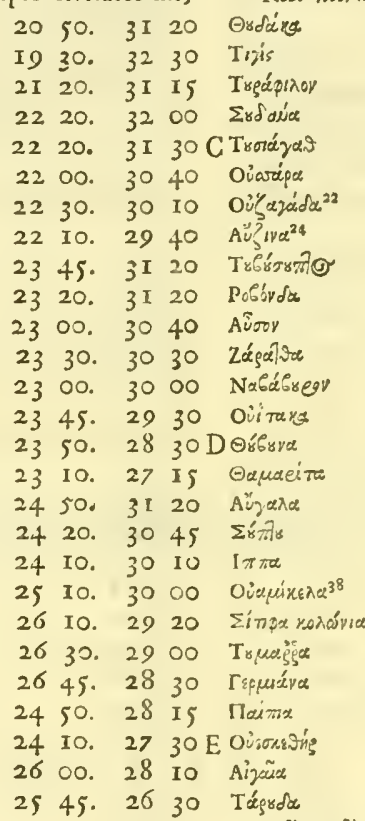

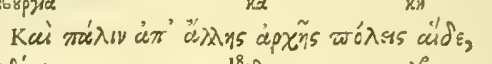

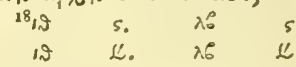

$\begin{array}{llll}x \alpha & \gamma & \gamma \alpha & 195\end{array}$

ne $\gamma . \quad \lambda \epsilon$

$x 6 \quad \gamma \cdot \lambda \alpha \quad{ }^{20}{ }_{5}$

$x 6 \quad \lambda \quad 2 I_{y}$

$x_{6}{ }^{23} 5 . \lambda$ s

$x 6$ s. $x=25 y$

26.6 \&. $\lambda \mu \quad \gamma$

$\begin{array}{llll}x y & \gamma & \lambda x & \gamma\end{array}$

${ }^{28} x y$ s. $\lambda$ s

$\begin{array}{llll}x . y & & \lambda & \\ i . \gamma & 29 \delta . & x .9 & 3^{\circ} 5\end{array}$

$x y \quad{ }^{31} s, \quad x n \quad 32 s$

$x y$ s. $x_{3}^{\prime \prime} \delta$

$25{ }^{33} y . \quad \lambda \alpha \quad \gamma$

x. ${ }^{34} 5 . \quad \lambda \quad 35 \delta$

$\begin{array}{llll}x .5 & 345 . & \lambda & 95 \\ x \delta & 36 & \lambda & 375\end{array}$

$39 \times 6$

$40 \%$ 5. $\frac{1}{4} \quad 41^{2}$

$x 542$.

xร $43 . \quad x \%$

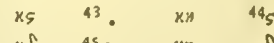

$x \delta \quad 4 s^{2} s_{0} \quad x n \quad \delta$

$\left.{ }_{48}^{x \delta} \quad{ }^{45} 5 . \quad x\right\} \quad{ }^{47} 7^{2}$

$x \&$ 508. $x .5$ $5 i^{2}$

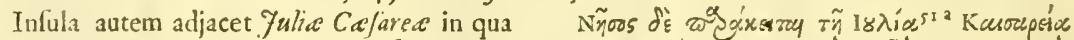
civitas eodem nomine, cujus gradus funt

I7 30.3340

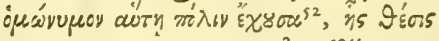

1) S3L. $\lambda \gamma \quad \gamma$

\section{A P H R I C E S I T U S.}

C A P. Apbrice latus occidentale terminatur Mau-

1II. ritania Cecfarien/i juxta expofitam lineam per Ainpjagan fluvium, cujus, ut fupra, gradus funt.

26 I5, 3145

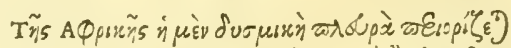

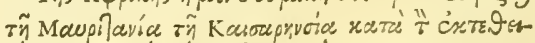

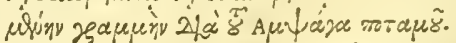

I In cod. Pal.\& aliis additur Koגánz. 2 In edit Servet. 3 I. 3 In MISS. \& editis yo. 4 In MSS. \& edit. 25. $\lambda \alpha s .5$ In edit. Alunft. \&c. Labdia. 6 o male forfan pros ut in edit. Bert. in MSS. \& editis aliis $\mathrm{L}_{\gamma} . \quad 7$ In MS.

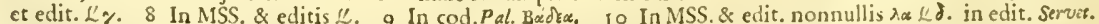
30 45. Is Ibid. \%. 12 1bid. 2 . 135 deeft in MISS. \& in edit. Servet. It In MSS. \& editis $x \alpha$. Is Male in edit. Bert $\lambda y$.junet. in MSS. \& $\epsilon d$. aliis $\lambda \gamma$. 16 Itid. L. I7 In ed. nonnallis phoemii. Tor parper deber forlan

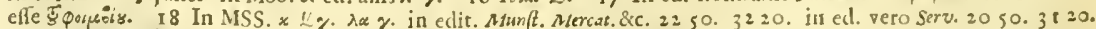

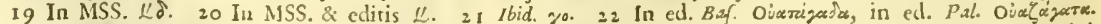
23 In MSS. \& edit. L. 24 In cod. Pal. Aǚra in aliis Aüusu vel Auxira. 25 In MSS. \& edit. yo. 26 Ibid. $x y<\delta$. in edit. Scoil pro $y$ adeft 40.27 In MISS. \& edit. nonnullis $\lambda$ yo. 28 In MSS. \& edit, $x y \not L . ~ \lambda \mathbb{L}$.

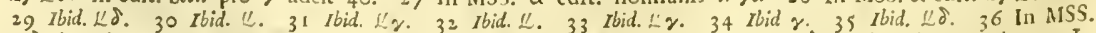

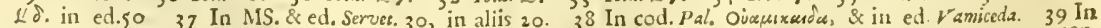
MSS. \& ed $x \varepsilon, 5.40$ Ibid. $x_{5}$. male in ed. Bert. $x$ 5. di,jundt. 41 In MSS. \& ed. $\% 42$ rbil. 4.43 In MISS, US. 44 In MSS.\&. ed. L. 45 Ibix. K\%. 46 In ed Servet. 30.47 In MSS.\&ed. L. 48 In MISS. \& ed. nonnullis

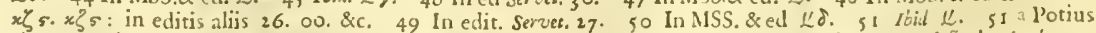

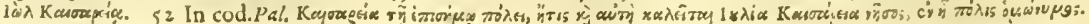
53 In MSS. . 


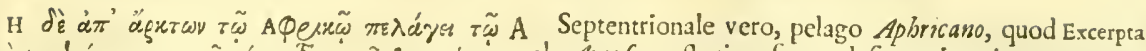

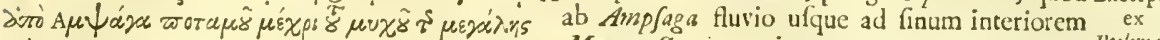
súgrews.

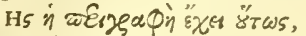

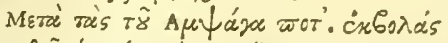

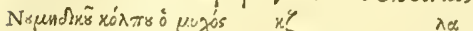
Kं́

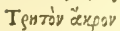

Próxidede

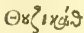

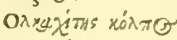

Taratu'n

Kóm

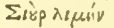

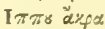

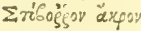

Apegdioio roxínice

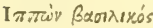

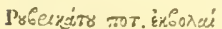

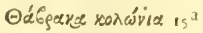

A Tirsare iréry

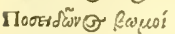

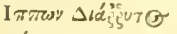

Qiviare

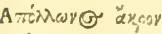

I $\pi^{\prime} x$.

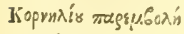

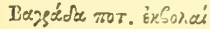

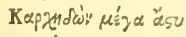

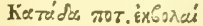

M $\alpha \tilde{\xi} \overline{\gamma \alpha}$

Kagmis

Nígree

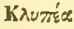

Epreã̄ex ărps

Antis

KrpoGis 32

Ní́x

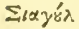

Apegdifioy

Adpó

Promives

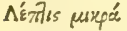

@ávos

Axerea

Procors

Bequions aैxp

Oinis.e

Tu.pgîges

G'curouts

Maxódacue

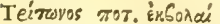
Káz $7 n^{\text {jt }}$

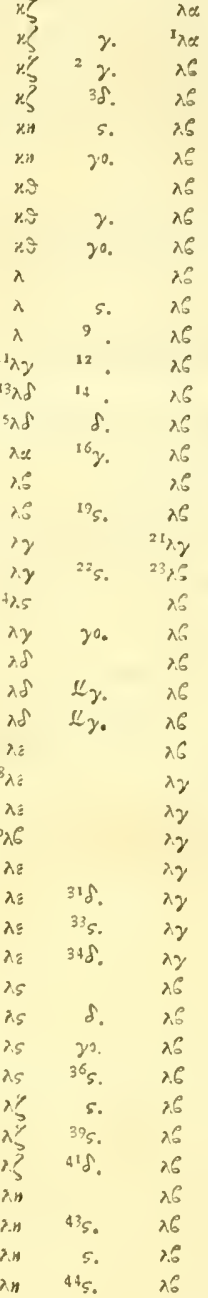

Magna Syrtis pertinet.

Cujus circumfcriptio fic fe habet,

Poft Amplagx flu. of iis

uf Numidici Sinus intima

5 Collops Magnus vel Cullu

2700.3145

es Tritum Promont.

4s Rulicada

sy Thuzicath .

${ }_{B}$ Olcachites finus

${ }_{5}^{6}$ Tacatuc

${ }_{7 y 16}$ Collops Parvus

yo Siur portas

8s Hippi Promont.

$8^{2} \gamma$ Stoborrum Promont.

${ }^{10} \mathrm{~s}$ Aphrodifium Colonia

$\delta$ Hippon-regius

of Rubricatifl.oftia

$\gamma$ Thabraca Colonia

"f C Apollinis Templum

${ }_{18} 8$ Neptuni Aræ

${ }^{20}{ }_{5}$ Hippon-irriguus Thinifla

\& Apollinis Promont.

Iryce

\& Cornelii caftrametatio

${ }^{25}, 0$ Bagradx flu. oflia

${ }_{26} y_{0}$ Carthago Urbs magna

${ }_{275}$ Caradx flu.oftia

goD Mazula

Carpis

${ }_{298} \mathrm{Nifua}$

y Clypea

Wis Mercurii Pronont.

$\gamma$ Afpis

5 Curobis

${ }^{3}$ sy Neapolis Colonia

"z Siagul

ro Aphrodifium

ro E Adrumettus Colonis

37y Rufpina

${ }^{38} 5$ Leptis parva

${ }^{40} \gamma$ Thapfus

${ }^{42} \gamma$ Achola

$\gamma$ Rufpæ

$\gamma$ Brachodes Promont.

s Ufilla

Taphrura

2745.3245

2740.3210

28 IO. 3230

28 40. 3200

2900.3230

2920.3225

2940.3240

3000.3245

3010,3220

$30 \quad 20.32 \quad 30$

3000.32 Is

$3045.32 \mathrm{IS}$

$3 I$ I 5.3220

3140.3250

3200.3250

32 30. 3245

33 00. 3230

33 IO. 33 Is

3340.3245

3340.3230

34 00. 3240

34 50. 3240

$3+50.32$ I0

3500.3240

3500.3300

3500.3310

3500.3320

$3500.33 \quad 35$

3520.3320

3530.33 I0

3545.3300

3600.3250

3615.3240

3640.3240

3650.3250

37 10. 32 10

$3730.32 \quad 30$

$3745 . \quad 3220$

38 o0. 3220

38 10. 3220

38 I0. 32 10

3830.3200

S Y R T IS P A R V E S I T US.

\begin{tabular}{|c|c|c|c|}
\hline$\lambda n$ & ${ }^{46} s$. & $\lambda a$ & ${ }^{47} y$ Then $x$ \\
\hline$\lambda n$ & ${ }^{48}{ }^{8}$. & $\lambda \alpha$ & \& F Macodama \\
\hline$\lambda_{i n}$ & 20. & $42>0$ & so. Trironis $f$ l. oflia \\
\hline & ${ }^{52} s_{\text {. }}$ & $\lambda$ & Tacape \\
\hline
\end{tabular}

$\begin{array}{llll}38 & 30 . & 3 \mathbf{I} & 20\end{array}$ 38 30. 3 I IS 3840.3200 $3^{8} 50.3030$

C A P.

III.

1 In ed. Servet. 32.2 In MISS. \& ed. $\angle \delta$. 3 Ibid. yo. In edit. Afunfl. \&c. Ruficada fita cit ante Trisum Promont. 4 In ed.Server.30. 5 In MSS. \&. ed. L. 6 Ibid. L. 7 Ined.Servet.35. 8 In ed.\&MSS $\angle \delta .83$ In ed. Servet. 40.9 In ed.\&MISS. $\%$. $1016 . \psi$. I Male in ed.Bert. $\lambda y$, in alis $30.12 \mathrm{In}$ MSS. $I$. . in ed. 20.13 Male

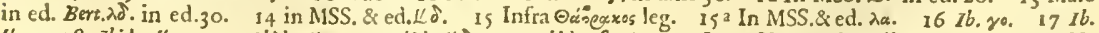

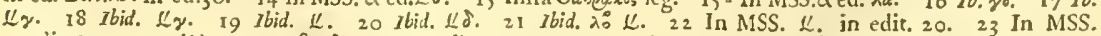
et edit. $\lambda \%$. 24 Ibid. $\lambda y$ yo. $\lambda_{n}^{\circ}\langle\delta \delta$. 25 In edit. Scrves. 20. 26 1bid. 20.27 1bid. 30.28 lbid. 33 oo. 3300. 29 In MSS. \& ed.s. 30 Male in ed.Bert. $\lambda$. . In MiSS. \& edit. $\lambda \varepsilon .317 b i d . \% .32$ In cod. Pal. Krpanoss. 33 In

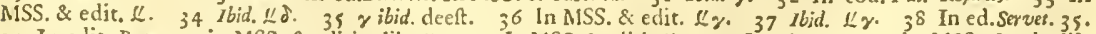
39 In edit. Rom.20; in MSS. \& editis aliis !.. 40 In NISS. \& editis $\ell .41$ In ed. Rom. 30 . in MSS. \& ed. aliis

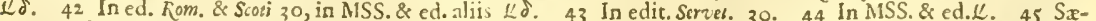
pius fcribitur Thene. 46 In MSS. \& edit. L. +7 In edit. Kom. \& Scot.40, in ed. Scrvet. deeft. 48 In MISS. \& ed. I. 49 In edit. Serves. 30.50 In MSS. \& edit. nonnullis $\ell \delta$. in edit. Rom.\& Scot. 30.51 In cod. Pal. \&c. Taxǵmm. in ed. nonnullis Tacapa vel Tracape. 52 In MSS. \& edit. Lr. 53 Ibid. L.

Orien- 
Excerpta Orientale vero latus [Apbrice] terminatur A ex poft interiorem finum Syrtis, inde linea verfus

Prolemso. meridiem ducta juxta Cyrenaicain ufque ad tinem,

cujus fitus

4700.2500

Meridionale vero latus terminatur linea qux expofitus duos fines jungit juxta Getuliam et deferta Libya.

Montes infignes in Provincia funt,

Buzara, cujus pars orientalis gradus habet

Et mons Audus

28 00. 2700

Et Thambes mons, ex quo fluit Rubricatus fluvius, cujus fines habene gradus

$$
\text { \& } 3200.2730
$$

Et mons qui dicitur Cirna

$$
3300.3000
$$
tur,

A quo paludes invicem contigux connectun-

\section{Et Hipponites palus}

Et Silara palus

3240.3230 $3300 . \quad 3100 \mathrm{C}$

Et Mamplarus mons, à quo fluit Bagradas flu. cujus fiucs continent gradus

$$
\begin{array}{lllll} 
& 33 & 00 . & 27 & 30 \\
36 & 30 . & 26 & 15
\end{array}
$$

Et yui vocatur mons Jovis

$$
37 \text { 30. } 3 \text { I } 15
$$

Et Valisletus mons, cujus fines continent gra-

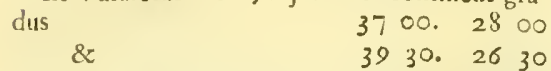

A quo fluit Triton amnis, \& in ipfo paludes, D 'Tritonis $\mathrm{fc}$.

Et Pallas palus

Et quæ vocatur Libya palus

$$
\begin{array}{llll}
3^{8} & 40 . & 29 & 40 \\
3^{8} & 30 & 29 & 15
\end{array}
$$$$
3^{8} 30.2815
$$$$
\text { * } * * *
$$

Tenent autem Occidentalia Apbrica nfque ad mare, CYRTESII \& NABATHRÆ. Polt hos, verfus folis ortum IONTII juxta Numidiam, Novamque Provinciain, ufque Thabra. cern. Poft METHENI, \& qui juxta Cartbaginem funt. Sub quibus LIBYI-PHOENICES. Poft, ufque Parvam Srtim, MACHY. NI, \& fib ipfis CINETHII; \& qui magis ad ortum vergunt ufque ad Cyniphum fl. NIGINTIMI; \& circa fluvium ipfum, LOTOPHAGI.

$$
\text { * } * * * * * * *
$$

Iterum autem CIRTESIIS, \& Numidia auftraliores, fub Audo monte, funt MISULAMI ; fub quibus NASABUTES; poft NISIBES. MISULAMIS autem anfiraliores funt MIADII; fub quibus MUSUNI; pottea, fub Thambe monte, SABUBURES; fub quibus HALIARDII \& SITAPHIUS campus.

A meridionali autem parte LIBOPHOENICUM eft Bazacitis regio, fub qua OZUTI;

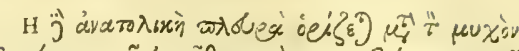

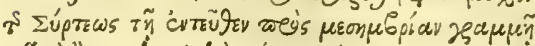

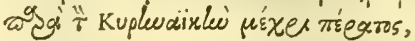

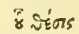

$\mu ?$

\author{
หน
}

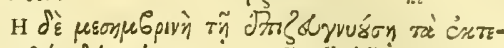

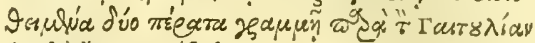

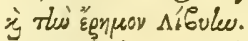

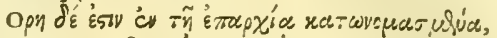

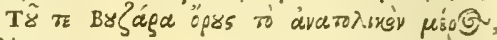
ชे भí⿴囗十

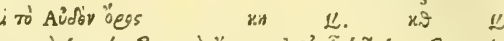

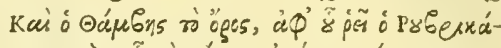

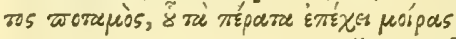

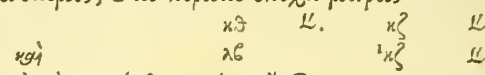

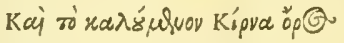

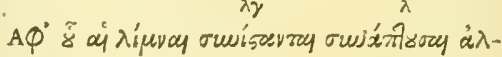
$\lambda \dot{\lambda} \lambda$ cess,

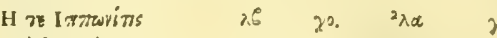
Kai í Eirapa $\lambda y \quad \lambda$

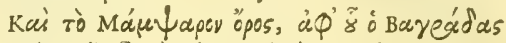

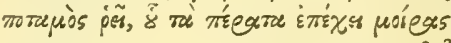

$\lambda y$ is ${ }_{3 x} x$ "s

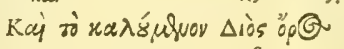
$\lambda$, L. $\lambda x \quad \delta$

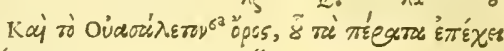
príeas

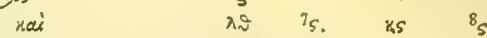

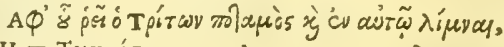

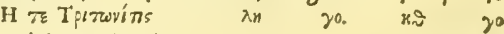

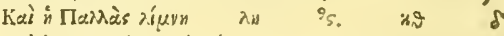

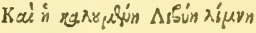

$* * * *$

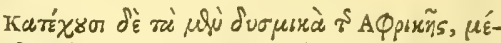

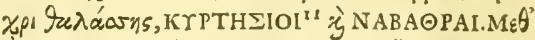

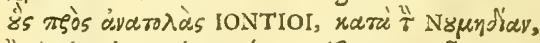

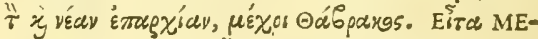

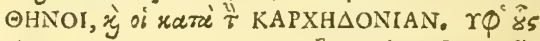

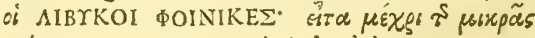

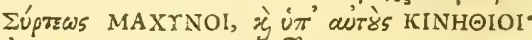

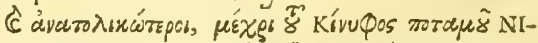

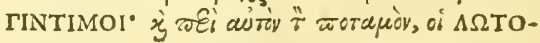
ФАГOI.

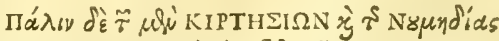

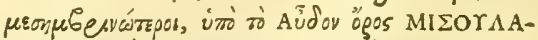

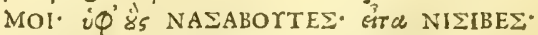

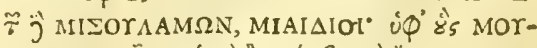
sorNOI E⿱宀⿰㇀丶㇀

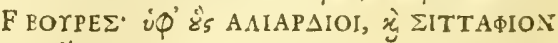

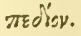

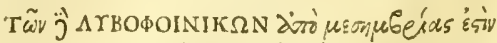

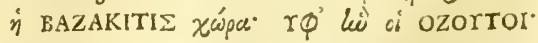

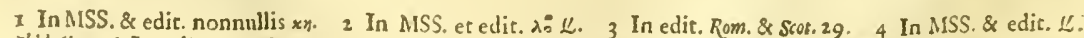
5 Ibid. L. 6 In edit. Rom. \& Scos. 24. 6 a ['.15. I. 4. Oiaránestey fcribitur. 7 In MSS. \& ed. \&. 8 Ibid. I. 9 lbid. $k$. 10 lbid. \&. II Male forlan pro KIPTHEIOI. 


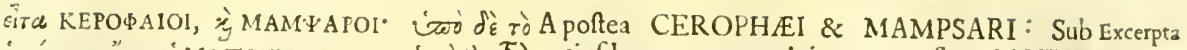

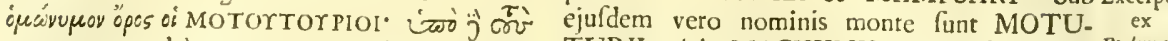

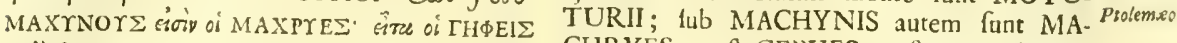

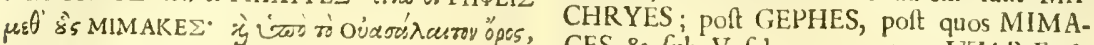

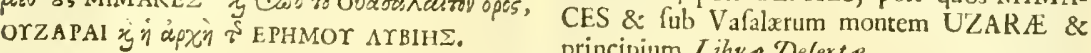
principium Libya Deferta.

$$
\text { * } * * * * * * * *
$$

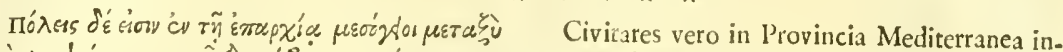

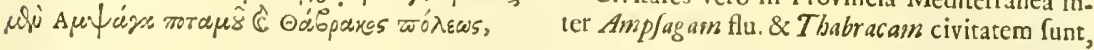

C I R T E S I O R U M quidem

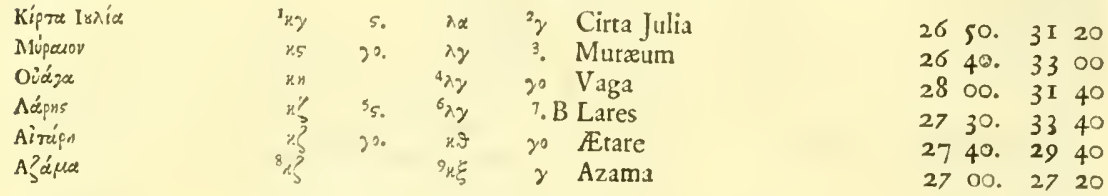

\begin{tabular}{|c|c|c|c|c|c|c|}
\hline 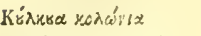 & R:A & ${ }^{10} 5$. & $\lambda z$ & Culcua Colonia & 2830. & \\
\hline 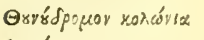 & $x n$ & $\%$ & 111,5 & Thunudronum Colonia & 2820. & 36 \\
\hline 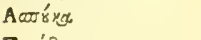 & $x=2$ & $I^{12} 2$. & $\lambda 6$ & Afpuca & 2930. & 32 \\
\hline Eipuis̄r & r.9 & ${ }^{15} 5$. & $\lambda_{2}$ & Similthu & 2910. & $3 I$ \\
\hline 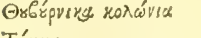 & $\lambda$ & & ${ }^{16} \lambda, \alpha$ & Thuburnica Colonis & 3000. & $3 I$ \\
\hline 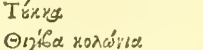 & $\begin{aligned} x .9 \\
10.9\end{aligned}$ & 17. & $\lambda x$ & Tucca & 2930. & $3 I$ \\
\hline 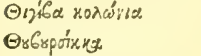 & 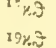 & & $\lambda x$ & $\gamma$ Thigiba Colonia & 2930. & 30 \\
\hline $\begin{array}{l}\text { Erbrpotixis } \\
\text { Oixios }\end{array}$ & $20^{2 n}$ & s. & $\begin{array}{l}\lambda \\
\lambda\end{array}$ & \& C Thliaburficca & 2020. & $3^{\circ}$ \\
\hline Táfopyo & $x i$ & $\delta$. & $\lambda \%$ & Gabiaphna & 3000. & 29 \\
\hline$\Delta \alpha \mu \pi \alpha u x_{x}=1$ & $x \hat{3}$ & & $\lambda$ & $\begin{array}{l}\text { Gaulaphna } \\
\text { Lambefa }\end{array}$ & 29 I 5 . & 31 \\
\hline
\end{tabular}

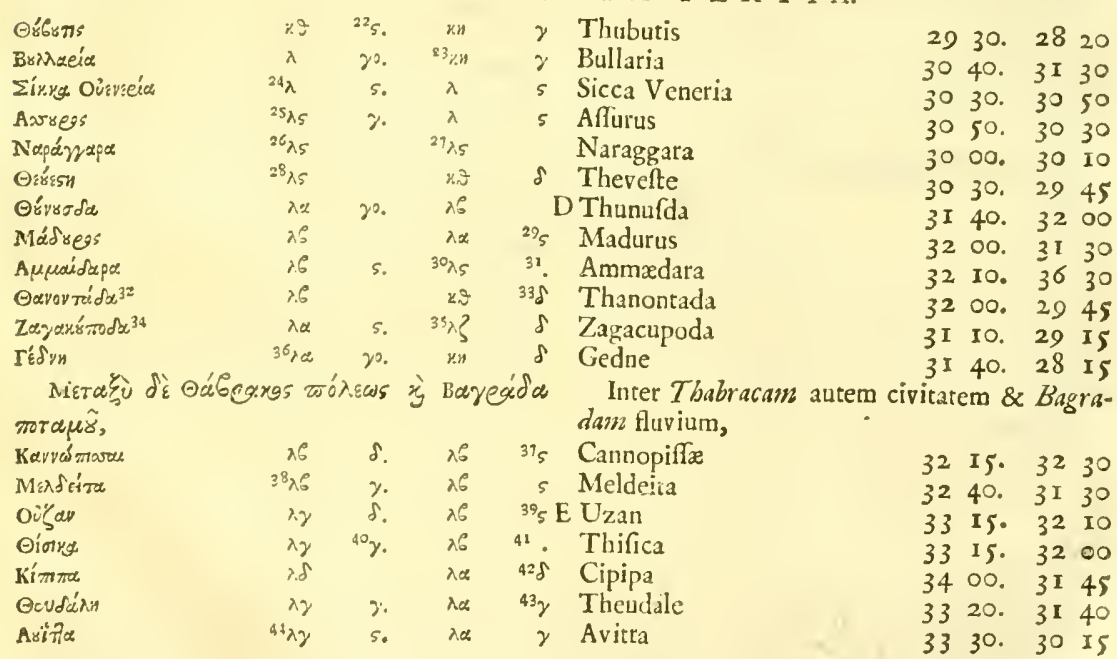

I InMSS. et ed. $x 5$ Ly. 2 In ed.Rom. 40. 3 In ed. Server. 3020.4 In MSS. \& ed. $\lambda \alpha .5$ 1b. L. 6 In ed.

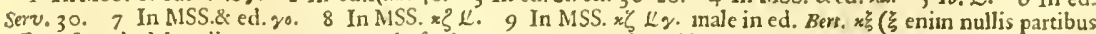
afiis refpondet) in edit.Kom. 3750 . male forfan pro 27 50. ut in MSS. 10 In MSS. et ed. $\not$. In In ed. Server 30. 12 In MSS. \& edit, L. ${ }_{13}$ Ibid, ‥ 14 in MSS. \& edit. nonnullis $\gamma$ deeft. 15 In MSS. \& e dit. nonnullis

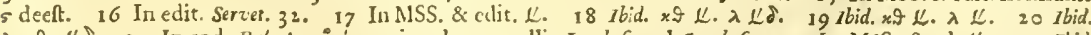

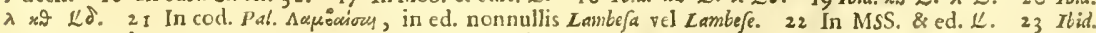

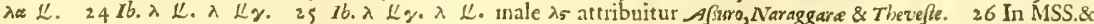

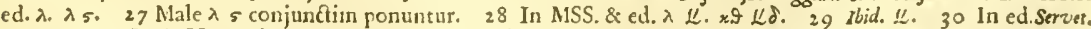
30 30; 31 In MSS. \& ed. $\mathcal{L} .32$ In ed. nonnullis Thanurada. 33 In MSS. \& ed. $\mathcal{\delta} \delta .34$ In cod. Pal. \& aliis

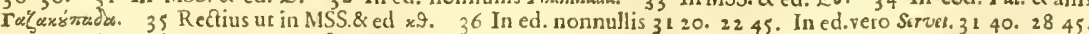
37 In MSS. \& ed. L. $38 \mathrm{Ibid}, \lambda_{0}^{\circ}$ yo. $\lambda \alpha$ L. 39 In ed. Rom. 3220 . in MSS. \& aliis edit $\lambda \alpha \gamma .40$ In MSS. \& edit. $\delta$. 4 I In ed.Scos. 45.42 In MSS. \& cdit. ${ }^{\delta} \delta .43$ Ibid. yo. in edit. Kom. 3240.44 In MSS. \& edit. $\lambda y$ U. $\lambda \delta$. 


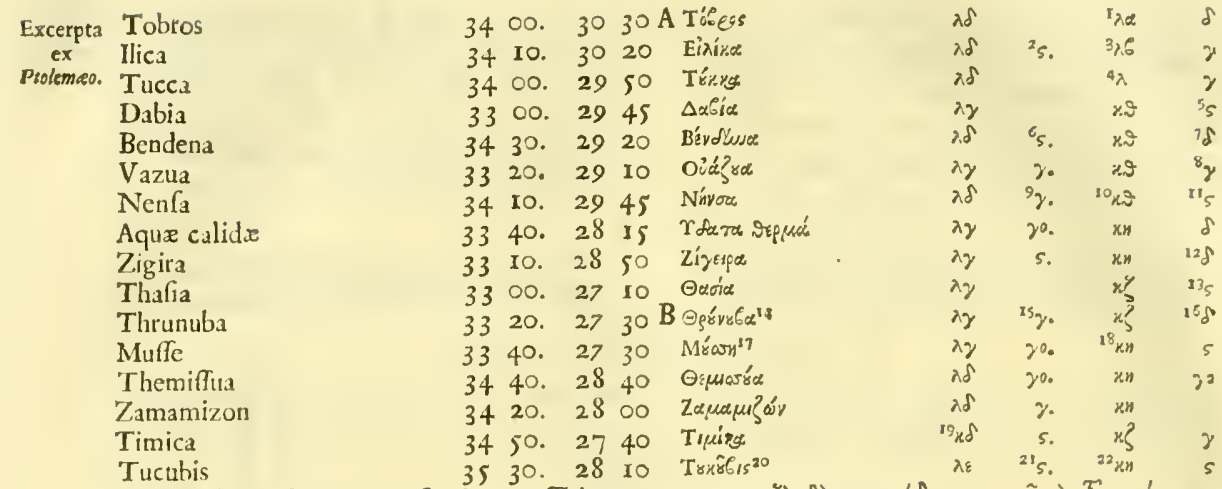

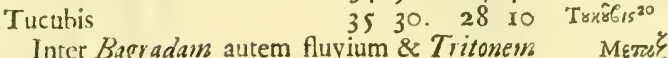

fl. fub Cartbagine quidem,

Maxula vetus

Vol

Themifa

Quina Colonia

Uthina

Abdeira

Mediccara

Thuburbo

Tucma

Bullaminfa

Cerbica

Nurum

Ticena

S.lura

Cilma

Vepillium

Thabba

Tichafa

Nigeta

Bunthum

Sub Adrumilto autem civitate,

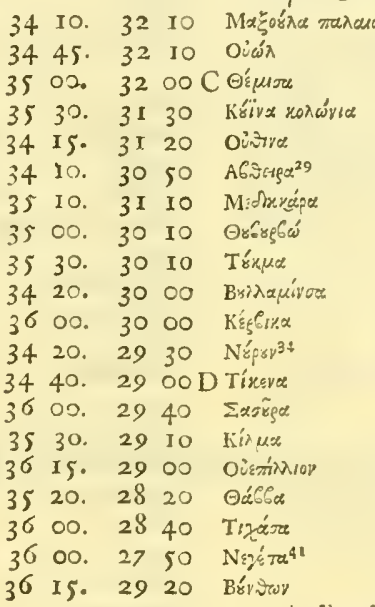

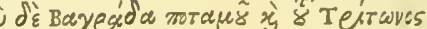

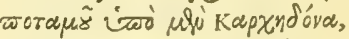

\begin{tabular}{|c|c|c|c|c|c|c|c|}
\hline \multicolumn{8}{|c|}{ 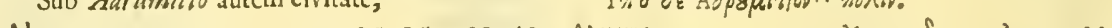 } \\
\hline Almæna & 35 Is. & 3040 & Anposves & $\lambda_{\varepsilon}$ & $\delta$. & $\lambda$ & ro \\
\hline Uricna & 3540. & 32 Is $\mathrm{E}$ & Oitinva & $\lambda \varepsilon$ & go. & $\lambda \epsilon$ & $45 \delta$ \\
\hline Chrabafa & 3600. & 3220 & 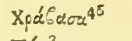 & ${ }^{4} 7 \lambda s$ & & $\lambda 6$ & $4^{48} y$ \\
\hline Turzo & 3540. & 3150 & T'́p? & $\lambda \varepsilon$ & jo. & $\lambda e x$ & 495 \\
\hline Ulizibirra & $3^{6} \circ$. & 3120 & OủM? & $\lambda s$ & & $\lambda \epsilon$ & $y$ \\
\hline Orbita & 3620. & 3220 & $\mathbf{O}_{\rho} \sigma 17 \alpha$ & $\lambda s$ & $\gamma$. & ${ }^{50} \times 6$ & $\sin$ \\
\hline Uzita & 3610. & 3220 & $0 y^{\prime \prime} / 7 x$ & $\lambda s$ & ${ }^{52} 5$. & $\lambda 6$ & $53 y$ \\
\hline Gifira & 3620 , & 3 I 45 & rítpe & 2.5 & ${ }^{54} \gamma$. & $\lambda \approx$ & 558 \\
\hline Zurmentum & 3700. & 3110 & 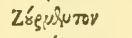 & $\lambda\}$ & & $\lambda x$ & ${ }_{36} \sigma_{S}$ \\
\hline Zalapa & 3645. & $3 I 45$ & 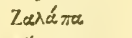 & $\lambda s$ & $37 \delta$. & $\lambda a$ & $5^{8} \delta$ \\
\hline Auguftum & 3620. & 3040 & $A_{u ̈ g 850 y}^{\prime \prime}$ & ${ }^{59} \lambda \gamma$ & $\gamma$. & $\lambda$ & ${ }^{60} \mathrm{\gamma}$ \\
\hline Leæ & $3^{6} 20$ & 30 IO $\mathrm{E}$ & secu & ${ }^{\sigma} \lambda_{\lambda \gamma}$ & & $\lambda$ & $\operatorname{lin}^{2}$ \\
\hline Avidus & 3640. & 3000 & Až̀tos & ${ }^{62} ; . y$ & $\gamma_{0}$ & $\lambda$ & \\
\hline
\end{tabular}

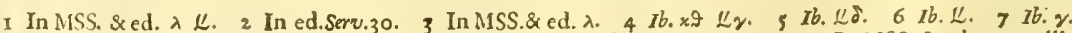

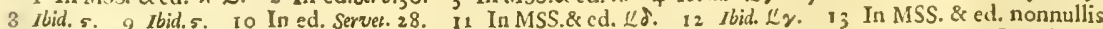

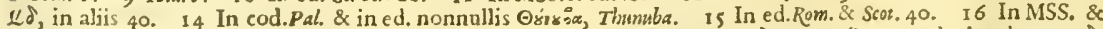

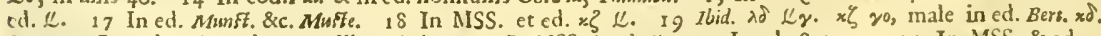
\&ce. 20 In cod. Pal. \& ed. nonnullis Tufcubis. 21 In MSS. 良 ed. L. 22 In ed. Scot. 27.23 In MSS. \& ed.s.

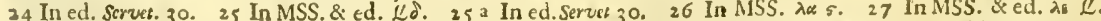

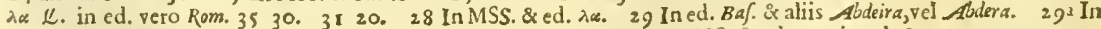
ed. Servet. 30,30 In MSS. \& ed. $12 \gamma .31$ in ed. Servet. 30.32 In MSS. \& ed. $\lambda . \alpha$. in ed. Scot. 3530.3045. 33 In ed. Servet. 5 deeft. 34 In ed. nonnullis Nuroli. 35 In MSS. \& ed. L. 36 tbid. yo. 37 1bud. yo. 3816.

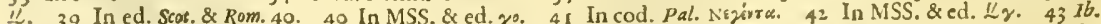

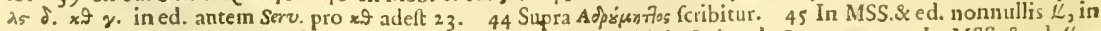
ed. Rom. 45.46 Legitur \& Chcubafa. 47 In ed. Rom. 35. 48 1bid. \& in ed. Scot. 40.49 In MSS. \& ed. Lq. so In ed. nonnullis 31 , in aliis 32 . 51 in MSS. \& edit. nonnullis $y$ deelt. in ed. Rom. 30.52 In MSS. \& ed. nomnullis $L_{\gamma}$, in ed. Rom. 45.53 In ed, Rom.

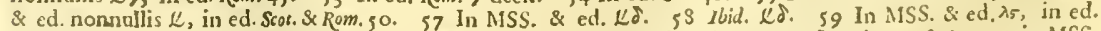

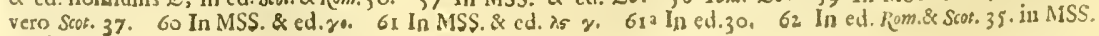
\& csl. aliis $\lambda_{5}$ yo, $\lambda_{\text {. }}$ 
EXCERPTA EX VETT. GEOGR.

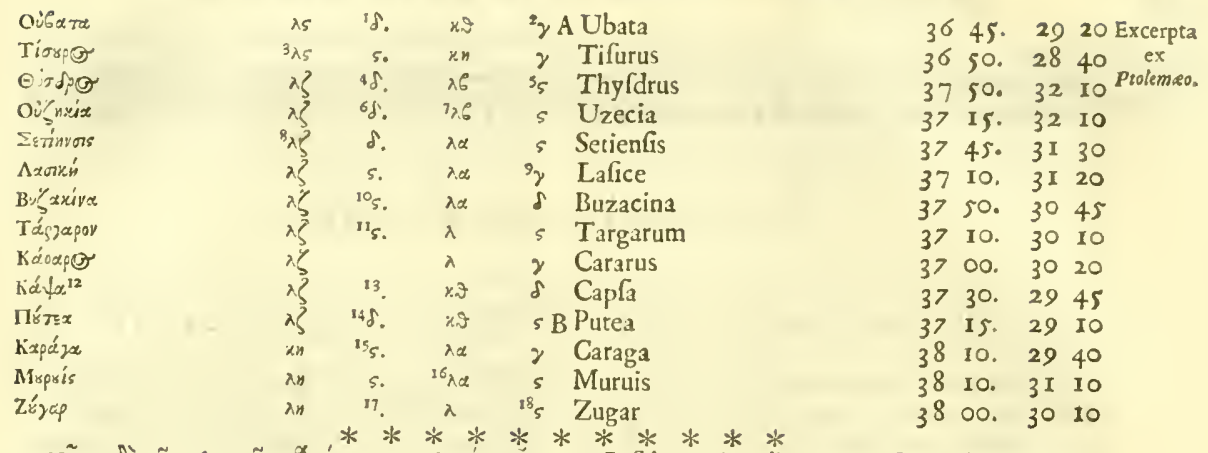

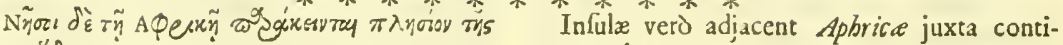
2iss, ais $\varepsilon$,

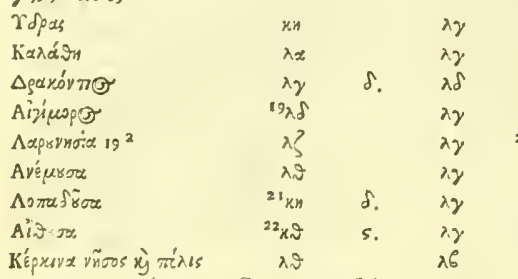

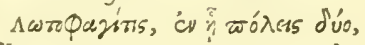

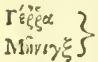

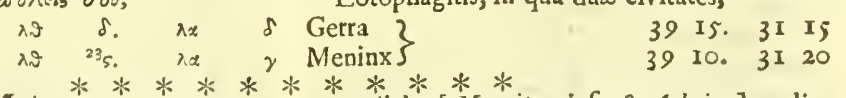

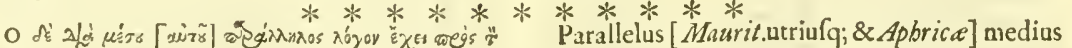

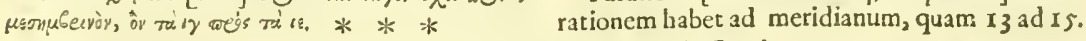

Mauritanic Cafarien/s urbium infignium,

28 00. 3300

3100.3340

33 I5. 34 I5

34 00. 33 10

3700.33 10

3900.3320

2815.3310

2910.3320

3900.3215
Ethufa

Circina

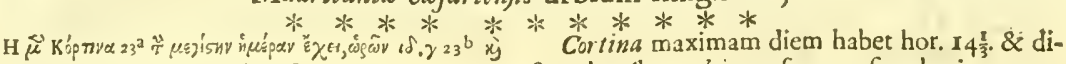

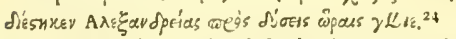

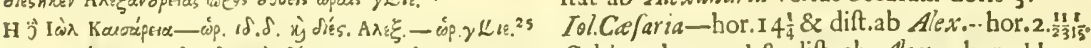

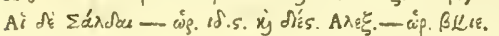

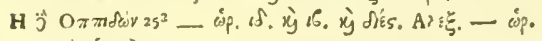
os ${ }^{26}{ }^{26} \gamma$ iे 18.

Salde - hor. $14 \frac{1}{6} \&$ dift. ab Alex. - hor. $2 \frac{1}{21} \frac{1}{5}$.

Oppidum [novum] - hor. $14 \frac{1}{2}$ fere. \& ditt. $a b$ Alex. - hor. 3 fere.

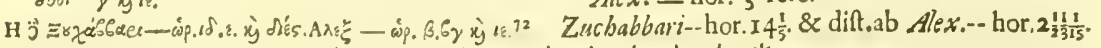

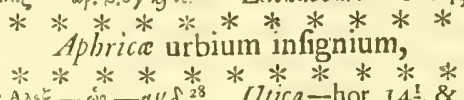

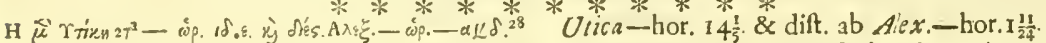

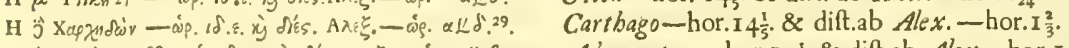

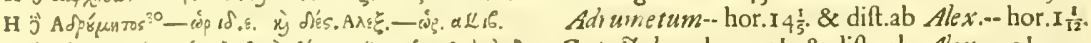

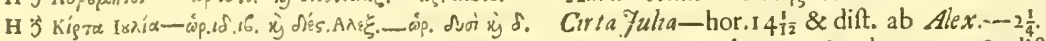

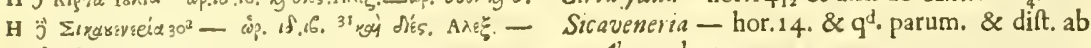
i.p. 6.

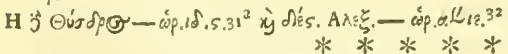
Alex.-hor.2.

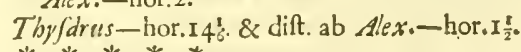

* * * * *

Scrapulos five Minutias Gradumn fignificaturi Græci, partes Affis notant,quinariis femper a fe invicem diftantes: nullifque
alii. quam iftis utuntur notarum compendiis. alii. quam iftis utuntur notarum compendiis.
Ex quo apparet omnes iftorum medios numeros (utpote 2.3.16.46.Sc.) qui in Latinis codicihus confpiciuntur, efte fuppofititios.

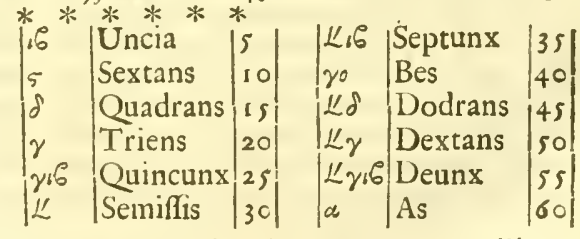

L IB,

VIII.

p. 232\%

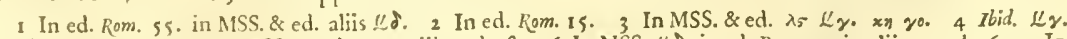
in ed. vero Rom. 15 . 5 In MSS. \& ed. nonnullis 5 deeft. 6 In MSS. L $\delta$, in ed. Rom. 45 , in aliis $55 \mathrm{rel} 56.7$ In

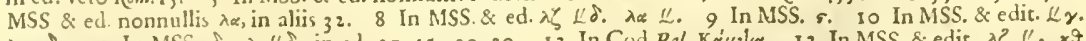

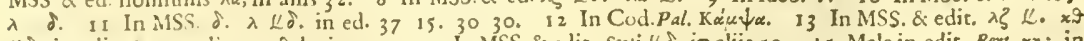
$\not 1 \delta$. in edit. $k$ om. male pro $x 2$ legitur 39 . It In MSS. \& edit. Scoti $\angle \delta$, in aliis 50.15 Male in edit. Bert, $x \eta$; in MSS \& ed $\lambda$ s. 59 \%, 16 In MSS. \& edit. $\lambda L \delta$, in ed. vero Rom. 3120.17 In edit. Rom. 38 15. 18 In edit servet. 30.19 In edit. Servet. 31 15. $3315.19^{3}$ Cod. pal. addit vĩoa duo. 20 In edit. Server. 30.

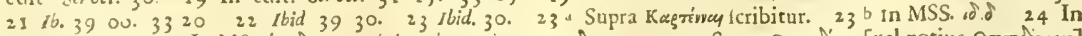

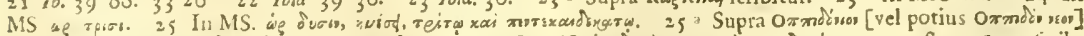

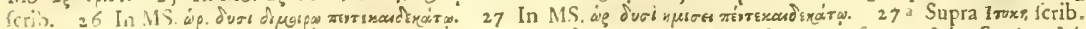

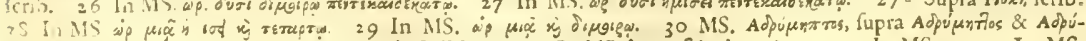

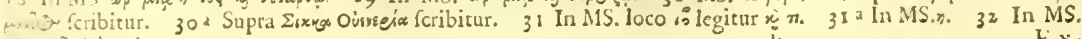




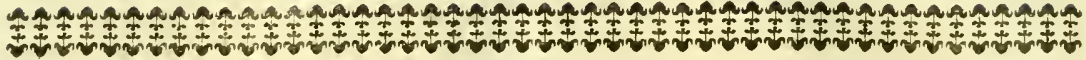

\author{
Excerpta ex P. Mela.
}

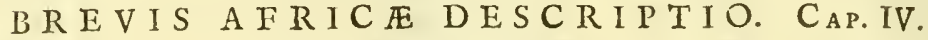

Frica ab orientis parte Nils terminata, Pe- A tum latus quod meridiem fpectat, ufque in Afra $A$ lago a cateris, brevior eft quidem quam confinia poffident. At fuper ea qua Libyco maEuropa; quia nec ufquam $A / i a$, \& non to. ris hujus litoribus obtenditur: longior tamen ipfa quam latior, \& quà ad fluvium attingit, lariffima. Utque inde procedit, ita media præcipuè in juga exurgens, pergir incurva ad occafum, ${ }^{*} \mathrm{fa}$ ftigatque fe molliter: \& ideo ex fpatio paulatim adductior, ubi finisur, ibi maximè angufta eft. Quantum incolitur,eximiè fertilis: verùm (quòd pleraque ejus inculta, \& aut arenis fterilibus obducta, aut ob fitim coeli terrarumque deferta funr, aut infeftantur multo, ac malefico genere animalium) vafta eft magis quam frequens. $\mathrm{Ma}$ re quo cingitur à feptentrione, Libycum; à meridie, Etbiopicun; ab occidente, Atlanticum dicimus. In ea parte qux Libyco adjacet, pro. xima Nilo provincia eft, quam Cyrenas vocant: deinde, cui totius Regionis vocabulo cognomen inditum eft, Africa. Cxtera Numide \& Mau$r i$ tenent: Fed Mauri \& in Allanticum pelagus $C$ expofiti. Ultra Nigrita funt, \& Pharufii, ufque ad Atbiopas. Hi \& reliqua hujus, \& to.

ri abluuntur, Libyes Esoypti funt, \& Leucoethiopes : \& natio frequens multiplexque Gectuli. Deinde latè vacat Regio, perpetuo tractu inbabitabilis. Tum primos ab oriente Garamuntas, pòtt Augilas \& Trogodytas, \& ultimos ad occafum Atlantas audimus. Intra (fi credere libet) vix jam homines, magifque femiferi Esppanes, \& Blemyes, \& Gampbajantes, \& Satyri, Gine tectis ac fedibus paffim vagi, habent potiùs terras, quam habitant. Hxc lumma noftri Orbis, hx maximx Partes: hx form $x$ gentefque Parrium.

Nunc exactius Oras fitufque dicturo, inde eft commodiffimum incipere, unde Terras noftrum pelagus ingreditur; \& ab iis potiffimum, qux influenti dextra funt : deinde ftringere litora ordine quo jacent, peragratifque omnibus qux mare atringunt, legere eriam illa qux cingit Oceanus; donec curfus incepti operis intra extraque circumvectus Orbem, illuc unde cœperit re: deat.

\section{PARTICUIARIS AFRIC无 DESCRIPTIO.}

\section{MAUR I T A N I A. CAP.V.}

Dißum eft Allanticum effe Oceanum, qui terras ab occidente contingeret. Hinc in No. ftrum Mare pergentibus, lava Hifpania, Mauritania dextra eft; ptimx partes, illa Europa, hæc Africa. Ejus oræ finis, MMulucba: caput atque exordium eft promontorium, quod Graci Ampelusian, Afri aliter, fed idem fignificante vocabulo, appellant. In eo eft Specus Herculi facer: \& ultra Specum Tinge oppidum pervetus, ab Antao (ut ferunt) conditum. Extat rei Signum, Parma elephantino tergori exfecta, ingens, \& ob magnitudinem nulli nunc ufuro habilis: quam locorum accolx ab illo geftatam pro vero habent, traduntque, \& inde eximiè colunt. Deinde eft mons praaltus, ei quem ex adverfo Hijpania attollit objectus: hunc Aby. ille quem diximus amnis eft, nunc gentium,olim

\section{N U M I D I A. CAP. VI.}

Ab eo Numidia ad ripas expofita fluminis Amplaga, fpatio quidem quàm Mauritania anguftior eft, verùm \& culta magis \& ditior. Ur. bium quas habet, maximæ funt, Cirta procul à mari, nune Sittianorum colonia ; quondam regum domus, \& cùm Syphacis foret, opulen-

utramque. Addir fama nominis fabulam, Her: culem ipfum junctos olim perpetuo jugo diremiffe colles,atque ita exclufum antea mole montium Oceanum, ad qux nunc inundat admiffum. Hine jam mare latius funditur, fummotafque $\mathrm{va-}$ ftiùs terras magno impetu inflectit. Cærerùm Regio ignobilis, \& vix quicquam illuftre forrita, parvis oppidis habitatur, parva flumina emitrit, folo quàm viris melior, \& fegnirie gentis obfeura. Ex his tamen qux commemorare non piget, montes funt alti, qui continenter \& quafi de induftria in ordinem expofiti,ob numerum, Septem, ob fimilitudinem Fratres nuncupantur : Tamuda fluvius,\&Rufadir, \& Siga, parvæ urbes; \& Portus, cui Magno eft cognomen ob fpatium. Mulucha ille quem diximus amnis eft, nunc gentium,olim

tiffima : Iol ad mare, aliquando ignobilis; nunc; quia $7 u b e$ regia fuir, $\&$ quذd Cefarea vocitatur, illuftris. Citra hanc ( $\mathrm{nam}$ in medio ferme litore fita eft) Cartenn \& $A r$ Finnaria funt oppiday \& 2uiza caftellum, \& Liturus finus, \& Sardabale Aurius: ulera, Mormmentum commune 
regix gentis, dcinde Tiofinm \& Rutbifia urbes, A cum oftreorumque fragmenta, faxa attrita (uti Excerpta \&. fluentes inter cas $/$ tueus \& Nabar, aliaque folent) fluctibus, \& non differentia marinis, infi- ex quæ taceri nullum rerum famxve difpendium $x \mathfrak{x}$ cauthu ancor $x$, \& alia ejufmodi figna atque ${ }^{P}$. Mrela. (ft. Interiùs, \& longè fatis a litore (fi fidem res veftigia effufi olim ufque ad ea loca pelagi, in capir) mirum ad modum, fpinæ pilcium, muri- campis nibil alentibus effe invenirique narramur.

\section{A F R I C A propric dicta. CA r. VII.}

Regio qux fequirur à promontorio Metagonio ad aras 'Pbilcnorum, propriè nomen Africe ufurpar. In ea funt oppids, Hippo Regius, \& Ruficade, \& Tabraca. Dein rria promontoria, Candidum, Apollinis, Mercurit, valte projecta in altum, duos grandes Sisus efficiunt. Hipponenferm vocant proximum ab Hippone Diarrby10, quod lirori ejus appofitum eft. In altero funt caltra Lacia, caftra Corsuelia, flumen Bagrada, Uica \& Cartbago, ambx inclytx, ambx a $P b c e-$ nicibus conditx: illa fato Caronis infignis, hæc fuo; nunc populi Romani colonia, olim imperii ejus pertinax emula; jam quidem iterum opulenta, etiam nunc ramen priorum excidio rerum, quam ope præfentium clarior. Hadrumetum, Leptis, Clupea, Acbolla, Tapbrura, Neapolis, hinc ad Syrtim adjacent, ut inter ignobilia ccleberrimx. Syrti finus eft centum ferè millia paffuum, qua mare accipit, patens; trecenta, qua cingit: verum importuofis atque atrox, \& ob vadorum frequentium brevia, magifque etiam ob alterno morus pelagi affluentis \& refluentis infeftus. Super hunc ingens palus amnem Tritona recipit, ipfa Tritonis: unde \& Minerve cognomen inditum eft, ut incolx arbitrantur, ibi geniræ: faciuntque ei fabulx aliquam fidem, quòd quem natalem ejus putant, ludicris virginum inter fe decertantium celebrant. Ultra eft Oea oppidum, \& Cynips fluvius per uberrima arva decidens: tum Leptis altera, \& Syrtis, nomine atque ingenio par priori; cxterum altero ferc̀ fpatio, quả dehifcit, quaque flexum agit, amplior. Ejus promontorium eft Boricn: ab eoque incipiens ora, quam Lotophagi tenuiffe dicuntur, ufque ad Pbycunta ( $\&$ id promontorium eft) importuofo litore pertinet. Arx ipfx nomen ex Pbilanis fraC tribus traxêre, qui contra Cyrenaicos mifí Car. thagine ad derimendum conditione bellum, diu jam de finibus, \& cum magnis amborum cladibus geftum; poftquam in eo quod convenerat non manebatur, ut ubi legati concurrerent, certo tempore utrinque diniffi, ibi termini ftatuerentur; pacti de integro, ut quicquid citrà eflet, popularibus cederet (mirum \& memoria dignitli. mum facinus!) hic fe vivos obrui pertulerunt.

\section{Y R E N A I C A. CAP. VIII.}

Inde ad Catabatmonos Cyrenaica provincia eft; $D$ calidus, atque ut illa procedir, ita calidior, rurfus in eaque funt, Ammonis oraculun, fidei inclytæ: \& Fons, quem Solis appellant: \& rupes quædam Auftro facra. Hæc cùm hominum manu attingitur, ille immodicus exfurgit, arenafque quafi maria agens fic fxvit, ut fluctibus. Fons media nocte fervet; mox \& paulatim tepefcens, fit luce frigidus; tunc ut Sol furgit, ita fubinde frigidior per meridiem maxime riget : fumit deinde tepores irerun; \& prima node cùm eft media, petfervet. In litore promontoria funt Zephyrion \& Naufathmos, portus $P_{a}$ ratonius, urbes Hefperia, Apollonia, Ptolemais, Arjincë, atque (unde terris, nomen eft) ipfa $C y$ rene. Catabathros vallis devexa in Egyptum, finit Africam. Oræ fic habitantur, ad noftum maximè ritum moratis cultoribus, nifi quèd quidam linguis differunt, \& cultu Deûm, quos patrios fervant, ac patrio more venerantur.

\section{A F R I A I N TER I O R. CA P.IX.}

Proximis null $x$ quidem urbes ftant, tamen domicilia funt quæ Mapalia appellantur. Victus afper, \& munditiis carens. Primores fagis velantur; vulgus beftiarum pecudumgue pellibus. Humi quics cpulæque capiuntur. Vafa ligno fiunt, aut cortice. Potus eft lac, fuccufque baccarum. Cibus eft caro, plurimum ferina: nam gregibus (quia id folum opimum eft) quoad poteft parcitur. Interiores etiam incultiùs, fequuntur vagi pecora: utque à pabulo ducta $F$ funt, ita fe ac tuguria fua promovent: atque ubi dies deficit, ibi noctem agunt. Quanquam in familias paffim \& fine lege difperfi, wihil in commune confultant: tamen quia fongulis aliquot fimul conjuges, \& plures ob id liberi agnatique funt, nufquam pauci. Ex his qui ultra delerta effe memorantur, Atlantes Solem execrantur, \& dum oritur, \&dum occidit, ut ipfis agrifque peltiferum. Nomina finguli non babent: non vefcuntur animalibus: neque illis in quiete qualia cæteris mortalibus vifere datur. Trogody $e^{*}$, nullarum opum domini, ftrident magis quam loquuncur, fpccus fubeunt, alunturque ferpentibus. Apud Garamantes etiam armenta funt, eaque obliqua cervice pafcuntur ; nam pronis directa in humum cornua officiunt. Nulli certa uxor eft. Ex his qui tam confufo paren. tum coitu paffím incerrique nafcuntur, quos pro fuis colant, form fimilitudine agnofcunt. Atsgila Manes tantùm Deos putant; per eos dejerant; cos ut oracula confulunt: precatique qua volunt, ubi tumulis incubuere, pro refponfis $\mathrm{fe}$ runt fomnia. Fominis corum folenne eft, no\&te qua nubunt, omnium ftupro parêre, qui cum munere advenerins: \& tam cum plurimis concubuifle, maximum decus; in rcliquum pudici- 
Excerpta tia infignis eft. Nudi funr Gamphafantes, ar-A greflus, aut colloquia patiuntur. Blemyis caex morumque omnium ignari: nec virare fciunt

P. Mola. tela, nec jacere: ideoque obvios fugiunt, neque aliorum, quàm quibus idem ingenii cft, aut conpita abfunt; vultus in pectore eft: Satyris, præter effigiem, nihil humani. Egipanum qux celebratur, ea forma elt. Hæc de Africa.

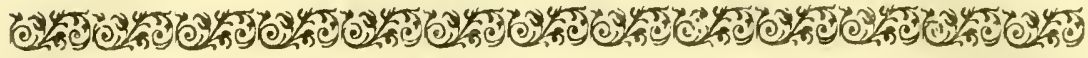

\section{Excer P A ex Plinio.}

\section{A F R I E DESCRIPTIO. LI в. V.}

\begin{abstract}
AFricam Graci Libyam appellavêre, quà mare ante eam Libycum incipiens Egyptio finitur. Nec alia pars terrarum pauciores recipit finus, longe $a b$ Occidente litorum obli- B tant.

quo Cpatio. Populorum ejus, oppidorum nomina, vel maxime funt ineffabilia preterquam ipforum linguis, \& alias caftella ferme inhabi-
\end{abstract}

\section{A URITA N I A. C A P. I.}

Principio terrarum Mauritanice appellantur, ufque ad C. Caefarem Germanici filium regna, fxvitia ejus in duas divifæ provincias. Promontorium Oceani extimum Ampelu/2a nominatur aे Gracis: Oppida fuêre, $L i \beta a, \&$ Cotta ultra columnas Herculis: nunc ett Tingi, quondam ab Antao conditum: poltea a Clandio Cafare, cilm coloniam faceret, appeliatum Traducta Fulis. Abelt à Belone oppido Betica, proximo trajeetu xxx. M. paff. Ab eo xxv.M. paft. in ora Oceani, colonia Augufi Fulia Conftantia Zilis, regum ditioni exempta, \& jura Beticam petere juffa: \& ab ea xxxir. M. paffuum colonia a Claudio Cafare facta Lixos, vel fabulofitimè antiquis narrata. Ibi regia Antai, certannenque cum Hercule : \& Helperidum horti. Affundicur æetuarium è mari flexuofo meatu, in quo draconis cultodix inftar fuiffe nunc interpretantur. Amplectirur intra fe infulam, quam folam è vicino tractu aliquanto excelfiore, non ramen $x$ fus maris inundar. Extat in ea \& ara Herculis, nec præter oleaftros aliud, ex narrato illo aurifero nemore. Minus profectò mirenrur porrentola Gracice mendacia, de iis \& amne Lixo prodita, qui cogitent noftros nuper paulo minus monftrifica quædam de iifdem tradidiffe. Prævalidam hanc urbem majoremque Carthagine magna : præterea ex adverfo ejus fitam, \& prope immenfo tractu ab Tingi: quxque alia Cornelius Nepos avidiffimè credidit. Ab LixoxL.M. in mediterraneo alrera Augufi colonia eft $B a b$. ba, Futia Campeftis appellata: \& tertia $B a$ nafa, exxv. M. Valentia cognominata. Ab ea $\mathrm{xxxv.} \mathrm{M.} \mathrm{pafl.} \mathrm{Volubile} \mathrm{oppidum,} \mathrm{tantundem} \mathrm{a}$ mari urroque diftans. Ar in ora a Lixo L. M. amnis Subur, præter Banafam coloniam defluens, magnificus \& navigabilis. Ab eo totidem M. paff. oppidum Sala, ejufdem nominis fluvio impofitum, jam folitudinibus vicinum, ele- $\mathrm{F}$ phantorumque gregibus infeftum, multò tamen magis Autololum gente, per quam iter eft ad montem Africe vel fabulofifimum Ailantem.

E mediis hunc arenis in cxlum atrolli prodiderunt, afperum, fquallentem, quà vergat ad li- tora Oceani, cui cognomen impofuit : eundem opacum, nemorofumque, \& fcarebris fontium riguum, qua fpectat Africam, fructibus omnium generum fpontè ita fubnafcentibus, ut nunquam fatietas voluptatibus defit. Incolarum neminem interdiu cerni : filere omnia, haud alio quam folitudinum horrore: fubire tacitam religionem animos propius accedentium, præterque horrorem elari fuper nubila, atque in viciniam lunaris circuli. Eundem noctibus micare crebris ignibus, Agipanum Sutyrorumque lafcivia impleri, tibiarum ac filtulie cantu, tympanorumque \& cymbalorum fonitu ftrepere. Hæc celebrati autores prodidêre, prater Herculi \& Perfeo laborata ibi. Spatium ad eum immenfum incertumque.

Fuêre \& Hannonis Carthaginien/zum ducis commentarii, Punicis rebus florentifimis exploDrare ambitum Africa juffi : quem fecuti plerique è Gracis nottrifque, \& alia quidem fabulofa, \& urbes multas ab eo conditas ibi prodidêre, quarum nec memoria ulla, nec veltigium extat.

Scipione Amiliano res in Africa gerente, $P_{0}$ lybius Annalium conditor, ab eo accepta claffe, fcrutandi illius orbis gratia circumvectus, prodidit à monte eo ad occafum verfus, faltus plenos feris, quas generat Africa, ad flumen Anatin cccclxxxv.M. paff. Ab eo Lixum ccv.M.paf= fuum : a Gaditano fieto cxir.M.paft.abeffe. Inde finum qui vocetur Saguti. Oppidum in promontorio Mulelacba. Flumina, Subur, \& Salain. Porrum Rutubis a Lixo ccxiri.M. paff. Inde promontorium Solis: portum Rifardir: Gatulos Autololes: flumen Cofenum: gentes, Scelatitos \& Mafatos. Flumen Mafatat: flumen 'Darat, in quo crocodilos gigni. Deinde finum DCXVI. M. paff. includi montis Barce promontorio excurrente in occafum, quod appel. lat Surrentizun. Poftea flumen Palfum, ultra quod Eibiopas Perorfos, quorum a rergo Pbarufios. Iis jungi medirerraneos Getulos Daras. At in ora Etbiopas Daratitss, flumen Bumbotum, crocodilis \& hippopotamis refertum. Ab 
eo montes perpetuos ufquc ad eum, quem Theôn A borum, proceritatem fpectabilem effe enodi nito-Excerpta ochema dicemus. Inde ad promontorium $\mathrm{He}$ - re, frondes cupreffis fimiles, prxterq; gravitatem ex Sperium navigatione dierum ac noctium $\mathrm{x}$, in odoris, tenui eas obduci lanugine: quibus addita Plinio. medio eo fpatio Allantem locavit, à cxteris arte, poffe, quales è bombyce, veftes confici. omnibus in extremis Mauritanice proditum.

Romana arma primùm, Claudio principe in Mauritania bellavêre, Ptoleñeum regem à $C$. Cafare interemptum ulcifcente liberto $\mathcal{E}$ demone, refugientibufque barbaris, ventum conftat ad montem Atlantem. * * * Verticem altis etiam æftate operiri nivibus. Decumis fe è̀ pervenifle caltris, \& ultra ad fluvium, qui $G$ er vocaretur, per folitudines nigri pulveris eminentibus interdum velut exuftis cauribus, loca inhabitabilia fervore, quanquam hy. berno tempore, expernen Qui proximos inha.

Indigenæ tamen tradunt in ora ab Sala cen-B bitent faltus, refertos elepliantorum, ferarumtum quinquaginta mill. paftum : flumen $A \int_{a-}$ que, \& ferpcutium omni genere, Cutrarios apnam marino haufu, fed portu fpectabile : mox pellari. Quippe victum ejus animalis promifcuum amnem quem vocant Fut: $a b$ eo ad Dyrin his effe, \& dividua ferarum vifcera. Junctam ( hoc enim Allanti nomen effe eorum lingua Ethiopum gentem, quos Perorfos vocant, faconvenit) ducenta mill. paffum interveniente tis conftat. $G$ aba Ptolemei pater qui prius utri. flumine, cui nomen ett $V$ ior. Ibi fama, exttare que Mauritawice imperavit, ftudiorum claricirca veftigia habitati quondam foli, vinearum tate memorabilior ctiam, quam regno, fimilia palmetorumque reliquias.

Suetonizs Pautinus, (quem Confulem vidimus) bam euphorbiam nomine ab inventore medico primus Romanoram ducum tranfgreffus quoque $\mathrm{C}$ fuo appellatam. Cujus lacteum fuccum miris Atlantem aliquor millium fpatio, prodidit de ex- laudibus celebrat in elaritate vifus, contraque celfitate quidem ejus, qux cxteri : imas radices ferpentes, \& venena omnia, privatim dicato vo. denfis altifg; repletas fylvis incognito gencre ar- lumine. ****

\section{TINGITANIA PROVINCIA. CAP.II.}

Tingitanice provincie longitudo CLxx. M. paftuum eft. Gentes in ea, quondam prxcipua Maurorum, unde uomen, quos plerique Maurufios dixerunt. Attenuata bellis ad paucas recidit familias. Proxima illi Malfafylorum fuerat, fed fimili modo extincta elt. Getule nunc tenent gentes, Baniure, multoque validiffimi Autololes: \& horum pars quondam $V_{e}$ funi, qui avulfi lis propriam fecêre gentem, vetfi ad $\mathcal{E}$ thiopas. Ipfa provincia ab Oriente montuofa, fert elephantos. In Abala quoque monte, \& quos Septem fratres a firmili altitudine appel. lant: ii freto imminent juncti Abila. $\mathrm{Ab}$ his ora intcrui maris. Flumen Tamuda navigabile, quondam \& oppidum. Flumen Land, \& ipfum navigiorum capax. Rufadir oppidum \& portus, Malvana fluvius navigabilis.

Siga oppidum ex adverfo Malacbe in Hi. Spanza fitx, Sypbacts regia, alterius jam Mauricansia. Namque diu regum nomina obtinuëre, ut Bogudrana appellaretur extima : itemque Boccbi, que nunc Cudarienjis. Ab ea Portus Magnus a fpatio appellatus, civium Rosnanorem oppidum. Amnis Mulucba, Boccbi Ma/Jafylo- runque finis. Quiza Xersitana peregtinorum oppidum, Arfennaria Latinorum, tribus millibus paffuum à mari. Cartenra colonia Augu$f i$, legio fecunda. Item colonia ejufdem deducta, cohorte pretoria, Gunugi. Promontorium Apollinis: oppidumque ibi celeberrimum Cefarea, antea vocitatum $T o l$, Fube regia, a Divo Claudio colonix jure donata : ejufdem juffu deductis veteranis, Oppidum novum: \& Latio da-

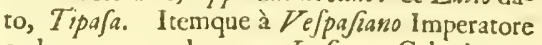
eodem munere donatum Icofion. Colonia $A u$ gufti Rufconid. Rufucurium civitate honora. tum a Claudio. Rufazus colonia Augufti. Salde colonia ejufdem. Item Igilyili. Oppidam Tucca impolitum mari, \& flumini Amplaga. Intus colonia Augufta, qux item Succabar: item Tubusuptus. Civitates: Timici, Tigave. Flumina: Sardabal, Aveus, Nabar: gens Macurebi : flumen Ufar: gens Nabades. Flumen Amplaga, abeft a Cajarea trecentis viginti \& duobus millibus paffuum. Utriufque Maurizanie longitudo decies triginta novem mill. Latitudo quadringentorum fexaginta feptem mill. paffuum.

N U M I D I A. CAP. III.

Ab Amplaga Nunidia eft, MafinifJa clara nomine, Metagonitis terra a Grecis appellata : Numida vero Nomades a permutandis pabulis, mapalia fua, hoc eft, domus, plauftris circumferentes. Oppida: Cullu, Ruficade, \& ab ea quadraginta octo M.paffuum in mediterraneo colo. nia Cirta, Sittianorum cognomine : \& alia intus Sicca: liberumque oppidum Bulla regia. At in ora Tacatua, Hipporegias, flumen Armua. Oppidum Tabraca civium Romanorum. Tufca fluvius, Numidia finis: nec præter marmoris $N u$ midici, ferarumque proventum aliud infigne.

\section{A F R I C A. CAP.IV.}

A Tufca, Zeugitana regio, \& quæ propriè vocetur Africa, eft. Tria promontoria : Candidum: mox Apollinis, adverfum Sardine : Mercurii, adverfum Sicilia, in altum procurren-G tia, duos efficiunt finus: Hipponenfern, proximum ab oppido, quod Hipponem dirutum vo. cant, Diarrbytum à Grecis dianm, propter aquarum irrigua. Cui finitimum Theudalis im. 
Excerpta

ex mune oppidum, longiùs à litore. Dein promonRomanorum, Catonis morte nobilis: flumen $B a$ grads. Locus, Caftra Cornelia : colonia Carthago magnx in veftigiis Carthaginis : colonia $\mathrm{Ma}$. xulla. Oppida : Carpi, Mifua, \& liberum Clu. pea in promontorio Mercurii. Item libera $\mathrm{Cu}_{\text {- }}$ rubis, Neapolis. Mox Africa ipfius alia diftinctio. Libypbonices vocantur, qui Byzacium incolunt. Ita appellatur regio ccL. M. paff. per circuitum, fertilitatis eximix, cum centefima fruge agricolis fœenus reddente terrâ. Hic oppida libera, Leptis, Adrumetum, Ruppina, T bapjus. Inde Tbena, Macomades, Tacape. Sabrata contingens Syrtum minorem, ad quam Numidice \& Africe ab Ampsaga longitudo ccccclxxx.M. paffuum: Latitudo, quà cognitum eft, cc. M. Ea pars, quam Africam appellavimus, dividitur in duas provincias, veterem \& novam, difcretas folla, inter Africanum fequentem \& reges, Thenas ufque perducta, quod oppidum a Cartbagine abeft ccxvi.Mill. paffuum.

Tertius finus dividitur in geminos, duarum Syrtium vadofo ac reciproco mari diros. Ad proximam, quæ minor eft, a Cartbagine ccc.M. paff. Polybius tradit: Ipfam centum M. paffuum aditu, ccc.M. ambitu. Et terra autem, fyderum obfervatione, ad eam per deferta arenis, perque ferpentes iter eft. Excipiant faltus repleti ferarum multirudine: \& introrfus elephantorum fo. litudine, mox deferta vafta, ultraque Garaman-1 tes, ab Augylis dierum xur. itinere diftantes. Super illos fuêre gens $\boldsymbol{P} f y$ lli, fuper quos lacus Lycomedis, defertis circumdatus. Augyla ipfi medio ferè fpacio locantur $a b$ Attbiopia, qux ad Occidentem vergit, \& à regione qux duas Syrtes interjacet, pari utrinque intervallo. Sed ****** $* *$ litore inter duas Syrtes, ccI. M. paffuum. Ibi civitas Ocen/is, Cynips fluvius ac regio. Oppida: Neapolis, Gaphara, Abrotcnum, Lepiis altera, qux cognominatur Magna. Inde Syrtis major, circuitu DCXXv. aditu autem CCCXI I. M. paffuum. Inde accolit gens $C_{1}$ fipadum. In inrimo frnu fuir ora Lotophagôn, quos quidam $A$ lachroas dixêre, ad Pbilenorum aras: ex arena funt ex. Ab his non procul à continente palus vafta amnem Triconem nomenque $a b$ eo accipit, Pallantias appellata Callimacbo, \& citra minorem Syrtim effe diets: à multis verò inter duas Syrtes. Promontorium, quod majorem includit, Borion appellatur. Ultra Cyrenaica provincia.

Ad hune finem Africa à fluvio Amplaga populos XxrI. haber, qui Romano parent imperio. In his colonias vI. prater jam fuprà dietas, $U$ tbinam, Tuburbin. Oppida civium Roman.xv. ex quibus in mediterraneo dicenda Azuritanum, Abutucenfe, Aborienfe, Canopicum, Cbilmanenfe, Simitiuen/e, T bunu/iden/e, Tubarnicen/e, Ty. nidrsmenfe, Tibigenfe, Ucitana duo, majus, \& minus: Vagenfe. Oppidum Latinum unum Ufalitanum. Oppidum ftipendiarium unum, $\mathrm{Ca}_{3}$ Atris Corneliis. Oppida libera triginta, ex quibus dicenda intus Acohtanum, A:baritanum, Avinenje, Abziritanum, Canopitanum, Melzutanum, Materen/e, Salapbitanum, Tufdritanum, Tipbicenfe, Tunicenfe, Theudenfe, Tageftenfe, Tigenfe, Ulufubritanum, Vagense aliud, Vicenfe, Zamenfe. Ex reliquo numero non civitates tantum, fed pleræque etiam nationes jure dici poffunr, ur Natabudes, Capfitani, Mifulani, Sabarbares, Maffyli, Nifives, Vamacures, Etbini, MNuffini, Marcbubii, \& tota Getulia ad flumen Nigrin, qui Africain ab Etthiopia dirimit.

*******

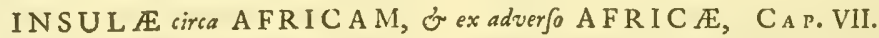

Infulas non ita multas complectuntur hæe ma. ria. Clatiffma eft Meninx, longitudine xxv.M. paffuum, latitudine xxir. ab Eratoftbene Loto phagitis appellata. Oppida habet duo, Menisgem ab Africa latere: \& altero, Thoar: ipfa a dextro Syrtis minoris promontorio paffibus cc. fita. Ab ea centum M.paff. contra levum, Cer. cina, cum urbe ejufdem nominis libera, longa xxv.M. paff. lata dimidium ejus, ubi plurimum : at in extremo non plus quinque M. paffuum.
Huic perparva, Carthaginem verfus, Cercinitis ponte jungitur. Ab his quinquaginta $M$ ferè Eaffuum Lopadufa, longa vi.M.paff. Mox Gaulos \& Galata, cujus terra fcorpionem, dirum animal Africa, necat. Dicuntur \& in Clupea emori, cujus ex adverfo Cofyra cum oppido. At contra Carthaginis finum dux Agimori arx, fcopuli verius, quàm infulæ, inter Siciliam maximè \& Sardiniam. Autores funt, \& has quondam ha. bitatas fublediffe.

\section{ExcERPTA ex Solino.}

\section{LIBYA. HORTI HESPERIDUM. MONS ATLAS. CAP. XXIV.}

$\mathrm{D}$ Hifpania eft excurfus in Libyam; nam Be- nia, fed cujus primus author Anteus fuit. Porlone progreffos, quod Batica oppidum eft, $\mathrm{F}$ rò quod in illo ambitu Egyptium finitur pelaultra interjacens fretum trium \& triginta millium gus, \& Libycum incipir, placuit ut Africain $L i$ paftuum Tingi excipit, Mauritanie nunc colo. byam diceremus. Quidam tamen Libyam à Li- 
bya Epapbi filia, Africam autem ab Afro $L i$-A quarum odor gravis,comæc cupreffi fimiles veltiun- Excerpta byis Herculis filio potius dictam receperunt. tur lanugine, fericis velleribus nihil viliore. In ex Lix quoque colonia in eodem tractu conftituta eo latere \& herba Euphorbia copiofa, cujus Solino. eft, ubi Antei regia, qui implicandis explican- fuccus ad oculariam proficit claritatem, nce medifque nexibus humi melius fciens, velut geni- diocriter percellit vim venenorum. Vertex femtus matre terra, ibidem ab Hercule victus eft. per nivalis. Saltus ejus quadrupedes, ac forpenNam de hortis He/peridum, \& pervigili draco- tes ferx, \& cum his Elephanti occupaverunt. ne, ne famæ licentia vulneretur fides, ratio hæc Silet per diem univerfus, nec fine horrote fecreeft. Flexuofo meatu xftuarium è mari fertur tus eft; lucet nocturnis ignibus: choris ÆEgipaadè frnuofis lateribus tortuofum, ut vifentibus num undique perfonatur: audiuntur \& cantus procul lapfus angueos fracta vertigine mentia- B tibiatum, \& tinnitus Cymbalorum per oram matur: idque quod hortos appellavête, circundat: ritimam. A Lixo abeft quinque \& ducentis unde pomorum cuftodem interpretantcs, ftruxe- millibus paffuum : Lix a Gaditano freto centum runt iter ad mendacium fabulandi. Sed hxc in- duodecim millibus. Habitatus antè ut indicat fula infinuata fnibus alvei recurrentis, $\&$ in qui- loci facies quondam cultu exercita, in qua uf. bufdam xquoris fpiris fita, præter arbores olea- que adhuc vitis \& palmx extat veftigium: apex ftri fimiles, \& aram facram Herculi, aliud nihil Perfeo \& Hercul pervius, cxteris inacceflus: præfert quo propaget vetuftatis memoriam. Ve- ita fidem ararum infcriptio palam facit. Qua rum ultra frutices aureos \& metalla frondentia, fpectat occafum, inter ipfum \& flumen Anation illud magis mirum, quod folum inferiore licet per quadringenta nonaginta fex millia pafluum libra depreffius, nunquam tamen acceffu freti fu- C infames beftiis fylvx obfident. Amnes circa eum perlabitur, fed obftaculo naturalis repaguli in non tacendi : quilicet feparentur intervallis amipfis marginibus hæret unda \& intimis orarum plioribus, tranfierunt tamen in quoddam Atlanfuperciliis fponte fluctus ingrui refiftuntur: fpe- tici nominis* minifterium. Afana marino hauctandum nimirum ingeniuan loci, planicies ma- ftu, Bambothum Crocodilis \& Hippopotamis net ficca, quamvis prona fuperveniant æquora. refertum. Ultra adluc amnis, qui atro colore Sala oppidum imminct Salc flumini. Ab hoc exit per intimas \& exuftas folitudines, qux torper Autololum gentem iter eft in Atlanticas fo- rente perpetuo, \& Sole nimio plus quam ignito, litudines. Allas mons è media arenarum confurgit vaftitate, \& eduatus in viciniam Lunaris circuli, ultra nubila caput condit: quà ad $\mathrm{O}-\mathrm{D}$ ceanum extenditur, cui a fe nomen dedit, manat fontibus, nemoribus inhorrefcit, rupibus afperatur, fqualet jejunio, humo nuda nec herbida : qua Africa contraverfus eft, felix nafcentibus fonte frugibus, arboribus proceris opacitimus, nunquam ab xftu vindicantur.

Hac de Allante, quem Mawi Adderin nominant, \& Hannonis Punici libri, \& noftri annales prodiderunt: Fuba etiam Ptolemai filius, qui utriufque Mauritaniae regno poticus eft: Suetonius quoque Paulinus fummam huic cognitioni impoluit manum, qui ultra Atlantem primus, \& penè folus Romana figna circumtulit.

$$
\text { M A URI T A N I A. ** C A P. XXV. }
$$

E Provinciis Mauritanis Tingitana, qua Solftitiali plagæ obvia eft, quaque porrigitur ad internum mare, exurgit montibus feptem: qui à fimilitudine Fratres appellati, freto imminent. Hi montes Elephantis frequentifimi.*** * Cajarien/ícoloniaCafaria ineft à Divo Claudio deducta, Boccbi prius regia, poftmodum $7 u$ -

ba indulgentia populi Romani dono data. Ineft \& oppidum Siga, quod babitatum Siphaci fuit. Nec ab Icofio taciti recedamus. Hercule enim illa tranfeunte, viginti qui a comitatu ejus defciverant, locum deligunt, jaciunt mœenia : ac ne quis impofito à fe nomine privatio gloriaretur, de condentium numero urbi nomen datum.

$$
\text { N U M I D I A. ** CA P. XXVI. }
$$

Quod eft a flumine Am/aga, Numidic datur. Hujus incolæ quandiu errarunt pabulationibus vagabundis, Nomedes dicti funt. Urbes in ea quamplurime nobilefque, fed Cirta emiin ea quamplurimx nobilefque, fed Cirta emi- midici urfi forma cateris præftant, rabie dunta-
net, dein Chulli purpurario fuco Tyriis velleri-
xat $\&$ villis profundioribus: nam genitura par bus comparatx. Omnis hxc regio finibus in $\mathrm{F}$ eft quoquo loco genitis. $* * *$ * $*$.

Zeugitanum limitem definit. Qua parte fylveftris eft, feras educat : qua jugis ardua eft, equos alit. Eximio etiam marmore predicatur. Nu-

\section{A FR I C A cum CYRE N A I C A Regione. C a P.XXVII.}

Omnis Africa d Zeugitano pede incipit, promontorio Apollinis Sardinia contraverfa: promontorio Mercurii procedens in frontem Sicanam. Proinde extenta in duas prominentias, quarum altera promontorium Candidum dicitur: alceram, qux eft in Cyrenaica regione, Pbucuntem vocant. Ea per finum Creticum oppofita
Creta infulx, contra Tenaron Laconica excurrit. Arenis Catabatbmi Agypto infinuata, cui proximi Cyrenenfes, extenditur inter duas Syrtes, quas inacceflas vadofum ac reciprocum ma. re efficit: cujus fali defeetus, vel incrementa haud promptum eft deprehendere, ita incertis motibus nunc in brevia crefcit dorfuofa, nune 
Excerpta inundatur $x$ ftibus inquietis : \& auctor eft $V$ ar-A que Servilio, C. Sempronio Coff. inter hac va. ex ro, perflabilem ibi terram ventis penetrantibus dula claffem Romanain impunè accepimus perSolino. fubitam vim fpiritus citiflime aut revomere maria, aut reforbere. Omnis hæc plaga ab $\mathcal{E}$. thiopia \& terminis A/ie Nigri flumine, qui $N_{i}$. lum parit, ab Hispanice freto fcinditur: latere, quo ad meridiem vergit, fontium inops \& infamis fiti: altrinfecus qua feptentrionem patitur, aquarum larga: in agto Byzaceno, qui patet paffuum ducenta vel amplius millia, glebis ita prepinguibus ut jacta ibi femina cum incremen- $B$ to centefimæ frugis renafcantut. Externos ibi plurimos convientaffe, argumentum de urbibus $\&$ locis dabimus. Borion promontorium, quod A quilone cæditur, Greci advenæ fic vocaverunt. Hipponem, Regiurn poltea diatum, item Hipponem alterum de interfluente freto Diarrbyion nuncupatum, nobiliffima oppida, equites Greci condiderunt. Clypeam civitatem Siculi extruunr, \& Ajpida primùm nominant. Veneriam etiam, in quam Veneris Erycince religiones tranftule- $C$ runt. Acbaci Tripohs liugua fua fignant de trium urbium numero, Oea, Sabrata, Leptis Magna. Philenis fratribus à laudis cupidine Graium vocamen datum. Adrymeto atque Carthagini auctor eft a Tyro populus: fed qux fuper Carthagine veraces libri prodidetunt, hoc loco reddam. Vrbem iftam, ut Cato in otatione Senatoria autumar, cùm rex Fapon rerum in $\mathrm{Li}$ bya potiretur, Eliffa mulier exftruxit domo $P$ bee nix, \& Cartbadam dixit, quod Pbonicum ore exprimit Civitatem novam. Mox fermone verfo in verbum $\mathcal{P}_{\text {unicum }}$ \& hæc Elif]a, \& illa Carthago dicta eft : qux poft annos leptingentos triginta feptem exciditur, quàm fuerat conftituta. Deinde à C. Graccbo colonis Italicis data, \& $Z_{u}$ nonia dicta, aliquantifper ignobilis, humili \& languido ftatu : demum in claritatem fecundx Car. thag inis, interjectis centum \&e duobus annis, $M$. Antonio, P.Dolabella Confulibus enituit, alterum polt urbem Romam terrarum decis. * * *

Inter Syrtes,p.38.A. quamvis terra pergentibus, iter fideribus deftinatur: nec aliter curfus patefcit: nam putris foli faciem aura mutat, \& minimolicet vento,tantam divetfitatem flatus efficit, fubinde perverfis fitibus locorum nulla indicia agnirioni relinquantur: cùm modò qux fuerant tumulis ardua, in valles refidunt : modò quæ vallibus preffa, cœtu pulveris aggerantur. Ita etiam continens naturam maris fui patitur: nec intereft ubi potius fint procell $x$, cùm ad exitium vian- $F$ tium elementis congruentibus in terris flabra $f_{x}$. viant, in mati terræ. Utræque Syrtes ducentis quinquaginta millibus paffuum feparantur. Aliquanto clementior, qux minor elt. $C_{n}$. deni-

fretaffe. In hoc finu Meninx infula poft Mynturnenfes paludes $C$. Mario fuit laiebra. Supra Garamantas Pfylli fuerunt, contra noxium virus muniti incredibili corporis firmitate. Soli morfibus anguium non interibant, \& quamvis dente lecali appetiri, incorrupta durabant fanitate. Recens eriam editos ferpentibus offerebant: fi effent partus adulteri, matrum crimina plectebanBitur interitu parvulorum: fi pudici, probos ortus a morte paterni fanguinis privilegium tuebatur. Sic originis fidem probabant venenis judicantibus. Sed hxc gens interivit à Nafamonibus capta: neque quicquam aliud præter opinionem de reftigio nominis fui $P \int y$ li reliquerunt. $N a$. famonitem lapidem $N$ afamones dant, fanguineum univerfum, nigris venulis adumbratum. In intimo receffu Syrtis majoris circa Pbilanorum aras Lotophagos fuille difcimus, nec incertum eft. A Pbilenorum aris non procul palus eft, quam Triton amnis influit, ubi fpeculatam fe $\mathrm{Ar}$ lium Deam crediderunt. Major Syrtis oftentat oppidum, Cyrenas rocant, quod Battus Lacedamonius Olympiade quinta \& quadragefima, rege Martio res Romanas tenente, anno poft Troiam captam quingentefimo octogefimo fexto condidit : quæ domus Callimacbo poëræ fuit patria. Inter hoc oppidum, \& templun Hammonis millia paffuum quadringenta funt. Templo Fons proximat Soli facer, qui humoris nexibus humum favillaticam ftringit, \& in cxfpitem folidat. In qua gleba non fine miraculo lucus viret, undique fecus agris arentibus. Illic \& lapis legitur, Hammonis vocant cornu: nam ita tortuofus eft \& inflexus, ut effigiem reddat cornusarietini. Fulgore aureo eft. Pr.edivina fomnia repræfentare dicitur fubjectus capiti incubantium. Et arbor eft Melopos nomine, ex qua profuit lentus hu. mor, quem à loco Hammoniacum nominamus. Apud Cyrenen/es preterea Sirpe gignitur, odoratis radicibus, virgulto herbido magis quadm arbufto: cujus è culmo exudat ftato tempore pingue rolcidum, idque pafcentium hircorum inhæret barbulis : ubi cùm arefactum inolevit guttis firiacis, legitur ad ufum menfarum, vel medelis. Dictum eft primum Lac Sirpicum, quoniam manat in modum lacteum : deinde ufu derivante $L a$. fer nominatum. Qux germina initio barbaric $x$ impreffionis vaftatis agris, poftea ob intoleranF dam vectigalis nimietatem, ferme penitus ipfi ac. colæ etuerunt. Cyrenis ab læva Africa eft, ab dextra Ægyptus, a fronte frevum \& importuofum mate, à tergo Barbarortsm varix nationes, \& folitudo inculta \&c. * * *

\section{GENS A M A TUM \&̋. CA P. XXVIII.}

Inter Nafamonas, \& Troglodytas geas Amantum eft, quæ falibus domos exftruunt: quos in modum cautium à montibus excitatos, ad ufum rdium cxmentitiis nectunt ftruicibus. 'Tanta ibi hujufce venæ copia eft, ut tecta faciant è $\mathrm{G}$ falinis. Hi funt Amantes, qui commercium cum Troglodytis habent Carbunculi gemmx.
Citra Amantes propiores Nafamonibus AsbyAe Lajere vivunt, hoc aguntur, hoc illis edule eft. *** Ex parte [ C $\mathrm{AP} . \mathrm{xxIx}$.] qua Cercma eft, accepimus Gauloèn Infulam in qua ferpens neque nafcieur, neque vivit invecta : propterea jactus ex ea quocunque gentium pulvis, arcet angues: fcorpiones fuperjactus jlico perimit. * * * 


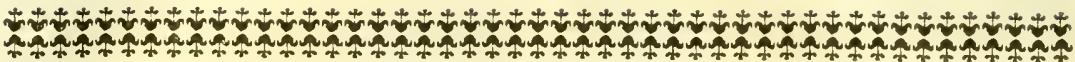

\section{EX C E R T A ex Itinerario.}

Columus Herculis.

A Tingi Mauretanie, id eft, ubi Bacuetes, o Macenites Barburi morantur, per maxitima loca Carthaginem ufque. M. P. xvisr. XIVIIIX.

Ab Exploratione, qua ad Mercurios dicitur, Tingi ulque.

Rufadder.

Cafarea Mauretanic.

Sildis.

Rufficcade.

Hippone Regio.

Carthagine.

M.P. cccxvin. B

M.P. ceccxerit.

Al.P. 'cccxvi11.

Litoris manfonibus bis.

Ad Mercurios.

Salaconia.

Thamufida.

Banafa.

Frigidis.

Lix Col.

Tabernis.

Zili.

Ad Mercuri.

Tingi Colonia. 열

A Tingi litoribus navigattr ufque ad Portus D Divinos.

Ad feptem Fratres.

Ad Abilem.

Ad Aquilam minorem.

Ad Aquilam majoren.

Ad Promuntorium Barbari

Txnia longa.

Cobucla.

Parietina.

Promuntorium

Ad fex Infulas.

Promuntorio Cannarum.

Promuntorio Ruifadi.

Ruffadder Col.

Ad tres Infulas.

Flumen Malva.

Flumen Mulva dirimit Mururetamias duss. Incipit Cafarienfis.

Lemnis.

Popleto flumen.

Ad Fratres.

Artifiga.

Portu Cæcili.

Siga Municip.
M.P. Clxxisil.

M.P. ccxvili.

M.P. ${ }^{2} \mathrm{CCXV}$.
M.P. ${ }^{3} \mathrm{CX} 11 \mathrm{1}$.

A Portu Sigenfi.

Camarata.

Ad Salfum flumen.

Ad Crifpas.

Gilva Colonia.

Caftra Puerorum.

Portus Divinos.

Portum Magnum

Quiza Municip.

Artenaria.

Cartenna Col.

I,ar Caltellum.

Cartili.

Gimugus.

Crefarea Colonia.

Tipafa Colonia.

Calac Calventi.

lcofum Colon.

Rufounize Colon.

M.P. clxxilu. Rulubbicari.

M.P. xvi. CCifi Nlunicip.

N.P. xxxil. Rufuccuro Col.

M.P. xxxi r. Iomnio Munic.

M.P. ${ }^{4 x \times 111 . ~ R u f a z i s ~ M u n i c . ~}$

M.P. xvı. Saldis Colon.

M.P. xvr. Alulubio.

M.P.xirs. Coba Municip.

M.P. v1. Igilgili Colon.

M.P. xvi11. Paccianis Matidix.

Chulli Munic.

Ruficcade.

Paratianis.

Culucitanis.

M.P. Lx. Tacatua.

M.P. ${ }^{5}$ xirit. Sulluco.

M.P. ${ }^{6}$ xi111. Hippone Regio Col.

M.P. ${ }^{7 \times 1111 . ~ A d ~ D i a n a m . ~}$

M.P. ${ }^{8}$ xil. Nalpotes.

M.P. xxing, Thabraca.

M.P. xxinl. Hippone Zarito.

M.P. xxi11. E Tuniza.

M.P. xxv. Membrone.

M.P.xı. Utica.

M.P. xxx. Ad Gallum Gallinacium.

M.P. L. Carthagine.

M.P. Xv.

M.P. LXV.

M.P. xIs.

A Carthagine Cirta.

Sititi

Calarea
M.P. IIx.

M.P. XII

M.P. 9 श11.

M.P.XXV.

M.P. ${ }^{10} \mathrm{~V}$.

M.P. XXIII.

M.P. xviti.

M.P. xxxvi.

M.P.X1.

M.P. XL.

M.P. XVIIT.

M.P. ${ }^{81}$ XIIII.

M.P. xv.

M.P.X11,

M.P. ${ }^{12} \times I I$.

M.P. XVI。

M.P. Xv.

M.P. XXXII,

M.P. Xv。

M.P. XXIITI.

M.P.XII.

M.P. XII.

M.P. XVIII.

M.P. xxxy i I 1 .

M.P. ${ }^{3}$ xxxv.

M.P. xxyrI.

M.Y. XXVIII.

M.P. "xxxuiti。

M.P. ${ }^{15} \times x \times v$.

M.P. LX.

M.P. L.

M.P. ${ }^{16} \mathrm{XxV}$.

M.P. ${ }^{77}$ XVIII.

M.P. ${ }^{88} \mathrm{XXY1}$,

M.P. XXI1.

M.P. Xxxil.

M.P. Xxxi1, M.P. XL.

M.P. ${ }^{19} \times 1111$.

M.P. L.X.

M.P. xx.

M.P. $x$.

M.P. vi.

M.P.xi1.

M.P. XY.

M.P. ${ }^{\circ} \mathrm{cccxx}$. M.P. c.

M.P. с сcr. Sic.

Swrita \& alii Tingi (ut nomina multa alia urbium) efferebant quarto cafu; fed enim inmerito. Conftac urbium nomina Latinitate labente fexto cafu, ac fi effent indeclinabilia, fuiffe prolata. Confentius in arte p. 203 o. Interdum, inquit, cffersmur novo modo, \& quafi nonoptozo, ut Curibus, Trallibus, Turribus, Sulcis, Servitiis, Tigavis. Vid. Weffelingii Notan in voce Tingi.

I Codex Vaticanus habet cxvI1.Weßel. = Exemplar Blandinianum habet cxv. Surit. 3 In nonnullis exemplar. cxcIIs. Id. 4 In Bl. xxxi11. Id. 5 In Bl. \& Neapolitano xxiIji.at in Longoliano xxxill. Id. 6 In

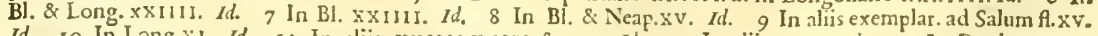
Id. Io In Long X. Id. 11 In aliis $\mathrm{xx} I 11 \mathrm{x} \times \mathrm{xI} \& \mathrm{XX}$. Id. 12 In aliis XXI1. Id. I3 In Regio exemp. xxv. Id. 14 In Reg. xxviJj. 1d. 15 In nonnull. Xxili1. 1.t. 16 In nonnull. L. Id. 17 In Reg. Xxv. Id.

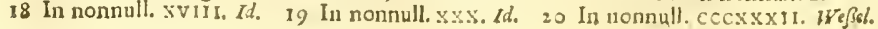


Excerpta Altieuros.

ex Admedera Colonia.

Jinurario. Thevefte Colonia.

Altaba.

Julti.

Mercimeri.

Macomadibus.

Sigus.

Cirta Colonia

Mileum.

Idicra.

Cuiculi.

Sitifi.

Perdices.

Cellas.

Macri.

Zabi.

Aras.

'Tatilti.

Auza.

Rapidi.

Tirinadi.

Caput Cilani.

Sufafar.

Aquis.

Crelarea.

\section{Iter ì Sitifi Suldus.}

Horrea.

Lesbi.

Tubufuptus.

Saldas.

Iter à Lambefe Sitifi.

Tadutti.

Nova Sparfa.

Gemellas.

Sitifi.

Iter a ThevefteperLambefen Sitif.M.P. Ccxir.

M.P. xirr.

M.P. XXXY1. M.P.

M.P.xv. A Ad Regias.

M.P.xxxiI. Tafaccora.

M.P. xxy, Caftra Nova.

xiris. Ballene Præfidio.

M.P. xxilit Gadaum Caftra.

M.t. xxi111. Vagal.

M.K. xxvir, Caltellum Tingitii.

M.P. xxv. Tigauda Municipio.

M.P. xxv. Oppido novo Col.

M.P. xxv. B Tigava Caftra.

MPxy. Malliana.

M.P. $\times x$ r. Sufafar

M.P. $x \times v$. Velifci.

M.P. 1 XxviIr, Tanaramufa Caftra.

M.P. xxv. Tamariceto Præfidio.

M.P. ${ }^{2} x_{x y}$. Rapida Caftra.

M.P. ${ }^{3} \mathrm{xxx}$. Ruluccuro Colonia.

M.P. XXIIII.

M.P. Xxv.

II.P.XVIII.

M1.P.Xx.

M.P.XVI.

M.P. $x x v$.

M.P. XVII

M.P. $x$ inI

M.P. $x_{11}$

M.P. $x \times x I_{1}$

M.P. 1 I.

M.P. $x \vee x$.

M.P. Xvilit

M.P. Xv.

M.P.XVI

M.P. XVI.

M.P. XVI

M.P. XII.

M.P. XLIII. Iter Rufuccuro Saldis, M.P. ${ }^{\circ} \mathrm{Cr} I$. Sic.

M.P. xxv. Tigif.

M.P. $\times x v$. Bidil Municipium.

M.P. Xvi. Tubufuptus.

M.P. Xvi. Saldis Colonia.

M.P. $\mathrm{x} I \mathrm{r}$

M.P. $x x \operatorname{li}^{2}$

M.P.XL.

M.P. $\operatorname{LXXIX}$. Sic.

Iter Saldis Igilgili. M. P. CLIx. Sic.

M.P. xvill Ad Sava Municipio.

M.P. xr111. D Sitifi Colonia.

M.P. $\times \times v$ Satafi.

M.P. xxv, Ad Bafilicam.

Ad Ficum.

Igilgili.

M.P. $x \times x$

M.P. XxV

M.P. XXIIII.

M.P. xvi.

M.P. XVI.

M.P. $x y$

M.P. $x \times x I 11$

Iter à Lambefe Girta. M.P. Lxxxiv. Sic.

Tamugadi.

Ad Rotam.

Ad Lacum Regium.

Cirta Colonia.

Iter à Mufti Cirta. M. P. cxcrx. Sic.

Timphadi.

Vegefela.

Maicula.

Glaudi.

Tamugadi.

Lambefe.

Diana.

Nova Petra.

Gemellas.

Sitifi.

M.P. xx. Sicca.

M.P.xviri Naraggara

M.P. Xxir. Thagura.

M.P. xxir. Tipala.

M.P. xirtr Gafaufula.

M.P. xxxri1. F Sigus.

M.P. XIIII. Cirta.

M.P. XXIr.

M.P. XXv

Iter à Cirta Hippone Regio M.P.xcri I. Sic.

Iter à Turri Cafaris Cirta. M.P. xI. Sic. Aquis Tibilitanis.

Ad Villam Servilianam.

M.P. $X Y$

Hippone Regio.

M. P. XXV

Sigus.

M.P.Xv.

M.P. $x \times y$.

Iter à Tamugadi Lamasbam. M.P. IxIr. Sic. G

Iter ab Hippone Regio Carthagine. M. P. ${ }^{8}$ CCXvili. Sic.

Tadutti.

Diana Veteranorum.

Lamasba.

M.P. xxvirr. Onellaba.

M.P. xv1. Ad Aquas.

M.P. XVIII. Simittu Colonia.

Bulla Regia.

Iter à Lamasba Sitif. M.P. LxI . Sic. Novis Aquilianis.

Iter à Lamasba Sitif. M.P. LxI . Sic. Novis Aquilia

Zarai.

M.P. $x \times v$.

M.P. XII. Tuburbo Minus.

M.P. xxv. HCigifa.

Carthagine.
M.P. xxx.

M.P. $x x$

M.P.Xx.

M.P. $x \times x i 1$ :

M.P. $\mathrm{xxx}$

M.P. 7 Xxxiv

M.P. xxxy.

M.P. XXXIXI.

M.P. XXV.
Perdicibus.

Sitifi.

Iter à Calanta ${ }^{5}$ Rufuccuro. M.P.cccxcinit.Sic.

Ad Rubras.

Ad Albulas.

Ad Dracones.
M.P. $\mathrm{xx}$.

M.P. $x x x$.

M.P. XIIII.
Item alio Itinere ab Hippone Regio Cartbagine. M. P. ${ }^{10} \mathrm{CCXXVIII.} \mathrm{Sic.}$

Tagalte.

M.P. LIII.

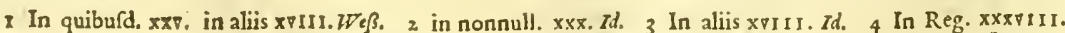
Swr. 5 In aliis Cala. 6 In Vatic. $x c r i x . W e \beta, 7$ In Reg. $x \times 17$. Sur. 8 In Vatic, cexxpr11. We $\beta$, g In non-

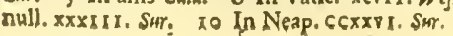


Naraggara.

Sicca Veneria.

Musti.

Membrefla.

Sicilibba.

Unuca.

Pertufa.

Cartlagine.

M.P. xxv. A Iter i Tufdro Therefte. M.P. cxcv. Sic. Excerpta M.P. $x \times x 11$.

M.P. Xxxi11. Vico Augufti.

M.P. xxxy. Aquis Regiis.

M.P.xvir. Mafclianis.

M.P.xirr. Sufctula.

M.P. vir. Cilio.

M.P.xiIII. Meneggere.

Iter à Thenis Thevefte. M.P. cIxxv. Sic.

Ovifee.

Amudarfa.

Autenti.

Sufetula.

Vegefela.

Mencgefem.

Theveite.

Iter ab Aquis Regis Sufbus. M.P.xuII I. Sic.

M.P. Xxy.

M.P. xxv.

M.P. $x x y$

M.P.xxx.

M.P. $x x x$.

M.P. $x x$

M.P.xx

M.P. Xv.

Marazanis.

Sufibus. ex

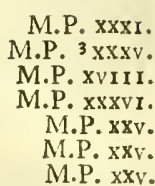

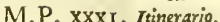
M.P. $x$ Y I

P. XXXVI.

M.P. $x \times$.

M.P. $x x y$.

B Item alio Itinere à Thevefte Tufdrum. M.P. CLXXXV. Sic.

Meneggere.

Cilio.

Sufctula.

Mafclianis.

Aquis Regiis.

Germaniciana.

Eliæ.
C Turdro.
M.P.xxv.

M.P. xxv.

M.P. xxv.

M.P. Xxxvi.

M.P. XVIII.

MiP.XX1III.

M.P. XVI

M.P.XYIII
1.P. XXVIII

Iter ab Affuris Thents. M.P. cXcII.

Tucca Terebinthina.

Sufibus.

Sufetula.

Nara.

Madaffuma.

Septimunicia.

Tabalta.

Macomadibus.

Thenis.

Iter ì Tuburbo per Vallos Tacapas. M. P. cCcvili. Sic.

Valiis.

Coreva.

Mufti.

Afluras.

Tucca Terebinthina.

Sufibus.

Sufetulam.

Nara.

Madaffuma.

Septimunicia.

Tabalta.

Cellis Ficentinis.

Tacapis.

M.P.xy.

M.P. XXv.

M.P.xxv.

M.P. xv.

M.P. $\times x v \cdot D$

M.P. xxy.

M.P. $x x$.

M.P. $x v$.

M.P.xv11.

Tuidro.

Marazanis.

Aquis Regiis.

Vico Augufti.

Adrumetum.

M.P. ${ }^{4}$ XXVIII.

M.P. $x x$.

M.P. $x x \times v$.

M.P. Xxv。

A Sufetula Clypea. M.P. ${ }^{3}$ ccxvi. Sic.

Mafclianis.

Aquis Regiis.

Vico Augufti.

Adrumetum.

Horrea.

Putput.

Curubi.

Vel Neapoli.

M.P. xviri. Clypeis

M.P. xx. I

M.P.Xxvi.

M.P. $x \times x$.

M.P. $\operatorname{xxxvI}$.

M.P.xVII

M.P.xxxv.

M.P. $x \times v$.

M.P.XVIII.

M.P. ${ }^{6} \mathrm{XXX}$.

M.P. $\times x \vee I$.

M.P. XII。

M.P. XX. M.P. $\operatorname{ccccxxI1}$

Iter à Carthagine in Byzantio Sufetula ufque. M.P. 'clXxir, Sic.

\section{Unuca.}

Vailis.

Coreva.

Mufti.

Affuras.

Tucca Terebinthina.

Sufibus.

Sufetula.

Iter à Carth.rgine per Adrumetum Sufetula ufque. M.P. схс. Sic.

Vina.

Putput.

Horrea Cielia.

Adrumetum.

Vico Augufti.

Aquis Regiis.

Mafclianis.

Sufctula.

I In nonnull. CLXul, Sur. 2 In nonnull. $X X 1 r, W e \beta .3$ Audius hoc eft intervallun millibus $x$, ut priora itinera indicant. Weff. 4 In Neap. Maratanis M.P. XVIII. Surr. 5 In Neap. \& Longol. ccexvi. Sur. 6 Supra ex Putput Vico Horrea Calia. M.P. xxxi I. Sur. 7 Vid. Not. 6.
M.P.Xi1.

M.P. $x \times v$.

M.P. $x \times v$

M.P. Xv.

M.P. $x x x i 1$.

M.P. Xxv, Iter à Carthagine Thenis.

M.P. xx. Inde Lepti Magna.

M.P. xxx. F Inde Alexandria.

M.P. xxx.

Maxula Prates.

Cafula

Curubi.

Clypeis.

M.P. x.

M. P.Xx.

M.P. $\times x v$

M.P. $\operatorname{ccxv}$ I 1 . M.P. DCCCCII. A Curthagine.

Maxula Civitate.

Vina Civitate.

Putput Vicus.

M.P. Xxir. Horrea Cælia Vicus.

.P. $x_{111}$. Adrumetum Colonia.

M.P.xxvi. Tufdro Colonia.

M.P.xx. G Ufula Civitas.

M.P. ${ }^{2} \times I 1$, Thenis Colonia.

M.P. xxv. Macomadibus Municipium.

Cellas Vicus.

Tacapas Colonia.

Agma five Fulgurita Villa.

Gitti M nicipium.

Ponte Zita Municipium.

M.P.xxxi I. Villa Magna, Villa Privata. P.P.X. Fifida Vicus.

.

M.P.x. Sabrata Colonia.

M.P. XVIII,

M.P. xxvisi,

M.P. $\mathrm{x}$

M.P. ${ }^{7} \mathrm{XXx}$.

M.P. xvili.

M.P.xVIII,

M.P. XxxiII.

M.P. $x \times x 11$.

M.P.XXiII.

M.P. Xxvi II.

M.P. XXVI.

M.P. Xxx.

M.P. $x \times v$.

M.P. $\times x \times v$.

M.P. xxx.

M.P. $x \times x i$.

M.P. XXVI.

M.P. $x^{x x}$.

M.P. $x \times v$. A Telepte Tacapas. M.P. cxirr. Sic.

M.P. $x$ III

Gemellas.

M.P. $\operatorname{xxir}$.

.


Excerpta Gremellas.

ex Caple.

Iinerario. 'Thafarte.

Aquas Tacapitanas.

Tacapas:

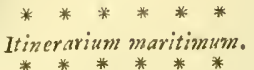

M.P. xxv. A Si Curubi.

M.P. xx1111. Si Neapolim.

M:P. xxxy. Si Adrumeto. Stadia ${ }^{2} \mathrm{MDXL}$

Stadia DCCCC.

Siadia $M C$

M.P.xvi1 1. Iter à Portu Augufti Urbis trajectus in Africam

Carthaginem. Stadia $\overline{\mathrm{VCCL}}$

A Lilybxo de Sicilia in Carthaginem. Stadia M. D.

A Caralis Sardiniz trajectus in Portum Augufti.

Stadia III

A Caralis trajectus in Africam Carthaginem. Stadia M.D.

A Maritima Infula trajectus in Africam, id eft

Stadia. 'DCcC. fcripta. Stadia. DCCCC.

Si Miffuam Givitatem Provincix. Stadia M.

A Miffua Curpos.

A Carpis Carthagine.

Stadia CCC.

Stadia CL.

Si autem non Carthagine, fed fuperius ad Libyam verfus volveris adplicare, debes venire de Sici-

lia ab Infula Maritima in Promuntorium Mercuri.

Si Clypea.

Stadia DCC.

Stadia DCC.

A Galata Tabracam in African. Stadia cc C.

Ante Promontorium Apollinis Agimurus Infula àrthagine. Seadia ccxxx

Infula Cercina. Hæc à Tacapis diftat Stadia DCXXI1.

Infula Girba, à Gitti de Tripoli Stadia xc.

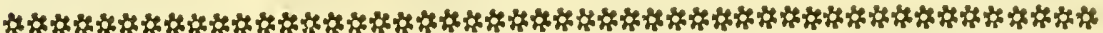

\section{ExcER PT a ex Athico; \& ex F. Honorii Excerptis.}

\section{OCEANI MERIDIANI CONTINENTIA.} Ex Euhico
p.47.

Maria i

Oceanus meridiunus bubet,

Infiulas xuri

Montes VI,

Provincias X1 I,

Oppida LX1v,
Flunina II,
Gentes Mazices mul-
tas.

Oceanis meridicmus babet maria,

Mare Carpathium \& Tyrrhenum.

Occani meridiani infula funt,

$\begin{array}{ll}\text { Sicilia, } & \text { Corfica, } \\ \text { Pontia, } & \text { Galata, } \\ \text { Carpathos, } & \text { Capraria, } \\ \text { Pantatoria } & \text { Fortunati, } \\ \text { Sardinia, } & \text { Egilio, } \\ \text { Cofrofa, } & \text { Syrtis minor, } \\ \text { Inara, } & \text { Catabathmon, } \\ \text { Syrtis major, } & \text { Girbe. } \\ \text { Loci Capri, } & \end{array}$

Oceani meridiani montes funt,

Pyramides,

Peronicæe,

Perratus',

Panteus, vel Panceus,

Atlas,

Oceanus meridianus babet provincias,

A.gyptum,
Atthiopian,
Africam,
Getuliam,
Leugi
Numidiam,
Libyan',

Pentapolim,

Tripolim,

Mauritaniam-Cafaream,

Mauritaniam-Sitifen-

iem,

Byzacium?

\section{Oceamus meridiamus babet oppida,}

Arabiam,

Nitiobres,

Folfam Trajani,

Thebeas,

Thebais,

Beronicen,

Ammon,

Tholomaidis,

Cyrenix

Fileno,

Naret:,

Oea,

Sabratam,

Leptis magnam,

Thacapas,

Dixilun 8 ,

Thenis,

Tapios,

Leptis ninorm,

Hadrumetum,

Neapolin,

Clypeis,

Carthaginem,

Uticam,

Hippone Zarito,

Thabracam,

Ippone regio,

Ruficcade,

Calli 9 ,

Saldis,

Quinque gentiani, Ruifuccura to, Tipafa,

Crefarea,

Chartennas,

Portus magnus,

Experides,

Ballos,

Laribus,

Siccens"s.

Obla,

Sufulis,

Affuris,

Zama regia,

Sufibus,

Suffetula,

Cilio,

Theleptis 12 ,

Capfe,

Admedera,

Thefueftis'3,

Madauros,

Tuburficunu, vel Tuburficumi,

Midorum,

Calaman,

Conftantinam,

Mileu,

Tamulyade,

Lambefre,

Sitifi,

Magrire,

[Tavi, vel] Zabi,

Tabufutia is Bioa16.

Oceanus meridianus babet fluminu duo,

Nilun \& Bagradam.

I Habet regium exemplar \& reliqua, Stadia Dcccc. Sur. 2 In Reg. C1J. L. in Neap. I. D. LX. Sur. 3 Melius ut in F. Honorii excerptis, Pansilaria. 4 Ibid. Beronice. 5 Ibicl. Feratus. 6 Ibid. Zengis. 7 Byzacium, vel Byzantium ut poftea fcribitur, fupplendum effe videtur eX 7 . Honorio, ut fux XII Prov. numero completa

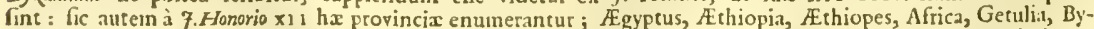
Zacium, Zeugis, Ninizia, Libya, Pentapolis, Trifpolis, Mauretania. 8 Ibid.Ibufdrum. g Ibid.Culli. Io Ibid. Ru-

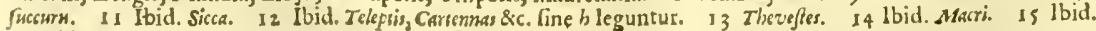
Tubrfubur. 16 Ibid. Bida. 
Horum Nilus, qui \& Geon appellatur, de fecre-Aoccafu habet Mauritaniam Sitifenfem : à meridie Excerpta tioribus promit: ied in exurdio in AEthiopia videtur, \& facit lacum magnum, qui currit in circulo, inftagnans millia CL I v \& exiens de eo lacu, pervenit ad cataractas vetcriores : conficit millia CCCCLXXIV.

Fluvius Bagrada cum Provincix Africe magnus nobilifque \& unicus fit, cur à majoribus* inter fluvios non nominatus hit ignoramus.

Oceanus meridianus babet invumerabiles Gentes, quæ nec colligi numero, nec exiftimari aut comprehendi præ interjacentibus eremis poffunt.

Africe (p.52.) principium eft à finibus $2 E g y p t i$ urbifque Alexandria, ubi Partbeno civitas fita elt, fuper hoc mare magnun, quod omnes plagas terraque medias interluit. Unde per loca, qux $\mathrm{Ca}$ tabatbmon vocaut, jam procul aे caltris Alexandr Magni, \& fuper lacum Galearum, deinde juxta fuperiores fines Auafitarum miffa in tranfverfum per Atbiopia deferta meridianum contingit oceanum. C Terminus Africa' eft qui \& Europuc: id eft, fauces Gaditani freti. Ultimus autem finis ejus eft mons Atlas, \& infulx, quas Fortunatas vocant.

$$
\text { * * * * * }
$$

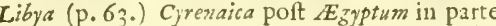
Africa prima eft. Hiec incipit a civitate Partbenio \& Catabathmo: inde fecundo mari ufque ad aras'Philenorum extenditur, \& ufque ad oceanum meridianum: qux habet gentes Libyorum, $E$ thiopum \& Garamantum. ubi eft ab oriente Egy-D ptus, à feptentrione mare Libycum, ab occafu Syrtes majores \& Troglodyta, qux habent ic contra infulam Calypjo, à meridie Atbiopicum oceanum.

Tripolis provincia, quæ eft \& Subventana, vel regio Arz" gum, ubi Lettis Magna civitas eft, qua Arruges per Africe limitem generaliter vocantur, habet ab otiente aras Pbilenorum inter Syrtes Majores \& Troglodytas: aे feptentrione mare Siculum, vel potius Adriaticum, \& Syrtes Ainores; ab E occafu Byzantirm, ufque ad lacum Salinarum; ì meridie barbaros, Getulos, Natauros \& Garamantas ufque ad oceanum Rtbiopicum pertingentes.

Zeuges prius non unius loci cognomentum, fed torius provincix fuit, velut in hodiernum ita à prudentibus accipitur. Byzantium eft, ubi ejus metropolis civitas Hadrumetus fita eft : Zeugis eft, ubi Carthago civiras conftituta eft.

Numidia vocitatur, ubı Hippos Regius \& Ruficcade civitates funt : habet ab oriente Syrtes Mizzores \& lacum Salinarum, à feptentrione mare noftrum, quod fpectat ad Siciliam \& Sardiniam : ab

montem Suggarcm, \& poft eos Atbiopum gentes pervagantes ufque ad oceanum IEtbiopicum.

Sitifenfis \& Cafarianjis Mauritanice funt, quæ habent ab oriente Numidiam, à feptentrione nuare noftrum, ab occafu flumen Malvam, à meridie montem Afrixim, qui dividit inter vivam terram \& arenas eremi jacentes ufque ad oceanum, in quibus oberrant Gangines Attiopes.

Tingi Mauritania Afric o ultima eft totius : hec habet ab oriente flumen Malvam, à feptentrione mare noftrum ufque ad fretum Gaditanm, quod inter Abylenc \& Calpis duobus promuntoriis coartatur: ab occidente habet Ailantem monten \& oceanum Atlanticum, lub africo Hefperium niontem, à meridie gentes Aulolum, quas nunc Galahdas vocant, ufque ad oceanum Hefp.rium contingentes.

Oceani meridiani fuminum ortus of egeftio.

Nilus *****

Fluvius (p.20.) Vagrada nafcitur in Tuburfacu Numidorum pergens per Zeugi inluftrans Regionem egerit in mari Tirreno difparfis crinibus Utice oppida diffunditur.

Fluvius Cartennas nafcitur in campo Mauro inde inluftrans litori maritimo Cefaricnfi mari inDergit.

Fluvius Malda nafcitur fub Infulas Fortunatas circuiens extremam partem Makritanic interdicens inter Barbares \& Vactzates vergit in mari quod appell atur Columne Erculis.

Fluvius Hefperides nafcitur I.IX oppidu in campo in circini rutunditate volbitur. influit in oce2ni ripas meridiani.

Occants meridianus quas gentes habeat.
Hieraficaminas gens,

Nabatæ gens,

Theriodes, Mufubei,

Curbiffenfes, Artennires,

Beitani, Barbares,

Begguenfes, Salamaggenites,

Feratefes, Bacuates,

Barzufulitani, Maffylii,

Fluminenfes, Abenna gens.
Garamantes, Mazices,

\section{Ex c E R P T A ex S.Rufo, P. Oroflo, Martiano Capella; \& Ifidoro Hispalenf.}

\section{E X G E R P T A E X S. R U F O.}

$I^{\mathrm{N}}$ Africam pro defenfione Siculorum Romana tranfmiffa funt Signa. Ter Africa rebellavit: ad extremum deleta per Publium Scipionem Carthagine, Provincia facta eft : nunc fub Proconfulibus agit. Numidia ab amicis regibus tenebatur: fed Fugurtha, ob necatos Adberbalem \& Hiemp $\int a-$ lem Micip $\int e$ regis filios, bellum indictum eft: \& eo per Metellum confulem attrito, per Marium ca- $G$ pto, in populi Romani poteftatem Numidia perve- nit. Mauritania à Boccbo rege obtentæ funt. Sed Excerpta fubacta omni Africa, Mauros Fuba rex tenebat; qui in cauffa belli civilis, à $\mathcal{F}_{\text {ulio }}$ Cefare victus, S. Rufe. mortem fibi propria manu confcivit. Ita Mauritanic noftræ effe coeperunt: ac per onsnem $A$ fricam fex Provincix tact $x$ funt. ipfa ubi Cartbago eft Proconfularis; Numidia, Confularis; $B y-$ zacium, Confularis; Tripolis, \& Mauritania dua, hoc elt, Sitifenfis \& C\&farienfis, funt Præfidiales.* *
Excerpta Hon .

.




\section{EXCERPTA EX P. OROSIO.}

Excerpta Tripolitana provincia qux \& Subventana, vel re-A meridie montes Uzarre: \& poft eos IEtbiopum ex gio Arzugum dicitur, ubi Leptis magna civitas eft, gentes: pervagantes ufque ad oceanum $\mathbb{E}$ tbioP. Orofo. quamvis Arzuges per longum Africe limiten generaliter vocentur, habet ab oriente aras Pbilenorum inter Syrtes Majores \& Troglodytas, ì feptentrione mare Siculum, vel potius Adriaticum, \& Syrtes Minores, ab occafu Byzacium ufque ad lacum Salinarum, à meridie barbaros Getulos, Notbabres, \& Garamantas, ufque ad oceanum Etbiopicum pertingentes. BYZACIUM, ZEUGIS, \& NUMIDIA. Zeugis autem prius non unius conventus, fed totius provinciæ generale fuilfe nomen invenimus. Byzacium ergo, ubi Adrumetus civitas, Zeugis ubi Cartbago magna, Numidia ubi Hippo Rcgius \& Ruficcada civitates funt: habent ab orieute Syrtes Minores \& lacum Salinarum, à feptentrione mare noftrum, quod fpectat ad Siciliam \& Sardiniam infulas, ab occafu Mauritaniam Sitifenfem, à

picum.

Sitifenfis \& Cefaricnfis Mauritania habet abcriente Numidiam, a feptentrione mare noftrum, ab occafu flumen Malvam, aे meridie montem Aftri$x i m$, qui dividit inter vivam terram \& arenas ja centes ufque ad oceanum : in quibus \& oberrant Gangincs Etbiopes. Tingitana Mauritania ultima eft Africa. Hæc habet ab oriente flumen $\mathrm{Mal}$ Bvam, a feptentrione mare noftrum ufque ad frecum Gaditanum, quod inter Abennen \& Calpen duo contraria fibi promontoria coartatur: ab occidente Atlanten montem, \& oceanum Atlanticum, fub africo Hefperium montem, à meridie gentes Aulolum, quas nunc Galaules vocant, ufque ad oceanum Hefperium contingentes. *** *

\section{EXCERPTA EX MARTIANO.}

Excerpta ex
***Velonenfis (P.I42.) Betbice civitas triginta tribus millibus à Tingi oppido difparatur, quæ co- lonia eft Mauritania Cafarienfis. Hujus auctor oppidi Anteus dicitur.

\section{E A F R I C A.}

Africa verò ac Libya dictia ab Afro Libe Hercu-Cultra provinciam Tingitanam, cujus longitudo cenlis filio. In confinio eft Eliffos colonia, in qua Regia Antaci luctamenque cum Hercule celebratur, \& Hcsperidum horti, illic xeftuarium flexuofum, quem draconem vigilem rumor vetuftatis allufit. Nec longè mons Atblas de gremio cacumen proferens arenarum. Hunc incolæ Adirim vocant ; ******* Nec plurimum diftant feptem montes, qui paritate cacuminis Fratres funt appellati, fed elephantorum pleni funt, ac

\section{DE DUABUS MAURITANIIS.}

Utrinfque Mauritania longitudo decies quadra-D tans Siciliam, quæ in altum procurrentia duos efginta trium millium, latitudo quadringentorum fexaginta reptem. Ab Amp Saga Numidia eft nomine celebrata. Numida Nomades dicti, cujus in nediterraneis colonia Cirta, \& interius Sicca, atque Bulla Regia. In ora vero littoris Hippo Regius ac Tabrachia. Interius Zetuitana regio, qux propriè vocatur Africa, habet hxc tria promontoria, Apollinis adverfum Sardiniam, Mercurii refpectum feptuaginta millium eft. Item Siga oppidum eft è regione Malacam urbem Hifpania contemplatur. In littore quoque Carcenna majufque oppidum Cafarea. Iten Icofium xquè coloniam. Item Rufconia \& Rufcurius, Salda etiam, cæeteraque civitates, atque Igilgili, \& Rufarus. Flumen verò Ampfaga abelt a Cajarca trecentis viginti duobus millibus.

\section{DE SECUNDO SINU AFRIC $Æ$.}

Mox alia diftinctio Libya, Phanices vocantur, we, Macomades, Tacape. Sabrata contingens Syrtim qui Byzantinum incolunt, qux regio ducentis quin- E Minorem, ad quam Numidia \& Africa ab Amp $\int a-$ quaginta millibus paffuum circuitur, cujus fatio centefimo meffis incremento foneratur. Hic oppida Puppup, Adrumetus, Leptis, Rufpa, Tap $\int u s$, The-

\section{DE TERTIO SINU.}

Tertius finus dividitur in geminos duarum Syrtium receffus, vadofo ac reciproco mari, fed $M i$ nor Syrtis ì Cartbagine abeft trecentis millibus, ad Majorem vero per deferta pergitur: qux ferpentibus diverfis, ac feris habitantur. Poft hæc Garamantes, fuper hos fuêre Pfillii. In deflexu civitas Ocenfis, \& Leptis Magna. Inde Syrtis Major, circuitus fexcentorum viginti quinque millium. Tunc Cyrenaica regio, eadem eft Pentapolitana Ammonis oraculo memorata, quod à Cyrenis abeft cccc. millibus paffum. 'Utbes maximæ ibi quinque, Berenice, Arfinoë, Ptolemaida, Apollonia, ipfaque Cyrene. Berenice autem in extremo Syr- tis cornu, ubi Hefperidum horti, fluvius Lethon: Lucus facer abeft â Lepti trecentis feptuaginta quinque millibus. Ab ea Arfanoë quadraginta tribus, \& deinceps Ptolomais viginti duobus, proculque Catabathmon \& Marmarides. Et in ora Syrtis Nafamones. Deinde Mareotis Maretonium. Inde Apis Egypti locus, à quo Parethonium in fexaginta duobus millibus. Inde Alexandria ducenta millia. Totius autem Africa a mari Atblantico longitudo cum inferiore Egypto, tricies quadringenta millia. Ab oceano ad Carthaginem magnam, undecies millies. Abea ad Canopum Nili proximum oftum, fexdecies millies octuaginta octo millia. 


\section{EXCERPTA EX ISIDORO.}

\section{DE LI B Y A. CAP. V.}

Libyadicta, $(\mathrm{p} \cdot 340$.) quod inde $L i b s$ flat, hoc eft, A to penè centefimo fruges renafcantur. IZeugis Excerpta Africus. Alii aiunt Epaphum fovis filium, qui Mem- ubi Carthago magna. ipfa eft \& vera Africa inter ex

phim in Asypto condidit, ex Cafiota uxore pro- Bizantium \& Numidiam fita a feptentrione mari Ifidoro. creaffe filiam Libyan, qux poltea in Africa regnum poffedit. Cujus ex numine terra Libya eft appellata. Africam autem nominatam quidam inde exiftimant, quafi apricam, quod fit aperta $\mathrm{Co}_{-}$ lo vel Soli, \& line horrore frigoris. Alii dicunt Africam appellari ab uno ex polteris Abraba de Cetbura, qui vocatus eft Afer, de quo fupra meminimus. Incipit autem a filibus Atgypti pergens B juxta meridiem per Etbiopian ufque ad Atblantem montem. A feptentionalı vero parte, mediterranco mari conjuncta clauditur, \& in Gaditan, freto finitur, habens provincias Libyam Cyreneno fem, Prntapolim, Tripolim, Bizantium, Cartkagincm, Numidiam, Mauritaniam Sitifenfem, Mauritaniam Cafaricnem, Mauritaniam Tringitanam, \& circa Solis ardorem Etbiopiam. S Libya Cyrenenfis in parte Africa prima eft, à Cyrcue urbe metropoli, qux eft in ejus finibus nuncupata. Hinc ab oriente Agyptus eft : ab occalu Sirtes Majores \& Troglodyta: i feptentrione mare Libycum: à meridie Etbioria, \& barbarorum varix nationes, \& folitudines inacceffibiles, quae etiam bafilifcos ferpentes creant. Pentapolis Græca lingua à quinque urbibus nuncupata, id eft, Berenice, Ceutria, $A$ pollonia, Ptolemais, ex quibus Ptolcmais \& Bcrenice à regibus nominatx funt. Eft autem Pentapolis Libye Cyrenenfi adjuncta, \& ejus finibus deputata. I Tripolitanam quoque provinciam Graci lingua fua defignant de numero trium magnarum urbium: Osca, Tabrace, Leftis Magne: hæc habet ab oriente Sirtes Majores \& Troglodytas, à feptentrione mare Adriaticum: ab occafu Bizantium: à meridie Getulos \& Garamantcs ufque ad Oceanum Etbiopicum pertendentes. GBizanzena regio ex duabus nobiliffimis urbibus nomen fortita eft, ex quibus una Adrumetus vocatur, altera Bizantium. Hxc fub Tripoli eft, patens pafuum ducenta vel amplitıs millia, foecunda oleis, \& gle- E ftruthiones. Olim etiam \& elephantis plena fuit, bis ita præpinguis ut jacto ibi femine, incremenSiculo juncta, \& à meridie ufque ad Getulorum regionem porrecta: cujus proxima quxque frugifera funt : ulteriora autem beftiis \& ferpentibus plena, atque onagris magnis in deferto vagantibus. Getulia autem Africa pars mediterranea eft. INunidia ab incolis paffim vagantibus fic vocata, quòd nullam certam haberent fedem. Nam lingua corum incerta fedes \& vagæ, Numidia dicuntur. Incipit autem à Humine Amifga, \& Zeugitanum limitem definit: habens ab ortu Sirtes Minores: à feptentrione mare quod intendit Sardiniam: ab occafu Mauritaniam Sitifenfem: à meridie Atbiopum gentes. regio campis prapinguis. Ubi autem fylveftris eft, feras educat, ubi jugis ardua, equos \& onagros procreat : eximio etıan marmore prædicatur, quod Numidicum dicitur. Habet urbes præcipuas Hipponen Regium, \& Suficadam. Mauritania vocata à colore popu-

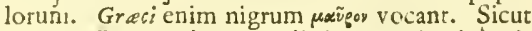
enim Gallia à candore populi, ita Mauritania à nigredine nomen fortita elt. Cujus prima provincia Mauritania Sitifenfis eft, qux Sitifi habet oppidum : à quo \& vocabulum traxiffe regio perhibetur. Mauritania verò $C a$ farienfis coloniæ Cofaria civitas fuit, \& nomen provinciz ex ea datum. Utræque igitur fibi conjunct: ab oriente Numidian habent: aे feptentrione mare magnum : ab occafu flumen Malvam: aे meridie montem $A$ frixim, qui difcernit inter focundam terram \& arenas jacentes ufque ad Oceanum. MMaritania Tingitana à Tingi metropolitaua hujus provinciz civitate vocata. Hæc ultima Africe exurgit aे montibus vrr, habens ab oriente flumen Malvam: à feptentrione fretum Gaditanum: ab occiduo Oceanum Atblanticum: à meridie Gaulalum gentes ufque ad Oceanum Hefperium pererrantes. regio gignens feras, fimias, dracones, \& quos fola nunc India parturit. * ** **

\section{Notitia Episcopatuum Ecclefix Africana.}

\section{PROVINCIE PROCONSULARIS.}

\begin{tabular}{|c|c|}
\hline $\begin{array}{l}\text { A Bbiritanorum ma- } \\
\text { jorum. } \\
\text { Abbiritanorum mino- } \\
\text { rum. } \\
\text { Abiddenfis. } \\
\text { Abitinenfis. } \\
\text { Aborenfis. } \\
\text { Abfafallenfis. } \\
\text { Abzeritenfis. } \\
\text { Advocatenfis. } \\
\text { Agenfis. } \\
\text { Altiburitanus. } \\
\text { Aptugnitanus. } \\
\text { Araditanus. } \\
\text { Affuritanus. } \\
\text { Aufanenfis. } \\
\text { Bencennenfs. } \\
\text { Bonuftenfis. } \\
\text { Bofetenfis. }\end{array}$ & $\begin{array}{l}\text { Bullenfis. } \\
\text { Bullenfium Regiorum } \\
\text { Bulnenfis. } \\
\text { Buritanus. } \\
\text { Cæciritanus. } \\
\text { Caniopitanorum. } \\
\text { Carpitanus. } \\
\text { Cefalenfis. } \\
\text { Cellenfis. } \\
\text { Ceffitanus. } \\
\text { Cilibienfis. } \\
\text { Clypienfis. } \\
\text { Cubdenfis. } \\
\text { Culufitanus. } \\
\text { Curubitanus. } \\
\text { Drufilianenfis. } \\
\text { Egugenfis. } \\
\text { Elefantarienfis. } \\
\text { Furnitanus. }\end{array}$ \\
\hline
\end{tabular}

Gifipenfis majoris.

Giutrambacarienfis.

Gunelenfis.

Hiltenfis.

Hipponienfis Diarrhy-

torum.

Hortenfis.

Labdenfis.

A Lacu dulce.

Larenfis.

Liberinenfis.

Mattianenfis.

Maxulitanus.

Meglapolitanus.

Melzitanus.

Memblofitanus.

Menibreffitanus.

Migirpenfis.

Miffuenfis.
Mullitanus.

Muftitanus.

Muzuenfis.

Naraggaritanus

Neapolitanus.

Numnulitanus.

Ofitanus.

Parienfis.

Pertufenfis.

Pienlis.

Pifitenfis.

Puppianenfis.

Puppitanus.

Rucumenfis.

Saienfis.

Sicilitanus.

Seminenfis.

A Senemfalis.

A Siccenni. 
Siccenfis.

Sicilibenfis.

Silemfilenfis.

Simidiccenfis.

Simittenfis.

Sinnuaritenfis.

Succubenfis

Taborenfis.

Tabracenfis.

Tabucenfis.

Tacapitanus.

Tacianæ-Montenfis.

Taduenfis.

Tagaratenfis.

Tagorenfis.

Tauracinenfis.

Amburenfis.

Ammederenfis.

Aquænovenfis.

Aquenfis.

Arenfis.

Arficaritanus.

Auguritanus.

Aurufulianenfis.

Aufucurrenfis.

Auzagenfis.

Azurenfis.

Babrenfis.

Bagaitanus.

Bamaccorenfis.

Bazaritanus.

Bazienus.

Belalitenfis.

Bofetanus.

Bucconienfis.

Burugiatenfis.

Cælianenfis.

Cæánienfis.

Calamenfis.

Caprenfis.

Cafarum Medianenfium.

Cafenfis Calanenfis.

Cafenfium Nigrenfium.

Caftellanus.

Caftello-Titulitanus.

Cataquenfis.

Centenarienfrs.

Centurienfis.

Centurionenfis

Ceramunenfis.

Conftantinienfis.

Cuiculitanus.

Cullitanus.

Dianenfis.

Abaradirenfis.

Abidenfis.

Acolitaneus.

Adrumetinus.

Afufenienfis.

Aggaritanus.

Aggeritanus.

Amudarfenfis.

Ancufenfis.

Aqux-Albenfis.

Aquenfium Regiorum.

Aquiabenfis.

Arfuritanus.

Autentenfis.

Auzagerenfis.

Bahannenfis.

Bennefenfis.

Bizacienfis.

Bulelianenfis.
Telenfis.

Tennonenfis.

Theodalenfis

Tiburicenfis.

Tiburnicenfis.

Tigimmenfis.

Tijucenfis.

Timidenfis.

Tinnifenfis.

Tifilitanus.

Titulitanus.

Tizzicenfis.

Trifipenfis.

Tuburbiranorum majorum.

Tuburititanorum mi- Vificenfis.

\section{PROVINCIA NUMIDI}

Fatenfis.

Feffeitanus.

Formenfis.

Foffalenfis.

Garbenfis.

Gaudiabenfis.

Gaurianenfis.

Gazaufalenfis.

Gemellenfis.

Germanienfis.

Gibbenfis.

Gilbenfis.

De Giru-Tarazi.

Guirenfis.

Hipponenfium-Regiorum.

Hofpitenfis.

Idafienfis.

Idicrenfis.

Jucundianenfis.

Izirianen fis.

Lamafuenfis.

Lambefitanus.

Lambienfis.

Lambiritenfis.

Lamiggigenfis.

Lamfuenfis.

Lamfortenfis.

Legenfis.

Liberalienfis.

Lugurenfis.

Madaurenfis.

Madenfis.

Magarmelitanus.

Marcellianenfis.

Magomazienfis.

Malculitanus

Matharenfis.

Maximianenfis.

\section{PROVINCIA BYZACENA.}

Cabarfuffenfis.

Capfenfis.

Carcabianenfis.

Carianenfis.

Cebaradefenfis.

Cellenfis.

Cenculianenfis.

Cillitanus.

Cincaritenfis.

Creperulenfis.

Cufrutenfis.

Cululitanus.

Cuftrenfis.

Dicenfis.

Decorianenfis.

Dionyfianenfis.

Durenfis.

Egnatienfis.

Elienfis.
Mazacenfis.

Metenfis.

Midlenfis.

Milevitanus.

Montenus.

Moxoritanus.

Mulienfis.

Municipenfis.

Muftitanus.

Mutugennenfis.

Naratcatenfis.

Nicibenfis.

Nobabarbarenfis.

Nobacæéareenfis.

Nobagermanienfis.

Nobafparfenfis.

Novapetrenfis.

Novatinenfis.

Octavenfis.

Putienfis.

Pudentianenfis.

Regianenfis.

Refpectenfis.

Refianenfis.

Rotarienfis.

Ruficcadienfis.

Rufticianenfis.

Seleucianenfis.

Siguitenfis.

Silenfis.

Sillitanus.

Sinitenfis.

Siftronianenfis.

Suavenfis.

Suficazienfis.

Tabudenfis.

Tacaratenfis.

Tagaftenfis.

Febianenfis.

Feraditanæ majoris.

Feraditan $x$ minoris.

Filacenfis.

Foratianenfis.

Forontonianenfis.

Frontonianenfis.

Gaguaritanus.

Gatianenfis.

Gernifitanus.

Gummitanus.

Gurgairenfis.

Hermianenfis.

Hierpinianenfis.

Hirenenfis.

Horrex Colienfis.

Jubaltianen fis.

Juncenfis.

Limmicenfis.
Mefarfeltenfis.
Volitanus.

Urcitanus.

Urugitanus.

Uticenfis.

Utinenfis.

Utinifenfis.

Utmenfis.

Uvazenfis.

Uzalenfis.

Utzipparitanorum.

Uzitenfis.

Zarnenfis.

Zemtenfis.

Zicenfis.

Zurenfis.

Tagorenfis.

Tamogadenfis.

Tegulatenfis.

Teveftinus.

Tharafenfis.

Tibilitanus.

Tigillavenfis.

Tigifitanus.

Tignicenfis.

Tiniftenfis.

Tapafenfis.

Tifeditenfis.

Tubinienfis.

Tuburnicenfis.

Tuburficenfis.

Tuccenfis.

A Turre Rotunda.

De Turres Ammeniarum.

Turris-Concordienfis.

Vadenfis.

Vadefitanus.

Vageatenfis.

Vagenfis.

Vagrotenfis.

Vaianenfis.

Velefitanus.

Vefelitanus.

Vefceritanus.

Vicenfis.

Villaregenfis.

Ullitanus.

Zabenfis.

Zamenfis.

Zaraitenfis.

Zattarenfis.

Zertenfis.

Zummenfis.

Leptiminenfis.

Macomadienfis.

Macrianenfis majoris.

Mandafumitanus.

Maraguienfis.

Marazanenfis.

Mafclianenfis.

Maffimanenfis.

Mactaritanus.

Mataritanus.

Materianenfis.

Medefeffitanus.

Admedianis Zabuniorum.

Mibiarcenfis.

Midicenfis.

Miditenfis.

Miricianenfis.

Mozotgoritanus. 


\section{EXCERPTA EX VETT. GEOGR.}

Muzucenfis.

Narentis.

Nationenfis.

Nebbitanus.

Ostabenfis.

Octabienfis.

Oppennenfis.

Pederodianenfis.

A Pifranis.

Praccau'enfis.

Pr $x$ fidienfis.

Putizienfis.

Quettorianenfis.

Rutinianenfis.

Rusfenfis.
Rufpitenfis.

Scebal ianenfis.

Seberianenfis.

Segermitenfis.

Septimunicienfis.

Sublectinus.

Sufetanus.

Sufetulenfis.

Sulianis.

Tagamutenfis.

Tagaraienfis.

Tayarbalenfis.

Talaptulenfis.

Tamazenus.

Tambaientis.
Taprurenfis.

Tapfenfis.

Tarafentis.

Tasfaltenfis.

Teleptenfis.

Temonianenfis.

Tenitanus,

Tetcitanus.

Theuzitanus.

Thufdritanus.

Ticenfis.

Tigienfis.

Tigualenfis.

Trofimianenfis.

Tubulbacenfis.
Tuccenfis.

Turenfis.

Turreblandenfis.

Turre-Tamallumenfis.

Tuzuritanus.

Vadentinianenfis.

Vararitanus.

Vaffinaffenfis.

Vegefelitanus.

A Vico-Ateri.

Victorianenfis.

Vitenfis.

Unuricopolitanus.

Ufilenfis.

Uzabirenfis.

\section{MAURITANIA CÆSARIENSIS ET TINGITANA.}

Adquefirenfis.

Adriniodentis.

Alamiliarenfis.

Aliulenfis.

Altabenfis.

Amaurenfis.

Ambienfis.

Aquenfis.

Arfinnaritanus.

Bacanarieufis.

Balianenfis.

Baparenfis.

Bartimifienfis.

Benepotenfis.

Bidenfis.

Bitenfis.

Bladienfis.

Boncarenfis.

Bulturienfis.

C:efarienfis.

Caltadrienfis

Caprenfis.

Caput-Cillenfis.

Cartennitanus.

Caftellanus.

Caftelli-Jabaritanus.

Caftelli-Mediani.

Caftelli-Tatroportenfis.

Caftellominoritanus,

Caftello-Ripenfis.

Caftranobenfis.

Caltrafeberianenfis.

Catabitanus.

Acufidenfis.

Aquæalbenfis,

Afiabenfis.

Afvoremixtenfis.

Caitellanus.

Cedamufenfis.

Celenfis.

Covienfis.

Equizetenfis.

Mimentianenfis.

Ficenfis.

Flumencifpenfis.

Girbitanus.

Abenfenfis.

Abifenfis.

Anguienfis.

Aptucenfis.

Arenenfis.
Catrenfis.

Catulenfis.

Ciffitanus.

Columpuatenfis.

Curniculanenfis.

Elefantarienfis.

Fallabenfis.

Fidolomenfis.

Flenucletenfis.

Florianenfis.

Flumenzeritauus.

Frontenfis.

Girumontenfis.

Gorenfis.

Gratianopolitanus.

Gunugitanus.

Gyparienfis.

Icofitanus.

Idenfis.

Jommitenfis.

Itenfis.

Juncenfis.

Lapidienfis.

Larenfis.

Majucenfis.

Malianenfis.

Mammillenfis.

Manazenenfium Regi orum.

Mafuccabenfis.

Maturbenfis.

Maurenfis.

Maurianenfis.

Maxitenfis.

Medienfis.

Minnenfis.

Muruftagenfis.

Muferticanus.

Nabalenfis.

Nasbicenfis.

Nobenfis.

Nobicenfis.

Novenfis.

Numidienfis.

Nurconenfis.

Obbenfis.

Oboritanus.

Oppidonebenfis.

Opinenfis.

Pamarienfis.

Quidienfis.

Regienfis.

Reperitanus.

Ruiaditanus.

Rufgunienfis.

Rufubiccarienfis.

Rufubiricanus.

Rufuccurritanus.

Rufucenfis.

Satafenfis.

Sereddelitanus.

Serrenfis.

Seitenfis.

Sfasferienfis.

Siccefitanus.

Siguitanus.

Sitenfis.

Subbaritanus.

\section{MAURITANIA SITIFENSIS.}

Gegitanus.

Ab Horrea Aninicenfi. Moptenfis.

Igilgitanus.

Jufitenfis.

Lemeiefenfis.

Lemfoctenfis.

Lefvitanus.

Macrenfis.

Macrianenfis.

Maronanenfis.

A Medianis Zabuniorum.

Nobalicianenfis.

Olivenfis.

Orienfis.

Partenienfis,

Perdicenfis.

Privatenfis.

Salditanus.

Satafenfis.

Serteitanus.

Sitifenfis.
Sucardenfis.

Sufaritanus.

Sufafaritanus.

Sugabbaritanus.

Summulenfis.

Tabazagenfis.

Taborentenfis.

Tabunienfis.

Tadamatenfis.

Talenfis.

Tamicenfis.

Tanudaienfis.

$T_{\text {afaccurenfis. }}$

Ternamufenfis.

Tifiltenfis.

Tigabitanus.

Tigamibenenfis:

Tigifitanus.

Timicitanus.

Timidanenis.

Tingarienfis.

Tipafitanus.

Tubunenfis.

Tufcamienfis.

Vagalitanus.

Vagenfis.

Vanarionenfis

Vannidenfis.

Ubabenfis.

Villænobenfis.

Viffalfenfis.

Voncarianenfis.

Ufinadenfis.

\section{PROVINCIA TRIPOLITANA.}

Leptimagnenfis.

Oeenfis.

Sabratenfis.

Tacapitanus.

I NCERTÆ PROVINCIÆ.

Aufugrabenfis.

Banzarenfis.

Bartanenfis.

Bazarididacenfis.

Belinienfis.
Betagbaritanus.

Botrianenfis.

Buflacenus.

Camicetenfis.

Canianenfis.
Socienfis.

Suriftenfis.

Tamagriftenfis.

Tamallenfis.

Tamafcaninenfis.

Tubienfis.

A Tubufubtu.

Tuccenfis.

Vamallenfis.

enis.

Zallatenfis. 
A Cemeriniano.

Cenenfis.

Cerbalitanus.

A Cibaliana.

Crefimenfis.

Druenfis.

Dufenfis.

Dufitanus.

Editianenfis.

Enerenfis.

Erumminenfis

Fiffanenfis.

Girbitanus.

Gittenfis.

Guzabetenfis.
Honoriopolitanus.

Lamzellenfis.

Laritenfis.

Lucimagnenfis.

Lupercianenfis.

Merferebitanus.

Milidienfis.

Mizigitanus,

Mugienfis.

Munacianenfis.

Murrenfis.

Nalaitenfis.

Nigizubitanus.

Nigrenfium-Majorum.

Pauzerenfis.
Pittanenfis.

Prifianenfis.

Rabautenfis.

Salaniz Giutfitenfis.

Samudartenfis.

Sebargenfis.

Selendetenfis.

Simingitenfis.

Sinniplenfis.

Sitipenfis.

Stabatenfis.

Sululitanus.

Tibaritanus.

Tibuzabetenfis.

Tifanianenfis.
Tugutianenfis.

$T$ nugaivenfis.

Tuutudentis.

Turenfis.

A Turre Alba.

Varianenfis.

Vatarbenfis.

Venfanenfis.

Verronenfis.

Vindenfis.

Vifenfis.

U.imarenfis.

Utimmenfis.

Zertenlis.

\section{IN DEX EP I S COPA T U U M qui fib aliis nominibus in No T I T I A reperiuntur.}

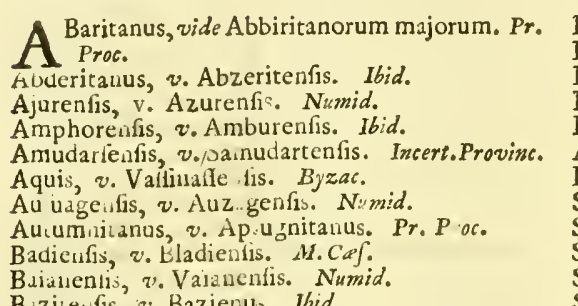

Buziteufis, $z$. Bazienus, Ibid.

Benevente.tis, v. Bencennenfis. Pr. Proc.

Berceritan s, $v$. Vefceritanus. Nimid.

Bilcenfis, v. Viltentis. Pr. Proc.

Boaneufi,, $v$. Bahannenfi. Byzac.

Bocconienfis, v. Bucconienfis. Nimid.

Bo?etanus, v. Bofetanus. Ibid.

Bull menfis, v. Bulelianenfis. Byzac。

Burcenfis, $v$. Burugiatenfis. Nimid.

Bufitanus, v. Bofetenfis. Pr. Proc.

Canapii, v. Caniopit anorum. Ibid.

A Cafis Silvanx, v. Sulianis. Byzac.

Caftrenfis, v. Cuftrenfis. I Ib.d.

Caftro-Galbenfis, v. Gilbenfis. Numid.

Cicfitanus, $v$. Ceffitanus. Fr. Proc.

Circenfis, v. Conftantinienfis. Nimid.

Circinitanus, v. Cincaritenfis. Bizac.

Cirtenfis, $v$. Conftantinienfis. $N_{w}$ mid.

Ciumtuturbonenfis, v. Tuburbitanorum majorum. Pr. Proc.

Culcitanenfis, v. Culufitanus. Ibid.

Cunculianenfis, v. Cenculianenfis. Byzac.

Elibienfis, v. Cilibienfis. Pr.Proc.

Eudalenfis, $v$. I beodalenfis. Ibid.

Feracimaienfis, v. Feraditanæ majoris. Byzac.

Fuffalenfis, v. Forfalenfis. Numid.

Gauvarizanus, v. Gagusritanus. Byxac.

Gazabianenfis, v. Gaudiabenfis. Numid.

Girenfis, v. Gu renfis. Ibid.

De Giru-Marcelli, $\approx$ Marcellianenfis, Ibid.

Giut\{enfis, v. Sa.arize Giutfenfis. Incert. Prov.

Helienfis, v. Elienfis. Byzac.

Hizirzadenfis, v. Izirianenfis. Numid.

Horrenfis, v. Orienfis. M. Sitif.

Jerafitenfis, $v$. Jufitenfis. Ibid.

I enfis, v. Hirenenfis. Byzac.

Irpianenfis, v. Hierpinianenfis, Ibid.

Leniellenfis, v. Lemeie enfis. M. Sitif.

Legifvolumini, v. Legenfis. Numid.

Manaccenferitanus, $\vartheta$. Manazenenfium regiorum. M.Cef.

Marrenfis, v. Murrenfis. Incert. Prov.

Milianerifis, v. Malianenfis. M. Cas.

Mozorenfis, v. Moptenfis. M. Sitif.

Municipii Togiæ, v. Tuggenfis. Prov, Proc.

Mutecitanus, v. Murertitanus. M.Cef.

Panatorieulis, $v$. Vanarionenfis. Ibid.
Pappianenfis, v. Puppianenfis. Pr. Proc.

Parienfis, v. Pienfis. Ibid.

Peradamienfis, v. Feraditan $x$ minoris. Byzac.

Poco-Feltis, v. Vilienfis. Prov. Proc.

Rebianenfis, v. tebiane..fis. Byzac.

A Robunda, v. A Turre ro unuâ. Nimid.

Rubicarientis, v. R inbiccarienfis. $M . C d \mathrm{f}$.

Sacubafenfis, v. Succubenfis. Pr.Proc.

Safuritanus, $v$. Arfuritanus. Byzac.

Sedelenfis, v. Selendecenfis. Incert. Prov:

Segermitanus, v. Gernifitanus, Byzac,

Septenfis, v. Seltenfis. M. Cus.

Seitenfis, v. Serrenfis. 1bid.

Simminenfis, v. Semiuenfis. Pr. Proc.

Sinitenfis, v. A Siccenrij. Ibid.

Sirnarenlis, v. Sinnuaritenfis. Ibid.

Suenfis, v. Saienfis. Ibid.

Suggitanus, $v$. Siguitenfis. Numid.

Tabadcarenfis, v. Tabazagenfis. M.Cef.

Tabaicenfis, v. Tabazagenfis. Ibid.

'Tablenfis, $v$. Talenfis. Ibid.

Tamadenfis, $v$. T anudaienfis. I I $b_{i} d$.

Tamazenfis, $v$. Tamicenfis. Ibid.

Tamazucenfis, $v$. Tamicen fis. Ibid.

Taraquenfi, $v$. Mara guseufis. Byzac.

Ticual enfis, $v$. Tigualenfis. $16 . d_{\text {. }}$

Tididitanas, $v$. Ti ecitenfis. Ni mid.

Tinnifenfis, v. Uiniferfis. Pr. Proc.

Tizienfis, $v$. Tigiznfis. Byzac.

Tonnonenfis, v. Tennonenfis. Pr. Proc。

Tullienfis Municipii, v. Municipenfis. Numid.

Tunonenfis, $v$. Tenionenfis" Pr.Proc.

Turditan s, v. Thufdritanus, Byzai.

Turenfis, v. Decorianenfis. Ibid.

Turufentis, $v$. Turudenfis. Pr. Proc.

Tuzudrumes, v. Thufdritanus. Byzac.

Tyficenlis, v. Tijucenfis. Pr. Proc.

Vabarenfis, v. Baparenfis. M.Ces.

Vadenfi:, $r$. Vagenfis. Numid.

Vagradenfis, v. Vageatenfis. Ibid.

Valentinianenfis, v. Vadentinianenfis. Byzac.

Vardimiftenfis, $v$. Bertimifienfis. M. C.ef.

Vazaritanus, v. Bazaritanus. Numid.

Uci-Majoris, v. Urcitanus. Pr. Proc.

Uci-Minoris, $v$. Uzitenfis. 1bid.

Verenfis, $v$. Ucreufis, Ibid.

Vici-Auguiti, v. Noba Cæfarienfis. Numid.

Vici-Cxiaris, v. Nobw Cxfarienfis. Ibid.

Vico-Pacentis, v. Vicenfis. Numid.

Unuzibirentis, $v$. Uzabirenfis. Byzac.

Voncarienfis, $v$. Boncarenfis. M. C. $\int$.

Uraci.anus, v. Urugitanus. Fr. Proc.

U-citanus, $v$. Urugitinus. Ibid.

Uimmirenfss, v. Utmenfis. Jbid.

Ucinunenfis, vel Utunnenfis, v.Utimmenfis. Incert. Prov.

Zellenfis, v. Telenfis. Pr. Proc.

Ziggenfis, v. Zicenlis. Ibid. 
4.

\section{Excerpta ex Notitia Dignitatum omnium tam Civilium quam Militarium in partibus Occidentis.}

D R xfectus PrxtotioIralix. \&c. \&c.

Proconful Afric x cujus Vicarii Sex.

Africa.

\&c. \&e.

Duces duodecim.

Limitis Mauritania Cafarienfis.

Limitis Tripolitani.

\&c. \&c.

Confulares viginti duo.

Per Afric am duo.

Byzautit, alias Byzatii.

Numidia.

\&c. \&c.

Præfides triginta unus.

Per Africam duo.
Mauritanic Sitifenfis.

Tripolitane.

\&c. \&c.

$* \star * * * * *$

Sub Difpofitione viri illuftris Prafedi Pretorio $I$ talia Direce es infra foripte.

Italia. Illyricum. Africa.

Provincix Italix decem \& feptem.

$* * * * * * *$

Illyrici fex.

Africx feptem. $\dagger$

Byzacium.

Nunidia.
Mauritania Sitifenfis.

Mauritania Cafarienfis.

Tripolis.

Prefectus Annone Africa.

Prafectus Fundorum Patrimonislium.

$\star * * * * * *$

Sub Difpofitione viri SpeIabilis Vicarii Africe.

Confulares.

BYZACII. NUMIDIE.

Præfides.

Tripolitane.

Mauritania Sitifenfis.

Mauritania Cefarienfis.

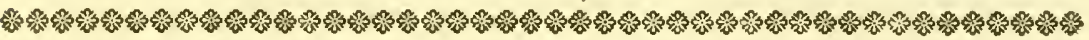

\section{Ex C E R P T A Ravennate Anonymo.}

\section{A $F \quad R$ I C A.}

I. A D partem meridianam, juxta Oceanum, A V. Item juxta Oceanum ponitur patria, qua diA eft patria fpatiofifima AEtbiopum, qux di- citur AEtbiopia iblobatis, quæ confinatur cum fucitur Auxkmitana, \& Candaciffs, \& Troglodytarum. perius dicta Attbiopia Garamantis. In qua Bibio-

II. Ad partem Oceani meridiani Attbiopici, ufque ad mare noitrum magnum $A$ Eypti, eft pa.ria, id eft, fpai iofifima Egyptus inferior \& fupeiior, qua nominatur Adnocura \& Mareotin. * * * *

III. Irem uxta limbum Oceani ponitur parria, qux dicitur Ȧtbiopia Ga:amantium, qux \& Aby/Je dicitur, qux confinalis exiftit pradict $\&$ Ethoop? Traglodytorum. In qua Garamantium pairia, non longè ab Oceano, thuvius Ger dilatiflı̀e currit. In qua patria Garamantium func montes, qui Nauvavon appellantur. In qua patria funt lacus, usus qui vicirur Lycumede, alius A.gita. Qui Atbiopes rupes montium habitare defcribuntur, propter immenfa ac validifima caumara. Ad froncem autem ejufdem Garamantium patria eft arida, deferta, montana, quæ dicitur Marmarydes, Naffamones, Letophagi, atque Blegmies. In qua patria nun-C quam civitares fliffe legimus.

IV. Item juxta mare maguum ponitur patria, qua dicitur Mauritanta, qua dicicur Cyrinen/'s. In qua patria plurimas fuiffe civitates legimus, ex quibus aliquantas defignare volumus, id eft, civitas Cyrenes, qux confinalis eft litoris maris magni cum Agabis civitate AEgyti: Itcm funt civitates, id eft Balacris, Canopolis, Callis, Ptolomaida, Thenchira, Adriani, Bernicide, Comiclano, Anabucis, Ar.e Pbilanortm. Per quam patriam tranfeunt plu-D rimaflumina, inter cetera quæ dicuntur Leon \& tria, dum multum exiltit caumofa, ipfi Mauri cavernas terræ habitant. In qua patria litus Oceani, atque in fuperioribus, maxımus atque fpatiofus detertus e ie defcribitur. In qua patria funt montes, qui dicuntur $T$ illiatodi. In qua patria non longe $\mathrm{ab}$ Uceano, per longum lupra icriptum, luvius $G e r$ dilatifime currit. Ad trontem autem, juxta B'blobatis patrix, per medio mulia f́patia, id eft, detcrta, qux lupra nominavimus, $j u x t a$ mare maynm ponitur patria nimis ipariolifima, quæ dicitur Africana. Cujus patriæ multæ⿱ funt, ut detcriptores philofophi dicunt, ex quibus ego legi Provinum atque Mclitianum genere Afros; fed \& Caftorium Romanorum philoiophum. Sed ego civitates inferius dictas fupradicta Africanse patriæ, fecundum Caftorium defignavi. In qua $A$ fricana patria plurimas fuiffe civitates legimus, ex quibus aliquantas defignare volumus; id eft civitas Tragulis, qux continalis eft litoris maris magni cum fupra Icriptis civitatibus Arophilonor um Cyronenfum. Item Zacaffania, Palma, Ifyri, Sacamadis, Pretorium, M'fol, Difio, Nadalus, Cifternas, Thubact is, Nivergi, Scemadana, Leptifmagna, Pon:tos, Sabrata, Cipfaria, Zita, Githi, Tacapas, Ad Oleaflrum, Macumadi's, Thenas, Taparura, Ufyla, Sublecte, Leptis minus, Rufpinus, Adrymeton, Horea, Neapolis, Clypeis, Sinuama, Carpas, Maxula, Thynus, Cartbago civitas magna, Gallo-Gallinacio, Antiqua Colonia, Ad pertufa, Cefinfa, Tyraria, Utica.

+ Vere non erant nifi VI Prov, computata in his etian Mauritania Cæfarienfi à Duce adminiftrata, \& fupra in Indice omiffa, quonian à Duce regebatur, \&: Africa, à Proconfule recta, ideoque ominffa, quia inter Confulares aut Prxfidiales non numeratur. Verum numerus augetur, quoniam inter prxdictas VIl Africx provincias Nritia Prxfectum annonx Africx, \& Prafectum fundorum patrimonialium recenlet. * *. Hi ramen provinciarum rectores non erant, fed quia amplam habebant adminiftrationem, Prxidibus comparabantur \& pars diacefis Aficanx habebantur. His ergo duobus prafectis adempiti, Provincix Africa VI remanebant, duc Confulares, Byzatium \& Numidia, tres Pralidiales, \& fi Notitia in indice in duas tantum ponat, fc Mauritaniz dux, Sirifentis, \& Catarienfis. \& Tripolis. His addenda eft Africa cuin P'roconfule. itaque funt VII Provincix. vid. Pancetol. Cominent: in Notitiann. p. 116. 
Item ad aliam partem defurer funt civitates, id A Arfenaria, Portsm magnum, Portun divinum, Aleft Marthe, Ajas, Lucerni', Asarmi, Auceritim, bulas. Item fuper aliam partem funt civitates, id Ad putea, Lamie, Afas, Verim, Tingimic, Putea, A- ett Signa mune, Rubras, Sita Colonia; Item ad aliam gafel, Nepte. Item ad aliam partem lunt civitates, parten, fupra jam dictam civitatem Saldas, eft ciid eft Capfalco, Bametbi, Abtan, Tiburbomains, O- vitas qua dicitur Tubufubros, Bidda monicip. Tigilencana, Bitbina, Viva, Bindavicus, Agcrtbel, Cal- fim, Repetiniana, Caftellum, Helepantaria, Aquilicabenedi, Arbelone, Thirufdront, Gruza, Elie, Teren- lidis. Item ad aliam partem funt civitates, id eft tun, Aquas Regis. Item ad aliam partem funt ci- Galaxian, Aucunafta, Lamarafum, Sufafa, Tabavitates, id eft Cabibus, Autbus, Themizec, Manzat, bac, Bambinide, Lecmelli, Balafadais, Baccis, TuAurine, Senana, Cytofori, Thamamulem, Mandate- bonis. Per quam Cafarienfem Mauritaniam plurimule, Selefua, Tarfete, Verofuos, Ad duodecimum, B ma cranfeunt flumina, inter cetera, quæ dicuntur, Leones. Item ad aliam partem funt civitates, id id eft Ufar, Agilaam, Mina, Sira, Tafagora, Ifaris, eft, Thalacte, Monianum, Majores, Batbmetim, Co- Nigreufis, Ligar \& Malba.

rebam, Aitigilen, Ballis, Utbumas, Unuca, Sciciliba, Tyris, Chiffduo, Membrifica. Tranfeunt autem per ipfam Africanam provinciam inter cetera flumina quæ dicuntur, id eft Cepfite, Torrews, \& Panazeron.

VI.Item juxta mare magnum, proxima ejurdem Africane regionis, rejacet patria, quæ dicitur $\mathbf{N u}$ midia Byzancium. Quam Numid:am iidem philofophi, qui fupra nominati funt quidem predictam Africanam regionem defignalle, ipfi \& eandem Numidiam defcripferunt. Sed dum non concordant in civitatibus inferius defignatis, ideo nos fecundum Caftorium Romanorum philotophum, fuprafcriptas civitates e ufdem Numidic nominavimus. In qua Numidia plurimas fuiffe civitates legimus, id eft civitas M:mbronem, qux confinatur juxta mare magnum cum jam prænominat a Utica civitate African regionis. Item civitas Timiffa, Hippone Zarefton, Tabraca, Tuniza, Armonaca, Ufuffa, Hippon regium, Sulucu, Zaca, Rufficade. Nam defuper funt in Numid:a civitates, id eft Semitum, Bulla regia, silma, Sigueffe, Sicabe, Thacora, Grgite, Narragara, Molas, Tipaja, Tibili, Fabianon, Cirta, Quartelli, Palunam, Villam-Cervinam, Lapifede, $\mathrm{No}$ vale, Berrice, Chulcul, Cornon, Baccaras, MileboColonia, Solbeania, Budaxicara, Thenebeftre, Centenarias, Gaufaparas, Pifcinas, Fufcinas, Falavi Marci, Thugurficus, A'tuburus, Mucea, Sufulus, Prafi- E din, Midias, Piffinas, Meffafilta, Duofumina, Simacbi, Lambrefe, Lambridin, Tamafgua, Orgentarium. Item ad aliam partem func civitates, id eft Labafudin, Labiara, rico Aureli, Germani, Thebefte. Item ad aliam partem funt civitates, id eft Thuraria, Thoburbi minus, Cbulcar, Elefantaria, Zicclla, Aovia, Miftin, Theblata, Vico Auguft, Tatia, Drufiliana, Piconi, Novis Aquis, Droxiliana, Siguiffe, Armajdum, Cirta, Gafibala, Medranis, Bagradas, Tepte Colonia, Gemellas, Pago Gemellin, Dabuas. Per quam Numidiam tranfeunt plurima flumina, inter cetera quæ dicuntur Armoniacks, Bagrada, Ubus, Mafaga, Abiga, Publitus, Sadinta, Ame $\int_{2}, A-$ dima, Limcletendum.

VII. Item fuper ipfam Numidiam, in montanis \& planiciis locis eft patria, qure dicitur Mauritasia quafi $R$ ubea, quæ \& Sitifenfis appellatur. $\mathrm{Cu}-$ jus fines à montibus, ufque ad mare magnum pertingunt; nam ad Oceanum nullo modo. Quam patriam fecundum caftorium nominavimus. In qua patria plurimas fuiffe civitates legimus, ex quibus aliquantas defignare volumus, id eft civitas Tuca, quæ juxta mare magnum dividit, incer fuperius dictam provinciam Numidiam, \& ipfam Mauritaniam Sitifenfoum. Item civitas Cbullu, $\mathrm{Pa}$ cianis, Igilgili, Choba mune, Horea, Mufubion. Item ad aliam partem funt civitates, id eft Amabu mune, Gaddo, Leb $x$, Balicin, Vicum, Mobziacia.

VIII. Iterum litus maris magni, eft patria quæ dicitur Mauritania Cafarienfis, quam fecundum Caftorium \& Lolianum philofophos defignavimus. In qua Cafarienfe Mauritania plurimas civitates fuiffe legimus, ex quibus aliquantas defignare volumus, id eft civitas Saldis, quæ juxta mare magnum confinatur, cum Muflubio civitate fuprafcriptæ Mauritanic Sitiferfis. Item juxta civitas Qtás, $\boldsymbol{R}$ feius mune, Lomnion, Ruficuron, Rufgunia, Icofion, Tipasa, Cefares, Gunugus, Larcaflellum, Cartenisa,

1X. Item juxta Oceanum ponitur patria, quxe dicitur Mauritania Perofis, vel Salinarum, quæconfinalis exiftit fuprafcriptæ Atbiopic Biblobatis. In qua Perofium MLauritania maximum defertum effe adfcribitur. In qua patria funt montes, qui dicuntur Lytricus; cujus patriæ poft terga, procul infra Oceanum, Tres Infule inveniuntur. Cujus patriz ad frontem per medium effent efpatia litus maris magni, ponicus patria, quæ dicicur Mauritania Tingitana. Iterum in montanis \& afperis, feu aridiffimis locis, in fuprafcripta Mauritania, quæ dicitur Perofis, quæ ponitur juxta Oceanum Se Mauritaniam Tingitanam, quæ ponitur juxta mare magnum, eft patria magna, qux dicitur Getulia, de qua in fua homelia refert S. Gregorius. In qua Getulia pro aqux inopia, dum longè ab Oceano, \& ad mare magnum amplius, \& flumina ibidem, quæ fiftunt minime, aliquantas fuifie civitates legimus, id eft Thurfurum, Tices, Speculum, Turres, Ciruas. Item litus maris magni juxta Mauritaniam Tingitanam. In qua plurimas tuiffe civitates leginus, ex quibus aliquantas defignare volumus, id eft civitas Tingis, Cadum Caftra, Caftra rova, $\mathrm{Ta}$ facora, Dracones, Tepidas, Fovea rotunda, Ripas Nigras, Sravulum Kegis, Ataba, Taxafora, Fulga, Figit, Gent, Subfelluit, Naffufa. Item ad aliam partem, juxta civitatem, quam diximus Tingin, funt civitates, id eft Turbice, Septemvenam. Per quam patriam, inter cetera tranfeunt Aumina, quæ dicitur Turbulenta, quam alii Davinam appellant.

$X$. Item juxta Oceanum, prope fuprafcriptam Mauritaniam Perofis, eft patria qua dicitur Egel. In qua patria, juxta Oceanum funt montes, ut mons Etbna, qui ardere fcribuntur. In qua patria, juxta Oceanum funt montes excelfi, qui appellantur Praxe. Cujus patrix ad frontem, multis miliaribus fpatiis, id eft litus maris magni, ponitur patria qux dicitur Mauritamia Tingitana.

$\mathrm{XI}$. Item litus maris magni ponitur prædicta Mauritania Gaditana, quæ litus maris magni confinalis exiftit prælatæ Mauritanie Tingitame. Quae Gaditan a patria fupradicta \& barbaro modo Abrida dicitur, ubi gens Vardalorum à Belifario devicta in Africa fugit, \& nunquam comparuit. Quam patriam ego fecundum multoties dictum caftorium defignavi. In qua Mauritania Gaditana plurimas fuife civitates legimus, ex quibus aliquantas defignare volumus, id eft civitas Pareatina, quæ litus maris magni ponitur prope predictum fluvium Malba, longe à portu Stgenje. Item civitas Tingi Colonia, Zili, Tabernis, Lix Colonia, Frigidis, Banafa, Gigantes, Oppido Novo, Tremulas, Septem Fratres, Tamufda, Sala, Gentiano, Explurazio, Boballica, Bobifcianis, Aquis Daticis, Bada, Tocolofron Bobabili, Bonivricis, Gudda, Bati, Argenti, Barluvli, Sidilium, Egelin, Lampica, Fons Afper, Nabia, Maura, Getuli, Selitia, Getulifofi, Getulidare, Turris Buconis, Paurif, Perora. Que fuperius dicta Mauritania Gaditana, quæe \& barbaro modo Abrida dicitur, conjungitur cum treto, qui dicitur Septegaditano qui dividit Mauritaniam ab Hifpania, id eft Africanam provinciam ab Europa. Per quam $\mathrm{Ga}$ ditanam provinciam plurima tranfeunt flumina, inter cetera qux dicuntur, id eft Subulcus, Uhis, Salenfis. ******

T A BUI A 


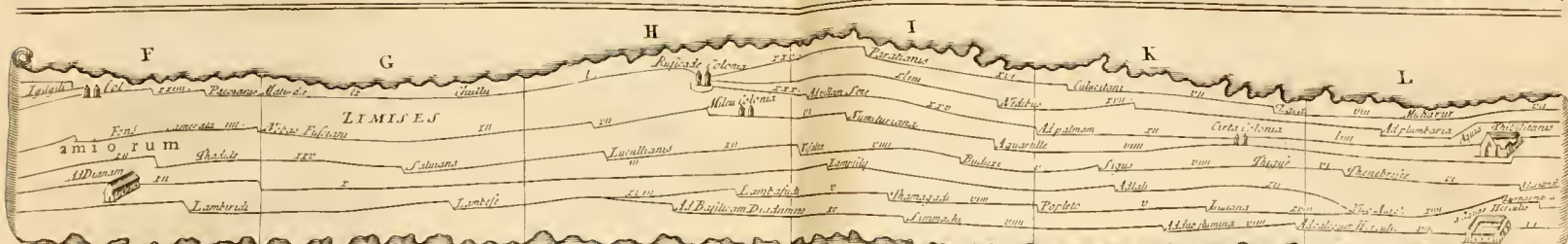

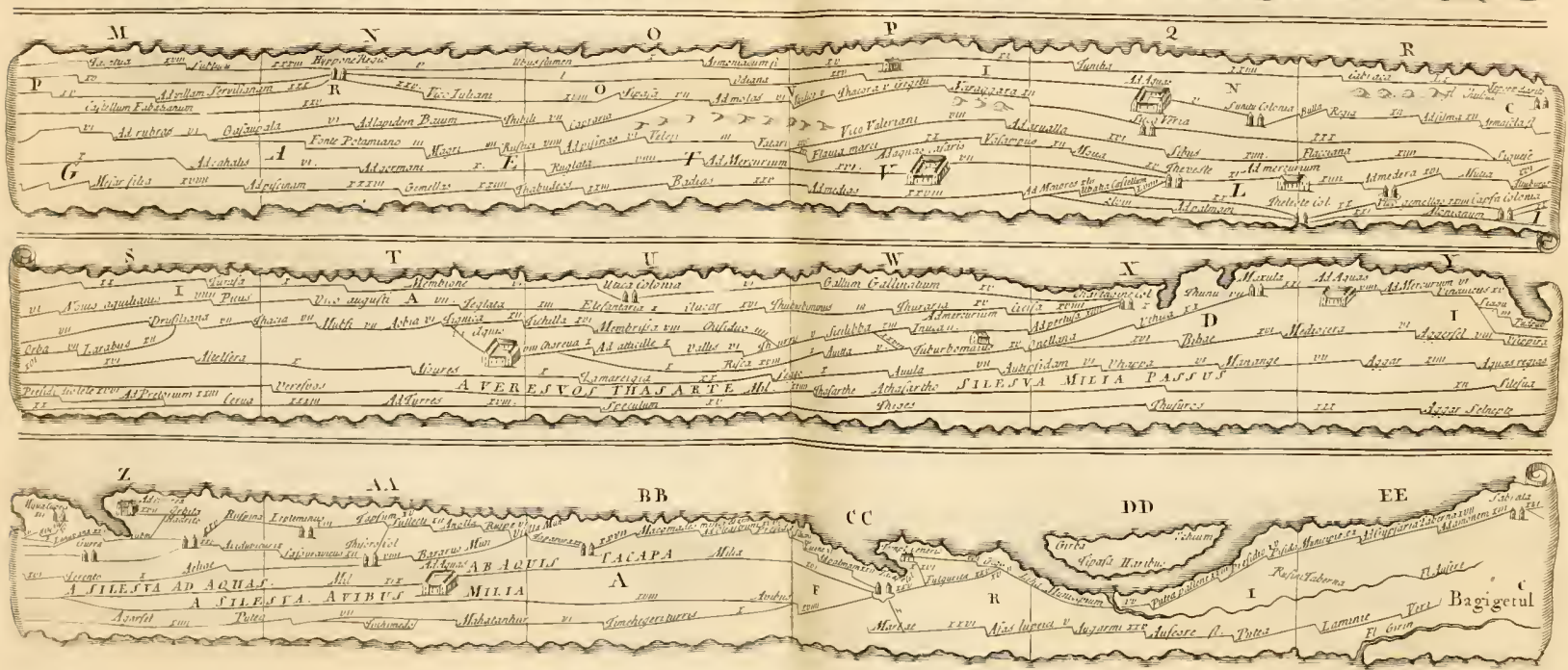





\section{S P E C I M E N}

PHYTOGRAPHIE AFRICANE \&C.

O R A

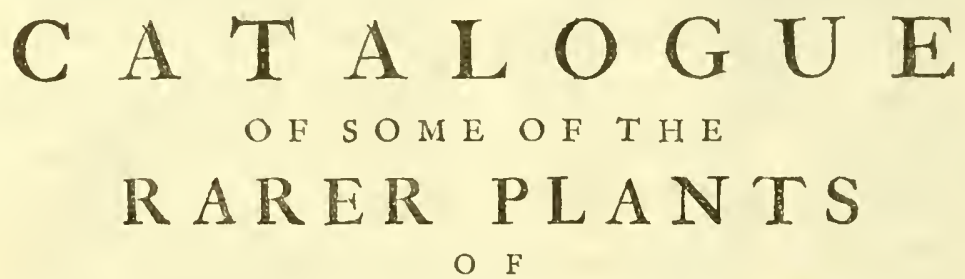

\section{$B A R B A R Y, E G Y P T$ and $A R A B I A$.}

'A

Bfinthiun arborefcens Lob. Ic. 753. J.B. III. 173 .

2 Abrinthium Santonicum Judaicum C. B.P. I 39. Sheab Arabum. Copiofe crefit in Arabia of it defertis Nimidice.

3 Acacia vera J. B. 1. 429. Cum unica fere arbor fit Arabia Pctrea, que conficicndis afferibus inferive poffit, verifimile videtur, effe Shictim S. $S S$.

4 Acanthus farivus vel mollis Virgilii C. B.P. 283 .

5 Acetofa Asyptia, rofeo Seminis involucro, folio lacero Lipp:

6 Acetofa rotundifolia, hortenfis, major Boerh. Ind. Al. II. 86.

7 Acerofa Ocymi folio, Neapolitana C. B. P. I1 4. I. R. H. 503.

8 Acetofa minor, lobis multifidis Bocc. Muf.

9 Adonis fylveftris, flore phoniceo, ejufque foliis longioribus C. B. P. 178 .

Io Adiantum five CapillusVeneris J.B.III.75I.

I Adiantum nigrum officinarum J. B.1II. $7+2$.

I2 Agrimonia minur, flore albo H. Cath. Boerh. Ind. Alt. 179 .

I Alchinilla Linarixe folio, calyce florum albo I. R. H. 500.

14. Alchimilla Linaria folio, floribus \& vafculis in foliorum alis feffilibus. His notis differt a precedenti Specic, que fores fert verfus ramulorum fummitates, longioribus pediculis barentes.

I5 Alchimilla minima montana Col. Ecphr.I. 1.16. Percepier Anglorum Lob.

16 Alaterinus Hifpanica, Celaftrus dicta Boerh. Ind. Alt. II. 213 .

17 Alhenna Alabum. Frutex eft floribus parvis, tetrapetalis, candidis, raccmofis, flaminibus octo, binatim, in pctalorum intervallis, nafcentibus, of $e$ calyce quadrifido exeuntibus, folvis myrtiformbus conjugatis, fructu fcce, quadriloculari, rarius iriloculari, feminibus, Aceto fa inftar, anculatis. Liguftrum Agypriacum latifolium C. B. P. 476. Cyprus Græcorum, Alcanna vel Henne Arabum, nunc Gracis Schenna, Rauwolf. \& Lug. Append. Cyprus Plinij five Alcanna Bell. Ep. 4. ad Cluf́.

I8 Alkekengi fructu parvo, verticillato l.R.H. I 5 I.

I9 Alkekengi frutefcens, foliis rotundis, arcte fibi invicem incumbentibus, floribus albis, calycibus apertioribus.

20 Allium anguftifolium umbellatum, flore albo I. R. H. $3^{85}$.

2 I Aline aquatica, Portulacx folio hirfuto. 22 Alfine maritima, Centum grana Cæfalpino dicta Pluk. Alm. 20. Herniaria Alfines tolio I. R. H. $50 \%$.

23 Alfine maritima, fupina, foliis Chamxfyces I. R. H. App. 665. Franca maritima, quadrifolia, annua, fupina, Chamaryces folio \& facie, flore ex albo purpuraficente Michel. Nov.Gen.23. Flos in quinque petala dividitur ad tubulum coburcntia; ball denuo petala Separantur or arcte ampledtuntur fructum oblongum, pentagonum, monangium, plurimis feminibus fotum. Calyx longus, friatus, quinqucfidus eft. Flores ardte geniculis ramulorum adrafcuntur.

24 Alfine Spergulx facie, media C. B. P.25I.

I.R.H.24. Spergula marina nottras J.B. I11.777.

25 Althxa humilis, repens, foliis Malva vulgaris, flore rubro.

26 Alyffon foliis lanceolatis, contertis, argenteis, Aofculis albis.

27 Alyffon incanum, Serpilli folio, fructu nudo I. R.H. 217.

28 Alyffon maritimum I. R. H. 2 I 7

29 Amaranthus fpicatus, Siculus, radice, perenni Bocc. Rar. 16.

30 Ammi majus C. B. P. I59. 1. R.H. 304.

31 Ammi perenne Mor. Umb. I. R. H. 305.

32 Anagallis cærulca, foliis longis, angutis,

ternis vel quaternis ex adverfo nafcentibus

C. B. P. $25 \%$.

33 Anagallis flore phoenicco C.B. P. 252.

34 Anagyris foetida C.B.P. 39I, 1.R.H. 647

35 Anonis annua erectior, latitolia, gluinofa, Lufitanica I. R. H. 409 .

${ }_{36}$ Anonis non frinofa, flore lutco, variegato C. B. P. 389 . I. R. H. 409 .

37 Anonis purpurea, perennis, foliis latioribus, rotundioribus, profunde ferratis H.Ox. II. I 70. I. R. H. 408 .

38 Anonis Sicula, alopecuroides I. R. H. 408. Anonis purpurca, oblongo, rotundo, prægrandi, integro ferrato folio lucido, fpica alopecuroide H. Cath. Anonis latifolia humilis, non fpiK nora, 
nofa, alopecuroides, flore rubello, Sicula Bocc. App. ad Mur.

39 Anonis vifcofa, fpinis carens, lutea, latifolia Bot. Monfp. Anonis non fpinofa, capreolis donata C. B.P. 389 .

to Autirrhinum latifolium, flore rubro, rictu

luteo Boerh. Ind. Alt. 233.

41 Aphaca Lob. Ic. 70.

42 Apium procumbens, craffiore folio.

43 A pocynum erectum, incanum, latifolium,

Malabaricum, floribus ex albo fuave-purpurafcentibus Par. Bat. 28. Boerh. Ind. Alt. 3 r3. Copiofe crefcit in rallibus prope montem Sinai.

44 Apocynum frutefcens, folio fubrotundo, minore, filiquis ftrictifimis.

45 Arbor Judæe Dod. Pempt. 786

46 Arbutus, Comarus Thecphrafti J.B. I. 83. 47 Ariftolochia rotunda J.B.III. 559. Boruftum Arabum.

48 Ariftolochia clematitis recta C. B. P. 307. 4) Ariftolochia Cretica, fcandens, altiffima, $\mathrm{Pi}$ itolcchiæ folijs Cor. 8. Ariftolochia clematutis ferpens C. B. P. 307.

5o Arum humile, Arifarum dictum, latifolium, piftillo brevi, hirfuto, incurvo H. L. Arifarum latifoliun majus C. B.P. Ig6.

5 I Afparagus five Corruda, fpinis biuncialibus, binis.

52 Afplenium five Ceterach J. B. III. 749 .

53 After conyzoides, foliis anguftis, crenatis.

54 After maritimus, flavus, folio in fummo obtufo H. L. Flor. I. 23. Boerh. Ind. Alt. 95. ก. 15.

55 After pratenfis, autumnalis, Conyzx folio I. R. H. 482. Helenium pratenfe autumnale, Conyz $x$ foliis, caulem amplectentibus Comm.Ac. R. Sc. Ann. 1720. p.303. 11. II.

56 Afterifcus peremnis, foliis longis, anguftis. 57 Alterifcus annuus, foliis ad florem rigidis I. R. H. 497. After Atticus Maffilioticus Tab. Ic. $86 \mathrm{~J}$.

58 Afterifcus annuus trianthophorus, Craffas Arabibus dictus. Folia Chamameli. Caly $x$ e fquamis tenuibus, albo virentibus conftat. Semiflofili finuati funt: Crenas laterales longiores, mediam breviorens babet. Suaviter olet.

59 Afterifcus maritimus, perennis, patulus I.R. H. 498. After fupinus, lignofus, siculus, Conyzæ odore Bocc. Mul. P. II. I61.

6o Aftragaloides Lufitanica I.R.H. 399. Aftragalus Boeticus Cluf. H. ccxxx11t. Foole el $\mathrm{Ha}_{a}$ loufe (f. Faba Apri) Arabum.

61 Aftragalus Africanus luteus odoratis Bot. Monfp. Aftragalus perennis foliis hirfutis, caule recto aphyllo, flore ochroleuco, odoratiffimo H. Ox. Il. 203. Caroube el Maizab (f. Siliqu3 Caprarum) Arabum.

62 Aftragalus annuus, anguftifolius, flofculis fubcrruleis, cauliculis adhrerentibus I.R.H.416. Aftragalus filiquis \& foliis hirfutis, foribus parvis $\mathrm{H}$. Ox. II. II 9 .

63 Aftragalus Bocticus five SecuridicaSicula, $f_{1}-$ liquis foliaceis Bocc. Rar. p.7. 'Tab.4. Aftragalus triangularis Munt. Phyt. Tab.Ic.

64 Aftragalus luteus, annuts, Monfpeliacus, procumbens H. Ox. II. I08. Securidaca lutea minor, corniculis recurvis C.B.P. 349 .

65 Aftragalus Monfpeffulanus J. B. II. 338. I.R.H. 416 .

66 Aftragalus pumilus, filiqua Epiglottidis forma I.R.H. 416 .

67 Aftragalus fupinus, filiquis villofis, glomeratis I.R.H. 46 .

68 Aftragalus tenuifolius, fore fulphureo, filiqृuis tenuiter recurvis.

69 Atractylis multiflora cærulea Comm. Ac. R.Sc. An.1718. p.171.n.8. Carthamus aculeatus Carlinx fulio, flore multiflici, velut umbellato Cor.33.
70 Atriplex angufto, oblongo, folio C.B.P.IIg. H. Ox. I1. Tab.32. Sect.5.

7 I Acriplex :naritima, Hifpanica, frutefcens \& procumbens I.R.H.505. Hort. Flth.46. Fig. 46. 72 Atriplex maritima pumila, Arabica, foliis villofis, fubrotundis. Folia unguis equini figura.

73 Atriplex olida, maritima, pumila, procumbens.

74 Azedarach Dod. Pempt. 848. I.R.H. 616. Eleab Arabum.

75 Balfamita Chryfanthemi fegetum folio, dilco amplo.

76 Baliamita foliis Agerati Comm. Ac. R. Sc. Ann.1719. P.28c. n.2. Bellis fpinofa, foliis Agerati C.B.P.260. Bellis finofa Pr. Aip. Ex.327.

77 Blattaria flore albo J. B. III. 874 .

78 Blattaria magno flore C. B. P. atir.

79 Bryonia alpera five alba, baccis rubris C. H.P. 297 .

80 Buglofum anguftiolium Lob. Ic. 76 .

8I Buglollum Creticum ma us, flore cxruleo, purpurafcente H.R. Par. 1.R.H. I34.

82 Bugloffum Lufitanicum, Echij tolio, undulato I.R.I. I 34 .

83 Bugloflum luteum, annuum, minimum I.R. H.I34. Anchufa lutea minor J.B. IlI. 583 .

8.1 Bugloffum radice rubra, five Anchula vulgatior, floribus cæaruleis I.R.H.134. Anchufa puniceis floribus C. B. P. 255

85 Bugloflim fylveftre majus nigrum C. B. P. 256. Borrago fylveftris annua diCandiaZan.H.48. 86 Bulbocaftanum minus C.B.P. 162.

87 Bulbocaftanum tenuiter incifo folio Lufitanium Vir. Luf. I.R.H.307.

88 Bulbocodium crocifolium, flore parvo, violaceo I.R. H. Cor.5c. Syfirynchium Theophrafti Col. Ec. I. 328.

89 Bupleurum perfoliatum, rotundifolium, annuum I.R.H. 3 Io. Perfoliata vulgatifima five arven fis C.B.P. 277 .

90 Bupleurum arborefcens Salicis folio I.R.H.

310. Selelı Ethiopicum fruticolum folio Periclymeni J.B. III. p.2. 197 .

91 Burfa Paftoris hiriuta, Erucre flore, ftilo prominente. Folia cblonga, furrata, caulem amplectentia. Siliqua birfuta, interdum ex adverfo pofita, brevibus pediculis in jpican digefer, Burja Pafioris for ura, fed majores of altius finuate. Septum medium Geranij feminis inftar exporrectum.

92 Cakile nuaritima, anguftiore folio Cor. 49 . 93 Cakile maritıma, ampliore folio Cor.49. Eruca nıritima, lacifolia, Italica, filiçua haftæ cufpidi funili C.B.P.99.

94 Calamintha Cretica, angufto, oblongo, folio I.R.H. 194.

95 Calcitrapa Hore fulphureo, procumbens, caule non alato. Jacea Cichoriı folio, Hore luteo, capite fpinofo Bocc. Rar. 15. Jacea orientalis fpinola, folio Eryfimi, flore luteo Buerh. Ind. Alt.I +1. In junioribus capitulis, fpirze fuperiores reliquis longiores funt, of caftanei coloris.

96 Calcirrapa laciniata, multiflora, minimo flore, albicante Comm. Ac. R. Sc. Ann. 1718. n.165. Carduus orientalis Calcirrapx folio, flore minimo Cor. 31. Jacea minor \&ic. Pluk. Alm. 192. Tab.39.f.4.

97 Calcitrapa lutea alato caulc, capite eriophoro Comm. Ac. R.Sc. Ann.1718. p.166.n.24. 98 Calcitrapa vulgaris, lutea, alato caule Comni. Ac. R. Sc. Ann. 1718. p. 166. n.21. Carduts Itellatus luteus, foljis Cyani C. B. P. $38 \%$ I. R. H. 440 .

99 Calcitrapoides Rapi folio, alato caule, flore purpureo coronato Comm. Ac. R. Sc. Ann. 1718. p. 168 . n. 1 .

100 Calcitrapoides Sonchi folio, capire magno turbinato Comm. Ac. R. Sc. A.an. 1718. p.16S. n. 10. Carduus ftellatus, latitolius, caulefcens C.B.P.387. 


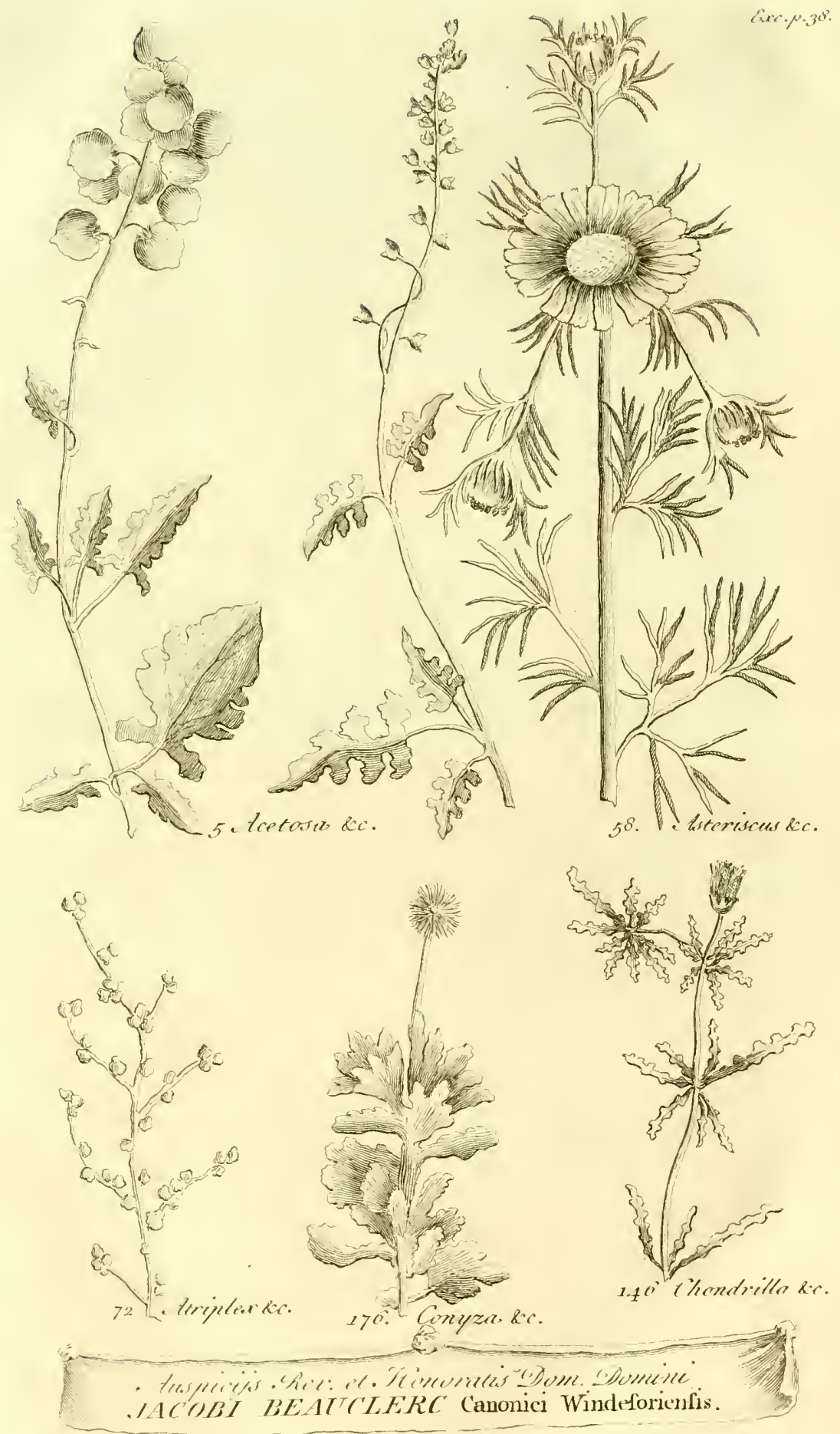




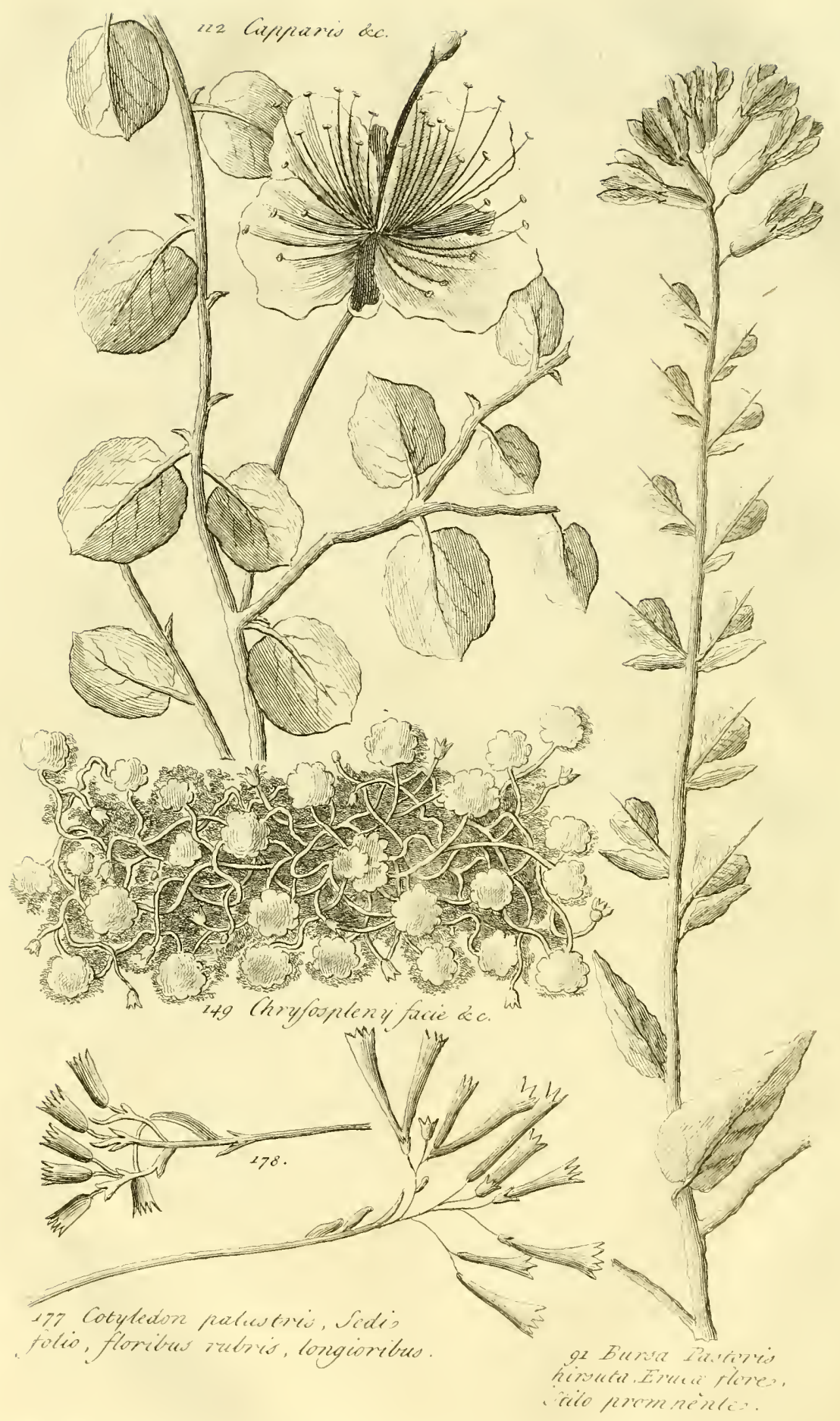




\section{Specimen Phytograpbice Africane \&c.}

ror Calcitrapoides Sphrocephalos, Erucx foli, Comm. Ac. R. Sc. Am. 1718. p. 168. 11. 8. Jacea Tingitana, centauroides \&rc. Pluk. Alm. I9I. Tab. 38 . 1.5 .

102 Calcitrapoides tenui olia, capitulis minoribus, fquan.is uriculpidabus Comm. Ac. R. Sc. Ann.I-I8. n.I7. Carduus Jacex folio, capitulis minuribus, cum fejuamis tricufpidibus I.R.H.t+2. 103 Cal heides foliis oblongis, cxfiis, crailis. Ca yc:m babet Implicen, $n: n$ fquanrofum, in quinque aut plires latas lacinias divefin. Simina yappoja funt \& rivata. Rami in bumum incumbunt.

Io+ Cumpanula rotunditolia, hirfita, faxatilis, foli , molii bocc. App. ad Nute

Ios Campanula hirluta, Ocymi folio, caulem ambiente, Hore pendulo Becc. Rar. 83. I. R. H. 112 .

Io6 Campanula arvenfis, erecta, major, Euphrafix lutex, feu Triffaginis Apulie toliis $\mathrm{H}$. Cath.

107 Campanula maxima, foliis latifimis, flore cxruleo C. B.P. 94. 1.R.H. 108. Trachelium majus Belgarum Cluf. Hift. CLXXII.

108 Campanula radice efculenta, Hore cæruleo H. L. Bat. I.R.H. I I .

Iog Cannacorus latifolius, vulgaris I.R.H.367. 1 o Capparis non fpinofa, fructu majore C. B. P. 4So. I.R.H. $=61$.

I I Capparis fpinofa, fructu minore, folio rotundo C.B.P. 480 . I.R.H. 261.

1 I 2 Caparis Arabica, fructu ovi magnitudine, femine piperis initar acri Bellon. Obf, 1,2,cap.6o. $\mathrm{No}^{\prime}$-ra tricubitalis eft. Folia habet glanca, craffa, fuccul uta, rotunda, uncializ. Fructus, quem vidi, pollicis fut magritudine, oblongus, rucumeris form $\hat{a}$, q"en Araberappollant Felfel Jibbel, i. e. Piper montanum. Copiofe cr.fet in via ad montem Sinai.

II 3 Carlina fore purpureo-rubente, patulo I. R.H. 500. Comm. Ac, R. Sc. Ann. 1718. p. $173 \cdot 11.4$.

II + Carlina acaulos, flore f́peciofo, purpureo, non radiato, radice gummifera, fucco albo \& rubro. Hujus radix Addad diciur. Vid. Leo. Defcript. Afr. 1.2. cap. penult.

I 5 Caryophyllus barbatu; fylveftris C. B. P. 209 .

116 Cafia Fiftula Alexandrina C.B.P. 403.

I17 Cafia Poetica Munfpelienfum Lob. Ic.

433. I.R.H. App. 664 . Cor.53.

i 8 Catanance quorundam Lugd. i go. Catanance cxrulea, femiflofculorum ordine fimplici

Comm. Ac.R.Sc. Ann.1721. P.215. n.1.

in 9 Catanance flore luteo, latiore folio I.R. H. 478. Stabe Plantarinis folio Pr. Alp. Exot. 28 .

120 Caucalis arvenfis echinata, latifolia C. B. P.I52. I.R.H. 323 .

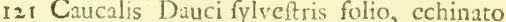
fructu Bot. Monfp. App. I.R.H. 323.

122 Caucalis follo Ccrefolij Riv. Fl. Pent.

Irreg. Cherophyllum fylvestre, feminibus brevibus hirfutis I.R.H. 3 I 4 .

123 Caucalis Myrrhidis folio, fore \& fructu parvo.

$12+$ Caucalis pumila maritima C. B. P. 153 . I. R. H. $3=3$.

I25 Cedrus folio Cuprefi, major, fructu flavefcente C.B.P. 487 .

I26 C.ltis fructu nigricante I. R. H. 6I2.

127 Centaurium luteum, perfoliatum C. B. P. 278.

128 Centaurium minus C.B.P. $2-8$.

129 Centaurium majus laciniatum, Africanum

H. R. Par. App. I. R. H. 44t. Rhaponticoides lutea, altifima, laciniata, capite magno Comm. Ac. R.Sc. Ann. 1718 . p. 180 . n. 30.

I 30 Centaurium majus incauum, humile, capite

Pini I.R H. +49. Rhaponticum humile, capitc magno Strobili Comm. Ac. R. Sc. Ann. 1718.
ค.1 $176 . n \cdot 3$.

I 3 Centaurium purpureum, minimum Mor.H. Bloef. \& H. Ox. II. 506

132 Cerinthe quorundam major, verficolore flore J.B.11I. 602. Clu1. H. CLXVIII. I.R.H.80. 133 Chamxdrytolia lumentofa Mafcatenfis Pluk. Alnı. p.97. Tab.275. f.6. In Numida vidi fine flore. Folia digztis adbarebant, Lappe capitulorum inftar. Ca'yx bexapkyllus. Simina oblonga, punctata, angulata, sofypio obvoluta.

13+ Chamxlea tricoccos C. B. P. 461, Boerh. Ind. Alt. I. 255.

135 Chamæleon Alpinus, Sonchi fpinofo, lucido folio, radice nigra, alato caule Bocc. Rar. 2. I 48. T.28. \& 105. Carcuus Cirfioides nitido glauco folio, capitulo fingulari Comm. Ac. R. Sิc. Ann.I718. n.9.

136 Chamemelum leucantliemum Hifpanicum, magno fiore C. B. Prod.70.

137. Chamemelum montanum, incanum Abfinthioides, Italicum Barr. Obf.11 I I. Ic.457. Comm. Ac. R. Sc. Ann.1720. p.318. n. [4. Leucanthemum Plinii Anguill. 18I. Variat nofirum calyce villofo, rufefcente, cum Italici calyx nigricet.

138 Chamæmelum fpeciofo tore, radice longa fervida. Pyrethrum vulgo o vetcrabus, Arabibus Gunturs dicitur. Hujus radicis magna quantitas ConAantinopolim \& Kairum tranfmittitur, of Saccharo condita in doloribus pectoris \& dentium comeditur. Floris radius amplus eff, fubtus purpureus. Difcus magnus, luteus, ad feminum maturitatem protuberans, fquamis rigidis fipatus.

139 Chamæmelum Lufitanicum latifolium five Coronopi folio Breyn. Cent.I. 149. f.74. Comm. Ac. R. Sc. Ann.1720. p.318. 11.9. Bellis pumila crenata, Agerati æmula, crenis bicornibus, afperiufculis Pluk. Alm.65. Tab. 17. f. 4.

140 ChamænerionSiculum glabrum majus \& nitidum, Amygdali foliol.R.H.303.DifflabArabum. I4I Chamxpitys mofchata, foliis ferratis, an prinla Diofcoridis C.B.P. 240. I.R.H. 208.

I42 Chamæpitys mofchata,foliis ferratis, flore luteo I.R.H. 208. Sande-gourab A rabum.

I 4 Chamæriphes feu Palma humilis, fpiuofa, folio flabelliformi J.B.Ill.37. Doom Arabum. Ad altitudinem vidi feptem aut seto pedum, ramis quotannis e fipite avulfis.

It+ Chenopodium annum humi fufum, folio breviori \& capillaceo I.R.H.5o6. Caniphoratæe congener C.B.P. +86 .

I45 Chenopodium Sedi folio minimo femine fplendente, amnum Boerh. Ind. Alt. II. 9 I.

1 6 Chondrilla minima, repens, Afplenii fcliolis pilofis.

147 Chryfanthemum foliis Matricariæ C.B.P. I34. I. R. H. 49 I.

48 Chryfanthemum folio minus fecto, glauco J. B. III. I.R.H. 492.

I 49 Chrylofplenii folis Planta aquatica, flore flavo, pentapetalo. Habitu eft birfuto, conglomerata, Cufcuta inflar. Flores long is pediculis annexi funt. Petala non fimbriata. Frudtus mitra epifscopalis formâ.Calyx integer arcte fructum a mplectitur.

150 Cicuta major C.B.P. I60. I.R.H. 306.

I 5 t Cinara acaulos, Tunetana, Tafga dicta, magno flore, fuaviter olente, anguitis Cineraria foliis, non fpinofis Till. H. Pif. p.4I. F.I. Tab.20. Radix optimi faporis eft of ab incolis comeditur.

152 Cinara fylveftris, non f́pinofa, flore cæruleo, foliis tenuius laciniatis.

153 Ciftus ladanifera, Monfp. C. B. P. 467. I.R.H.260. Ciftus Ladanifera five Ledon Monfpeffulanum, angufto folio nigricans J. B. II. 10.

154 Ciftus latifolius, magno flore Barr. Icon. 1315 . Obf. $5+7$.

155 Clematitis five Flammula repens C.B.P. 300.1.R.H.293.

156 Clematis peregrina, foliis Pyri incifis C. B. P. 300 .

$\mathrm{K}_{2} \quad$ I 57 Clino- 
If 7 Clinopodium Lufitanicum, fpicatum \& verticillatum I. R. H. Iv2. Prunella Lufitanica capice reticulato, folio Pedicularis Tournefort:i H. Ox. III. 363. Bitumen redolet tota Planta, \& fos magis fimilis videtur Moldavice quam Clinopodii. Miki enim videbutur babere galeain quadrifidam, barbam bifidam.

I5 8 Clymenum Hifpanicum, flore vario, filiqua plana I.R.H.396. Lathy rus vicioides, vexillo rubro, labialibus peralis roftum ambientibus caruleis, filiqua plana $\mathrm{H} . \mathrm{Ox} .11 .56$.

I 9 Clymenum, quod Vicia maxima, Galegx folis majoribus, tetraphylla vel pentaphylla, binatim floribus e viridi flavefcentibus H. Cath.

160 Cnicus cxruleus afperior C. B. P. 378. I. R. H. 450 .

61 Cnicus exiouus capite cancellato, femine tomentofo I. R. H. 45 I. Crocodiloides exigua, purpurafcente coma Comm. Ac. R. Sc. Ann.I 7 I 8 . p. $162,11.2$.

$16_{2}$ Cnicus carulcus, humilis, montis Lupi H. L. B. I. R. H. 4 I. Carduncellus mont is Lupi Lob. Ic. 20. J. B.I1]. 92. Radix dulcis or edulis ef, Gernafidee dicta ab Arabibus.

163 Colocynthis pumila, Arabica, fructu Nucis Juglandis magnitudine, cortice lævi.

164 Colocynthis pumila, echinata, Arabica, itriis duodecim luteis \& viridibus variegata.

165 Convolvulus Althxæ folio Cluf. H.XLix

Convolvulus peregrinus pulcher, folio Betonica

J. B. II. 150. I. R. H. 85 .

166 Convolvulus argenteus elegantiffmus foliis tenuiter incifis I. R. H. 8\%.

I67 Convolvulus Africanus, vulgaris minoris facie, flore ninimo Raij Hift. III. $375^{\circ}$

168 Convolvulus Græcus, Sagitt:e foliis, flore albo Cur. I.

I69 Convolvulus maritimus, noftras, rotundifolius H. Ox. II. I I. Soldanclla Dud. Pempt. 395 .

170 Corchorus five Melochia J. B. II. 982 . I. R. H. 259 .

if Cors carulea maritima C. B. P. Hanzærah Arabum, cujus decoctionem in Lue Ínerea copiofe jumunt.

172 Coris carulea maritima, foliis brevioribus, magis confertis.

173 Coronilla caule Geniftx fungofo I. R. H. 650.

174 Coronilla maritima, glauco folio I. R. H. 650.

175 Conyza caulibus rubentibus, tenuioribus, fore luteo, nudo Bot. Monfp. I. R. H.455.

I 76 Conyza tomentora, Polij foliis crenatis. Planta bac triuncialis eft, fuaveolens, floribus funguLaribus.

177 Cotyledon paluftris, Sedi folio, foribus rubris, longioribus. Flores oblongi funt, Centaurij minoris facie, \& in umbella quaf nafuntur.

178 Cotyledon paluftris, Sedi folio, floribus luteis, brevioribus.

179 Crambe fpinofiffima Arabica, foliis longis, anguitis, floribus in foliorum alis.

180 Crepis Chondrilla folio Comm. Ac. R.Sc. Ann. 1721. p. 195.

I 8 I Crepis folio leviter dentato Comm. Ac. R. Sc. Ann. 1721. p. 195.n. I. Sonchus lrevis, anguftifolius C. B. P. I24. I. R. H. 475. Boerh. Ind, Alt. 85. Terra Crepola o Trinciatella veteribus.

I 82 Cyanus humilis, albus, Hieracii folio I.

R. H. 416 .

183 Cyanus humilis, Hieracii folio, flore purpureo 1.R. H. $4+6$.

18+ Cynoglofum Creticum argenteo, angufto, folio C. B. P. 257 . I. R. H. I 40

185 Cynogloffum argentcum, $\mathrm{H}$ re rofeo $\mathrm{H}$. Cath. Cynoglofum Narbonenfe H. Eyft

186 Cynogloffum Hifpanicum, anguftifolium, flore obfoleto: Variat fore candido.

187 Cynoglofium Myofotidis foliis incanis, flore parvo, ruberrimo. Variat folis \& foribus majoribus.

188 Cyprefius fructu quadrivalvi, foliis Equifeti inftar articulatis. Mediam videtur habere naturain inter Arbores of Frutices; nunquan enim vidi altiorem quindecim pedibus. Folia late virent, in quibus multe fquanula, ut in aliis fpecirbus, $a p$ parent; fed, Equifcti inflar, crebris articulationibus fibi invicem pyxidatim conjunguntur.

189 Cyperus humilis, fpinis brevibus, rotundis, conglomeratis Buxbaum Cent. $1 . \mathrm{p} \cdot 3+$. Tab. 55. f. I.

190 Cyrifus argenteus, linifolius, Infularum Strechadum I. R. H. 647.

I 91 Cyrifus foliis fubrotundis, glabris, floribus amplis glomeratis, pendulis.

192 Cytifus hiriutus J. B. I. 327. I. R. H.64\%.

193 Cytifus hum:lis, argenteus, anguftifolius,

I. R. H. 648 .

r 94 Cytifus foliis, oblongis, fefflibus, glabris, frliquis comprellis, incanis. Folia in fummitatibus plcrumque fngularia funt, \& ipfa fummitates aculeata.

I95 Cytifus minoribus foliis, ramulis tenellis, villowis C. B. P. 390. I. R. H. 647.

196 Cytifus fpinofus H.L.B. I. R. H. 6,8 .

197 Daucus Hifpanicus, umbella maxima El.

Bot. I. R.H. 308 .

I98 Daucus maritimus lucidus I. R. H. $30 \%$. Gingidium folio Chrophylli C.B.P. I 5 I.

199 Dens Leonis foliis radiatis Bot.Monfp.295. 200 Dens Leonis ramofus, maximus, foliis pilofis, finuatis, pedalibus. Hieracium Platyneuron, Burfa Pattoris cxfura, pilofo folio H.Cath, Raij H. IlI. I 45.

201 DigitalisVerbafci folio, purpurea, minor, perennis, Hifpanica Barr. Jc. 1183 . Obf. I8\%.

202 Doronicum Plantaginis folio C. B. P. 18 . Variat folits birfutis of glabris.

203 Dorycnium Monfpelienfium Lob. Ic. 5 I. 1. R.H. 391 .

204 Dracunculus polyphyllus C. B. P. 195. Dracontium Dod. Pempt. 320.

205 Drypis Theophrafti Anguill. Spina umbella foliis vidua C. B. P. 388 .

206 Echinopus Orientalis, Acanthi aculeati folio, capite magno fpinofo cervileo Cor. 14. Comm. Ac. R. Sc. Anll. 1718. P.15I. n. 4. 2c7 Echum Creticum latifolium rubrum C. B. P. 154 .

208 Echium Scorpioides, fpicis longis, plerumque recurvis, Horbus parvis, purpureis. 209 Echium Tingitanum, altillimum, flore variegato H. Ox. III. 140. Pluk. Alm. I33.

210 Elychryfum feu Stocchas Citrina anguftifolia C. B. P. 264 . I. R. H. 452 .

2 I Elychryfum Gnaphaloides, floribus in frictiorem umbellam congeftis.

212 Elychryfum fylveftre latifolium, fore magno, fingulari I. R. H. 452. Comm. Ac. R.

Sc. Aun. 17 Iy. d.291. n.6.

213 Elychryfum fylvettre latifolium fore parvo, fingulari I.R.H. 452 .

$21+$ Ephedra maritima, major I.R.H.663.

215 Equifetum arvente, longioribus feris C. $B$.

P. 16. I. R.H. 533 .

216 Erica humilis, cortice cinereo, Arbuti fore C.B.P. 486 . I.K.H. 602.

217 Erica toliis Corios multiflora J. B. 1. 356.

I.R.H. 602. Erica Juniperifolia, dente fruticans,

Narbonenfis Lob. Ubr. 620 .

2I 8 Eruca Hore albo, foliis fellibus, Burfa Paftoris.

219 Eruca major, fativa, annua, flore albo, friato J.B. 1I. 859 .

220 Eruca pumila, foribus albis, foliis laciniatis

22 I Eruca 


\section{Specimen Phytographice Africance \&c.}

22 I Eruca Romana feu Gentilis, filiqua angutta, folio laco J. B. II. 860. Eruca tylveftris, flore albo Barr. Ic. I 32 .

222 Eryngium amelyyftinum, Lufitanicum, folio longiori 1. R. H. 327. Eryngium minus, montanum, Hore cæruleo, pulchro Vir. Lufit.

223 Eryngium foliis anguftis, digitatis $\mathrm{Hcl}$ lebori.

$22+$ Eryngium Lufitanicum, latifolium, vulgari fimile l.R.H. 327

225 Eryngium muntanum, pumilum C. B.P. 386. I.R.H. 327 .

226 Eryngium planum, minus C. B. P. 386

I.R.H. 327 .

227 Eryngium planum, medium, folijs oblongis. Ab Eryngio latifolio plano C.B.P. 386 diftinguitur, foliis ad canlem longioribus, magis ferratis, o magis fpinofis. Ab Eryngio plano minori C. B. P. foliis amplioribus, in pediculum non contraftis, capitulis minus frequcntibus \& f pinofis diffirt. folio.

228 Eryfimum incanum Arabicum, Mari

229 Fagonia Arabica, longiflimis aculeis armata. Folia angufta just, fucculente, \& Rorifmariti inflar rugofa.

230 Fagonia Cretica frinofa I.R.II. 265.

231 Fabago Arabica, teretifolia, flore coccineo. Fagonioides Memphitica, virens obfcurius, folio craffiori, bidigitato, tereti, fructu cylindraceo Lipp. MiS. apud Pnyt. Sherard. Ox.

232 Fonisculum Lufitanicum minimum acre I.R.H. 312 .

233 Fonum Grxcum fylveftre C. B. P. 348. Fœnum Græcum fylveftre Dalechampii Lugd. 48 I. J.B. II. 365 .

$23+$ Fœnum Grxcum fylveftre alterum, polyceration C.B.P. $3+8$. I.R.H. 409.

225 Ferrum equinum minus, filiqua in fummitate fingulari.

236 Ferula folio Fœniculi, femine latiore \& ro:undiore J.B.Ill.2. I3.

237 Ferula Galbanifera Lob. Ic. 779. I.R.H. 321.

238 Filago fupina, capitulis rotundis, tomento obfitis Barr. Obf. 999. Leontopodium verius Diofcoridis, Hifpanicum ejufdem Icon. 296.

239 Filicula Euphrafix foliis conjuyatis.

2 to Filicula ra i ofa, Lufitanica, pinnulis ad Ceterach accedentibus 1.R.H. 542. H.R.Monfp. 79. Ic, \& Defcript. Filicula Smyrnica, pinnulis ro:undis, minimis Pet. Gaz. T. 75. f. 4 .

2 ti Filix Lonchitidis facic, foliis anguftis, pellucidis, auriculatis.

242 Filix marina, Anglica Park. Th.1045.

243 Filix mas, non ramofa, pinnulis latis, auriculatis, fpinotis Ger. Emac. II 30 . Pluk. Alm. 152. Tab. 179. f. 6 .

${ }^{2}+4$ Filix ramofa, major, pinnulis obtufis, non dentatis C.B.P. 357 . I.R.H. $53^{6}$.

245 Fraxinus cxcelfior C. B.P. 416 . I. R. H. 576.

246 Fritillaria præcox, purpurea, variegata I.R.H.377.

$2+7$ Fumaria major, fcandens foliorum pediculis, fore majore pallidiorc H.Ox. II. 261 .

$2+8$ Fungus Mauritanicus, versucofus, ruber

Pet.Gaz. Tab.39. f.8. Cynomorion purpureum officinarum Michelii Nov. Gen. p. 17. Tab.12. Orobanchen Mauritanicam appellavi Obf. p.264. Tota planta eff fubflantia rubre furgof $a^{\prime}$, glande five capitulo florigcro fucco rubro fcatente; foribus famineis, conftipatis, ardte femina dura, rotundula, amplectentibus.

249 Galeopfis Hifpanica, frutefcens, Teucrii folio I. R. H. 186. Sepibus conficiendis infervit prope Algerium. Per maturitatom, fimina pulpa molli, nigra, bacce infar, involuta funt.
250 Galeopfis annua, Hifpanica, rotundiore folio l.R.H. Marrubium nigrum, Hifpanicun vel Ocymaftrum Valentinum Cluffi1 Park.Th. +5 . Labium floris inferius integrum eft.

251 Galeoplis paluftris Betonicx folio, flore variegato I.R.H.185. Clotung Fliteal.

252 Gallium luteum C.B.P. 335. 1.R.H. 115 . 253 Genifta juncea J.B.1. 345 . I.R.H. $6+3$.

254 Genitta-Spartium Lufitanicum, filiqua

falcata I. R. H. $6+6$.

255 Genifta-Spartium procumbens, Germanico fimile, foliis anguftioribus.

256 Geranium batrachoides, folio Aconiti C. B.P. $317 \cdot$. I.R.H. 266.

257 Geraniun Chium, vernun, Caryophyllatx folio Cor. 20.

$25^{\circ}$ Geranium Cicuræ folio, mofcatum C. B. P. 319. I.R.H. 268.

259 Geranium Cicutze folio, acu longifima C.

B.P. 3 I9. Prodr. 138. I. R. H. 268.

260 Geranium pufillum, argenteum, Heliotropii minoris tolio. Folia, calyces of rofrum argentea funt. Folia eleganter firiata. Pediculi aphylli.

261 Geranium Robertıanum C. B. P. 319.

J. R. H. 268 .

262 Geranium fupinum, rotundo Batrachicidis craffo, tomentolo folio, radice rufefcente, longius radicata I. R. H. 269. Bocc. Muf. Y. Il. Tab. 128. p. 160.

263 Gingidium umberla oblonga C.B.P. I51. Vifnaga J.B. III. .. 31 .

$26+$ Gladiolus floribus uno verfu difpofitis, major C.B.P. +1' Gladiolus five Xiphion J. B. II. 701 .

265 Glaucium flore luteo I. R. H. 254.

266 Glaucium flore violaceo I.R.H. 254

267 Glcbularia fruticora, Myrti folio, rigido, nunc tridentato, nunc plano. Teffelgab Arabum.

268 Gnaphalium maritimum C. B. P. 263.

I. R. H. $46 \mathrm{I}$.

269 Gnaphalium umbellatum, minimum J. B.

III. 26. 162. Comm. Ac. R. Sc. Ann. 1719. p.

$314 . \pi .1$.

270 Gnaplaloides Lufitanica I.R.H. 439.

271 Gramen alopecuroides maximum J. B.

Spica divila Scherardi Scheuchz. Agroft. 247.

272 Gramen anthoxanthum, fpicatum J.B. II. 466. I.R.H. 518.

273 Gramen arvenfe, panicula crifpa C. B.

Th. 32 .

274 Gramen avenaceum, montanum, fpica fimplici, ariftis recurvis $\mathrm{R}$ aij $\mathrm{H}_{\mathrm{ift}}$ I 290.

275 Gramen avenaceum, pratenfe, panicula fquamofa \& villofa H. Ox. III. 213 . Sect. 8. T. 7. ก. 18 .

276 Feftuca avenacea fterilis, paniculis confertis, erectioribus, ariftis brevioribus Raij Synop. 261 .

277 Feftuca altera capitulis duris C.B.P. 10 Th. 151 .

278 Gramen avenaceum, ftrigofius, utriculis lanugine albicantibus. $A$ Gramine avenac. utric. lanugine Havefc. I.R.H. $\{25$. differt locufis minus fparfis, anguffioribus, arifis tenuioribus, lanugine verfus bafin ó ad fimen candidâ. Porro locufece bujus fimplices funt, \& fementantum untm lanuginofum, nudum continent, cujus apex arifla fimpli: terminatur, cum illius locufte gemina contineant femina calyce $f$. Squama involuta, quorum arifia e latere vel dorfo calycis exit.

279 Gramen Barcinonenfe, panicula denfa, aurca l.R.H. 523.

280 Gramen Bromoides, feftucea tenuique panicula minus Barr. Ic. 76. 2 .

281 Gramen Cyperoides, anguftifelium, fpica

\{padiceo-viridi, majus C.B.P. 6. Prodr. 13.J. B. II. 495 .

282 Gramen Cyperoides, aquaticum, majus, panicula Cyperi longi, ex craltioribus glumis L. compacta, 
compacta, \& brevibus petiolis donata Læl. Triumf. in Obf. J. Bapt. Fratris.

283 Gramen dactylum, Siculum, multiplicipanicula, fpicis ab eodem exortu geminis Raij Hift.II. 271. Pluk. Alth. 175. Tab. 92, f.I. I.R.H. 521. $28+$ Gramen dactylon, radice repente, five officinarum I.R.H. 520 .

285 Gramen dactylon, fpica gemina, triunciali, glabra \& ariftata Michel. Cat. H. Pif. Gramen bicorne five Diftachyopheron Bocc. Rar. 20.

286 Gramen humile, capitulis glomeratis, pungentibus. Palmari eft altitudine; caulibus tenuibus uno alterove folio glabro cinctis, quorum fummitatibus capitulum najictur rotundum, epluribus fpicis brevibus, e quatuor aut quinque glumarkm paribus, ariftis brevifjimis, rigidis terminatis, conflatum.

287 Gramen Loliaceum radice repente, five Gramen officinarum I.R.H. 516.

288 Gramen minus, panicula rigida, denfiore \& ampliore I.R.H. 522 .

289 Gramen montanum, panicula miliacea, fparfa C.B.Prod. 17.

290 Gramen nemorofum, fpicis parvis, afperis C. B. P. 7 .

291 Gramen panicula fpicata, villofum, 10cuftis villofis Scheuchz. Agroft. $2+8$.

292 Gramen paniceum, fpica fimplici afpera

C.B.P. 8. Panicum fylveftre dictum \& Dens caninus. I. J.B.II. $4+3$.

293 Gramen paniculatum, locuftis maximis, phoniceis, tremulis 1.R.H. 523 .

294 Gramen paniculatum, minus, locuftis magnis, tremulis I.R.H. 523 .

295 Gramell pratenfe, capillare, paniculatum, locuftis parvis llavefcentibus. Foliz ad radicem capillaria, conferta, ad culmum latiufcula, panicula fpeciofa, e locuftis muticis e tribus aut quatuor fquamarum ad margines argentearum paribus compofita.

296 Gramen pratenfe, paniculatum, medium

I. R. H. $52 \mathrm{I}$.

297 Gramen ferotinum arvenfe, panicula contractiore, pyramidali Raij Synopf. Il. 259.

298 Gramen Sparteum, fpicatun, foliis mucronatis, brevioribus C. B. P. 5. Th. 68. Difs Arabum.

299 Gramen fpica hirfuta, ad gramen cu Gros accedens J.B.II. 438 .

300 Granen fpicatum, folio afpero C.B.Th. 45 . 301 Gramen fpicatum, fpica fubrotunda, echinata I.R.H. 519 .

302 Gramen tremulum maximum C.B.Th.24. 303 Gramen Typhoides, molle C.B. Scheuch.

Agroft. 246.

304 Gratiolx affinis Hyffopifolia major, Lufitanica Flor. Bat.69. Raij Hift. 11I. 526.

305 Hedypnois Cretica, minor annua Cor. 36.

306 Hedyfarum annuum, filiqua afpera, undulata, intorta I.R.H. 4 or.

307 Hedyfarum clypeatum, flore fuaviter rubente Eyft. I. R. H. 40 I. Sellah Arabum, quo faginantur pccora per totam Africam.

308 Hedyfarum procumbens, anıuum, anguttioribus foliis. Onobrychis major, humi projecta, longulo, cordato foliolo, floribus rubris clypeatis, articulatis, filiquis iparfis $\mathrm{H}$. Cath. Raij Hift. III. 457 .

309 Helianthemim Creticum, annuum, lato Plantaginis folio Cor. 18.

$310 \mathrm{Hclianthemum}$ flore maculofo $\mathrm{Col} .2 .77$. I.R.H. 250. Ciftus flore pallido, punicante macula infignito C.B.P. 465.

3II Helianthemum folio Thymi glabro I.R. H. 249 .

312 Helianthemum frutefcens, folioMajoran $x$ incano I. R. H. 249. Ciftus incanus Majoranæ folio Hifpanicus Barr. Ic. 313 .

3r3 Helianthemum Halimi minoris folio Barr. Obr. 527 . Ic. 287 .
314 Helianthemum luteum, Thymi durioris folio Barr. Obf. 521 . Ic. +41 .

3 is Helianthemum Orientale, frutefcens, folio Olex, flore luteo Sher. Boerh. Ind. Alt. 276.

316 Helianthemum Salicis tolio I. R. H. $2+9$

317 Helianthemum fupinum, Polygoni folio, hifpido \& glutinofo.

318 Helianthemum vulgare, flore luteo J. B.

II. 15 . I.R.H. 248 .

319 Heliotropij facie Planta, lanuginofa, ferruginea, pediculis fingularibus. Folia babet $\mathrm{H}_{\epsilon-}$ liotropij minoris, crafja, villofa; calyces speciofos, multifidos; femina quaterna, nuda, ovata, nigerrima. Florem non vidi.

320 Helotropium majus Diofcoridis C. B. P. 253. I.R.H. I 39 .

321 Helitropium majus autumnale, Jafmini odore I. R.H. 139.

322 Helitropium, quod Myofotis fcorpioides, lacifolia, hirfuta Merret Pin. Raij Syn.1 I I. Ed.3. p. 229 .

323 Hemionitis vulgaris C.B.P. 353

324 Herniaria fruticofa, viciculis lignofis C.B. P. 382 . I.R.H. 507.

325 Herniaria glabra J.B. III. 378 .

326 Hefperis hirfuta, lutea, Bellidis folio dentato. Similis eft Barbarec murali $7 . B$. Fed folia pediculis ad caulem longioribus barent, of fores lutei funt rariores.

327 Hefperis incana, afpera, foliis frietiffimis. 328 Herperis maritima, latifolia, filiqua tricuspide I.R.H. 223 .

329 Hefperis maritima, perfoliata, Bellidis folio, glabro. Non eft eadem Planta cum Hefperide marit. perfoliat. parva flore cæruleo Pluk. Alm. 183. Jed differt ab ea foliis brevioribus, glabris, fucculentis, minus dentatis, flore majore, fimili Hefperidis maritimæ fupinæ exiguæ I.R.H. 222 . a qua foliis caulem amplectentibus, ottufioribus of glabris difinguitur.

330 Hieracium anguftifolium, parce dentatum, floribus in extremitatibus caulium fingularibus. 331 Hieracium calyce barbato Col. 1I. 28 . Hieracium barbatum, medio nigrum nuinus $\mathrm{H}$. L. Bat.

332 Hieracium magnum Dalechampii Lugd. 569. I. R. H. 470. Hedypnois Monfe effulana five Dens Leonis Monfpefulanus J.B. 11. 1036 . 333 Hieracium fpeciofum, fquamofo calyce, Lycopi folio craffo, fubtus incano.

$33+$ Hieracium villofum, Sonchus lanatus Dalechampii dictum Raij Hift. $=31$. I. R. H. 470.

335 Horminum fylvente, Lavandula flore C.B.P. 237 .

336 Horminum Verben $x$ lacinis anguftifolium Triumf. Obf. Ic. \& Defcr. 66.

337 Hyacinthus obfoletior Hifpanicus ferctinus Cluf. H. $17 \%$.

338 Hyofcymus allusvulgaris Cluf.H.Lxxxiv. 339 Hypecoon Orientale Fumarix folio Cor.17. 3 to Hypecoon tenuiore folio I.R.H.230.

341 Hypericum five Androf xmum magnum Canarienfe ramofum, copiofis floribus, fruticofun Pluk. Alm. 189. Tab. 302. f. 1 .

$3+2$ Jacea acau'os lutea, Erucre folio, fquamarum ciliis candidis. Radix dulcis, efculenta eft, \& ab Arabibus Toffs dicitur.

$3+3$ Jacea annua, foliis laciniatis, ferratis, purpuralcente flore I.R.H.+44. Rhaponticoides \&.c. Comm. Ac. R. Sc. Ann. 1718. p.179. n. 21 .

$3++$ Jacea foliis Cichoraceis villoris, altifima, flore purpureo 1.R.H. $4+4$. Rhaponticoides \&c. Comm. Ac. R. Sc. Ann. 1718. p. 179. n. 20.

345 Jacolæa Hifpanica, minus laciniata, petalis breviffimis I.R.H. 486. Comm. Ac. R. Sc. Ann. 1720. p. 298. n. 21.

346 Jacea purpurea, Atractylidis facic. $\mathrm{Hu}$ jufce Plante fquame unicujpides funt, ciliis ad marginem brevioribus.

$3+7$ Jacobxa 


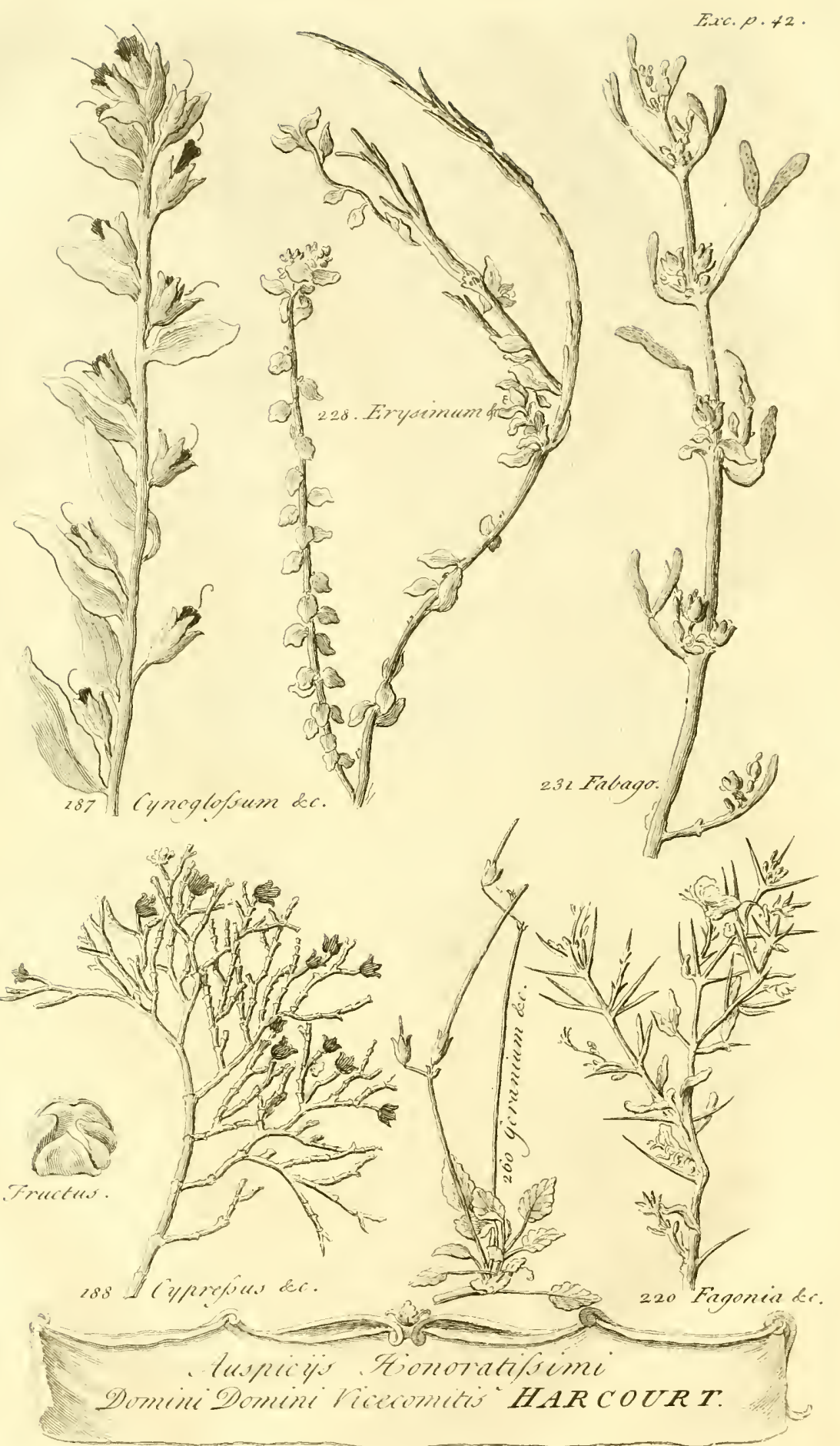




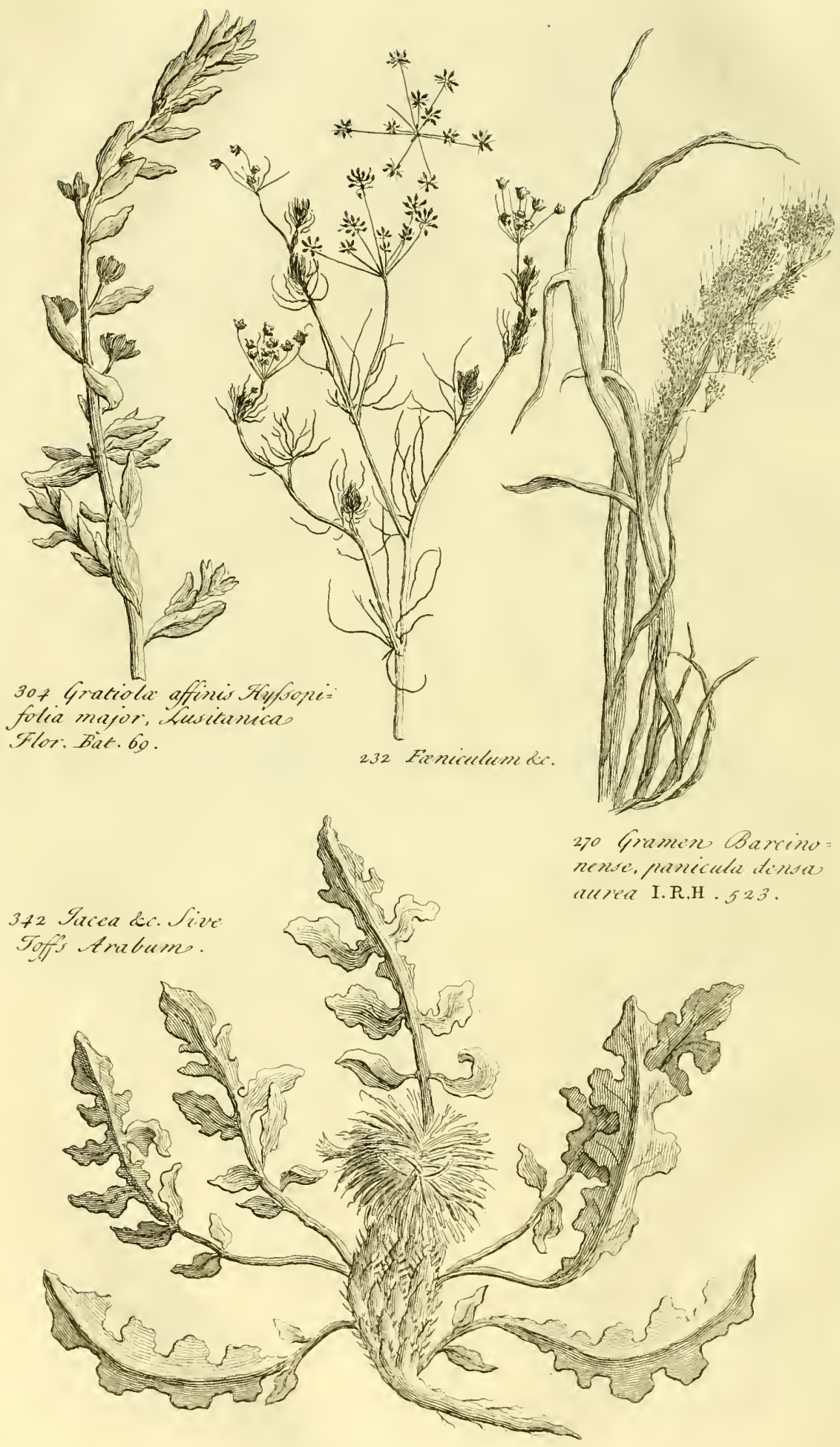




\section{Specimen Phytographice Africance \&c.}

$3+7$ Jacobæa Adonidis foliis, floribus in umbellas dipofitis. Differt a Jacobæa multifida umbellata annua Bocc. Rar. F.94. quod lacinia foliorum tenuiorcs funt \& magis crecta $a^{\prime}$; o quod capithlor:sm femifloficuli jpocioi ores funt.

$3+8$ Jalminoides aculeatum, Salicis folio, fore parvo, ex albo purpurafcente Michel. N.Gen. p. 225. Tab.105.t.1.

349 Jafminoides aculeatum Polygoni folio, fioribus parvis albidis. Frutefcit, farmentis longis, tenvibus propendentibus. Spinc tenucs, cortex ramorum incanus tenuique villo obfitis.

$350 \mathrm{Jafminum}$ luteum, vulgo dictum bacciferum C. B. P. 398.

35 I Ilex aculeata, cocciglandifera C.B.P. 425 . I. R. H. 583 .

352 Juniperus major, bacca cærulea C. B.P. 489 . 1.R H. 589 .

353 Kali fpinolum, foliis craffioribus \& brevioribus I. R. H. $2+7$. Pluk. Alm. 202.

$35+$ Kali membranaceum, foliis anguftis conjugatis. Faticm babet Kali foliis angutticribus fpinofis I. R.H. 247. fod folia femper ex adverfo mafcunt: of femina illius carent folitis membranaceis. 355 Kecmia Eyyptiaca, Vitis tolio, parvo flore 1.R.H.100. Bamia J.B.II. 959.

356 Ketmia veficaria Africana, flore amplo, purpureo. A Ketmia vefic. Afric. Tourneforti differt folior:m fermentis longicribus; frequentius ferratis; calycis $\int e g$ mertis anguftioribus of longioribus; flore ampliore, toto purpureo.

357 Ketmia palurtris, flore purpureo I.R.H.100.

358 Lachryma Jobi latiore folio I.R.H. 532 .

359 Lathyrus fativus, flore \& fructu minore five Kerfailah Arabum. Facicrn babet Latbyri, qui

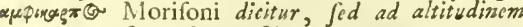
quinque aut fex pedum crefcit.

360 Lavandula multifido folio Clur. Hift. 345 . J. B. III. 28 I.

361 Leucoium maritimum, finuato folio C.B.P. 201. I.R.H.221.

$36_{2}$ Leucoium fylveftre, latifolium, flofculo albido, parvo Raij Hift. I. 786 .

$3^{6} 3$ Limonium caulıbus alatis, Afplenii foliis, minus afperis, calycibus acutioribus, flavefcentibus. El Khaddab Arabum.

$3^{6}+$ Limonium caulibus alatis, foliis minus finuofis, calycibus cx viridi cæruleis.

365 Limonium peregrinum Afplenii foliis C B. P. 192. I. R. H. $34^{2}$. Limonium pulchrum Rauwolfii Park. Th. 1235. Variat nofirum ab hac Rauwolfianâ fpccie, quod tota facie nig ricet, of birfutius to, cum illa rufefcat, cum calicbus cosruleis pallidioribus.

366 Limonium minus, obtufo folio, viminibus foliatis Barr. Ic. 806 . Obl.690. Limonium minus J. B. III. App. 877 .

367 Limoniun foliis Halimi Broff. 1.R.H. 342. 368 Limonium maritimum minimum C. B. Prod. 99. Bocc. Rar. F.25, 26. f. 3 .

369 Limonum galliferum, foliis cylindraceis. Florem babet pulchrum, ruberrimum. Folia incana, quafi Saccharo iwcriffata. Galle ovales caulibus adnafuntur, non uno, fed plurimis foraminilus pertus:

370 Linaria Bellidis folio C. B. P. 312. Prod. 106. I.R.H. 179 .

37 I Linaria foliis fubrotundis, Horibus e foliorum alis nafcentibus. Rami ples'umque uno verfu difpofiti funt.

372 Linaria Myrfinites, fiore luteo, rictu purpureo. Ef Linaria Myrfinites triphylla, flore candide fulphureo, rictu croceo, brachiata $\mathrm{H}$. Cath. Nofira babet folia plerumque bina ex adverfo pofita; florem luteum; rictum purpurcum.

373 Linaria faxatilis, Serpilli folio I. R. H. 169 .

374 Linaria fegetum Nummulariæ folio, au rito \& villofo, flore luteo I.R.H.169.
375 Linaria Sicula multicaulis, folio Mollugilis Bocc. Rar. 38 .

376 Litraria Siculix acccdens, Molluginis folio breviori.

377 Linaria triphylla, exigua, calcari praxlongo.

378 Linaria Valentina Cluf. H. 35. I. R. H. 169. Park. Par. Linaria triphylla minor lutea C. B. P. 212 。

379 Linum foliis afperis, umbellatum, luteum Bot. Monfp. C. B. P. 214 . I. R. H. 340.

380 Linum maritimum, luteum C. B.P. 214. I.R.H. 340.

381 Linum maximum Africanum, flore cæruleo Voik. Fl. Nov. Linum fativum, latifolium, Africanum, fructu majore I. R. H. 339 .

382 Lotus argentea Cretica Pluk. Alm. 226. T. 3 +. . . 1 .

383 Lotus corniculata, filiquis fingularibus; vel binıs, tenuis J.B. Il. 356 .

$3^{8}+$ Lotus Græca, maritima, folio glauco \& velut argenteo Cor. 27.

385 Lotus humilis, filiqua falcata, e foliorum alis fingulari.

386 Lotus five Melilotus, pentaphyllos, minor glabra C.B.P. 332. I.R.H. 402.

387 Lotus pentaphyllos, filiqua cornuta C. B. P. 332. Tritolium five Lotus Hierazune, edulis, filiquofa J. B. Il. 365 .

388 Lotus rubra, filiqua angulofa C.B.P. 332 Boerh. Ind. Alt. II. 37. Lotus filiquofa, fiore fufco, tetragonolobos J.B. 1I. 388 .

389 Lotus filiquis Urnithopodii C. B. P. 332. I.R.H. 403 .

390 Lotus villofa, altiflima, flore glomerato .R.H. 403 .

391 Lunaria fruticofa, perennis, incana, Leucoij folio Cor. 15. In Arabia inveni.

392 Lupinus anguftifolius, cæruleus, elatior Raij Hift. 908. I.R.H. 392.

393 Lupinus lanuginofus, latifolius, humilis, flore cæruleo purpurafcente, ftoloniferus $\mathrm{H}$.

Cath. Tota planta eft ferruginei coloris.

394 Luteola herba, Salicis folio C. B. P. 100. I.K.H. 423 .

395 Lychnis foliis glabris, calyce duriure Bocc. Rar. p. 27. I.R.H. 337.

396 Lychnis Lufitanica Bellidis folio, flore carneo I.R.H. 338.

397 Lychnis Lufitanica paluftris, folliculo ftriato I.R.H. 338.

398 Lychnis Orientalis Beupleuri folio Cor.24 399 Lychnis fegetum, rubra, foliis Perfoliatæ C. B. P. 204. 1.R.H. 335 •

400 Lychnis fupina, pumila, Bellidis foliis craffis, flore bifido, purpureo, calyce ftriato, turgido Raij Hift. Ill. 481.

401 Lychnis fylveftris anguftifolia, cauliculis turgidis, ftriatis C. B. P. 205.

402 Lychnis fylveftris, quæ Behen album vulgo C. B.P. Ad altitudinem crefcit 6 aut 7 pedum. 403 Lychnis fylveftris, flofculo rubro, vix confpicuo Grifl. Vir. Lufit. Vifcago Lufitanica, flore rubello, vix confpicuo H. Elth. p. 433 . f. 406 .

404 Lycopus paluftris glaber I. R. H. I9I.

405 Lyfimachia lutea humilis, Polygala folio. 406 Marrubium album, villofum C. B. P.230.

\section{Prodr. 110.}

407 Marrubium Hifpanicum, fupinum, calyce ftellato \& aculeato I.R.H.192. Alynfum Galeni Cluf. Hifp. 387 .

408 Medica magno fructu, aculeis furfum \& deorfum tendentibus I.R.H. $4 \mathrm{I}$.

409 Medica marina Lob. Ic. 38. He Medice fpeciofiores funt ex aliis plurimis, qua in Africa fponte nafcuntur.

410 Melongena Ariftolochiæ foliis, fructu longo, violaceo. Flores purpurei funt, frellatim 


\section{Specimen Phytographice Africane \&c.}

divifi, o minores quam in aliis fpeciebus, que in Africa coluntur.

4 I I Mefembrianthemum perfoliatum, foliis exiguis, monacanthis. Similis eft Planta fpecimini Plante Sicces Mefembrianthemi perfoliati folis minoribus, diacanthis Hort. Elth. Sed tota palidior eft, foliis paulo brevioribus of confertioribus, rectis, non reflexis, illius infiar. Caterum folia triquetra fint, apice jpinofo terminata. Non mibs contigit Rorem videre.

fr 2 Mufa fructu cucumerino, longiori Plum. 24. Mauz, Mufa Alp. Ėgypt. 78,79,80.

113 Mufcari obfoletiori Hore Cluf. Hift. 178. I. R. H. $3+8$.

$4^{1}+$ Muícus ceranoides Palmenfis, comis digitatis, Orchili (Argol) dictus Muf. Per. 436. Gazoph. Nat.1I. Tab. 7. f. I2. Fucus capillal is tinctorius J. B. IlI. 796 .

415 Mufcus terreftris Lufitanicus Cluf. Hift. CCXLIX.

416 Myrrhis annua, alba, hirfuta, nodora, Paitinacre fylveftris folio candicante Hort. Cath. Raij Hift. 1lI. 254 .

417 Myrrhis annua Lufitanica, femine villofo, Paltinacx fativa folio I.R.H. 315. Panax Siculum \&c. Bocc. Rar. I.

418 Myrtus latitolia Bxtica I. vel foliis laurinis C.B.P. 460. 1.R.H. 6 to. Copinfe crefcit in dumotis, cum alits fpeciebus, que folia babent anguffiora.

4 I 9 Nafturtium Alpinum, Bellidis folio, majus C.B.P. 105. Prodr. 46. Non eft Naftirtij Species, pertinet enim ad Plantas filiquofas.

420 Nerium floribus rubefcentibus C. B.P. 464. Oleander, Laurus rofea Lob. Ic.364. Difflab Arabum.

4:1 Nigella anguftifolia, flore majore, fimplici caruleo C.B.P. 145. I.R.H. 258.

+32 Nigella fiore minore fimplici, candido

C.B.P. It F. I.R.H. 258 .

$4=3$ Niffolia vulgaris I.R.H. 656.

$4^{2}+$ Ochrus folio vel integro, vel divifo, capreolos emitrente l.R.H. 396. Cor. 27.

425 Ocnanthe Apii folio C.B.P. 162. I.R.H.

312. Foliola umbellis partialibus fubjeita, plurima

babet, latiora, quam in alits Speriebus funt.

+26 Oenanthe aquatica, tenuifolia, major, bulbulis radicum longifimis Cat. PI. Agr. Flor. Hort. Pif. Tillij.

4:7 Oenoplia fpinofa C. B. P. $477^{\circ}$ Nabca folits Rhamni vel Jujubx J.B.I. 1.6. c. 39.

428 Onobrychis Apula, perennis, erecta, folii

Vicix, floribus albicantibus, lineis rubris diftin-

ctis, in fpica denfa congeftis, fructu aculeato

Michel. Cat. H. Pif.

429 Onobrychis feu caput Gallinaceum minus, fructu maximo, infigniter echinato Triumf. ap. ad Frat. 65. 1.R.H. 590.

430 Onobrychis fructu echinato, minor C. B. P. 350 . 1.R.H. 390 .

43 I Onobrychis Orientalis, argentea, fructu echinato minimo Cor. 26.

432 Orchis anguftifolia, anthropomorphos, fpica laxori, flavefcente.

433 Orchis anthropomorphos, foliis latis, obtufis, capitulis globolis, purpurafcentibus.

$43+$ Orchis barbata, odore hirci, breviore latioreque folio C.B.P. 82. J.R.H. 433.

435 Orchis flore nudi hominis effigien reprafentans, fxmina C.B.P. 82. I.R.H.433.

436 Orchis foliis maculatis, fpica denfa, rubra.

437 Orchis fucum refercns, colore rubiginofo C.B.P. 83 .

438 Orchis fucum referens, labello gibbofo.

439 Orchis militaris, pratenfis, humilior I.R. H. 432 .

440 Orchis montana Italica, lingua oblonga altera C. B.P. $8+$ I.R.H. 434 .
4+1 Orchis montana Italica, lingua trifida Burier. Camp. Elyf. Tab. 2. p. 204. Ic.

442 Orchis myodes, lutea, Lufitanica Breyn. Cent. IOI. Tab. 45 .

443 Orchis odore hirci, minor C. B. P. 82. I.R.H. 433 .

444 Urchis odorata, fpica rubra, floribus parvulis, mufcitormibus.

445 Orchis palmara, Sambuci odore, floribus purpureis C.B.P. 86. 1.R.H. 435 .

446 Origanum vulgare fpontaneum J. B. III. 236. Origanum fylveitre, Cunila bubula C.B.P. 223. Zatter Arabum.

447 Ornithogaluin cxruleum Lufitanicum latifolium I.R.H. 35 I.

448 Ornithogalum umbellatum, maximum C. B.P. 69. I. R. H. 378 .

449 Onthogalum uinbellatum medium, anguititolium C.B.P. 70. 1.R.H. 378 .

450 Ornithopodio affinis, hiriuta, Scorpioides C. b.P. 350 .

45 I Urnithopodiun Portulacæ folio I. R. H. 400.

452 Orobanche flore freciofo, fimbriato, ruberrimo. Folia per caules babet angufta, of joliola foribus subjecta in longos senuefque mucrones excunt. 453 Urobanche Hore minore J. B. II. 78I. I.R.H. 176 .

$4 j 4$ Orobanche major, Caryophyllum olens C.B.P. 87. I.R.H. 175 .

455 Orobanche ramofa, floribus furpurafcentibus C.B.P. 88. I.R.H. I76.

456 Orobus foliis anguftiffimis, radice tubeiofa.

457 Orobus latifolius, parvo flcre, purrereo C.B.P. 35I. I.R.H. 393.

458 Uryza omnium Authorum.

459 Oxyacautha Arabica, fructu magno, eduli. Faciem babet Oxyacanthre vulgaris, fed fructus ad Cirafi vel Azarole magnitudinem accedit. Copiofe crefcit in monte S. Catharine e regione montis Sinat. 460 Palma dactylifera, five Nabbal Arabum : cujus fructus $T_{\text {w }}$ mmar ; ramuli foridd appellantur. Triginta plus dactylcrum ( five Tummar) Species apudZebenfes \& Jereedenfes enumi rantur; quarum Trunfliah intter grandiores or molliores, Deglutnôre inter dulciores o confervationi aptiffimas reputantur. 46r Palma minor C. B. P. 506. Palma humilis Hifpanica, fpinofa \& non fpinofa J. B. I. 369. Chimeriphes Dod. Penipt. Palma folio plicatili, f. flabelliformi, humilis Raij Hift. II. I 369 . Intcrdum ad altitudinem crefoit 6 aut 8 pedum, avulfis quotannis e trunco, ut in Palma, ramulis.

462 Papaver erraticum, capitulo oblongo, hifpido I.K.H.238. Argemone capitulo breviore, hifpido J. B. IIl. 396 .

463 ParonychiaNarbonenfis, erectaI.R.H. 508. 464 Pedicularis Cretica maritima, amplioribus foliis \& floribus Cor. 9.

465 Pedicularss Cretica fpicata, maxima, Jutea Cor. 9.

466 Pedicularis lutea, vifcofa, fcrrata, pra tenfis I. R. H. I72.

$4^{57}$ Pedicularis purpurea, annua, minima, verna I.R.H.172. Euphrafia purpurea minor C. B. Prod, $11 \mathrm{I}$.

468 Pedicularis Teucrij folio, pediculo infidente, flore parvo ruberrimo.

469 Pelecinus vulgaris I. R. H. 4I7

470 Perficaria latifolia major \& mitior, foliis \& caule maculatis, fpica craffiori Cat. P1. Agr. Flor. Michet. Cat. H. Pif.

47 I Phalangium, parvo flore, ramofum C. B. P. 29. I. R. H. 368.

472 Phalangium pulchrius, non ramofum J. B. II. 635 .

473 Phillyrea anguitifolia, minus ferrata Comm. Ac. R. Sc. Ann.1 722, p. 108. n. 7. Phillyrea anguttifolia fpinofa I. R. H. 596.

474 Phillyrea 


\section{Specimen Phytographice Africane \&c.}

47t Phillyre a folio LiguftriC. B.P.476. Comm. Ac. R. Sc. Ann. 1722. p. 198. 11.8.

$475 \mathrm{Ph}$ llyre 1 Hitpanica, Nerij folio I. R. H. 596. Conm. Ac. R. Sc. Ann. 1722. p.198. n. 6. 476 Pinus fylveftris vulgaris, Genevenfis J.B.I. P. 2. $p .253$.

477 Psmpinella Sanguiforia minor, femine majore \& crafliore Bot. Menlp.

478 Periploca foliis anguftis, confertis, floribus ex viridi flarefcentibus. Folia parva rigida, q:adam obtufa, quadam acutiora, ad genicula plurimanafcuntir. Flores pediculis brevibus barent, e fetalis anzufris compofit:

479 Phlomis lutea, villofa, perfoliata, verticillis crebrioribus. Folia incana, mollia, propemodum triang laria arefe caulcm amplectuntur, o ab co perforantur.

480 Phlomis Narbonenfis, folio Hormini, flore purpurafcente 1.R.H. 178.

481 Pi um fylveftre Clufii Hift. ccxxIx.

482 Pinpinella Oenanthes foliis, multum brachiata, plerumque nuda. Graveolens eft Planta, quam copiole inveni fuper ripas Fluminis Salfi, inter montes Al Bee-ban dictos. Caules tenues funt, duri, candidi, buc illuc difforti, cum umbellis parvulis albis. 483 Plantago anguftifolia minima Maffilienfis,

Lagopi capitulo I.R.H. 127.

$48+$ Plantago anguftifolia paniculis Lagopi C. B. P. I 89 . I.R.H. 127 .

485 Plantago anguftifolia, ferrata, Hifpanica

C. B.Y.18\%. I. R.H.12-. Barr. Obf. I22. Ic. 749 . 486 Plumbago quorundam Clú́ H. cxxiII.

H. Ox. III. $59 \%$.

487 Polium Valentinum, fruticofum, angurtifolium, flore albo Barr. Obi. 331. Ic. $10+8$.

488 Polygala vulgaris, major J. B. III. $38 \%$.

489 Polygonum folio oblongo, crenato. Folía ancian longa junt, tcriam uncia partem lata, utringue acuminata, o por margines texuiter crenata. Flores bradteati funt, monopetali, candidi, lituris, ut in Oruithogalo, viridibus notati.

490 Polygonum maritimum, latifolium C. B.

P. 281 . I.R.H. 510.

49I Populus alba, majoribus foliis C.B.P.429. Safsaff vulgo Arabibus: vox, quan Salici, mefcio quo jure, attribuunt Rauwolfius of alii , nifi communis fit omnibus arboribus aquaticis.

492 Populus nigra C.B.P. 429

493 Pfeudodictamnus Hifpanicus, foliis crifpis \& rugofis I. R. H. I 88.

III. 513 .

495 Pulegium J.B.III. 2. 256.

496 Pulmonaria vulgaris, naculofo folio Cluf. H. CLX1X.

497 Quercus vulgaris brevibus pediculis J.B.I.2. 70. In Africa bac jpecies retinct falia per totum annum. Glans dulcis eft, o ab Africantis tofta come-

ditur. Altitudinem riginti pedum non excedit. Folic

babet Quercus latifolice a CaSp. Baubino depitta ad Mattb. p. 179 .

498 Ranunculus arvenfis echinatus C.B.P.179.

499 Ranunculus aquaticus, hederaceus, flore albo, parvo I.R.H. 286 .

500 Ranunculus aquaticus, folio rotundo \& capillaceo C. B. P. 180 . I. R. H. 291 .

50I Ranuaculus Lufitanicus, folio fubrotundo, parvo flore I. R.H. 286 .

502 Ranunculus vernus, rotundifolius, minor I. R. H. 286.

503 Refeda Calcitrapx folio, majore \& rarius divifo, perennis.

504 Reieda foliis Calcitrapx, flore albo Mor. H. R. Blœe. I.R.H. 423.

505 Refeda minor vulgaris I. R. H. 423.

506 Rhagadiolus minus brachiatus, folio ampliore vix dentato.

507 Rhamnus Hifpanicus, Buxi folio minore

I. R. H. 593 .
508 Rhamnus Siculus, pentaphyllos Bocc.Rar. 43. Copiofe cr fcit prope Warran. Frutex efi fpinojus, folius in extremitatibus plerumque triffidis, fure berbaceo, lutefcente Zizipki, pintaptalo, calyce integro, bacca monopyrena, ruberrma, cduli, officulo ovali, Momordica' feminis figurá.

509 Rhus folio Ulini C. B. P. AI 4

5 Io Ricinoides, ex quo paratur Tournefol Gallorum, folio oblongo \& villofo Cor.3. I.R.H.45. 511 Ricinus vulgaris C. B. P. 432. Palina Chrifti, vulgo.

512 Rofa fylveftris, rotundirolia, glabra, purpurea, calycibus eleganter foliatis.

513 Rofmarinus fruticofus, nobilis, tenuiore folio J. B. Il. 25 .

$51+$ Rubeola vulgaris, quadrifolia, lævis, floribus purpurafcentibus I. R. H. I 30.

515 Rubeola vulgaris quadrifolia, lavis, floribus obfoletis Michel Cat. H. Pif.

5I6 Rubia tinctorum fativa C.B.P.333. Fooab

Arabum.

517 Rufcus latifolius, fructu folio innafcente

I. R. H. 79 .

18 Rufcus myrtifolius aculeatus I.R.H. 79.

519 Ruta minor, trifoliata, incana, procumbens.

520 Ruta fylvertris, Fumaria foliis. Ruta fylveftris minor C.B.P. 336 .

521 Salicornia geniculata, fempervirens Cor. 5I. Salicornia arborefcens fine geniculis Buxbaum Cent. I. p. 6.

522 Salix ramulis villofis, foliis laurinis, fuperne nigricantibus.

523 Samolus Valerandi J. B. III. 791.

524 Santolina Africana Corymbifera, Coronopi folio anguftiore I.R.H. $46 \mathrm{I}$. Elychryfum Africanum, inodorum, glabrum Bot. Monip. App. 308. Defcrip.

525 Santolina repens \& canefcens I.R.H. 460 . Comm. Ac. R. Sc. An11, I7 I9. p.3 II. n. 4. Abrotanum fornina, repens, canefcens C.B.P. 137.

526 Satureia faxatilis, tenuifolia, compactis foliolis Bocc.Muf.168. T.I1 19. Satureia feu Thymbra frutefcens, Pafferinæ Tragi foliis anguftioribus H. Cath. 197 .

527 Saxifraga rotundifolia, alba C. B. P. 309. I. R. H. 252 .

528 Scandix femine roftrato, vulgarisC.B.P.I 52 . 529 Scabiofa Africana frutefcens Par. Bat. Ic. \& Defcr. Boerh. Ind. Alt. 128. Afterocephalus Afer, frutefcens, maximus Comm. Ac. R. Sc. Ann. 1722. p. 180. n. II. Hanc appellari (Phil. Tranf. 411. p.182. Octob. I729) Scabiofam flore pallide purpureo, capitulo oblongo, foliis fuperioribus incifis, inferioribus integris, ferratis. Tertianos dolores, mirum in modum, mitigat of removet. Vid. Obf. p. $26+$

530 Scabiofa capitulo globofo, minor C. B. P. 270 .

53I Scabiofa montana, fruticofa, reclinatis Achillex nafcentis foliis H. Cath. 1. R. H. 465 . Pterocephalus Achillex foliis Comm. Ac. R. Sc. Ann. I722. p. 184. n.3.

532 Scabiofa prolifera, foliacea, femine membranaceo majore H. Ox. III. 50. n. 4I. Afterocephalus annuus, humilis, integrifolius Comm. Ac. R. Sc. Ann. 1722. P.I82. n.23.

533 Scabiofa ftcllata, folio laciniato, major C.B.P. 27 I. I.R.H. 465 .' Afterocephalus annuus major, laciniatus, capite pulchro, globofo Comm. Ac. R. Sc. Aun. 1722. p.182. n. 20.

534 Scabiofa ftellata minima C. B. P. 271. Prod. I 25. Item Scabiofa maritima, parva J. B. III. $25 \cdot \mathrm{p} \cdot 7$.

535 Scabiofa tenuifolia, flore cæruleo H. Eyft. O. 9. Tab. 10. f. 3. Afterocephalus fubincanus, Sophire foliis Comm. Ac. R. Sc. Ann. 1722. p. 179. n. 4 .

536 Sclarea folio mucronato, flore cæruleo, punctato. Folia pedalia funt, laciniat a Dent is Leonis 
infar, longo mucrone terminata. Flos dilutè carulefcit, cum punctulis purpurafcentibus ubique difperfis. 537 Sclarea rugofo, verrucolo \& laciniato folio I. R. H. 150. Itiner. Vol. Il. p. 255.

538 Sclarea vulgaris lanuginofa, ampliffimo folio I. R. H. I 79. Athiopis Dod. Pempt. I 48.

539 Sc rpioides Beupleuri folio, corniculis afperis, magis in fe contortis \& convolutis $\mathrm{H}$. Ox. II. I27. I. R. H. 402. Hac or reliqua jpecies que adbuc innotuerunt, ubique fponte proveniunt.

540 Scorzonera laciniatis toliis I. R. H. 477 Barr. Obf 1049. Scorzoneroides vulgaris Comm Ac. R. Sc.Ann.1 72 N p.209. n.I. Varietatem bujus obfervavi, ckm foliis in medio latioribus, laciniis ad latera brevioribus, extrema verùm lacinia angutta, pralonga.

$54 \mathrm{I}$ Scorzonera Orientalis, foliis Calcitrapæ fore Havefcente Cor.36. Scorzoneroides Refed folis nonnihil limilibus Comm. Ac. R. Sc. Ann. I721 : p. $209 \cdot \mathrm{n} \cdot 2$.

542 Scrophularia foliis Filicis modo laciniatis, vel Ruta Canina latifolia C. B. P. 236 . I. R I. 167 .

543 Scrophularia Ruta Canina dicta vulgaris C. B. P. 236 . I. R. H. 167 :

544 Scrophularia Hifpanica Sambuci folio glabro I.R.H. I66. Variat foliis birfutis.

$5+5$ Scrophularia Lufitanica fruteicens, Verbenæ foliis 1. R. H. 167 .

546 Scrophularia Meliffe folio I. R. H. I66.

547 Scrophularia Orientalis, Chryfanthemi

folio, flore minimo, variegato Cor. 9.

548 Scrophularia faxatilis, lucida, Laferpiti

Maffilienfis foliis Bocc. Muf.2. I66. I.R.H. I67.

549 Sedum minus luteum, folio acuto C. B. P.

283 . I.R.H. 263.

550 Sedum vermiculare, pumilum, glabrum, floribus parvis, cæruleis.

55 I Serpillum vulgare majus C. B. P.220. Serpillum erectum Riviu. Irreg. Mon.

552 Sena Orientalis, fruticofa, Sophera dicta

H.L. Bat.

553 Sideritis Gloribus luteis, Meliffa foliis, verticillis fpinofis. Ocymaftro Valentino Clufi fimilis eft, fed folia babet minus obtufa, flores luteos of fpicam productiorem.

554 Sideritis purpurea, foliis longis, ferratis. Galea floris amplifima ef, \& folna longis pediculis adnectuntur. Calyx, ut in priori, aculeatus.

555 Sideritis purpurea, anguftifolia, non ferrata. Folia fuperior a Rorifmarini magnitudine. Verticilli longius diftant, $e$ floribus of calycibus rarioribus, aculeatis, conflati.

556 Sinapi album, filiqua hirfuta, femine albo Q rufo J. B. II. 856 .

557 Sinapiftrum trifoliatum, anguftifolium, afperum, filiqua latiori. Siliqua $\int e$ quiuncialis eft, fabra, foliorum or caulis inflar. Semina villofa. Folia inferiora terna, fuperior a fimplicia. Tota Planta vifcofa eft.

$55^{\delta}$ Sinapiftrum triplıyllum, fcabrum, floribus faturate rubris. Tota planta prioris inftar, vifcofa eft, fed folia babet latiora of longiora, Hyfjopi figura of magnitudine; caules crafjzores; fiores dengius of umbellatim fere in fummitate congefti.

559 Sifymbrium aquaticum Matth. 487 . I.R. H. 226. Gernou-nu/b A rabum.

560 Sifyrinchium medium C.B.P.41. Sifyrinchium ninus Cluf. H.216.

$56 \mathrm{I}$ Sium arvenfe, foliis inferioribus fubrotundis, fuperioribus plerumque trifidis \& laciniatis. $56_{2}$ Smilax afpera fructu rubente C.B. P. 296.

I. R.H. 564 .

563 Sonchus anguftifolius, maritimus C. B. P. I24. I. R. H. 475. Pluk. Alm. 354. Tab.62. f. 5. 564 Sonchus afper, laciniatus, Creticus C. B. P. 124. I. R. H. $474^{\circ}$ Item Hieracium majus, foliis Sonchi, femine curvo C. B. P.127.

565 Sorbus Aucuparia J. B. I. 62. I. R. H. $634^{\circ}$
566 Statice Lugd. I I 90. I.R. H. 340.

567 Stoechas Arabica vulgu dicta J. B.III. 277

568 Stoechas tolio ferrato C. B. P. 216 . Dod.

Pempt. 275. Boerh. Ind. Alt. 153.

569 Suber latifolium, perpetuo virens C. B. P. 424 . 1. R. H. 584 .

$57^{\circ}$ Tamarifcus Madrafparana, Cupreffi facie Muf.Pet.681. Tamarifus lindix Orientalis Belgarum xmula, ramulis Cuprefi: Autocorea Malab. Pluk. Mantif. 177. Phyt. Tab.445. f. 4. Copiofe crefoit per totam African.

571 Tamnus racemolus, flore minore, luteo, palleficente I. R. H. IO3.

572 Telephium Myoiotidis foliis, amplioribus conjugatis. Summitates ramulorum Heliotropij infar refectuntur. Florum petala paria funt; vafcula

fimplicia; trivalvia; plura femina continentia.

573 Terebinthus vulgaris C.B.P. 4 co. I.R.H. 579. Bo-tum Arabum.

574 Teucrium C. B. P. 247. Chamedrys frutefcens, Teucrium vulgo 1.R.H. 204.

575 'Teucrium Delphinij folio, non ramofum. Flos albidus eft, fpeciojus, ad fingula genicula gemel-

lus. Caulis quadrangularis, fimplex. Folia glatra. 576 Thapfia five Turbith Garganicum, fenine latifimo J. B. III. 2. 50. I. R. H. 322. Boneffa Algerienfium, cujus radicem mulicres comedunt, ut pinguiores fiant.

577 Thapfia foliis Coronopi divifura, fegmenris obtufioribus, fubtus incanis, five Toufailet Arabum.

578 Thapfia foliis Coronopi divifura, viridioribus \& acutioribus, five Edreefe Arabum.

579 Tha fia tenuiore folio Apula I.R.H. 322. Panax Afclepium, Millefolii folio \&c. H. Cath. 580 Thalictrum fpeciocififimum, glaucum femine \& caule ftriato J. B. III. 486 .

581 Thlafpi Vaccarix folio, incano, minus C.B.P. 106. Prod. 47.

582 Thlafpidium foliis anguftis, argenteis, fiuctu parvo.

583 Thlafpidium folio fubrotundo, dentato, fructu majori.

584 Thlafpidium Raphani folio I.R.H. 214.

585 Thymbra tenuiffimis Erica foliis, verticillatim congeftis.

586 Thymelxa foliis Lini C.B.P. $46_{3}$. I.R.H. 594.

58 Thymelrea tomentofa, foliis Sedi minoris C.B.P. 463.I.R.H. 595. Sanamunda forte Mauritanica flore luteo Pet. Gaz. Tab. 38. f. 8. Maintenan Arabum, ex qua foopas conficiunt.

588 Tinus Corni fominæ foliis, fubhirfutis Comm. Ac. R. Sc. Ann. 1722. p. I99. n. I. Tinus prior Clufij H. 49. I.R.H. 607.

589 Tithymalus Characias, folio ferrato C. B. P. 290. T. R. H. 87.

590 Tithymalus five Efula exigua C.B.P. 29r. I.R.H. 86

59I 'Tithymalus maritimus C.B.P.29I.I.R.H.86' 592 Tithymalus verrucofus J. B.III. 673 .

593 Traclelium azureum umbelliferum Pon. Bald. Ital. 44. I. R. H. I 30.

594 Tragacantha calyce veficario, fpinis recurvis.

595 Tragopogon gramineis foliis hirfutis $\mathrm{C}$.

B. P. 275 .

596 Tragopogon graminifolium, glabrum, flore dilute incarnato Comm. Ac. R. Sc. Ann. I 72 I. p.203. n. 3 .

597 Tribulus terreftris, minor, incanus, Hifpanicus Barr. Ic. 558 . Obf. 562 .

598 Trichomanes five Polytrichon Officina. rum C.B.P. 256 .

599 Trifolium Bitumen redolens C.B.P. 327. I.R.H. 404. Trifolium Bitumen redolens, anguftifolium Boerh. Ind. Alt. II. 32.

600 Trifolium album tricoccum fubterraneum, reticulatum $\mathrm{H}$. Ox. II. 138 . Sect.II. T. I 4. f. 5 . 


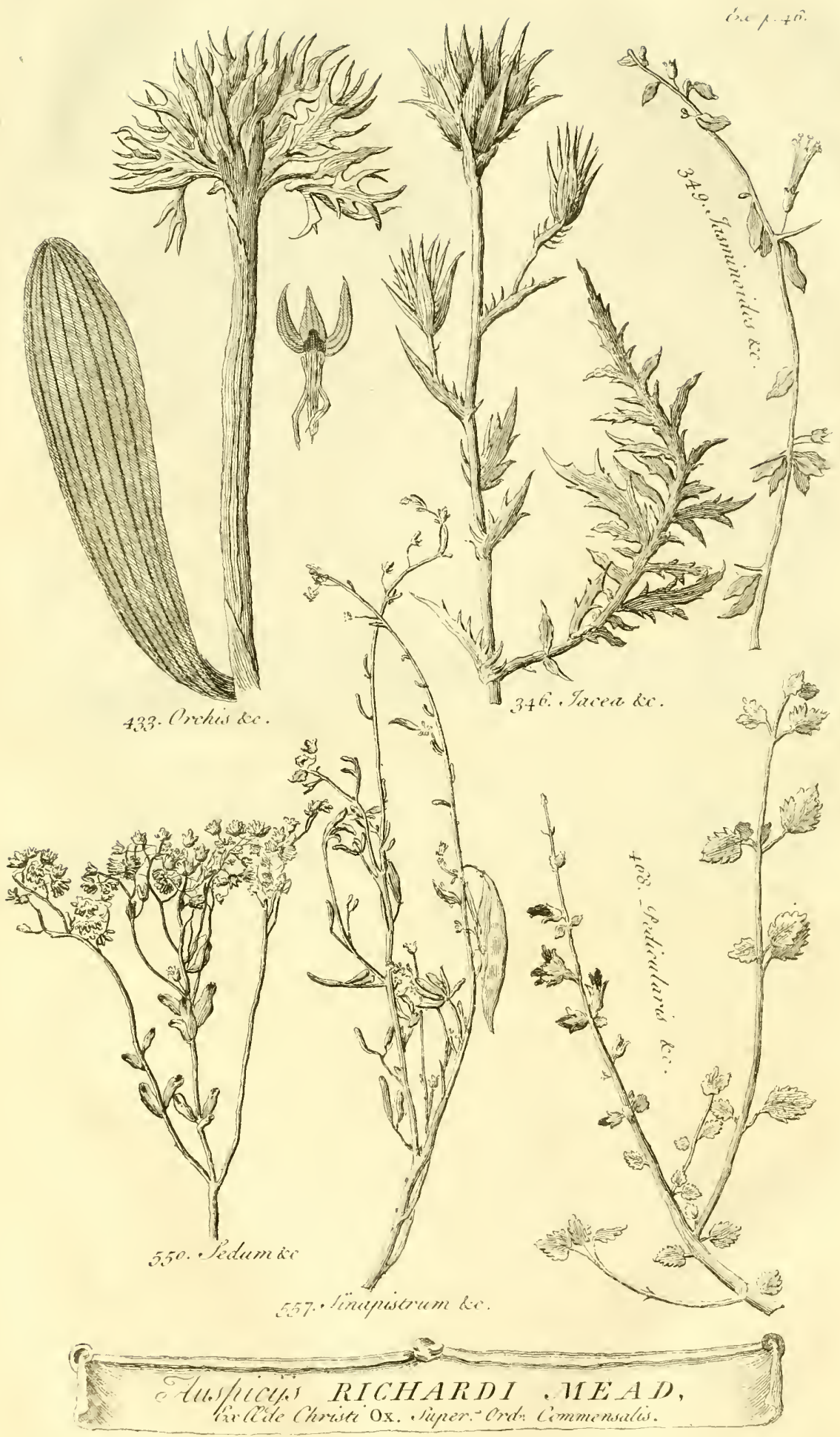




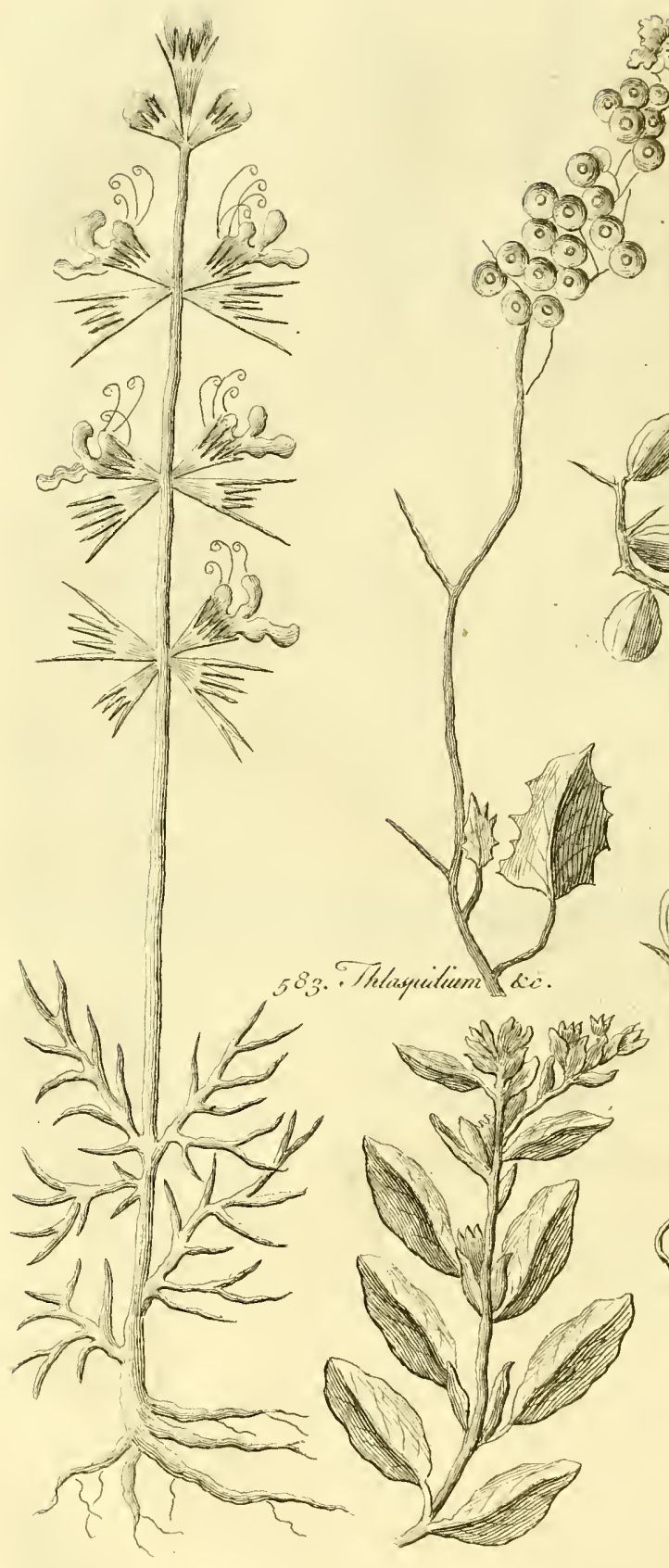

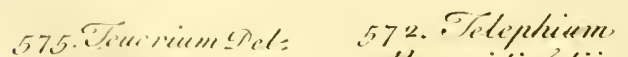

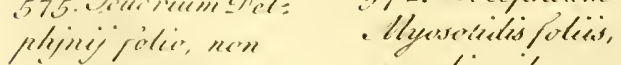
samer um. amplevirtius com: jeyeles.

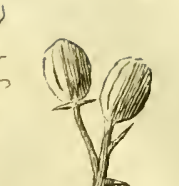




\section{Specimen Phytographice Africane \&c.}

GoI Trifolium Apulum anıuım, rotundifolium, glabrum, folis alba macula notatis, flore purpurafcente, calyce veficario $M$ lichel. $\mathrm{H}$. Pif.

602 Tritium humifurum, glabrum, foliis ciliaribus Vaill. B.Par. 195.

603 Trifolium globolun, repens C.B.P. 329. Prod.143. 1.R.H. 405.

$60+$ Trifulium glomerulis tomentofis, per caulium longitudinem J. B. II. 379. Trifolium capitulo fquamofo lævi C. B. P. 32\%. Prod. I40.

I.R.IH. +05.

605 Trifolium montanum, anguftifolium, fpicatum C.B.P. 32I. I.R.H. 405.

606 Trifolium ftellatum, purpureum, Monfpeffulanum J.B. II. 376 .

607 Turritis vulgari fimilis, fed fruticofior.

608 Valeriana aquatica, minor, flore minore

Raij Hift. 389 . I. R. H. 132.

609 Valeriana foliis Calcitrapæ C. B. P. 164.

I. R. H. I 32

610 Valeriana rubra C.B.P. 165. I.R.H. I 3 I. 6 I I Valerianella arvenfis, humilis, foliis ferratis I.R.H. 132.

612 Veronica aquatica, major, folio cblongo H. Ox. II. 323 .

$61_{3}$ Veronica Chia, Cymbularix folio verna, flore albo, umbilico viretcente Cor.7

6 I 4 Veronica Hofculis cauliculis; a dhærentibus

H. Ox. II. 322 .

615 Vicia anguftifolia, purpuro-violacea, filiqua lata, glabra Bot. Monip.

616 Vicia flore luteo, pallido, filiquis craffis, hirfutis, propendentibus H. Ox. II. 62. Tab. =1. 5. App.

617 Vicia latifolia, glabra, Horibus pallidis, filiqua lata, glabra. Carina of ale albe funt; galea fubfufca; filigna lata, unciam longa.

618 Vicia fegetum, cum filiquis plurimis, hirfutis C. B. P. 345 .

619 Vicia fylveftris lutea, filiqua hirfuta, nondum defcripta C. B. P. 345 . I. R. H. 398 .

$6 z 0$ Viola fruticofa, longifolia, flore amplo, fubcrruleo. $A$ Viola Hifpanica fruticofa longifolia I.R.H. 42 I. differt foliis latioribus of floribus magis fpeciofis.

621 Viola Martia, arborefcens, purpurea C. B. P. 199. I. R. H. 420.

622 Virga aurea minor, foliis glutinofis \& gravcolentibus I. R. H. 484. Comm. Ac. R. 'Sc. Ann. 1720. p. 308. n. I8.

623 Vitex foliis angultioribus, Cannabis modo difpofitis C. B. P. 475 . I.R.H.603.

624 Vulneraria tlore \& capitulis majoribus. None eft cadem Planta cum Vulneraria flore purpurafcente I.R.H. 59 I.

625 Vulneraria Hifpan ca, Ornithopodij filiquis. Coronopus ex Cod. Cæfareo Dod. Pempt. 109.

626 Xanthium five Lappa minor J. B. III. 572.

627 Xeranthemum flore fimplici, purpureo, minore I. R. H. +49 . Comm. Ac. R. Sc. Ann. 1718. p.175. n. 4 .

628 Xiphion minus, flore luteo, inodoro I.

R. H. 364. Iris Mauritanica Cluf. Cur. Poft. in fol. 24 .

629 Xylon five Goffipium herbaceum J. B. I. 343. I. R. H. IOI.

630 Zacintha five Cichoreum verrucarium Matel. 505. I. R. H. 476.

63I Ziziphus Dod. Pempt. 807. I. R. H. 627

Jujubx majores, oblongæ C.B.P. +46 . Zizipha Sativa J. B. I. 40. Hujus fructus ab Africanis Afafifa dicitur, unde forfan Zizipka vel Zizipbus.

632 Ziziphus fylveftris l.R. H. 627. 'Zizipha fylveftris intocunda H. Cath. (Secundum specimen Hor. Sicci Sherardiani Oxonice affervatum, Seedra Arabum, quæ \& Lotus veterum. Habitus Rhamni. Flores ut iz Zizipho. Fructus dulcior, rotundior, minor, Pruni fylvefiris magnitudine. Officulum magnum ut in Zizipho. Seedra porro fructus fert paffim, Grofularic inflar, per ramos fparfos; quum fujuba furculis tenuibus, pedalibus, quotannis e ramorum extremitatibus pullulantibus, mafcuntur. Zizipbus etiam ad altitudinem viginti pedum aut plus excrefcit; caudice magno, rimofo; ranis difortis, in extrcmitatibus nodofis; foliis oblongis, majoribus. Seedra vero plerumque non nifi tricibitalis aut quadricubitalis eft, ramulis plurimis ex eadem radice plerumgue exeuntibus, levioribus, candidioribus, rectioribus, cum folits parvulis, rotundis, rigidioribus. Sponte nafcitur cum alibi, tum pracipue in loco Regni Tunetanorum, Jereed nuncupato, que quondam Pars fuit Lotophagorum Regionis. Vid. Obf. p. 225, 226. Fructum maturum commedi menfibus Decembri \& fanuario.

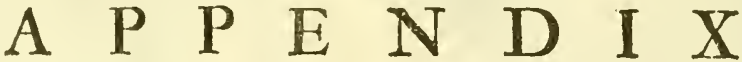

D E

\section{Coralliis \& eorum Affinibus.}

${ }^{2} \mathrm{~A}$ Lcyonium candidum, cretaceum, lamellatum Maris Numidici. Lamella, ordine irregulari invicem connexa, cavernas formant variarum figurarum.

2 Corallum album. Maris Numidici eft of ejufdem forme of babitus cum Corallo rubro fod rarius invenitur.

3 Corallum rubrum I. R. H. 572. Tab. 339. Copiofe colligitur a pifcatoribus Gallicis, apud $\mathrm{La}$ Calle demorantibus, in mari Numidico.

4. Efchara Rondeletij I33. J. B.III. 809. Retepora Efchara marina lmp. 630. ex mari Numidico.

5 Fucus pennam referens I. R. H. 569 . Penna marina J. B. III. 802. Imp. 650. Ut Fucorum bec Species, inter Zooplyta interdum numcratur, locum perperam dedi inter Pifces Obf. p. 259. Pifcatores Algerienfes interdum retibus cxtrabunt, wbi per noctem lumen Spargit, Cicindela inftar, ut proxinniores pifces dignofci poffint.

6 Fungus coralloides lamellatus Maris Rubri. Fungus lapideus Cluf. Hift. 124. Rar. Mur. Befl. T.27.26. f. 3. J. B. 813. Ic. I, 2. Forman \& figuram fere Jemper imitatur Fungi icreftris, gui nunc planus eft, nunc gibbofus, pileatus, aut clypeiformis. Sed lamina jemper in fuperiori fuperficie, dum inferior in piffillo de finit.

7 Fungus coralloides rofaceus M. R. Pars inferior pifillo innititur; fuperior in acetabula. lamellis plurimis friata, explicatur.

8 Fungus coralloides, encephaloides, gyris in medio fulcatis, lamellatis ferratis Boerh. Ind. 
Alt. p. 1. Lapis fungites, cerebriformis Raij H. App. 1850. In piflillo definit, fed latiori, guam in lamellata aut rofacea Jpecie. Ex Mari Rubro.

9 Fungus Aftroites, ftellis contiguis, parvulis M. R. Stelle nimirum angulate, docimam uncise partem in diametro non fuperant. In formâ f.re femper globulari crefoit bac Fungorum fpecies, cum alive fequentes, vario modo rupes operiunt, nes ulle forme $\int p e c i f i c e$ conplant. Vid. Obf. p. 385 .

Io Fungus Aftroites, ftellis contiguis majoribus M.R. Stellse ad quartam uncice partem accedunt, of nun fint rotund $x^{2}$, nunc ovata.

i1 Fungus Attroites, ftellis contiguis, laniellatis, rotundis M.R. Stelle in bac jpecie femiunciales funt, cum lamellis profundioribus \& crafforibis.

12 Funcus Aftroites, ftellis contiguis, profundis, angulatis M.R. Hujus Stelle etiam femiunciales fint \& profunde, pentagone aut bexagonic fisura, cum lamellis minoribus.

13 Fungus Aftroites, tuberofus, Stellis rarioribus M.R. Stello exigua, clegantes, figuram pre fe ferunt Omphalodis Lufit. Lini-folio I. R.H. I 40.

14 Fungus Aftroites elegans, Stellis rarioribus, papillatis, rotundis M.R. Stella paulo majores quam inz nona Specie, cum radiis afperis, punctatis, eminentibus.

Is Fungus Aftroites, ftellis rarioribus, acetabulis minus profundis M. R. Stelle tertiam uncia partem occupant, rotunde aut ovate figure, minus praterea eminent, cum radiis levioribus, \& intcrvallis Stellarum magis fulcatis.

16 Fungus Aftroites, parum ramofus, ftellis rarioribus, papillatis $M$. R. Stelle $u t$ in $14^{a}$. Specie fed laviores.

17 Fungus tubulatus \& Atellatus M.R. Coraliis affinibus Madrepora J. B. III. 807. Madrepora Imp. 7 $20 . E x$ cylindris five tubulis multis conftat, fafciatim difpofitis; extremitatibus plerumque prominentibus of in fellas definentibus. Variat tubulis rotundis ovatis, of compreffes. Ad hanc Speciem referri poteft Foffile illud Grew's piped waxen Vein dictum.

18 Fungus eburneus, pyxidatus, compreffus. Lavis eft ex attritu maris; licet primitus rugofa fuiffe vidcatur bac fpecies, inflar Foffle illud Plectronites dictum, quod etiam ad Fungum bunc referr; debet.

19 Keratophyton arboreum, nigrum Boerh. Ind. Alt. p.6. Corallium nigrum five Antipathes J. B. III. 804. Lob. Ic. 251. Rami in bac fpecie plerumque intertexti funt, cum materia quadam, core fimili, bic illic interfperfa. Ex Mari Numidico.

20 Keratophyton cinereum, ftriatum, tuberculis minoribus M. N. Pedalis eft bac pecies, ramis redtis, minus frequentibus. Tubercula, Nicotiane feminibus equalia, ubique per ramulos difperguntur.

21 Keratophyton cinereum, Aabelliforme, nodofum, ramis frequentioribus, huc illuc diftortis M. N. Formam Litbopbyti flabelliformis babet nifi quod rami non funt intertexti. Pedalis aut al tior eft bac Jpecies; friata etiam, cum tuberculis, ut in priori, fed paulo majoribus, acutioribus, of frequentioribus.

22 Kcratophyton cinereum, fragile, ericæforme, ramis pinnatis M. N. 'Tubercula undique circa ramulos, Erica foliorum inftar, vel quaficatenatim difpofita funt.

23 Keratophyton rufefcens, ramulis capillaceis, fparfis M.N. Cubitalis eft bec Jpecies, cum tuberculis parvulis, quefi evanefcentibus.

$2+$ Keratophyton rubrum, Algerienle, Virgulti facic. Tuberculis totum obfiritur, parvulis, furjum Spectantibus, inftar vafculorum Flantaginis, fed minoribus. Tricubitalis eft, cum ramis laxiori modo

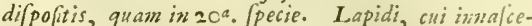
batur, plurima Somina, Lentis magnitudine, introrfum emarginata, lapidea, fubfufca adbarebant; grorum unum poftea turgcbat, quafi germine foctum, of colorem rubrum, Corallinum, afsumebat. Ex Mari Algerienf.

5 Madrepora Aögorarosidís candida, ramulis brevibus obtufis, uno verfu difpofitis $M . R$. Plauta Saxea Aöortarusdòis Cluf. H. Exot. 1.6. cap.7. Variat colore fujco. In utraque fpecie tubircula junt aperta.

Hrc \& fequentes fpecies, Aöporavieidis dicuntur quod "Rami Abrotani feminx (a non" nullis Chamæcypariffus Plinij exiftimati) folic"rum formam poene referebant; nam brevibus "rubulis, inftar minutiffimorum foliorum con"ftabant, eadam ferie, ut illa, difpofitis, fed "magis multiplici, quia pauci quaternis, pleri"que quinis, fenis \& feptenis, interdum etiam "pluribus ordinibus compacti erant: in craili"oribus autem ramis, qui quodammodo candi"c cabant, fere artrita erant illa folia, ut dumtaxar "foramina relicta apparerent tanquam foliorum " tubulatorum veftigia. Cluf. Exot. 1.6. cap. 7. p. 123.

26 Madrcpora Aopotesoed is repens, ramulis longioribus uno verfu difpufitis M.R. Fufci eff coloris, cum tuberculis minoribus, apcrtis, fod afperioribus.

27 Madrepora Aogernesoesdìs nodofior, tuberculis uno verfu difpofitis M.R. Elufdem eft coloris cum priori, fed minus ramofa, cum ramis craffioribus.

28 Madrepora A ipeozuocidis ramofior, tuberculis furfum fpectantibus M.R. Candida eft, ckm ramis acutis, erectioribus.

29 Madrepora A obotavosdis ramofior, tuberculis longioribus, claufis, furfum fpectantibus M.R. Rami acuti funt, ut in priori, fed viridefcunt, of umbellatim quafe nafcuntur.

30 Madrepora Aopotasoeson's ramofior, ruberculis horizontaliter difpofitis M.R. Tubercula aperta funt, of rami magis fparfi quam in procedent; specie.

3I Madrepora Aftroites flavefcens, nodofa, minus ramofa M.R. Corallium ftellatum, minus rubrum J. B. III. 806. Imp. 718 .

Loco tuberculoram, bac or fequentes fpecies, afteriis five ficllis exiguis planis ubique notantur, fropterca Aftroites audit, \& ab Abrotanis diffinguitur.

32. Madrepora Aftroites humilis, ceratiformis M.R. Ramuli in bac fpecie rotund's funt, or in extrcmitatibus acuti.

33 Madrepora Aftroites major, ceratiformis, ramulis obtufis, planis, n1agis difperfis M.R.

34 Madrepora Aftroites major, ceratiformis, ramulis obtufis, planis, confertis $\mathrm{M}$. R.

35 Madrepora Aftroites, Quercus marinæe vulgaris facie, ramis connatis M.R.

36 Madrepora maxima arborea I. R. H. 573. Porus magnus J. B. III. 807. Imp. 624. Ex mari Numidico.

37 Madrepora tubulis elegantcr coagmentatis conftans, ruberrimis Boerh. Ind. Alt. p. 6. Tubularia purpurea I.R.H. 575. Coralliis affinis; Alcyonium fiftulofum rubrum J. B. III. 808 . H. Ox. IIl. Tab. \& fig. ultima. Ex Mari Rubro, ubi fpecimina vidi longitudine fe quipedali, latitudine pedali. 


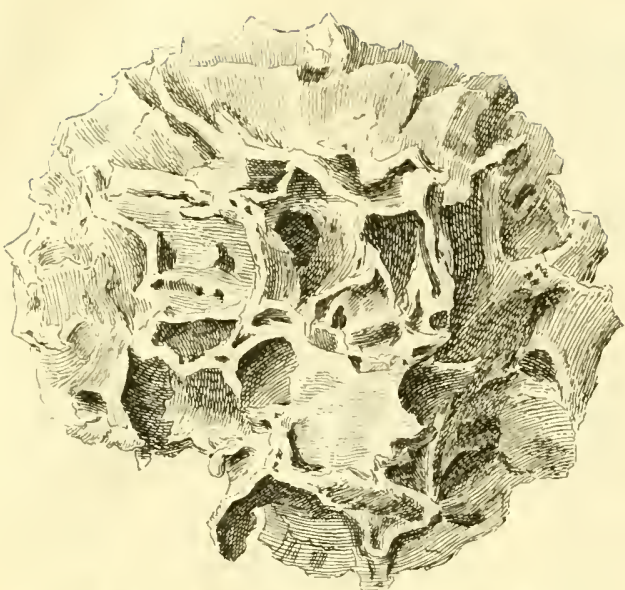

1. Hlyomium inndedum, iretuxerm,

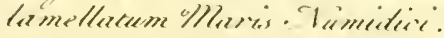

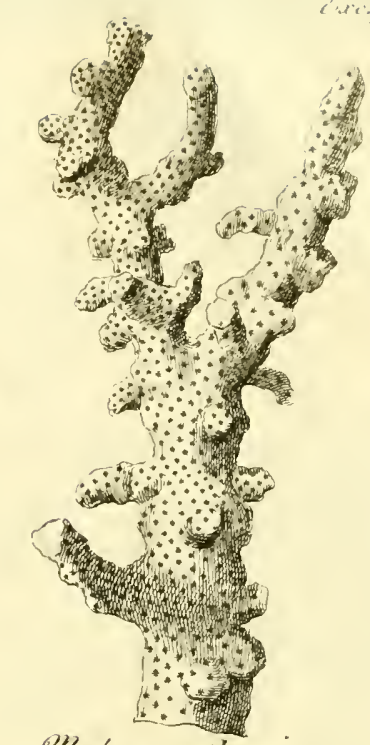

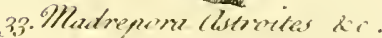

तुी

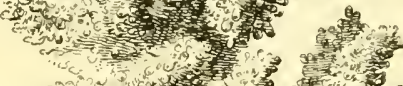
Ex mor ont on (

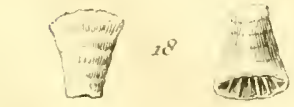

18. Trunapes elurneter dec.
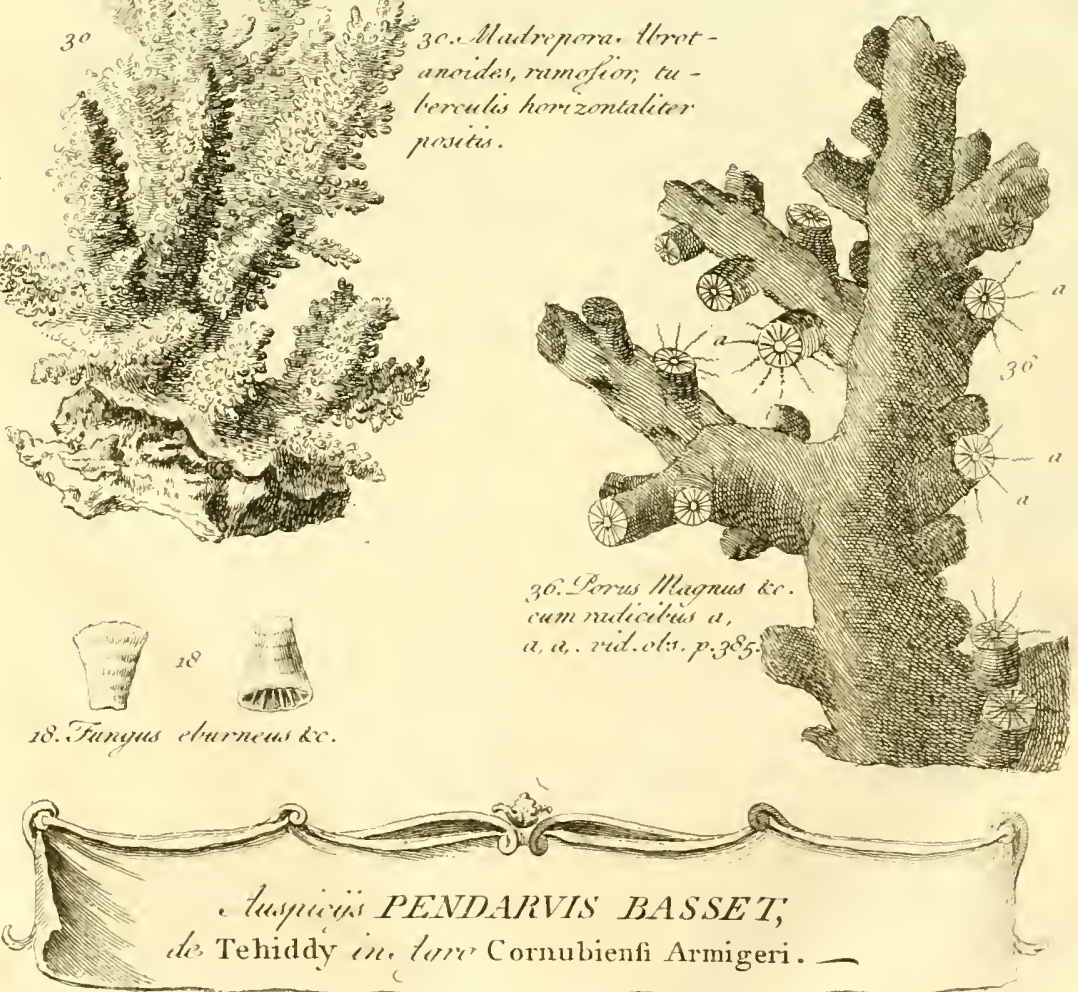



\section{A T A L O G U S}

\section{Fossilium QUORUNDAM RARIORUM}

\section{E Rupibus $\oplus$ Lapicidinis}

\section{A F R I C F}

${ }^{r} \mathrm{~A}$

Culeus cylindraceus, ftriatus, bullis parvulis obtufis infignitus. Radiolus cucumerino minori accedens, teretiformis Lhuidij Lithophy]acij Brit. 1030. Formam babet aculei Ecbini laticlavij, bullis donati Obf. 0.387.

2 Aculeus cylindraceus, triatus, bullis parvulis acutis notatus.

3 Aculeus levis, quadratus.

4 Balanus cinercus, foffilis.

5 Belemnices Succinı adinftar pellucidus, quibufdam Lapis Lisccurius Lh. Lithoph. 1707.

6 Buccinites cancellatus, eburneus. Har or sequens fpecics figuram habent Cocblearum friatarum Lifteri Sect. V. cap. 7. de Concbyl.

7 Buccinites cancellatus, ruber, cum vermiculo adfito.

8 Corallium ramulofum, perfractum Lh. Lith. 92. Tab. 3. f.92. Noftrum pyxidatim feu in acetabulis varie furme crefcit, quorum plurimi comprefji funt. In rupibus Oranenfibus frequens.

9 Corallium tenuius ramofum, album, elegantiffimum.

10 Echinites bullis parvulis, raris, ordine irregulari pofitis.

II Echinites difcoides, lævis, gibbofior.

12 Echinites galeatus, fpoliatus, feu ex toto filiceus, vulgaris Lh. Lith. 956. Brontias five Ombria ovalis Plot. H. Ox. T.2.f.14. \& T.3.f.I. Noftrum in dorfo paulo gibbofus eft.

13 Echinorum laticlaviorum fcuta varia.

14 Echinites pentaphylloides, lixvis, gibbofus, ad oris aperturam fulcatus.

I5 Echinites pileatus, feu figura conoide vel quodammodo tubinata; five Brontia prina $L$ asbmundi Lh. Lith. 96z.

16 Fungi pyxidati foffilis, qui vulgo Plectronites dicitur, varia fpecimina:

17 Fungus foffilis rugofus \& ftriatus, gibbofior.

18 Fungus foftilis, rugofus, magis depreffus, ruga intermedia, longiori.

I9 Madreporæ Impcrati foffilis, varia etiam fpecimina.

20 Myconites rotundus, compreffus. Ovorum pifcium quorundam mafja fofjilis eft, quam Nomades
Thevefini nummum effe exiftimant in lapidem cons verfum.

2 I Oftracites confragofus lividus, ftriis inæqualibus imbricatis, \& margine finuato \& donatus.

22 Palma forfilis. Hoc specimen mibi dedit $\mathrm{V} . \mathrm{Cl}$. Dom. Le Maire, quod cum aliis foffilibus, Ecbinis filicet of Concbyliis, recepit e Ras Sem in Regione Barcx. Eundem caudicem, eofdemque fibrarum ductus o ordines pre fe ftrt, quibus lignum ipfius Arboris vive infunitur. Trunci integri interdum ibidem inveniuntur.

23 Pectinites eburneus, fex aut feptem ftriis elatioribus, lævibus, incifuris afperiufculis infignitus. Triuncialis fore eft in sircuitu, or cqualiter auritus. Stria ejus of incifura aqualia conchylij Spatia occupant.

24 Pectinites elegans, ftriis quinque aut fex elatioribus, majoribus, intermediis tribus minoribus, magis depreflis.

${ }_{25}$ Pectinites lævis, parvulus, ftriis crebris, ad bafin tenuiter fulcatis.

26 Pectinites lævis, undecim aut duodectm ftriis comprelfis infignitus. Ad pectines ex utraque parte aqualiter auritos pertinct. Fafciis crebirr.mis, tenuifimis eleganter notatus eft. Medio dorfo cavus, ubi frice of fafcia evanefcunt.

27 Pectinites magnus ftriis quindecim aut pluribus, bullatis, elatioribus, incifuris in termediis drepreflioribus, afperis. Magnitudine \& figura convenit cum PcEtine primo Lifteri, nif quod nofter incequaliter auritus eft.

28 Pectinites parvulus, ftriis crebris, afperis eleganter notatus.

29 Pectunculites exigıus, confractus, tenuiter ftriatus.

3o Pectunculites polyleptogynglymus, fpeciofus, leviter fafciatus. Docem uncias fuperat in circuitu. Cretacei coloris eft, intus fragmentis variorum conchyliorum foffilium repletus.

3 Retepora foffilis, cinerea.

32 Terebratula vulgo, five Conchites vertice perforato. Varia bujujce Conchylij, ut \& Pectirum genera, ubique per Africam, Afiam, Arabiam \& in ipfis Pyramidum Gradibus, inveniuntur.

33 Trochites nodofus, luteus, femiuncialis.

\section{E Lapidibus pracipue P Y R A M IDU M, ๑o locis circumjacentibus.}

34 Aculeus cylindraceus, bullatus. Non friata eft bac aculeorum Jpecies ut reliqua fere omnes ques funt bullate. Ad magnitudinem penne anferincaut cygne interdum accedit.

35 Aculeus latus, compreffus, livis, fubcxruleus. Dimidiam uncic partem latus eft.
36 Aftaci foffilis brachij articulus extimus \& maximus. Aftacum totum vidi in lapide inclufum banc tamen partem mibi folummodo contigis evellere.

37 Chamæpholadis anguftr, intus fafciatæ, nucleus.

N $\quad 3^{8}$ Chamites 
38 Chamites, planus, cincreus, rotundulus, roitro acuto. Circinira miner Lh. Lith. 741. 39 Echinites laticlavius compreffus, femiuncialis, ordinibus bullarum binis, juxta pofitis.

40 Echinites pentaphylloides, ftris æqualibus, umbone aperto. Plus quam pedalis eft in circuitu, dorfo parum elato of apcrto. In deferto Marah inveni, in via ad montem Sinai.

41 Iclithyodos, vulgo Bufonites dictus, gibbofus, luteus.

42 Ichthyodos, vulgo Glofopetra dictus, acutus, femipellucidus, margine utrinque lævi.

t3 Lithoxylon ferruginei coloris. Fragmenta plurima varice magnitudinis ubique jacent in Ifthmo inter Kairum \& Suez.

44 Madrepora aftroites forfilis, Quercus marinæ̈ facie.

45 Madreporæ Imperati, Pori magni \& Corallii cujufdam flavi coloris, fragmenta plurima forfilia.

46 Pholas cinerens, forfilis, uncialis, lævis. Figurâ convenit cum Pholade involucro fpoliato Lh.Lithoph. Tab.10.f.878. nifr quod nofier major efl. 47 Rhombi cylindracei, parvuli, nucleus.

48 Turbinites compreflus, fafciatus, fefquiuncialis. Albidus eft, fuore intus refulgens. Figura fere convenit cum $\Sigma \alpha \lambda \pi r \gamma$ r Fab. Colum. Aquat. \&c. Obferv. p. LV.

\section{E Rupibus precipue L.A O D I CE $₫$ ๑ Scalce Tyriorum.}

4 Aculèi Echinorum foffiles, Lapides fudaici vulgo dicti. Horum ubique varietatcs quamiplurima. 50 Aculeus lævis, turgidus, Lapidis Judaici forma \& magnitudine.

5i Aculeus levis, Pyri vel Fici-formis. Hic or pracedens lividi coloris funt.

52. Aculeus lævis, cylindraceus, cinereus. Pennam corvinam craffitie aquat.

53 Aculeus torofus, minor Lh. Lith. 1047.

54 Aculeus torofus, feu ramufculis infignitus, major. A procedenti differt, quod, ramufculis (aculeis potius) exceptis, totus levis fit, cum alter friis altis notetur.

55 Aculeus idem cum 53 . fpecie. Variat ballis afperioribus.

56 Echinites afperior, pentaphylloides, ftriis majoribus, xqualibus.

57 Echinites lævis, pentaphylloides, poftica parte gibbofiori, anteriori fulcata. Ex quinque futuris five priis quibus infignitur bac fpecies, tres anteriores longe, fpeciofe funt, (quarum media fulcata eft; ) alterec duce rotunda, exigua.

58 Locuftx forficula vel ferrula interior $L$. Lith. 1246. Tab. 14. f. 1246.

59 Pecturiculites lacunatus minor L.Lith.n.684. 60 Porus minimus, reticulatus Lh. Lithoph. n. 94. Tab. 3. 94. speciminum noftrorum alia cylindracea funt, alia compreffa, quorim unum o alterum arcuatum eft, in margine cleganter finuofum.

61 Pifcium foffilium varia genera, ad Inebianos accedentia forma, fitu \& materia.

62 Squilla fofflis, Cujus Icon exkibetur in Muf. Befl. nifi quod noftra minor eft.

Preter hæc, plus centum alia Foffilium genera, una cum Echinis, Coralliis \&c eorum affinibus, Vafibus, Icunculifque quamplnrimis ex Africa olim tranfmifi, \& Celeberrimo Woodwardio confervanda commendavi. 111 o interim defuncto, dum ipfc apud exteras gentes commoratus fui, eorundem nullam plane rationem reddere voluerunt Teftamenti Curatores, fed ea aut vendebant aut retinebant omnia, tam meo, quam Hiftorix Naturalis Studioforum detrimento.

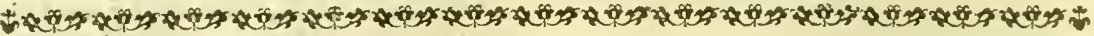

\section{Pisces NONNULLI RaRIORES}

QU I M A R I A

\section{ALGERIENSIUM \& TUNITANORUM}

\section{FRE QUEN T A N T.}

i Lphæites five Cynæedus Rondel. 1 70 . Raij A Synopf. Pifcium p. 137.

2 Afellus mollis major 3 Raij Synop. p. 55,56 .

4 Aurita omnium Authorum Raij Synop.p. 12 I. Feraffa Maurorum.

5 Bugloffis, Linguacula, \& Solea Rondel. p. 320. Raij Synop. 33.

6 Canis Carcharias five Lamia Rondel. p. 18. 7 Catulus minor vulgaris Raij Synop. 22.

8 Cephalus Rondel. 260. Mugil Raij Syn.84. 9 Cuculus Aldrovandi Raij Synop. 89.

10 Draco five Arancus Plinij Rondel. $30 \mathrm{r}$ Raij Synop. pI.

II Faber live Gallus marinus Rondel. 328. Raij Synop. 99. a nomnullis Pifcis St.Petri dicitur.

12 Galeus Acanthias fivc Spinax Rondel. 373.

Raij Synop. 21.

13 Galcus lævis Rondel. 375. Raij Synop. 22. $1+$ Glaucus Aldrov. p. 302. Amia Salvian. fig.

\& p. 121. Leccia (Leechy vulgo) Romæ \& Liburni Raij Synop. 93.

Is Hirundo Rondel. 284. Milvus Salvian.

fig. \& pag. 187. Raij Synop. 89.

16 Hirundo vera Veterum Salvian, fig. \& pag.

185. Mugil alatus Rondel. 26\%.

I7 Lupuis Rondel. 268. Raij Synop. 83.

18 Mairo Kifpan. Alaizab f. Capra Maurorum.
19 Mormyrus Rondel. 153. Raij Synop. 134. Maura vulgo Hifpanis.

20 Mullus barbatus Rondel. 290. Raij Synop. 90. Triglia Italss. Rouget Gallis. Locis quamplurimis Salmonetta.

21 Muræna Rondel. 403. Muræna omnium Authorum Raij Synop. 34.

22 Orthragorifcus five Luna Pifcis Rondel.424. Mola Salvian. fig. 154. pag. 155. Raij Synop. 51. 23 Pagrus Rondel. 142 . Raij Synop. 131. $2+$ Paltinaca capite obtufo five bufonio. Aquila Romanis \& Neapolitanis; nec non fecunda Paftinacre fpecies Rondel. 338. Raij Synop. 23. 25 Pelamys vera five Thynnus Ariftotelis Rondel. 245. Raij Synop. 88.

26 Perca marina Rondel.182. Raij Synop.I 40. 27 Polypus orbicularis, exiguus, mari innatans Obr. 259 \& 385 . Urtica marina foluta Fab. Col. Aquat. \&c. F. Xx. Xxi1.

28 Rảia clavata Rondel. 353. Raij Synop. 26. 29 Raia oxyrrbynchos, Squatine facie, unico fpinarum ordine donata. Raia fecunda oxyrrhynchos five Bos antiquorum Rondel. 347 .

30 Salpa Rondel. 154. Raij Synop. 134.

3 I Sargus Rondel. 122. Raij Synop. 130.

32 Scorpius minor five Scorprena Rondel.142. Raij Synop. 142.

33 Serpens 
FossILIA.

Kn 20

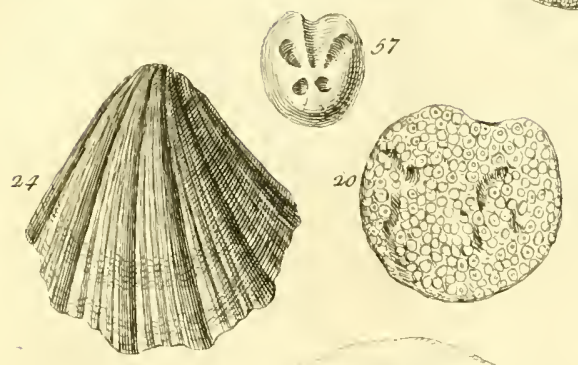

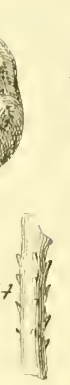
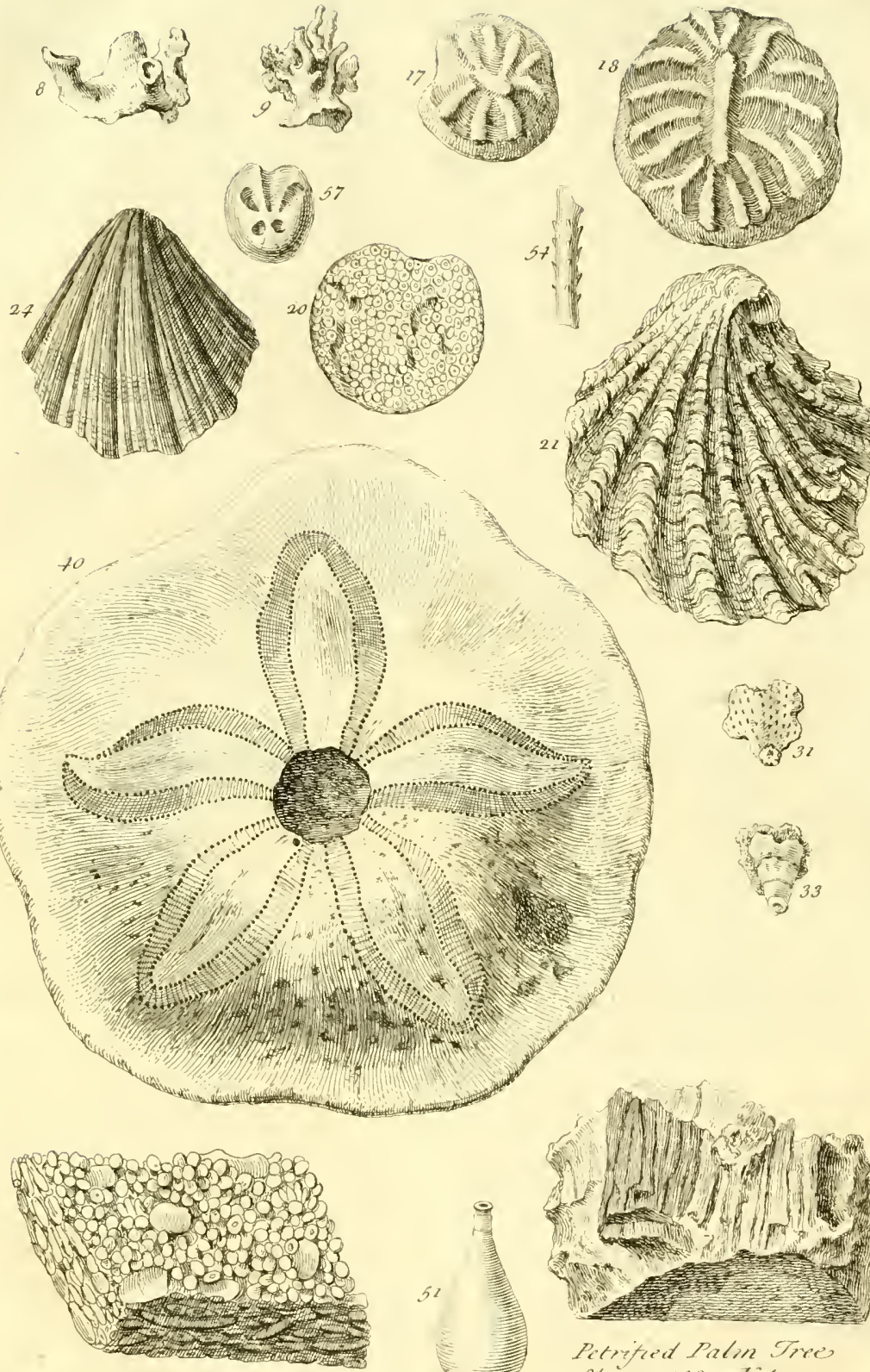

Pisolitha obs.p.420'. lot. 2 .
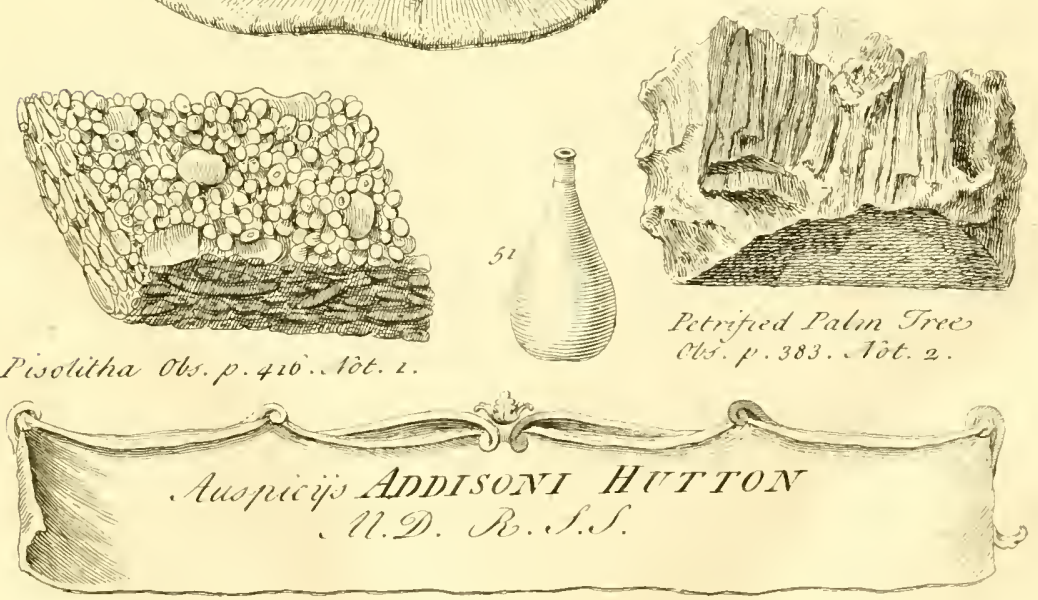



\section{Pifces nonnulli Rariores \&c.}

33. Serpens mari uus, caudâ compreffi, pinnis cincta, in orânigris. Myrus Rond.Gefnero p. $68 \mathrm{r}$. 34 Squatina dorfo lari, alis in cxtremitaribus clavatis.

35 Torpedo maculis pentagonice pofitis, nigris.

36 Trachurus Rondel. I 33 . Raij Synop. 92.
37 Turdus miuor cxrulcus.

38 Turctus minor fufcus, maculatus, pinnis brancnialibus aure 1 , aliis ex viridicarulefcentibus.

39 Turdus mimor viridis Raij Synop. 137.

40 Umbra Rondel. 132. Raij Synop. 95.

4I Lygrna Rondel. 389 . Raij Synop. 20

\section{Conchylia quedam rarior a Maris Mediterranei $\sigma 0$ Rubri.}

I Uris marina major, latior, plurimis foraSect. 7. 1., 2.

2 Balanus purpurafcens, capitis apcrtura valde patenti. Nins rupibus adbaret, nunc Corallinis, a't Matirice cuidam Madrepore affini, a Penecillis o Vermiculis perforate.

3 Balanus purpurafcens, ventricofior, capite minus aperto.

4 Buccinum ampullaceum fufcum, clavicula nodofa.

s Buccinumampullaceum, roftratum, itriatum, triplici ordiue muricum exalperatum Lift. Hift. Conch. Sect.1 3. n. 22. Purpura altera muricata Aquat. \& Terr. Obf. Lxiv. Ic. Lx. five Murex parvus roftratus Fab. Col. Defc.

6 Buccinum ampullaceum, roftratum, (leviter) ftriatum, muricatum, ex duplici ordine in ima parte primi orbis Lift. H. Conch. Sect.1 3. n. 20. Variat colore eburuso of fufco.

7 Buccinum ampullaceum tenue, roftro leviter finuofo, profunde \& rarius fulcato Lilt. $\mathrm{H}$. Conch. Sect. 12, n. 18.

8 Buccinum bilingue ftriatum labro propatulo. Labrum noftriplanum eft, fine digito, aliter figuram pre se fert n. 20. Lift. H. Conchyl. Sect. 12.

9 Buccinum bilingue, roftro recurvo, labro producto, clavicula muricata. Variat inter n.I9. \& 28. Lilt. H. Conch. SeAt. I 5. n. I.

10 Buccinum breviroftrum nodofum Lift. $\mathrm{H}$. Conch. Sect. 15. n. i. Purpura violacea Fab. Col. Purpur. Ic. \& Defcript. F.1.

II Buccinum maximum, varicgatum ac ftria tum Fab. Col. Aquat. \& Terreft. Obr. LıIs. Ic. Defcript. Lis.

I2 Buccinum recurviroftrum, ftriatum, quinque aut fex muricum ordinibus afperum.

I3 Buccinum roftratum, candidum, leviter ftriatum, finuofum Lift. H. Conch. S. 14 ..

$I_{4}$ Buccinum roftra um, labro duplicato, quafi triangulari Lift. H. Conch. Sect. 14. n. 27.

I5 Buccinum roftratum lacie, labro fimplici, alte ftriatum ad intervalla Liit. H. Conch. Sect. I. . 11. 27.

I6 Buccinum roftratum, triplici ordine nuricum canaliculatorum horridun Lift. H. Conch. Sect. I4. n. 4r. Purpura five Murex pelagius, marmoreus Fab. Col. Ic. LX. Defcr. LXII.

17 Chamarum \& Tellinarum, margine læevi \& dencato, multa gencra.

I8 Cochlea variegata, denfe \& admodum tenuiter ftriata, item quolibet orbe duæ intignes ftrix parallcl $x$, bullatie Lift. H. Conch. Sect.4 n. 60 .

rg Concha margaritifera plerifque : Berberi antiquis Indis didta Leit. H. Conch. 1.3. S.I.n.56.

20 Concha marina marmorea imbricata Lift. H. Conch. 1. 3. ก. I II.

21 ConcharumVeneris varietates quamplurime. 22. Mufculus polyleptogynglymus, eleganter ftriatus, roftris a cardine remotis. Mufculus Matthioli Lift. H. Conch. 1.2. Sect. 6. n.208.

23 Nautilus maximus denfe ftriatus, auritus.

Nautilus C A L C E O L. Nautıli primum genus Ariftot. fecundum Bell. \& Aldrov. Lift. Hift. Conch. Sect. 4.11 .7$.

$2+$ Nerita albidus, ad columellam dentatus, ftriis magnis \& parvisalternatim difpofitis donatus. 25 Oltrea roftro craffo, elato, in aciem comprelfo.

26 Patella major ftriata, rufclcens, intus eburnea, verticc acuto. Ovalis eff figura', pedenque fire babet in circuitu.

27 Patellarum verticibus intcgris \& perforatis varia genera.

28 Pećten parvus, inequaliter auritus, tenuiter admodum ftriatus. Mlazna colorum varictate ubique reperitur bac Jpeczes \& mari Rubro \&o Mediterraneo.

29 Pecten ruber, aqu 1 liter auritus, 13 ftriarum, dorfo compreffo laviori. Strie of canalichlifpatia equalia occupant.

3o Pectunculus cinereus, afper, anguftior, tenuiter \& creberrime ftriatus.

3I Pectunculus craffus, cburneus, alte itriatus, orbicularis. Variat colore rufefcente.

32 Pećtunculus eburneus, dorfo in aciem comprelfo Lift. H. Conch. 1. 3. Sect. 5. 11.rzz.

33 Pectunculus in medio leviter ftriatus, intus lividi coloris. Strix \& fafciæ viridefcunt; caeterun albidus eft, \& ad figuram accedit n, 169。 Lift. H. Conch. 1.3. Seet.;.

34 Pectunculorum lrvium, triquetrorum varia genera.

35 Pe尺tunculus polyleptogynglymus craffus, profunde fulcatus, luteus. Ad figuram accedit n. 70 Lift.H.Conch.1.3.Par.1. Sed nofer duplo major ef. 36 Pectunculus polyl. lævis, rufefcens, farciis albidis.

37 Pectunculus polyl. cancellatus, oblongus, margine cx una parte productiori. Margo ubique mufco fimbriatus eft. Figura convenit cum Cliama nigra Rondeletii Lift. I. Conch. 1.3. n.260.

38 Pectunculus recurvirofter, medio lævis, ad marginem fafciis rugofis, quafi Corallinis, notatus. Non diffrnilis eft formá patell's vertice adunco.

39 Pectunculus rufefcens, ftriis magnis compreffis, in dorfo leviter fulcatis, in margine echinatis.

40 Pefunculorum ftriatorum, roftris rectis \& recurvis, infinita generz.

4I Pinna magna, imbricata, five muricata Lilt. H. Conch. 1. 3. n. 21 t. Nacre vel Nakker vulgo maris Mediterranti; cujks Barba, Scrici inftar mollis, fuit forfan By/fus Antiquorum.

42 Solcn rectus, ex purpura radiatus Lift. $H$ Conch. 1. 2. n. 256.

43 Spliondylus coccineus, ftriatus, roftro lato, cx una parte auriculato.

44 Sphondylus eburneus, lamellatus, roftro acuto, rccurvo. Lamelle plerumque pyxidation pofite funt, o Balanos forma referunt.

45 Trochus clavicula breviori, ftriis eleganter nodofis.

45 Idem ftriis inferioribus nodofis, fuperioribus muricatis.

47 Idem muricatus, clavicula magis exporrecta. 48 Troclus pyramidalis, erectus, rufefcens, lavis, orbibus latis, in imis partibus folum nodofis. Icon apud Jonit. H. de Exang. p. 36. Tab. I Jub titalo Trochi magni. Turbo maximus Perficus verior Fab. Col.Aq. \& Terr.Obf, Lxv, Tab.Lx. 49 Trochus pyramidalis, ftriatus, muricibus radiatim ad marginen difpofitis Lift. $H$. Conch. Sect. 8. n.9. 
A

\section{O C A B U L A R Y \\ O F T H E}

\section{SHOWIAH Tongue.}

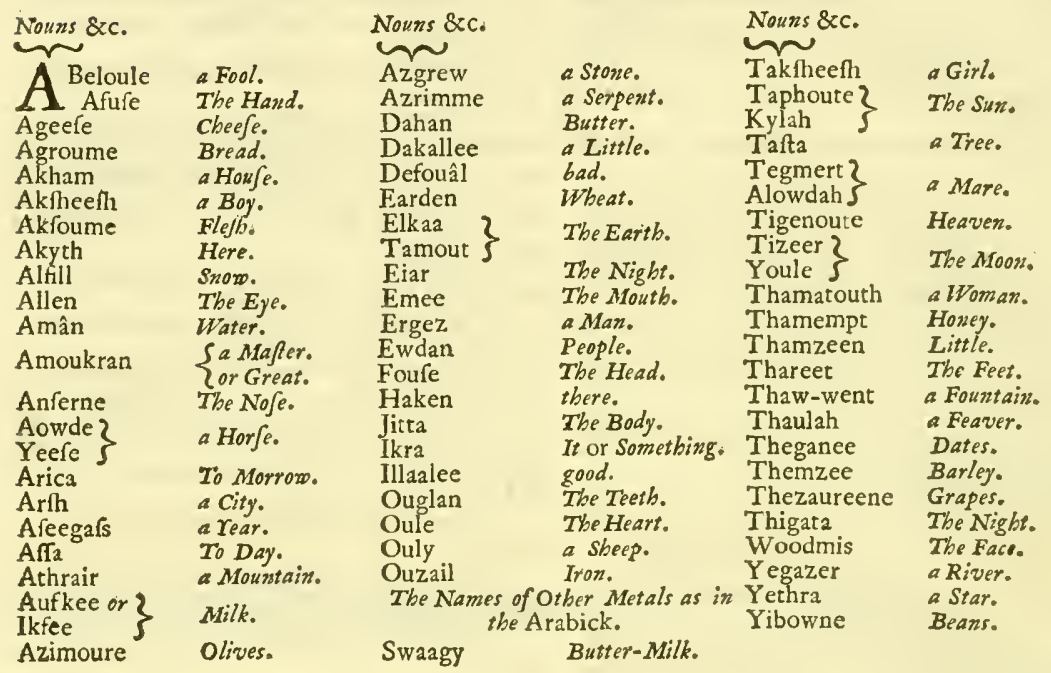

\section{The Declenfion of Nouns and PR ONOUNS.}

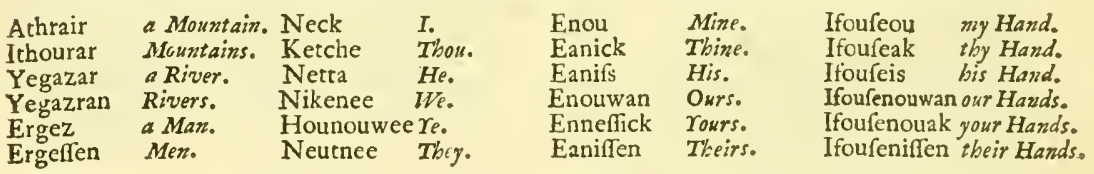

\section{E R B s, with their Conjugations.}

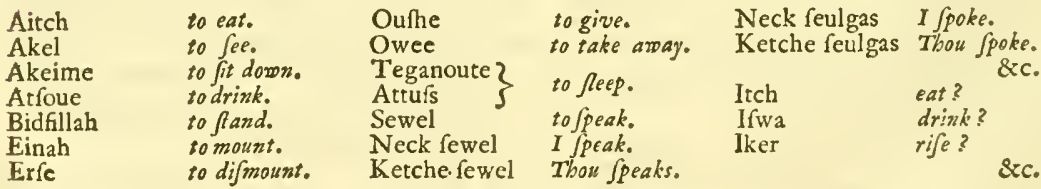

\section{N U M B R S and PhrAses.}

\begin{tabular}{|c|c|c|c|}
\hline Ewan & One. & Word for give me? as & $\begin{array}{l}\text { thirffy. } \\
\text { Kadefh affegaffen themeurtaye }\end{array}$ \\
\hline $\begin{array}{l}\text { Seen } \\
\text { The otbe }\end{array}$ & $\begin{array}{l}\text { Two. } \\
\text { Numbers as in the }\end{array}$ & $\begin{array}{l}\text { Ifkee ikra adet thâg, neck alou- } \\
\text { zagh? Give me to eat, for I am }\end{array}$ & $\begin{array}{l}\text { Kadefh affegaffen themeurtaye } \\
\text { akyth? How many Years bave }\end{array}$ \\
\hline $\begin{array}{l}\text { Manee illa } \\
\text { Oulhee eide } \\
\text { Oufhedoura } \\
\text { itkee alfo }\end{array}$ & $\begin{array}{l}\text { Arabick. } \\
\text { xhere is it? } \\
\text { give me that? } \\
\text { I give it. } \\
\text { or If gee is another }\end{array}$ & $\begin{array}{l}\text { bungry? } \\
\text { Ifkee ikra wamani adefwaag, neck } \\
\text { foudagah? Give me Water to drink, } \\
\text { for I am thirfly? } \\
\text { Neck urfedaag ikra. I am not }\end{array}$ & $\begin{array}{l}\text { You been bere? } \\
\text { Ergez illâlee oury tagadt ikra. } \\
\text { A good Man fears notbing. } \\
\text { Ergez defoûal tagedt. } \\
\text { A bad Man is afraid. }\end{array}$ \\
\hline
\end{tabular}




\section{INSCRIPTIOANTIQUA}

RUPIBUS INSCULPTA PROPE

Defertum de $S I N$.

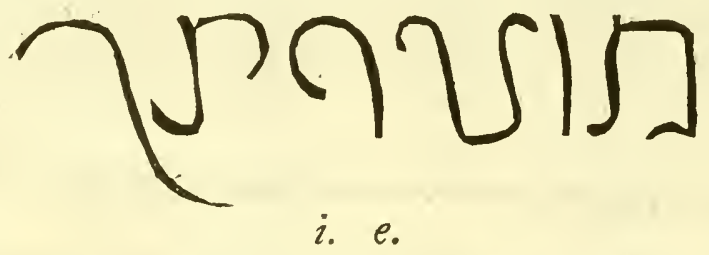

it Pluvia Mannx רפo

$\mathrm{O}^{\text {Uefte lettere trovai intagliate in una pietra mente cavare; mà vicino à detta pietra ve ne }}$ grande nel deferto de $S m$, dove Dio mandò fono delle altre pur feritte in diverfi lati, qual la Manna alli figlioli d'Ifrael; fotto lequali pa- pietre fi trovano alla parte Orientale del deferto reva anco intagliata la figura del Gomor, mifura de $\sin$ nella bocca propria della Valle, per dove della Manna, che fi doveva raccoglere, come fi paffa da Sin per andar in Rafidim. Fra. appare nel Eifodo al c. 16. e di fotto a detta fi- Tomafo da Novara apud Kirch. OEdip. Egypt.

gura vi fono molte altre lettere, mà per l'anti- Gymn. Hierogl. Claff. II. p.Izo.
chita quafi perfe e guafte, ne fi poffono intera-

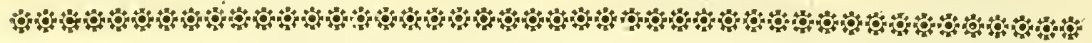

T $\quad \mathrm{H} \quad \mathrm{E}$

\section{SEVERAL STATIONS}

O F T H E

\section{HAD $7 E E S$ or P I L G R I M S}

I N T H E I R

JoU R N Y to $M E C C A$.

viz.

\section{From $K A I R O$ to}

\begin{tabular}{|c|c|c|c|c|c|}
\hline \multicolumn{3}{|c|}{ Deraje ${ }^{2}$. } & \multicolumn{3}{|c|}{ Deraje. } \\
\hline BIRQUE EL HADJE & 80 & a Pond of Water. & Maggyre el Shouribe ${ }^{2}$ & 230 & running water. \\
\hline Dar el Sultan & 200 & No water. & Ain el Kafaab & 220 & running mater. \\
\hline Adjeroute & 200 & bitter water. & Callah Mowlah & 220 & good mater. \\
\hline Rafty-watter & 180 & no water. & Sheck Murzooke & 180 & good water. \\
\hline Teah-wahad & 200 & no roater. & Callah Azlem & $x 90$ & bad mater. \\
\hline Callah Nahhar & 220 & good water. & Aftabel Anter & 230 & good mater. \\
\hline Ally & 230 & no water. & Callah Watiah & 200 & good mater. \\
\hline Callah Accaba & 220 & good water. & Akrah & 250 & bad water. \\
\hline Thare el Hamar & 200 & no water. & Hunneck & 180 & 220 mater. \\
\hline Shirfah & 240 & no pater. & Howry & 200 & bad matcr. \\
\hline
\end{tabular}

2 Each Deraje 80 is equal to four Minutes of an Hour. 2 Shouibe the fame with 7 ethro, who is fuppofed to have lived bere. 
Deraje.

Ne-bat

Houdaaral

Cafabah Yembah

Sakeefah

Bedder Houneene ?

Sebeely $\mathrm{M}_{1-f o n n e}$
200

goodwater.

bad water.

220 runwing water.

$200 \quad n 0$ water.

80 running mater.

240 nowater.

Raaky Me-kat 2
Kadeedah
Afphaan
Wed cl Fathmah
MEccA
Arafat 4

Deraje.

230 good ratir.

$220 \quad 31$ mater.

200 runing water.

200 rinning mater.

120 Zim-zems.

The Pilgrims in thcir Return from Mecca, vifit the Sepulclere of tbeir Prophet at Medina, which lyes at the Difance of there Stations from Bedder Houneene, in the following Manucr, viz. from thence to

\author{
Sakara Yedeedah \\ Kubbourou Showledâhy \\ MedeEna Mownowârah
}

Deraje.

$\begin{array}{ll}180 & \text { goed water. } \\ 230 & \text { no water. } \\ 200 & \end{array}$

Here the pilgrims arrive the Night of the New Moon and perform feveral religious Ceremonies; lighting up a Number of the H. City they are Lamps, and dhe Heads and approaching, they Pravies with Napkins. 3 This Well, which lyes near thmael, from the Prefence of Sarah. Gen. 23.19 .4 Here each Perfon the Wildernefs, when She was driven out, with her Son Ij/mael, from the Prefence of Sarah. Gen. $25.19 .44 f_{a c}$ ) according to

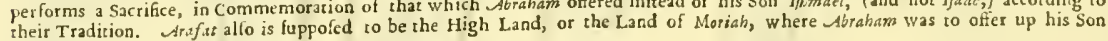
their Tradition.
Gen, 22, 1, 2.

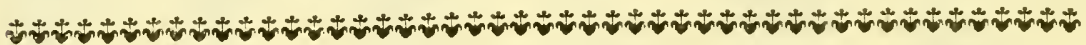

\section{Mefure de la grande Pyramide de Memphis.}

$\mathrm{C}^{\mathrm{E}}$

Ette Pyramide eft orienteć aux 4 parties du Mond, Eft, Oueft, Nord, Sud.

L'entrée eft du coté du Nord.

La porte n'eft tout a fait au milieu, le coteOueft etant plus long que celui de l'Eit, d'environ 30 pieds.

La porte eft elevée 45 pieds au deffus du terrain.

Hauteur perpendiculaire de la Piramide, 500 pieds.

Longeur des Cotez 670 pieds.

Ier Canal d'entrée quiva en defcendant, 3 pieds 6 pouces en quarree.

Longueur du dit Canal, $8+$ pieds.

Pente du dit 35 degrees.

Le Canal eft termine par la fable qu'il faut netoyer pour entrer a gauche, en entrant eft une efpace de voute rompue d'environ trois toifes de diametre pour donner communication au Canal montant.

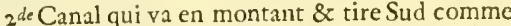
le premier Canal defcendant \& antrefois ils $\mathrm{s}^{3}$ embouchoient l'une a l'autre.

Longueur du dit Canal 96 picds.

Larguer \&Hauteur 3 pieds 6 pouces en quarrée.

Au bout du Canal montant eit a droite un puits fec creusè en partie dans le Roc d'environ 27 toifes de profondeur composè de 4 boyaux, un droit, un oblique, au bout du quel eft un repofoir, \& encore un droit ix puis un oblique qui aboutit a du fable.

Au bout du meme Canal montant eft unc plateforme, fa longueur 12 pieds, largeur 3 pieds 4 pouces. Cette plateforme s'unit a un $3^{\text {me Canal }}$ de niveau,

Longueur du dit Canal 113 pieds.

Hauteur \& Largeur 3.

Chambre d'en bas, Longueur 18 pieds.

Largeur 16.

Plateforme de la Chambre en dos d’àne chaque côtè 10 pieds.

Hauteur des murs jufqu' au dos d' âne I I pieds 3 pouces.

Il y a un trou de 10 a 12 pas de profondeur dans la ditc Chambre a gauche en entrant, les pierres qu'on a tirez du trou font repanclues dans la Chambre; a l'entrée de ce trou paroit une Niche.

$4^{e}$ Canal qui eft auffi montant, fa voute prefq en dos d'ane, Longueur 136 pieds. Larguer entre les mures 6 pieds \& demi. Larguer de la tranchce entre les Banquettes 3 pieds \& demi.

Les deux Banquettes chacune un pied \& demi de large \& de haut.

Mortaifes dans les Banquettes chacune un pied 8 pouces de long, 5 ou 6 pouces de large.

Leur profondeur d'environ un demi pied. Diftance d'une mortaife a l'autre 3 pieds \& environ un tiers. Nombre de mortaifes 56 . c'eft a dire 28 fur chaque Banquette.

Hauteur de la voute du $4^{e}$ Canal 22 pieds \& demi eft neuf Pierres chacune de deux pieds $\frac{1}{2}$ de haut fommées d'un plancher de la largeur de tranchee inferieure.

De 9 pierres de la voute 7 feulement font fortantes, leur faillée eft de 2 pouces $\frac{1}{2}$.

$\mathrm{Au}$ bout da $4^{e}$ Canal eft un $5^{e}$ Canal de niveau; qui aboutit a une grande Chambre mortuaire. Longueur 21 pieds. - Largeur 3 pieds 8 pouces.

Hauteur inegale, car vers le millicu il y ane efpece d'Entrefole avec de Canalures, les deux tiers de ce $5^{e}$ Canal font revetu de marmor granit.

Grande Chambre ou Salc mortuaire, tcute encruftée de granit, pavé, plancher \& murailles. Longucur 32 pieds.-Largeur 16. Hauteur idem in 5 pierres coales. Plancher de 7 grandes pierres traverfent la Sale, par la largeur \& deux pieıres aux dcux bouts lefquelles entrent a moitie dans le mur.

Au fond de la Sale \& a droit, a 4 pieds \& 4 pouces de mur, eft le Tombeau de Granit fans couvercle, d'une feule pierre. Il refonne comme une cloche. Hautcur de Tombcau 3 pieds $2 x$ demi. Longueur 7.Largeur 3.Epaifeur demipied,

A droit du Tombeau dans le coin a terre on voit un trou long de trois pas \& profond d'environ 2 toifes fait a pres coup.

11 y a deux trous a la muraille de la Sale proche de la Porte, l'un a droit, l'autre a ganche, $d^{\prime}$ environ deux pieds en quarrée, on ne connoit pas leur longucur, ils ont cté fait en meme tems que la Pyramide. 


\section{Remarques fur le Natron.}

E Natron ou Nitre d'Egypte a cté connu des anciens; il clt produic dans deux Lacs, dont Pline purle avec éloge; il les place entre les villes de Naucrate \& de Memphis. Strabon pote ces deux Lacs Nicrieux dans la Prefecture N.triotique, proche les Villes de Hermopolis \& $\mathrm{Mo}$ mempbis, vers les Canaux, qui coulent dans la Mareote: toutes ces autorités fe confirment par lis fituation prefente des deux Lacs de Natront. L'un des decix Lacs Nitrieux, nommé le grand Lac, occupe un terrain de quatre ou cinq lieus de long, fur une licue de large dans le defert de Scété ou Nıtrie; il n'eft pas eluigné des monaftéres de Saint Nacaire, de Notre Dame de Suriens \& des Grecs; \& il n'elt qu'a une grande journée à l'Oüeft du Nil \& a deux de Memphisvers le Caire, \& autant de Nascrate vers Alexandrie \& la Mer.

L'autre Lac nommé an Arabe Nehilc, a trois lienës de long, fur une $\&$ demie de large; il s' etend au pied de la mont agne à l'Oüeft \& a douze ou quinze mille de l'ancienne Hirmopolis parva, aujourd'hui Damanclour, Capitale de la Province Bebsirè, autrefois Nitriotique, affez pres de la Mareote \& à une journce d' Alexandric.

Dans ces deux Lacs le Natron eft couvert d'un pied ou deux d'eau; il s'enfonce en terre jufqu' à quatre ou cinq pieds de profundeur; on le coupe avec de longues barres de fer pointues par le bas; ce qu' on a coupé eft remplacé l'annee fuivante, on quelques années aprés, par un nouveau Sel
Nitre qui fort dut fein de la teıre. Pour entretenir fa fecondite, les Arabes ont foin de remplir les places ruides de maticres étrangeres, telles qu' elles foicur, fable, bouë, offemens, cadavres d' animaux, chameaux, chevaux, ânes \& autres. toutes ces matieres font propres à fe réduire, \& fe reduifent en effet en vrai Nitre, de forte que les travailleurs revenant un ou deux ans aprés dans les memes quırtiers, qu’ils avoient épuisés, y trouvent nouvelle recolre à recueillir.

Pline fe trompe guand il afture dans le livre cité ci deffus, que le Nil agit dans les falines du Natron, commele Merdans celles du fel, c'eft à dire que la Production du Natron c'épend de l'eat dcuce, qui innonde ces Lacs; point du tout, les deux Lacs font inacceffible par leur fivuation haute \& fupérieure aux inondations du Fleuve. Il eft sûr pourtant, que la pluye, la roféce, la bruine \& les broüillards font les veritables peres du Natron, qu'ils en hâtent la formation dasis le fein de la terre, qu'ils le multiplient \& le rendent rouge; cette couleur eft le meilleure de toutes, on en voit auffi da blanc, cu jaune ix du noir.***

Outre le Nitron, on recueílle dans certains quartiers des deux Lacs, du Sel ordinaire \& fort blanc; 'ou y trouve zuifi du Sel gemme, qui vient en petits morceaux d'une figure Piramidale, $c^{3}$ elt-a-dire quarrée par le bas, \& finiffant en pointe. Ce dernier Sel ne paroît qu' au Printems.

\section{The Method of making Sal Armoniac in Egypt.}

SAL Armoniac is made of Dung, of which Camel's is efteemed the ftrongeit and beft. The little Boys and Girls run about the Streets of Kairo, with Baskets in their Hands, picking up the Dung, which they carry and fell to the Keepers of the Bagnios; or, if they keep it for their own burning, they afterwards fell the Soot at the Place where the Sal Armoniac is made. Alfo the Villages round about Kairo, where they burn little elfe than Dung, bring in their Quota, but the beft is gathered from the Bagnios, where it cruits upon the WVall about half a Finger's Breadth. They mix it all together, and put it into large globular Glaffes, about the Size of a
Peck, having a fmall Vent like the Neck of a Bottle, but thorter. Thefe Glaffes are thin as a Water, but are ftrength'ned by a treble Coat of Dirt, the Mouths of them being luted with a piece of wet Cotton. They are placed over the Furnace in a thick Bed of Afhes, nothing but the Ncck appearing, and kept there two Days and $2 \mathrm{Night}$, with a continual ftrong Fire. The Steam fwells up the Cotton, and forms a Pafte at the Vent-hole, hind'ring thereby the Salts from evaporating, which, being confined, ftick to the Top of the Bottle, and are, upon breaking it, taken out in thofe large Cakes, which they fend to England.

\section{An Account of the Weather at Alexandria in Egypt, in the Months of January and February, A. D. 1639.}

$\mathbf{J}$

AN. r. Faire, the Wind little and Sourherly.
. Faire.

3. Faire, at $\mathrm{N}$ ight it rained a little.

4. Clowdy and rainy in the Afternoon, and at Night.

5. Clowdy, rainy and windy N. VV.

$\odot$ 6. Very rainy and windy. N. W.

7. Rainy and windy. N.W. all Day and Night.

8. Rainy in the Morning, very windy all Day

and Night, at the latter End of the Night very rainy, the Wind was N.W.

9. The Morning very rainy and windy, at Night very rainy and windy. N.W.

I0. All Day very rainy and windy. N.W. The Rain falls in fudden Gufts, afterwards a little faire, then again clowdy and rainy. At Night it rained very much, and in the Morning fnowed.

II. Friday, it rained, the Afternoon fairc, at Night rainy, N.W. 
12. Saturday in the Morning rainy, the Afternoon faire; and at Night little Wind.

13. Sunday faire, a little Wind. N.N.W.

I 4. Monday little Wind S. E. faire.

I5. Faire little Wind. S. E. the Air full of Vapours, fo that alihough no Clowds, yet the Body of the Sun thined not bright.

16. Faire little Wind. S. E

1\%. Faire little Wind. S. E. Thefe four Days, efpecially the two laft, though no Clowds, yet a Caligo all Day and Night, fo that the Sun gave but a weak thadow, and the Stars little light; this Caligo or hazy Weather arofe partly from the Rains that fell before, and partly from the urual overflowing of Nilus.

18. Friday like Thurfday, or rather worfe, the E.S. E. Wind being gre.

10. Saturday like Friday.

20. Sunday the Wind N. and clowdy, Night faire.

2I. Monday the Wind N. W. faire.

22. Tuefday faire, the Wind $N$. W. it rained a little towards Night the Wind $g$.

23. Wednefday fair Day and Night, theWind N. W. The Wind fomewhat $\mathrm{gt}^{\mathrm{t}}$

24. Clowdy, at Night it rained much. N.W 25. Sometimes faire, fometimes clowdy.N.W. about 4. P. M. it rained fo likewile, at Night very much.

26. Saturday very windy. N.W. and often rainy.

$27 \bigcirc$ In the Day very windy. N. W. fometimes rainy, at Night faire, no great Wind but full of Vapours, fo that the Pole Star nor the Yards could be clearly feell.

28. In the Day a dusky Sky all over, yet not many Clowds, the Sum could not be feen, fo at Night, in the Night it rained a little, the Winds Ealt.

29. The Sky full of Vapours, but not foobfcure as the 28. a Quarter of an Hour before Sun fet, the Sun being immerft in the Vapours, about the
Horizon feemed for a while like burning Iron; or like the Moon as I have feen fometimes in an Eclipfe, as the grew low or half, more or lefs arpeared, and fo by Degrees, till the upper Edge, at laft fhe was quite loft, though not below the Horizon. This may fomething ferve to fliew the Manner of thefe Vapours above 4. P. M. the N.N.W. begun to blow, all Night faire.

30. Faire. N.N.W

3I. Faire, fo 'till Io at Night, then it grew dusky from Store of Vapours by the Eaft Wind.

Fcbr. I. Clowdy at Night, faire, fometimes clowdy, a very great N.W. Wind and fome Rain. 2. Clowdy, faire, rainy, N.N.W. Wind ge Saturday at Night.

3. $\odot$ Very windy, N.N.W. often rainy Day and Night, very cold.

4. Monday very windy N. N.W. Day and Night, often rainy, very cold.

5. Tuefday very windy and clowdy.

6. Wednefday little Wind N. at Night obfcure.

7. Thurfday obfcure and dusky, litrle Wind.

8. Faire, little Wind, at Night the Wind

Northerly, and it rained much.

9. Saturday Morning rainy, Afternoon fair, Wind E. at Night.

10. Very faire Day and Night Wind N.

II. Faire, rainy. N.W.

12. (Faire Day and Night.?

13.
15.
16. Very fairc. $\quad$ little Wind Nor-

17. I faw 2 Spots in the $\odot$.

18. I went to Cairo.

19. Very faire.

20. Faire and obfcure.

2I. Obfcure, at Night it rained much, being at Shimone a great Village fome 50 Miles from Cairo, on the outfide of the River for fear of Rogues, and there I faw Boats of Leather, and 2 Men failing upon 225 Pots.

\section{An Account of the Same, A. D. I6 38 .}

The Merid. Altitude of the Sunne taken by my Braffe Quadrant of 7 Fcet, and fometimes by the Braffe Sextans of 4 Feet, without refpect to Refraction or Parallax.

Decem. 3 d. Having well rectified my Inftrumellts.

4. St. Vet. Tuefday

the Obferv. very good.

5. Obfervat. good.

Quadr. 35

SQuadr. 35

\{Sext. 35

$\{$ Sext 35

6. Obfervat. good.

SQuadr. 35

SSext, 35

7. Obferv. good.

$\left\{\begin{array}{l}\text { Quadr. } 35 \\ \text { Sext. } 35\end{array}\right.$

8. (3 or 4 Days paft it was windy) Qu. 35

9. Clowdy.

10. Clowdy, at N. windy and rainy. Qu. $35 \quad \frac{12}{35}$

II. It was windy clowdy and rainy, I obf. well in the breaking up of a Clowd.

The Obfervations which were hitherto made of the Sunne by the Brafie Quadrant, were by taking of the Shadow on the Top of the Rular by the other Sight or Top at the End. Thefe which follow were taken by letting the Shadow of the Cylindar fall upon one of the Faces, which is thus marked I.

Decemb. 2I. St. Vet.

the Wind Northerly, the Obr. good.

Jan. 2. St. Vet.

3. St. Vet.

4. St. Vet.
12. Clowdy and rainy.

13. Clowdy.

14. Very windy, in the Morn- Qu. $35 \frac{136}{300}$ ing it rained much.

15. Clowdy.

16. Sunday the Obf. good, it was Qu. 35. $\frac{1}{2}$ very clear and no Wind.

17. Clowdy and Windy.

18. Tuefday noWind, theObr. good. Q41.35 $\frac{182}{5 \% 5}$

I g. No Wind no Clowdes.

20. 2

2I. Clowdy or rainy thefe 3 Days.

22. The Obf. good, at 3 o'Clock, Qu. 35. 28 and in the Night it rained much the Wind wefterly.

$24,25.26,27,28.29$. It rained exceedingly Day and Night, with great Winds from the W.N.W.

Jan. 25. St. Vet. the Quadrant

with the Rular, the Cylindar Qu. 42. 206 being broken, the Obf. good. N.W. 300 Jan. 26. Clowdy.

Jan. 27. Sunday Obf. good N.W

Jan. 28. Obfcure. Wind Eaft. 


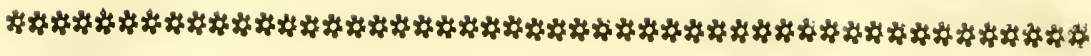

\section{E X C E R P T A \\ E Kalkafenda de Nilo \& Nilometro.}

A M de Nili incremento, \& decremento. Et quidem quoad incrementi ejus menfuram variant fententix.

'Tradit A'-Mas'udi ex Arabum fententia Nilum sugeri ex aliis fluminibus \& fontibus; atque inde effe quod in incremento ejus cætera flumina \& fontes imminumntur ; \& quando ipfe decrefcit, alia fumina fontefque augentur. Hanc fententiam confirmat id quod refert $A$-Kodbái ex authoritate Abdallabi filii Omar, \& (Amrai) filii $A l-A f$, qui dixerunt Nilum Egypti effe fluviortm principem, cui obfequ intur omnia flumina Orientis \& Occidentis; adeo ut quando extenditur, fuppeditent ei flumina aquas fuas; nam in gratiam ejus erumpere fecit Deus terram in fontes; ac tandem curfus ejus, quoufque Deus voluit, pervenit indicavitque Deus, feu juffit unicuique illorum (fuminum), ut ad originem fuam revertarur. Tum ait ex Irdorum opinione incrementum \& decrementum ejus oriri ex imbribus copiofis, quod quidem dignofcitur ex accelfu \& receffu; feu ortu \& occalu fiderum, \& pluviarum abundantia, nubiumque confiftentia.

Dicunt Copti incrementum Nili fieri ex fontibus featurientibus in ripis ejus, quos vidit non nemo, qui profectus luftravic fuperiora ejus. Huic fententi $x$ favet id quod tradit $A l$-Kodha' $i$ ex authoritate Vezid filii Abn Hhabib, fcilicet Moáviam filium $A b n$ Sofian, cui Deus tit propitius, ita alloquutum fuiffe Ca'abum cognonento Al-Abbbâr: obfecrote, per Deum! an invenifti in libro De potentis \& gloriofi hujus Nili fieri mentionem Refprndit ille: Utique, per Deum! nempe Deus potens \& gloriofus revelat (per Angelum) ei quolibet amo duabus vicibus, ut egrediatur, dicendo: Deus jubet te ut Huas. Et Auit, prout preferripfit ei Deus. Tum poftea revelat ei Deus (per Angelum) dicendo ei: O Nile, Deus jubet te, IIt defcendas. Haud dubium autem quin onnia hac verba mox allata ad hoc dictum referenda fint. Hoc eft-igitur fundamentum cxterorum omnium.

Semper autem incipiunt obfervare incrementum die quinto menfis $B * n a$, qui eft unus e menfibus Coptorum. Et nocte duodecima ejufdem ponderatur lutum; atque tunc per hoc æeftimant incrementum Nili, pro!t more confueto evenire facit Deus excelfus, ut de luto ficco guod fuftulit aqua $\mathrm{Nili}$, pondus accipiatur fexdecim drachmarum accuratè, rum illud folio, vel aliqua re fimili involvant ponantque in cifta, vel arca, ant aliquo vafe hujurmodi, tum Oriente Sole illud ponderant. Et pro ratione augmenti ponderis, incrementum N:li xitimatur, cuilibet grano filiqu:e attribuendo incrementum unius cubiti, fupra pondus fexdecim drachmarum.

Die vigefimo fexto ejufdem (menfis Bøna) accipitur fuperficies fluminis, $\mathbb{E}$ ad illam menfuratur fundamentum Nilometri fecundùm quod ftatuendum eft incrementum.

Die vigefimo feptimo proclamatur fupra illud (fundamentum) incrementum. Unicuique autem cubito attribuuntur viginti octo digiti, donec compleantur duodecim cubiti, quorum finguli continent viginti quatuor digitos. Et quando pervenit (incrementum) ad fexdecim cubitos, quod eft punctum altitudinis, quoSultan canalem Al-Kabera perrumpit. Eftque dies ille adeo ce- lebris, folemnifque \& infrgnis ut cum eo nullus in toto orbe comparandus veniat.

Eo ipfo die progrefiùs Nili nuncia ad cæteras regni plagas deferenda perferibuntur, \& cum eis tabellarii iter arripiunt, tuncque progreffus Nili ad fummum apicem pervenit.

A menfe Mefri, qui eft unus è Coptorum menfibus

In Niruz, qui eft primus dies menfis Tot, frequens ubique canalium \& oftiorum fit fectio. Qua occafione oriuntur contentiones, \& nonnunquam inter fe digladiantur.

Deinde fubfidere incipit Nilus.

In fefto crucis, qui dies eft decimus feptimus menfis Tot fupra dicti, fit fectio majoris partis reliquorum oltiorum.

Refert Al-Kodba'i ex Ebn Asir, aliifque è Coptis fupramemoratis, quod quando aqua, die duodecimo menfis $M$ Mefri, elevatur ad altitudinem duodecim cubitorum, is eft annus aqux; alioquin aqua decrefcit. Quando autem aqua pervenit ad fexdecim cubitos, ante Nûrûz (feu primum diem menfis $T o t$ ) tunc aqua ad completum finem pervenit ; tum potior pars progreflûs ejus ( $\mathrm{Nili})$ fiet in medietate priore menfis $\mathrm{Me} / \mathrm{r} i$, \& nonnunquam in medietate pofteriore ejufdem menfis, vel etiam so tardiùs. Et die octavo menfis Baba fiet terminus incrementi ejus.

Vidi in libro qui infcribitur Tarikh $\mathrm{Al}$-Nil, i. e. Hiftoria Nili, quod anno (Hegira') feptingentefimo octavo tardius evenit fummus ejus progreffus ufque ad diem decimum nonum menfis $B a b a$, quo clevatus fuit ad fexdecim cubitos, \& portea auctus fuit ad duos digitos intra duos dies, uno digito per diem, poftquam homines petierunt aquam quatuor vicibus, cui fimile nihil unquam auditum fuerat in prioribus fæculis.

Enim vero fuerat conftans confuetudo, ut z momento quo cxpit proclamari incrementum ejus, die fcilicet vigefimo feptimo menfis $A b i b$ ufque ad finem menfis $B$ rna, effet augmentum ejus leve circiter duorum digitorum ufque ad ferè decimum diem; ut plurimum enim increfcebat hoc modo: Deinde ineunte menfe Mefri invalefcebat incrementun ejus augebaturque ufque ad decem (digito uno quoque die) \& non ulterius ; aliquando verò infra hujúmodi. Maximus porro numerus digitorum, quo fiebar incrementum ejus, erat prope fummum apicem progreffüs, adeo ur fre effet feptuaginta digitorum (unoquoque die)

Jam verò admiratione dignum eft quod eo ipto die quo ad fummum apicem progreffus eft, pariter alfurgit ad feptuaginta digitos: tum mane diei quo ad fummum apicem pervenit, adhuc augetur duobus digitis vel circiter; atque ita complet incrementum luum. In fine menfis $B a b a$ incrementum ejus eft modicum; ceffatcue augeri propter inopiam qua laborat menfis Baba, cum eo menfe parum admodum aquæ in Nilum influat.

Narrat Abdol-Rabbman filius Abdollab filii AlHhacam, aliique, quod quando Molemi Egypeo potiti funt, incolx ejus ad $A m r u$ filium $A l-A s$, ineunte menfe $B z n a$ venerunt, dixeruntque illi: O Emire, i. e. Imperator circa hunc Nilum noftrum eft rraditio, ut non fuat nifi certa conditione, qux fic fe habet, nempe quando appetit dies duodecimus hujus menfis (B*na, apprehendimus puellam virginem de confenfu patris \& 
marris, quibus pro illa amplam gratificationem exhibemus, tum hanc puellam preciofitimo apparatu adornatam in fluvium projicinus. Quibus auditis refpondit Amrî: Non habemus talem confuetudinem in religione Elamifmi. Interea morati funt illi per duos menfes videlicet $A b i b$ \& Mefri. At Nilus nequaquam auctus fuit vel parum vel multum.

Quod cum vidiffet $A m r \hat{u}$, ea de re certiorem fecit Imperatorem fidelium Omar filium AlKbettab, fcripfitque in fine epiftolx: Anne inclinas, ut ita fiat?

Refcripfit Omar ad Nilum ipfum Epiftolam magnificentîa plenam his verbis.

Abdalla Omar, Imperator fidelium, Nilo Egypti. Porrò: Quod fi fponte \& proprio motu fluere nolis, fcito effe Dcum unum victorem qui poteft te cogere ut fluss. Interea nos Deum obnixè precamur ut te fluere faciat. (Vale)

Hanc Epiftolam nifit ad Amrü, qui illam in Nilum projecit. Quo facto incol:e Egypti avidè fucceffum hujus Epiltolx pristolabantur. Et mane furgentes die cincis, viderunt Nilum increinento jam perveniffe ad altitudinem fexdecim cubitorum:

Traditio eft fimile quid accidiffe temporibus Mofis, cui pax. Scilicet Deus Nilum cohibuerat, ne increfceret; quare volebant rebellare: cum autem $\boldsymbol{M} n \int \mathrm{e} m$ precibus interpellafient, ille pro eis rogavit, ut flueret $N i / k s$, fperans fore ut ad fidem converterentur, cumque mane furrexiffent, ecce jam Deus fluere fecerat Nilum, adeo ut illa nocte ad fexdecim cubitos excreviffet.

Vidi in Hiftoria Nili fupra laudata, quod temporibus $A$ l-Monfanfer , unius è Kbalifis Fatemitis

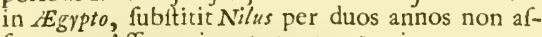
furgens. Affurrexit autem anno tertio : permanfit autem ufque ad annum quintum non defcendens. Deinde defcendit fuo confueto tempore, \& effluxit aqua de terra; fed nemo inventus fuic qui illam feminaret propter hominum paucitatem. Poftea anno fexto affurrexit Nilus, tum fubftirit ufque ad finem anni feptimi, adeo ut non relicta fuerit transfufio ejus ab hommibus, neque relictum fuerit ullum animal quadrupes incedens preter afinos quibus trahebatur currus Kbalife AlMoftanfer. Deinde fubitò ad apicem evectus fuit Nilus fexdecim cubitorum in una nocte, poltquam antea facile tranivadabatur a littore acl littus, \& minima altitudo fupra ordinariam fuperficiem Nili fuerat in decremento, unius cubiti \& decem digitorum. Atque hoc evenit inde $a b$ anno Hegire ufque ad finem anni octingentefimi, duabus rantùn vicibus: Quarum prima fuit anno centefimo fexagefimo quinto Hegires, eo enim anno Nilus pervenit ad altitudinem quatuordecim cubitorum, \& quatuordecim digitorum, fecunda autem fuit anno quadringentefimo octogefimo quinto, quo Nilus pervenit ad altitudinem feptemdecim cubitorum, \& quinque digitorum.

Tale quid fimile accidit noftro tempore, anno videlicet octingentefimo fexto, volo dicere punctum ad quod pertigit fuperficies Nili in incremento ejus, ex eo quod vidi fdclineatum ad finem annifeptingentefimi vigefimi quinti quod pertigit ad novem cubitos.

Audivi 'quemdam hominem dicentem quod anno feptingentefimo fexagefimo quinto fuperficies Nili elevata fuit ad duodecim cubitos; \& minima altitudo ad quanı pertigit decrementum in fine incrementi, fuiffe duodecim cubitorum cum duobus digitis. Atque hoc idem evenerat auno quadringentefimo vigefimo quarto: volo dicere punctum ad quod pervenerat tempore fupra dicto, nempe ad octodecim cubitos; 3 deo ut mirarentur homines de Nilo, quod auctus fuerit ad novemdecim cubitos temporibus $\mathrm{Omar}$ filii Abdall-Aziz. tum nocte feptima eo ufque pervenerit ut fupra viginti cubitos excefferit, in aliquot temporis intervallis.

Mirabile etiam illud fuit quod anno trecentefimo feptuagefimo nono fuperficies Nili ad novem cubitos tantum procefferit, nec tamen ullums inde fecutum fuit damnum, fed ad quindecim cubitos pervenit, cum quinque digitis.

Plurimis annis, in quibus fuperficies Nili fuit infra duos cubitos, fummus apex incrementipervenit ufque ad octodecim cubitos.

Jam de Nilometris. Refert Ebrabim flius $W$ WafifShak, in libro rerum mirabilium, primum qui Nilo Nilometrum appofuit, fuiffe Khaflamum feptimum Egypti Regunı antediluvianorum. Is Pifcinam ingentem conftruxit fuper quam duas figuras æneas aquilarum unius mafculæ alterius foeminx impofuir ; juffitque ei adfiftere facerdotes $\&$ doctos viros, qui die quodam anni peculiari, verba quxdam immurmurantes, alterutram ambarum aquilarunı ad fibilandum allicerent. Quod fi marcula fibilaret, id pro bono omme fauitoque nuncio augurabantur, fore ut Nili amplum incrementum tieret. Quod fi verò fomina fibilaret, malum omen interpretabantur de defectu incrementi. Quare prohoc anno cibos neceffarios \& annonam providebant.

Dicit Al-Mas'ûdî: Audivi à ceetu incolarum urbis Gizah, qui dicebant foferkmm, cui pax, quo tempore extruxit Pyramides, etian Nilometrum fufcepiffe ad dignofcendam Nili ancrementi $\&$ decrementi menfuram.

Dicit $A l-K o d b a^{\prime} \hat{\imath}$, idque in urbe Nemplbis : fertur autem Nilum primo menfuratum fuiffe in territorio dicto Almab, donec extructum fuit Nilometrum Mempkis, \& Coptos hoc Nilometro ufos fuiffe quo ufque abolitum fuit.

Dico ego : Locus Nilometri in Memphis ad hoc ufque tempus dignofcitur in vicinia Pyramidum aे Fofepbo extructarum, qua parte fita eft urbecula nomine Al-Badreflin. Aiunt illos ibi Nilum menfuraffe lapidibus aggentis \& plumbo ferruginatis.

Dicit Al-Mas'û́ti quod Dalücab cognomento Vetula, Agypti regina poft (fubmerfum) Pharaonem Nilometrum parvun in cubitos diftinctum pofuit in urbe Anfena. Aljud etiam Nilometrum pofuit in urbe Ekmim. Romani pofuerunt Nilometrum in caftello Cerx.

Dicit $A l$-Kodbầ : Ante expugnationem (Ag per Moflemos) erat Nilometrum in Kai-fareab AlAcfab in $A l$-Foflát, donec $M i f(c m i$ unum ex ipforum fabrica extruxerint inter arcem \& mare.

Cum itaque veniffet E/amifmz:s, \& Ægyptus debellata effet, tunc temporis Nilometr: $m$ in $M: m$ pbi, \& Nillis mcnfurabatur in Mempbi, \& menfor in locum dictum Al-Keta ingrediebatur, ibique proclamabat.

Poftea extruxit Amrî filius Al-As Nilometrum in $A \int \mathrm{man}$ (Syene); tum aliud in Dandarah.

Deinde in diebus $M 0^{\prime}$ 'aviah extruxit Nilometrum in Anfersa.

Cum autem Egypto praeffet Abdall-Aziz filius Marwân extruxit Nilometrum parvum cubitis notatum in Hbolvân in ditione Al-Foftât fito.

Tum quando gubernavit A âmab filius $Z$ aid cognomento Al-Banukhî̀ extruxit Nilometrum in infula $A l$-Saná'ab, qux nunc audit $A l$-Raudhab, (i. e. hortus amænus) juffu Solaîman filii $A b d a^{\prime}$ ' Malec, unius è Kbalifis filiis Omaiab, anno Hegire nonagefimo feptimo. Illudque eft cxterorum maximum in cubitos diftinctum.

Denique exftruxit Al-Mlâmún Nilometrum in inferiore parte terrx infulæ predictx, anno ducentefimo feptimo, gubcrnante Fovptum razid filio Abda'l-Malec. Atque illud eft (Nilometrum) quo utuntur ufque ad hoc tempus noftrum.

Chriftani habebant regimen Nilometri, fed illos amovit Al-Mlatamakkel, \& lutic regr nini prapofuit $A b u^{\prime} l$-Radadum Abda'llam filium Abda'l-Salàm Al-Mk̂dab, virum probum. Perfeveratque Nilo- 
metrum in $x$ dificio fuo integrum ufque in prefen= tem diem. Illudque infuper reparavit Akbmed ben $T$ thûkin anno ducentefino quinquagefimo nono.

Quilibet cubius continet viginti octo digitos donec compleacur elevatio ayuix ad duodecim cubitos. Deinde cubitus fit viginti quatuor dıgitorum.

Quando igitur volunt fupponere hanc elevationem pertigille ad fexdecin cubitos, diftribuunt duos cubitos redundantes qui continent viginti octo digitos, inter duodecim cubitos quorum unufquilque continet viginti quatuor digitos. Sicque fit quilibet cubitus viginti octo cubitorum.

Dicic $A^{\prime}-$ Kodba' ${ }^{\prime}:$ Ratio hujus eft, quemadmodum refert Al-Hbnfain Mobkammed filius A'sdo'l-Man'an in Epiftola fua, quod Molemi, quando E'sypto potiti fune, expofuerunt Omaro filio Al-Kbittab, cui Deus fic propitius, id quod agrè lerebant incolx Aispti de caritate annonx quo tempore Nilus fubfidebat in termino juxta Niometrm illorum plufquam decurtatio ejus. Qux res cogebat illos colligere commeatum in anguitioris aunonie tempus, quæ collectio adhuc cogebat augere pretium annonx.

Er fcriplit Omar ad Amrú fcifcitans ab co rei veritatem.

Refpondit Anrâ his verbis: Equidem reperi, inquifitione facta, ut $E g$ gtus irrigetur, quatenus incolæ ejus annonx penuria non laborent, unum terminum effe debere, ut Nilus increfcat ad quatuordecim ctibitos, alterum autem terminum, quo univerla Egyptus irrigetur, quatenus pra neceffario fuperabundet, adeo ut relinquatur apud ipfos alterius anni provifio, effe debere, ut Nilus increfcat ad fexdecim cubitos. Inveni etiam duo effe extrema requaliter timenda circa exceffum \& defectum elevationis aqux, \& inundationis ; videlicer duodecim cubitos pro defectu, \& octodecin pro exceflu.

Qua de re Omar, cui Deus fit propitius, in confilium advoeavit $A h \hat{~ f i l i u m ~} A b \hat{u}$ Táleb, qui confilium dedit, ut ad illum feribens juberet $\mathrm{Ni}$ lometrum ab eo exftrui, \& ut duos cubitos duodecim cubitis iuper adderet, \& id quod poft eos refiduum elfer, luper fundamento relinqueret.

Dicit $A l-K o d b ' a \hat{s}$ : Ubi obferva quod noftro tempore facta eft corruptio fiuviorum, \& imminutio ftatûs rerum, cujus argumentum cft quod Nilometra antiqua regonis $A l-S a^{3} i d$ à primo ad ultimum conftanter habuerunt viginti quatuor digitos pro uno quoque cubito fine ulla additione ad hunc numerum.

Dicit $A^{\prime}$-Mas'ûdî́: Qundo Nilus compleverat alticudinem quiudecim cubitorum, \& ingrediebatur decimum fextum cubitum, tunc emergebat bonum nonnullis hominibus, neque nimium rigabatur terra. Sed hinc fiebat imminutio tributorum Soltani. Quando autem pervenicbat incrementum ad fexdecim cubitcs, tunc complebatur tributum Soltani, \& homines multo proventu abundabant; eoque inundabatur quarta pars regionis, fed hoc erat nocivum jumentis propter defectum pabuli.

Tum alt : Summum denique incrementorum generalium, quod utilitatem regioni univerfa afferebat fuit illud, quod affurgebat ad feptemdecim cubitos. Atque fufficientiam omnimodam, \& fatietatem univerire terra ejus complebat.

Quando autem poftquam increvit Nilus ad decimum feptimum cubitum, provehitur ad decimum octavum, tunc inundatur quarta pars $\mathbb{E}$ gypti, \& nocumento eft nonnullis prediis. Atque, inquit, ita fe habet incrementorum pars maxima. Ego dico: Talis erat rerum ftatus in eo, quo fcribebat tempore, \& ante illud, talifque currens modus, prout ille memoriæ prodidit, in annis plurimis ufque ad annum feptingentifimum preteritum. At vero hoc noftro tempore (videlicet anno 806.) folum terræe elevatum eft ex eo quod eam invafit è luto, quod aqua fecum volvit fingulis annis, adeò ut pontes exfuperaverit.****

\section{Nummi nonnulli ab Auctore in A F r I c A collecti, quique in ea Regione cufi fuiffe videntur.}

${ }^{\prime} \mathrm{R}$ E X I V B A'. Caput Jubx, diadematum.

\section{KAEOПATPA ${ }^{2}$ BARIAECA.}

Crocodilus 3 .

2 D. N. IVSTINIANVS P.P. AVG 4.
Caput Juftiniani diadematum.

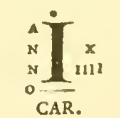

I Juba, quem exhibet hic Nummus, fecundus fait iftius nominis, qui urorem duxit Cleopatram 2, cognomine selenen, Antonij Triunviri \& Cleoparre Agypti Reginx, filiam. Filium habuit Ptolemaum, Regum Numidarum

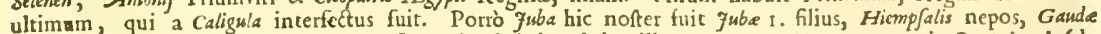
pronepos, Mlafinifes pronepotis nepos. Ita enim fe habet feries illa Regum Numidarm, quain in R. Keineccio (de Famil. Tab. 43. p. 329.) interruptain videmus, ut fidem facit Inferiptio hac fequens antiqua, quam in arce Carthaginis Nove apud Hifpaniam invenit mecamque communicavit V. R. Pa. Simenes.

$$
\begin{aligned}
& \text { REG I I V B A E R E G I S } \\
& \text { IVB A E F I L IO R E G IS } \\
& \text { I E M P A L IS N. RE G I S G A V D. } \\
& \text { P R O NE P O T I S M A S I N I S A E } \\
& \text { P R O N E P O T I S N E P O T I } \\
& \pi \text { VIR QVIINQ. PA T RON O } \\
& \mathrm{C} O \mathrm{I}, \mathrm{O} \mathrm{N} \text {. }
\end{aligned}
$$

3 Crocodilus, arpote Nilosicum Animal, Syınbolum fuit Egypti, unde Cleopatra duxit originem: 4 Nummus hic defcribitur 2 Mcdiobarba de Imp. Rom. Numilin P.564. Ed. Milam. 1683.

$$
P_{2}
$$


3. KARTAGO, in Epigraphe.

Miles'ftat, finiftra haftain tenens.

Capur Equi decurforii : of in Exerg. XXI.

Numni fequentes nec una nec altera parte in-

foripti funt: quorum decem priores exbibent

4 Caput Cetcris, ornatum ${ }^{2}$ fpicis; interdum etiam cornu bubulo 3 ; \& inauribus.

Equum 4 ftantem, cervice erecto. Ad pedem tria puncta, forma triangulari pofita.

5 AL. Equum ftantem, cum annulo.

6 AL. Equum ftantem, cervice reflexo.

7 AL. Equum ftantcm, cervice reflexo, cum Lunula 5.

8 AL. Equum currentem.

9 AL. Equum ftantem cum Palma ${ }^{6}$.

IO AL. Equum defultorium, cervice re-

flexo, pedem dextrum elevantem.

II A L. Equum, cervice reflexo, pedem dextrum elevantem.

12 Al. Caput Equi 7.

(1) al. Caput Equi, cum uncix nota.
14 Caput diadematum, barba prominente \& acuta.

Equus currens.

I5 Caput diadematum, barba prominente \& acuta. Cincinnis in orbem tortis feu calamiftratis.

Equus currens, cum Palmæ ramulo 8.

16 Idem: quod Jubx majoris, ob rultus fimilitudinem, effe videtur.

Equus gtadiens, cum ftella 9.

17 Caput Jovis Ammonis :0.

Elephas".

18 CaputHerculis ${ }^{\prime 2}$,pelle leonino amictum.

Leo gradicus $\$$.

19 Palma, cum dactylis.

Pegafus ${ }^{14 .}$

20 AI. Equus ftans, cervice erecto.

2 I AL. Caput Equi.

Ex are omnes, prater quartum of quintum, quorum bic ex argento, alter ex auro conficitur.

I Belifarius forfan, qui devikto Gilimert, Carthaginem Imperio Romano seftituit. Numerus $\times x$, \& Nun. XıII in priori nummo, Annos Regni fuftiniani defignant: vir. A. D. $547 . \& 540$. Vid. Mediobarb. ut fupra. 2 Ceres

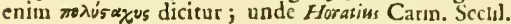

$$
\text { - Spicea donat }
$$

Quxque etian Dea frugifera eft, ideoque fxpius cernitur in nummis Africe, Sicilie, Egypti, aliarumqueRegionuın, qux olin, propter tritici \& frumenti ubertatem, celeberrimx fuerunt. 3 Ceres ctiam, qux cadern cum Ifide eft,

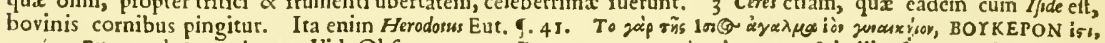

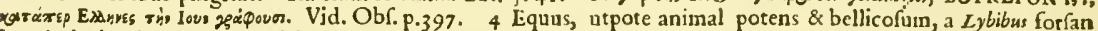
imprimis domitum, Infigne fuit Mauritanie, Numidia \& Carhaginienfum Regionis. Numide enin, ab antiquiftunis temporbus, ob equitationem \& in equis educandis folertian, palmam cxteris gentibus prxripuerunt. Puncta forte pondus vel valorem indicant; ut annulus in fequenti. Velfin Nurnmus in una aut altera Carthaginiensum CoIonia, apud Siciliam i. e. Trinacriam, cufus fuit, per puncta totidem iftius Infula Promontoria denotari poffint. 5 Lunula five Crefcens Symbolum fuit Iffiti, i. c. Crreris, Dex frugiferx. Vid. Not. \& Obf. ut fupra, 6 Africa, (prxcipue interiores ejus pattes, ) xque dactylis abundat, ac Egypsss, Ydume, Babylon \&ic. ideoque Palmam pro Infigni fuo five Symbolo xquo jure vendicare poffit. Vid. Obf. p.85. 132. 558.211 . 7 Hoc Symbolum referre poffumus ad caput Equi inventuin in jactis Carthaginis fundarnentis. In primis fundamensis caput bubulum inventum eft; quod aufpitium quidem fructuofe serree fed laboriofe, perpetuóque ferve urbis fuis: propier quod in alium locum urbs tranPlata. Ibi quoque equi caput repertum, bellicofum posentemque pofulum futursm fignificans, urbi aujpicatam fedem dedit. Juft. 1. 18. 5. Sic etiam Virgilius Æ.n. 1. 1.445.

$$
\begin{aligned}
& \text { Lucss in Urbe fuit media, Letij/smus umbra; } \\
& \text { Quo primum jackari undis or uxrbine Pani } \\
& \text { Effodere loco İgnum, quod regia fano } \\
& \text { Monftrarat, caput acris egri : fic nam fore bello } \\
& \text { Egregiam of facilem vietu per fralla gentem. }
\end{aligned}
$$

8 Palmx ramulus vel victorian quandaun ab hofte portatam, vel 7 mbam minorem, (modo numuus hic fub.e Senioris eft,) defignare poteft. Artenidorus quippe audior eft (Onsir. I. э. cap. 79.) Principasm liberos per ramos palmarsm defignari. Unde certe haud male collegifle videtur Triftanus, fignatos in quodam Conflantii numino tres Palux ramos, denotare tres magni Confansin filios. Spanh. De Ufu \&c. Numifn. Difr. 6. p. 336. 9 Per Stellan, Virtus forfan Solis in frugibus producendis viribufque prolificis \& bellicofis equis addendis denotetur. Quidni ctiam Hrsperus effe poflit? Ut enitn hac Paftoris ftella eft, Numidis certe, utpote vitam paftoralen agentibus, feinper grata effet \& veneranda. Stella, in quodaun Battiadorum nummo, Apollinem denotabat in eo tractu Sacerdotein, fecunduin Begerum (Thef. Brand. Vol. I. p. 518 .) $\mathrm{rel}$ Regcin e Ludis equeftribus victorem revertentem, Stella feu Sole duce, fecunduin Spanbemium Dilf. 6. P 300. 10 In Lybia, Templum \& Oraculum celeberrimum olin fovi Ammoni conditum fuit: Ammoni illi nempe, qui idem effe perhibetur cum Chamo, cui Egyptij \& Lybes debent origineın. II Tempore, quo cufus fuir hic nummus, elephantes frequentes errabant in Septentrionalibus Africe partibus, ut patet in Exc. p. 20. F. p. 21. B. Ita etiain Poeta, de Africa Joquens.

$$
\text { Et vastos Elephantat habet, fevofque Leones }
$$

Manil. I. 4.

12 Bersules neinpe Lybirus, cujus fama, propter certamen cum Ansao (Exc p. 20. C.) Arain apud Livon. (ibid. D.) Specus in Promontorio Ampelufia diEto (Exc. p.18. D.) Colunnafque (ibid. E.) femper fuir inter Afros celeberrima. 13 Per Leonem hic exhibitum, intelligi poteft vel Africe Symbolum, qux a Poeta nuncupatur

$$
\text { Lronum }
$$

vel Leo ab Hercule interfectus. I4 Numınus hic etiam inter Africanos numesandus eft, licet altera parte Pegafum, Corinthiorum Symbolum, exhibeat. Palma quippe hic expreffa, racemos fuos profert propendentes, urpore dactylis onuftos, qux apud Corinshum, ob regionis frigiditatem, nulla alia effe pofit quam fterilis. 1'raterea ut Pegafus nihil aliud fit nifi celer equus, tale Infigne optime Africe conveniet, ob celeruin nompe equoruins in ea terrarum parte proventum. Vid. Trtji. Colument. Tom. I. p. 89. \& Sparheim. Differ. 5. P. 277. 
(a) 3is

(15)

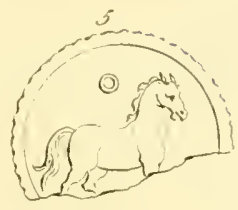

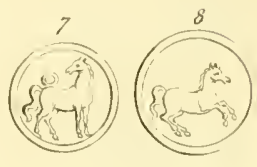

(3iv) (3itid
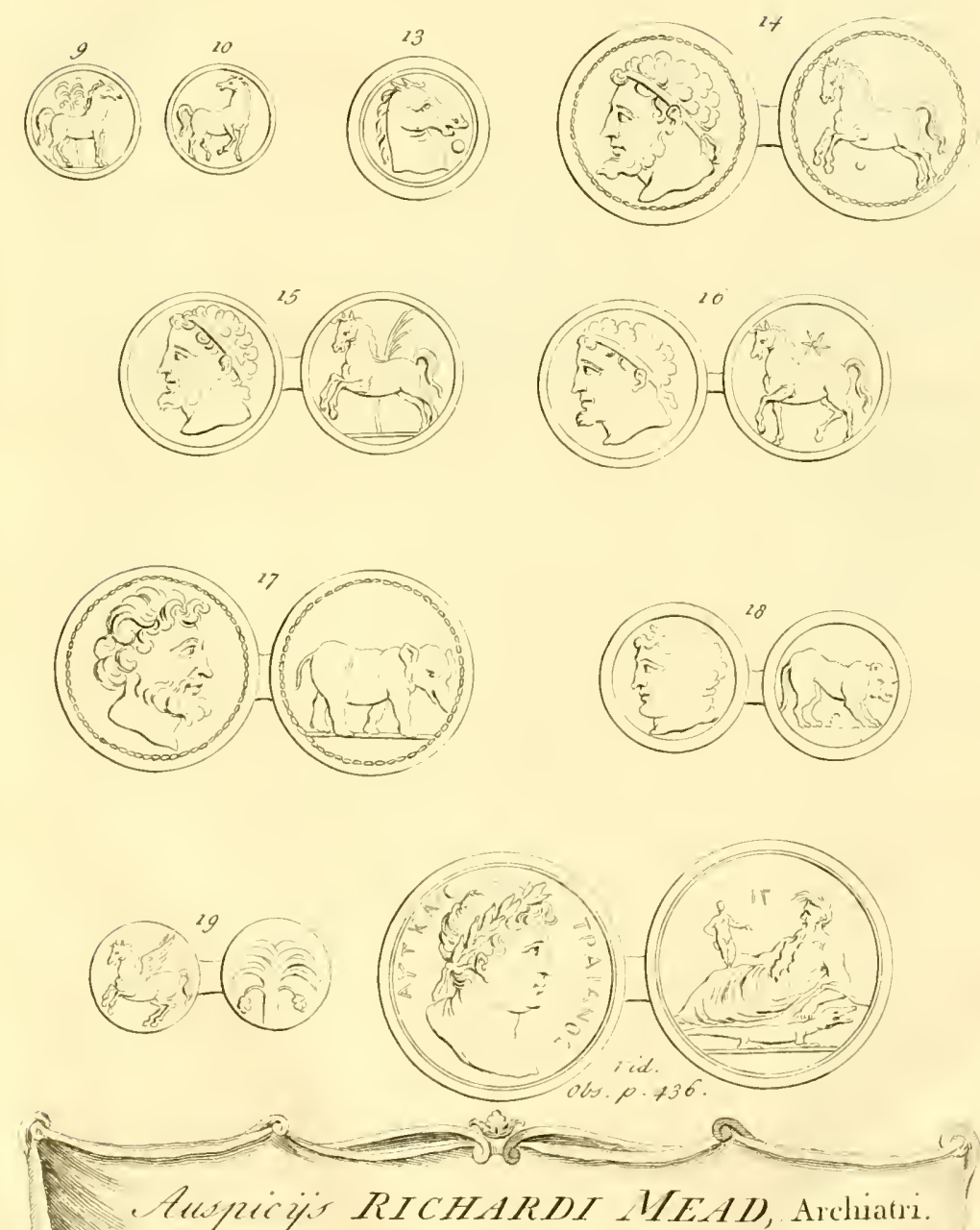

$\mathrm{T} \mathrm{H} \mathrm{E}$

\section{I

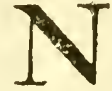 \\ D E

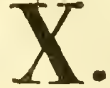

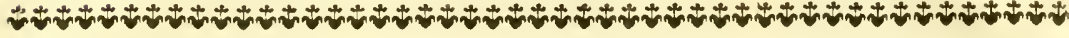

Wo The Letter $p$ denotes the Page; $N$, the Notes; $E$, with the Number after it, the refpective Page of the Collection of Papers inferted after the Obfervations.

\section{A.}

$A^{B d s}$ el Wed, the Timice. P 52 .

Accaba(Mountains)p. ro3.357

Ach Bobba, the Percnopierus.

Oripelorgus, or Rachamah. p.38s. Achole, p. 193.

Acilla, p. 193 .

Accroude (the River) p. 196

Acra Inf. p. 18.

Addace, vid. Lidmee.

Ades. p. 156 .

Adge-dee (the River) piss.

Adjerouse, the Feroopolis $\mathrm{p} \cdot 342.378$.

Adrowa (Arabs) p.73.

Adrumeirm, p.161. 186. now t.erklat. p.162.

Egimurus Inf. p.146.

Egypt. vid. Egypt.

Africa Propria. p. to1.141.

Afrikeah. p.s.

Ailah, vid. Eloth.

Ain Azell. p.15.

- Be/eef, p.78.

-Diflah, 85

- el Fostah, p. 106.

- -el Kelb, p.1 13.

- Kidran, or the Fountain of Tar. p.84.

- Maithie. P. 86

-Ow-heide. p. 117.

- Rummel. p. 112.

Air, the Temperature of $\mathrm{jt}$ in Barbary. $\mathrm{P} 217$. in Syria. F.358.

si-yacouse (the Diftrict) p.110.

Akker, the River and City. p.327.

Al Aleab, the Cotmza. p.164.

Alleggah (the Ruins of) p: 123.

Alexandria, the Ports \&ic. of it $\mathrm{P} 338$

Algiers; the Limits and Extent of

the Kingdoin. P 121. it's Courts of Judicature. $\mathrm{P} 314$ the Office of the Cady. P.315. of the Principal Minifters who fit in the Gate. ibid. the Punilhments. ibid. and p. 3 t6. Turk not punified publickly. P. 316 it's Alliances with Chrifian Princes. ibid. how their feveral Interefts are inaintained. P 317-8. the Defcription of the City, Ports, Navy \&ic. of Algiers.p. 68 .

Algier, the Anticnt Jcofrum. p.71. the Government; wherein it con1ifts. P. 3 10. the Dey, his Power, Character, and Election. p. 311 . frequently cur off. $i$ ibid. the Forces of this Kingdom. p. 312. the Method of keeping the Arabs in Subjection ibid how their Atmy is recruited. p.313. their Officers ibid. the Revenue. p. 314. the pay of the Army. ibid.

Al Hennab. p. 265 . E. 37.

Al-sleßer, vid. Kairo.
Amalekires, their Situation. p.345. Ammer, Geinlian Arabs, or Kabylet. p. 88.

Imnis Trajanus, the Khalis that runs through Kairo. P.340. 437.

Amplaga $A$. now Wed el Kiber. p. 92,93 .

Andaloufe (the Town of) 0.22 .

Ang-gadd, the Arabs andDefert.p. 16.

Animals; the Sacred Animals of

Egypr. p.395. Others received alfo into their Sacred Writings. ibid.

Parts alfo of Animals. p. 397.

Diffetent Animals combined together. p.398.

Anounah (the Ruins of) p.123.

Antaradut, or Tortofa. p. 325 .

Antilope, or Gazell. p.243.

Aparea, now El Hammah, or $\mathrm{Ha}$ math. $\mathrm{p} .325$.

Aphrodifum. p.164.

Apoltinit Promont. p. 146

Aque Calide. p.157.

Aque Calide Colonia. p.64.

Aquilaria p.158.

Aquis Reqiis. $\mathrm{p} 202$.

Aque Tibilitane. p.12t.

Arabs, of the Tell. p. 107. or Kabyles. p.86. given to Superftition.p.305. to Sorcery andWitcheraft. p.306. adminifter Juftice among themfelves. p.309. the Power of doing which, does not always defcend froin Father to Son. p. 310. in what inanner they fleep. p. 287. they go bare-headed. p. 291. their method of Eating. p. 297. are gond Riders. p. 299

Arabs, vid. Bedoween, their Manner's and Cuftorns. p.300. their method of Saluting one another p. 301 . hofpitable to Strangers. ibid always in War with one another. p.302.

Arades, or Arpad, now Row-wadde.

p.325.
Arbailah or Arbaal. p.52.

Arca of Arka, the Seat of the Sirkies. p.327.

Architeeture; to what Degree known in Barbary. p.273.

Arbew (the River) P.34.

Atts and Sciences little encouraged in Barbary. P. $26 \mathrm{t}$.

Arzew, the antient Arfenaria. p.28. Appis. p. 159 .

Aljurus or Afjuras. p.198.

Aslas, (the Mountains of) p. 7. 18. 67.88

Aurafiant, theirComplexions.p. 120. Auzia. 81.

Azeefe (Arabs) p. 60.

$B$,

Baxl-tzephon. p. 346 .
Baboure (Mountain) p. 104

Babylon or Latopolis. p.343.

Babyloniani, their Cantle. p. 340.

Back-Houfes, the Canacula. p. 280.

Bagai, (the Ruins of) the Bagafis.

p. I3 I.

Bagrada. p.l129. I46, 147 .

Bahyre Pharaoune. p.211

Bahyras, what? p 69.

Baideah, what? p. 346 .

Bainah (the Ruins of) p.117.

Baniuri. p.66.

Banturari, 0.57, 60.

Barbary, the Provinces of it. p.5,6i

N. 6,7 . from whence the Name. P.I. N. I.

Barbata (the River) p.Ig.

Bareekah, (the l'lains and River of) P. 113.

Barometer, how affected in Barbary.

p. 218 . not affected with Earthquakes. p. 234

Bajlion. p. 98 .

Batral, vid. Raz el Amorybe. P. 43:

Bedowiens; their manner of Life.

p. 286. 300 . vid. Arabs.

Beeban, or Gates, p.102.

Beja, or Bay-jah, the Vacca. p. 165 Bekker el Wa/ls. p. 242 .

Belus (River) now $K$ ardanah. p 332. Benjamin (the Tribe of) p. 333 . Beni, the meaning of it. P.I7.N." Beni Abbefs. p.102.

- Ammer. p.52.

- Beleit. p.92.

_Boomaforde. p.git

Boo Taleb. p.I I

- Friganah, an inhorpitable Clan.

p. 93 .

Halcefa. P. 76

- Haleel. ibid.

Headjah. p. 37.

I Iah. p.91.

- Maad. jbid.

-Menafjer. P.39.

Menaßcr. p.6r.

- Mezzab, the Melanogesuli.p.86.

- ivida. p. 60.

- Raflid, or Arax. p.61.

Sala. p. 76. 122.

-Smeal. p.58.

Snoufe. p. 47.

-Welbaan. p.93. 121

- rifra. p.39.61.

rimnal. p. 60

Zeian. p. 28.

ZZeneßel, or fefneten. p.r7. N. I.

Zerwall. p. 54.

Berin.Jbll, the IIl. P.43.

Berque el Hadge. p. 437 .

Bery-gan (Village) P. 86.

$B e s_{1}$ or Viceroys of Algiers, their

Power. p. 6.

Biker, the Canopess. p.337.

Biledulgerid, or Blaid el feridde. p 5 . $\mathrm{Q}$ 
Birds ; the curious Species of $B$ arbary. P. 251.

Bifcara, the Capital of Zaab. P. 133 Bitumen, how raifed from the Bottom of the Dead Sea. P.374, the Quality of it. p.375.

Bizacium, not fo fertil as the Antients have inade it. p.185. 228 . now the Winter Circuit of the Kingdom of Tiunis P. 141

Bizeria, the Hippo Diarrhytus, or

Zaritus. p.144.

Blaid el Mladoone, vid. Tefefjad.

Blaid el Fereed, F.5. or Feridde. p.2 10 Bleda or Bleeda. p.43. the Bida Colon. 74 the Defcription of it, ibid. Boccôre; tlieir Tine of being ripe. p. $364 \cdot 370$.

Bone, (the City) or Blaid el Aneb,

the Aphrodifum. P. 96 .

Booberak (River) P 74.

Booficjoone (Dahkrah) p.8s.

Boo-Hadjar, or Agar. p.19I.

Boobalwan (Arabs) p. 61

Boohammam (Diftrict) p. 122

Boujeial, the Port, the antient Sarda. p.89. the City, sbid. the antient salde. ibid.

Boujereab, (the Mountain and Dajbkrahs of ) p. 67

Boo-khammel (Arabs) p.54.

Boomuggar (Diftrict of ) p. 115.

Boorinen (the Mountain) p. 101.

Boofaada, a Collection of Dajblrahs. p. 85 .

Boofhatier, or Utica. p. 148

Botargo, what? p. 155 .

Brada, or Bagrada. p.146, $147^{\circ}$

Brak; what it fignifies. p. 255 .

Bread; the Arabs \&c. great Eaters of it. p. 296

Bredeals (the Diftrict of) P.5 I.

Bresk, the Canuccis. p.37.

Budrome, the River. p.73.

Bugdoora, the River. p. 74 .

Bugia, vid. Boojeiah.

Burgh Hamza, the Awzia, P.80.

- Majanah. p. 107.

Swarary. p.78.

Tißsumfeely. p. 58

-Twill, the Turris Cafaris. p.124.

Burnoofe, or Cloak, without Seam, the Palliwm. p.200.

Burwakeah, the Diftict. p.78.

Buddera, the Plains of. p. 166 .

Butter, the Method of making it in Barbary. p.24t.

Buzara Mons. p. 100.

Ciecias, p. 359 , or Hellefpontias, p.360 what Ariftosle obferves of it P 361 .

Cairo, vid. Kairo.

Calamos, now Kalcmony. P. $33^{\circ}$

Callah or Calah, what it inports

9.53. Callah (el) the Town. p 53

the antient Ginlwi or Apfar. ibid.

Callat Shimmah. p 35 .

Calle $(L a)$ p.98.

Camarata or Tranfrant. p, 2 r

Cainel, capable of great Fatigue. p. 239 . the Structure of their Stomachs, p.239. N. 1. providentially created for the Service of the Deferts. p. $3^{89}$.

Canaftel (the Village and Arabs) p. 28.

Canopy, what? p. 287.

Canopss, the Falhion sic. of the

Veffel. p. 425.

Canopus or Bikeer. P.337.

Canuccis or Bresk. P. 376
Cape Blanco, the Promonsorium Candi-

dum and Pulchrom. P.142.

_Boujerône, vid. Sebba Rous.

- Bon or Raf-addar, the Promont.

Mercurij. P.159.

Brullos p.337.

- Falcon, or Ras el Harfffa. p.22. Ferrati. p. 28.

-Ferro. p. 95.

- Hone, or Ras Humneine or Mellack. the Prom. Magnum. p. I 8 .

- $7 v \%$, or fibbel Diß. p. $35^{\circ}$

-Negro. P.142.

- Serra. ibid.

-Tennes or Nackos. p. 37.

-Zibeeb, p. 145. the Promontor. Apollinis. P. 146.

Capoudia, the Caput Vada, \& Ammonis Promont. p.193.

Caps, of the Arabs, like the antient Tiara. P 292.

Capfa. p. 209.

Catcates; rarely putrify in the Deferts of Arabia. p. 379. Several Carcaffes of Men and Cartle found preferred at Saibah. P.379. N. I.

Carpis. P $157^{\circ}$

Cartennus fl. or Sikke. p. 32.

Carthage. p.150. the Extent of it. p.152. it's Aqueduets. p. 153

Carthaginienfrum Regio. P. 141.

Cartili or Tedderi. p. 35 .

Caflareen, the Col. Scillizana. p. 202.

Casir Altyre, (Plains of ) p.108.

Cafir Aleite, the Civilas Siagitana. p.162, 163

Cajlosla (Arabs) p 80

Caftra Germanorum, or Dah-muß. p. 37

Catharine (St.) Her Convent at Mfount Sinai. p.350. Her Bones preferved there. P.35 I.

Cattle (Black) of Barbary lefs than thofe of England, p. 240 . yield lefs Milk. p. 241. The Number, and Kinds of thein in Barbary. p. 238.239 .242$.

Cement, how inade. p. 286.

Chalcorychii Montes. p. 17 .

Chameleon. p. 249,250 .

Cheefe, in Barbary, made chiefly

of Sheep's and Goat'sMilk.p.241.

Cheop's Toinb, failly fo called. p.418.

it gives, by ftriking, the Mufical

Note Flami. 1.42 1 .

Chinalaph of now the Shelliff. p.34.

Chinue. P. 106

chozala, now fimmel. p. 42.

Chryftal; fone curious Species of it. P. 235.

Cirat (the River) p.32.

Cirta, or Conftanina. p.125.

Cirtefii. p. 121.

Clybea, the Clupea, ot Clypea, or A $\operatorname{\Pi I\Sigma }$. p. 159.

Cordamusii. p. rog.

Conacula, or Back-Houfes. p.280.

Coleah (el), the Village. P.46. the antient Cafe Calventi. ibid.

Cologlies, who? p.313.

CoInınodities, of Barbary, for Ex-

portation. p. 295

Conftantina, or Cirta. p.125.

Coral, the method of it"s Vegetation. p. 385 . a Catalogue of Corals. E. $47^{-8}$

Coran, vid Koran. ibid.

Corn; the Time of Sowing it. p.220. the inethod of treading it out. p. 221 . and of lodging it in Pits. ibid. how they grind it. p. 296.

Corondel, part of the Defert of
Marah. P.349.

Corloe (River) p.73.

Cothon, what it imports. P.39. N.3

Crocodiles, rarely feen in the lowet Egypt P.427.

Crop, the Quantity of one in Batbary. p. 220

Crypire; (or Sepulchral Chambers;) near $L$ arikea. P.323. That of $\mathrm{St}$. Teckla. ibid. Thofe at ferw alem, Tortola \&c. p. 324

Cubit; various Accounts of this Meafure. p. 433-6. various Meafures of the fame Denomination. ibid.

Cull, the Cullu, Chulli or Collops Magnus. P.94

Curobis. p. 160.

D.

Dab or $T / a b$ (Lizard) p. 250.

Dackbul (the Diftrict) p.I59.

Dagon's Temple, the Falhion of it. p. 283 .

Dah-musis, the Caftra Germanorum. p. 37.

Daman Ifrael. P.376. the Saphan of the Scriptures, ibid.

Dami-ate, the Thamiathis. p. 337.

Dammer Cappy. P.103.

Dan (the Iribe of) p.333.

Dalbkrah, or inud-walled Village. p. 7288.

Date Tree, not in Perfection in Galilee \&.c. p. 370 .

Dead; great Refpect paid by the $M a$. bometans, in carrying them to their Graves, p.284. no mourning for thein, p. 285 . buried genetally without the City. ibid.

Deer; the Size of thofe in Barbary. p. 243.

Deik Bou çah. p. 106.

Delia ; from whence it commenced.

Delly' (the Town of) the antient Rufcurium. p. 88.

Demass, the Thapfus. p. $19 \mathrm{r}$.

Defert; the plain Part of it looks like the Sea. p. 378 . Bodies of all Kinds magnified in it. ibid.

Dews, very pleneiful, in Arabia. p. 379 .

Diana, now Tagourainah. p. 110

Dimmidde (Dalhkrah) p. 86.

Difon, vid. Lidmee.

Diftempers, curcd by Sactifices. p. 306 .

Douma; what? p. 266.

Dou-wanne; what? 0.283 .

Dow-war, Dow-warah or Dou.waral, what it fignifies. p.32. N.*. p.287. Dra el Aizajh. p. 8.

mel Hammar, ibid.

- el Mainscnan. ibjd.

Dromedary; how it differs from the Cannel. p.240.

Drufes. p. 376 .

Dry Diet, or छmpoparia. p.35 I.

Dryins. P. 54

Dubbah, or Hiena. p. 246.

Duc.e. p. rog.

Duccia, what? 0.64 . N. I.

Dudaim, what fuppofed to be at prefent. p. 369 .

Durdus (Mons) p. 54.

Durgana (Atabs) p.73.

Dya, a Pond and Morafs. p. 79.

E.

Earths; the different Sorts in Bar bary. p.236.

Earshowakes 
Eurthquakes, ofually aftetRain.p. 234. their frequency in Barbary, ibid. at Sea, ibid.

Ede Tepelaar. p. 85.

Edom (the Land of) p. 335,336 the Defcription of it. p. 377

F.ducation; the Method of it in Barbary. p. 262.

Egypt; does not abound much in Plants.p.427.in what manner the Soil of it may be fuppofed to have increafed. p.433. Sevetal Argu inents to prove it to be the Gift of the Nite. p. 436. The Increafe of Soil agreeable to theScriptureFra of the Flood, and the Difperfion of Mankind. p.442.

Egype, formerly the Seat of Learning. $\mathrm{p} .389$. gave Grece her Arts and Scicnces. p.390. The Coaf of it low. p. 336. The River of it. p. 335 .

Egyptians, their Symbolical Learning. P.391. what it related to. ibid. no proper Key ro it. ibid. The Veracity of their Hiftory to be called in Queftion. p.417.

Elalia, the Achola, or Acilla. p.193.

$\boldsymbol{E}$-Fimah (Arabs) F. 108.

Elewsherss, the cold Stream, the Boundary of syria, and Phanice. p. 329.

Elim, the Wells. p.350. and PalmTrees. ibid.

El Mildegab (Plains) p. $\$ 4$.

Eloth, Elana, Ailab, or Alana. F. 355 .

Em-dou-kbul, (Village) F. 114.

Emeer, what? P.310. N. 3

Employments; how the Twks, nfoors and Arabs employ their Time. p. 298.9

Engines, for raifing Water in Egrpe.

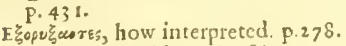

Etham, (the Wildernels of ) P.345. the Saracene. jbid.

Euroclydon, a Levanier. P. 358. not Euroaquilo. P. 359.

Exion-gaber, or the Pors of Gold. p. 356 .

$$
\text { F. }
$$

Faadh, like the Leopard. p. 245. Faradcefe, the Aphrodifum. p.164. Fara(beeje, (Arabs) p.214.

Fernan, (the Mountain of) $p .76=37$.

Fereanals, the Thala. p. 207 , and Telepte. p 208.

Figs; the Succelition of them from the Beginning of Summer to the Spring, p.370. the Time of Figs, itid. their Kinds. p. $z=6$.

Figig, a Knot of DateVillages. p $5 \mathbf{I}$. Finh, thofe that arc curious in Barbary. P. 259 . E. 50.

Fi/brall, the Tragelaphus. p. 243.

Flectah, (Arabs) p.54.

Flux, (of the Sea) the Hcight of ir at Swez. p. 378

Fofiil Shells, in Arabia. p. 383 . a Caralogue of rlietn. E. 49 , 5o.

Food, the feveral Sorts in Barbary. p. 297 .

Fountains, very rare in Arabia. p. 379. the different Qualities of them. p. 380.

Fowling, the Method of it in Barbary. p. $3 \mathrm{co}$

Fretilih (Fountain) P.54.

Frigeab (Diftrict of) P. $14 \mathrm{t}$

Fruit, what hinds are produced in Barbary. P. 224 \&. .

\section{G.}

$G$ abs, the Epichus, and Tacape. p 196. Getulia. p. 8. N. 4. how fituated. p. 136 .

$G$ afsa, the Capfe or Capfa. p.209

Gaine; the Variety in Syria. P 375.

Gar el Mailab. p. 146 .

Gardeial, (Village) p. 86.

Gardens of Barbary; no Regulariry obferved in the laying them out, p. 227. the Kitchen Garden, p. 223. the Fruit Garden, p.224.

Garvancos, the cicer or Chick Pea ; called Leblebbi when parched. p. 222 .

Gazell, what? p. 243.4. N. 1. or Anilope.

Geeza, p. 28. the Nemplais, p. 341 . Geldings, none in Baibary. p. $2+2$. Gellabat Snaan $p 130$.

Gellah, p. 148. the Castra Cornelia. p. 150.

Gelma or Kalmal, the Calama. p.122.

Gemella. p. 105.

Goographers; Extracts out of the anrienteft of them. E. $1-36$.

Gilma, the Cilma, or Oppidum Chilmanenfe. 1). 205.

Ginetia, vid. Shibeardor.

Giran, the antient Arina. p. 53.

Girfah (Arabs) p. 123.

Gluc; a particular Sort ufed in Barbary. p.286.

Go-jeeda, (the Town of) p. 56 .

Gorbata, the Orbita. P. 210.

Gorya (Kabyles) p. 60 .

Golben, (the Land of) p.341 \&ic.

Grain; the different Sorts of it in Barbary. p.221.

Grarah (Village) p.86.

Gray-Hounds of Syria, their Shape. p. 375 .

Grinding, at the Mill. p. 297.

Grosto, an extraordinary one near Belimont, p. 373. a Rivulet rifing up in it. ibid.

Gun-Powder, or Ba-ronte. p. 230.

Gurba, the Curobis. p. 160.

Gubies, p. 61. 288, the Falhion of them, the Magalia. ibid.

Gurlos, or Hammam Gurbos, the Corpis and Aque Calide. p. 157

Gurgoure (Kabyles) p. 103.

$G$ urmaat (the River) p.43

Gyplum. p.235.

Gyp Saria, vid. Hunneine. p. 20.

H.

Habeeba (the Inland) p.22.

Habits, of the People of Barbary from p. 289 , to 294 . Hykes, anfwering to the Peplut or Toga, p.290. Bumoofe, or ifecrsov. p.292. Sirdles, the Fafhion of them, ibid. Linuen, little wore by the Arabs, p. 293. Shirts, how Ihaped, ibid. the Undrefs of the Women, ibid. Stabrals (the River) P.3 t and Arabs, 1. 32.

Hacljar el Tammar. p. It8.

Soudah. p. It6.

Tinerie. 0.79 .

Fadjees or Pilynims ; their Stations

from Kairo io Alecca. E. 53.

Hadyoute, (the Plain of) p. 66 .

Hanamet, not the antient Adrume-

moum, but the Siagul. p.t61.

Hameefe (the River) p. 72.

Honmal, the sique Tibilitane, p. $\{2 \mathrm{r}$.

Hammah $(c l)$ the Village and Riru-

let. p.2 13 .
Fammaine, (Rivulet and Ruins) P 31 .

Hammams, Bagnio's or Stoves, the different Kinds of them jn Barbary, p. 231. 1heir refpective Situations, p. 233. their Watet weighed bydrosiaucally, ibid.

Hammam el Elma, P. 78.

Leef, p. 157 .

- Melwan, p. 228.

-Meskomeen, p. 121.23 t.

-Monfa, p.350.

Truzza, p. 202

Sedy Aly ben Joube, p. 3 I.

- Pharaoune, 1) 380.

Hammee/c (the Creek) p.35.

Hamza (the I'lains of ) $\mathrm{p} 80$.

Har-arr, (Arabi) p. 51 .

Haratch, (the River) p. 72.

Harbeene, (the Rivulet of ) p.34.78

Har/bgoane, (the Port of) P 19 .

Haflocm, (the River) p. 38.42 . the Aiabs, P.5 2.

Hawking; a Diverlion of the People of Barbary, P. 300. and of Syria, P. 375 .

Heliopolis, or on, now Mazte-reals, P. 343 .

Eeliopolitan Nomos, the Land of Eamefes, p. $34^{2}$.

Henna, vid. Albennab.

Henneiflbath, (Arabs) p. 129.

Herba (el) (the Ruins of) p. 62.85 what it fignifies, p. 78 .

Herkla, the Heraclea and Adrumetum, p. 186.

Heroopolis, now Ad,eroute, p. $34^{2}$.

Herpiditani, p. 17.

Hieroglyphicks, vid.Symbolical Learning, Egyprians, \&C.

Hippo, or Hippo Regius, P.97. whas it fignifies, ibid.

Hippo Dirutus, Diarrhyzus, or Zaritus, P1 I4. the Lake, ibid. the Port, P.1 45 .

Hipponenfis Sinus. ibid.

Hipponites, p. 165 .

Hippopotamus, P. 427.

Hirmam (Dalhkrah) p. 84

Hiroth, p. 346. what it denotes, p. 347 .

Holy Land, the Fertility of it, p.365. it's Olive-yards and Vine yards, p.367. Honey, F.366 \&.c. Plants, p. 368 .

Honbaara, not the Buftard, p. 253.

Foreb, from whonce the Nane, P 383. N. 2 .

Horfe, the Qualities of a good one, p.238,

Houfes (of Barbary) their Falhion, P 273. their Porches, ibid. Impluvium, p. 274. the Court, ibid. the Court Maded by a Veil or Awning, ibid. their Cloyfters, ibid. Stairs, p.276. Terraces, ibid. Paraper Wall, p. 277.

Hubbed, (the Village) p.50.

Humreine (the Port of) or Cacili, p. 18.

Hunting, the Method of it, p.299.

Hulmal (el) (the Plains of) p. 12.

Hyena or Dubbah, p. 246.

Hyle, what it denotes, p. 116.

Hyle ben Aly (Arabs) ibid.

Fydrals (the Ruins of) p.198. the Tlunudronum. ibid.

Fyke or Blanket, $p, 289$. the Peplus, Toga \&ic. P 290.

fackall or Dheeb, p. 247 . not the Lyon's Provider, ibid.

Jaffarkal, what? p. 308 . 


\section{TH E I N D E X.}

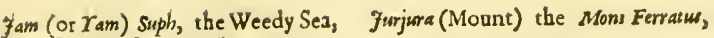
or Gulph of Heroopolit, p. 349.

Ibis, ( embalined) p. 422 . now a

rare Bird in Egypt, p. $4 \geq 8$.

Itofium, now Algiers, p. 71.

Icuncule, a Variety found in Egyp? p. 425 .

femme, the Tifdra, p. 206 .

Fendill (Arabs) p. 60

Ferba, or Gerba, the Ifl. p. 197.

Forboa, the Defcription of it, p.248. the $\Delta i x \& s$, not the Saphan, ibid.

fericho, it's Palin Trees, p.37t.

feridd $(e l)$ or fereed, i.e. the Dry Country, p. 2 ro.

Ferufalem (theSituation of it) p.334.

Fessne, or Plain; the large one near Tripoly, p. 326 .

jezeire (el) vid. Algiers, p. 71.

Ignis fatwus, an extraordinary one, P. 363 .

fibbel Agreefe, p. I 09 .

- Atiackah, or Mountain of Deliverance, p. 348 .

- Aurefs, the Mons Aurafius and Mons Awdus. P. 1t?.

-Decra, p. 80.90.

-Dif, or Mountain of Reedy

Grafs, p.35.

-Dive, P.59. the Mons Tranfcel$\operatorname{lenfis}$ ibid.

- Filiaan, p. 109.

Haddeffa, p. 229. the Quality of the Salt of it.

- I-ate, p.I $1 \mathrm{t}$.

-Iskell or Cirna, p.165.

- Karkar, p. $5 \mathrm{t}$.

- Ker, p. 28 .

- Megala, p. 202.

- Minifs, p. 35. the Salt of it, p. 229.

Seilat, p. 85 .

- Suffian, p. 113 .

- IVoofgar, p. 106.

Fijel, the rgilgili, p. 92

fillebba, a hort bodied Tunick p. 292.

Fimmah, (Church) p.284. N. 1.

fimmeelab, the Gemelle, p. ros.

Fimmel, the Tegea, p.zo5. the Chozala, p. 42.

fin-enne (River) p. 84 .

Finnet (the Creek of ) p. 73. what it fignifies, p. 74.

Fird, the Aniinal of that Name, p. 248.

Immifea, (the Port of) p.2 1

Inoculation, of the Small Pox, difcouraged in Barbary, p. 265 .

Infects, of Barbary, p. 255 .

In/hilla, the Ufilla, p. 193

Inftruments, fuch as were ufed in the Syunbolical Writings of the Eeyptians, p. 403. Mulical, ufed in Barbary, p. 268-9 \&c.

Iol, what it imports, p. 39 N.r.

fordan, (the River) p.373. the Bignefs of it, p.374. what Quantiry of Vapour is drawn from it every Day, ibid.

foube (el) p. 16

Joupaide or Gentlcmen, P. 57

Fowam al Mingrah, p.112.

Forries If. the Taricbie, p. 192

Fris, fone species of it in Barbary, P. 235 .

I achar (the Tribe of) $\mathrm{p} .33^{2}$

Ifraelises, the Road they took to the Red Sea, p. 344.

$y$ fer (the River) or Afura. p. 19.

mdea, vid. Holy Land.

Fudah (the Tribe of) p.333.

Yrjeb, of the Seedrab, p.226. p. 77 .

$K$.

Kabyleah, Kabyles, or African Families, p. 8 . 289. their Way of living, p. 288 .

Kade/h, p. 335-6. 354

Kaide, what it fignifies, p. 30. N.".

Kairspan, the Vico Augufti, p.200.

Kairo, Cairo, or Al Kabirah, called Al-Mefjer, p. 340. the City of Ramefjes, p. 343

Kalories, or Greek Priefts, live a ftrict Life, 351 .

Kardanah, or Belus fl. p. 332 .

Kasbaire, the Satafi, p. 104-5.

Kegquas ( 2 /a ràn) how it unay be interpreted, p.279

Keff, the Sicca Veneria, p. 179.

Kermes Nafara, the Opunsia, or prickly Pear, p. 227.

Khadarah (el) (the Ruins of) the Zucchabbari. p.59.

Khafilah, what it imports, p.4 1. N.*.

Kiblah, what it denotes, p. 284

Kifbon, (the River) the Sources \& of it, p.33t.

$X i$ er, the ABurws, p. 198.

Kitchen Gardens of Barbary, what they produce, p. 223.

Kolrum (the Sea of) p. 349

Koran, or Coran, the principal Book that is learnt in the Moori/h Schools, p. 262.

Kou-kou (the Dajbkrah of ) p.tot.

Kubbah or Cubba, what it lignifies, p. 80.

Kubber Romeah, P. 4

Kulmeera, or Lar Cafiellsm, p. 33.

Kumrab, an Animal betwixt an Afs and a Cow, p. 239

\section{$\boldsymbol{L}$.}

Lake of Marks, p. 2 I , the Trironis Palus, palus Libya, and palus Pallas, p. 212-3.

Lakb.dar, (Kabyles) p. II 6.

Latikea, or Laodices ad Mare, the Situation of it, p. $3^{21}$. the Ruins \&ic. p.322. feveral crypse near it, p. 323 .

Lambefe or Lambefa, p. 118.

Lar Caflellum, p. 33.

Lataff (Arabs) ibid.

Lasopolis or Babylon, p. 343

Laturus Sinus, or Har/bgoont, P. I 9.

Leblebby, the Pigeon's Dung of the Scriptures, p. 223.

Leffah; the Dipfas, p.25: the Antipathy betwixt it and the Chame. leon, ibid.

Lemnir, p. 16.

Lempsa, the Leptis parva, p. I91.

Lentils, fuppofed to be petrified, p. 4 I 6. N. 1.

L'erba, the Lambefe, p. II 8 .

Lerwee, vid. Fi/bsall.

Lesbath (the Diftrict of) p. IIz.

Levanters, or ftrong eafterly Winds, p. 358.361 . Veflels appear to be inagnified in them, p. 362 .

Libanus, (the Mountains of ) cover-

ed in Winter with Snow, p. 362.

Libya, p. 8 N. 4

Lidmee or Addace, or Sirepficeros, or Pygarg, P. 243.

Lorbu/s, the Laribus Col. p.176.

Lotophagitis Inf. the Brachion, and Meninx, P.197.

Lotus; the Fruit of is, from whence
Larhaal (Kabyles) p. 60. the Lotophagi took their Name, p.225. the fame with the Seedrah of the Arabs, p. 226 . E. 47.

Lowpaat or Lowaase, Gatwlian Arabs, or Kabyles, p. 58.86.

Lowhareah, the Aquilaria, p.I58.

Ltoo-taiah; Village and Mountair of Salt, p. 116.

Lyon, p.244. not afraid of Women ibid. the Way of catching them, p. 245. preyeth chiefly upon the Wild Boar, 249.

\section{$M$}

Machurebi, p. 66

Machures, ibid.

Macbusit, p. 55.61 .

Madagh (the Port of) p. 22.

Madder (the Diftrict) p. 54.

Madrepores, vid. Coral, P. 384.

Mafragg (River) the Rubricatus, p.98.

Magalia, or Gurbies, p. 228

Magreb al Awfat, al Acksa, p.s.N.s.

Magrowah (the Diftrict) and Arabs, p. $55 \cdot 76$.

Maguzzel (the Spindles, their roinancic Situation, p.326.

Maharefs, the Macodama, p. 195.

Mahamall (the Village of) p. 13 I

Majanah (the Plains of) p. 106

Maihary, vid. Dromedary, p. 240.

Maihrga (Mountain) p. 85.

Mail' Calbem, p.110.

Mailiff (Arabs) P. 54.

Maifearda, p. 16.

Makerra (the River) p.3I.

Malchubii, p. 107.

Malububalus Mons, p. 56

Maliana, Malliana, P. 62.64

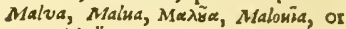
Mul.looia, p. 10,11. or Malvana, 15 the fame with the Anlucha, Molochath and chylemath, P. I I, I 2, I 3, 14,15 .

Mampfarus Mons, p. 101.

Maniana (the Village) p. 62 .

Manna; the Infcription relating to it, E. 53.

Manfourah, (the City of) p.so.

Manfoureats ( the River) the Sifaris, p. 91.

Mapalia, the Tents of the Bedorseens, p. 286.

Marab (the Defert of ) p. 349.

Marabburts, their Title hercditary p. 306. fome of thein linpoltors, p. 307 .

Marathes, now the Serpens Formsain, P.325.

Marble; noQuarries of it in Barbary, p.235.ThebaicMarble in greatPlenty in Arabia, p. 381 . the Bulhy Marble, or Embufcatum of Mount Sinai, p. 382 .

Marriage, how it is performed at Algiers, p.303. Upon Forfeiture of the Portion, the Algerines can put away their Wires, ibid.

Mafafran, (the River) p. 17. 46 what it fignifies. ibid.

Mafayran (the Town) p. 32.

Mafcar, (the Town,) the antient

Vifioria, p. 53 .

Mafclianis, p. 202.

Majbarta, what? p. 65 .

Maflefylii, p. 54 .

Mathematical Figures, wfed in the Symbolical Writings of the $\boldsymbol{E}$ grprians, p. 404.

Mathennaticks, litcle known in Bar-

bary, p. 267 .

Marma-ia (Arabs) p. 60.

Mlastamoris, what ? p. 22 I. 


\section{T H E I N D X.}

Niatter, the Oppidum Materense, F. 165 Mlatuareah, the Heliopolis, p. 343.

Matritaniz; the Difagreement of Authors about their Extent, p.y. their Boundaries were always the fanc, F. $\mathrm{I}_{3}$.

Mfawizanise Tingitana, why fo called, ibid.

-Cefarienfos, why fo called, ibid. the antient Boundarics of it, p.6. N. 10.14 .

--Sitifenfis, p. 6. N. 10. p.101.

Aazices, P 57.60

Mazoniah, (Atabs) F. 100.

Marouna (the Town) p.54

Medals; fome fuppofed to have been itruck in Barbary, E. 59.

Medea (el) the Town of ) or Ajrica, p. 192 , the Lamida, with the Defcription of it, p. 74. the Heraclism, p. 337.

Medrafbem (the Monument) p. 10.

Aleclah (the City of) the Mrikvum p. 106.

Megreefe (Mlount) p 104.

Mejerdah (River) the Bagrala of Brada, P.i 46. vid. Bograd.z.

Asi jiddah, P.57.

Arelanogretili, who? F. 8. 86. 135. 136.

Mfllack, F. IS. vid. Cape Hone.

Asemon (the Ruins of) P.57.

Mcmounturroy, a Sepulchral Monument, ibid.

Aremplis, now Geez, P. 34 r. the

Seat of the Egyptian Kings, ibid.

Afcritl Feire, the Vacca, p. 205.

Aenzil, the Zeta, ibid.

Merdaß (River) p.73. Arabs, 99.

Asereega (the Ruins and Baths of) P. 64,65 .

Meribah (the Rock of) p.352.

A terjejal (Village) p. 61 .

Aters' Agoleite, P. 35 .

- el Amouflse, $\mathrm{p} 43$.

- el Berber, or Polt Genoc/e, p.95

-el Dajaje, p. 74.

- el Dhabanne, p. 63

- el Fabm, p. 89.

- - el Kiber, or Tle Grear Port, p. 22. - el Zeitoune, p. 93.

Mefaff, or C: Ferrat, p. 28.

Arefergeen (the Village) P. 51 .

Arefjeclah (Town of ) p. 112.

Metagranisis Terra, p.10r.

Metagonium Prowont. P. 94

Metafin, vid. Temendfule.

Metrijiah (the Plains of) p. 65.

Mettfe-conbe, or perforated Rock, p. 89.

Mezzya (Kabyles) p. 76

Aticéitj, p. 120

Midly or Midiley (the Plains of) p. 31.52 .

Midroe, the Village and Rivulct, p. 3458 .

Migdol, p. 346.

mikeas, Nilefope, or Mcafuring Pillar, p. 433 .

afiliana (River) the Carada, P. 157.

Mina (River) p. 34.

Mindas (Diftrict) p. 56

Minerals; the different Sorts in Barbary, p. 236 . in Arabia, 381 Mifua, P. 157.

Mifulami, p.120.

Mioccatce (the Mountains of ) p. $34 t$.

Alunaster (the City of) p. 190.

Alons Balbu;, p.184.

Nonfters; not produced in $\mathrm{Bar}$ bary, p. 261 .

Monies Garaphi, p. 64

Aroraifah, the Maxula, p. 157.
Moraick Pavement, at Seedy Dostde, p. 157.

Molques; their Fathion, p. 283.

Nownal, (the Diftrift of ) p. 122 .

stuckat el Had ar, p. 115 .

Niuclidab (el) the Ford, P. 32.

Atuconi, p. 101, 10z.

Nummies, ftand upright, p. 419 . their Defcription, P $422 \mathrm{irc}$

Mulick; the different Airs of it in Barbory, p. 268 .9.

Minskecia Net, p. 287 .

Minftewalo (Mountain) p.108-9.1 16. $M N / l i$, P 179.

Mriftrgannim (the Town of) F. 32.

the Cartenna, P 33.

Niysli-anah (the River) p. I 31 .

\section{N.}

Nabal, the Neapolis, p.t6t.

Nabasheans, p. 354 .

Nackos or Natioufe, i.e. the Bell, the promont. Afollinis. p. 37.

Nadagara or Naragara, F. 130.

Nadies (Arabs) p. Ioo.

Nalor (the 'Town) p. 56.

Nabar el Berd, the Co'd Riter, Ol'

Cold Waters, the Eleutherus, P.328.

Nahar $\mathrm{Waf} / \mathrm{cl}$ (the River) p.34

Nizlaura, the Scala Trrionim, the Co.

lour \&.. of the Rocks of $i t, p \cdot 372$.

Nalava fl. p. 90

Natron; how it is produced, E. 55 . Neardee (Kabyles) the danger of attacking them, p. 117 .

Nedroma or Nedrûme, p. 47.

Nemem/hah (Arabs) p. 131

Vic-korve (the Garriton of) p.115.

Nif-rowah (the Diftrict) p.zII.

Nije-daimals, the castiverbera, or Uromaltix, p. 250

Nile; the Pelusiac Branch, p. 337. the Pallmetic, ibid. the inendefian, ibid. the Tanitic, ibid. the Sebennitic, ibid. the Bolbutic, ibid. the carnopic, ibid. how the Nile is bounded on each Side, p. $34 \mathrm{t}$. the Caufc of it's Inundation, f. 432. the Quantity of Mud brought down by it, ibid. the Quality of the Mud, ibid. the limport of the Nane, P.433. the Depth of it in Winter, p. 435 . the Proportion in which it increaleth, p. 436. Sixteen Cubits the ufual Standard, ibid.

Nile,cope or Nilometrum, F. 433 . the Cubit, by which it is divided, ibid. Kalkafendas's Account of it, E.57. Nif-rag (the Fountain) P. 31.

Nifjal (River) P. 74.

Nomades, p. 3 .

Numetation; a particular Method of it among the Eafkrn Merchants, p. 267

Numidia; the Difagteennent of antient Authors about it, p. 9.

Nimidia Propria, p. 6. N. $1,2$. Maj3lorsm, p. 6. N. 7. 101. -Nlaj] c/ylorum, p. 6. N.9.

\section{O.}

Obelisks; how conveyed from the Quarry, p. 381 . the Matter of thim, $p$ 410. how the Hierogly. thicks werc engraven upon them, ibid. the I'roportion of the Parts, ibid. they were dedicated to the Sun, p. 411 . emblematical of Fire, ibid. The cbelish at Matsereah, F 4:2. erested by Sochis, p. 413. Olecs, or Back-Houfes, p. 280. (moley Sinarb (the Ruins of) P.IIz.
Oran, vid. If arran, p. 24 \&s

Oripelargus, P 388 .

Orthofia, p. 328 .

Palsws, 0.324.

Palm Tree; how is is propagated, p. 224. the Honcy of the Palin Tree, p.225, the Age of it, ibid. vid. Date Tree.

Panther or Lcopard, p. 244.

Paralysick; the letting duwn of him conlidercd, p. 277

Paran (the Defert and Convent of) p. 355 .

Parentalia, performed by the Moors, p. 285 .

Pebbles; rlseVariety of Colours in thole of Egyps and Arabia, P.383. Petra, or Aice, or Kekem, p. 354.

lectrified Village, vid. Ras Sem.

Petrified Olives, Meloms \&ic. of the Foly Land, P.372.

Phaamah, (the Rivulet of) the Phoemins, p. 80.

Pharos; the Difance of it formerly frowl Egyts, P. 338 .

Ph.zиนfi, p. 86.

Philofopher's Stone (the) a good Crop, p. 237.

phanice, from whence the Name p. 371 . N. 4.

phla Inf. p. 212

Phirurefus Mons, p. 58.

Ihyfick; the prefent State of it in Barbary, P. 264.

Pigeon's Dung, or Lebletby, p.223.

Pihabhir oth, p. 346 .

Pillar of Holojerncs's Bcd, p. 287.

Plaifter of Terrace, howinade, p. 286.

Plants of Arabia, P. 383. thore of the Red Sca, viz. Corals, Mladieporet \&.c. F. 384 . thofe that were ufed in the Symbolical Writings of the Exyprians, p. 400 . how refrethed in Egyp:, p. $43 \mathrm{1}$. a Catalogue of the curious Plants of Barbary \&c. E. $37 \cdots+7$.

Pliny, a Copier of Mela, p. 13.15 Pompey'sFanily, $\mathrm{p} 63$.His Pillar, $\mathrm{p} \cdot 338$. Porcupine; the cafting of it'sQuills. p. 249 . N. 4 .

Porzo Farina, p. 146. or Gar el Mai. la $h_{\text {, }}$ the Rascinona.

Portus Divini, p. 24.29

Portus Aagnus, p. 22, 23.

Poyfon, of the Scorpion \&c. how cured, p. 259.

Pox (Sinall) how treated in Bar. bary, p. 264-5.

Prophecy; the Pretenfions they inake to it, P. 308. a Prophecy, promiling to the Christians a Reftoration of all they loft to the Turks and Saracens, p. 309.

Province (the) of Ticmjan, p. r.

Provincia Nova, p. 6.

-Proconfularis, P.14I.

Vetus, ibid.

Provilions, very cheap in Barbary, p. 296.

Pulfe (the feveral Sorts of) p.222.

I'unithunents in Barbary, P.3 Is.

Pyramids, of Egypt, their Diftance from Geeza, p. 341. Emblematical of Fire, p. 411 . Dedicated to the Sun, ibid. 'Their Planes regard the Four Quarters of the World, p. 412. Their Dimenfrons differcntly laid down, $\mathrm{P}$ : 414. No Horizonial Bale whereby to Mieafure them, ibid. None of chem were finilhed, ibid. They were not to confint of Steps 


\section{T H E I N D X.}

P. Their Stones not brough from the Trojan Mountains, $4: 6$ No Account of theji Founders, or the Tine of their Foundation ibid or for what Ufe they were intended, P.417. 418.420. Their Infide little known to the Antients, ibid. The Meafure of them, E. 54 .

Prgarg, vid.Lidmee.

Quail; a species without the hinder Toe, F. 253 .

Quaraniania (the Mountains of ) p. 333 .

Quarries, F. 381 . vid. Marble.

Querkyne/s In. tilc Circina, and circinitis, p.193.

$$
R .
$$

Fachamah, or Geer Eagle, p.3\$8.

Raigah (A rabs) p. 108.

Raili cones in Barbary with W. and $N$. Winds, $p .218$. The Quantity of it that falls in a Year, F. 2 19. The rainy Seafon is in Winter, ibid. The forme and the latter Rains in Barbary p.220. in Syria, p.363. upon the Coaft of Egypt, p. 43 I. E. 55.

ramefes, p. $34 t$. the Heliopolitan Nomos, P. 342.

Ra/hig, what it fignifies, p. 56 .

Ras, or Head Land, p. 19. N. 1.

- Accon-natter, 0.67.

-cl Ainune, p. I1:.

el Amosylh, P. 43.

el Hamralo, p. 95. the Hippi

Promont.

_ el Terff, p. 38 .

_ Haded, p. 95.

- Hadeed, P. 95.

- Scm, the Petrifications there

found, p. 383 . N. 2 .

Rafoula (Arabs) p. 73.

Red Sea, or the Sea of Fdom, or Yam Souph, i. e. the Weedy Sea, p.387.

Regia (River) P. 73.

Remedies; fuch as are ufed in Barbary, p. 264. that againt the Plague, p. 266 .

Rephidim, $\mathrm{p} 352$.

Reubon (the Tribe of ) p. 333.

Rhades, or Ades, pols 6.

Rice; how raifed in E\&ypt, p. 430.

Fomaleab (the l'lains of ) P. 53 .

Rou-wadde, or Rou-ad, the Aradus, or Arpad, p. 325.

Roo-eena (the Brook) p. 58

Rozetio, or Rafid, p. 337 .

Rufcinona, p. 146.

Riggga, the Caraga, p. 207.

Ruficada, now Saigasa. p. 94 .

Ruspina, p. 190

\section{$S$.}

Sadry (Mountains) p. 85 . Sachratain (Mountains) p. 47.

sadlock, what? p. 303 .

Salsaleel, the Ru/pina, p. 190

Sahara (the) or Sah-ra, P.

Sahul (tlie Diftrict of ) p 214

Sgigata, the Ruficada, P. 94.

Salampfij, P. 107 .

Sal Armoniac; how it is made, E.55.

Sal Gem, P. 230.

Salec7o, the Sulledti, p. 192.

Saline, or Salt Pits of Arzew, p.229. thofe of the Gulessa; of the shous \&c. ibid.

Salt; the great Quantities of it in Barbary, P.228. The Salt of the Mountains of Lwo-taiah, $\mathrm{F}, 220$ of the Lake of Marks, $p, 230$. of the stribkabr, ibid.
Salt Petre, or Mailah haij; how it is made, p. 230

Salt Petre Works, p. 22\$.

Salt Pits, of Arzerw, .30

Salt Works, upon the Coaft of Syria, p. 372 .

Sand; the Dijfts of it in Arabia, P. 378 .

Saphan, not the ferboa, p.249. bus the Daman Ifrael, p. 376. Saracene, the Wildernefs of Elham, P. 345 .

Sarmah, what? p.303. N. 2

Salbee, a peculiar Species of the Apricot, p.226.

Sava Alunicipium, p. 104

Sbeebah, the antient Riria, p. 53. the Tucca Tcrebinthina, p. 199.

Scala Tyriorum, vid. Naleura.

Scandarea, the Alexandria, p.338.

Scenise, p. 3. 5. N. 3.

Scilliand (the River) p.19S.

scillitana Col. F. 202

Scorpion, p. 258

Sdur, or Sinur (che Defert of) P.349.

Sebba Rous, p. 93. the Trium, or Afetagonizum, p.94.

Scbbeine Aine, or Seventy Fountains, p. 34 .

Sebowe (the Diftrict of) p. sor.

Seedy, the Meaning of it, p.16. N **

Serdy Abdel Abuss, the Muftis P. 179. Abdelmoumcn, p. 16 Abid, p. 57 .

- Ammer Buck-tewah, p. 148.

Alboure; his Hiftory, p. 307

ben Mulha-lah; his Hittory, ibid. - Boofeide, P.154.01 Cape Carthage.

Boumadian, P 50.

- Braliam, P.t08.

- Braham Aflemmr, p. 84 . - Braham Barabeifa, p. 76.

-Dorsde, the Milua, p. 157.

- Ebly, his Hamman, p. 50 Embarak Efmati, 107.

-Ferje, or Via, p. 67.

- Hablbee, p. 80

Hallif; p. 67

- Hamet ben Dreese, p. Iol.

- Hamiza, p. 80.

Lafcar, p. 134.

- Neemon, p. 128.

Occuba, P. 134 .

- Rougeife (Mountains) p.124.

- You/eph, p. 63

Seiboufe (the Rivel' of) the Armua. p. 97 .

Seir (Mount;) the compating of

it, P. 354 .

Selenires, p. 235 .

Senbadgab (Arabs) F. 99.

Seniore (the Ruinis of) P. 123

Sepulchires; how the Moorilb onses are built, p. 285 .

Serpent-Eaters in Kairo, p. 430.

their Dances, ibid.

Serpents, very numerous in Egypt, P. 429 .

Seseef, the Sitifi or Sitipha, p. 107.

Seven Sleepers, faid to be buried at Nichow/e, p. 115.

Sfax, (thie City of ) P.194.

Shbai. bee (the Ruins of) p. 124.

Sheep, the different Sorts in Baro bary, $p, 24 t$.

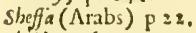

Shekb; what? p. 310. N.2.

Shelliff (the River) the chinalaph,

Shells; thofe of the Fed Sca, p.387.

a Catalogue of them, E. 5 s.

Shell Filh, p. 260

shenooah, (Mlouptain) p. 42 .
Sherfbell, the Fol Cefarea, P. 14. 38 . 39. \&ै.

Shibeardou, or Gat el Bcr-rany ; the

Defcription of it, $\mathrm{r}, 246$.

Shibkah or Sibkah; what ? p. 230

Slibkab) Ellowdeah, p. 211.

Shirga (Aribs) p.co.

Short, what it denotes, p. I14

Showiah Tongue, p.288. a Vocab!l

lary of it, E. 52 .

Shrub we bi $u b, \mathrm{p} \cdot 43.73$.

Shur (the Defert of ) 1). 349 .

Shurfal (Arabs) p. 89 .

Shurph el graab, or Pinnacle of the

Ravens, p. 50.

Sibkah, or Sh:blah, p. 5 1. 2;0.

Sid. vid. Scedy.

Siga, p.14. N. 4. and p. 19, 20, 21. or sigum, ibid.

Sik.ack (River) p. 19.

Silk, a Diain \&ic. p. 31

Sikke or Cutrennus, p. 32 .

Silke (Rivar) p. 31.

Simeon (clie Tribe of) p.335.

Simyra, $\mathrm{p} \cdot 327$.

$\operatorname{Sin}$ (the Wildernels of) p. $35^{\circ}$

Sinalb (the Ruins of) the Opfico-

neum. p. 57 .

Sinai; (the Mountain and Defert of ) P. 350 . and 352 . fiom whence the Name, 1) $3 s_{3}$. the

Garden of the Convent, p. 384 . $\sin 2 n$ (the Brook) p.21.(City)p 50 . Sinus Num dicus, p. 93.95 .

Sirbonis (the Lake) p. 336.

Sirkah (River) p. 120.

Sifara palus, p. 165.

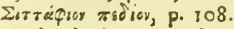

Siyab Ghugh, or Black Ears, p. 247.

Skinkôre, a Water Lizard, p 376.

Skins, the Bottles of the Scripture, P. 304.

Slcepers, vid. Seven \&c.

Soil, the Quality of it in Barbary, p. 228. in Syria, P 364.

Solyman (the Town of ) p. 157.

Sorf cl Tell (the Diltrict of it) P. 21.

Sour Gujlan, the Anzia, P. So.

S.W.Wind, or Ajricus, p. 218.

Sowing Time in Barbary, p, 220 ,

in the Foly Lanil, p. 364.

Spar, P 235.

Spaitla, the Suficula, p. 20 .

Sphinx; covered with Sand, p $42 \mathrm{t}$.

a fquare Hole upon the Rump,

ibidanother upon theHead, $\mathrm{p} .4_{22}$

Spining; the feveral Kinds in $B a r-$ bary, p. 231.

Stations, of the Ifraelites, not always a D.1y's Journey, P.344.

Irim, a Veil, p. 278 .

Stone; the Quality of it in Barbary,

p. 235. difierent Kinds of it, ibid.

Stone Coflins of Egrts, their FaThion, P. 419.

Sior $x_{2}$ vid. Sgigata.

Storks; their Hiftory, p. 428.

Sirata, great Breaches in thein, in fone of the Miountains of Aratia, p. 383.

Sirepficeros, vid. Lidmee.

Succoth, a Place of Tents, P. 344. Sutratah (Diftrict and Arabs) P.107.

Suez, theCity of that Name, p.34. ninety Miles froin Kairo, ibid. Supb or Souph, what? P. 386-7. N, I. Sufrah, what? P. 80. N. 2.

Suf-jimmar (River) p. 92 . Stuminam (River) 10. 9 !.

Summasa (Kabyles) p. 76.

Sumro, the Simyra, orTaximyin, iz 27.

Swics, or Suories, p. 377 .

Surf $f f$, the Surfura, p. z<6. 


\section{T H E ' I N D E X.}

Sufa (the City of) o 189

Sinfeltim (River) p. 56.

Swamma, (the Ruins of) P. 55 .

Siveede, or Stvidde (Arabs) what the

Name fignifies, p 56.

Swords, longoncs found in Ruins, p. 65 .

SycomorelWood; the Durablenels of it, $P$ 423

Syria, (the Inhabitants of, ) P. 376.

Symbolical Learning; vir. the

Symbols of $\mathrm{nfiris}, \mathrm{P} \cdot 392$. of 1 /is, 394 ic. vid. Egyptians.

Syrtis, the Niture of it, p. 19.9

Tabarka, the Thabraca, or Tabrace, p. 99. 142.

Tacape, p. 196.

Tacapizane (Aqut) p. 197.

Tacatux, p. 95.

Tackumbrcet, vid. Sien, p. 19

Tajarony (Mountains) p. 52

Tajna (River) p. 1819.20.

Tagadcmy. Torgdont, Tigedent, Tigri-

dent \&.c. p. 55

Taygals (the Rnins of) p. 109

Tagiar(the River)p.31.theBrook,p.54.

Tagousainah, the Diana. p. 10y.

Tayulmenmers, P. 5 .

T.zjen, what ! p. 296

Taziah, cr Chameleon, the Same with

the Letaa, or Lizard, Lev.11. 3. p. 250.

Taleb, vicl Thulby.

Taleelet (River) P. 31 .

Talk, p. 235 .

Tanis f. P. 195. Clay, 36. N.1.

Taphitis Promont. p. 159

Tutubr, the Taduti, p. 1 to

Tarr or Tympanum, P. 269.

Traimjra, $\mathrm{p} \cdot 327$.

Tebecritum, vid. Tackumbrect, P. I g.

Teddeler, vid Dellys.

Teddert (the Bay) the Cartile, p. 35.

Teleßsad, the Tipa/a, P. 43.

Tejsert (the River) p. 38

Tefrece (Kabyles) P. 104 .

Tifre, (Village) p. 47 .

Telalusis, p. 50.

rell, or Land fioper for Tillage,p.2.

Telepse, p. 203.

Tellarlce e (Mountains of) P. 124 .

Temendfure, the Rufgunise Col. p 72.

Temlosike, the Sigus, P. I24.

Tent, the l'illar of it, F. 287 .

Terrace, how mude, p. 286.

Tefloure (the Town of ) p. 160.

Tefailah (Mountains and City) the Astacilis, F. 52.

Tezzoute, the Lambefe, p. 118 .

Thabbanne, (Serpent) or Thebanus Ophites, F. 251 .

Thaince, the Thena or Thine, p. 194.

Thala, p. 207.

Thalcb or Thulby, who? p. 268 .

Thambes Mons. W. IOt.

Thapjus, p. 191.

Thena of Thene, p.194.

Therme, Spaws, \& \&. p. 231

Thereate el Gannim, P. 85 .

Thermometer, how affeeted with IIeat and Cold, in Earbary, 217.

Thiburficum or Thuburficca, $\mathrm{P} .173$.

Thulby, who they are, p.80. N.1.

Tial, beni Ifrael, what? P. 346.

Tiffelh, the Therefle, p. 130.

Tineh, the Pelus fum, p. 336. What it denotes, p.36. N.1

Tipfa, or Tibej]a, the Tipasa, p.101.

Tifdra, P. 206

Titurie, what it fignifies, F. $7 \%$

-Dolh, ibid.

Gevie, ibisl.
Tiemfan, Tromefen, or Telemfan, the City, p. 47. the Lanigara, p.49. what it denotes, p.so. N.1.

Trmiga, (the Town and Mountain of) $p .58$.

Tnil\} or Tennis, P. 36. the fignification of it, N. 1. ibid.

Tnifs, the Carcome, p. 37 .

Tnifianr, Sorcerers, p. 36

Tobacco, the Culture of it at Latikea, p. 365 .

Tor, rlie paran of ptolem $\gamma_{3}$ p. 353.

Tortofa, or Deir-dofe, the. Amorradus, P. 324

Tozer, thic Tifures, p.211.

Tructe; P. 205. the Wellern Moors trade with a People they never fee, l). 302 .

Tranframe, ol Camarata, p. 21

Trara, the Nountanns, P. 47.

Travelling; the Method of it in Barbary, and the Livan, vid. the Sufety of it in the Tingitania Preface. p. 17.

Tromelen, vid. Tlem an.

Tclerifan, vid. Tlemjan.

Tres Infule, f. 16.

Tretum l'romont. p. 89.

Tribute, collected by the feveral $V$ iceroys of the Kinglom of $A$ l. giers, P. 87.

Ticris, $\mathrm{F} .330$

Tripoly, the Situation of it, ibid.

Triton (River) p. 197.213.

Tritum proniont. p. 94.

Tubna, the Thubuna, p. It 4 .

Tuburbo, the Tuburbum Minu, p. 167.

Tubcrnoke, the Oppidum Tuburnicenfe,

Tuberfoke, the Thiburfoumbure, p.1 73.

Tucca Terebinthina, p. 199.

Tuckereats (the Ruins of) p. 58 .

Tuckufh (Village) p. 95 .

Tuc-cabor, the Tuccabori, p.I 68.

Tingert, the Capital ofl'albrag,p.135. Tulenfij, 1). 66.

Tenga, the Thigiba Col. p. 171 .

Tunis; the Extent of the City, p. 155-6. of the Kingdom in general, p. 139. it's Limits and Extent, p. 140. not divided into l'rovinces, $\mathrm{p} . \mathrm{I}+\mathrm{I}$.

Turressa Chica, P. 67

Tivent, the Artifge, p. 18

Tyre; it's Ports \&.c. p. 330 , why called Sur, p. 331 .

Ubbo, what it fignifies, p.97. N. *

Vegetation of Coral, Madrepores \&C p. 385 .

Via, F. 67

Villages (ofBarbary) how built,p. 16

raegivon, what it fignifies, p. $28 \mathrm{t}$.

Urbya (Arabs) and their Salt Pits, ?. 78.

Erchins, Stars, Shelis \&c. of the ked Sea, p.387. Es t.

Ufilla, p. 193 .

Utenfils; fuch as were ufed in the Symbolical Writings of the $E$ gyprians, P. 402 .

Utica, now Boofhater, p. I 48 .

$$
\text { IV. }
$$

Wadreag, the Inhabitants, p. 8 . the Diltrict and Villages of it, 1). 134.

Wamre (rhe Diftrigt of) p. 78 .

Wan-najb-rccel, p. 34. the Mons Za. lacbus, p. 58 .

Wannorigal (Mount) p. 103.

Warran or Oran, p. 24. the antient Quiza, p. ะs.
Warral; the Lizard of that Nime, P.250. aflected with Mlatick, 4:9 Warif].t, (the Brook) p. 5t.

Wa/b, what it denores, 12.242. N.1.

Watcr, how railech in ryot, p.431.

Water-Spouts, how occilioned, P. 362 .

Weather; an Account of it in $B$ are bary, p. 21?. in Syria, p.358. in Arabia, p. 378. at Aleaandria, E. 55 .

Weaving ; how performed in Barbary, P. 289 .

Wcd (the Meaning of it) $p .2 \mathrm{I}$ N. **.

IVed Adjedee, the Gir. P.133.

- Alluse, p. 90.

-el Abde, p. $3 \mathrm{~s}$.

- el Boofellam, p gr.

-cl DJahab, p. 10+.

- el Ers. p. 99.

- el Fuddah, or Rirer of Plate, p. 34.

- el Ham, p. 84

- el Hammam, P. 3 1. 45.

-ricck, P. 46 .

-cl Kajaab, \}. 22.

-cl Kafaab, p.III.

el Kiber, the Ampraga, P. 92

-el Alailab, or Flumen Saljum,

P. 21.23 .51 .78 .85 .91 .92 .

- el Rsmmel, p. 92

- el Serrati, p. 130.

-el Shati-er, p. 85 .

-el Shifja, p. 46.

-el Zeitoune, P. 73.

-rl Zaine, the Tufca, P.99.

Wedjer, the Rivcr, P. 46 . H'elled, the Mccuring of it, F. I7.
$\mathrm{N}$ **.

W'clled Abdenore, p. I $6.108 \cdots 9$.

- Ajebbj, p. 104.

Sly, p. 52.

- Araimah, P. 109.

- Aityah, an inhofpitable Clan. 1. 93

-Boofreed, p. 60.

-.-Seedy Boogannim, p.214.

- Booker, p. 57.

- Boogiff, P. 214.

- Boo Samm, p. 60.

- Broozeefe, P. 121 .

- Braham, P 123

-Draaje, F. 113.

-Scedy Eeja, p. 84

- Eijah, p.109.

- - Secdy Fiadjeras, p. 84

— Faleef, P. 57.

-Halfa, p. 50.

- Hircaat, p. $3 \mathrm{t} 6$

-I-ate, p. 60 .

- Inanne, p. $7 \%$.

- Mafa, P. 60.

- Mranfoure, p. 102

-Mairhie, p. 86.

- Maubie, F. 214,

- Mellecke, p. 86.

- Moufa ben Adullah, P. so.

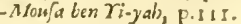

Noile, p. 86.

- Omran, p. 214.

- Oufreed, 13.55 .

- Seide, P. 159. 214.

- Seleema, p. 55 .

-Soulah, 1?. 134.

- Spaiber, p. 60

Uxeire, ibid.

-Wheedam, P. 55 .

Yagoube, p. 87.214 .

- rots.noofe, p. 36 .

-Zeire, p. 50

Winds; which the noft ficquen:

in Barbary, p. 218

$R=$ Wives 


\section{T H E I N D E X.}

Wires; little Regard paid to them in Barbary, P. 303. do all the Drudgery of the Family, ibid.

Worm; the Eggs of the SilkWorm, how preferved, P. 364 .

Woodcock; called by the Moors the Afs of the Partriges, p. 253.

Women, of Barbary, always veiled, p. 293. their Head Drefs, p 294. their Eye Lids tinged with Lead Oar, ibid great Beauties, P.304. paft Child-bearing at thircy, ibid. how they welcome the Arrival of their Guefts, P 3 os. how punith. ed, p.306.

Wooje-da, or Gragida, p. 16. N.1.

Wool-haja (the Arabi or Africans) p.19.

Woorgah (Arabs) p 130. 214.

Wurglab (the Inhabitants of) p. 8. the Asetropolis of the Miclanogetuli, p. 135 .

Wurra (Kabyles) p. 76.

$r$.

Yam Suph, or Weedy Sea, p. 386 .

Yifmoute (Fountain) p. 76.

riffer (River) the Serbeiis, P.73.

$z$.

$Z a a b$, the Zebe, p.8. the Extent and Situation of it, P. 132. it's Vil- lages, P. $133-4$

Zaccone, Oyl of it, P. 369

Zagrwan (River) p. 80.

Zainat (the Ruins of) P. 109

Zakoukit, what? p. 110. N.1.

Zalachus Mons. p. 58.

Zammorah (the Town of) p. 103.

Zaggos, the Mountains and Salt

pits, p.89.

Zamah (River) p.94

Zcckar (Mlounrains) p.85.

Zeedee-my (the Ruins of) p. 58 .

Zeedaamah (Arabs) P. 54 .

Zeenah, or publick Feftival, p. 273. Zeidoure (the Plains of) p. 2 I. 51 .

Zemarites, their Seat, p.327.

Zenati (Arabs and River)p.123.142. Ze-reefa (Arabs) p. $55^{\circ}$

Zerwatty, what? p. 300 .

Zeugitana Regio, now the Summer

Circuit, P. 14I.

Zhoore (River) P. 93.

Ziganeah (Arabs and Mountains)

P.I 24 .

Zin (the Defert of) p. 335

Zmalah, what it imports, p.42.107. Zour el Hamam, orPigeonIfland, p. 35.

Zowan, Zotv-aan, Zowv-wan or Zag-

wan, the Town, Mountain, and

Village, p. 153.184 .

Zowah (River) p. 91.

owamoore, or Zimbra, the AEgimuriss,

p. 146.

Zung-gar (Ruins and Fountain) p. 153. the Zucchara, p. I48.

Zurreike (Serpent) or faculus, p.25I

$Z$ woispah, or Moorifh Suldiers, p.312.

Zwoos ah (Kabyles) P.101.

Znowiah, who? p. 84

Zygantes, p.185.

\section{W OR DS omitted.}

Al. Kahol, or Lead Ore; how the Women tinge their Eyes with ir, p. 294.

AOI $\triangle O I$, or Rhapfodifts, p. 269.

Bosargo, what? P155. N. t.

Catacombs at Alexandria, P. 338.N.3. Cufcaffowe, p. 296. N 2 .

Dibfe, whiat? p. 367. N. 3

Dollar; the Value, p. $87 . \mathrm{N}$ s. the

fignification of it, P. 314. N.1.

Drufes, p. 377 .

Eating; viz. the Method of exting in Barbary, p. 297

Haleluiah, P. 305

Hebron, P. 367 .

Fenoume or finoune, what ? p. 233.306 . Lapis fudaicus, a Remedy againt the Sione, p. 373. N. I.

Locufts; their Hiftory, p.257 \&ic. Mackpelah (the Care of) p.367.

Mandrakes; what they are fuppofed to be ofc.

Manufactories of Barbary, p. 295.

\section{$F \quad I \quad N \quad I \quad S$.}

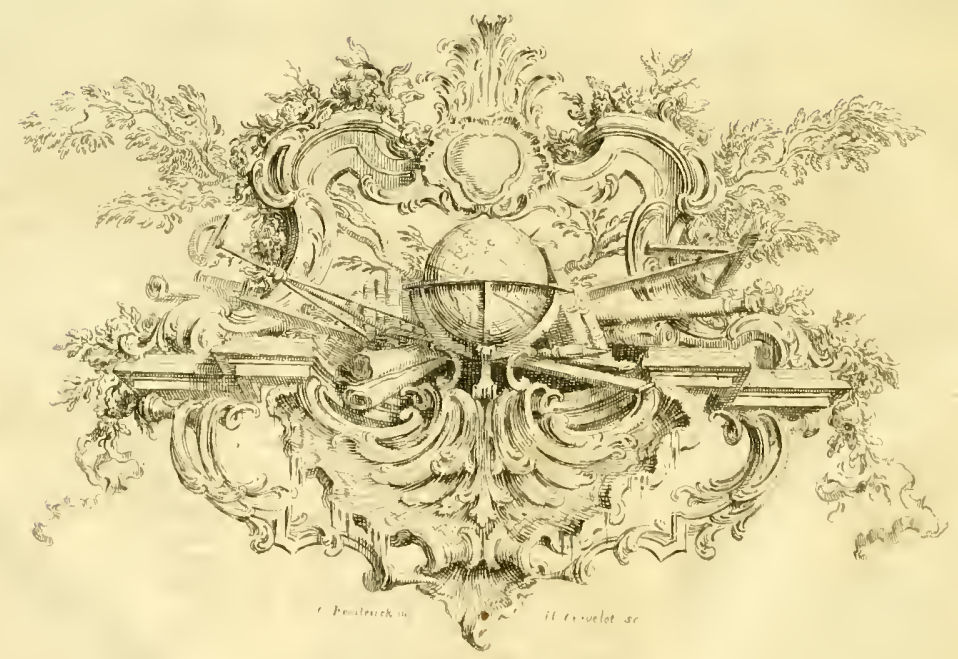







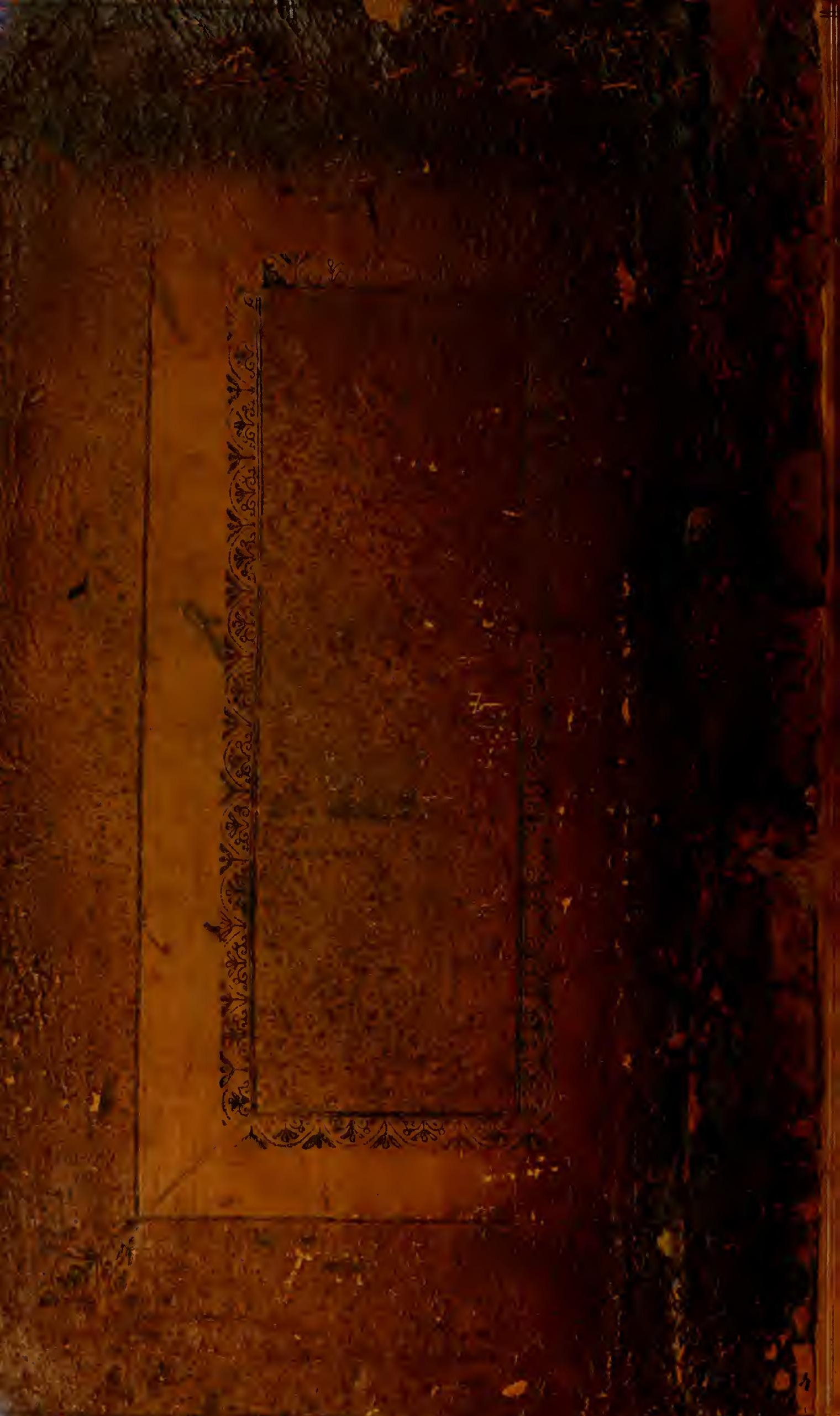

